\title{
The Prehistoric Sites at Choke Canyon Reservoir, Southern Texas: Results of Phase II Archaeological Investigations
}

Grant D. Hall

Center for Archaeological Research

Thomas R. Hester

Center for Archaeological Research

Stephen L. Black

Department of Anthropology, Texas State University

Follow this and additional works at: https://scholarworks.sfasu.edu/ita

Part of the American Material Culture Commons, Archaeological Anthropology Commons, Environmental Studies Commons, Other American Studies Commons, Other Arts and Humanities Commons, Other History of Art, Architecture, and Archaeology Commons, and the United States History Commons

Tell us how this article helped you.

This Article is brought to you for free and open access by the Center for Regional Heritage Research at SFA ScholarWorks. It has been accepted for inclusion in Index of Texas Archaeology: Open Access Gray Literature from the Lone Star State by an authorized editor of SFA ScholarWorks. For more information, please contact cdsscholarworks@sfasu.edu. 


\section{The Prehistoric Sites at Choke Canyon Reservoir, Southern Texas: Results of Phase II Archaeological Investigations \\ Creative Commons License \\ (c) (1) (9)}

This work is licensed under a Creative Commons Attribution-NonCommercial 4.0 International License 


\section{THE PREHISTORIC SITES AT CHOKE CANYON RESERVOIR, SOUTHERN TEXAS : RESULTS OF PHASE II ARCHAEOLOGICAL INVESTIGATIONS}

Grant D. Hall, Thomas R. Hester, and Stephen L. Black

\section{With Contributions By}

Frank Asaro, Elizabeth Frkuska, Richard G. Holloway Cristi Assad Hunter, Helen Michel, Fred W. Nelson

D. Gentry Steele, and Fred Stross

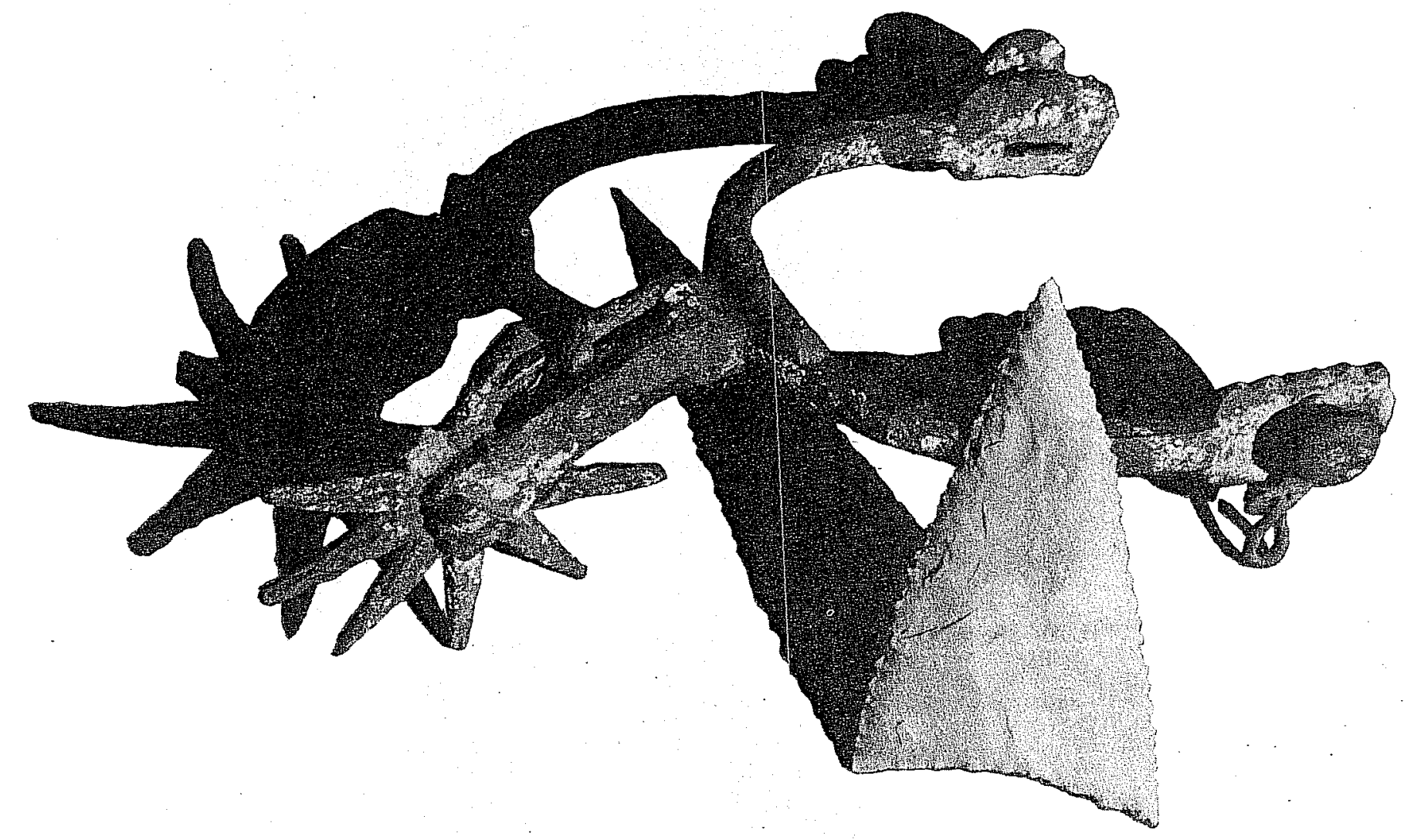

Center for Archaeological Research

The University of Texas at San Antonio

Choke Canyon Series: Volume 10 

THE PREHISTORIC SITES AT CHOKE CANYON RESERVOIR, SOUTHERN TEXAS:

RESULTS OF PHASE II ARCHAEOLOGICAL INVESTIGATIONS

Grant D. Ha11, Thomas R. Hester, and Stephen L. Black

With Contributions by

Frank Asaro, Elizabeth Frkuska, Richard G. Holloway, Cristi Assad Hunter, Helen Michel, Fred W. Nelson,

D. Gentry Steele, and Fred Stross

Center for Archaeological Research

The University of Texas at San Antonio ${ }^{\circledR}$

Choke Canyon Series: Volume 10 



\section{TABLE OF CONTENTS}

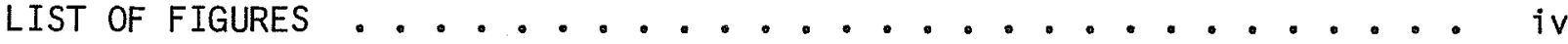

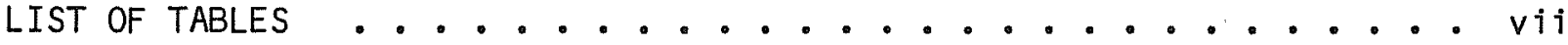

FOREWORD (Thomas R. Hester) . . . . . . . . . . . . . . . ix

ABSTRACT ................................... $\times$. . . . . .

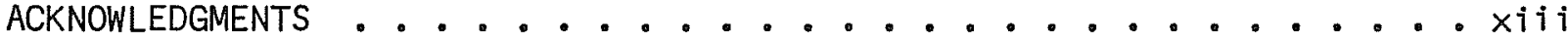

INTRODUCTION ............................ . . . . . . 1

THE NATURAL SETTING

ARCHAEOLOGICAL BACKGROUND ....................... . 7

RESEARCH GOALS . . . . . . . . . . . . . . . . . . . . . . . . 9

TECHNICAL PROCEDURES . . . . . . . . . . . . . . . . . . . . . 11

Extensive Excavations . . . . . . . . . . . . . . . . . . . 11

Site Evaluations . . . . . . . . . . . . . . . . . . 13

Mapping . . . . . . . . . . . . . . . . . . . . . 14

Laboratory Processing . . . . . . . . . . . . . . . . . . 14

THE PHASE II SITE INVESTIGATIONS . . . . . . . . . . . . . . . . . 15

Site Group 1 . . . . . . . . . . . . . . . . . . . 16

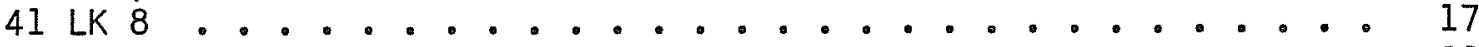

$41 \operatorname{LK~} 201$.......................... 31

41 LK 128 . . . . . . . . . . . . . . . . . . . 31

$41 \operatorname{LK~} 121$........................ . . . . 46

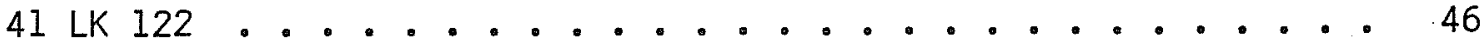

41 LK 127 . . . . . . . . . . . . . . . . . . 47

41 LK 199 . . . . . . . . . . . . . . . . . 48

Site Group 2 . . . . . . . . . . . . . . . . . . 49

41 LK 153 . . . . . . . . . . . . . . . . . 50

41 LK 133 ......................... 50

41 LK 136 . . . . . . . . . . . . . . . . . 55

41 LK 149 . . . . . . . . . . . . . . . . . 55

41 LK 150 . . . . . . . . . . . . . . . . . . . 57

41 LK 142 .......................... 57

41 LK 145 . . . . . . . . . . . ...... 58

Site Group 3 . . . . . . . . . . . . . . . . . . . 59

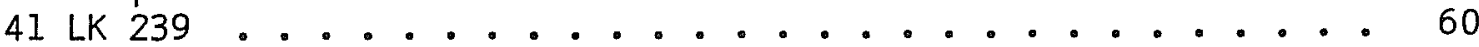

41 LK 190 ......................... 60

$41 \operatorname{LK} 191$. . . . . . . . . . . . . . . 60

41 LK 158 . . . . . . . . . . . . . . . . 62

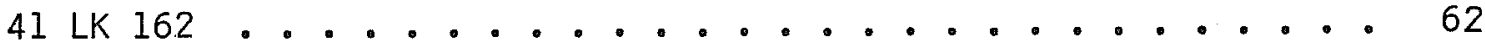

4] LK 180 ..................... . . 63

41 LK I81 ....................... 63

41 LK 182 . . . . . . . . . . . . . . 63

$41 \operatorname{LK} 176$. . . . . . . . . . . . . . 64

41 LK 185 . . . . . . . . . . . . . . . . . . 64

41 LK 241 . . . . . . . . . . . . . . . . . . . 67

41 LK 174 ......................... . . . 67

41 LK 173 ........................... 68

41 LK 170 ......................... 68

$41 \operatorname{LK} 234$....................... . . . . 69

Site Group 4 . . . . . . . . . . . . . . . . . 69

41 LK 14 ....................... . . . 70

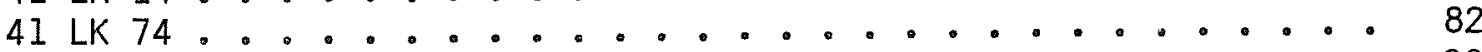

41 LK 236 ........................ 88 
Site Group 5... . . . . . . . . . . . . . . 89

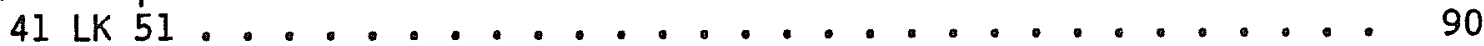

41 LK 53 ............................ 102

41 LK 243 ...................... . . . 109

41 LK 245 . . . . . . . . . . . . . . . . . . . 116

$41 \operatorname{LK} 247$....................... . . . . 116

Site Group 6 . . . . . . . . . . . . . . . . . . 117

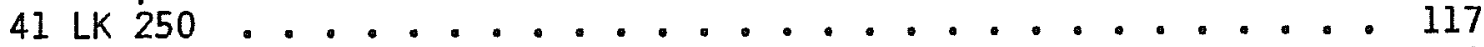

$41 \operatorname{LK} 252$. . . . . . . . . . . . . . . . . . . . 121

$41 \operatorname{LK} 253$. . . . . . . . . . . . . . . . . . . 122

Site Group 7 . . . . . . . . . . . . . . . . . . . 123

41 MC 196 ....................... . . 123

41 MC 201 . . . . . . . . . . . . . . . . . . . 127

41 MC 209 . . . . . . . . . . . . . . . . . . 127

41 MC 213 . . . . . . . . . . . . . . . . . . . . 128

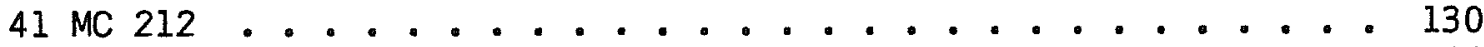

Site Group 8 . . . . . . . . . . . . . . . . . . 130

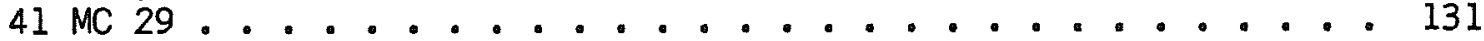

41 MC 55 .......................... 137

41 MC 234 ..................... . . . 148

41 MC 235 ...................... . . . . . . . . . . . . . . . . .

Site Group 9 . . . . . . . . . . . . . . . . . . . 149

41 MC 238 . . . . . . . . . . . . . . . . 149

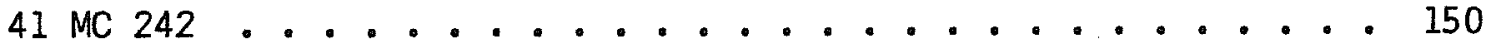

Site Group 10 . . . . . . . . . . . . . . . . 151

41 MC 296 . . . . . . . . . . . . . . . . . 152

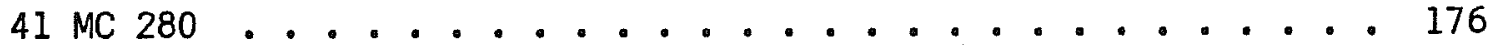

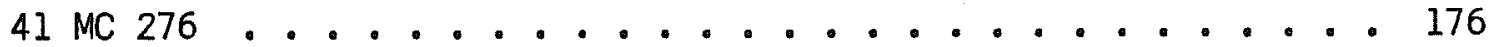

Site Group 11 . . . . . . . . . . . . . . . . . 177

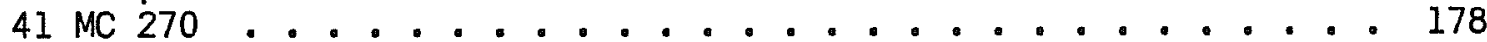

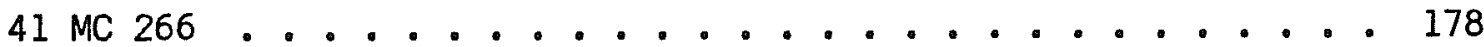

41 MC 282 . . . . . . . . . . . . . . . . 180

41 MC 284 ............................ 180

41 MC 286 . . . . . . . . . . . . . . . . . . . . 181

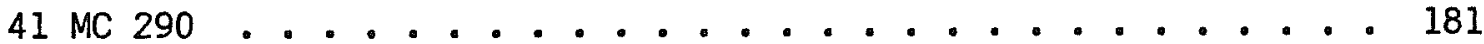

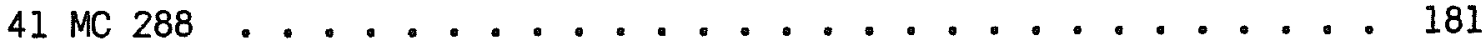

41 MC 293 ............................. 182

41 MC 294 . . . . . . . . . . . . . . . . . . 183

Site Group 12 . . . . . . . . . . . . . . . . . 184

41 MC 94 ........................ 184

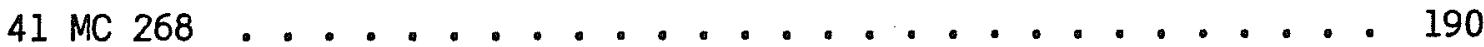

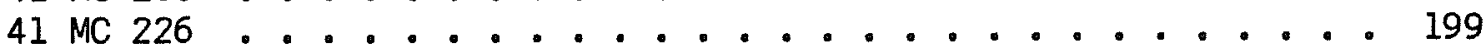

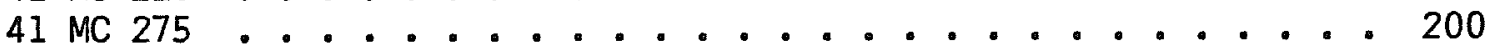

Site Group 13 . . . . . . . . . . . . . . . . . . 202

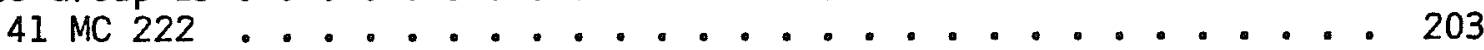

41 MC 246 . . . . . . . . . . . .......... 226

41 MC 257 . . . . . . . . . . . . . . . . . 228

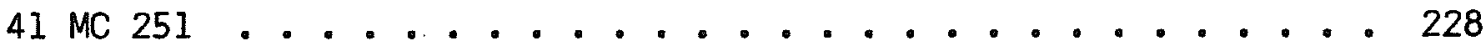

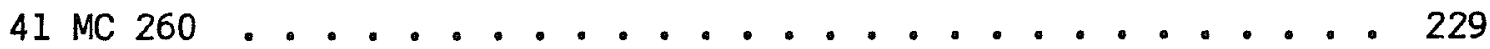

ARTIFACTS . . . . . . . . . . . . . . . . . . . . . 230

Lithic Artifacts ....................... 231

Chipped Stone .......................... 231

Cores ......................... . . 231

Thick Bifaces................... . . . 245 
Thin Bifaces ................... 255

Distally Beveled Bifaces and Unifaces ........... 289

Unifaces .................... 305

Trimmed Flakes .................... 310

Obsidian Core Fragment ................. 316

Debitage ....................... 316

Hammerstones ........................ 320

Modified Sandstone . . . . . . . . . . . . . . . . 320

Modified Quartzite.................... . . . . 329

Miscellaneous Lithic Artifacts and Materials ......... 331

Satin Spar Gypsum . . . . . . . . . . . . . . . . 331

Ferruginous Sandstone . . . . . . . . . . . . . 333

Hematite Concretions ................. 333

Ocher ....................... 333

Modified Siltstone ................. 334

Bone Artifacts ....................... 334

Marine Shell Artifacts .................. 335

Modifjed Mussel Shell ................... 337

Prehistoric Ceramics (Stephen L. Black) . . . . . . . . . . 337

Ceramic Background . . . . . . . . . . . . . . . 338

Phase I Ceramic Analysis . . . . . . . . . . . . . . 340

Ceramic Terminology . . . . . . . . . . . . . . . 341

Attribute Coding Values . . . . . . . . . . . . . 345

Phase II Methodology . . . . . . . . . . . . . . 347

Site Group Descriptions . . . . . . . . . . . . . . . 349

Aborigina1 Ceramics--Summary and Interpretations . . . . . . 376

The Bone-Tempered Ceramic Tradition of South and Central Texas . . 389

Metal Knife Blade.................... . 391

CONCLUSIONS . . . . . . . . . . . . . . . . . . . 391

Establishing Site Significance . . . . . . . . . . . . 392

The Conduct of Phase II Investigations . . . . . . . . . . 393

A Cultural/Chronological Summary of Choke Canyon Prehistory . . . . 393

Suggestions for Future Research ............... . 406

Specific Problems for Future Research . . . . . . . . . . . . 412

NATIONAL REGISTER SITES .................... . 415

REFERENCES CITED ......................... 416

APPENDIX I. SCOPE OF WORK . . . . . . . . . . . . . . . . . 429

APPENDIX II. MACROBOTANICAL ANALYSIS OF PHASE II MATERIALS FROM THE

CHOKE CANYON RESERVOIR AREA, TEXAS

Richard G. Holloway . . . . . . . . . . . . . . . . .

APPENDIX III. ANALYSIS OF VERTEBRATE FAUNAL REMAINS FROM 41 MC 222 AND

41 MC 296, MCMULLEN COUNTY, TEXAS

D. Gentry Steele and Cristi Assad Hunter . . . . . . . . . . . . 452

APPENDIX IV. COMPUTER DOCUMENTATION: THE PHASE II PRIMER

Elizabeth G. Frkuska .................... 503

APPENDIX $V$. TRACE ELEMENT AND GEOLOGIC SOURCES STUDIES OF AN OBSIDIAN

ARTIFACT FROM SITE 41 LK 51, LIVE OAK COUNTY, TEXAS

Thomas R. Hester, Frank Asaro, Helen Miche1, Fred Stross, and

Fred W. Nelson . . . . . . . . . . . . . . . 510

APPENDIX VI. GENERAL DATA TABLES ................ 523

Material Analysis Records . . . . . . . . . . . . . . 523

Debitage Table . . . . . . . . . . . . . . . . 540

Radiocarbon Assays . . . . . . . . . . . . . . . . . . 577

APPENDIX VII. PERMANENT SITE MARKER INFORMATION . . . . . . . . . . 592 


\section{LIST OF FIGURES}

1. Site Map .................. folded insert

2. Topographic Map of 41 LK 8 and Surrounding Area . . . . . . 18

3. Plan of Excavations and Trenches at 41 LK 8 ......... 20

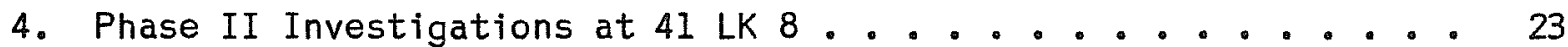

5. Profile Sketch of South and West Walls at 41 LK 8, Area A . . . 24

6. Profile Sketch of Eastern Wall at 41 LK 8, Backhoe Trench 16... 27

7. Feature 2 Plan at 41 LK 8, Area B .............. 29

8. Schematic Sketch of Major Cultural Features at 41 LK 128 . . . . 33

9. Topographic Map of 41 LK 128 and Surrounding Area . . . . . . . 34

10. Plan of Surface Features and Excavation Units at $4 I$ LK 128 . . . 35

11. Phase II Investigations at 41 LK 8 and 41 LK $128 \ldots . . . . . . .37$

12. Plans of Feature 2 and Hearth 13 at 41 LK 128 . . . . . . . . 39

13. Hearth 2 Plan and Cross Section at 41 LK $128 \ldots . . . . . . . .43$

14. Hearth 17 Plan and Cross Section at 41 LK 128 . . . . . . . . 45

15. Phase II Investigations at 41 LK 128, 4 I LK 133, and 41 LK 185 . 53

16. Site and Feature Plans (Hearths 2 and 7) at 41 LK $133 \ldots 54$

17. Topographic Map of 41 LK 14 and Surrounding Area . . . . . . . . 71

18. Plan of Excavations at 41 LK 14 . . . . . . . . . . . . . 73

19. Profile Sketch Along El000 Line from N1008 to N1011 at 41 LK 14,

Area A ................... . . 76

20. Profile Sketch Along N1006 Line from E958 to E960 at 41 LK 14,

Area B..................... 78

21. Phase II Investigations at 41 LK 14 and 41 LK 51 . . . . . . 81

22. Topographic Map of 41 LK 74 and Surrounding Area . . . . . . . . 83

23. Site Extent and Unit Locations at 41 LK 74 .......... . 84

24. Topographic Map of 41 LK 51, 41 LK 53, and Surrounding Area . . . 91

25. Plan of Excavations at 41 LK 51 .................. 93

26. Profile Sketch Along E985 Line from N998 to N1000 at 41 LK 51 ,

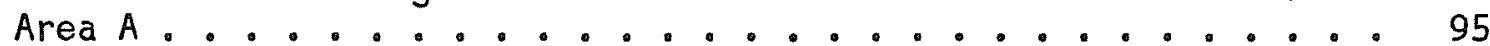

27. Plan of Feature 5 at 41 LK 51 . . . . . . . . . . . . . 97

28. Plan of Feature 6 at 41 LK 51 . . . . . . . . . . . . . . . 98

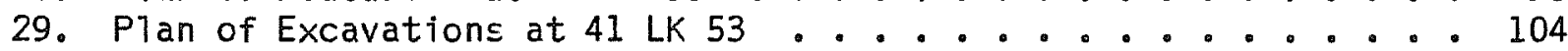

30. Profile Sketch Along E1005 Line from N1000 to N1003 at 41 LK 53.106

31. Plan of Feature 2 at 41 LK 53 ............... 108

32. Phase II Investigations at 41 LK 53 and 41 LK $243 \ldots$....... 111

33. Plans of Site and Feature at 41 LK $243 \ldots . . . . . . . . .113$

34. Views of 41 LK 247, 41 MC 196, 41 MC 213, and 41 MC 212 ..... 119

35. Area and Test Pit Locations at 41 MC 196 ............ . 124

36. Distribution of Burned Sandstone Concentrations at 41 MC 213 . . . 129

37. Topographic Map of 41 MC 29 and Surrounding Area . . . . . . . . 132

38. Plan Showing Site Extent and Unit Locations at 41 MC 29 . . . . 134

39. Plan of Features 2 and 3 at 41 MC 29.............. 136

40. Views of 41 MC 29 and 41 MC 55 ................... . . . . 139

41. Topographic Map of 41 MC 55 and Surrounding Area . . . . . . . 140

42. Plan of Site Extent and Unit Locations at 41 MC 55 ....... 142

43. Area D Plan at 41 MC 55 ............................... 146

44. Topographic Map of 41 MC 296 and Surrounding Area . . . . . . 153

45. Site Extent and Excavation Plan at 41 MC 296 .......... . 154

46. Views of 41 MC 296: Local Environment, Excavations in Progress, and Habitational Features .............. 157

47. Profile Sketch of North Wal1 of N10.27 E999 at 41 MC 296. Area A - 160 
48. Area A, Feature 1 Plan, Level $6(99.10-99.00 \mathrm{~m})$ at 41 MC $296 . . .162$

49. Area B, Feature 2 Plan, Leve1s 5-7 (99.10-98.80 m) at 41 MC 296. 166

50. Views of 41 MC 296, 41 MC 276, and 41 MC 270 ......... 169

51. Topographic Map of 41 MC 94 and Surrounding Area . . . . . . 185

52. Test Pit Locations at 41 MC 94 ............... . . 187

53. Local Topography and Plan of Excavations at 41 MC 268 . . . . . 191

54. Plan of Features 3 and 4 at 41 MC $268 \ldots \ldots . \ldots 195$

55. Views of 41 MC 266, 41 MC 94, 41 MC 268, and 41 MC 275 ..... 197

56. Topographic Map of 41 MC 222 and Surrounding Area . . . . . . . 204

57. Site Extent and Plan of Excavations at 41 MC $222 \ldots 206$

58. Views From Phase I Investigations at 41 MC $222 \ldots . . \ldots 211$

59. Plan of Bone Bed Excavation at 41 MC 222 During Phase I

Investigations ......................... 212

60. Main Excavation Block Debris Distributions at 41 MC 222 . . . . 214

61. Main Excavation Block Feature Distributions at 41 MC 222 .... 216

62. Plan of Features 3, 4, 5, and 8 at 41 MC $222 \ldots 218$

63. Views of 41 MC 222 During Phase II Investigations . . . . . . 221

64. Plan of Feature 7 at 41 MC $222 \ldots 222$

65. Profiles Along Selected Transects in Main Excavation Block at

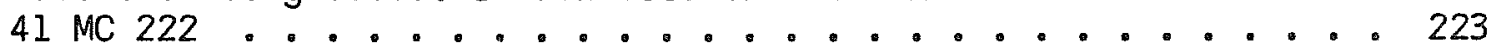

66. Views of 41 MC 222, 41 MC 246, 41 MC 257, and 41 MC 260 ..... 225

67. Cores: Groups 1 and 2 .................. 236

68. Cores: Group 2--Possible Tools .............. 238

69. Cores: Groups 3 and 4 ..................... 240

70. Cores: Groups 5 and 6 .................... . . 242

71. Cores: Groups 2 and 5--Possible Tools and Group 7 . . . . . . . 244

72. Thick Bifaces: Groups 1, 2, and 3............... 249

73. Thick Bifaces: Groups 4, 5, 6, and 7 ............. 252

74. Thin Bifaces: Group 1, Forms 1, 2, and 6 . . . . . . . . . 262

75. Thin Bifaces: Group 1, Form 3................. 265

76. Thin Bifaces: Group 1, Forms 4, 5, and 7.......... 268

77. Thin Bifaces: Group 2, Forms 1 and 2 ............ 270

78. Thin Bifaces: Group 3, Forms 1 and 2 and Group 4, Form 2 . . . 277

79. Thin Bifaces: Group 4, Forms 1, 3, and 4........... 282

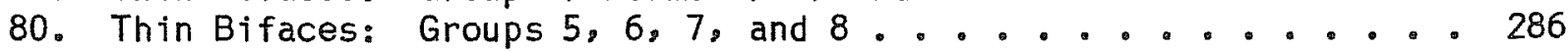

81. Distally Beveled Bifaces and Unifaces: Group 1 and Group 2,

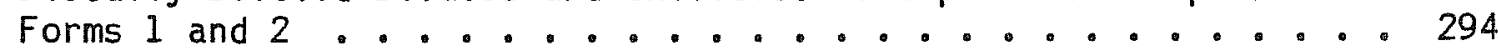

82. Distally Beveled Bifaces and Unifaces: Group 3, Forms 1, 2.

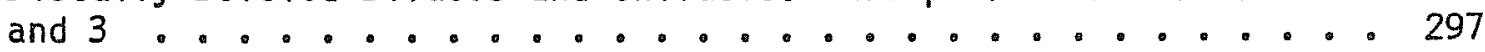

83. Distally Beveled Bifaces and Unifaces: Group 4, Group 5, and

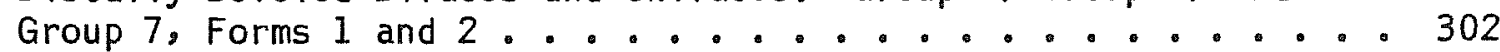

84. Distally Beveled Bifaces and Unifaces: Group 6 . . . . . . . 303

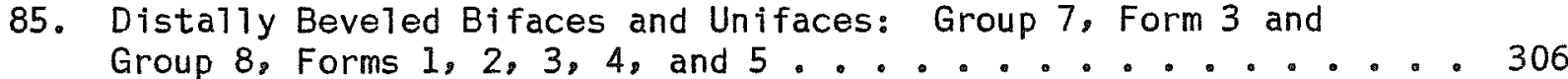

86. Unifaces: Groups 1, 2, 3, 4, and 5............... 309

87. Trimmed Flakes: Groups 1, 2, 3 (Forms 1, 2, 3, 4, and 5), and 4, 314

88. Modified Sandstone: Group 1, Form 1, Specimens 1 and 13 . . . . 324

89. Modified Sandstone: Group 1, Form 1, Specimens 2 and 17 . . . . 326

90. Modified Sandstone: Group 2, Forms 1 and 2 . . . . . . . . . 328

91. Modified Sandstone: Group 2, Form 1 and Group 3, and Modified

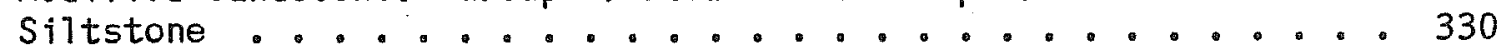

92. Artifacts of Ferruginous Sandstone, Gypsums Hammerstones, Metal
Knife Blade, and Modified Quartzite . . . . . . . . . 332 
93. Bone Artifacts, Marine Shell Artifacts, and Modified Mussel

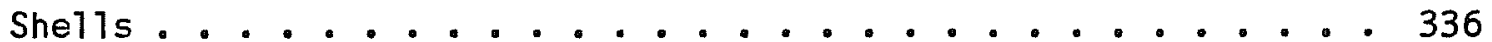

94. Core Characteristics and Sherd Condition of Prehistoric Ceramics . 342

95. Rim Sherds and Figurine Fragment . . . . . . . . . . . . . . 344

96. Figurine Fragments from 41 MC 296 . . . . . . . . . . . . . . . 374

97. Distribution of the Number of Identified Elements per Cubic Meter

(NISP) for the Artiodacty1s, Lagomorphs, and Rodents Recovered

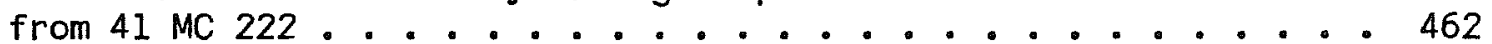

98. Distribution of the Number of Identified Elements per Cubic Meter (NISP) for the Artiodactyls, Lagomorphs, and Rodents Recovered

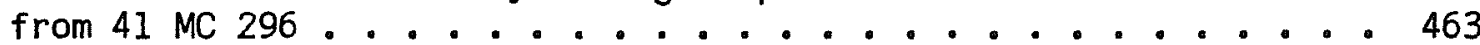

99. Distribution of the Number of Identified Elements per Cubic Meter (NISP) for the Artiodactyls, Lagomorphs, and Rodents Recovered

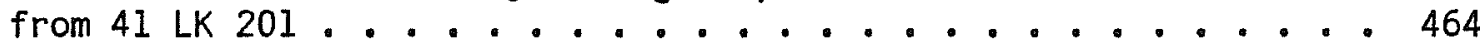

100. Block Chart Illustrating the Relative Percentages During the Late Prehistoric and Late Archaic of the Artiodactyls, Lagomorphs, and Rodents Recovered from 41 MC 296 ............ 466

101. Block Chart Illustrating the Relative Percentages During the Late Prehistoric and Late Archaic of the Artiodactyls, Lagomorphs, and Rodents Recovered from 4I LK 201 . . . . . . . . . . 467

102. Material Analysis Form, Choke Canyon Project, Phase II . . . . . 504

103. An Example of a Parameters File Used in Conjunction with NRP's Main System Program To Generate Data Sets . . . . . . . . . 506

104. An Example of a Table That Can Be Generated Utilizing the NRP Data Based Computer System . . . . . . . . . . . . . 507

105. Data Set for a SPSS Program Studyl SPSS . . . . . . . . . . 508

106. Location of Sites with Escondido/Malad Obsidian in Texas . . . . 517

107. Calibrated Radiocarbon Assays, Nueces River Project . . . . . . 586

108. Calibrated Radiocarbon Assay Pairs . . . . . . . . . . . 589 


\section{LIST OF TABLES}

1. Summary of Hearth Data at Site 41 LK 128 . . . . . . . . . 42

2. Summary of Hearth Data at Site 41 LK 133 . . . . . . . . . . 56

3. Artifacts Recovered from Site 41 MC 222 . . . . . . . . . 219

4. Provenience of Cores by Site . . . . . . . . . . . . . 233

5. Provenience of Cores Recovered in Phase II Excavations . . . . 234

6. Provenience of Thick Bifaces by Site . . . . . . . . . . . . . 247

7. Provenience of Thick Bifaces Recovered in Phase II Excavations . . 248

8. Provenience of Thin Bifaces by Site . . . . . . . . . . . . 256

9. Provenience and Metric Data for Stemmed Thin Bifaces . . . . . . 258

10. Provenience and Metric Data for Thin Bifaces Group 2, Form 1 - . 272

11. Metric Data for Certain Unstemmed Thin Bifaces . . . . . . . . 273

12. Specimen Numbers by Site--Certain Unstemmed Thin Bifaces . . . . . 274

13. Provenience of Certain Unstemmed Thin Bifaces Recovered in

Excavations .................. 275

14. Provenience and Metric Data for Thin Bifaces Group 3, Form 1 • . 276

15. Provenience and Metric Data for Thin Bifaces Group 4, Form 1 . . 279

16. Provenience and Metric Data for Thin Bifaces Group 4, Form 2 . . 281

17. Provenience and Metric Data for Thin Bifaces Group 4, Form 3 . . 283

18. Provenience and Metric Data for Thin Bifaces Group 5 . . . . . 285

19. Provenience and Metric Data for Thin Bifaces Group 6 . . . . . 287

20. Provenience and Metric Data for Thin Bifaces Group 7 . . . . 287

21. Provenience and Metric Data for Thin Bifaces Group 8 . . . . . 288

22. Provenience Data for Thin Bifaces Groups 9 and 10 . . . . . . 290

23. Site Provenience for Distally Beveled Bifaces and Unifaces . . . 293

24. Site Provenience for Unifaces . . . . . . . . . . . . . . 311

25. Site Provenience for Trimmed Flakes . . . . . . . . . . . 311

26. Debitage Totals by Site . . . . . . . . . . . . . . . . 317

27. Total and Percentage of Debitage Recovered During Phase II

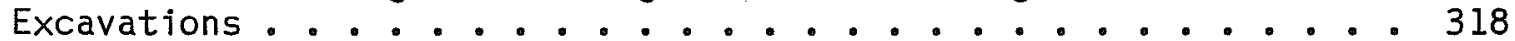

28. Provenience of Modified Sandstone by Site . . . . . . . . . . 321

29. Provenience of Modified Sandstone Recovered in Excavations . . . 322

30. Roundness of Sedimentary Particles . . . . . . . . . . . . 346

31. Wentworth's Size Classification .............. 347

32. Choke Canyon Aboriginal Ceramics--Site Group Summary . . . . . 378

33. Results of Charcoal Analysis from 41 LK 51 . . . . . . . . . 438

34. Results of Charcoal Analysis from 41 LK 128 . . . . . . . . . 439

35. Results of Charcoal Analysis from 41 LK 201 . . . . . . . . . . 440

36. Results of Charcoal Analysis from 41 MC 55 . . . . . . . . . . . 441

37. Results of Charcoal Analysis from 41 MC 296 . . . . . . . . . . . . 442

38. List of the Vertebrate Taxa Recovered from 41 MC 222 . . . . . 453

39. List of the Vertebrate Taxa Recovered from 41 MC 296 . . . . . . . 454

40. Listing of the Number of Identified Elements (NISP) Recovered from Each 10-cm Level of 41 MC 222 for the Artiodacty1s, Lagomorphs, and Rodents . . . . . . . . . . . . . . . . . . . . .

41. Listing of the Number of Identified Elements (NISP) Recovered from Each 10-cm Level of 41 MC 296 for the Artiodactyls, Lagomorphs, and Rodents . . . . . ....................

42. Listing of the Number of Identified Elements (NISP) Recovered from Each 10-cm Level of 41 LK 201 for the Artiodacty 15, Lagomorphs, and Rodents........................... . 
43. Two-Way Tables of Bone Frequencies for the Artiodactyls, Rodents, and Lagomorphs Recovered from 41 MC 296 and 41 LK 201 . . . . . . 465

44. Habitats and Faunal Affinities from 41 MC 222 and 41 MC 296 . . . . 471

45. Comparative Measurements for Lagomorphs Indigenous to Texas . . . 488

46. The Discriminant Function, Section Point for Distinguishing Sylvilagus audubonij and S. floridanus ........... . 490

47. Provenience by Lot Number for Site 41 MC 222 . . . . . . . . . 495

48. Provenience by Lot Number for Site 41 MC 296 . . . . . . . . . . . 497

49. Abundances of Elements by Neutron Activation Analysis in Parts per Million (except where otherwise indicated) ......... 512

50. Separation of Source Heterogeneity from Procedural Errors

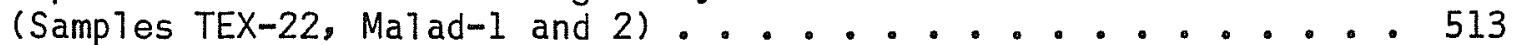

51. XRF Results on Escondido Ranch Type Artifacts and Malad, Idaho, Source Samples .................. 514

52. Concordance of Analyzed Artifacts of Escondido Ranch Type from

Texas and Source Samples Analyzed from Malad, Idaho . . . . . 515

53. Provenience and Context of Escondido/Malad Obsidian Artifacts from Texas Sites ............... 518

54. Obsidian of the Malad Source from Oklahoma Archaeological Sites . 521

55. Material Analysis Records . . . . . . . . . . . . 524

56. Debitage Analysis for Phase II Investigations . . . . . . . . 541

57. Area, Unit, and Leve1 Groupings and Horizon Combinations for Each Site ........................ . . 578

58. Radiocarbon Assays for Phase II Investigations . . . . . . . 583

59. Radiocarbon Dates from Phase II Excavations at Choke Canyon

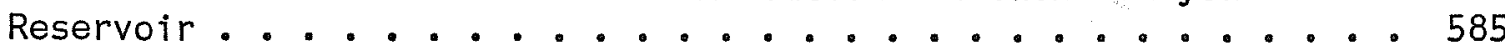




\section{FOREWORD}

We have what Swanton aptly describes as a cultural sink. Archaeological exploration, which has never been systematicaliy attempted there, may bring something to 1ight; but nothing very notable is expected. ...

A. L. Kroeber

Cultural and Natural Areas of Native North America, 1939.

The quote with which I begin this Foreword is a description of the state of archaeological and ethnohistorical affairs in southern Texas at the end of the fourth decade of the 20th century. Such a perception endured for another 25 or 30 years and may be shared by some North American archaeologists even to the present day. However, it has now become clear that the only "cultural sink" in southern Texas was the lacunae of scientific data, not the cultural or biological failings of its native peoples. The achievements of the Choke Canyon project, initiated in 1977, in terms of archaeological, ethnohistorical and historical research, resulted from a program of 1 ong-range, systematic scientific investigations. These studies focused on a specific portion of southern Texas, along a key river drainage, and have now provided us with a greatly enhanced view of the prehistory and early history of this region.

This present volume summarizes the results of Choke Canyon archaeological research. While it emphasizes the Phase II mitigation excavations, it also draws together material from earlier field and laboratory work. With this volume, compiled almost entirely through the efforts of Grant D. Hal 1, we have a wealth of data from a number of sites, information on tool kits, subsistence, chronology, trade, and other key facets of the archaeological record. Furthermore, the results are meticulously detailed, providing a source of continuing information for future research in southern Texas prehistory.

In the grand scheme of world prehistory, "nothing very notable," in Kroeber's words, has yet emerged--or is 1 ikely to emerge--from the study of south Texas prehistory. There is no major architecture, and there are no contributions to be made to the study of the evolution of states and empires. Even the delineation of a regional culture history, let alone the processes of culture change, has been hard to wrest from the south Texas site deposits. This domain was marked in prehistoric, and into early historic times, by hunting and gathering 1 ifeways that stretch back 11,000 years. The study of hunters and gatherers has been in fashion, of 1 ate, in contemporary archaeological 1 iterature; it will, perforce, always be in vogue in southern Texas. Such studies will continue to be important as we examine the mechanisms of regional resource utilization and the processes that effected culture change in response to climatic or other conditions. These are worthwhile, and "notable," endeavors and may have something to tell us, with our water shortages and other 20th-century problems, about how we might better exist in this environment that was, for so many millenia, their home. 
As is the case in the progress of any science, and particularly in archaeology, cultural characterizations written 45 years ago by Kroeber or those five years ago by this author, are destined to be replaced. This is certainly true here with the vast new contributions, by Hall and his many field and laboratory associates, to the advancement of southern Texas archaeological research.

Thomas R. Hester

October 24, 1985 


\section{ABSTRACT}

Reported in this volume are the results of archaeological investigations at 72 prehistoric sites located in the basin of Choke Canyon Reservoir on the Frio River in Live Oak and McMullen Counties, southern Texas. The sites investigated in this study will be affected in one way or another by a 1 ake formed after construction of Choke Canyon Dam, a project of the United States Bureau of Reclamation (USBR). The research was sponsored by the USBR as the second and final phase of a two-stage program of archaeological investigations designed to mitigate damage or destruction of cultural resources resulting from dam construction and subsequent long-term inundation of a large area of the Frio River valley.

Methods used to study Choke Canyon's prehistoric sites during the Phase II investigation were various types of subsurface excavations, documentation of surface features and characteristics, and collection of artifacts from site surfaces.

The people who inhabited the Choke Canyon region in prehistoric times, representing an approximate span of 10,000 years, existed as mobile hunter/gatherer bands. They subsisted by tapping virtualiy every conceivable source of edible natural food.

A full spectrum of animals, from 1 owly field mice and 1 izards up to bison and deer, was exploited by various techniques of hunting, trapping, and catching. Large land snails and mussels were sources of meat food that Choke Canyon's prehistoric people could easily gather. Gar, drum, and turtles were taken from local creeks, sloughs, and the river, perhaps using spears, nets, or weirs. Analysis of vertebrate faunal remains, results of which are presented herein, rather conclusively demonstrates that Late Prehistoric people exploited big game species more commonly than did their Archaic period predecessors.

Floral products must also have comprised a substantial portion of the foods consumed by Choke Canyon's prehistoric inhabitants. Direct evidence of plant food utilization is nonexistent on the sites. However, the very common occurrence of sandstone manos and metates implies heavy reliance on seeds, nuts, or beans. A150, the tremendous amount of burned rock that accumulated in Archaic components at many sites, often found as very carefully constructed hearth features, suggests that baking or roasting activities were extremely common. Roots, tubers, stalks, and other edible plant parts may have been what was being prepared in these facilities.

Diagnostic artifacts recovered from prehistoric sites at Choke Canyon during the various phases of archaeological investigation clearly indicate that the general vicinity witnessed aboriginal activity from Paleo-Indian times up through the early Historic period. Evidence of Paleo-Indian people is 1 imited to surface finds along the valley margin and on high, ancient terrace formations down in the river valley. No in situ subsurface Paleo-Indian components have yet been isolated at Choke Canyon. Where previously the earliest subsurface component known at Choke Canyon dated to the Middle Archaic period (ca. 3400 B.C. to 2400 B.C.), the Phase II excavations 1 ed to discovery of an Early Archaic component dating to the period from 5000 B.C. 
to 4000 B.C. While recognizable Paleo-Indian. Early Archaic, and Middle Archaic components are relatively scarce, the Late Archaic and Late Prehistoric periods are amply represented in the prehistoric sites at Choke Canyon. Phase II investigations also produced the first clear indication of an aboriginal component containing evidence of contact with Anglo-Europeans in early historic times.

The bulk of cultural, paleobotanical, and vertebrate faunal data representing the prehistory of Choke Canyon indicates that floral and faunal communities and the general climatic regime remained essentially unchanged from at least 4000 B.C. up to the period in historic times when certain 1 ivestock and 1 and management practices led to a drastic expansion of brush communities and severe erosion of formerly stable 1 and surfaces.

KEYWORDS: Texas, archaeology, excavation, mitigation, prehistory, Archaic, and Late Prehistoric. 


\section{ACKNOWLEDGMENTS}

The authors gratefully acknow ledge contributions made by the fol 1 owing individuals as the data in this volume was gathered, analyzed, and reported.

\section{EIELD DIRECTORS}

Kenneth M. Brown (JuTy 1980 to Apri1 1981)

A1 B. Wesolowsky (April 1981 to November 1981)

Robert L. Stiba (Assistant Fjeld Director - July 1980 to November 1981)

\section{EIELD CREW}

David Brown

Joan De Costa

Laura Ford

Joe Garant

Jan Guy

Ladd Hockey

Ann Howel1s

Sam Laskowski

George Lew is

Jerrilyn McLerran
Mike Woerner

\section{LABORATORY STAEE}

C. Lynn Highley, Director

OFFICE STAFE

Mary Lou Ell is

Beverly Ewald

EDITOR

Sharon Quirk

GRAPHICS
Kerry Barte]

Verdie Cook

Bruce ETlis
Truett Roberts

Erwin Roemer

Kathy Bareiss Roemer

Ralph Snavely

Lee Spencer

Mary Standifer

Denise Steele

Greg Sundborg

$\mathrm{Jim}$ Warren

Richard Wilshusen

Courtenay Jones

Kathy Hodgin

Ann Young

Celedonio Garcia

John Poindexter

Kathy Bareiss Roemer 


\section{U.S. BUREAU OF RECLAMATION}

Peter Aberle

Norma Armstrong

Jim Bayne

Van Button

Matilda Cuevas

Asa Davis

Ernie Enlow

Meeks Etchieson

Bobbie Ferguson

Allen C. Gates

Cecil Womack

DATA PROCESSING

Darre1 Baker

LOCAL RESIDENTS

Sam Bracken

Henry Dusek
Don Hildebrand Chuck Hill

Stephen Ireland

Don McCabe

Ronald Mills

Robert Oram

Harold Pendleton

Fred Robinson

Bob Rowe11

Weldon Spinks
Elizabeth Frkuska

Hank and Fay Hester

Bill Tul1is

RADIOCARBON ASSAYS

Salvatore Valastro - Radiocarbon Laboratory, The University of Texas at Austin

\section{ROCK TYPE IDENTIFICATIONS}

Weldon W. Hammond - Division of Earth and Physical Sciences, The University of Texas at San Antonio

Members of the 1981 Texas Archeological Society Summer Field School, especialty

Roseanne Henna

Prince Mackenzie

UTSA ADMINISTRATION

Rudolph Gomez

Gary L. Hammon

Dwight F. Henderson

Barbara Johnson
Bil1 Richmond

Shirley Van Der Veer

The special and indispensable direction, support, and assistance of Thomas $R$. Hester and Mary Lou E 11 is of the Center for Archaeological Research are gratefully recognized and very much appreciated. 


\section{INTRODUCTION}

This report and three companion volumes contain the results of final archaeological field investigations at Choke Canyon Reservoir in Live Oak and McMulien Counties, southern Texas. The research program documented in these volumes was carried out under terms of Contract No. 0-07-5B-V0835 issued to the Center for Archaeological Research. The University of Texas at San Antonio (CAR-UTSA) by the U.S. Bureau of Reclamation (USBR). This investigation was required under the National Historic Preservation Act of 1966, as amended. Other relevant legal instruments include Executive Order 11593 and Public Law 93-291. The specific program of Phase II research was as stipulated in a Memorandum of Agreement dated June 5, 1980, and signed by the Chairman of the Advisory Council on Historic Preservation, the Southwest Regional Director of the USBR, and the Texas State Historic Preservation Officer. This research represents the culmination of nearly 16 years of cultural resource mitigation efforts at Choke Canyon. The archaeological surveys, site testing programs, and extensive excavations that have taken place at Choke Canyon provide a body of data that, in the future, will serve to characterize and represent sites effectively eliminated from the study universe by inundation and related impacts brought about by the creation of Choke Canyon Reservoir.

The long period of cultural resource investigation at Choke Canyon has al ready resulted in a substantial amount of published information. Published reports concerned primarily with the prehistoric resources at Choke Canyon include the fol 1 owing:

"Archeological Survey of Palmetto Bend and Choke Canyon Reservoir, Texas" (Wakefield 1968)

"Cultura1 Resource Survey of Choke Canyon Reservoir, Live Oak and McMulien Counties, Texas" (Lynn, Fox, and OMa1ley 1977)

"Historic Indian Groups of the Choke Canyon Reservoir and Surrounding Area, Southern Texas" (Campbel 1 and Campbe1 1 1981)

"An Archaeological Survey of a Portion of the Choke Canyon Reservoir Area in McMullen and Live Oak Counties, Texas" (Thoms, Montgomery, and Portnoy 1981)

"The 1979 Archaeological Survey of Portions of the Choke Canyon Reservoir in Live Oak and McMulien Counties, Texas" (Roemer 1981)

"Archaeological Investigations at Choke Canyon Reservoir, South Texas: The Phase I Findings" (Ha 1 1, Black, and Graves 1982)

"Archaeological Testing and Collecting at Choke Canyon Reservoir, Nueces River Project, Texas" (Weed and Shafer 1981)

"Excavations at 41 LK 67, A Prehistoric Site in the Choke Canyon Reservoir, South Texas" (Brown et a1. 1982)

"Excavations at Sites 41 LK $31 / 32$ and 41 LK 202 in the Choke Canyon Reservoir, South Texas" (Scott and Fox 1982) 
Four additional reports present findings made in Phase II, the final stage of cultural resource investigations at Choke Canyon. In addition to this volume, Phase II findings are published under the following titles:

"A Study of Five Historic Cemeteries at Choke Canyon Reservoir, Live Oak and McMullen Counties, Texas" (Fox 1984)

"Archaeological Investigations at Historic Sites in the Choke Canyon Reservoir, Southern Texas" (Fox 1986)

"Archaeological Investigations at 41 LK 201, Choke Canyon Reservoir, Southern Texas" (Highley 1986)

A scope of work detailing the basic contract requirements of Phase II research is included as Appendix I to this report. This scope of work is derived from an unpublished planning document entitled "F inal Recommendations for Phase II Archaeological Investigations in the Choke Canyon Reservoir, Nueces River Project, Texas" that was submitted to the USBR by the CAR-UTSA in 1979 following completion of Phase I investigations. As events transpired, the scope of work was followed closely with only one major exception. Site 41 MC 246, a prehistoric site tested early in Phase II, was recommended for extensive excavation. The site turned out to be located on 1 and where the USBR negotiated on $1 \mathrm{y}$ flowage easement instead of outright purchase. The owner of the property refused permission for further archaeological investigation of $41 \mathrm{MC} 246$, the site located on his 1 and. In 1 ieu of work at 41 MC 246, CAR personnel monitored the relocation of five of Choke Canyon's historic cemeteries (Fox 1984), a task that was not included in the original scope of work.

This report deals with all prehistoric site investigations conducted during Phase II with the exception of site 41 LK 201 (Highley 1986). Findings made at Choke Canyon's historic sites are reported by Fox (1986).

\section{THE NATURAL SETTING}

Choke Canyon Reservoir is located on the coastal plain of south Texas roughly midway between the southern margin of the Edwards Plateau and the Gulf of Mexico. The dam is situated about $6.4 \mathrm{~km}$ (four miles) west of the town of Three Rivers. This location is equidistant between the cities of San Antonio $144 \mathrm{~km}$ (90 miles) to the north and Corpus Christi to the southeast. The reservoir is primarily intended to meet growing urban-industrial water needs in Corpus Christi. Secondary benefits will be a decrease in the severity of floods on the Nueces River below the dam and recreation for residents of the area and region.

The Frio River rises to the northwest of Choke Canyon in the 1 imestone hill country of central Texas. Shortly after cutting down through the hills of the Edwards Plateau, the Frio River is joined on the coastal plain by three major tributaries: the Sabinal and Leona Rivers and Hondo Creek. Fed both by springs and runoff from the Edwards PIateau, much of the water from these drainages soaks down into aquifers on the coastal plain before reaching the 
Choke Canyon area. Tributaries of the Frio River, the Atascosa River and San Miguel Creek, originate on the coastal plain and serve primarily as channels for runoff. As a consequence, the Frio River flows at Choke Canyon only when there has been substantial rain locally or in the headwaters. In times of little rain, the Frio River is slow moving or stil1, but usual 1 y does contain water in pools along the channe1 (U.S. Department of the Interior 1975:B-1). In historic times, the river at Choke Canyon has been known to dry up completely during periods of severe drought.

A short distance downstream from the dam, the Frio River is joined by the Atascosa River. Si ightly farther to the south, the Frio River meets the Nueces River. The town of Three Rivers is named for the confluence of these drainages. The general trend of these rivers, as for all major rivers on the Texas coastal plain, is southeasterly. As they approach Choke Canyon, however, the Nueces River and, to a lesser extent, the Frio River swing northeastward against the prevailing regional pattern. This divergence is caused by a line of low-lying hills trending northeast to southwest down the middle of the coastal plain roughly parallel to the shore of the Gulf. The hil 15 are formed by an outcrop of resistant rocks called the Oakville-Bordas Escarpment. The Frio, Atascosa, and Nueces Rivers are forced by these resistant hills to converge into a single channel in finally breaching the barrier. From the constriction of these major river systems, the name "Choke Canyon" is derived (Lynn, Fox, and O'Ma1ley 1977:6). At the escarpment, the Nueces River collects drainage from 17,000 square miles of southwestern Texas and then returns to the regional drainage pattern as it courses $144 \mathrm{~km}$ (90 miles) southeast to its mouth in Nueces Bay at Corpus Christi. An excellent illustration of the major physiographic features of south Texas is provided in Figure 1 of the THC survey report by Lynn. Fox, and O'Ma11ey (1977:5).

Choke Canyon is located on the Rio Grande Plain, a subdivision of the West Gulf Coastal Plain physiographic province. The climate of the region is described as semiarid or subtropical, with rain averaging 23 inches a year. The area is subject to the effects of hurricanes from August through October. Rainfall rates of from 25 to 35 inches in a five-day period have been recorded in south Texas following hurricane landfalls on the coast (Grozier et a 1. 1968). Winters are short and mild; the summers are 1 ong and hot (Orton 1964:3). Winds b 10 from the southeast during most of the year. Short-term bursts of cold north winds mark the passage of "northers" during the winter. Temperature averages $74^{\circ} \mathrm{F}$ through the year with heat extremes up to $105^{\circ} \mathrm{F}$ being much more common than very infrequent periods when temperatures below $20^{\circ} \mathrm{F}$ are experienced.

The Rio Grande Plain is level to gently rolling, with the exception of scattered 1 ines of hills formed along resistant sedimentary rock outcrops. The Oakville-Bordas Escarpment along the eastern margin of the reservoir is one good example of hill terrain in south Texas. Other relief on the plain is the result of erosion along the vast network of drainages feeding into the major river val leys.

At Choke Canyon, the Frio River has carved a broad, 1ow-relief al 1uvial valley into Tertiary sediments of varying resistances. Soil developed over these Tertiary deposits and al 1uvium covers almost a 11 of the reservoir basin. Bedrock outcrops in some places: along the river channel, in 
gul1ies, and on high hills (U.S. Department of the Interior 1975:B-9). Gravels are distributed as 1 ag pavements along the valley margins, as terrace deposits on the floodplain, and in bars along the river channel. Deep loams are the most common type of soil found in the area. Differences in the soils across the basin primarily reflect variations in content of clays, sands, and grave1. Hard, clayey 1 oam is most common. Choke Canyon soils are generally alkaline and highly calcareous. A detailed discussion of soils in the project area is provided by Bunker (1982).

Elevational differences are modest, but definitely apparent at Choke Canyon. The highest point in the vicinity is the top of Skillet Mountain near the west end of the reservoir. The elevation there is $113 \mathrm{~m}$ (372 feet) above mean sea level (MSL). Directly below Skillet Mountain, the channel of the Frio River is at an elevation of $64 \mathrm{~km}$ (210 feet) above MSL. The elevation contrast of about $48 \mathrm{~m}$ (160 feet) between these two features constitutes the most drastic topographic relief anywhere in the reservoir. Downstream near the dam, the up 1 ands rise to maximums of between 76 and $91 \mathrm{~m}$ ( 250 and 300 feet) above MSL, with the river channel below running from 36-51 $\mathrm{m}$ (120-170 feet) above MSL. Throughout most of the valley, the Frio River flows in a we 11-entrenched channel with a width of $45 \mathrm{~m}$ (150 feet) or 1ess. The river has a gradient of about two to three feet per mile (ibid.:B-1).

In the project area, the Frio River's valley is broadest across the eastern half of the reservoir. Valley width varies from four to five miles. At the east end, the dam is footed on bedrock of the Catahoula Formation, a Miocene deposit consisting of tuff, tuffaceous sand, and sandstone interbedded with tuff, clay, and silt. Outcrops of Catahoula tuff form fairly prominent margins to the valley. Tuffaceous sedimentary rock from the outcrops was used extensively by prehistoric people for hearth construction on sites at this end of the valley. Another interesting component of the Catahoula Formation is pumice. Pieces of pumice have been found on prehistoric sites in the area, but there is no evidence that the material was used by prehistoric people.

The 01 igocene Frio Formation trends across the midsection of the Choke Canyon basin. This deposit consists of dark gray green clays interbedded with shales and sand. Gypsum, occurring in a distinctive form called "satin spar," is found as seams in the Frio Formation. After being eroded out and stream rolled, satin spar gypsum cobbles assume a distinctive oblong shape. These gypsum cobbles have been found on prehistoric sites at Choke Canyon and were apparentiy used by the site occupants. Not as resistant to the effects of erosion as formations flanking the east and west, the Frio Formation supports gradually sloping valley margins with fewer abrupt transitions from val ley to up 1 and.

Westward from Cal1 iham, a sma 11 community 1 ocated $12.8 \mathrm{~km}$ (eight miles) upstream from the dam, systems of the Eocene Jackson Group crop out. Consisting of interbedded clays, ash, and sands, the group contains a unit of resistant sandstone which forms bluffs at the western end of the reservoir basin. In this half of the valley, the steepest margins, including Skillet Mountain, are along the southern side. The northern side of the val ley at the western end rises more gradually away from the river. The val ley narrows appreciably in passing through the Jackson Group. There is a corresponding 
reduction in the width of the floodplain. In some places along the southern valley margin, there is 1 ittle or no floodplain zone between river and uplands.

Sandstone of the Jackson Group was heavily utilized by the area's prehistoric inhabitants. In prehistoric sites across the western half of the basin, sandstone was used almost exclusively in construction of hearths. Sandstone was also used to make grinding slabs, manos, and a variety of abraders.

Major upland tributaries to the Frio River in the project area are San Miguel Creek, Opossum Creek, and Willow Hollow on the north side and Salt Creek on the south side. Upland drainage systems are not as extensive on the south side of the Frio River as on the north, because of the narrow divide between the Nueces and Frio River systems. Runoff waters are shared between the two. The larger tributaries such as San Miguel Creek and Opossum Creek have deeply entrenched channels and we11-developed terrace systems in their 1 ower reaches.

Landform features in the Frio River floodplain include the channel of the river, relict channels (sloughs), remnants of ancient terrace systems, and tributary drainages of varying magnitudes. The river channel is moderately sinuous. It swings into a big reverse S-curve northwest of Ca11 iham. The early historic community of Yarbrough Bend sprang up along this stretch of the river in the 1850s. The straight courses and bends in the river channe1 reflect 1 local bedrock fractures and 1 ineations. At normal rates of flow, the river has both deep pools and shallows. Gravel and, less frequently, bedrock are exposed along the shallow stretches. Several oxbow lakes on the floodplain evidence minor changes in the channel's course. Other more obscure drainage traces suggest even older and more dramatic shifts in the channel's path through the valley. A number of sharp bends in the modern channel would eventualiy produce new oxbow cutoffs were the river not to be dammed. A few of the prominent sloughs contain water on a more-or-less permanent basis. Others are filled only when the river rises to flood stage or when there is locally heavy rainfal 1 .

Remnants of older, higher terraces are apparent on the floodplain at Choke Canyon, especially in the wider section of the valley at the eastern end. Such features are of particular archaeological interest because they are old, relatively stable surfaces where the 1 ikel ihood of encountering early prehistoric cultural remains is greater than on younger, more dynamic surfaces.

Major and minor drainages channelling runoff water from the uplands are responsible for much of the erosion on the floodplain and for severe erosion along the valley walls. Where the slough channels tend to be broad and Ushaped in cross section, the drainage channels are narrow and V-shaped. Gul 1 ies are much more common along the sides of drainages than they are along the sloughs, probably because the natural levees 1 ining the sloughs effectively block runoff. In some instances, older relict channels have been pirated by upland drainage and are now serving as major arteries of floodplain runoff. 
One of the foremost distinctions of the Rio Grande Plain is its vegetation. Referred to as "brush country" (Ingl is 1964:1), common elements of the south Texas floral community include mesquite, acacias (b1ackbrush, guaji110, huisache, and catclaw), cenizo, prickly pear, and whitebrush. At Choke Canyon, 28,900 acres are covered in brush and forest; about 6500 acres are in cultivation; and 3200 acres are in native pasture (U.S. Department of the Interior 1975:A-11). Acacias, especial1y blackbrush and guajillo, are the prevailing upland and valley margin vegetation around Choke Canyon. Along the channels of the Frio River and San Miguel and Opossum Creeks, a narrow band of large trees grows including 1 ive oak, willow, elm, sugarberry, hackberry, ash, and pecan. Arbors of mustang grapevines form dense canopies in treetops along certain stretches of the river. On the floodplain between the river channel and valley margins, mesquite, whitebrush, huisache, prickly pear, spiny hackberry, and Texas persimmon are common. Although they may grow almost anywhere on the floodplain, a 11 of these species tend to be locally denser and more luxuriant along the drainages and sloughs. All the cultivated 1 and 1 ies in the floodplain, with most of the acreage located at the eastern end of the basin where the plain is wider. Pastures occur both on the floodplain and in the uplands.

A number of the modern-day trees and plants at Choke Canyon wou $1 \mathrm{~d} 1 \mathrm{ike} 1 \mathrm{y}$ have been economical1y important to the area's prehistoric inhabitants. The present distribution of vegetation in and around Choke Canyon does not accurately reflect floral patterns known for the area in early historic times. Upland areas were formerly covered in grass with trees and brush growing only in localized or scattered communities if at al1 (Inglis 1964:44, 50). River valleys and channels of major upland drainages were apparently wooded, but it is not clear how dense and widespread this growth was. Early explorers observed the presence of oaks, other 1 arge trees, mesquite, and thorny brush in the floodplains and along drainages in southern Texas.

The available data do not yet permit a full reconstruction of plant communities existing at any given time in Choke Canyon's prehistory. However, based on the 1 imited evidence avallable at present, one may speculate that many of the tree and plant species now found at Choke Canyon were in the area as much as 3000 years ago and perhaps 1 onger. A much more critical unknown from the standpoint of prehistoric subsistence pursuits is the density in which some of the more important trees and plants may have occurred in the region. Ethnohistoric data (Campbe 11 and Campbe11 1981) demonstrate the extreme importance of prickly pear fruit to many early historic Indian groups in south Texas. Mesquite beans, acorns, hackberries, pecans, the beans of guajil10 and other acacias, mustang grapes, spiny hackberry fruit, persimmons, and many kinds of grass seed are modern p 1 ant products found in substantial quantities at Choke Canyon which, assuming that they were available in sufficient amounts, would have been important considerations in planning seasonal hunting and gathering strategies. The Spanish dagger and narrow leaf yucca are two other plants now found at Choke Canyon that may have been important to prehistoric people as sources of fiber for manufacture into a variety of woven goods.

Choke Canyon is located in the Tamaulipan Biotic Province as defined by BTair (1950). White-tailed deer are the most common large game animal now in the area. Antelope were common in the uplands in early historic times prior to 
brush encroachment (Ingl is 1964:89). The archaeological record indicates that bison ranged into the territory during the Late Prehistoric period. Other animals commonly seen include javelina, coyote, bobcat, raccoon, opossum, skunk, jackrabbit, cottontail rabbit, badger, squirrels, rats, and mice. Birds often seen include wild turkey, hawk, quail, dove, duck, vulture, crane, and ow 1. Snakes, especially the Western Diamondback rattlesnake, are numerous in the area, as we 11 as 1 izards and turtles (both 1 and and water). The river, creeks, and sloughs contain a number of species such as alligator, gar, carp, drum, catfish, numerous small fish, bul1frog, and musse1. The 1 and snail Rabdotus is common in the brush country and was heavily exploited by prehistoric people as a protein source. Lists of faunal remains recovered from archaeological deposits at Choke Canyon are provided in Appendix III.

\section{ARCHAEOLOGICAL BACKGROUND}

A comprehensive treatment of the archaeological background for Choke Canyon and surrounding areas of south Texas has been provided by Graves (Ha 11 , B 1ack, and Graves 1982:7-26) and wi 11 not be repeated here. Exce 11 ent background studies dealing with southern Texas archaeology and prehistory are also provided by Hester (1980) in Digging Into South Texas Prehistory and by Baskin (Ma1 louf, Baskin, and Killen 1977:57-88). These works should be consulted for background information related to the research reported in this volume.

In addition, the reader should be aware of a number of publications on south Texas archaeology that have appeared over the past two or three years. We will briefly review these published materials here. Although there continues to be a number of archaeological surveys of varying scales, there have been very few excavations outside the Choke Canyon area in south Texas, and most of these are 1 imited in scope.

An exception is the major excavation project at site $41 \mathrm{JW} 8$, the Clemente and Herminia Hinojosa site, north of Alice in Jim Wel 15 County. Excavated by the Center for Archaeological Research in 1981 (B1 ack $n_{0} d_{0}$ ), the site is a major Late Prehistoric occupation of the Toyah phase or horizon. Much information was obtained on intrasite patterning, resource exploitation, and tool kits. Distinctive artifacts recovered were Perdiz arrow points, small end scrapers, beveled knives, and bone-tempered ceramics. This site is especial iy important for comparative purposes with the Late Prehistoric sites in the Choke Canyon Reservoir area (cf. Highley 1986).

The Loma Sandia site (4I LK 28; see Fig. 1, folded insert) is located approximately $8 \mathrm{~km}$ east of Choke Canyon Dam. Excavations were conducted at this site in 1977 and 1978 by archaeologists from the Texas Department of Highways and Public Transportation prior to its destruction as Interstate Highway 37 was built through the area. Loma Sandia yielded cultural debris evidencing activity on the site from Paleo-Indian through Late Prehistoric times. The most outstanding result of excavations was the recovery of skeletal remains of about 180 individuals along with associated grave inclusions (especial1y Castroville dart points) which suggest that this cemetery developed around 500 B.C. Analysis and interpretation of the Loma 
Sandia findings, now being carried out by Anna Jean Taylor at the CAR-UTSA, should substantially alter certain conceptions of south Texas prehistory.

To the west of Choke Canyon, intensive testing was done at site 41 ZV 263 in Zavala County (Gibson n.d.). The site is located along the Nueces River and contains a sequence of occupations ranging from probable Late Paleo-Indian, through the Archaic, and into the Late Prehistoric period. Scal1orn, Frio, and Ensor points represent early phase Late Prehistoric and Transitional Archaic occupations. The Middle Archaic is represented by Tortugas and Pedernales points, while the Early Archaic diagnostics are Nol an and Early Triangular points. The deepest diagnostic, apparently representative of Late Paleo-Indian habitations at the site, is a Lerma point. Gibson (n.d.) suggests that this specimen may be related to the Smal1 Projectile Point Tradition of the Paleo-Indian era in northeastern Mexico (cf. Epstein 1980).

There have been a number of archaeological surveys throughout south Texas in the past few years. Many have consisted of sma11-scale survey of pub 1 ic properties scheduled for use as city parks, airports, etc., while others have been done as the result of federal and state environmental statues. A sample of these studies includes Lukowski (1984), Snavely (1984), and Warren (1984a, 1984b).

Larger surveys, often accompanied by evaluative testing, have also been pub 1 ished. In the coasta 1 zone, there are survey data reported by Prewitt (1984) from San Patricio County. This site is located within the proposed Baker's Port development, and further investigations are planned. Other surveys in this area have been conducted by Espey. Huston and Associates, Inc.s (1981) in Will acy County; Day, Laurens-Day, and Prewitt (1981) in Hidalgo and WiTlacy Counties; and Jurgens and Whitsett (1981) in Aransas County.

In the interior of south Texas, major survey and testing programs have been done along the Rio Grande near Laredo (McGraw 1983) and near Falcon Dam (Kotter 1980), in Duval County (McGraw, Van Note, and Jones n.d.; Day 1981), in the "sand sheet" area of Brooks County (McGraw n.d.), and in Zavala County (KeTly et al. n.d.; McGraw and Knepper n.d.). Nearer to Choke Canyon is a sma 11 survey done by Snavely (1984) in Live Oak County.

Field research by avocational archaeologists, along with the documentation of private collections, has been published primarily through La Tierra, the journal of the Southern Texas Archaeological Association. Particularly relevant to the Choke Canyon area are published reports on collections, ranging from $\mathrm{Paleo-Indian}$ to Late Prehistoric in age, from McMulien County (Beasley 1982; Dusek 1983; Kelly 1983; Woerner and Highley 1983) and from the western portions of San Patricio and Nueces Counties along the Nueces River drainage (Chandler 1982a, 1983, 1984; Chandler, Knol 1e, and Knol 1e 1983). In nearby Karnes County, a recent paper by Mitche11, Chandler, and Kel1y (1984) describes a burial and other materials from an important Late Archaic site. Among the diagnostics are Marcos points and corner tang bifaces ("knives").

Ethnohistoric research, of the type done by Campbe11 and Campbe11 (1981) at Choke Canyon, has continued for other parts of south Texas. Significant contributions include Campbe17's (1984) study of the Cacaxt1e Indians of 
southern Texas and northeastern Mexico, as well as research into the Indians of the San Antonio Spanish Colonial missions (Campbel1 and Campbe11 1985).

\section{RESEARCH GOALS}

The goals of Phase II investigations at Choke Canyon's prehistoric sites are in most ways consistent with problem orientations that have dictated earlier programs of research in the reservoir basin (Lynn, Fox, and O'Ma11ey 1977; Hal 1. Black, and Graves 1982:26-28).

The structuring and refinement of the cultural/chronological framework is a critical need in the on-going study of south Texas prehistory. The region has lagged behind other areas of the state, especially central Texas and the Trans-Pecos area, due partly to the fact that proportionately less work has been done over the years, but al so because of the character and context of the remains evidencing local prehistoric sites. Prehistoric sites at Choke Canyon containing well-stratified multiple components, sites yielding notable numbers of potential time-diagnostic artifacts (primarily chipped stone tools), and/or sites where carbon derived from prehistoric habitational activities was well preserved were heavily investigated in Phase II. Quite often, any site that had one or more of the characteristics 1 isted above also tended to contain intact, we11-integrated habitational features and, 1 ess often, vertebrate faunal materials. Thus, sites offering the best potential for elucidating the cultural/chronological scheme often produced types of data that were very useful in dealing with other research problems.

The study of subsistence systems for the prehistoric populations of southern Texas has proved to be a frustrating endeavor, but progress is nevertheless slowly being made. The remains most commonly recovered for analysis include such things as mussel shells, large land snail shel1s, and bones of vertebrate anima 1s. These kinds of debris are interpreted as direct evidence of certain foods consumed by prehistoric people at the Choke Canyon sites. Indirect 1 ines of evidence concerning subsistence habits include such items as manos and metates, presumed cooking facilities such as hearths and pits, certain plant species identifications made from carbonized remains, and variations in quantities of burned rock from site to site. Pollen and phyto1 ith research has not been productive. Pollen is apparently not preserved in adequate quantities to permit reliable interpretation. Phytolith research has been plagued by a number of problems, not all of which are directly related to collection, analysis, and interpretation. Considering the strengths and limitations of possible avenues of research into prehistoric subsistence habits as evidenced at Choke Canyon sites, the Phase II program was, to a certain extent, weighted toward sites yielding vertebrate faunal remains. They offer the double advantage of permitting inferences concerning both human subsistence and paleoenvironment. More generally, subsistencerelated data recovery occurred during Phase II investigations in the course of standard archaeological procedures of debris recovery, measured $p 1$ an sketching, and soil matrix collection (especially from hearth and pit features).

Study of prehistoric human settiement systems influenced the Phase II investigations at Choke Canyon to the extent that an effort was made to 
sample a wide range, geographically speaking, of the known sites in the reservoir basin. The objective here, of course, was to gather data demonstrating how people distributed themselves across the 1 andscape through the various periods of prehistory. Time-diagnostic artifacts collected from the sites constitute the evidence most often used in determining the period of prehistoric activity represented. Less often, radiocarbon-derived dates are available to aid in such determinations. After components were identified, habitational debris representative of the site was sampled and/or noted. Intersite comparisons of general site characteristics and location, periods of cultural activity represented, and kinds of cultural debris/features deposited lead to inferences concerning settlement patterns through time.

Technological systems and tool kits are necessarily related areas of study in south Texas prehistoric archaeology. Chipped stone tools and by-products of chipped stone tool manufacture are, next to burned rock, the overwhelmingly predominate elements of debris collections from prehistoric sites at Choke Canyon, as well as everywhere else in southern Texas. Based on tools and technology, clear differences between the Archaic and Late Prehistoric periods are recognized. A continuing problem--one to which Phase II efforts were addressed--is to further refine what is known of technologies and tool kits representing subperiods, especially in the lengthy time span of the Archaic, but also including the Late Prehistoric. Such refinements and clarifications aid in building chronologies, in studying settlement systems, and in analyzing subsistence orientations.

Reconstructing the environment(s) within which prehistoric people 1 ived continues to be a very important aspect of prehistoric research in south Texas. As discussed above concerning subsistence systems, pollen and phyto1 ith research has not produced satisfactory results. Out of the Phase I archaeological research conducted at Choke Canyon, vertebrate faunal remains and plant species identifications made from carbonized wood did produce useful information about local paleoenvironment. This situation again suggested the desirability of concentrating Phase II efforts at sites yielding animal bone and/or carbonized plant remains, a comparatively rare occurrence at Choke Canyon. Recognition of the importance of vertebrate faunal remains and carbonized materials to studies of prehistoric human subsistence and paleoenvironmental reconstructions led to a strong emphasis on the analysis and interpretation of these types of remains which were studied by expert consultants (see Appendices II and III).

Finally, results of Phase II research in all of its aspects would be aimed at formulating as broad and complete a picture of prehistoric 1 ifeways as possible. Through analysis and interpretation of Phase II data, it should be possible to address the questions of "when," "why," and "under what circumstances" did prehistoric human groups populate the Choke Canyon study area. To these ends, the research documented in this volume is directed. 


\section{TECHNICAI. PROCEDURES}

As Phase II archaeological investigations were conducted on prehistoric sites at Choke Canyon, a variety of field procedures were employed. The sites to be investigated consisted of one group recommended for extensive excavations based on findings made during Phase I investigations. Sites in a second, 1 arger group were to be assessed in terms of their potential for further extensive excavations (see Appendix I).

\section{EXTENSIVE EXCAYATIONS}

Thirteen prehistoric sites received a level of investigative attention designated as "extensive excavation." At 11 of these sites, archaeological grid systems were established. The grids were oriented to cardinal (magnetic) directions. North-south and/or east-west baselines emanated from an arbitrarily selected point. At all sites except 41 MC 222, the point was assigned coordinates of $\mathrm{N} 1000$ El000 m. At $41 \mathrm{MC} 222$, the central point was designated N100 ElO0 mo Baselines were set with the aid of a survey transit. The transit was centered over the central grid stake and oriented to magnetic north to set north-south 1 ines. Magnetic declination from true north was $9^{\circ}$ in 1968. East-west baselines were set by rotating the transit $90^{\circ}$ off of magnetic north. Further subdivision of site areas into metric units was accomplished using the transit and measuring tapes. The basic unit of excavation was $1 \mathrm{~m}^{2}$. The coordinates at the southwest corner of each unit served as unit designators. Coordinates increased to the north and east. As discussed in individual site descriptions, USBR surveyors later placed permanent site markers on each extensive excavation site and determined their exact locations expressed as Modified Texas State Plane coordinates. Archaeological grid systems were "tied in" to the USBR permanent markers as a means of recording their locations.

Due to their great size and/or heavy brush cover, two extensive excavation sites were not gridded in the same way as the 11 sites discussed above. At 41 LK 128 and 41 MC 94, excavation areas were staked out independently of one another. Each $1-m^{2}$ unit was assigned a test pit number rather than metric coordinates. Test pit unit blocks were oriented to magnetic north using either the survey transit or a Brunton compass.

Vertical control was established at all extensive excavation sites by selecting a stable datum point, usually a steel spike driven into a large tree trunk, and assigning it an arbitrary elevation of $100 \mathrm{~m}$. Vertical readings in excavations were then taken relative to this arbitrary datum with the aid of a survey transit and leveling rod. USBR surveyors 1 ater calculated true elevations for vertical datums at each extensive excavation site.

At 41 LK 8, a backhoe was used to dig a series of trenches across the site. Excavation areas were selected on the basis of observations made in trench profiles. At all other extensive excavation sites, Phase II unit locations were based on earlier test pit findings. 
Prior to commencement of excavations in each $1-m^{2}$ unit, surface elevations were taken to provide a record of $10 c a 1$ ized topography before any alterations took place. Matrix was removed from units by hand excavation using shovels and trowels. At all sites units were excavated in arbitrary vertical increments of $10 \mathrm{~cm}$ except 41 MC 222 where $5-\mathrm{cm}$ levels were excavated. Using the transit and stadia, floors were leveled on even increments of $10 \mathrm{~cm}$ relative to the primary datum elevation of $100 \mathrm{~m}$ (such as 99.40, 99.30, etc.). Each level was also given a consecutive number starting with Level 1 at the top and so forth on down to the bottom of the unit. At most of the sites, excavated matrix was dry screened through 1/4-inch mesh hardware cloth. At 41 LK 201, 41 MC 222, and 41 MC 296, some water screening was done, and matrix from selected units was washed through window screen (see individual site discussions for details). All material (except roots, modern wood fragments, animal droppings, insects, insect parts and residues, worms, and fragments of 1 arge 1 and snails) screened from excavated matrix was collected. The collections from each level were placed in paper bags (sometimes 1 ined with plastic bags) labeled with the following information: site number, unit coordinates, level, names of excavators and screeners, and the date of excavation.

As a general rule, the exact provenience of artifacts and other cultural debris encountered as excavations proceeded was not recorded unless there was reason to bel ieve that the objects were constituents of definable habitational or activity features. Elements of features such as hearthstones, mussel shel1, snail she11, animal bone, chipped stone tools, debitage, and soil discolorations, were left in situ. Such features were recorded on measured plan and profile sketches and were photographed using both color and black-and-white film. Matrix samples were collected from most features. In most cases, features were cross sectioned to establish presence or absence of subsurface structure.

Carbon encountered in fill and in features was collected in sealed aluminum foil 1 pouches 7 abeled with appropriate provenience information. Large chunks of carbon having potential for wood species identification purposes were wrapped in tissue paper and placed in plastic vials or other protective containers labeled with provenience data. Fragile materials recovered in excavations, such as bone and modified she11, were also wrapped in tissue and/or foil or placed in vials or boxes for added protection during transport back to the 1aboratory.

Column matrix samples were collected from one or more of the unit b 1 ocks excavated at extensive excavation sites and also from some of the tested sites. Columns were located on unit walls having profiles more-or-less representative of the excavation area in general. Obviously disturbed deposits were avoided. Prior to removal of the samples, the profiles were usually sketched and photographed. Exact column locations and vertical collection increments were recorded on the measured profile drawings. Each sample was taken from a block $10-\mathrm{cm}$ thick, $15-\mathrm{cm}$ wide, and $10-\mathrm{cm}$ deep in the profile face. The vertical $10-\mathrm{cm}$ increments correspond to the vertical levels excavated from units in each area. Samples were placed in plastic7 ined paper bags and 7 abeled with appropriate provenience information. 
Written records of the excavations were kept in a daily journal, general site notes, level notes, feature notes, and a photographic journal. The daily journal was kept by the field director. In it were recorded a summary of each day's activities and a general discussion of findings. The most copious written records were the level notes filled out upon conclusion of each level of excavation in a $1-\mathrm{m}^{2}$ unit. In these notes, the basic observations and findings made in each level were detailed. When features were isolated in a level, the level notes were augmented by feature descriptions and measured plan drawings. In the photographic journal, the subject, exposure number, photographer, and date were recorded for each photograph taken during the course of Phase II investigations.

Upon conclusion of excavations at each site, units were completely backfilled, either by hand or mechanically.

\section{SITE EYALUATIONS}

A total of 59 prehistoric sites underwent varying degrees of Phase II investigation intended to provide: (1) data permitting assessment of each site's potential for further investigation; and (2) a sample of the prehistoric cultural remains evidencing each. Investigation of these sites began with crew members making a thorough reconnaissance of the site surface to familiarize themselves with its extent and character. Two or more shovel tests were then excavated at promising locations indicated by surface residues, topographic setting, or gully exposures. Shovel tests were generally about $50 \mathrm{~cm}^{2}$, but no real effort was made to insure uniformity in test size. Matrix excavated from shovel tests was not screened. Cultural debris noted as digging occurred was collected. Observations made as shovel tests were excavated were recorded in field notes. Results of shovel tests influenced decisions concerning whether or not controlled test excavations would be conducted on a particular site.

Test pits were excavated at eight of the prehistoric sites investigated during Phase II. Unit locations were usually based on findings made in shovel tests or upon subsurface observations possible in walls of gullies. The technical procedures applied in test pits are the same as those described for extensive excavations, except that vertical readings were taken with the aid of level 1 ines and measuring tapes.

At sites where controlled testing did not appear warranted, collections of surface artifacts were made. Depending upon circumstances encountered at each site, the surface collections might be provenienced or unprovenienced. Provenienced collections were made at sites where the distribution of artifacts and/or exposed habitational features suggested an opportunity to demonstrate patterning of prehistoric cultural activity. In making such collections, locations of individual artifacts were recorded on a plan map using an a 1 idade, plane table, and leveling rod or measuring tape. Once located, the artifact was given a number that was recorded on the p 1 an and on an individual collection bag. Feature locations were also plotted on the plan maps. Where the character of surface debris warranted, "dog leash" samples were collected. In this procedure, a center point of the area containing the cultural debris to be collected was determined and located on 
the plan map. Using a measuring tape, the debris within an 80-cm radius of the recorded 1 ocus was then collected. When the distribution of surface debris on a site demonstrated no apparently significant patterning, unprovenienced collections were made. Except in the case of "dog leash" samp 1es, where a 11 debris was collected, surface collections made during Phase II investigations were restricted to potential time- and functiondiagnostic artifacts.

\section{MAPPING}

During the Phase II archaeological investigations at Choke Canyon, extensive topographic mapping was unnecessary as the USBR provided excel lent map coverage for the entire reservoir. Maps with a contour interval of two feet were available for al1 of Choke Canyon. Portions of these maps are reproduced in this report to provide "area topography" coverage for 11 of the extensive excavation sites. A second set of maps, covering only an area of roughly 5000 acres in the dam and borrow areas, was drawn with a 50-cm contour interva1. On both sets of maps, presentation of modern cultura 1 features such as roads, houses, fencelines, and utility 1 ines was extremely detailed and accurate. On plane table and alidade maps produced during Phase II investigations, site limits, archaeological grids, test pit locations, provenienced artifacts, and other important features were "tiedin" to distinctive modern cultural features (fence and road intersections, utility poles, houses, wel1s, etc.) appearing on the USBR maps. By this means, the relationship between sites and local topography was recorded. In addition, USBR surveyors placed permanent monuments at a number of the extensive excavation sites. They calculated horizontal and vertical proveniences for these markers in terms of Modified Texas State Plane coordinates and feet above mean sea leve1, respectively. Data concerning these permanent site markers are presented in Appendix VII.

\section{LABORATORY PROCESSIMG}

Materials collected in the field were brought back to the CAR 1 aboratory at The University of Texas at San Antonio on a weekly basis. Each bag of material was assigned a catalogue lot number which was initially written on the outside of the bag. Each site had a separate sequence of consecutive lot numbers, the first number assigned for the site being "Lot I" and so on. On sites where excavations took place, the aggregate of material from each level of each unit of excavation was assigned a lot number. Whenever possible, material collections from levels were assigned lot numbers in the same sequence as they were removed from the unit. Surface-collected materials were assigned lot numbers followed by a "0." For provenienced surface artifacts, the lot number was followed in parentheses by the artifact's P1ane Table Map (PTM) number.

Materials that would not be harmed by immersion were washed in tap water and then air dried. Particularly fragile items were dry cleaned by hand. Ceramic sherds were gently washed, but not brushed. Carbon sample packets were opened and the contents allowed to dry thoroughly before being resealed. 
After being washed and dried, materials in each lot were sorted into analytical classes. These classes are 1 isted on a sample Material Analysis Form presented in Appendix VI. A record form was then filled out for each lot of material. Precise counts, weights, and measurements were recorded for materials in the various analytical classes. This form was structured to accommodate transfer of data from form to computer.

After their counts and weights were recorded, tuff, sandstone, fire-fractured rock, and pebbles from general level collections were then discarded. Larger objects (primarily 1 ithic artifacts) to undergo later special studies were labeled in ink with site, catalogue, and (if appropriate) PTM numbers. Labels were then coated with clear varnish. Many of the large ceramic sherds were also marked in this way, a procedure that hindered 1 ater analysis of the sherds. Classes composed of numerous smaller specimens, such as chert debitage, mussel shel1, snail shel1, and bone were enclosed in plastic bags labeled with site and lot number.

After completion of special studies, whose procedures are described in 1 ater sections of this report, much of the Phase II collection was segregated by material class (such as debitage, faunal remains, 1and snail, mussel shell, chert cores, etc.) and stored in pasteboard boxes. The boxes are 1 abeled with "Choke Canyon Phase II," the type of material contained, and the numbers of the sites from which the enclosed materials were collected. Artifacts most 1 ikely to be in demand for future comparative purposes are stored in drawered cases for easy access.

A1 1 notes, plan maps, drawings, photographs, and material collections generated during Phase II archaeological investigations at Choke Canyon wi11 be permanently housed in the facilities of the Center for Archaeological Research. The University of Texas at San Antonio. Also housed at The University of Texas at San Antonio are the notes, photographs, and material collections resulting from the archaeological survey of Choke Canyon conducted by the Texas Historical Commission (Lynn, Fox, and O'Malley 1977). A smal1 amount of material collected at Choke Canyon during early studies carried out by the Texas Archeological Salvage Project (Wakefield 1968) and the Coastal Bend Archeological Society is housed at the Texas Archeological Research Laboratory. Bal cones Research Center. The University of Texas at Austin.

\section{THE PHASE II SITE INVESTIGATIONS}

Information collected at 72 prehistoric sites investigated during the Phase II field program at Choke Canyon is presented in this section. The work at 41 LK 201 is touched on only briefly in this study. A comprehensive treatment of the findings made at this site is provided by. Highley (1986).

The 72 sites discussed in this report are divided into 13 groups based primarily on their geographic proximity to one another. As in the report of Phase I research (Hall, Black, and Graves 1982), the site groups are presented in an order that proceeds generally from east to west, starting in the Choke Canyon Dam area and then extending up the Frio River valley to the western end of the reservoir basin. Beyond this, however, there is 1 ittle 
correspondence between the groups as defined for each different phase of investigation. For each group, individual site discussions are prefaced by a 7 isting of sites comprising the group, the investigative procedures applied at each, and a general description of the area containing the group. Locations of sites included in this discussion, as well as other known prehistoric and historic sites at Choke Canyon, are shown in Figure 1 (folded insert).

This section deals with descriptions of the sites, discussions of investigative procedures applied, and summaries of resultant findings. The artifacts and other material remains recovered from the sites and the results of special studies performed on certain categories of material (such as radiocarbon assays, wood spectes identifications, faunal remains, ceramics, and 1 ithics) are given only brief mention in this section. Detailed information on material recovery and results of special studies are provided in 1 ater sections. For some of the artifacts mentioned below--most often chipped stone specimens--group, form, and specimen numbers are provided. These numbers relate the artifacts to the organizational scheme used in the descriptive artifact section that follows. Also mentioned are data tables (Appendix VI) and special studies (Appendices II, III, and IV). In particular, the Material Analysis Records in Appendix VI are frequently referenced or summarized.

\section{SIIE GROUP 1}

Extensive Test

Excavation Pits

41 LK 8

41 LK 201

41 LK 128

\section{Surface Collections \\ Provenienced Unprovenienced \\ Resurvey or \\ Shovel Tests}
41 LK 127
41 LK 121
41 LK 199
41 LK 122

In Site Group 1 are seven prehistoric sites located on the floodplain of the Frio River immediately upstream from Choke Canyon Dam. The area containing the sites measures about $2.6 \mathrm{~km}$ north-south and $2.7 \mathrm{~km}$ east-west. The Catahoula Formation crops out immediately east of 41 LK 8 . Major 1andform features in the area are the river channel, floodplain, a relict river channel (slough), an upland drainage, some natural levees, and a pronounced terrace remnant.

Located in the borrow area where f 111 material for the dam was extracted, sites 41 LK 8 and 41 LK 201 underwent dramatic changes in 1 ocal appearance between Phase I and Phase II archaeological investigations. The 1 and around these sites was denuded of vegetation. Huge borrow pits were excavated to the northeast, east, and southeast of 41 LK 201. Tremendous mounds of $f 111$ material were stockpiled east of 41 LK 8. Through al1 of these major modifications, USBR engineers worked in close cooperation with archaeologists to insure that clearing and borrow activities resulted in no damage to archaeologlcal sites scheduled for Phase II investigations. Construction- 
related changes in the vicinity of 41 LK 8 are $i 17$ ustrated in Figure 16, $f$ of the Phase I report (Ha 1 1, Black, and Graves 1982:87), which shows the site before brush clearing occurred, and in Figure 4,a of this report, showing roughly the same view after brush was cleared and construction commenced.

Five of the sites in Group 1 are located on the north side of the Frio River. The floodplain on this side is very narrow. It gives way quickly to gravel and brush-covered upland slopes where several of the sites occur. Because it is rugged and rocky, the 1 and containing sites 41 LK 121, 41 LK 122, 41 LK 127, and 41 LK 128 served on ly as cattle pasturage and was never cultivated. Between these sites and 41 LK 8 , floodp 1 ain deposits deepen, probably because the area has received alluvium fed down to the valley by some major upland drainages trending in from the northwest (Fig. 1, folded insert). Immediately south and west of 41 LK 8 , the floodp 1 a in supported some larger trees and dense riparian undergrowth. Site 41 LK 8 is situated on a very unusual terrace remnant forming a distinct knoll out in the floodplain. East, north, and northwest of 41 LK 8 are terraces and valley margin slopes blanketed with 7 ag gravels. Good $i 17$ ustrations of the general terrain and the $1 \mathrm{ag}$ gravels are provided in Phase I reports (Ha) 1, Black, and Graves 1982:99, Fig. 20; Brown et a1. 1982:105, Fig. 3).

Group 1 sites 41 LK 199 and 41 LK 201 are 1 ocated on the south side of the river where the floodplain is very broad and $f 1$ at, and the soils are deep. Immediately west and southwest of 41 LK 201 was a cleared field that was more-or-less continuously cultivated and planted (usually with grain sorghum) during the course of Phase I and Phase II investigations. Elsewhere, there was both open pasture and dense mesquite trees or riparian forest.

There are two major relict channel systems in the area of Site Group 1. One leaves the modern river channel off the northwest end of 41 LK 20I, trends southeast between 41 LK 41 and 41 LK 59, then turns northeast past 41 LK 91 and reenters the river channel. On the north side of the Frio River, there is a channel scar apparent on the floodplain southwest of 41 LK 8.

\section{LK 8}

Site 41 LK 8 was recorded in 1970 by members of the Coastal Bend Archeological Society (CBAS). It is an open prehistoric site situated on a terrace remnant forming a distinct knol 1 out on the floodplain (Fig. 2 ; Fig. $4, a$ ). The terrace remnant is oblong with a length of roughly $300 \mathrm{~m}$ west-northwest to east-southeast. The knol1 is between $150 \mathrm{~m}$ and $200 \mathrm{~m}$ in width (northsouth). In recent times, a residence and outbuildings were constructed on the crest of the knol1. The foundations of these structures and much historic debris and garbage were very much in evidence as archaeological investigations occurred on the site. The crest of the knoll was clear of brush, but a number of 1 arge mesquite trees remained around the buildings to provide shade. The slopes of the kno11, except for the east end where the road entered, were heavily covered with brush and mesquite trees.

The highest part of the knoll containing 41 LK 8 is about $5 \mathrm{~m}$ above the level of the floodplain and as much as $12 \mathrm{~m}$ above the channel of the Frio River. The river currently flows through a channel a short distance southeast of 
Figure 2. Topographic Map of 41LK8 and Surrounding Area.

PAGE 18 REDACTED 
41 LK 8 (Fig. 2). A relict channel curves down from the northwest, runs along the southern edge of 41 LK 8 , and meets the modern channel off the southeast end of the terrace remnant. North of 41 LK 8 there is a 10 area that gives way to the slope of the valley margin. The slopes are blanketed with lag gravels. East of 41 LK 8 is a heavily eroded area characterized by deep gulities.

Phase I investigation at 41 LK 8 involved excavation of four $1-m^{2}$ test pits (Ha 11. Black, and Graves 1982:85-92). Findings made in these test pits prompted the following negative pronouncement:

A 1 though the site had previously yielded artifacts suggesting a long span of prehistoric activity (Lynn, Fox, and OMalley 1977:237-242), the CAR testing effort at 41 LK 8 did not yie1d a particularly impressive set of results. No habitational features were isolated, no recognizable time-diagnostic artifacts were recovered, preservation of prehistoric organic remains (bone and carbon, in particular) was poor, and although horizons were defined in two test pits, there was no clear-cut visible stratigraphy in the excavated deposits. The results are particularly disappointing because the terrace remnant containing the site is an unusually high topographic feature for a floodplain setting and is 1 ikely one of the older surfaces present in the Choke Canyon floodplain (Hall, B1ack, and Graves 1982:92).

As recommendations for Phase II research were formulated, the site's unusual characteristics overrode the test pit results. Referring to $41 \mathrm{LK} 8$ in the final recommendations, the following statement was made:

- - its highly unusual physiographic character (that is, an obvious prominence out on the floodplain), its age as a geologic feature, and its sandy matrix are factors suggesting a strong potential for the existence of Paleo-Indian and Early Archaic components and perhaps an aboriginal cemetery. Though these conjectures were not in any way substantiated by the Phase I test excavations, the regional settlement pattern (for instance, the 1 arge Archaic cemetery, 41 LK 28, situated on a sandy hil1 five miles east of 41 LK 8 ) permits speculation to this extent. The possibility that such phenomena will be encountered at 41 LK 8 should be taken into consideration as plans for investigating the site are formulated (Center for Archaeological Research 1979:1415).

The Phase II archaeological investigation at 41 LK 8 was conducted in July and August 1980. During nine work days, 11 crew members 1 abored a total of 656 person hours at the site. Activities at the site were excavation of unit blocks in three areas, monitoring of backhoe trench excavations, feature and profile recording, and plan mapping.

An excavation grid was established on the surface of 41 LK 8 . The baseline extended more-or-less along the crest of the knoll (Fig. 3). A nail driven into the trunk of a large mesquite tree near the center of the site served as the vertical datum. USBR surveyors later calculated an elevation of $55 \mathrm{~m}$ 


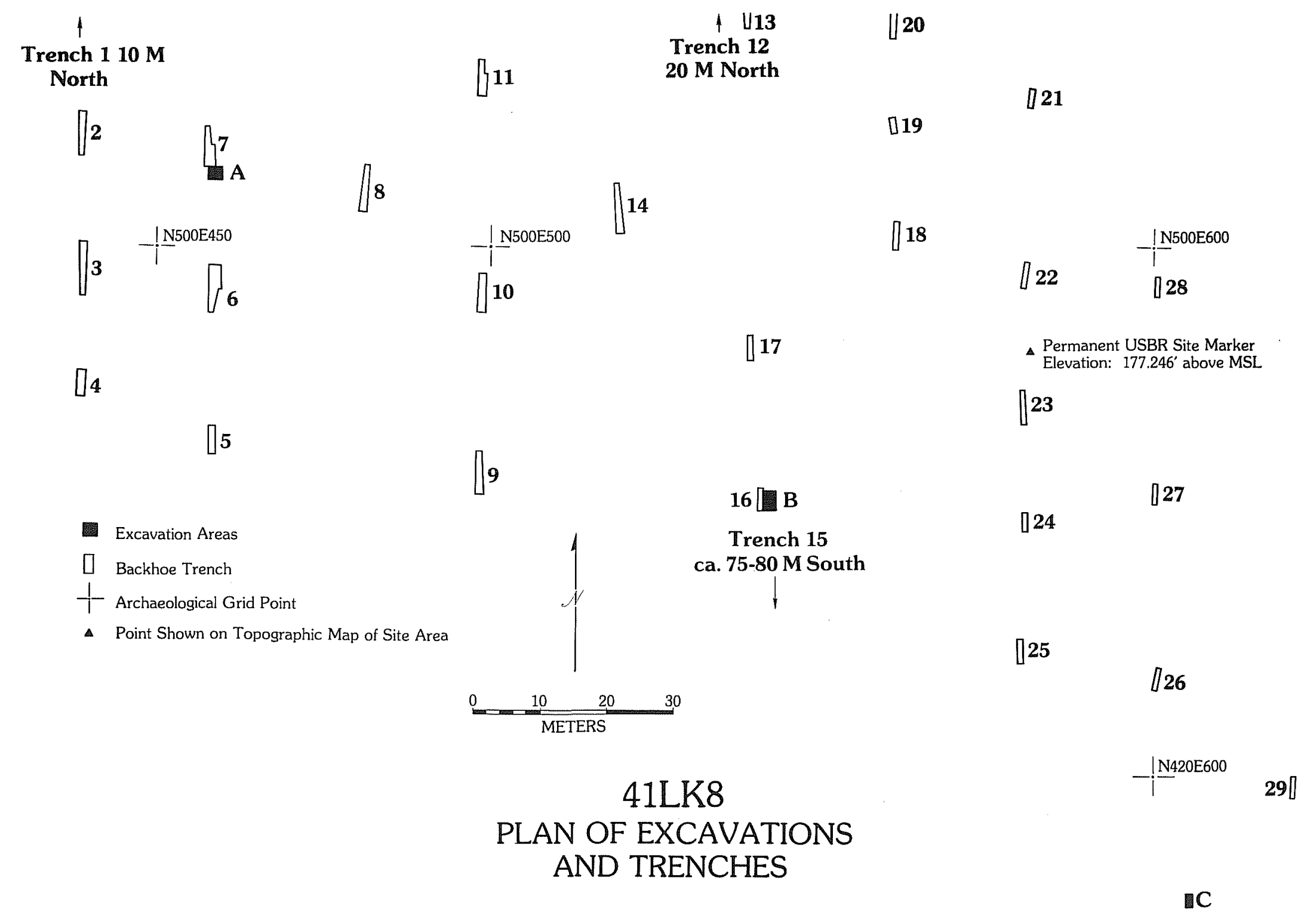

Figure 3. Plan of Excavations and Trenches at 41 LK 8. 
(179.82 feet) above mean sea level (MSL) for the nail in the tree trunk. They also placed a permanent site marker at the east end of the site and determined its location, expressed in Modified Texas State Plane Coordinates. The monument location is shown in Figures 2 and 3 . An elevation of $54 \mathrm{~m}$ (177.246 feet) above MSL was calculated for the. top of this monument.

Using a backhoe, 29 short trenches were excavated across 41 LK 8. Locations of these trenches are shown in Figure 3. The purposes of the trenches were to: (1) isolate areas containing maximum subsurface concentrations of prehistoric cultural debris and/or habitational features; (2) aid in determining the ful1 horizontal and vertical extent of prehistoric cultural remains in the site; and (3) reveal the physical structure of the knoll as evidenced in subsurface deposits.

Two of the blocks of excavation units, designated Areas A and $B$, were staked out at 41 LK 8 based on observations made in the backhoe trenches. Areas $A$ and $B$ were located by Trenches 7 and 16, respectively, where tuffaceous rock habitational features were seen in wall profiles (Fig. 3). A third block of units, Area $C$, was judgmentally located at the southeast end of the site to samp le its deposits. Prehistoric cultural debris (chert debitage, mussel she 11, tuffaceous rock, and fire-fractured rock) was found in varying amounts in a 11 trenches excavated on the site. General1y, however, the greatest amounts of cultural debris came from trenches dug on the higher parts of the knol1. Trench data also verified that the knoll is indeed a terrace remnant. Trench 6 provided one of the deepest cuts into the site. Down to a depth of approximately $2 \mathrm{~m}$, the profile of Trench 6 is much 1 ike those shown in Figures 5 and 6 . From 2 to $3 \mathrm{~cm}$, there was a layer of pure sand showing bedding planes. At $3 \mathrm{~m}$ below the surface, there was a gravel bed containing pebbles or cobbles in the $5-7 \mathrm{~cm}$ diameter range.

The excavation designated Area $A$ at 41 LK 8 consisted of four $1-m^{2}$ units forming a 2-m ${ }^{2}$ block at the south end of Trench 7 (Fig. 3). This location is on the highest part of the knoll or terrace remnant containing the site (Fig. '4,b,C). Each of the four units in the area was excavated in arbitrary 10-cm vertical levels. The units and number of levels excavated at each are as follows: N510 E459 (17 levels), N510 E458 (20 1evels), N511 E458 (17 leve1s), and N511 E459 (17 leve1s). Elevations at modern ground level ranged from 100.06 to $100.09 \mathrm{~m}$.

The Area A excavations revealed a fine silty sand deposit in three visually distinguishable zones. From the ground surface to a depth of $30 \mathrm{~cm}$ was a zone of dark brown silty sand forming an A horizon. Between $30 \mathrm{~cm}$ and $110 \mathrm{~cm}$ below the surface was a dark brownish gray silty sand. Below $110 \mathrm{~cm}$, a complicated intermixture of soil colors, al1 silty sands, was evidenced (Fig. 5). The intermixing appears to have been the result of pervasive bioturbation (rodents, roots, etc.) in the zone. In the lower levels, increased calcium carbonate mottling and caliche nodules were noted.

Twentieth-century artifacts such as glass fragments, wire nails, and other metal artifacts were found to a depth of $30 \mathrm{~cm}$ in Area $A$. Major classes of prehistoric cultural debris recovered from the Area $A$ excavation are presented below. This summary includes the combined material recovery from a 11 four units comprising Area $A$. The collection is divided into three 


\section{Figure 4. Phase II Investigations At 41 LK 8.}

a, view looking south to 41 LK 8 from the valley margin on the north side of the Frio River. Land in the foreground and background has been cleared for construction. Compare this scene with Figure 16, $f$ in Ha11, Black, and Graves (1982:87);

b. view looking west at 41 LK 8 across the central prominence of the knoll to the Area A excavations;

c. Area A excavations in progress at 41 LK 8. The view is south down the length of Trench 7. This is the highest elevation on the terrace remnant knoll containing the site;

d. Area B at 41 LK 8 prior to excavation. Stringlines mark the units to be excavated on the east side of Trench 16;

e, Feature 2 in Area B at 41 LK 8. $V$ iew is down and to the south. Scale is $30 \mathrm{~cm}$ in length;

f, the eastern and southern wall profiles of the Area $B$ excavation at 41 LK 8. Stones comprising Feature 2 rested on the floor level shown. 

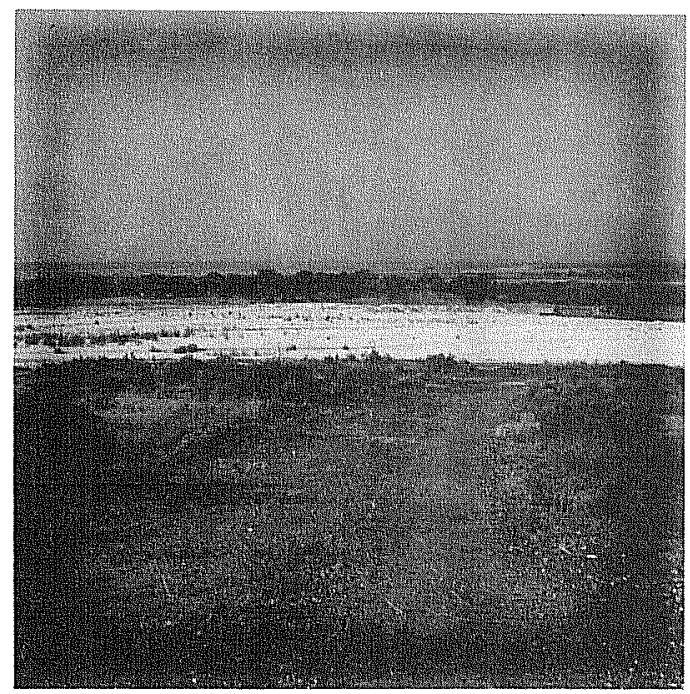

a

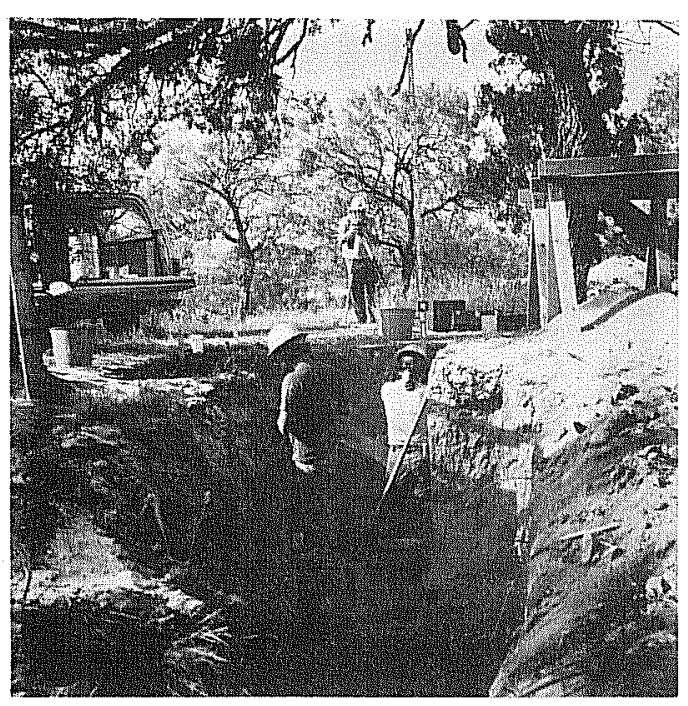

c

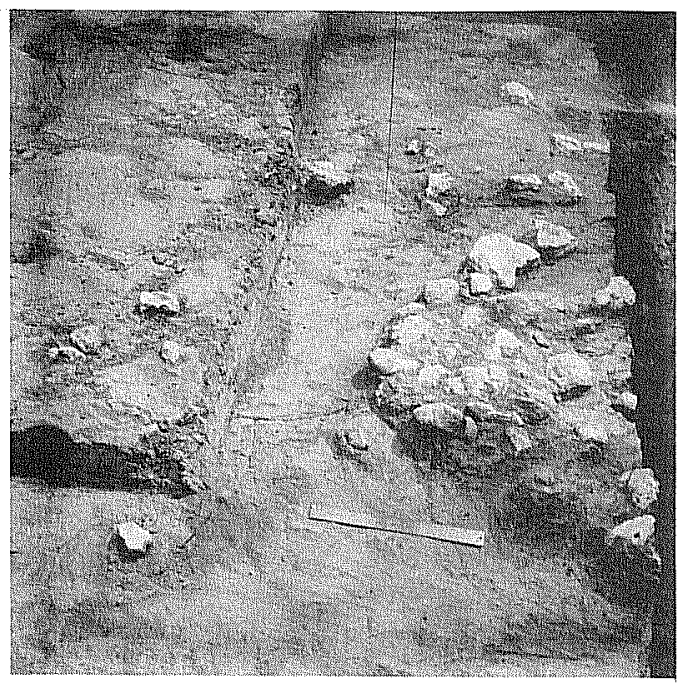

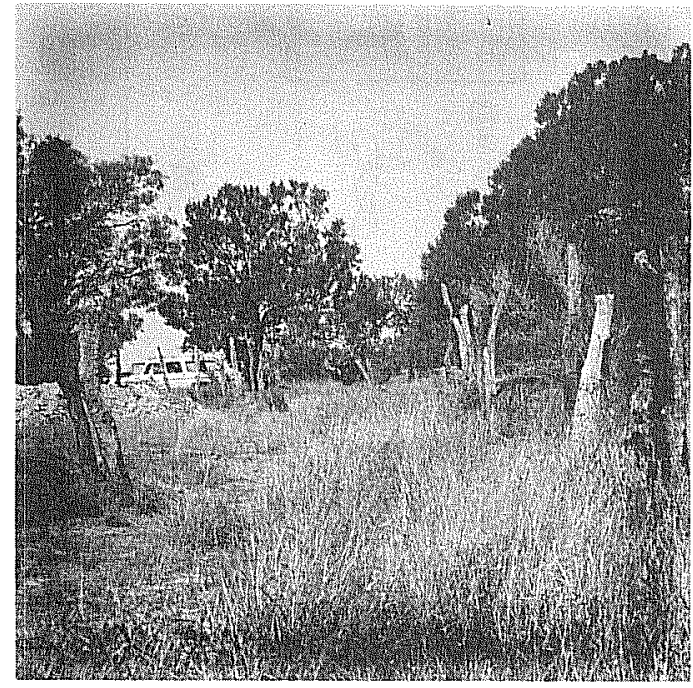

b

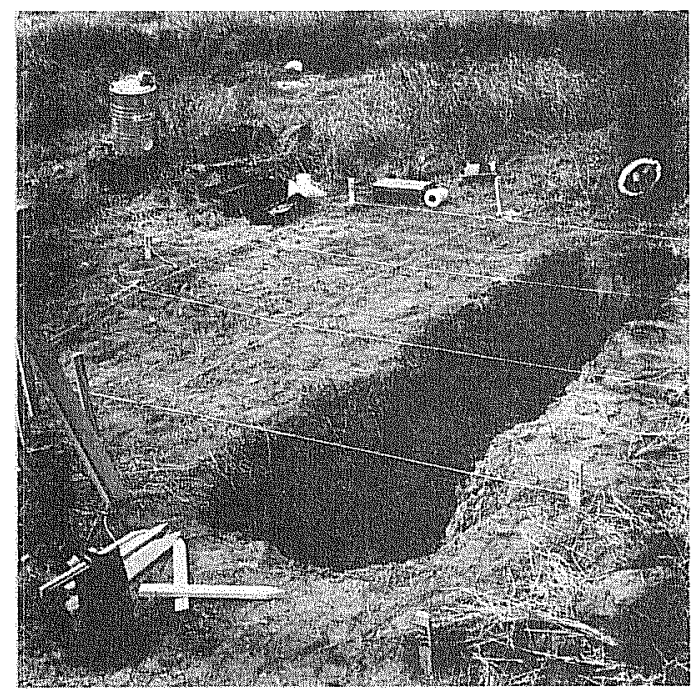

d

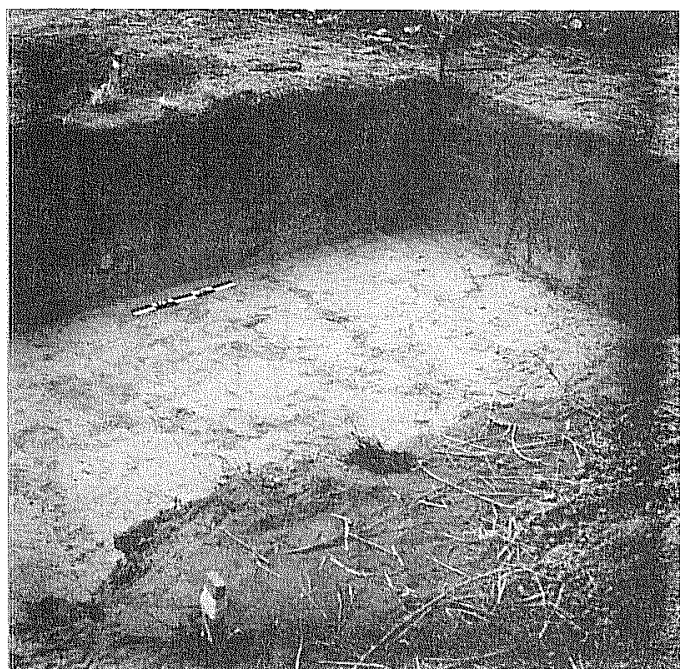




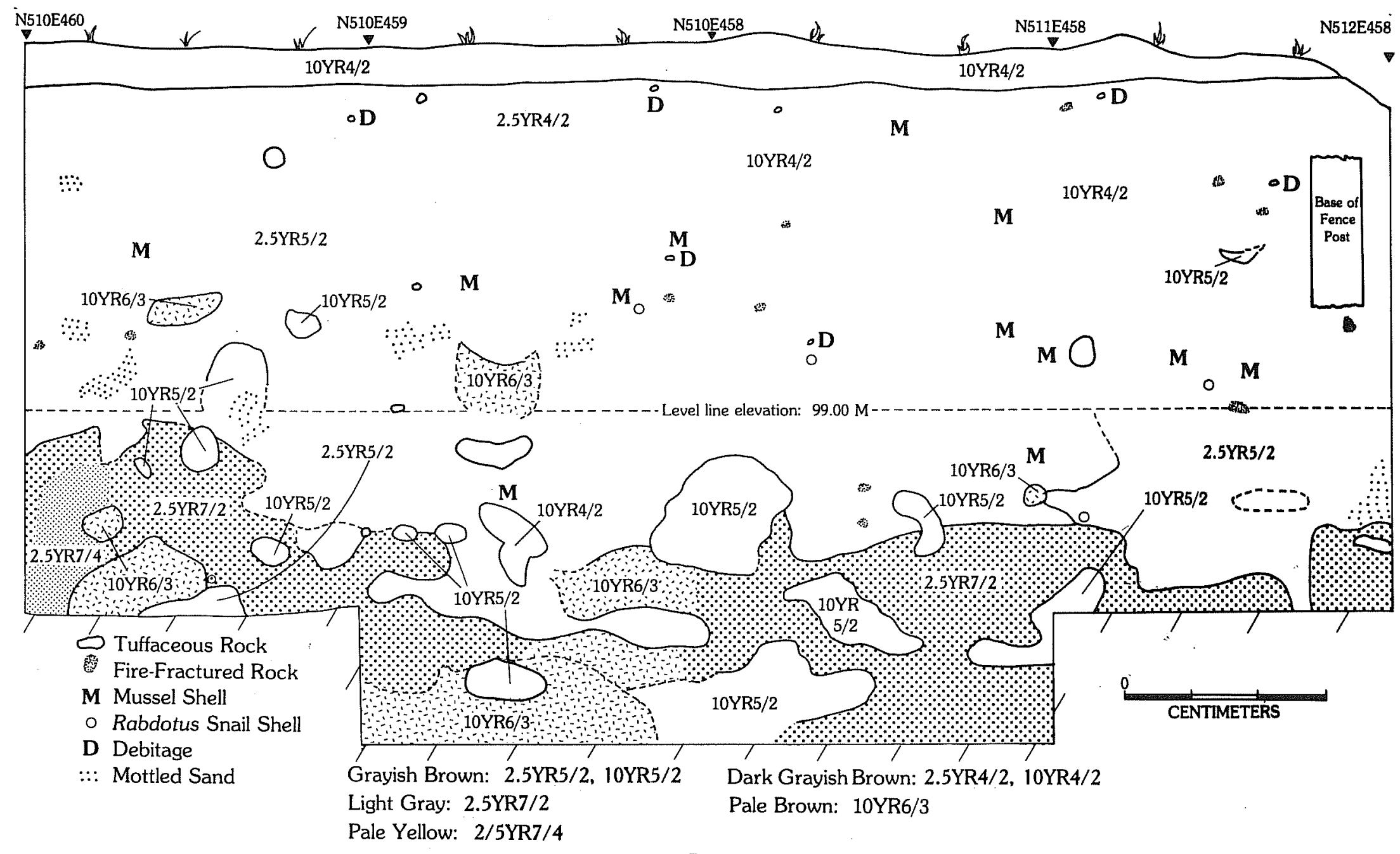

\section{$41 \mathrm{LK} 8$}

AREA A PROFILE SKETCH OF SOUTH AND WEST WALLS

Figure 5. Profile Sketch of South and West Walls at 41 LK 8, Area A. 
"horizons." The horizon divisions are based on variations in material recovery down through the deposit. In defining these horizons, the operating assumption is that al1 of the cultural material recovered from the 2-m-thick deposit in Area $A$ is not the result of a single prehistoric habitational event on the site. Rather, the cultural debris represents repeated visits to the site by aboriginal groups through hundreds of years of time. However, due to the nature of the cultural activity and circumstances of the depositional environment, there are no clear-cut divisions (such as zones of sterile deposit or "living floors") apparent. Horizons are defined using both vertical provenience and perceived fluctuations in material recovery. When horizons are presented here and elsewhere in this report, the uppermost levels are referred to as "Horizon 1," the next group of levels down as "Horizon 2," and so forth. For sites where horizons are presented, the deepest horizon would presumably contain debris representing the ear 1 iest periods of cultural activity on the site. In this sense, the horizons represent a very basic application of the 1 aw of superpositioning.

In Area $A$, the levels are broken down into horizons as follows: Horizon 1 , Leve1s 1-6; Horizon 2, Leve1s 7-11; Horizon 3, Leve1s 12-17 or 20. Area A combined unit recovery, by selected material classes, is as follows:

Horizon 1 Horizon 2 Horizon 3

$\begin{array}{lrrr}\text { Tuff Weight* (grams) } & 534 & 1160 & 508 \\ \text { Sandstone Weight (grams) } & 3 & 0 & 0 \\ \text { Fire-Fractured Rock Weight** (grams) } & 503 & 663 & 279 \\ \text { Musse1 She11 Umbo Count } & 159 & 141 & 71 \\ \text { Musse1 She11 Weight*** (grams) } & 39 & 50 & 15 \\ \text { Rabdotus Shel1 Count**** } & 245 & 478 & 448 \\ \text { Bone Weight (grams) } & 1.4 & 0.8 & 1.4 \\ \text { Primary Flake Count } & 9 & 11 & 11 \\ \text { Secondary Flake Count } & 161 & 119 & 63 \\ \text { Tertiary Flake Count } & 344 & 264 & 135 \\ \text { Chip Count } & 674 & 568 & 279\end{array}$

The following notes apply to all material recovery summaries presented in this section.

* This category contains the various types of tuffaceous sedimentary rocks (sandstone, siltstone, mudstone) derived from the Catahoula Formation. "Tuffaceous sedimentary rock(s)" and "tuff" are terms used interchangeably in the text.

**Throughout this volume, the category of "Fire-Fractured Rock" represents a combination of apparently nonartifactual chert, quartzite, and petrified wood broken as a result of being burned.

***"Musse1 She11 Weight" represents a combination of umbo and nonumbo she11 fragments.

**** "Rabdotus Shel1 Count" is of whole shells only. 
Counts and weights for each class of material are provided on a unit and level basis in the Material Analysis Records, Appendix VI.

One habitational feature was encountered during the excavation of Area $A$. The feature was a smal1 cluster of tuffaceous rock, a part of which was $v$ isible in the south end of Trench 7. Recognition of this feature in the trench prompted location of the Area A units. Designated Feature l, this cluster of 12 tuffaceous rocks was exposed in Level 8 (99.40-99.30 elevation) of Unit N511 E458. A single layer construct, Feature 1 had an irregular outline shape. It was approximately $38 \mathrm{~cm}$ in length and width. Rocks comprising the feature were in the 4 to $12 \mathrm{~cm}$ diameter size range. No artifacts were directly associated with the feature, and it contained no carbon.

A number of artifacts were recovered from the Area A excavation. Horizon 1 yielded two chert cores (one, Group 3; one, Group 5), three thin bifaces (Group 3, Form 2, Specimen 10; Group 4, Form 1, Specimen 1; one, Group 9), and a marine shel 1 bead (Specimen 1). From Horizon 2 came six chert cores (one, Group 1; two, Group 2; two, Group 6; one, Group 8), two thin bifaces (Group 4, Form 4, Specimen 121; one, Group 9), and one marine shel1 bead (Specimen 2). Horizon 3 yielded three chert cores (one, Group 1; one, Group 3; one, Group 6) and two thin bifaces (Group 2, Form 2, Specimen 12; one, Group 10).

Area $B$ at 41 LK 8 was located in the south-central part of the site along the eastern side of Trench 16 ( $F$ ig. 3). A 1 ayer of rock observed in the east wall of Trench 16 (Fig. 6) led to the selection of this location for controlled excavation. Area $B$ was composed of six units. Coordinates for the units and the number of levels excavated at each are as follows: N460 E541 (eight leve1s), N460 E542 (eight levels), N461 E541 (eight levels), N461 E542 (eight leve1s), N462 E541 (seven 1eve1s), and N462 E542 (eight levels). The three units on the E542 1 ine measured a ful1 $1 \mathrm{~m}^{2}$. The three units on the E54l 1 ine were truncated by Trench 16 and were thus not comp 1 ete $1-\mathrm{m}^{2}$ units (Fig. $4, d$ ).

Excavations in Area $B$ revealed a deposit containing a much higher clay content than did deposits in Area A. Units were excavated in arbitrary vertical levels of $10 \mathrm{~cm}$. Surface elevations ranged from 97.95 to $98.05 \mathrm{~m}$. From the surface to a depth of $20 \mathrm{~cm}$, matrix was a gray brown silty sand containing numerous 20 th-century artifacts such as glass sherds, wire, nails, bottle caps, etc. (Zone 3, Fig. 6). This upper deposit a 1 so contained much gravel and mortar related to modern construction activities in the vicinity. The next $50 \mathrm{~cm}$ of deposit was a dark brownish gray clayey sand (Zone 2, Fig. 6). Historic artifacts decreased substantially as quantities of prehistoric cultural debris increased. The floor of the Area $B$ excavation was at the base of this Zone 2 deposit (Fig. 4,f). Trench 16 revealed the deposit beneath Area $B$ to be a yellowish tan sandy clay mottled with calcium carbonate. This deepest zone also exhibited layers of caliche nodules (Zone 3, Fig. 6). Very 1 ittle cultural debris was noted in Zone 3.

Prehistoric cultural debris recovered from the Area $B$ excavation is combined into two horizons. Horizon 1 contains materials recovered from Levels 1-4, and Horizon 2 contains the materials from Levels 5-7 or 8. The six units from Area $B$ yielded the following: 


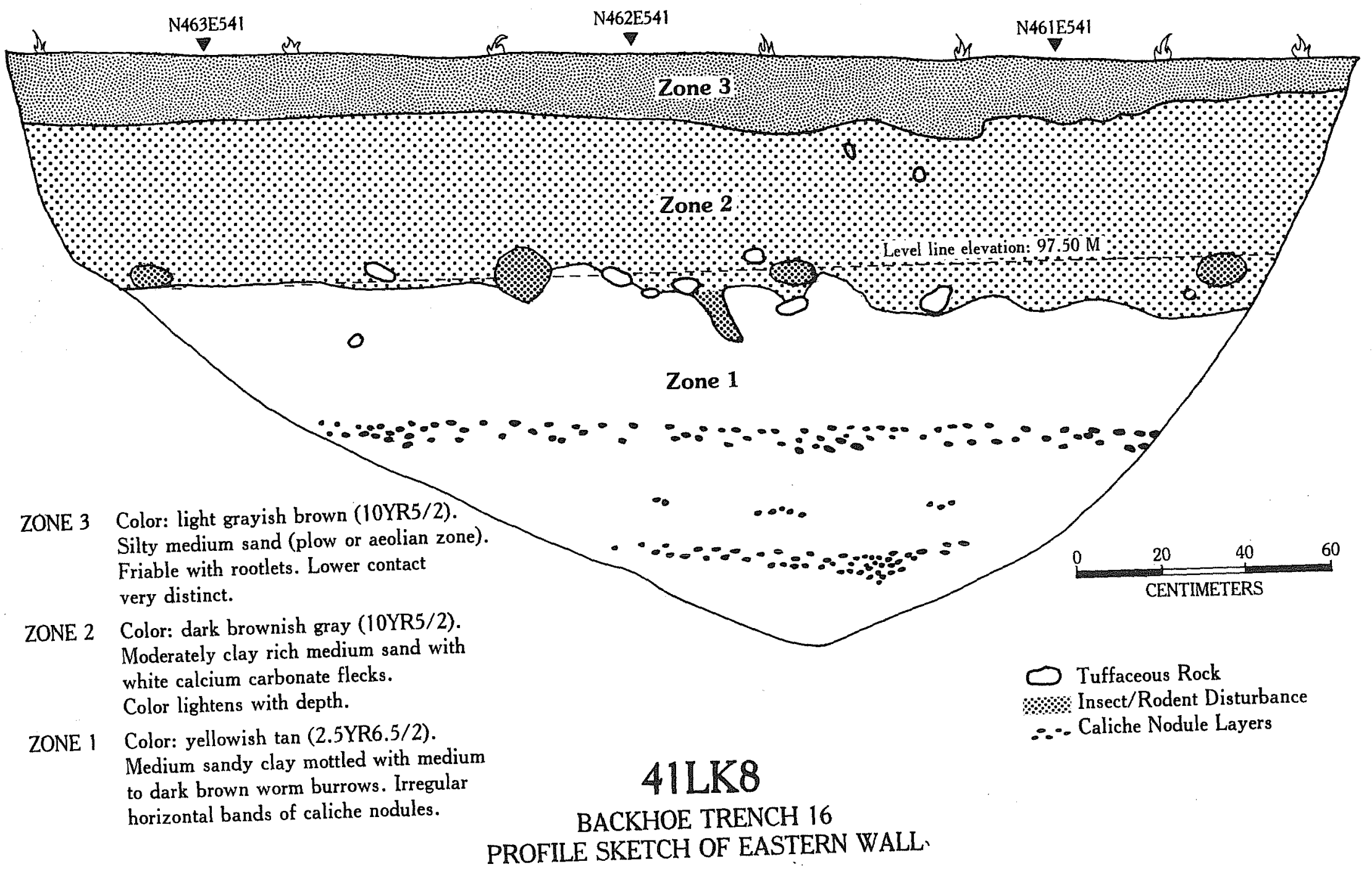

Figure 6. Profile Sketch of Eastern Wa11 at 41 LK 8, Backhoe Trench 16. 
Horizon 1 Horizon 2

Tuff Weight (grams)

Sandstone Weight (grams)

Fire-Fractured Rock Weight (grams)

Musse1 She11 Umbo Count

Mussel She11 Weight (grams)

Rabdotus She 11 Count

Bone Weight (grams)

Primary Flake Count

Secondary Flake Count

Tertiary Flake Count

Chip Count

$\begin{array}{rr}260 & 440 \\ 0 & 14 \\ 385 & 288 \\ 49 & 45 \\ 8 & 11 \\ 36 & 203 \\ 0.5 & 0 \\ 18 & 11 \\ 143 & 57 \\ 251 & 119 \\ 545 & 214\end{array}$

The layer of rock first seen in the east wall profile of Trench 16 was part of a more extensive rock cluster exposed in the Area B excavation and designated Feature 2 (Figs. 4,e; 7). Consisting predominant7y of tuffaceous rock, Feature 2 was a single layer construct resting on a $p 1$ ane approximately $60 \mathrm{~cm}$ below surface $(97.40 \mathrm{~m})$. The central part of the feature consisted of $30+$ tuffaceous rocks arranged in a subcircular cluster measuring $90 \mathrm{~cm}$ northsouth and $60 \mathrm{~cm}$ east-west (this dimension truncated by excavation of Trench 16). Outward from this central cluster were more widely scattered rocks (Fig. 7). Amidst the tuff were approximately 15 mostiy smaller pieces of fire-fractured rock, some chert debitage, a chert core, and a single piece of sandstone. Diameters of individual tuffaceous stones ranged from 5 to $15 \mathrm{~cm}$, averaging 8 to $10 \mathrm{~cm}$. Much of the debitage appeared to have been burned. Carbon was noted to occur on $7 y$ as infrequent flecks in the feature area.

Horizon $I$ in Area $B$ (consisting of Levels 1-4) yielded seven chert cores (two, Group 1; one, Group 2; two, Group 5; two, Group 6) and five thin bifaces (Group 1, Form 2, Specimen 1 [a Morhiss dart point]; one, Group 9; three, Group 10). From Horizon 2 (Leve1s 5-7 or 8) came three chert cores (one, Group 1; one, Group 5; one, Group 6) and one thin biface fragment (Group 10).

Area $C$ was located at the extreme southeastern end of 41 LK 8 (Fig. 3 ). This location is on the flank of the knoll and thus at a considerably lower elevation than the other excavations. Short gullies cutting up into the knol 1 near the Area $C$ units exposed a considerable amount of prehistoric debris, especially mussel shell and fire-fractured rock. A Fairland dart point (thin bifaces Group 1, Form 3, Specimen 11) was found on the surface. The Area $C$ units were staked out on an adjacent, uneroded piece of ground.

Area $C$ consisted of on $7 y$ two $1-m^{2}$ units: N400 E605 (11 levels) and N401 E605 (11 levels). Surface elevations in the units ranged from 95.48 to $95.55 \mathrm{~m}$. Excavations revealed a very compact dark brown $\mathrm{clayey}$ sand from the surface down through Level 5 (down to $50 \mathrm{~cm}$ ). In Leve 16 , the deposit changed to a 7 ight gray brown sandy $c l$ ay that extended down to the bottom of the units (approximately $110 \mathrm{~cm}$ below surface). Two horizons are defined with in the Area C deposits. Horizon 1 represents Levels 1-6. Horizon 2 contains Leve1s 7-11. Rates of recovery for selected classes of material from Area C are as follows: 


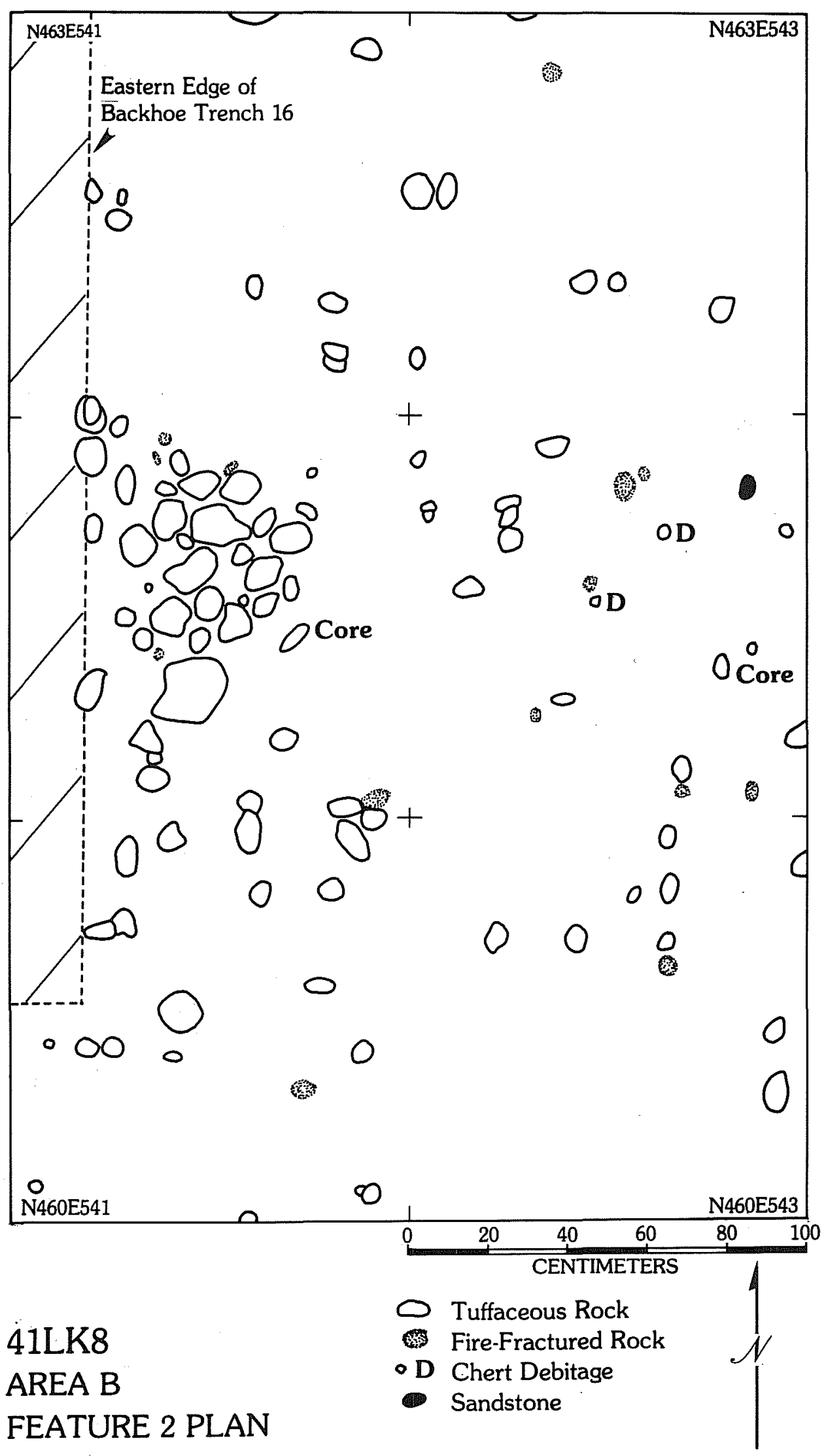

Figure 7. Feature 2 Plan at 41 LK 8, Area B. 
Horizon 1 Horizon 2

Tuff Weight (grams)

Sandstone Weight (grams)

Firewractured Rock Weight (grams)

Mussel Shel1 Umbo Count

Mussel Shell Weight (grams)

Rabdotus She11 Count

Bone Weight (grams)

Primary Flake Count

Secondary Flake Count

Tertiary Flake Count

Chip Count

$\begin{array}{rr}92 & 194 \\ 0 & 0 \\ 146 & 114 \\ 566 & 130 \\ 252 & 57 \\ 89 & 63 \\ 0 & 0 \\ 9 & 5 \\ 46 & 30 \\ 77 & 40 \\ 100 & 85\end{array}$

Other artifacts recovered from Area $C$ include a thin biface fragment from Horizon I (Group 9) and, from Horizon 2, one thick biface (Group 8) and a stemmed thin biface (early expanding stem Group 1, Form 3, Specimen 18).

In general, the data collected at 41 LK 8 during the Phase II investigation confirm previous assessments of the site. Results of Phase I testing demonstrated that the site's deposits offered 1 imited potential for data gain (Ha1 1, Black, and Graves 1982:92). The site as a relatively unique 7 andform setting, that is, a sandy rise, led to an overriding supposition that it might contain rare Paleo-Indian or Early Archaic components and possibiy an aboriginal cemetery.

Site 41 LK 8 appears to have been inhabited primarily during the Middle Archaic and Late Archaic periods. This conclusion is based on the recovery of various stemmed and unstemmed thin bifaces from the surface and subsurface of the site. Dart points such as the Morhiss (Group 1, Form 2, Specimen 1) from Area B, the Fairland (Group 1, Form 3, Specimen 11) from Area C, several triangular thin bifaces (Group 2, Form 2, Specimen 12; Group 3, Form 2, Specimen 10; Group 4, Form 1, Specimen 1; and Group 4, Form 4, Specimen 121) from Area $A_{s}$ and a distally beveled biface (Group 2, Form 1) are al1 suggestive of Middle Archaic to Late Archaic activity. Interestingly, there was no additional material recovered in Phase I or Phase II investigations to reconfirm a Late Prehistoric component evidenced by potsherds previously found on the site (Lynn, Fox, and O'Malley 1977:91). Habitation of the site, during the Late Prehistoric, must have been minimal. Likewise, in Phase II, the Paleo-Indian and Early Archaic periods are only vaguely hinted at by the recovery of a basally ground 7 anceolate thin biface (Group 3, Form 2, Specimen 25, Plainview?) and a stemmed thin biface (Group 1, Form 3, Specimen 18, early expanding stem?).

Deposits excavated in Areas $A, B$, and C at 41 LK 8 yielded substantial quantities of faunal remains in the form of musse 1 and snail she $11 \mathrm{~s}$, but almost no bone. Beyond the fact that the prehistoric inhabitants were gathering mussels and snails, there is 1 ittle direct evidence upon which to base subsistence inferences at this site. It is interesting to note that no seed/nut processing tools (called grinding slabs and stones or manos and metates) have been found at 41 LK 8 . This negative evidence suggests that perhaps seed or nut processing was not an important subsistence activity for the vicinity or time of year when prehistoric people lived on the site. 
Data collected in controlled excavations, as trenches were dug, and in surface observations at 41 LK 8 indicate that clusters of rock exemplified by Features 1 and 2 are extremely common in the subsurface throughout the site area. This situation is reminiscent of findings made at 41 LK 67, a valley margin site located just east of 41 LK 8 (Brown et a 1. 1982). At 41 LK 67 , the tuffaceous rock clusters were single 1 ayer constructs and occurred in surprising numbers across the site. A7though 41 LK 67 was clearly occupied during Late Prehistoric times, the majority of the tuffaceous rock features were probably constructed during the Middle Archaic or Late Archaic. Carbon was present in some of the 41 LK 67 features, and they are assumed to have functioned as hearths. It is suggested that 41 LK 8 and 41 LK 67 were inhabited by prehistoric people at roughly the same time and for the same reasons; this conclusion is based on the general similarities in habitational features and other debris they left behind.

\section{LK 201}

This extremely important prehistoric site, 41 LK 201, was recorded in 1977 by archaeologists from Texas Tech University (Thoms, Montgomery, and Portnoy 1981). The site was subsequentiy tested during the course of Phase I investigations (Ha11, B 1 ack, and Graves 1982:64-81). In three test units excavated at the southeastern end of 41 LK 201, prehistoric cultural remains representing Archaic and Late Prehistoric components were recovered from clearly stratified deposits extending down as much as $2 \mathrm{~m}$ below the surface in certain areas. In addition to being usefully stratified and deep, the 41 LK 201 deposits yielded much animal bone and a number of time-diagnostic chipped stone artifacts. Some of the most delicate and unusual prehistoric habitational features known at Choke Canyon were also revealed. Further, the features contained carbon in quantities adequate for radiocarbon assay and wood species identifications. Based on these outstanding qualities, 41 LK 201 was at the forefront among sites recommended for Phase II investigation.

Phase II excavations were conducted by the CAR field team and by members of an archaeological field school (summer 1981) from the Department of Anthropology, The University of Texas at San Antonio, under the direction of Dr. T. R. Hester. Results of the Phase II investigations at 41 LK 201 and the field school investigations are presented in Volume 11 of the Choke Canyon report series (Highley 1986). Chipped stone artifacts (except for debitage) recovered at 41 LK 201 are classified in the artifact section of this report. For artifact illustrations and al1 other essentials of the investigation, consult Highley (1986).

\section{LK 128}

Site 41 LK 128 was recorded in 1977 by surveyors from Texas Tech University (Thoms, Montgomery, and Portnoy 1981:41). The site is located on the north side of the Frio River (Fig. 1, folded insert). It trends from northwest to southeast for approximately $700 \mathrm{~m}$. The northwest end is $300 \mathrm{~m}$ in width tapering down to about $150 \mathrm{~m}$ at the southeast end. Most of the prehistoric 
cultural debris evidencing the site occurs on a second terrace above the Frio River (Fig. 8). The northeastern side of 41 LK 128 is bounded by the margin of the river valley, a high outcrop of the Catahoula Formation. The terrace surface containing the site slopes gently from southwest to northeast. The terrace is heavily eroded and densely covered with low brush species (blackbrush, mesquite, yucca, cacti, guaji110; Fig. 11,a). Long, deep gul1ies cut up into the terrace faces both above and below the main site area (Figs. $8 ; 9$ ).

The surficial extent of 41 LK 128 is general1y indicated by 1 ight scatters of mussel she11, chert debitage, and fire-fractured rock. Within the site, there are two areas where exposed habitational features and greater densities of surficial cultural debris indicate that more intensive prehistoric activity occurred here than elsewhere on the site. One of these areas is characterized by numerous exposed hearth features and the other by some quite extensive accumulations of mussel shel1 (Fig. 8). It was on these particular areas of concentrated remains that effort was focused during the Phase II investigation.

Phase II field activities at 41 LK 128 were excavation of fourteen $1-m^{2}$ units in three separate unit blocks and mapping and documentation of 21 hearth features and three mussel she 11 concentrations. The CAR crew worked at the site in September and October 1981. The seven members of the crew worked a total of 650 person hours at 41 LK 128.

As 41 LK 128 had an exceptional1y rugged surface and was densely covered with thorny brush, a horizontal grid system was not established on the site. Instead, blocks of units were independently laid out in each area of the site selected for excavation. These unit blocks were oriented along north-south 1 ines as determined with a Brunton compass. Each 1-m² unit was designated a "Test Pit" and given a serial number. Vertical datums were al so independently established in each excavation area. These consisted of points assigned arbitrary elevations of $100.000 \mathrm{~m}$. Test pit locations and vertical datums were later recorded on a plan map (Fig. 10).

Test Pits 1-4 formed a $2-\mathrm{m}^{2}$ excavation area located to sample the character and content of one of the mussel she 11 concentrations exposed on the surface of 41 LK 128 (Figs. 10; 11,b). Starting elevations for the four units ranged from 99.70 to $99.73 \mathrm{~m}$. In three units, two 10-cm-thick 1evels were excavated. In Test Pit 3, four 10-cm-thick levels were removed. Soil encountered in these units was described as a dark grayish brown silty clay loam. Rates of recovery for selected materials from Test Pits $1-4$ are as fol lows (a11 levels combined):

$\begin{array}{crrr}\text { Test } & \text { Iest } & \text { Test } & \text { Test } \\ \text { Pit 1 } & \text { Pit 2 } & \text { Pit 3 } & \text { Pit 4 } \\ 0.6 & 7 & 9 & 0 \\ 15 & 61 & 78 & 57 \\ 52 & 84 & 81 & 62 \\ 721 & 185 & 772 & 354 \\ 48 & 50 & 96 & 43\end{array}$

Tuff Weight (grams)

Sandstone Weight (grams)

Fire-Fractured Rock Weight (grams)

Mussel Shel1 Umbo Count

Mussel Shel1 Weight (grams) 


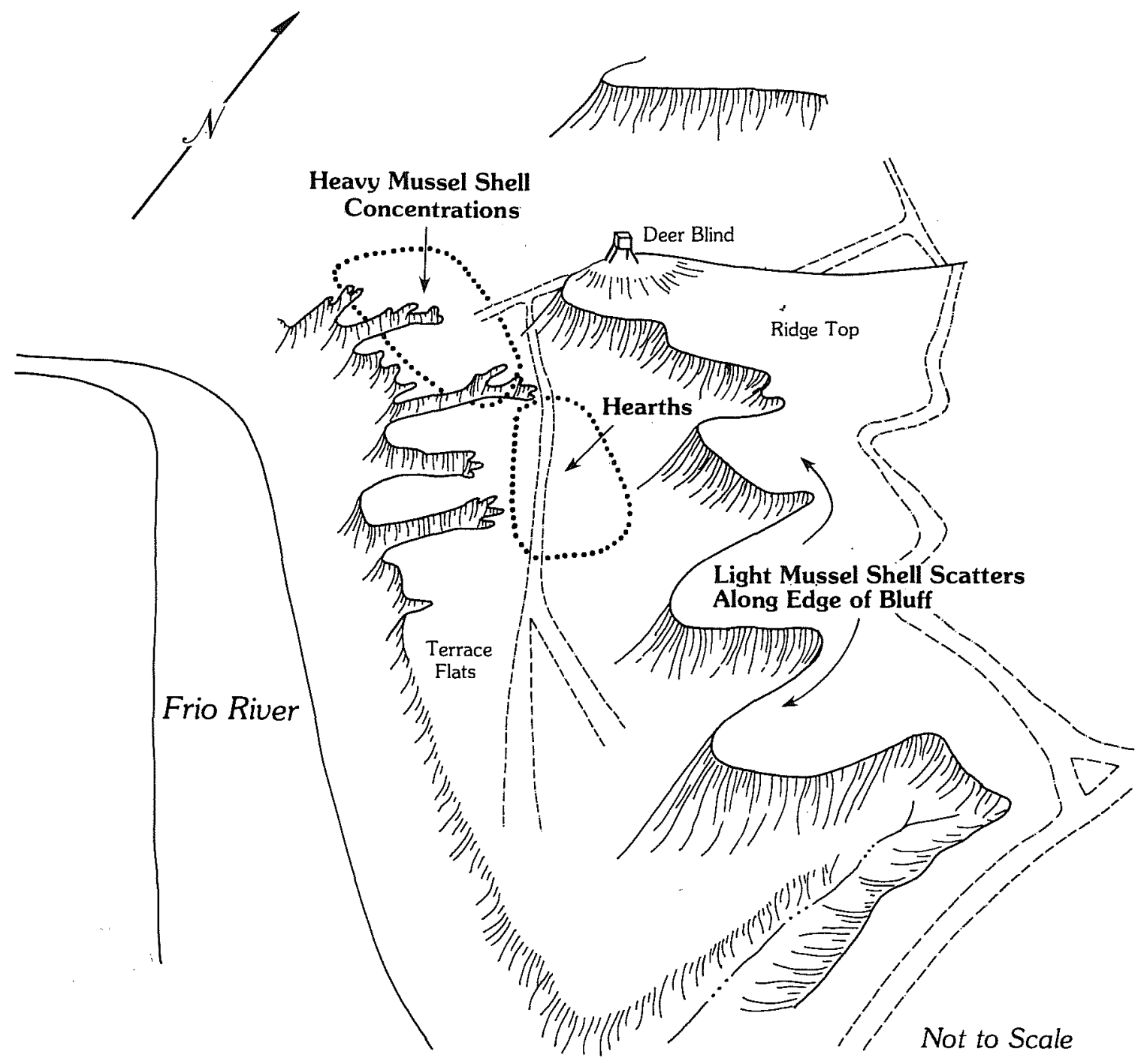

41LK128

SCHEMATIC SKETCH OF MAJOR CULTURAL FEATURES

Figure 8. Schematic Sketch of Major Cultural Features at 41 LK 128. 
Figure 9. Topographic Map of 41LK128 and Surrounding Area.

PAGE 34 REDACTED 


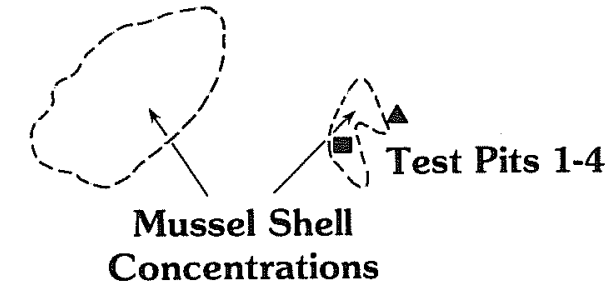

Concentrations

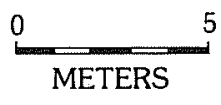

Excavations

- Numbered Hearth Feature

A Points shown on topographic map coverage of site

\section{LK128}

PLAN OF SURFACE FEATURES AND EXCAVATION UNITS
150

$$
3 \circ \quad 10
$$

$$
190
$$

20

40

50

20 o

Test Pits 11-12

140

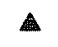

17

Test Pits 9, 10, 13, 14 Test Pits 5-8

12

90

Mussel Shell

Concentration

Figure 10. Plan of Surface Features and Excavation Units at 41 LK 128. 
Figure 11. Phase II Investigations at 41 LK 8 and 41 LK 128.

a, view south across 41 LK 128. Cleared areas of the Frio River floodplain are visible in the background. Vegetation is predominantly mesquite trees, blackbrush, and guaj1110;

b, view looking southwest across typical scatter of mussel shel1 at 41 LK 128. The ground cover and degree of erosion evident in this illustration are characteristic of the site in general;

c, Hearth 2 at 4 I LK 128 after being cross sectioned;

d. Hearth 17 at 41 LK 128 after being cross sectioned. Note the darkly stained soil beneath the rock layer;

e, Hearth 2 at 41 LK 128;

f, Hearth 13 at 41 LK 128 after being cross sectioned. 


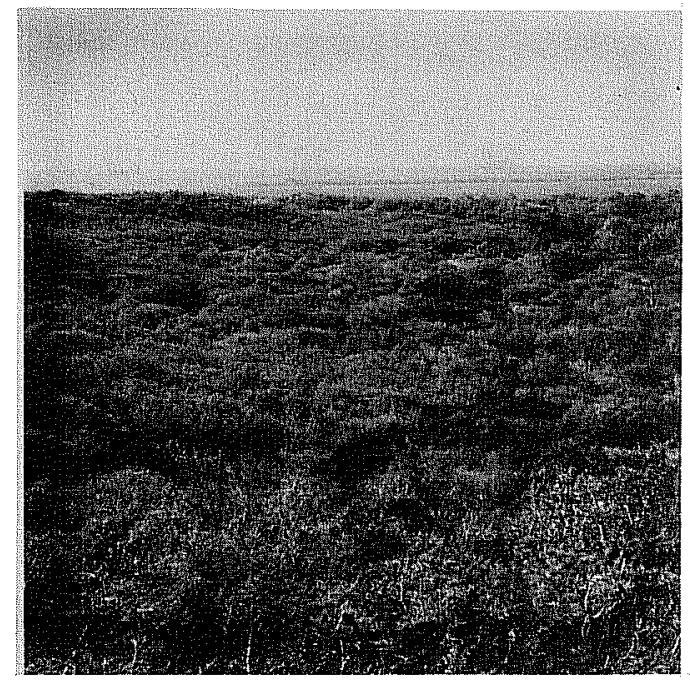

$a$

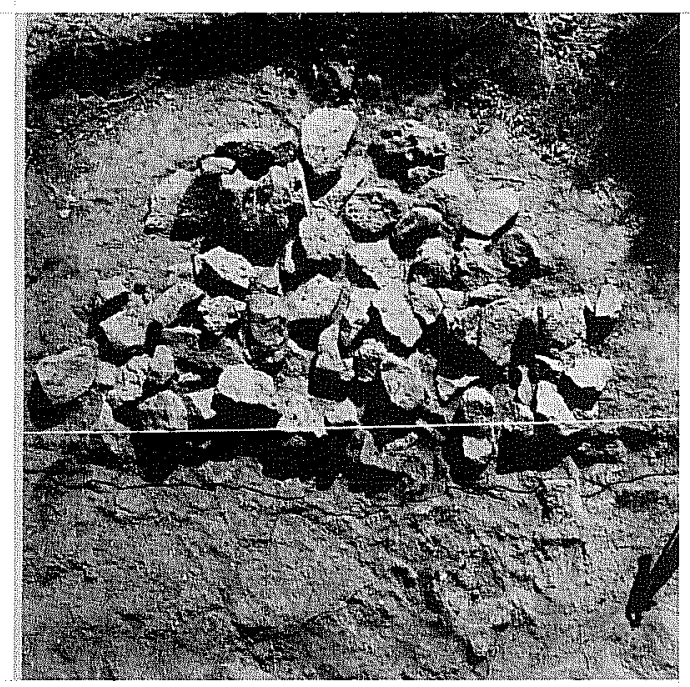

c

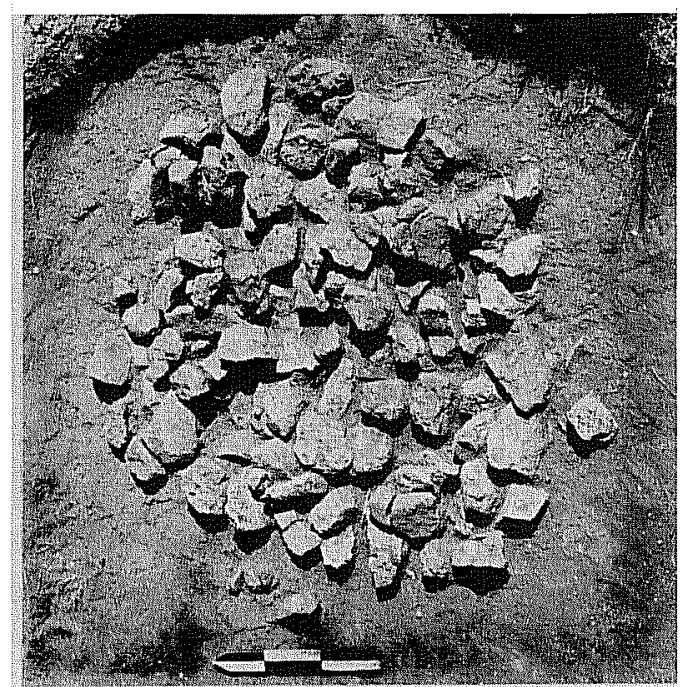

e

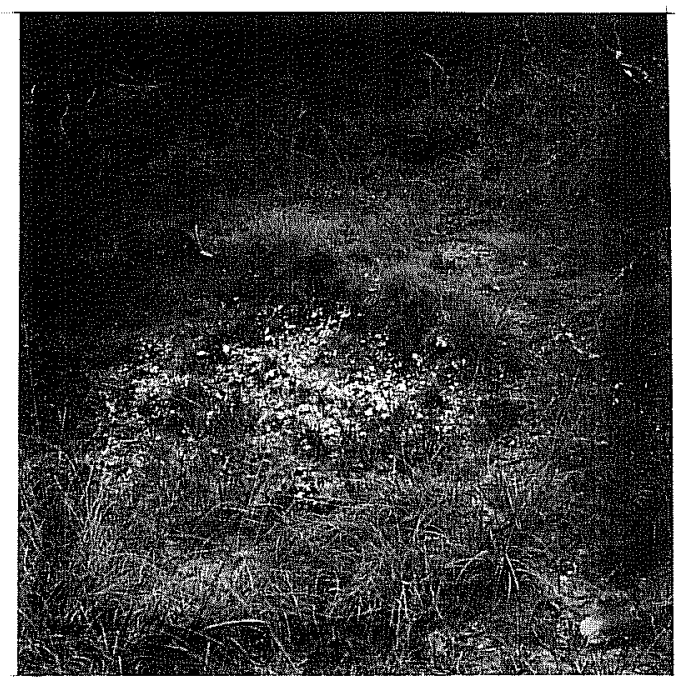

b

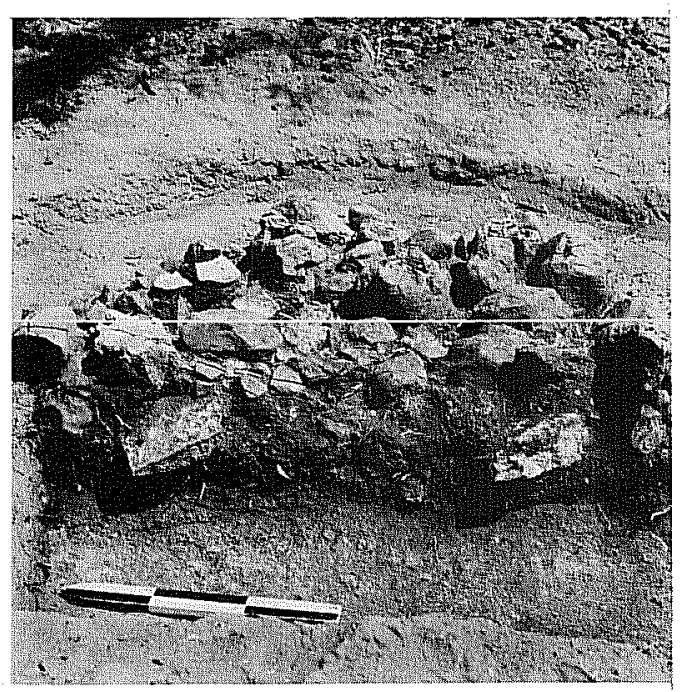

d

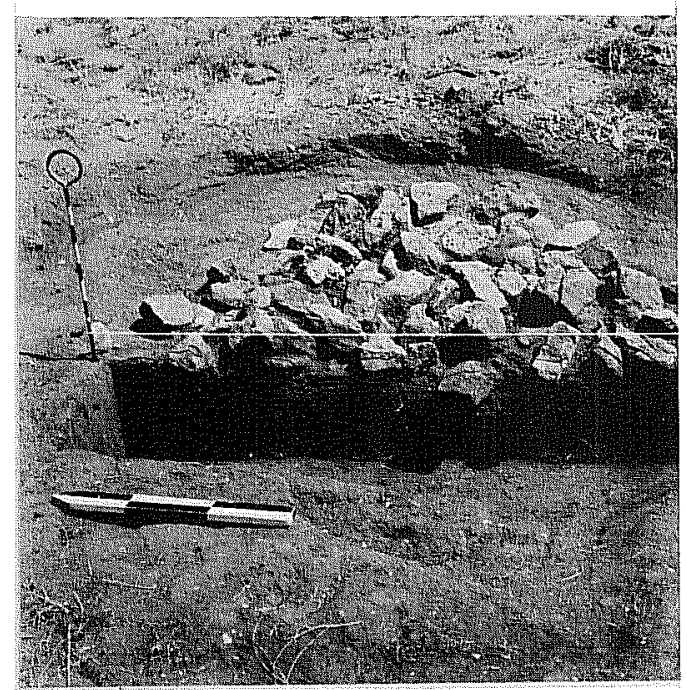

f 


$\begin{array}{lrrrr}\text { Rabdotus Shel1 Count } & 18 & 54 & 20 & 29 \\ \text { Bone Weight (grams) } & 0 & 0 & 0 & 0 \\ \text { Primary Flake Count } & 0 & 4 & 2 & 3 \\ \text { Secondary Flake Count } & 9 & 21 & 22 & 10 \\ \text { Tertiary Flake Count } & 12 & 18 & 34 & 13 \\ \text { Chip Count } & 12 & 46 & 43 & 17\end{array}$

Other artifacts recovered from Test Pits 1-4 include two chert cores (one, Group 5; one, Group 6), a thin biface fragment (Group 10), and one piece of satin spar gypsum.

Test Pits 5-8 and Test Pits 9, 10, 13, and 14 were located on the east and west sides of Hearth 13 ( $F$ igs. 10; 11,f; 15,a-d). Each group of four units formed a $2-m^{2}$ excavation on either side of the hearth. Hearth 13 was contained within a third $2-\mathrm{m}^{2}$ block that was only partially excavated as the hearth was further exposed (Fig. 12). Levels in these units were 10-cm thick. Units were excavated to varying depths as follows: Test Pit 5, eight levels; Test Pit 6, four levels; Test Pit 7, eight leve1s; Test Pit 8, four levels; Test Pit 9, two levels; Test Pit 10, two levels; Test Pit 13, one leve1; and Test Pit 14, one level. Again, the soil matrix was a dark grayish brown silty clay loam. Starting elevations at the surface of the units ranged from 99.61 to $99.84 \mathrm{~m}$. In Test Pits 5-8, rates of recovery for selected classes of debris are as follows (a11 levels combined):

$\frac{\text { Test }}{\text { Pit } 5} \quad \frac{\text { Test }}{\text { Pit } 6} \quad \frac{\text { Test }}{\text { Pit } 7} \quad \frac{\text { Test }}{\text { Pit } 8}$

$\begin{array}{lrrrr}\text { Tuff Weight (grams) } & 17 & 6 & 13 & 0 \\ \text { Sandstone Weight (grams) } & 145 & 78 & 302 & 42 \\ \text { Fire-Fractured Rock Weight (grams) } & 55 & 31 & 69 & 27 \\ \text { Musse1 She17 Umbo Count } & 188 & 129 & 227 & 140 \\ \text { Mussel She17 Weight (grams) } & 95 & 61 & 123 & 77 \\ \text { Rabdotus She17 Count } & 1023 & 686 & 1122 & 578 \\ \text { Bone Weight (grams) } & 89 & 38 & 22 & 12 \\ \text { Primary Flake Count } & 5 & 11 & 8 & 8 \\ \text { Secondary Flake Count } & 64 & 82 & 116 & 101 \\ \text { Tertiary Flake Count } & 98 & 84 & 169 & 168 \\ \text { Chip Count } & 163 & 142 & 322 & 309\end{array}$

Additional artifacts found in these units include eight chert cores (three, Group 3; one, Group 4; two, Group 5; and two, Group 6), one thick biface (Group 8), 14 thin bifaces (two, Group 1, Form 4, Specimens 56 and 57 [Perdiz arrow points]; two, Group 4, Form 4, Specimens 16 and 123; one, Group 4, Form 3, Specimen 2; one, Group 9; seven, Group 10), and two trimmed flakes (Group 3, Form 1, Specimen 1 and Group 4, Form 1).

Test Pits 9, 10, 13, and 14 formed a 2-m ${ }^{2}$ unit on the west side of Hearth 13 (Figs. 10; 12). These units yielded the following materials (all levels comb ined): 


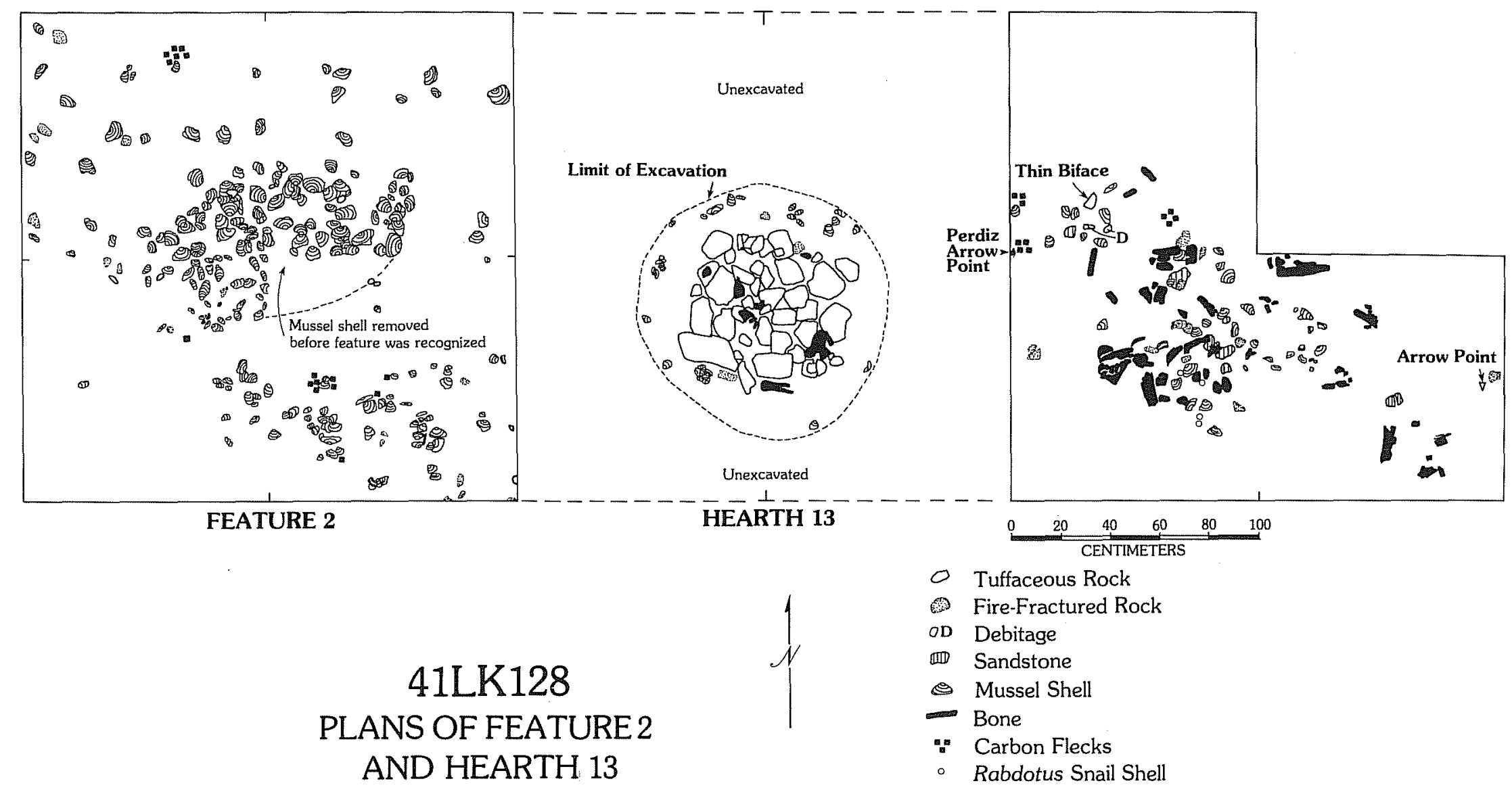

Figure 12. Plans of Feature 2 and Hearth 13 at 41 LK 128. 


$\begin{array}{lcccc} & \text { Test } & \text { Test } & \text { Test } & \text { Test } \\ & \text { Pit9 } & \text { Pit 10 } & \text { Pit 13 } & \text { Rit 14 } \\ \text { Tuff Weight (grams) } & 1 & 0 & 0 & 0.5 \\ \text { Sandstone Weight (grams) } & 32 & 32 & 16 & 11 \\ \text { Fire-Fractured Rock Weight (grams) } & 26 & 36 & 5 & 8 \\ \text { Musse1 She17 Umbo Count } & 97 & 74 & 52 & 72 \\ \text { Musse1 She11 Weight (grams) } & 28 & 54 & 31 & 58 \\ \text { Rabdotus Shel1 Count } & 566 & 273 & 105 & 202 \\ \text { Bone Weight (grams) } & 1 & 1 & 0.3 & 0.1 \\ \text { Primary Flake Count } & 2 & 1 & 0 & 3 \\ \text { Secondary Flake Count } & 19 & 16 & 5 & 8 \\ \text { Tertiary Flake Count } & 23 & 28 & 14 & 30 \\ \text { Chip Count } & 57 & 48 & 36 & 42\end{array}$

Other artifactual materials found in the above four units include four chert cores (two, Group 3; one, Group 4; and one, Group 5), one thick biface (Group 4), and three thin bifaces (one, Group 6, Form 1; one, Group 9; and one, Group 10).

The combined excavation effort in and beside Hearth 13 at 41 LK 128 yie lded data illustrated in Figure 12. The hearth is a single-layer construct, roughly circular in outline, with a diameter of approximately $60 \mathrm{~cm}$. It is composed of tuffaceous rocks. The tuff totaled 52 pieces weighing $24.42 \mathrm{~kg}$. Maximum size ranges for these rocks were: one at $25 \mathrm{~cm}$, 5 ix at $13-15 \mathrm{~cm}$, nine at 11-12 cm, eight at 8-10 cms and 28 at $3-7 \mathrm{~cm}$. Fragments of bone and musse 1 she 11 were scattered amidst and around the rock cluster. One Perdiz arrow point (thin bifaces Group 1, Form 4, Specimen 58) was found as Hearth 13 was exposed. Units excavated to the east of the hearth contained a relatively dense scatter of animal bone (probably deer) and mussel shel1. Two Perdiz points came from these units. To the west of Hearth 13, excavations revealed the concentration of mussel she11s and Rabdotus she $11 \mathrm{~s}$ designated as Feature 2. Chert debitage and cores were recovered from units on both sides of the hearth, but there was more debitage of all types on the east side. (Test Pits 5-8).

Unfortunately, Hearth 13 did not yield carbon in quantities sufficient for radiocarbon assay. However, the presence of three Perdiz arrow points in the immediate vicinity permits tentative assignment of this particular feature to the 7 atter years of the Late Prehistoric period. Given the Late Prehistoric presence indicated by the Perdiz points, it is noteworthy that no prehistoric ceramic sherds were found by Hearth 13. A few sherds were found elsewhere on the site.

Roughiy $5 \mathrm{~m}$ northeast of Hearth 13, another block of two $1-\mathrm{m}^{2}$ units was excavated (Fig. 10). Designated Test Pits 11 and 12, these units were located between Hearths 14 and 20 to sample an area where numerous Late Prehistoric artifacts were observed on the surface. Test Pit 1l, with surface elevations averaging $100.90 \mathrm{~m}$, was excavated in five 10-cm-thick leve1s. Test Pit 12, where surface elevations averaged $100.96 \mathrm{~m}$, was taken down only two levels. Soil in the units was described as 1 ight grayish brown sandy clay loam. Rates of recovery for selected classes of material from Test Pits 11 and 12 are as follows (al1 levels combined): 


$\begin{array}{lcc} & \text { Test } & \text { Test } \\ & \text { Pit } 11 & \text { Pit 12 } \\ \text { Tuff Weight (grams) } & 0 & 10 \\ \text { Sandstone Weight (grams) } & 98 & 29 \\ \text { Fire-Fractured Rock Weight (weight) } & 39 & 44 \\ \text { Mussel She11 Umbo Count } & 26 & 36 \\ \text { Mussel She11 Weight (grams) } & 18 & 18 \\ \text { Rabdotus Shell Count } & 514 & 248 \\ \text { Bone Weight (grams) } & 0.5 & 0 \\ \text { Primary Flake Count } & 3 & 4 \\ \text { Secondary Flake Count } & 18 & 13 \\ \text { Tertiary Flake Count } & 22 & 28 \\ \text { Chip Count } & 77 & 80\end{array}$

A chert core (Group 1) was found in Test Pit 11 . Three thin biface fragments (three, Group 10) were recovered from Test Pit 12.

In addition to Hearth 13, data concerning 20 other hearth features was collected at 41 LK 128. Locations of these hearths are plotted in Figure 10. Hearths 2, 9, and 17 are described individual1y. Descriptive information for the remaining features is summarized in Table 1 .

Hearth 2 (Figs. $11, c, e ; 13$ )

Hearth 2 is composed of tuffaceous rocks densely packed into a circular area measuring $83 \mathrm{~cm}$ north-south and $90 \mathrm{~cm}$ east-west. It was sectioned along a north-south 1 ine to reveal more about its subsurface structure. In cross section, the feature was found to consist of a single layer of rock. Substantial amounts of carbon were collected from amidst and beneath the stones. Two radiocarbon assays (TX-4671, TX-4674) yielded ages of A.D. 980 and A.D. 1180 (MASCA corrected) for Hearth 2. The species Diospyros (Texas persimmon?) was recognized as a wood burned to form the carbon found in this hearth (see Appendix II). After being sectioned, Hearth 2 was dismantled. Components consisted of 158 pieces of tuffaceous rock weighing $28.85 \mathrm{~kg}$. Size ranges of these rocks were as fol lows: one at $18 \mathrm{~cm}, 10$ at $13-15 \mathrm{~cm}, 32$ at 10-12 cm, 50 at 8-10 cm, 24 at $6-8 \mathrm{~cm}, 16$ at 5-6 cm, and 25 at $3-5 \mathrm{~cm}$ (maximum dimension of each rock). One piece of fire-fractured rock, weighing $0.14 \mathrm{~kg}$ and being $8 \mathrm{~cm}$ in diameter, was found in the hearth. The hearth also contained two pieces of conglomerate, both weighing $0.4 \mathrm{~kg}$ and with diameters of 6 and $8 \mathrm{~cm}$.

\section{Hearth 9}

Hearth 9, is oblong in out 1 ine shape, and measures $110 \mathrm{~cm}$ north-south and $140 \mathrm{~cm}$ east-west. This feature was further exposed and cross sectioned. Carbon collected from within the feature was submitted for radiocarbon assay and yielded an age of A.D. 1310 (TX-4670, MASCA corrected). The section made through the feature revealed it to be a single 1 ayer of rock. Hearth 9 was composed of 156 pieces of tuffaceous rock weighing $56.2 \mathrm{~kg}$ and 47 pieces of 
TABLE 1. SUMMARY OF HEARTH DATA AT SITE 41 LK 128

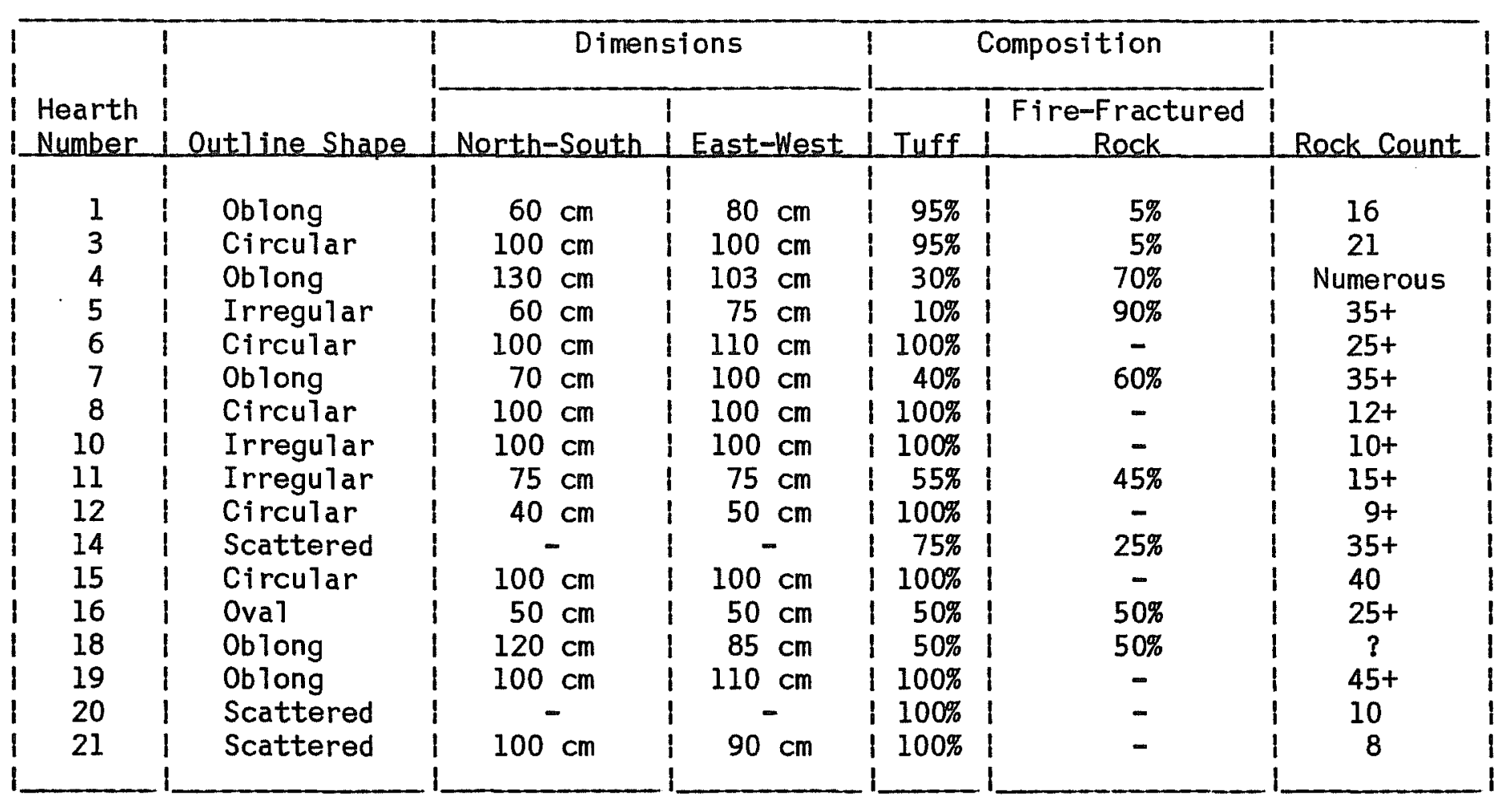



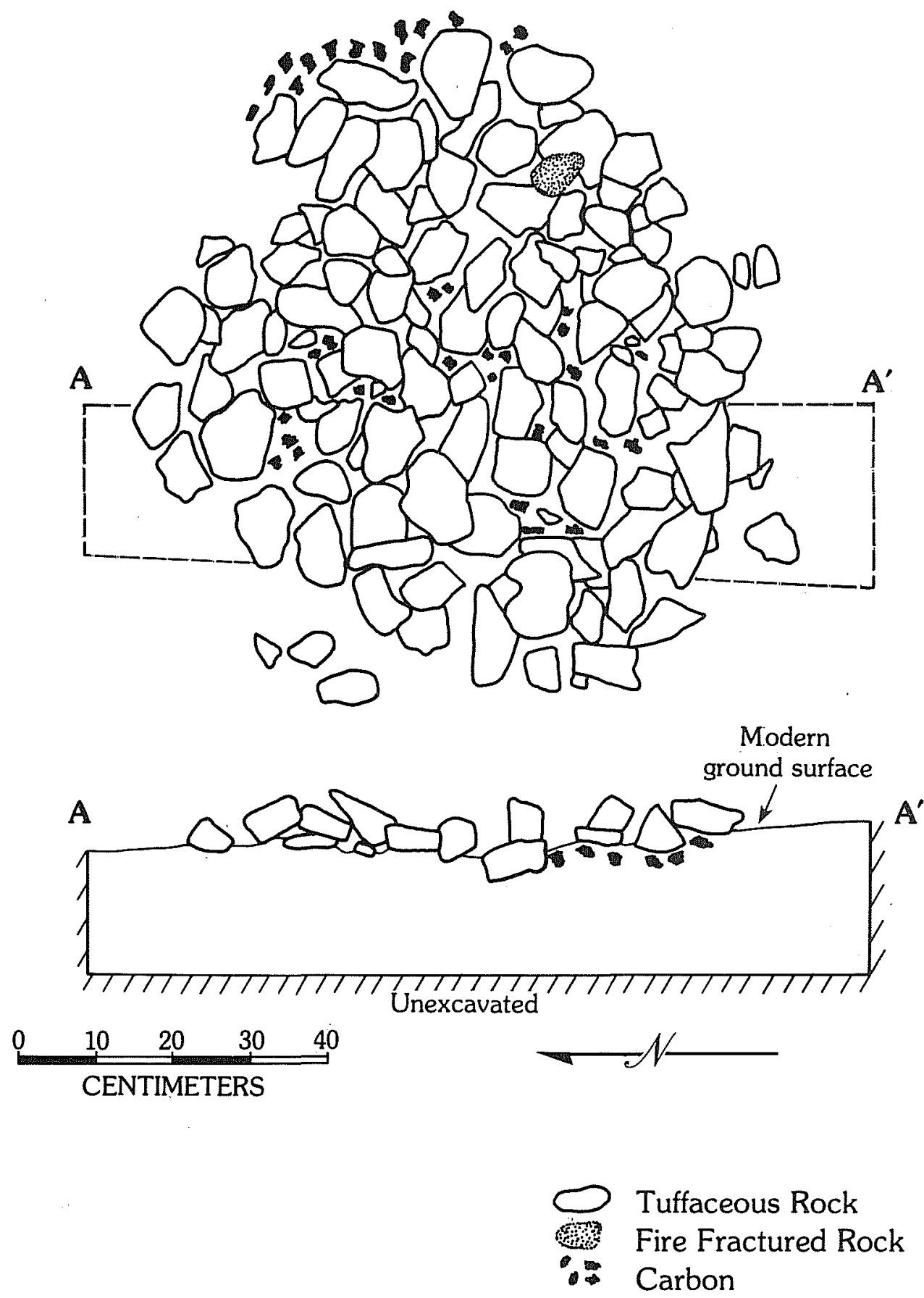

\section{LK128}

HEARTH 2

PLAN AND CROSS SECTION

Figure 13. Hearth 2 Plan and Cross Section at 41 LK 128. 
fire-fractured rock weighing $6.7 \mathrm{~kg}$. Ranges of maximum dimensions on these rocks were: eight at $16 \mathrm{~cm}, 118$ at $9-15 \mathrm{~cm}$, and 87 at $1-8 \mathrm{~cm}$.

Hearth 17 (Figs. 11,d; 14)

Hearth 17 provides an example of a feature composed predominantly of firefractured rock. Subcircular in outline, this rock cluster measures $116 \mathrm{~cm}$ north-south and $130 \mathrm{~cm}$ east-west. It was cross sectioned along a north-south 1 ine down the middle of the cluster (Fig. 14). A very shallow basin-shaped structure was exposed in the subsurface. Radiocarbon assays of carbon samples collected from Hearth 17 yielded ages of A.D. 1180 and A.D. 1300 (TX4675, TX-4676, MASCA corrected). Prosop 1s (mesquite?) was identified as the wood burned to form the carbon found in this feature (see Appendix II). Fragments of fire-fractured rock totaled 260 pieces weighing $42.3 \mathrm{~kg}$. Counts by maximum length ranges were: nine at $11-15 \mathrm{~cm}, 43$ at 8-10 cm, 46 at 5$7 \mathrm{~cm}$, and 162 at $3-5 \mathrm{~cm}$. The hearth also contained 42 pieces of tuff weighing $12.85 \mathrm{~kg}$. Size ranges for these tuffaceous rocks were: two at $19 \mathrm{~cm}$, five at $13-15 \mathrm{~cm}, 24$ at $10-12 \mathrm{~cm}$, five at 7-10 cm, and six at $3-6 \mathrm{~cm}$.

Additional artifacts collected from the surface of 41 LK 128 are three thick bifaces (one, Group 1; one, Group 2; one, Group 9), seven thin bifaces (Group 1, Form 3, Specimen 14 [Fair1and]; Group 1, Form 3, Specimen 27 [unclassified stemmed dart point]; three, Group 2, Form 1; one, Group 4, Form 1; and one, Group 8), one distally beveled biface (Group 1, Specimen 3), one uniface (Group 3, Specimen 2), one piece of modified sandstone (Group 1, Form 2), one piece of satin spar gypsum, and four sherds of aboriginal pottery.

Data col lected, during the Phase II investigation at 41 LK 128 , evidence habitation of the site by prehistoric people during the Late Archaic and Late Prehistoric periods. Late Archaic activity is suggested by stemmed dart points and a distally beveled biface collected from the surface of the site. Late Prehistoric activities are indicated by arrow points, sherds of pottery, and a series of radiocarbon assays. Although Late Prehistoric habitation is clearly demonstrated, the arrow points and radiocarbon dates do not permit any narrowing of the chronological focus within the period. The radiocarbon assays, yielding corrected dates ranging from A.D. 980 to A.D. 1310, suggest activity in the earlier centuries of the Late Prehistoric period while the Perdiz arrow points evidence a later time period in the Late Prehistoric. Unfortunately, no radiocarbon assays were possible for the one excavation where the Perdiz points were recovered (Hearth 13, Feature 2 vicinity). It is significant that no artifacts clearly diagnostic of the early Late Prehistoric (specifical1y, Scallorn arrow points) were recovered. If the radiocarbon results are accurate, it seems that diagnostics such as Scal1orn points should have been found at 41 LK 128. The Scallorn type may be represented by certain fragmentary arrow points (thin bifaces Group 1 , Form 7, Specimens 5-10), but their incomplete condition precludes definitive identification.

The four habitational features--Hearths 2, 9, 13, and 17--yielded radiocarbon assays or time-diagnostic artifacts affiliating them with the Late Prehistoric period. The Late Archaic artifacts found on the surface of 


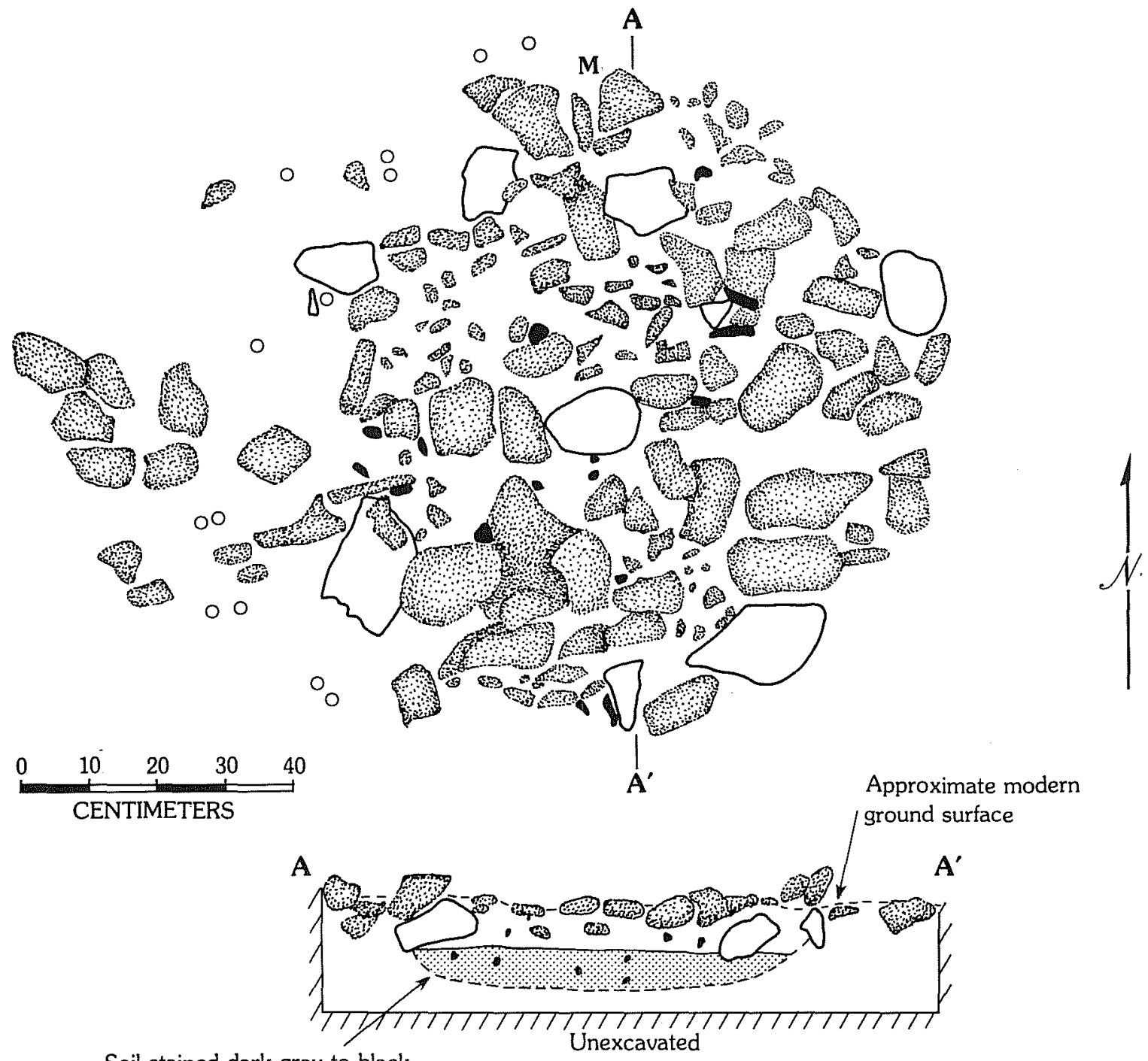

Soil stained dark gray to black

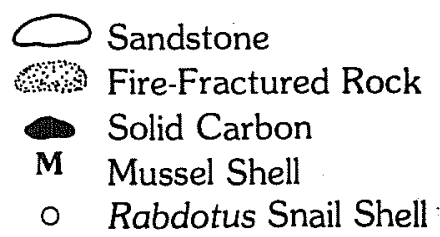

41LK128

HEARTH 17

PLAN AND CROSS SECTION

Figure 14. Hearth 17 P1 an and Cross Section at 41 LK 128. 
41 LK 128 were not closely associated with the hearth features. It would be unreasonable to automatically assign the remaining hearth features to the Late Prehistoric period based on such i imited data. The extensive surface scatters of mussel she17, an outstanding characteristic of 41 LK 128, cannot be assigned to a particular cultura1/temporal period with data currently available.

The habitational features and mussel she 11 deposits found at 41 LK 128 probably resulted from repeated intervals of encampment on the location through the Late Archaic and Late Prehistoric periods. Data observed or collected do not permit statements concerning the size of human groups that inhabited the site nor is there clear indication of duration of encampment. Identification of wood species burned to produce carbon found in several of the hearths clearly demonstrate that at least certain elements of the modern brush communities (Acacia, Prosopis, Diospyros) were present when prehistoric people were $1 \mathrm{iving}$ on the site. It is possible, but difficult to imagine, that the brush cover was as thick on the site surface during periods of prehistoric habitation as at present (Fig. 11,a).

Evidence for prehistoric subsistence pursuits recovered at 41 LK 128 is musse1 she11, Rabdotus snail she11, bones of deer and other animals, and a single grinding slab fragment. In this respect, the investigation at 41 LK 128 provides no new insights.

\section{LK 121}

Site 41 LK 121 is located on the north (1eft) side of the Frio River (Fig. 1 , folded insert). It is a very smal1 site, measuring on $7 y 75 \mathrm{~m}$ east-west and $50 \mathrm{~m}$ north-south. The modern channel of the river flows about $150 \mathrm{~m}$ to the southeast. An upland drainage channel, tributary to the Frio River, feeds down along the southern margin of the site. The site proper is on the first terrace above the river. Behind (north) the site, a moderately steep, gravelly slope rises and marks another, older terrace. The site surface is covered with native grasses, cacti, acacias, and mesquite trees.

Musse 1 she11, tuffaceous rock, and chert debitage exposed in the bank of the tributary channel evidence the character and extent of 41 LK 121 . CAR activities at this site were an uncontrolled surface collection and the documentation and collection of a surficially exposed mussel shell feature. This mussel she 11 feature was $2 \mathrm{~m}$ in diameter and extended down about $20 \mathrm{~cm}$ into the subsurface. Artifacts collected are a thick biface (Group 6, Form 1) and a distally beveled biface (Group 1, Specimen 2). The distally beveled biface indicates that the site was occupied, at least in part, sometime during the Archaic.

\section{LK 122}

Site 41 LK 122 is located on the crest of an upland hill $400 \mathrm{~m}$ north of the Frio River (Fig. 1, folded insert). As recorded by Texas Tech surveyors, the site is subcircular in outline with a diameter of about $300 \mathrm{~m}$ (Thoms, Montgomery, and Portnoy 1981). A portion of the site occurs in a cultivated 
field. A fringe of brush around the field includes mesquite trees, acacias, yucca, prickly pear, and grasses. Limits of the site were determined on the basis of surface scatters of chert debitage, burned rock, and mussel and snail shel1s.

CAR Phase II activities at 41 LK 122 were further definition of site 1 imits, an uncontrolled surface artifact collection, and excavation of two shovel tests. Survey of the site surface revealed that prehistoric cultural debris was most densely concentrated on the surface at the highest part of the hill. This area of approximately $250 \mathrm{~m}^{2}$ is located immediately north of the site's historic component, designated 41 LK 123 (Fig. 1, folded insert). In this area, relatively dense scatters of fire-fractured rock were observed, mostly in the cultivated field where surface visibility was better. Shovel tests revealed that prehistoric cultural debris is confined essentially to the surface and that controlled subsurface testing would not be productive. Apparentiy an ancient river terrace, the soil matrix was characterized as a tan sandy clay.

Artifacts recovered from the surface of 41 LK 122 are 18 chert cores (one, Group 1; one, Group 2; one, Group 3; five, Group 5; six, Group 6; and four, Group 9), two thick bifaces (one, Group 6. Form 1; one, Group 8), and eight thin bifaces (one, Group 1, Form 1, Specimen 3 [Be11]; Group 1, Form 3, Specimen 20 ["Early Expanding Stem"]; Group 1, Form 3, Specimen 25; Group 1, Form 3, Specimen 26; and four, Group 10). The presence of Be11 and "Early Expanding Stem" dart points at 41 LK 122 indicates that the site was occupied during the Early Archaic, known components of which are very scarce at Choke Canyon. Thus, these findings are significant in that they permit definition of another focus of early human activity in the region. Although not unquestionabiy associated with these eariy diagnostic artifacts, the firefractured rock, mussel shel1, and snail shell observed on the site surface in the same areas where the dart points were recovered may provide 1 imited evidence of subsistence pursuits for the Early Archaic.

\section{LK 127}

Located on the north side of the Frio River valley and just southeast of 41 LK 128 (Fig. I, folded insert), site 41 LK 127 was recorded by Texas Tech surveyors as being oblong in outline with dimensions of approximately $250 \mathrm{~m}$ northwest-southeast and 100 mi north-south (Thoms, Montgomery, and Portnoy 1981). Site 41 LK 127 is positioned on the eroded, sloping face of an ancient terrace that forms the northern margin of the river val ley. This same terrace runs along the northeastern boundary of 41 LK 128 . The site surface is densely covered with acacias, cacti, mesquite trees, and native grasses.

During Phase II investigation of 41 LK 127, activities of the CAR crew were further survey of the site, excavation of three shovel tests, and a controlled surface collection. Careful inspection revealed that prehistoric cultural activity had apparently been most intense within a roughiy circular area (about $60 \mathrm{~m}$ in diameter) at the southeastern end of the site. There, a round spur or projection extends out from the old, high terrace containing the site. On the southwestern slope or face of the spur, chert debitage and 
fire-fractured rock were found to be most heavily concentrated on the surface. Over the remainder of the site, there is scattered chert debitage, fire-fractured rock, and mussel she11, but only in very low densities.

Three shovel tests excavated upslope on the terrace edge revealed that cultural debris extended 35 to $40 \mathrm{~cm}$ into the subsurface. The matrix in the tests was described as a light grayish brown sandy loam from the surface to a depth of $30 \mathrm{~cm}$. This deposit contained musse1 she11, Rabdotus snail she11, chert debitage, fire-fractured rock, tuffaceous rocks, and numerous streamrolled pebbles. Between 30 and $55 \mathrm{~cm}$ below the surface, the matrix changed to a 1 ight tannish brown sandy loam. From 55 to $70 \mathrm{~cm}$ below the surface, the matrix color changed to yellowish tan and caliche nodules began to appear. The occurrence of gravel throughout the deposit, other signs of bioturbation, and the fact that bone and integrated features were not isolated in the subsurface were all factors indicating that controlled excavations would not be worthwhile at 41 LK 127.

A controlled collection of surface artifacts was conducted at 41 LK 127 . An alidade and plane table were used to plot the locations of individual artifacts as we 11 as the $10 \mathrm{ci}$ of six "dog leash" collection areas, each having a radius of $80 \mathrm{~cm}$. The map resulting from this collection effort is on file at the CAR-UTSA.

Artifacts collected from the surface of 41 LK 127 are 21 chert cores (four, Group 2; one, Group 3; seven, Group 5; one, Group 6; one, Group 7; and seven, Group 9), nine thick bifaces (one, Group 1; one, Group 2: two. Group 5 ; one, Group 6. Form 1; one, Group 6, Form 2; one, Group 8; and two, Group 9), 14 thin bifaces (two, Group 2, Form 1; two, Group 2, Form 2; two, Group 4, Form 4; five, Group 9; and three, Group 10), and one distally beveled biface (Group 3, Form 1). The occurrence of chert cores and bifaces, both in relatively numerous quantities at 41 LK 127, suggest that production of chipped stone tools was a major activity. In this instance, prehistoric inhabitants were probably taking advantage of the lag gravels strewn across the face of the terrace as a source of raw material.

The predominance of unstemmed thin bifaces and the single distally beveled biface found at 41 LK 127 indicate that the site was inhabited during the Middle Archaic and/or Late Archaic periods. The presence of fire-fractured rock and a smal1 amount of musse1 she 11 suggest that the location was a campsite as wel1 as a source of raw material for chipped stone tool manufacture.

\section{LK 199}

Site 41 LK 199 is located on the floodplain approximately $1 \mathrm{~km}$ south of the Frio River (Fig l, folded insert). It is situated on the northwestern crest and flank of an ancient terrace forming a ridge that parallels the southern side of the river valiey. As recorded by the Texas Tech survey crew. 41 LK 199 measures $480 \mathrm{~m}$ north-south and $160 \mathrm{~m}$ east-west. The northern end of the site was cleared of brush and in use as pastureland prior to the archaeological survey. The southern end was stili covered with thick brush when the site was recorded. The site contains both prehistoric and ear $1 \mathrm{y}$ 
historic (Anglo-European) components. The historic component, a home site, was badly damaged when brush was cleared from the northern end of the site. Prehistoric cultural activity was evidenced by a 1 ight scatter of burned tuffaceous rock, chipped stone artifacts, fire-fractured rock, and chert debitage. The distribution of these materials was used to define the limits of the site.

The Phase II investigation conducted by the CAR crew at 41 LK 199 was concerned only with the prehistoric component(s). Six shovel tests were excavated, and a controlled surface artifact collection was made. In careful survey of the site surface, the crew noted that most of the artifacts were exposed along a dirt field road running through its southern half. All of the artifacts mentioned below came from the roadway. Three shovel tests were placed at the north end of the site and three at the south end. In a 11 cases, the very smal1 amounts of prehistoric cultural debris noted were confined to the upper 10 to $15 \mathrm{~cm}$ of deposit. Results of shovel testing indicated that controlled excavations would likely not be worth the effort at 41 LK 199.

Artifacts collected from the surface of 41 LK 199 are 37 cores (one, Group I; one, Group 2; four, Group 3; two, Group 5; nine, Group 6; one, Group 7; 19, Group 9), 12 thick bifaces (one, Group 2; one, Group 3; one, Group 4; one, Group 7, Form 1; two, Group 7, Form 3; three, Group 8; three, Group 9), 21 thin bifaces (three, Group 2, Form 2; one, Group 3, Form 2; three, Group 4, Form 4; one, Group 5; 13, Group 10), two distally beveled bifaces (one, Group 3, Form 2; one, Group 8, Form 5), and one uniface (Group 5). Outstanding among these specimens for purposes of cultural/chronological diagnosis is a P1ainview fragment (thin bifaces Group 3, Form 2, Specimen 25; Fig. 78). This specimen indicates that 41 LK 199 was inhabited during the Paleo-Indian period. The remaining thin biface specimens and the distally beveled tools are generally indicative of Archaic period activity, but it is impossible to narrow the time range of prehistoric occupation any further than this.

\section{SITE GROUP 2}

Extensive Test

Excavation

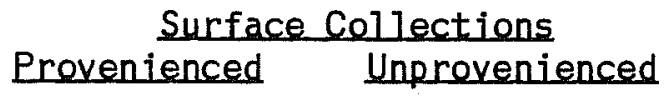

41 LK 149

41 LK 145
Resurvey or Shovel Tests

41 LK 153

41 LK 136

41 LK 150

The seven sites making up Site Group 2 are located within a series of major up 1 and drainage channels feeding into the Frio River from the north side of the valley (Fig. 1, folded insert). The area containing the sites is located just off the north end of Choke Canyon Dam, then extending north for $2.5 \mathrm{~km}$. The main channel into which at least six other lesser channels feed is called Willow Hollow. The major channels feeding down to Willow Hollow drain 1 and 
as much as $10 \mathrm{~km}$ to the north-northwest of the Frio River. The channels only run water when heavy rains result in runoff from the uplands. The brush cover in the vicinity of Site Group 2 is the densest to be found anywhere at Choke Canyon. The higher slopes of the drainages are covered with brush species such as blackbrush, guajillo, mesquite, prickly pear, and yucca. Down closer to the channels, whitebrush predominates along with mesquite trees and cacti. The very formidable task of conducting an archaeological survey in this vicinity was accomp 1 ished in 1977 by a crew from Texas Tech University (Thoms, Montgomery, and Portnoy 1981). A11 sites in Group 2, as well as a number of others in the area, were recorded by this crew.

\section{LK 153}

Site 41 LK 153 is a small prehistoric site located in the middle reaches of the Willow Hollow drainage system (Fig. l, folded insert). The site is subcircular in outline with a northeast to southwest long axis of less than 30 to $50 \mathrm{~cm}$ and a width of $20 \mathrm{~m}$. It rests on the western slope of a northsouth ridge separating two of the Wi1low Hol10w tributary drainages. The surface is covered with mesquite trees, acacias, cacti, and native grasses. In the site record, the Texas Tech surveyors noted that cobbles were exposed on the slope and suggested that 41 LK 153 might be a quarry. They a 150 observed a 1 ight scatter of chert debitage, two thick bifaces, some chert cores, and burned rock on the surface. Site limits were established on the basis of the observed debris distribution.

During Phase II investigations, the CAR crew resurveyed 41 LK 153 , making basically the same observations as were previously recorded for the site. As there was apparently no subsurface extent to the site, and no time- or function-diagnostic artifacts were found on the surface, no controlled testing or surface collecting was attempted. The site is suggested to have functioned as a quarry, but its period of usage during prehistoric times cannot be demonstrated.

\section{LK 133}

Located east-northeast of 41 LK 153, site 41 LK 133 is situated in the upper reaches of a short, southwesterly trending tributary drainage ( $F$ ig. 1, folded insert). The main site area is on a relatively flat terrace beside (west of) the drainage channel. This area is flanked by the main channel to the east and a pronounced gu $11 \mathrm{y}$ to the west (Figs. 15,e; 16). Texas Tech surveyors estimated site dimensions to be $150 \mathrm{~m}$ north-south and $45 \mathrm{~m}$ east-west. Although portions of the site had obviously been destroyed as erosional gu 11 ies cut up either side, they estimated that perhaps $80 \%$ of the site remained intact in the flat terrace between. Subsurface prehistoric cultural debris was visible in the wall profiles of both gullies.

During Phase II investigation of 41 LK 133, activities of the CAR crew were excavation of two shovel tests and two test pits, documentation of 10 hearth features exposed on the site surface, and a provenience-controlled collection of surface artifacts. Based on observations made in two shovel tests excavated in the central site area and subsurface conditions visible in gully 
wa115, the southern extent of 41 LK 133 was judged to offer the best potential for productive controlled excavations. Consequently, locations for Test Pits 1 and 2 were selected in that area of the site (Fig. 16).

Test Pit 1 was placed in the south-central area of 41 LK 133. It was excavated to a depth of $90 \mathrm{~cm}$ below the surface (nine 10-cm-thick 1eve1s). From surface to a depth of $50 \mathrm{~cm}$, the matrix was a dark grayish brown sandy loam. Below the $50 \mathrm{~cm}$ depth, the matrix changed in color and consistency to a tannish gray silty sand. Debris recovered from this unit is divided into two horizons, Horizon 1 containing material from Levels $1-4$ and Horizon 2 containing the materials from Leve1s 5-9. Rates of recovery for selected classes of materials from Test Pit 1 are as follows:

Horizon 1 Horizon 2

Tuff Weight (grams)

Sandstone Weight (grams)

Fire-Fractured Rock Weight (grams)

Mussel She11 Umbo Count

Mussel Shel1 Weight (grams)

Rabdotus She11 Count

Bone Weight (grams)

Primary Flake Count

Secondary Flake Count

Tertiary Flake Count

Chip Count

$\begin{array}{cc}24 & 12 \\ 6 & 0.4 \\ 252 & 112 \\ 1 & 1 \\ 1.4 & 0.2 \\ 265 & 93 \\ 1.6 & 0 \\ 0 & 1 \\ 2 & 1 \\ 7 & 1 \\ 14 & 6\end{array}$

Test Pit 1 yielded no additional artifacts. A small amount of carbon was found in Level 3.

Test Pit 2 was placed about $15 \mathrm{~m}$ south of Test Pit I (Fig. 16). Seven 10-cmthick levels of matrix were excavated from this unit. The soil matrix was described as dark grayish brown sandy loam down into Level 6 . In Level 6 and below, the soil color lightened to tannish brown. Two horizons are defined in Test Pit 2. Horizon 1 contains the materials recovered from Levels $1-3$. Horizon 2 contains debris from Levels 4-7. Rates of recovery for selected classes of debris representing each horizon in Test Pit 2 are as follows:

Horizon 1 Horizon 2

Tuff Weight (grams)

Sandstone Weight (grams)

Fire-Fractured Rock Weight (grams)

Mussel She11 Umbo Count

Mussel Shel1 Weight (grams)

Rabdotus She11 Count

Bone Weight (grams)

Primary Flake Count

Secondary Flake Count

Tertiary Flake Count

Chip Count

$\begin{array}{cc}11 & 3 \\ 0.2 & 1.3 \\ 100 & 69 \\ 7 & 2 \\ 3.5 & 3 \\ 167 & 87 \\ 0.1 & 0 \\ 1 & 1 \\ 2 & 2 \\ 2 & 2 \\ 5 & 6\end{array}$

No additional artifacts were recovered from Test $P$ it 2. 
Figure 15. Phase II Investigations at 41 LK 128, 41 LK 133, and 41 LK 185.

a, Hearth 13 at 41 LK 128;

b. plan view of bone and mussel she 11 concentration in Test Pit 5 (Leve1 2, 99.60-99.50) at 41 LK 128;

c, overview of Feature 2 in Test Pits 9, 10, 13, and 14 at 41 LK 128;

d, closeup of Feature 2 at 41 LK 128;

e, view north to wall of erosional gully where prehistoric debris was exposed at 41 LK 133;

f, view is to the north across the east end of 41 LK 185 in the vicinity of Test Pit 2. 


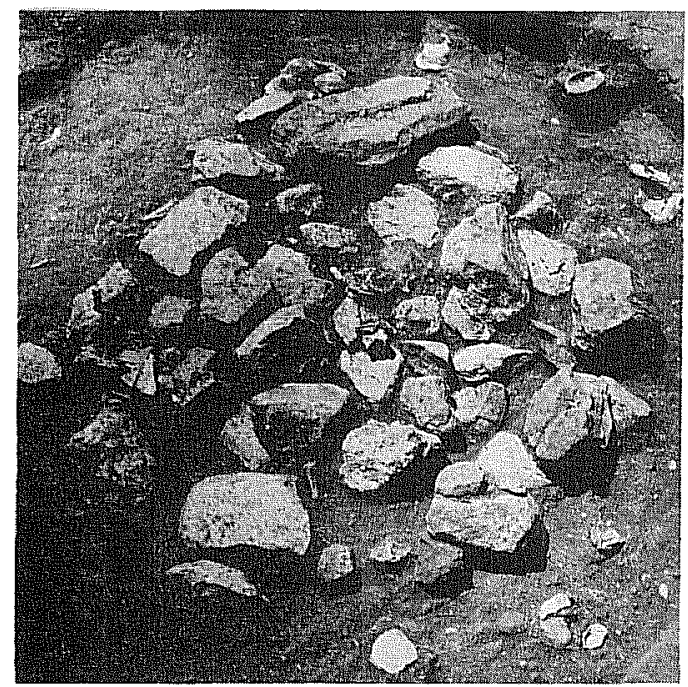

a

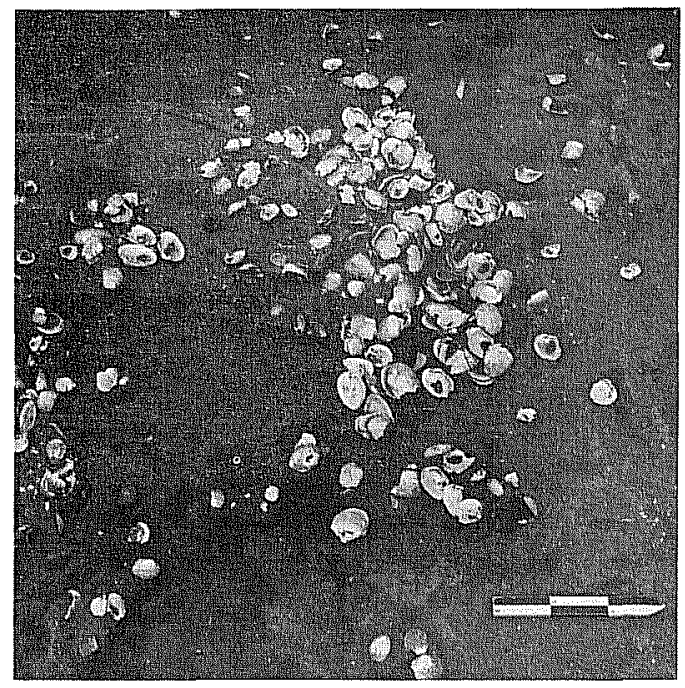

c

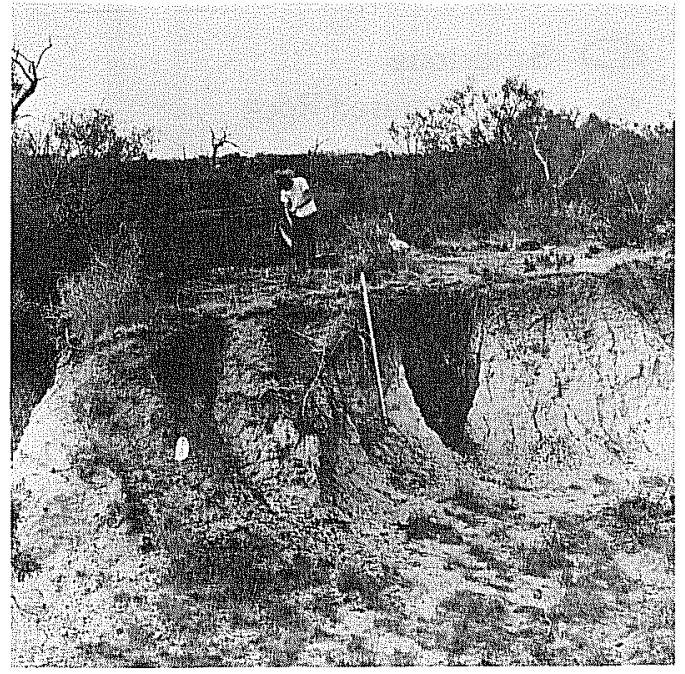

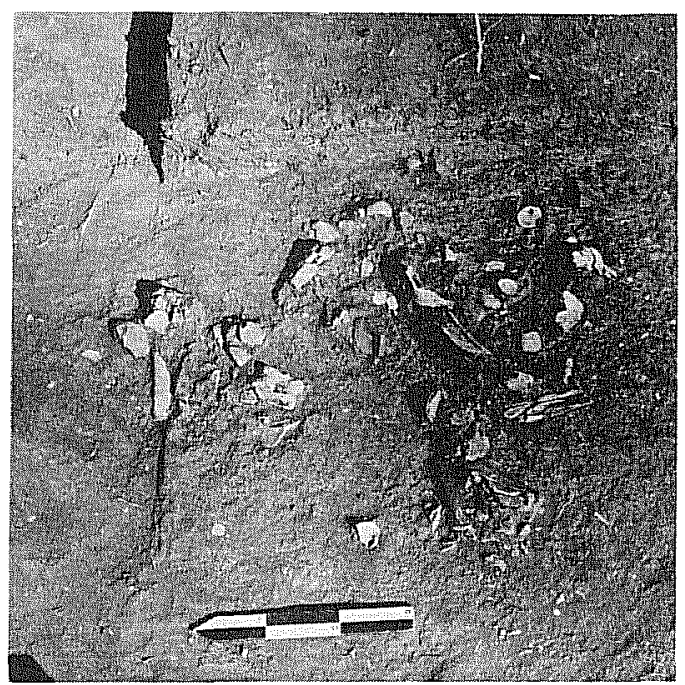

b

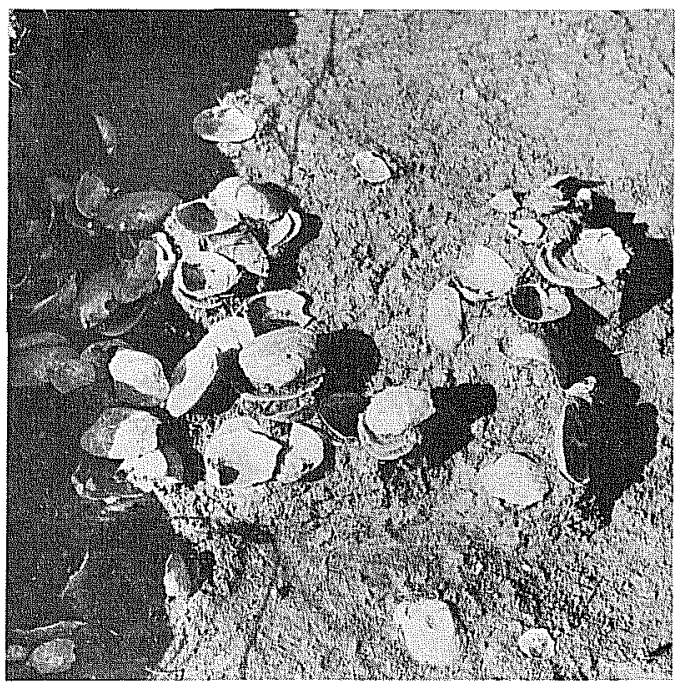

d

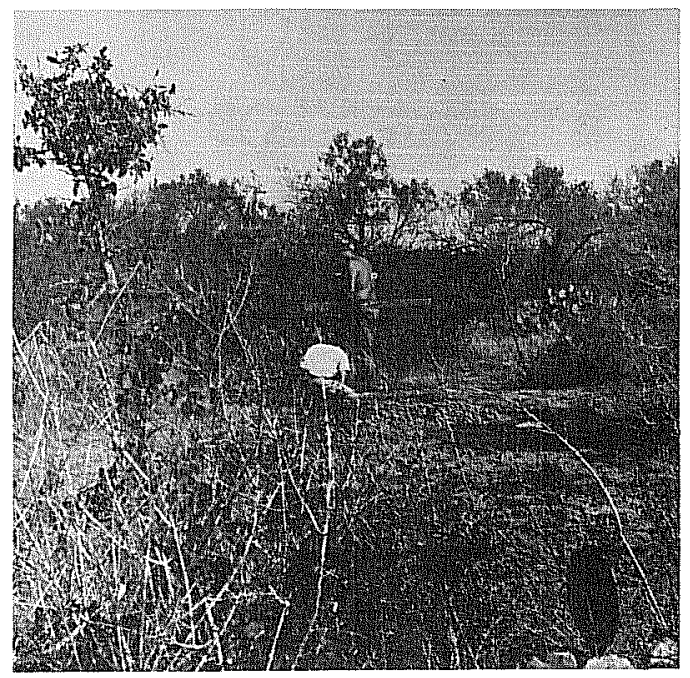




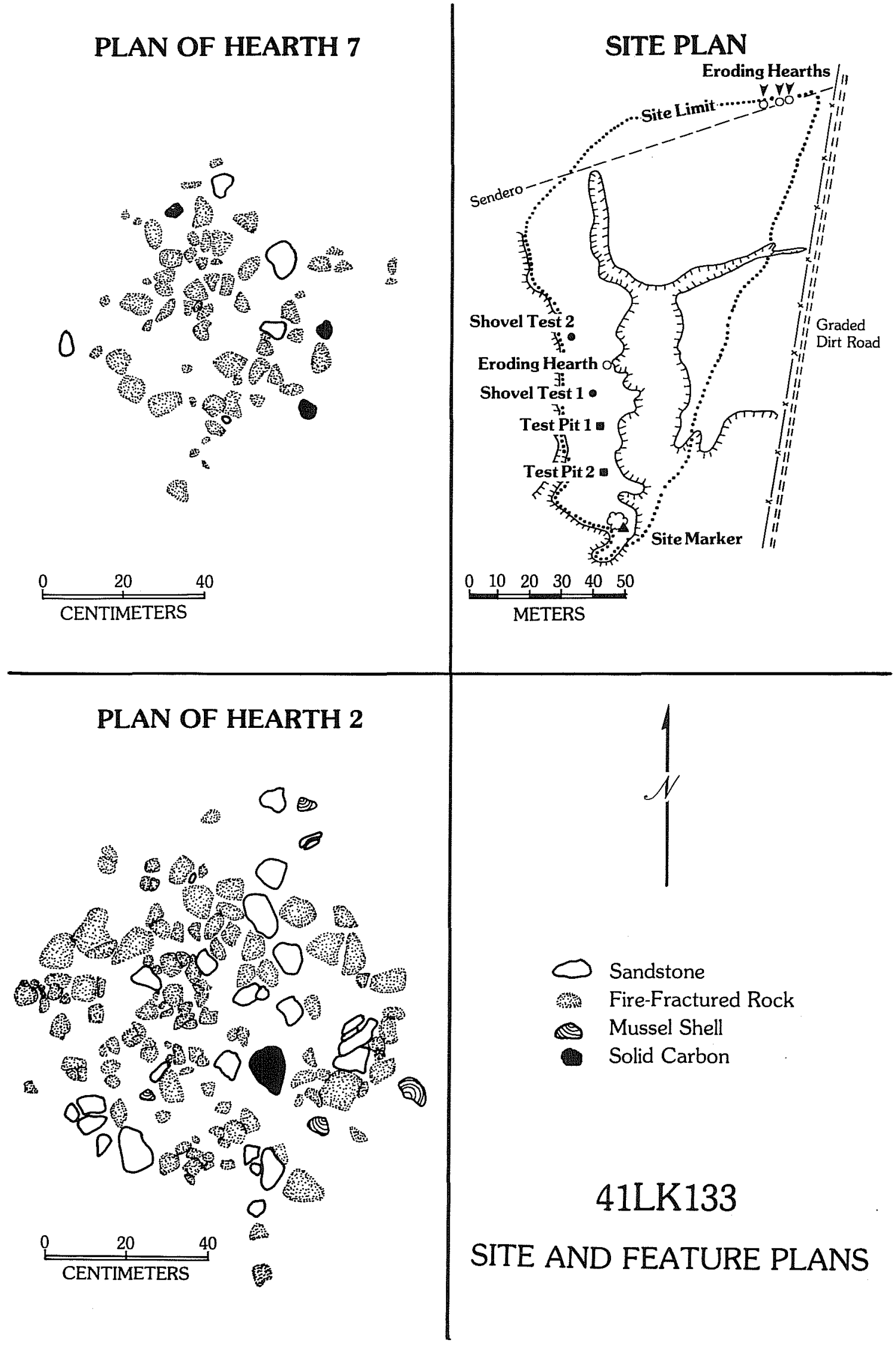

Figure 16. Site and Feature Plans (Hearths 2 and 7) at 41 LK 133. 
Information concerning the 10 hearth features found exposed on the surface of 41 LK 133 is summarized in Table 2. A plane table map showing the locations of the features and locations of individually mapped surface artifacts is on file at the CAR-UTSA. Plan maps of Hearths 2 and 7 are shown in Figure 16. Carbon was found in small to minute quantities in Hearths 1, 2, 5, and 7 . No radiocarbon assays or wood species identifications were attempted with these specimens.

The following chipped stone artifacts were recovered from the surface of 41 LK 133. The locations of many of these specimens are plotted on a p 1 an map filed at the CAR-UTSA. The specimens are four cores cone, Group 1; one, Group 3; one, Group 5; one, Group 9), four thick bifaces (one, Group 1; one, Group 2; one, Group 7, Form 2; one, Group 9), six thin bifaces (one, Group 2, Form 1; one, Group 3. Form 2; one, Group 4, Form 1; one, Group 4, Form 3; one, Group 4, Form 4; one, Group 10), one distally beveled biface (Group 6), one uniface (Group 3), and one trimmed flake (Group 4).

The above assemblage strongly indicates that people inhabited 4 I LK 133 during the Middle Archaic and perhaps Late Archaic times. The number of hearths recognized in eroded areas on the site surface suggests that the site served as a habitation or camp. Great numbers of Rabdotus snail shel1, a sma 11 amount of musse 1 she11, and minute remnants of anima 1 bone are the on $1 y$ materials surviving to provide evidence of subsistence pursuits during the times when the site was occupied.

\section{LK 136}

Located west of 4 I LK 133, site 41 LK 136 is at the southwestern end of a sloping ridge formed between two smal1 drainages cutting down from the up 1 ands (Fig. 1, folded insert). As recorded by the Texas Tech surveyors, 41 LK 136 measures $45 \times 85 \mathrm{~m}$. Brush cover consisting of mesquite trees, soapbush, spiny hackberry, agarita, yucca, and prickly pear is quite thick on the site surface.

During the Phase II investigations, the CAR crew resurveyed $41 \mathrm{LK} 136$. The original site marker could not be found. The CAR crew did relocate two of the three concentrations of chert knapping debris recorded on the site by the Texas Tech crew. These concentrations consisted of a small amount of debitage and some tested cores. No time-diagnostic chipped stone tools or other artifacts were found anywhere on the site surface. Primarily for this reason. no collection was made at 41 LK 136, and it was concluded that the site warranted no further investigation. It seems to have been a quarry area where people were testing natural cobbles that b 1 anket the slopes in the area.

\section{LK 149}

Site 41 LK 149 was recorded by Texas Tech surveyors in the upper reaches of one of the major tributary drainage channels (Fig. 1, folded insert). Site dimensions were recorded as $80 \times 100 \mathrm{~m}$. The site rests on the west (right) 
TABLE 2. SUMMARY OF HEARTH DATA AT SITE 41 LK 133

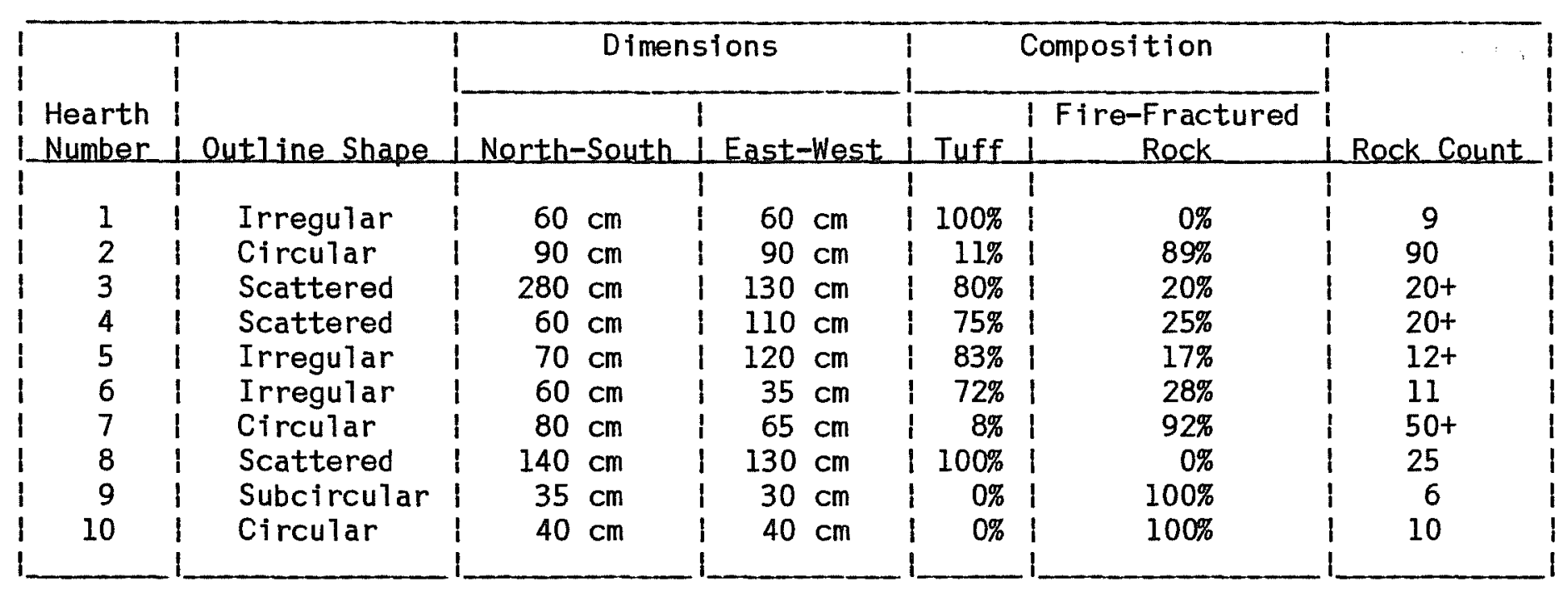


bank of the drainage channel on a broad, relatively flat terrace surface. The site surface is covered with thick brush.

The CAR crew relocated 41 LK 149, noting a scatter of prehistoric cultural debris about $20 \mathrm{~m}$ in diameter. A shovel test excavated in this area revealed that controlled excavations would not be productive. The only artifact collected from 41 LK 149 was a thick biface (Group 1). No cultural and/or chronological estimates are possible with only this one artifact recovered. Careful examination of the site surface yielded no additional time- or function-diagnostic artifacts.

\section{LK 150}

A tiny $(15 \times 15 \mathrm{~m})$ prehistoric site, 41 LK 150, was recorded just a short distance north of 41 LK 149 by the Texas Tech crew (Fig. 1, folded insert). Like 41 LK 136, 41 LK 150 is apparent1y a "quarry station" or p 1 ace where some natural cobbles were tested for possible use in stone tool manufacture. The CAR crew did not relocate this site during the course of Phase II investigations.

\section{LK 142}

Site 41 LK 142 is evidenced in a heavily eroded area on the east bank of a stock pond formed by damming a short upland drainage channel. As recorded by the Texas Tech survey crew, $4 I$ LK 142 has dimensions of $80 \times 115 \mathrm{~m}$. In 1 ess eroded areas, the site surface supports a thick stand of brush including whitebrush, mesquite, a 11 thorn, spiny hackberry, agarita, soapbush, yucca, and prickly pear. The Texas Tech crew defined 41 LK 142 on the basis of chert debitage, fire-fractured rock, and Rabdotus snail shel $1 \mathrm{~s}$ exposed on the surface. Four hearths composed of fire-fractured rock were observed in the walls of erosional scars.

Returning to 41 LK 142 for Phase II investigation, the CAR crew carefu $17 \mathrm{y}$ reexamined the site surface. Comment was again made on the severity of erosion in the site area. In gullies trending east-west through the site, much prehistoric debris was noted--fire-fractured rock, chert debitage (some pieces patinated), a small amount of mussel she11, some tuffaceous rock, and numerous Rabdotus snail shel1s.

Additional Phase II activities at 41 LK 142 included excavation of four shovel tests, a controlled test pit, and an unprovenienced col lection of surface artifacts. Findings made in the shovel tests were not encouraging. There was 7 ittle observed in the subsurface to warrant test pitting. Test Pit 1 was located adjacent to a gully where a cluster of flakes, many of them apparentiy from the same core, was found eroding out of the gul1y wal1. Examination of the wall profile revealed in situ flakes 50 to $60 \mathrm{~cm}$ below the surface. This suggested buried, intact deposits. Test Pit 1, placed in less eroded ground to the north of the gul1y, was meant to sample this buried material. 
Test pit 1 was excavated to a depth of $60 \mathrm{~cm}$ below the surface (six 10-cmthick 1eve1s). The soil was described as dark grayish brown clay loam down into Leve $14(30$ to $40 \mathrm{~cm})$. In Leve 1 4, a 1 ight tannish brown sandy clay appeared. It contained numerous stream-rolled pebbles. Very 1 ittle cultural debris was recovered from Levels 5 and 6 . The debris recovery summarized below came from Levels 1-4 excavated from the unit. Rates of recovery for selected classes of debris from Test Pit 1 are as follows:

\section{All Levels Combined}

Tuff Weight (grams)

Sandstone Weight (grams)

Fire-Fractured Rock Weight (grams)

Mussel She11 Umbo Count

Mussel She17 Weight (grams)

Rabdotus She11 Count

Bone Weight (grams)

Primary Flake Count

Secondary Flake Count

Tertiary Flake Count

Chip Count

0.6
9
157
1
3
21
0
3
11
7
16

Test Pit 1 also yielded two chert cores (one, Group 1; one, Group 5) from Levels 3 and 5.

Other artifacts recovered from the surface of 41 LK 142 were two cores (two, Group 2), one thick biface (Group 1), and nine thin bifaces (one, Group 2, Form 1; one, Group 2, Form 2; one, Group 3, Form 1; one, Group 4, Form 3; three, Group 4, Form 4; two, Group 9). The 1arge, unstemmed thin bifaces predominating in this collection indicate that 41 LK 142 was occupied by human groups during Middle Archaic and/or Late Archaic times. The test pit findings and the surface artifact scatter suggest that this particular site was not as intensively inhabited as were some of the others. Material yields from the test pit were quite low. The Phase II work at 41 LK 142 provides no new insights into Archaic 1 ifeways at Choke Canyon.

\section{LK 145}

Site 41 LK 145 is located in the upper reaches of one of the major tributary channels about $5 \mathrm{~km}$ north of the Frio River (Fig. l, folded insert). The site is on the right (west) bank of the drainage. Its surface is covered with brush species such as soapbush, whitebrush, spiny hackberry, mesquite, agarita, prickly pear, and some native grasses. The Texas Tech survey crew estimated site dimensions to be $10 \times 60 \mathrm{~m}$, with the long axis running northsouth. Cutbanks about $1.5 \mathrm{~m}$ in height parallel each side of the drainage. Prehistoric cultural debris was observed eroding from the face of the cutbank on the west side. The debris consists of smal1 amounts of chert cores, debitage, and fire-fractured rock. During Phase II investigations, the CAR crew reinspected the site surface and dug two shovel tests into the subsurface. Little cultural debris was recognized in these tests. The only artifact collected from the site was a chert core (Group 4). The findings suggest that 41 LK 145 functioned primarily as a source of raw material for 
chipped stone tool manufacture. Numerous cobbles are exposed in the vicinity, mainly along the eroded drainage channel. The period of activity by prehistoric people is not apparent from the remains visible on the site.

\section{SITE GROUP 3}

Extensive Excavation
Iest

Pits

41 LK 185
Surface Collections Provenienced Unprovenienced

41 LK 191

41 LK 162

41 LK 181

41 LK 182

41 LK 176

41 LK 174

41 LK 173
Resurvey or Shovel Tests

41 LK 239

41 LK 190

41 LK 158

41 LK 180

41 LK 241

41 LK 170

41 LK 234

The 15 prehistoric sites making up Site Group 3 are located along the southern margin of the Frio River valley from 1.0 to $7.0 \mathrm{~km}$ west (upstream) of the southern end of Choke Canyon Dam. The area containing the site group incorporates two major 1 andform features. Seven of the sites are located on the slope or leading edge of the valley wall. This valley margin is formed by old, high alluvial terraces that are draped over the tuffaceous Catahoula Formation. Outcrops of the Catahoula Formation occur in the site group area. but are not nearly as prominent as on the north side of the valley. Through thousands of years the ancient terraces forming the val 1 ey wa 11 have been eroded, and grave1s, which settled out on the surface as lighter deposits, were carried away. The gravel forms a thick blanket over the crest and slopes of the valley wal1. The gravelly, soil-poor slopes are thick 1 y covered with brush, especially guajil10, blackbrush, mesquite, and prickly pear.

The other major landform feature in the Site Group 3 area is a broad expanse of the Frio River floodplain. Such areas have been referred to as "fossil" floodplains (Lynn, Fox, and 0'Mal 1ey 1977:9) because they are composed of much older alluvial terrace deposits not frequently flooded by the modern river. Soils are thicker and richer down on the floodplain and support dense stands of mesquite, prickly pear, and other brush species. Also, because of the better soils and flatter terrain, there are parts of the floodplain in the Site Group 3 area that have been cleared for croplands or cattle pasturage.

Two minor up 1 and drainage channels cut down from south to north across the site group area. Runoff is minimal as the divide between drainage basins of the Frio and Nueces Rivers is just a short distance south. A $10 w-r e 1$ ief drainage channel trends from southwest to northeast across the floodplain. The concentration of sites recorded along this channel suggests that site visibility is highly dependent on where erosion has occurred down in the floodplain. 


\section{LK 239}

Site 41 LK 239 is 1 ocated on the crest and flanks of a valley margin hill overlooking the Frio River valley (Fig. l, folded insert). The site was recorded by CAR surveyors in 1979. The surveyors defined roughly circular boundaries to the site. Prehistoric cultural debris is widely and 1 ightly scattered over an area with a diameter of 400 to $600 \mathrm{~m}$. The site surface is covered with 1 ag gravels in a matrix of gray silt. Outcrops of Catahou 1 a tuff also occur in the site area. The site is heavily covered with brush. Acacias, cenizo, mesquite, spiny hackberry, and native grasses are present.

CAR surveyors defined 41 LK 239 as a quarry site where prehistoric peop 1 e were taking advantage of natural 1 ag gravels as raw materials for manufacture of chipped stone tools. This assessment was based on observation of numerous chert cores and chert debitage (mostiy primary and secondary flakes) on the site surface.

During Phase II investigations, the CAR crew resurveyed the surface of 41 LK 239. No time- or function-diagnostic artifacts were found. Inspection of erosional gullies cutting through the site revealed that the subsurface contained 1ittle or no prehistoric debris. Phase II findings only reconfirm the probable function of 41 LK 239 as a quarry. In the absence of timediagnostic artifacts, it is impossible to suggest when prehistoric peop le were active at this location.

\section{LK 190}

A smal1 site, 41 LK 190, is located a short distance down slope (westnorthwest) from 41 LK 239 (Fig. 1, folded insert). The site is located at the foot of the valley wall as it meets the floodplain. A drainage channel cuts down from the up 1 and just east of 41 LK 190. The channel has been dammed to form a stock tank. Recorded by Texas Tech surveyors, 41 LK 190 was noted to have dimensions of $41 \times 60 \mathrm{~m}$. The surface is heavily eroded and thickly covered with mesquite, cactus, and acacias. Site 1 imits were defined by scatters of burned rock and chert debitage. The CAR crew returned to 41 LK 190 during the Phase II investigation. The site was reinspected, and two shovel tests were excavated. Prehistoric cultural debris in the form of chert cores and debitage, tuffaceous rock, and Rabdotus snail shel1s was observed to be scattered very lightly over the surface, especially in some cattle trails that meandered across the site. No time- or functiondiagnostic artifacts were found, and the shovel tests indicated that controlied subsurface excavations would not be productive.

\section{LK 191}

Located at the juncture of the valley margin slope with the floodplain like 41 LK 190, site 41 LK 191 was recorded by the Texas Tech surveyors as having dimensions of $25 \times 220 \mathrm{~m}$ (Fig. l, folded insert). The site surface was moderately eroded and partially covered with brush such as blackbrush, mesquite, guajil10, and cactus. Modern-day slope terracing caused extensive disturbance north to south down the length of the site. The site was defined 
by the distribution of burned rock, chert debitage, chipped stone tools, mussel she11s, and snail shells across its surface. Artifacts observed at 41 LK 191 by the Texas Tech crew included a distal 1y beveled biface, one "large thin biface," and one "smal 1 tear-shaped biface." These specimens suggested that the site had been occupied in Middle Archaic and/or Late Archaic times.

Returning to 41 LK 191 for Phase II investigation, the CAR crew resurveyed the site, dug five shovel tests, documented some features eroding from the site, and made an unprovenienced collection of surface artifacts. Disturbance caused by construction of a terrace across the site was again noted. Artifacts were exposed most noticeably in the area of the terrace and along a field road running through a portion of the site. Four badly eroded and scattered tuffaceous rock hearths were observed along this road. One hearth was selected for complete exposure. As found, only four pieces of tuffaceous rock were visible on the surface. Excavation in and around these rocks revealed a circular, single layer cluster of approximately 30 tuffaceous rocks. The rock cluster had a diameter of $50 \mathrm{~cm}$. Individual stones averaged about $10 \mathrm{~cm}$ in diameter. Away from (east of) the roadbed, buried portions of the feature were as much as $35 \mathrm{~cm}$ below ground. About 40 Rabdotus snail shells were recovered from the matrix. Otherwise, no artifacts were found as the feature was cleared. No carbon was noted in this rock cluster.

The five shovel tests excavated at 41 LK 191 went down 65 to $75 \mathrm{~cm}$ below the surface. They revealed a matrix characterized as a dark gray silty loam down to $50 \mathrm{~cm}$ below the surface, a gray silty $10 a m$ from 50 to $70 \mathrm{~cm}$ below, and a 1 ight gray silty 10 am below $70 \mathrm{~cm}$. In al 1 shovel tests, the matrix was described as very fine and 100se, and Rabdotus snail shel 15 were very common. Only small amounts of cultural debris-mostly chert debitage and tuff--were recovered. Though the shovel tests revealed that 41 LK 191 holds a 1 imited amount of potentially useful subsurface data, the allocation of further effort at the site was not judged as important as other Phase II excavation priorities at Choke Canyon. No further investigations were attempted.

Artifacts collected from the surface of 41 LK 191 were two cores (Group 1), six thin bifaces (one, Group 2, Form 1; three, Group 9; and two, Group 10), one distal1y beveled tool (Group 8, Form 1), and one piece of modified sandstone (Group 1, Form 3). As time-diagnostics, these artifacts confirm human activity on the site in the Middle Archaic and/or Late Archaic periods. With respect to subsistence pursuits of the prehistoric inhabitants, two things are noteworthy. First, there is relatively 1 ittle mussel shell in evidence, but there are numerous Rabdotus snail shel1s. Usualiy, these two types of shel1 occur in more equal proportions relative to one another. Second, a grinding slab fragment (modified sandstone Group 1, Form 3) was found at 41 LK 191. This artifact suggests that prehistoric people may have processed seed, nut, or bean foods while inhabiting the site. For whatever reason, evidence for such activity is uncommon in sites at the east end of the Choke Canyon study area. 


\section{LK 158}

Site 41 LK 158 occurs on the northeast slope of a gentle hill out on the floodplain (Fig. I, folded insert). It is about $2.5 \mathrm{~km}$ south of the Frio River and $0.8 \mathrm{~km}$ north of the valley margin. As recorded by the Texas Tech surveyors. $41 \mathrm{LK} 158$ measures $200 \mathrm{~m}$ northwest to southeast and is about $75 \mathrm{~m}$ in width. Described by the recorders as a very thin surface scatter of debitage and burned rock, the site is in a grass-covered pasture that was likely root plowed at sometime in the past. The Texas Tech crew noted that approximately $70 \%$ of the cultural debris visible on the surface was burned rock. They also found two biface fragments, one a distal piece and the other a Tortugas dart point.

Phase II investigation of 4 LK 158 by the CAR crew consisted of a resurvey of the site surface and excavation of a shovel test. At that time, no timeor function-diagnostic artifacts were found on the surface. No artifacts were collected. A shovel test excavated $60 \mathrm{~cm}$ into the subsurface revealed a 1 ight brown sandy loam containing sma 11 grave1s, but no prehistoric cultura 1 debris. No further work was done at 41 LK 158.

\section{LK 162}

Exposed by erosion and deflation along the bed of a dirt field road, 41 LK 162 has somewhat unusual dimensions of $5 \times 125 \mathrm{~m}$, its 1 ong axis is east-west along the road (Fig. 1, folded insert). The site occurs in an open pasture covered with grass. It is on the surface of an old terrace that slopes northwestward down into a shallow drainage that has been incised into the terrace. The site is evidenced by a light surface scatter of burned rock and chert debitage.

The CAR crew conducted an unprovenienced surface collection and excavated a series of 14 shovel tests during the Phase II investigation. The shovel tests were excavated to depths ranging from 30 to $60 \mathrm{~cm}$. A dark brown sandy silt formed the subsurface deposit. These shovel tests revealed that the surface scatter accurately delimits the horizontal extent of cultural debris in subsurface deposits. The subsurface deposit was found to contain cultural debris in smal1 amounts between the surface and a depth of $20 \mathrm{~cm}$. Coupled with the probability that the area was root plowed, the low productivity of subsurface deposits indicated that excavation of controlled test pits would not be a worthwhile effort at 41 LK 162.

An unprovenienced collection of artifacts from the surface of 41 LK 162 yielded six chert cores (two, Group 5; four, Group 9), two thick bifaces (one, Group 7, Form 1; one, Group 7, Form 4), and five thin bifaces (one, Group 1, Form 3; one, Group 4, Form 4; three, Group 10). The stemmed thin biface (Group 1, Form 3, Specimen 36) is classified as a Zavala dart point. Habitation of the site during Middle Archaic and/or Late Archaic time is indicated. 


\section{LK 180}

Site 41 LK 180 was recorded by the Texas Tech surveyors. It is situated midway up the slope marking the transition from floodplain to valley wall on the south side of the Frio River valley (Fig. I, folded insert). The Texas Tech crew assigned dimensions of $60 \times 130 \mathrm{~m}$ to 41 LK 180 . They characterized the site as being "a moderate scatter of burned rock consisting mostiy of fire-fractured rock and chipped stone materials." The surveyors also noted that 41 LK 180 yielded the first ground stone artifacts they had seen on the south side of the Frio River.

Returning to $41 \mathrm{LK}$ 180, the CAR crew noted the brush cover and extensive erosion on the site surface. Mesquite, spiny hackberry, soapbush, prickly pear, and native grasses form a thick ground cover. In numerous sma 11 and large gullies cutting through the site, smal1 amounts of prehistoric cultural debris were noted in profiles between the surface and a depth of $20 \mathrm{~cm}$. Widely scattered surface debris consisting of chert debitage, tuffaceous rock, Rabdotus snail she115, and natural gravels and cobbles was noted. Two badly eroded and scattered tuffaceous stone hearths were seen. None of the ground stone artifacts reported by the Texas Tech crew could be relocated nor were any additional time- or function-diagnostic artifacts found. No shovel testing was done at 41 LK 180 because it was obvious from examining the walls of gulijies running through the site that the subsurface contained no significant deposits of prehistoric cultural debris.

\section{LK 181}

Located down slope and a short distance north-northeast of 41 LK 180 , 41 LK 181 was recorded by Texas Tech surveyors as having dimensions of $90 \times 110 \mathrm{~m}$ (Fig. 1, folded insert). The site is covered with a moderately thick stand of brush including mesquite, spiny hackberry, prickly pear, and grasses. The surface is quite badly eroded with a number of smal1 gul1ies running across the site. Prehistoric cultural debris observed on the surface was chert debitage, chert cores, fire-fractured rock, mussel she11 fragments, Rabdotus snail shel1s, and a few chipped stone tools. Several badly scattered tuffaceous stone features were noted along and in the gullies on the site. The CAR crew collected two thin biface fragments from the site (one, Group 2, Form 2; and one, Group 4, Form 4). Ground stone fragments reported by the Texas Tech surveyors could not be relocated. Subsurface exposures revealed in the walls of gullies showed that minor amounts of debris were buried in the site, but that controlled testing would not be productive.

\section{LK 182}

Site 4 LK 182 is on a gentle hillside down on the floodplain and overlooks a drainage channel flowing north-south over the floodplain immediately to the west of the site (Fig. 1, folded insert). As recorded by the Texas Tech surveyors, 41 LK 182 is irregular in outline shape with dimensions of $150 \times 200 \mathrm{~m}$. The site was delimited on the basis of burned rock, chert debitage, mussel she11, and Rabdotus snail shell scattered over the surface. 
Debris such as pieces of metal and sherds of crockery evidenced recent historic activity in the vicinity. The site surface is thickly covered with whitebrush, mesquite, acacias, cactus, and grasses.

During Phase II investigations, the CAR crew did an unprovenienced col lection of surface artifacts and excavated four shove 1 tests at 41 LK 182. The shovel tests revealed a 1 imited amount of prehistoric debris in the upper $20 \mathrm{~cm}$ of deposit at the north end of the site. The tests at the south end produced little or no subsurface debris. The matrix containing the site was a dark grayish brown sandy loam from the surface to a depth of 20 to $30 \mathrm{~cm}$. Below, the matrix changed to a 1 ight tan sandy loam. Shovel test findings indicated that controlled excavation was not warranted.

Among the artifacts collected from the surface of 41 LK 182 by the CAR crew were three cores (one, Group 3; one, Group 6; one, Group 9), two thick bifaces (one, Group 2; one, Group 4), one thin biface (Group 10), two distally beveled tools (both Group 4), and one trimmed flake (Group 3 , Form 5). The Group 4 distally beveled tools suggest that the site was inhabited during the Late Archaic.

\section{LK 176}

Much like 41 LK 182 in outline configuration, 41 LK 176 is located south of 41 LK 182 on the slope above (east of) the same upland drainage channe 1 (Fig. 1, folded insert). Dimensions of $30 \times 150 \mathrm{~m}$ were determined by the Texas Tech survey crew based on the distribution of a "wide and uniform scatter of burnt rock and chipped stone products and by-products." The site surface is covered with dense stands of whitebrush, mesquite, spiny hackberry, prickly pear, and grasses.

Phase II efforts by the CAR crew at 41 LK 176 consisted of a resurvey of the site, excavation of two shovel tests, and an unprovenienced col lection of surface artifacts. A shovel test placed at the northwest end of the site was excavated to a depth of $50 \mathrm{~cm}$; the entire deposit was a very dark grayish brown silty loam. Very sma 11 amounts of burned rock, debitage, and sna 11 shel1s were noted. A second shovel test was located in the south-central area of the site. No cultural debris was found in this test. The single artifact collected at 41 LK 176 was a thin biface fragment (Group 9 ). Distally beveled tools and a sherd of aboriginal pottery found on this site by the Texas Tech surveyors indicate that it was inhabited in Middle Archaic and/or Late Archaic and Late Prehistoric times.

\section{LK 185}

Site 41 LK 185, evidenced by a surface scatter of chert debitage and burned rock, was located by the Texas Tech surveyors on a gentle hillside or terrace slope over looking the channel of an intermittent upland drainage (Fig. 1 , folded insert). The surveyors recognized the site as being oval in outline with dimensions of $40 \times 60 \mathrm{~m}$. The site surface is covered with mesquite, prickly pear, and native grasses (Fig. 15,f). 
During Phase II investigations, the CAR crew excavated three shovel tests and three test pits at 41 LK 185. Locations of numerous artifacts found on the site surface were recorded on a plane table map. Shovel tests revealed that controlled test pits would likely yield useful information. Test Pits 1 and 3 were staked out near Shovel Tests 1 and 2.

Test Pit 1 was placed in the west-central area of 41 LK 185 . Just north of the test pit location was a particularly heavy concentration of prehistoric cultural debris exposed in a deflated area. An apparently undeflated spot near the debris exposure was selected for the test pit. Test Pit 1 was excavated to a depth of $70 \mathrm{~cm}$ below the surface (seven 10-cm-thick levels). From the surface to a depth of $50 \mathrm{~cm}$, the deposit was characterized as dark brown sandy clay loam. Matrix in Levels 6 and 7 was described as 1 ight brownish gray sandy loam. Debris recovered from this unit is divided into two horizon assemblages. Horizon 1 contains debris from Levels 1-3. Horizon 2 contains debris from Levels 4-7. Rates of recovery for selected classes of debris from Test Pit 1 are as follows:

\section{Horizon 1 Horizon 2}

Tuff Weight (grams)

Sandstone Weight (grams)

Fire-Fractured Rock Weight (grams)

Mussel Shel1 Umbo Count

Musse1 She11 Weight (grams)

Rabdotus She11 Count

Bone Weight (grams)

Primary Flake Count

Secondary Flake Count

Tertiary Flake Count

Chip Count

$\begin{array}{rr}7 & 20 \\ 8 & 3 \\ 8 & 4 \\ 76 & 14 \\ 29 & 8 \\ 189 & 77 \\ 1 & 0 \\ 0 & 0 \\ 6 & 6 \\ 12 & 8 \\ 17 & 9\end{array}$

No additional artifacts were found in Test Pit 1.

Test Pit 2 was excavated to a depth of $50 \mathrm{~cm}$ below the surface in four vertical levels (the first was $20 \mathrm{~cm}$ thick). The matrix was a dark grayish brown sandy loam down to about $35 \mathrm{~cm}$ below the surface. At this elevation, the matrix color changed to brown sandy clay silt. In Level 4 (40 to $50 \mathrm{~cm}$ below surfacel, a yellowish brown silty clay was observed. Two concentrations of carbon, each 6 to $8 \mathrm{~cm}$ in diameter, were first defined at about $28 \mathrm{~cm}$ below the surface. The carbon concentrations were cross sectioned. On 1 y about $3 \mathrm{~cm}$ thick, the carbon appears to have followed either rodent runs or root molds and, thus, was determined to be of modern origin and not related to prehistoric cultural activity on the site. The cross section also revealed that deposits were fairly recent, probably colluvial slope wash. Debris recovered from the five levels excavated in Test Pit 2 is presented as a single assemb 1 age. No horizons were recognized. Rates of recovery for selected classes of debris from Test Pit 2 are as follows: 


\section{All Levels Combined}

Tuff Weight (grams)

Sandstone Weight (grams)

Fire-Fractured Rock Weight (grams) 28

Mussel She11 Umbo Count 15

Mussel She11 Weight (grams) 3

Rabdotus She11 Count $\quad 45$

Bone Weight (grams) 0

Primary Flake Count 1

Secondary Flake Count $\quad 14$

Tertiary Flake Count 10

Chip Count $\quad 37$

No additional artifacts were recovered from Test Pit 2.

Test Pit 3 at 41 LK 185 was located near the southeast end of the site, adjacent to an eroded animal trail in which some mussel shell and debitage were exposed. This unit is east of, and down slope from. Test Pit 2. Findings made in a shovel test excavated near the location selected for Test Pit 3 demonstrated the productive content of the subsurface. This unit was also excavated to a depth of $70 \mathrm{~cm}$ below the surface (seven 10-cm-thick levels). Down through Level $5(50 \mathrm{~cm}$ below surface) the soil matrix was described as brownish gray sandy silty loam. In Level 6 , the soil changed to a light yellowish tan loam with a high clay content. The debris recovered from Test Pit 3 is presented as two horizon assemblages with the same level groupings as in Test Pit 1 (see above). Recovery rates for selected classes of debris for these two horizons in Test Pit 3 are as follows:

Horizon 1 Horizon 2

$\begin{array}{lrr}\text { Tuff Weight (grams) } & 26 & 38 \\ \text { Sandstone Weight (grams) } & 0 & 19 \\ \text { Fire-Fractured Rock Weight (grams) } & 9 & 9 \\ \text { Mussel She11 Umbo Count } & 52 & 39 \\ \text { Mussel Shell Weight (grams) } & 11 & 14 \\ \text { Rabdotus Shel1 Count } & 73 & 112 \\ \text { Bone Weight (grams) } & 0 & 0 \\ \text { Primary Flake Count } & 1 & 1 \\ \text { Secondary Flake Count } & 4 & 8 \\ \text { Tertiary Flake Count } & 8 & 8 \\ \text { Chip Count } & 13 & 12\end{array}$

No other artifacts were recovered from Test Pit 3.

Numerous artifacts were collected from the surface of 41 LK 185. Using a plane table and alidade, locations of many of these specimens were plotted on a plan map now filed at the CAR-UTSA. The following artifacts were collected: eight cores (two, Group 1; one, Group 4; three, Group 5; one, Group 6: one, Group 9), three thick bifaces (one, Group 3; one, Group 7 , Form 3; one, Group 7, Form 4), 16 thin bifaces (Group 1, Form 1, Specimen 8; Group 1, Form 3, Specimens 15 and 35; Group 1, Form 5, Specimen 21; one, Group 2, Form 1; one, Group 2, Form 2; one, Group 3, Form 1; one, Group 3, 
Form 2; one, Group 4, Form 1; one, Group 4, Form 4; three, Group 9; threes Group 10), one distally beveled tool (Group 9), two pieces of modified sandstone (one, Group 2, Form 2; one, Group 3), one piece of modified quartzite, and two sherds of aboriginal pottery.

The variety of artifacts collected at 41 LK 185 indicates quite clearly that the site was inhabited during the Late Archaic and Late Prehistoric periods. Use of the site by Late Archaic peoples is evidenced by smaller stemmed dart points, one of which is typed Fairland (Group 1, Form 3, Specimen 15). A distally beveled tool (Group 9) and six forms of unstemmed thin bifaces (Groups 2, 3, and 4) are also probably related to Late Archaic inhabitants. Sherds of aboriginal pottery and a stemmed arrow point (thin bifaces Group $1_{\text {s }}$ Form 5, Specimen 21) are specimens diagnostic of the Late Prehistoric. It is unfortunate that no time-diagnostic artifacts were recovered from the three controlled test excavations placed in the site. It is probably safe to assume, however, that the Late Prehistoric is represented by Horizon 1 materials, and the Late Archaic is represented by Horizon 2 materials in Test Pits 1 and 3. A comparison of horizon assemblages from these two units reveals no significant differences in material classes representing the two cultural periods.

\section{LK 241}

Site 41 LK 241 is a large, open prehistoric site recorded by the CAR survey crew in 1979. Located on a ridge on the southern valley margin, the site has dimensions of $600 \mathrm{~m}$ north-northeast to south-southwest and is about $200 \mathrm{~m}$ wide (Fig. I, folded insert). The site surface is heavily covered in brush with guajillo, spiny hackberry, agarita, prickly pear, and soapbush all very common. Like much of the valley margin, the ridge upon which the site occurs is characterized by outcrops of Catahoula Formation tuff and extensive surface deposits of 1 ag grave1. A thin mantle of gray silt is evident in some areas. Materials observed on the site by the CAR survey crew were 1 arge cortex flakes, numerous cores, 10 thick bifaces, and two distally beveled tools (Guadalupe and Clear Fork types). Also noted in the original survey was a buried cluster of tuffaceous rock exposed in a road cut along the new route of State Highway 72 around the southern margin of Choke Canyon Lake.

Reexamination of 41 LK 241 by the CAR crew during the Phase II investigation revealed that the site served primarily as a source of raw materials in the manufacture of chipped stone tools. A shovel test excavated in the northcentral area of the site revealed the deposit to be a thin soil permeated with gravels and no prehistoric cultural debris. No additional artifacts were collected from this locality.

\section{LK 174}

Site 41 LK 174 is located down slope to the northwest of 41 LK 241 (Fig. I. folded insert). It is on the slope of the valley margin. As recorded by Texas Tech surveyors, 41 LK 174 has an irregular outline shape with dimensions of $200 \times 375 \mathrm{~m}$. The surface is densely covered with prickly pear. acacias, mesquite trees, and whitebrush. Noted in the original survey were 
two badly disturbed hearths, chert debitage, mussel she11, and Rabdotus snai1 shel1. Distribution of these materials across the surface was used to define the site's 1 imits.

Activities of the CAR crew at 41 LK 174 during Phase II investigations consisted of excavation of three shovel tests and an unprovenienced collection of surface artifacts. Shovel test results indicated that the site holds 1 ittle or no potential for productive subsurface excavations. Artifacts collected from the surface were one thin biface fragment (Group 4, Form 4) and three pieces of modified sandstone (two, Group 2, Form 2; one, Group 3). These specimens do not permit definitive diagnosis of the period of cultural activity at 41 LK 174.

\section{LK 173}

Located west-northwest of 41 LK 174, 41 LK 173 is slightly farther down slope from the valley margin (Fig. 1, folded insert). This site was located and recorded by the Texas Tech survey crew. This crew defined an irregular subcircular outline shape for the site and estimated its dimensions to be $500 \times 600 \mathrm{~m}$. The surface is covered with brush, primarily whitebrush and prickly pear. Extensive surface deposits of $1 \mathrm{ag}$ gravel and the presence of numerous cortex $f 1$ akes led to definition of 41 LK 173 as a quarry site.

Revisiting 41 LK 173 during Phase II investigations, the CAR crew concurred with the Texas Tech assessment that the site had functioned primarily as a quarry. The crew noted the gravel pavement and primary reduction flakes. No mussel she11. fire-fractured rock, or rock clusters--all considered to be signs of habitational activity--were seen. Activities on the site consisted of shovel testing and an unprovenienced collection of surface artifacts. The three shovel tests excavated in the site revealed that its deposits are extremely shallow and contain almost no prehistoric cultural debris. Artifacts collected from the surface were two cores (one, Group 1; one, Group 3), five thick bifaces (three, Group 1; one, Group 3; one, Group 7, Form 1), and one thin biface fragment (Group 4, Form 3). The cultura1/ chronological period(s) during which prehistoric activity occurred at 41 LK 173 is not evident from these remains.

\section{LK 170}

Situated on the floodplain about $2 \mathrm{~km}$ north of the valley margin and $1.5 \mathrm{~km}$ south of the Frio River, 41 LK 170 is a tiny site recorded by the Texas Tech crew (Fig. 1, folded insert). It consists of a sma 11 hearth eroding from a dirt road and a very light scatter of burned tuffaceous rock occurring over an area $20 \times 40 \mathrm{~m}$. The site surface supports a moderately thick stand of huisache, spiny hackberry, soapbush, mesquite, and various weeds and grasses. During Phase II field work, the CAR crew excavated two shovel tests at 41 LK 170. The subsurface yielded an insignificant amount of cultural debris, and controlled testing did not appear to be warranted. Careful examination of the site surface revealed no time- or function-diagnostic artifacts. 


\section{LK 234}

Site 41 LK 234 is a prehistoric site located along the western side of an intermittent drainage channel out on the floodplain (Fig. 1 , folded insert). Recorded by surveyors from the CAR-UTSA, this site was defined as being roughly circular in outline shape with a diameter of $60 \mathrm{~m}$. The site is evidenced by a relatively heavy scatter of debitage, burned rock, and mussel and Rabdotus snail shel 1 s on a slight rise covered with grass, weeds, and retama. In the original survey, artifacts including an Ensor dart point fragment, a hammerstone, chert cores, and some other thin biface fragments were noted. Returning to the site for Phase II work, the CAR crew was unable to relocate these specimens. It is speculated that artifact collectors hit the site sometime between when it was recorded and when the Phase II investigation occurred. In five shovel tests excavated by the CAR crew, variable observations were made. One shovel test yielded evidence of substantial prehistoric cultural debris in the upper $20 \mathrm{~cm}$ of deposit. The other four tests showed little or no debris occurring over the remainder of the site. The site is located in a cleared pasture, and it is assumed that brush clearing and root plowing took place in the vicinity. For this reason, no controlled testing was attempted.

\section{SIIE GROUP 4}

Extensive Test

Excavation Pits

41 LK 14

41 LK 74
Surface Collections

Provenienced Unprovenienced
Resurvey or Shovel. Tests

41 LK 236

The three sites making up Group 4 are situated on the south side of the Frio River between 5 and $8 \mathrm{~km}$ west of Choke Canyon Dam (Fig. 1, folded insert). Two of the three sites, 41 LK 14 and 41 LK 74, rest on high, sandy terrace remnants that are relatively close to the modern Frio River, but are nevertheless considerably older than the active terrace systems immediately alongside the river. The river meanders quite extensively in its course between 41 LK 74 and 41 LK 14 (Fig. I, folded insert). A1though far apart, these two sites rest on the same terrace system at elevations of 160 feet to 180 feet above mean sea level. The leading edge of this old terrace system arcs in a southeasterly direction away from 41 LK 74, where it is immediately above the Frio River, trends as much as $1 \mathrm{~km}$ away from (south of) the river, then swings back to the northeast where it is again close to the river in the vicinity of 41 LK 14. The face or slope of this old terrace as it leads down to the active floodplain is heavily eroded. Two major upland drainage channels cut down from higher reaches of the floodplain to the south. Lateral erosion along these drainages has extensively altered the configuration of the terrace system.

The 1 and encompassing Site Group 4 supports heavy stands of brush or riparian forest in some areas and elsewhere has been cleared for use as pasture or 
crop 1 and. Site 41 LK 74 occurs in a brushy area while 41 LK 14 is mostly within a cultivated field. Situated immediately alongside the modern channel of the Frio River, 41 LK 236 is partially within a cleared, grass-covered pasture. A fringe of riparian forest grows along its other side.

\section{LK 14}

Recorded in 1970 by members of the Coastal Bend Archeological Society (CBAS), 41 LK 14 occurs on a Pleistocene terrace remnant forming a distinct rise overlooking the channel and active floodplain of the Frio River (Figs. 1 , folded insert; 17). Based on the distribution of prehistoric cultural debris on the surface, dimensions of this site are set at $200 \mathrm{~m}$ north-south and $180 \mathrm{~m}$ east-west. The river is downhill and approximately $200 \mathrm{~m}$ north of the site. A substantial deposit of gravel and cobbles occurs in the river channel just below the site. Much of this gravel probably originated from within the old terrace, gradually being washed out and reworked through hundreds of years. The central and western two-thirds of 41 LK 14 are located in a cultivated field that had gone into disuse at the time of Phase II investigations. On the site's northern slope and over much of its eastern end were mesquite trees, whitebrush, spiny hackberry, narrow leaf yucca, elm trees, and prickly pear (Fig. 2l,a). A strip of brush was in the otherwise cleared central part of the site. At the north end of the brush strip was a 1 arge, circular water cistern that once supplied water to cattle. Shortly after Phase II work was completed, this cistern and all vegetation were removed. At the foot of the terrace below the site began the riparian forest that grew on the river's first terrace. This, too, was cleared shortly after archaeological excavations were completed.

Site 41 LK 14 was tested by surveyors from the Texas Historical Commission (THC), who excavated a $1-\mathrm{m}^{2}$ unit $80 \mathrm{~cm}$ down into the 5 ite (Lynn, Fox, and OMa1 1ey 1977:143-149). Chert cores and debitage and fire-fractured rock were recovered from the test pit. No time- or function-diagnostic artifacts were found in the test pit. However, based on numerous artifacts collected by CBAS and THC surveyors from the surface of 41 LK 14, it was apparent that the site was occupied during the Paleo-Indian. Archaic, and Late Prehistoric periods (ibid.:149). Findings made by the THC researchers 1 ed to the following conclusion:

Considering the shallow nature of the archeological deposits, it is possible that the relatively dense concentration of cultural materials at Site 41 LK 14 represents numerous reoccupations of the site over a long time span. For this reason, in future archeological investigations it probably will be difficult to isolate occupational evidence precisely in space and time. However, data concerning site function and frequency of occupation within general cultural/chronological periods could be recovered which would be useful in intersite comparisons (Lynn, Fox, and OMalley 1977:149).

In Phase I investigations, the CAR crew excavated four $1-\mathrm{m}^{2}$ test pits at 41 LK 14 (Ha11, Black, and Graves 1982:104-110). The following observations were made: 
Figure 17. Topographic Map of 41LK14 and Surrounding Area.

PAGE 71 REDACTED 
The findings made during the CAR investigation at 41 LK 14 support the THC analysts' suggestion that the site was occupied from PaleoIndian through Late Prehistoric times. Early activity is evidenced by the Angostura specimen and at least two of the distally beveled tools, including Clear Fork and Guadalupe tools. The other distally beveled tools and a wide array of thin bifaces, some stemmed and many unstemmed, appear to represent the entire time span of the Archaic. Late Prehistoric activity is demonstrated by the presence of arrow points and aboriginal pottery on the site. Testing revealed a substantial deposit of prehistoric debris in the subsurface, but few recognized time-diagnostic tools were found in controlled excavations. The vast majority came from the surface, suggesting that the deposits have undergone considerable disturbance (ibid.:110).

The Phase I findings also evidenced heavy usage of mussels, snails, and some fish (drum) by the prehistoric inhabitants of 41 LK 14. Plant food processing was also inferred from the relatively numerous grinding 51 ab (metate) fragments found on the surface. Materials recovered from the test pits were divided into two horizon assemblages. The upper horizon. consisting of debris recovered from Levels 1-4 (surface to a depth of $40 \mathrm{~cm}$ ), was suggested to represent the span from Middle Archaic to Late Prehistoric times. The lower horizon (Levels 5-7 or 9) was suggested to contain debris representing the Late $\mathrm{Pa} 1$ eo-Indian and/or Early Archaic periods (Ha11, B1ack, and Graves 1982:110). It was the potential for isolation of intact PaleoIndian and/or Early Archaic components in the subsurface of 41 LK 14 that led to the site being recommended for Phase II investigation (Center for Archaeological Research 1979:16-17).

The Phase II archaeological investigation at 41 LK 14 was conducted in May and June 1981. During 11 work days, 10 crew members 1 abored a tota 1 of 600 person hours at the site. Activities at the site were excavation of unit blocks in two areas, feature and profile recording, and plan mapping.

Horizontal control was established on the surface of 41 LK 14 by setting an east-west baseline running through the central area of the site. $A$ nail 1 driven into the trunk of a mesquite tree just north of the Area $A$ excavation served as the vertical datum. USBR surveyors later calculated an elevation of 182.964 feet above MSL for this nail. They also placed a permanent site marker at the N1014 El000 grid mark (Figs. 17; 18). Its exact 1ocation, expressed in Modified Texas State Plane Coordinates, was recorded.

A group of nine $1-m^{2}$ units forming a $3 \times 3-m^{2}$ excavation pit was staked out at a location immediately northwest of the spot where Test Pit 1 was placed in Phase I investigations (Fig. 18). The pit formed by these nine units was designated Area $A_{\text {. }}$ This location was selected for two reasons. First, the test excavated nearby had shown that prehistoric debris was present in substantial amounts in the subsurface. Second, the general area had not been cleared of brush and cultivated as had the rest of the site. Thus, there was the opportunity for sampling deposits that had not been disturbed by root plowing and subsequent agricultural practices. 
Test Pit 2 (1977)

41LK14

PLAN OF EXCAVATIONS

Excavations

Archaeological Grid Point

Point Located on Topographic Map Coverage of Site

Test Pit 3 (1977)

Cultivated Field

Test Pit 4 (1977)

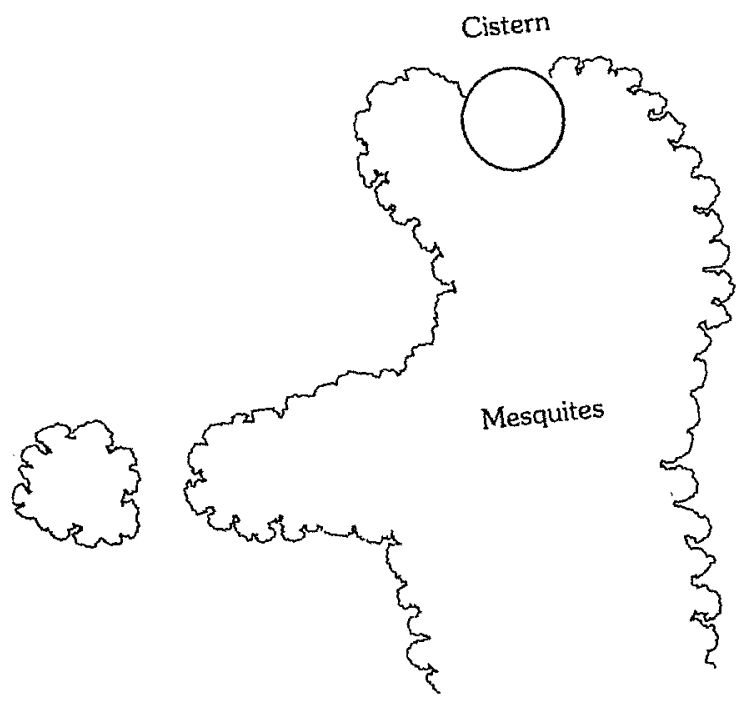

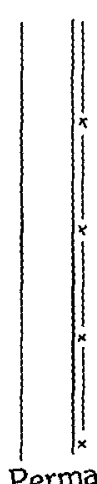

ont USBR Site Marker $182.18^{\prime}$ above MSL (N1014E1000)

A

Test Pit $1(1977)$

$B$
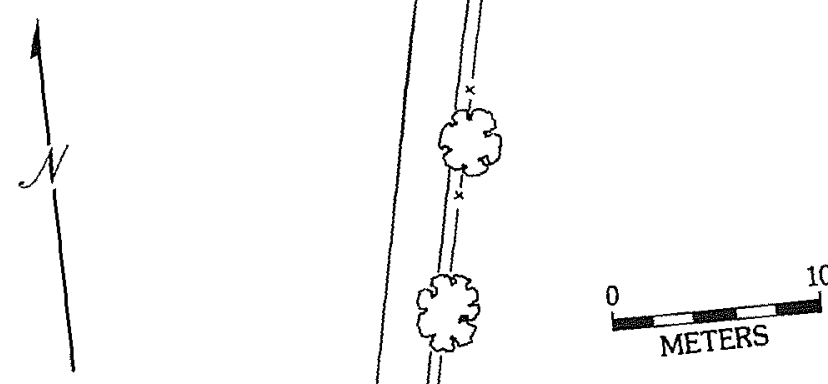

METERS

Figure 18. Plan of Excavations at 41 UK 14. 
The units comprising Area $A$ at 41 LK 14 were excavated in arbitrary 10-cmthick vertical levels. The nine units and the number of levels excavated at each are as follows: N1008 E1000 (1l leve1s), N1008 El001 (nine levels), N1008 E1002 (nine levels), N1009 El000 (nine levels), N1009 El001 (nine levels), N1009 El002 (nine levels), N1010 El000 (11 levels), N1010 El001 (nine levels), N1010 El002 (nine levels). Surface elevations in these units ranged from 99.71 to $99.77 \mathrm{~m}$. Debris recovered from the Area $A$ units is presented as two horizon assemb 1 ages. Horizon 1 contains a 11 debris from Levels 1-5 in the nine units. Horizon 2 contains debris recovered from Levels 6-9 or 11. Rates of recovery for selected classes of debris from each horizon in Area $A$ are as follows:

\section{Harizon 1 Horizon 2}

Tuff Weight (grams)
Sandstone Weight (grams)
Fire-Fractured Rock Weight (grams)
Musse1 She11 Umbo Count
Musse1 She 11 Weight (grams)
Rabdotus She11 Count
Bone Weight (grams)
Primary Flake Count
Secondary Flake Count
Tertiary Flake Count
Chip Count

$\begin{array}{rr}639 & 859 \\ 284 & 62 \\ 2940 & 2821 \\ 1236 & 499 \\ 617 & 181 \\ 3873 & 2308 \\ 0.5 & 0.4 \\ 29 & 9 \\ 327 & 175 \\ 487 & 374 \\ 720 & 423\end{array}$

Additional artifacts recovered from the Area $A$ excavations are 1 isted below:

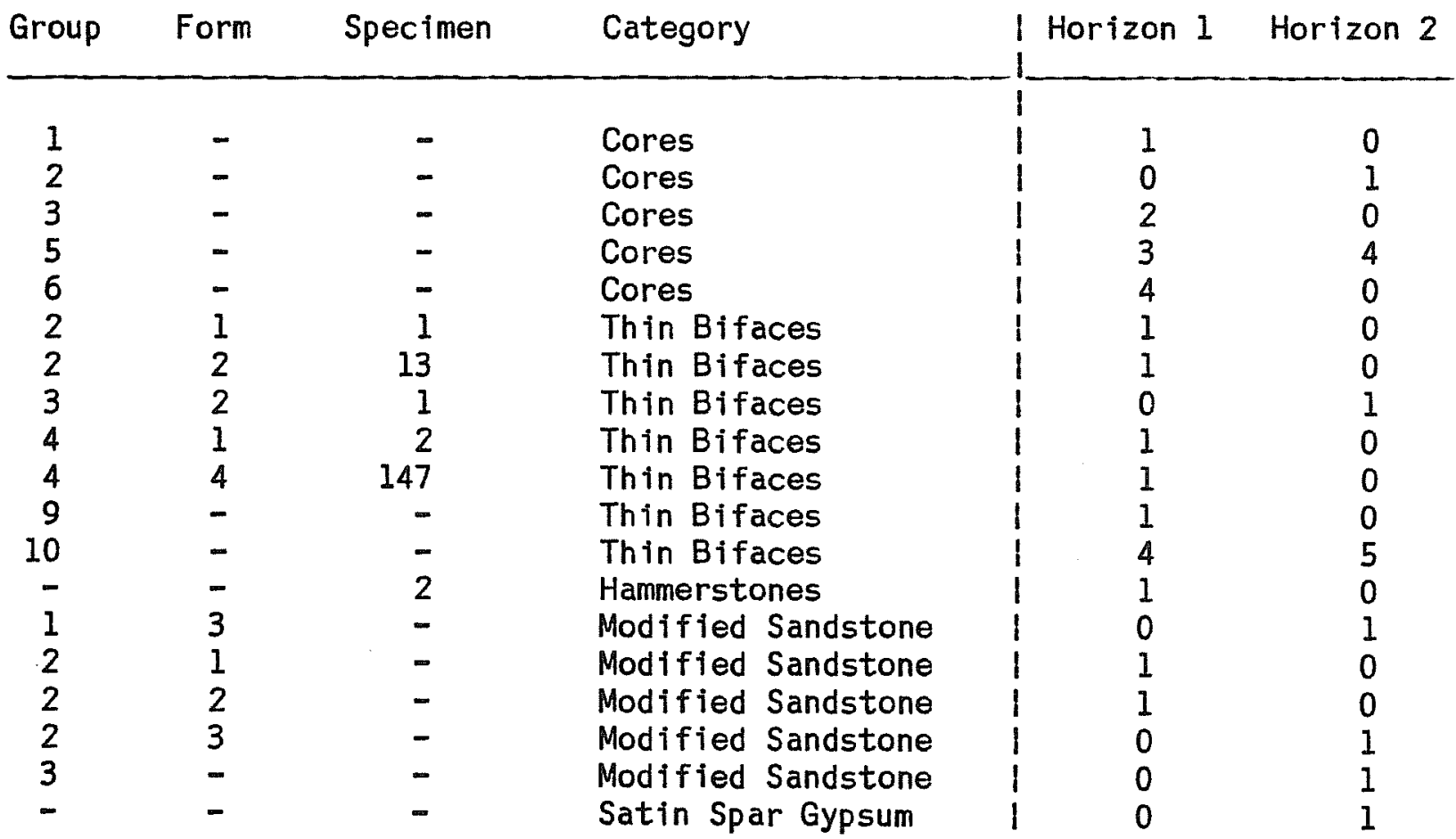


One habitational feature was defined in the Area A excavation at 41 LK 14. Designated Feature 1, a concentration of burned rock was isolated in Level 6 (99.30-99.20) of Units N1008 E1000 and N1008 El001. Approximate1y 50 stones (40 pieces of fire-fractured rock and 10 pieces of sandstone) were arranged in a roughly oval-shaped cluster with maximum dimensions of $1 \mathrm{~m}$ northeast to southwest and $45 \mathrm{~cm}$ northwest to southeast. The feature is essentially a single-1ayer construct with the difference in elevation between the bottom of the lowest rock and top of the highest being from 6 to $7.5 \mathrm{~cm}$. The rocks averaged about $4 \times 4 \mathrm{~cm}$ in size. Numerous very smal1 spal1s of firefractured rock were noted mixed in with the 1 arger stones. Three 1 arge pieces of musse 1 she 11 and numerous smaller pieces were noted amidst the rock. Rabdotus snail shel15, chert debitage, and pea gravels were also observed. No carbon was found in Feature 1 .

Soil zonation encountered in the Area $A$ excavation is illustrated and described in Figures 19 and 2l,b. Prehistoric cultural debris was confined for the most part to Zones 3 and 4 composing the upper $90 \mathrm{~cm}$ of deposit on the site. Zones 1 and 2 were sterile. Also shown in Figure 19 is the location of a soil sample column. Soil samples were taken at 10-cm intervals from surface to the bottom of the excavation. These samples are curated at the CAR-UTSA and are intended to serve as a permanent record of preinundation soil character.

The Area $B$ excavation at 41 LK 14 was composed of four $1-m^{2}$ units forming a $2-m^{2}$ b lock. Located in the central area of the site, Area $B$ was 7 ocated on the basis of findings made in Test Pit 3 immediately to the north (Fig. 18 ). Artifacts recovered from this test pit, as wel 1 as from the surface in the immediate vicinity, indicated that Late Prehistoric activity had been particularly intense in this part of the site. Area B was meant to sample this Late Prehistoric component as wel1 as deeper, older components. The four units in Area $B$ and the number of levels excavated at each are as follows: N1006 E958 (eight leve1s), N1006 E959 (eight leve1s), N1007 E958 (eight leve1s). N1007 E959 (eight leve1s). Surface elevations for the units ranged from 100.26 to $100.29 \mathrm{~m}$. Debris recovered as Area B was excavated is divided into two assemblages. Horizon 1 contains debris recovered from Levels $1-4$ in al1 four units. Horizon 2 represents the debris from Levels 58. Rates of recovery for selected classes of debris for Area $B$ horizons are as follows:

$\begin{array}{cc}\text { Horizon } 1 & \text { Horizon 2 } \\ 191 & 249 \\ 150 & 248 \\ 1146 & 1280 \\ 446 & 183 \\ 351 & 84 \\ 302 & 637 \\ 1.5 & 0.6 \\ 7 & 12 \\ 185 & 181 \\ 295 & 330 \\ 602 & 508\end{array}$

Tuff Weight (grams)

Sandstone Weight (grams)

Fire-Fractured Rock Weight (grams)

Musse1 Shel1 Umbo Count

Mussel She11 Weight (grams)

Rabdotus She11 Count

Bone Weight (grams)

Primary Flake Count

Secondary Flake Count

Tertiary Flake Count

Chip Count

602 


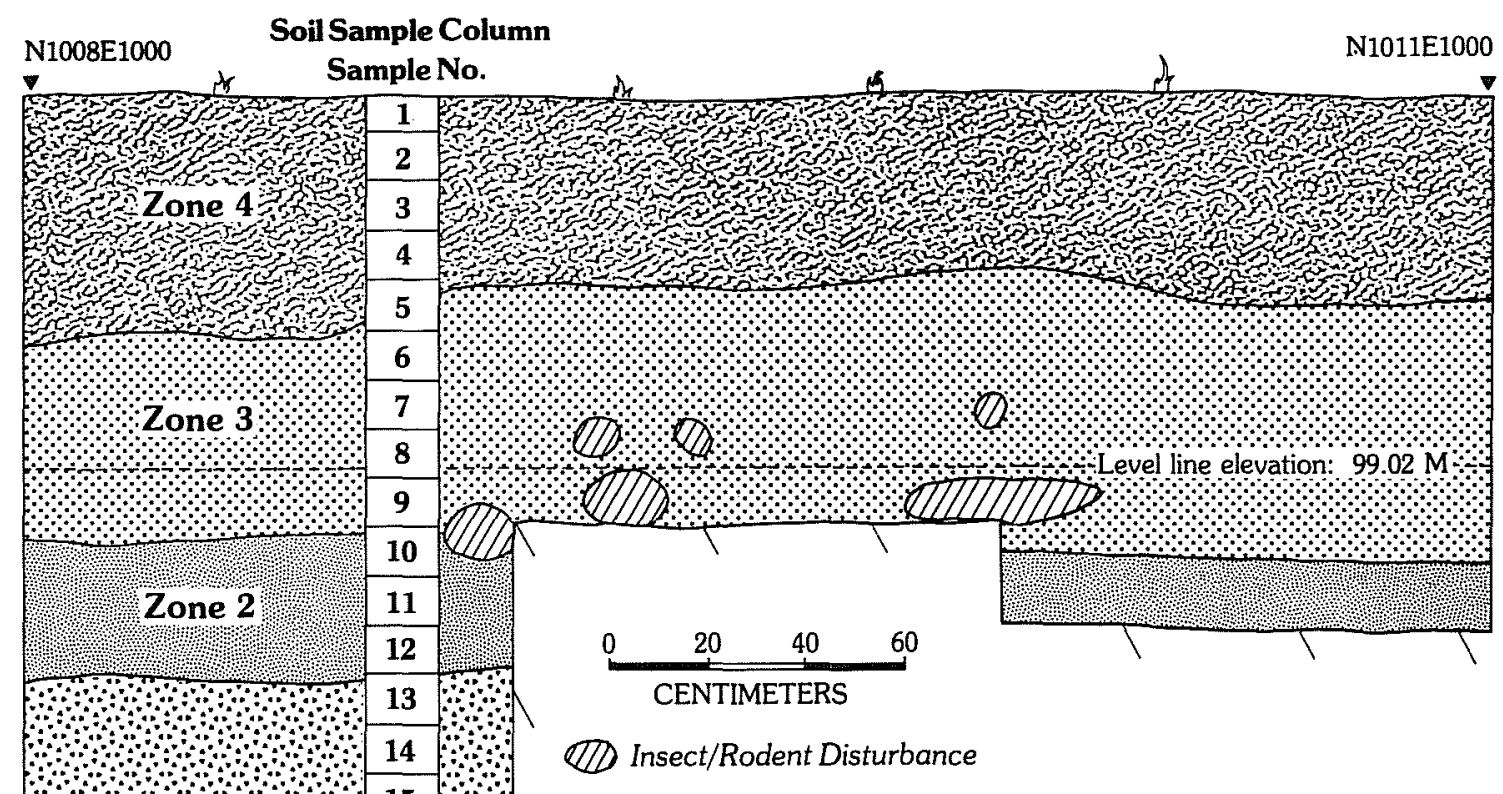

Zone 4 Color: very dark grayish brown (10YR3/2). A sandy loam with inclusions of mussel shell, land snail shell, fire-fractured rock, chert flakes and river pebbles. Distinguished from Zone 2 by sandier texture and higher humic content.

Zone 3 Color: brown (10YR5/3). A loam, inclusions are the same as in Zone 4.

Zone 2 Color: mottled with spots of very pale brown (10YR8/3), brown (10YR5/3) and grayish brown (10YR5/2). Inclusions consist of a few river pebbles and carbonate concretions. No cultural material.

Zone 1 Color: yellowish brown (10YR5/4). A sand with carbonate concretions as the main inclusions. Small lines of darker matrix (filled cracks or root molds?)

41LK14 AREA A run vertically through the zone. No cultural materials.

PROFILE SKETCH ALONG E1000 LINE FROM N1008 TO N1011

Figure 19. Profile Sketch Along El000 Line from N1008 to N1011 at 41 LK 14. Area A. 
Additiona 1 artifacts recovered from the Area $B$ excavations are 1 isted below:

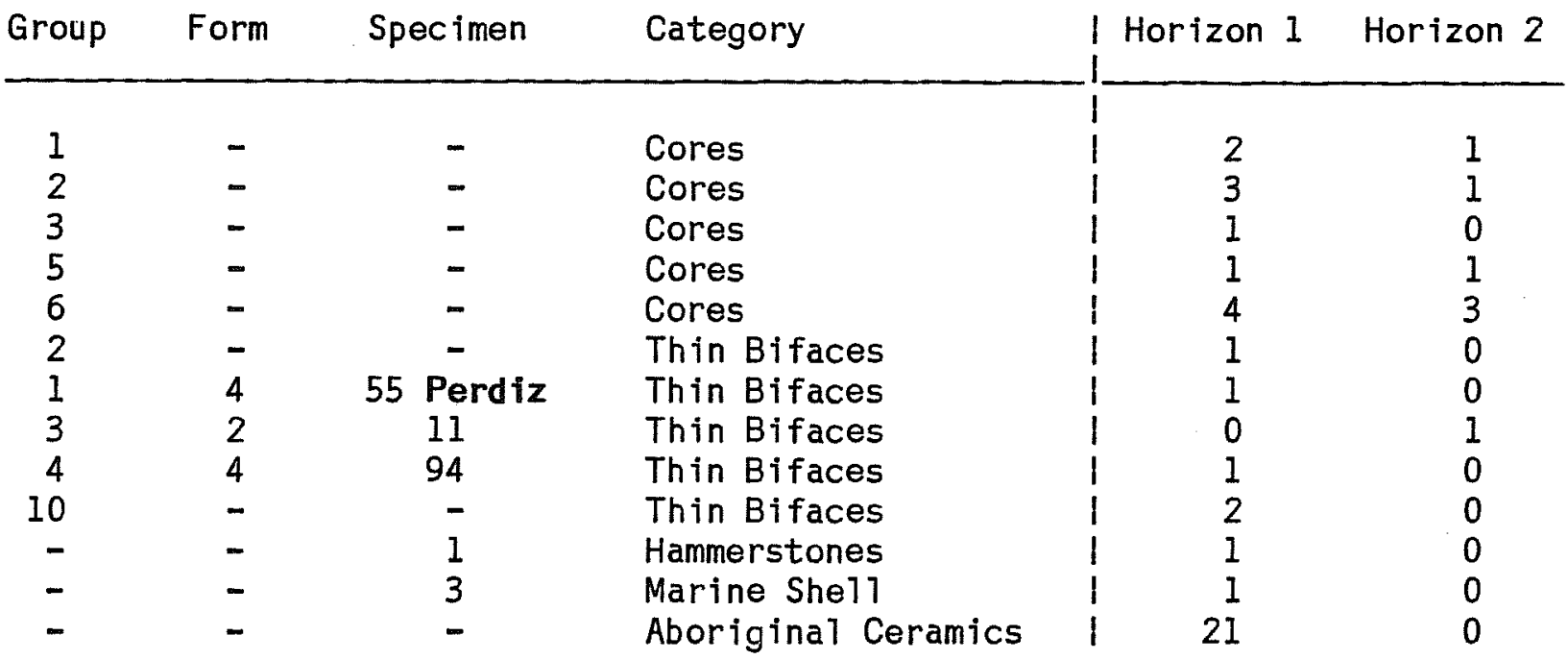

No habitational features were encountered in Area B.

Soil zones recognized in the wa 11 profiles of Area $B$ are $i 11$ ustrated in Figure 20. More zones were defined in Area $B$ than Area $A$, probabliy because Area $B$ was located in a part of the site that had been cultivated for a number of years. Zone 6 is a plow zone, and Zone 5 may also be a product of soil cultivation. The location of a soil sample column is a 1 so shown in Figure 20. Samples collected from this column are curated at the CAR-UTSA.

Additional artifacts include 58 core fragments (core Group 9) and two cobbles (Group 10). Most of these specimens were recovered in excavations, but provenience is not provided.

The following specimens were collected from the surface of 41 LK 14. Locations of most of these specimens are plotted on a plan map filed at the CAR-UTSA.

Cores: one, Group 2; one, Group 7.

Thick Bifaces: one, Group 1; one, Group 6, Form 2.

Thin Bifaces: Group 1, Form 1, Specimen 6; Group 1, Form 3, Specimen 22; Group 1, Form 5, Specimen 1 (Scal1orn arrow points); two, Group 2, Form 1; one, Group 2, Form 2; four, Group 4, Form 4; one, Group 5; four, Group 9; three, Group 10.

Distally Beveled Tools: one, Group 2, Form 1; one, Group 3, Form 2; one, Group 4 .

Uniface: one, Group 1.

The assemb 1 age of artifacts recovered during Phase II archaeological investigations at 41 LK 14 again demonstrates that the 1 ocal ity attracted human settlers through thousands of years of prehistory. The total artifact 
41LK14

PROFILE SKETCH ALONG N1006 LINE FROM E958 TO E960

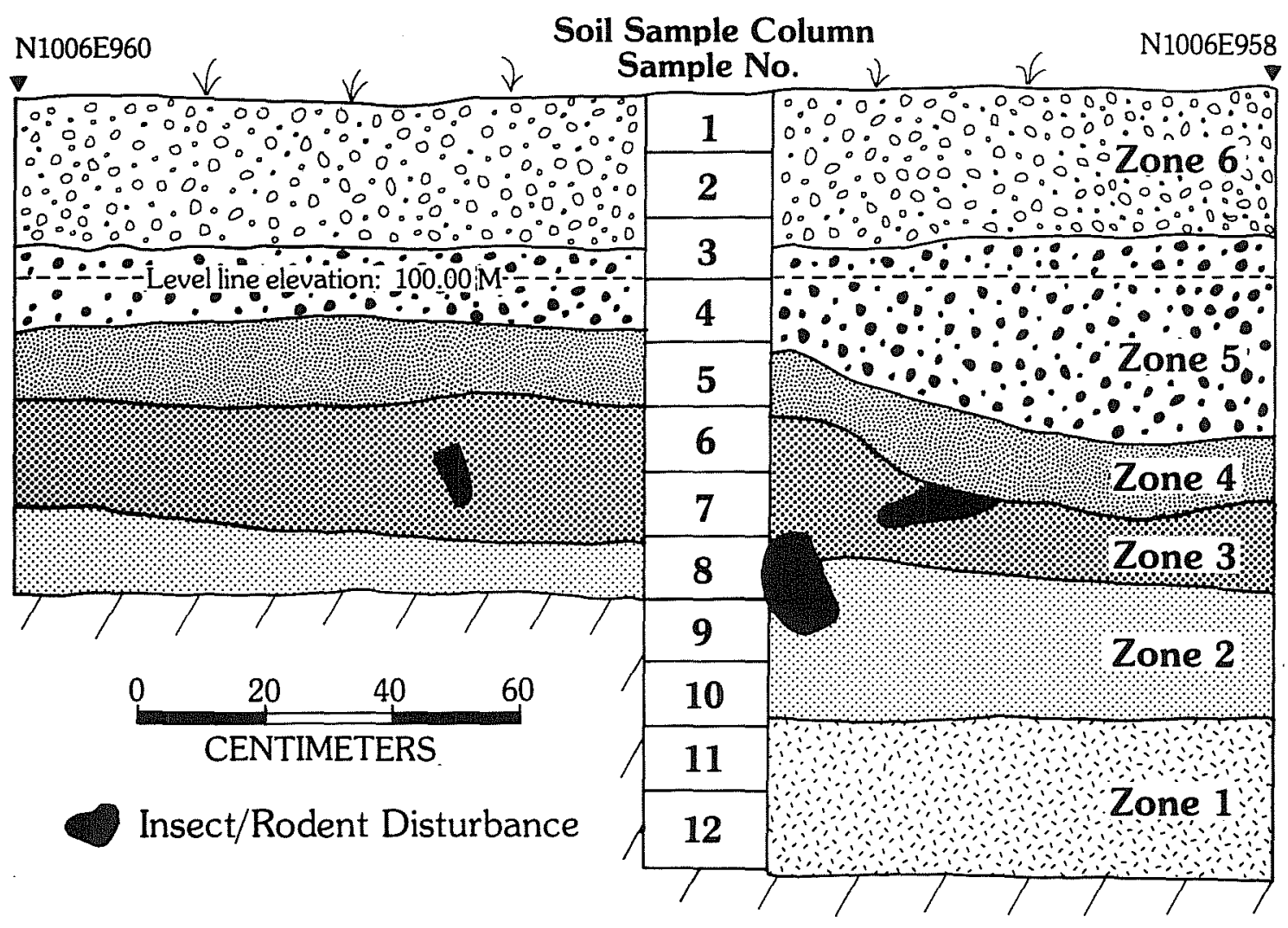

Zone 6 Color: very dark grayish brown (10YR3/2). A plow zone in fine sandy loam containing broken mussel shell, fire-fractured rock, pebbles, carbon flecks, and chert flakes.

Zone 5 Same as Zone 6, but below plow zone.

Zone 4 Color: dark grayish brown (10YR4/2). A sandy loam containing more fire-fractured rocks and less mussel and snail shell than zones above.

Zone 3 Color: dark brown (10YR4/3). A loam constituting the transition between $\mathrm{A}$ and $\mathrm{B}$ horizons. Cultural material present in disturbed areas only.

Zone 2 Color: yellowish brown (10YR5/4). A clay loam with inclusions of river pebbles and sand. No cultural material.

Zone 1 Color: mottled from white to light yellowish brown (10YR8/2-10YR6/4). A clay loam streaked with calcium carbonate. No cultural material.

Figure 20. Profile Sketch A1ong N1006 Line from E958 to E960 at 41 LK 14, Area B. 
assemb 1 age recovered during a 11 phases of archaeological research at the site constitutes one of the more remarkable and outstanding single site collections known in the region. With benefit of knowledge gained through broader subsurface probing accomplished during Phase II excavations, it appears that the rich and varied assemblage of artifacts collected from the surface will be the site's major contribution to the study of regional prehistory.

The Phase II excavations at 41 LK 14 did not, as was hoped, result in definition of Paleo-Indian or Early Archaic components in the subsurface. An intact, relatively we11-integrated habitational feature was found in the lower reaches of the deposit, but associated chipped stone tools do not permit a temporal assignment, other than to say it was 1 ikely constructed sometime during the lengthy Archaic period. The contrast between the numerous and varied diagnostic artifacts found on the surface of 41 LK 14 and the meager assemblage recovered from the excavations is characteristic of many sites at Choke Canyon. Because of this, attempts at dating cultural remains by comparative means are often frustrated. Further, the one feature isolated at 41 LK 14 contained no carbon that might have been used for age determination through radiocarbon assay.

Several general observations are possible based on analysis of debris recovered from the Phase II excavations at 41 LK 14. First, fire-fractured rock is by far the most common nonartifactual stone in the deposits. This clearly indicates that gravel deposits existed near the site in prehistoric times just as they now occur in the river channel below the site. Cobbles from this source were the most available form of stone for use in hearth construction. Much less common at 41 LK 14 is sandstone derived from the Jackson Group to the west, and tuffaceous siltstone (tuffaceous rock) from the Catahoula Formation to the east.

The gravel deposits near 4 LK 14 further served prehistoric inhabitants of the site as a source of raw materials for stone tool manufacture. The numbers of cores and core fragments, of thin biface fragments, and the quantities of debitage revealed in the excavations evidence the importance of tool making as an activity on the site.

Mussel1 shel1s, Rabdotus snail shel1s, a small amount of animal bone, and sandstone grinding tools (manos and metate fragments) are believed to be remnants or indications of food items consumed by prehistoric people as they camped at 41 LK 14. In both the Area A and Area B excavations, Horizon $I$ yielded more than double the number of mussel shell umbos as did Horizon 2. In Area A, Rabdotus snail shells were more common in Horizon 1 than Horizon 2. The opposite was true in Area B. The small quantities of animal bone found in each area demonstrate that vertebrate meat foods were being brought to the camp. The soils at 41 LK 14 are apparently not conducive to preservation of bone. It is suggested that the small amount of bone recovered is only a fraction of what may have been 1 eft by the prehistoric inhabitants. Modified sandstone artifacts in the form of a grinding $s 1 a b$ fragment (metate) and three manos were collected on the site. These tools suggest that seeds and/or nuts may have been processed for food. Thus, the evidence for prehistoric subsistence pursuits yielded by 41 LK 14 deposits is not much different from most other sites in the area. 
Figure 21. Phase II Investigations at 41 LK 14 and 41 LK 51.

a, view looking north across 41 LK 14. The crew members are working in the $3 \times 3-m$ pit designated Area $A$;

b, the west wall of Area $A$, a $3 \times 3-m$ excavation, along the E1000 line from N1008 to N1011 at 41 LK 14;

c, a view looking west-southwest across the Area A excavations at 41 LK 51;

d, the Area A excavations in progress at 41 LK 51, looking west;

e, Feature 6 in Level 12 (98.70-99.60) of Unit N998 E981 at 41 LK 51;

f, detail of carbonized wood in Level 15 (98.40-98.30) of Unit N998 E982 at 41 LK 51. Identified as either Acacia or Prosopis, a portion of this carbon was submitted for radiocarbon assay. The assays yielded ages ranging from 5130 B.C. $(T X-4690)$ to 4450 B.C. $(T X-4691)$. 


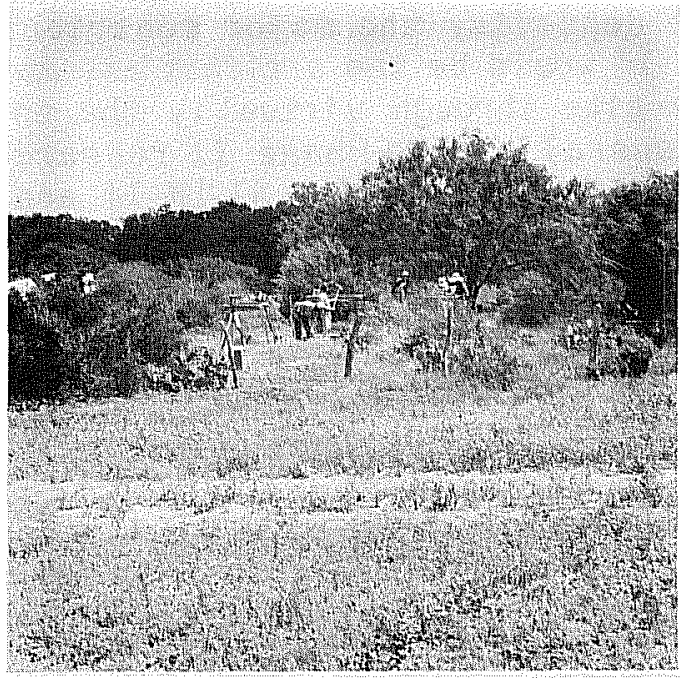

o
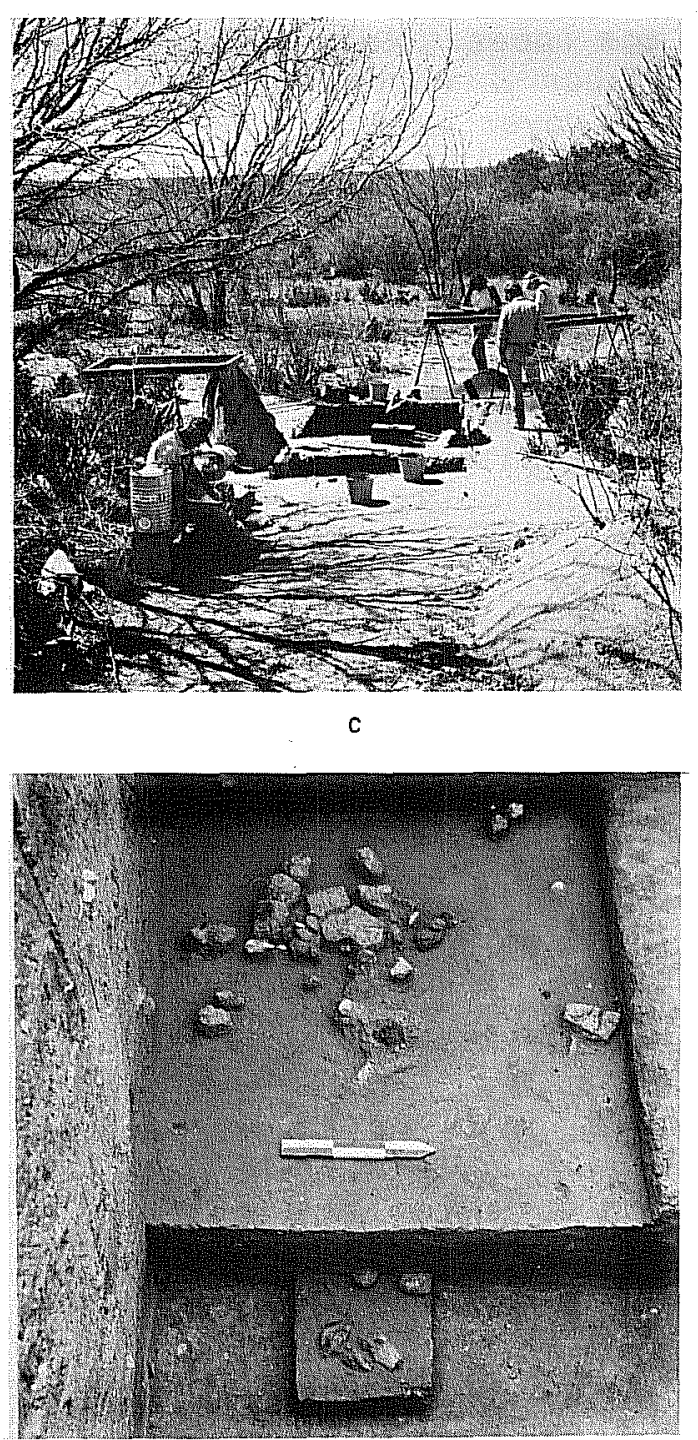

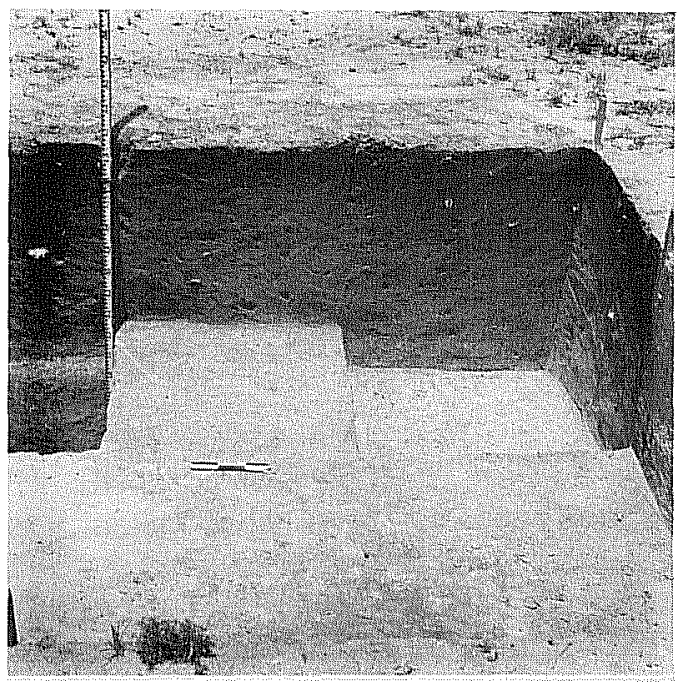

b

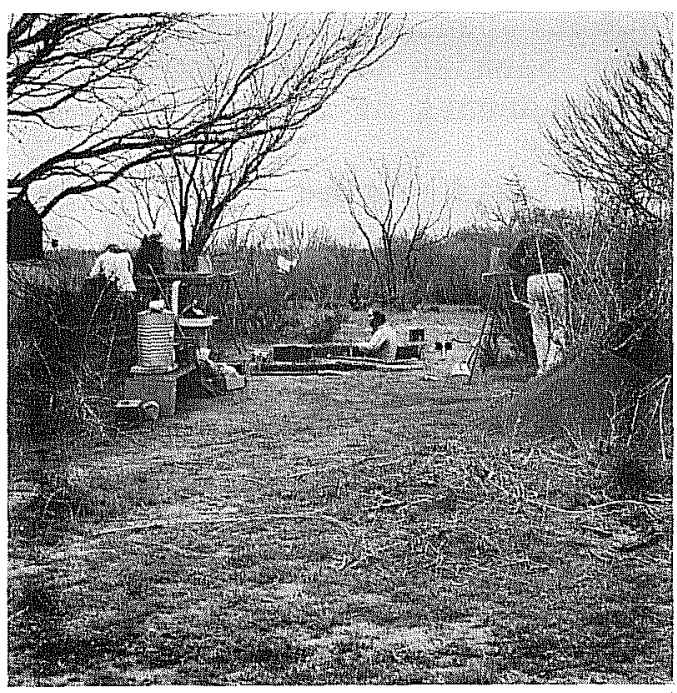

d

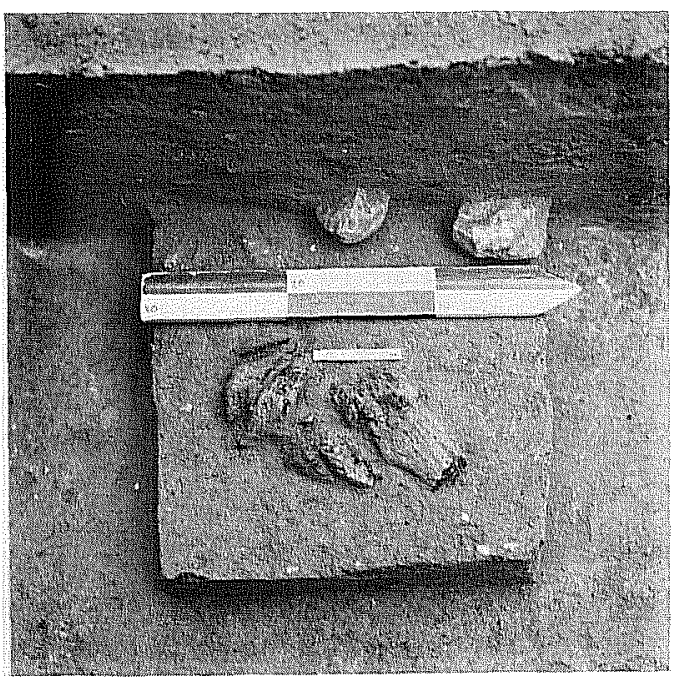


With the failure to isolate recognizable components of the Paleo-Indian or Early Archaic periods in its subsurface deposits, the major contribution resulting from the investigation at 41 LK 14 would be the artifact assemb 1 age that demonstrates human habitation of the site through virtualiy the entire span of the region's prehistory. More general1y, the Phase II research at 41 LK 14 has shown that old terraces of the type containing 41 LK 14 are not good locations for subsurface excavations.

\section{LK 74}

Like 41 LK 14, site 41 LK 74 occurs on an old terrace remnant overlooking the Frio River on its south side (Figs. 1, folded insert; 22). Recorded by archaeologists from the Texas Historical Commission, the site has dimensions of about $300 \mathrm{~m}$ northwest to southeast and is $150 \mathrm{~m}$ in width. The outline shape of 41 LK 74 is very irregular (Fig. 23). Erosion along the slope of the terrace upon which the site rests has formed two lobes which project a short distance out from the general line of the terrace system. Prehistoric cultural debris such as fire-fractured rock, debitage, and mussel shell is concentrated on the crests of these terrace lobes. Mesquite, narrow leaf yucca, Spanish dagger, persimmon, spiny hackberry, whitebrush, and guayacan are components of the moderate to dense brush cover over much of the site.

THC analysts 1 isted 41 LK 74 as containing Pre-Archaic to Terminal Archaic components (Lynn, Fox, and OMM11ey 1977:44). The CAR crew excavated four $1-m^{2}$ test pits on the site during Phase I investigations. A surface artifact collection was a 1 so made (Ha 1 1, B 1 ack, and Graves 1982:144-148). The test excavations revealed that deposits bearing cultural debris extended down from 40 to $60 \mathrm{~cm}$ below the surface. Debris recovered consisted primarily of burned rock, mussel she11, and debitage. Diagnostic chipped stone artifacts recovered from the test pits and collected from the surface tended to verify the time span of prehistoric activity proposed for the site by the THC archaeologists. Like 41 LK 14, 41 LK 74 was selected for extensive excavation during Phase II investigations because it had the potential for yielding more information about earlier periods in the prehistoric cultural sequence.

In 1 ate May and early June of 1981, excavations were conducted at 41 LK 74 by the CAR crew and members of the Texas Archeological Society (TAS) who were participating in the TAS Summer Field School. Twenty-eight people leight CAR crew members and 20 TAS workers) worked for 11 days at 41 LK 74, th is effort resulted in an expenditure of 580 person hours on the site investigation.

An excavation grid was 1 aid out on the surface of 41 LK 74. A nail driven into a tree trunk served as the vertical datum. USBR surveyors later calculated a true elevation of 198.133 feet above MSL for the archaeological datum nail. They a 1 so replaced a Phase I CAR site marker with a permanent marker and determined its exact location, expressed in Modified Texas State Plane Coordinates.

Phase II excavations at 41 LK 74 took place in seven areas, one of them (Area B) located in the west-central portion of the site and the others (Areas $A, C, D, F, G$, and $H$ ) at the site's east end ( $F$ ig. 23). Areas $A$ and $B$ 
Figure 22. Topographic Map of 41LK74 and Surrounding Area.

PAGE 83 REDACTED 


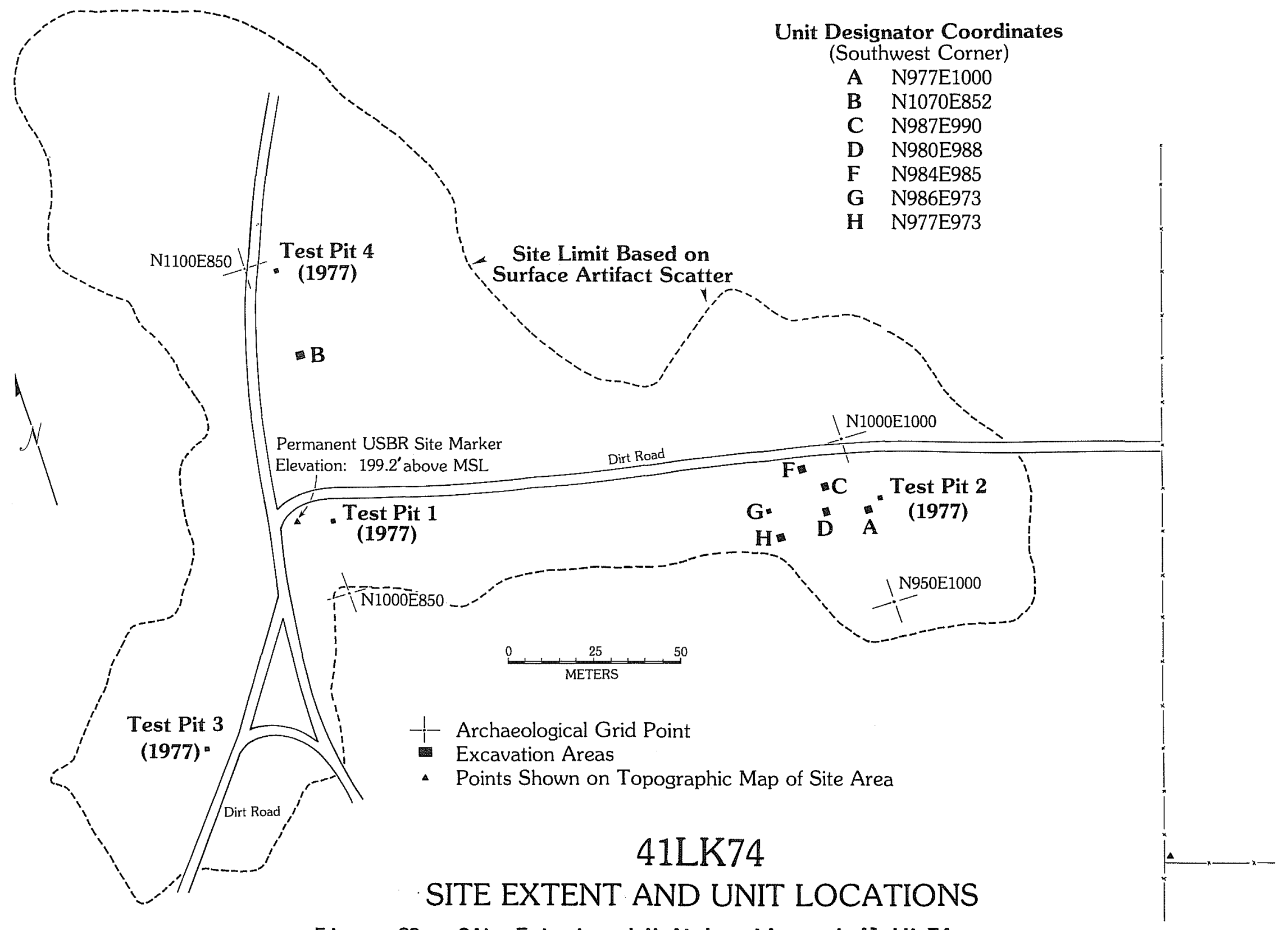

Figure 23. Site Extent and Unit Locations at 41 LK 74. 
were excavated by the CAR crew. The other excavations were done by the TAS crew. Areas $A$ and $B$, excavated first, were located on the bas is of findings made during the Phase I testing operation. The yields from Test Pits 2 and 4 suggested that these particular locations would be good for further, more extensive excavations. Findings made in Area A prompted $p 1$ acement of the additional excavation areas worked at the east end of 41 LK 74 by the TAS crew. The seven areas excavated were composed of from one to four $1-\mathrm{m}^{2}$ units. The units were excavated in 10-cm-thick vertical levels.

Area $B$, the one Phase II excavation at the west end of 41 LK 74, consisted of the following four units: N1070 E857 (four levels), N1070 E858 (four leve1s), N1071 E857 (six leve1s), and N1071 E858 (four leve1s). Surface elevations for these units ranged from $100.28 \mathrm{~m}$ to $100.32 \mathrm{~m}$. From surface down through Level 3 ( $\pm 30 \mathrm{~cm}$ below surface) the soil matrix was described as grayish brown sandy silt. In Level 4, the soil matrix changed to yellowish brown clayey loam. Two horizons are defined in Area $B$ based on variations in rates of recovery down through the deposit. Horizon 1 contains debris from Leve 151 and 2. Horizon 2 represents Leve1s 3-4 or 6. Rates of recovery for selected classes of debris from the two horizons defined in Area B are as follows:

Horizon 1 Horizon 2

$\begin{array}{lcc}\text { Tuff Weight (grams) } & 98 & 106 \\ \text { Sandstone Weight (grams) } & 177 & 109 \\ \text { Fire-Fractured Rock Weight (grams) } & 782 & 362 \\ \text { Mussel She11 Umbo Count } & 392 & 150 \\ \text { Musse1 She11 Weight (grams) } & 196 & 112 \\ \text { Rabdotus Shel1 Count } & 381 & 383 \\ \text { Bone Weight (grams) } & 2.8 & 0.4 \\ \text { Primary Flake Count } & 6 & 2 \\ \text { Secondary Flake Count } & 94 & 44 \\ \text { Tertiary Flake Count } & 129 & 60 \\ \text { Chip Count } & 244 & 95\end{array}$

No habitational features were defined in the Area B excavation.

Other artifacts found in Area B are listed below:

\begin{tabular}{cccl|cc} 
Group & Form & Specimen & Category & Horizon 1 & Horizon 2 \\
\hline 1 & - & - & Cores & 1 & 0 \\
5 & - & - & Cores & 3 & 1 \\
7 & 2 & - & Thick Bifaces & 0 & 1 \\
8 & - & - & Thick Bifaces & 1 & 1 \\
4 & 4 & 12 & Thin Bifaces & 0 & 1 \\
9 & - & - & Thin Bifaces & 1 & 0 \\
10 & - & - & Thin Bifaces & 1 & 1 \\
1 & 2 & - & Modified Sandstone & 0 & 1 \\
- & - & - & Satin Spar Gypsum & 0 & 0 \\
- & - & - & Modified Mussel Shel1 & 1 & 1
\end{tabular}


Six unit blocks--designated Areas $A, C, D, F, G$, and $\mathrm{H}$--were excavated at the east end of 41 LK 74 ( $F i g .23$ ). Units constituting each area, as well as the number of 10-cm-thick levels excavated in each, are as follows: Area A--N977 E1000 (four leve1s), N977 El001 (five leve1s), N978 El000 (four leve1s), N978 El001 (four levels); Area C--N987 E990 (two leve1s), N987 E991 (four leve1s), N988 E990 (two leve1s), N988 E981 (four 1eve1s); Area D--N980 E989 (two levels), N981 E988 (two levels), N981 E989 (one level); Area F--N994 E985 (two levels), N994 E986 (four levels), N995 E981 (one leve1), N995 E985 (three 1eve1s), N995 E986 (three leve1s); Area G--N986 E973 (one 1eve1); Area H--N977 E973 (four leve1s), N977 E974 (one leve1), N978 E973 (one leve1). N978 E974 (four levels). Surface elevation ranges for each area were as follows: Area A, 99.69-99.63 m; Area C, 99.45-99.36 m; Area D, 99.7099.64 m; Area F, 99.16-99.12 m; Area G, 99.50-99.43 m; and Area H, 99.56$99.55 \mathrm{~m}$. The soil matrix in all of these units was characterized as grayish brown fine sandy loam from the surface to a depth of 30 to $40 \mathrm{~cm}$. Below this leve1, soil changed in color to grayish tan. Horizons were not defined in any of these areas. Rates of recovery for selected classes of debris recovered from each of these six areas (al1 units and levels combined) are as follows:

Tuff Weight (grams)

Sandstone Weight (grams)

Fire-Fractured Rock Weight (grams)

Mussel Shel1 Umbo Count Mussel Shel1 Weight (grams)

Rabdotus She11 Count Bone Weight (grams)

Primary Flake Count Secondary Flake Count Tertiary Flake Count Chip Count

\section{Areas}

$\begin{array}{rrrrrr}\text { A } & \text { C } & \text { D } & \text { E } & \text { G } & \text { H } \\ 170 & 129 & 57 & 67 & 8 & 122 \\ 298 & 173 & 123 & 401 & 12 & 91 \\ 1267 & 1672 & 793 & 2043 & 258 & 776 \\ & & & & & \\ 327 & 449 & 260 & 177 & 17 & 284 \\ 112 & 184 & 56 & 61 & 4 & 25 \\ 96 & 121 & 62 & 187 & 16 & 122 \\ 0 & 0 & 0.7 & 0 & 0 & 0 \\ 12 & 10 & 6 & 21 & 0 & 0 \\ 233 & 101 & 57 & 83 & 5 & 25 \\ 366 & 171 & 93 & 103 & 4 & 24 \\ 680 & 546 & 92 & 243 & 16 & 145\end{array}$

One habitational feature was isolated in the Area F excavation at 41 LK 74. It consisted of a scattered cluster of fire-fractured rock and sandstone. The scatter measured $2 \mathrm{~m}$ east-west and rough $1 \mathrm{y} 1.2 \mathrm{~m}$ north-south. Elevations on the surface, where the rocks composing the feature rested, ranged from 98.77 to $98.87 \mathrm{~m}$. Approximately 70 rocks made up this loose cluster. Sixty of these rocks were fire fractured, and 10 were sandstone. They ranged in size from 3 to $10 \mathrm{~cm}$ (maximum dimension). The rocks occurred in a single layer. A few fragments of mussel shel1 were found amidst the stone. No carbon was noted.

Additional artifacts recovered from Areas $A, C, D, E, G$, and $H$ are 1 isted below: 


\begin{tabular}{|c|c|c|c|c|c|}
\hline Group & Form & Specimen & Category & I Area & Count \\
\hline & $=$ & & & 1 & \\
\hline 1 & - & $\overline{-}$ & $\begin{array}{l}\text { Cores } \\
\text { Cores }\end{array}$ & $\begin{array}{l}A \\
F\end{array}$ & $\frac{1}{1}$ \\
\hline 2 & - & - & Cores & $\mathrm{C}$ & $\begin{array}{l}1 \\
1\end{array}$ \\
\hline 5 & - & - & Cores & $A$ & 2 \\
\hline- & - & - & Cores & $\mathrm{C}$ & 3 \\
\hline$\overline{-}$ & - & - & Cores & $F$ & 2 \\
\hline 6 & - & - & Cores & $A$ & 2 \\
\hline 3 & - & - & Thick Bifaces & $A$ & $\bar{l}$ \\
\hline 7 & 3 & - & Thick Bifaces & $A$ & 1 \\
\hline 9 & - & - & Thick Bifaces & $D$ & 1 \\
\hline 1 & 1 & 4 & Thin Bifaces & C & 1 \\
\hline 2 & 1 & 6 & Thin Bifaces & C & 1 \\
\hline 2 & 2 & 16 & Thin Bifaces & C & 1 \\
\hline 1 & 3 & 37 Zavala & Thin Bifaces & $D$ & 1 \\
\hline 2 & 2 & 29 & Thin Bifaces & $D$ & 1 \\
\hline 4 & 1 & 10 & Thin Bifaces & D & 1 \\
\hline 9 & - & - & Thin Bifaces & A & 3 \\
\hline- & - & - & Thin Bifaces & $\mathrm{C}$ & 1 \\
\hline 10 & - & - & Thin Bifaces & $D$ & 1 \\
\hline- & - & - & Satin Spar Gypsum & $F$ & 2 \\
\hline- & - & $-\infty$ & Modified Mussel Shell & $F$ & 3 \\
\hline
\end{tabular}

The artifacts col lected from the surface of 41 LK 74 during the course of Phase II investigations were three thick bifaces (one, Group 6, Form 1; one, Group 7, Form 1; and one, Group 8), four thin bifaces (one, Group 2, Form 2; one, Group 3, Form 2: one, Group 9; and one, Group 10), and two distal1y beveled tools (one, Group 8, Form 3; one, Group 9).

Identical in terms of 1 andform setting, 41 LK 74 and 41 LK 14 are a 1 so similar in terms of content of prehistoric cultural debris. Situated on the geologic unit known as the Frio Formation, 41 LK 74 did not offer to prehistoric inhabitants the substantial quantities of tuffaceous rock, profusely available from the Catahoula Formation to the east, or sandstone, massive outcrops of which are exposed to the west as part of Jackson Group geologic strata. What was available locally was gravel and cobble material on the surfaces of old terraces and in bars down in the river channel. The cobbles were hauled up to the main prehistoric activity areas on 41 LK 74 to build hearths and as raw material for chipped stone tool manufacture, and were 1 eft as the residues of fire-fractured rock and debitage that were recovered in large quantities during the archaeological excavations on the site. The deposits containing prehistoric cultural debris at 41 LK 74 were not quite as deep as those at 41 LK 74. Consequent7y, there was even less of an opportunity to recognize debris accumulations resulting from the different periods of prehistoric occupation.

The Phase II assemblage of artifacts collected at 41 LK 74 genera 11 y supports previous assessments to the effect that the site was $v$ isited off and on by human groups through the entire time span of the Archaic. No additional artifacts clearly diagnostic of the Paleo-Indian period were found. A substantial collection of sherds of aboriginal pottery came from the Area $B$ 
excavation. These sherds indicate that Late Prehistoric people were camping in that part of the site. Evidence of Late Prehistoric activity had not surfaced previously. The numerous cores, some thick bifaces, a variety of thin bifaces and biface fragments, and much debitage shows that chipped stone tool making was a somewhat more important activity at 41 LK 74 than at many sites. Here again, the easy access to cobbles on the terrace and in the river channel is the likeliest explanation for increased knapping activity.

The Phase II findings at 41 LK 74 provide no new insights into subsistence habits of the area's prehistoric residents. Musse 11 she11, Rabdotus snail she 11s, and a tiny collection of unidentifiable bone are probably remnants of food consumed by the prehistoric inhabitants. A single sandstone grinding implement might be interpreted as evidence of seed or nut food processing.

From the standpoint of habitational feature and activity area recognition, the findings in the excavations at 41 LK 74 were disappointing. The single hearth feature isolated in Area $F$ was very poorly integrated and really did not provide much useful information. It is likely that prehistoric habitational debris deposited on 41 LK 74 was not buried quick $7 y$ due to the location on a high, old terrace surface where soil deposition was very slow to take place. The cultural remains were probably exposed to disruptive processes such as weathering, erosion, animal movement, and, perhaps most significantly, the activities of later prehistoric inhabitants of the same area. These circumstances probably dictated against the survival of we11integrated habitational features at 41 LK 74 and also prevented the remains from becoming clearly stratified.

\section{LK 236}

Whereas 41 LK 14 and 41 LK 74 occur on high, old terraces above the Frio River, site 41 LK 236 is situated on a 1 ow, active terrace immediately alongside the river (Fig. 1, folded insert). Recorded in 1979 by the CAR survey team, this site has an east-west 1 ength of $700 \mathrm{~m}$, but is on $1 \mathrm{y}$ about $50 \mathrm{~m}$ in width. Most of the site is in a cleared pasture. The northern edge of the site paralleling the Frio River supports riparian vegetation in the form of elm and willow trees, briars, and mustang grape vines. The site was identified on the basis of mussel she11, fire-fractured rock, and debitage observed eroding from the terrace face leading down to the river channel. A much 1 ighter scatter of prehistoric debris out in the pasture was used to define site 1 imits. Sherds of aboriginal pottery seen by the survey crew evidenced a Late Prehistoric component on the site.

During Phase II investigations at 4 I LK 236, the CAR crew excavated seven shovel tests at various locations down the length of the site. The shovel tests revealed that the Late Prehistoric component is buried about $30 \mathrm{~cm}$ below the surface. The range management practices (i.e., brush clearing and root plowing) leading to the establishment of the grass-covered pasture are assumed to have caused considerable disruption of this sha110w1y buried Late Prehistoric component. A second cultural horizon was defined at from 60 to $70 \mathrm{~cm}$ below the surface. A probable hearth feature constructed of sandstone rocks was isolated at $70 \mathrm{~cm}$ below the surface in Test Pit 7 . Below $70 \mathrm{~cm}$, to as much as $120 \mathrm{~cm}$ below the surface, the amount of prehistoric cultural 
debris decreased rapidly. The single artifact collected from 41 LK 236 was a trimmed flake (Group 3, Form 1).

By all indications, 41 LK 236 was a site worthy of controlled excavations. Its deposits were clearly stratified into at least two cultural components, and the lower component contained an integrated habitational feature. Although the shovel tests went no deeper than $1.2 \mathrm{~m}$ below the surface, the 1 andform situation of the site on an active, apparently deep first terrace of the Frio River permits speculation that it may contain older, deeper components much 1 ike those found in 41 LK 31/32, a terrace site located a short distance downstream (Scott and Fox 1982). Other priorities in the Phase II excavation program precluded additional investigations at 41 LK 236.

\section{SIIE GROUP 5}

$\begin{array}{ll}\text { Extensive } & \text { Test } \\ \text { Excavation } & \text { Pits }\end{array}$ Provenienced Unprovenienced

41 LK 51

41 LK 53
41 LK 243
Resurvey or Shovel Tests

41 LK 245

41 LK 247

The five sites in Group 5 are located on the northern side of the Frio River val ley from 5.5 to $8.0 \mathrm{~km}$ west of Choke Canyon Dam (Fig. l, folded insert). The two major sites in the group, 41 LK 51 and 41 LK 53, are located along a wel1-developed channel that now carries runoff from 1 arge areas of floodplain and uplands to the north and northwest of the sites. Known as Opossum Hollow, this drainage is a relict channel of either the Frio River or Opossum Creek. It runs more-or-1ess east to west through the site group area. The distance north from the hollow to the valley margin varies from 0.3 to $1.0 \mathrm{~km}$. Over this area, a number of north-south feeder channels cut down from the valley margin and meet the hollow. Along the hollow, ground relief is not pronounced, being mainly the result of natural levee and terrace development and erosion along the hollow and feeder channels. The surface slopes gently upward from the channel to the adjacent valley margin. Bedrock in the area is the Jackson Group. It is buried beneath a thick mantle of al luvium on the floodplain, but does crop out in some places along the valley margin. The valley margin north of the site group area is characterized by dense lag gravel pavement. Sandstone, a component of the Jackson Group, al so appears on the valley margin slopes. Floral patterns are quite diverse in the area. Riparian species such as elm, oak, and hackberry grow along the channel of Opossum Hollow. On the floodplain terrace surfaces north and south of the hollow, thickets of mesquite, whitebrush, spiny hackberry, and prickly pear form moderate to dense ground cover. Along the valley margin are dense stands of blackbrush and guajillo. 


\section{LK 51}

Site 41 LK 51 is an open prehistoric site paralleling the south ( $r i g h t$ ) bank of Opossum Hollow for an east-west distance of nearly $2.0 \mathrm{~km}$ (Figs. 1, folded insert; 24). It is estimated to be about $50 \mathrm{~m}$ in width. The site rests on a series of low terraces and natural levees beside the channel of Opossum Hollow. The condition of the site surface varies greatly from largely undisturbed to heavily eroded. Erosion has been more severe over the eastern half of the site. The erosion occurs mainly in a narrow band along the bank of the hollow. Long, shallow gullies and large deflated areas are common in this portion of the site. The eastern end of 41 LK 51 was partially cleared of brush at sometime in the recent past. However, whitebrush, prickly pear, and smal1 mesquites have again grown to form a 10 , dense brush cover. Native brush grows in dense thickets over the western half of 41 LK 51. Mesquite, whitebrush, spiny hackberry, guayacan, prickly pear, tasaji110, and various grasses are common at this end of the site. In the western central area of the site, there is a natural levee that forms a locally higher bank along the hollow for a distance of at least $200 \mathrm{~m}$ east-west (Fig. 24). This area was relatively intact except for some minor gullying and deflation at its eastern end. Dense surface concentrations of fire-fractured rock, sandstone, debitage, and mussel shel1 characterize the eroded and deflated areas of the site.

Site 41 LK 51 was original1y recorded by THC surveyors. They 1 isted the site as containing Archaic (undifferentiated) and Late Prehistoric components (Lynn, Fox, and O'Mal ley 1977:44). The CAR crew excavated three 1-m ${ }^{2}$ test pits and made a collection of surface artifacts during the Phase I investigation of 41 LK 51 (Ha11, Black, and Graves 1982:132-135). Analysis of the Phase I data established the presence of Midd le Archaic, Late Archaic, and Late Prehistoric components within the site. In Test Pit 3, excavated to a depth of $120 \mathrm{~cm}$ below the surface, three debris horizons were defined (ibid.:134-135). Based on the test pit findings, it appeared that productive, we11-preserved subsurface deposits of prehistoric cultural debris were present over most of the area between Test Pits 2 and 3 . Deposits in the vicinity of Test Pit 3 looked especially promising.

Phase II archaeological investigations at 41 LK 51 took place in March and June 1981. During 10 days in March, a seven member CAR crew worked in the Area A excavations for a tota 1 of 528 person hours. In June 1981, members of the Texas Archeological Society participating in the summer field school at Choke Canyon worked at 41 LK 51 for seven days. Numbering between 15 and 40 individua1s, the TAS members invested over 500 person hours of effort at the site. Thus, a tota 1 of over 1000 person hours was expended in the Phase II investigation of 41 LK 51.

An excavation grid was set out at 41 LK 5l. A steel spike driven into the trunk of a mesquite tree near the Area $A$ excavation served as the vertical datum. USBR surveyors 1 ater calculated a true elevation of 181.756 feet above MSL for this datum. They also placed a permanent marker along the baseline for the archaeological grid system and determined its exact location expressed as Modified Texas State Plane Coordinates. 
Figure 24. Topographic Map of 41LK51 41LK53 and Surrounding Area.

PAGE 91 REDACTED 
Five areas, designated Areas A to E, were excavated at 41 LK 51 (Fig. 25). Area $A$ was $p 1$ aced at the same 1 ocation as Test Pit 3 , excavated during the Phase I investigation. This area was worked by the CAR crew. It consisted of six $1-\mathrm{m}^{2}$ units, each of which was dug in arbitrary vertical 1evels of $10 \mathrm{~cm}$ (Fig. 2l,c,d). The six units and number of 10-cm-thick levels excavated in each are as follows: N998 E981 (17 1eve1s), N998 E982 (17 leve1s), N998 E984 (17 1eve1s), N999 E981 (17 leve1s), N999 E982 (17 1eve1s), and $N 999$ E984 (2l leve1s). Surface elevations ranged from 99.76 to $99.78 \mathrm{~m}$. Four debris horizons were defined within the deposit excavated from Area $A$. The horizons defined and the levels each represents are Horizon 1, Levels 14; Horizon 2, Levels 5-9; Horizon 3, Levels 10-13; and Horizon 4, Levels 1417 or 21. Rates of recovery for selected classes of debris from the four horizons defined in Area $A$ at 41 LK 51 are as follows:

Horizons

$\begin{array}{lrrrr} & 1 & 2 & 3 & 4 \\ \text { Tuff Weight (grams) } & 93 & 240 & 54 & 18 \\ \text { Sandstone Weight (grams) } & 494 & 809 & 1486 & 550 \\ \text { Fire-Fractured Rock Weight (grams) } & 1266 & 1929 & 1502 & 168 \\ \text { Musse1 She11 Umbo Count } & 664 & 637 & 359 & 202 \\ \text { Musse1 Shel1 Weight (grams) } & 270 & 181 & 111 & 66 \\ \text { Rabdotus Shel1 Count } & 1536 & 3568 & 2407 & 1812 \\ \text { Bone Weight (grams) } & 19 & 19 & 1 & 2 \\ \text { Primary Flake Count } & 8 & 12 & 18 & 8 \\ \text { Secondary Flake Count } & 164 & 232 & 310 & 151 \\ \text { Tertiary Flake Count } & 375 & 538 & 720 & 400 \\ \text { Chip Count } & 691 & 1003 & 1368 & 742\end{array}$

Other artifacts recovered from the four horizons defined in the Area $A$ units are 1 isted below:

\begin{tabular}{|c|c|c|c|c|c|c|c|c|}
\hline \multirow[b]{2}{*}{ Group } & \multirow[b]{2}{*}{ Form } & \multirow[b]{2}{*}{ Specimen } & \multirow[b]{2}{*}{ Category } & \multicolumn{2}{|c|}{$\begin{array}{l}1 \\
1\end{array}$} & \multicolumn{2}{|c|}{$\begin{array}{l}\text { Area A } \\
\text { Horizor }\end{array}$} & \multirow[b]{2}{*}{4} \\
\hline & & & & $i$ & 1 & 2 & 3 & \\
\hline & & & & & & & & \\
\hline 1 & - & - & Cores & $i$ & 0 & 1 & 0 & 0 \\
\hline 2 & - & - & Cores & i & 2 & 0 & 1 & 1 \\
\hline 3 & - & - & Cores & 1 & 0 & 3 & 3 & 0 \\
\hline 5 & - & - & Cores & i & 1 & 1 & 1 & 0 \\
\hline 6 & - & - & Cores & i & 1 & 0 & $\overline{0}$ & 1 \\
\hline 1 & - & - & Thick Bifaces & i & 0 & 1 & 0 & 0 \\
\hline 2 & - & - & Thick Bifaces & i & 0 & 0 & 1 & 0 \\
\hline 7 & 1 & - & Thick Bifaces & 1 & 0 & 1 & 1 & 0 \\
\hline 8 & - & - & Thick Bifaces & i & 1 & 0 & 0 & 0 \\
\hline 9 & - & - & Thick Bifaces & $i$ & 0 & 1 & 0 & 0 \\
\hline 1 & 3 & 19 & Thin Bifaces & 1 & 0 & 0 & 0 & 1 \\
\hline 1 & 6 & 1 & Thin Bifaces & $i$ & 1 & 0 & 0 & 0 \\
\hline 1 & 7 & 1 & Thin Bifaces & i & 1 & 0 & 0 & 0 \\
\hline 2 & 1 & 4 & Thin Bifaces & $i$ & 0 & 1 & 0 & 0 \\
\hline 2 & 2 & 15 & Thin Bifaces & 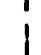 & 0 & 0 & 0 & 1 \\
\hline
\end{tabular}



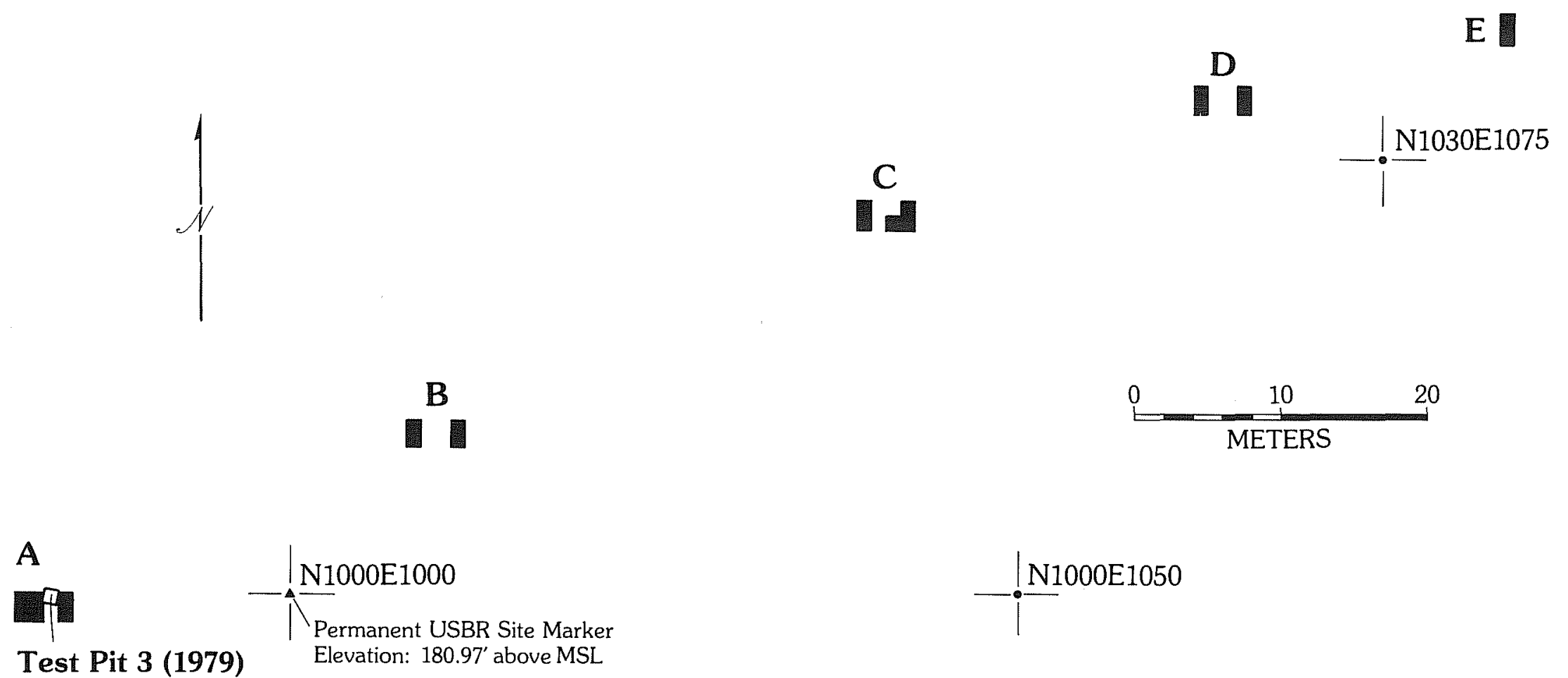

4 Point Shown on Topographic Map of Site

Excavation Area

I-Archaeological Grid Point

\section{LK51 \\ PLAN OF EXCAVATIONS}

Figure 25. Plan of Excavations at 41 LK 51. 


\begin{tabular}{|c|c|c|c|c|c|c|c|}
\hline 2 & 2 & 27 & Thin Bifaces & 1 & 0 & 0 & 1 \\
\hline 3 & 1 & 1 & Thin Bifaces & 1 & 0 & 0 & 0 \\
\hline 3 & 2 & 12 & Thin Bifaces & 1 & 0 & 0 & 1 \\
\hline 4 & 1 & 5 & Thin Bifaces & i & 1 & 0 & 0 \\
\hline 4 & 1 & 6 & Thin Bifaces & 1 & 0 & 0 & 0 \\
\hline 4 & 1 & 7 & Thin Bifaces & i & 9 & 1 & 0 \\
\hline 4 & 4 & 4 & Thin Bifaces & $i$ & 0 & 0 & 0 \\
\hline 4 & 4 & 5 & Thin Bifaces & 1 & 0 & 0 & 0 \\
\hline 4 & 4 & 6 & Thin Bifaces & 1 & 0 & 0 & 0 \\
\hline 4 & 4 & 96 & Thin Bifaces & 1 & 1 & 0 & 0 \\
\hline 5 & - & 2 & Thin Bifaces & 1 & 0 & 1 & 0 \\
\hline 8 & - & 8 & Thin Bifaces & 1 & 0 & 0 & 0 \\
\hline 9 & - & - & Thin Bifaces & i & 2 & 3 & 1 \\
\hline 10 & - & - & Thin Bifaces & i & 6 & 0 & 2 \\
\hline 3 & 4 & 1 & Trimmed Flake & $i$ & 0 & 0 & 0 \\
\hline 1 & 3 & - & Modified Sandstone & 1 & 0 & 1 & 0 \\
\hline 2 & 2 & - & Modified Sandstone & 1 & 0 & 1 & 1 \\
\hline 2 & 3 & - & Modified Sandstone & 1 & 3 & 1 & 0 \\
\hline 3 & - & - & Modified Sandstone & 1 & 1 & 0 & 1 \\
\hline- & - & - & Ocher & 1 & 0 & 2 & 1 \\
\hline- & - & 1 & Modified Bone & I & 0 & 1 & 0 \\
\hline- & - & 4 & Marine Shell & 1 & 0 & 0 & 1 \\
\hline- & - & - & Aboriginal Ceramics & i & 44 & 1 & 0 \\
\hline
\end{tabular}

Soil characteristics and zonation observed in the Area A excavation are summarized in Figure 26. The location of a soil sample column collected from this excavation is also shown. Samples collected from the column are curated at the CAR-UTSA.

Six features were recorded during the course of excavations in Area $A$ at 41 LK 51. Feature 1 was a concentration of burned clay and sandstone isolated in Horizon 2 (Levels 5 and $6,99.40$ to $99.20 \mathrm{~m}$ ) in the northeast corner of Unit $N 999$ E982. The feature has a semicircular out 1 ine shape, appearing to be perhaps a quarter or third of a circular, more extensive feature that extends beyond the limits of the unit. Dimensions of the exposed portion of the feature are $20 \mathrm{~cm}$ north-south and $60 \mathrm{~cm}$ east-west. It is composed of 12 pieces of burned clay, 18 pieces of sandstone, two firefractured rocks, and some debitage. Significantly, all of the clay and three of the largest pieces of sandstone were found in Leve1 5 (99.40 to $99.30 \mathrm{~m})$. After these materials were removed, the remainder of the sandstone was found over the same area at a slightly deeper elevation (99.26 to $99.29 \mathrm{~m}$ ). A smal1 amount of carbon was collected. The sample was inadequate for the purpose of radiocarbon assay.

Feature 2 in Area A was first recognized in Leve1 $3(99.60$ to $99.50 \mathrm{~m})$ of Unit $N 998$ E984. Consisting of a mass of carbonized wood, this feature was subsequently determined to be a burned stump or root. Excavation in the next level revealed portions of unburned wood in the same mass of material.

Feature 3 at 41 LK 51 was defined in Horizon 2 (Leve1 6, 99.30 to 99.20 m) of Unit $N 998 \mathrm{E} 991$ in Area A. Consisting of a somewhat heavier scatter of mussel she11, sandstone, fire-fractured rock, debitage, and bone, the feature was 


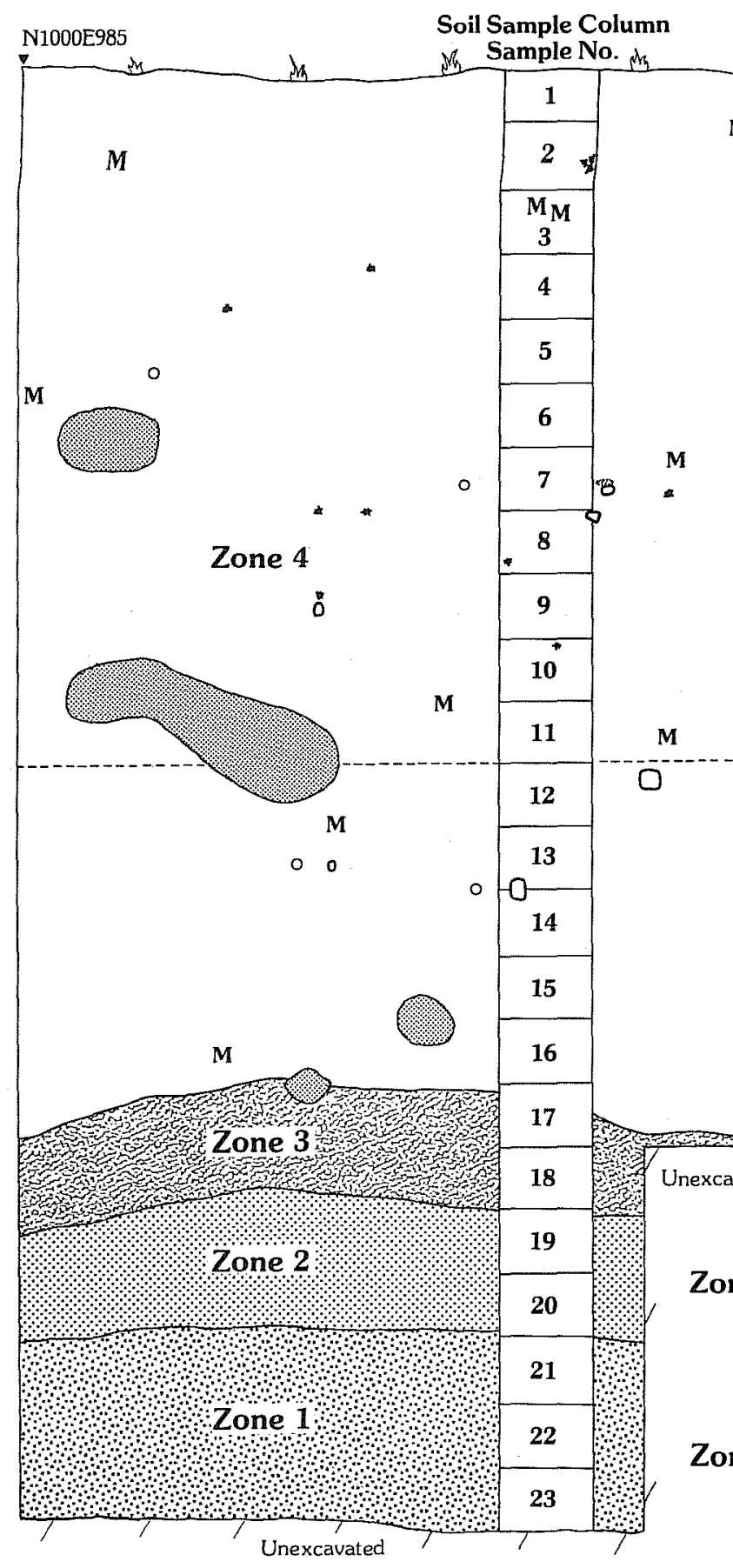

$O$ Sandstone

Fire-Fractured Rock

- Solid Carbon

* Carbon Flecks M Mussel Shell

41LK51
- Rabdotus Snail Shell

B Bone

Do Debitage

\%Insect/Rodent

Disturbance

AREA A

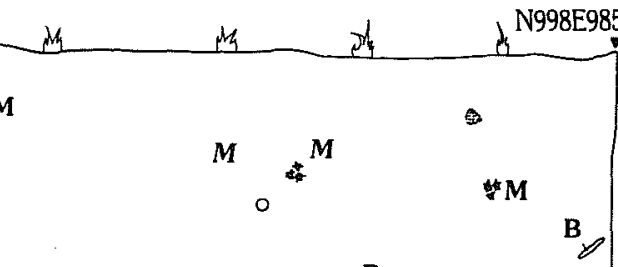

* * Bo Bo * * * * *

$\mathrm{M}_{-\mathrm{B}}^{\mathrm{B}^{\mathrm{P}}}$

$*$
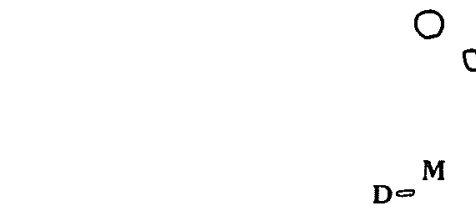
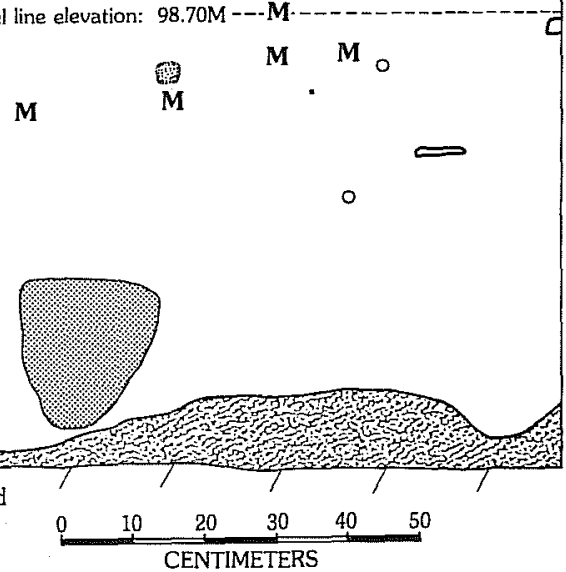

Zone 4 Color: very dark grayish brown (10YR3/2). A clayey loam containing cultural material primarily in the upper $1.3 \mathrm{M}$ of deposit.

Zone 3 Color: light yellowish brown (10YR6/4). A loam containing some carbonate concretions. No cultural material.

Zone 2 Color: light yellowish brown (10YR6/4). A compact sandy clay loam with abundant carbonate concretions. No cultural material.

Zone 1 Color: very pale brown to light yellowish brown (10YR7/4-6/4). Compact sandy clay loam. No cultural material.

\section{PROFILE SKETCH ALONG E985 LINE FROM N998 TO N1000}

Figure 26. Profile Sketch A10ng E985 Line from N998 to N1000 at 41 LK 51 , Area A. 
found to have no integrity. It was simply a localiy heavier accumulation of midden debris.

Feature 4 was a small, single layer cluster of sandstone isolated in Horizon 2 (Leve1 9, 98.90 to $98.80 \mathrm{~m}$ ) of Unit N998 E982. Composed of about 12 pieces of sandstone arranged in a subcircular cluster, the feature measured $40 \mathrm{~cm}$ in diameter. A few pieces of chert debitage were scattered in among the sandstones. No carbon was observed.

Feature 5 consisted of a tight concentration of fire-fractured rock and looser concentrations of tuff and sandstone exposed in Leve 111 (98.80 to $98.70 \mathrm{~m}$ ) of Units $N 999 \mathrm{E981}$ and $\mathrm{N} 999 \mathrm{E982}$ ( $\mathrm{F}$ ig. 27). The recovery level is within Horizon 3. The main portion of the feature occurs in Unit N999 E981 where there is a dense concentration of fire-fractured rock and spalis in the northwest corner. A large biface fragment was found in this concentration. Notable amounts of burned chert debitage also occurred along with the firefractured rock. Scattered out in a band trending from northeast to southwest across the central part of the units was a $1005 e 1 y$ consolidated group of tuffaceous rock, sandstone, and fire-fractured rock. Mussel shells were found amidst these rocks. There was 1 ittle vertical separation ( $\pm 8 \mathrm{~cm}$ ) between al1 components of the feature. Mussel she11 (not too much), Rabdotus snail shel15, debitage, and more fire-fractured rock were recovered from the matrix excavated from the level. The feature was essentially a single layer construct. Only flecks of carbon were seen in and around the feature.

Feature 6 was encountered in Level $12(98.70$ to $98.60 \mathrm{~m})$ of Unit N998 E981 (Figs. $21, e, f ; 28$ ). It consists of a subcircular, single 7 ayer cluster of more than 30 tuffaceous rocks, four pieces of sandstone, and elght pieces of fire-fractured rock. The feature is roughly $50 \mathrm{~cm}$ in diameter. The tuffaceous rock fragments appear to be part of a large piece of tuff that was originaliy used to bulld the feature. The soil around the rocks had a burned appearance, but no distinct pit was visible. Several pieces of debitage were scattered around the feature as were some mussel shel1 fragments, Rabdotus snail shel15, and a few, poorly preserved bone fragments. A large chunk of carbon was found among the rocks (Fig. 28). Feature 6 occurred in Horizon 4.

Twenty centimeters be 1 ow and just east of Feature 6, a mass of carbonized wood was found in Horizon 4 (Level 15, 98.40 to $98.30 \mathrm{~m}$ ) of Unit N998 E982 in Area $A$ (Figs. 2l,e,f; 28). This carbon is apparently not a result of the same activity period that resulted in creation of Feature 6 . The carbon was split into two samples and submitted to the Radiocarbon Laboratory, The University of Texas at Austin, for assay. The two samples, TX-4690 and TX4691, ylelded corrected ages 5130 to 5110 B.C. and 4450 B.C., respectively. The wood burned to form the carbon has been identified as Acacla or Prosopls (see Appendices II and VI).

Areas $B, C, D$, and $E$ at 41 LK 51 were excavated in June 1981 by members of the Texas Archeological Society Summer Field School. Because the field school was seven days in length and severely hampered by unseasonable rainfall. only the upper two horizons were sampled in these four excavation areas. Area locations are shown in Figure 25. 


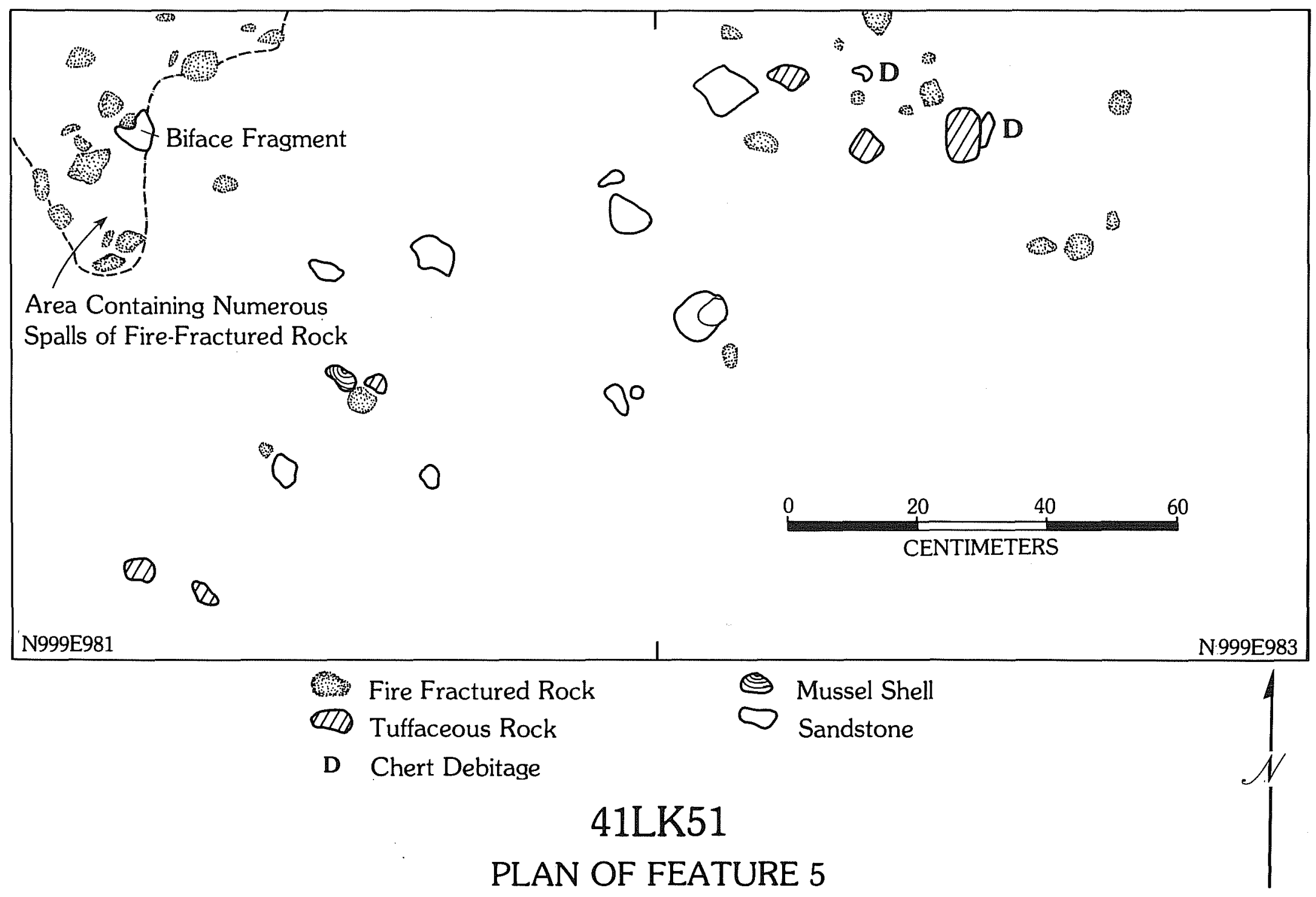

Figure 27. Plan of Feature 5 at 41 UK 51.

$\mathscr{v}$ 


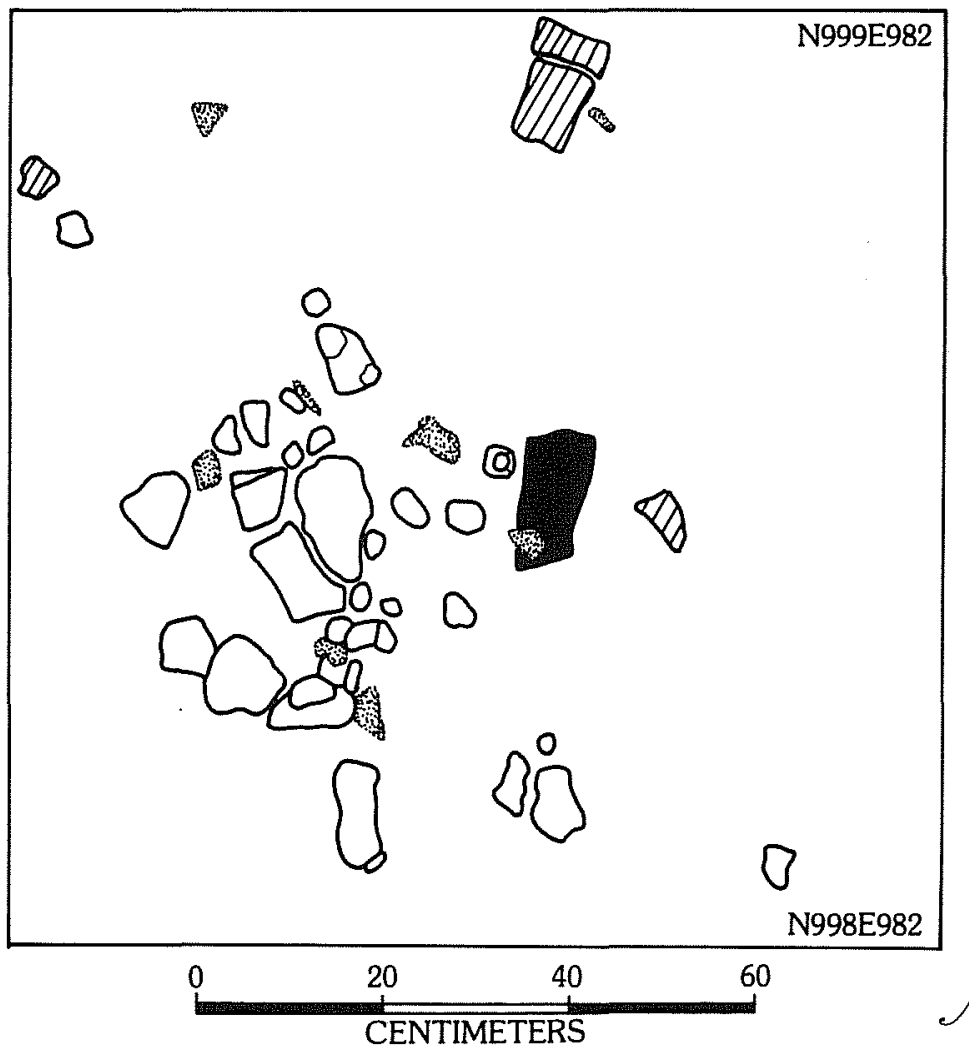

$\circlearrowright$ Tuffaceous Rock

Sandstone

Fire-Fractured Rock

Solid Carbon

FEATURE 6

N998E981

LEVEL 12 (98.70-.60)

CARBONIZED WOOD

N998E982

LEVEL 15 (98.40-.30)

Thin Biface $\triangle$

(8-8)

\section{LK51}

FEATURE PLANS

Figure 28. Plan of Feature 6 at 41 LK 51. 
Area B consisted of four $1-\mathrm{m}^{2}$ units. Unit coordinates and number of $10-\mathrm{cm}-$ thick levels excavated in each unit are as follows: N1010 El008 (one level), N1010 El011 (11 levels), N1011 El008 (two levels), and N1011 El011 (eight levels). Surface elevations ranged from 99.85 to $99.91 \mathrm{~m}$. Of these four units, only Unit N1010 ElOll went deep enough to provide a useful sample of Horizon 2 material. In this unit, Horizon 1 represents material from Levels 1-4 and Horizon 2, Levels 5-11. Rates of recovery for selected classes of debris from the Area $B$ excavations are as follows:

\begin{tabular}{|c|c|c|}
\hline \multicolumn{2}{|c|}{ Unit N1010 E1011 } & \multirow{2}{*}{$\begin{array}{l}\text { A]1 Other } \\
\text { Levels }\end{array}$} \\
\hline & & \\
\hline 1 & 2 & \\
\hline 53 & 176 & 91 \\
\hline 69 & 384 & 161 \\
\hline 155 & 376 & 485 \\
\hline 55 & 35 & 355 \\
\hline 30 & 13 & 125 \\
\hline 269 & 995 & 625 \\
\hline 2 & 3 & 2 \\
\hline 2 & 3 & 1 \\
\hline 15 & 36 & 28 \\
\hline 23 & 57 & 33 \\
\hline 111 & 174 & 179 \\
\hline
\end{tabular}

Also recovered from the Area B excavation at 41 LK 51 were four cores (two, Group 2; one, Group 3; one, Group 5), six thin bifaces (Group 1, Form 7, Specimen 2; Group 5, Specimen 3; four, Group 10), a distally beveled tool (Group 3, Form 1, Specimen 2), a piece of modified sandstone (Group 1, Form 2), and two sherds of aboriginal ceramics.

Area $C$ consisted of five $1-\mathrm{m}^{2}$ units. Unit coordinates and number of 10-cmthick levels excavated in each unit are as follows: N1025 E1039 (four levels), N1025 E1041 (six levels), N1025 E1042 (five levels), N1026 El039 (five leve1s), and N1026 El042 (four levels). Surface elevations ranged from 99.86 to $99.89 \mathrm{~m}$. No horizon separations were recognized in the Area C units. Rates of recovery for selected classes of debris from all units and levels of Area $C$ are as fol lows:

Areac

All Levels Combined

Tuff Weight (grams)

555

Sandstone Weight (grams)

1182

Fire-Fractured Rock Weight (grams) 2882

Mussel She11 Umbo Count 553

Mussel She11 Weight (grams) 184

Rabdotus She11 Count 1919

Bone Weight (grams) 76

Primary Flake Count $\quad 12$

Secondary Flake Count $\quad 151$

Tertiary Flake Count $\quad 392$

$\begin{array}{lr}\text { Chip Count } & 1221\end{array}$ 
Other artifacts recovered in Area C at 41 LK 51 include five cores (one, Group 1; one, Group 2; three, Group 5), two thick bifaces (one, Group 6, Form 2; one, Group 7, Form 1), 11 thin bifaces (Group 1, Form 3, Specimen 12 [Fair1and]; Group 1, Form 3, Specimen 13 [Fairland]; Group 3, Form 1, Specimen 2; Group 3, Form 2, Specimen 2; Group 4, Form 1, Specimen 8; Group 4, Form 4, Specimen 7; one, Group 9; four, Group 10), one dista11y beveled tool (Group 3, Form 1, Specimen 1), four pieces of modified sandstone (one, Group 1, Form 3; two, Group 2, Form 3; one, Group 3), one piece of modified quartzite (Specimen 1), and one piece of satin spar gypsum. A very unusual artifact recovered from Level 1 (surface to $99.80 \mathrm{~m}$ ) of Unit N1026 El042 of Area $C$ was a chunk of obsidian debitage. This artifact is discussed in more detail in Appendix $V$.

Four $1-m^{2}$ units made up Area $D$ at 41 LK 51. Unit coordinates and number of 10-cm-thick levels excavated in each unit are as follows: N1033 E1062 (three levels, N1033 El065 (10 leve1s), N1034 El062 (three leve1s), and N1034 El065 (10 1eve1s). Surface elevations ranged from 99.75 to $99.79 \mathrm{~m}$. Units N1033 E1065 and N1034 E1065 reached depths of $100 \mathrm{~cm}$ below the surface, and it was possible to identify two horizons within the material recovery. For these two units, Horizon 1 contains debris recovered from Levels 1-5, and Horizon 2 contains debris from Leve1s 6-10. Rates of recovery for selected classes of debris from Area $D$ are as follows:

\begin{tabular}{|c|c|c|c|}
\hline & N10: & $\frac{t}{4 \text { EI }}$ & All Other \\
\hline & 1 & 2 & Levels \\
\hline Tuff Weight (grams) & 79 & 95 & 21 \\
\hline Sandstone Weight (grams) & 74 & 341 & 46 \\
\hline Fire-Fractured Rock Weight (grams) & 592 & 1332 & 134 \\
\hline Mussel Shel1 Umbo Count & 238 & 87 & 69 \\
\hline Mussel Shell Weight (grams) & 55 & 27 & 31 \\
\hline Rabdotus She11 Count & 198 & 437 & 85 \\
\hline Bone Weight (grams) & 4 & 18 & 1 \\
\hline Primary Flake Count & 5 & 2 & 1 \\
\hline Secondary Flake Count & 26 & 102 & 14 \\
\hline Tertiary Flake Count & 40 & 101 & 12 \\
\hline Chip Count & 190 & 275 & 81 \\
\hline
\end{tabular}

Additional artifacts recovered from the Area D excavation at 41 LK 51 are four cores (Group 5), one thick biface (Group 7, Form 1), 11 thin bifaces (Group 1, Form 2, Specimen 3 [Langtry]; Group 1, Form 3, Specimen 1 [Ensor]; Group 1, Form 4, Specimen 1 [Perdiz]; Group 1, Form 7, Specimen 3; Group 1, Form 7, Specimen 4; one, Group 9; five, Group 10), one distally beveled tool (Group 8, Form 1, Specimen 1), one piece of modified sandstone (Group 2, Form 2), and two sherds of aboriginal ceramics.

Two $1-m^{2}$ units made up Area $E$ at 41 LK 51. Four 10-cm-thick levels were excavated in Unit N1038 E1083, and five levels were excavated in Unit N1039 E1083. Surface elevations ranged from 99.65 to $99.69 \mathrm{~m}$. No horizons were defined for these units. Rates of recovery for selected classes of debris for Area $E$ are as follows: 
All Levels Combined

Tuff Weight (grams)

16

Sandstone Weight (grams)

Fire-Fractured Rock Weight (grams)

Musse 7 Shell Umbo Count

Mussel She11 Weight (grams)

Rabdotus Shell Count

Bone Weight (grams)

Primary Flake Count

Secondary Flake Count

Tertiary Flake Count

Chip Count

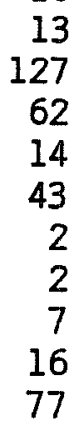

One additional artifact, a thin biface (Group 3, Form 2, Specimen 13), was recovered from Area E.

The Phase II archaeological investigation at 4 L LK 51 produced valuable new information concerning the prehistory of Choke Canyon. Horizon 4 defined deep in the Area $A$ excavation has yielded the oldest radiocarbon dates yet obtained for cultural deposits in the region. The radiocarbon assays designated $T X-4690$ and $T X-4691$ gave corrected ages of 5130 to 5110 B.C. and 4450 B.C., respectively. These assays are 1000 to 1700 years 01 der than assays from site 41 LK $31 / 32$ (TX-2920, TX-2921), dates that previous $7 y$ evidenced the oldest in situ subsurface deposits of cultural material known for the area (Scott and Fox 1982:88): The recovery of a stemmed dart point (thin bifaces Group 1, Form 3, Specimen 19) tentatively identified as an "early expanding stem" (possibly of the Bandy type after Word and Douglas 1970) offers further evidence for the presence of an Early Archaic component deep in the site. Quite remarkable is the fact that carbon from the same source that yielded samples for the above radiocarbon assays has been identified as either acacia or mesquite. This evidence permits the suggestion that many components of the modern brush community at Choke Canyon were present in the area 6000 to 7000 years ago (see further discussion in Appendix II). Six other thin bifaces or biface fragments recovered from Horizon 4 in Area $A$ are not as clearly indicative of the Early Archaic. These were identified as unstemmed triangular and leaf-shaped forms having straight, concave, and convex bases (thin bifaces Groups 2, 3, and 4). Comparing the cultural debris recovery from Horizon 4 with assemblages representing the other three horizons in Area $A$, there are substantially smal ler amounts of fire-fractured rock and mussel she 11 in Horizon 4, but otherwise the collections are much the same. Likewise, the single habitational feature (Feature 6) isolated in Horizon 4 is not remarkably different from features found in higher horizons.

Horizons 2 and 3 in Area $A$ at $4 I$ LK 51 are assumed to contain remnants of Middle Archaic and Late Archaic cultural activities on the site. This assessment is based primarily on bracketing temporal information provided by the Early Archaic indicators in Horizon 4 and the Late Prehistoric diagnostics in Horizon 1. The chipped stone tools found in Horizons 2 and 3 do not aid appreciably in establishing cultural/chronological affiliations for the remains. Judging from the number of habitational features (Features 1, 3, 4, and 5) and the relatively greater amounts of debris 
recovered, Horizons 2 and 3 represent periods during which the site was most intensively occupied.

In the remaining four Phase II excavations at $41 \mathrm{LK} \mathrm{51}$, only the upper two horizons were sampled with Horizon I receiving the most attention. Some additional sherds of aboriginal pottery, a Perdiz arrow point, and dart points of the Ensor and Fairland types show fairly conclusively that deposits excavated in these areas represent the Late Archaic and Late Prehistoric periods. Smaller, triangular distally beveled tools recovered from two of the areas are also suggestive of a Late Archaic component. No additional habitational features were found in Areas $B$ to $E$. The obsidian chunk found in Level 1 of an Area $C$ unit would appear to date to Late Prehistoric times based mainly on its stratigraphic context. This obsidian is of the "Escondido Ranch" type, recently traced back to a source in Idaho (see Appendix $V$ ).

The Phase II findings at 41 LK 51 do not appreciably 111 uminate prehistoric subsistence habits for any of the cultural/chronological periods represented by the debris collections made in the excavation areas. As usual, mussel she11, Rabdotus snail shel1s, and a small amount of mostly unidentifiable animal bone are present. As previously noted, there was substantially less mussel she 11 recovered from Horizon 4 in Area A than from the three horizons above. Fragments of modified sandstone probably representing manos and metates were found on $7 y$ in Horizons $1-3$ of Area $A$. No such artifacts were found in Horizon 4. The absence of grinding implements and the lesser amounts of mussel shel1 in Horizon 4 are cited as evidence of possible dietary distinctions between the Early Archaic (Horizon 4) and later cultural periods (Horizons 1-3).

\section{LK 53}

On the north (1eft) bank of Opossum Hol low opposite the west end of 41 LK 51 is site 41 LK 53 (Fig. l, folded insert). It contains both prehistoric and historic components. The site rests on a natural levee paralleling the hol low for an east-west distance of about $500 \mathrm{~m}$. The site is about $200 \mathrm{~m}$ wide (north-south) as recorded by THC surveyors. The site surface is in fairly good condition, being only moderately deflated along a narrow strip beside the hollow. Brush cover on the site varies from patchy to dense. Whitebrush is very common as are mesquites, prickly pear, acacia, guayacan, and Mexican persimmon.

Phase I investigations at 41 LK 53 consisted of excavation of three $1-m^{2}$ test pits and collection of surface artifacts (Ha) 1, Black, and Graves 1982:135139). The test pits ranged in depth from $70 \mathrm{~cm}$ to $1.1 \mathrm{~m}$. Debris collections were divided into upper and lower horizons. Analysis of chipped stone tools found on 41 LK 53 indicated that the site was inhabited during the Middle Archaic and Late Archaic periods (ibid.:138). The previously unrecorded historic component at the west end of 41 LK 53 evidenced 1 ate 19th- and early 20th-century activity.

The primary Phase II investigation at 41 LK 53 was concerned only with the prehistoric components in the site. The historic component, was later 
investigated by members of the Texas Archeological Society Summer Field School (Fox 1986). Phase II work was done at 41 LK 53 by a CAR crew over a 10-day period in March and April 1981. The eight persons making up this crew spent a total of 536 hours working on the site.

Horizontal control for the Phase II excavations at 41 LK 53 was established by arbitrarily setting an east-west baseline in the immediate area of excavations using a survey transit. For vertical control, a steel spike was driven into the trunk of a mesquite tree north of the excavation area. USBR surveyors 1 ater calculated a true elevation of 181.529 feet above MSL for this datum nai1. They also placed a permanent marker on the site and recorded its 1 ocation in terms of Modified Texas State Plane Coordinates (Figs. 24; 29).

Selection of a location for Phase II excavations at 41 LK 53 was based on findings made in the Phase I testing operation and on the site's surface condition. Test pit findings suggested that deposits in the vicinity of Test Pit 2 would yield the best results. A location approximately $25 \mathrm{~m}$ west of Test Pit 2 was chosen for its proximity to the test pit and because the ground surface showed no signs of disturbance such as would be caused by erosion or brush clearing. An excavation area consisting of nine $1-\mathrm{m}^{2}$ units arranged into a $3-m^{2}$ b 1 ock was 1 aid out (Figs. $29 ; 32$,a). Coordinates for the nine units and number of $10-\mathrm{cm}$-thick levels excavated in each are as follows: N1000 El002 (11 levels), N1000 El003 (11 leve1s), N1000 El004 (17 leve1s), N1001 El002 (11 levels), N1001 El003 (11 leve1s), N1001 El004 (11 leve1s), N1002 El002 (11 leve1s), NI002 El003 (II levels), and N1002 El004 (11 levels). Surface elevations for these units ranged from 99.63 to $99.66 \mathrm{~m}$.

Cultural debris recovered as the $3-m^{2}$ unit block was excavated at 41 LK 53 permitted definition of four horizons down through the deposit. Horizons and corresponding excavation levels are Horizon I, Levels 1-3; Horizon 2, Levels 4-7; Horizon 3, Levels 8-11, and Horizon 4, Levels 12-17 (on $7 y$ in Unit N1000 E1004). Rates of recovery for selected classes of debris for these four horizons are as follows:

Horizons

$\begin{array}{lrrrr} & 1 & 2 & 3 & 4 \\ \text { Tuff Weight (grams) } & & & & 0 \\ \text { Sandstone Weight (grams) } & 4 & 85 & 47 & 56 \\ \text { Fire-Fractured Rock Weight (grams) } & 229 & 978 & 1559 & 72 \\ \text { Musse1 She11 Umbo Count } & 164 & 2585 & 3676 & 4 \\ \text { Musse1 She11 Weight (grams) } & 47 & 151 & 120 & 1 \\ \text { Rabdotus Shel1 Count } & 999 & 4572 & 3261 & 62 \\ \text { Bone Weight (grams) } & 0.8 & 2.9 & 1.1 & 0.1 \\ \text { Primary Flake Count } & 7 & 7 & 10 & 1 \\ \text { Secondary Flake Count } & 122 & 171 & 207 & 2 \\ \text { Tertiary Flake Count } & 253 & 356 & 560 & 14 \\ \text { Chip Count } & 476 & 781 & 1100 & 18\end{array}$




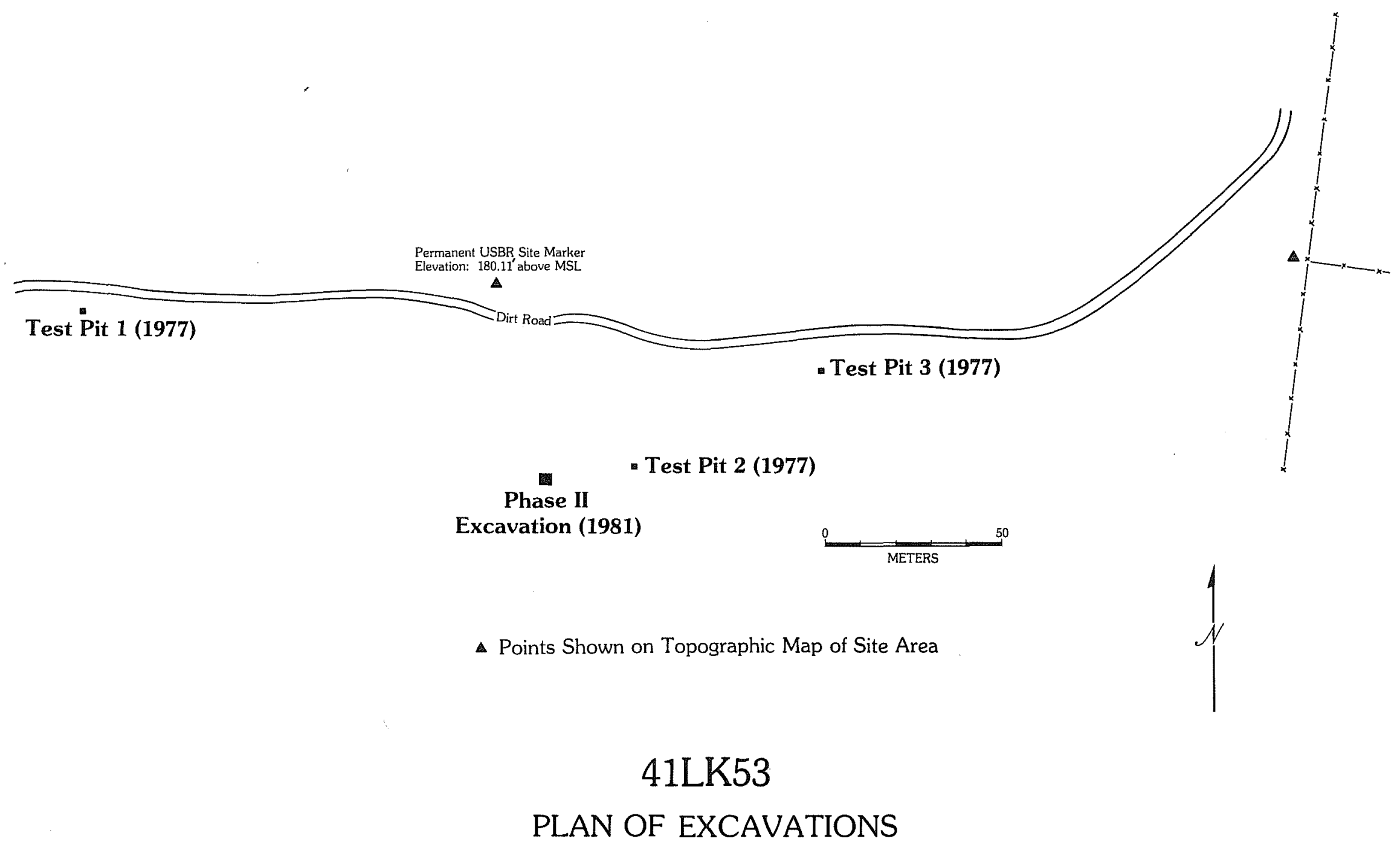

Figure 29. Plan of Excavations at 41 LK 53. 
Other artifacts recovered in the Phase II excavations at 41 LK 53 are 1 isted below.

\begin{tabular}{|c|c|c|c|c|c|c|c|c|}
\hline \multirow[b]{2}{*}{ Group } & \multirow[b]{2}{*}{ Form } & \multirow[b]{2}{*}{ Specimen } & \multirow[b]{2}{*}{ Category } & 1 & \multicolumn{4}{|c|}{ Horizons } \\
\hline & & & & 1 & 1 & 2 & 3 & 4 \\
\hline & & & & $i$ & & & & \\
\hline 1 & - & - & Cores & $i$ & 0 & 1 & 1 & 0 \\
\hline 2 & - & - & Cores & 1 & 0 & 1 & 0 & 0 \\
\hline 3 & - & - & Cores & $i$ & 0 & 0 & 2 & 0 \\
\hline 5 & - & - & Cores & 1 & 0 & 3 & 0 & 0 \\
\hline 6 & 2 & - & Thick Bifaces & $i$ & 0 & 0 & 1 & 0 \\
\hline 1 & 1 & 7 & Thin Bifaces & $i$ & 1 & 0 & 0 & 0 \\
\hline 1 & 3 & 24 & Thin Bifaces & $i$ & 1 & 0 & 0 & 0 \\
\hline 1 & 4 & 2 Perdiz & Thin Bifaces & $i$ & 1 & 0 & 0 & 0 \\
\hline 1 & 5 & 2 Scallorn & Thin Bifaces & $i$ & 1 & 0 & 0 & 0 \\
\hline 1 & 5 & 20 & Thin Bifaces & $i$ & 0 & 1 & 0 & 0 \\
\hline 2 & 2 & 28 & Thin Bifaces & $i$ & 0 & 0 & 1 & 0 \\
\hline 3 & 1 & 3 & Thin Bifaces & $i$ & 0 & 0 & 1 & 0 \\
\hline 4 & 1 & 9 & Thin Bifaces & $i$ & 1 & 0 & 0 & 0 \\
\hline 4 & 3 & 1 & Thin Bifaces & 1 & 1 & 0 & 0 & 0 \\
\hline 4 & 4 & - & Thin Bifaces & $i$ & 1 & 2 & 3 & 0 \\
\hline 9 & - & - & Thin Bifaces & 1 & 2 & 1 & 0 & 0 \\
\hline 10 & - & - & Thin Bifaces & $i$ & 2 & 4 & 2 & 0 \\
\hline 2 & 1 & - & Modified Sandstone & $i$ & 0 & 1 & 0 & 0 \\
\hline 2 & 3 & - & Modified Sandstone & $i$ & 1 & 1 & 1 & 0 \\
\hline 3 & - & - & Modified Sandstone & $i$ & 0 & 2 & $i$ & 0 \\
\hline
\end{tabular}

The zonation and certain characteristics of the soil deposits encountered in the Phase II excavation block at 41 LK 53 are 117 ustrated in Figure 30 (also see Fig. 32,d). Also shown in this figure is the location of a soil sample column. Samples from this column are curated at the CAR-UTSA.

Two habitational features were encountered as excavations took place at 41 LK 53. Feature 1 was a rock scatter found in Level $8(99.00$ to $98.90 \mathrm{~m})$ of Units N1000 E1002 and N1000 El003. It consists of about 65 rocks distributed over an area measuring $108 \mathrm{~cm}$ north-south and $160 \mathrm{~cm}$ east-west. Rough $7 y$ 50\% of the material was fire-fractured rock with tuff and sandstone each comprising about $25 \%$ of the remainder. The stones were in a single 1 ayer over the feature area. Carbon flecking was observed amidst the rocks but no substantial samples were collected. Numerous Rabdotus snail shells, some mussel shell fragments, and debitage were collected from the soil matrix in and around the feature.

Feature 2 was another rock cluster found in Levels 10 and 11 (98.80 to $98.60 \mathrm{~m})$ with portions distributed over eight of the nine units making up the excavation (Figs. 31 ; 32,b,c). It is composed of approximately 140 rocks, 30 to $40 \%$ of which are fire-fractured rocks, perhaps 55\% sandstone, and a very sma 11 percentage of tuff rock. The feature extends 2.9 m north-south and $2.7 \mathrm{~m}$ east-west. The area where rock was most concentrated was along the dividing 1 ine between Units N1001 El002 and N1001 El003. Although its original configuration is unknown, it appears that Feature 2 has been badly disturbed. One possibility is that massive rodent activity evidenced in the 


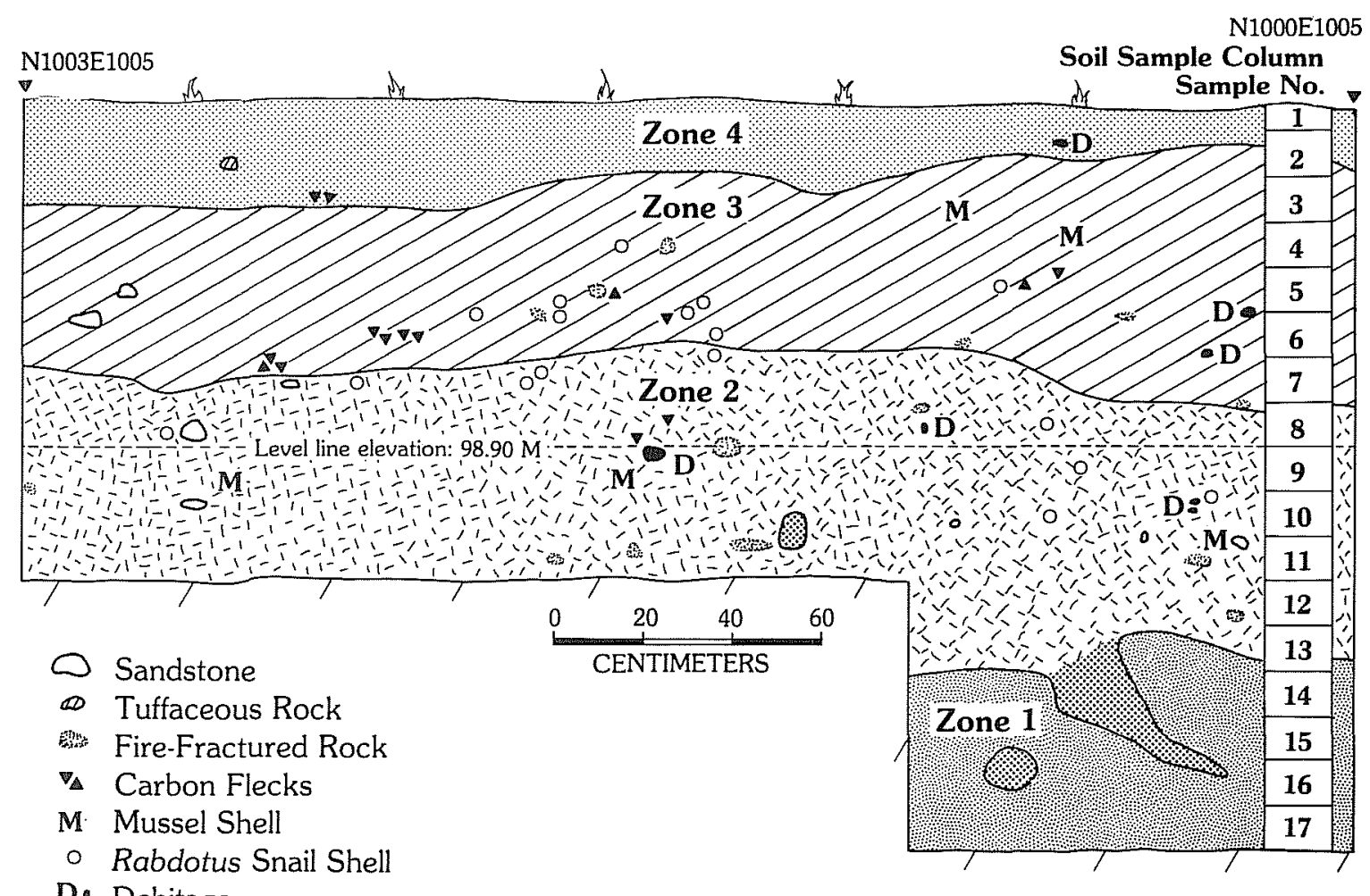

Do Debitage

\%. Insect/Rodent Disturbance

Zone 4 Color: very dark grayish brown (10YR3/2-moist). Silty clay loam.

Zone 3 Color: very dark grayish brown (10YR3/2-moist). Sandy clay loam.

Zone 2 Color: brown (10YR5/3-moist). Silty clay loam.

Zone 1 Color: very pale brown (10YR7/4-moist). Clayey sand.

\section{$41 \mathrm{LK} 53$ \\ PROFILE SKETCH ALONG E1005 LINE FROM N1000 TO N1003}

Figure 30. Profile Sketch Along El005 Line from N1000 to N1003 at 41 LK 53. 
feature area resulted in postdepositional redistribution of feature components. Some of the sandstone in the main concentration was orange red in color as if it had been exposed to heat. Most of the rocks were fistsized or smaller with on $1 y$ six or so having dimensions in the 10 to $13 \mathrm{~cm}$ range. Mussel she11, snail shel1, and one fish otolith were found scattered among the rocks of this feature. Carbon flecking was noted, but it seemed to occur mostly in stained areas related to rodent activity. One biface fragment (thin bifaces Group 4, Form 4, Specimen 97) was found in the feature.

In addition to the two rock scatters defined as features in the excavation at 41 LK 53, there were six smaller, poorly integrated rock groupings recorded. Unit, level, approximate size, and constitution of these smal1 rock clusters were as. fol lows:
Unit
Leve1
Size
Composition

$\begin{array}{lrll}\text { N1000 El003 } & 6 & 60 \times 80 \mathrm{~cm} & 4 \text { sandstones, } 5 \text { fire-fractured rocks } \\ \text { N1000 E1003 } & 9 & 20 \times 50 \mathrm{~cm} & 3 \text { sandstones, } 3 \text { fire-fractured rocks } \\ \text { N1000 E1004 } & 12 & 25 \times 30 \mathrm{~cm} & 10 \text { fire-fractured rocks } \\ \text { N1001 El002 } & 8 & 30 \times 30 \mathrm{~cm} & 3 \text { sandstones, } 5 \text { fire-fractured rocks } \\ \text { N1002 E1002 } & 7 & 30 \times 40 \mathrm{~cm} & \begin{array}{c}\text { tuffaceous rock, snails, musse1 } \\ \text { she } 11, \text { debitage }\end{array} \\ \text { N1002 E1004 } & 5 & 10 \times 20 \mathrm{~cm} & 14 \text { sandstones }\end{array}$

The Phase II investigation conducted at 41 LK 53 reconfirmed the presence of probably Middle Archaic and Late Archaic components in the site and added a previously undetected Late Prehistoric component. Generally speaking, the variety of artifacts recovered in Phase I investigations (especially surface collected specimens) provided a much better selection of time-diagnostic chipped stone artifacts than did the Phase II excavation. The few stemmed thin bifaces and more prevalent unstemmed thin bifaces found in the excavations are not overly useful in attempting to refine the cultura1/ chronological sequence for 41 LK 53.

Perhaps the most important information provided by the Phase II excavation is the evidence for repeated habitation of the site through the Archaic and into the Late Prehistoric. The two features and six smaller rock clusters evidence a series of encampments on the site through time. Concurrent with prehistoric human activity, there was gradual aggradation of deposits on the site, a 1 ikely sign that the present hollow was once a more active water course. Deposits were not accumulating rapidly enough to provide separation of prehistoric cultural debris resulting from successive habitations into discrete, definable stratigraphic units. Although apparently disrupted before burial, the rock clusters nevertheless mark 1 iving surfaces that could not have been identified solely on the basis of the other debris classes recovered.

At 41 LK 53, and at many similar Choke Canyon sites, the combination of slow surface aggradation and repeated human habitational events have caused a vertical "blurring" of habitational detritus that effectively eliminates definition of stratigraphic units any more sensitive than the horizon strata 


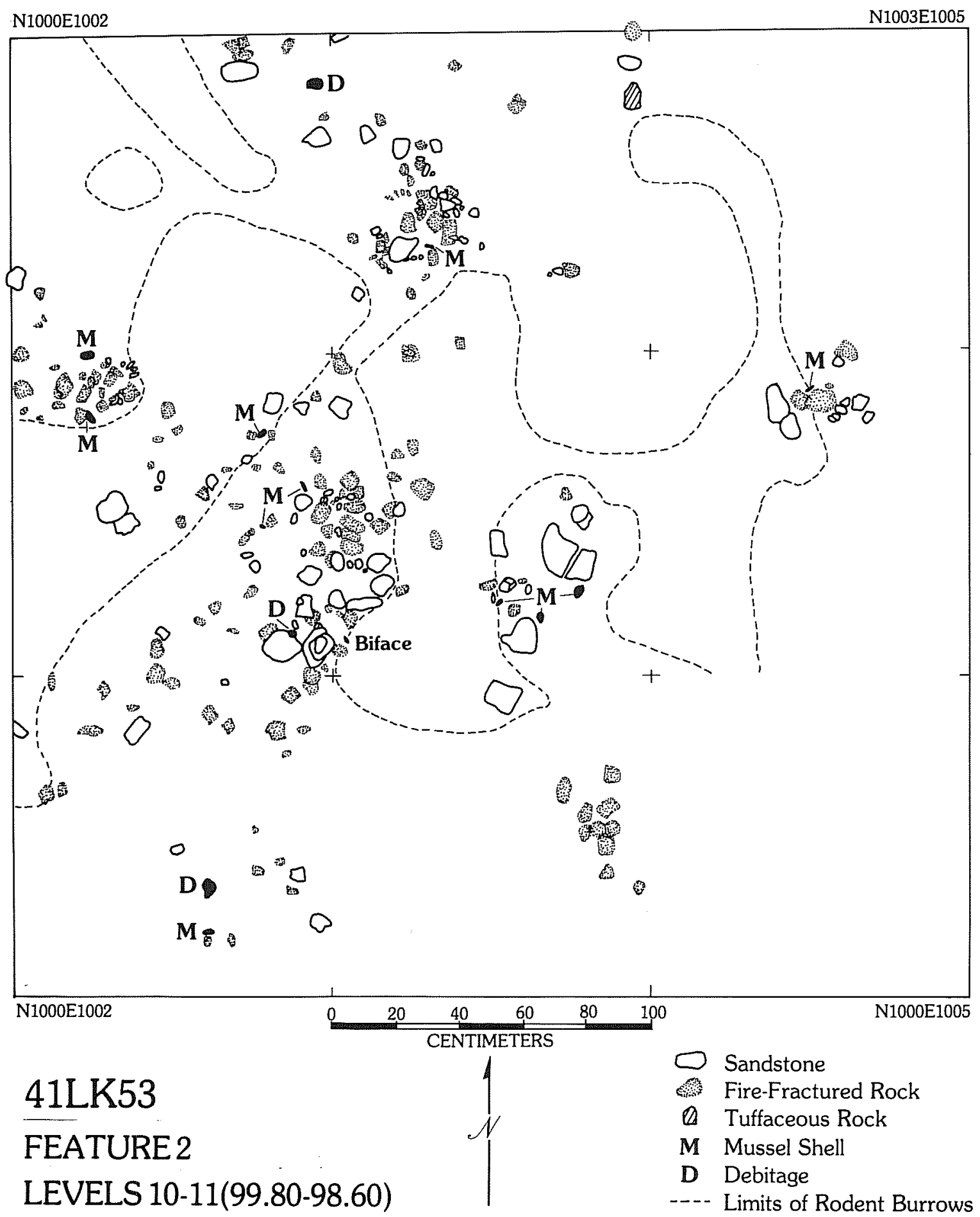

Figure 31. Plan of Feature 2 at 41 LK 53. 
used for analyzing and comparing debris collections in this study. Where debitage, mussel shel15, snail shel1s, and other small debris have undergone a vertical melding process through the centuries, the rock clusters held more firmly and survived to provide insights into the sequencing of prehistoric human activity at 41 LK 53 that might not otherwise have been available.

\section{LK 243}

Site 41 LK 243 was located in 1979 by the CAR survey crew. It is located at the foot of the northern Frio River valley margin (Fig. 1, folded insert). The surveyors recorded dimensions of $130 \mathrm{~m}$ northeast to southwest for the site. The southern end of 41 LK 243 is about $125 \mathrm{~m}$ north of the Opossum Hollow channel. The site surface slopes upward from southwest to northeast and then the valley margin rises quite steeply up above the site to the northeast. The surface in the site area supports a fairly dense brush cover including mesquite, soapbush, whitebrush, guajil10, spiny hackberry, cactus, and various grasses (Fig. 32,e). Some areas of the site are heavily eroded with active gullies coursing downhill through the area. Upslope on the valley wall there is a heavy pavement of lag gravels on the surface.

As 41 LK 243 was initially documented, CAR surveyors noted "semi-distinct concentrations" of mussel she 11 and fire-fractured rock exposed on the surface. Elsewhere the site was characterized by a heavy scatter of firefractured rock, chert debitage, mussel she 11 fragments, and snail she11s. Sherds of aboriginal pottery, a distally beveled tool, several thin biface fragments, and pieces of modified sandstone were among artifacts observed at the site by CAR surveyors.

The CAR crew returned to 41 LK 243 to conduct Phase II investigations in November 1980. Looking the site over once again, comment was made on the severe gullying and sheetwash apparent over most of the site. Near the central part of the site, a layer of gravel (up to cobble size) was noted to be eroding from a gully wall about a meter below the surface. Site dimensions were adjusted slightly to $145 \mathrm{~m}$ east-west by $140 \mathrm{~m}$ north-south. The site was judged to rest on a terrace remnant so badly eroded that no part of the original floodplain remains.

Phase II activities carried out at 41 LK 243 by the CAR crew were excavation of four $1-\mathrm{m}^{2}$ test pits, four shovel tests, production of a $\mathrm{p} 1$ an map showing individual locations of 59 artifacts and a number of habitational features, mapping and collection of three mussel shel1 concentrations, four "dog leash" surface collections ( $80 \mathrm{~cm}$ radius), in situ exposure of a surface hearth, and an uncontrol led collection of surface artifacts.

Test Pit 1 was located in the east-central area of 41 LK 243 (Fig. 33). This unit was excavated to a depth of $60 \mathrm{~cm}$ bel ow the surface (six 10-cm-thick levels). Matrix excavated from the test pit was described as dark brown sandy silt from top to bottom. The debris recovered from Test Pit $I$ is divided into two horizon assemblages. Horizon 1 contains debris from Levels 1-3, and Horizon 2 contains the debris from Levels 4-6. Rates of recovery for selected classes of debris recovered from the horizons in this unit are as follows: 
Figure 32. Phase II Investigations at 41 LK 53 and 41 LK 243.

a, view looking northwest across the Phase II excavations at 41 LK 53. Note the dense brush cover everywhere on the site and the valley margin on the horizon in the upper right corner of the picture;

b. exposure and recording of Feature 2 underway at 41 LK 53;

c. view looking down and west into the $3-\mathrm{m}^{2}$ pit excavated during Phase II investigations at 41 LK 53. Feature 2 in Levels 9-11 (98.90 to 98.60$)$ is shown ful1y exposed. See Figure 31 for additional details;

d. view of the east wal 1 profile of the $3-m^{2}$ pit excavated during Phase II investigations at 41 LK 53. See Figure 30 for further details;

e, view east of testing underway at 41 LK 243. The unit is Test Pit 1 located at the site's east end. Note mussel and snail shells eroding from gully in foreground;

f. plan view of Hearth 4 exposed at 41 LK 243. 


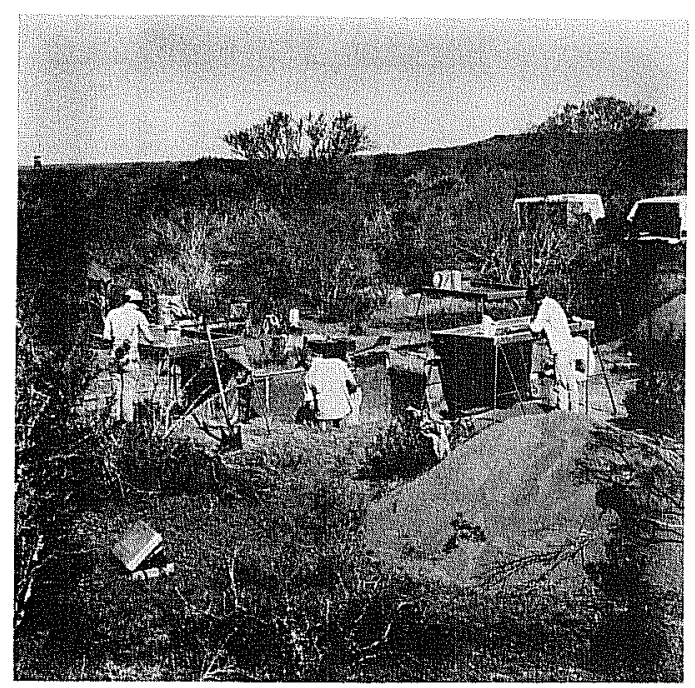

a

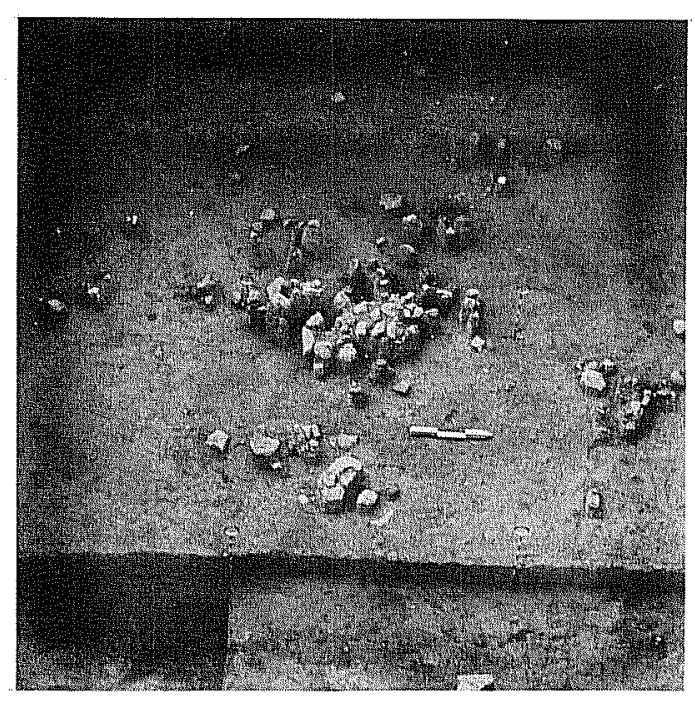

c

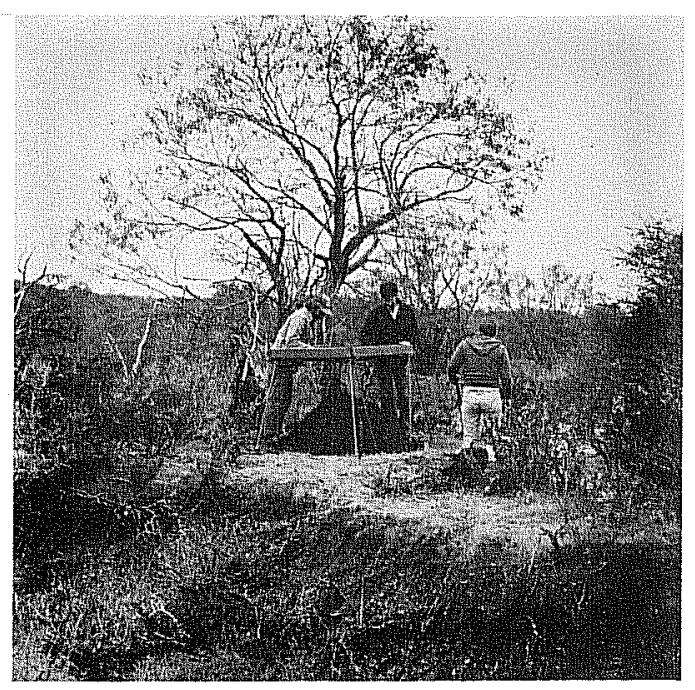

e

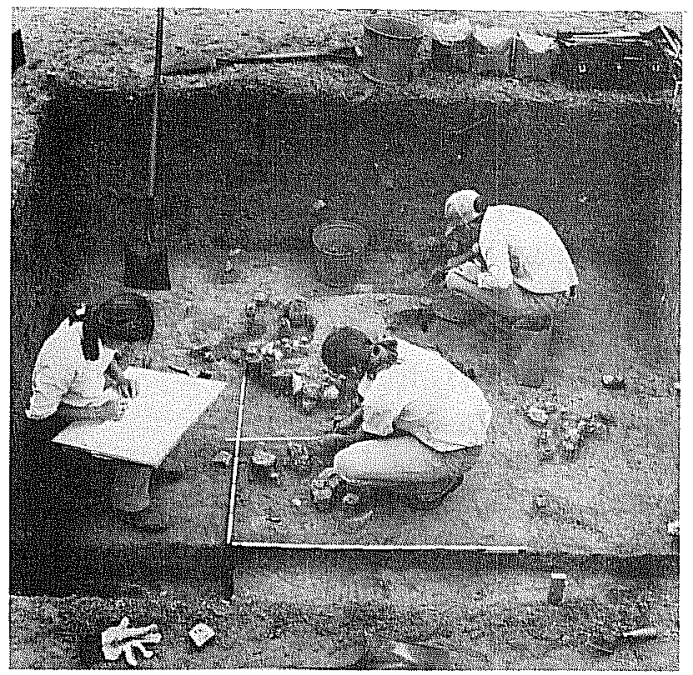

b

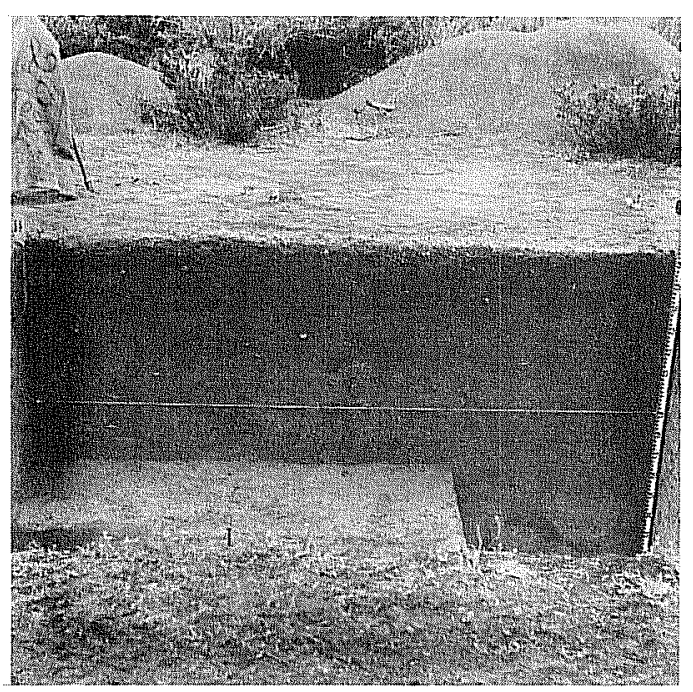

d

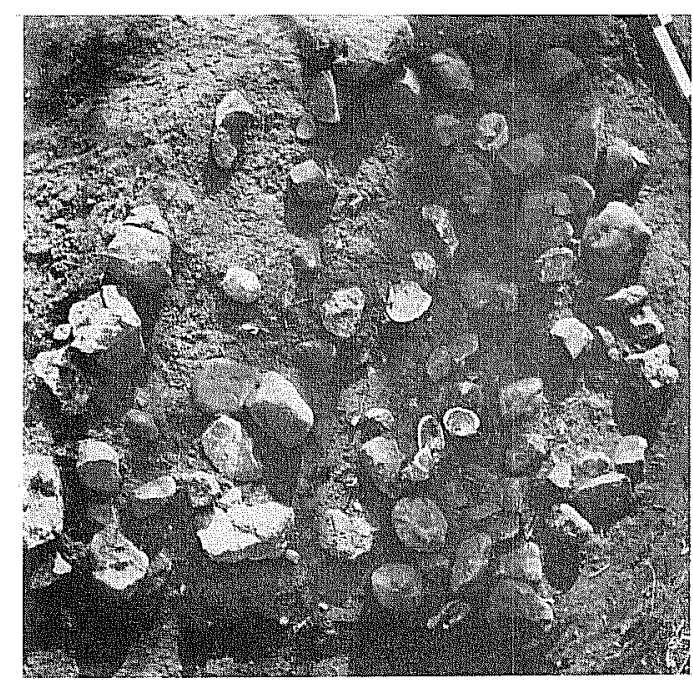


Horizon 1 Horizon 2

Tuff Weight (grams)

$\begin{array}{rc}13 & 31 \\ 14 & 50 \\ 168 & 374 \\ 55 & 28 \\ 18 & 12 \\ 93 & 136 \\ 0 & 0.1 \\ 1 & 0 \\ 13 & 25 \\ 18 & 24 \\ 82 & 39\end{array}$

Other artifacts found in Test Pit 1 include a core (Group 1 from Leve 14 ), two thick bifaces (Group 1 from Leve1 3; Group 7, Form 5 from Leve1 5), a thin biface fragment (Group 4, Form 4, Specimen 34 from Leve1 2), and a distally beveled tool (Group 8, Form 4, Specimen 1 from Level 5). Level 2 yielded a small carbon sample. In Level 4 (30 to $40 \mathrm{~cm}$ below surface), a loose scatter of about 20 pieces of fire-fractured rock was exposed in situ. It was not well integrated to warrant designation as a feature.

Test Pit 2 was located in the northwestern part of 41 LK 243 (Fig. 33). This pit was dug to a depth of $50 \mathrm{~cm}$ below the surface through a soil matrix described as very dark brown sandy clay loam. Amounts of material recovered from this test (a)1 levels combined) are as follows:

\section{Test Pit 2 \\ (A11 Leve1s)}

Tuff Weight (grams)

12

Sandstone Weight (grams)

Fire-Fractured Rock Weight (grams)

0.2

Mussel She11 Umbo Count

61

Musse1 Shel1 Weight (grams)

21

Rabdotus She11 Count

4

Bone Weight (grams)

70

Primary Flake Count

0

Secondary Flake Count

2

Tertiary Flake Count

17

Chip Count

18

No other artifacts were recovered from Test Pit 2 nor were any habitational features recognized.

Test Pit 3 was $p 1$ aced in the west-central area of 41 LK 243 (Fig. 33). It was excavated to a depth of $100 \mathrm{~cm}$ below the surface. Two horizons were defined. Horizon 1 represents Leve $151-5$, and Horizon 2 represents Levels 610. Rates of debris recovery for Test Pit 3 are as follows: 


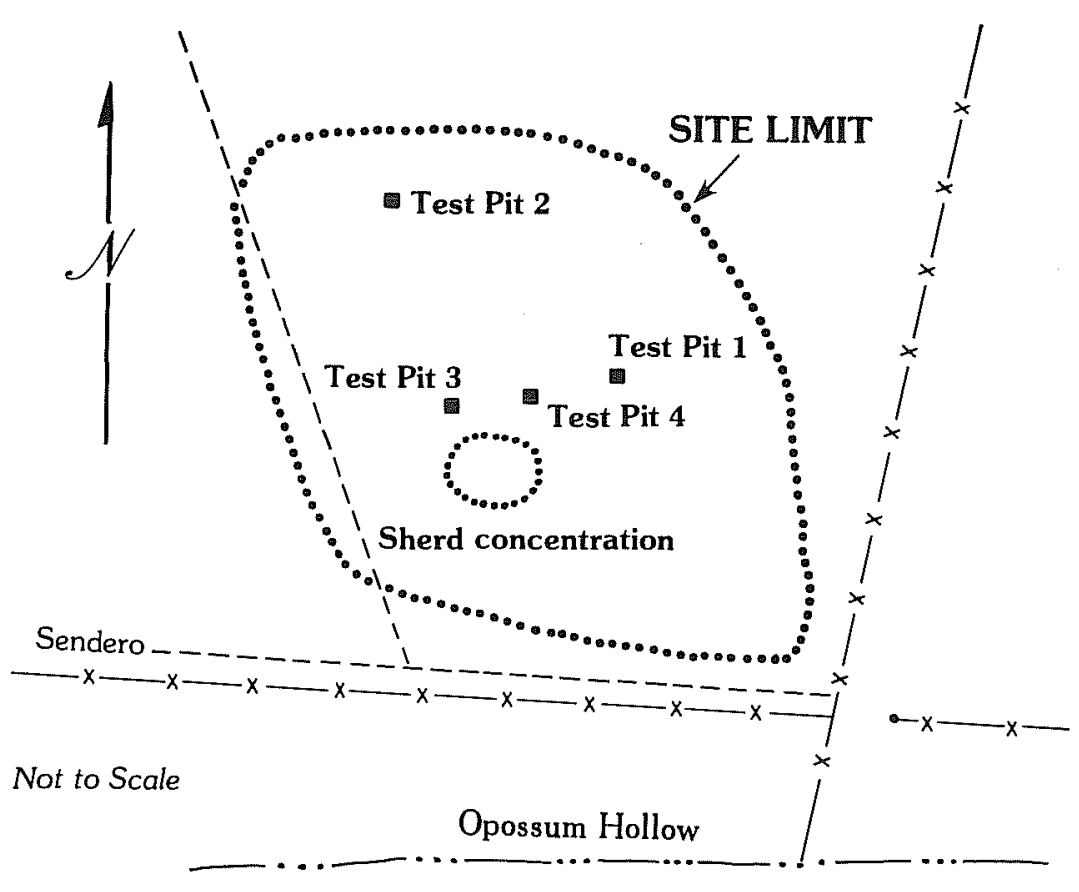

SCHEMATIC PLAN OF SITE

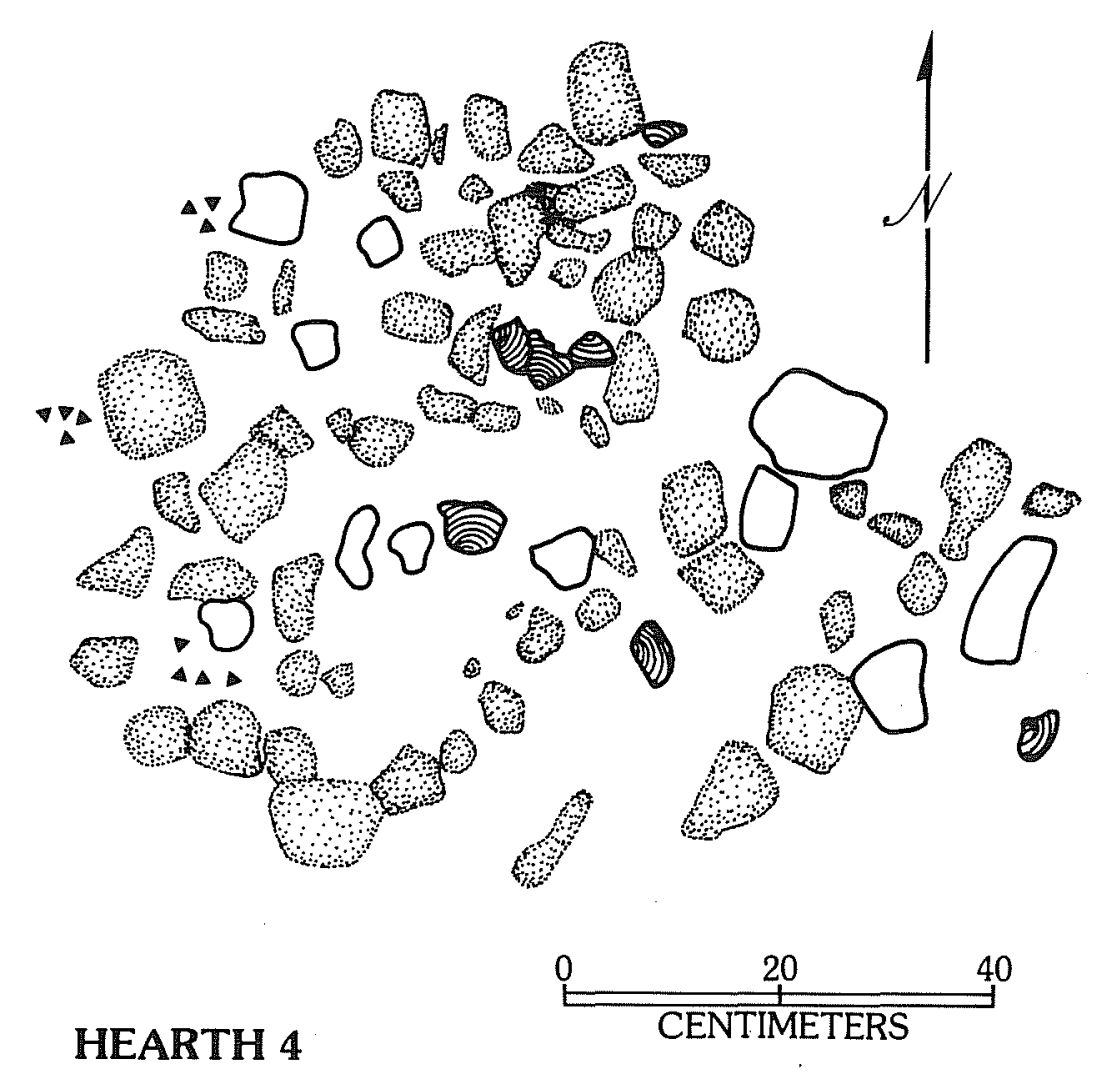

Mussel Shell
Murbon Flecking

\section{LK243}

\section{PLANS OF SITE AND FEATURE}

Figure 33. Plans of Site and Feature at 41 LK 243. 
Horizon 1 Horizon 2

Tuff Weight (grams)

Sandstone Weight (grams)

Fire-Fractured Rock Weight (grams)

$\begin{array}{rc}7 & 0.1 \\ 34 & 58 \\ 144 & 145 \\ 82 & 11 \\ 18 & 21 \\ 241 & 167 \\ 0.1 & 0.8 \\ 0 & 3 \\ 35 & 25 \\ 44 & 24 \\ 54 & 55\end{array}$

The soil matrix encountered in Test Pit 3 varied considerably. From the surface to a depth of $50 \mathrm{~cm}$, the matrix was a soft, 1oose brown sandy 1oam. Below $50 \mathrm{~cm}$, the matrix became a more compact dark grayish brown sandy loam with carbonate mott1ing. In Level 9 (80 to $90 \mathrm{~cm}$ below the surface), 1 arge cobbles $(7 \mathrm{~cm}$ diameter) began to appear. These cobbles were apparently part of the same gravel layer observed in the gully nearby. No additional artifacts were found in Test Pit 3, and no habitational features were encountered.

Test Pit 4 at 41 LK 243 was located midway between Test Pits 1 and 3 at the approximate center of the site (Fig. 33). This unit was excavated to a depth of $40 \mathrm{~cm}$ through matrix described as dark grayish brown sandy silt containing much smal1 gravel. No horizons were defined for the debris recovered. Rates of recovery for selected classes of debris found in Test Pit 4 are shown below. Other artifacts recovered from the unit were two cores (one, Group 5 and one, Group 6, both from Leve 1 1).

\section{Test Pit 4 \\ (A11 Leve1s)}

$\begin{array}{lr}\text { Tuff Weight (grams) } & 10 \\ \text { Sandstone Weight (grams) } & 77 \\ \text { Fire-Fractured Rock Weight (grams) } & 520 \\ \text { Mussel She17 Umbo Count } & 48 \\ \text { Musse1 She11 Weight (grams) } & 20 \\ \text { Rabdotus She11 Count } & 301 \\ \text { Bone Weight (grams) } & 0 \\ \text { Primary Flake Count } & 0 \\ \text { Secondary Flake Count } & 14 \\ \text { Tertiary Flake Count } & 23 \\ \text { Chip Count } & 104\end{array}$

Habitational features found exposed on the surface of 41 LK 243 were seven apparent hearth features and three mussel she11 concentrations. Locations of a11 of these features were plotted on a plan map of the site (on file at the CAR-UTSA). With one exception, the hearths were sma11, badly disrupted clusters of fire-fractured rock. They were judged to hold 1 ittle information potentia1. One feature, designated Hearth 4, seemed to be on 1 y partially exposed and was not as disintegrated as the other six. Excavation of this 
feature resulted in exposure of the hearth as shown in Figures 32, $\mathrm{f}$ and 33. Hearth 4 was revealed to be a single-1ayer cluster of approximately 60 pieces of fire-fractured rock and 11 pieces of sandstone. The feature was subcircular in outline with a maximum diameter of $90 \mathrm{~cm}$. Five mussel shell values were found amidst the rocks, and a small amount of carbon was collected. Debitage and Rabdotus snail shells were also recovered in small amounts from the matrix removed to expose the feature. A core (Group 3) and two grinding 51 ab fragments (modified sandstone Group 1, Form 3; and Group 2, Form 3) were also found in the hearth. The three mussel shel 1 concentrations mentioned above were collected after being plotted on the site map.

Seventy-five artifacts were collected from the surface of 41 LK 243. Locations of 59 of these specimens were recorded on the site $p 1$ an map (on file at the CAR-UTSA). These artifacts are 16 cores (three, Group 2; three, Group 3; three, Group 5; one, Group 7; six, Group 9), 12 thick bifaces (one, Group 1; three, Group 2; one, Group 3; one, Group 6, Form 1; one, Group 6, Form 2; one, Group 7, Form 1; three, Group 8; one, Group 9), 26 thin bifaces (Group 1, Form 2, Specimen 8; Group 1, Form 3, Specimen 4 [Ensor]; Group 1, Form 5, Specimen 5 [Scal1 orn]; one, Group 2, Form 2; one, Group 3, Form 2; one, Group 4, Form 3; one, Group 4, Form 4; one, Group 5; one, Group 8; 10 , Group 9; six, Group 10), four distally beveled tools (one, Group 3, Form 1; one, Group 3, Form 2; one, Group 4; one, Group 8, Form 2), one trimmed flake (Group 3, Form 2), eight pieces of modified sandstone (three, Group 1, Form 3; one, Group 2, Form 1; three, Group 2, Form 2; one, Group 2, Form 3), and eight sherds of aboriginal pottery.

Information recovered during Phase II investigations at 4 I LK 243 clearly demonstrates prehistoric activity on the site in Late Archaic and Late Prehistoric times. The Late Archaic period is represented by diagnostics such as the Ensor dart point (thin bifaces Group 1, Form 3, Specimen 4) and the small triangular and subtriangular distally beveled tools (Groups 3 and 4). Other specimens, such as a 1arge, stemmed thin biface (Group 1, Form 2, Specimen 8) and distally beveled tools (Group 8, Forms 2 and 4) may denote pre-Late Archaic human activity at 41 LK 243, but are not as clearly diagnostic as the previous specimens. The sherds of aboriginal pottery and a Scallorn arrow point (thin bifaces Group 1, Form 5, Specimen 5) are diagnostic of the Late Prehistoric.

The quantities of prehistoric human habitational debris and features exposed on the surface of 41 LK 243, the severe erosion actively occurring on the site surface, and the indications of colluvial deposition (i.e., numerous sma 11, stream-rolled pebbles) seen in the test pits a 11 suggest that the site and its remains have been considerably altered by natural destructive processes for a long period of time. Artifacts, features, and debris observed, recorded, and/or collected on the surface tell much more about the site's prehistoric inhabitants than do the test pit findings. The 1 arge quantities of debris, features, and chipped stone artifacts would also indicate that 41 LK 243 was an attractive camping locale. Opossum Hol low was probably an active stream channel carrying water on a more regular basis during certain periods of prehistory. The natural outcrops of gravel uphil1 from the site provided a source of raw material for stone tool manufacture. The site is also conveniently located between floodplain and upland environments, thereby making it easier for prehistoric people to exploit a more 
varied range of food resources. These characteristics 1 ikely were the attractions at 41 LK 243.

\section{LK 245}

Located north-northwest of $4 I$ LK 243, 41 LK 245 is in a similar setting, though slightly higher on the valley margin slope (Fig. 1, folded insert). Recorded in 1979 by the CAR survey crew, this fairly smal1 prehistoric site has approximate dimensions of $70 \mathrm{~m}$ northeast to southwest and $100 \mathrm{~m}$ northwest to southeast. It is situated in the upper reaches of a short, steep up 1 and drainage channel that is a minor tributary to a secondary feeder channel of Opossum Hollow. Brush cover is very dense over the surface. Mesquite, guaji110, whitebrush, and soapbush grow in profusion. The site surface has suffered moderate to heavy erosion with gullying and sheetwash being very much in evidence. The site was evidenced to the surveyors by a 1 ight scatter of debitage and three distinct scatters of fire-fractured rock, each several meters in width. A few biface fragments, a dart point (untyped), and some Rabdotus snail shel1s were noted amidst the fire-fractured rock.

After a careful search, the CAR crew failed to relocate site 41 LK 245 during Phase II investigations. Therefore, no additional information was collected for the site.

\section{LK 247}

Site 41 LK 247 was recorded by the CAR survey crew in 1979. It is located on the western side of a 1ong, narrow ridge extending out from the up 1 and southward into the Frio River valley (Fig. 1, folded insert). This upland projection constitutes the valley margin and apparentiy consists of eroded outcrops of Jackson Group sandstone covered with a dense pavement of $1 \mathrm{ag}$ gravels. Isolated remnants of ancient alluvial terraces also occur around the peninsula. The site occurs in the upper reaches of an east-west drainage channel cutting up the west side of the peninsula. The site surface supports moderately dense stands of guaji110, soapbush, spiny hackberry, and sparse grasses. Site dimensions were estimated by the survey as $70 \mathrm{~m}$ north-south and $120 \mathrm{~m}$ east-west. Deep gul1ies cut across the site and have caused extensive disturbance and destruction of prehistoric cultural remains on the site. A scatter of debitage, mussel she11, Rabdotus snail she11, and firefractured rock was used to define the site limits (Fig. 34,a).

Returning to 41 LK 247 for Phase II investigations, the CAR crew judged surface disturbance to have been so severe that only an unprovenienced collection of surface artifacts was warranted. Unfortunately, however, after careful inspection of the site area, the CAR crew failed to relocate any of the artifacts reported from the site by the 1979 survey crew. It appears that artifact collectors scoured the site subsequent to the survey and took al1 of the artifacts originaliy reported. These included an Ensor dart point, a Tortugas dart point, and several thin biface fragments. These 1 imited materials suggest that 41 LK 247 was inhabited during the Middle Archaic and Late Archaic periods. 
SITE GROUP 6

Extensive Test

Excavation Pits

Surface Collections
Provenienced Unprovenienced

Resurvey or Shovel Tests

41 LK $250 \quad 41$ LK 252

41 LK 253

The three prehistoric sites making up Group 6 occur in the upper reaches of a major up 1 and drainage system feeding down from the north into the Opossum Hollow drainage. The area containing the site group is 8.0 to $8.7 \mathrm{~km}$ northwest of Choke Canyon Dam (Fig. 1, folded insert). The sites are only a short distance east of the Live Oak-McMullen County line. A small valley formed by four major tributary drainage channels and numerous lesser drainages cuts northward for a considerable distance into the uplands. The val1 ey margin slopes are formed of ancient alluvial terrace remnants and exposures of the Jackson Group Formation. Lag gravels form extensive pavements along the slopes. The entire area is heavily covered with brush. Erosion along the channels and on the valley margin slopes has been surveyed. The modern channel of the Frio River runs $5 \mathrm{~km}$ to the south of Site Group 6 . The valley of Opossum Creek is about $3 \mathrm{~km}$ to the west across an upland area.

\section{LK 250}

Site 41 LK 250 is located on the western margin of the sma 11 valley formed by the several upland drainage channels down to the Frio River from the north (Fig. 1, folded insert). Recorded by the CAR survey crew in 1979, 4I LK 250 is situated on the valley margin slope in the upper reaches of a short, steep upland drainage gully that is a tributary to the bigger channels down in the val1ey. The site is relatively smal1, having dimensions of on 1 y $40 \mathrm{~m}$ northsouth and $60 \mathrm{~m}$ east-west. There is heavy brush cover over the site surface, including blackbrush, spiny hackberry, persimmon, soapbush, al1thorn. mesquite, and agarita. Lag gravels occur as a surface pavement uphil1 from the site area. The surface is heavily eroded. The site was defined and delimited on the basis of a moderate to heavy surface scatter of debitage, fire-fractured rock, and stone tool fragments observed primarily in gullies cutting through the site.

During Phase II investigations at 41 LK 250, the CAR crew excavated a $1-\mathrm{m}^{2}$ test pit, made a shovel test, and conducted a provenienced collection of surface artifacts. A large, deep gully at the north end of the site revealed in its walls a layer of fire-fractured rock and debitage at a depth of about $60 \mathrm{~cm}$ below the surface. Test $P$ it 1 was staked out in an uneroded remnant adjacent to this gul1y. This test pit was excavated to a depth of $110 \mathrm{~cm}$ below the surface (eleven 10-cm-thick levels). From the surface to a depth of $80 \mathrm{~cm}$, the matrix in this unit was described as dark grayish brown clayey loam having a blocky, stiff consistency. Beneath $80 \mathrm{~cm}$, the matrix was tannish brown silty loam speckled with carbonate nodules. Three debris horizons were defined for this test pit. Horizon 1 contains debris recovered from Levels 1-3, Horizon 2 contains the debris from Levels 4-8, and Horizon 3 
Figure 34. Views of 41 LK 247, 41 MC 196, 41 MC 213, and 41 MC 212.

a. view south across one area of 41 LK 247 showing fire-fractured rock, mussel she11, Rabdotus snal1 she11, and debitage exposed on the site surface by erosion. Debris exposures such as this are typical of many of the prehistoric sites at Choke Canyon;

b. scene at 41 MC 196 looking east across drainage channel to area of Test Pit 2, where excavations are in progress;

c, view looking north across Area C of 41 MC 196. Test Pit 3 excavation in progress;

d. a concentration of fire-fractured rock exposed on the surface in Area $E$ of 41 MC 196;

e, view of 41 MC 213 looking east-southeast from hill above site area;

f, view looking northwest across 41 MC 212 from val ley margin hillside above the site. 


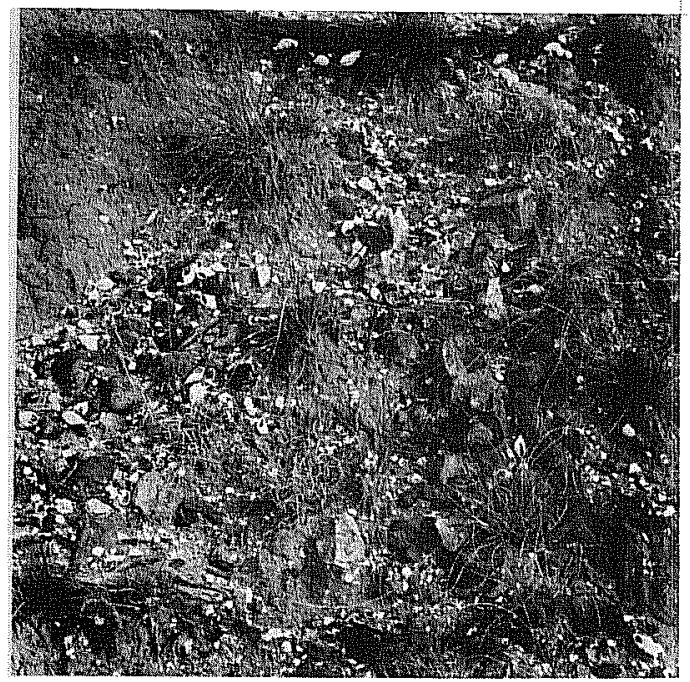

$a$

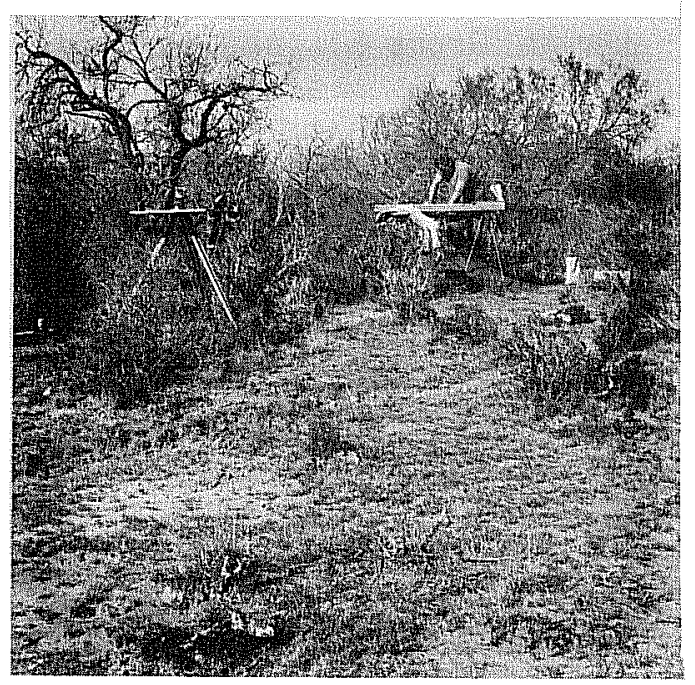

c

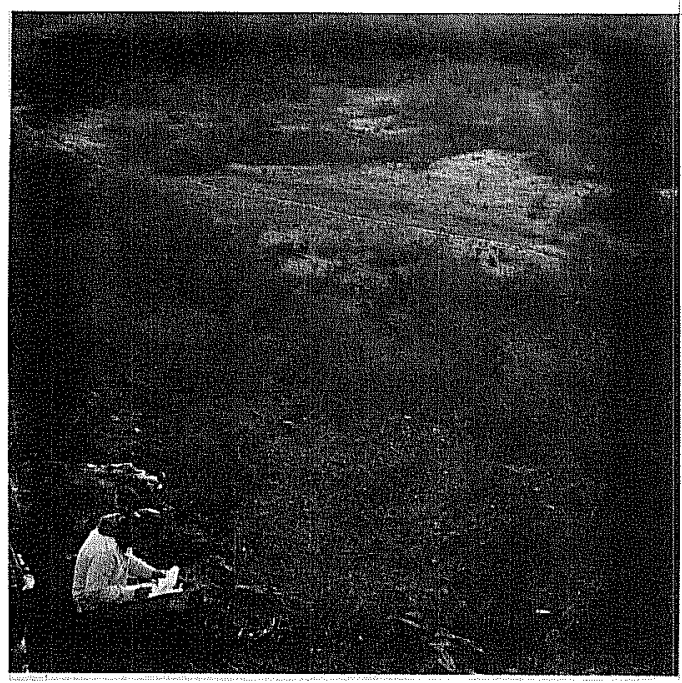

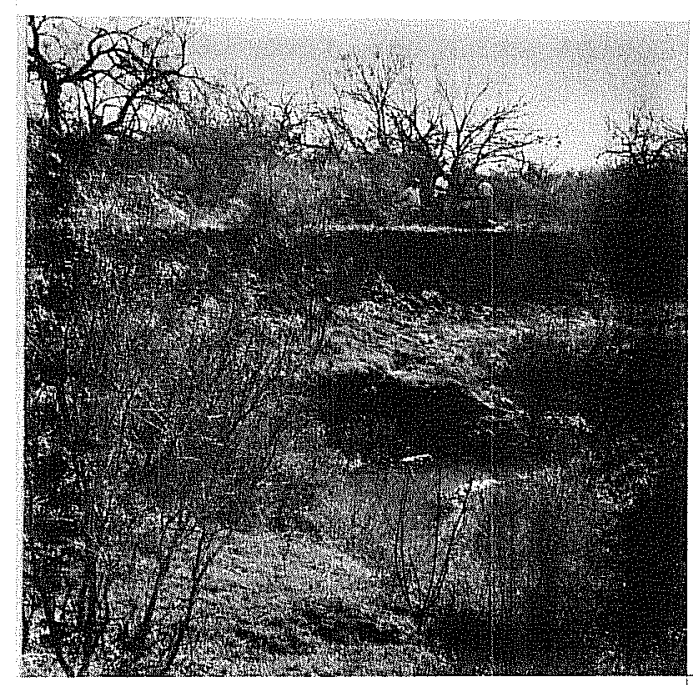

\section{b}

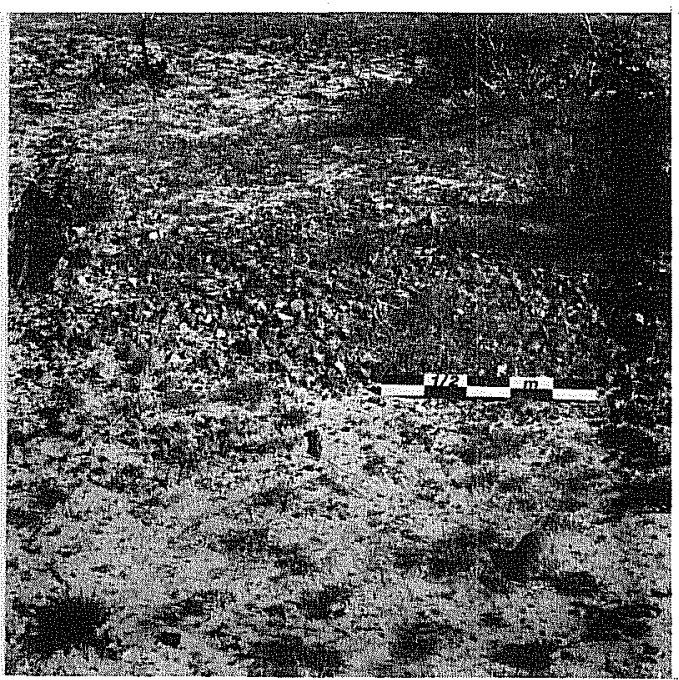

d

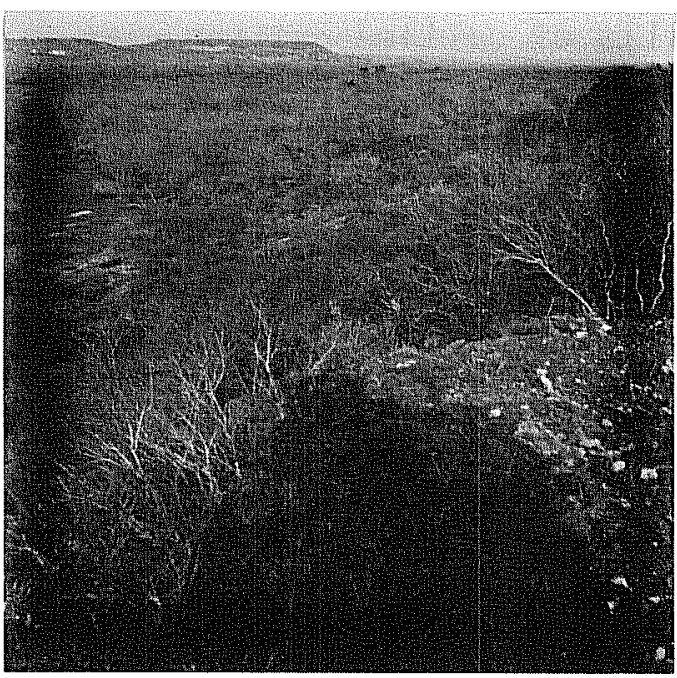

f 
contains material from Levels 9-11. Rates of recovery for selected classes of debris from these three horizons are as follows:

$\begin{array}{cccc}\text { Horizon 1 } & \text { Horizon 2 } & \text { Horizon 3 } \\ 3 & & & \\ 69 & 178 & 13 \\ 652 & 1019 & 29 \\ 2 & 1648 & 518 \\ 3 & 6 & 7 \\ 89 & 3 & 0.2 \\ 0.1 & 491 & 36 \\ 3 & 0.1 & 0 \\ 18 & 5 & 1 \\ 23 & 30 & 10 \\ 82 & 31 & 5 \\ & 86 & 20\end{array}$

The following additional artifacts, al1 from Horizon 2, were also recovered: seven cores (one, Group 1; three, Group 2; three, Group 5), one thick biface (Group 1), two thin bifaces (one, Group 2, Form 1; one, Group 10), one trimmed flake (Group 4), and one piece of modified sandstone (Group 1 , Form 3).

The artifacts recovered from the surface of 41 LK 250 are seven cores (four, Group 3; two, Group 5; and one, Group 9), one thick biface (Group 6, Form 2), 10 thin bifaces (Group 1, Form 3, Specimen 28; two, Group 2, Form 2; one, Group 4, Form 4; three, Group 9; three, Group 10), one distally beveled tool (Group 3, Form 2), four pieces of modified sandstone (one, Group 1, Form 1; one, Group 1, Form 3; one, Group 2, Form 2; one, Group 3), and one marine shel1 artifact (Specimen 6). Locations of many of these specimens were. plotted on a plan map of the site (on file at the CAR-UTSA).

The Phase II work at 41 LK 250 resulted in sampling an unusual habitational feature in the form of a midden of fire-fractured rock. The feature was represented by a 30 to $40 \mathrm{~cm}$-thick layer of virtually solid fire-fractured rock recovered from Horizon 2 of Test Pit 1. It was also visible in the walls of gullies cutting down through the site. The full horizontal extent of this 1 ayer of rock was not determined. Clearly, however, the feature represents a substantial expenditure of energy on the part of the prehistoric people who inhabited the site.

The array of chipped stone tools found at 41 LK 250, especially items such as a stemmed thin biface (Group 1, Form 3, Specimen 28) and a distally beveled tool (Group 3, Form 2), indicate human activity on the site during the Late Archaic period. It is suggested that the midden of fire-fractured rock also dates to this period. The cores, thick bifaces, thin bifaces, and debitage recovered from the site show that local 1 ag gravels were being utilized by prehistoric inhabitants for production of stone tools. It is noteworthy that so 1 ittle mussel she 11 was collected from the test pit. Rabdotus snail she11s were recovered in predictable quantities. Mano and metate fragments (modified sandstone Groups 1 and 2) were also found. Animal bone, mostly unidentifiable, occurred in very low amounts. One unusual artifact recovered 
at 41 LK 250 is a tabular bead made from the colume 11 a of a marine whe $1 \mathrm{k}$ shel1 (Specimen 6, Busycon sp.).

\section{LK 252}

Site 41 LK 252 is located northwest of 41 LK 250 on the opposite (east) side of the drainage channel valley (Fig. 1, folded insert). It is situated on the gentle slope of the valley margin. As recorded by the CAR surveyors in 1979, 41 LK 252 is oval in out 1 ine shape with dimensions of about $100 \mathrm{~m}$ north-south and $250 \mathrm{~m}$ east-west. The site surface is moderately to heavily eroded and supports fairly thick stands of brush, including acacias, guajil10, soapbush, agarita, mesquite, and sparse grasses. Lag gravels occur as a surface pavement throughout the area. The admittedly vague limits of 41 LK 252 were defined by the survey crew on the basis of a light surface scatter of debitage and fire-fractured rock. One particularly heavy concentration of fire-fractured rock, covering an area of about $4 \mathrm{~m}^{2}$, was noted on the surface. Five thick bifaces, a hammerstone, and approximately 20 cores were observed during the initial site reconnaissance.

Returning to 41 LK 252 for Phase II investigations, the CAR crew excavated three shovel tests and made a provenienced collection of surface artifacts. Shovel tests ranged in depth from 45 to $55 \mathrm{~cm}$. Matrix in the upper $40 \mathrm{~cm}$ varied from 7 ight tannish brown clayey loam to grayish brown sandy loam. The upper $20 \mathrm{~cm}$ contained substantial amounts of fire-fractured rock, debitage, snail shells, and numerous stream-rolled pebbles. Beneath $40 \mathrm{~cm}$, the matrix was described as yellowish white stiff clayey loam. Findings made in these shovel tests indicated that control led excavations were not warranted at 41 LK 252.

Thirty artifacts were collected from the surface of 41 LK 252. Locations of many of these specimens were plotted on a plan map of the site (on file at the CAR-UTSA). The artifacts recovered are four cores (one, Group 1; two, Group 3; one, Group 6), 17 thick bifaces (one, Group 2; one, Group 3; four, Group 4; three, Group 6, Form 2; two, Group 7, Form 1; one, Group 7, Form 2; and three, Group 8), six thin bifaces (three, Group 4, Form 4; one, Group 5; two. Group 10), two distally beveled tools (one, Group 3, Form 1; one, Group 7, Form 2), and one uniface (Group 5). This array of specimens indicates site usage during the Middle Archaic and/or Late Archaic periods. The number of thick bifaces found indicates that chipped stone tool manufacture was one important prehistoric activity on the site.

Many of the artifacts collected at 41 LK 252 were found in and around a locally heavier concentration of fire-fractured rock exposed on the surface along the southern edge of the site. Dimensions for this fire-fractured rock feature were set at $30 \times 30 \mathrm{~m}$. The feature, and the array of chipped stone tools recovered from it, are remarkably similar to the findings made at 41 LK 250. 


\section{LK 253}

Site 41 LK 253 is located far back up in the drainage valley, but is down in the floodplain rather than on the valley margin as are sites 41 LK 250 and 41 LK 252 (Fig. 1, folded insert). The site is cut through north to south by two drainage channels near the head of the valley. As recorded by CAR surveyors in 1979, 41 LK 253 has dimensions of $100 \mathrm{~m}$ north-south and $130 \mathrm{~m}$ east-west. Vegetation is moderately thick on the surface. Mesquite, soapbush, spiny hackberry, whitebrush, prickly pear, and low grasses are all present. The surface is moderately eroded in some places. Near the drainage channels, parts of the site surface have been silted over. The site 1 imits were defined on the basis of a 1 ight to moderate scatter of fire-fractured rock and debitage across the surface. Lag gravels are distributed throughout the area.

CAR Phase II activities at 41 LK 253 were excavation of four shovel tests and a provenienced collection of surface artifacts. In the shovel tests, cultural debris was confined to the upper $20 \mathrm{~cm}$ of deposit. Shovel test results indicated that controlled excavations would not be worthwhile.

Twenty-three chipped stone tool specimens were collected from the surface of 41 LK 253. Locations of most of these specimens were recorded on a $p 1$ an map of the site (on file at the CAR-UTSA). The artifacts were identified as two cores (one, Group 3; one, Group 5), eight thick bifaces (two, Group 1; two, Group 2; one, Group 4; one, Group 6. Form 2; two, Group 7, Form 1), 12 thin bifaces (one, Group 2, Form 1; one, Group 3, Form 1; one, Group 3, Form 2; five, Group 4, Form 4; four, Group 9), and one distally beveled tool (Group 3, Form 3). Again, these specimens indicate that prehistoric activity occurred at this site during the Late Archaic. Relatively numerous thick bifaces and thin biface fragments show that local gravels were providing raw material for chipped stone tool making, apparently one of the important activities on the site.

The three sites in Group 6, 41 LK 250, 41 LK 252, and 41 LK 253, were found to be remarkably similar in character and content. The sites share in common their physiographic setting, the presence of massive amounts of firefractured rock, a chipped stone tool assemblage generally diagnostic of the Late Archaic, ample evidence that stone tool manufacture was an important activity at each site, and the absence or 1 ow frequency of musse 1 she 11 and/or animal bone. The pattern emerging from this data suggests that certain locations in the transition zone from floodp 1 a in to up 1 and became more important in the Late Archaic. Activities that resulted in the tremendous amounts of fire-fractured rock evidenced in these sites cannot currently be identified, but are undoubtedly a key to development of the sites. The small quantities of mussel shells, so common at most other prehistoric sites at Choke Canyon, suggest that the people were not heavily exploiting riverine and floodplain food resources when they 1 ived on these sites. A t though no supporting evidence is currently recognized, it seems likely that the fire-fractured rock is derived from the construction and use of rock-1 ined oven pits that Late Archaic people were using to prepare some kind of plant food for consumption. With the number of cores, thick bifaces, and thin biface fragments found on these three sites, it is clear that prehistoric people were putting local gravels to good use as raw material for 
manufacture of chipped stone tools. Gravels are so widespread throughout the Choke Canyon region that it is unlikely the people came to these sites specifically for this reason. The knapping must surely have been of subsidiary importance to whatever the food gathering emphasis was at the time the sites were inhabited. An alternative, though less probable explanation for the accumulations of fire-fractured rock, is that they are residues from chert heat treating (annealing) operations at the sites. However, examination of chipped stone tools from the sites has not shown evidence of heat treatment. More generally, it is important to emphasize that this settlement pattern, at least in this particular area, appears to be a mode of existence for Late Archaic people. The pattern likely says something very important about conditions existing during that particular time period.

\section{SIIE GROUR 7}

Extensive Test

Excavation Rits

41 MC 196
Surface Collections

Provenienced Unprovenienced

41 MC 213
Resurvey or Shovel Tests

41 MC 201

41 MC 209

41 MC 212

Site Group 7 is 1 ocated in the upper reaches of the Opossum Creek val1ey 10 to $14 \mathrm{~km}$ northwest of Choke Canyon Dam (Fig. 1, folded insert). Opossum Creek is a major upland drainage system that feeds down to the Frio River from the northwest. The sites in Group 7 are 3 to $7 \mathrm{~km}$ upstream from the creek's juncture with the river. The creek valley ranges in width from $0.4 \mathrm{~km}$ at the northwest end of the site group area to $1.35 \mathrm{~km}$ at the southeast end. The creek channel is quite sinuous and, in the site group area, is fed by 10 short, steep drainage channels coming down from the uplands to the east and west. Storage tanks, pipelines, and pumps related to oil industry activity are very common. Brush cover is heavy and erosion moderate to severe. Lag gravels occur as surface pavement almost everywhere, but are especially common on the slopes leading up out of the Opossum Creek valley.

\section{MC 196}

Site 41 MC 196 is a very large prehistoric site recorded by the Texas Tech survey crew in 1977. It is located on the left (east) bank of Opossum Creek from 3 to $4 \mathrm{~km}$ upstream from the Frio River (Fig. 1, folded insert). As recorded by the Texas Tech surveyors, 41 MC 196 measures $1.3 \mathrm{~km}$ north-south and $0.4 \mathrm{~km}$ east-west. The east-west width encompasses virtually the entire floodplain from the creek channel eastward to the valley wall (Fig. 35).

In Phase II investigations, the CAR crew began by resurveying 41 MC 196. The crew defined seven areas within the site boundaries where prehistoric cultural activities appear to have been much more intense than in intervening 
Figure 35. Area and Test Pit Locations at 41MC196.

PAGE 124 REDACTED 
zones. These locally heavier accumulations of prehistoric cultural debris were designated Areas A to G (Fig. 35). Most of the designated areas occur on locally higher ground such as terrace remnants or levees formed by the creek. By examination of topographic maps and field observations, the surveyors were able to identify relict channels paralleling the present course of Opossum Creek. Some of the more prominent channel scars are shown in Figure 35. Additional Phase II activities at 41 MC 196 included excavation of three $1-\mathrm{m}^{2}$ test pits, some shovel testing, and a provenienced collection of surface artifacts.

Located on the east side of a major north-south trending relict channel scar, Area $A$ was unusual in that it was not situated on a topographic high as were the other areas. Dimensions of this area were estimated at $10 \mathrm{~m} \times 26 \mathrm{~m}$ with the long axis running north-northwest to south-southeast. The area was defined on the basis of fire-fractured rock, debitage, and sandstone exposed on the surface. A large, complete metate (modified sandstone Group 1 , Form 1) was found at the north end. A 1 ighter scatter of cultural debris extends northward from the primary concentration, appearing to follow a low ridge going in that direction (Fig. 35).

Test Pit 1 was excavated in Area A at 41 MC 196. This unit went down $60 \mathrm{~cm}$ bel ow the surface (six 10-cm-thick leve1s). Matrixwas described as dark brown clayey loam from the surface down into Level 3. In Level 4, grayish white carbonate mottling began to show up and increased in each subsequent leve1. No horizons were defined in the debris recovered from Test Pit 1. Rates of recovery for selected classes of debris from Test Pits 1-3 (Test Pits 2 and 3 to be discussed below) are as follows:

Test Pits

$\begin{array}{lccc} & 1 & 2 & 3 \\ \text { Tuff Weight (grams) } & & 0 & 0 \\ \text { Sandstone Weight (grams) } & 1 & 9 & 47 \\ \text { Fire-Fractured Rock Weight (grams) } & 98 & 17 & 39 \\ \text { Musse1 She17 Umbo Count } & 1 & 3 & 2 \\ \text { Musse1 She17 Weight (grams) } & 0.3 & 0.6 & 4.7 \\ \text { Rabdotus She11 Count } & 246 & 0 & 72 \\ \text { Bone Weight (grams) } & 4.8 & 0 . & 1.8 \\ \text { Primary Flake Count } & 4 & 0 & 1 \\ \text { Secondary Flake Count } & 26 & 12 & 40 \\ \text { Tertiary Flake Count } & 22 & 13 & 37 \\ \text { Chip Count } & 85 & 11 & 62\end{array}$

Test Pit 1 also yielded three cores (one, Group 3; two, Group 5), two thin biface fragments (one, Group 9; one, Group 10), and five pieces of modified sandstone (three, Group 1, Form 3; two, Group 2, Form 1).

A sma11, sing1e layer cluster of sandstone was exposed in Level 2 (10-20 cm below the surface) of Test Pit 1. Subcircular with a diameter of $60 \mathrm{~cm}$, this feature was composed of about 40 pieces of sandstone and seven pieces of fire-fractured rock, al1 having maximum dimensions of 1 ess than $8 \mathrm{~cm}$. A smal1 amount of carbon was collected from this feature. 
Area B was defined rough 1 y 375 m northwest of Area A above a cutbank along the present channel of Opossum Creek (Figs. 34,b; 35). An i11-defined 1ayer of prehistoric cultural debris was seen in the cutbank face from 40 to $65 \mathrm{~cm}$ below the surface. A relatively heavy scatter of debris also 1 ittered the talus slope below the bank. Test Pit 2 was staked out about $2 \mathrm{~m}$ back from the edge of the cutbank. The unit was excavated to a depth of $60 \mathrm{~cm}$ in six 10-cm-thick vertical levels. From the surface to a depth of $14 \mathrm{~cm}$, the matrix was 1 ight grayish brown sandy loam. From $15 \mathrm{~cm}$ to the bottom of the unit, the soil was dark grayish brown clayey loam with carbonate speck 1 ing increasing with depth. Rates of recovery for selected classes of debris from Test Pit 2 are shown above. A piece of modified sandstone (Group I, Form 3) was found in Level 2.

Area $C$ has the most dense accumulation of prehistoric cultural debris found anywhere on 41 MC 196. The area occurs on a low ridge trending northeast to southwest (Fig. 35). The ridge is bounded east and west by relict channel scars. Area $\mathrm{C}$ was recognized and delimited on the basis of fire-fractured rock, mussel shel1, bone, and debitage distributed across the surface, especially in the backdirt of numerous animal burrows.

Test Pit 3 was excavated in Area C at 41 MC 196 (Fig. 34,C). It was excavated to a depth of $50 \mathrm{~cm}$ below the surface; the matrix was described as dark grayish brown sandy loam. Debris recovery for all levels combined is presented above. Two cores (Group 5) were the only additional artifacts found in the test pit.

A hearth was isolated in Level 5 (40 to $50 \mathrm{~cm}$ below the surface) of Test Pit 3. It was composed of 47 pieces of sandstone arranged in a subcircular, single layer cluster with dimensions of $50 \times 75 \mathrm{~cm}$. Rocks in the center of the feature were 5 to $7 \mathrm{~cm}$ in diameter. Outlying stones were 3 to $4 \mathrm{~cm}$ in diameter. A small amount of carbon was collected from amidst the rocks.

A second hearth feature was found partialiy exposed on the surface of Area C. Located about $18.5 \mathrm{~m}$ west of Test Pit 3, this feature consisted of an ovalshaped, single layer cluster of 20 pieces of sandstone. Dimensions of the feature were $31 \mathrm{~cm}$ east-west by $35 \mathrm{~cm}$ north-south. Stones ranged in size from 4 to $5 \mathrm{~cm}$. Partial1y exposed in the side of a 1 arge erosional gu $11 \mathrm{y}$, this feature appeared to be buried about $20 \mathrm{~cm}$ below the surface. Musse 1 she11, turtle bone, and Rabdotus snail shells were scattered around on the surface in the immediate area.

Area $D$ is the northernmost concentration of cultural debris recognized at 41 MC 196 (Fig. 35). This smal1 area was defined by the distribution of burned sandstone and debitage in two erosional gul1ies. Shovel test results indicated that controlled testing was not warranted in the area.

Areas $E, F$, and $G$ were defined in the southern half of 41 MC 196 (Figs. 34,d; 35). Shovel tests excavated in each of these areas revealed no deposits worthy of controlled test excavations.

The artifacts collected from the surface of 41 MC 196 are three cores (one, Group 3; two, Group 5), one thick biface (Group 3), 21 thin bifaces (Group 1, Form 1. Specimen 2 [Morhiss]; Group 1, Form 2, Specimen 4 [Langtry]; Group 1, 
Form 6, Specimen 3 [dart point stem]; one, Group 2, Form 1; three, Group 2, Form 2; one, Group 4, Form 1; one, Group 4, Form 3; four, Group 4, Form 4; five, Group 9; three, Group 10), seven distally beveled tools (one, Group 3 . Form 1; two, Group 3, Form 3; two, Group 4; one, Group 8, Form 5; one, Group 9), two unifaces (one, Group 2, one, Group 4), one trimmed flake (Group 4), and 32 pieces of modified sandstone (two, Group 1, Form 1; 17 Group 1, Form 3; one, Group 2, Form 1; six, Group 2, Form 2; six, Group 2, Form 3). Locations of many of these specimens were recorded on a $\mathrm{p} 7$ an map of the site (on file at the CAR-UTSA).

The array of artifacts recovered from the surface of 41 MC 196 indicates that cultural debris marking the site was deposited during the Middle Archaic and/or Late Archaic period(s). The Langtry and Morhiss dart points, the unstemmed thin bifaces, and the distally beveled tools are the diagnostics upon which the estimate of period of occupation is based. Unspecified activities resulting in substantial accumulations of fire-fractured rock are again evidenced. In the case of $41 \mathrm{MC}$ 196, the fire-fractured rock concentrations occur at intervals along the floodplain of Opossum Creek. Most probably, each discrete concentration (i.e., Areas $A$ to $G$ ) represents a separate habitational event on the site. The distribution of these areas down the site graphically illustrates the concept of the "generalized resource area" offered as a settlement mode for prehistoric people at Choke Canyon (Lynn, Fox, and O'Malley 1977:172; Hal1, Black, and Graves 1982:475). Like sites in Group 6 discussed above, the combination of masses of firefractured rock, relatively numerous seed/nut processing tools (modified sandstone specimens), and virtual absence of mussel shell again suggests a subsistence orientation focused away from riverine resources. Heavy reliance on some type of plant food is inferred.

\section{$41 \mathrm{MC} 201$}

Site 41 MC 201 was recorded and extensively investigated by the Texas Tech surveyors in 1977 (Thoms, Montgomery, and Portnoy 1981:173-187). It is positioned on a slight rise formed by a natural levee along the left (east) bank of Opossum Creek (Fig. I, folded insert). A substantial up 1 and drainage channel trends down from the northeast and meets Opossum Creek off the southeast end of 41 MC 201. As recorded by the Texas Tech crew, the site has a northwest-southeast 1 ength of $300 \mathrm{~m}$ and a width of 75 to $100 \mathrm{~m}$. The site surface is described as moderately eroded and covered with scattered clumps of brush. Debris evidencing the site consists of a "large relatively uniform scatter of burnt rock and chipped stone." Numerous eroded hearths were also noted on the surface. Carbon coll lected from one of these features (Hearth 23) yielded a radiocarbon assay indicating an age of 1140 to 1110 B.C. (TX3020. MASCA corrected; Ha 1 1, B 1 ack, and Graves 1982:652). The Texas Tech investigation of $41 \mathrm{MC} 201$ was judged adequate, and no additional Phase II investigation was attempted.

\section{MC 209}

Site 41 MC 209 was recorded and extensively investigated by the Texas Tech surveyors in 1977 (Thoms, Montgomery, and Portnoy 1981:187-196). The site is 
located in the upper reaches of the Opossum Creek val1ey (Fig. I, folded insert) on the right (south) bank of Opossum Creek between the channe 1 and valley margin. The site is irregular in outline shape and has an. east-west length of $550 \mathrm{~m}$ and a width of $100 \mathrm{~m}$. Its surface is severely eroded. Texas Tech surveyors estimated that at 1east $85 \%$ of the site had been eroded and deflated.

The 1977 investigation included a provenienced surface collection of numerous artifacts and documentation of a number of surface features. Given the extremely eroded condition of the site surface and the comprehensiveness of the Texas Tech research, no additional Phase II investigation was attempted at 41 MC 209.

\section{MC 213}

Located northwest across the Opossum Creek valley from 41 MC 209, 41 MC 213 is situated on the slope of the valley above the left (east) bank of the creek (Fig. 1, folded insert). Recorded by the Texas Tech survey crew, $41 \mathrm{MC} 213$ has a northeast-southwest length of $195 \mathrm{~m}$ and a width of $60 \mathrm{~m}$. The site is at the foot of a prominent southwest projecting sandstone ridge that shelters it from the north ( $F$ ig. $34, e$ ). A 1 arge southwest-trending gu $11 y$ system cuts through the middle of the site, reaching depths of $2 \mathrm{~m}$ in some places. Most of the prehistoric cultural debris evidencing the site is exposed in the sides of these gullies. Brush cover is moderate on the site. Mesquite, acacias, and grasses are present. Site 41 MC 213 is evidenced by dense, but localized scatters of fire-fractured sandstone, fire-fractured rock, and debitage. A number of senderos (rough roadways bul1dozed through the brush) crisscross the site, contributing significantly to disruption of prehistoric cultural remains present.

Phase II activities of the CAR crew at 41 MC 213 consisted of production of a plan map showing the distribution of sandstone accumulations across the site, excavation of two shovel tests, and a provenienced collection of 57 artifacts from the surface. The plan of sandstone concentrations is shown in Figure 36. The excavation of two shovel tests into the subsurface confirmed what was apparent from conditions on the surface. The site was badly deflated and most of the prehistoric cultural debris rests on the surface or near-surface. Control led excavations were not warranted.

The following artifacts were collected from the surface of 41 MC 213: seven thick bifaces (one, Group 1; one, Group 2; one, Group 6, Form 2; two, Group 7, Form 1; one, Group 7, Form 2; one, Group 8), 39 thin bifaces (Group 1, Form 1, Specimen 1 [Pederna1es]; Group 1, Form 1, Specimen 11; Group 1, Form 2, Specimen 5 [Langtry]; Group 1, Form 3, Specimen 5 [Ensor]; Group 1, Form 3, Specimen 30; three, Group 2, Form 1; one, Group 2, Form 2; one, Group 3, Form 2; two, Group 4, Form 1; one, Group 4, Form 3; 10 , Group 4, Form 4; one, Group 5; two, Group 6; one, Group 8; seven, Group 9; five, Group 10), eight distal1y beveled tools (one, Group 2, Form 1; three, Group 3, Form 2; two, Group 3, Form 3; one, Group 6; one, Group 8, Form 5), and three metates (modified sandstone Group 1, Form 1). The 1ocations of most specimens are recorded on a $p 1$ an map of the site (on file at the CARUTSA). The diagnostic forms among these specimens indicate that the site was 


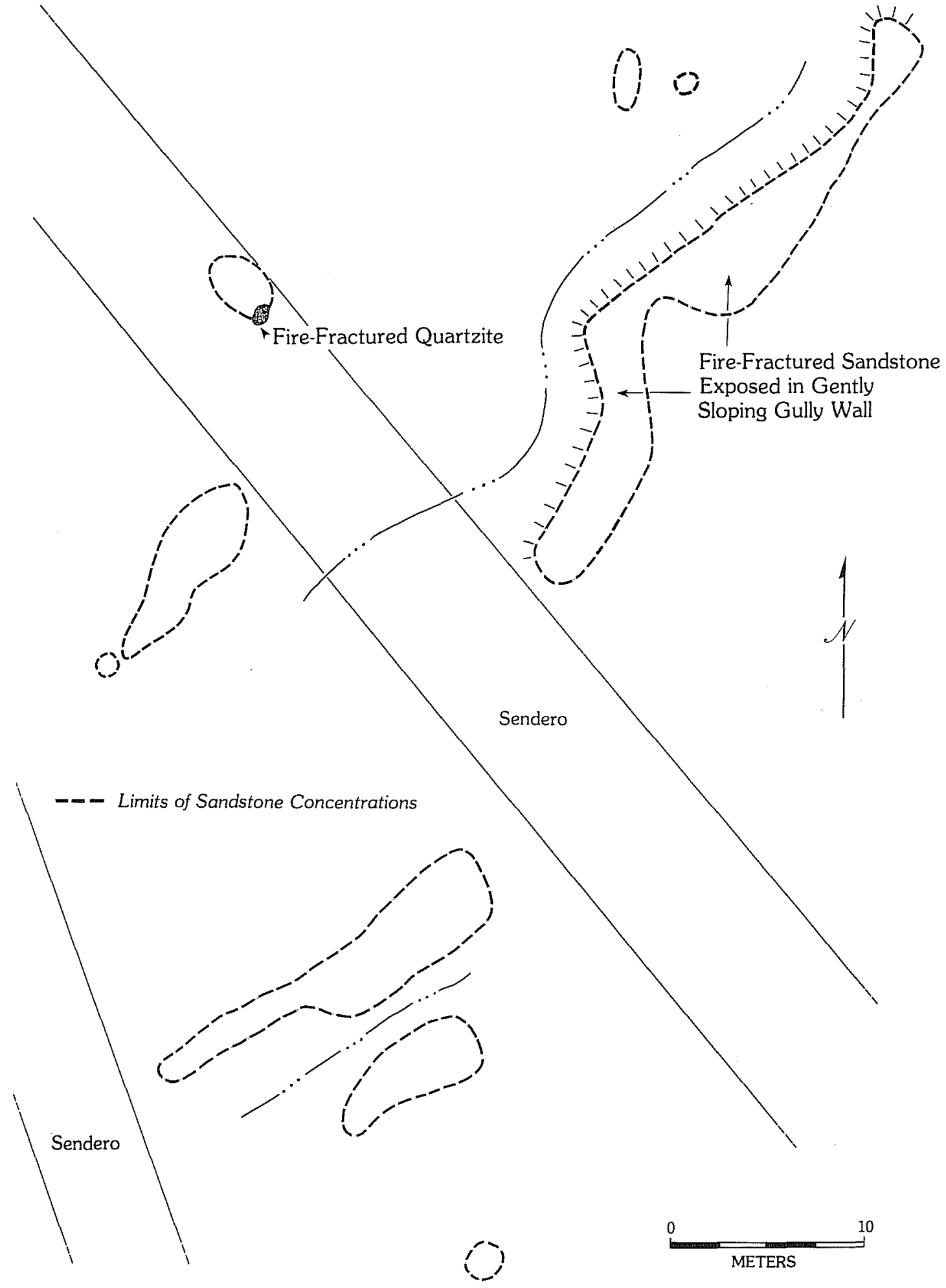

$41 \mathrm{MC} 213$

DISTRIBUTION OF BURNED SANDSTONE CONCENTRATIONS

Figure 36. Distribution of Burned Sandstone Concentrations at 41 MC 213. 
inhabited in Middle Archaic and Late Archaic times. These periods are indicated by the Pedernales and Langtry dart points (Midd Te Archaic), the Ensor dart point (Late Archaic), and a variety of unstemmed thin bifaces and distally beveled tools (both Middle Archaic and Late Archaic).

The Middle Archaic to Late Archaic age, massive deposits of burned sandstone, presence of manos and metates, and essential absence of mussel shel1 place 41 MC 213 in a class with 41 MC 196, 41 MC 201, 41 MC 209, and the sites in Site Group 6, al1 discussed above.

\section{$41 M 212$}

Site 41 MC 212 is located northwest of 41 MC 213 down on the floodplain in the upper reaches of Opossum Creek (Fig. 1, folded insert). It is bisected by the course of a tributary channel trending down to the creek from the north. Recorded by the Texas Tech surveyors, 41 MC 212 has an east-west dimension of $400 \mathrm{~m}$ and a north-south dimension of $100 \mathrm{~m}$. The surface is moderately eroded and covered with brush ( $F$ ig. 34,f). The site is evidenced by disrupted sandstone hearths, debitage, and fire-fractured rock distributed throughout the area, especially on the south side of the drainage channel.

The CAR Phase II investigation at 41 MC 212 consisted of an unprovenienced artifact collection and excavation of two shovel tests. The shovel tests, reaching depths of 55 to $60 \mathrm{~cm}$ below the surface, showed the site's subsurface to hold 1 ittle or no potential for productive controlled excavations.

Col lection of artifacts from the surface of 41 MC 212 yielded three thick bifaces (one, Group 5; two, Group 7, Form 3), 12 thin bifaces (one, Group I, Form 1; three, Group 2, Form 2; one, Group 3, Form 1; five, Group 4, Form 4; one, Group 9; one, Group 10), two distally beveled tools (one, Group 3, Form 1; one, Group 3, Form 2), and one piece of modified sandstone (Group 2 , Form 2). Based on this array of artifacts, 41 MC 212 is suggested to have been inhabited during Middle Archaic and/or Late Archaic times.

\section{SIIE GROUP 8}

$\begin{array}{llll}\text { Extensive } & \text { Test } & \text { Surface Collections } & \text { Resurvey or } \\ \text { Excavation } & \text { Pits } & \text { Provenienced Unprovenienced } & \text { Shovel Tests }\end{array}$

41 MC 29

41 MC 235

41 MC 234

41 MC 55

In Site Group 8, sites are located on both the north and south sides of the Frio River. The site group area is 12 to $14 \mathrm{~km}$ west (upstream) of Choke Canyon Dam and from 2 to $4 \mathrm{~km}$ west of the old Cal1iham town site. Two of the sites, 41 MC 234 and 41 MC 235, occur down in the valley of Salt Creek, an intermittent upland drainage channel tributary to the Frio River. The 
channel of Salt Creek trends down northeastward from the divide between the Frio and Nueces watersheds. The channel runs west of old Calliham and then meets the Frio River north of the town. The creek valley has been mostly cleared of brush in its lower reaches. The upper (southwest) end of the creek drainage is still heavily covered with brush in most areas. Salt Creek, especially in its lower reaches southwest and west of Calliham, has exposed natural seams of satin spar gypsum, a distinctive component of the Frio Formation. Oblong, rounded cobbles of this unusua? rock have been seen at a number of Choke Canyon sites. Such cobbles were also found as grave furnishings at Loma Sandia (4I LK 28), an Archaic period cemetery 1 ocated just east of Choke Canyon (Fig. 1 , folded insert).

The other two sites in Site Group 8, 41 MC 29 and 41 MC 55, are located down near the active floodplain of the Frio River. Both sites overlook relict channe1s. The relict channels are referred to as "sloughs" or "resacas." "Resaca" is the Spanish word for this type of feature (a south Texas-northern Mexico Spanish usage of the word). The slough on the east side of 41 MC 55 is a substantial feature and holds water on a year-round basis. Dense riparian vegetation grows on the Frio River floodplain in the area between 41 MC 29 and 4I MC 55. The valley margin is a relatively steep, brush- and grave1-covered slope on 7 y $500 \mathrm{~m}$ south of 41 MC 55. On the north side of the Frio River the valley slopes more gradually up away from 41 MC 29 to high, old alluvial terraces. The southern margin of the valley consists of exposures of sandstone belonging to the Jackson Group. This bedrock formation is partially covered by a mantle of old terrace alluvium and $1 \mathrm{ag}$ grave1s.

\section{MC 29}

Site 41 MC 29 is located on the north side of the Frio River. It is situated on the edge of a terrace overlooking a relict channel scar in which a 1 ake forms during periods of flooding and/or heavy 1 ocal rainfal1 (Figs. l, folded insert; 37). The site is on the north (1eft) bank of the slough. As recorded by THC surveyors, the site measures $250 \mathrm{~m}$ northeast-southwest and $150 \mathrm{~m}$ northwest-southeast. The surface is covered with a moderately thick stand of brush, interspersed with open, grass-covered clearings ( $F$ ig, $40, a$ ). Erosion has been severe along the terrace slope forming the site's north side. Back from the terrace edge, there are localized areas of surface deflation, but substantial portions of the site remain apparently undisturbed.

In Phase I investigations at 41 MC 29, three $1-m^{2}$ test pits were excavated (Ha11, B1ack, and Graves 1982:179-184). The test pits revealed that prehistoric cultural debris was contained in the upper $60 \mathrm{~cm}$ of deposit on the site. Collections of cultural debris were divided into upper and lower horizons. The upper horizon contained materials from the first $30 \mathrm{~cm}$ of deposit. A Late Prehistoric affiliation was determined for the upper horizon based on the arrow point specimens it yielded. The lower horizon was suggested to contain a Late Archaic component based on radiocarbon assay of a carbon sample from a habitational feature recognized in the horizon. This radiocarbon assay yielded an age of 390 to 270 B.C. (TX-2873, MASCA corrected). 
Figure 37. Topographic Map of 41MC29 and Surrounding Area.

PAGE 132 REDACTED 
Phase II investigations at 4 I MC 29 took p 1 ace over a four day period in April 1981. During that time, nine CAR crew members spent a total of 288 person hours working on the site.

A grid system for horizontal control was set on the surface of 41 MC 29. A point on a nearby site marker placed during Phase I investigations served as the vertical datum. USBR surveyors 1 ater calculated a true elevation of 198.07 feet above MSL for this vertical datum. They then replaced the original site marker with a permanent marker and calculated its exact location in terms of Modified Texas State Plane Coordinates (Figs. 37; 38).

Nine $1-m^{2}$ units were 1 aid out to form a $3-m^{2}$ excavation block for Phase II work at 41 MC 29. The excavation block was placed off the southern edge of Test Pits 1 and 3 from Phase I (Fig. 38). The unit-block was placed in hopes of retrieving a larger sample of materials indicated by the test pits, especia11y the Late Archaic feature isolated in the lower horizon. Unit designator coordinates and number of $10-\mathrm{cm}-t h i c k$ levels excavated in each unit are N997 El011 (six leve1s), N997 El012 (seven levels), N997 El013 (seven leve1s), N998 El011 (six leve1s), N998 El012 (six levels), N998 El013 (six levels), N999 El011 (six, levels), N999 E1012 (six levels), and N999 El013 (six levels). Surface elevations for the above units ranged from $99.85 \mathrm{~m}$ to $99.93 \mathrm{~m}$. The soil matrix excavated from these units was described as dark grayish brown silty clay loam from the surface down into Level 4 (30$40 \mathrm{~cm}$ below the surface). In Leve1 4, the soil became 1 ighter brown in color. In Leve1 5, the soil changed to 1 ight yel lowish brown silty clay loam. This soil color and consistency continued to the bottom of the excavation.

Prehistoric cultural debris recovered from the Phase II excavation block at 41 MC 29 is divided into two horizons in the same way as were materials recovered from the Phase I test pits. Horizon 1 contains debris recovered from Levels 1-3 in the nine units. Horizon 2 consists of the debris recovery from Levels 4-6 or 7. Rates of recovery for selected classes of debris are as follows for the two horizons:

\section{Horizon 1 Horizon 2}

Tuff Weight (grams)

Sandstone Weight (grams)

Fire-Fractured Rock Weight (grams)

Mussel Shel1 Umbo Count

Mussel She11 Weight (grams)

Rabdotus She11 Count

Bone Weight (grams)

Primary Flake Count

Secondary Flake Count

Tertiary Flake Count

Chip Count

$\begin{array}{rr}0 & 3 \\ 416 & 1573 \\ 57 & 62 \\ 96 & 103 \\ 49 & 64 \\ 169 & 972 \\ 1.4 & 3.5 \\ 10 & 5 \\ 72 & 62 \\ 150 & 56 \\ 225 & 99\end{array}$

Additional artifacts found in the Phase II excavation at 41 MC 29 from Horizon 1 were four thin bifaces (two, Group 4, Form 4; two, Group 10), two pieces of modified sandstone (one, Group 1, Form 3; one, Group 2, Form 2), one piece of ocher, and a piece of modified siltstone. Horizon 2 yielded two 


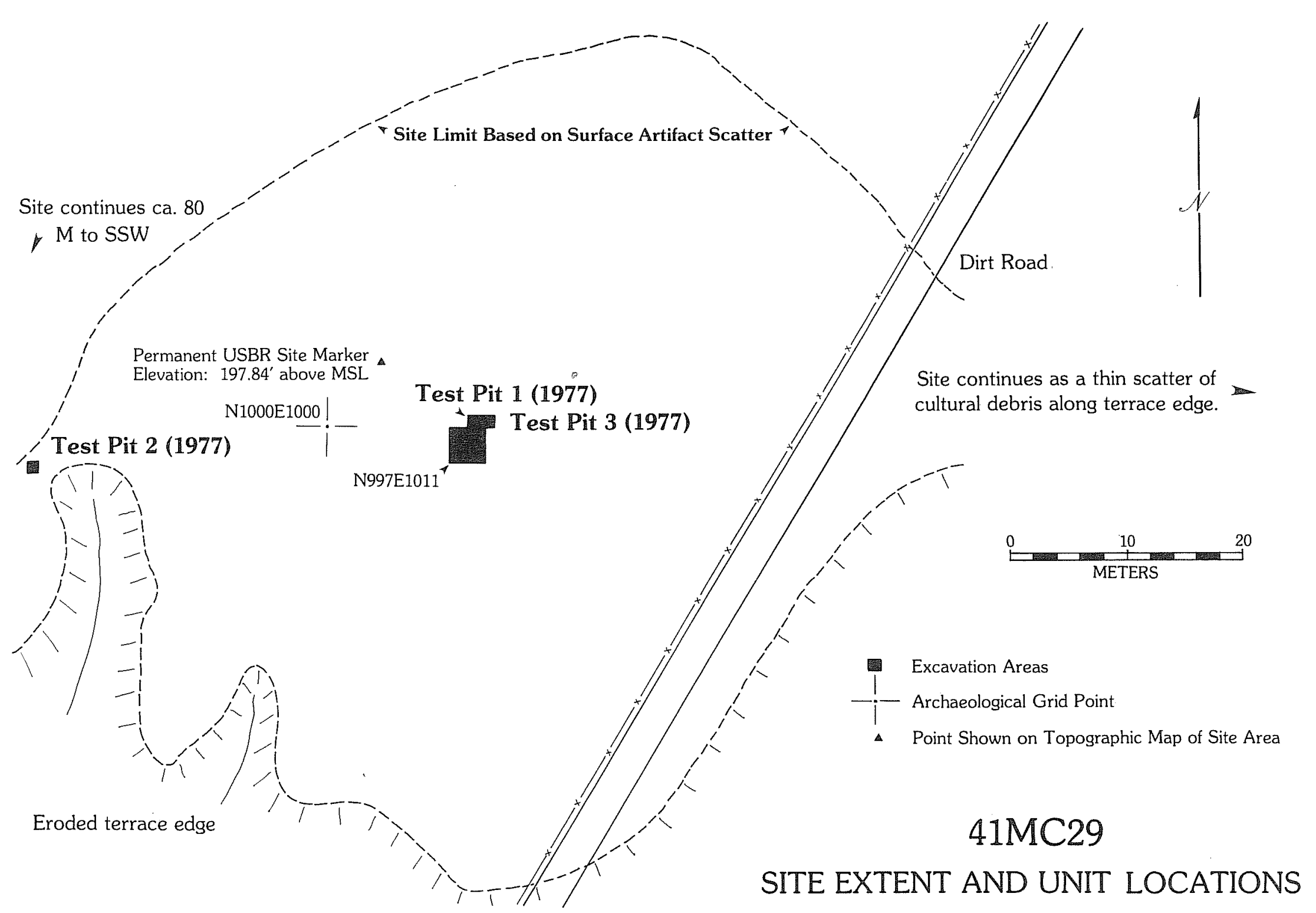

Figure 38. Plan Showing Site Extent and Unit Locations at 41 MC 29. 
cores (one, Group 2; one, Group 6), one thick biface (Group 9), and four pieces of modified sandstone (one, Group 1, Form 3; one, Group 2, Form 2; one, Group 2, Form 3; one, Group 3).

Two habitational features, a rock cluster, and a filled pit, were isolated at the bottom of Horizon 2 (Figs. 39; 40,b,c). Feature 2 was a cluster of about 38 pieces of burned sandstone. The feature was scattered across two units, N998 E1013 and N999 E1013, in Leve1 $6(99.40$ to $99.30 \mathrm{~m})$. The actual range of elevations in the feature was from 99.40 to $99.34 \mathrm{~m}$. The area where most of the feature components were concentrated was in Unit N998 E1013. Pieces of sandstone and a patch of carbon flecking covered a roughly circular area 40 to $50 \mathrm{~cm}$ in diameter (Fig. 39). Other pieces of sandstone and a small amount of carbon were widely scattered to the north and south of the main concentration. Several pieces of debitage, two or three mussel she 11 valves, and a piece of fire-fractured rock were also noted in and around Feature 2. The rocks occurred in a single 1 ayer.

Feature 3 was encountered about one meter south of Feature 2 in Unit N997 E1013. It was first recognized in Leve1 6 (at $99.76 \mathrm{~m}$ ). The feature was traced down to a maximum depth of $99.26 \mathrm{~m}$. Feature 3 consists of a subcircular pit that had a diameter of about $40 \mathrm{~cm}$. Around this filled pit was an area of stained soil flecked with carbon that was somewhat more extensive than the pit outline. This stained area continued into the south and west walls of the unit. Matrix removed from the filled pit was described as very dark grayish brown silty clay loam mottled with burned clay, carbon flecks, and white ash. Also noted in the fill were burned mussel shell fragments, burned bone, and small pieces of sandstone. Other mottled, stained patches were observed to the east of the primary feature area (Fig. 39). Carbon collected from Feature 3 was submitted for radiocarbon assay in two separate samples. The assays yielded ages of 410 B.C. and 60 B.C. to A.D. 10 (TX-4688 and TX-4689, MASCA corrected). These dates bracket the age of 390 to 270 B.C. (TX-2873) yielded by the Phase I assay.

At 41 MC 29, Feature 1, recorded during Phase I investigations (Ha11, B1ack, and Graves 1982:180, 183), and Features 2 and 3 a 11 appear to occur on the same 1 iving surface within the site. Dates resulting from radiocarbon assay of carbon samples recovered from two of the features have provided an age range of 410 B.C. to A.D. 10. It is primarily on the basis of radiocarbon ages that the Horizon 2 remains at 41 MC 29 are assigned to the Late Archaic period. No recognized time-diagnostic artifacts were recovered from the Horizon 2 excavations. However, probable Late Archaic chipped stone tools (distally beveled tool forms) have been surface collected on the site. Horizon 2 yielded no Late Prehistoric materials.

The smal1 filled pit (Feature 3) isolated in the Horizon 2 Late Archaic component at 41 MC 29 is not a common type of habitational feature at Choke Canyon. The presence of burned musse 1 she 11 and smal1 animal bones, ash. burned clay, and carbon in the pit fill could indicate either that it was a cooking facility or a trash receptacle.

Findings made in Test Pits 1 and 3, during Phase $I$ investigations, indicated that Horizon 1 materials at 41 MC 29 represent human activity during the Late Prehistoric period. The Phase II excavations yielded no additional 


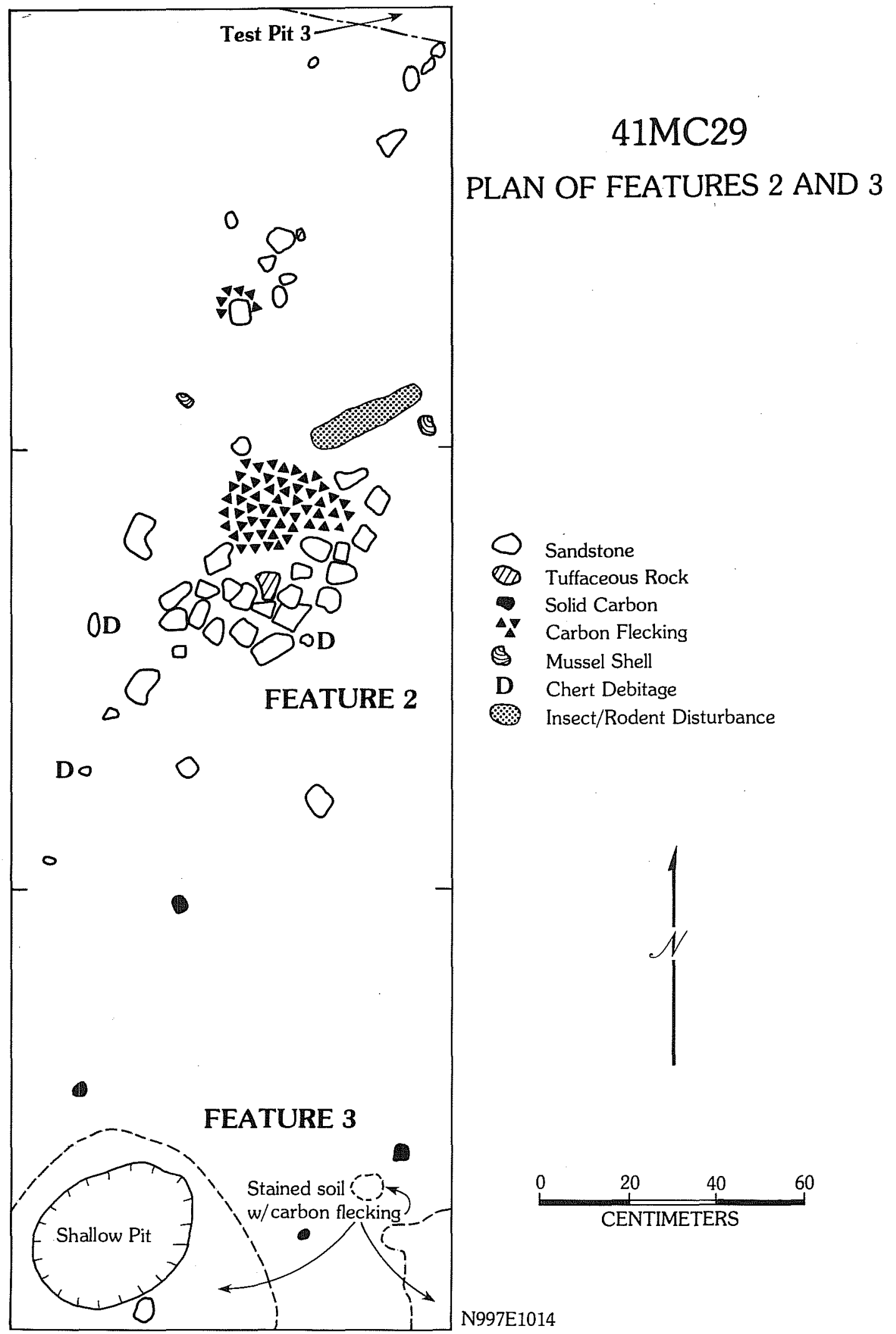

Figure 39. Plan of Features 2 and 3 at 41 MC 29. 
recognized Late Prehistoric diagnostics. Nevertheless, Horizon 1 is suggested to contain remains of a Late Prehistoric component.

Artifacts collected from the surface of 41 MC 29 during Phase II were one core (Group 6) and two distal1y beveled tools (one, Group 3, Form 2; one, Group 9). Recovery of the Group 3, Form 2 distally beveled tool brings the tota 1 of Group 3 tools to four for the site (two, Group 3, Form 2; and one, Group 3, Form 3 were found in Phase I). Al1 are 1 ikely derived from the Horizon 2 component, the Group 3 distally beveled tools are suggested to be fairly reliable Late Archaic diagnostics.

Results of the Phase II investigation at 41 MC 29 provide no new insights into subsistence habits for either the Late Archaic or Late Prehistoric periods. A possible contrast in diets is indicated by the fact that Horizon 2 (Late Archaic) yielded much more sandstone and Rabdotus snail shell than did Horizon 1 (Late Prehistoric). Both horizons contained musse1 she11, animal bone, and sandstone grinding implements in roughly equal quantities.

\section{MC 55}

Site 41 MC 55 rests on a second terrace and levee system above the active floodplain on the south (right) bank of the Frio River (Fig. 1, folded insert). Recorded 1 imits for the site are $600 \mathrm{~m}$ northwest to southeast and a width of from 100 to $150 \mathrm{~m}$. The Frio River is within $75 \mathrm{~m}$ of the site's west end, but then bends northward and is $300 \mathrm{~m}$ or more north of the greater portion of 41 MC 55 (Fig. 4I). Relict channel scars are, however, visible at the foot of the terrace slope, constituting the northern edge of the site. It appears as if the river flowed immediately beneath the site at sometime in the past. The site is bordered on the east by a 1 arge oxbow 1 ake which trends north-northeast to south-southwest and is about $500 \mathrm{~m}$ 1ong. Next to this lake in the northeast corner of 41 MC 55, there is a $10 \mathrm{w}$, but distinct rise formed by a natural levee along the relict channel containing the 1 ake. The eastern third of the site is covered with a dense growth of whitebrush and scattered large mesquite trees (Fig. 40,d). High piles of tree trunks, $1 \mathrm{imbs}$, and other brush occur here and there at this end of the site, an indication that the surface was mechanically cleared of brush not long ago. The whitebrush has apparently reestablished itself since the clearing took place. Along the terrace slopes on the eastern and northern margins of the site grow elms, large mesquite trees, spiny hackberry, and a variety of low brush species. Along the immediate edge of the oxbow lake, especially on its eastern side, immense cottonwood trees are growing. The 1 ake is 1 ined with dense mustang grape canopies. The western portion of the site is in a cleared, grass-covered pasture. There are barns and corrals at the extreme western end. Mesquite and other brush grow only in a narrow fringe along the immediate edge of the terrace.

Phase I investigations at 41 MC 55 consisted of excavation of three $1-m^{2}$ test pits, collection of surface artifacts, and a thorough inspection of the entire site surface. Based on the results of this initial investigation, the eastern end of the site was determined to hold the most productive subsurface deposits of prehistoric cultural debris. Test pits at this end of the site revealed both Archaic and Late Prehistoric components stratified within the 
Figure 40 . Views of 41 MC 29 and 41 MC 55.

as view looking east across Phase II excavation area at 41 MC 29;

b, an overview of Feature 2, a burned sandstone accumulation in Level $6(99.40$ to $99.30 \mathrm{~m})$ of Units N998 E1013 and N999 E1013 at 41 MC 29;

c. shown is Feature 3 (a filled pit) at 41 MC 29 with the fill partially removed. Unit floors (N997 El012 and N997 E1013) are at $99.20 \mathrm{~m}$ elevation;

d, view looking north across area of Phase II excavations at 41 MC 55;

e, overview of feature debris exposed in Area D at 41 MC 55, looking south (photograph by Prince George Mckenzie, Texas Archeological Society);

f, overhead view of chert cobble and bone concentration in Area $D$ of 41 MC 55. The unit is N1008 El015 at an elevation of $99.30 \mathrm{~m}$ (photograph by Prince George Mckenzie, Texas Archeological Society). 


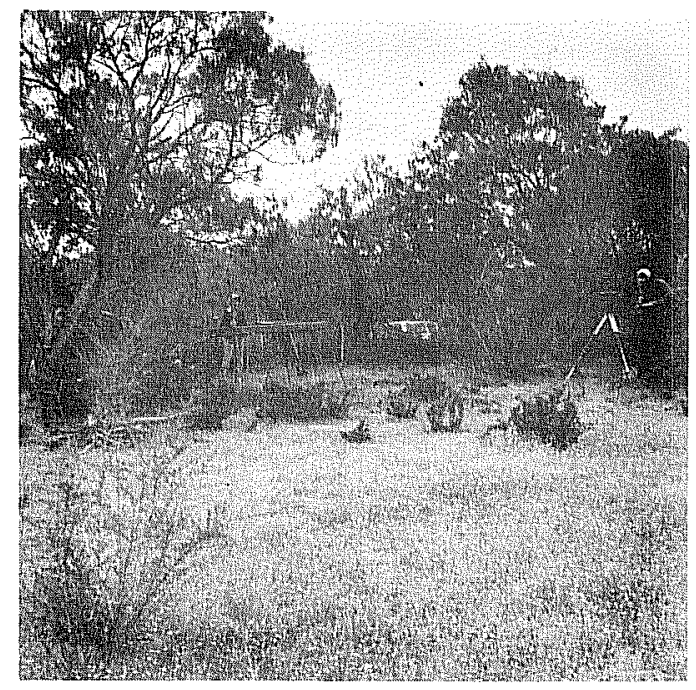

a

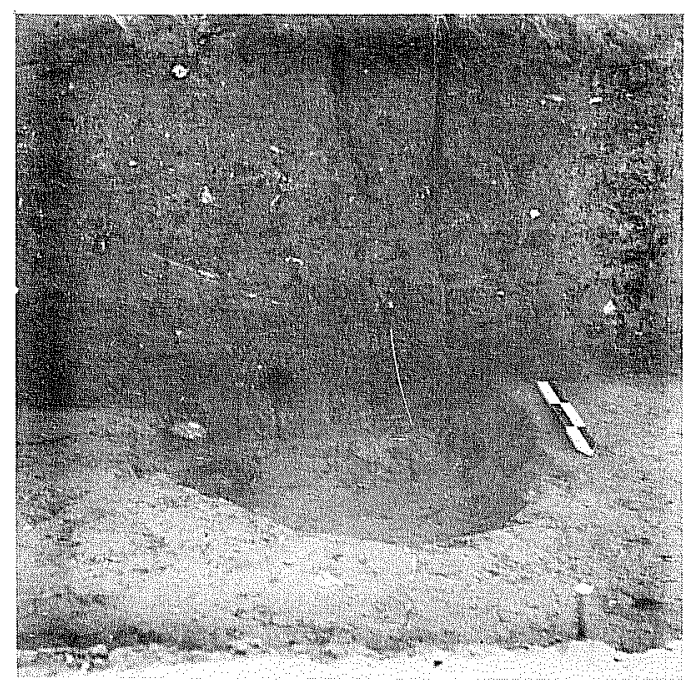

c

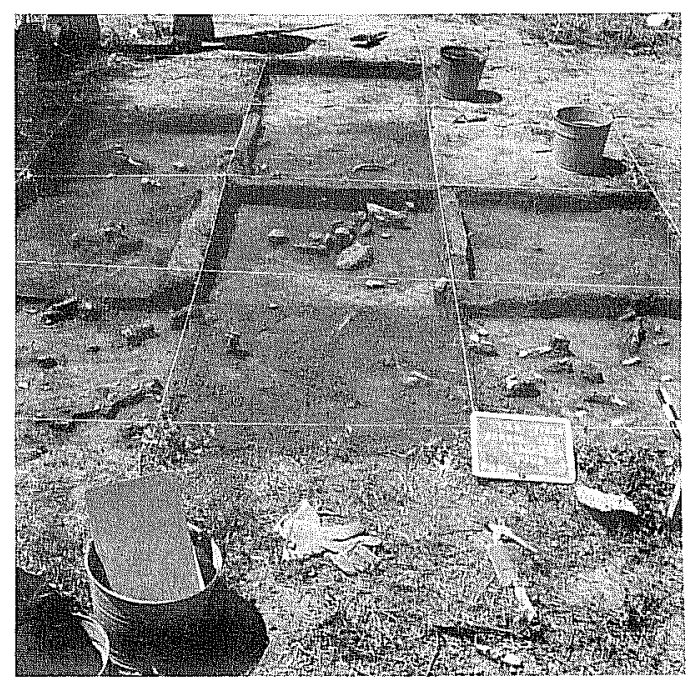

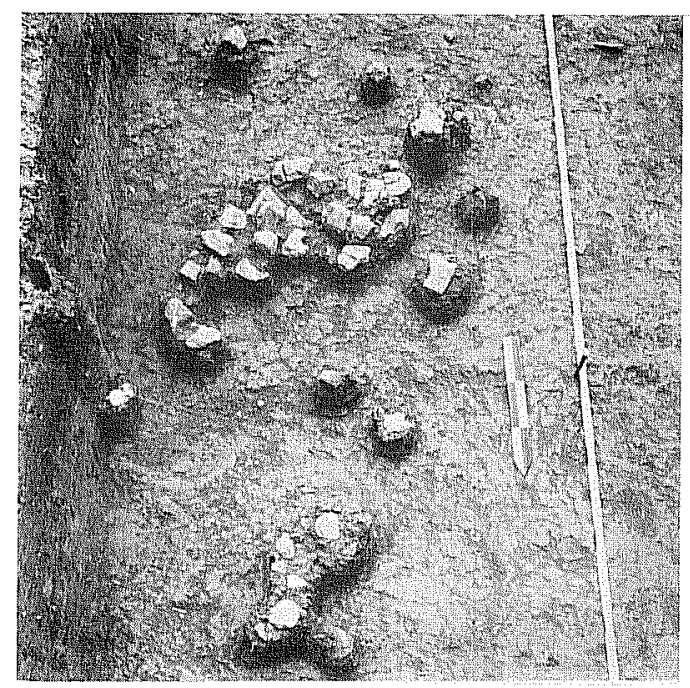

b

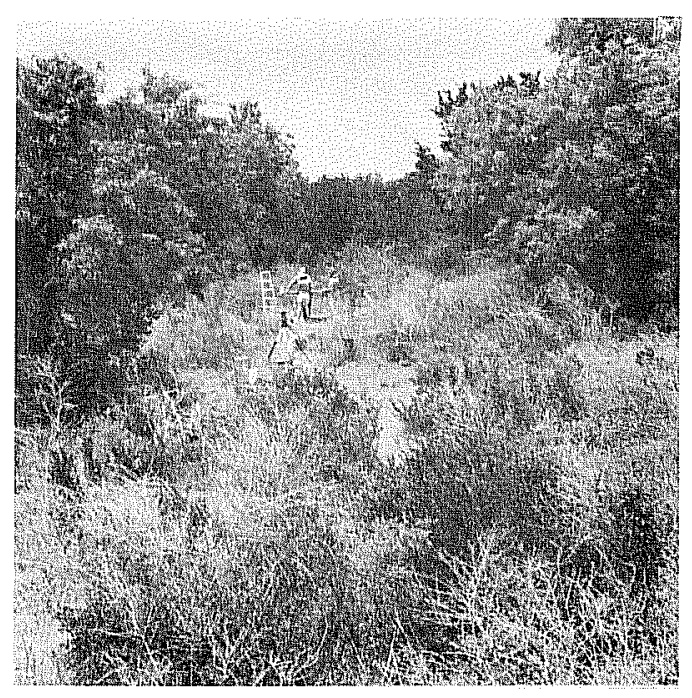

d

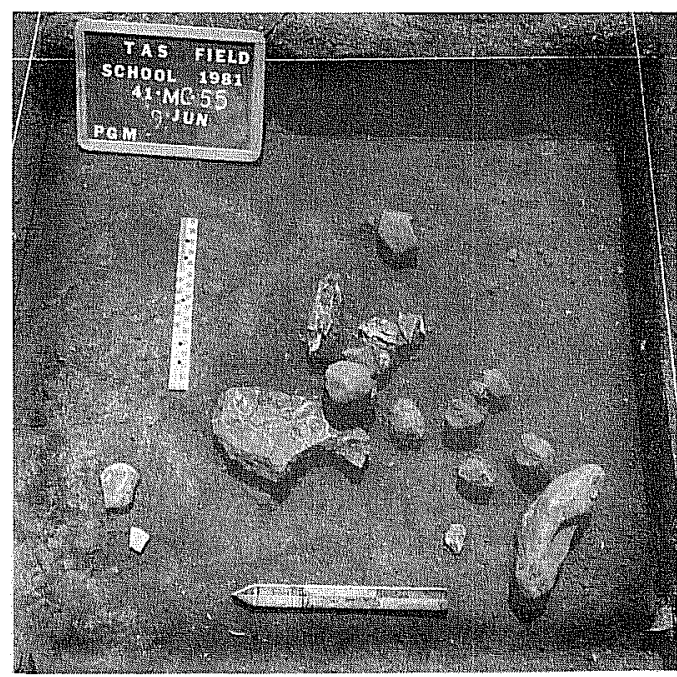

f 
Figure 41. Topographic Map of 41MC55 and Surrounding Area.

PAGE 140 REDACTED 
upper 80 to $100 \mathrm{~cm}$ of deposit. In addition to being stratified, the deposits yielded relatively more animal bone than most of the other prehistoric sites tested during Phase I. The recovery of asphaltum, asphaltum-coated pottery, and marine she 11 artifacts in the test pits and from the surface suggested an unusual coastal relationship for the Late Prehistoric inhabitants of the site (Ha 1 1, Black, and Graves 1982:192-196).

The Phase II investigation at 41 MC 55 occurred in May and June 1981. During a four day period in May, nine members of the CAR crew spent 288 person hours excavating Areas $A$ and $B$. Twenty-nine members of the Texas Archeologica 1 Society (TAS) participating in the summer field school excavated in Areas $C$, $D$, and $E$ over a four day period in June. Field school participants expended an estimated 392 person hours of effort at 41 MC 55.

A grid providing horizontal control was established at 41 MC 55. A spike driven into the trunk of a large mesquite tree north of the N1000 El000 stake served as the vertical datum for archaeological excavations. USBR surveyors 1 ater determined a true elevation of 199.07 feet above MSL for this vertical datum. They also replaced the N1000 El000 stake with a permanent metal site marker. Its exact location expressed in Modified Texas State Plane Coordinates was calculated.

Test pit results and surface conditions indicated that virtualiy the entire area between Phase I Test Pits $I$ and 3 would likely contain productive deposits of prehistoric cultural debris in the subsurface (Fig. 42). The Phase II Area $A$ units were located farther back from (west of) the oxbow 1 ake to aid in determining the density of subsurface prehistoric debris in that zone of the site.

Area $A$ consisted of two $1-m^{2}$ units. Coordinates for these units and number of 10-cm-thick levels excavated from each are N1017 E999 (12 1 evels) and N1018 E999 (eight leve1s). Surface elevations for these two units ranged from 99.39 to $99.40 \mathrm{~m}$. From the surface down through Leve1 9 (98.60 to $98.50 \mathrm{~m}$ ), soil matrix in Area $A$ was described as medium to 1 ight grayish brown silty clay loam. In Level 10, the soil changed to very pale brown silty clay. Two horizons were defined based on debris recovery from the Area A excavation. Horizon 1 contains debris from Levels 1-3, and Horizon 2 contains the debris from Levels 4-12. Rates of recovery for selected classes of debris from these two horizons are as follows:

Horizon 1 Horizon 2

Tuff Weight (grams)

Sandstone Weight (grams)

Fire-Fractured Rock Weight (grams)

Mussel Shell Umbo Count

Musse1 She11 Weight (grams)

Rabdotus She11 Count

Bone Weight (grams)

Primary Flake Count

Secondary Flake Count

Tertiary Flake Count

Chip Count

$\begin{array}{rr}0 & 0 \\ 33 & 225 \\ 2 & 6 \\ 39 & 177 \\ 27 & 55 \\ 37 & 54 \\ 7 & 2 \\ 0 & 0 \\ 12 & 25 \\ 17 & 47 \\ 32 & 77\end{array}$




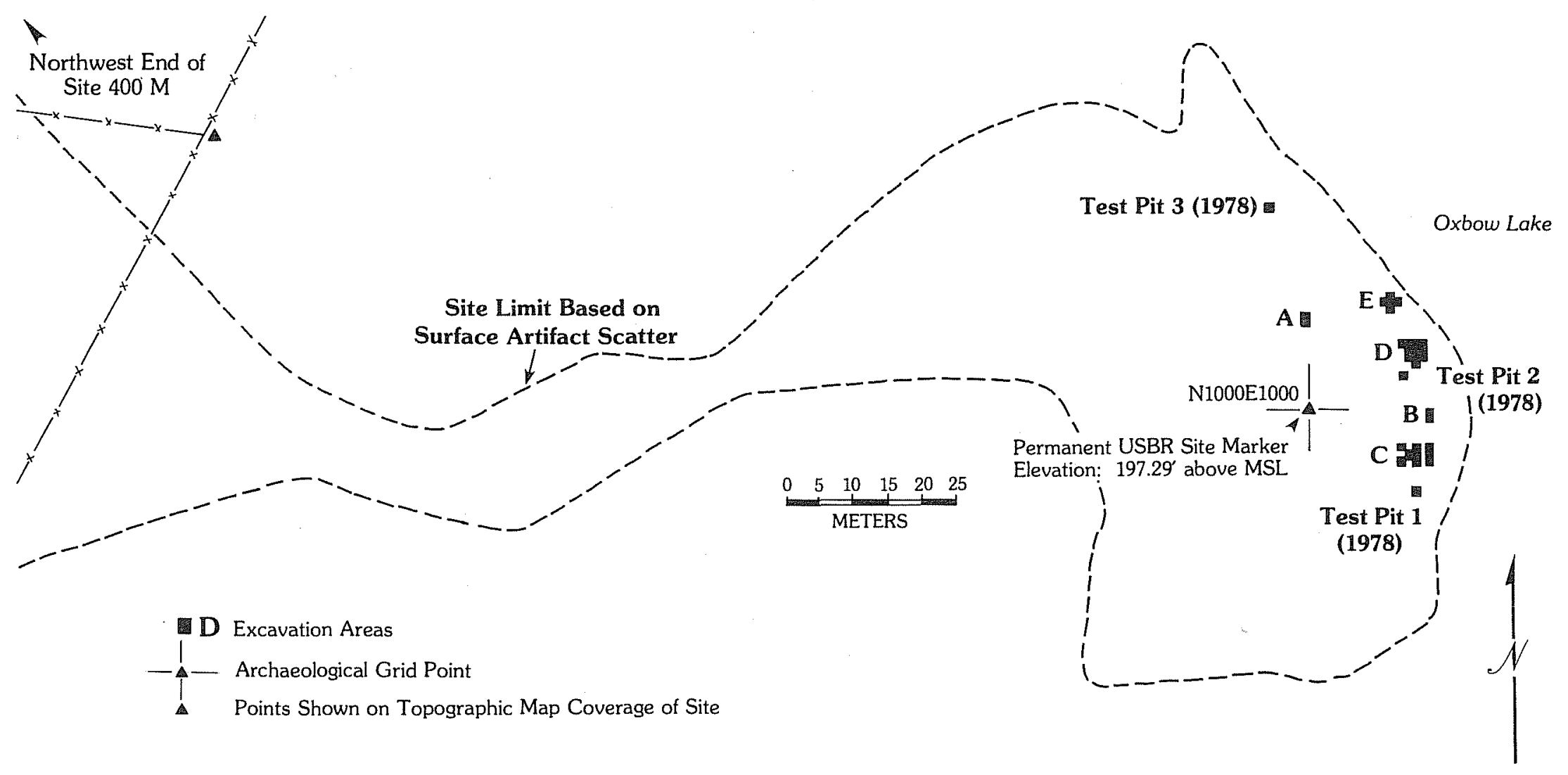

\section{MC55}

\section{SITE EXTENT AND UNIT LOCATIONS}

Figure 42. Plan of Site Extent and Unit Locations at 41 MC 55. 
Three additional artifacts--one thick biface (Group 1), one thin biface (Group 4, Form 2, Specimen 15), and a piece of satin spar gypsum-were also recovered from Area $A$. The thin biface came from Horizon 1 and the other two specimens from Horizon 2.

A cluster of sandstone was found in Level $9(98.60$ to $98.50 \mathrm{~m})$ of Unit N1017 E999 in Area A. Designated Feature 1, there were 15 pieces of sandstone distributed in a northeast-southwest linear pattern. A main concentration of 13 pieces of sandstone was confined to a $30-\times 50-\mathrm{cm}$ area in the southwest corner of the unit. Four of the pieces of sandstone continued into the south wal1. There were also two pieces of fire-fractured rock with the sandstones. The feature appears to have been constructed in a single layer, but a maximum vertical difference of $12 \mathrm{~cm}$ was noted between the base of the highest and lowest components. Rocks in Feature 1 ranged from $4-8 \mathrm{~cm}$ in maximum dimension. Light carbon flecking was noted in the feature matrix, and a smal1 sample of carbon was collected.

The Phase II excavation designated Area B at 41 MC 55 also consisted of two $1-m^{2}$ units. The excavation was located roughly midway between Phase I Test Pits 1 and 2 (Fig. 42). Coordinates for the Area B units and number of 10-cm-thick levels excavated in each are N998 E1017 (six levels) and N999 E1017 (nine levels). Surface elevations ranged from 99.36 to $99.40 \mathrm{~m}$. The soil excavated in Area B was described as very dark grayish brown clay loam from the surface to the base of excavations. Calcium carbonate nodules began appearing in Level 7 and increased down into Level 9. Two horizons are defined for Area B with 1evel assignments as follows: Horizon 1, Levels 1-3; Horizon 2, Levels 4-9. These two horizons yielded the following:

Horizon 1 Horizon 2

Tuff Weight (grams)

Sandstone Weight (grams)

Fire-Fractured Rock Weight (grams)

Mussel Shel1 Umbo Count

Mussel She11 Weight (grams)

Rabdotus She11 Count

Bone Weight (grams)

Primary Flake Count

Secondary Flake Count

Tertiary Flake Count

Chip Count

$\begin{array}{rc}0 & 0 \\ 84 & 48 \\ 3 & 15 \\ 22 & 16 \\ 22 & 3 \\ 29 & 34 \\ 50 & 0.5 \\ 3 & 0 \\ 23 & 9 \\ 35 & 12 \\ 118 & 25\end{array}$

Other artifacts recovered from Horizon 1 of Area B include two cores (Group 5), an arrow point fragment (thin bifaces Group 1, Form 7, Specimen 22), two trimmed flakes (Group 2, Specimen 2; Group 3, Form 5 , Specimen 2), and five sherds of aboriginal pottery. From Horizon 2 came one core (Group 1), one thick biface (Group 6, Form 2), one piece of modified sandstone (Group 1, Form 3), and a piece of ocher.

Level $2(99.30$ to $99.20 \mathrm{~m})$ in both units of Area B contained a dense Late Prehistoric midden deposit consisting of bison, deer, and bird bone, debitage, mussel she11, sandstone, and carbon. Affiliation with the Late Prehistoric period is based on the presence of potsherds and an arrow point 
fragment amidst the midden debris. Results of excavations elsewhere at 41 MC 55, especially Area D (discussed below), reveal that the Area B Late Prehistoric materials are a smal1 portion of a much more extensive 1 iving surface. A plan map showing the in situ distribution of the midden materials in Leve 12 of Area B was drawn. Due to the 1 imited horizontal extent of this particular excavation, the plan is not illustrated.

The Area $C$ excavation at 41 MC 55 consisted of nine $1-m^{2}$ units $p 1$ aced between Test Pit 1 and Area B (Fig. 42). Coordinates for the nine units and the number of 10-cm-thick levels excavated in each are $\mathrm{N992}$ El013 (one leve1), N992 El015 (one leve1), N992 El017 (one leve1), N993 Elol4 (one 1evel), N993 El015 (one leve1), N993 El017 (one leve1), N994 El013 (one leve1), N994 El015 (two leve1s), and N994 E1017 (two leve1s). Starting elevations for the units ranged from 99.37 to $99.43 \mathrm{~m}$. The Area C units were excavated by participants in the TAS Summer Field School. Cultural debris recovered corresponds to Horizon 1 collections as defined elsewhere on the site. Rates of recovery for selected classes of debris from the combined units and levels of Areas C, D, and $E$ (Areas $D$ and $E$ are discussed below) are as follows:

$\begin{array}{rrrr}\text { Area C } & & \text { Area } & \text { Area } \\ 1 & & & \\ 50 & & 313 & 0 \\ 43 & 51 & 57 \\ 52 & 62 & 5 \\ 18 & 73 & 49 \\ 33 & 244 & 47 \\ 58 & 185 & 37 \\ 2 & 16 & 3 \\ 28 & 142 & 7 \\ 33 & 296 & 76 \\ 117 & 989 & 265\end{array}$

Additional artifacts found in Area $C$ are one core (Group 6), four thin bifaces (Group 1, Form 4, Specimen 72 [Perdiz]; Group 1, Form 4, Specimen 85 [C1 iffton]; one, Group 6, Form 3; one, Group 10), one piece of modified sandstone (Group 1, Form 2), a piece of ocher, and 25 sherds of aboriginal pottery.

Eleven $1-m^{2}$ units made up Area D at 41 MC 55. This unit-block was located northeast of Test Pit 2 (Fig. 42). Coordinates for the Area D units and the number of 10-cm-thick levels excavated in each are N1006 El015 (two levels), N1007 E1014 (two leve1s), N1007 E1015 (three leve1s), N1007 E1016 (two leve1s), N1008 El014 (three leve1s), N1008 E1015 (two levels), N1008 El016 (two leve1s), N1009 El013 (two leve1s), N1009 El014 (one level), N1009 E1015 (two leve1s), and N1009 E1016 (two levels). Surface elevations in these units ranged from 99.36 to $99.45 \mathrm{~m}$. Area D excavations were also carried out by members of the TAS Summer Field School. Cultural debris collected in Area $D$ corresponds to the Horizon 1 assemblages defined elsewhere on the site. Rates of recovery for selected classes of debris from all units and levels of Area D combined are shown above. 
Area D also yielded the following artifacts: 12 cores (four, Group 1; three, Group 3; two, Group 4; three, Group 5), six thin bifaces (Group 1, Form 4 , Specimen 29 [Perdiz]; Group 1, Form 4, Specimen 30 [Perdiz]; Group 3, Form 1, Specimen 8; Group 4, Form 4, Specimen 130; one, Group 9; one, Group 10), one trimmed flake (Group 3, Form 3, Specimen 2), three pieces of modified sandstone (one, Group 1, Form 3; two, Group 2, Form 3), two hammerstones (Specimens 3 and 4), one piece of ocher, and 150 sherds of aboriginal pottery.

The size of the Area $D$ excavation and the careful recording job done by TAS excavators resulted in an informative plan map of the Late Prehistoric activity surface illustrated in Figures $40, e, f$ and 43 . Figure 43 shows the patterning of sandstone, animal bone (primarily bison), mussel she11, carbon, debitage, chipped stone tools, and potsherds encountered in the Area $D$ units.

Area $E$ consisted of four $1-m^{2}$ units located along the edge of the 51 ough north of Area D and east of Area A (Fig. 42). Coordinates for each unit and the number of 10-cm-thick levels excavated in each are N1014 El011 (one leve1), N1015 E1010 (one leve1), N1015 E1012 (one 1eve1), and N1016 E1011 (one level). Surface elevations ranged from 99.32 to $99.39 \mathrm{~m}$. Rates of recovery for selected classes of debris from Area $E$ are shown above. Also recovered in Area $E$ excavations were two cores (Group 5), two thin bifaces (Group 1, Form 4, Specimen 86 [Perdiz]; one, Group 9), a uniface (Group 5 , Specimen 3), two pieces of modified sandstone (both Group 1, Form 3), a hammerstone (Specimen 5), and one sherd of aboriginal pottery.

A carbon sample collected from Levels 2 and 3 of the Area $A$ excavations at 41 MC 55 was divided into two separate samples and submitted to the Radiocarbon Laboratory. The University of Texas at Austin, for assay. Assay of the two samples yielded radjocarbon dates of A.D. $1420(T X-4692)$ and A.D. 1230 (TX-4693) (MASCA corrected). Additional carbon samples from 41 MC 55 were analyzed to determine the species of woods burned to form the carbon. Acacia sp./Prosopis sp. and unidentified hardwoods were most common in the collection of samples examined (see Appendix II).

The Phase II investigation at 41 MC 55 produced a smal1 amount of information concerning a probable Late Archaic component within the site and, due primarily to the efforts of the Texas Archeological Society Summer Field School participants, a substantial body of data relating to a wel1-preserved Late Prehistoric component in the site.

Confined glimpses of a component buried 60 to $90 \mathrm{~cm}$ beneath the surface of 41 MC 55 were provided by excavations in Areas A and B. No recognized diagnostic artifacts of the Archaic period were found in the Phase II excavations. However, a stemmed dart point (thin bifaces Group 1, Form 3 ) and a sma 11 distal1y beveled tool (Group 3, Form 3) collected from the surface of 41 MC 55 during Phase I investigations permits the suggestion that this earlier component dates to the Late Archaic (Ha 1 1, Black, and Graves 1982:196). The smal1 cluster of sandstone exposed in Horizon 2 of Area $A$ demonstrates that the component contains intact habitational features. Mussel she 11 and Rabdotus snail shell are probable residues of foods consumed on the site by Late Archaic residents. 


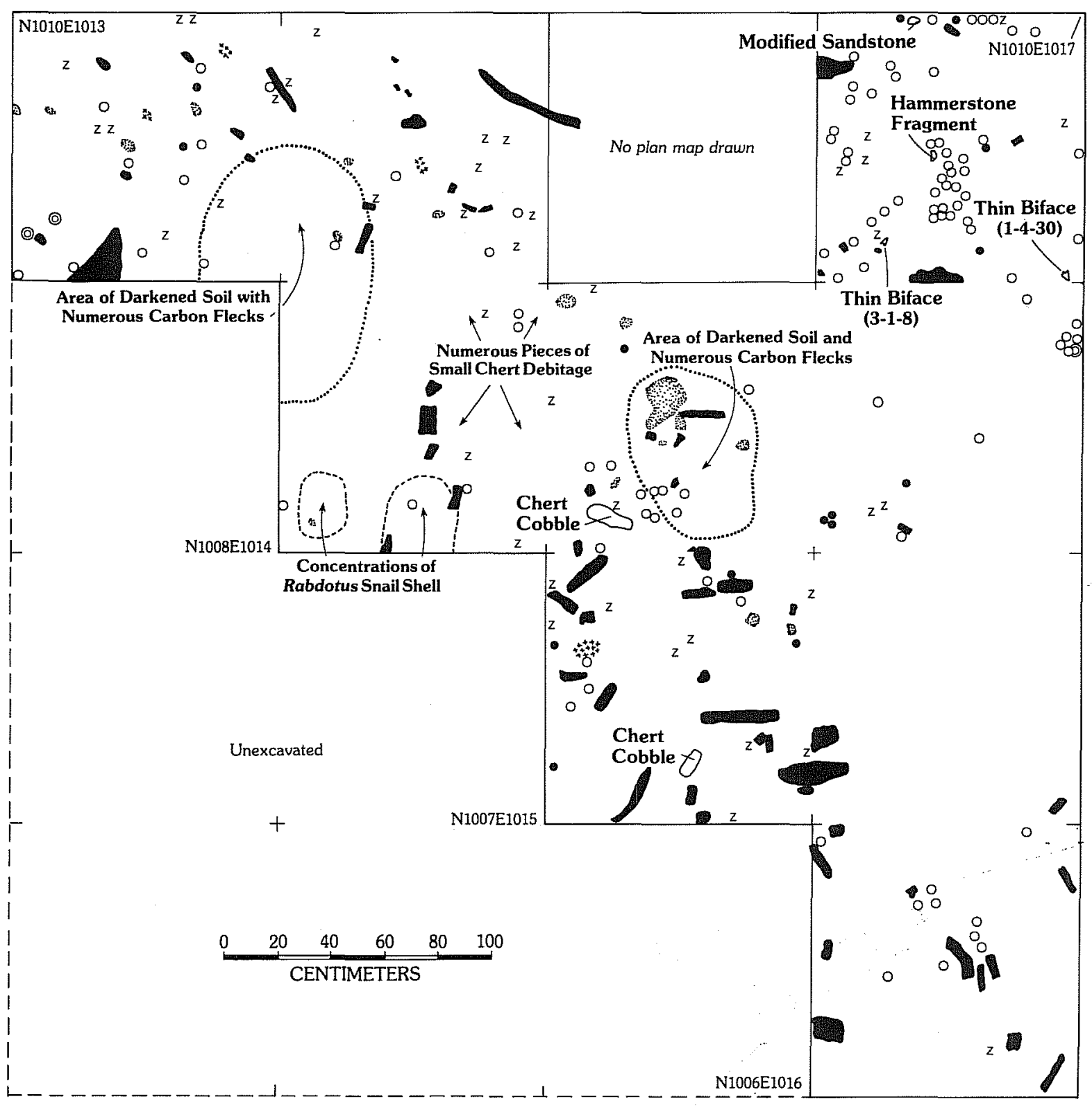

$\begin{array}{ll}\text { Sandstone } & \text { ○ Chert Debitage } \\ \text { z Mone } & \text { - Chert Tool } \\ \text { f* Carbon Flecking } & \text { - Potsherd }\end{array}$

41MC55

AREA D PLAN

Figure 43. Area D Plan at 41 MC 55. 
An extensive and highly productive Late Prehistoric component was evidenced in all of the excavation areas at 41 MC 55. Debris representing this component was contained in the upper $30 \mathrm{~cm}$ of deposit on the site, this particular vertical increment of deposit and the cultural debris it contained are referred to as Horizon 1. The actual surface upon which Late Prehistoric people were active appears to have been in Level 2 , or 10 to $20 \mathrm{~cm}$ beneath the modern site surface.

The Late Prehistoric camp at 41 MC 55 was inhabited by-people who hunted bison, possessed the bow and arrow, and had pottery vessels. Animal bone, principally bison, but including other smaller animals as wel1, was recovered in substantial quantities from Areas $B, C$, and $D$. One major activity evidenced on the site was the butchering of one or more bison. In Area $D$, the proximity of the bone to apparent hearth and chert knapping activity areas indicates that the butchering was being done in the midst of other more general habitational activities.

The array of chipped stone tools representing the Late Prehistoric component at $41 \mathrm{MC} 55$ is very typical for the region, especially at sites where bison bone also occurs. Perhaps the most diagnostic specimens are the Perdiz arrow points (thin bifaces Group 1, Form 4) and the beveled knives (thin bifaces Group 4, Form 2). Other triangular, unstemmed thin biface forms (Group 3, Form 1; Group 4, Form 4; and Group 6, Form 3) are also characteristic, if less distinctive, Late Prehistoric tool forms. Unifaces (Group 5, Specimen 3) and trimmed flakes (Group 2, Form 2; Group 3, Form 3; and Group 3, Form 5) are also a hall mark of Late Prehistoric components. The frequent co-occurrence of beveled knives and certain distinctive forms of unifacial and trimmed flake tools with bison bone strongly suggests that these tool forms functioned in butchering and hide preparation capacities.

Chipped stone tool manufacture is strongly evidenced by remains in the Late Prehistoric component at 41 MC 55. Numerous cores, thin bifaces, biface fragments, hammerstones, and debitage are the knapping-related tools and byproducts represented in the Horizon 1 assemblage. Especially diagnostic of the iate Prehistoric period are cores in Groups 3, 4, and 5. Significantiy, the two thick bifaces recovered at 41 MC 55 (Group 1; Group 6, Form 2) came from the Archaic deposits of Horizon 2. Late Prehistoric tool making was oriented toward core-flake reduction, whereas Archaic period flintknappers used a core-biface technology more commonly.

In addition to bison and other lesser vertebrates, the Late Prehistoric inhabitants of 41 MC 55 also appear to have been gathering musse 15 and 7 arge 1 and snails as supplemental meat foods. Manos and metate fragments (modified sandstone Groups 1 and 2) suggest that they were also preparing seed or nut foods on the site. Close association of the above materials with potsherds indicates that pottery vessels were used extensively as an aid in food preparation (see Prehistoric Ceramics section for a more detailed discussion).

Remarkably, no additional marine shell artifacts were found in the Phase II excavations at 41 MC 55. Recovery of two pieces of marine shell from Phase I test pits and some asphaltum on potsherds, 1 ed to the suggestion that the Late Prehistoric inhabitants of the site had coastal contacts of some type 
(Ha11, Black, and Graves 1982:196). Although no additional marine shell was found, more asphaltum-coated pottery and a smal1, unstemmed thin biface (Group 3, Form 2, Specimen 8) typed tentatively as a McGloin point offer further support for a coastal affiliation. In this respect, the Late Prehistoric component at 41 MC 55 is quite atypical in comparison to other such components known at Choke Canyon.

Radiocarbon assay of two carbon samples from Horizon 1 deposits at 41 MC 55 yielded ambiguous results. The samples were derived from a single collection made in the Area A excavation. The resultant ages (MASCA corrected) of A.D. 1420 (TX-4692) and A.D. 1230 (TX-4693) are thus inexp 1 icably divergent. Radiocarbon dates from other sites at Choke Canyon (4I LK 201, 41 MC 296) suggest that TX-4692 is a more accurate age for the type of remains seen at 41 MC 55. Identification of Prosopis sp. or Acacia sp. as wood burned to produce much of the carbon collected from Horizon 1 deposits suggests that the present brush community existed on or near the site in prehistoric times.

\section{MC 234}

Site 41 MC 234 is an open prehistoric site recorded by the CAR crew during 1979 survey operations. It is located on the left (west) bank of the Salt Creek drainage southwest of the old Calliham town site (Fig. I, folded insert). The site's southeast end is within 50 to $75 \mathrm{~m}$ of the creek channel. It is oblong in out 1 ine shape with dimensions of $100 \mathrm{~m}$ east-west and $200 \mathrm{~m}$ north-south. The site surface is moderately eroded and covered with brush species such as mesquite trees, prickly pear, soapbush, spiny hackberry, yucca, and grasses. Prehistoric cultural activity is evidenced at this location by a relatively dense surface scatter of debitage, mussel shel1. sandstone, fire-fractured rock, and chipped stone tools.

Activities of the CAR crew during Phase II investigations at 41 MC 234 consisted of excavation of two shovel tests and an unprovenienced collection of surface artifacts. The shovel tests revealed that the subsurface held 1 ittle potential for controlled excavations. Artifacts collected at 41 MC 234 were one thick biface (Group 7, Form 4), five thin bifaces (one, Group 1, Form 6; one, Group 2, Form 1; three, Group 2, Form 2), and one uniface (Group 2). One of the thin bifaces (Group 2, Form 2, Specimen 42) exhibits fine diagonal ribbon flaking characteristic of Paleo-Indian tool traditions and, indeed, this specimen is believed to be a Paleo-Indian point fragment, possibly of the Plainview type. Otherwise, the 4I MC 234 artifact assemb 1 age suggests that cultural activity occurred on the site sometime during the Archaic period.

\section{MC 235}

Site 41 MC 235 is also located on the left (west) side of the Salt Creek drainage. This site is about $400 \mathrm{~m}$ northwest of $41 \mathrm{MC} 234$ on a low, narrow ridge trending southwest to northeast (Fig. 1, folded insert). The low ridge appears to have been formed by erosion along Salt Creek and a minor tributary channel north of the site. Site 41 MC 235 is oriented with its 1 ong axis running east-northeast to west-southwest. It has a long oval outline shape 
with dimensions of $50 \times 200 \mathrm{~m}$. Scattered vegetation on the moderately eroded surface includes mesquite trees, spiny hackberry, whitebrush, a 1 thorn, prick 1 y pear, other cacti, and various grasses. This site was recorded by the CAR survey crew in 1979. It was defined on the basis of a 1 ight scatter of debitage, a few cores, some fire-fractured rock, sandstone, and chipped stone tools observed on the surface. One badly disturbed sandstone concentration, probably a hearth remnant, was seen.

In Phase II, the CAR crew resurveyed 4 I MC 235 . Inspection of gully walls showed that prehistoric cultural debris was confined to the upper 10 to $15 \mathrm{~cm}$ of deposit on the site. Shovel tests were judged unnecessary. An unprovenienced surface collection yielded three thick bifaces (one, Group 3; one, Group 5; one, Group 7, Form 1) and 10 thin bifaces (one, Group 4, Form 3; five, Group 4, Form 4; four, Group 9). This array of specimens indicates that cultural activity occurred on the site sometime during the Archaic period.

\section{SIIE GROIP 9}

Extensive Test Excavation Pits

Surface Collections
Provenienced Unprovenienced

41 MC 238
Resurvey or Shove] Tests

41 MC 242

The two sites in Group 9 are located on the right (west) side of the Frio River between 14 and $15 \mathrm{~km}$ west of Choke Canyon Dam. This area is at the lower end of the huge reverse-S curve in the Frio River known as Yarbrough Bend ( $F$ ig. I, folded insert). The sites are situated on a low second terrace above the Frio River's modern channel. Relict channel scars are apparent on the floodplain between the sites and the river. Following floods and/or periods of heavy $10 \mathrm{cal}$ rainfa11, the channel scars hold water to form 1ong, narrow ponds. The sites and surrounding areas are heavily covered in brush, especialiy mesquite and whitebrush. To the west are cleared fields and pastures higher on the floodplain. Valley margin slopes covered with a pavement of $1 \mathrm{ag}$ gravels are 1 ocated rough 1 y $500 \mathrm{~m}$ west of the sites. The adjacent segment of the Frio River has the deepest water of any stretch in the Choke Canyon basin.

\section{MC 238}

Site 41 MC 238 is 1 ocated along the edge of the second terrace above the Frio River and overlooks a meander scar (relict channel) immediately to the east (Fig. 1, folded insert). The site is elongate in outline, following the terrace edge for a northeast to southwest distance of $230 \mathrm{~m}$. It is about $20 \mathrm{~m}$ wide. Piles of brush and scraped areas visible on the surface indicated that the site had been bul1 dozed not long before the Phase II investigation. Between the brush clearing and natural erosion, the site surface was heavily 
disturbed. Moderate to heavy brush cover here and there on the site were guaji110, mesquite trees, weeds, and grasses.

Phase II investigations at 41 MC 238 consisted of a series of shovel tests and a provenienced collection of surface artifacts. The five shovel tests excavated at various locations on the site revealed that the subsurface contained negligible amounts of prehistoric cultural debris. One badly disrupted cluster of 12 pieces of sandstone exposed in a bulldozed area was sketched.

Thirty-nine prehistoric artifacts were collected from the surface of 41 MC 238. Locations of these artifacts were plotted on a p 1 an map of the site (on file at the CAR-UTSA). The artifact assemblage representing this site consists of four cores (three, Group 3; one, Group 9), six thick bifaces (three, Group 1; one, Group 6, Form 2; one, Group 8; one, Group 9), 16 thin bifaces (Group 1, Form 2, Specimen 6 [Langtry]; Group 1, Form 3, Specimen 31; three, Group 2, Form 2; one, Group 3, Form 2; three, Group 4, Form 4; one, Group 8; two, Group 9; four, Group 10), five distally beveled tools (one, Group 3. Form 1; two, Group 3, Form 3; one, Group 4; one, Group 7, Form 2), and eight pieces of modified sandstone (one, Group 1, Form 1; two, Group l, Form 3; three, Group 2, Form 2; one, Group 2, Form 3; one, Group 3).

Diagnostic forms included in the above assemblage indicate that 41 MC 238 was inhabited during the Middle Archaic and/or Late Archaic periods. The Langtry dart point (thin bifaces Group 1, Form 2, Specimen 6) is a Midd1e Archaic diagnostic in the Trans-Pecos area of southwest Texas. The Choke Canyon Langtry specimens are not exactly 1 ike the type as it occurs in the TransPecos area. Further, the type has not yet been recovered from radiocarbondated deposits in southern Texas. The array of distally beveled tools found at 41 MC 238 suggests that the site was inhabited during Late Archaic times. Elsewhere at Choke Canyon, the smaller distally beveled tool forms, designated in this report as Groups 3 and 4, have been found in Late Archaic context.

Musse1 she11, Rabdotus snail she $11 \mathrm{~s}$, and a number of grinding imp 1 ements (modified sandstone Groups 1-3) provide evidence of some of the food items consumed by the site's prehistoric inhabitants.

\section{MC 242}

Site 41 MC 242 is located on the same terrace and about $500 \mathrm{~m}$ southwest of 41 MC 238 (Fig. 1, folded insert). Like 41 MC 238, 41 MC 242 was located and recorded by the CAR crew during the 1979 survey. Situated on a natural levee rise above a relict channel of the Frio River, 41 MC 242 is roughly oval in outline shape and measures $100 \times 150 \mathrm{~m}$. The surface is moderately eroded and densely covered with mesquite trees, whitebrush, grasses, and weeds. A dirt road following $\bar{a}$ powerline bisects the site north to south. The surveyors noted a badly eroded sandstone cluster in the road. The presence of a Perdiz arrow point and a "beveled knife" indicated to them that the site was inhabited during the Late Prehistoric period. 
Phase II work at 41 MC 242 consisted of excavation of several shovel tests, documentation of the sandstone cluster exposed on the surface, and an unprovenienced collection of surface artifacts. The five shovel tests placed around the site revealed very little prehistoric debris in the subsurface. The smal1 amount of cultural material was in the upper $20 \mathrm{~cm}$ of deposit. Findings made in the shovel tests indicated that controlled excavations were not warranted. The sandstone hearth feature noted by the surveyors in 1979 was relocated. Eroding from the dirt road cutting through the site, this feature was further exposed during Phase II work. It consisted of about 20 pieces of sandstone and 10 pieces of fire-fractured rock arranged in two smal1 clusters, the centers of which were about $60 \mathrm{~cm}$ apart. One cluster was $20 \mathrm{~cm}$ in diameter, the other about $30 \mathrm{~cm}$ in diameter. The 1arger, somewhat looser cluster to the northeast contained eight pieces of sandstone and five pieces of fire-fractured rock. Also recognized in this portion of the feature were a deer bone fragment, a mussel shel1, and a grinding 51 ab (metate) fragment. Carbon flecking was noted amidst the rocks. The smaller, tighter cluster to the southwest had 12 pieces of sandstone and five pieces of fire-fractured rock. There was a substantial amount of carbon in the center of the cluster. Six or eight pieces of debitage were scattered to the west and south of this concentration.

An unprovenienced collection of surface artifacts at 41 MC 242 yielded two cores (one, Group 4; one, Group 7), one thick biface (Group 1), three thin bifaces (one, Group 4, Form 4; two, Group 9), one trimmed flake (Group 2), and two pieces of modified sandstone (one, Group 1, Form 3; one, Group 2, Form 2). The Late Prehistoric diagnostic artifacts reported by the surveyors were not relocated, suggesting that artifact collectors had scoured the site subsequent to the 1979 survey. The Phase II artifact collection contains no recognized time-diagnostic specimens.

\section{SITE GROUR 10}

Extensive Test Excavation Pits

41 MC 296

Surface Collections
Provenienced Unprovenienced

41 MC 276
Resurvey or Shovel Tests

41 MC 280

The three sites comprising Site Group 10 are located in the E1m Creek drainage system from 16 to $18 \mathrm{~km}$ west-northwest of Choke Canyon Dam. $E 1 \mathrm{~m}$ Creek, an intermittent stream, and its tributaries drain a 1 arge area to the north of Yarbrough Bend on the Frio River. The main Elm Creek channel originates $8 \mathrm{~km}$ or more northwest of its juncture with the Frio River (Fig. 1, folded insert). As the Elm Creek channel feeds down in the Frio River valley, it assumes an easterly course for a couple of kilometers and then bends southward to meet the Frio River. The floodplain it traverses is exceptionally broad, relatively featureless, and heavily covered in brush. The local geologic formation is the Jackson Group, the most noteworthy component of which is we 1 1-cemented sandstone. Outcrops of Jackson Group sandstone form the impressive topographic rise known as Opossum Hil1. This 
hi11, or ridge, trends north-northwest to south-southeast and separates the E1m Creek and Opossum Creek drainages. Lesser prominences formed of resistant Jackson Group sandstones occur on the north and northwest sides of the $E 1 \mathrm{~m}$ Creek valley. E1m Creek supports a substantial gallery of riparian forest species, predominant among them are oak and elm trees. The floodplain between Elm Creek and the Frio River supports huge mesquite trees, Mexican persimmon, prickly pear, whitebrush, and other brush species. The main creek channel is 1 ined with natural levees and terraces. These features, coupled with findings made in prehistoric sites along its banks, indicate that Elm Creek was once a much more substantial watercourse than currently.

\section{$41 \mathrm{MC} 296$}

Site 41 MC 296 is an open aboriginal campsite situated on the right (south) bank of Elm Creek approximately $2.5 \mathrm{~km}$ upstream from the creek's juncture with the Frio River (Figs. 1, folded insert; 44). The site is about $500 \mathrm{~m}$ south of the Jackson Group sandstone outcrops forming the northern val 1 ey margin in the area (Fig. 46,a). Recorded by the CAR survey crew in August 1979, 41 MC 296 measures about $20 \mathrm{~m}$ north-south and $250 \mathrm{~m}$ east-west. The site is broadly U-shaped reflecting a similar bend in the adjacent Elm Creek channe1. The site surface is in relatively good shape; eroded spots are on $7 y$ along the immediate edge of the creek channel (Fig. 46,b). Moderate to dense brush cover is present. Dense stands of whitebrush are in some portions. Mesquite trees, spiny hackberry, soapbush, prickly pear, al1thorn, and persimmon are elsewhere. The creek margin supports oak and elm trees (F ig. $46, \mathrm{C}$ ).

Site 41 MC 296 was both tested and extensively excavated during the course of Phase II investigations. The CAR crew excavated three $1-\mathrm{m}^{2}$ test pits on the site in January 1981. Based on the excellent results of the testing operation, further excavations were conducted at the site in April and May 1981, by the CAR crew and in June 1981, by participants in the Texas Archeological Society Summer Field School. The combined efforts of six to nine CAR crew members over a period of 23 work days resulted in an expenditure of 1376 person hours on the investigation at 41 MC 296. Although severely hampered by rainfall during the week of the TAS Summer Field School, participants numbering from 15 to 28 nevertheless were able to work a total of 360 person hours during five days in June 1981. Over 1700 person hours of effort were thus invested in the Phase II investigation at 41 MC 296.

Locations for the three test pits initial1y excavated at 41 MC 296 were arbitrarily selected (Fig. 45). Test Pits 1 and 2 were located in the eastcentral area of the site. Test Pit 3 was placed in the west-central part of the site. Very productive deposits found in Test Pits 1 and 2 prompted location of the excavation blocks designated Areas $A$ and $B$, and subsequentiy Areas $C, D, E$, and $G$. The excavation areas were laid out according to a grid system, the origin of which was an arbitrarily selected point south of Area $A$ (N1010 El000, Fig. 45). Vertical control was provided by a spike driven into the trunk of a mesquite tree located on the north side of the excavations. USBR surveyors later determined a true elevation of 214.86 feet above MSL for this vertical datum. They also placed a permanent marker on the site 
Figure 44. Topographic Map of 41MC296 and Surrounding Area.

PAGE 153 REDACTED 
Figure 45. Site Extent and Excavation Plan at 41MC296.

PAGE 154 REDACTED 
(Fig. 45) and calculated its exact location in terms of Modified Texas State Plane coordinates.

Major unit blocks and test pits excavated during Phase II investigations at 41 MC 296 cluster at two locations in the east-central area of the site (Fig. 45). Reflecting their proximity to one another, Test Pit 2 and Areas A and $D$ wil 11 be presented and discussed together. Likewise, Test Pit $I$ and Areas $B, C$, and $E$ will be treated together. Area G, a separate unit-block to the west, is presented by itself.

Test Pit 2 was the easternmost Phase II excavation at 41 MC 296 (Fig. 45). Excavated to a depth of $90 \mathrm{~cm}$ below the surface (nine 10-cm-thick levels), the unit yielded prehistoric cultural debris that has been divided into three horizon assemblages. Soil matrix from the surface to a depth of $50 \mathrm{~cm}$ was described as medium to dark brown silty clay loam. In Level $6(50$ to $60 \mathrm{~cm}$ below surface), the soil changed to grayish brown silty clay loam and in Level 9 to 1 ight brown silty clay loam. This test pit was excavated prior to placement of the $100 \mathrm{~m}$ arbitrary vertical datum. Surface elevations relative to the datum are therefore unavailable. Horizon divisions for the debris assemb 1 age from Test Pit 2 are Horizon 1, Levels 1 and 2; Horizon 2, Levels 3 and 4 ; and Horizon 3, Levels 5-9. Rates of recovery for selected classes of debris are as follows:

\section{Horizon 1 Horizon 2 Horizon 3}

$\begin{array}{lrrr}\text { Tuff Weight (grams) } & 0 & 0 & 0 \\ \text { Sandstone Weight (grams) } & 46 & 76 & 124 \\ \text { Fire-Fractured Rock Weight (grams) } & 14 & 7 & 15 \\ \text { Mussel She11 Umbo Count } & 48 & 26 & 18 \\ \text { Musse1 She11 Weight (grams) } & 38 & 10 & 6 \\ \text { Rabdotus Shel1 Count } & 10 & 41 & 35 \\ \text { Bone Weight (grams) } & 4 & 3 & 18 \\ \text { Primary Flake Count } & 4 & 2 & 2 \\ \text { Secondary Flake Count } & 8 & 31 & 9 \\ \text { Tertiary Flake Count } & 30 & 40 & 38 \\ \text { Chip Count } & 77 & 116 & 68\end{array}$

Other artifacts recovered from Horizon 1 of Test $P$ it 2 include two thin bifaces (Group 1, Form 7, Specimen 27; one, Group 10) and a trimmed flake (Group. 3, Form 1, Specimen 8). Horizon 2 yielded a thin biface fragment (Group 9) and a piece of modified sandstone (Group 1, Form 3). A most unusual find made in Horizon 3 of Test Pit 2 was a complete sandstone grinding slab (metate, modified sandstone Group 1, Form 1, Specimen 13) and a hand grinder (mano, modified sandstone Group 2, Form 1, Specimen 2). The mano was resting above the metate, the two being separated by from $1-3 \mathrm{~cm}$ of soil matrix (Figs. 46,e,f). Although unearthed in Level 8 (70 to $80 \mathrm{~cm}$ below the surface), the lowest point on the underside of the metate rested on a plane $90 \mathrm{~cm}$ below the surface (as measured with tape and level 1 ine from the ground surface at the unit's southwest corner). This mano and metate probably relate to the same prehistoric habitational episode that resulted in deposition of Feature 1 in Area $A$ to be discussed in more detail below. 
Figure 46. Views of 41 MC 296: Local Environment, Excavations in Progress, and Habitational Features.

a. view east-northeast from the central area of 41 MC 296. Low line of hills visible along the horizon marks resistant outcrops of Jackson Group sandstone. The ridge is called Opossum Hil1. The Elm Creek channel is to the left (north);

b. looking north up the bank of Elm Creek to the main excavation area at 41 MC 296;

c, view northwest of Area $A$ and Area $B$ excavations in progress at 41 MC 296. Note the whitebrush in the foreground and the large mesquite and oak trees in the background;

d, view Tooking east across the Area A excavation to Area $B$ at 41 MC 296;

e, mano and metate found in situ in Level 8 of Test Pit 2 at 41 MC 296, looking south;

f, overhead photograph of mano and metate in Test Pit 2 at 41 MC 296. 


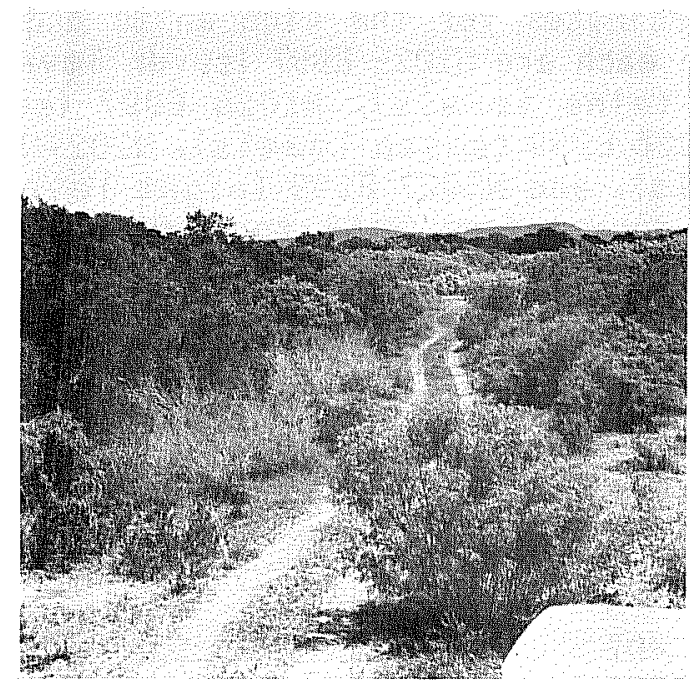

a

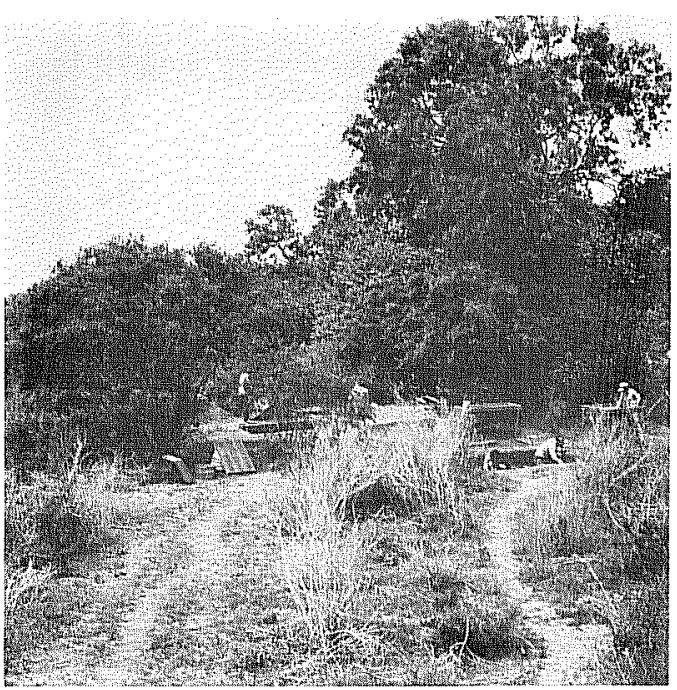

c

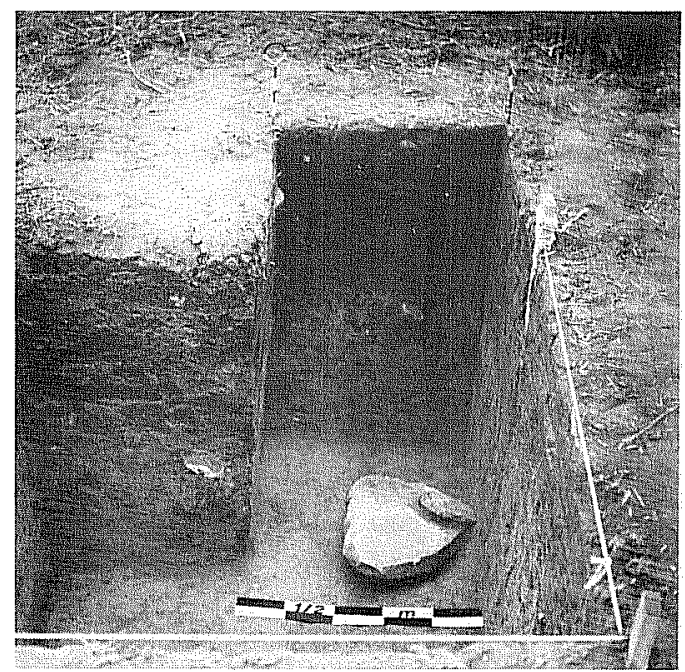

e

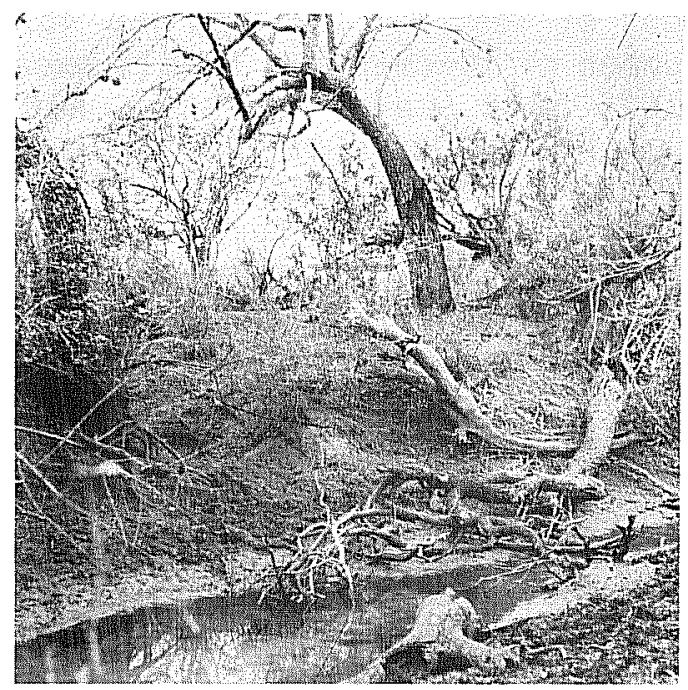

b

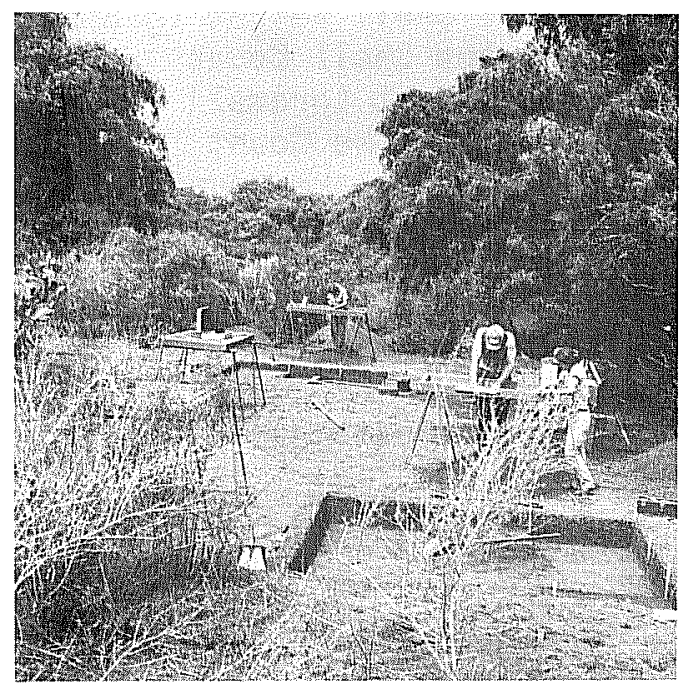

d

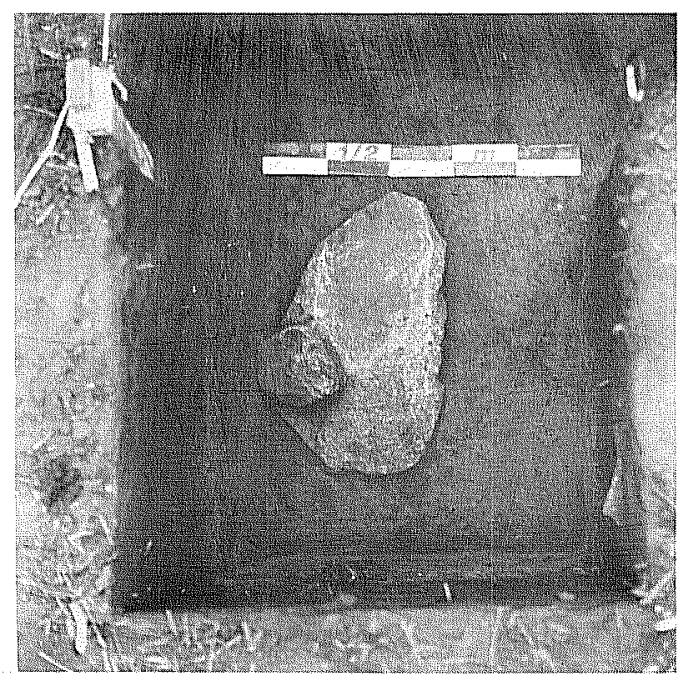


Area $A$ at 41 MC 296 consisted of nine $1-m^{2}$ units forming a $3-m^{2}$ block just west of Test Pit 2 (Figs. 45; 46,d). Coordinates for the nine units and the number of 10-cm-thick levels excavated in each are N1025 E997 (seven levels), N1025 E998 (seven 1eve1s), N1025 E999 (nine leve1s), N1026 E997 (seven leve1s), N1026 E998 (seven leve1s), N1026 E999 (seven 1eve1s), N1027 E997 (seven leve1s), N1027 E998 (seven leve1s), and N1027 E999 (eight leve1s). Surface elevations for the Area A units ranged from 99.55 to $99.60 \mathrm{~m}$. Soil characteristics in Area A were 1 ike those described for Test Pit 2 above. Three horizons were defined for Area $A$. Level groupings for the horizons are Horizon 1, Levels 1 and 2; Horizon 2, Leve1s 3 and 4; and Horizon 3, Levels 5-7 or 8. Rates of recovery for selected classes of debris from the Area $A$ horizons are as follows:

Horizon 1 Horizon 2 Horizon 3

$\begin{array}{lrrr}\text { Tuff Weight (grams) } & 0 & 0 & 0 \\ \text { Sandstone Weight (grams) } & 407 & 688 & 3281 \\ \text { Fire-Fractured Rock Weight (grams) } & 202 & 136 & 144 \\ \text { Musse1 She17 Umbo Count } & 121 & 162 & 100 \\ \text { Musse] She11 Weight (grams) } & 35 & 49 & 34 \\ \text { Rabdotus She11 Count } & 135 & 346 & 472 \\ \text { Bone Weight (grams) } & 29 & 26 & 19 \\ \text { Primary Flake Count } & 22 & 11 & 6 \\ \text { Secondary Flake Count } & 311 & 229 & 184 \\ \text { Tertiary Flake Count } & 657 & 457 & 315 \\ \text { Chip Count } & 1057 & 712 & 446\end{array}$

Area $A$ also yielded the following artifacts:

\begin{tabular}{|c|c|c|c|c|c|c|}
\hline Group & Form & Specimen & Category & I Horizon 1 & Horizon 2 & Horizon 3 \\
\hline & & & & I & & \\
\hline 1 & - & - & Cores & 0 & 0 & 1 \\
\hline 2 & - & - & Cores & 1 & 0 & 0 \\
\hline 3 & - & - & Cores & 1 & 0 & 0 \\
\hline 4 & - & - & Cores & 1 & 0 & 0 \\
\hline 5 & - & - & Cores & 2 & 2 & 1 \\
\hline 2 & - & - & Thick Bifaces & 0 & 0 & 1 \\
\hline 6 & 1 & - & Thick Bifaces & 0 & 1 & 0 \\
\hline 1 & 3 & 19 & Thin Bifaces Ensor & 0 & 0 & 1 \\
\hline 1 & 3 & 34 & Thin Bifaces & 0 & 1 & 0 \\
\hline 1 & 3 & 38 & Thin Bifaces Zavala & 0 & 0 & 1 \\
\hline 1 & 4 & 48 & Thin Bifaces Perdiz & 1 & 0 & 0 \\
\hline 1 & 4 & 49 & Thin Bifaces Perdiz & 1 & 0 & 0 \\
\hline $\bar{I}$ & 4 & 50 & Thin Bifaces Perdiz & 0 & 1 & 0 \\
\hline $\bar{I}$ & 5 & 11 & Thin Bifaces Scallorn & 0 & 1 & 0 \\
\hline 1 & 5 & 27 & Thin Bifaces & 0 & 1 & 0 \\
\hline$i$ & 5 & 28 & Thin Bifaces & 1 & 0 & 0 \\
\hline 1 & 5 & 29 & Thin Bifaces & 0 & 1 & 0 \\
\hline 1 & 7 & 44 & Thin Bifaces & 1 & 0 & 0 \\
\hline 4 & 2 & 23 & Thin Bifaces & 0 & 1 & 0 \\
\hline 4 & 3 & 25 & Thin Bifaces & 0 & 0 & 1 \\
\hline 4 & 4 & 90 & Thin Bifaces & 0 & 1 & 0 \\
\hline
\end{tabular}




\begin{tabular}{rrrl|llll}
4 & 4 & 91 & Thin Bifaces & & 0 & 1 & 0 \\
4 & 4 & 169 & Thin Bifaces & 1 & 1 & 0 & 0 \\
4 & 4 & 170 & Thin Bifaces & 1 & 1 & 0 & 0 \\
9 & - & - & Thin Bifaces & 2 & 0 & 0 \\
10 & - & - & Thin Bifaces & 1 & 5 & 1 & 2 \\
2 & - & 4 & Trimmed Flakes & 1 & 1 & 0 & 0 \\
3 & 5 & 3 & Trimmed Flakes & 1 & 0 & 0 \\
1 & 2 & - & Modified Sandstone & 1 & 0 & 1 & 0 \\
1 & 3 & - & Modified Sandstone & 3 & 1 & 2 \\
2 & 3 & - & Modified Sandstone & 1 & 1 & 0 & 1 \\
3 & - & - & Modified Sandstone & 1 & 0 & 0 & 2 \\
- & - & - & Satin Spar Gypsum & 1 & 0 & 0 & 1 \\
- & - & - & Ocher & 1 & 2 & 3 \\
- & - & 4 & Bone Bead & 1 & 0 & 0 \\
- & - & 8 & Marine Shel1 & 1 & 0 & 0 & 1 \\
- & - & - & Aboriginal Ceramics & 9 & 4 & 0 \\
- & - & - & Metal Knife Blade & 1 & 1 & 0 & 0
\end{tabular}

One unit in Area A, N1027 E999, was excavated to a depth of $2.7 \mathrm{~m}$ (ca. $96.90 \mathrm{~m}$ ) below the surface to test for more deeply buried cultural debris and to provide more information on the character of subsurface deposits in the site. A profile drawing of the north wall of this unit and brief descriptions of recognized soil zones are provided in Figure 47. No cultural debris was encountered beneath the Zone 4-Zone 3 contact at approximately $80 \mathrm{~cm}$ bel ow the surface.

One habitational feature, an extensive accumulation of burned sandstone, was defined in the Area $A$ excavation (Figs. 48; 50,b). Portions of Feature 1 occurred in Level $6(99.10$ to $99.00 \mathrm{~m})$ in a 11 nine units of the $3-\mathrm{m}^{2}$ area. Although most components of the feature were in Level 6 , the high and 10 w elevations on individual objects ranged from $99.11 \mathrm{~m}$ (Level 5 ) to 98.90 (Leve1 7). It is thus probable that the mano and metate found in Test Pit 2 were deposited during the same activity episode as resulted in the Feature 1 remains. There is a circular, though scattered, configuration to the rock cluster (more obvious in Fig. 50,b than in Fig. 48). Other debris observed amidst the sandstone pieces were chert debitage, mussel and Rabdotus she11s, carbon, and flecks of burned clay. Much of the Horizon 3 debris 1 isted above for Area $A$ came from the matrix in and around Feature 1. Based on the presence of carbon, burned clay, and the fired appearance of the sandstone, it is.assumed that Feature 1 functioned as a hearth. Postdepositional processes apparently caused partial disintegration and scattering of the feature components.

Area $D$ was a $1-\times 3-m$ pit located a meter off the west side of Area $A$ (Fig. 45). These units were excavated by participants in the TAS Summer Field School during June 1981. Coordinates for the three Area $D$ units and the number of 10-cm-thick levels excavated in each are N1025 E995 (six levels), N1026 E995 (six levels), and N1027 E995 (six levels). Surface elevations for the Area $D$ units ranged from 99.57 to $99.60 \mathrm{~m}$. Three horizons are defined within the assemblage of debris gathered from the Area $D$ units. Level groupings are the same as described for Test Pit 2 and Area $A$ above. Rates of recovery for selected classes of debris from the three horizons in Area $D$ are as follows: 


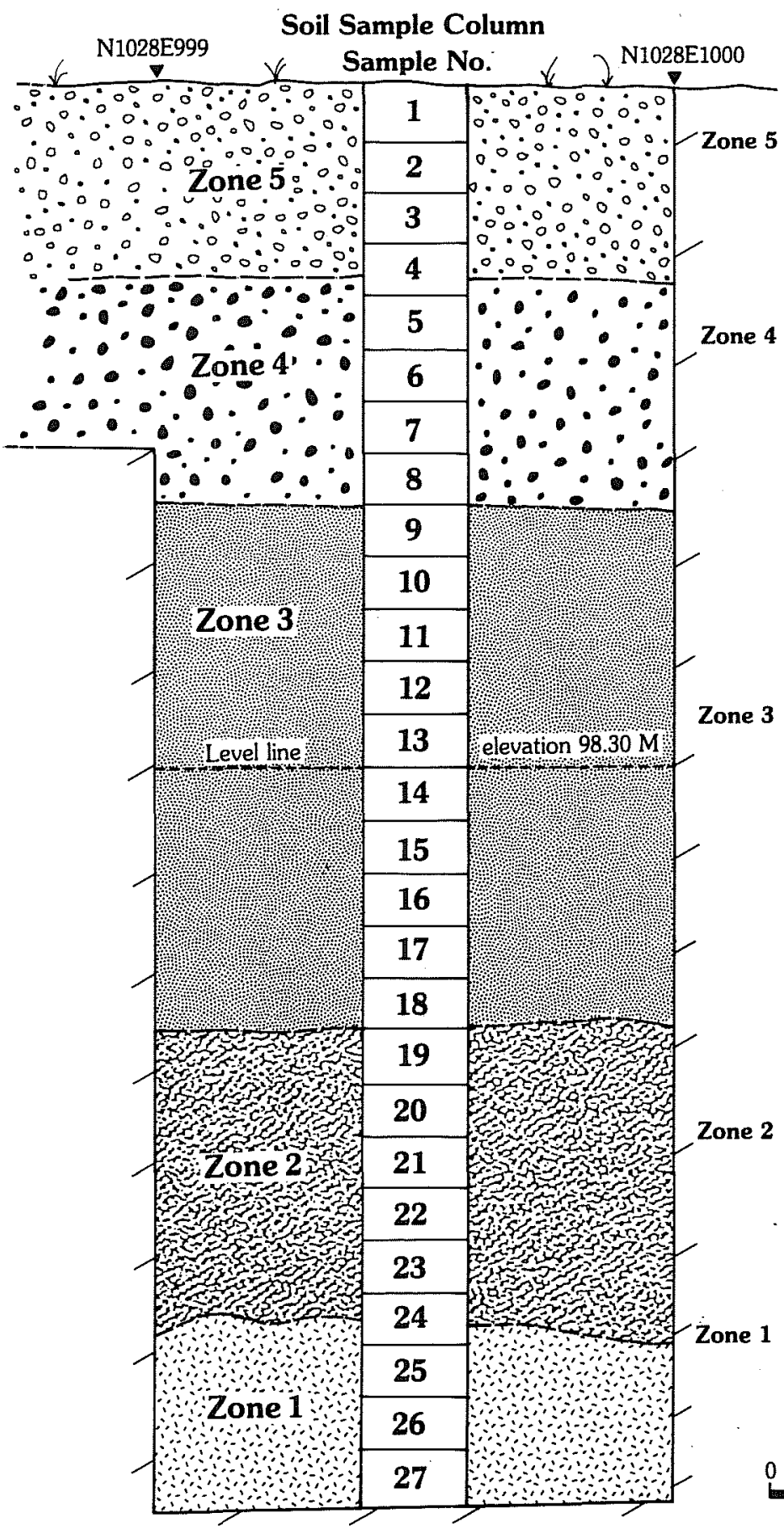

Color: very dark gray (10YR 3/1-wet). Friable clay loam with roots and organic matter. Cultural material.

Color: dark gray to very dark gray (10YR4/1 to $3 / 1$-wet). Homogenous clay loam. Slightly lighter in color than Zone 5. Also fewer roots and less organic matter. Cultural material.

Color: dark grayish brown grading into brown (10YR4/2 to $5 / 3$-wet). Silty/fine sandy clay. Content of fine sand increases toward base of zone. No cultural material.

Color: brown (10YR5/3-wet). Homogeneous, compact silty clay with scattered small caliche nodules. No cultural material.

41MC296

AREA A PROFILE SKETCH

NORTH WALL OF N1027E999

Color: pale brown (10YR6/3-wet). Homogeneous, very compact clay with occasional white caliche film on blocky peds. No cultural material.

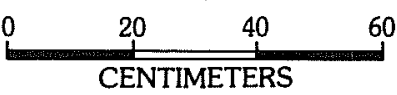




\section{Horizon 1 Horizon 2 Horizon 3}

Tuff Weight (grams)

Sandstone Weight (grams)

Fire-Fractured Rock Weight (grams)

Musse1 Shel1 Umbo Count

Mussel Shel1 Weight (grams)

Rabdotus She11 Count

Bone Weight (grams)

Primary Flake Count

Secondary Flake Count

Tertiary Flake Count

Chip Count

$\begin{array}{rr}0 & 4 \\ 34 & 340 \\ 293 & 62 \\ 44 & 32 \\ 6 & 20 \\ 27 & 83 \\ 2 & 106 \\ 6 & 2 \\ 36 & 30 \\ 17 & 33 \\ 132 & 109\end{array}$

0
641
28
16
7
107
5
3
44
80
71

Additional artifacts found in Area $D$ horizons are as follows:

Group Form Specimen Category 1 Horizon 1 Horizon 2 Horizon 3

\begin{tabular}{lrrl|lll}
\hline 2 & - & - & Cores & 0 & 0 & 1 \\
5 & - & - & Cores & 1 & 1 & 0 \\
8 & - & - & Thick Bifaces & 1 & 0 & 0 \\
1 & 3 & 39 & Thin Bifaces Zavala & 1 & 0 & 0 \\
1 & 4 & 83 & Thin Bifaces Perdiz & 1 & 0 & 0 \\
1 & 7 & 46 & Thin Bifaces & 1 & 0 & 0 \\
4 & 2 & 24 & Thin Bifaces & 1 & 0 & 0 \\
4 & 4 & 171 & Thin Bifaces & 1 & 0 & 0 \\
9 & - & - & Thin Bifaces & 0 & 0 & 1 \\
4 & - & 3 & Unifaces & 1 & 0 & 0 \\
1 & - & 2 & Trimmed Flakes & 0 & 0 & 1 \\
1 & 2 & - & Modified Sandstone & 0 & 0 & 1 \\
1 & 3 & - & Modified Sandstone & 0 & 1 & 0 \\
2 & 1 & - & Modified Sandstone & 0 & 0 & 1 \\
2 & 3 & - & Modified Sandstone & 0 & 1 & 0 \\
- & - & - & Ocher & 0 & 0 & 1 \\
- & - & 9 & Marine She11 & 0 & 0 & 1
\end{tabular}

A second group of excavation blocks was located around Test Pit 1 at 41 MC 296 (Fig. 45). In addition to the $1-\mathrm{m}^{2}$ test pit, there are unit-blocks designated Areas B, C, and E. Selection of a location for the test pit was arbitrary. Findings made in the test prompted $\mathrm{placement}$ of the Area $\mathrm{B}$ units and, subsequentiy, Areas $C$ and $E$.

Test Pit 1 was excavated to a depth of $140 \mathrm{~cm}$ below the surface (fourteen 10-cm-thick levels). Soil matrix excavated from this unit was described as dark grayish brown silty loam from the surface to a depth of $95 \mathrm{~cm}$. Beneath this depth, the soil changed to very light yellowish brown or tan sandy silt 1 aced with flecks of calcium carbonate. Three horizons are defined within the debris collection from Test Pit l. Horizon 1 contains debris recovered from Levels 1 and 2. Horizon 2 contains debris from Levels 3 and 4. 


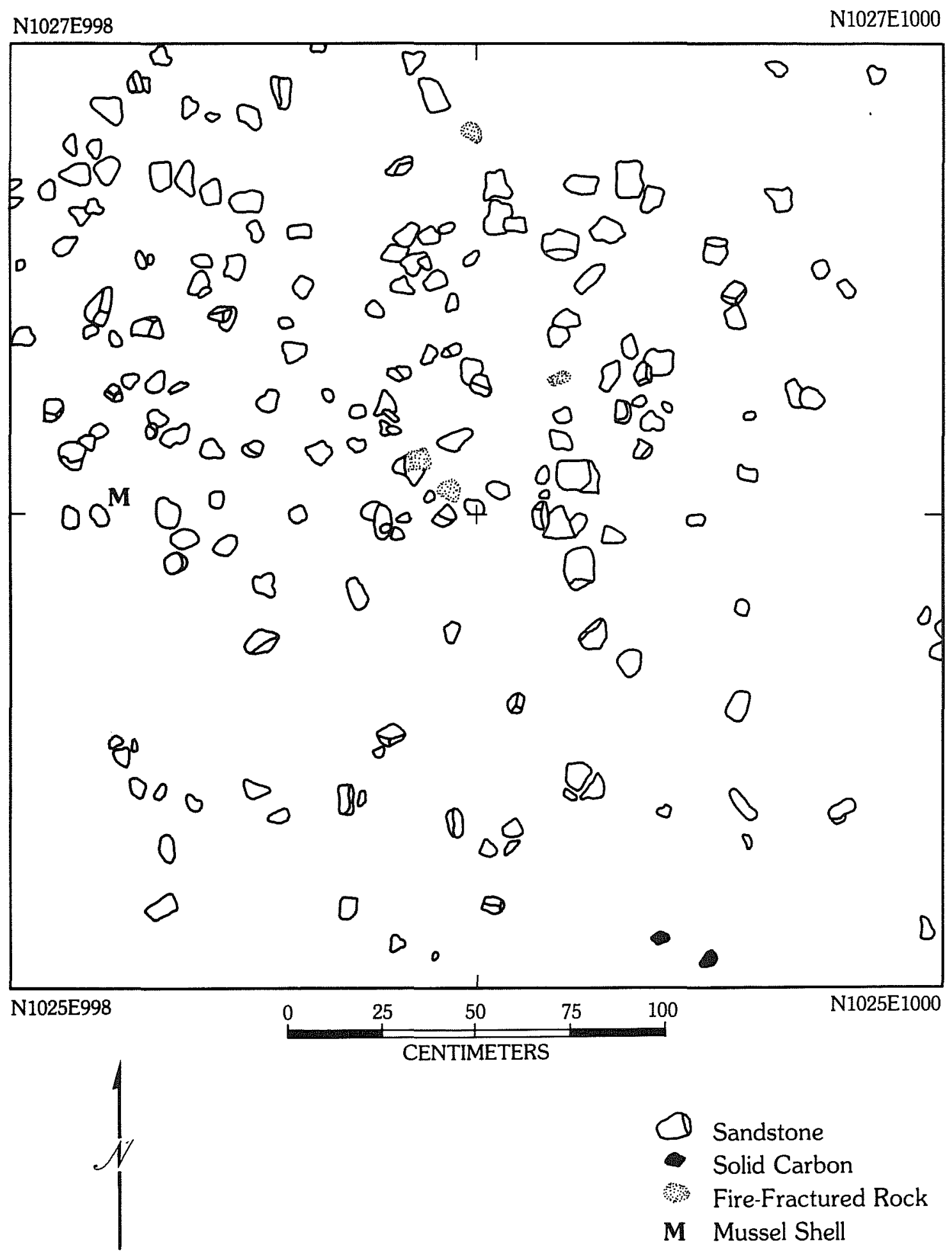

\section{MC296}

AREA A FEATURE 1 PLAN

LEVEL 6 (99.10-99.00)

Figure 48. Area A, Feature 1 Plan, Level $6(99.10-99.00 \mathrm{~m})$ at $41 \mathrm{MC} 296$. 
Horizon 3 represents Leve1s 5-14. Rates of recovery for selected classes of debris from the three horizons defined in this test are as follows:

\section{Horizon 1 Horizon 2 Horizon 3}

$\begin{array}{lrrr}\text { Tuff Weight (grams) } & 1 & 0 & 0 \\ \text { Sandstone Weight (grams) } & 175 & 265 & 1442 \\ \text { Fire-Fractured Rock Weight (grams) } & 25 & 33 & 48 \\ \text { Musse1 She11 Umbo Count } & 25 & 59 & 34 \\ \text { Musse1 She11 Weight (grams) } & 21 & 12 & 11 \\ \text { Rabdotus Shel1 Count } & 62 & 104 & 141 \\ \text { Bone Weight (grams) } & 23 & 8 & 8 \\ \text { Primary Flake Count } & 6 & 1 & 1 \\ \text { Secondary Flake Count } & 47 & 43 & 55 \\ \text { Tertiary Flake Count } & 78 & 55 & 82 \\ \text { Chip Count } & 114 & 27 & 139\end{array}$

Other artifact specimens from Test Pit 1 are as follows:

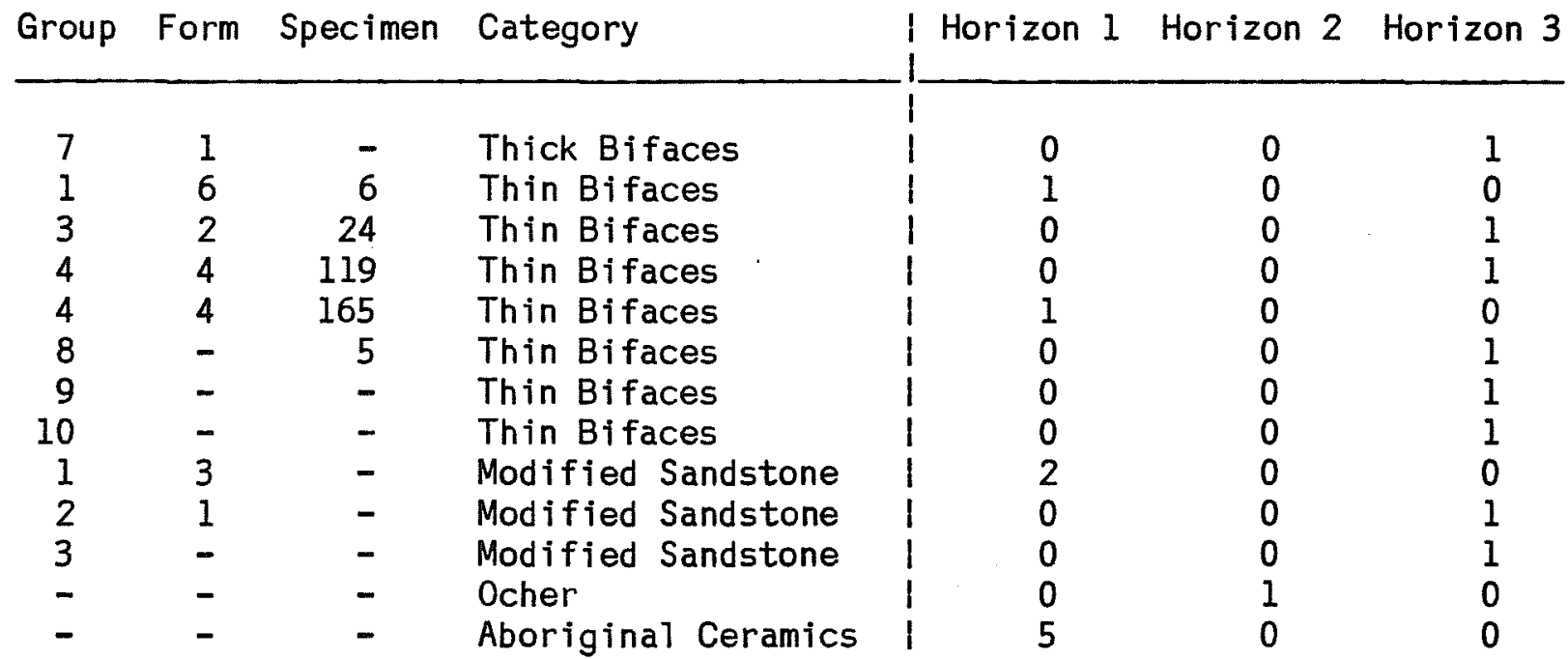

The Area B excavation was laid out along the south side of Test Pit 1 (Figs. $45 ; 50, a$ ). It consisted of $n$ ine $1-m^{2}$ units forming a $3-m^{2}$ block. Unit coordinates and number of 10-cm-thick levels excavated in each are N1022 E985 (10 leve1s), N1022 E986 (10 leve1s), N1022 E987 (nine leve1s), N1023 E985 (nine leve1s), N1023 E986 (nine leve1s), N1023 E987 (nine levels), N1024 E985 (nine 1eve1s), N1024 E986 (nine levels), and N1024 E987 (nine leve1s). Surface elevations ranged from 99.55 to $99.57 \mathrm{~m}$. Soil characteristics for Area $B$ deposits are essentially like those described for Test Pit 1 above. Three horizons were defined for debris recovered from the Area B units. Horizon 1 contains debris from Levels 1 and 2, Horizon 2 from Levels 3 and 4, and Horizon 3 from Levels 5-9 or 10. Rates of recovery for selected classes of debris are as fol lows: 
Horizon 1 Horizon 2 Horizon 3

$\begin{array}{lrrr}\text { Tuff Weight (grams) } & 0 & 0 & 0.3 \\ \text { Sandstone Weight (grams) } & 2186 & 2151 & 5745 \\ \text { Fire-Fractured Rock Weight (grams) } & 551 & 421 & 537 \\ \text { Musse] Shel1 Umbo Count } & 544 & 656 & 657 \\ \text { Musse] She11 Weight (grams) } & 164 & 205 & 162 \\ \text { Rabdotus She17 Count } & 805 & 908 & 1258 \\ \text { Bone Weight (grams) } & 136 & 60 & 76 \\ \text { Primary Flake Count } & 40 & 14 & 19 \\ \text { Secondary Flake Count } & 571 & 212 & 306 \\ \text { Tertiary Flake Count } & 1282 & 405 & 543 \\ \text { Chip Count } & 2985 & 1131 & 1314\end{array}$

Additional artifacts found in Area B excavations, by horizon, are listed below:

\begin{tabular}{|c|c|c|c|c|c|c|}
\hline Group & Form & Specimen & Category & Horizon 1 & Horizon 2 & Horizon 3 \\
\hline & & & & 1 & & \\
\hline 1 & - & - & Cores & 0 & 0 & 2 \\
\hline 2 & - & - & Cores & 3 & 2 & 1 \\
\hline 3 & - & - & Cores & 1 & 0 & 0 \\
\hline 4 & - & - & Cores & 0 & 0 & 1 \\
\hline 5 & - & - & Cores & 0 & 3 & 3 \\
\hline- & - & - & Cores & 0 & 3 & 4 \\
\hline 6 & - & - & Cores & 6 & 1 & 7 \\
\hline 7 & - & - & Cores & 0 & 0 & 2 \\
\hline 4 & - & - & Thick Bifaces & 1 & 0 & 0 \\
\hline 6 & 2 & - & Thick Bifaces & 0 & 1 & 0 \\
\hline 7 & 1 & - & Thick Bifaces & 2 & 1 & 1 \\
\hline 1 & 2 & 12 & Thin Bifaces & 1 & 0 & 0 \\
\hline 1 & 2 & 14 & Thin Bifaces & 1 & 0 & 0 \\
\hline 1 & 4 & $33-47$ & Thin Bifaces Perdiz & $1 \overline{4}$ & 1 & 0 \\
\hline 1 & 4 & $77-82$ & Thin Bifaces Perdiz & 6 & $\overline{0}$ & 0 \\
\hline 1 & 4 & 87 & Thin Bifaces Cliffton & 0 & 1 & 0 \\
\hline$\overline{1}$ & 5 & 10 & Thin Bifaces Scallorn & 0 & $\overline{0}$ & 1 \\
\hline 1 & 5 & 19 & Thin Bifaces Edwards & 0 & 1 & 0 \\
\hline 1 & 7 & $28-43$ & Thin Bifaces & 12 & 3 & 1 \\
\hline 2 & 1 & 32 & Thin Bifaces & 0 & 0 & 1 \\
\hline 4 & 2 & 21 & Thin Bifaces & 0 & 1 & 0 \\
\hline 4 & 2 & 22 & Thin Bifaces & 1 & 0 & 0 \\
\hline 4 & 4 & $86-89$ & Thin Bifaces & 2 & 1 & 1 \\
\hline 4 & 4 & 120 & Thin Bifaces & 0 & 0 & 1 \\
\hline 4 & 4 & $145-146$ & Thin Bifaces & 1 & 0 & 1 \\
\hline 4 & 4 & $166-168$ & Thin Bifaces & 3 & 0 & 0 \\
\hline 8 & - & 6 & Thin Bifaces & 0 & 1 & 0 \\
\hline 8 & - & 7 & Thin Bifaces & 1 & 0 & 0 \\
\hline 9 & - & - & Thin Bifaces & 9 & 2 & 3 \\
\hline 10 & - & - & Thin Bifaces & 11 & 5 & 1 \\
\hline 3 & 3 & 13 & Distally Beveled Tools & 0 & 1 & 0 \\
\hline 5 & $=$ & 4 & Unifaces & 1 & 0 & 0 \\
\hline 1 & 2 & - & Modified Sandstone & 0 & 2 & 0 \\
\hline
\end{tabular}




$\begin{array}{llllllll}1 & 3 & - & \text { Modified Sandstone } & & 7 & 6 & 6 \\ 2 & 1 & - & \text { Modified Sandstone } & 1 & 2 & 2 & 0 \\ 2 & 2 & - & \text { Modified Sandstone } & 1 & 2 & 2 & 2 \\ 2 & 3 & - & \text { Modified Sandstone } & 1 & 0 & 2 & 5 \\ 3 & - & - & \text { Modified Sandstone } & 1 & 0 & 1 & 1 \\ - & - & - & \text { Ocher } & 1 & 0 & 1 & 2 \\ - & - & 1-3 & \text { Bone Beads } & 1 & 1 & 2 & 0 \\ - & - & 3-4 & \text { Bone Aw1/Pins } & 1 & 0 & 1 & 1 \\ - & - & 7 & \text { Marine She11 } & 1 & 1 & 0 & 0 \\ - & - & - & \text { Aboriginal Ceramics } & 1 & 15 & 1 & 1\end{array}$

Two habitational features were documented in the Area $B$ excavations at 41 MC 296. In Feature 2, an extensive scatter of sandstone and firefractured rock occurred in al1 nine units of Area B (Figs. 49; $50, \mathrm{c}$ ). Components of Feature 2 were present in Levels 5-7 (99.10 to $98.80 \mathrm{~m})$. There was no intentional patterning of rocks recognized in the feature. other debris, such as debitage, chipped stone tools, animal bone, mussel shells, snail she11s, and modified sandstone, was mixed in with the rock. All of the Horizon 3 debris and artifacts 1 isted above are related to this feature.

A second habitational feature isolated in Area B occurred in Levels 9 and 10 $(98.70$ to $98.50 \mathrm{~m}$ ) of Units N1022 E985 and N1022 E986. This was a sma11, discrete cluster of sandstone measuring $46 \mathrm{~cm}$ east-west and $28 \mathrm{~cm}$ northsouth. The feature probably extended south into unexcavated deposits. Twenty-one pieces of sandstone ranging from 4 to $8 \mathrm{~cm}$ in maximum dimension comprised Feature 3. The rocks were stacked. Thirteen pieces were on top in Level 9. The remaining sandstones were exposed underneath in Level 10.

Area C consisted of three $1-m^{2}$ units located a meter east of Area $B$ (Fig. 45). Forming a $1-\times 3-\mathrm{m}$ b 1ock, the Area $\mathrm{C}$ units and number of $10-\mathrm{cm}-$ thick levels excavated in each are N1022 E989 (two leve1s), N1023 E989 (four levels), and N1024 E989 (four levels). Surface elevations for the units averaged $99.60 \mathrm{~m}$. Area $\mathrm{C}$ was excavated by participants in the TAS Summer Field School of 1981. As the three units were not completely excavated, only Horizons 1 and 2 are represented in the area's debris collection. As elsewhere at 41 MC 296, Horizon 1 contains debris from Leve 151 and 2, and Horizon 2 contains debris from Levels 3 and 4 . Rates of debris recovery for the two horizons in Area $C$ are shown below.

Horizon 1 Horizon 2

Tuff Weight (grams)

Sandstone Weight (grams)

Fire-Fractured Rock Weight (grams)

Mussel Shell Umbo Count

Mussel Shell Weight (grams)

Rabdotus She11 Count

Bone Weight (grams)

Primary Flake Count

Secondary Flake Count

Tertiary Flake Count

Chip Count

0

157

129

103

25

69

48

2

30

58

198
0

373

110

59

27

159

87

5

53

69

136 


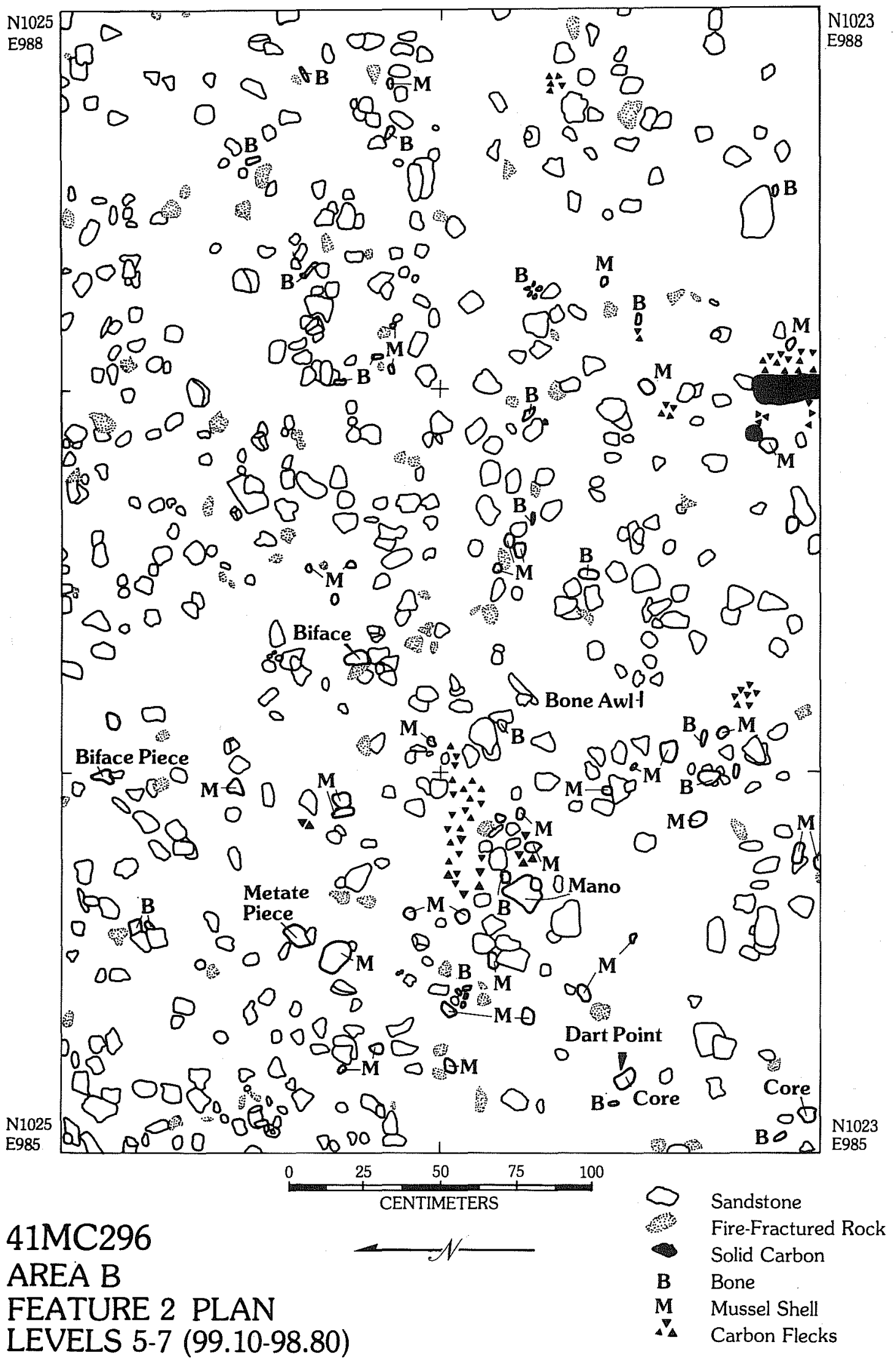

Figure 49. Area B, Feature 2 Plan, Levels 5-7 $(99.10-98.80 \mathrm{~m})$ at 41 MC 296. 
Other artifacts recovered from Area $\mathrm{C}$ are as follows:

\begin{tabular}{rrrl|lc} 
Group & Form & Specimen & Category & Horizon 1 & Horizon 2 \\
\hline 6 & - & - & Cores & 0 & 1 \\
7 & 1 & - & Thick Bifaces & 0 & 1 \\
9 & 1 & - & Thick Bifaces & 0 & 1 \\
1 & 4 & 54 & Thin Bifaces Perdiz & 1 & 0 \\
1 & 7 & 47 & Thin Bifaces & 0 & 1 \\
3 & 1 & 11 & Thin Bifaces & 1 & 0 \\
9 & - & - & Thin Bifaces & 0 & 1 \\
10 & - & - & Thin Bifaces & 2 & 1 \\
1 & 3 & - & Modified Sandstone & 3 & 3 \\
2 & 2 & - & Modified Sandstone & 0 & 1 \\
2 & 3 & - & Ocher & 2 & 1 \\
- & - & $5-9$ & Bone Beads & 1 & 0 \\
- & - & - & Aboriginal Ceramics & 0 & 5 \\
- & - & &
\end{tabular}

Two $1-\mathrm{m}^{2}$ units made up Area $E$ at 41 MC 296 (Fig. 45). Located on the north side of Test Pit 1, coordinates for the Area E units are N1026 E986 (three levels) and N1027 E986 (four levels). Surface elevations for Area E units averaged $99.60 \mathrm{~m}$. The units were excavated by TAS Summer Field School workers in June 1981. The area was not completely excavated, and therefore the debris collection contains materials representing only Horizon 1 (Levels 1 and 2) and Horizon 2 (Levels 3 and 4). Rates of recovery for selected classes of debris recovered from the two horizons are as follows:

Horizon 1 Horizon 2

Tuff Weight (grams)

Sandstone Weight (grams)

Fire-Fractured Rock Weight (grams)

Musse1 She11 Umbo Count

Mussel Shel1 Weight (grams)

Rabdotus Shel1 Count

Bone Weight (grams)

Primary Flake Count

Secondary Flake Count

Tertiary Flake Count

Chip Count

$\begin{array}{rr}0.5 & 4 \\ 163 & 221 \\ 32 & 48 \\ 34 & 44 \\ 11 & 16 \\ 35 & 113 \\ 45 & 5 \\ 7 & 1 \\ 61 & 20 \\ 124 & 52 \\ 301 & 120\end{array}$

Additional artifacts from Area $E$ are 1 isted below.

\begin{tabular}{cccl:cc} 
Group & Form & Specimen & Category & Horizon 1 & Horizon 2 \\
\hline 1 & - & - & Cores & 1 & 0 \\
3 & - & - & Cores & 1 & 0 \\
7 & 1 & - & Thick Bifaces & 1 & 0 \\
9 & - & - & Thick Bifaces & 1 & 0 \\
1 & 4 & 53 & Thin Bifaces Perdiz & 1 & 0
\end{tabular}


Figure 50. Views of 41 MC 296, 41 MC 276, and 41 MC 270.

a, view northwest of excavations in progress at 41 MC 296;

b. portions of Feature 1 exposed in Area A at 41 MC 296;

c) portions of Feature 2 exposed in Area B at 41 MC 296. This $v$ iew shows only the feature components exposed in one level of excavation. Compare with Figure 49 showing all feature components from three levels;

d, view looking north across Area A at 41 MC 276. Note severe deflation and pavement of prehistoric cultural debris on the site surface;

e, a view of the Frio River looking downstream near 41 MC 270;

f, view llooking north at shovel testing in progress at 41 MC 270; note the thick grass cover and absence of brush from this cleared and improved pasture. 


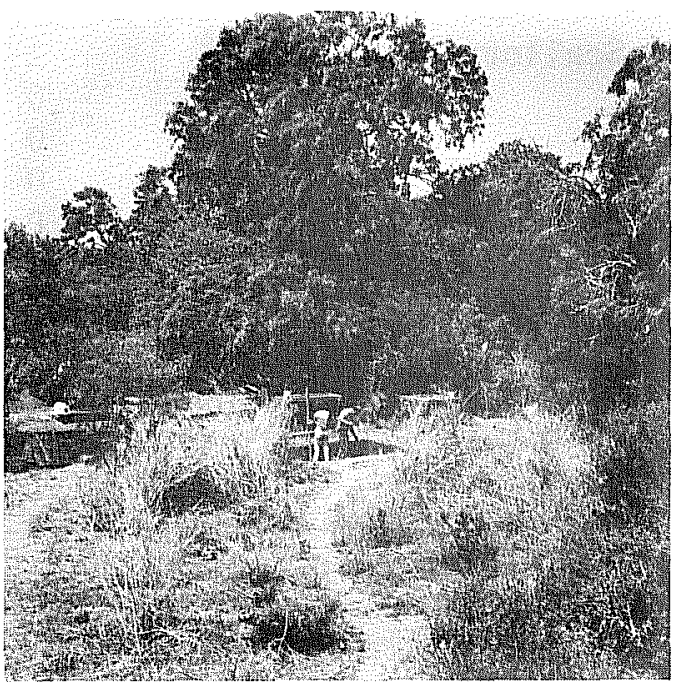

a

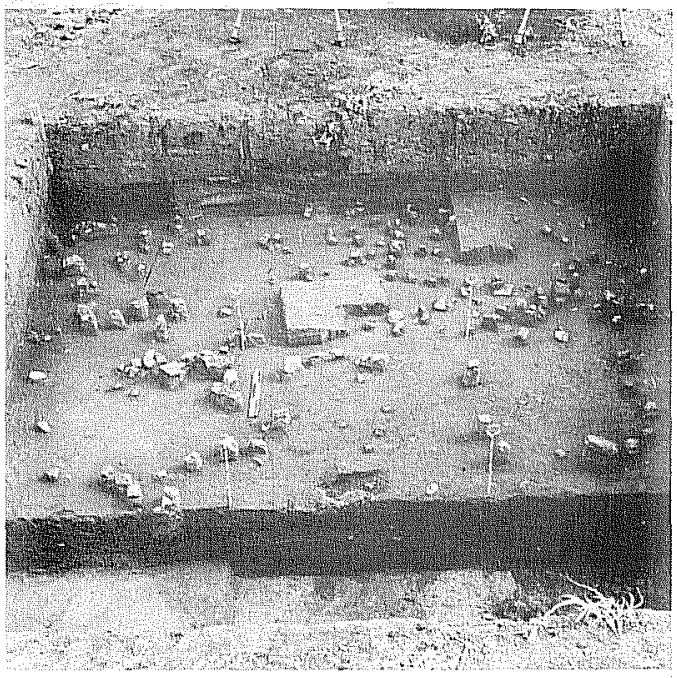

c

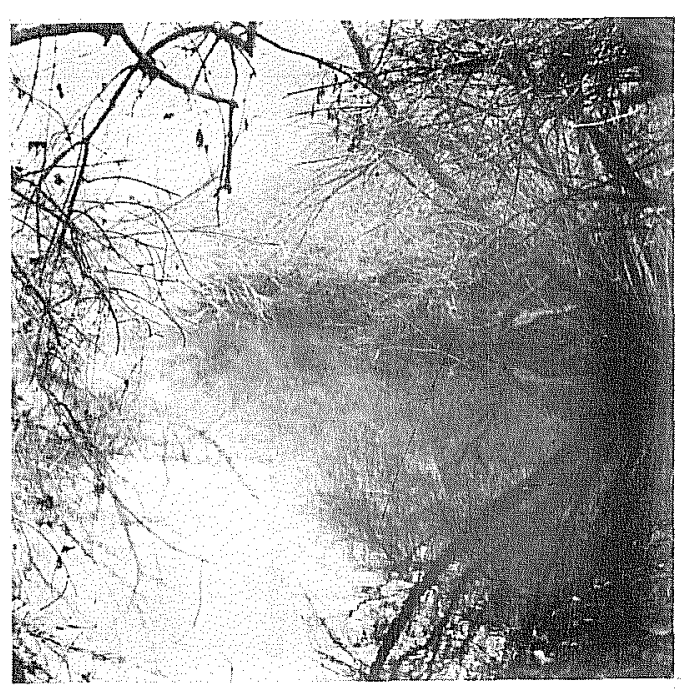

e

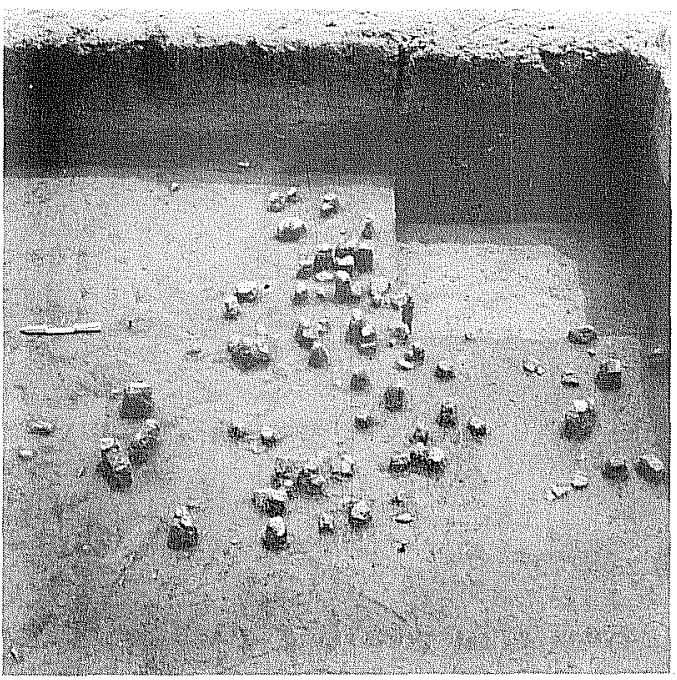

b

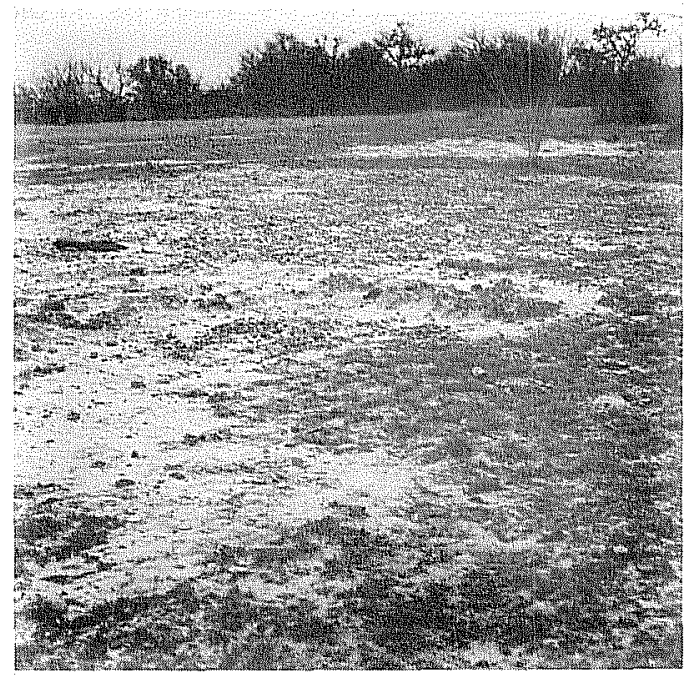

d

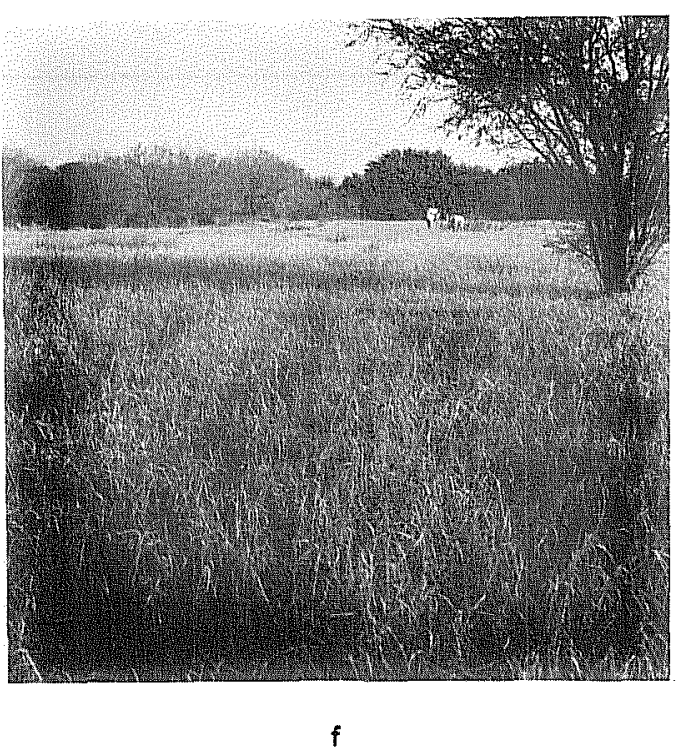




\begin{tabular}{rrrl|ll}
1 & 5 & 14 & Thin Bifaces Scallorn & 0 & 1 \\
1 & 7 & 45 & Thin Bifaces & 1 & 0 \\
4 & 2 & 25 & Thin Bifaces & 1 & 0 \\
4 & 4 & 92 & Thin Bifaces & 1 & 0 \\
9 & - & - & Thin Bifaces & 1 & 0 \\
10 & - & - & Thin Bifaces & 3 & 0 \\
- & - & - & Aboriginal Ceramics & 3 & 0
\end{tabular}

Area $G$ was a block of two $1-m^{2}$ units located northwest of Areas $B, C$, and $E$ (Fig. 45). Unit coordinates and number of 10-cm-thick levels excavated are N1026 E978 (five leve1s) and N1027 E978 (six leve1s). Surface elevations for these units averaged $99.60 \mathrm{~m}$. Excavations were conducted by participants in the TAS Summer Field School. Although three horizons are defined for the area, it should be noted that Horizon 3 is not fully represented because the excavations were not carried a 11 the way to the bottom of the cultural deposits. Horizon/level groupings for Area G are Horizon 1, Leve1s 1 and 2; Horizon 2, Levels 3 and 4; and Horizon 3, Levels 5 and 6. Rates of recovery for selected classes of debris from the Area $G$ horizons are as follows:

\section{Horizon 1 Horizon 2 Horizon 3}

$\begin{array}{lrrr}\text { Tuff Weight (grams) } & 13 & 11 & 4 \\ \text { Sandstone Weight (grams) } & 128 & 243 & 545 \\ \text { Fire-Fractured Rock Weight (grams) } & 64 & 128 & 101 \\ \text { Mussel She11 Umbo Count } & 11 & 40 & 21 \\ \text { Musse1 She11 Weight (grams) } & 3 & 15 & 12 \\ \text { Rabdotus She17 Count } & 29 & 104 & 116 \\ \text { Bone Weight (grams) } & 10 & 8 & 6 \\ \text { Primary Flake Count } & 2 & 4 & 1 \\ \text { Secondary Flake Count } & 32 & 34 & 29 \\ \text { Tertiary Flake Count } & 40 & 37 & 47 \\ \text { Chip Count } & 207 & 334 & 162\end{array}$

Area $G$ also yielded the following artifacts:

\begin{tabular}{|c|c|c|c|c|c|c|}
\hline Group & Form & Specimen & Category & I Horizon 1 & Horizon 2 & Horizon 3 \\
\hline 1 & - & - & Cores & 1 & 0 & 0 \\
\hline 3 & - & - & Cores & 2 & 0 & 0 \\
\hline 1 & 3 & 10 & Thin Bifaces Ensor & 0 & 0 & 1 \\
\hline 1 & 4 & 51 & Thin Bifaces Perdiz & 1 & 0 & $\overline{0}$ \\
\hline 1 & 4 & 52 & Thin Bifaces Perdiz & 1 & 0 & 0 \\
\hline 1 & 5 & 12 & Thin Bifaces Scallorn & 0 & 1 & 0 \\
\hline 1 & 5 & 13 & Thin Bifaces Scaliorn & 1 & 0 & 0 \\
\hline 2 & 1 & 33 & Thin Bifaces & 0 & 1 & 0 \\
\hline 9 & - & - & Thin Bifaces & 2 & 1 & 1 \\
\hline 10 & - & - & Thin Bifaces & $\bar{l}$ & 1 & 1 \\
\hline 1 & 3 & - & Modified Sandstone & 0 & 1 & 5 \\
\hline 2 & 3 & - & Modified Sandstone & 0 & 1 & 1 \\
\hline- & - & - & Aboriginal Ceramics & 1 & 0 & 0 \\
\hline
\end{tabular}


Test Pit 3 was located near the presumed western end of 41 MC 296. On 1 y three 10-cm-thick levels were excavated. Two horizons were defined for the materials recovered. Horizon 1 contains debris from Levels 1 and 2. Horizon 2 represents debris from Leve1 3. Rates of recovery from these two horizons are shown below.

Horizon 1 Horizon 2

Tuff Weight (grams)

Sandstone Weight (grams)

Fire-Fractured Rock Weight (grams)

Mussel Shel1 Umbo Count

Mussel She11 Weight (grams)

Rabdotus Shell Count

Bone Weight (grams)

Primary Flake Count

Secondary Flake Count

Tertiary Flake Count

Chip Count

$\begin{array}{lr}0 & 0 \\ 8 & 4 \\ 1 & 1 \\ 0 & 0 \\ 0.4 & 0 \\ 0 & 0 \\ 0.1 & 0 \\ 1 & 0 \\ 9 & 2 \\ 12 & 5 \\ 17 & 12\end{array}$

Deposits at 41 MC 296 were exceptionally productive in terms of vertebrate faunal remains and carbonized wood associated with prehistoric cultural debris in the subsurface. It is assumed that the bone and carbon are byproducts of prehistoric human activity on the site. Recovery of these materials permitted identification of vertebrate and wood species and radiocarbon assay.

Site 41 MC 296 is one of three prehistoric sites excavated during Phase II investigations at Choke Canyon that yielded large collections of vertebrate faunal material. The other two sites are 41 LK 201, discussed in detaj1 by Highley (1986), and 41 MC 222 (Skillet Mountain No. 4), to be discussed iater in this report. Identification and interpretation of vertebrate fauna 1 remains from 41 MC 296 and 41 MC 222 are the subjects of Appendix III to this report. Common names for animals identified from bones recovered at 41 MC 296 are as fol lows:

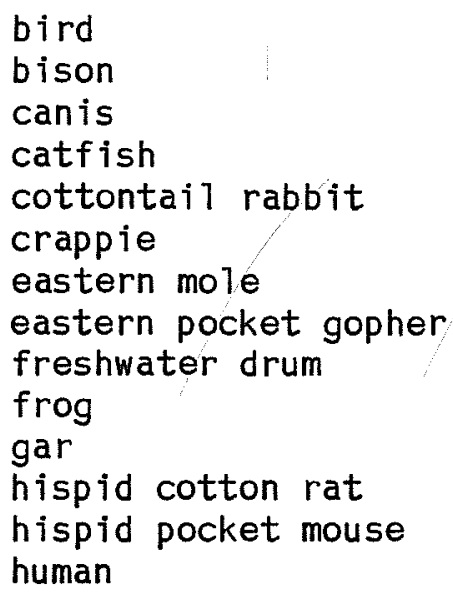

Several pertinent observations have resulted from analysis of the 41 MC 296 vertebrate collection (see Appendix III for a ful1 discussion). Some of the 
fish bones were of a size suggesting that they could not have been caught by spearing or hooking. This evidence implies that the prehistoric inhabitants of 41 MC 296 (and 41 MC 222) had some other technique for catching sma 11 fish, perhaps with traps or nets. There is "abundant evidence" to indicate that 41 MC 296 was occupied by prehistoric people during the spring and/or summer seasons. One pintail duck bone recovered from a Horizon 3 level offers scant evidence for habitation of the site in the fall/winter season sometime during the Late Archaic period. Comparison and statistical analysis of Late Archaic and Late Prehistoric vertebrate faunal remains from 41 MC 296 and 41 LK 201 demonstrate that Late Prehistoric people p 1 aced a greater emphasis on procurement of 7 arge animals, principally bison, but also deer, antelope, and peccary, than did Archaic people. Final 1y, the array of vertebrate fauna evidenced by the bone collection permits projection of the Tamau 1 ipan Biotic Province back into prehistory.

Carbon was recovered from virtually al1 units and levels in the Phase II excavations at 41 MC 296. Identification and interpretation of wood species burned to form some of the carbon recovered from the site are presented in Appendix II. Identification of much of the carbon as being derived from Prosopis sp. and/or Acacia sp. is the most important result of this particular study. Stratigraphic context and associated radiocarbon ages for the Prosopis sp./Acacia sp. samples indicate that the species was (were) growing in the Choke Canyon vicinity in prehistoric times.

Carbon recovered from the deposits at 41 MC 296 were submitted for assay to the Radiocarbon Laboratory. The University of Texas at Austin. Assay of these samples yielded the following radiocarbon ages:

TX-Number Horizon Uncorrected Age MASCA Corrected Age

$\begin{array}{llcc}T X-4677^{*} & 1 & 430 \pm 80 & \text { A.D. } 1430 \\ \text { TX-4678 } & 1 & 330 \pm 60 & \text { A.D. } 1520 \\ \text { TX-4682* } & 1 & 450 \pm 60 & \text { A.D. } 1430 \\ \text { TX-4683* } & 1 & 290 \pm 50 & \text { A.D. } 1520-1610 \\ T X-4684 & 1 & 320 \pm 50 & \text { A.D. } 1510-1590 \\ \text { TX-4685* } & 2 & 780 \pm 60 & \text { A.D. } 1200-1220 \\ T X-4686 * & 750 \pm 70 & \text { A.D. } 1230 \\ \text { TX-4687* } & 2 & 1110 \pm 60 & \text { A.D. } 910 \\ T X-4679 * * & 2 & 2020 \pm 70 & \text { A.D. } 30-50 \\ \text { TX-4680** } & 3 & 1440 \pm 80 & \text { A.D. } 590 \\ \text { TX-4681*** } & 3 & 1860 \pm 60 & \text { A.D. } 160 \\ \text { TX-4669*** } & 3 & 2090 \pm 60 & \text { 100-10 B.C. }\end{array}$

*These samples were composed of aggregates of carbon collected from the same vertical excavation 1 evels within two or more contiguous $1-m^{2}$ units (see Table 58 in Appendix VI for unit and level proveniences).

**TX-4679 and TX-4680 were derived from the same source, a 1 arge carbon sample collected from Feature 2 in Level 6 of the Area B excavation.

***TX-4681 and TX-4669 were derived from the same source, a 1 arge carbon sample collected from Feature 2 in Level 7 of the Area B excavation. 
Resultant age ranges provided for the three horizons defined in the deposits at 41 MC 296 are Horizon 1, A.D. 1430 to A.D. 1610; Horizon 2, A.D. 910 to A.D. 1230; Horizon 3, 100 B.C. to A.D. 590.

Site 41 MC 296 ranks as one of the several most important prehistoric sites investigated during Phase II research at Choke Canyon. Outstanding characteristics of this site were (1) its multicomponent, wel1-stratified deposits; (2) the quantities of animal bone and carbon preserved; and (3) the number of time- and function-diagnostic artifacts recovered from each horizon in the site's deposits.

The site contains three components. The earliest, represented by Horizon 3 materials, dates to the Late Archaic period. Radiocarbon assays of samples collected from this Late Archaic component yield an age range of 100 B.C. to A.D. 590. If the 1 atest of four radiocarbon ages for the component is dropped (TX-4680, A.D. 590), there is a span of 100 B.C. to A.D. 160. Further analysis of carbon samples from Horizon 3 indicates that Prosop is and/or Acacia were species present in the area at the time of site habitation by Late Archaic people. Wood from these species was probably being used to fuel their fires.

A summary of the major artifact categories by horizon at 41 MC 296 is shown below.

\begin{tabular}{|c|c|c|c|c|c|c|}
\hline Group & Form & Type & Category & $\begin{array}{c}\text { Horizon } \\
1\end{array}$ & $\begin{array}{c}\text { Horizon } \\
2\end{array}$ & $\begin{array}{c}\text { Horizon } \\
3\end{array}$ \\
\hline & & & & 1 & & \\
\hline 1 & - & - & Cores & 1 & 0 & 3 \\
\hline 2 & - & - & Cores & 5 & 2 & 2 \\
\hline 3 & - & - & Cores & 5 & 0 & 0 \\
\hline 4 & - & - & Cores & 1 & 0 & 1 \\
\hline 5 & - & - & Cores & 3 & 6 & 5 \\
\hline 6 & - & - & Cores & 6 & 2 & 7 \\
\hline 7 & - & - & Cores & 0 & 0 & 2 \\
\hline (A)1 & Groups: & 5) - & Thick Bifaces & 6 & 5 & 3 \\
\hline 1 & 2 & - & Thin Bifaces & 2 & 0 & 0 \\
\hline 1 & 3 & Ensor, Zavala & Thin Bifaces & 1 & 1 & 3 \\
\hline 1 & 4 & Perdiz & Thin Bifaces & i 27 & 3 & 0 \\
\hline 1 & 5 & $\begin{array}{c}\text { Scal lorn, } \\
\text { Edwards }\end{array}$ & Thin Bifaces & 2 & 6 & 1 \\
\hline 1 & 7 & $\begin{array}{l}\text { arrow point } \\
\text { fragments }\end{array}$ & Thin Bifaces & 16 & 4 & 1 \\
\hline 2 & 1 & - & Thin Bifaces & 0 & 1 & 1 \\
\hline 3 & - & Mission? & Thin Bifaces & 1 & 0 & 1 \\
\hline 4 & 2 & $\begin{array}{l}\text { "beveled } \\
\text { knives" }\end{array}$ & Thin Bifaces & ! & 2 & 0 \\
\hline 4 & 4 & - & Thin Bifaces & i 11 & 3 & 4 \\
\hline 1 & 3 & (Specimen 13) & Distaliy Beveled Toolsi & 0 & 1 & 0 \\
\hline (A) 17 & Groups: & 5) - & Unifaces & 2 & 0 & 0 \\
\hline (A) 1 & Groups & ¡) - & Trimmed Flakes & 3 & 0 & 1 \\
\hline
\end{tabular}




\begin{tabular}{rlll|rrr}
1 & - & metate fragment & Modified Sandstone & 17 & 16 & 16 \\
2 & - & manos & Modified Sandstone & 8 & 11 & 11 \\
3 & - & grooved pieces & Modified Sandstone & 0 & 1 & 4 \\
- & - & - & Bone Beads & 2 & 7 & 0 \\
- & - & - & Marine Shel1 & 1 & 0 & 2 \\
- & - & sherds & Aboriginal Ceramics & 32 & 5 & 1
\end{tabular}

In terms of these formal artifact categories, the Late Archaic component is distinguished from the two later components by the presence of expanding stem dart points (Ensor type) and by relatively massive quantities of sandstone, exemp 1 ified by Features 1 and 2 (also compare rates of recovery in horizon debris count/weight 1 ists above). The essential absence from Horizon 3 of arrow points, both expanding and contracting stemmed; "beveled knives"; unifaces; trimmed flakes; and aboriginal ceramics is also cited as an important distinction. It is significant that a 17 three horizons yielded roughly equal numbers of ground sandstone artifacts, here assumed to have functioned as manos and metates (now mostly fragmentary) to process seeds and nuts. The uniform distribution of these grinding tools among the horizons suggests that seed and nut foods were of equal importance to al 1 of the people who inhabited the site through time. In terms of meat foods, the Late Archaic inhabitants of 41 MC 296 seem to have been hunting, catching, or collecting a wide spectrum of animals. Rabdotus snail shel1s occur somewhat more frequently in Horizon 3 than in the overlying horizons. Mussel shells are present in roughly equal amounts among al1 horizons. In terms of vertebrate fauna, most of the species identified occur in Late Archaic and Late Prehistoric components. However, no frogs, no antelope, and fewer bison are indicated in Horizon 3. The mysterious deposits of sandstone in the Late Archaic Horizon 3 levels 1 ikely hold the key to a major, but at present unidentified difference in subsistence pursuits. In this respect, the Horizon 3 component at 41 MC 296 is remarkab $7 y$ 1ike the Archaic components at such sites as 41 LK 250, 41 LK 252, 41 LK 253, and 41 MC 209 where massive accumulations of sandstone or fire-fractured rock were also present.

Horizon 2 and Horizon 1 at 41 MC 296 represent early Late Prehistoric and 1 ate Late Prehistoric components, respectively. Radiocarbon assays available for the Horizon 2 materials indicate that they were deposited during a time span from A.D. 910 to A.D. 1230. Sca110rn and Edwards arrow points are the primary diagnostic artifacts in the component. Major artifactual differences between Horizon 2 and Horizon 1 are that Horizon 2 yielded no unifaces or trimmed flakes and many fewer sherds of pottery than did Horizon 1. Horizon 2 also contained a distal1y beveled tool (Group 3, Form 3 , Specimen 13).

Horizon 3, termed a 1 ate Late Prehistoric component at 41 MC 296, is radiocarbon dated to the time period from A.D. 1430 to A.D. 1610. Diagnostic artifacts of the component are Perdiz arrow points, "beveled knives" (thin bifaces Group 4, Form 2), certain unifaces and trimmed flakes, and relatively numerous sherds of aboriginal pottery. Two quite unusual artifacts in the Horizon 1 assemb 1 age are a heavily corroded meta 1 "case knifell blade and a very sma11, triangular arrow point suggested to represent the Guerrero type. These two objects suggest that the latest aboriginal occupants of 41 MC 296 had contact with Europeans. The Horizon 1 component is further distinguished 
from the two earlier horizons by evidence of more intensive production of chipped stone tools. Horizon 1 generally yielded more debitage of a 11 classes (see especially the yields for Areas $A$ and $B$ ) as well as the most cores, thick bifaces, performs, and manufacturing failures (thin bifaces Group 1, Form 7 and Group 4, Form 4).

A1though it is proposed that three distinct components exist within the deposits at 41 MC 296, there are a number of presumed component-diagnostic artifacts that were recovered from horizons other than the ones they are suggested to represent. Horizon 3, for instance, yielded a Scallorn arrow point, an arrow point fragment, and a sherd of aboriginal pottery. These atypical artifacts 1 ikely worked their way down into Horizon 3 from 1 ater deposits through agencies of postdepositional disturbance such as rodent/ insect burrows and mechanical action of the soil. The occurrence of these Late Prehistoric diagnostics in Late Archaic context is insignificant in terms of interpreting the prehistoric cultures involved, but is meaningful in demonstrating that cultural debris is subject to postdepositional vertical movements.

The mixing of diagnostics between Horizons 1 and 2 presents more of a problem. The two stemmed dart points (thin bifaces Group 1, Form 2) found in Horizon 1 are probably artifacts collected from an Archaic period camp and reused by someone during the Late Prehistoric period. Contracting stem arrow points (thin bifaces Group 1, Form 4) are most common in Horizon 1 (27 specimens), but three specimens were also recovered in Horizon 2. Expanding stem arrow points (thin bifaces Group 1, Form 5) predominate in Horizon 2, but two specimens were also found in Horizon 1. Other categories where vertical provenience might have a bearing on interpretation of culture history include the "beveled knives" (thin bifaces Group 4, Form 2) and sherds of aboriginal ceramics. Horizon 1 yielded three beveled knives and 32 potsherds. There were two beveled knives and five potsherds in Horizon 2. Clearly there is not a distinct separation between the Horizon 1 and Horizon 2 components with respect to artifacts suggested as diagnostic of each. If, however, allowance is made for vertical migration of cultural debris as suggested by the occurrence of Late Prehistoric debris in Horizon 3, it remains possible to suggest that Horizons 1 and 2 represent cultural1y and temporal1y discrete components.

Two artifacts found in Horizon 1--the metal "case knife" blade and a sma11, triangular arrow point (thin bifaces Group 3, Form 1, Specimen 11)--indicate that Indians having contact with Anglo-European settlers inhabited 41 MC 296 in early historic times.

As previously discussed, the only major differences in subsistence orientations recognized between the Late Archaic and Late Prehistoric components at 41 MC 296 are that: (1) the Late Prehistoric people hunted antelope and more bison in addition to a wide variety of smaller animals; and (2) the Late Archaic people were doing something, probably related to food preparation, that resulted in deposition of great quantities of burned sandstone. A greater emphasis on procurement of antelope, bison, and whitetailed deer (common in both Late Prehistoric and Late Archaic context) is reflected in the tool assemblages for the Late Prehistoric components, especially Horizon 1. Tools such as the numerous arrow points used to kill 
the animals, "beveled knives" used in butchering and skinning, and unifaces and trimmed flakes aiding in hide preparation all indicate an economy that was geared much more toward the procurement and subsequent processing of 1 arge animals. On the other hand, the Late Prehistoric remains also clearly indicate that efforts were expended on a diversity of other food sources such as seeds and nuts (inferred from grinding tools), musse1s, 1 arge 1 and snails, and a variety of smaller aquatic and terrestrial fauna. By contrast, there are fewer special function tools in the Late Archaic assemblage. Grinding imp 1 ements are present to indicate seed and nut processing. Mussels and large snails were also gathered. A variety of animals, all of them smaller creatures except for deer, were hunted, trapped, or caught by hand. The enigmatic accumulations of sandstone resulting from habitation of 41 MC 296 by Late Archaic people probably holds an important unknown key to understanding their subsistence orientation.

\section{MC 280}

Site 41 MC 280 is located northwest of 41 MC 296 on the slopes 1eading up from the E1m Creek val1ey (Fig. 1, folded insert). Recorded by the CAR survey crew in 1979, this site has a long oval outl ine shape with dimensions of $500 \mathrm{~m}$ north-south and $200 \mathrm{~m}$ east-west. The southern end of $41 \mathrm{MC} 280$ is on the floodplain of $E 1 \mathrm{~m}$ Creek and comes within $75 \mathrm{~m}$ of the present creek channel. The site then rises to the north following the slope of the valley margin. A ridge or projection of the upland sticks out (south) into the site area. The surface is densely covered with brush and is moderately to severely eroded. The survey crew defined the site on the basis of an extensive surface scatter of debitage, fire-fractured rock, sandstone, musse 1 she11, snail shel1, and chipped stone tools. Two sandstone accumulations, probably hearth features, were observed eroding from a field road running through the site area. Late Prehistoric activity was indicated by the presence of a Scallorn arrow point on the surface. Cores and bifaces were also noted. The 1 andowner reported to the survey team that the site surface had been repeatedly scoured by artifact collectors through the years. This site was not relocated during the course of Phase II investigations.

\section{MC 276}

In its upper reaches, the Elm Creek drainage system bifurcates. One channel heads out due north and the other, 1 arger channel, trends off to the northwest. The open prehistoric site designated 41 MC 276 is located on the floodp 1 ain of the $E 1 \mathrm{~m}$ Creek channel system that heads up to the northwest (Fig. 1, folded insert). Recorded by the CAR surveyors in 1979, 41 MC 276 is situated on the right (west) bank of the major channel running down the valley in this area. This particular channel runs along the east side of the valley. Two lesser channels occur west of the site. A long oval in outline shape, 41 MC 276 measures 150 m north-northeast to south-southwest and is $50 \mathrm{~m}$ wide. One portion of the site occurs in a cultivated field covered with pasture grass, weeds, cactus, and a few retama trees. The eastern half of the site paralleling the creek drainage is brush covered. Mesquite trees, soapbush, spiny hackberry, and whitebrush are present. The cleared area of the site was designated Area $A$ and the brushy portion Area B. The surface of 
Area $A$ is badly deflated. The deflation has revealed a moderately heavy scatter of fire-fractured rock, sandstone, debitage, and chipped stone tools (Fig. 50,d). Area B is heavily gullied, and a similar array of prehistoric cultural debris is exposed.

Phase II activities at 41 MC 276 were a control led collection of surface artifacts and excavation of four shovel tests. The shovel tests revealed that cultural debris was confined to the upper $10 \mathrm{~cm}$ of deposit on the site. These findings indicated that controlled test excavations would not be worthwhile.

Twenty-six artifacts were collected from the surface of 41 MC 276. Most came from Area A, but three specimens were a1so collected in Area $B$. Location of each specimen was recorded on a plan map of the site area (on file at the CAR-UTSA). The artifact assemblage recovered are three cores (one, Group 1; one, Group 5; one, Group 9), four thick bifaces (one, Group 4; one, Group 7, Form 1; one, Group 8; one, Group 9), 14 thin bifaces (Group 1, Form 1, Specimen 13; two, Group 2, Form 1; three, Group 4, Form 4; one, Group 5; one, Group 6; one, Group 8; one, Group 9; four, Group 10), two distal1y beveled tools (two, Group 3, Form 1), one uniface (Group 2), and one piece of modified sandstone (Group 2, Form 2). Certain specimens in this array indicate that cultural activity occurred at 41 MC 276 in Middle Archaic and/or Late Archaic times.

SITE GROUP 11

Extensive Test

Excavation Pits

Surface Collections
Provenienced Unprovenienced

41 MC 266

41 MC 270

41 MC 288
41 MC 282

41 MC 284

41 MC 293
Resurvey or

Shovel Tests

The nine sites comprising Group 11 occur in an area located from 17 to $21 \mathrm{~km}$ upstream from Choke Canyon Dam. Two of the sites are situated on up 1 and spurs overlooking the river valley. The rest are down on the Frio River floodplain. With one exception, 41 MC 266, al1 of the Group 11 sites are on the south side of the river. Roughly the western half of the site group area, on both sides of the river, consists of cleared fields used for crop production or cattle pasturage. Reflecting the merging of San Miguel Creek with the Frio River, the floodplain is exceptionally broad through this area. A riparian forest grows in a gallery along the channel of the Frio River. A narrow fringe of brush parallels the outer edges of the gallery forest. In the eastern half of the site group area, the Frio River runs up against an extensive northeasterly trending upland peninsula formed of resistant outcrops of Jackson Group sandstone (Fig. I, folded insert). The Frio River floodplain narrows down to a width of on 1 y 50 to $100 \mathrm{~m}$ along a stretch of 1.0 to $1.5 \mathrm{~km}$ on the south side of the valley. The riparian forest following the 
river channel continues through this area. Outward from the river on both sides at the eastern end of the Group 11 area, the 1 and is covered with dense stands of brush. Prehistoric sites down on the floodplain rest on levees and terraces of varying ages formed by alluvial processes of the Frio River. Relict channel scars are apparent in certain areas. Four short, steep up 1 and drainage channels cut down across the south side of the floodplain from the up 1 ands. At the east end of the site group area, the sandstone outcrops of the Jackson Group form a quite steep, rocky margin to the southern side of the valley. Two sites in the group, 41 MC 282 and 41 MC 284, are situated on up 1 and spurs sticking out from the south side of the valley. San Miguel Creek, the biggest local tributary to the Frio River, joins the river just off the northern end of 41 MC 270 ( $F i g .1$, folded insert).

\section{MC 270}

Site 41 MC 270 is located on the southeast (right) bank of the Frio River very near its juncture with San Miguel Creek (Fig. 1, folded insert). The site rests on a 1 ow second terrace 100 to $150 \mathrm{~m}$ from the modern river channel (Fig. 50,e). Long and narrow in outline shape, the site measures $400 \mathrm{~m}$ north-northeast to south-southwest and is about $75 \mathrm{~m}$ in width. The floodplain area containing the site is from 200 to $400 \mathrm{~m}$ in width, the steep sandstone slopes of the valley margin are 200 to $300 \mathrm{~m}$ southeast and east of $41 \mathrm{MC} 270$. The site occurs partially within a cleared field planted in coasta 1 Bermuda and partial1y in brush (Fig. 50,f). Mesquite, guaji110, soapbush, and 10w, leafy vegetation are present in the brush-covered areas. Hardwoods and dense canopies of mustang grapes grow along the river to the west. The site was evidenced to CAR surveyors by a light, but extensive surface scatter consisting of debitage, mussel shell, fire-fractured chert, burned sandstone, 1 and snail she115, cores, and a few chipped stone tools.

Activities of the CAR crew during Phase II investigations at 41 MC 270 were a provenienced collection of surface artifacts and excavation of five shovel tests. Shovel test results indicated that further controlled excavations were not warranted. Twenty "dog leash" samples of surface artifacts were collected. Locations of the sample units were recorded on a plan map (filed at the CAR-UTSA). The following artifacts were collected: 22 cores (three, Group 2; two, Group 3; one, Group 4; five, Group 5; two, Group 6; two, Group 7; eight, Group 9), four thick bifaces (two, Group 1; one, Group 3; one, Group 7, Form 1), five thin bifaces (one, Group 4, Form 3; two, Group 4, Form 4; one, Group 9; one, Group 10), one distal1y beveled tool (Group 3, Form 2), one trimmed flake (Group 4), and five pieces of modified sandstone (two, Group 1, Form 3; three, Group 2, Form 2). Use of the site during the Middle Archaic and/or Late Archaic periods is indicated; this assessment is based primarily on the single distally beveled tool recovered.

\section{MC 266}

Site 41 MC 266 is located on the north side of the Frio River above a relict channel scar roughly $200 \mathrm{~m}$ north of the modern channel (Fig. 1, folded insert). As recorded by CAR surveyors during the 1979 survey, 41 MC 266 is oval in outline and measures $125 \mathrm{~m}$ east-west and $50 \mathrm{~m}$ north-south. A dirt 
road bisects the site along its east-west axis. It rests on a relatively high bluff, or terrace remnant overlooking a relict Frio River channel scar downhill to the south. The face of this bluff is heavily eroded. The site surface is covered with mesquite trees, soapbush, spiny hackberry, cactus, and grasses. Prehistoric cultural debris consisting of a heavy surface scatter of fire-fractured rock, burned sandstone, debitage, mussel she 11 , and snail shell was used to define the site 1 imits. This debris was exposed mainly in the roadbed and on the heavily eroded slope of the bluff ( $F$ ig. 55,a). One highly disturbed rock cluster was observed eroding from the bluff face by the surveyors. The 7 andowner reported that the site had been collected periodically through the years. He claimed to have found sherds of aboriginal pottery on the site.

Returning to 41 MC 266 for Phase II investigations, the CAR crew excavated four shovel tests, documented some habitational features exposed on the surface, and made an unprovenienced collection of surface artifacts. Three of the shovel tests were $p 1$ aced in uneroded areas back away from the b 7 uff face in the northern half of the site. Although some prehistoric cultural debris was found, the incidence was quite low. A fourth test excavated uphill from rock clusters eroding from the bluff face revealed a very productive zone extending from 20 to $65 \mathrm{~cm}$ below the surface. This zone was described as a "midden deposit" due to its rich consistency, and dark grayish black color. It contained much burned sandstone, two bifaces, numerous Rabdotus snail shells, fire-fractured rock, a few pieces of mussel she11, and numerous pieces of debitage.

Three rock clusters, or hearths, were found eroding from the lower areas of the bluff face. A sketch map showing locations of these features and the shovel tests was drawn (on file at the CAR-UTSA). Hearth 1 measured $40 \mathrm{~cm}$ east-west and $50 \mathrm{~cm}$ north-south. It was composed of about 10 pieces of sandstone (fist-sized) and 10 smaller pieces of fire-fractured rock. Debitage and sma 71 pieces of burned rock were scattered around this feature. Hearth 2 was on 7 y $2 \mathrm{~m}$ northeast of Hearth 1 . It measured approximately $90 \mathrm{~cm}$ north-south and $65 \mathrm{~cm}$ east-west. There were 15 pieces of sandstone in a tight, central cluster of about $40 \times 40 \mathrm{~cm}$. There were 10 more sandstones scattered to the south and west. Hearth 3 was found $50 \mathrm{~m}$ northeast of Hearths 1 and 2, also at the foot of the eroding bluff slope. It was heavily disturbed by erosion. The feature covered an area measuring $65 \mathrm{~cm}$ northsouth and $60 \mathrm{~cm}$ east-west. It was composed of 35 pieces of sandstone and two pieces of fire-fractured rock. A fairly dense scatter of debitage, burned sandstone, and cores occurred immediately around Hearth 3.

On 7 y two thin bifaces (one, Group 3, Form 2; one, Group 4, Form 4) were collected at 41 MC 266. A stemmed dart point traced in the field notes and tentatively identified as a Fairland type was apparentiy lost or mislabeled as it does not appear in the artifact tables. Based only on specimens gathered by CAR workers, 41 MC 266 appears to have been inhabited during the Late Archaic period. If, however, the 1 andowner's report of aboriginal potsherds is taken into consideration, a Late Prehistoric component would also be indicated. The dense accumulations of burned sandstone noted on the surface and in the subsurface are 1 ike the Late Archaic sandstone deposits at 41 MC 296 and elsewhere. This provides additional evidence of a Late Archaic component at this site. 


\section{MC 282}

Site 41 MC 282 is situated on the north end of a spur or ridge of upland projecting out (north) into the Frio River valley (Fig. 1, folded insert). The valley margin upon which the site rests is formed of outcrops of Jackson Group sandstone. The modern channel of the Frio River is directly below 41 MC 282 at the foot of the valley margin slope. The site is subcircular to broadly oval in out 1 ine shape and measures approximately $150 \times 150 \mathrm{~m}$. Moderate erosion and brush cover consisting of mesquite, blackbrush, whitebrush, prickly pear, spiny hackberry, and tall grasses characterize the surface. CAR surveyors, who recorded this site in 1979, found that it contained both prehistoric and historic components. Data concerning the historic component is reported by Fox (1986). Prehistoric cultural activity was evidenced on the site by a light surface scatter of debitage, cores, and chipped stone tools.

An unprovenienced collection of surface artifacts was done by the CAR crew at 41 MC 282 during Phase II investigations. The following artifacts were collected: three cores (two, Group 6; one, Group 9), 11 thick bifaces (three, Group 2; two, Group 3; one, Group 4; four, Group 7, Form 1; one, Group 7, Form 3), five thin bifaces (four, Group 4, Form 4; one, Group 10), three dista 11 y beveled tools (one, Group 3, Form 1; one, Group 7, Form 1; one, Group 8, Form 1), one uniface (Group 3), one trimmed f1ake (Group 4), and one piece of modified sandstone (Group 1, Form 1). Prehistoric cultural activity on the site during the Middle Archaic and Late Archaic periods is indicated by this artifact assemblage, particularly the distally beveled tools. The relatively large number of thick bifaces recovered suggests that chipped stone tool manufacture was one important activity on the site. The presence of a sandstone metate (modified sandstone Group 1, Form 1) imp 1 ies that food processing and more general habitational activities also occurred there.

\section{4}

Located southwest of 41 MC 282, 41 MC 284 is another site located on the sandstone bluffs at the edge of the river valley (Fig. 1, folded insert). The site is ova 1 in out 1 ine shape with dimensions of $120 \mathrm{~m}$ east-west and $300 \mathrm{~m}$ north-northeast to south-southwest. Moderately heavy stands of brush on the site surface include mesquite, blackbrush, spiny hackberry, cactus, soapbush, tasajillo, whitebrush, and grasses. Sandstone is exposed in the bluff face on the north and west sides of the site. Short up 1 and drainage channels cut down to the river on the northeast and southwest sides of 41 MC 284. Like 41 MC 282, both prehistoric and historic components are evidenced. The Phase II investigation consisted of an unprovenienced collection of surface artifacts. Specimens recovered were two thick bifaces (one, Group 2; one, Group 6, Form 1), one thin biface (Group 4, Form 4), and one distally beveled tool (Group 8, Form 1). Prehistoric cultural activity sometime during the Archaic period is indicated. 


\section{MC 286}

Site 41 MC 286 is located on a natural terrace levee along the right (south) bank of the modern Frio River channel (Fig. 1, folded insert). Following the trend of the levee, 41 MC 286 is 1 ong and narrow. As recorded by the CAR surveyors in 1979, it measures $225 \mathrm{~m}$ east-west and is about $75 \mathrm{~m}$ wide. An up 1 and drainage channel meets the Frio River off the west end of the site. Mesquite, persimmon, spiny hackberry, soapbush, catclaw, whitebrush, and grasses form a light to moderate brush cover over the site. The slope forming the northern side of the site is gullied, and the main site area has deflated areas. Prehistoric cultural debris evidencing the site is exposed primarily in these areas of erosion. Cultural material observed during initial reconnaissance were fire-fractured rock, mussel she11, a sherd of aboriginal pottery, and thin bifaces including unstemmed triangular forms and a Perdiz arrow point.

During Phase II investigations, 41 MC 286 was shovel tested and a number of surface artifacts were flagged for collection. Shovel tests excavated on the site, as well as subsurface exposures in gul1y wal1s, revealed that cultural debris was confined to the upper $20 \mathrm{~cm}$ of deposit and held 1 ittle potential for control led excavations. Unfortunately, the surface artifacts flagged one day, and scheduled for controlled collection the following day, were apparentiy taken by artifact collectors in the crew's absence from the site. Sketches of some of the artifacts in the field notes show a stemmed dart point classified as a Frio type, two unstemmed triangular thin bifaces, a number of thin biface fragments, and some thick bifaces. Based on these records and data recorded in the site survey record, it appears that 41 MC 286 was inhabited during the Late Archaic and Late Prehistoric periods.

\section{MC 290}

Site 41 MC 290 is a smal1 historic site located on the left (west) bank of an upland drainage channel that cuts down through the southern floodplain of the Frio River (Fig. 1, folded insert). The site is about $400 \mathrm{~m}$ south of the river and perhaps $100 \mathrm{~m}$ west of the drainage channe1. The site area is covered with scattered mesquite trees and patches of whitebrush. It is evidenced by sandstone building rock strewn over a 50-m radius around a 2-mlong section of cut sandstone blocks laid in a row. This single-layer row consists of at least five blocks and may have functioned as the corner of a house foundation or a chimney base. Two ceramic artifacts, a white ironstone dinner plate base fragment, and a basal/side fragment of a white ironstone bow 1 were observed 15-20 m east of the in situ structured remnant. Severa? sections of heavy gauge smooth wire and a metal pan fragment were also noted in the vicinity of the structure. A sketch map of the site area was drawn (on file at the CAR-UTSA).

\section{MC 288}

Site 41 MC 288 occurs on an old, high floodplain terrace about $100 \mathrm{~m}$ south of the modern Frio River channel (Fig. lo folded insert). It 1 ies immediately 
west of an up 1 and drainage that comes down across the floodp 1 ain from the south. As recorded by the CAR survey crew in 1979, the site is subcircular to oval in outline shape with dimensions of $250 \times 250 \mathrm{~m}$. The western half of the site is in a cleared field. The eastern half is covered with mesquite trees, soapbush, acacias, and grasses. The surface is moderately to heavily eroded, the erosion is especially severe near the upland drainage channel. The surveyors defined both prehistoric and historic components at 41 MC 288. The site 1 imits were defined on the basis of prehistoric debris scattered over the surface. Occurring in 1 ight to moderate densities on the surface are debitage, musse1 she11. Rabdotus snail she11s, fire-fractured rock, and chipped stone tools. Debris evidencing the historic component is confined to higher ground in the cleared field at the west end.

Phase II activities at 41 MC 288 were excavation of four shovel tests, col1ection of six "dog leash" samples of surface debris, and a controlled collection of some additional surface artifacts. This investigation was concerned only with the site's prehistoric remains. The shovel tests revealed very 1 ittle cultural debris in the subsurface. The few materials that did occur were confined to the upper $20 \mathrm{~cm}$ of deposit. The results indicated that controlled excavations would not prove worthwhile.

In addition to the six "dog 1eash" samples, 19 artifacts were collected from the surface of 41 MC 288. Location of each specimen was recorded on a plan map prior to collection. The plan map showing individual artifact proveniences and "dog leash" sample locations is on file at the CAR-UTSA. Artifacts collected are four cores (one, Group 1; one, Group 2; one, Group 3; one, Group 5), four thick bifaces (one, Group 5; one, Group 6, Form 1; two, Group 7, Form 1), six thin bifaces (Group 1, Form 3, Specimen 33; two, Group 4, Form 4; two, Group 9; one, Group 10), two distally beveled tools (two, Group 8, Form 5), one trimmed $f 1$ ake (Group 3, Form 1), and two pieces of modified sandstone ( $t w o$, Group 2, Form 2). Based on the stemmed dart point (thin bifaces Group 1, Form 3, Specimen 33) and two distally beveled tools in the collection, prehistoric cultural activity is suggested to have occurred during the Middle Archaic period at 41 MC 288.

\section{MC 293}

Site 41 MC 293 is located on a floodplain terrace along the south (right) bank of the Frio River (Fig. 1, folded insert). Its western side is bounded by an upland drainage channel that meets the Frio River just off the site's north end. As recorded by CAR surveyors in 1979, 41 MC 293 is oval in outline with dimensions of $150 \mathrm{~m}$ east-west and $200 \mathrm{~m}$ north-south. Most of the site occurs within a cleared field used for agriculture. The survey crew recognized both prehistoric and historic components. Sandstone building blocks thought to have once formed part of a historic structure were found in a gul1y off the north end of the site. This debris had apparently been bulldozed from its original location when the 1 and was cleared.

Activities of the CAR crew at 41 MC 293 during the Phase II investigation were excavation of two shovel tests, drawing a sketch map of the site area, and making an unprovenienced collection of surface artifacts. Locations of 
sandstone block scatters were shown on the sketch map (on file at the CARUTSA), but the investigation was mainly concerned with the prehistoric component. The two shovel tests revealed that only a smal1 amount of cultural debris was present in the subsurface. It is assumed that agricultural practices have resulted in considerable disturbance of cultural remains on this site. Controlled testing did not appear necessary. The following artifacts were collected from the surface of 41 MC 293: two cores (one, Group 2; one, Group 5), three thick bifaces (one, Group 2; one, Group 7. Form 3; one, Group 9), five thin bifaces (one, Group 3, Form 2; two, Group 4, Form 4; two, Group 10), one piece of modified sandstone (one, Group 2, Form 2), and one sherd of aboriginal pottery. This 1 imited array of artifacts indicates that this site was inhabited during the Late Prehistoric period.

\section{MC 294}

This long, narrow site is situated on a natural levee paralleling the right (south) bank of the Frio River ( $F i g$. 1, folded insert). Its 1 ong axis running east-west, $41 \mathrm{MC} 294$ is estimated to be $900 \mathrm{~m}$ in length and $100 \mathrm{~m}$ in width. Most of the site occurs in a cultivated field. A fringe of brush grows along the northern side by the river. Soapbush, mesquite, prick $1 y$ pear, and grasses are present. Near the middle of the site, a bend in the channel brings the Frio River to within $25 \mathrm{~m}$. Elsewhere, the river is 100 to $250 \mathrm{~m}$ north. The western half of 41 MC 294 is paralleled by a relict channel, or slough, of the Frio River. This slough is 25 to $50 \mathrm{~m}$ down slope from the site's northern edge. A prehistoric site, 41 MC 294 was defined by the CAR surveyors on the basis of a $1 \mathrm{ight}$, but extensive surface scatter including debitage, fire-fractured rock, sandstone, mussel she11, Rabdotus snail she11, and chipped stone tools. Surface concentrations of prehistoric cultural debris were greatest in the bed of a field road running virtualiy the entire length of the site. Evidence of both Late Archaic and Late Prehistoric occupations was recognized by the surveyors.

In Phase II investigations at 41 MC 294, five shovel tests were excavated, a site sketch map was drawn, and an unprovenienced collection of surface artifacts was made. The shovel tests generally indicated that controlled excavations were not warranted for the site. The uncontrolled collection of surface artifacts resulted in accumulation of the fol 1 owing assemb 1 age: three cores (two, Group 2; one, Group 3), four thick bifaces (one, Group 1; one, Group 2; one, Group 6, Form 1; one, Group 7, Form 2), 12 thin bifaces (one, Group 1, Form 7; one, Group 2, Form 2; one, Group 3, Form 2; one, Group 4, Form 2; one, Group 4, Form 3; three, Group 4, Form 4; two, Group 9; two, Group 10), one distally beveled tool (Group 8, Form 3), one trimmed flake (Group 4), two pieces of modified sandstone (one, Group 2, Form 1; one, Group 2, Form 2), and one sherd of aboriginal pottery. Certain of these specimens indicate Late Prehistoric and Archaic (undifferentiated) components are present at 41 MC 294. 


\section{SIIE GROUP 12}

Extensive

Excavation

41 MC 94

41 MC 268
Iest

Pits
Surface Collections
Provenienced Unprovenienced

41 MC 226

41 MC 275
Resurvey or Shovel Tests

(

The Site Group 12 area is located on the north side of the Frio River valley 18 to $21 \mathrm{~km}$ west of Choke Canyon Dam. The four sites composing this group are situated on the floodplains of the Frio River and San Miguel Creek. The coalescence of these two major drainage systems has resulted in a complex geomorphological setting. Two of the four sites are beside relict channel scars of the creek and river. The location and orientation of certain relict channels between the river and creek suggest that San Miguel Creek has changed course in its lower reaches a number of times. Much of the 1 and in the site group area has been cleared of brush and subsequently cultivated or planted in grass for cattle pasturage. The area is especially rich in terms of gravel deposits. The gravel occurs in extensive bars in both the Frio and San Miguel channe1s. It also occurs as 1 ag pavement on the slopes of older alluvial terraces, especially in the area north of 41 MC 94. The closest outcrops of sandstone are located along the northeast side of the San Miguel Creek valley where the creek has cut through the Jackson Group formation.

\section{MC 94}

Site 41 MC 94 is a long, narrow prehistoric site resting on a natural terrace levee paralleling the north (left) bank of the Frio River (Figs. 1, folded insert; 51). The site measures $800 \mathrm{~m}$ northeast-southwest and is less than $100 \mathrm{~m}$ wide. A relict channel scar runs along the northern edge of the site. The site is entirely within a cultivated field. Riparian species such as elm, oak, ash, and hackberry grow along the southern edge of the site, while mesquite, spiny hackberry, persimmon, prickly pear, allthorn, and huisache grow along the relict channel scar to the north (Fig. 55,b).

Originaliy recorded by surveyors from the Texas Historical Commission (Lynn, Fox, and O'Ma1 1ey 1977), 41 MC 94 was tested by CAR workers during Phase I investigations (Hal1, B 1 ack, and Graves 1982:202-203). A total of 168 artifacts was col lected from the surface, and shovel tests indicated that controlled excavations on the site might yield useful results. Timediagnostic specimens in the artifact collection indicated that the site had been occupied from Late Paleo-Indian to Late Prehistoric times. The numerous cores, thick bifaces, and thin biface fragments in the Phase I assemb 1 age suggested that chipped stone tool manufacture had been an important activity on the site (ibid.).

In Phase II investigations at 41 MC 94, six $1-m^{2}$ units were excavated at three different locations on the site. Due to its great length, no attempt was made to establish a site-wide horizontal grid system. Instead, the 
Figure 51. Topographic Map of 41MC94 and Surrounding Area.

PAGE 185 REDACTED 
excavation units were located relative to datums set at the northeast and southwest ends of the site (Figs. $51 ;$ 52). Datum $A$ is at the northeast end, and units designated Test Pits 1 and 2 were placed nearby. Datum $B$ is at the southwest end. Test Pits 3 and 4 and Test Pits 5 and 6 were staked out south of Datum B. Each of these two sets of units formed unit-blocks measuring $1 \times 2 \mathrm{~m}$. For vertical control, Datums $A$ and $B$ were each assigned arbitrary elevations of $100.00 \mathrm{~m}$. Elevation readings in Test Pits 1 and 2 were taken relative to Datum A. Elevations taken in Test $P$ its 3-6 were relative to Datum B. USBR surveyors 1 ater rep 1 aced Datums $A$ and $B$ with permanent site markers. True elevations for the arbitrary $100.00 \mathrm{~m}$ marks in each area were calculated as follows: Datum A, 219.83 feet above MSL and Datum B, 221.53 feet above MSL. True elevations for the permanent markers rep 1 acing Datums $A$ and $B$ are shown in Figure 52. The USBR surveyors also determined exact locations for each of these datums according to Modified Texas State Plane coordinates.

Test Pits 1 and 2, 1ocated at the northeast end of 41 MC 94 near Datum A, were intended to sample subsurface deposits in an area of the site where a substantial amount of prehistoric cultural debris was on the surface. Test Pit 1 was excavated to a depth of $80 \mathrm{~cm}$ below the surface (eight 10-cm-thick leveis) with surface elevations of 99.70 to $99.72 \mathrm{~m}$. Test Pit 2 went down $90 \mathrm{~cm}$ below the surface and had starting elevations ranging from 99.77 to $99.79 \mathrm{~m}$. Soll matrix in both units was described as dark grayish brown silty clay loam all the way down. Two horizons are defined for these units. Horizon 1 contains the debris recovered from Levels 1 to 4 . Horizon 2 represents the materials found in Levels 5-8 or 9. Rates of recovery for selected classes of debris for the two horizons in Test Pits 1 and 2 are as follows:

\begin{tabular}{cc}
\multicolumn{2}{c}{ Test Pit 1 } \\
Horizon 1 & Horizon 2 \\
0.3 & 0 \\
68 & 71 \\
83 & 312 \\
11 & 11 \\
2 & 3 \\
418 & 168 \\
0 & 0.9 \\
1 & 3 \\
14 & 31 \\
12 & 52 \\
28 & 104 \\
Test Pit 2 \\
Horizon 1 Horizon 2
\end{tabular}

Tuff Weight (grams)

$\begin{array}{rc}0 & 0 \\ 62 & 101 \\ 190 & 324 \\ 63 & 32 \\ 15 & 12 \\ 615 & 212 \\ 0.1 & 0.1\end{array}$

Tuff Weight (grams)

Sandstone Weight (grams)

Fire-Fractured Rock Weight (grams)

Mussel She11 Umbo Count

Mussel Shell Weight (grams)

Rabdotus Shell Count

Bone Weight (grams)

Primary Flake Count

Secondary Flake Count

Tertiary Flake Count

Chip Count

Sandstone Weight (grams)

Fire-Fractured Rock Weight (grams)

Mussel Shell Umbo Count

Mussel Shel1 Weight (grams)

Rabdotus Shell Count

Bone Weight (grams) 
Figure 52. Test Pit locations at 41MC94.

PAGE 187 REDACTED 

Secondary Flake Count Tertiary Flake Count Chip Count
Primary Flake Count

$\begin{array}{rr}3 & 2 \\ 30 & 33 \\ 27 & .66 \\ 50 & 90\end{array}$

Horizon 1 in Test Pits 1 and 2 a 1 so yielded one core (Group 4) and two thin bifaces (Group 1, Form 7, Specimen 23; one, Group 9). In Horizon 2 there were two cores (one, Group 4, one, Group 5), four thin bifaces (one, Group 4, Form 4; one, Group 9; two, Group 10), two pieces of modified sandstone (two, Group 2, Form 3), a piece of modified mussel she11 (Specimen 5), and one sherd of aboriginal pottery. No habitational features were recognized in Test Pits 1 and 2 .

Test Pits 3-6 were placed south of Datum B at the southwest end of 41 MC 94 (Fig. 52). It was in this area of the site that shovel tests were excavated during Phase I investigations. Test Pits 3 and 4 , together forming a 1$\times 2-\mathrm{m}$ pit, were excavated to depths of $70 \mathrm{~cm}$ (seven 10-cm-thick 1evels) and $90 \mathrm{~cm}$ (nine 10-cm-thick leve1s), respectively. Surface elevations ranged from 99.74 to $99.85 \mathrm{~m}$. The soil matrix was again described as dark grayish brown silty clay loam all the way down through the profile. Two horizons are defined for Test Pits 3 and 4. Horizon 1 consists of debris from Levels 1-4, and Horizon 2, the debris from Levels 5-7 or 9. Rates of debris recovery for Test Pits 3 and 4 are as follows:

\begin{tabular}{cr}
\multicolumn{2}{c}{ Test Pit 3 } \\
Horizon 1 & Herizon 2 \\
0 & 0 \\
131 & 151 \\
75 & 19 \\
16 & 11 \\
7 & 4 \\
215 & 510 \\
0 & 0 \\
1 & 0 \\
37 & 7 \\
67 & 8 \\
103 & 11 \\
\multicolumn{2}{l}{ Iest. Pit 4 } \\
Horizon 1 Horizon 2
\end{tabular}

Tuff Weight (grams)

Sandstone Weight (grams)

$\begin{array}{rr}0 & 0 \\ 114 & 221 \\ 61 & 27 \\ 17 & 13 \\ 4 & 3 \\ 254 & 546 \\ 0.1 & 0 \\ 2 & 1 \\ 48 & 7 \\ 85 & 12 \\ 128 & 24\end{array}$


Also recovered from Horizon 1 deposits in these two units were two thin bifaces (Group 1, Form 3, Specimen 29; one, Group 10), a distally beveled tool (Group 3, Form 2, Specimen 8), a piece of modified sandstone (Group 1, Form 3), and a piece of satin spar gypsum. One thin biface fragment (Group 4, Form 4) was recovered from Horizon 2.

Test Pits 5 and 6 were located in the area between Test Pits 3 and 4 and Datum B (Fig. 52). These two units a 1 so formed a $1-\times 2-m$ pit. Test Pit 5 went to a depth of $60 \mathrm{~cm}$ below the surface (starting elevations ranging from 99.91 to $99.93 \mathrm{~m}$ ). Test Pit 6 went to a depth of $80 \mathrm{~cm}$ (starting elevations ranging from 99.93 to $99.94 \mathrm{~m})$. As el sewhere at $41 \mathrm{MC} 94$, the excavated matrix was described as grayish brown silty clay loam. Two horizons are defined for these units. Horizon 1 represents Levels 1-4. Horizon 2 represents Levels 5-6 or 8. Rates of recovery for selected classes of debris from Test Pits 5 and 6 are as follows:

\begin{tabular}{|c|c|c|}
\hline & Test & it 5 \\
\hline & Horizon 1 & Herizon 2 \\
\hline Tuff Weight (grams) & 0 & 0 \\
\hline Sandstone Weight (grams) & 62 & 25 \\
\hline Fire-Fractured Rock Weight (grams) & 28 & 25 \\
\hline Mussel Shell Umbo Count & 14 & 7 \\
\hline Mussel Shell Weight (grams) & 6 & 3 \\
\hline Rabdotus She 11 Count & 117 & 237 \\
\hline Bone Weight (grams) & 0 & 0 \\
\hline Primary Flake Count & 0 & 2 \\
\hline Secondary Flake Count & 9 & 7 \\
\hline Tertiary Flake Count & 30 & 23 \\
\hline Chip Count & 75 & 39 \\
\hline & Iest & it 6 \\
\hline & Horizon 1 & Horizon 2 \\
\hline Tuff Weight (grams) & 6 & 0 \\
\hline Sandstone Weight (grams) & 46 & 16 \\
\hline Fire-Fractured Rock Weight (grams) & 12 & 6 \\
\hline Musse1 Shel1 Umbo Count & 9 & 5 \\
\hline Mussel Shell Weight (grams) & 3 & 3 \\
\hline Rabdotus She 17 Count & 132 & 548 \\
\hline Bone Weight (grams) & 0 & 0.1 \\
\hline Primary Flake Count & 1 & 0 \\
\hline Secondary Flake Count & 19 & 10 \\
\hline Tertiary Flake Count & 77 & 24 \\
\hline Chip Count & 53 & 47 \\
\hline
\end{tabular}

Horizon 1 yielded two additional artifacts, one thin biface fragment (Group 10) and a distally beveled tool (Group 3, Form 2, Specimen 9).

Data recovered during Phase II investigations at 41 MC 94 reaffirm the presence of Late Archaic and Late Prehistoric components in the site, but provide no additional recognized evidence of Late Paleo-Indian or Early Archaic components previously suggested on the basis of Phase I findings. 
Severe mixing of prehistoric cultural debris in the subsurface is suggested by the vertical provenience of certain time-diagnostic artifacts recovered from the Phase II test pits. Distally beveled tools (Group 3, Form 2, Specimens 8 and 9), both probably Middle Archaic and/or Late Archaic diagnostics, were found in Horizon 1 of Test Pits 3 and 5. Other indicators suggest that Horizon 1 should contain Late Prehistoric remains. Likewise, a sherd of aboriginal pottery was recovered from Horizon 2 (Leve1 9) in Test Pit 1. A11 other indications are that Horizon 2 represents Archaic period activity at 41 MC 94. These test pit findings, coupled with the numerous and diverse artifacts collected from the surface in Phase $I$, demonstrate that the prehistoric cultural remains at 41 MC 94 have been severely churned, probably as a result of agricultural practices on the 1 and containing the site. In retrospect, the controlled surface collections made on the site in Phase I were probably the best method of studying its character.

As a result of findings made during Phase I investigations at 41 MC 94, it was concluded that chipped stone tool manufacture was a common activity on the site (Ha11, Black, and Graves 1982:203). Nearby gravel deposits eroding from terrace slopes north of the site were cited as a possible attraction to the site. The Phase I surface collection contained an unusually 1 arge collection of sandstone manos and metates, indicating that seed and nut processing was an important subsistence activity in the vicinity. The Phase II test pits also yielded some information related to subsistence that is probably significant. Of particular interest is the fact that mussel she 11 occurred in relatively low amounts, and Rabdotus snail she $11 \mathrm{~s}$ were recovered in unusually great numbers. Probably reflecting the proximity of gravel deposits, sandstone and fire-fractured rock occur in nearly equal amounts in the subsurface at 41 MC 94.

\section{MC 268}

The lower reaches of the floodplain between the Frio River and San Miguel Creek bear evidence of a complicated geomorphological history resulting from the merging of two major alluvial systems and migration of channels within their valleys. Site 41 MC 268 is located on a terrace remnant bounded to the north and west by a relict channel that connects San Miguel Creek to the Frio River (Figs. 1, folded insert; 53). A relict channel of San Miguel Creek runs along the east side of the site. The eastern edge of 41 MC 268 is now within 100 to $300 \mathrm{~m}$ of the modern channel of San Miguel Creek, currently flowing to the east (Fig. 55, C). Recorded by the CAR crew during the 1979 survey, 41 MC 268 is oval in outline shape with dimensions of $100 \mathrm{~m}$ east-west by $300 \mathrm{~m}$ north-south. Much of the western portion of this site occurs in a cleared, cultivated field. The sitels eastern portion, paralleling the slough or relict channel scar, supports a brush cover including mesquite and retama. The site was evidenced to surveyors by a surface scatter of prehistoric cultural debris composed mainly of debitage, but also including fire-fractured rock, mussel shel1, and chipped stone tools. Expanding stem dart points (one of the Ensor type), a Scallorn arrow point, and sherds of aboriginal pottery were noted on the surface by the surveyors.

Phase II investigations occurred at 41 MC 268 in August 1981. A CAR field crew of 10 persons worked seven days for a total of 560 person hours. 
Figure 53. Local Topography and Plan of Excavations at 41MC268.

PAGE 191 REDACTED 
An excavation grid was established at 41 MC 268. A nail driven into a post along a fence line bisecting the site north to south served as the vertical datum. USBR surveyors 1 ater calculated a true elevation of 224.95 feet above MSL for this datum nail. They also placed a permanent site marker at 41 MC 268 and determined its exact 1ocation expressed in Modified Texas State Plane Coordinates (Fig. 53). A true elevation of 220.46 feet above MSL was calculated for the permanent marker.

Three $1-m^{2}$ test pits and two $2-m^{2}$ unit blocks were excavated at 41 MC 268 . Test pit locations were judgmentally selected on the basis of surface indications. The unit blocks were positioned on the basis of test pit findings.

Test Pit 1 was placed in the cleared field along the fence 7 ine at the north end of 41 MC 268 ( $F$ ig. 53). It was excavated to a depth of $70 \mathrm{~cm}$ bel ow the surface (seven $10-\mathrm{cm}-$ thick 1 evel $\mathrm{s}$ ). From the surface to a depth of $40 \mathrm{~cm}$, the matrix was described as medium brown sandy $10 a m$. In Leve1 5, the soil changed to 1 ight grayish brown sandy clay $10 a m$. Debris recovery for Test Pits $1-3$ is summarized as follows:

\section{Iest Pit 1 Iest Pit 2 Iest Pit 3}

Tuff Weight (grams)

Sandstone Weight (grams)

Fire-Fractured Rock Weight (grams)

Musse1 She11 Umbo Count

Mussel She11 Weight (grams)

Rabdotus Shel1 Count

Bone Weight (grams)

Primary Flake Count

Secondary Flake Count

Tertiary Flake Count

Chip Count

$\begin{array}{rrr}0 & 0 & 16 \\ 15 & 257 & 241 \\ 8 & 251 & 268 \\ 13 & 62 & 16 \\ 5 & 15 & 6 \\ 5 & 191 & 7 \\ 0.2 & 2 & 4 \\ 0 & 6 & 15 \\ 26 & 63 & 76 \\ 28 & 85 & 156 \\ 52 & 122 & 181\end{array}$

Also found in Test Pit 1 were a thin biface fragment (Group 10) and one piece of modified sandstone (Group 1, Form 2). No habitational features were recognized in this unit.

Test Pit 2 was excavated in the south-central area of 41 MC 268 (Fig. 53). This unit reached a final depth of $80 \mathrm{~cm}$ below the surface (eight $10-\mathrm{cm}-$ thick levels). Soil matrix throughout was described as 1 ight brown sandy silt. Rates of recovery for selected classes of debris are shown above. Also recovered from Test Pit 2 were four cores (one, Group 1; one, Group 4; two, Group 5) and a distally beveled tool (Group 3, Form 3, Specimen 10).

Feature 1, a cluster of burned sandstone, was defined in Leve $18(70-80 \mathrm{~cm}$ below the surface) of Test Pit 2 at 41 MC 268 (Fig. 55,e). Approximately 22 fist-sized pieces of sandstone made up the cluster. The exposed portion of this feature measured $24 \times 32 \mathrm{~cm}$. It appeared to continue beyond the 1 imits of the excavation and, projecting from the exposed portion, was probably subcircular in overall outline shape. No carbon was found in or immediately around this feature. 
Test Pit 3 was excavated in the north-central area of 41 MC 268 (Fig. 53). The unit was excavated to a depth of $50 \mathrm{~cm}$ below the surface in a matrix described as dark brown sandy loam. Rates of recovery for selected classes of debris from Test Pit 3 are shown above. Also found in Test Pit 3 were five cores (one, Group 2; one, Group 3; one, Group 4; one, Group 5; one, Group 6) and one piece of modified sandstone (Group 3). An accumu 1 ation of fire-fractured rock, isolated in Level 5 (40-50 cm below the surface) of Test Pit 3, was designated Feature 2. Consisting of about 30 pieces of firefractured rock. Feature 2 had dimensions of $40 \mathrm{~cm}$ northeast to southwest and $80 \mathrm{~cm}$ northwest to southeast. A smal1 amount of carbon was collected from amidst the feature components. A sma 11 amount of mussel she11 and a few lumps of fired clay were also found in the feature.

Findings made in Test Pit 2 indicated that that particular area of 41 MC 268 offered the best potential for further controlled excavations. Consequently, the two blocks of units designated Areas $A$ and $B$ were placed south and west, respectively, of Test Pit 2 (Fig. 53).

Area $A$ consisted of four $1-m^{2}$ units forming a 2-m $m^{2}$ block. Coordinates for the units and number of 10-cm-thick levels excavated in each are N995 E998 (11 1eve1s), N995 E999 (eight leve1s), N996 E998 (11 leve1s), and N996 E999 (eight levels). Surface elevations for these units ranged from 99.42 to $99.47 \mathrm{~m}$. The upper $10 \mathrm{~cm}$ of deposit in the area was described as 1 ight grayish tan sandy 1 oam. The remainder of the deposit was dark brown sandy loam. In two of the Area A units. N995 E998 and N996 E998, two distinct horizons of debris were perceived. In these units, Horizon 1 represents debris recovered from Levels 1-6. Horizon 2 contains the materials found in Levels 7-11. Rates of recovery for selected classes of debris in the Area $A$ units are as fol lows:

$\begin{array}{cc}\frac{\text { Units N995 E998 }}{\text { and N996 E998 }} & \frac{\text { Other Units }}{\text { All Levels }} \\ \text { Horizon 1 Horizon } 2 & \text { Combined }\end{array}$

Tuff Weight (grams)

Sandstone Weight (grams)

Fire-Fractured Rock Weight (grams)

Mussel Shell Umbo Count

Mussel Shel1 Weight (grams)

Rabdotus Shell Count

Bone Weight (grams)

Primary Flake Count

Secondary Flake Count

Tertiary Flake Count

Chip Count
11

540

725

29

15

78

3

11

110

143

277

$\begin{array}{rr}0 & 2 \\ 83 & 1075 \\ 91 & 1352 \\ 50 & 73 \\ 8 & 12 \\ 258 & 73 \\ 0 & 1 \\ 0 & 5 \\ 30 & 72 \\ 60 & 97 \\ 99 & 143\end{array}$

The Horizon 1 deposits in Area $A$ also yielded the following artifacts: five cores (one, Group 2; one, Group 3; three, Group 5), six thin bifaces (Group 1. Form 5, Specimen 9 [Sca11orn]; three, Group 9; two, Group 10), and six pieces of modified sandstone (one, Group 1, Form 3; four, Group 2, Form 2; one, Group 2, Form 3). From Horizon 2 came one core (Group 7), one thin biface fragment (Group 9), and one piece of modified sandstone (Group 2, Form 1). 
Two distinct clusters of sandstone and fire-fractured rock were exposed in Levels 5-7 (99.10 to $98.80 \mathrm{~m})$ of Area A (Figs. 54; 55,d). Designated Features 3 and 4 , these clusters 1 ikely represent a single prehistoric habitation event at 41 MC 268. Feature 3. more-or-less circular in outline shape, measured $45 \mathrm{~cm}$ north-south and $40 \mathrm{~cm}$ east-west. It was made up of 30 pieces of sandstone, 15 pieces of fire-fractured rock, and five pieces of tuff. Rocks ranged in size from 3 to $8 \mathrm{~cm}$. A few flecks of carbon were scattered among the rocks. Smal1 amounts of mussel she11, burned bone, and fired clay were also noted.

Located southeast of Eeature 3, Feature 4 was somewhat 1 arger (Figs. 54; $55, d)$. The major cluster of rocks in this feature measured $80 \mathrm{~cm}$ north-south and $60 \mathrm{~cm}$ east-west. A tight cluster of the 1 argest rocks occurred in the central area. Roughly circular, this cluster had a diameter of about $30 \mathrm{~cm}$. A concentration of carbon occurred within this central cluster. Approximate 1 y 80 pieces of fire-fractured rock and 30 pieces of sandstone made up the feature. A few pieces of mussel shel1 were al so found in the feature. Both Feature 3 and Feature 4 were essentialiy single-1ayer constructs.

Area $B$ was $p l$ aced out in the cleared field west of Test Pit 2 and Area $A$ (Fig. 53). The area consisted of four $1-m^{2}$ units forming a $2-m^{2}$ block. Coordinates for these units and the number of $10-\mathrm{cm}-$ thick 1 evels excavated in each are N994 E982 (four levels), N994 E983 (11 levels), N995 E982 (six levels), and $N 995 \mathrm{E} 983$ (four levels). Surface elevations for the units in Area B ranged from 99.47 to $99.49 \mathrm{~m}$. The soil encountered as the Area B units were excavated was described as follows: surface to a depth of $40 \mathrm{~cm}$ was very dark grayish brown sandy loam, 40 to $80 \mathrm{~cm}$ below the surface was dark grayish brown silty $10 \mathrm{am}$, and 80 to $110 \mathrm{~cm}$ below the surface was tannish brown sandy loam with carbonate flecking. For the one deepest unit in Area B, N994 E983, two horizons are defined. Horizon 1 contains debris recovered from Levels 1-6, and Horizon 2 contains the debris from Levels 711. The other three units yielded material that essential1y corresponds to Horizon 1 as defined in $N 994$ E983. The units yielded selected classes of debris as shown below.

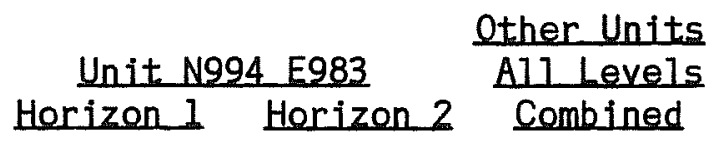

Tuff Weight (grams)

Sandstone Weight (grams)

Fire-Fractured Rock Weight (grams)

Musse1 Shell Umbo Count

Mussel She11 Weight (grams)

Rabdotus She11 Count

Bone Weight (grams)

Primary Flake Count

Secondary Flake Count

Tertiary Flake Count

Chip Count

$\begin{array}{rrr}0 & 0 & 2 \\ 106 & 100 & 383 \\ 63 & 184 & 258 \\ 48 & 227 & 73 \\ 321 & 536 & 45 \\ 15 & 276 & 35 \\ 0.4 & 0 & 2 \\ 9 & 1 & 19 \\ 39 & 8 & 127 \\ 53 & 14 & 139 \\ 113 & 13 & 285\end{array}$

Horizon 1 deposits in Area $B$ also yielded the following artifacts: 10 cores (four, Group 2; two, Group 3; one, Group 4; two, Group 5; one, Group 7), two 


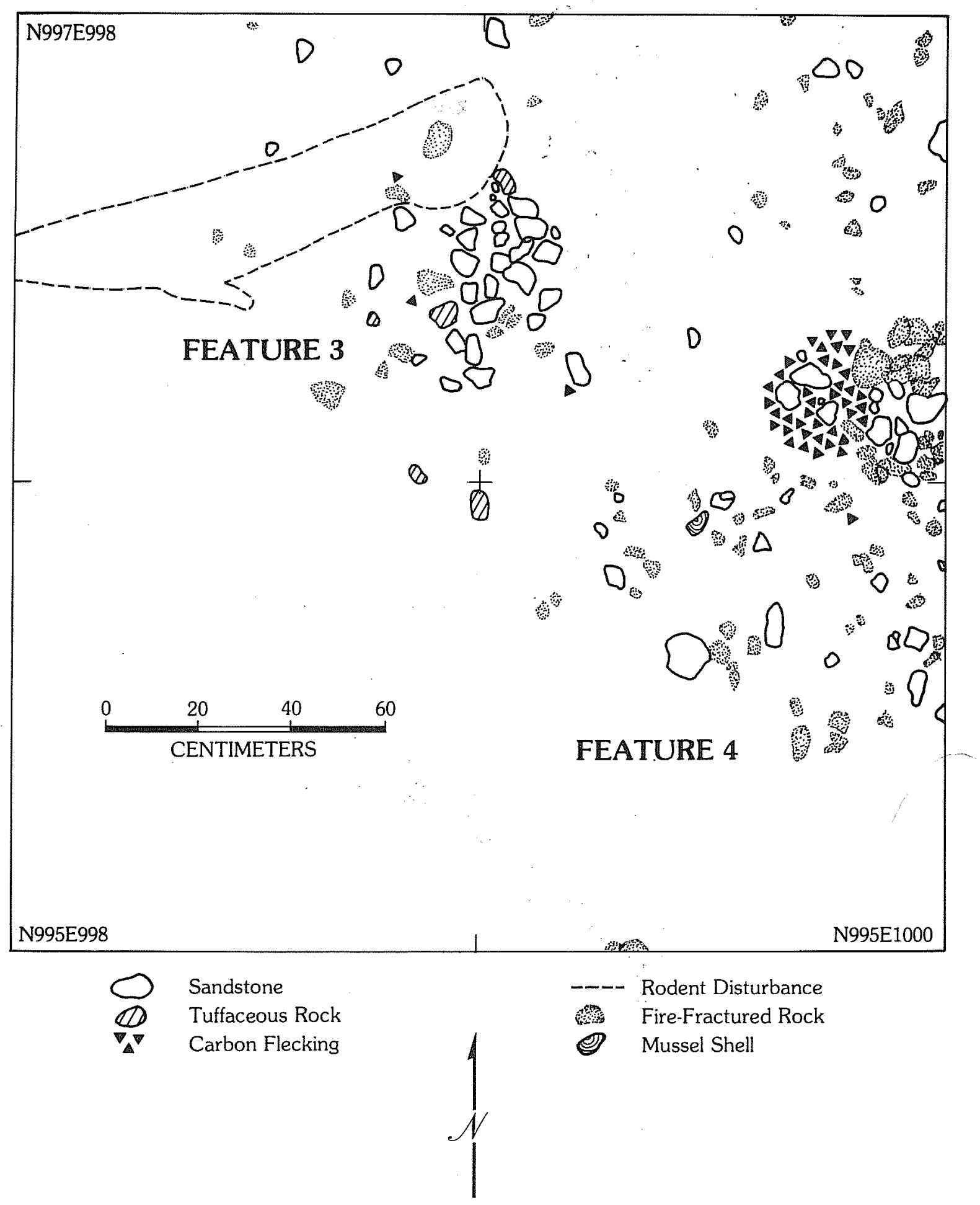

\section{$41 \mathrm{MC} 268$}

PLAN OF FEATURES 3 AND 4

Figure 54. Plan of Features 3 and 4 at 41 MC 268. 
Figure 55. Views of 41 MC 266, 41 MC 94, 41 MC 268, and 41 MC 275.

a. View of the eroded bluff face at 41 MC 266 looking north and upslope at the site's west end;

b. general view of excavations in progress at 41 MC 94;

c, a view of San Miguel Creek looking southeast in the vicinity of 41 MC 268;

d. $\quad$ iew of Features 3 and 4 exposed in the Area $A$ excavations at 41 MC 268;

e, view of Feature 1 in Test Pit 2 at 41 MC 268;

f. view of the east end of 41 MC 275 looking west-southwest. 


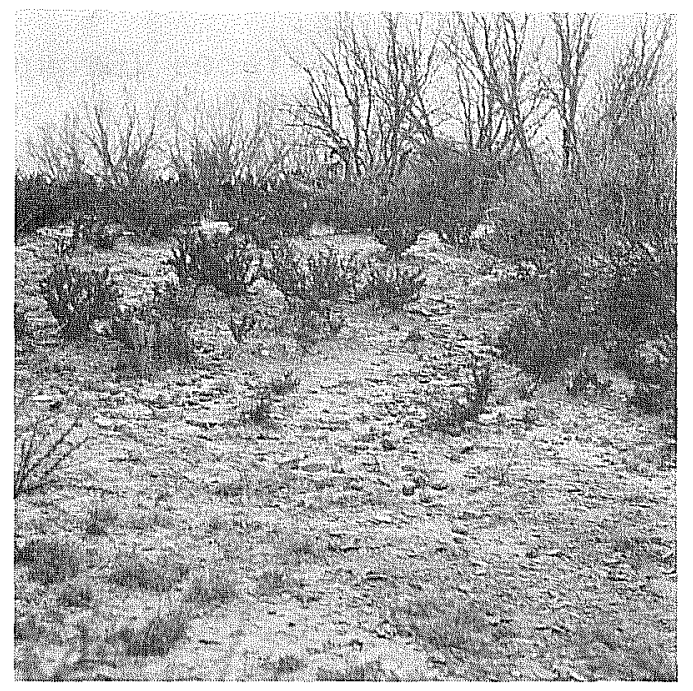

a

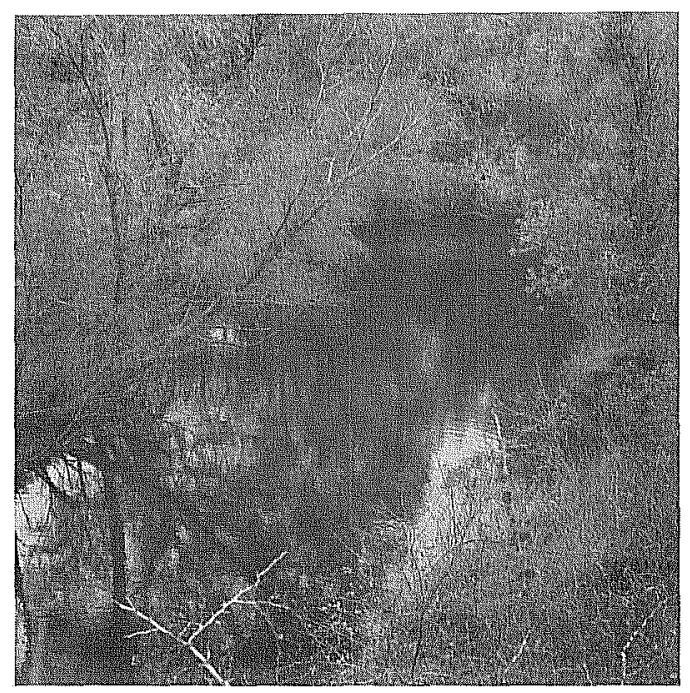

c

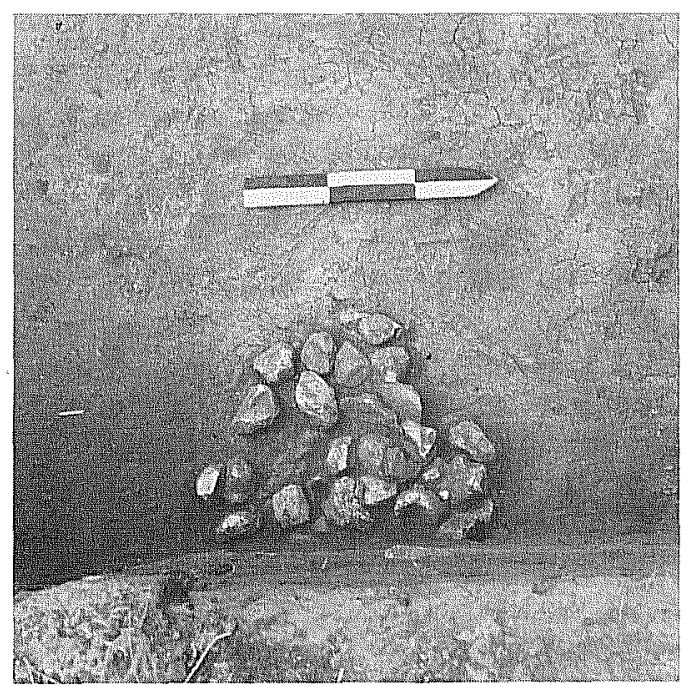

e

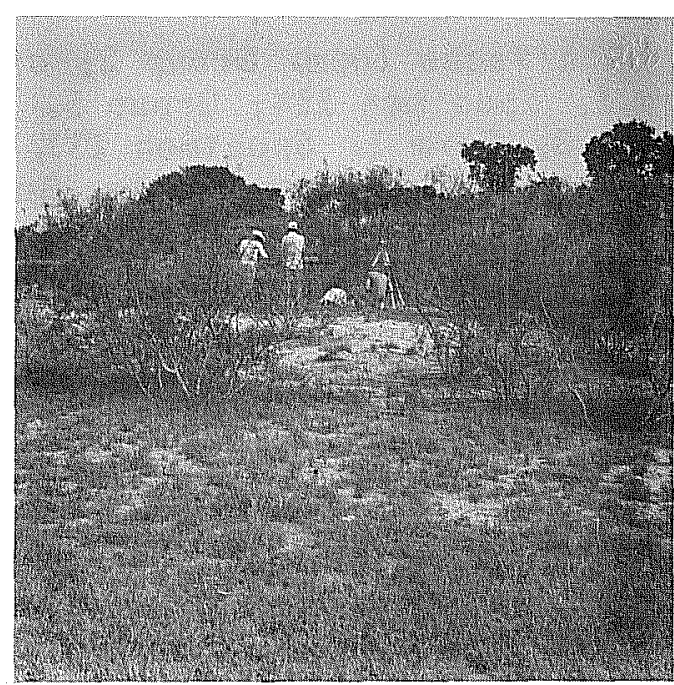

b

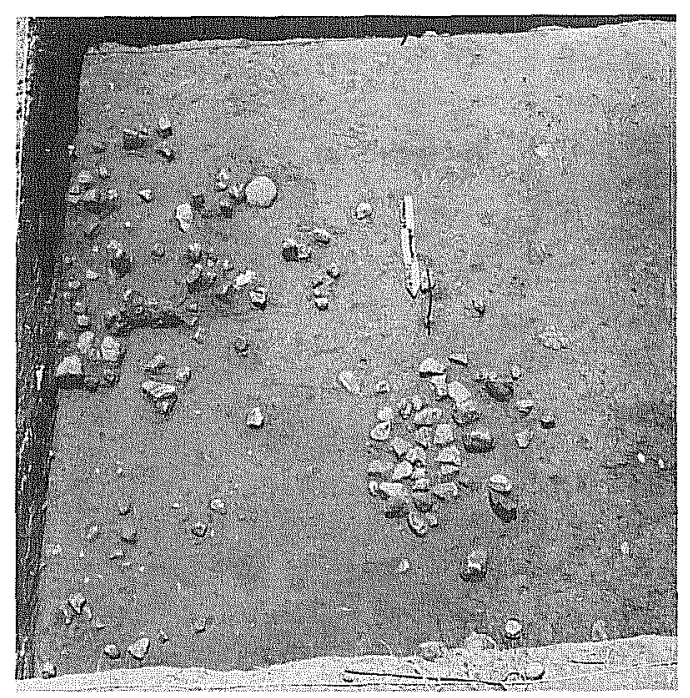

d

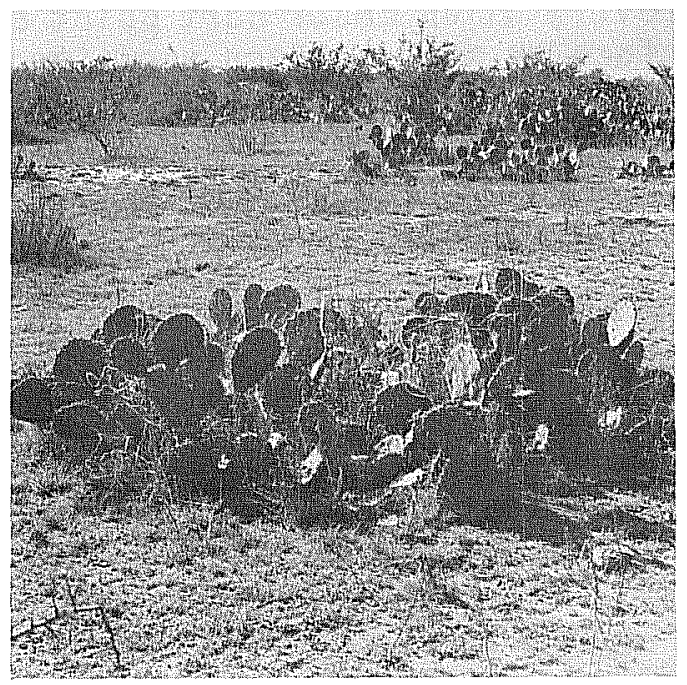

$f$ 
thick bifaces (one, Group 2; one, Group 4), two thin bifaces (Group 4 , Form 4, Specimen 114; Group 5, Specimen 9), one distally beveled tool (Group 3, Form 1, Specimen 13), and seven pleces of modified sandstone (three, Group 1, Form 3; one, Group 2, Form 1; two, Group 2, Form 3; one, Group 3). From Horizon 2 came one distally beveled tool (Group 3, Form 3 , Specimen 11).

In Unit N994 E983 of Area B, a lens of mussel shel1 was encountered in Level $9(98.70$ to $98.60 \mathrm{~m})$. The 7 ens was on $1 \mathrm{y}$ about $2 \mathrm{~cm}$ thick. Two pieces of sandstone, a piece of fire-fractured rock, and some Rabdotus snail shells were found along with the mussel shells.

The following artifacts were collected from the surface of 41 MC 268: five cores (one, Group 1; one, Group 2; one, Group 3; two, Group 5), eight thick bifaces (one, Group 1; two, Group 2; one, Group 3; one, Group 6, Form 2; one, Group 7. Form 1; one, Group 7, Form 4; one, Group 9), 18 thin bifaces (Group 1, Form 2, Specimen 13; Group 1, Form 3, Specimen 8 [Ensor]; Group 1, Form 4, Specimen 31 [Perdiz]; Group 1, Form 5, Specimen 18 [Edwards]; Group 1, Form 6, Specimen 5; two, Group 3, Form 2; four, Group 4, Form 4; one, Group 7: six, Group 9), two distal1y beveled tools (Group 3, Form 2, Specimen 17; Group 3, Form 3, Specimen 12), two unifaces (Group 2, Specimen 4; Group 2, Specimen 6), one trimmed flake (Group 4, Specimen 7), and 24 pieces of modified sandstone (one, Group 1, Form 1; two, Group 1. Form 2; four, Group 1, Form 3; one, Group 2, Form 1; 11, Group 2, Form 2; four, Group 2, Form 3; one, Group 3). Locations of most specimens were plotted on a plan map of the site (on file at the CAR-UTSA).

The Phase II investigations at 41 MC 268 reveal that the site contains Late Archaic and Late Prehistoric components. The site's component representation, geomorphological setting, and character of habitational features are reminiscent of the situation at 41 MC 296 and a few other sites where Late Archaic and Late Prehistoric remains occur in the upper meter of deposits. Un 1 ike 41 MC 296, the prehistoric cultural debris representing each component at 41 MC 268 appears to have been churned and otherwise disturbed, probably a result of clearing and cultivating the field containing much of the site. Recovery of an Ensor dart point and three distally beveled tools from the surface or near surface are cited as bits of evidence indicating that the components have been disrupted to a certain extent. These specimens are Late Archaic diagnostics and should not have occurred in the upper levels of deposit or on the surface.

Cores, thick bifaces, thin biface fragments, and debitage were recovered in quantities at 41 MC 268 suggesting that stone tool making was an important activity on the site, especially during the Late Prehistoric. The mix of Perdiz, Edwards, and Scallorn points in the thin biface assemblage suggests that both early and late Late Prehistoric occupations took place on the site. It is interesting to note that al1 five of the distally beveled tools recovered from 41 MC 268 were categorized into Group 3. The Group 3 forms had previously been suggested as possible Late Archaic diagnostics (Ha 11 , B Tack, and Graves 1982:465). Untfaces and trimmed flakes in the 41 MC 268 collection are in keeping with expectations, given the presence of the arrow points. Surprisingly, no aboriginal pottery was collected during Phase II 
work at 41 MC 268. This is more 11 kely a samp 1 ing error rather than evidence of absence of pottery from the site.

The ful 1 range of grinding imp 1 ements represented by modified sandstone Groups 1 and 2 in the 41 MC 268 assemb 1 age indicates that seeds, nuts, and/or beans were important sources of food to the prehistoric inhabitants. Musse 1 shel1 and Rabdotus snail shel 1 s are also present as probable residues of foods consumed on the site. A small amount of animal bone survived in the deposits to evidence procurement of vertebrate meat foods. Rock clusters present in Archaic context may represent an important, but currently unidentified, subsistence activity.

\section{MC 226}

Site 41 MC 226 is a small prehistoric site located on the floodplain midway between the modern channels of the Frio River and San Miguel Creek (Fig. 1 , folded insert). It is about $600 \mathrm{~m}$ from each drainage. Site 41 MC 226 was recorded in 1977 by surveyors from Texas Tech University (Thoms, Montgomery, and Portnoy 1981). The site is circular in outline shape with a diameter of $100 \mathrm{~m}$. It is situated on an old, high terrace remnant forming a low, rounded hillock or rise. Relict channel scars surround the site, as evidenced on topographic map coverage for the area. A cleared field densely covered with coastal Bermuda grass contains 41 MC 226. It was evidenced to the surveyors as a surface scatter of fire-fractured rock and debitage.

Phase II investigations at 41 MC 226 consisted of excavation of two shove tests, collection of two "dog leash" samples of surface debris, and an unprovenienced collection of surface artifacts. The CAR crew defined an area of heavier surface debris concentration on the southwest side of the rise. The area measures approximately $40 \mathrm{~m}$ northeast to southwest and $10 \mathrm{~m}$ northwest to southeast. Shovel tests were placed near the center of the site and along its southeastern edge. Both revealed very 1 ittle cultural debris in the subsurface. The profile of Shovel Test 1 , excavated near the center of 41 MC 226, was described as follows:

surface to $18 \mathrm{~cm}$ : A horizon - sandy loam, 10ose, moist, gray brown (10 YR 3.5/2) with organic staining, abundant chert gravel, some cultural debris (debitage and fire-fractured rock). No carbon. snails, or mussel shell noted. Fairly homogeneous.

$18 \mathrm{~cm}$ to $34 \mathrm{~cm}$ : B horizon (probab1e)-compact bright orange, 1 ight 1y mottled with gray insect burrows derived from A horizon. Gravel is less common than above. A couple of pieces of debitage were noted. Color: 4 YR 4.5/4.5.

$34 \mathrm{~cm}$ to $55 \mathrm{~cm}$ : extremely compact yel low tan (10 YR 3.5/6.5) sandy claycementlike consistency. White, smal1 (3 $\mathrm{mm}$ diameter) caliche nodules present below $50 \mathrm{~cm}$. Mottled with brown clay. 
Though revealing interesting profiles, the shovel tests made at 41 MC 226 indicated that control led excavations would not yield worthwhile results.

The following artifacts were collected from the surface of 41 MC 226 during Phase II investigations: three cores (one, Group 2; one, Group 3; one, Group 5), 11 thick bifaces (one, Group 2; one, Group 5; one, Group 6, Form 1; four, Group 7, Form 1; one, Group 7, Form 3; one, Group 8; two, Group 9), four thin bifaces (one, Group 2, Form 2; one, Group 3, Form 1; two, Group 10), and five distally beveled tools (one, Group 2, Form 1; two, Group 3. Form 1; one, Group 7. Form 4; one, Group 8, Form 4). Based on the presence of a possible "early triangular" thin biface (Group 3, Form l, Specimen 10) and the unusual array of distally beveled tools, habitation of 41 MC 226 during Late Paleo-Indian or Early Archaic times is suggested.

\section{5}

Site 41 MC 275 is located on the left (north) bank of San Miguel Creek on the floodplain between the creek channel and the valley margin slopes (Fig. l. folded insert). As recorded by the CAR survey crew in 1979, this site measures $250 \mathrm{~m}$ north-south and $500 \mathrm{~m}$ east-west. A relict channel scar now serving as an upland drainage runs along the south side. The valley margin slopes constitute the site's northern boundary. The surface is moderately to heavily eroded. Ground cover varies from open, grass-covered stretches to heavy, 7 ow brush including acacia, prick 1 y pear, mesquite, and whitebrush (Fig. 55,f). The site was recognized by a surface scatter consisting primarily of debitage and fire-fractured rock. The heaviest concentrations of prehistoric cultural debris on the surface were noted at the eastern end of the site, designated Area $A_{\text {. }}$. Three surface clusters of sandstone were noted by CAR surveyors in this area. Sherds of aboriginal pottery were also observed. The western end of 41 MC 275, designated Area B, is characterized by a 1 ag gravel pavement showing signs of prehistoric quarry activity.

Phase II activities at 41 MC 275 consisted of excavation of two shovel tests, a provenience-controlled collection of surface artifacts, and locational recording of habitational features exposed on the site surface. Test Pit l, 1 ocated in the east-central area of the site, was excavated to a depth of $65 \mathrm{~cm}$ below the surface into a matrix described as brown sandy loam. A smal1 amount of debitage and fire-fractured rock was noted down to $40 \mathrm{~cm}$ below the surface. Between 40 and $65 \mathrm{~cm}$ below the surface, there was an increase in debitage, fire-fractured rock, sandstone, and natural gravels. A piece of bone and a thin biface fragment were found at a depth of $50 \mathrm{~cm}$. At 60 to $65 \mathrm{~cm}$, a cluster of eight pieces of sandstone was encountered. Flecks of carbon were observed among the stones in this feature.

Shovel Test 2 was also excavated in the east-central area of 41 MC 275 . It was $p 1$ aced in a relatively uneroded spot adjacent to a deflated, gul 1 ied area where much prehistoric cultural debris was exposed on the surface. Dark brown silty sand extended from the surface to a depth of $50 \mathrm{~cm}$. From 50 to $80 \mathrm{~cm}$ below the surface, the soil continued to be dark brown in color, but became dry, hard, and compact. Between the surface and a depth of $20 \mathrm{~cm}$, only a smal1 amount of cultural debris was seen. The quantity of debris, including fire-fractured rock, debitage, and sandstone, increased noticeably 
in deposits from 20 to $50 \mathrm{~cm}$ below the surface. An unstemmed thin biface (Group 2, Form 1, Specimen 28) was found at a depth of $50 \mathrm{~cm}$. Below $50 \mathrm{~cm}$, the amount of cultural debris again decreased.

Over 125 artifacts were collected from the surface of 41 MC 275. Locations of many of these specimens, as well as several surface features, are recorded on a plan map of the site (on file at the CAR-UTSA). The following artifact assemb lage was gathered: 11 cores (one, Group 1; one, Group 2; two, Group 3; one, Group 4; two, Group 5; one, Group 7; three, Group 9), 14 thick bifaces (two, Group 1; two, Group 2; two, Group 3; three, Group 4; one, Group 6, Form 2; two, Group 7, Form 1; one, Group 7, Form 3; one, Group 9), 35 thin bifaces (Group 1, Form 1, Specimen 2 [Pedernales]; Group 1, Form 1, Specimen 12; Group 1, Form 2, Specimen 9; Group 1, Form 4, Specimen 32 [Perdiz]; Group 1, Form 5, Specimen 25; Group 1, Form 7. Specimen 25; one, Group 2, Form 2; one, Group 3, Form 2; seven, Group 4, Form 4; three, Group 6; seven, Group 9; 10, Group 10), four pieces of modified sandstone (one, Group 1, Form 2; two, Group 1, Form 3; one, Group 2, Form 2), one piece of satin spar gypsum, and 60 sherds of aboriginal pottery.

The artifact array representing 41 MC 275 is unusual in that a Middle Archaic component is indicated by 1 arge, stemmed thin bifaces, including a Pedernales dart point. Though it may simply be a sampling error, it is al so unusual that no distally beveled tools were found on the site. In other respects, such as geomorphological setting and character of Archaic debris in the subsurface, the Archaic component at 41 MC 275 is comparable to a number of other sites in the area. The sandstone cluster found at a depth of 60 to $65 \mathrm{~cm}$ in Shovel Test 1 presumably represents the Archaic component and is a common feature for the period.

Activity during the Late Prehistoric period is evidenced at 41 MC 275 by both expanding stem and contracting stem arrow points and by a large collection of potsherds.

The array of cores, thick bifaces, and thin biface fragments in the 41 MC 275 collection indicate that the 1 ag gravel deposits at the site's west end were being exploited in chipped stone tool making activities.

In summary, the findings made at 41 MC 275 are significant in that they suggest a somewhat earlier development for a particular settlement pattern that became very common in the Late Archaic and continued into the Late Prehistoric period. This pattern involved the increased utilization of site areas along the valley margins on or near floodplain/upland interfaces. Common to the Archaic components in this setting are substantial accumulations of rock that apparently formed some type of hearth. Seed and nut grinding implements (manos and metates) and evidence of more intensive chipped stone tool manufacture are also common on these sites. Location of many such sites on or near 1 ag gravel deposits is their convenient access to raw materials needed for tool manufacture. Whatever the settlement impetus may have been, the 41 MC 275 data indicate that the pattern may have begun to develop in the Middle Archaic. 
SITE GROUP 13

Extensive Test

Excavation Pits

41 MC 222
Surface Collections

Provenienced Unprovenienced

Resurvey or Shovel Tests

41 MC 246

41 MC 257

41 MC 251

41 MC 260

The Group 13 sites are 1 ocated from 24 to $29 \mathrm{~km}$ upstream from Choke Canyon Dam. Along this stretch of the Frio River valley, the southern side is 1 ined by relatively precipitous bluffs or cuestas formed in outcrops of resistant Jackson Group sandstone. The highest hill on the valley margin is known as Skillet Mountain (1ocation of 41 MC 76). It has a maximum elevation of 372 feet above MSL. Between 41 MC 222 and 41 MC 260, the easternmost and westernmost sites on the southern side of the valley, two major up 1 and drainage channels cut down (north) to feed into the Frio River. The drainage known as Black Hill Hollow follows a course around the western flank of Skillet Mountain. Sloppy Hollow is farther west. It meets the Frio River between 41 MC 254 and 41 MC 255. A third major upland drainage, Hackberry Hollow, splits 41 MC 260 and continues northwest to meet the Frio River near 41 MC 257. Each major upland drainage has smaller tributary branches, some of which have cut quite deeply into the sandstone hills lining the valley. The bluff tops and bluff faces on the south side are densely covered with low, thorny brush. Blackbrush is extremely common, as is cenizo. Some 1 ag gravels occur on the south side of the valley, apparently eroded from older alluvial terrace deposits draped over the flanks of the hilis.

The north side of the Frio River valley in the Group 13 area slopes rather gentiy uphill northward from the river. The resistant Jackson Group sandstones do not appear on that side of the river. The relatively flat, deep alluvial terraces have been extensively cleared for use as pastures and cropland. Where brush still grows, the deep soils support large mesquites, whitebrush, prickly pear, persimmon, spiny hackberry, and a variety of other species.

The active Frio River floodplain is relatively narrow through the Site Group 13 vicinity. The valley is especially narrow along the southern side because the river has collided with the line of steep sandstone bluffs. The Frio River has been quite active in its migrations back and forth across the valley. This activity has left a number of relict channels that carry water at flood stage and hold water after floods recede. A gallery of riparian forest grows along the river channe1. The zone between the river and valley margin supports brush species such as mesquite, prickly pear, whitebrush, and spiny hackberry. A grove of big oak trees is located just south of 41 MC 222. 


\section{MC 222}

An important prehistoric site, 41 MC 222, was found and recorded by CAR workers in 1977 as Phase I investigations were being conducted at nearby sites (Ha11, Black, and Graves 1982:238-246). At that time, the 1 and containing these particular sites was still under private ownership. Extensive areas of the floodplain on the south side of the Frio River were being cleared of brush to facilitate the handling of cattle. The brush was being cleared with a bul1dozer equipped with a 12-foot blade on the front end and a drag made of anchor chain and train rails pulled along behind (Fig. 58,d).

Inspection by the CAR crew of a new 1 y cleared location revealed that the bul1dozer had turned up 1 arge pieces of animal bone, debitage, musse 1 shel1, sherds of aboriginal pottery, chipped tools, and tool fragments. Most of th is material came out of one deep blade swath cut by the bullidozer from east to west across the area. The b Tade appeared to have cut down about $30 \mathrm{~cm}$ below the original ground surface in this swath, but it was difficult to tell where the original surface was exactly. Tree trunks, brush, and the bladed earth were pushed off into a relict channel (slough) running along the western margin of the area containing the debris exposure. In the deepest reaches of the blade cut, other large bone pieces were still partially buried in relatively undisturbed condition.

Designated as Skillet Mountain No. 4, this site was later assigned the permanent designation of 41 MC 222. It rests on a crescent-shaped natural levee. This natural levee forms a distinct rise inside a tight oxbow in a relict channel running more-or-less east-west through the area (Figs. 1 , folded insert; 56). The upstream end of this channel cuts away from the Frio River just west of 41 MC 79 some $500 \mathrm{~m}$ west-northwest of $41 \mathrm{MC} 222$. The channel again meets the river $1300 \mathrm{~m}$ northwest of the site just northwest of 41 MC 78. The channel general1y follows a semicircular course trending southward away from the modern channel of the Frio River and runs up against the sandstone bluffs composing the southern valley wall. Skillet Mountain, the highest of these bluffs, is $600 \mathrm{~m}$ southwest of 41 MC 222 ( $F$ ig. $58, a, c$ ). A slightly lower bench in the bluffline is within $300 \mathrm{~m}$ of the site (Fig. 56).

Site 41 MC 222 is at the western end of an east-west trending lake having a length of about $500 \mathrm{~m}$. The 1 ake is contained in the relict channel and is fed by an abandoned oil well which now flows salty water. Upstream from the west end of the 1 ake, the slough trends northwest for about $150 \mathrm{~m}$ and then makes an abrupt turn back to the southeast for about the same distance. The channel then makes a much more gradual turn back to the northwest. The natural levee rise on the south (right) side of the channel inside the oxbow trends in the same direction as does the oxbow--from southeast to northwest.

From a central prominence, the natural levee rise containing 41 MC 222 slopes down to the southeast and northwest to meet the slough channel. The main site area 1 ies on the prominence of the rise with prehistoric cultural debris al so being scattered down the southern and southeastern slopes. On the surface, cultural debris was visibie over an area measuring approximately $48 \mathrm{~m}$ northwest to southeast and from 5 to $12 \mathrm{~m}$ southwest to northeast. 
Figure 56. Topographic Map of 41MC222 and Surrounding Area.

PAGE 204 REDACTED 
Due to the brush clearing done prior to its discovery, the surface of 41 MC 222 was essential1y denuded of vegetation during Phase I investigations in 1977 (Fig. 58,b,e). By 1980, when Phase II excavations occurred, the site surface was covered with grass, weeds, and al 1 thorn bushes. Immediately south of the site area is a large grove of oak trees growing beside the slough channel. Mesquite, elm, huisache, retama, persimmon, sugar hackberry, and various grasses are on the floodplain around 41 MC 222 (Fig.63,b).

Horizontal and vertical controls for archaeological excavations were established at 41 MC 222 during Phase I investigations. A steel spike driven into the truck of an oak tree south of the main site area was assigned an arbitrary elevation of $100.00 \mathrm{~m}$ (Fig. 57). USBR surveyors 1 ater calculated a true elevation of 223.07 feet above MSL for the N100 E100 marker (top of rebar rod). The elevation on this marker relative to the $100.00 \mathrm{~m}$ arbitrary datum used in archaeological investigations was 98.75. The true elevation of the vertical datum spike in the trunk of the oak tree was thus 227.17 feet above MSL. The USBR surveyors a 1 so determined the exact location of the N100 El00 marker, expressed as Modified Texas State Plane coordinates.

During Phase I work at 41 MC 222, eleven $1-m^{2}$ units were excavated (Figs. 57; 61). One block of seven units was staked out over the bone exposed by the bul1dozer. A plan map of debris exposed as this block was excavated is shown in Figure 59 (a1so Fig. 58,f). Rates of recovery for certain classes of debris are $i 17$ ustrated in Figure 60. A second group of four units forming a $2-m^{2}$ block was al so excavated during Phase I work at 41 MC 222 (Figs. 57; 61). A summary of debris recovery rates for these units is provided in Figure 60 .

Analysis of data recovered during the Phase I excavations at 41 MC 222 resulted in definition of an early Late Prehistoric component for the site. Two radiocarbon assays (TX-2875 and $T X-2876)$ indicated a corrected age range of A.D. 1260 to A.D. 1290 for the period of habitation on the site. A straight stem arrow point, several unclassifiable stemmed arrow point fragments, and numerous sherds of aboriginal pottery were the main diagnostic artifacts recovered. Most of the large bone pieces collected during Phase I work at 41 MC 222 were derived from bison. Other species represented in the Phase I vertebrate faunal assemblage included rat, raccoon, jackrabbit, snake, gopher, mouse, bird, wild turkey, gar, bobcat, Canis sp., javelina, and deer. Other subsistence-related residues found on the site were musse 1 she1 1 s (Cyrtonaias tampicoensis, Lampsilis sp.), Rabdotus snail she11s, and fragments of sandstone manos and metates.

The assessment of 41 MC 222 upon completion of Phase I analysis was as follows:

Skillet Mountain No. 4 (41 MC 222) stands out clearly as a prehistoric site of major importance among all sites studied during Phase I investigations at Choke Canyon. The site apparently contains only Late Prehistoric remains and so offers a period assemblage unadulterated by debris from earlier periods of activity. Fauna 1... and floral ... remains are exceptional1y wel 1 preserved in the deposits. The distribution of cultural debris observed in the limited excavations conducted on the site 


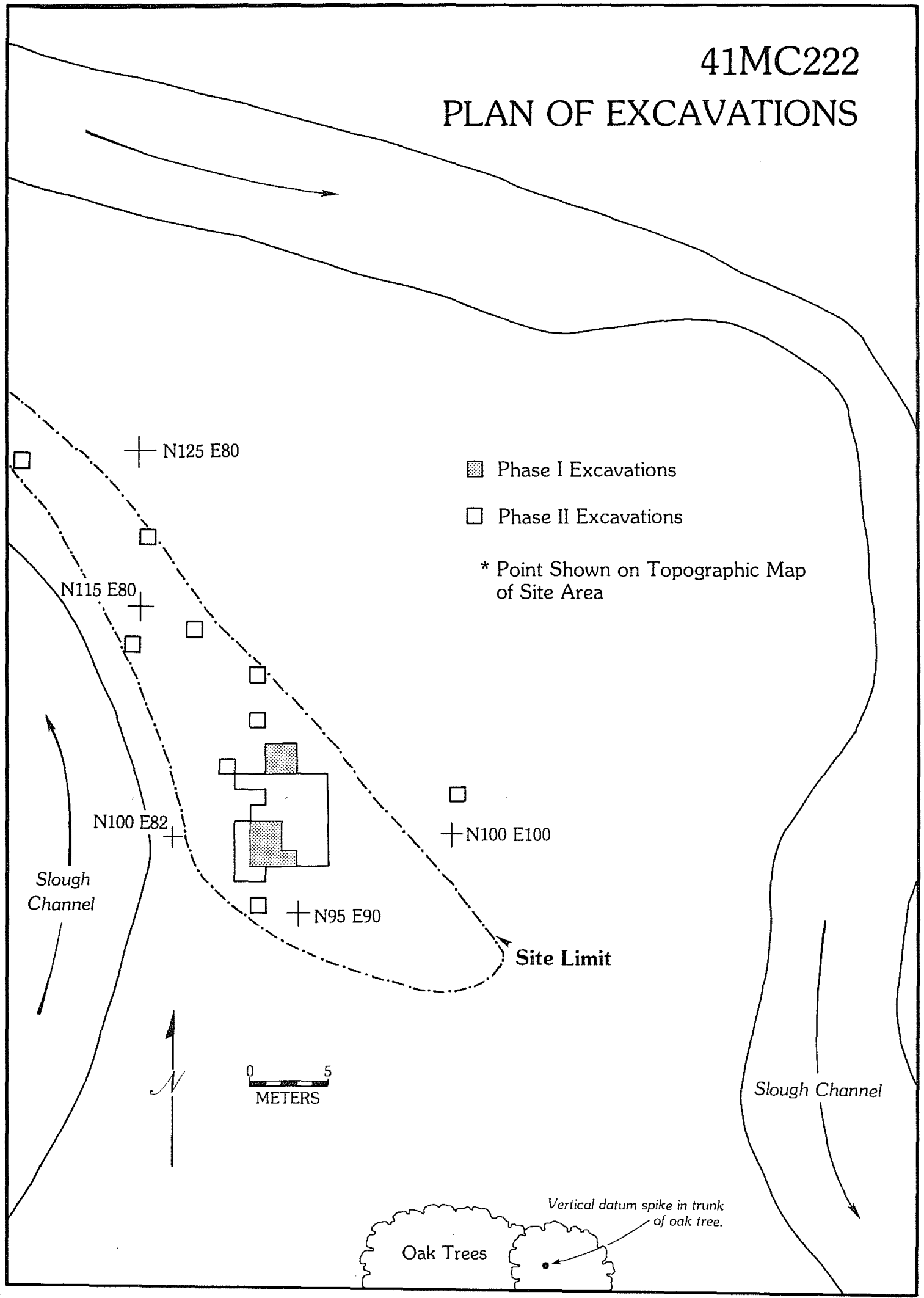

Figure 57. Site Extent and Plan of Excavations at 41 MC 222. 
suggests that remains are, to a certain extent, patterned according to the prehistoric activities resulting in their generation and deposition. This site unquestionably deserves further: more intensfve investigations (Ha 1 1, Black, and Graves 1982:246).

The Phase II investigation at 41 MC 222 took place in September and October 1980. Over 25 days, a crew of seven CAR workers expended a total of 1400 person hours on the site. In June 1981, participants in the Texas Archeological Society Summer Field School worked an additional 76 person hours on the site.

In Phase II, 36 additional $1-\mathrm{m}^{2}$ units were excavated at 41 MC 222. Twentyeight of these were part of the "main excavation block," the core of which was the Phase I unit blocks (Figs. 57; 61; 63, c, d). The remaining eight $1-\mathrm{m}^{2}$ units were designated "test pits." One of these test pits was to the south of the main excavation block, another to the east, and six to the northeast (Fig. 57). The Phase II units of the main excavation block were intended to increase exposure of the prehistoric activity area recognized through Phase I investigation. The eight test pits were placed to reveal the extent and character of prehistoric culturai remains elsewhere on the site. To select lacations for these test pits, the map of the site area as defined in Phase I was divided into $3221-\mathrm{m}^{2}$ units. These map units were divided into 16 sampling strata from northwest to southeast down the length of the site. A stratified random sampling $p l a n$ was then used to draw one unit from each b 1 ock of 20 (the southernmost block had 22 squares) using a random numbers table.

In keeping with technical procedures applied in Phase I, the Phase II units in the main excavation block at 41 MC 222 were excavated in arbitrary 5-cmthick vertical levels. The eight test pits were excavated in arbitrary levels of $10 \mathrm{~cm}$. Insofar as possible, the cultural debris exposed in each level of each unit was left in situ until its provenience could be recorded on a plan map. Al1 matrix excavated from Phase II units was water-washed through screens to promote recovery of debris. In the main excavation block. the matrix from 23 units was washed through 1/4-inch mesh hardware cloth. The following five units were designated as fine screen units: N99 E86, N99 E91. N101 E91. N103 E86, and N103 E91. Matrix excavated from these five units was first washed through $1 / 8$-inch mesh hardware cloth to produce a coarse fraction and then through window screen (ca. 1/16-inch mesh) to produce a fine fraction.

Rates of recovery for selected classes of prehistoric cultural debris from the 36 units excavated during Phase II investigations at 41 MC 222 are summarized on page 208. Each count or weight represents recovery for a 11 levels in a particular unit. Starting elevations on the surface of each unit are also shown. Debris distributions for units in the main excavation block are graphically represented in Figure 60. Soil matrix in the units was described as very dark gray or grayish brown. fine-grained, clay-rich sediment having a blocky structure with low sand and silt content. The soil covering the prehistoric cultural debris at 41 MC 222 is primarily alluvial materlal deposited when the Frio River has flooded and gone over its banks and covered substantial segments of the floodplain (Fig. 63,a). 


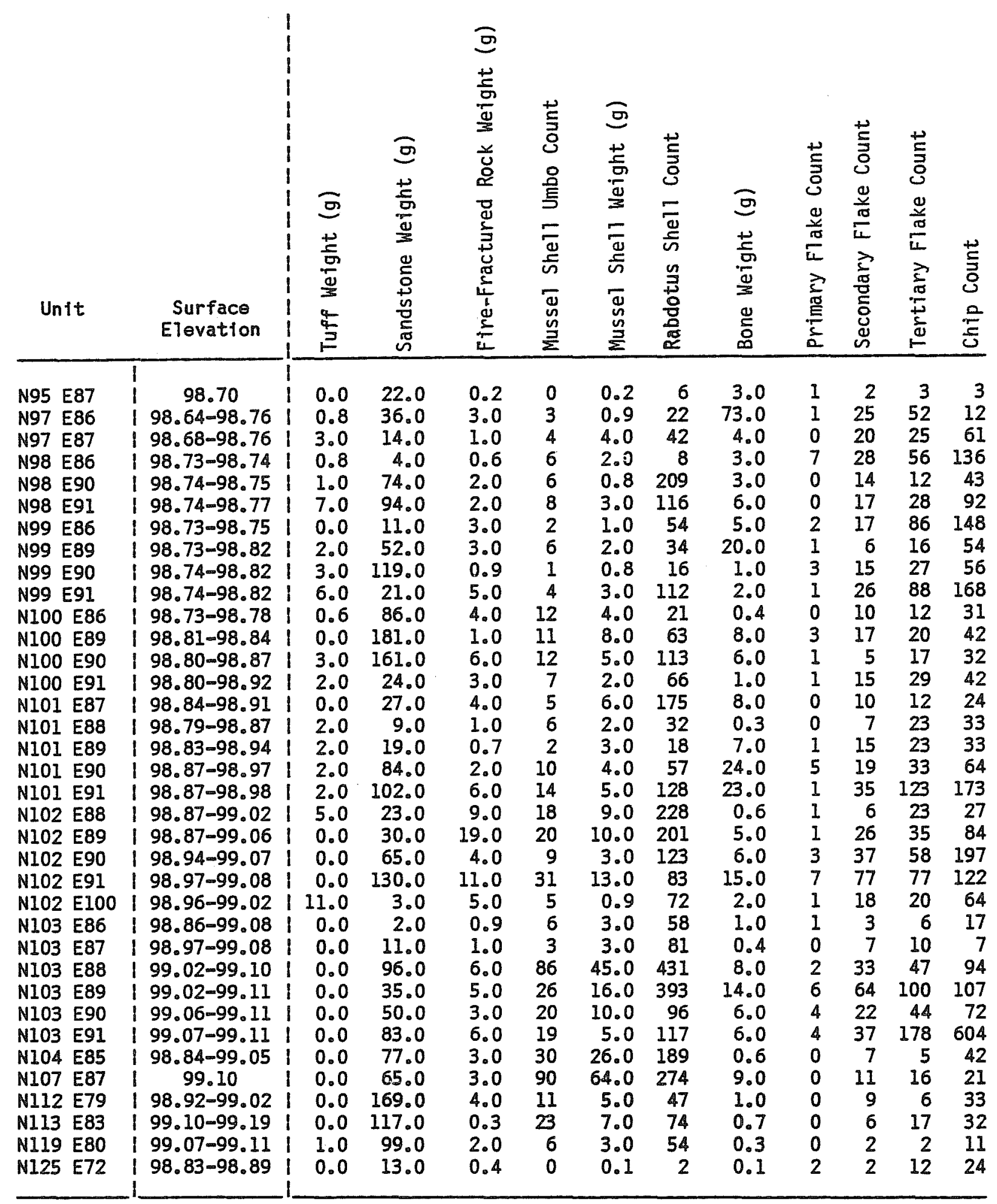

Phase II excavations at 41 MC 222 resulted in definition of seven additional prehistoric habitational features. The bone bed exposed and documented during Phase I work is designated Feature I (Fig. 59) and is discussed in detail in the Phase I report (Hall, Black, and Graves 1982:239-243). 
Features 2, 3, 4, 5, 7, and 8 were found in Phase II excavations in the main excavation block (Figs. $61 ; 62 ; 64$ ). Feature 6 occurred in one of the test pits (Unit NII2 E79) to the north of the main excavation.

Feature 2 was defined primarily as an extensive, irregularly shaped accumu 1ation of sandstone (Figs. 62; 63,e). Portions of the feature were located in each of four units--N102 E89, N102 E90, N103 E90, and N103 E9l. The sandstone accumulation has a 1 inear configuration trending northeast to southwest. Down its long axis, the feature measures approximately $220 \mathrm{~cm}$. At its widest, it is about $63 \mathrm{~cm}$. Over 100 pieces of sandstone make up the cluster. They range in size (maximum dimension) from $10 \mathrm{~cm}$ to $3 \mathrm{~cm}$. Feature 2 is essentially a flat, single layer construct. It does, however, slope from north to south (Fig. 65), and in some cases, the sandstones are stacked one on top of the other. There was no basin or other subsurface structure noticed beneath the sandstone. Other debris scattered amidst the sandstone included debitage, musse1 she11, Rabdotus snai1 she11s, anima 1 bone, carbon, and chipped stone tools. Artifacts found in the Feature 2 area are four cores (one, Group 2; one, Group 5; one, Group 6), five thin bifaces (Group 1, Form 5, Specimen 7 [Scal10rn]; Group 1, Form 5, Specimen 8 [Sca11 arn]; one, Group 9; two, Group 10), two pieces of modified sandstone (one, Group 1, Form 1; one, Group 1, Form 2), one piece of modified bone (aw 1 or pin?), and 59 sherds of aboriginal pottery. The pottery found near Feature 2 accurred as two 1 arge vessel sections that had been broken in situ into a number of sherds (Figs. $62 ; 64, b$ ). Carbon samples recovered from Feature 2 were submitted for radiocarbon assay. Proveniences of the two samples submitted for assay were TX-4666, Unit N103 E91, Leve1 4, elevation 98.95-98.90 $\mathrm{m}$ and TX-4694, Unit N102 E90, Leve1 3, elevation 98.95-98.85 m. Both of these samples came from within soil pedestals supporting constituents of Feature 2. Ages yielded by the radiocarbon assays were:

$\begin{array}{ccc} & \begin{array}{c}\text { Uncorrected } \\ \text { Age }\end{array} & \begin{array}{c}\text { MASCA Corrected } \\ \text { Age }\end{array} \\ \text { TX-4666 } & 360 \pm 60 & \text { A.D. } 1470 \text { to } 1500 \\ \text { TX-4694 } & 540 \pm 60 & \text { A.D. } 1390\end{array}$

Feature 3 was a sma 17, tight cluster of 27 pieces of sandstone encountered in Units N99 E90, N100 E90, and NI00 E9I (Fig. 62). This sandstone cluster covered an oval area with dimensions of $50 \mathrm{~cm}$ northeast to southwest and $30 \mathrm{~cm}$ northwest to southeast. The elevation range represented by constituents of Feature 3 was 98.77 to $98.63 \mathrm{~m}$. Rocks ranged in size (maximum dimension) from 6 to $20 \mathrm{~cm}$. Function of this feature is problematica 1. There was no carbon or burned bone to clearly indicate that it was a hearth. It was a single 1 ayer construct and had no recognizable basin or structure beneath it.

Feature 4 was a concentration of Rabdotus snail shel1s defined in Units N98 E90 and N98 E91 (Figs. 61; 62). The feature appeared to continue into adjacent unexcavated units to the south (N97 E90 and N97 E91). The exposed portion of. Feature 4 was semicircular in out 1 ine with a diameter of $60 \mathrm{~cm}$ (east-west). The snail shell concentration was lens shape in cross section with a maximum central thickness of $7 \mathrm{~cm}$. The elevation range was 98.70 to 
Figure 58. Views Fron Phase I Investigations at 41 MC 222.

a, view looking northeast across the frio River valiey from the "summit" of Skil let Mountain (elevation 372 feet above MSL). Note Jackson Group cuestas along southern val 7 ey margin at right. The Frio River runs through the gallery of large trees near the center of photograph. Site 4I MC 222 is located downhil1 to the left:

b, overview looking north of Phase I excavations in progress at 41 MC 222. Note effects of brush clearing on site. The Frio River is located in the tall trees in the background:

c. view looking south across 41 MC 17 to Skillet Mountain at the center of the photograph on the horizon:

d. brush drag made of train rails and anchor chain. Pulled by a bu 17 dozer, it was this drag that exposed 41 MC 222 as brush was being cleared on the floodplain;

e, view looking southwest across 41 MC 222 to sandstone bluffs along south side of valley. Site lies between slough channel in foreground and large oak tree in background;

fo bison bone exposed in Phase I excavations at 41 MC 222. 

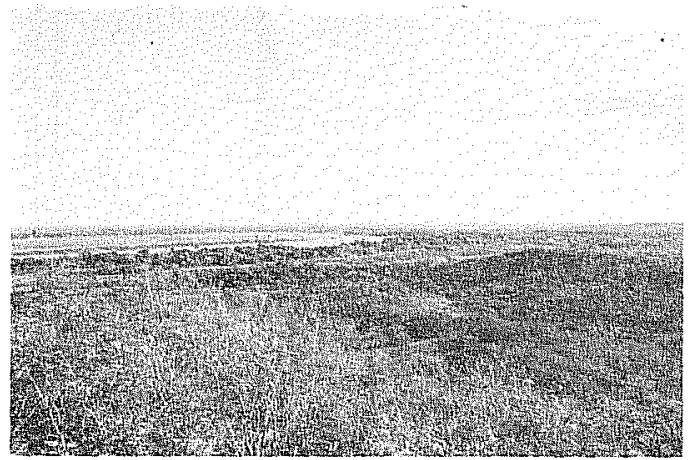

a

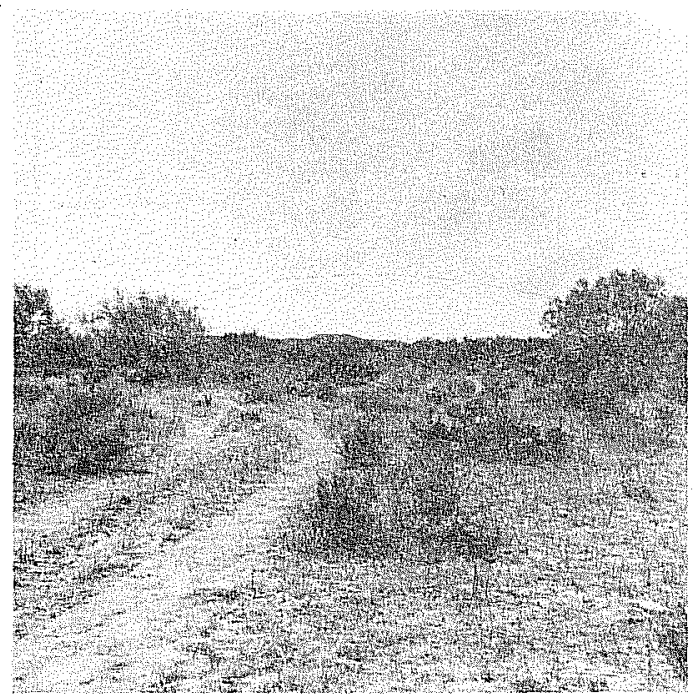

c

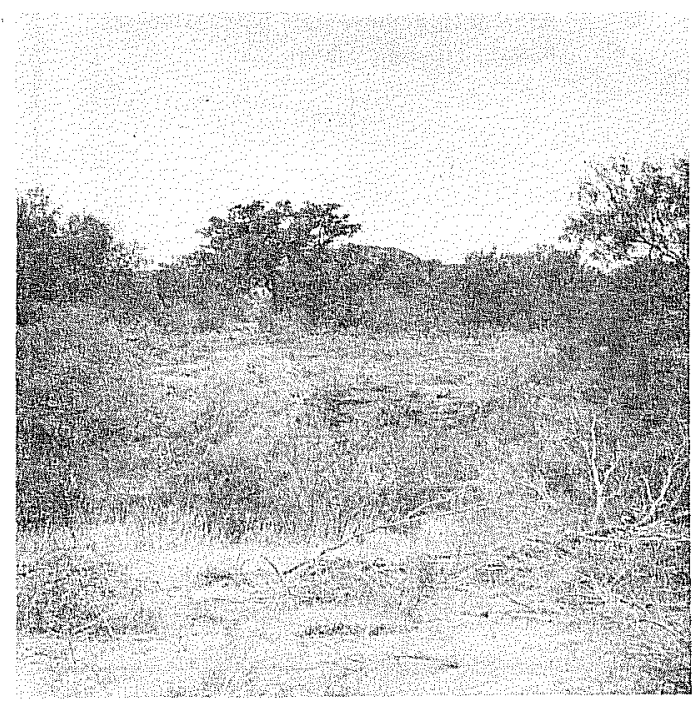

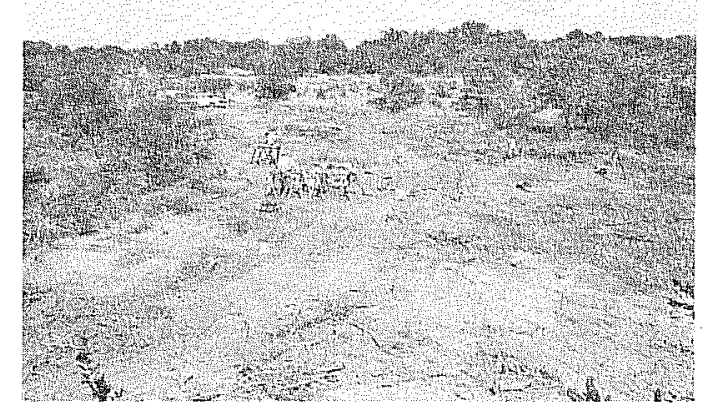

b

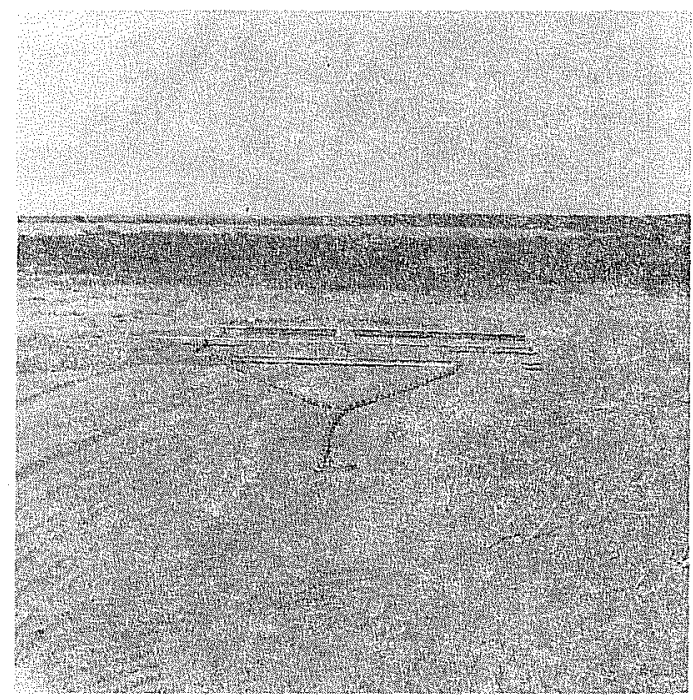

$d$

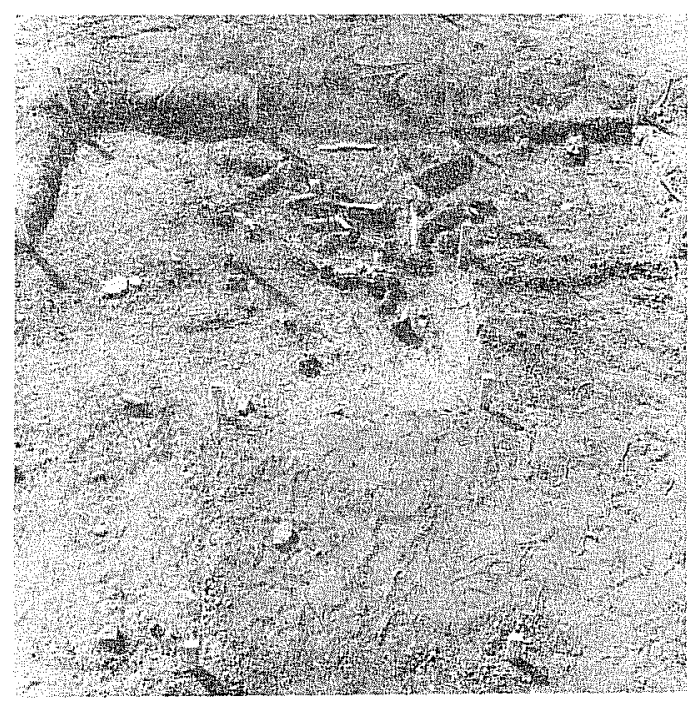


212

PLAN OF BONE BED EXCAVATION

DURING PHASE I INVESTIGATIONS

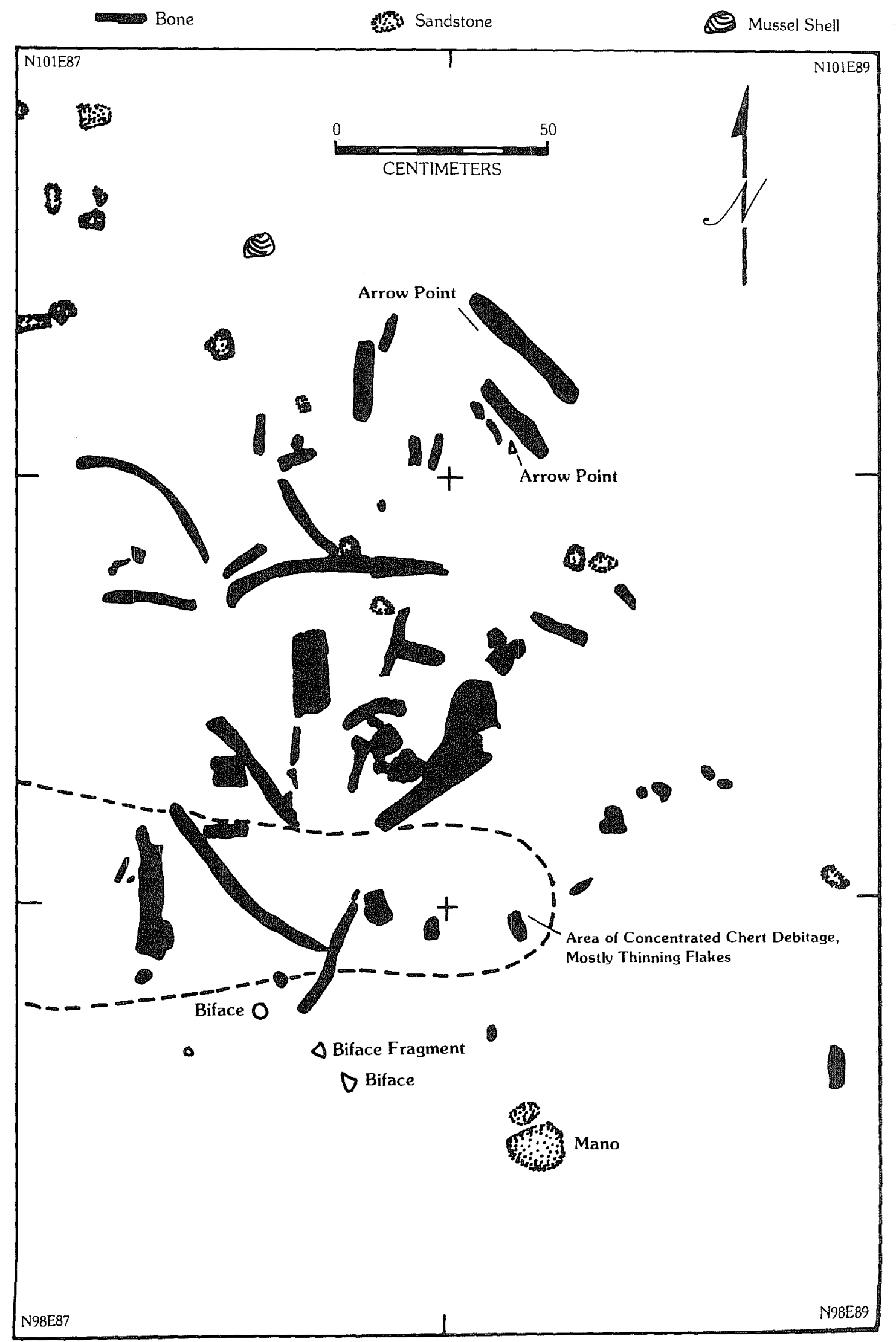

Figure 59. Plan of Bone Bed Excavation at 41 MC 222 During Phase I Investigations. 
$98.63 \mathrm{~m}$. Found near Feature 4 were a core (Group I) and a thin biface fragment (Group 10).

Feature 5 was a concentration of chert knapping debris (core fragments and debitage) isolated in Unit N103 E89 (Figs. 61;62;66,a). The feature was contained in Level 4 (98.95 to $98.90 \mathrm{~m})$. Roughly oval in outline shape, it measures $30 \mathrm{~cm}$ east-west and $25 \mathrm{~cm}$ north-south. Debitage in lesser amounts extends southward about $25 \mathrm{~cm}$ from the main concentration. Feature thickness was $5 \mathrm{~cm}$. The inventory of items composing Feature 5 was as follows: two smal1 mussel shel1 fragments, one smal1 bone fragment, 23 cortex flakes, 21 small interior thinning flakes, and two small cores. Fifteen pieces of debitage were of dark brown chert, and 13 pieces were of 1 ight tannish brown chert. Pieces of debitage ranged in size from 1 ess than $1 \mathrm{~cm}$ up to $7 \mathrm{~cm}$ in length for some of the large cortex flakes. The two cores in the feature were each about $7 \mathrm{~cm}$ 1ong, $5 \mathrm{~cm}$ in width, and $5 \mathrm{~cm}$ in thickness. Outward from the primary cluster composing the feature, 24 additional cortex flakes and 17 interior thinning flakes were also noted.

Feature 6 was encountered north of the main excavation b lock in Unit N112 E79. The feature appeared to continue into adjacent unexcavated Units N112 E79, NI12 E80, N113 E79, and N113 E80. It consisted of eight 10osely clustered pieces of sandstone covering an area of $84 \mathrm{~cm}$ east-west by $44 \mathrm{~cm}$ north-south. The elevation range on highest and lowest constituents of Feature 6 was from 98.61 to $98.66 \mathrm{~m}$. A carbon sample and a small bone fragment were recovered from matrix between pieces of sandstone.

Feature 7 was made up of 10 Rabdotus snail shel1s, 10 pieces of debitage, 15 bone fragments, and one piece of sandstone (Figs. 61; 64; 66, C). This feature was found in Units N97 E86 and N97 E87. The materials 1 isted above were part of the fill in a shallow pit that had a diameter of approximately $60 \mathrm{~cm}$ and maximum depth of 18 to $21 \mathrm{~cm}$. In addition to the material remains, the pit was evidenced by an area of very dark gray soil that stood out against the more general grayish brown soil characteristic of the site deposits. An estimated $90 \%$ of the bone in the feature was burned. Several pieces of carbon and fired clay were found in the pit fill. The presence of the burned bone, fired clay, and discolored soil in and immediately around Feature 7 clearly indicates that a fire burned at that location. Two loose clusters of debitage appear to overlap this feature (Fig. 64). Other artifacts found in the two $1-\mathrm{m}^{2}$ units containing Feature 7 were two cores (one, Group 5; one, Group 7), three pieces of modified sandstone (one, Group 2, Form 3; two, Group 2, Form 3), and eight sherds of aboriginal pottery.

Feature 8 was a concentration of Rabdotus snail shel $1 \mathrm{~s}$ 10cated along the northern edge of Units N103 E90 and NI03 E91 (Figs. 61; 62; 63,f). The feature occurred in Level $6(98.85$ to $98.80 \mathrm{~m})$. The snail she11 was concentrated in a semicircular area measuring $70 \mathrm{~cm}$ east-west and $40 \mathrm{~cm}$ north-south. It appeared to continue into unexcavated units along the north side of the main excavation block. It is estimated that 50 Rabdotus shells made up the concentration. Most of the shells were large, but there were al so some smal1 shel1s in the group. Also in the feature area were three mussel shel1s, four pieces of sandstone, some smal1 bones, five pieces of debitage, and one piece of fire-fractured chert. Feature 8 is beneath the 
MAIN EXCAVATION BLOCK

DEBRIS DISTRIBUTIONS

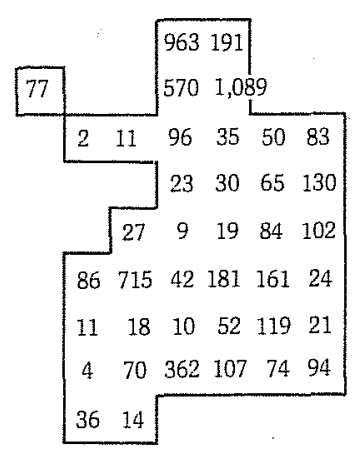

Sandstone

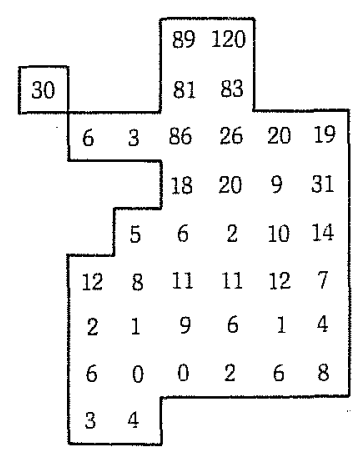

Mussel Shell Umbos

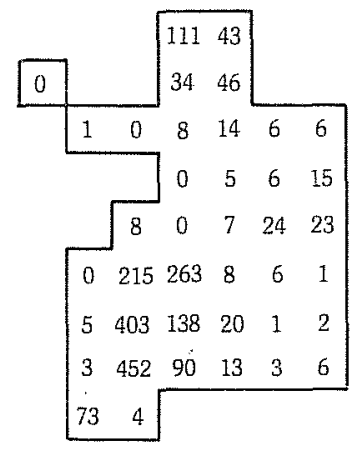

\section{Bone}

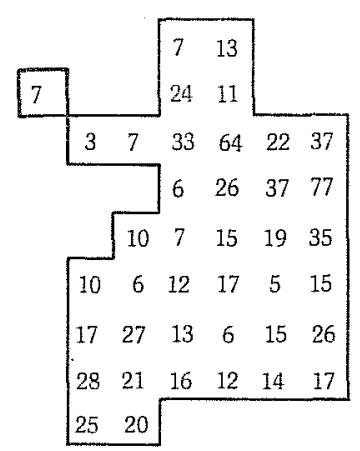

Each number represents recovery for a $1 \mathrm{~m}^{2}$ unit, all levels combined.

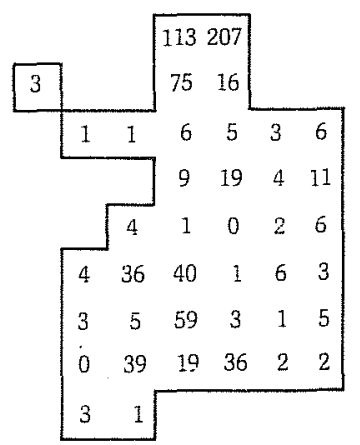

Fire-Fractured Rock

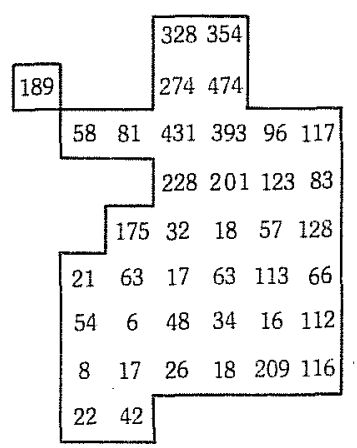

Rabdotus Snail Shells
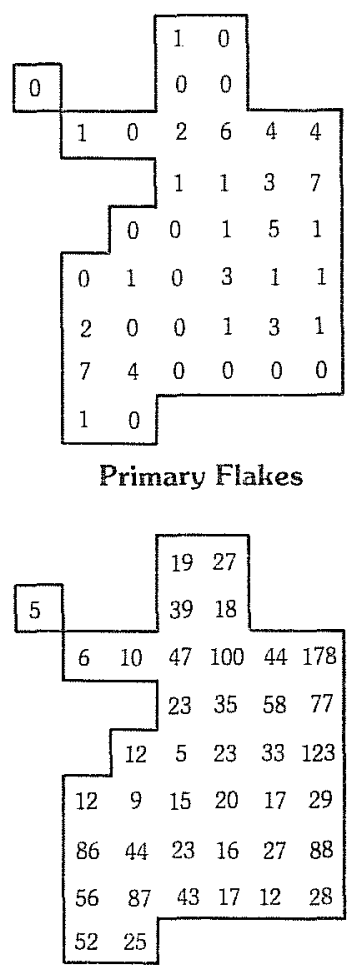

Tertiary Flakes

Figure 60. Main Excavation Block Debris Distributions at 41 MC 222. 
northern extent of Feature 2. The two features are separated by 10 to $15 \mathrm{~cm}$ of deposit (Fig. 65).

Figure 65 il Tustrates the vertical relationship of several features and the stratigraphic position of certain time-diagnostic artifacts (arrow points) revealed during the course of Phase II excavations at 41 MC 222. The elevations of Features 2, 3, and 4 suggest that they were all formed on the same living surface. The surface apparently sloped from north to south as indicated by the slant of Feature $2^{\prime} \mathrm{s}$ basal elevations and by lower elevations on Features 3 and 4 . The occurrence of Feature 8 at depths of 10 to $15 \mathrm{~cm}$ below Feature 2 could be interpreted either as evidence of an earlier 1 iving surface on the site or as the remnants of a shallow pit dug from the same surface upon which Feature 2 rested.

An analysis of vertebrate faunal remains recovered during Phase II excavations at 41. MC 222 is provided in Appendix III. The following animals are represented in the bone collection: bison, deer, javel ina, Camis sp. bobcat, al1igator, rattlesnake, rabbits rat, turtle, 1izard, frog, catfish, gar, and fish. These vertebrate remains indicate that 41 MC 222 was inhabited by prehistoric groups in the spring and/or summer seasons.

Data resulting from the Phase II investigation at 41 MC 222 denonstrate that the site 1 imits defined in Phase I on the basis of surface indications are reasonably accurate. Rates of debris recovery in the $1-m^{2}$ test pits placed northwest of the main excavation block suggest that the area of most intensive cultural activity extended northuest to Unit NI12 E79. The heaviest prehistoric activity thus occurred over an area measuring approximately $30 \mathrm{~m}$ northwest to southeast and $10 \mathrm{~m}$ east-west.

The time-diagnostic artifacts and radiocarbon assays recovered in Phase II reinforce the Phase. I assessment of 41 MC 222 as being strictly a Late Prehistoric encampment. The principal diagnostic artifacts are the Scal1ori. Edwards, and straight stem arrow points (thin bifaces Group 1, Form 4 ; and Group 1, Form 5), and the relatively numerous sherds of aboriginal pottery. Based on data available from other sites at Choke Canyon and el sewhere in southern Texas, these arrow point types represent the earlier years of the Late Prehistoric period. Two radiocarbon assays from Phase I (TX -2875 and TX-2876; Ha 1 1. B $1 \mathrm{ack}$, and Graves 1982:652) and two from Phase II (TX-4666 and TX-4694) have yielded corrected ages ranging from A.D. 1247 to A.D. 1500 for the episode of prehistoric cultural activity at 41 MC 222.

That 41 MC 222 was inhabited during the early years of the Late Prehistoric period is quite clearly established. The number of discrete habitational episodes represented by the remains on the site is a more difficult problem to deal with. The intact, well-integrated condition of habitational features documented within the site can be cited as evidence supporting the fdea that the site was used only once for a short period of time. On the other hand. the vertical distribution of debris through up to $40 \mathrm{~cm}$ of deposit might be suggested to indicate intervals between habitational episodes during which accretion of the site surface occurred. It would not be unreasonable to account for vertical distributions of debris as being the result of postdepositional bioturbation and/or the effects of gravity on certain of the materials. The stratigraphic relationship of Features 2 and 8 is certainly 


\section{MC222 \\ FEATURE DISTRIBUTION \\ MAIN EXCAVATION BLOCK}

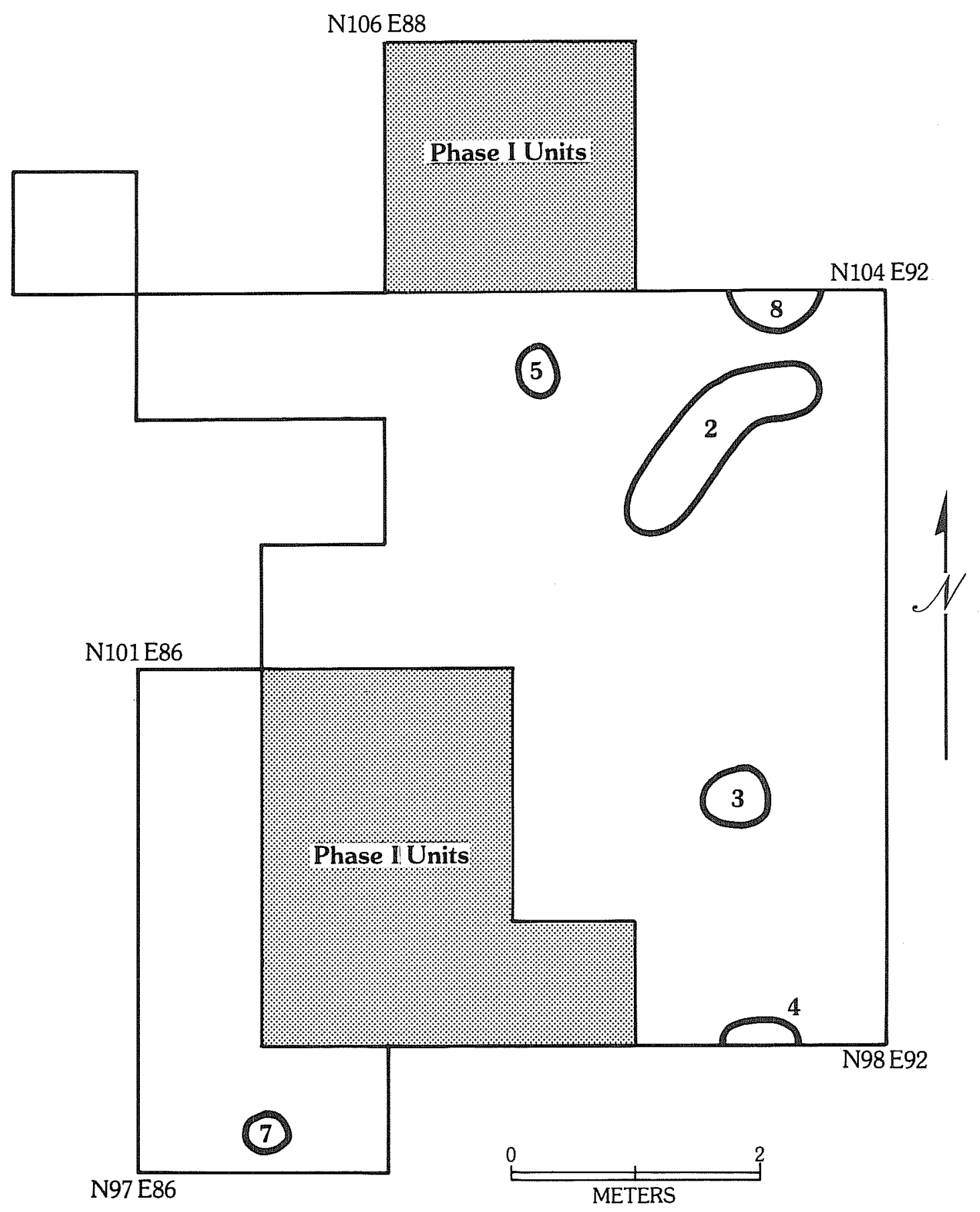

Figure 61. Main Excavation Block Feature Distributions at 41 MC 222. 
suggestive of successive periods of habitation. It is significant, however, that al1 of the defined features except for Feature 2 seem to occur on the same living surface if certain allowances for natural slope are made. Regardless of the number of habitational episodes represented, the 41 MC 222 remains unquestionably represent a comparatively short segment in the total temporal span of Choke Canyon's prehistory. The Phase I observation that the site assemblage is important as a sort of "time capsu 1e," unadulterated by earlier (and later) cultural debris, is still indicated and is one of the very important aspects about the site.

The array of artifactual material resulting from prehistoric cultural activity at 41 MC 222 is significant in terms of both what is present and what is absent. Generally speaking, there is not a great deal of diversity in the assemblage. There are cores, a 1 imited selection of thin bifaces, mano and metate fragments, a single bone aw 7 or pin, and sherds of pottery. Notably absent from the assemblage are thick bifaces, distally beveled tools, unifaces, and trimmed flakes (see summary of artifacts recovered at 41 MC 222 in $\mathrm{Tab} 1 \mathrm{e} 3$ ).

The absence of thick bifaces and distally beveled tools supports the contention that people were not camping at 41 MC 222 during the Archaic period. In the Archaic, chipped stone tool manufacture was oriented around a core-biface reduction technique where production failures in the thick biface stage were quite frequent, the result being that thick bifaces are common elements of the archaeological record. Chipped stone tool manufacture in the Late Prehistoric period involved a core-flake reduction process that bypassed the thick biface stage. Ample evidence of chert knapping was found at 41 MC 222 in the form of cores, thin biface fragments, and debitage. Feature 5 combines a 11 of these materials in a very explicit example of a chert knapping event that occurred on the site. Chipped stone tool manufacture was certainly an activity at the site, but the techniques utilized resulted in no thick bifaces discarded on the site. Evidence gathered elsewhere at Choke Canyon, and more generally throughout southern Texas, shows that distally beveled tools are diagnostic of the Archaic. As such, distally beveled tools would not be expected on a Late Prehistoric site.

Where the absence of thick bifaces and distally beveled tools from the Late Prehistoric assemblage at 41 MC 222 is predictable, it is noteworthy that deposits on the site yielded no unifaces or trimmed flakes. These tools are known to occur in Late Prehistoric context, most commonly in conjunction with Perdiz arrow points, pottery, and bison bone. As 41 MC 222 appears to be an early Late Prehistoric site, it may be suggested that specialized tools 1 ike the unifaces and trimmed $f 1$ akes should be assigned to the later years of the Late Prehistoric with components defined by presence of Perdiz arrow points and associated materials.

The arrow points recovered during Phase II work at 41 MC 222 are the Scal1 orn and Edwards types, both of which are characterized by expanding stems. Also in the collection are three arrow points with straight stems (thin bifaces Group 1, Form 4, Specimens 74-76). A similar arrow point was collected from the site in Phase I (thin bifaces Group 1, Form 5, Specimen 17; Hal 1, B1ack, and Graves 1982:295). Two other untyped arrow points were also found (thin bifaces Group 1, Form 5, Specimens 22 and 23). Together, these arrow points 


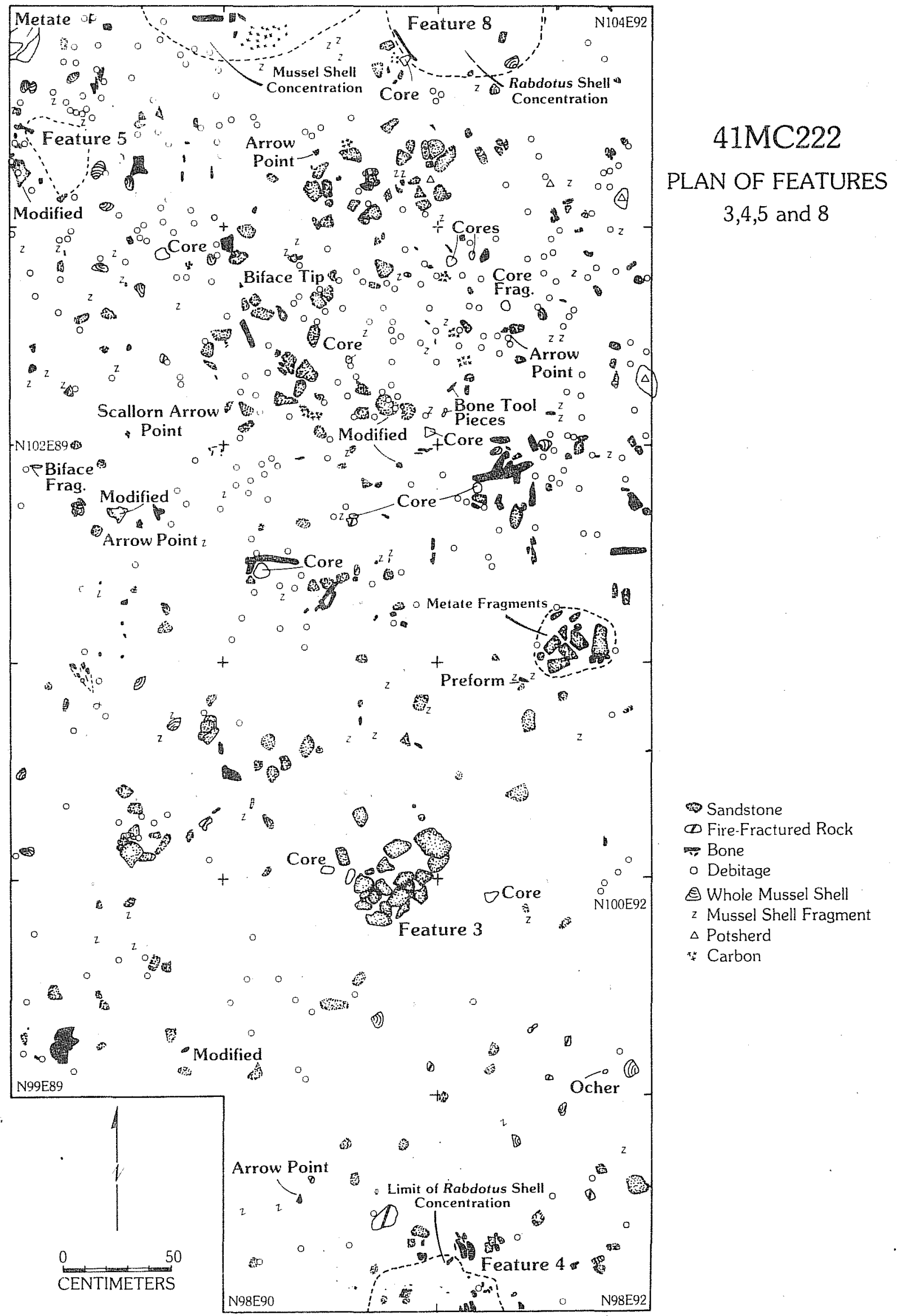

Figure 62. Plan of Features 3,4,5, and 8 at 41222. 
TABLE 3. ARTIFACTS RECOVERED FROM SITE 41 MC 222

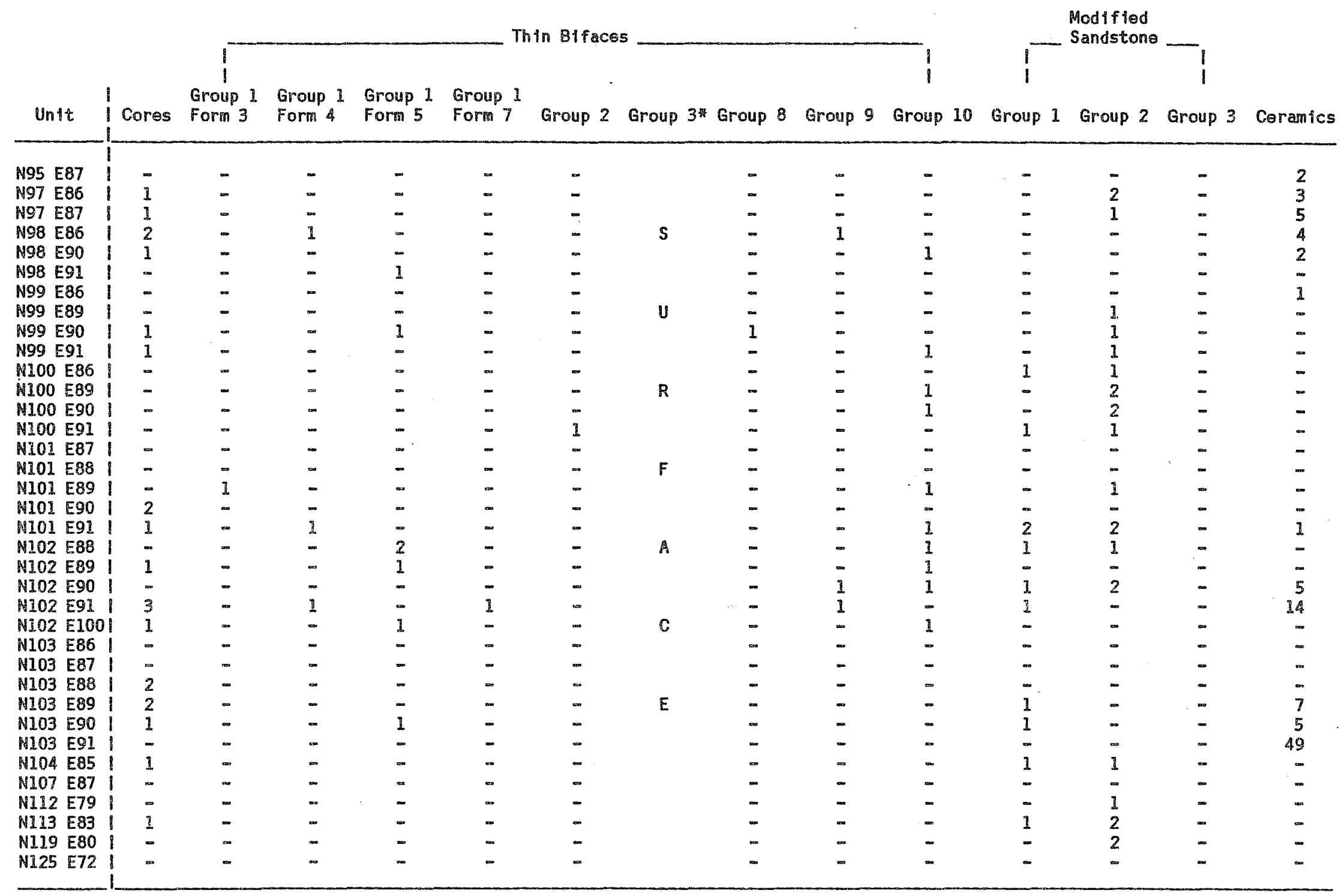

* A total of 39 Group 3 thin blfaces was recovered from the surface. 
Figure 63. Views of 41 MC 222 During Phase II Investigations.

a. view looking northwest across the Frio River valley during a major flood in June 1981. The trailer seen on the island out in the river marks the location of 41 MC 222;

b, a view of the slough channel on the east side of 41 MC 222. The channel forms an oxbow completely circling the site;

c, excavations in progress in the main unit block at 41 MC 222;

d, view looking north across main excavation block at 41 MC 222 upon completion of Phase II investigations;

e, overview of Feature 2 at 41 MC 222;

f, overview of Feature 8 at 41 MC 222. 


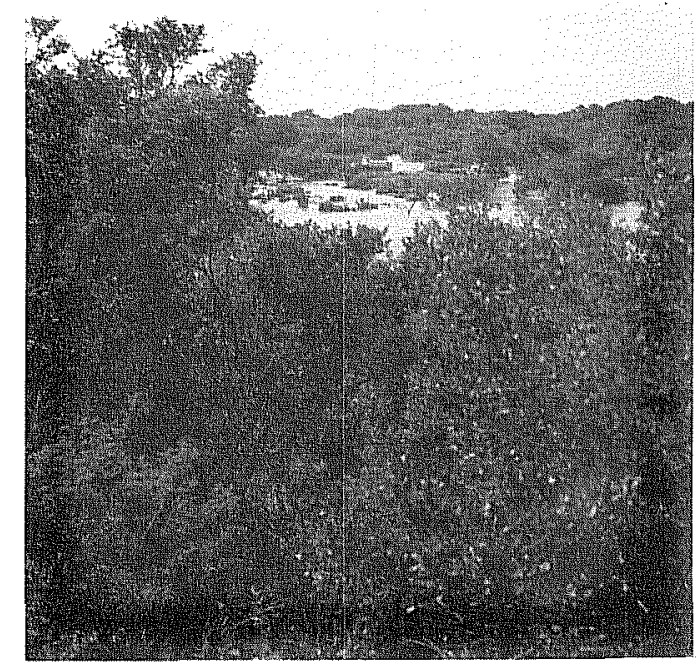

0

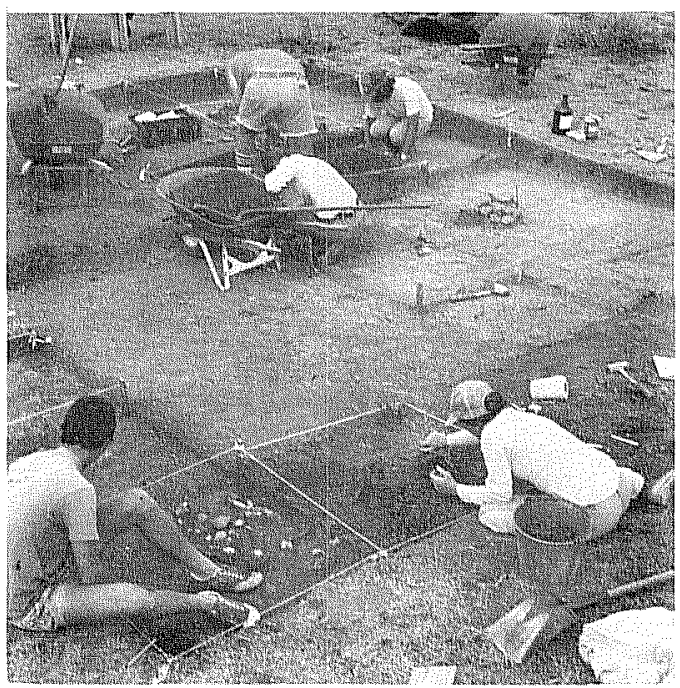

C

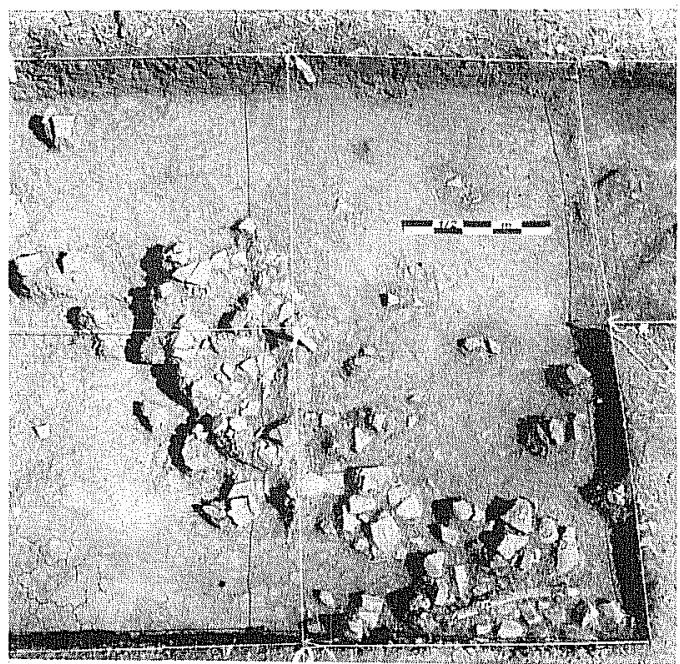

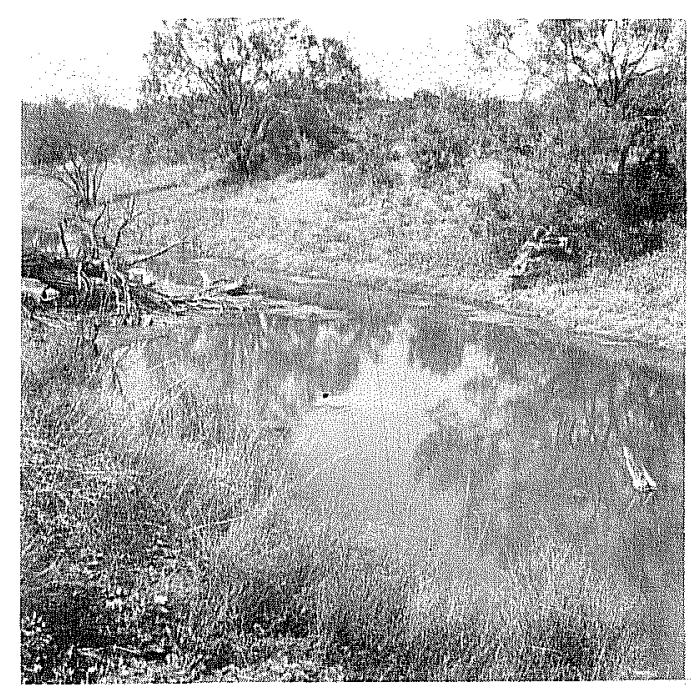

b

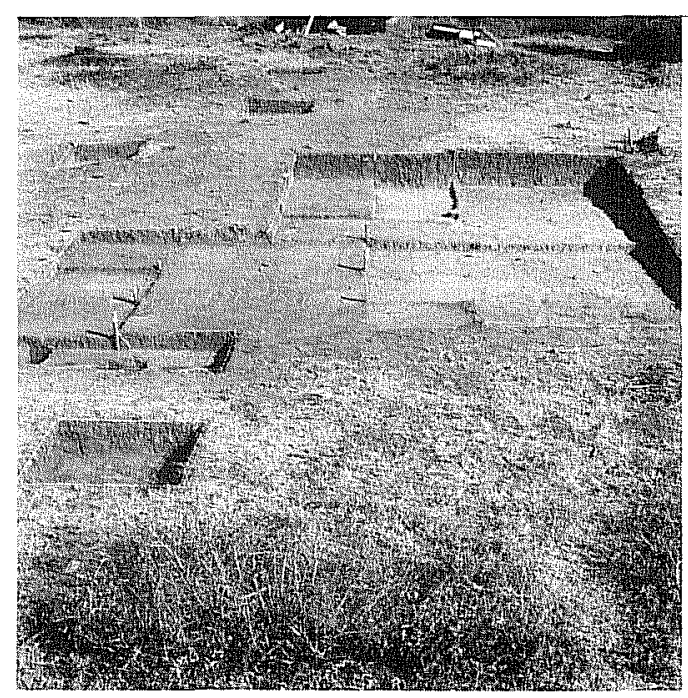

d

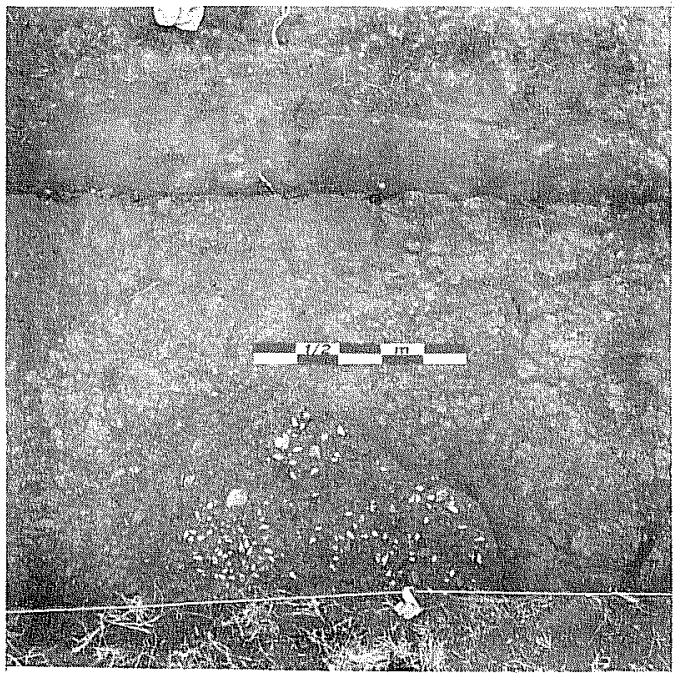


$41 \mathrm{MC} 222$

PLAN OF FEATURE 7

Sandstone

W2 Fire-Fractured Rock

Bone

Debitage

Z Mussel Shell Fragment

4. Whole Mussel Shell

$\mho^{*} \times$ Carbon Flecking

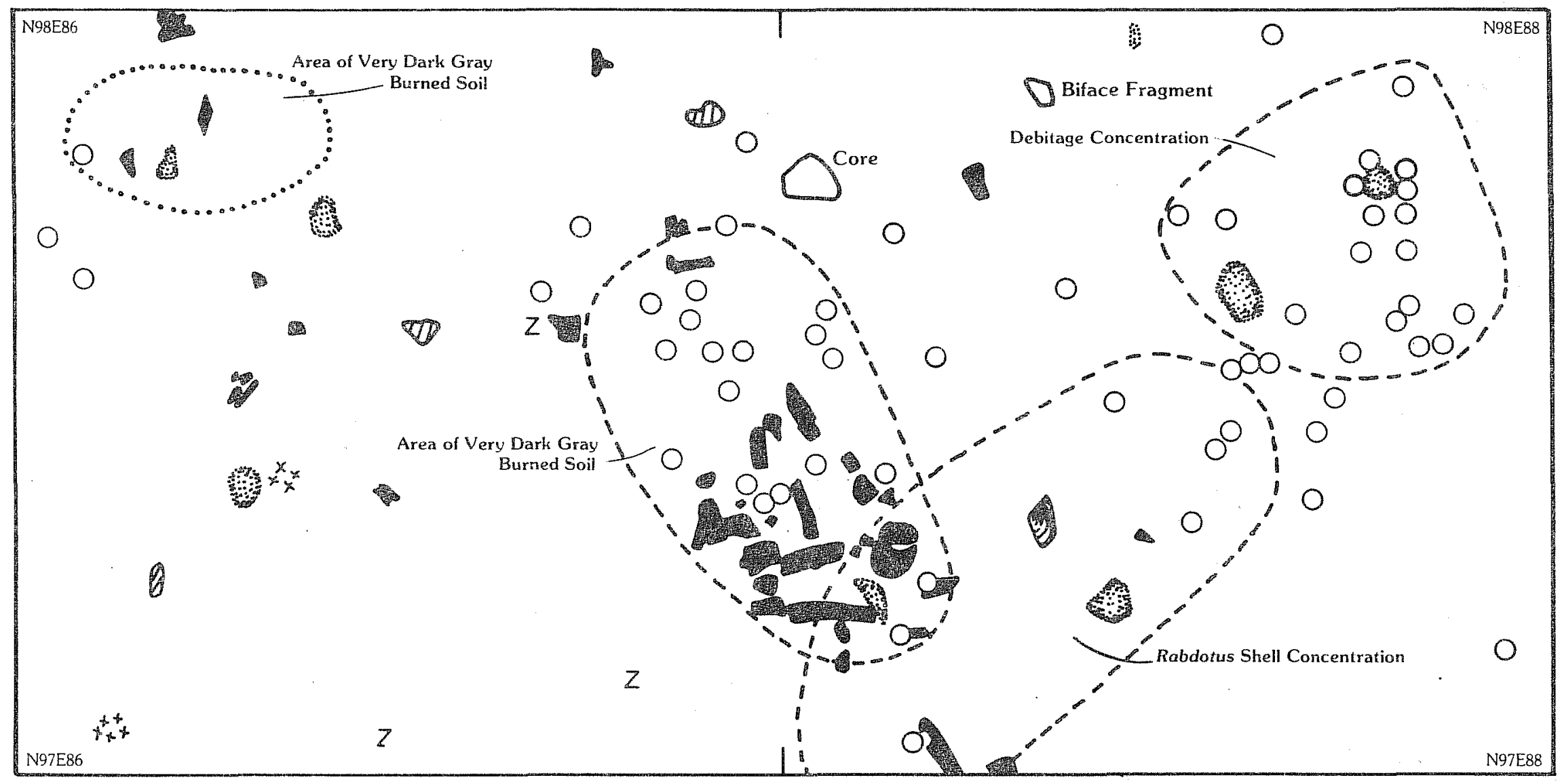

Figure 64. Plan of Feature 7 at 41 MC 222. 


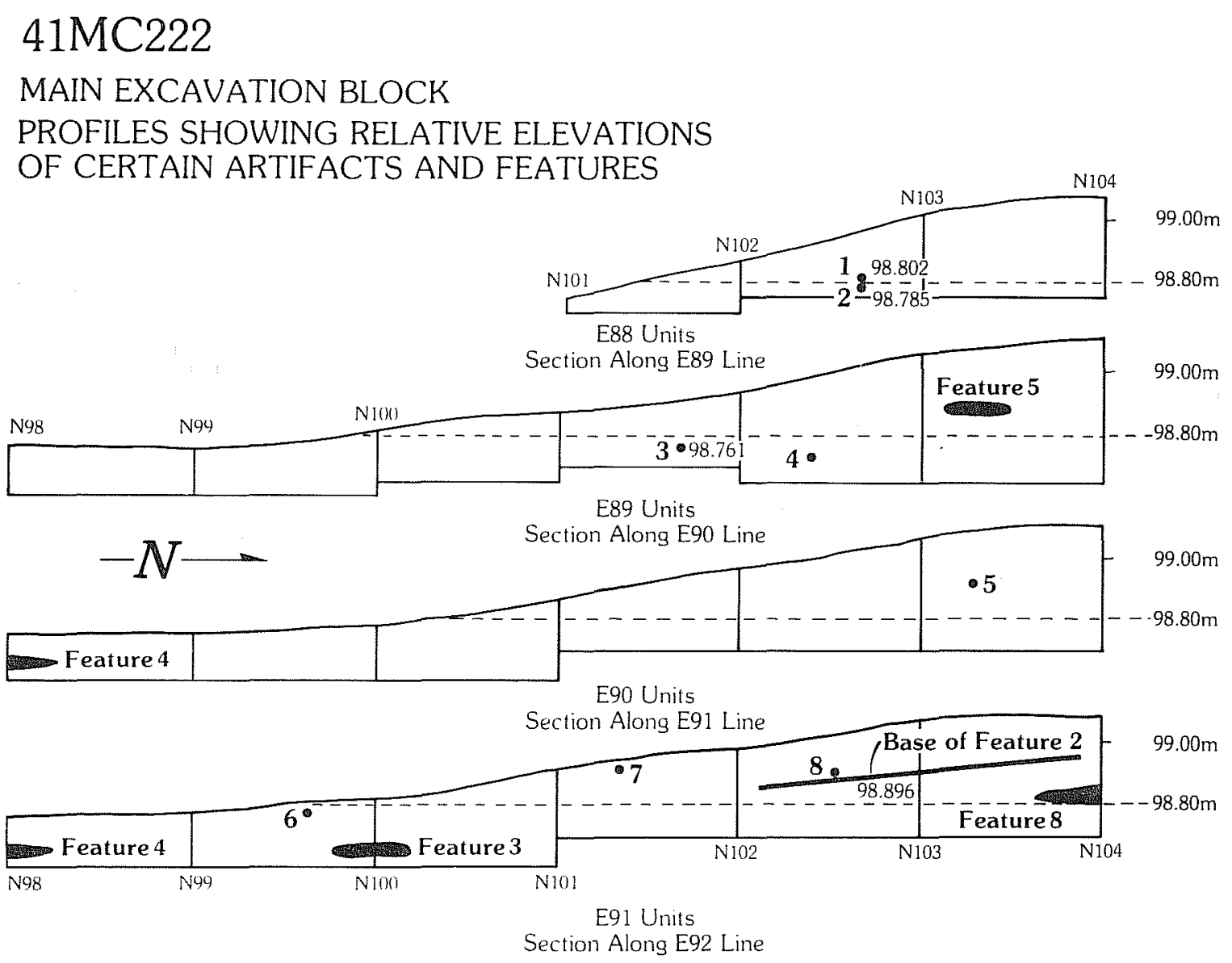

1 Thin Biface Group 1 Form 5 Specimen 22

2 Thin Biface Group 1 Form 5 Specimen 23

3 Thin Biface Group 1 Form 3 Specimen 6 (Ensor)

4 Thin Biface Group 1 Form 5 Specimen 7 (Scallorn)

5 Thin Biface Group 1 Form 5 Specimen 8 (Scallorn)

6 Thin Biface Group 1 Form 5 Specimen 24

7 Thin Biface Group 1 Form 4 Specimen 75 (Straight Stem)

8 Thin Biface Group 1 Form 4 Specimen 76 (Straight Stem)

Figure 65. Profiles Along Selected Transects in Main Excavation Block at 41 MC 222. 
Figure 66. Vieus of 41 MC 222, 41 MC 246, 41 MC 257, and 41 MC 260 .

a, overview of Feature 5 at 41 MC 222;

b, in situ view of sherds forming 7 arge pottery vessel fragment in IJnit N103 E91 at 41 MC 222;

c, overview of Feature 7 at 41 MC 222;

d, view looking east to cutbank where deeply buried prehistoric cultural debris was exposed at 41 MC 246;

e, view looking northeast across the main site area at 41 MC 257; The channel of the Frio River is marked by the trees in the background;

fo a concentration of sandstone on the surface in Area $B$ of 41 MC 260. 

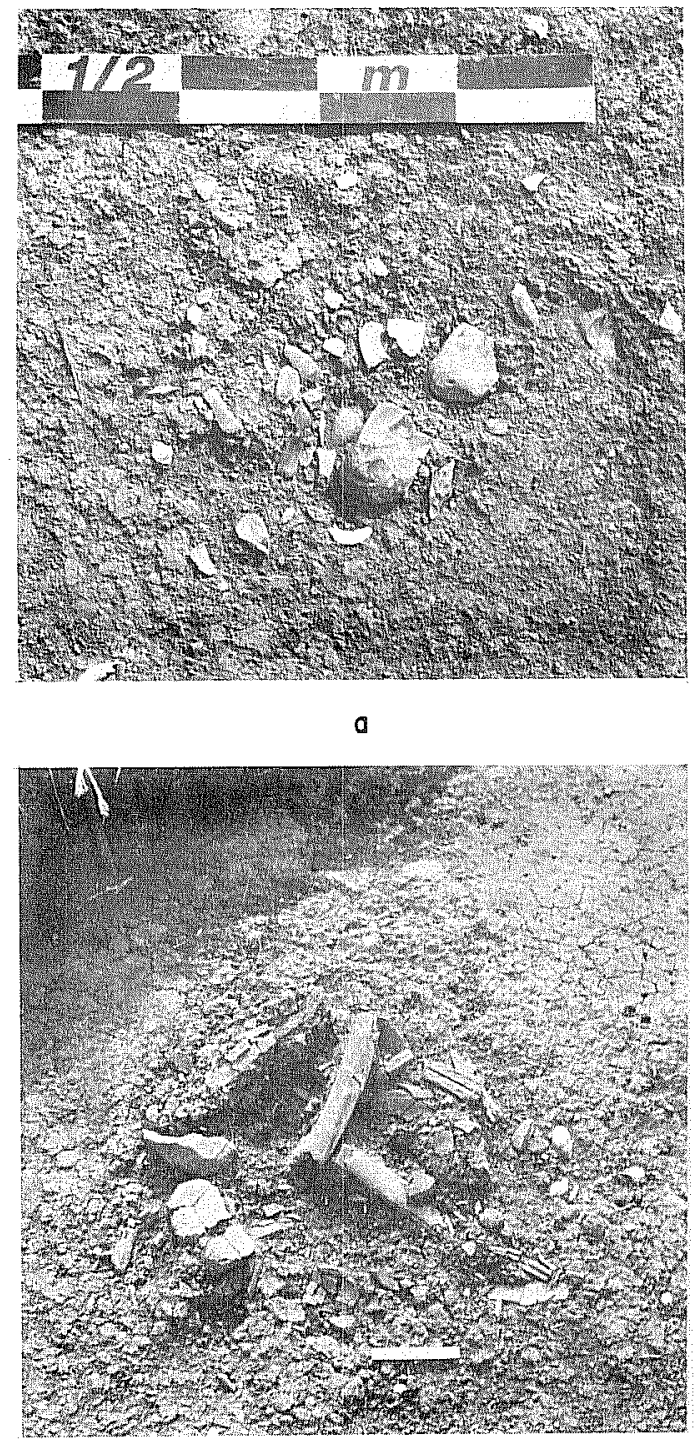

c

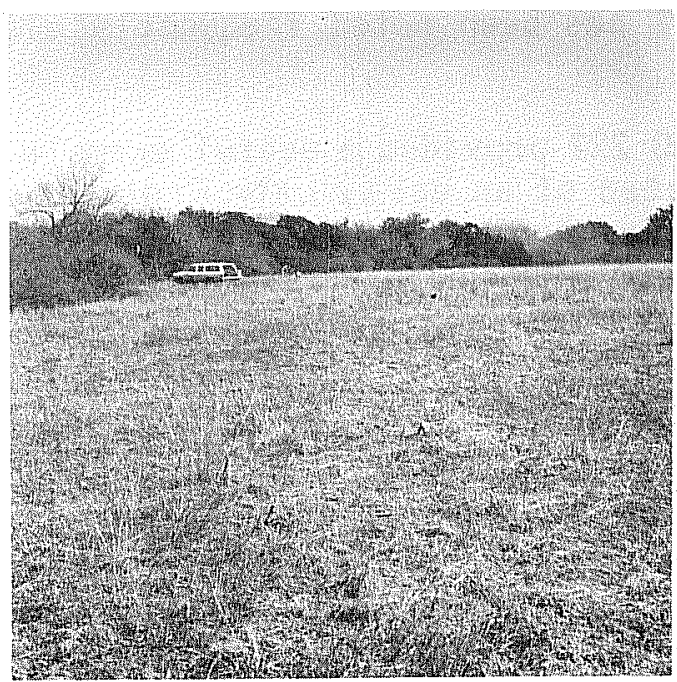

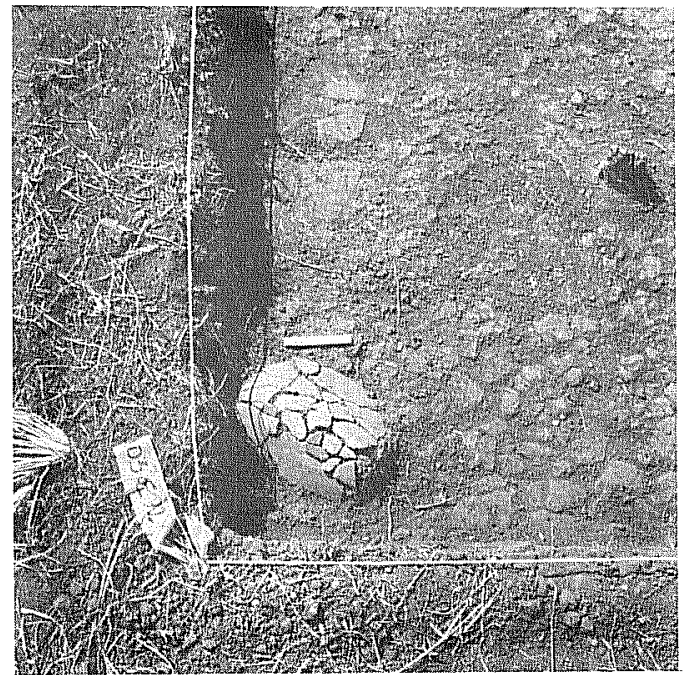

b

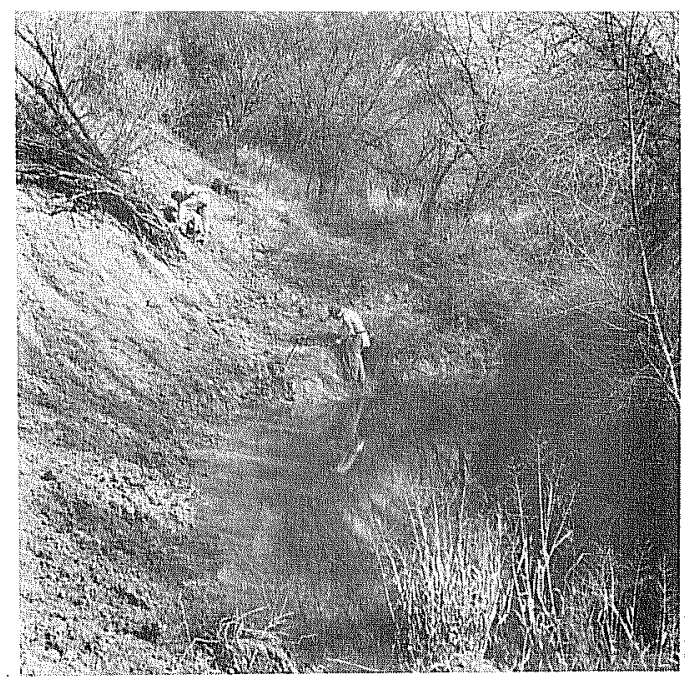

$d$

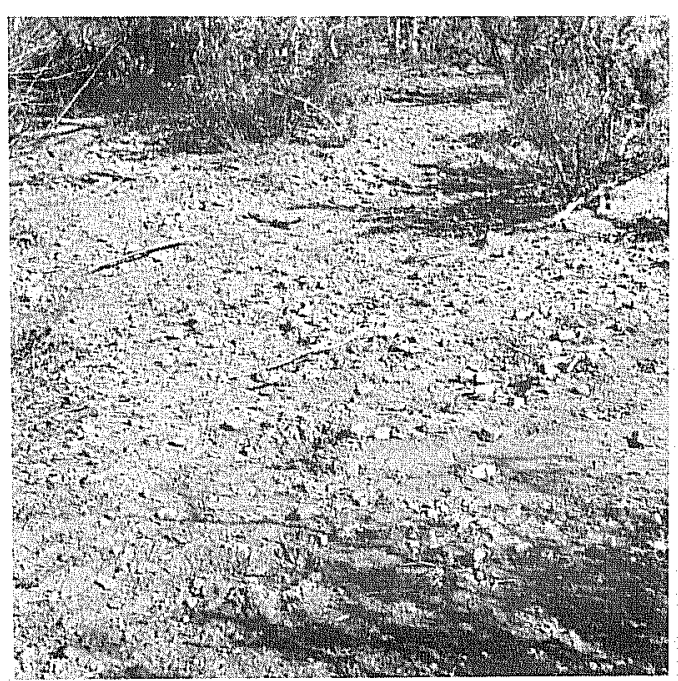


form a useful type collection for the early Late Prehistoric period at Choke Canyon. The single Ensor dart point (thin bifaces Group 1, Form 3 , Specimen 6), a Late Archaic diagnostic type, was probably curated from an older site by a Late Prehistoric inhabitant of 41 MC 222. Other thin bifaces recovered from 4I MC 222 are three unstemmed triangular pieces with straight or concave bases (Group 2, Form 1, Specimen 23; Group 2, Form 2; Group 3 , Form 2) and a pointed implement with a rounded proximal end (Group 8 , Specimen 13). Fourteen distal and medial thin biface fragments were al so found (four, Group 9; 10, Group 10).

The faunal remains, grinding implements, and habitational features discovered at 41 MC 222 provide one of the most complete records of subsistence pursuit evidence available for a prehistoric site at Choke Canyon (given the 1 imitations of archaeological preservation characteristic of these open sites). The vertebrate species identified from bones found in the deposits, as 1 isted above, show that the people were hunting, trapping, and catching a diversity of animals that provided them with meat foods. Shells of mussels and 1 arge 1 and snails are abundant in the site and indicate that these creatures also contributed meat food to the diet. The numerous fragments of sandstone manos and metates (modified sandstone Groups 1 and 2) suggest that the people were processing seeds, nuts, or beans for use as food. These tools may also have aided in the crushing or splintering of bone for marrow and fat extraction. This is suggested by numerous fragments of 1 arge (i.e., bison- or deer-size) bones found in the site. The practice is also well documented in ethnographic studies of $P 1$ ains Indian cultures that relied heavily on bison for their livelihood. Rock clusters such as Features 2 and 3 are suggested to have functioned in the cooking of animal meat foods and/or the processing of animal by-products, such as bones. No specific food item can be directly associated with these probable cooking facilities. Bone, mussel she11, and snail she11 are scattered rather uniformly around a 11 of the features. Bison bone does seem to cluster in the Phase I excavation area designated Feature 1 (Fig. 59) and around Feature 2 (Fig. 62). These bone scatters are suggested to represent butchering and meat roasting activity areas, respectively. Clusters of Rabdotus snail shel1, sometimes accompanied by mussel shel15, are represented by Features 4 and 8 at 41 MC 222. The cooccurrence of snail shell and mussel shell has been noted frequently elsewhere on prehistoric sites at Choke Canyon.

The body of information recovered from 41 MC 222 provides a useful examp $1 e$ of an archaeological assemblage to be expected of an early Late Prehistoric encampment at Choke Canyon and more generally throughout southern Texas.

\section{MC 246}

Site 41 MC 246 is located on a floodplain terrace north of the Frio River at the far western end of Choke Canyon (Fig. I, folded insert). It was located and recorded by the CAR survey team in 1979. The surveyors defined the site as having an irregular outline shape with dimensions of $150 \mathrm{~m}$ north-south and $300 \mathrm{~m}$ east-west. The surface is covered with mesquite trees, spiny hackberry, cactus, soapbush, guaji110, and grasses. The terrace surface consists of brown silty loam that is only moderately eroded. Just west of 41 MC 246 , a relict Frio River channel bifurcates, and branches of the channe? run 
around either side (north and south) of the site. The branches rejoin off the east end of 41 MC 246. Erosion of the terrace containing 41 MC 246 by floodwaters running through the relict channels has left some steep, sharp faces cut into the flanks of the terrace ( $F$ ig. 66,d). The valiey margin occurs a short distance north of 41 MC 246 (1ocation of 41 MC 247 in Fig. 1 , folded insert). The valley margin bears a surface pavement of 1 ag gravel. The site was evidenced over most of its extent by only a very 1 ight scatter of debitage, a few cores and thin bifaces, and mussel and snail shells. Along the southeastern edge of the site, examination of a cutbank along the relict channel revealed prehistoric cultural debris coming out of a deeply buried horizon in the site.

Phase II activities of the CAR crew at 41 MC 246 consisted of an uncontrol 1 ed collection of surface artifacts, shovel testing, and a careful inspection of the cutbank where the survey team had noted deeply buried cultural material.

Subsequent to the 1979 survey, the face of the cutbank on the southeast side of 41 MC 246 slumped off. The fallen earth formed a veneer that masked in situ deposits. It was necessary to cut a clean profile back into the bank in order to properly study the deposits. Examination of this profile revealed a buried 1 ayer of prehistoric cultural debris estimated to be $4 \mathrm{~m}$ below the average surface elevation of the terrace and a meter above the water level in the relict channel. Three biface fragments, a core, and a number of pieces of debitage were recovered from this 1 ayer. Another profile face cleaned further to the east revealed a thin, carbon-stained stratum situated at roughly the same elevation as the layer bearing the artifacts. The stratum sloped downward (south) toward the relict channel.

Two shovel tests were excavated on the terrace surface above the cutbank at 41 MC 246. Both were within 10 to $15 \mathrm{~m}$ of the terrace edge. Excavated to a depth of $50 \mathrm{~cm}$, virtually no cultural debris was observed in the subsurface.

The following artifacts were collected from the surface of 41 MC 246 (including the cutbank specimens): two cores (one, Group 2; one, Group 9), two thick bifaces (one, Group 7, Form 1; one, Group 7, Form 4), seven thin biface fragments (one, Group 2, Form 2; one, Group 4, Form 4; two, Group 9; three, Group 10), one distally beveled tool (Group 3, Form 2), and two unifaces (one, Group 1 ; one, Group 3). The distally beveled tool is a possible Late Archaic diagnostic, and the unifaces may represent Late Prehistoric activity. Generally, however, the assemblage suggests undifferentiated Archaic activity on the site.

The initial Phase II activities at 41 MC 246 were intended to aid in an assessment of the site's potential for extensive excavation. The deeply buried cultural debris seen in the cutbank, its provenience suggesting great antiquity, provided adequate grounds for recommending further excavations at the site. Approached for permission to conduct further investigations at the site on his property, the landowner refused. Therefore, no additional study of 41 MC 246 was possible. 


\section{$41 M 257$}

Site 41 MC 257 is also located on a floodplain terrace at the west end of Choke Canyon (Fig. I, folded insert). This site occurs on the right (south) bank of the active channel of the Frio River. It was recorded by the CAR crew during the 1979 survey. Oval in outline shape, dimensions of $70 \mathrm{~m}$ north-south and $125 \mathrm{~m}$ east-west were defined for 41 MC 257 . Most of the site is in a cleared, cultivated field. A fringe of riparian forest grows by the river channel on the north side (Fig. 66,e). It was defined on the basis of a 1 ight scatter of debitage and fairly dense scatters of mussel she11. The surveyors also noted a stemmed dart point, an unstemmed thin biface, some cores, and a thick biface on the site surface.

Phase II activities of the CAR crew at 41 MC 257 consisted of an unprovenienced surface collection and excavation of two shovel tests. The shovel test $p l a c e d$ in the central area revealed 1 ittle prehistoric cultural debris in the subsurface. A second test excavated at the site's east end showed a 1 ayer of cultural debris in the zone from 50 to $80 \mathrm{~cm}$ below the surface. Pieces of sandstone, Rabdotus snail she11s, debitage, and a thin biface were recovered from this buried zone. The findings made in this shovel test indicated that 41 MC 257 warranted further testing. However, the site is located in flowage easement that remains in private ownership and which will be subjected to short term inundation on $1 \mathrm{y}$. For these reasons, no further work was attempted.

The following artifacts were collected from the surface of $41 \mathrm{MC} 257$ : one thick biface (Group 9), two thin bifaces (one, Group 4, Form 4; one, Group 10), one trimmed flake (one, Group 3. Form 1), and two pieces of modified sandstone (one, Group 1, Form 1; one, Group 2, Form 2). These specimens, along with specimens documented by the surveyors, indicate that undifferentiated Archaic cultural activity occurred on the site.

\section{MC 251}

Site 41 MC 251 is located on the valley margin slopes north of the confluence of Salt Branch with the Frio River (Fig. I, folded insert). As defined by the CAR surveyors in 1979, 41 MC 251 is oval in outline shape. It measures $100 \mathrm{~m}$ northeast-southwest and $150 \mathrm{~m}$ northwest-southeast. However, the ful1 northeastward extent of the site could not be determined as it extended onto privately owned property. The site is about $100 \mathrm{~m}$ from the channel of Salt Branch, a rather extensive upland drainage system that feeds down to the Frio River from the northwest. The site surface supports scattered clumps of soapbush, mesquite, and whitebrush. The surface is heavily eroded, and deep gul 1 ies have formed. The site is characterized by a moderate to heavy surface scatter of debitage, concentrations of mussel shel1, sandstone, snail she11s, and chipped stone tools. The surveyors found a hearth feature eroding from a gul1y wa 11 . It was about $50 \mathrm{~cm}$ below the existing ground surface.

Phase II investigations at 41 MC 251 consisted of documentation of habitational features exposed on the surface, excavation of seven shovel tests, and collection of surface artifacts. Four habitational features were 
observed eroding from the wal1s of gul1ies cutting through the site. The remains evidencing these features were usualiy on the surface, but some were still buried by as much as $25 \mathrm{~cm}$ of deposit. Two rock clusters were found at the west end of 41 MC 251. One consisted of six scattered pieces of sandstone with no artifacts. The second feature at the west end was a cluster of five large pieces of fire-fractured rock. Along the southern margin of the site, a mussel shell concentration was located. The accumu1 ation had a diameter of $40 \mathrm{~cm}$ and consisted of about 20 musse 1 she 11 valves and numerous fragments. In the west-central area of the site, there was a fire-fractured rock concentration with a diameter of $1 \mathrm{~m}$. Musse 1 shel1 fragments, Rabdotus snail she11s, debitage, and a distal1y beveled tool were noted immediately around this feature.

The shovel tests excavated at 41 MC 251, along with subsurface exposures provided by numerous gul1ies, demonstrate that prehistoric cultural debris was confined to the upper $25 \mathrm{~cm}$ of deposit. The site's shallow depth and the severity of erosion rendered 41 MC 251 unsuitable for control led excavations.

An unprovenienced collection of artifacts from the surface of 41 MC 251 yielded the following specimens: one core (Group 4), seven thick bifaces (one, Group 2; one, Group 5; one, Group 6, Form 2; two, Group 7, Form 1; one, Group 8, one, Group 9), 16 thin bifaces (Group 1, Form 3, Specimen 32; one, Group 3, Form 2; two, Group 4, Form 1; one, Group 4, Form 3; four, Group 4, Form 4; one, Group 5; one, Group 6; two, Group 9; three, Group 10), two distally beveled tools (Group 3, Form 1; Group 3, Form 3), and one piece of modified sandstone (Group 1, Form 3). The sma11, stemmed dart point and distally beveled tools indicate that 41 MC 251 was inhabited during the Late Archaic period.

\section{MC 260}

Site 41 MC 260 is located on the floodplain near the southern side of the Frio River valley at Choke Canyon's west end (Fig. I, folded insert). Site 41 MC 260 is cut in two by the channel of Hackberry Hol 1ow, an upland drainage system that feeds down from areas south of the river. As recorded by the CAR surveyors in 1979, 41 MC 260 is subcircular in outline shape with dimensions of $100 \mathrm{~m}$ east-west and $125 \mathrm{~m}$ north-south. The western half of the site, located in a cultivated field, was designated Area $A_{\text {. }}$ The eastern half of the site was designated Area B. Brush grows in strips along the banks of Hackberry Hollow and in Area B. The brush cover consists of mesquite, soapbush, whitebrush, spiny hackberry, and grasses. Prehistoric debris evidencing this site was heavy scatters of burned sandstone, much debitage, mussel she11, and numerous chipped stone tools. Stemmed dart points, distally beveled tools, prehistoric potsherds, and a possible arrow point preform observed by the surveyors led them to suggest Archaic and Late Prehistoric components were present at this site.

During Phase II work at 41 MC 260, the CAR crew made a controlled collection of surface artifacts and excavated four shovel tests. The shovel tests excavated in Area $A$ revealed a layer of prehistoric cultural debris extending from 25 to $45 \mathrm{~cm}$ beneath the site surface. The principal constituent of this 
1 ayer was burned sandstone. Snails, mussel she11, and debitage were also present.

Area $B$ at 41 MC 260 consisted primarily of a surface scatter of sandstone measuring about $35 \mathrm{~m}$ north-south and 10 to $15 \mathrm{~m}$ east-west (Fig. 66, f). The heaviest concentration of sandstone occurs at the south end of the Area $B$ scatter where erosion along a gully has exposed more subsurface debris. Much debitage and Rabdotus snail she 11 is also scattered amidst the sandstone. Shovel tests in Area $B$ showed that cultural debris was essentially confined to the surface; erosion and deflation apparently removed most of the matrix that once held the material.

A provenienced collection effort at 41 MC 260 yielded the following specimens: two cores (one, Group 3; one, Group 7), two thick bifaces (two, Group 2), eight thin bifaces (Group 1, Form 2, Specimen 11; Group 1, Form 3 , Specimen 7 [Ensor]; Group 1, Form 3, Specimen 17 [Fairland]; one, Group 2, Form 1; two, Group 4, Form 4; one, Group 9; one, Group 10), two dista11y beveled tools (two, Group 3, Form 2), and three pieces of modified sandstone (one, Group 1, Form 3; two, Group 2, Form 1). Two of the stemmed dart points (Ensor and Fairland) and the distally beveled tools clearly indicate that 41 MC 260 was inhabited during Late Archaic times. Although a Late Prehistoric component was unquestionably evidenced to the survey crew in 1979, there was no additional material clearly diagnostic of the Late Prehistoric recognized during the Phase II investigation.

At 41 MC 260, the presence of Late Archaic and Late Prehistoric components, the artifact assemblage, and the deposits of burned sandstone are characteristics similar to certain of the valley margin sites investigated on the north side of the Frio River valley. This would include such localities as 41 MC 296 in Site Group 10; 41 MC 209, 41 MC 212, and 41 MC 213 in Site Group 7; and 41 LK 250, 41 LK 252, and 41 LK 253 in Site Group 6. Site 41 MC 260 differs only slightly in that it is somewhat farther removed from the steep valley margin slopes. Nevertheless, it is within $200 \mathrm{~m}$ of sandstone outcrops of the Jackson Group just to the east. The tool assemblage and accumulation of sandstone indicate that the Late Archaic inhabitants of 41 MC 260 were involved in roughly the same range of activities as were the people who generated debris found at the sites 1 isted above. Also in keeping with the pattern recognized at sites on the northern valley margin, there is subsequent Late Prehistoric habitation of the site.

\section{ARTIFACTS}

The artifacts recovered during the Phase II archaeological investigations at Choke Canyon are organized into five classes of material in the fol lowing descriptive section. The first four classes--consisting of 1 ithics, she11. bone, and ceramics-contain aboriginal artifacts or by-products of aboriginal activity. The fifth material class--historic artifacts-mcontains metal, glass, ceramics, and bone which, with few exceptions, are related to AngloEuropean activities on the prehistoric sites investigated during Phase II. 


\section{LUTHIC ARTIFACTS}

Lithic artifacts are organized and described below in a manner consistent with presentation of similar data resulting from the Phase I investigation (Ha11, B1ack, and Graves 1982:239-387). As the basic characteristics used to divide specimens of the various 1 ithic categories into distinct group and form classifications have not been altered from the original presentation, descriptive entries and type definitions are taken, often verbatim, from the Phase I report (ibid.). This is meant to insure compatibility between reports and, it is hoped, will make it somewhat easjer for the reader to integrate data resulting from the two separate phases of investigation. Also for the sake of consistency, the 1 ithic (and other prehistoric) artifacts recovered at site 41 LK 201 are included in this analysis even though they are comprehensively treated in a separate volume of this research series (Highley 1986). However, data presentations in Highley's volume does not necessarily conform to the present treatment in all respects.

The 1 ithic artifacts are organized into 10 categories for purposes of analysis and description: cores, thick bifaces, thin bifaces, distally beveled bifaces and unifaces, unifaces, trimmed flakes, debitage, hammerstones, ground stone, and miscellaneous artifacts and materials. The first six categories are a 11 chipped stone artifacts and by-products of chipped stone tool manufacture. Chert, occurring as stream-rolled cobbles up to $15 \mathrm{~cm}$ in diameter, is found at numerous locations in the Choke Canyon area. Colors common in these local cherts include cream, gray, tan, and brown. Also used in chipped stone tool manufacture were sandstone, quartzite, petrified wood, chalcedony, jasper, and gray siliceous quartzite. All of these rocks are also easily obtained in cobble form from $10 c a 1$ gravel deposits. After chert, sandstone is the next most common 1 ithic raw material represented in the Choke Canyon collections. Sandstone was used to make grinding slabs, manos, and grooved abraders. The Eocene Jackson Group, outcrops of which are common along the Frio River between Cal1iham and Tilden, yields high grade sandstone and is a likely source of raw material in making the slabs, manos, and abraders recovered from the prehistoric sites at choke Canyon. Miscellaneous 1 ithic artifacts and materials include gypsum, ferruginous sandstone, ocher, and hematite concretions. Except for the gypsum. which is derived from the Frio Formation in the local area, these miscellaneous rock types were 1 ikely brought in from other areas.

Unless otherwise indicated, all dimensions and weights are in centimeters and grams, respectively. An asterisk (*) placed next to a number indicates measurements or weights for incomplete specimens; an asterisk with no number indicates measurement or weight not taken.

\section{CHIPPED STONE}

\section{Cores (789 specimens)}

Cores are stream-rol led cobbles or 1 arge, thick flakes from which two or more flakes have been struck, possibly to produce flakes or to reduce the cobble or flake into a finished tool form. The cores are grouped according to the direction(s) from which flakes were struck, striking platform preparation, 
striking platform morphology, size, shape, and degree of reduction. The foll lowing groupings are used:

\author{
Group 1. Natural Platform \\ Group 2. Bidirectiona1, Natural and Prepared Platforms \\ Group 3. Multidirectional, Natural and Prepared Platforms, Single and \\ Multiple Facets \\ Group 4. Unidirectional, Prepared Platforms, Single Facet \\ Group 5. Multidirectiona1, Natural and Prepared Platforms, Single Facet \\ Group 6. Core Nuclei \\ Group 7. Flat, Circular to Elliptical in Outline, Unifacially Cortex \\ Covered \\ Group 8. Tested Cobbles \\ Group 9. Core Fragments \\ Group 10. Unmodified Cobbles
}

The directional references pertain to trends of $f l$ ake scars relative to one another on the cobble or flake. Where a prepared platform was used, the $f 1$ akes struck to form the platform are not considered when the core is grouped according to direction of flake removals. For unidirectional cores, flakes were removed in the same direction relative to the platform such that the remaining scars parallel or overlap one another en echelon. On bidirectional cores, flakes were removed from opposite directions of the same platform area. The scars of multidirectional cores run in trends other than parallel or opposite one another; flakes were struck both from the same and different platforms. Natural platforms consist of the cobble's cortex. Prepared platforms occur where a single flake scar forms the striking surface. Multiple facet platforms are made when the scars of two or more removals merge to form ridges in the striking area. Direction of flake removal and platform character were used to sort cores into Groups 1-5. Size, outline, and degree of reduction were used to sort cores into Groups 68.

Provenience data for all core groups are provided in Tables 4 and 5.

\title{
Group 1. Natura1 Platform (63 specimens)
}

Group 1 cores are cortex-covered cobbles from which flakes have been removed using natural platforms. The cobbles are irregularly shaped, varying from round to oval to angular. The majority are flaked multidirectional1y. This particular group is not subdivided according to direction of $f 1$ ake removals, since so few scars are present on each specimen. Flake scars tend to be confined to one end or edge. Most of the specimens within this group retain 80-95\% of the cortex. Some retain as 7 ittle as $50 \%$ of the cortex. The ranges of metric attributes for Group 1 are as follows:

Maximum Minimum Average

$\begin{array}{lrrr}\text { Length: } & 15.0 & 4.1 & 8.0 \\ \text { Width: } & 12.3 & 4.4 & 7.6 \\ \text { Thickness: } & 7.4 & 2.5 & 4.6 \\ \text { Weight: } & 1763.0 & 61.8 & 394.0\end{array}$

Examples of Group 1 cores are illustrated in Figure 67. 
TABLE 4. PROVENIENCE OF CORES BY SITE

\begin{tabular}{|c|c|c|c|c|c|c|c|c|c|c|}
\hline Site No. & Group 1 & Group 2 & Group 3 & Group 4 & Group 5 & Group 6 & Group 7 & Group 8 & Group 9 & Group 10 \\
\hline 41LK8 & 5 & 3 & 2 & & 5 & 6 & & 1 & 6 & 1 \\
\hline $41 \mathrm{LK} 14$ & 4 & 6 & 2 & $\therefore$ & 9 & 11 & 1 & & 58 & 2 \\
\hline $41 \mathrm{LK} 27$ & & 1 & 1 & & 1 & & & & 1 & \\
\hline $41 L K 53$ & 3 & 1 & 2 & & 3 & & & & 5 & \\
\hline \multicolumn{11}{|l|}{41 LK66 } \\
\hline $411 K 69$ & & & & & & & & & 1 & \\
\hline $41 \mathrm{LK} 74$ & 3 & 1 & & & 12 & 2 & & & 24 & 2 \\
\hline 41 LK 122 & 1 & 1 & 1 & & 5 & 6 & & & 4 & \\
\hline $41 \mathrm{LK} 127$ & & 4 & 1 & & 7 & 1 & 1 & & 7 & \\
\hline $41 L K 128$ & & & 5 & 2 & 4 & 3 & & & 12 & 1 \\
\hline $41 \mathrm{LK} 133$ & 1 & & 1 & & 1 & & & & 1 & \\
\hline $41 \mathrm{LK} 142$ & & 3 & & & 1 & & & & & \\
\hline $41 \mathrm{LK} 145$ & & & & 1 & & & & & & \\
\hline \multicolumn{11}{|l|}{$41 \mathrm{LK} 181$} \\
\hline 41LK1B2 & & & 1 & & & 1 & & & 1 & \\
\hline 41 LK185 & 2 & & & 1 & 3 & 1 & & & 1 & \\
\hline $41 \mathrm{LK} 191$ & 2 & & & & & & & & & \\
\hline 41LK197 & & & & & & & & & 1 & \\
\hline 41 LK199 & 1 & 1 & 4 & & 2 & 9 & 1 & & 19 & \\
\hline 41LK201 & 17 & 12 & $B$ & & 18 & 13 & & & 34 & \\
\hline \multicolumn{11}{|l|}{$41 \mathrm{LK} 236$} \\
\hline $41 \mathrm{LK} 243$ & 1 & 3 & 4 & & 4 & 1 & 1 & & 6 & \\
\hline $41 \mathrm{LK} 247$ & & & & & & & & & & \\
\hline $41 \mathrm{LK} 250$ & 1 & 3 & 4 & & 5 & & & & 1 & \\
\hline 41LK252 & 1 & & 2 & & & 1 & & & & \\
\hline $41 \mathrm{LK} 253$ & & & 1 & & 1 & & & & & \\
\hline & & & & & & & & & & \\
\hline 41 MC79 & & & & & & & & & & \\
\hline $41 \mathrm{MC} 94$ & & & & 2 & 1 & & & 1 & & 1 \\
\hline $41 \mathrm{MC} 192$ & & & & & & & & & & \\
\hline $41 \mathrm{MC} 193$ & & & & & & & & & & \\
\hline $41 \mathrm{MC} 194$ & & & & & & & & & & \\
\hline $41 M C 196$ & & & 2 & & 6 & & & & & 冫 \\
\hline $41 \mathrm{MC} 212$ & & & & & & & & & & \\
\hline $41 \mathrm{MC} 213$ & & & & & & & & & & \\
\hline $41 \mathrm{MC} 214$ & & & & & & & & & & \\
\hline $41 \mathrm{MC} 222$ & 2 & 4 & 4 & 1 & 5 & 7 & 1 & & 8 & \\
\hline $41 \mathrm{MC} 226$ & & 1 & 1 & & 1 & & & & & \\
\hline $41 \mathrm{MC} 234$ & & & & & & & & $\cdot$ & & \\
\hline $41 \mathrm{MC} 235$ & & & & & & & & & & \\
\hline $41 \mathrm{MC} 238$ & & & 3 & & & & & & 1 & \\
\hline $41 \mathrm{MC} 242$ & & & & 1 & & & $1^{2}$ & & & \\
\hline $41 \mathrm{MC} 246$ & & 1 & & & & & & & 1 & \\
\hline $41 \mathrm{MC} 251$ & & & & 1 & & & & & & \\
\hline $41 \mathrm{MC} 257$ & & & & & & & & & & \\
\hline $41 \mathrm{MC} 260$ & & & 1 & & & & 1 & & & \\
\hline $41 \mathrm{MC} 266$ & & & & & & & & & & \\
\hline $41 \mathrm{MC} 267$ & & & & & & & & & & \\
\hline $41 \mathrm{MC} 26 \mathrm{~B}$ & 2 & 7 & .5 & 3 & 10 & 1 & 2 & & 5 & 3 \\
\hline $41 \mathrm{MC} 270$ & & 3 & 2 & 1 & 5 & 2 & 2 & & 8 & \\
\hline $41 \mathrm{MC275}$ & 1 & 1 & 2 & 1 & 2 & & 1 & & 3 & \\
\hline $41 \mathrm{MC} 276$ & 1 & & & & 1 & & & & 1 & \\
\hline $41 \mathrm{MC} 282$ & & & & & & 2 & & & 1 & \\
\hline $41 \mathrm{MC} 284$ & & & & & . & & & & & \\
\hline
\end{tabular}


TABLE 5. PROVENIENCE OF CORES RECOVERED IN PHASE II EXCAVATIONS

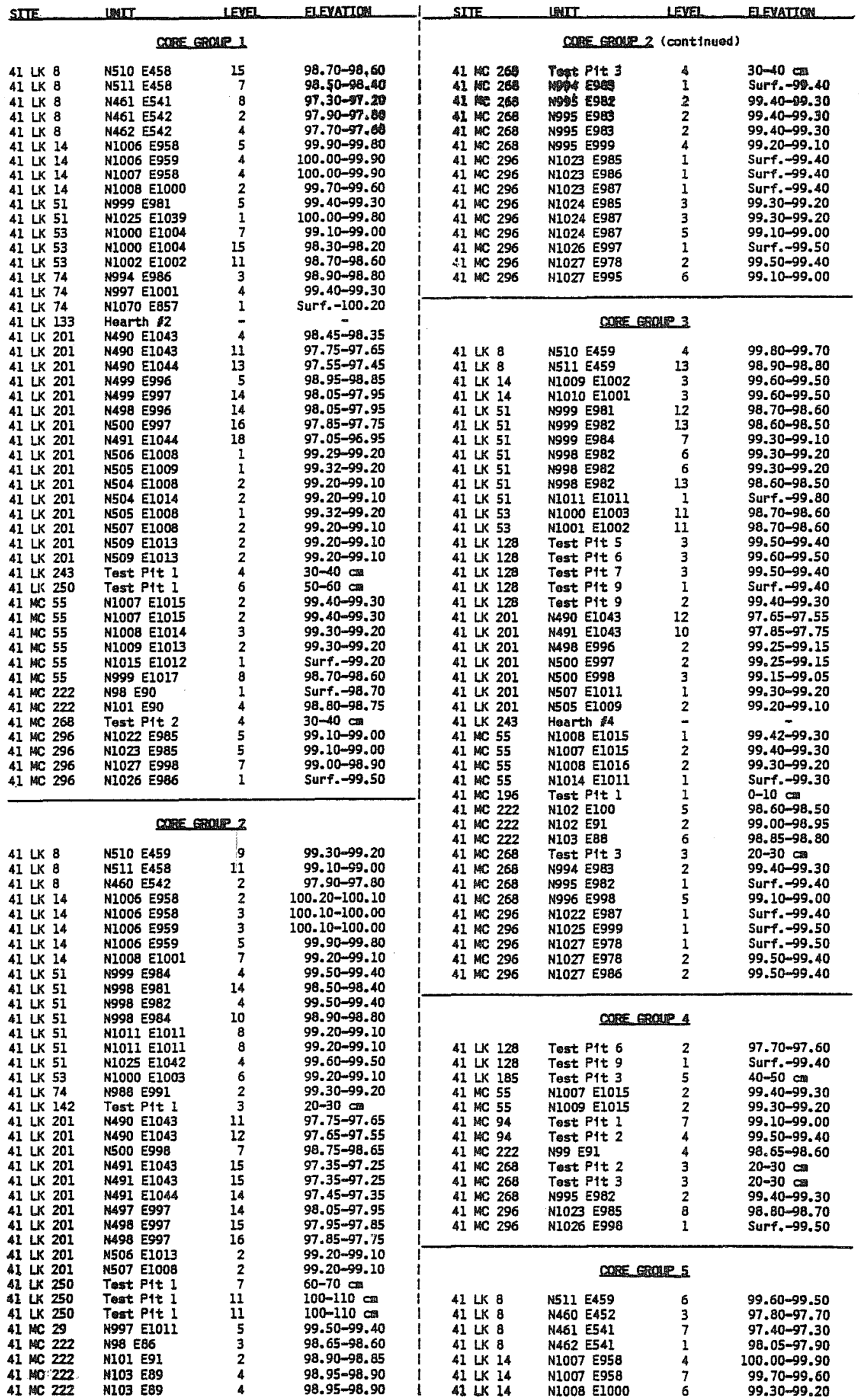


TABLE 5. (continued)

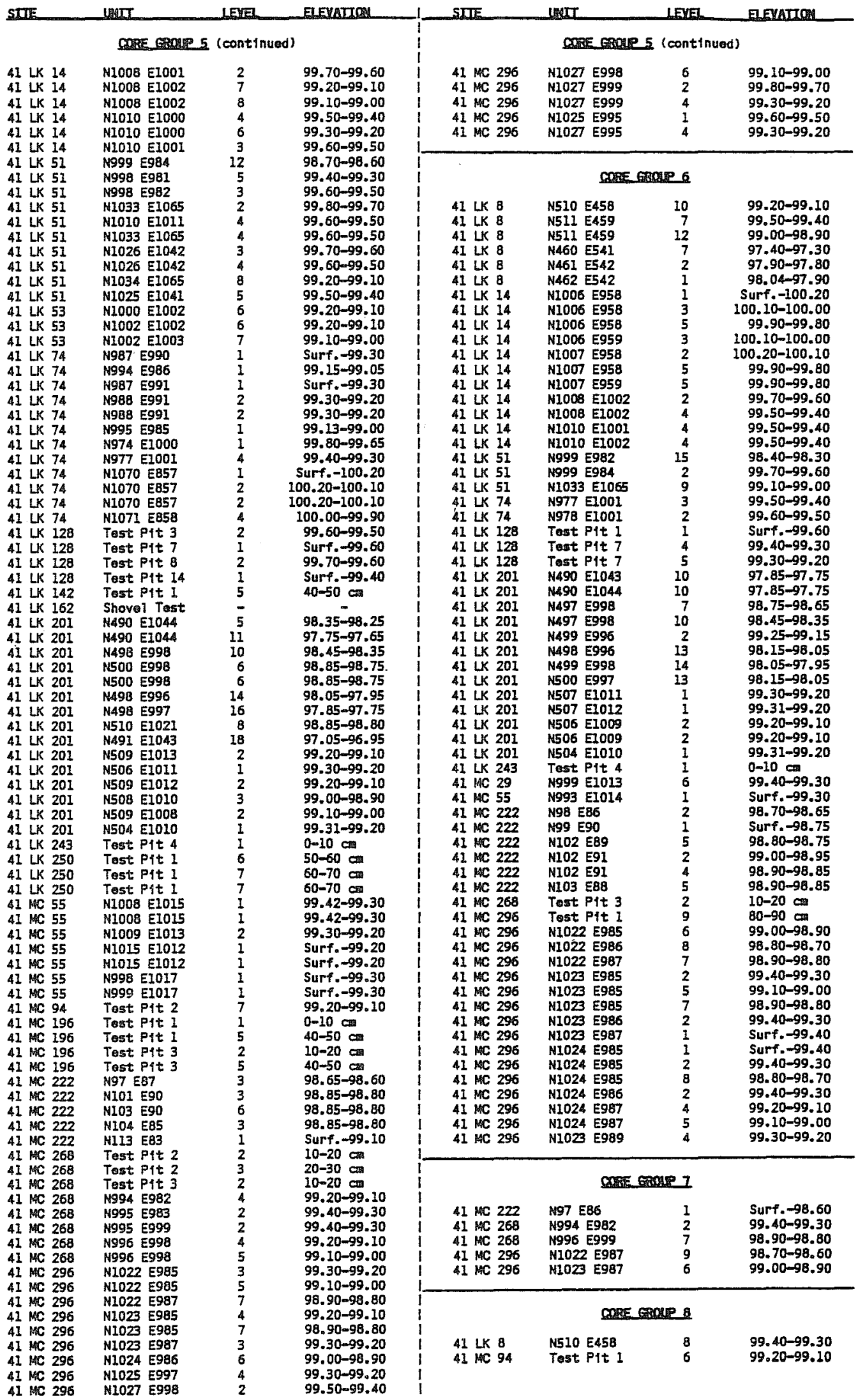



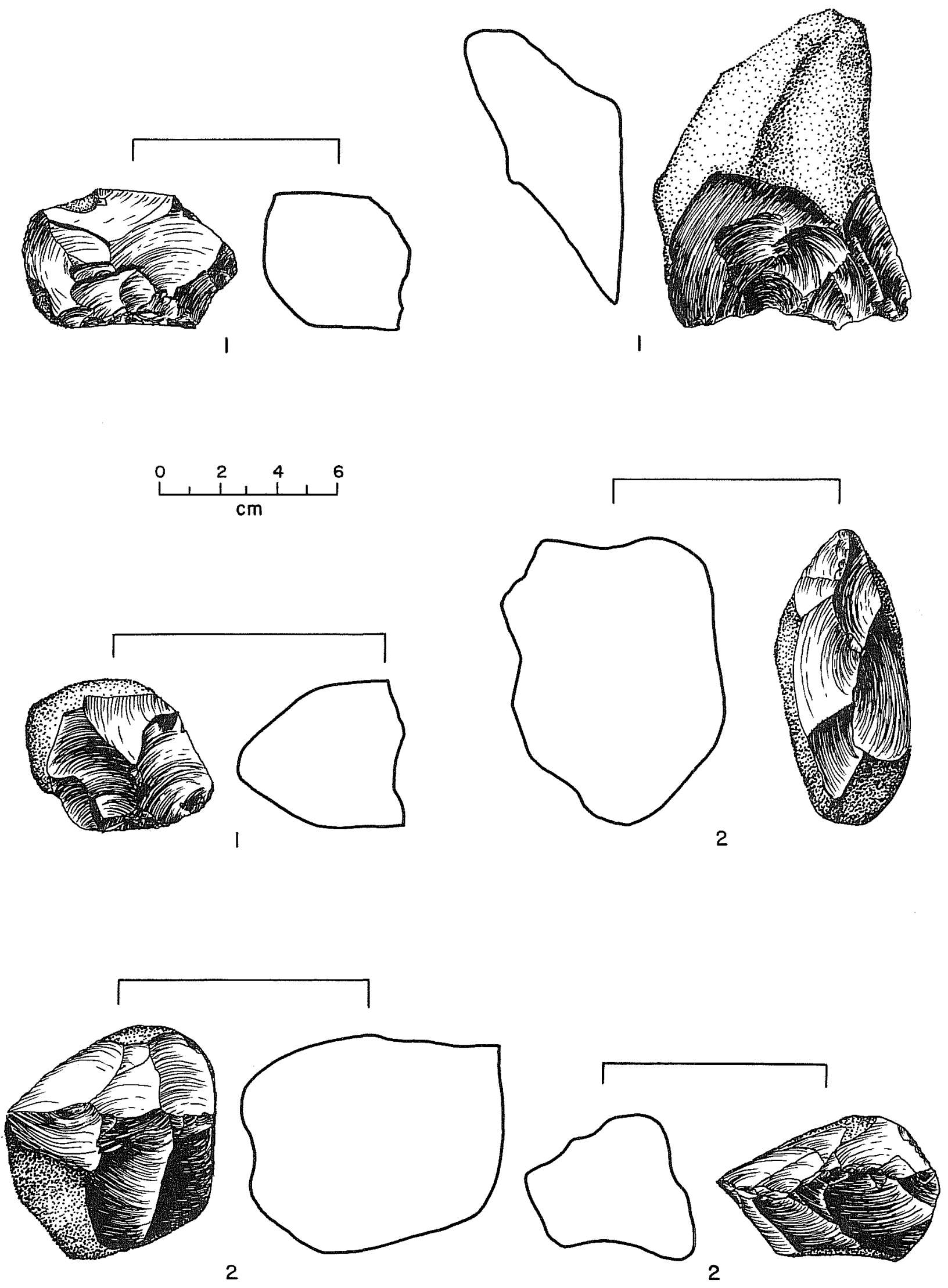

Figure 67. Cores: Groups 1 and 2. Number beneath artifact indicates core group number. 
Group 1. Core--Possible Tool

One Group 1 core is shaped to suggest use as a "chopping" or "scraping" tool. This specimen is roughly subcircular in outline shape and has the following dimensions: length, $8.2 \mathrm{~cm}$; width, $6.8 \mathrm{~cm}$; and thickness, $2.9 \mathrm{~cm}$. From one margin of the piece, comprising about one-third the circumference, flakes have been removed using natural platforms to form a relatively sharp edge. Opposite this edge, the broad, cortex-covered end forms a comfortable grip. There are no obvious signs of wear to provide additional evidence of usage as a tool. The specimen was recovered at 41 LK 173 in Shovel Test 1. The specimen is not illustrated.

\section{Group 2. Bidirectional, Natural and Prepared Platforms (78 specimens)}

Group 2 cores are made of cobbles struck bidirectionally at one end or along one side. Flakes were removed initially using natural cortex platforms. Flake scars resulting from initial removals were then used as platforms for flake removals from the opposite direction. Specimens exhibit two to eight 1 arge $\mathrm{flake}$ scars. Most specimens retain $80-95 \%$ of the cortex; some retain as 1 ittle as $50 \%$ of the cortex. The ranges of metric attributes for Group 2 specimens are as follows:

$\begin{array}{lrrr} & \text { Maximum } & \text { Minimum } & \text { Average } \\ \text { Length: } & 11.4 & 4.9 & 8.5 \\ \text { Width: } & 8.7 & 3.7 & 6.9 \\ \text { Thickness: } & 5.9 & 2.6 & 4.4 \\ \text { Weight: } & 779.0 & 58.0 & 309.0\end{array}$

Examples of cores in Group 2 are illustrated in Figure 67.

\section{Group 2. Cores--Possible Tools}

Ten of the Group 2 cores were worked into forms suggesting use as "chopping" and/or "scraping" tools. In outl ine shape, nine specimens are elliptical or subcircular; Specimen 4 is a narrow, elongate shape. The possible tools in Group 2 are characterized by sharp, bidirectionally knapped edges at one end and smooth, rounded cortex at the opposite end. Functional usage of these specimens as tools is inferred solely on the basis of the comfortable, convenient feel of the cortex end when held in the hand, the sharp edge at the opposite end, and the battered, crushed appearance of the flaked edges. Admitted $7 y$, these features may simply be the result of flake production or biface thinning processes completely unrelated to the intentional manufacture of a chopping or scraping tool. Specimen 4 (Fig. 68) is unusual in that its shape and the angle of its knapped end are morphologically similar to those of the Guadalupe tool (Distally Beveled Biface and Uniface Group 6), examples of which are described below. Specimen 7 (Fig. 71) is distinguished both by the material of which it is made--sandstone--and by three intersecting 1 ines scratched into its face forming an asterisklike design. A surface recovery from 41 MC 268, the 1 ine pattern on Specimen 7 may have been formed as the 

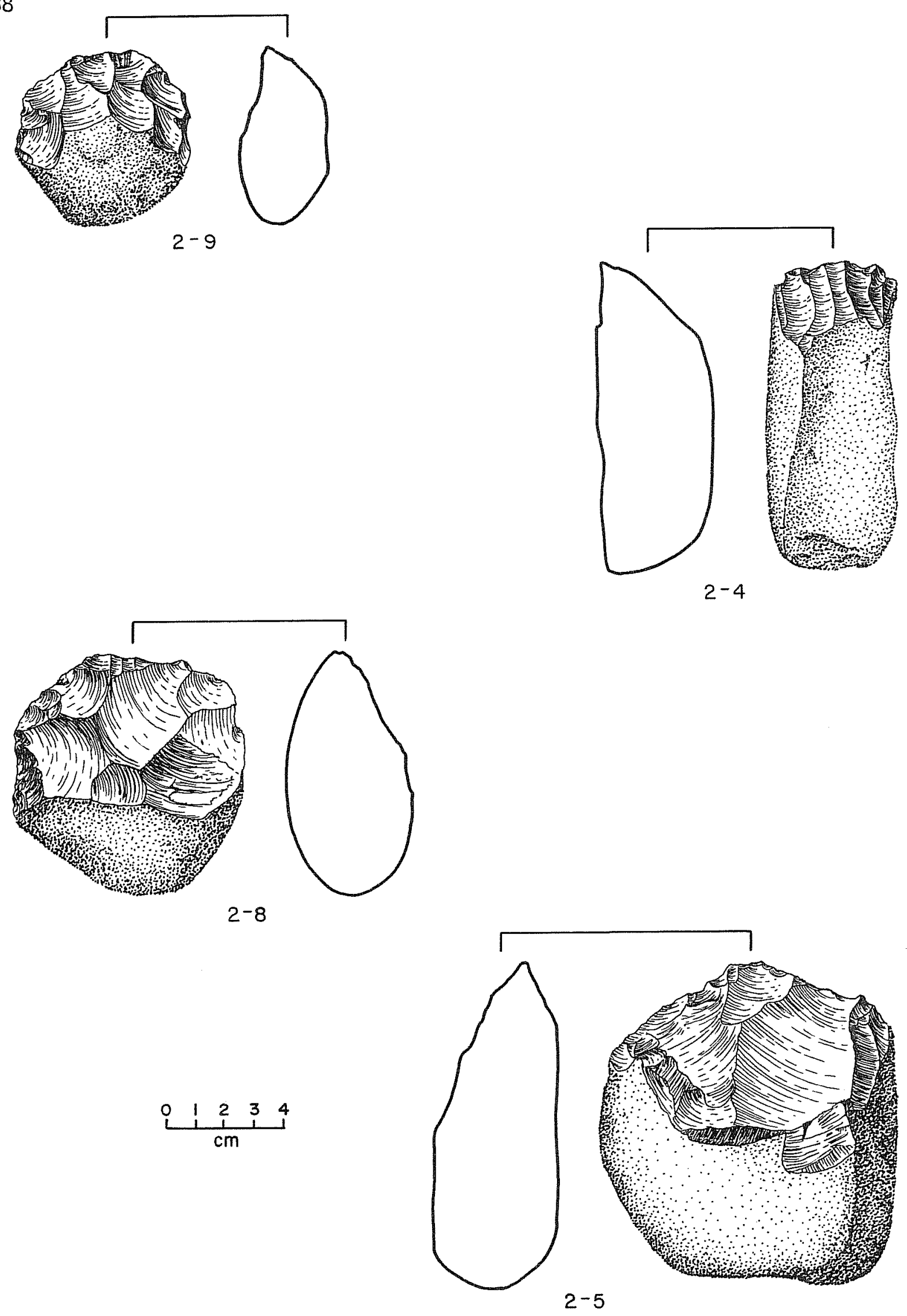

Figure 68. Cores: Group 2--Possible Tools. Numbers beneath artifact indicate core group and specimen number, respectively. 
piece was run over by farm machinery. Site provenience and metric attributes for these 10 specimens are as follows:

Specimen Number

Site

Unit Level Length

Figure

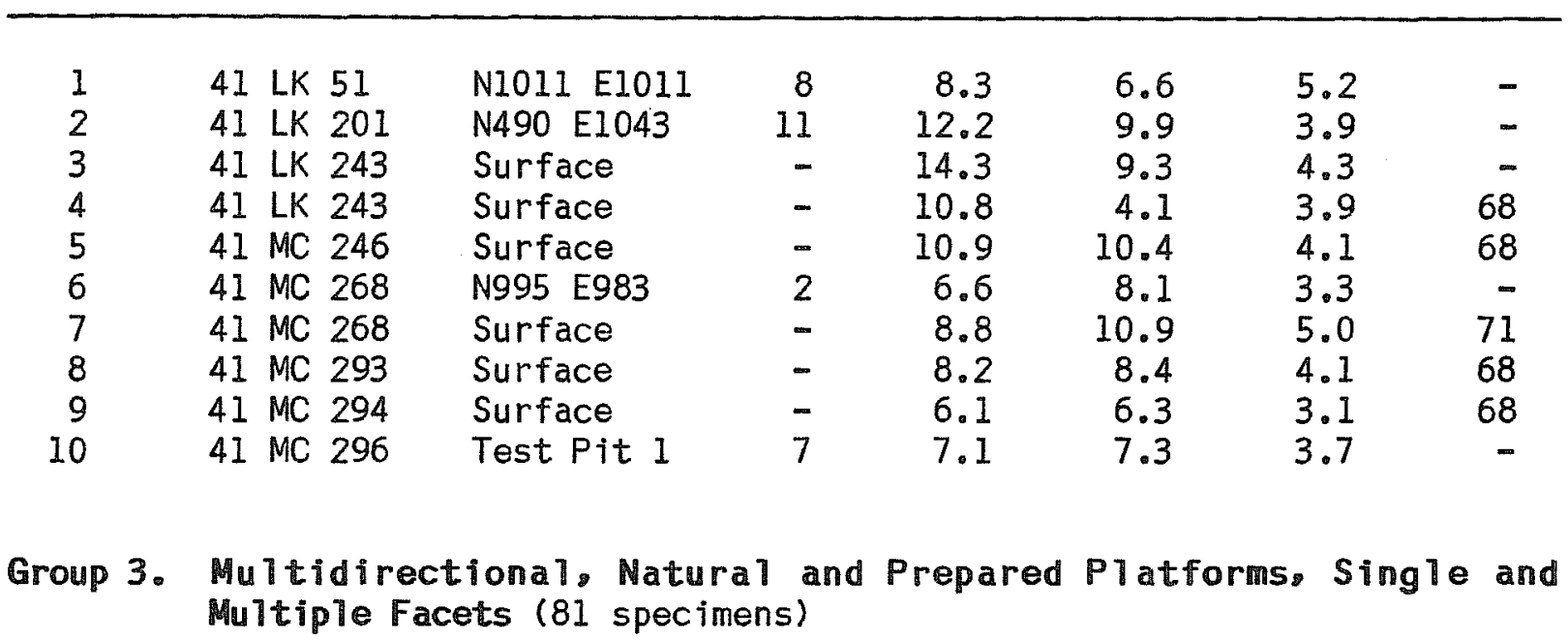

Group 3 cores have both natural and prepared platforms with single and multiple facets from which flakes have been removed multidirectionally. The group includes cobbles and 1 arge, thick flakes derived from cobbles. The cobble cores generally reflect the shape of the original unmodified cobble and retain up to $90 \%$ of their cortex. Many of the $f 7$ akes retain no cortex. The ranges of metric attributes of Group 3 specimens are as follows:

$\begin{array}{lrrr} & \text { Maximum } & \text { Minimum } & \text { Average } \\ \text { Length: } & & & \\ \text { Width: } & 12.5 & 3.6 & 7.5 \\ \text { Thickness: } & 9.7 & 4.2 & 5.6 \\ \text { Weight: } & 5.6 & 3.5 & 4.4 \\ & 770.0 & 68.0 & 206.0\end{array}$

Examples of Group 3 cores are illustrated in Figure 69.

\section{Group 3. Cores--Possible Tools}

Four Group 3 cores have shapes suggesting use as "chopping" or "scraping" tools. The specimens range from oval to subcircular in outline. The general description for the possible tools in Group 2, provided above, also applies to these specimens. Specimen $I$ is made of chalcedony and constitutes the largest piece of the material recovered in the archaeological investigations at Choke Canyon. Specimen 3 exhibits a glossy or waxy sheen over its flaked faces and is mottled reddish orange and gray in color. These characteristics suggest that the core was heat treated. Generaliy similar in overall configuration to the Group 2 specimens 111 ustrated in Figure 68, no Group 3 possible tool examples are illustrated. Site provenience and metric attributes for these four specimens are as fol $10 w 5$ : 

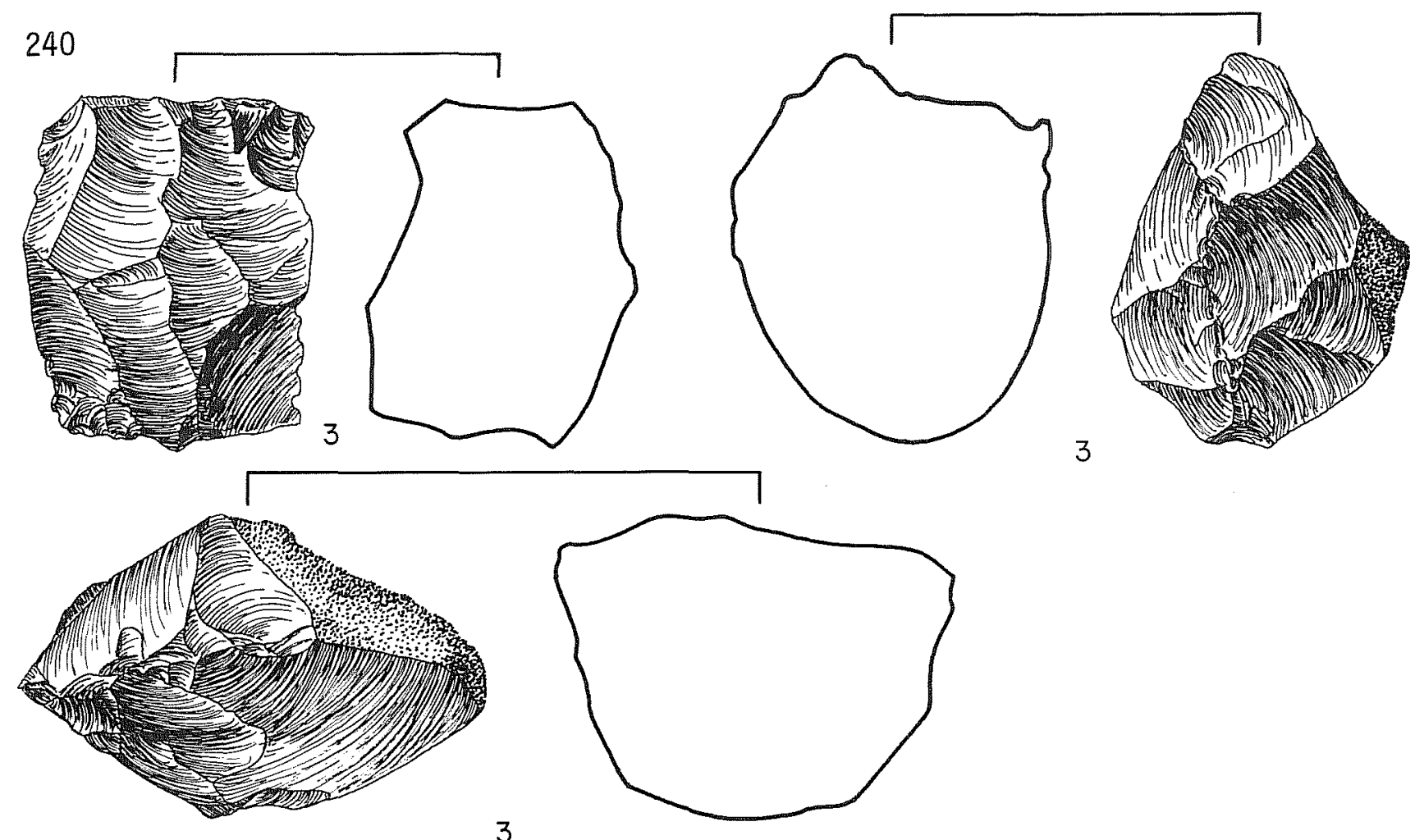

3
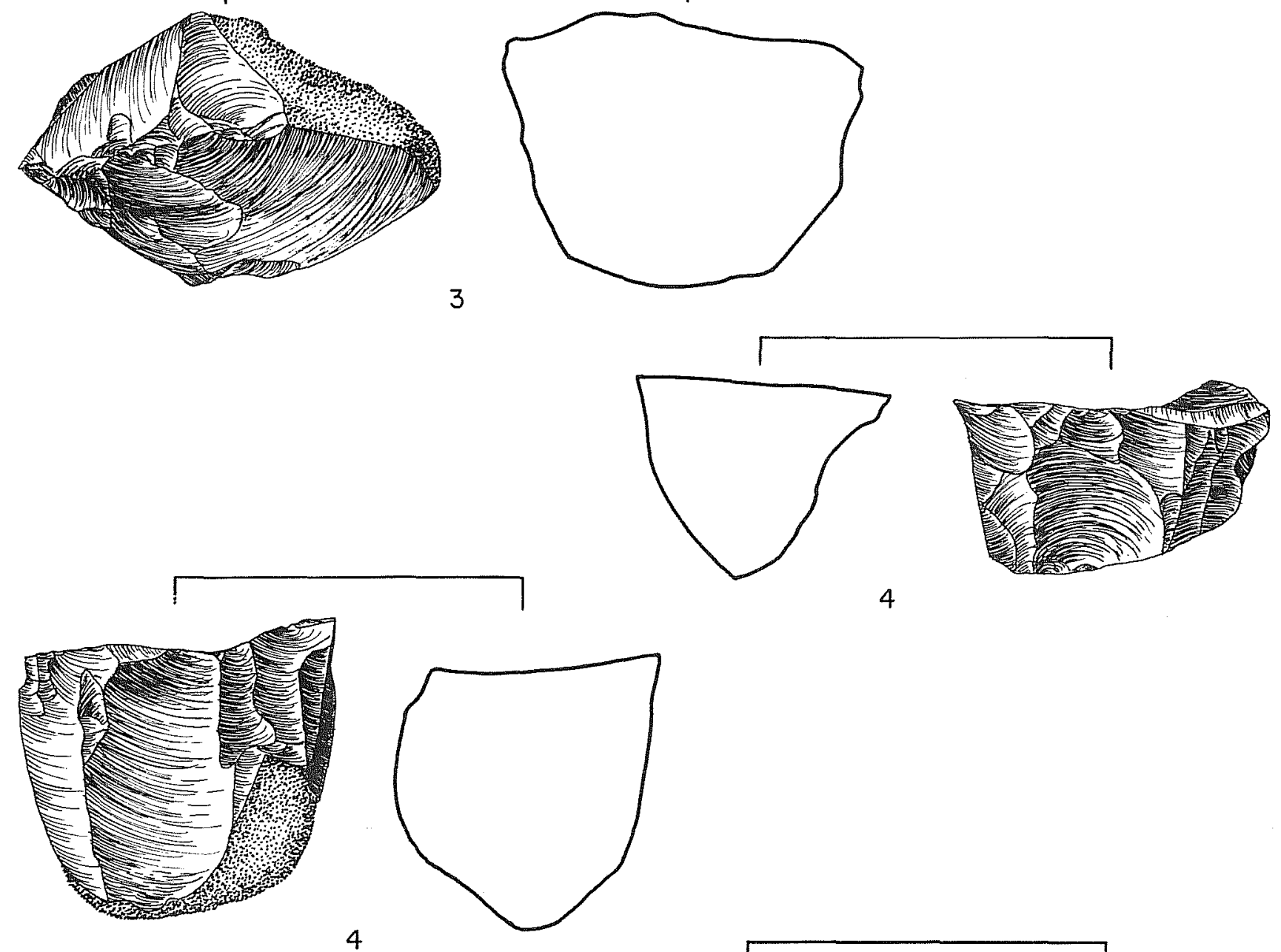

4

4
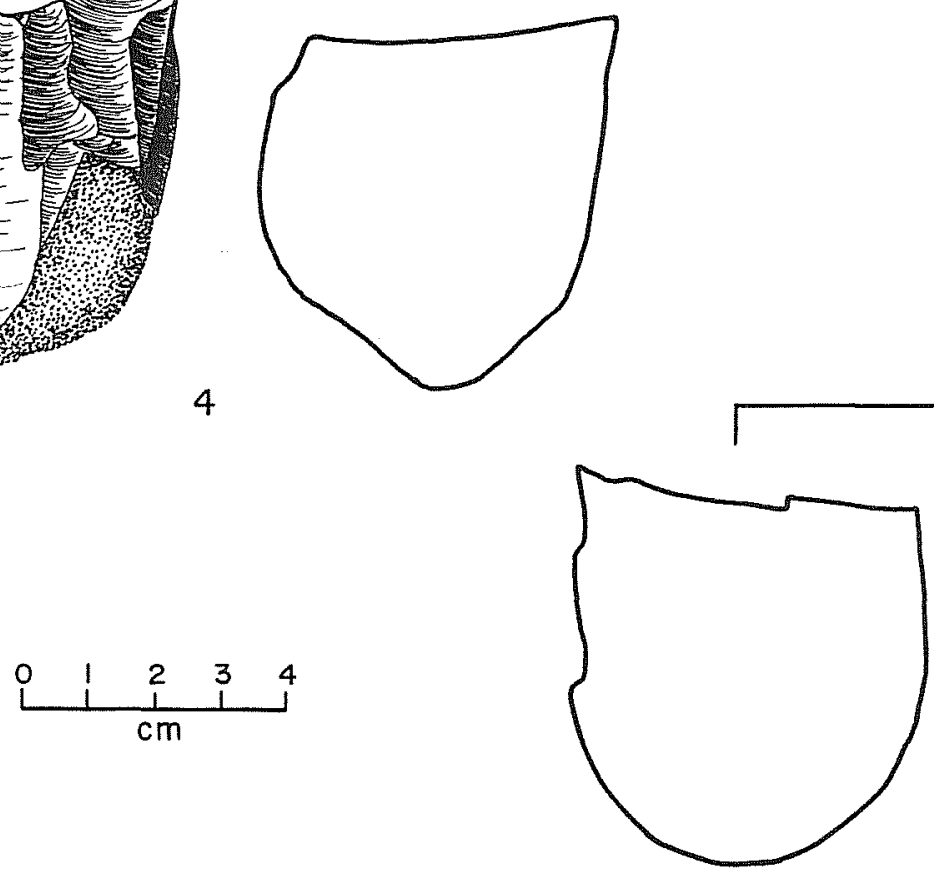

4

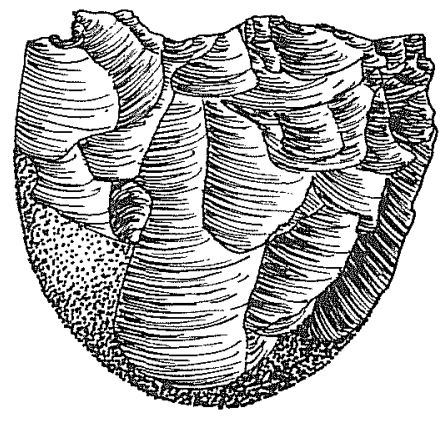

Figure 69. Cores: Groups 3 and 4. Number beneath artifact indicates core group number. 
Specimen

Number

Site

Unit

Leve1 Length

Width Thickness

\begin{tabular}{rllllrll}
\hline 1 & 41 & LK 199 & Surface & - & 11.2 & 9.6 & 4.8 \\
2 & 41 MC 55 & N1008 E1016 & 2 & 7.5 & 5.5 & 4.4 \\
3 & 41 MC 226 & Surface & - & 9.9 & 7.9 & 4.3 \\
4 & 41 MC 288 & Surface & - & 14.2 & 9.6 & 2.5
\end{tabular}

Group 4. Unidirectional, Prepared Platform, Single Facet (18 specimens)

Core Group 4 specimens are characterized by prepared, single facet platforms from which flakes have been unidirectionally removed, usually more-or-less perpendicular to the prepared platform. Platforms were prepared by sp 1 itting a cobble or by knocking a large flake from the cobble. In some cases, 1 arge $f 1$ akes served as the core. Most Group 4 specimens retain $50-80 \%$ of the cortex; some retain 25\% or 1ess. The ranges of dimensions for Core Group 4 specimens are as follows:

Maximum Minimum Average

$\begin{array}{lrrr}\text { Length: } & 8.6 & 4.2 & 6.2 \\ \text { Width: } & 7.7 & 3.8 & 5.2 \\ \text { Thickness: } & 5.5 & 3.1 & 3.6 \\ \text { Weight: } & 429.0 & 69.0 & 154.0\end{array}$

Examples of Group 4 cores are illustrated in Figure 69.

Group 5. Multidirectional. Natural and Prepared P1atforms, Single Facet (151 specimens)

Core Group 5 specimens show evidence of $f 1$ akes struck multidirectionaliy from single facet prepared and natural platforms. Most specimens retain 25-50\% of the cortex. The ranges of metric attributes for Group 5 specimens are as follows:

Maximum Minimum Average

$\begin{array}{lrrr}\text { Length: } & 10.0 & 4.1 & 7.7 \\ \text { Width: } & 8.7 & 4.3 & 5.6 \\ \text { Thickness: } & 6.1 & 2.3 & 4.5 \\ \text { Weight: } & 690.0 & 52.0 & 239.0\end{array}$

Examples of Group 5 cores are illustrated in Figure 70.

Group 5. Cores--Possible Tools

Three of the Group 5 cores may have functioned as tools. Specimen 1, made of petrified wood, is subtriangular in outline. Similar to the possible tools described for Core Groups 2 and 3, it has a rounded, cortex-covered broad end 

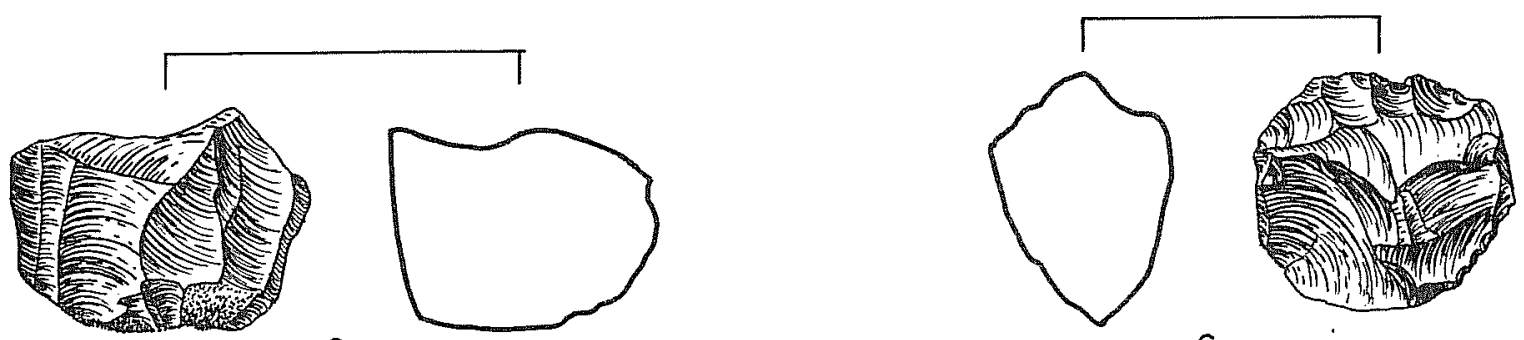

6

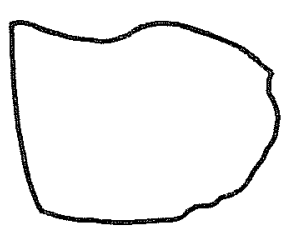

6

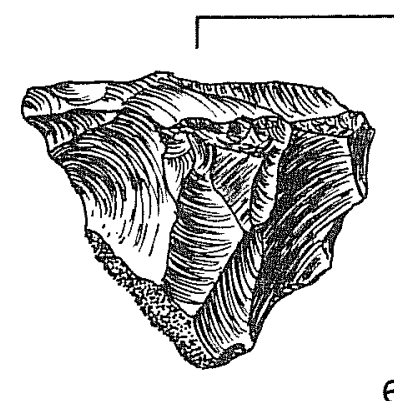

6
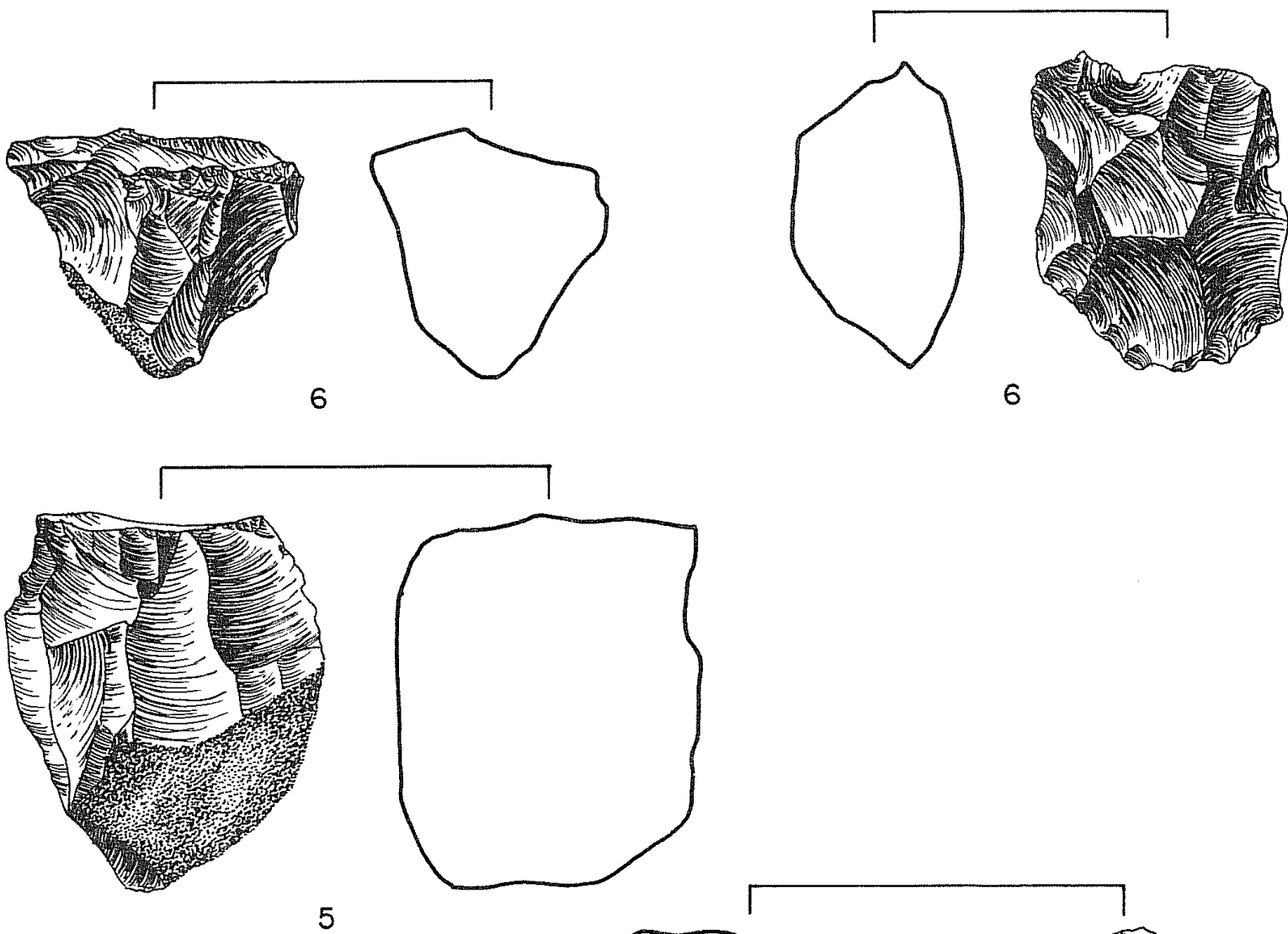

6

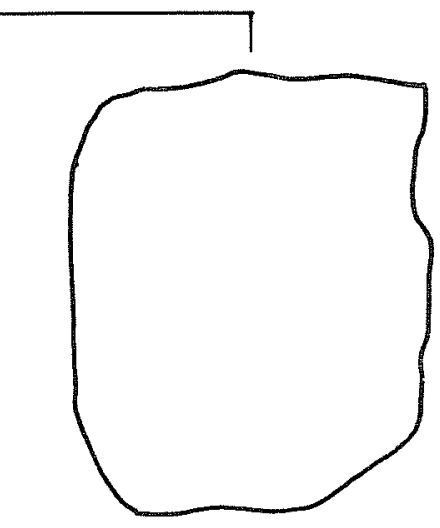

5
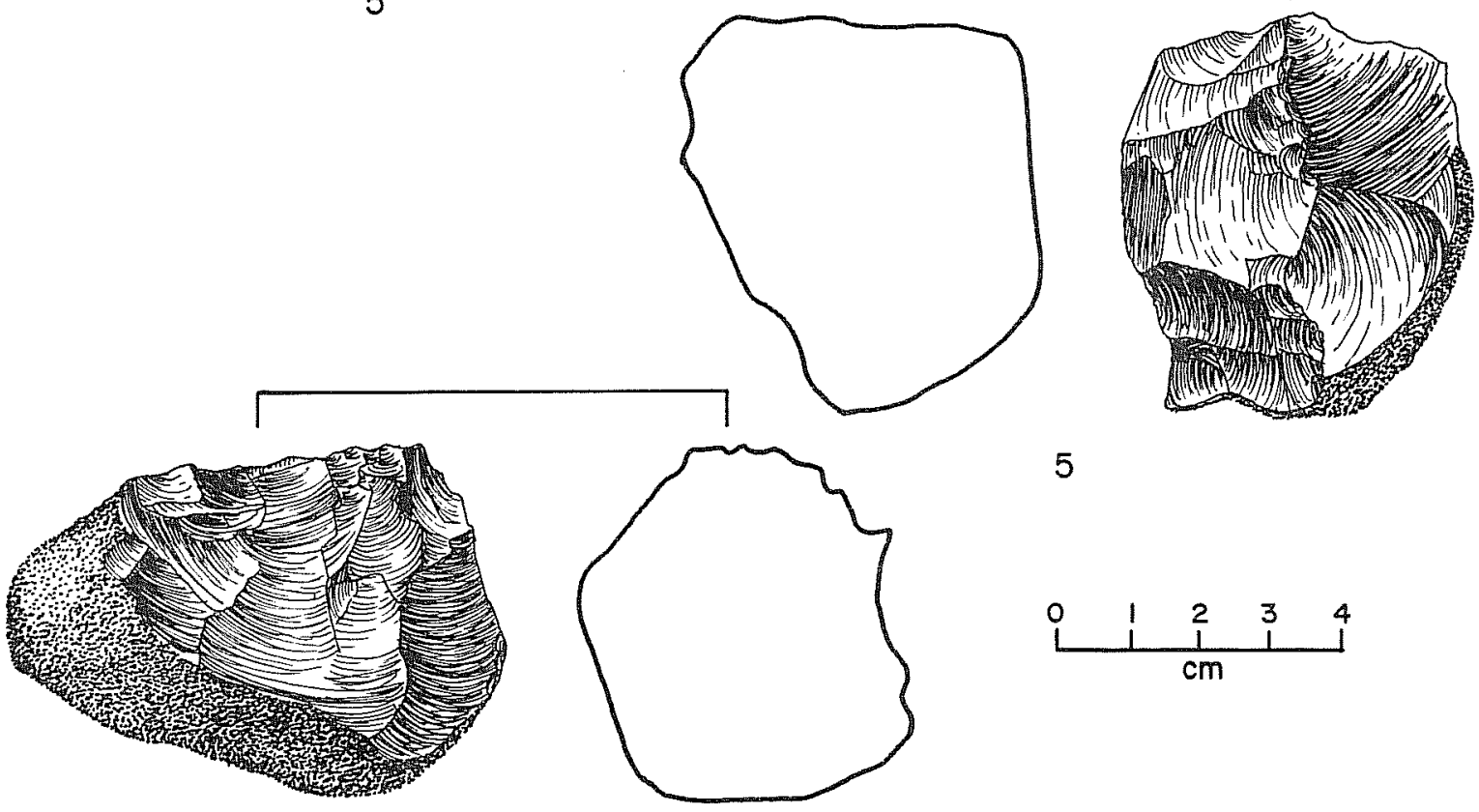

5

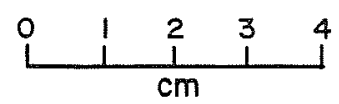

5

Figure 70. Cores: Groups 5 and 6. Number beneath artifact indicates core group number. 
opposite a sharp edge formed by removing flakes from a prepared platform around one end and two sides (Fig. 71). Specimen 2 is similar except that the presumed working edge runs along only one side of the piece. Specimen 3 is especially remarkable in that its function as a tool is clearly evidenced by pronounced smoothing and rounding of the flaked edge. This specimen most certainly was used to perform some type of scraping task that smoothed rather than crushed the working edge. Dimensions, site provenience, and, where app 7 icable, subsurface provenience, are as follows:

Specimen

Number

Site

Unit

Leve1

Length

Width Thickness

$\begin{array}{rlllrrrr}1 & 41 & \text { LK } 8 & \text { Surface } & - & 10.4 & 8.9 & 3.8 \\ 2 & 41 \text { LK } 74 & \text { N994 E986 } & 1 & 10.7 & 6.8 & 4.0 \\ 3 & 41 \text { LK } 201 & \text { N498 E998 } & 10 & 8.0 & 9.1 & 5.3\end{array}$

Group 6. Core Nuclei (9I specimens)

Group 6 specimens are core nuclei or exhausted cores that have been reduced to the point where further flake removal is impossible or impractical. All are smaller than the average-sized specimens of other core groups. Shapes vary considerably from oval to subcircular to angular and irregular. Flake scars indicate use of cortex and prepared platforms with single and multiple facets. Flakes were removed mu 1 tidirectiona11y. Platforms are common 1 y crushed or battered. Many specimens retain no cortex; some retain $25 \%$ or 1ess, and a smaller number retain 50\% of their cortex. The ranges of metric attributes for Group 6 specimens are as follows:

$\begin{array}{lrrr} & \text { Maximum } & \text { Minimum } & \text { Average } \\ \text { Length: } & 6.5 & 3.5 & \\ \text { Width: } & 4.2 & 3.2 & 4.7 \\ \text { Thickness: } & 3.1 & 2.0 & 3.7 \\ \text { Weight: } & 83.0 & 19.0 & 2.4 \\ & & & 43.0\end{array}$

\section{Group 7. Flat, Circular to El 1 iptical in Outline, Unifacially Cortex Covered (15 specimens)}

Core Group 7 specimens are flat, circular to elliptical in outline, and moreor-less biconvex in cross section. On most specimens, one face is completely covered with cortex. On others, two or more flake removals from the cortex face have eliminated from 10-50\% of the cortex. The other face is covered by flake scars of removals made from peripheral cortex platforms. Most of the specimens are portions of split cobbles or large flakes derived from cobbles. The ranges of metric attributes for Group 7 specimens are as follows: 

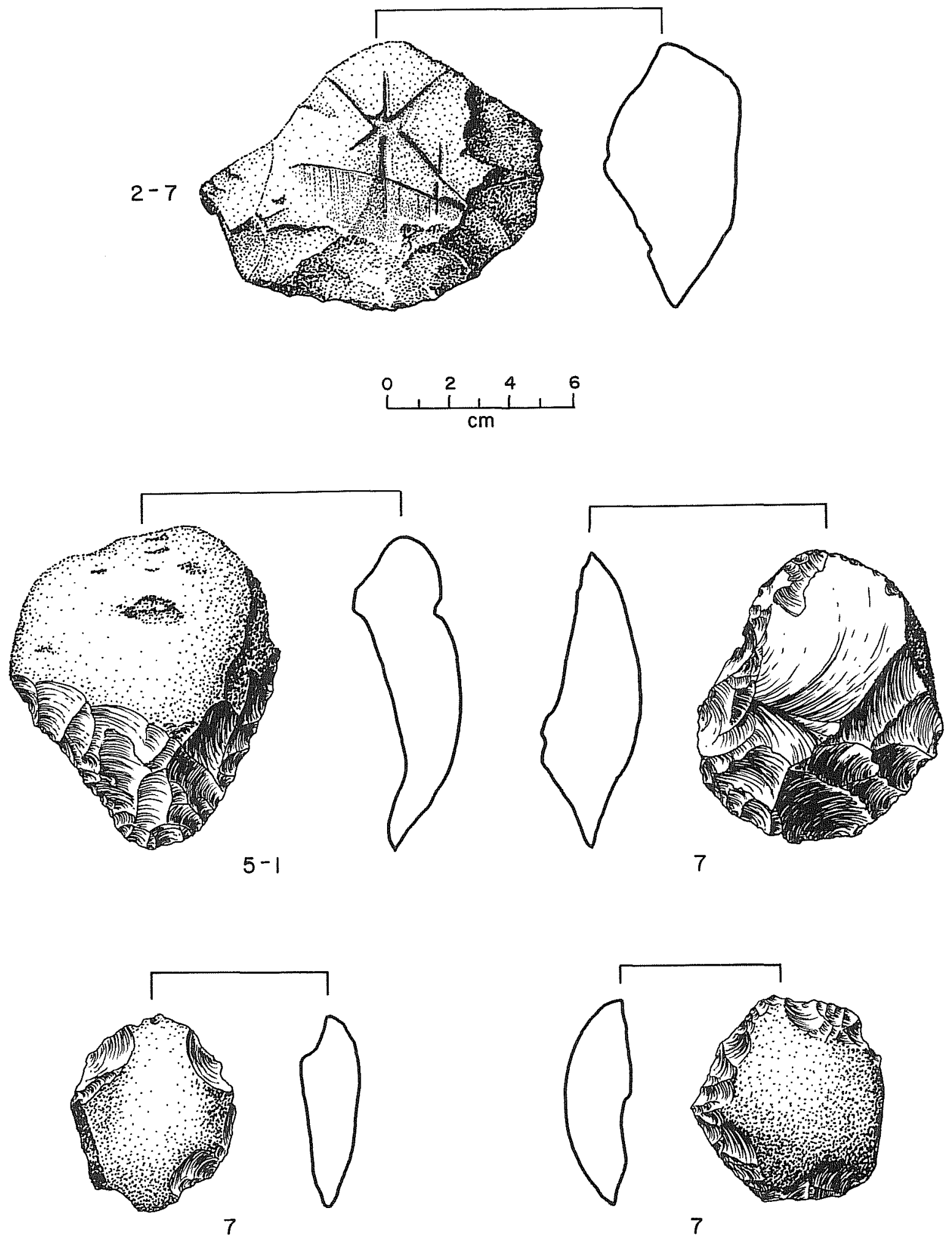

Figure 71. Cores: Groups 2 and 5--Possible Tools and Group 7. Numbers beneath artifact indicate group and specimen number, respectively. 
Maximum Minimum Average

$\begin{array}{lrrr}\text { Length: } & 9.7 & 4.7 & 6.5 \\ \text { Width: } & 8.2 & 4.1 & 5.3 \\ \text { Thickness: } & 3.9 & 2.0 & 2.3 \\ \text { Weight: } & 297.0 & 39.0 & 88.0\end{array}$

Examples of Group 7 cores are illustrated in Figure 71.

Group 8. Tested Cobbles (2 specimens)

Core Group 8 specimens are cortex-covered cobbles from which one to four natural platform flakes have been removed, possibly to "test" the quality of the material. The metric attributes for the two Group 8 specimens are as follows: Specimen 1--1ength, 10.0; width, 6.0; thickness, 5.2; weight, 463.0. Specimen 2--1ength, 10.1; width, 9.7; thickness, 4.1; weight, 613.0. Group 8 specimens are not $i 17$ ustrated.

\section{Group 9. Core Fragments (279 specimens)}

Core Group 9 specimens are unclassifiable core fragments. Most are believed to be remnants of shattered cores and trimmings resulting from $p l a t f o r m$ preparation and general shaping. No metric attributes are provided, and no specimens are illustrated.

\section{Group 10. Unmodified Cobbles (11 specimens)}

Core Group 10 specimens are unmodified, cortex-covered cobbles. These specimens are not actually cores, but may have been brought to the sites with the intention of eventual reduction. Sizes range from a maximum of $12.7 \times 5.0 \times 3.6 \mathrm{~cm}$ to a minimum of $5.4 \times 3.5 \times 3.1 \mathrm{~cm}$. No Group 10 specimens are $i 17$ ustrated.

\section{Ihick Bifaces (267 specimens)}

The thick biface specimens are percussion-flaked bifaces which (1) measure $1.3 \mathrm{~cm}$ or more in thickness; (2) exhibit 10-30 flake scars, each greater than $1 \mathrm{~cm}^{2}$; and (3) do not have forms or wear patterns suggestive of their function. A11 are assumed to be discarded manufacturing failures; however, careful microscopic examination of edges might reveal that some were used as too 75 . Both cobb le cores and flake cores were used in production of these specimens. Many specimens retain cortex on one or both faces, the degree of coverage on either face ranging from $80 \%$ to traces. The majority of specimens retain thick knots, or ridges, usually centrally located and surrounded by severe hinge fractures. The distinction between bifacial cores and thick bifaces, especially Groups 1-4 thick bifaces, should be clearly. noted. Bifacial cores exhibit less than nine flake scars and are usually thinned more at one end than the other. Thick bifaces have 10 or more flake scars and are usually thinned more uniformly than the cores. It is 
emphasized that the distinction made between cores and bifaces is arbitrary. Some of the bifacial cores may have been intended for reduction to finished bifacial tools. Likewise, artifacts grouped as thick bifaces, especially in Groups 1-4, could easily have been flake sources and not intended for reduction to finished bifacial tools. The distinction is made merely to facilitate and standardize the descriptive classifications. The thick bifaces are divided into nine morphological groupings as follows:

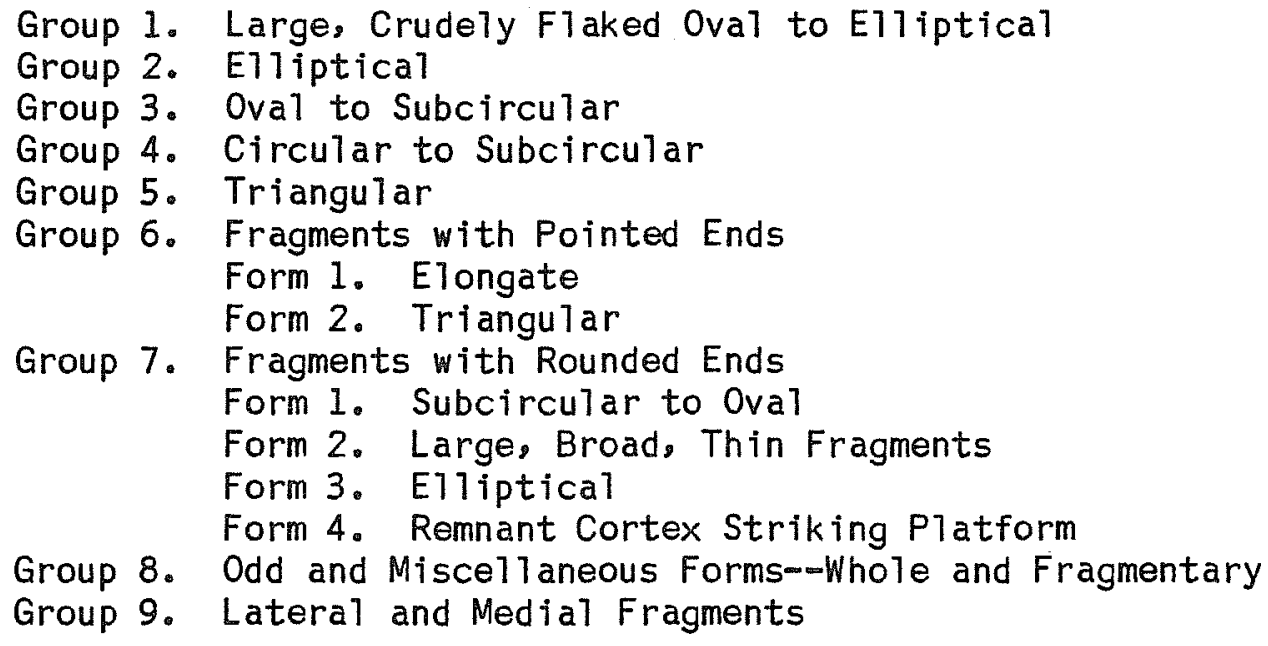

Provenience data for all thick biface groups are provided in Tables 6 and 7 .

\section{Group 1. Large, Crudely Flaked Oval to E1liptical (30 specimens)}

Group 1 thick bifaces are mostly oval to el1iptical and represent the 1 argest and most crudely flaked thick biface specimens. A few are irregularly shaped or subrectangular. It is apparent from these out 1 ine configurations, and from cortex remnants, that relatively fiat, oval to subcircular and elliptical cobbles were selected for reduction. Flakes were struck from both natural and prepared platforms around the periphery in attempts to thin the cobbles. Edges are very sinuous. Most specimens exhibit a pronounced central ridge or knot on one or both face(s), often consisting of cortex that apparently could not be further thinned. Most are thick and biconvex in cross section. In most cases, the specimens are longer than they are wide. The amount of cortex retained ranges from 50\% to traces; however, most retain 25\% or less. The total number of distinct flake scars greater than $1 \mathrm{~cm}^{2}$ on both faces of the Group 1 thick bifaces ranges from 10-30 scars. Metric attributes for Group 1 specimens range as follows:

$\begin{array}{lrrr} & \text { Maximum } & \text { Minimum } & \text { Average } \\ \text { Length: } & 13.2 & 6.7 & 8.6 \\ \text { Width: } & 6.2 & 4.2 & 5.7 \\ \text { Thickness: } & 4.2 & 2.3 & 3.0 \\ \text { Weight: } & 267.0 & 67.0 & 144.0\end{array}$

Examples of Group I thick bifaces are shown in Figure 72. 
TABLE 6. PROVENIENCE OF THICK BIFACES BY SITE

\begin{tabular}{|c|c|c|c|c|c|c|c|c|c|c|c|c|c|}
\hline \multirow{2}{*}{$\begin{array}{l}\text { SITE } \\
\text { No. }\end{array}$} & \multirow{2}{*}{$\begin{array}{c}\text { GROUP } \\
1\end{array}$} & \multirow{2}{*}{$\begin{array}{c}\text { GROUP } \\
2\end{array}$} & \multirow{2}{*}{$\begin{array}{c}\text { GROUP } \\
3\end{array}$} & GROUP & CROUP & & UP 6 & & & & & GROUP & GROUP \\
\hline & & & & 4 & 5 & FORM 1 & FOAM 2 & 1 & 2 & 3 & 4 & 8 & 9 \\
\hline 41 LKR & & & & & & & & & & & & 1 & \\
\hline 41LK14 & 1 & 1 & & & & & 1 & & & & & & \\
\hline 41 LK 27 & & 2 & 1 & & & & 1 & & & & & & \\
\hline 41LK51 & 1 & 1 & & & & & 1 & -4 & & & & 1 & 1 \\
\hline 41 LK53 & & & & & & & 1 & & & & & & \\
\hline 41LK66 & & & & & & & & & & & & & \\
\hline 41LKB9 & & & & & & & & & & & & & 1 \\
\hline $41 \mathrm{LK} 74$ & & & 1 & & & 1 & & 1 & 1 & 1 & & 3 & 1 \\
\hline $41 L K 120$ & & & & 2 & & & & 1 & & & & & \\
\hline $41 L K 121$ & & & & & & 1 & & & & & & & \\
\hline $41 \mathrm{LK} 122$ & & & & & & 1 & & & & & & 1 & \\
\hline 41LK127 & 1 & 1 & & & 2 & 1 & 1 & & & & & 1 & 2 \\
\hline $41 \angle K 128$ & 2 & 1 & & 1 & & & & & & & & 1 & 1 \\
\hline $41 L K 133$ & 1 & 1 & & & & & & & 1 & & & & 1 \\
\hline $41 \mathrm{LK} 142$ & 1. & & & & & & & & & & - & & \\
\hline $41 \mathrm{LK} 145$ & & & & & & & & & & & & & \\
\hline $41 \mathrm{LK} 149$ & 1 & & & & & & & & & & & & \\
\hline 41 LK 162 & & & & & & & & 1 & & & 1 & & \\
\hline $41 L K 173$ & 3 & & 1 & & & & & 1 & & & & & \\
\hline 41 LK174 & & & & & & & & & & & & & \\
\hline $41 \mathrm{LK} 176$ & & & & & & & & & & & & & \\
\hline 41 LK 181 & & & & & & & & & & & & & \\
\hline $41 L K 1 B 2$ & & 1 & & 1 & & & & & & & & & \\
\hline $41 \mathrm{LK} 185$ & & & 1 & & & & & & & 1 & 1 & & 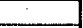 \\
\hline 41LK191 & & & & & & & & & & & & & \\
\hline 41LK197 & & & 1 & & & & & & & & & & \\
\hline 41LK199 & & 1 & 1 & $\cdot 1$ & & & & 1 & & 2 & & 3 & 3 \\
\hline 41 LK201 & & 1 & 2 & & & & & 3 & & 2 & & 5 & 5 \\
\hline $41 L K 236$ & & & & & & & & & & & & & \\
\hline 41 LK243 & 2 & 3 & 1 & & & 1 & 1 & 1 & & 2 & & 3 & 1 \\
\hline 41 LK247 & & & & & & & & & & & & & \\
\hline 41LK250 & 1 & & & & & & 1 & & & & & & \\
\hline 41LK252 & & 1 & 1 & 4. & & & 3 & 2 & 1 & 2 & & 3 & \\
\hline $41 L K 253$ & 2 & 2 & & 1 & & & 1 & 2 & & & & & \\
\hline & & & & & & $=$ & & & & & & & \\
\hline $41 M C 7$ & & & & & & & & & & & & & \\
\hline $41 \mathrm{MC} 10$ & & & & & & & & & & & & & \\
\hline $41 \mathrm{MCl} 14$ & & & & & & & & & & & & & \\
\hline $41 \mathrm{MC} 15$ & & & & & & & & & 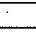 & & & & \\
\hline $41 \mathrm{MC} 17$ & & & & & & & & & & & & & \\
\hline $41 \mathrm{MC29}$ & & & & & & & & & & & & & 1 \\
\hline $41 \mathrm{MC} 55$ & 2 & & & & & & 1 & & & & & & \\
\hline $41 \mathrm{MC} 67$ & & & & & & & & & & & & & \\
\hline $41 M C 75$ & & & & & & & & & & & & & \\
\hline $41 \mathrm{MC79}$ & & & & & & & & & & & & & \\
\hline $41 \mathrm{MC} 94$ & & & & & & & & & & & & & \\
\hline $41 \mathrm{MC} 192$ & & & 1 & & 1 & & & & & 1 & & & 1 \\
\hline $41 \mathrm{MC} 193$ & & & & & & & & & & - & & & \\
\hline $41 \mathrm{MC} 194$ & & & & & & & & & & & & & \\
\hline $41 \mathrm{MC} 196$ & & & 1 & & & & & & & & & & \\
\hline $41 \mathrm{MC2} 12$ & & & & & 1 & $\cdot$ & & & & 2 & & & \\
\hline $41 \mathrm{MC} 213$ & 1 & 1 & & & & & 1 & 2 & 1 & & 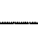 & 1 & \\
\hline $41 M C 214$ & & & & & & & & & & & & & \\
\hline $41 \mathrm{MC222}$ & & & & & & & & & & & & & \\
\hline $41 \mathrm{MC} 226$ & & 1 & & & 1 & 1 & & 4 & & 1 & & 1 & 2 \\
\hline $41 \mathrm{MC} 234$ & & & & & & & & & & & 1 & & \\
\hline $41 \mathrm{MC} 235$ & & & 1 & & 1 & & & 1 & & & & & \\
\hline $41 \mathrm{MC} 238$ & 3 & . & & & & & 1 & - & & . & & 1 & 1 \\
\hline $41 \mathrm{MC242}$ & 1 & & & & & & & & & & & & \\
\hline $41 \mathrm{MC} 246$ & & & & & & & & 1 & & & 1 & & \\
\hline $41 \mathrm{MC251}$ & & 1 & & & 1 & & 1 & 2 & & & & 1 & 1 \\
\hline $41 \mathrm{MC} 257$ & & & & & & & & & & & & & 1 \\
\hline $41 M C 260$ & & 2 & & & & & & & & & & & \\
\hline $41 \mathrm{MC266}$ & & & & & & & & & & & & & \\
\hline $41 \mathrm{MC2} 67$ & & & & & & & & & & & & & \\
\hline $41 \mathrm{MC} 268$ & 1 & 3 & 1 & 1 & & & 1 & 1 & & & 1 & & 1 \\
\hline $41 \mathrm{MC} 270$ & 2 & & 1 & & & & & 1 & & & & & \\
\hline $41 \mathrm{MC} 275$ & 2 & 2 & 2 & 3 & & & 1 & 2 & & 1 & & & 1 \\
\hline $41 M C 276$ & & & & 1 & & & & 1 & & & & 1 & 1 \\
\hline $41 \mathrm{MC} 282$ & & 3 & 2 & 1 & & & & 4 & & 1 & & & \\
\hline $41 \mathrm{MC} 284$ & & 1 & & & & 1 & & & & & & & \\
\hline $41 M C 288$ & & & & & 1 & 1 & & 2 & & & & & \\
\hline $41 \mathrm{MC} 293$ & & 1 & & & & & & & & 1 & & & 1 \\
\hline $41 \mathrm{MC294}$ & 1 & 1 & & & & 1 & & & 1 & & & & \\
\hline $41 \mathrm{MC296}$ & 1 & 1 & 1 & 3 & & 1 & 1 & 7 & & & & 1 & 2 \\
\hline
\end{tabular}


TABLE 7. PROVENIENCE OF THICK BIFACES RECOVERED IN PHASE II EXCAVATIONS

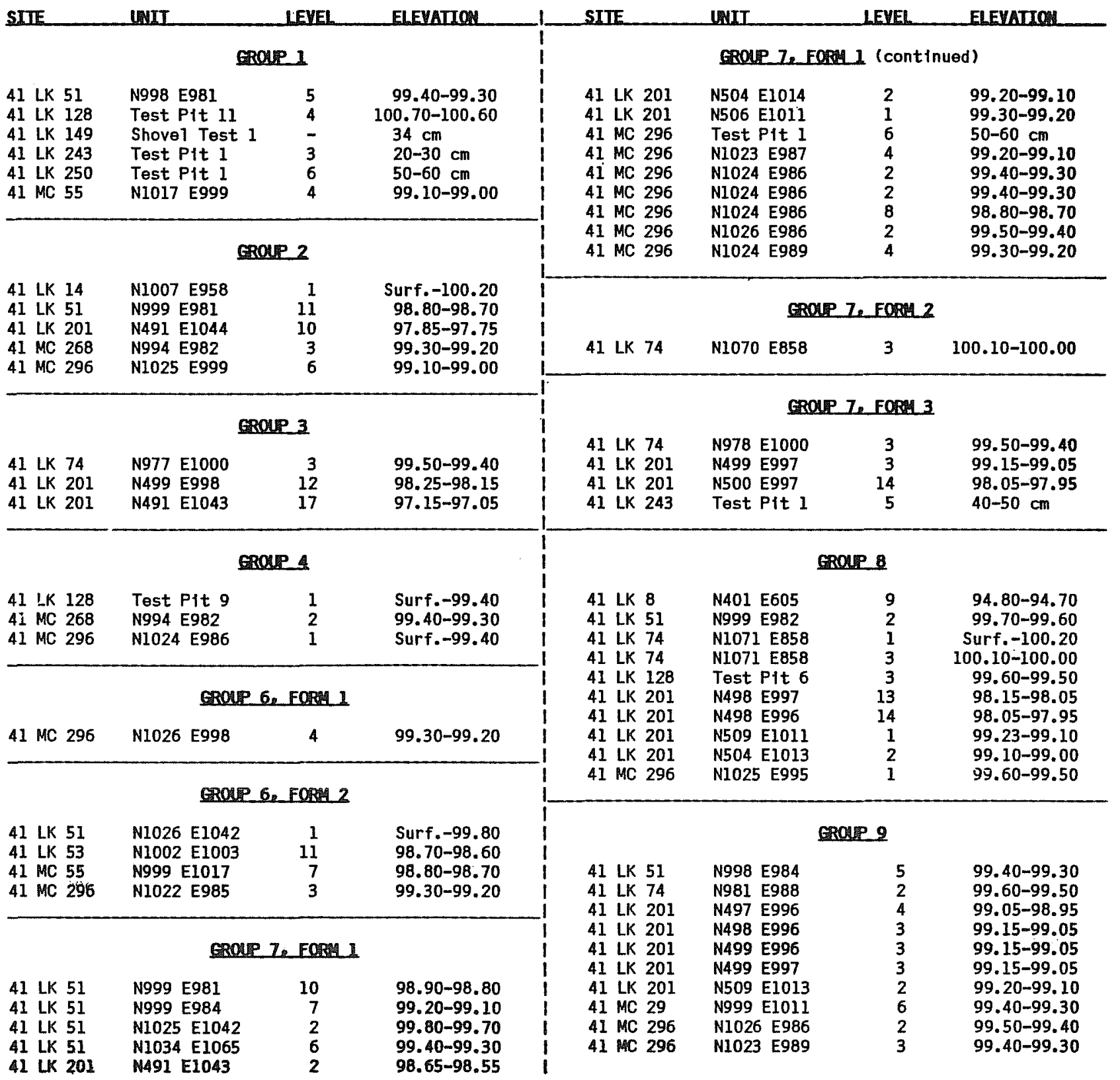




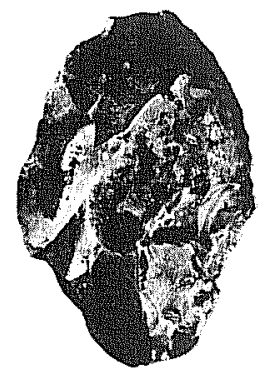

3

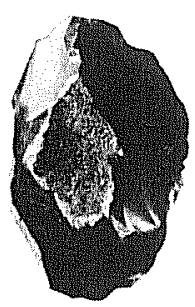

3

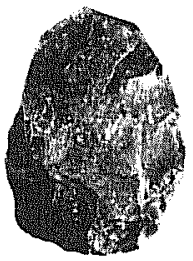

3

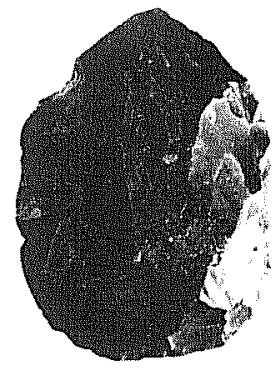

3
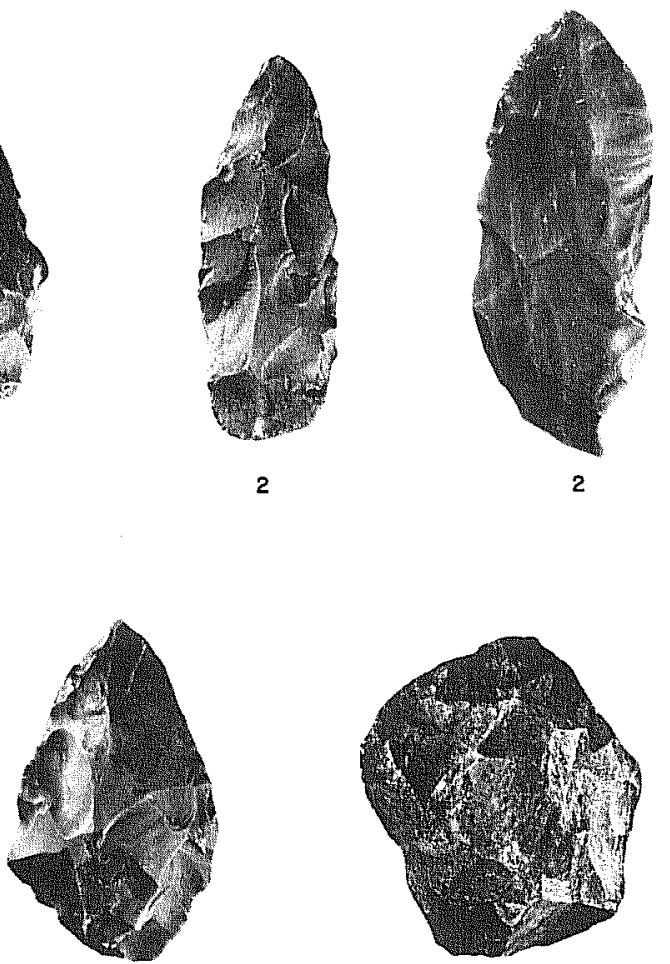

2

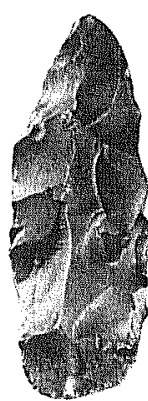

2

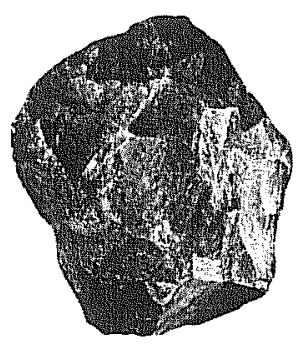

1

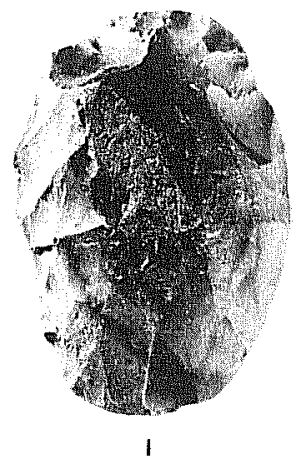

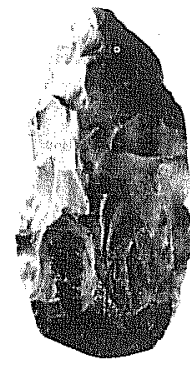

2

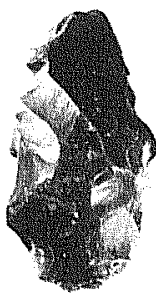

2
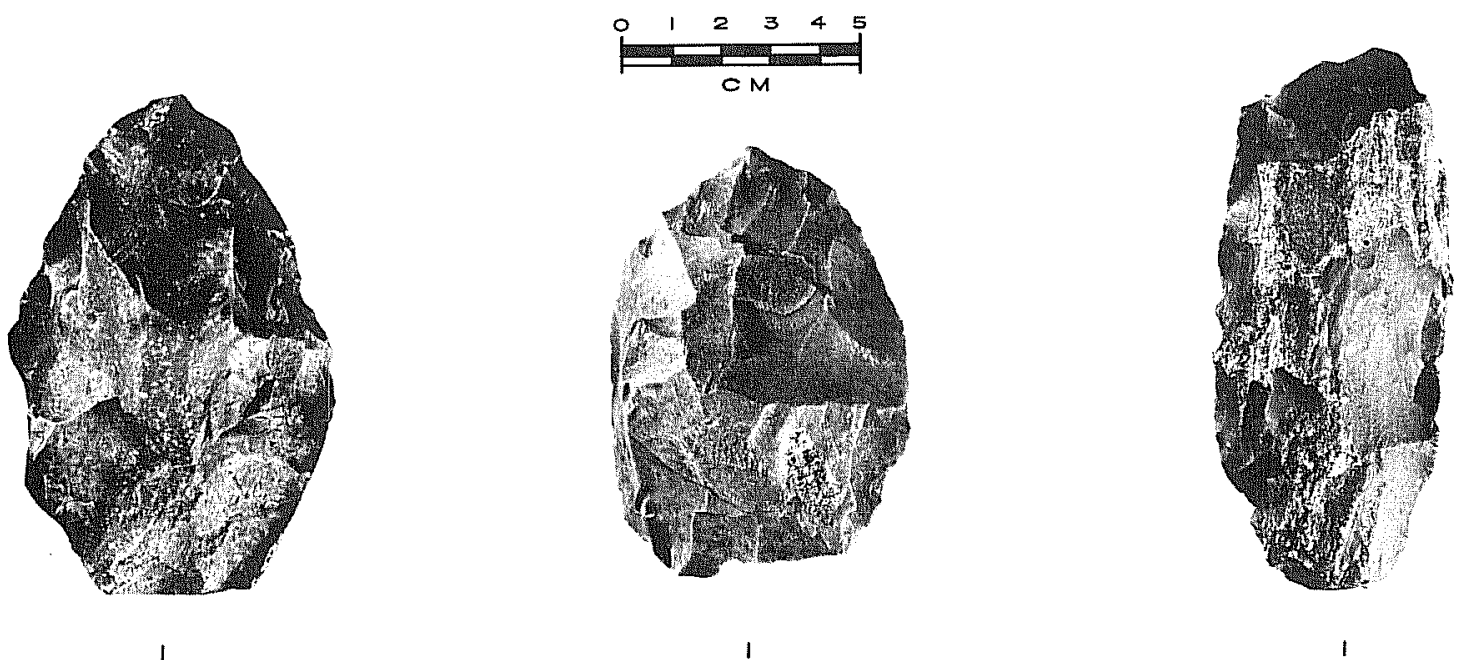

Figure 72. Thick Bifaces: Groups 1, 2, and 3. Number beneath artifact indicates group number. 


\section{Group 2. Elliptical (33 specimens)}

Group 2 thick biface specimens are elliptical in greater or lesser degrees of uniformity with edges varying from moderately undulating and sinuous to fairly smooth and straight. In cross section, most are biconvex, although some are plano-convex. Group 2 specimens are uniformly smaller and flatter than Group 1 thick bifaces, but still retain the thick central ridges suggestive of thinning difficulties. Group 2 specimens are pronouncedly more elongate than oval; the lengths are consistently two times the width. Thicknesses more nearly approach widths than those of Group 1 thick bifaces. The total number of $f 1$ ake scars greater than $1 \mathrm{~cm}^{2}$ on both faces of the Group 2 thick bifaces ranges from 10-32 scars. Metric attributes for Group 2 specimens range as follows:

Maximum Minimum Average

$\begin{array}{lrrr}\text { Length: } & 9.3 & 5.8 & 7.4 \\ \text { Width: } & 4.4 & 3.1 & 3.8 \\ \text { Thickness: } & 2.1 & 1.5 & 1.8 \\ \text { Weight: } & 76.0 & 24.0 & 51.0\end{array}$

Examples of Group 2 thick bifaces are illustrated in Figure 72.

Group 3. Oval to Subcircular (20 specimens)

Group 3 thick biface specimens are oval to subcircular in outline form. Edges vary from moderately undulating and sinuous to fairly smooth and straight. Most specimens are biconvex in cross section, although there are plano-convex examples. The widths of Group 3 bifaces are more nearly equal their lengths, and the thickness of most specimens is less than half the width. Total number of $f 7$ ake scars greater than $1 \mathrm{~cm}^{2}$ on both faces of the Group 3 thick bifaces ranges from 11-28 scars. Metric attributes for Group 3 specimens range as fol lows:

$\begin{array}{lrrr} & \text { Maximum } & \text { Minimum } & \text { Average } \\ \text { Length: } & 7.2 & 4.9 & 6.0 \\ \text { Width: } & 5.2 & 3.7 & 4.4 \\ \text { Thickness: } & 2.2 & 1.3 & 1.9 \\ \text { Weight: } & 86.0 & 24.0 & 54.0\end{array}$

Examples of Group 3 thick bifaces are illustrated in Figure 72.

Group 4. Circular to Subcircular (19 specimens)

Group 4 thick biface specimens are circular to subcircular in out 1 ine. Edges are moderately sinuous and undulating. Cross sections are mostly biconvex with a few plano-convex specimens also represented. Widths equal, or nearly equal. lengths. Thicknesses range from one-half to three-quarters of the length and width dimensions. Total number of flake scars greater than $1 \mathrm{~cm}^{2}$ 
on both faces ranges from 11-25 scars. The ranges of metric attributes for Group 4 thick bifaces are as follows:

$\begin{array}{rrr}\text { Maximum } & \text { Minimum } & \text { Average } \\ 7.5 & & \\ 7.4 & 4.4 & 5.8 \\ 1.8 & 4.1 & 5.1 \\ 111.0 & 1.7 & 1.9 \\ & 37.0 & 57.0\end{array}$

Examples of Group 4 thick bifaces are illustrated in Figure 73.

Group 5. Triangular (8 specimens)

Group 5 thick biface specimens are triangular with slightly sinuous to straight edges and biconvex cross sections. Lengths approach twice the widths in most cases. Thicknesses are usually about half the widths. All specimens retain 1 ess than $25 \%$ cortex. Number of $f 1$ ake scars greater than $1 \mathrm{~cm}^{2}$ on both faces ranges from 12-26 scars. The ranges of metric attributes for Group 5 specimens are as follows:

Maximum Minimum Average

$\begin{array}{lrrr}\text { Length: } & 7.3 & 4.4 & 6.9 \\ \text { Width: } & 4.5 & 3.5 & 4.1 \\ \text { Thickness: } & 2.4 & 1.6 & 1.7 \\ \text { Weight: } & 67.0 & 26.0 & 46.0\end{array}$

Examples of Group 5 thick bifaces are shown in Figure 73.

Group 6. Fragments with Pointed Ends (28 specimens)

Thick biface Group 6 specimens are fragments with pointed ends. The group is further divided into two forms--elongate and triangular--based on outline. A1 1 are probab1y incomplete examp 1 es of Group 2 (e11iptica 1) and Group 5 (triangular) thick bifaces. Except that they are broken, the Group 6 specimens are otherwise similar to Group 2 and Group 5 with respect to cross section shape, degree of cortex remova1, and number of flake scars. Metric attribute ranges are given below for Forms 1 and 2. Length and width ranges represent incomplete measurements due to the fragmentation of the specimens. Examples of Group 6 specimens are shown in Figure 73.

Eorm 1. Elongate (10 specimens)

$\begin{array}{lccc} & \text { Maximum } & \text { Minimum } & \text { Average } \\ \text { Length: } & 9.4^{*} & 4.7^{*} & 6.3^{*} \\ \text { Width: } & 4.3 & 2.5 & 3.5 \\ \text { Thickness: } & 1.3 & 1.5 & 1.6 \\ \text { Weight: } & 49.0^{*} & 17.0^{*} & 40.0^{*}\end{array}$




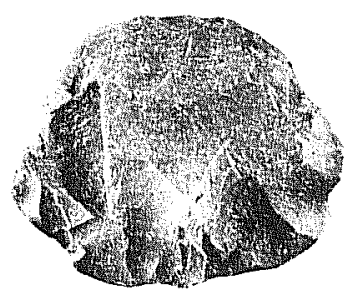

4

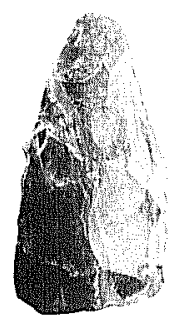

5

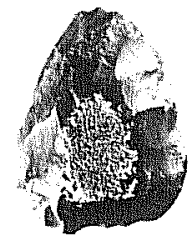

5
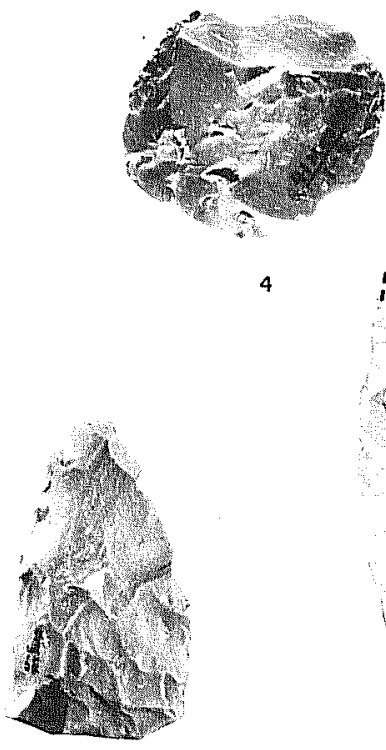

5

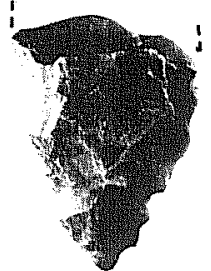

6-2

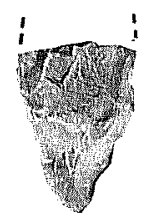

6- 2

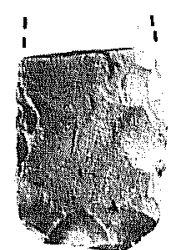

7-1

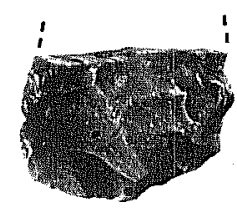

$7-1$

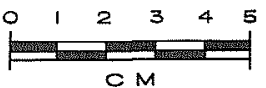

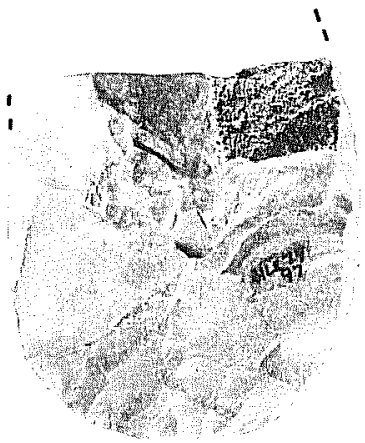

$7-2$

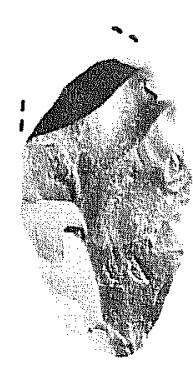

$7-4$

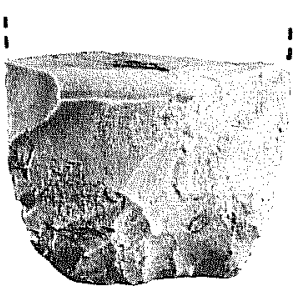

$7-2$

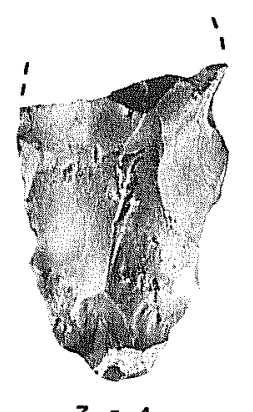

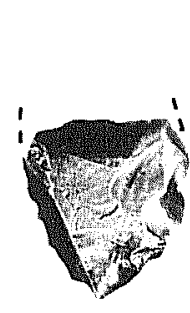

$7-3$

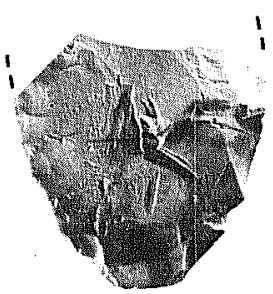

$7-3$

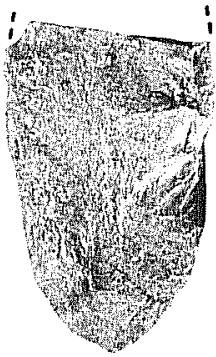

6-1

$6-1$

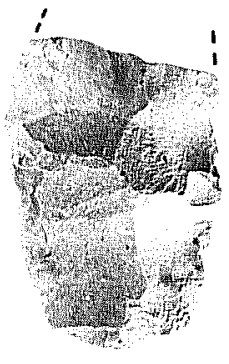

$7-1$

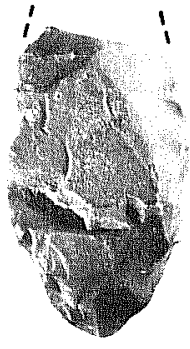

$7-3$
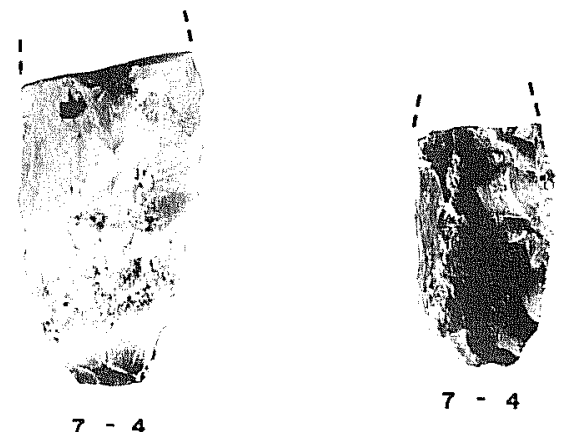

$7=4$

Figure 73. Thick Bifaces: Groups 4, 5, 6, and 7. Numbers beneath artifact indicate group and form number, respectively. 
Eorm 2. Triangular (18 specimens)

$\begin{array}{ccc}\text { Maximum } & \text { Minimum } & \text { Average } \\ 6.2^{*} & 3.5^{*} & 5.2^{*} \\ 6.0 & 2.2 & 4.6 \\ 2.0 & 1.3 & 1.7 \\ 71.0^{*} & 9.0^{*} & 38.0 *\end{array}$

Group 7. Fragments with Rounded Ends (72 specimens)

Group 7 thick biface specimens are fragments with rounded ends as a common characteristic. The group is further subdivided into four forms. Form 1 specimens are broken examples of Group 2 (elliptical) and/or Group 3 (oval to subcircular) thick bifaces. Form 2 specimens are fragments of 1 arge, broad, relatively thin bifaces, not analogous to any of the previously described thick biface groups. The Form 2 specimens probab 1 y represent failures in attempts to produce large, knifelike thin bifaces (e.g.s Group 4, Form 3 thin bifaces). Form 3 specimens may be fragments of Group 2 (el1iptical) thick bifaces in that their broken lengths substantial1y exceed their widths. Form 4 specimens are unique in that a cortex striking platform is preserved on the rounded end. Cross section, degree of cortex removal, and number of flake scars of Group 7 specimens are similar to thick biface Groups 2 and 3. Metric attribute ranges are given below for Forms 1-4. Length and weight ranges represent incomplete measurements due to the fragmentation of the specimens. Examples of Group 7 thick bifaces are 117 ustrated in Figure 73.

Eorm 1. Fragments of Subcircular and Oval Bifaces (45 specimens)

$\begin{array}{lccc} & \text { Maximum } & \text { Minimum } & \text { Average } \\ \text { Length: } & 7.5^{*} & 2.7^{*} & 4.5^{*} \\ \text { Width: } & 4.4 & 4.3 & 4.5 \\ \text { Thickness: } & 1.9 & 1.4 & 1.6 \\ \text { Weight: } & 81.0^{*} & 15.0 * & 40.0 *\end{array}$

Form 2. Large, Broad, Thin Fragments (five specimens)

$\begin{array}{lccc} & \text { Maximum } & \text { Minimum } & \text { Average } \\ \text { Length: } & 7.5^{*} & 4.6^{*} & 5.9^{*} \\ \text { Width: } & 7.1 & 5.7 & 6.6 \\ \text { Thickness: } & 2.3 & 1.6 & 1.5 \\ \text { Weight: } & 151.0^{*} & 52.0^{*} & 65.0 *\end{array}$


Eorm 3. Elliptical (17 specimens)

Maximum Minimum Average

$\begin{array}{lccc}\text { Length: } & 7.1^{*} & 3.3^{*} & 4.6 * \\ \text { Width: } & 5.0 & 3.6 & 4.1 \\ \text { Thickness: } & 1.9 & 1.2 & 1.5 \\ \text { Weight: } & 53.0^{*} & 15.0^{*} & 30.0^{*}\end{array}$

Eorm 4. Cortex Striking Platform (five specimens)

Maximum Minimum Average

$\begin{array}{lccc}\text { Length: } & 7.3^{*} & 4.6^{*} & 6.2^{*} \\ \text { Width: } & 3.7 & 2.8 & 3.8 \\ \text { Thickness: } & 2.5 & 1.9 & 1.8 \\ \text { Weight: } & 61.0^{*} & 36.0^{*} & 46.0^{*}\end{array}$

Group 8. Odd and Miscellaneous Forms-Whole and Fragmentary (28 specimens)

Group 8 thick biface specimens are whole and fragmentary with odd and miscellaneous shapes unlike any of the previously described groups. Metric attribute ranges for Group 8 specimens are as follows:

Maximum

Length:

Width:

Thickness:

Weight:
8.5

3.9

2.0

64.0
Minimum

2.7

3.4

1.4

14.0
Average

5.4

3.9

2.0

49.0

Group 8 specimens are not illustrated.

Group 9. Lateral and Medial Fragments (29 specimens)

Group 9 thick bifaces are unclassifiable fragments, probably derived from specimens from previously described thick biface groupings. Metric attribute ranges for Group 9 specimens are given below. Length, width, and weight are incomplete measurements, due to fragmentation of the specimens.

$\begin{array}{lccc} & \text { Maximum } & \text { Minimum } & \text { Average } \\ \text { Length: } & 5.8 * & 2.0 * & 4.4^{*} \\ \text { Width: } & 5.2^{*} & 3.1 * & 3.5^{*} \\ \text { Thickness: } & 2.0 & 1.6 & 1.5 \\ \text { Weight: } & 89.0 * & 13.0 * & 26.0 *\end{array}$

Group 9 specimens are not illustrated. 
Ihln Blfaces (1095 specimens)

Specimens classed as thin bifaces measure less than $1.3 \mathrm{~cm}$ thick: generally have straight, smooth edges; and show signs of being worked into their present shapes more by pressure flaking than by percussion. Only rarely is cortex retained on these specimens. Flake scars are generally much less than $1 \mathrm{~cm}^{2}$ in area and coalesce to the extent that it is impossible to count them. Functional categories bel ieved to be represented are dart points, arrow points, knives, and manufacturing failures. To avoid implying function with terminology, the thin bifaces are divided into groups and forms based on general morphological characteristics. The group divisions are based primarily on outline and size. Forms reflect more specific details such as thickness, workmanship, and manufacture. Previously established type names have been given to groups or individual artifacts when confident assignment was possible. If the group, type, or specimen is diagnostic of a time period, the age range is noted along with a reference to the source from which the reference is derived. The time ranges given for diagnostic types are derived from the better known chronologies developed for central Texas and the Trans-Pecos area. Now, however, with the radiocarbon assays resulting from two phases of investigations at Choke Canyon, as well as from investigations at a number of other south Texas sites, there is a substantial body of absolute chronological data now available for reference. Where appropriate, these are mentioned as individual artifacts and described. Site proveniences for thin bifaces are provided in Tab 1 es 8 and 9. Except for Groups 9 and 10 (not 11 lustrated), a 11 groups are $i 11$ ustrated in Figures 7480. The thin bifaces are divided into 10 morphological groupings as follows:

\begin{tabular}{|c|c|}
\hline coup 1. & $\begin{array}{l}\text { Stemmed } \\
\text { Form 1. Large with Straight Stems } \\
\text { Form 2. Large with Contracting Stems } \\
\text { Form 3. Large with Expanding Stems } \\
\text { Form 4. Small with Contracting Stems } \\
\text { Form 5. Small with Expanding Stems } \\
\text { Form 6. Unclassifiable Fragments of Large Stemmed Bifaces } \\
\text { Form 7. Unclassifiable Fragments of Smal1 Stemmed Bifaces }\end{array}$ \\
\hline roup 2. & $\begin{array}{l}\text { Unstemmed with Straight Bases } \\
\text { Form 1. Complete Triangular } \\
\text { Form 2. Proximal Fragments }\end{array}$ \\
\hline & $\begin{array}{l}\text { Unstemmed with Concave Bases } \\
\text { Form 1. Complete Triangular } \\
\text { Form 2. Proximal Fragments }\end{array}$ \\
\hline roup 4. & $\begin{array}{l}\text { Unstemmed with Convex to Semicircular Bases } \\
\text { Form 1. Complete Triangular } \\
\text { Form 2. Steeply Beveled Blades } \\
\text { Form 3. Oval to Elliptical } \\
\text { Form 4. Fragments with Convex to Semicircular Ends }\end{array}$ \\
\hline $\begin{array}{l}\text { roup } 5 . \\
\text { roup } 6 . \\
\text { roup } 7 . \\
\text { roup } 8 . \\
\text { roup } 9 . \\
\text { roup } 10\end{array}$ & $\begin{array}{l}\text { Unstemmed Leaf Shaped } \\
\text { Circular to Subcircular } \\
\text { Diamond Shaped } \\
\text { Bifaces with Sharp. Slender Projections } \\
\text { Fragments with Pointed Ends } \\
\text { Lateral and Medial Fragments }\end{array}$ \\
\hline
\end{tabular}


TABLE 8. PROVENIENCE OF THIN BIFACES BY SITE

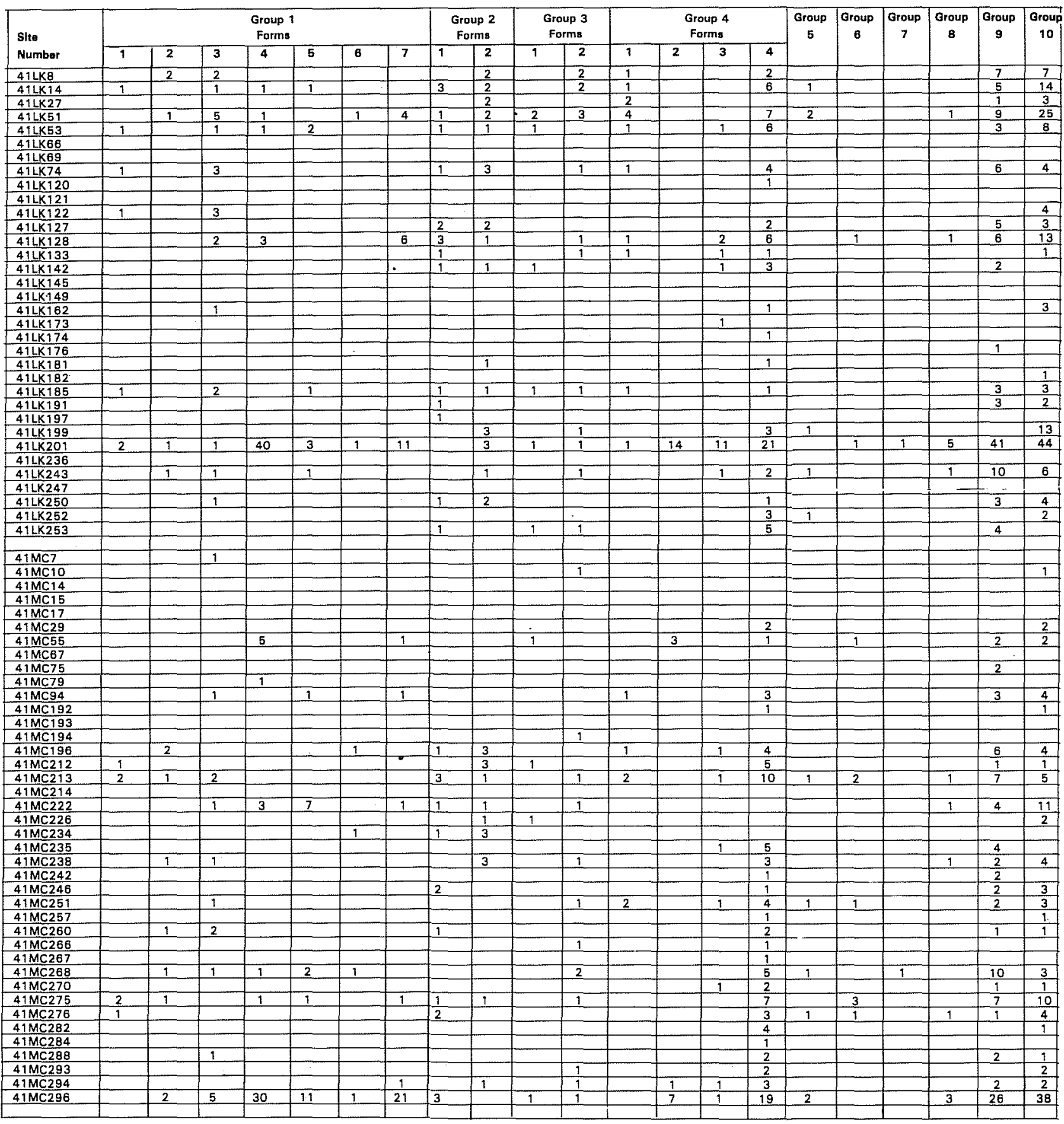


For stemmed specimens, the following metric attributes are given:

Length--maximum dimension from distal tip to base.

Width--maximum dimension from blade edge to blade edge, usually occurring at the juncture of blade and stem.

Thickness--maximum dimension at thickest part of specimen, regardiess of overall location.

Stem Length--the dimension from the stem base to the juncture of stem and blade.

Stem Width--widest dimension of the stem.

Neck Width--dimension of the stem at the stem/blade juncture.

Weight--in grams as determined on a triple beam balance scale.

For unstemmed specimens, only length, width, thickness, and weight attributes are given. These same attributes were presented for the Phase I collection from Choke Canyon, but definitions for each dimension were inadvertently left out of the report (Hall, Black, and Graves 1982:282).

Group 1. Stemmed (236 specimens)

Form 1. Large with Straight Stems (13 specimens)

Thin biface Group 1, Form I specimens are large, stemmed bifaces with moreor-less straight stems with parallel edges. Four of the specimens represent previously established dart point typological groups, Pedernales and Bell. There is considerable diversity among the remaining nine specimens. Provenience and metric data are provided in Table 9.

Specimens 1-2, 5: Pedernales. On Specimen 1, one blade edge is straight, the other is slightly concave. The shoulders are moderately barbed. Stem edges are straight, and the base is broadly concave. The asymmetrical shaping of the blade edges suggests use of the piece as a cutting tool. Specimen 2 consists of a proximal fragment on $7 y$. The shoulders appear to be rounded rather than barbed. The base is notched by a narrow, deep $(0.4 \mathrm{~cm})$ concavity quite different from Specimen 1. Specimen 5 was recovered in subsurface excavations at 41 LK 201 (Highley 1986). The Pedernales type is a Middle Archaic diagnostic in central Texas. No specimens have been recovered from dated subsurface context at Choke Canyon.

Specimen 3: Be11. Specimen 3 1acks a distal tip and appears to have been retouched along the $b 7$ ade edges subsequent to breakage. The blade edges are crooked and roughly serrated. Both barbs, normally quite long on the Be11 type, are broken. Stem edges and base are more-or-less straight. The base has been thinned by removal of flakes from the basal edge. The Be 11 type is an Early Archaic diagnostic in central Texas, but has not been recovered from dated subsurface context at Choke Canyon.

Specimen 4: This specimen has slightly convex blade edges and very weak shoulders. The base is broadly concave. Deposits yielding the specimen have been radiocarbon dated to between 1300 B.C. (TX-3022) and 660 B.C. (TX-4673). 
TABLE 9. PROVENIENCE AND METRIC DATA FOR STEMMED THIN BIFACES

\begin{tabular}{|c|c|c|c|c|c|c|c|c|c|c|c|c|c|}
\hline Group & Form & Spect- & Type & Slte & Lot No. & & lence & Langth & Width & Thick- & Stem & Stem & Neck \\
\hline & & men No. & & & & Unit & Level & & & & & Width & Width \\
\hline 1 & 1 & 1 & \begin{tabular}{|c|} 
Pedernales \\
\end{tabular} & $41 \mathrm{MC} 213$ & $2-42$ & Surface & & 5.1 & 2.6 & 0.6 & 1.6 & 1.7 & 1.8 \\
\hline 1 & 1 & 2 & \begin{tabular}{|l|} 
Pedernales \\
\end{tabular} & $41 \mathrm{MC275}$ & $5-13$ & Surface & & $\div$ & 3.2 & 0.7 & 1.7 & 1.9 & 1.9 \\
\hline 1 & 1 & 3 & \begin{tabular}{|l|l|} 
Bell \\
\end{tabular} & $41 L K 122$ & $2-2$ & Surface & & $3.3^{*}$ & 3.0 & 0.5 & 1.3 & 1.5 & 1.5 \\
\hline 1 & 1 & 4 & & 41 LK74 & 41 & N988E991 & Surf.-99.30 & 6.3 & 2.1 & 0.6 & 1.6 & 2.0 & 1.9 \\
\hline 1 & 1 & 5 & Padernales & 41 LK201 & 404 & N498E996 & $97.65 \cdot .55$ & 7.1 & 2.2 & 0.9 & 1.5 & 2.2 & 2.1 \\
\hline 1 & 9 & 6 & & 41 LK14 & 300.0 & \begin{tabular}{|l|} 
Surface \\
\end{tabular} & & $5.5^{*}$ & 3.1 & 0.9 & 1.7 & 2.1 & 2.1 \\
\hline 1 & 1 & 7 & & 41 LK53 & 106 & N1001E1003 & 99.68 .60 & $\div$ & 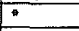 & 0.5 & 0.8 & 1.1 & 1.0 \\
\hline 1 & 1 & 8 & & 41 LK185 & $48-25$ & $\begin{array}{l}\text { Surface } \\
\end{array}$ & & $5.2^{\circ}$ & $2.6^{*}$ & 0.7 & 1.3 & 2.1 & 2.0 \\
\hline 1 & 1 & 9 & & $41 \mathrm{LK} 201$ & 167 & N49OE 1044 & $97.85-.75$ & 8.9 & 2.6 & 0.9 & 2.3 & 2.2 & 2.2 \\
\hline 1 & 1 & 10 & & $41 \mathrm{MC2} 212$ & 1.0 & \begin{tabular}{|l|} 
Surface \\
\end{tabular} & & $4.2^{\circ}$ & 2.5 & 0.6 & 1.0 & 1.7 & 1.8 \\
\hline 1 & 1 & 11 & & $41 \mathrm{MC213}$ & $2-18$ & Surface & & $5.9^{\circ}$ & 2.5 & 0.9 & 1.5 & 2.1 & 2.1 \\
\hline 1 & 1 & 12 & & $41 \mathrm{MC} 275$ & $5-4$ & Surface & & & 2.5 & 0.8 & 1.5 & 1.6 & 1.7 \\
\hline 1 & 1 & 13 & & $41 \mathrm{MC} 276$ & $1-3$ & \begin{tabular}{|l|} 
Surface \\
\end{tabular} & & 5.7 & 2.4 & 1.0 & 1.2 & 2.0 & 1.9 \\
\hline 1 & 2 & 1 & Morhiss & $41 \mathrm{LK} 8$ & 120 & $\begin{array}{l}\text { N460E542 } \\
\end{array}$ & $97.80-.70$ & 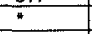 & 3.3 & 0.8 & 1.9 & 2.1 & 2.1 \\
\hline 1 & 2 & 2 & Morhiss & $41 \mathrm{MC} 196$ & 27.0 & Surface & & 6.8 & 2.6 & 0.8 & 1.9 & 2.3 & 2.3 \\
\hline 1 & 2 & 3 & Langtry & 41LK551 & 325 & N1034E1065 & $99.10-99.00$ & $\div$ & $\bullet$ & 0.7 & 2.1 & 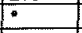 & 1.5 \\
\hline 1 & 2 & 4 & \begin{tabular}{|l|} 
Langitry \\
\end{tabular} & $41 \mathrm{MC} 196$ & $23-0$ & Surfaco & & 5.7 & 3.3 & 0.6 & 1.8 & 1.8 & 1.8 \\
\hline 1 & 2 & 5 & Langtry & $41 \mathrm{MC} 213$ & $2-15$ & Surface & & 6.8 & $2.9^{\circ}$ & 0.5 & 1.5 & 1.5 & 1.5 \\
\hline 1 & 2 & 6 & \begin{tabular}{|l} 
Langtry \\
\end{tabular} & $41 \mathrm{MC} 238$ & $2-0$ & Surface & & $\because$ & $3.8^{*}$ & 0.6 & 1.8 & 1.9 & 1.9 \\
\hline 1 & 2 & 7 & $\begin{array}{l}\text { Morhiss } \\
\end{array}$ & $41 \mathrm{LK} 201$ & 305 & N500E998 & $98.85-75$ & 6.5 & 2.5 & 0.9 & 1.8 & 1.9 & 1.9 \\
\hline 1 & 2 & 8 & & 41 LK243 & $26-37$ & Surfaca & & 7.0 & 2.3 & 0.8 & 1.4 & 1.9 & 1.9 \\
\hline 1 & 2 & 9 & & $41 \mathrm{MC} 275$ & $5-2$ & Surfaca & & 5.4 & 2.9 & 0.7 & 1.4 & 1.2 & 1.2 \\
\hline 1 & 2 & 10 & & 411KK & $198-0$ & Surfaca & & $3.9^{*}$ & 1.9 & 0.8 & 1.0 & 1.2 & 1.2 \\
\hline 1 & 2 & 11 & & $41 \mathrm{MC} 260$ & 1.8 & Surface & & $4.3^{\circ}$ & 2.1 & 0.7 & 1.1 & 1.3 & 1.3 \\
\hline 1 & 2 & 12 & & $41 M C 296$ & 89 & N1023E987 & Surf.-99.40 & 4.4 & 1.9 & 0.7 & 0.8 & 1.4 & 1.4 \\
\hline 1 & 2 & 13 & & $41 \mathrm{MC268}$ & $21-18$ & Surface & & 3.2 & 1.9 & 0.5 & 0.6 & 1.2 & 1.2 \\
\hline 1 & 2 & 14 & & $41 \mathrm{MC} 296$ & 90 & N1023E987 & $99.40-30$ & 3.6 & 1.8 & 0.7 & 1.5 & 1.5 & 1.5 \\
\hline 1 & 3 & 1 & \begin{tabular}{|l} 
Ensor \\
\end{tabular} & 41 LK51 & 301 & N1034E1065 & $99.60 \cdot .50$ & 3.0 & 1.8 & \begin{tabular}{|l|}
0.7 \\
0.7
\end{tabular} & $\frac{1.2}{1.2}$ & $\frac{1.0}{1.9}$ & $\frac{1.0}{1.5}$ \\
\hline 1 & 3 & 2 & Ensor & 41 LK 74 & 42 & Surface & & $3.6^{*}$ & 2.1 & 0.6 & 1.0 & 2.1 & 1.4 \\
\hline 1 & 3 & 3 & \begin{tabular}{|l|} 
Ensor \\
\end{tabular} & 41 LK 74 & $112-0$ & Surfaco & & 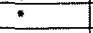 & 2.2 & 0.6 & 1.0 & 1.9 & 1.5 \\
\hline 1 & 3 & 4 & $\begin{array}{l}\text { Ensor } \\
\end{array}$ & 41 LK243 & $26-21$ & Surface & & $\cdot$ & 2.2 & 0.7 & 1.1 & 2.2 & 1.5 \\
\hline$\frac{1}{1}$ & 3 & $\frac{4}{5}$ & Ensor & $41 \mathrm{MC} 213$ & $2-54$ & \begin{tabular}{|l} 
Surfaco \\
\end{tabular} & & 3.9 & 2.1 & 0.7 & 0.9 & $\frac{2.2}{1.6}$ & 1.4 \\
\hline 1 & 3 & 6 & \begin{tabular}{|l} 
Ensor \\
\end{tabular} & $41 M C 222$ & $163-4$ & \begin{tabular}{|l|} 
N101E89 \\
\end{tabular} & $98.80-.75$ & 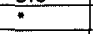 & 2.1 & 0.7 & 1.2 & $\because .0$ & 1.4 \\
\hline 1 & 3 & 7 & Ensor & $41 \mathrm{MC} 260$ & 1.15 & \begin{tabular}{|l} 
Surface \\
\end{tabular} & & 4.1 & 2.0 & 0.9 & 1.4 & 1.9 & 1.6 \\
\hline 1 & 3 & 8 & Ensor & $41 \mathrm{MC} 288$ & $91-60$ & \begin{tabular}{|l|} 
Surface \\
\end{tabular} & & 3.8 & 2.0 & 0.5 & 1.0 & 1.9 & 1.7 \\
\hline 1 & 3 & 9 & Ensor & $41 \mathrm{MC} 296$ & 173 & $\begin{array}{l}\text { N1027E9997 } \\
\end{array}$ & $99.20-10$ & 4.6 & \begin{tabular}{|l|}
2.3 \\
\end{tabular} & 0.7 & 1.1 & 2.4 & 1.9 \\
\hline 1 & 3 & 10 & Ensor & $41 \mathrm{MC2} 29 \mathrm{~B}$ & 225 & N1027E978 & $99.20-10$ & 3.2 & 2.3 & 0.6 & 1.1 & 2.3 & 1.7 \\
\hline 1 & 3 & 11 & Fairland & 41 LK8 & $199-0$ & \begin{tabular}{|l|} 
Surface \\
\end{tabular} & & $\div$ & 2.4 & 0.6 & 1.1 & 2.5 & 1.7 \\
\hline 1 & 3 & 12 & Fairland & $471 K 51$ & 282 & \begin{tabular}{|l|} 
N1026E1042 \\
\end{tabular} & $99.80-.70$ & 4.5 & 2.2 & 0.5 & 1.3 & 2.3 & 1.8 \\
\hline 1 & 3 & 13 & Fairland & 41LK51 & 311 & N1026E1039 & $99.70-.60$ & 4.0 & 2.0 & 0.6 & 1.1 & 2.1 & 1.8 \\
\hline 1 & 3 & 14 & Fsirfand & 41 LK128 & $46-26$ & Surface & & 4.7 & 2.0 & 0.7 & 1.0 & 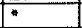 & 1.5 \\
\hline 1 & 3 & 15 & Fairland & 41 LK185 & $14-14$ & Surface & & 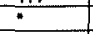 & $2.2^{*}$ & 0.8 & 1.2 & 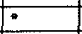 & 1.8 \\
\hline 1 & 3 & 16 & Fairland & $41 \mathrm{MC} 7$ & 0 & Surface & & 4.4 & 1.7 & 0.7 & 1.4 & 1.8 & 1.4 \\
\hline 1 & 3 & 17 & Fairlend. & $41 \mathrm{MC} 260$ & 3 & \begin{tabular}{|l|} 
Surface \\
\end{tabular} & & 4.5 & 2.0 & 1.6 & 1.2 & 2.0 & 1.6 \\
\hline 1 & 3 & 18 & Early Exp. Stem & 49 LKR & 189 & N400EBOS & $94.90-.80$ & 5.0 & 1.9 & 0.7 & 1.3 & 2.0 & 1.4 \\
\hline 1 & 3 & 19 & Early Exp. Stem & 41 LK51 & 209 & N998E981 & $98.40-30$ & 4.0 & $\div$ & 0.5 & 0.8 & 1.6 & 1.3 \\
\hline 1 & 3 & 20 & Early Exp. Stem & 41 LK122 & $2-3$ & \begin{tabular}{|l} 
Surfaca \\
\end{tabular} & & $3.0^{*}$ & $3.0^{\circ}$ & 0.6 & 1.2 & 1.8 & 1.3 \\
\hline 1 & 3 & 21 & \begin{tabular}{|l|} 
Ensor \\
\end{tabular} & $41 \mathrm{LK} 201$ & 184 & N491E1043 & $97.75 . .65$ & 4.5 & 2.1 & 0.8 & 1.3 & $*$ & 1.4 \\
\hline 1 & $\frac{5}{3}$ & 22 & & 41 LK 14 & $300-0$ & Surface & & $6.0^{\prime \prime}$ & 2.3 & 0.9 & 1.9 & 2.3 & 2.0 \\
\hline 1 & 3 & 23 & & $41 L K 51$ & 162 & \begin{tabular}{|l} 
N999E982 \\
\end{tabular} & $99.30-.20$ & 6.4 & 2.7 & 0.5 & 1.0 & 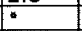 & 1.5 \\
\hline 1 & 3 & 24 & & $41 \_$K53 & 108 & N1001E1003 & $99.50-.40$ & 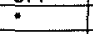 & $\because$ & 0.6 & 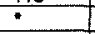 & 2.0 & 1.4 \\
\hline 1 & 3 & 25 & & $41 \mathrm{LK} 122$ & $2-1$ & Surfaca & & $4.5^{\circ}$ & 1.9 & 0.6 & $*$ & 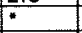 & 0.8 \\
\hline 1 & 3 & 26 & & $41 \mathrm{LK} 122$ & $2-4$ & Surface & & 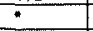 & 1.9 & 0.7 & 1.2 & . & 1.0 \\
\hline 1 & 3 & $27 \mid$ & & $41 L K 128$ & $46-28$ & Surface & & 4.7 & 2.1 & 0.8 & 1.5 & $2: 0$ & 1.8 \\
\hline 1 & 3 & 28 & & $41 \mathrm{LK} 250$ & $12-5$ & Surfaco & & $3.0^{\circ}$ & 2.2 & 0.6 & 1.0 & 1.3 & 1.2 \\
\hline 1 & 3 & 29 & & $41 \mathrm{MC} 94$ & 203 & Test Pit 4 & Surf.-99.70 & 3.0 & -2 & 0.5 & 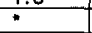 & 2.3 & .4 \\
\hline 1 & 3 & 30 & & $41 \mathrm{MC} 213$ & $2-64$ & Surface & & $\because$ & 3.0 & 0.7 & \begin{tabular}{|l|}
1.4 \\
\end{tabular} & $\div$ & 1.7 \\
\hline 1 & 3 & 31 & & $41 \mathrm{MC2} 38$ & $1-4$ & Surface & & $5.7^{*}$ & 2.5 & 0.7 & 1.1 & 1.7 & 1.3 \\
\hline 1 & 3 & 32 & & $41 \mathrm{MC} 251$ & 1.0 & Surface & & 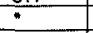 & $2.0^{*}$ & 0.6 & 0.9 & 1.4 & 1.0 \\
\hline 1 & 3 & \begin{tabular}{|l|}
33 \\
\end{tabular} & & $41 \mathrm{MC} 288$ & $8-19$ & Surface & & $*$ & 2.2 & 0.7 & 1.1 & 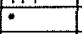 & 1.5 \\
\hline 9 & 3 & \begin{tabular}{|l|}
34 \\
\end{tabular} & & $41 \mathrm{MC} 296$ & 179 & N1027E998 & $99.30-.20$ & 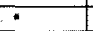 & 1.8 & 0.5 & 1.2 & 1.7 & 1.5 \\
\hline 1 & 3 & \begin{tabular}{|l|}
35 \\
\end{tabular} & & 41LK185 & $16-16$ & Surface & & 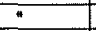 & 1.5 & 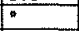 & 1.2 & 1.4 & 1.1 \\
\hline 1 & 3 & \begin{tabular}{|l|}
36 \\
36
\end{tabular} & Zavala & \begin{tabular}{|l|}
$41 L K 162$ \\
\end{tabular} & $1-0$ & Surfaco & & $3.7^{\circ}$ & 1.8 & 0.8 & 1.0 & 1.4 & 1.4 \\
\hline 1 & $\frac{5}{3}$ & 37 & Zavala & $491 \mathrm{~L} 74$ & 56 & N981E988 & $99.70-60$ & 2.9 & 1.6 & 0.6 & 0.9 & 1.2 & 1.1 \\
\hline 1 & 3 & 38 & Zavala & $41 M C 296$ & 173 & N1027E997 & $99.20-10$ & 4.3 & 2.0 & 0.6 & 0.9 & 1.7 & 1.6 \\
\hline 1 & 3 & 39 & Zavala & \begin{tabular}{|l|}
$41 \mathrm{MC} 296$ \\
\end{tabular} & 201 & N1025E995 & $99.60-.50$ & 3.7 & 1.5 & 0.6 & 0.9 & 1.6 & 1.4 \\
\hline 1 & 4 & 1 & Pordiz & 411 LK51 & 298 & N1033E1062 & $99.60-.50$ & $\div$ & $\because$ & 0.2 & 1.0 & 0.6 & 0.6 \\
\hline 1 & 4 & 2 & Perdiz & 41 LK53 & 95 & N1001E1002 & Surf.-99.60 & 2.4 & 1.3 & 0.3 & 0.8 & 0.7 & 0.7 \\
\hline 1 & 4 & 3 & Pardiz & $41 \mathrm{LK} 201$ & 222 & N497E997 & $99.05-98.95$ & 3.6 & 1.5 & 0.5 & 1.2 & 0.7 & 0.7 \\
\hline 1 & 4 & 4 & \begin{tabular}{|l|} 
Perdiz \\
\end{tabular} & 41LK201 & 239 & N498E998 & $99.25-99.15$ & 3.0 & 1.7 & 0.3 & 0.9 & 0.6 & 0.6 \\
\hline 1 & 4 & 5 & \begin{tabular}{|l|} 
Perdiz \\
\end{tabular} & 41LK201 & 240 & N498E996 & $99.15-99.05$ & 4.6 & 1.4 & 0.4 & 1.3 & 0.7 & 0.7 \\
\hline 1 & 4 & 6 & \begin{tabular}{|l} 
Perdiz \\
\end{tabular} & 41 LK207 & 247 & N498E997 & $99.15-99.05$ & 3.1 & 1.8 & 0.5 & 0.9 & 0.7 & 0.7 \\
\hline 1 & 4 & 7 & Perdiz & $41 \mathrm{LK} 201$ & 247 & N498E997 & $99.15-99.05$ & 2.5 & 1.2 & 0.2 & 0.8 & 0.5 & 0.5 \\
\hline 1 & 4 & 8 & Perdiz & $41 \mathrm{LK} 201$ & 247 & N498E997 & $99.15-99.05$ & $-\frac{2.0}{5.0}$ & $\frac{1.2}{1.8}$ & 0.6 & $\begin{array}{l}0.8 \\
1.2\end{array}$ & 0.8 & 0.8 \\
\hline 1 & 4 & 9 & Perdiz & $41 L K 201$ & 270 & N499E997 & $99.25-99.15$ & 0.0 & 1.0 & 0.3 & 1.2 & 0.0 & 0.8 \\
\hline 1 & 4 & 10 & \begin{tabular}{|l|} 
Perdiz \\
\end{tabular} & 41 LK201 & 271 & N499E997 & 99.15 .05 & 3.1 & 1.5 & 0.3 & 1.2 & 0.7 & 0.7 \\
\hline 1 & 4 & 11 & Perdiz & 41LK201 & 278 & N499E998 & $99.15-.05$ & 3.5 & 1.9 & & $\frac{1.2}{0.9}$ & 0.8 & $\begin{array}{l}0.1 \\
0.8\end{array}$ \\
\hline 1 & 4 & 12 & Perdiz & 41LK201 & 294 & N500E997 & $99.15-.05$ & $\frac{3.0}{3.1}$ & $\frac{1.9}{1.7}$ & 0.3 & 0.8 & 0.5 & 0.5 \\
\hline 1 & 4 & 13 & \begin{tabular}{|l|} 
Perdiz \\
\end{tabular} & 41 LK201 & 300 & N500E998 & 99.15 .05 & $\frac{3.1}{-3.1}$ & $\frac{1.1}{1.7}$ & 0.3 & 1.1 & 0.6 & 0.6 \\
\hline 1 & 4 & 14 & Perdiz & 41 LK201 & 300 & N500E998 & $99.15-.05$ & -2.5 & 1.6 & 0.3 & 1.0 & 0.7 & 0.7 \\
\hline 1 & 4 & 15 & Perdiz & $41 \mathrm{LK} 201$ & $487-0$ & Surfaca & & $\frac{2.3}{3.5}$ & 1.5 & 0.3 & 0.8 & 0.6 & $\frac{.17}{0.6}$ \\
\hline 1 & 4 & 16 & Perdiz & 41LK201 & 654 & N5OBE1010 & $99.30-.20$ & 3. & $\frac{1.2}{1.4}$ & 0.2 & 0.7 & 0.6 & 0.6 \\
\hline 1 & 4 & 17 & Pardiz & 41 LK201 & $657-14$ & N507E1010 & $99.30-.20$ & 3.0 & 1.7 & 0.3 & $\frac{0.1}{1.1}$ & 0.7 & 0.7 \\
\hline
\end{tabular}


TABLE 9. (continued)

\begin{tabular}{|c|c|c|c|c|c|c|c|c|c|c|c|c|c|c|}
\hline Group & Form & Speci- & Typo & Site & Lot No. & Prov & nes & Langth & Width & Thick- & Stem & Stem & Nock & Wolght \\
\hline & & $\operatorname{men} \mathrm{No}$. & & & & Unit & Level & & & ness & Longth & Width & Width & \\
\hline 1 & 4 & 18 & Perdiz & $41 \mathrm{LK} 201$ & $659-45$ & N506E 1008 & $99.29-.20$ & 2.5 & 1.4 & 0.2 & 0.6 & 0.5 & 0.5 & 0.7 \\
\hline 1 & 4 & 19 & Perdiz & $41 \mathrm{LK} 201$ & 696 & N506E1009 & $99.20-.10$ & 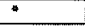 & 1.2 & 0.2 & 0.6 & 0.4 & 0.4 & 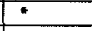 \\
\hline 1 & 4 & 20 & Perdiz & 41 LK201 & 699 & N508E1012 & $99.20-10$ & $*$ & 1.7 & 0.3 & 0.6 & 0.6 & 0.6 & 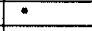 \\
\hline 1 & 4 & 21 & Perdiz & 41LK201 & $700-66$ & N508E1013 & $99.20-10$ & 2.2 & 1.6 & 0.2 & 0.7 & 0.6 & 0.6 & 0.7 \\
\hline 1 & 4 & 22 & Pordiz. & 41 LK201 & $702-111$ & N509E1013 & $99.20-.10$ & 2.3 & 1.5 & 0.3 & 1.0 & 0.5 & 0.5 & 0.7 \\
\hline 1 & 4 & 23 & Perdiz & 41 LK201 & 707 & N504E1008 & $99.20-10$ & 2.3 & $*$ & 0.3 & 1.0 & 0.5 & 0.5 & $*$ \\
\hline 1 & 4 & 24 & Perdiz & $41 \mathrm{LK} 201$ & 707 & N504E1008 & $99.20-.10$ & 2.7 & 1.3 & 0.2 & 0.9 & 0.6 & 0.6 & 0.6 \\
\hline 1 & 4 & 25 & Perdiz & 41 LK201 & $720-144$ & N504E1012 & $99.20-10$ & 1.4 & 7.3 & 0.2 & 0.6 & 0.4 & 0.4 & 0.5 \\
\hline 1 & 4 & 26 & Perdiz & 41 LK201 & $720-145$ & N504E1012 & $99.20-.10$ & 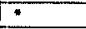 & 1.3 & 0.3 & 0.7 & 0.5 & 0.5 & $n$ \\
\hline 1 & 4 & 27 & Perdiz & 41 LK201 & 722 & N505E 1012 & $99.20-10$ & - & - & 0.2 & 0.9 & 0.7 & 0.7 & $*$ \\
\hline 1 & 4 & 28 & Perdiz & 41 LK201 & 723 & N505E1013 & $99.20-.10$ & * & * & 0.2 & 0.9 & 0.6 & 0.6 & 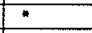 \\
\hline 1 & 4 & 29 & Perdiz & 41 MC55 & 78 & N1007E1016 & $99.30-.20$ & " & 1.6 & 0.3 & 0.7 & 0.7 & 0.7 & $*$ \\
\hline 1 & 4 & 30 & Perdiz & $41 \mathrm{MC} 55$ & 79 & N1009E1016 & $99.30-20$ & 2.8 & 1.4 & 0.3 & 0.7 & 0.5 & 0.5 & 0.9 \\
\hline 1 & 4 & 31 & Perdiz & $41 \mathrm{MC} 268$ & 93 & Surface & & $\cdots$ & 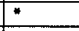 & 0.3 & 1.2 & 0.5 & 0.5 & $*$ \\
\hline 1 & 4 & 32 & Perdiz & $41 \mathrm{MC27}$ & $5-24$ & Surface & & 2.0 & 1.4 & 0.2 & 0.5 & 0.4 & 0.4 & 0.8 \\
\hline 9 & 4 & 33 & Perdiz & $41 \mathrm{MC2} 296$ & 41 & $N 1022$ E985 & Surf. -99.40 & 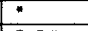 & 1.2 & 0.3 & 0.8 & 0.6 & 0.6 & $*$ \\
\hline 1 & 4 & 34 & Perdiz & $41 \mathrm{MC} 296$ & 42 & N1022E985 & $99.40-.30$ & $2.0^{\circ}$ & 2.0 & 0.3 & 0.8 & 0.6 & 0.6 & $0.9 *$ \\
\hline 1 & 4 & 35 & Perdiz & $41 \mathrm{MC296}$ & 43 & N1022E985 & $99.30-.20$ & $\cdot$ & 1.5 & 0.3 & 1.1 & 0.4 & 0.4 & 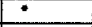 \\
\hline 1 & 4 & 36 & Perdiz & $41 \mathrm{MC2} 26$ & 51 & N1022E986 & Surf. -99.40 & 2.4 & 1.3 & 0.4 & 0.8 & 0.5 & 0.5 & 0.9 \\
\hline 1 & 4 & 37 & Perdiz & $41 \mathrm{MC} 296$ & 51 & N1022E986 & Surf. -99.40 & 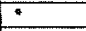 & 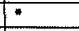 & 0.2 & 0.9 & 0.5 & 0.5 & 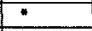 \\
\hline 1 & 4 & 38 & Perdiz & $41 \mathrm{MC} 296$ & 51 & N1022E986 & Surf. -99.40 & 1 & 1.6 & 0.3 & 0.9 & 0.5 & 0.5 & 4 \\
\hline 1 & 4 & 39 & Perdiz & $41 \mathrm{MC} 296$ & 51 & N1022E986 & Surf. -99.40 & 3.1 & 1.9 & 0.3 & 1.1 & 0.5 & 0.5 & 1.0 \\
\hline 1 & 4 & 40 & Perdiz & $41 \mathrm{MC} 296$ & 51 & N1022E986 & Surf. -99.40 & 3.7 & 1.4 & 0.3 & 0.8 & 0.7 & 0.7 & 1.3 \\
\hline 1 & 4 & 41 & Perdiz & $41 \mathrm{MC296}$ & 51 & N1022E986 & Surf. -99.40 & 3.1 & 1.2 & 0.3 & 0.8 & 0.5 & 0.5 & 1.0 \\
\hline 1 & 4 & 42 & Perdiz & $41 \mathrm{MC} 296$ & 51 & $N 10225986$ & Surf -99.40 & 3.8 & 1.7 & 0.3 & 1.1 & 0.6 & 0.6 & 1.5 \\
\hline 1 & 4 & 43 & Perdiz & $41 \mathrm{MC} 296$ & 61 & N1022E987 & Surf. 99.40 & $*$ & - & 0.2 & 0.7 & 0.5 & 0.5 & $\cdot$ \\
\hline 1 & 4 & 44 & Perdiz & $41 \mathrm{MC} 296$ & 62 & $\mathrm{~N} 1022 \mathrm{E} 987$ & $99.40 \cdot 30$ & * & - & 0.2 & 0.9 & 0.4 & 0.4 & $\cdot$ \\
\hline 1 & 4 & 45 & Perdiz & $41 \mathrm{MC} 296$ & 70 & N1023E985 & Surf. -99.40 & - & . & 0.3 & 0.8 & 0.4 & 0.4 & 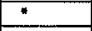 \\
\hline 1 & 4 & 46 & Perdiz & $41 \mathrm{MC296}$ & 79 & N1023E986 & Surf. -99.40 & " & 1.7 & 0.3 & 1.2 & 0.4 & 0.4 & $\cdot$ \\
\hline 1 & 4 & 47 & Perdiz & $41 \mathrm{MC296}$ & 98 & N1024E985 & Surf.-99.40 & 2.5 & 1.6 & 0.3 & 0.7 & 0.6 & 0.6 & 1.2 \\
\hline 1 & 4 & 48 & Perdiz & $41 \mathrm{MC} 296$ & 126 & N1025E997 & $99.50-.40$ & * & 1.4 & 0.3 & 1.2 & 0.5 & 0.5 & 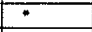 \\
\hline 1 & 4 & 49 & Perdiz & $41 \mathrm{MC} 296$ & 133 & N1025E998 & $99.50-.40$ & " & 1.4 & 0.2 & 0.9 & 0.5 & 0.5 & $*$ \\
\hline 1 & 4 & 50 & Perdiz & $41 \mathrm{MC} 296$ & 157 & N1026E998 & $99.40-.30$ & $2.6^{\circ}$ & 1.6 & 0.4 & 0.8 & 0.6 & 0.6 & $1.3^{*}$ \\
\hline 1 & 4 & 51 & Perdiz & $41 \mathrm{MC} 296$ & 198 & N1026E978 & $99.50-40$ & 3.7 & 1.2 & 0.3 & 0.9 & 0.5 & 0.5 & 1.2 \\
\hline 1 & 4 & 52 & Perdiz & $41 \mathrm{MC296}$ & 206 & N1025E997 & Surface & 3.0 & 2.0 & 0.3 & 1.1 & 0.8 & 0.8 & 2.4 \\
\hline 1 & 4 & 53 & Perdiz & $41 \mathrm{MC2} 296$ & 214 & $\mathrm{~N} 1027 \mathrm{Eg} 86$ & $99.50-.40$ & 2.9 & 1.6 & 0.3 & 0.9 & 0.6 & 0.6 & 1.3 \\
\hline 1 & 4 & 54 & Perdiz & $41 M C 296$ & 231 & N1023E989 & Surf.-9g.50 & 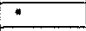 & 1.5 & 0.2 & 0.9 & 0.6 & 0.6 & 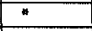 \\
\hline 1 & 4 & 55 & Perdiz & $41 \mathrm{LK} 14$ & 196 & N1007E958 & Surt. -100.20 & * & 1.4 & 0.3 & 0.6 & 0.6 & 0.5 & $\div$ \\
\hline 1 & 4 & 56 & Perdiz & 41 LK 128 & 33 & Test Pit $\mathrm{B}$ & $99.70-60$ & 2.8 & $"$ & 0.2 & 1.0 & 0.8 & 0.8 & $*$ \\
\hline 1 & 4 & 57 & Perdiz & $41 L K 128$ & 26 & Test Pit 7 & $99.50-.40$ & $*$ & 2.1 & 0.3 & 0.9 & 0.6 & 0.6 & $*$ \\
\hline 1 & 4 & 58 & Perdiz & $41 L K 128$ & 45 & Hearth 13 & & - & n & 0.2 & 1.1 & 0.5 & 0.6 & $*$ \\
\hline 1 & 4 & 59 & Perdiz & 41LK2O1 & 149 & N490E 1043 & $98.35-.25$ & . & 1.7 & 0.3 & 0.8 & 0.8 & 0.8 & $\div$ \\
\hline 1 & 4 & 60 & Perdiz & 41LK201 & 301 & N500E998 & $99.05-99.95$ & $\because$ & 1.4 & 0.2 & - & 0.7 & 0.7 & $\div$ \\
\hline 1 & 4 & 61 & Perdiz & $41 L K 201$ & $489-0$ & Surface & & 2.9 & 1.4 & 0.3 & 0.7 & 0.5 & 0.5 & 0.8 \\
\hline 1 & 4 & 62 & Perdiz & $41 \mathrm{LK} 201$ & 652 & N509E1010 & $99.23-10$ & 1.9 & 1.3 & 0.2 & 0.5 & 0.5 & 0.5 & 0.5 \\
\hline 1 & 4 & 63 & Perdiz & 41LK201 & $669-54$ & N506E1012 & $99.31-.20$ & $3.3^{*}$ & 1.3 & 0.2 & 0.7 & 0.6 & 0.6 & $\therefore$ \\
\hline 1 & 4 & 64 & Perdiz & 41LK201 & 696 & N506E1009 & $99.20-10$ & 2.4 & 1.2 & 0.2 & 0.6 & 0.5 & 0.5 & 0.5 \\
\hline 1 & 4 & 65 & Perdiz & 41 LK201 & 699 & N508E1012 & $99.20-10$ & 2.5 & 1.6 & 0.2 & 0.6 & 0.8 & 0.7 & 0.9 \\
\hline 1 & 4 & 66 & Perdiz & $41 \mathrm{LK} 201$ & 701 & N509E 1012 & $99.20-.10$ & 1.1 & 0.9 & 0.2 & 0.5 & 0.5 & 0.5 & 0.3 \\
\hline 1 & 4 & 67 & Perdiz & $41 \mathrm{LK}_{20} \mathrm{O}^{+}$ & 679 & N504E1008 & $99.32-.20$ & 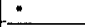 & 1.4 & 0.2 & 0.8 & 0.7 & 0.7 & $*$ \\
\hline 1 & 4 & 68 & Cliffton & $41\lfloor K 201$ & 700 & N508E1013 & $99.20-10$ & $\div$ & 1.8 & 0.5 & 0.5 & 0.8 & 0.8 & $*$ \\
\hline 1 & 4 & 69 & Cliffton & 41LK201 & 701 & N509E 1012 & $99.20-.10$ & 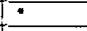 & 1.5 & 0.3 & 0.5 & 0.6 & 0.6 & 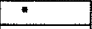 \\
\hline 1 & 4 & 70 & Perdiz & 41 LK201 & $703-135$ & N506E 1010 & $99.20-10$ & 3.5 & $*$ & 0.3 & 0.6 & 0.7 & 0.5 & 1.0 \\
\hline 1 & 4 & 71 & Perdiz & $41 \mathrm{LK} 201$ & $707-102$ & $\mathrm{~N} 504 \mathrm{E} 1008$ & $99.20-.10$ & $2.8^{\circ}$ & $\div$ & 0.3 & $*$ & 0.5 & 0.5 & $*$ \\
\hline 1 & 4 & 72 & Perdiz & $41 \mathrm{MC} 55$ & 62 & N994E1015 & $99.30-.20$ & 2.2 & 1.3 & 0.3 & 0.6 & 0.5 & 0.5 & 0.6 \\
\hline 1 & 4 & 73 & Perdiz & $41 \mathrm{MC} 79$ & 2 & Surface & & 2.7 & $\div$ & 0.3 & 1.0 & 0.6 & 0.6 & $\div$ \\
\hline 1 & 4 & 74 & Straight Stom & $41 \mathrm{MC} 222$ & 116 & N98E96 & $98.70-.65$ & 2.3 & 1.8 & 0.4 & 0.6 & . & 0.6 & $1.2^{\circ}$ \\
\hline 1 & 4 & 75 & Straight Stem & $41 \mathrm{MC} 222$ & 170 & N101E91 & Surf. -98.90 & 3.1 & 2.4 & 0,4 & 0.5 & 0.6 & 0.6 & 1.8 \\
\hline 1 & 4 & 76 & Straight Stem & $41 \mathrm{MC} 222$ & $205-10$ & N102E91 & $98.95-.90$ & 2.6 & 1.8 & 0.4 & 0.6 & 0.6 & 0.6 & $1.6^{*}$ \\
\hline 1 & 4 & 77 & Pardiz & $41 \mathrm{MC296}$ & 41 & N1022E985 & Surf. -99.40 & 2.2 & 1.9 & 0.2 & 0.9 & 0.6 & 0.6 & 1.0 \\
\hline 1 & 4 & 78 & Perdiz & $41 \mathrm{MC296}$ & 61 & N1022E987 & Surf- -99.40 & $\Rightarrow$ & 1.5 & 0.4 & 0.5 & 0.6 & 0.6 & 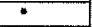 \\
\hline 1 & 4 & 79 & Perdiz & $41 \mathrm{MC2} 96$ & 62 & N1022E987 & $99.40-.30$ & $2.5^{*}$ & 2.0 & 0.3 & 0.8 & 0.8 & 0.8 & $\cdot$ \\
\hline 1 & 4 & 80 & Perdiz & $41 M C 296$ & 70 & N1023E985 & Surf. -99.40 & 2.8 & $*$ & 0.3 & 0.5 & 0.6 & 0.6 & 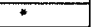 \\
\hline 1 & 4 & 81 & Perdiz & $41 \mathrm{MC2} 26$ & 80 & N1023E986 & $99.40-.30$ & $2.7^{\circ}$ & " & 0.3 & 0.7 & 0.6 & 0.6 & 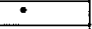 \\
\hline 1 & 4 & 82 & Perdiz & $41 \mathrm{MC2} 26$ & 90 & N1023E987 & $99.40-.30$ & 3.7 & 1 & 0.3 & 0.8 & 0.6 & 0.6 & 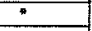 \\
\hline 1 & 4 & 83 & Perdiz & $41 \mathrm{MC296}$ & 201 & N1025E995 & $99.60-.50$ & $3.6^{*}$ & 1.5 & 0.3 & 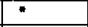 & 0.5 & 0.5 & 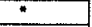 \\
\hline 1 & 4 & 84 & Perdiz & $41 \mathrm{LK2O} 1$ & 278 & N499E99B & $99.15-.05$ & 2.5 & 1.6 & 0.4 & 0.5 & 0.6 & 0.6 & 1.5 \\
\hline 1 & 4 & 85 & Cliffton & $41 \mathrm{MC5} 5$ & 60 & N993E1015 & Surf. -99.30 & 2.9 & 2.1 & 0.5 & 0.6 & 0.9 & 0.9 & $*$ \\
\hline 1 & 4 & 86 & Perdiz & $41 \mathrm{MC5} 5$ & 85 & N1018E1011 & Surf. -99.30 & 3.8 & 2.4 & 0.3 & 1.0 & 1.0 & 1.0 & 2.2 \\
\hline 1 & 4 & 87 & Cliffton & $41 \mathrm{MC296}$ & 72 & N1023E985 & $99.30-.20$ & 3.8 & 1.9 & 0.3 & 0.6 & 0.9 & 0.9 & 2.9 \\
\hline 1 & 5 & 1 & Scallorn & $41 \mathrm{LK} 14$ & $300-0$ & Surface & & 2.5 & 1.4 & 0.4 & 0.9 & 0.9 & 0.5 & 1.0 \\
\hline 1 & 5 & 2 & Scallorn & 41 LKE 3 & 97 & N1001E1002 & $99.50-40$ & 2.9 & 1.3 & 0.5 & 0.8 & $0.8^{*}$ & 0.6 & $1.3^{*}$ \\
\hline 1 & 5 & 3 & Scallorn & 41LK201 & 680 & N504E 1009 & $99.32-.20$ & $1.6^{*}$ & 1.3 & 0.2 & 0.4 & 0.8 & 0.5 & $\cdots$ \\
\hline 1 & 5 & 4 & Scallorn & $41 \mathrm{LK} 201$ & $690-61$ & N509E1011 & $99.10-99,00$ & $2.4^{*}$ & 1.3 & 0.2 & 0.5 & 0.7 & 0.5 & $0.7^{*}$ \\
\hline 1 & 5 & 5 & Scallorn & $41 \mathrm{LK} 243$ & 26.53 & Surface & & $2.0^{*}$ & 1.6 & 0.3 & 0.5 & 1.0 & 0.7 & $1.0^{\circ}$ \\
\hline 1 & 5 & 6 & Scallarn & $41 \mathrm{MC9} 4$ & 177 & Surface & & $4.1^{*}$ & 1.8 & 0.4 & 0.7 & $1.6^{\circ}$ & 1.0 & $3.5^{*}$ \\
\hline 1 & 5 & 7 & Scellorn & $41 M C 222$ & 186 & N102E89 & $98.75-.70$ & 3.1 & 1.7 & 0.4 & 0.8 & 1.2 & 0.7 & 2.0 \\
\hline 1 & 5 & 8 & Scallorn & $41 \mathrm{MC222}$ & 231 & N103E9C & $98.95-.90$ & 2.8 & 1.8 & 0.3 & 0.6 & 1.7 & 0.9 & 1.6 \\
\hline 1 & 5 & 9 & Scallorn & $41 \mathrm{MC2} 28$ & 67 & N995E999 & $99.20-10$ & 2.9 & 1.3 & 0.5 & 0.6 & 1.0 & 0.7 & 1.5 \\
\hline 1 & 5 & 10 & Scallorn & $41 \mathrm{MC296}$ & 65 & N1022E987 & $99.10-99.00$ & $3.1^{*}$ & 1.7 & 0.5 & 0.6 & 1.2 & 0.7 & $2.2 *$ \\
\hline 1 & 5 & 11 & Scallorn & $41 \mathrm{MC} 296$ & 135 & N1025E99B & $99.30-99.20$ & $2.5^{\circ}$ & 1.6 & 0.4 & 0.7 & 1.3 & 0.6 & $1.5^{*}$ \\
\hline 1 & 5 & 12 & Scallorn & $41 \mathrm{MC} 296$ & 208 & N1026E978 & $99.40-30$ & $2.6^{\circ}$ & 1.6 & 0.3 & 0.7 & 1.6 & 0.7 & $1.5^{*}$ \\
\hline
\end{tabular}


TABLE 9. (continued)

\begin{tabular}{|c|c|c|c|c|c|c|c|c|c|c|c|c|c|c|}
\hline \multirow[t]{2}{*}{ Group } & \multirow[t]{2}{*}{ Form } & \multirow{2}{*}{$\begin{array}{l}\text { Specl- } \\
\text { men No. }\end{array}$} & \multirow[t]{2}{*}{ Type } & \multirow[t]{2}{*}{ Sito } & Lot No. & Pros & ance & Langth & Width & Thlck- & Stem & Stem & Neck & Wolght \\
\hline & & & & & & Unit & Level & & & & Length & Width & Width & \\
\hline 1 & 5 & 13 & Scallorn & $41 \mathrm{MC} 296$ & 210 & N1027E978 & $99.50-40$ & 2.3 & 1.7 & 0.4 & 0.7 & 1.2 & 0.7 & 1.2 \\
\hline 1 & 5 & 14 & Scallorn & $41 \mathrm{MC} 296$ & 234 & N1027E986 & $99.30-.20$ & 3.4 & 1.4 & 0.5 & 0.8 & 1.2 & 0.6 & 1.5 \\
\hline 1 & 5 & 15 & Edwards & $41 \mathrm{LK} 201$ & $721-170$ & N504E1013 & $99.10-99.00$ & $3.0^{\circ}$ & $1.4^{*}$ & 0.5 & 1.2 & 1.4 & 0.5 & $*$ \\
\hline 1 & 5 & 16 & Edwards & $41 \mathrm{MC} 222$ & 132 & N99E9O & Surf.-98.75 & 3.7 & $1.7^{*}$ & 0.5 & 0.7 & $*$ & 0.8 & $2.3^{*}$ \\
\hline 1 & 5 & 17 & Edwards & $41 \mathrm{MC2} 22$ & 198 & N102E100 & $98.80-.70$ & 2.6 & 1.9 & 0.4 & 0.6 & 1,4 & 0.8 & 1.4 \\
\hline 1 & 5 & 18 & Edwards & $41 \mathrm{MC} 268$ & $21-26$ & Surface & & $*$ & 2.5 & 0.4 & 0.9 & $*$ & 0.7 & $\star$ \\
\hline 1 & 5 & 19 & Edwards & $41 \mathrm{MC} 298$ & 109 & N1024E986 & $99.30-.20$ & 2.5 & $7.4^{*}$ & 0.4 & 0.7 & 1.5 & 0.7 & 1.3 \\
\hline 1 & 5 & 20 & & $41 \mathrm{LK} 53$ & 99 & N1001E1002 & $99.30-.20$ & $2.5^{*}$ & 1.4 & 0.6 & 0.8 & 1.3 & 0.8 & $1.6^{*}$ \\
\hline 1 & 5 & 21 & & 41 LK185 & $18-18$ & Surface & & $3.4^{*}$ & 1.6 & 0.4 & 0.9 & 1.4 & 0.6 & 1.5 \\
\hline 1 & 5 & 22 & & $41 \mathrm{MC222}$ & 179.8 & N102E8B & $98.85-.80$ & $2.1 *$ & 1.7 & 0.5 & 0.9 & 1.3 & 0.8 & 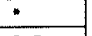 \\
\hline 1 & 5 & 23 & & $41 \mathrm{MC} 222$ & $179-19$ & N102E88 & $98.85-.80$ & 3.7 & 1.7 & 0.6 & 0.6 & 0.8 & 0.8 & 2.3 \\
\hline 1 & 5 & 24 & Stem Only & $41 \mathrm{MC222}$ & 136 & N99E91 & Surf. -98.75 & 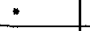 & $*$ & 0.3 & 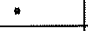 & 1.8 & 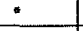 & $*$ \\
\hline 1 & 5 & 25 & Stem Only & $41 \mathrm{MC} 275$ & 2.0 & Surface & & $*$ & $\bullet$ & 0.4 & $\bullet$ & 1.8 & 0.7 & 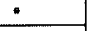 \\
\hline 1 & 5 & 26 & Stem Only & $41 \mathrm{MC298}$ & 2 & Test Pit 1 & $10-20 \mathrm{~cm}$. & - & $*$ & 0.2 & 0.7 & $\cdot$ & 0.5 & 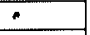 \\
\hline 1 & 5 & 27 & Stem Only & $41 \mathrm{MC298}$ & 135 & N1025E998 & $99.30-.20$ & 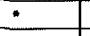 & $\cdot$ & 0.3 & $\div$ & $1.4^{*}$ & $\div$ & $*$ \\
\hline 1 & 5 & 28 & Stem Only & $41 \mathrm{MC} 296$ & 140 & N1025E999 & $99.50-.40$ & $\therefore$ & $\cdot$ & 0.4 & $\cdot$ & $*$ & 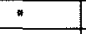 & - \\
\hline 1 & 5 & 29 & Stem Only & $41 \mathrm{MC} 296$ & 178 & N1027E998 & $99.40-.30$ & 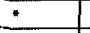 & $*$ & 0.3 & $*$ & 1.7 & 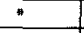 & $*$ \\
\hline 1 & 5 & 30 & Stam Only & $41 \mathrm{MC} 296$ & 191 & Surface & & 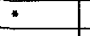 & $\cdot$ & 0.4 & $*$ & 1.4 & 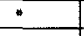 & $*$ \\
\hline 1 & 6 & 1 & Untyped & $411 K 51$ & 160 & N999E982 & $99.50-.40$ & $6.5^{\circ}$ & 1.7 & 0.8 & $\cdot$ &. & 1.3 & $8.7^{*}$ \\
\hline 1 & 6 & 2 & Dart Point & $41 \mathrm{LK} 201$ & $727-167$ & \begin{tabular}{|l|} 
N505E1011 \\
\end{tabular} & $99.31-.20$ & 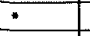 & $3.4^{*}$ & 0.6 & 2.0 & $2.4^{*}$ & 1.9 & 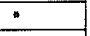 \\
\hline 1 & 6 & 3 & Fragments & $41 \mathrm{MC} 196$ & 27.0 & Surface & & $7.7^{*}$ & 2.0 & 1.0 & 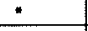 & $*$ & 1.5 & $14.4^{*}$ \\
\hline 1 & 6 & 4 & & $41 \mathrm{MC2} 234$ & 1.0 & Surface & & $2.8^{*}$ & 1.7 & 0.5 & $\cdot$ & 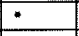 & 1.0 & $2.8^{\circ}$ \\
\hline 1 & $\theta$ & 5 & & $41 \mathrm{MC268}$ & $21-8$ & Surface & & $\therefore$ & 2.4 & 0.6 & $*$ & + & $\div$ & $*$ \\
\hline 1 & 6 & 6 & & $41 \mathrm{MC2} 296$ & 2 & Test Pit 1 & $10-20 \mathrm{~cm}$ & $\therefore$ & $*$ & 0.6 & 0.4 & 1.9 & 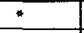 & $\cdot$ \\
\hline 1 & 7 & 1 & Untyped & 41LK51 & 141 & N999E981 & $99.70-.60$ & $2.5^{*}$ & $1.9^{\circ}$ & 0.4 & $*$ & $*$ & 0.6 & 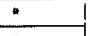 \\
\hline 1 & 7 & 2 & Arrow Point & 41 LK5 1 & 272 & N1010E 1008 & Surf.-99.80 & $*$ & 1.4 & 0.3 & 0.5 & 0.8 & 0.8 & $*$ \\
\hline 1 & 7 & 3 & Fragments & 41LK51 & 287 & N1033E1062 & $99.70-.60$ & $2.5^{*}$ & 1.7 & 0.3 & $\cdot$ & 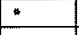 & 0.5 & $1.2^{\circ}$ \\
\hline 1 & 7 & 4 & & 41LK51 & 300 & N1033E1065 & $99.50-.40$ & $2.6^{\circ}$ & 1.8 & 0.5 & $\cdot$ & $*$ & 0.6 & $2.1^{*}$ \\
\hline 1 & 7 & 5 & & 41 LK1 28 & 22 & Teat Pit 6 & $99.60-.50$ & $3.1^{*}$ & 2.4 & 0.3 & $*$ & 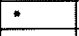 & $"$ & $1.8^{*}$ \\
\hline 1 & 7 & 6 & & 41 LK 128 & 23 & Test Pit 6 & $99.50-.40$ & $2.7^{\circ}$ & 2.1 & 0.2 & 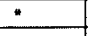 & $*$ & 0.6 & $1.1^{\circ}$ \\
\hline 1 & 7 & 7 & & 41LK128 & 33 & Test Pit 8 & $99.70-.60$ & $2.2^{\circ}$ & 1.6 & 0.2 & $*$ & $\cdot$ & 0.7 & $0.9^{*}$ \\
\hline 1 & 7 & 8 & & 41LK128 & $47-0$ & Hearth 18 & & 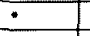 & 1.7 & 0.3 & $*$ & - & 0.6 & + \\
\hline 1 & 7 & 9 & & 41 LK128 & 61 & Test Pit 10 & Level 2 & $4.3^{*}$ & 1.6 & 0.4 & * & $*$ & 0.5 & $2.2^{\prime \prime}$ \\
\hline 1 & 7 & 10 & & $41 L K 128$ & 64 & Test Pit 16 & Level 1 & $2.3^{\circ}$ & $*$ & 0.2 & . & $"$ & 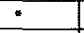 & $\star$ \\
\hline 1 & 7 & 11 & & 41LK201 & 221 & N497E997 & $99.15-.05$ & 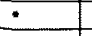 & 1.8 & 0.4 & $*$ & $*$ & $\div$ & $\div$ \\
\hline 1 & 7 & 12 & & 41 LK201 & 230 & N497E998 & $99.15-.05$ & 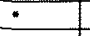 & $1.5^{*}$ & 0.3 & $\cdot$ & $"$ & $\therefore$ & $*$ \\
\hline 1 & 7 & 13 & & $41 \mathrm{LK201}$ & 248 & N49BE997 & $99.05-98.95$ & - & 1.6 & 0.4 & $*$ & 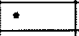 & 0.8 & 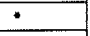 \\
\hline 1 & 7 & 14 & & 41LK201 & 272 & N499E997 & $99.05-98.95$ & $2.8^{*}$ & 2.1 & 0.2 & $\cdot$ & 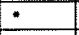 & 0.8 & $1.6^{\circ}$ \\
\hline 1 & 7 & 15 & & $41 L K 201$ & 653 & N509E1011 & $99.23-10$ & $0.9^{*}$ & 1.2 & 0.2 & $*$ & $\cdot$ & 0.4 & $\cdot$ \\
\hline 1 & 7 & 16 & & 41 LK201 & $689-82$ & NEO9E1010 & $99.10-99.00$ & $2.9^{*}$ & $1.3^{*}$ & 0.2 & * & - & 0.5 & $0.6^{*}$ \\
\hline 1 & 7 & 17 & & $41 L K 201$ & 698 & N507E1009 & $99.20-10$ & 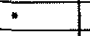 & 1.5 & 0.2 & $\cdot$ & * & 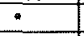 & 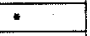 \\
\hline 1 & 7 & 18 & & $41 \mathrm{LK} 201$ & $719-159$ & N508E1008 & $99.10-99.00$ & + & 1.7 & 0.3 & $\div$ & $*$ & $\cdot$ & * \\
\hline 1 & 7 & 19 & & $41 \mathrm{LK} 201$ & 719.161 & N508E1008 & $99.10-99.00$ & $\therefore$ & $1.4^{\circ}$ & 0.2 & $\div$ & $*$ & 0.5 & $\cdot$ \\
\hline 1 & 7 & 20 & 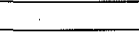 & 41 LK201 & $720-143$ & N5O4E 01012 & $99.20-10$ & $2.0^{*}$ & 1.5 & 0.2 & $\div$ & 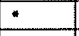 & $\div$ & $*$ \\
\hline 1 & 7 & 21 & & 41 LK201 & 723 & N5O5E 1013 & $99.20-.10$ & $2.7^{*}$ & $*$ & 0.3 & $\dot{*}$ & 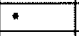 & $\div$ & \\
\hline 1 & 7 & 22 & & $41 \mathrm{MC5} 5$ & 94 & N999E1017 & Surf. -99.30 & $2.2^{*}$ & 1.3 & 0.3 & " & $\cdot$ & 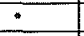 & . \\
\hline 1 & 7 & 23 & & $41 \mathrm{MC9} 4$ & 187 & Test Pit 2 & Surt. -99.70 & $2.9^{*}$ & + & 0.5 &. & . & $*$ & + \\
\hline 1 & 7 & 24 & & $41 \mathrm{MC222}$ & 208 & N102E91 & $98.80-.75$ & $\therefore$ & 1.4 & 0.4 & $\cdot$ & $*$ & $\div$ & $\cdot$ \\
\hline 1 & 7 & 25 & & $41 \mathrm{MC2} 275$ & 5.27 & Surface & & $1.8^{*}$ & 1.5 & 0.2 & * & $*$ & $*$ & $\cdot$ \\
\hline 1 & 7 & 26 & & $41 \mathrm{MC2} 24$ & 3.0 & Surface & & $2.5^{\circ}$ & 1.5 & 0.3 & $\cdot$ & $*$ & 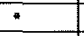 & $\cdot$ \\
\hline 1 & 7 & 27 & & $41 \mathrm{MC} 296$ & 16 & Tegt Pit 2 & $10-20 \mathrm{~cm}$. & $2.1 *$ & 1.5 & 0.3 & " & $\cdot$ & 0.5 & 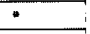 \\
\hline 1 & 7 & 28 & & $41 M C 296$ & 41 & N1022E985 & Surt. -99.40 & $\therefore$ & $*$ & 0.2 & $*$ & 0.7 & 0.7 & $*$ \\
\hline 1 & 7 & 29 & & $41 \mathrm{MC} 296$ & 61 & N1022E987 & Surf. -99.40 & 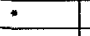 & 1.4 & 0.3 & $\cdot$ & $\bullet$ & $\stackrel{*}{*}$ & $\div$ \\
\hline 1 & 7 & 30 & & $41 \mathrm{MC2} 296$ & 61 & N1022E987 & Surt. -99.40 & $3.0^{\circ}$ & 1.6 & 0.3 & $*$ & $*$ & 0.6 & $*$ \\
\hline 1 & 7 & 31 & & $41 \mathrm{MC} 296$ & 81 & N1022E987 & Surf.-99.40 & 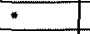 & 1.0 & 0.2 & $\cdot$ & $\cdot$ & 0.4 & $\cdot$ \\
\hline 1 & 7 & 32 & & $41 \mathrm{MC} 296$ & 72 & N1023E985 & $99.30-.20$ & $2.2^{*}$ & $1.5^{*}$ & 0.3 & $*$ & $\bullet$ & $*$ & $\cdot$ \\
\hline 1 & 7 & 33 & & $41 \mathrm{MC} 296$ & 72 & N1023E985 & $99.30-.20$ & $2.3^{*}$ & $*$ & 0.2 & 1.0 & 0.9 & 0.9 & $\cdot$ \\
\hline 1 & 7 & 34 & & $41 \mathrm{MC} 296$ & 74 & N1023E985 & $99.10-99.00$ & $2.2^{*}$ & 1.8 & 0.4 & $*$ & $\cdot$ & $\div$ & $\cdot$ \\
\hline 1 & 7 & 35 & & $41 M C 296$ & 79 & N1023E98B & Surf. -99.40 & $2.3^{*}$ & $*$ & 0.3 & $*$ & $*$ & 0.5 & $\div$ \\
\hline 1 & 7 & 36 & & $41 M C 296$ & 79 & N1023E986 & Surf. -99.40 & $2.4^{*}$ & 1.1 & 0.3 & $\cdot$ & $*$ & 0.4 & $*$ \\
\hline 1 & 7 & 37 & & $41 \mathrm{MC} 296$ & 79 & N1023E98B & Surf. -99.40 & $2.3^{\circ}$ & 1.5 & 0.3 & 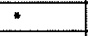 & $\div$ & 0.6 & 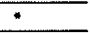 \\
\hline 1 & 7 & 38 & & $41 \mathrm{MC296}$ & 91 & N1023E987 & $99.30-.20$ & 1.8 & $1.2^{*}$ & 0.3 & $*$ & 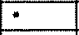 & $*$ & $*$ \\
\hline 1 & 7 & 39 & & $41 \mathrm{MC} 296$ & 98 & N1024E985 & Surf. -99.40 & $2.4^{\circ}$ & 1.6 & 0.3 & 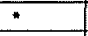 & 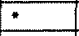 & 0.5 & $*$ \\
\hline 1 & 7 & 40 & & $41 \mathrm{MC} 296$ & 98 & N1024E985 & Surf.-99.40 & $1.8^{*}$ & 1.2 & 0.2 & $*$ & $\cdot$ & 0.7 & $\cdot$ \\
\hline 1 & 7 & 41 & & $41 \mathrm{MC} 296$ & 99 & N1024E985 & $99.40-.30$ & $3.3^{*}$ & 1.9 & 0.4 & $*$ & $*$ & $*$ & $*$ \\
\hline 1 & 7 & 42 & & $41 \mathrm{MC} 290$ & 108 & N1024E986 & $99.40-.30$ & - & $*$ & 0.2 & * & $*$ & 0.7 & $\therefore$ \\
\hline 1 & 7 & 43 & & $41 \mathrm{MC2} 296$ & 116 & N1024E987 & Surf.-99.40 & $\div$ & $1.8^{*}$ & 0.3 & 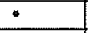 & $\cdot$ & 0.5 & 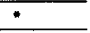 \\
\hline 1 & 7 & 44 & & $41 \mathrm{MC} 296$ & 133 & N1025E998 & 99.50 .40 & $3.0^{\circ}$ & 2.4 & 0.3 & $*$ & - & 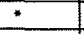 & $*$ \\
\hline 1 & 7 & 45 & & $41 \mathrm{MC} 296$ & 214 & N1027E986 & $99.50-.40$ & $1.5^{*}$ & 0.9 & 0.2 & $*$ & $\bullet$ & 0.5 & $\div$ \\
\hline 1 & 7 & 46 & & $41 \mathrm{MC} 296$ & 217 & N1026E995 & $99.50-.40$ & $\div$ & 1.4 & 0.2 & $*$ & $*$ & $\div$ & $*$ \\
\hline 1 & 7 & 47 & & $41 \mathrm{MC} 296$ & 227 & N1024E989 & $99.40-.30$ & $\div$ & $\div$ & 0.3 & 1.2 & 1.2 & 1.2 & $\cdot$ \\
\hline
\end{tabular}


Specimen 6: Specimen 6 1acks a distal tip and a portion of the base. The b 1 ade edges are convex, and the shou 1 ders are moderate 1 y pronounced. The basal morphology is obscure due to breakage. The distal end seems to have been reworked.

Specimen 7: The distal tip, one barb, and 1 ateral edge are missing from Specimen 7. The surviving barb is pronounced, and the basal edge is straight. The specimen is made of chalcedony.

Specimen 8: Burning has caused extensive potlidding on this specimen, and its color has been altered to a purplish gray. Blade edges are irregular. The shoulders are weak. Basal edge morphology cannot be determined.

Specimen 9: The blade edges of Specimen 9 are slightly concave and a ternately beveled. This configuration suggests use of the piece as a hafted cutting tool. Shoulder morphology is asymmetrical. One shoulder is moderately pronounced while the other is very weak. The base is straight. The piece has been burned, resulting in two large pot 1 ids on one face. Specimen 9 was recovered in excavations at 41 LK 201. Deposits yielding the piece have been radiocarbon dated to 480 B.C. $(T X-4665)$.

Specimen 10: The distal end on Specimen 10 was apparently shattered by impact and then reworked. Blade edges are irregularly convex. The stem is asymmetrical with a straight base.

Specimen 11: The distal tip is missing from Specimen 11. It is similar to Specimens 4 and 5 above except that the base is not as pronouncedly concave. B1 ade edges are straight. The shoulders are weak.

Specimen 12: The distal half of Specimen 12 is missing. Shoulders are moderately pronounced, but not barbed. The base is notched by a sha 110 w concavity.

Specimen 13: Biade edges are slightly convex. Shoulders are weak. The stem is short with a convex base.

\section{Form 2. Large with Contracting Stems (14 specimens)}

Seven of these dart points fall into the previously established types of Morhiss and Langtry. The remaining specimens do not conform to any currentiy established types.

Specimens 1-2, 7: Morhiss. Specimen 1 lacks its distal half. Specimen 2 has straight blade edges with alternate beveling. Specimen 7 was recovered from deposits at 41 LK 201 (see Highley 1986 for descriptive information). Shoulders are 1 ightly to moderately pronounced, but not barbed. Stem edges are straight with boldiy convex bases imparting a bulbous appearance to the stems. Radiocarbon assays from deposits yielding Morhiss points in Goliad County place the type in the time period of 1250-500 B.C. (D. E. Fox 1979a:62). 

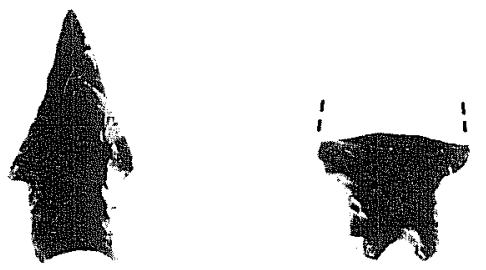

$1-1-1$

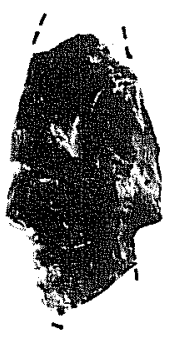

$1-1-6$

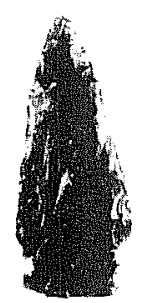

$1-1-13$

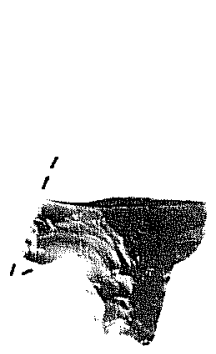

$1-2-6$

$1-1-2$

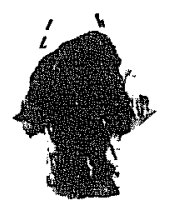

$1-1-3$

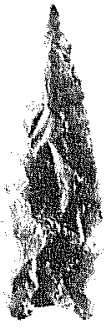

$1-1-4$

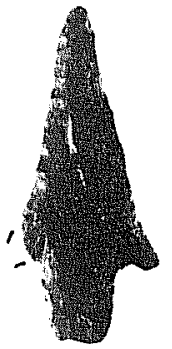

$1-2-5$

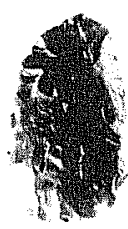

$1-1-10$
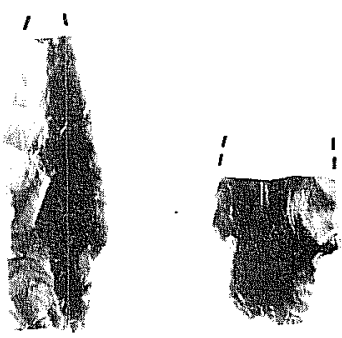

$1-1-8$
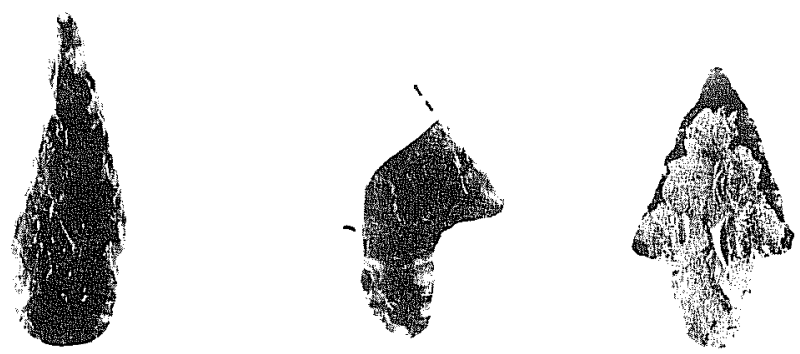

$1-2-2$

$1-2-3$

$1-2-4$
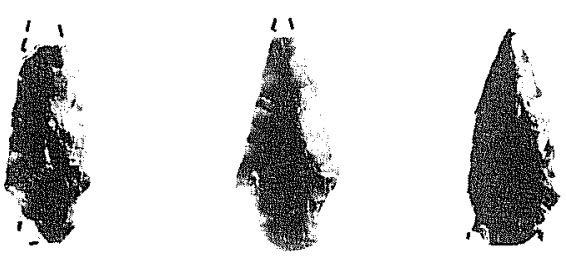

$1-2-9$

$1-2-10$

$\mid-2-11$

$1-2-12$
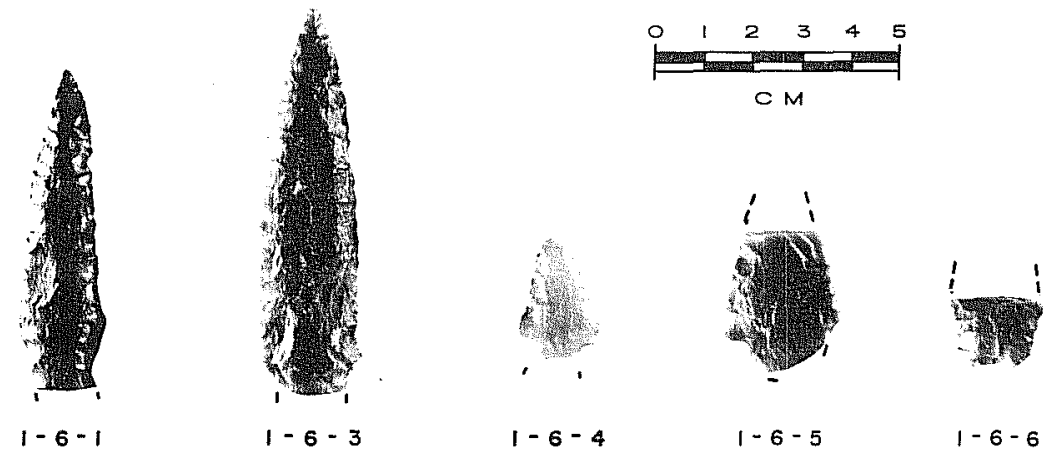

$1-6-3$

Figure 74. Thin Bifaces: Group 1, Forms 1, 2, and 6. Numbers beneath artifact indicate group, form, and specimen number, respectively. 
Specimens 3-6: Langtry. Typed Langtry, the specimens from Choke Canyon are not exactly like the Langtry points from the Trans-Pecos region in Texas. It is probably better to refer to the Choke Canyon specimens as southwest Texas variants of the classic Langtry form. Blade edges are straight to slightly concave. Shoulders are very strong. Wide stems contract slightly to rounded bases. Specimen 3 was recovered from subsurface deposits at 41 LK 51 , but no associated radiocarbon samples were found. Specimen 4 is heavily patinated over its entire surface with the exception of the blade edges. The piece was apparently picked up and reused a considerable time after it was first dropped.

Specimen 8: Blade edges are slightly convex, and the shoulders are very weak. Stem edges contract slightly to a rounded base.

Specimen 9: This unusual biface has straight blade edges; weak, rounded shoulders; and a sharply tapering stem.

Specimens 10-14: The smallest specimens in the form 2 grouping. these pieces a 11 have straight to slightiy convex b1ade edges with short stems and rounded bases. Shoulders are moderate to weak.

\section{Eorm 3. Large with Expanding Stems (39 specimens)}

Seventeen of the Form 3 dart points are categorized as Ensor and Fairland. Four specimens are referred to as "Early Expanding Stem." The remaining 18 specimens do not clearly fit any currently recognized typological groupings.

Specimens 1-10, 21: Ensor. B1ades are triangular with straight to slightly convex blade edges. Shoulders are strong, sometimes with slight barbs. Stems are short and expand strongly to straight or slightly convex bases. A 11 specimens are side notched. Specimens 1, 3, and 4 are made of chalcedony. The rest are made of fine-grained chert. Specimen 21 was from 41 LK 201 (see Highley 1986 for descriptive information). The Ensor type is diagnostic of the Late or Terminal Archaic period in central Texas and the Trans-Pecos. Specimens 9 and 10, recovered in subsurface excavations at 41 MC 296, came from deposits radiocarbon dated between 100 B.C. (TX-4669) and A.D. 590 (TX-4680). Previously, excavations at 41 LK 67 yielded Ensor points from a Late Archaic component dating between 1590 B.C. and 660 B.C. (Brown et a 1. 1982:97). Based on the central Texas chronology, the time range estab 1 ished at 41 LK 67 wou $7 d$ be too early for Ensor. The range of Phase II dates presented above is more in 7 ine with the dating of Ensor in central Texas.

Specimens 11-17: Fairland. Blades are triangular. Blade edges are straight to slightly convex. Shoulders are moderately strong, but more rounded than barbed. Stems flare strongly to concave bases.

Specimens 18-20: "Early Expanding Stem." These three specimens are not assignable to any formally established types, but their overal1 shape places them within the morphological range of "Early Expanding Stem" points, which represent Early Archaic components at a number of sites in central and southern Texas. Specimen 18 has moderately convex blade edges, weak 
shoulders, and a strongly flared stem with concave base. It is somewhat 1 ike the Fairland type, but is more gracile and finely flaked. Specimen 18 was found $80 \mathrm{~cm}$ below the surface at $41 \mathrm{LK} 8$. There are no radiocarbon dates for the zone yielding this point. Specimen 19 has concave blade edges that form a sharp, slender distal tip. Although they are missing, the piece apparently had pronounced barbs. The stem is short and has a basal notch. The general outline and fine workmanship shown in this specimen are characteristic of the Bandy type reported from Baker Cave by Word and Douglas (1970). Specimen 19 was recovered at 41 LK 51 in deposits radiocarbon dated to the period from 5130 B.C. $(T X-4690)$ to 4450 B.C. (TX-4691). Specimen 20 has convex blade edges, strong barbs, a straight base, and 1 acks a distal end. The specimen is heavily patinated.

Specimen 22: This unusual stemmed biface has straight to slightly convex blade edges, very weak shoulders, and a rounded or lobate stem. No similar specimens are known from Choke Canyon. The blade is slightly beveled on a ternate sides.

Specimen 23: Long, thin, and finely worked, this specimen has sightly convex blade edges with small barbs and a short stem. Basal configuration cannot be determined due to breakage. The "waxy" appearance of this specimen suggests that the material of which it is made was heat treated. This point may be a 7 arge Ensor form typical of central Texas and Trans-Pecos Late Archaic assemblages.

Specimen 24: A stem fragment on 1y, this specimen flares at the base. The base is slightly concave.

Specimen 25: This piece has straight blade edges, small barbs, and a smal1 stem. It apparently 1 ay on the surface 1 ong enough to become 1 ight 1 y patinated and was then retrieved at some later date. This retrieval is evidenced by retouch along the blade edges which has removed some of the patination on the surface.

Specimen 26: Lacking its distal half, Specimen 26 has broad side notches forming weak shoulders and a narrow stem with straight base.

Specimen 27: This piece has convex, crudely asymmetrical blade edges, shallow side notches, and a straight base. One face retains cortex over most of its surface.

Specimen 28: Made of translucent white chalcedony, Specimen 28 has straight blade edges, small barbs, and a short stem with straight base.

Specimen 29: This specimen consists only of a strongly flared stem fragment with a broadly concave base. It is similar to the base on Fairland dart points.

Specimen 30: This specimen consists of a proximal half only. Blade edges appear to have been convex. Broad, shallow side notches form weak shoulders and a short stem with convex base. 

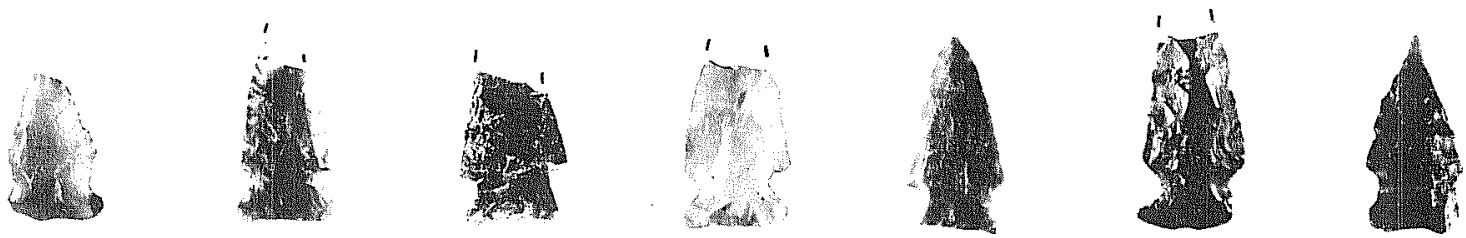

$1-3-1$

$1-3-2$

$1-3-3$

$1-3-4$

$1-3-5$

$1-3-6$

$1-3-7$
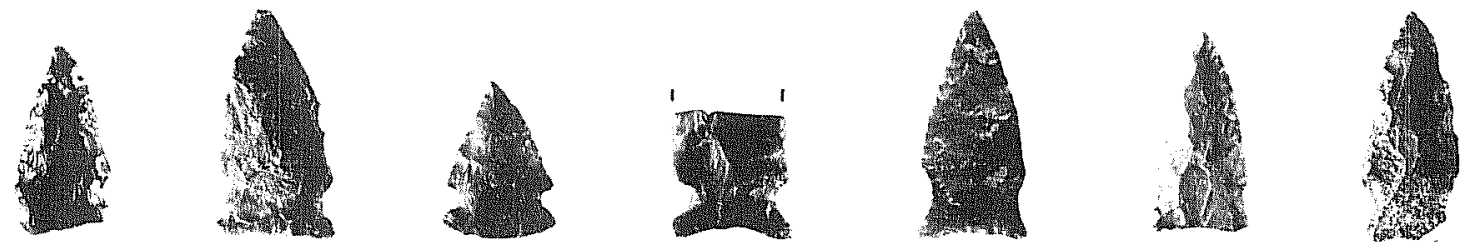

$1-3-8$

$1-3-9$

$1-3-10$

$1-3-11$

$1-3-12$

$1-3-13$

$1-3-14$
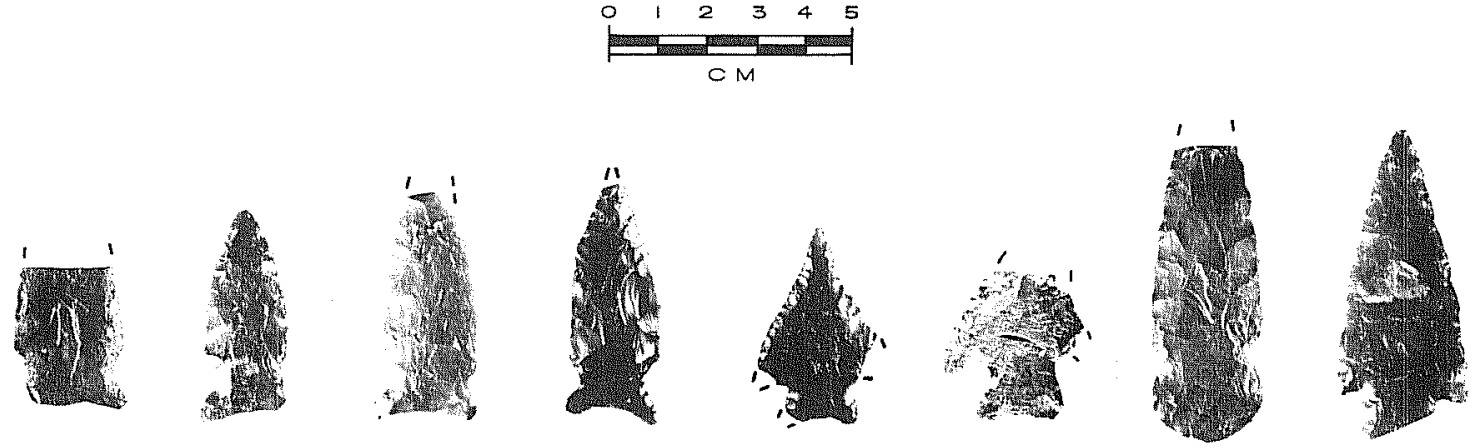

$1-3-15$

$1-3-16$

$1-3-17$

$1-3-18$

$1-3-19$

$1-3-20$

$1-3-22$

$1-3-23$
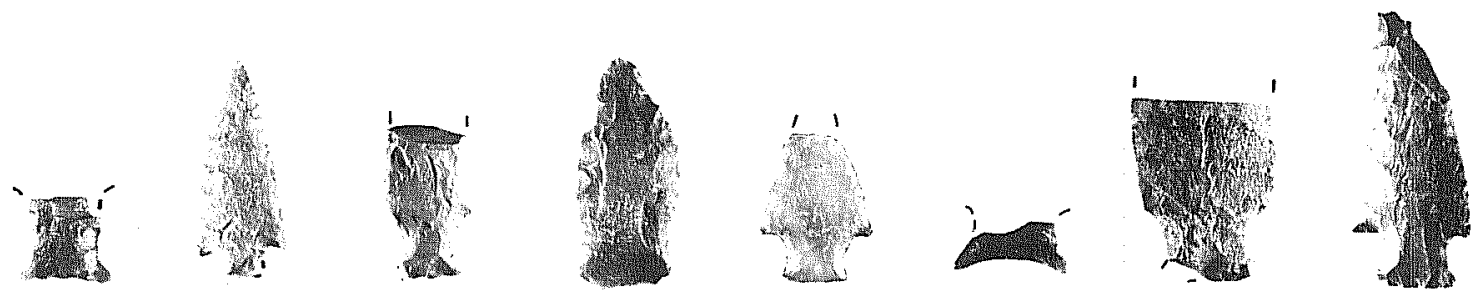

$1-3-24$

$1-3-25$

$1-3-26$

$1-3-27$

$1-3-28$

$1-3-29$

$1-3-30$

$|-3-3|$
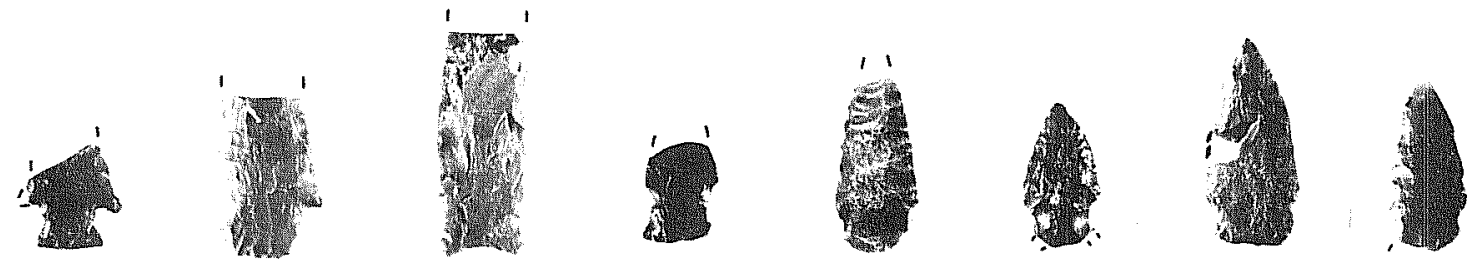

$1-3-32$

$1-3-33$

$1-3-34$

$1-3-35$

$1-3-36$

$1-3-37$

$1-3-38$

$1-3-39$

Figure 75. Thin Bifaces: Group 1, Form 3. Numbers beneath artifact indicate group, form, and specimen number, respectively. 
Specimen 31: Specimen 31 has straight blade edges. The distal tip seems to have been removed by impact fracture. Small barbs give way to a short stem with a straight base.

Specimen 32: The distal half is missing. Moderate barbs are formed by corner notching. The base is slightly convex.

Specimen 33: Specimen 33 lacks the distal half. It has straight blade edges, smal1 barbs, and an asymmetrical stem with a straight base.

Specimen 34: This specimen lacks its distal end. Blade edges are slightly convex. The stem is formed by very broad, shal 10 side notches. The stem flares slightly and has a concave base. This piece was recovered at 41 MC 296 in deposits radiocarbon dated to the period between 100 B.C. (TX-. 4669) and A.D. $590(T X-4680)$.

Specimen 35: This piece lacks its distal end. Shallow side notches form weak shoulders and a short stem with a convex base.

Specimens 36-39: Zavala. These diminutive stemmed points have been informally typed Zavalla by Hester and Hill (1975) as a result of their investigations in southwest Texas. The points have slightly convex blade edges with smal1 side notches. The stems are distinguished by striking platforms preserved at the base. The bases are asymmetrically convex. Specimen 39 is made of chalcedony. Specimens 38 and 39 were recovered in excavations at 41 MC 296. Deposits yielding these specimens have been radiocarbon dated to the period from A.D. 910 (TX-4687) to A.D. 1520 (TX4678). A Late Prehistoric affiliation for this type is consistent with findings made by Hester and $\mathrm{Hi} 11$ (ibid.).

\section{Eorm 4. Small with Straight or Contracting Stems (87 specimens)}

Eighty of the specimens in this form grouping are typed Perdiz. There are four examples of the $\mathrm{Cl} 1 \mathrm{iffton}$ type (Specimens 68, 69, 85, and 87). The Cliffton type is simply a preform of Perdiz. There are three specimens with straight stems (Specimens 74, 75, and 76). A1 1 of these straight stemmed specimens were found along with expanding stemmed Edwards arrow points at 41 MC 222 in deposits previously radiocarbon dated to the period from A.D. 1260 to 1290 (Ha1 1, B 1 ack, and Graves 1982:652).

The Perdiz points display considerable variation in blade morphology. Blade edges may be convex, straight, or concave. A1l are moderately to strongly barbed. Stems usually contract to a point, but may also be rounded at the base. The specimens show a relatively great range of overall 1 engths, widths, and stem 1engths. The greatest difference in length $(3.9 \mathrm{~cm})$ is between Specimen $8(5 \mathrm{~cm})$ and Specimen $66(1.1 \mathrm{~cm})$. The widest piece is Specimen $86(2.4 \mathrm{~cm})$. Specimen 46 has the longest stem $(1.6 \mathrm{~cm})$.

By virtue of their atypical blade configurations, two of the Perdiz specimens (Specimens 17 and 52) are suggested to have been used as hafted end scrapers. The distal ends of these two pieces are rounded rather than pointed. 
Eorm 5. Small with Expanding Stems (30 specimens)

Specimens 1-14: Scal1orn. Blades are triangular. Blade edges are straight to slightly convex. Blade edges of Specimens 1 and 2 are serrated. Shoulders are strongly barbed. Side- and corner-notching forms expanding stems with straight, concave, or convex bases. Basal width is variable, but. usually slightly less than the width at the shoulders. Specimen 5 is made of translucent white chalcedony. The rest are of chert.

Specimens 15-19: Edwards. Blades are triangular with straight to slightly convex edges. The blades of Specimen 18 are heavily serrated. Shoulders are strongly barbed. The specimens are deeply corner notched. The stems flare downward to the same width as the shoulders. The bases are pronounced $1 \mathrm{y}$ concave. The type is described by Sol1berger (1978:14).

Specimen 20: Blade is triangular. Blade edges are slightly convex. Stem is formed by broad, U-shaped side notches. Stem flares to shoulder width and has a straight base.

Specimen 21: Blade is triangular with deeply serrated edges. U-shaped side notches form an expanding stem with a straight base. The piece is made of brownish white opaque chalcedony.

Specimen 22: Blade is triangular (distal end gone) with straight edges. Broad, U-shaped side notches form an expanding stem with a convex base. This specimen is made of frosted white, translucent chalcedony. It was recovered from deposits at 41 MC 222 radiocarbon dated between A.D. 1290 and 1300 (Ha11, Black, and Graves 1982:652).

Specimen 23: B 1 ade is triangular in out 1 ine with slight 1 y concave edges. The shoulders are moderately pronounced, but not barbed. The stem expands very slightly to a convex base. The specimen was apparentiy burned, turning it a grayish white color with some crazing evident on the surface. It was recovered from the same provenience at 41 MC 222 as Specimen 22 above. It is very similar in general form to the straight stemmed specimens (Group 1 . Form 4, Specimens 74-76) described above.

Specimens 24-30: Consisting of stem fragments only, al1 of these specimens likely represent the Scallorn type, but positive identification is not possible.

\section{Eorm 6. Unclassifiable Fragments of Large Stemmed Bifaces (6 specimens)}

Specimen 1: A long, slender piece, this specimen has asymmetrical blade edges, one slightly concave and the other slight $1 y$ convex. The piece appears to have been resharpened along the edges forming a relatively steep bevel on both faces and sides. The longitudinal midsection is unusually thick in relation to the width. Very weak shoulders give way to what appears to have been a mildiy expanding stem. The specimen is made of fine-grained petrified wood. 


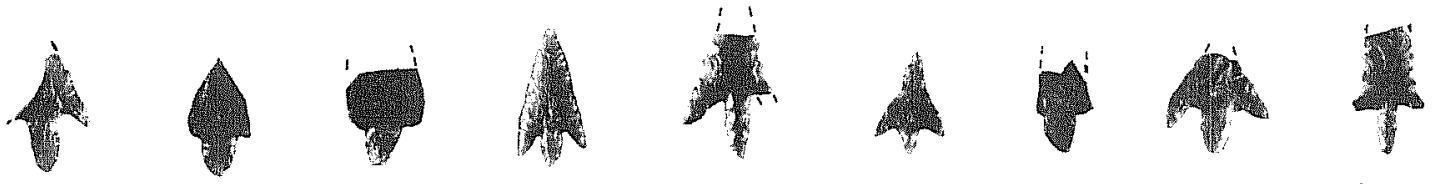

$1-4-32 \quad 1-4-33 \quad 1-4-34 \quad 1-4-35$
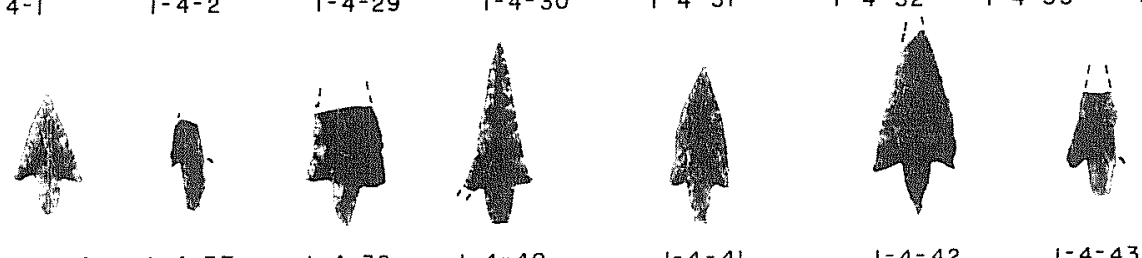

4

$1-4-36 \quad 1-4-37 \quad 1-4-38$

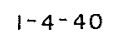

$|-4-4|$

$1-4-42$

$-4-44 \quad 1-4-45$
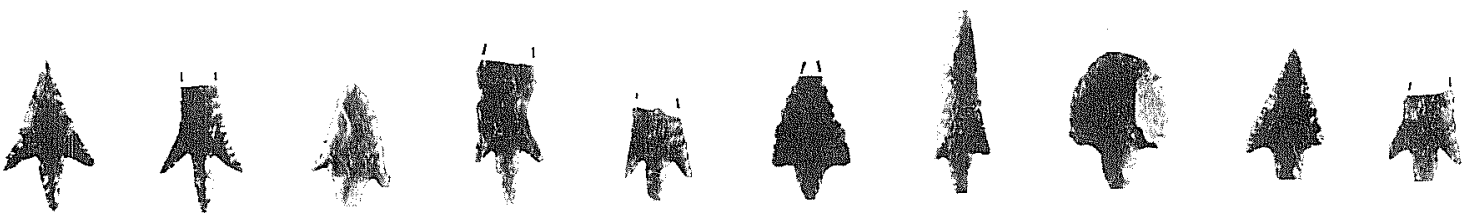

$1-4-39$

$1-4-46$

$1-4-47$

$1-4-48$

$1-4-49$

$1-4-50$

$|-4-5|$

$1-4-52$

$1-4-53$

$1-4-54$
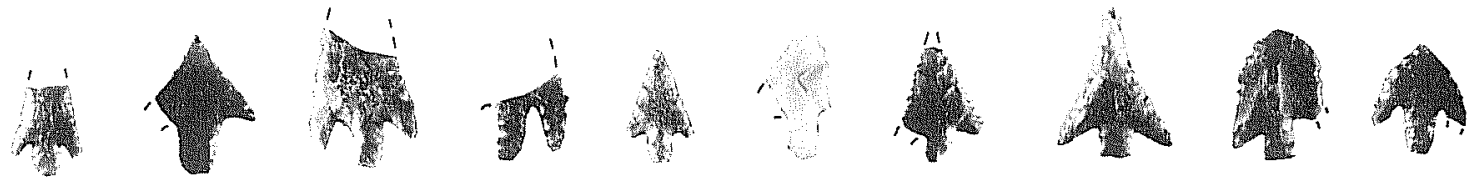

$1-4-55 \quad 1-4-56$

$1-4-57$

$1-4-58 \quad 1-4-72 \quad 1-4-73 \quad 1-4-74$

$1-4-75$

$1-4-76 \quad 1-4-77$
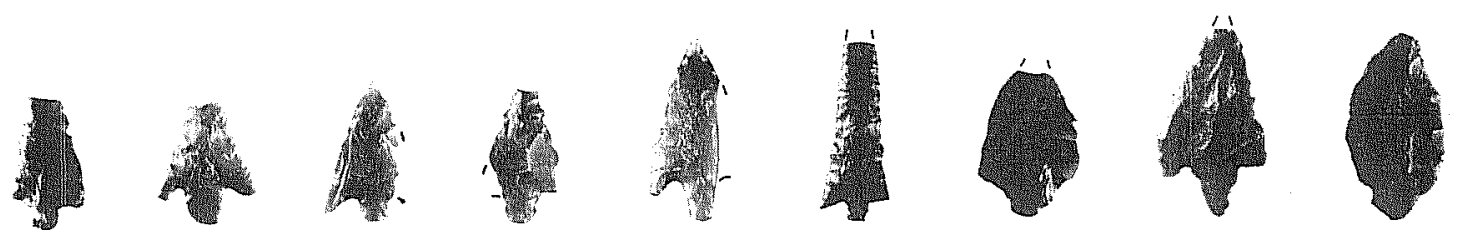

$1-4-78 \quad 1-4-79$

$1-4-80 \quad|-4-8|$

$1-4-82$

$1-4-83$

$1-4-85$

$1-4-86 \quad 1-4-87$
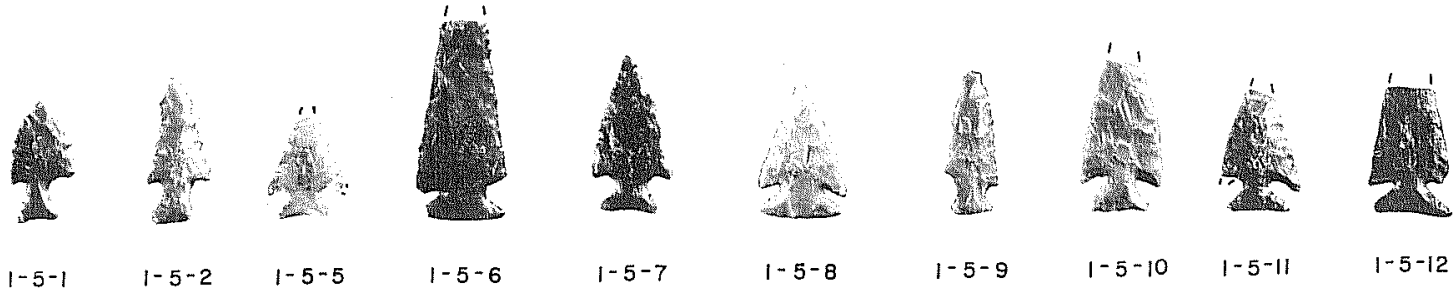

$1-5-7$

$1-5-8$

$1-5-9$

$1-5-10$

$-5-12$

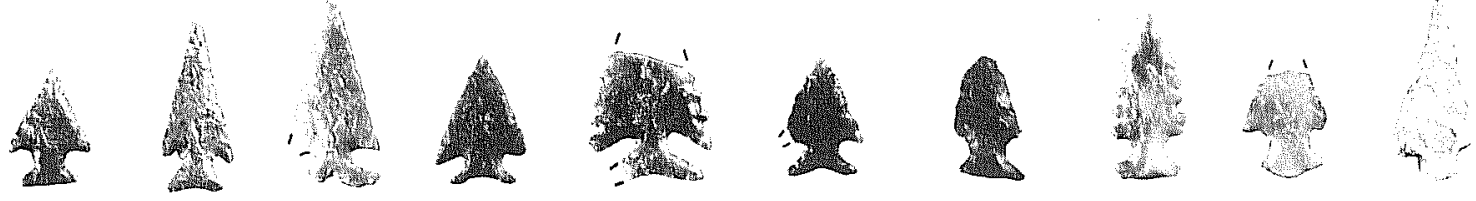

$1-5-13 \quad 1-5-14 \quad 1-5-16 \quad 1-5-17 \quad 1-5-18$
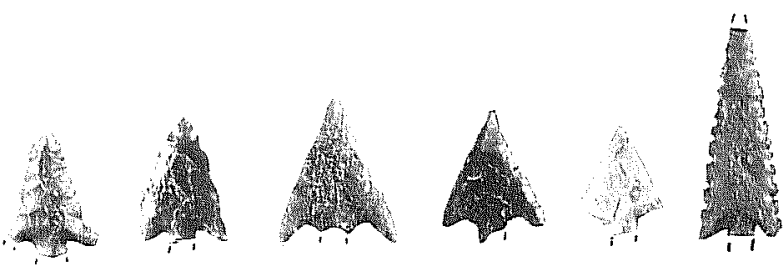

$1-5-20 \quad 1-5-21$

$1-5-22 \quad 1-5-23$

$1-7-1$

$1-7-4$

$1-7-5$

$1-7-6$

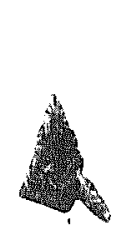

$\frac{0123}{C M}$
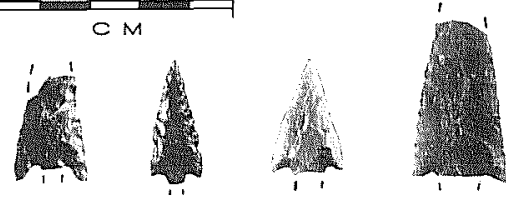

Figure 76. Thin Bifaces: Group 1, Forms 4, 5, and 7. Numbers beneath artifact indicate group, form, and specimen number, respectively. 
Specimen 2: This unusual piece is very irregular in outline shape. There is the appearance of a disproportionately large stem at one end formed by shall low notches worked in from two opposing sides. A hafted knife or scraper is suggested. The piece was recovered from Late Prehistoric context at 41 LK 201 (see Highley 1986).

Specimen 3: The blade of this specimen is long and slender with slightly convex edges. The shoulders are very weak. Only small vestiges of the stem remain. The piece was burned, resulting in potlid fractures on one face.

Specimen 4: The blade is triangular with slightly concave blade edges, apparentiy a result of resharpening. The distal tip is thick and blunt. The shou 1 ders appear to have been moderately barbed. The stem was formed by basal notching and is straight. The piece is made of tan, opaque chalcedony.

Specimen 5: Consisting of a midsection and portion of stem on 1 y, this specimen apparently had a triangular blade with straight edges. Shoulders are weak 1 y barbed.

Specimen 6: This specimen consists of a stem only. The stem contracts slightiy to a concave base.

Eorm 7. Unclassifiable Fragments of Small Stemmed Bifaces (47 specimens)

Thin biface Group 1, Form 7 specimens are smal1 distal, medial, and proximal fragments, all believed to be pieces of arrow points. Most are well within the general range of characteristics described for the Perdiz, Scallorn, and Edwards types presented above. Provenience and metric data for these specimens are shown in Table 9.

\section{Group 2. Unstemned with Straight Bases (77 specimens)}

Form 1. Complete Triangular (33 specimens)

Group 2, Form 1 specimens are more-or-less triangular in out 1 ine. Blade edges may be slightly convex, straight, or slightly concave. Specimens 1,3 , 10, and 18 are classic examples of the Tortugas type. The Tortugas form is characterized by steep, alternately beveled blade edges, by carefully thinned basa 1 portions, and by a prominent thickening in the midsection and toward the distal tip. Phase II work at Choke Canyon has unfortunately not provided any additional control over the temporal occurrence of Tortugas. Specimens 5 and 16 are distinguished by their fine flaking and thinness. They are suggested to be examples of the "Early Triangular" form diagnostic of the Early Archaic in central Texas. Specimen 5 has one concave blade edge. apparently formed as the piece was resharpened. It may have functioned as a. cutting tool. Found at 4 I LK 53, Specimen 5 is heavily patinated. From 41 LK 197, Specimen 16 is moderately patinated on one face. Specimen 23 has a sma 11 notch started near the base on one blade. Recovered at 41 MC 222, this thin, wel1-flaked piece is likely an arrow point preform. Specimen 33 exhibits steep alternate blade beveling, but is smaller, thinner, and general $7 y$ better worked than is typical of the Tortugas type discussed above. 

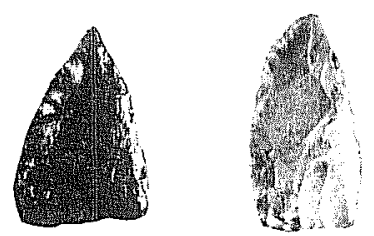

$2-1-1$

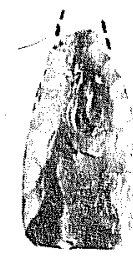

$2-1-3$

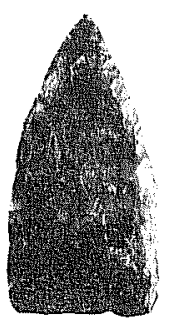

$2-1-4$

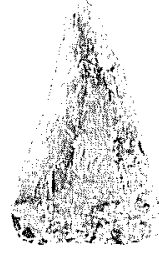

$2-1-5$

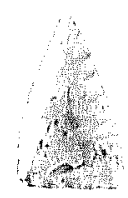

$2-1-6$

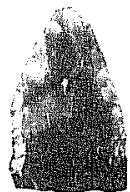

$2-1-7$
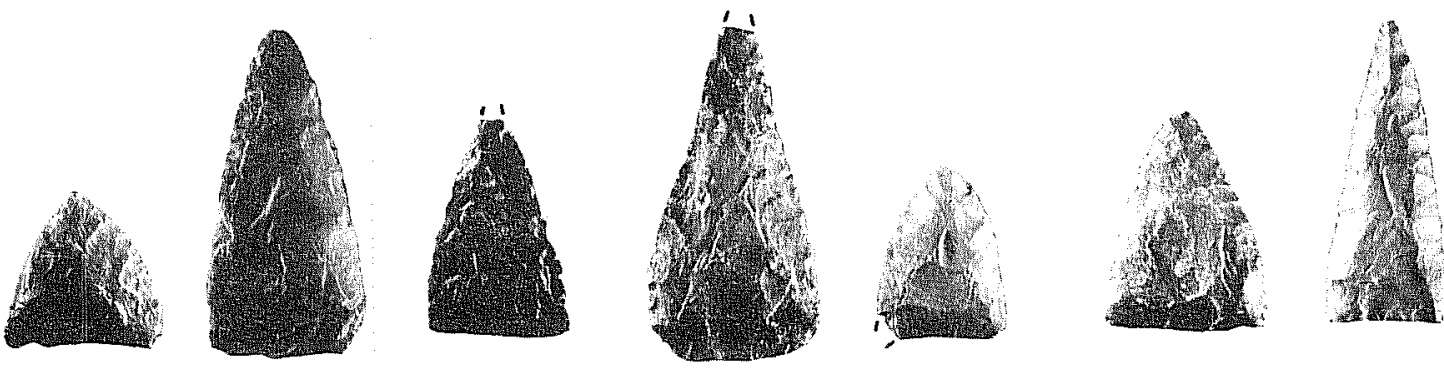

$2-1-8$

$2-1-11$

$2-1-16$

$2-1-17$

$2-1-18$

$2-1-10$

$2-1-19$
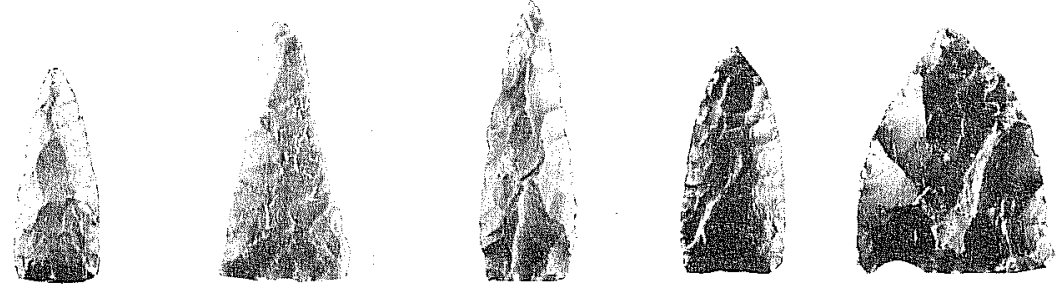

$2-1-27$
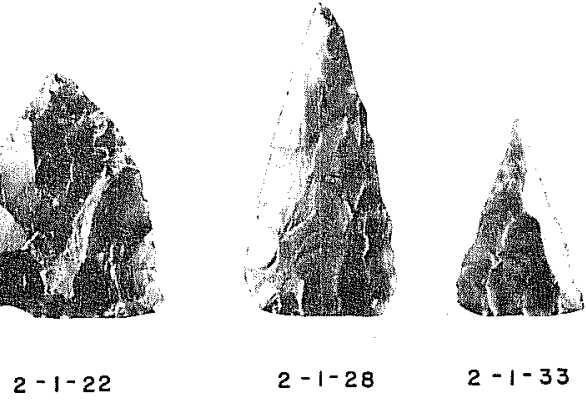

$2-1-24$

$2-1-25$

$2-1-20$

$2-1-28$

$2-1-33$

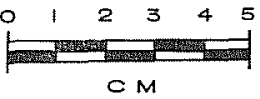

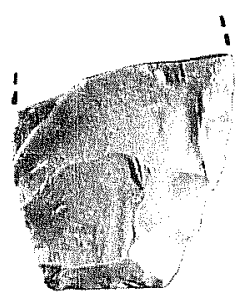

$2-2-2$

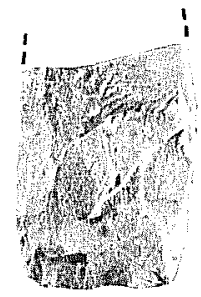

$2-2-3$

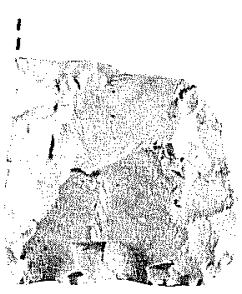

$2-2-6$

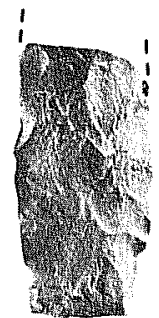

$2-2-11$

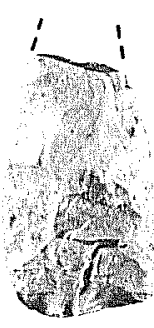

$2-2-14$
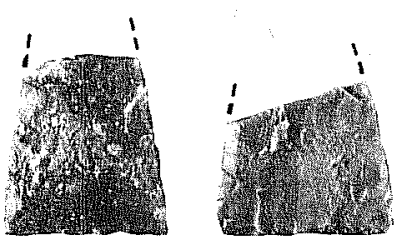

$2-2-15$

$2-2-21$

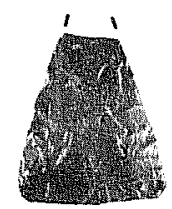

$2-2-28$

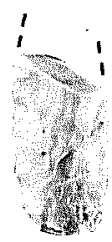

$2-2-29$

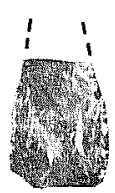

$2-2-32$

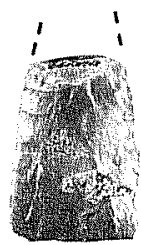

$2-2-34$

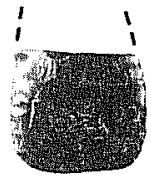

$2-2-36$

Figure 77. Thin Bifaces: Group 2, Forms 1 and 2. Numbers beneath artifact indicate group, form, and specimen number, respectively. 
Specimen 33 was recovered from probab 1e Late Prehistoric context at 41 MC 296 in deposits radiocarbon dated between A.D. 910 and A.D. 1230. Specimen 1 is made of petrified wood. A17 others are chert. Provenience and metric data for the Group 2, Form 1 specimens are shown in Table 10.

\section{Eorm 2. Proximal Fragments (44 specimens)}

Specimens 1-7: Specimens 1-7 are broader and thicker than other form 2 specimens. Remnant blade edges are convex. Flaking is rough. They are similar to the Group 5 thick biface specimens described above and are 1 ikely manufacturing failures.

Specimens 8-11: Generally longer relative to their width in comparison to others in this form grouping. Specimens 8-11 are also suggested to be manufacturing failures rather than completed tools.

Specimens 12-44: Remnant blade edges on these specimens are straight or convex. Basal corners range from sharp and angular to slightly rounded. Bases are more-or-less straight. Although not complete, the original out 7 ine shape of most of these specimens appears to have been triangular, much 1 ike the Group 2, Form I thin biface specimens described above. Thin and well flaked, it is difficult to tell whether these specimens were broken in manufacture or by use. Specimens 14, 16, 43, and 44 are heavily patinated. Specimen 32 is made of clear chalcedony. The rest are of fine-grained chert. Specimen 42 is distinguished by fine, diagonal ribbon flaking on both faces and by basal blade edge grinding. The edge grinding extends from the basal corners upward $1.8 \mathrm{~cm}$ al ong the blade edges. The specimen is definitely a Paleo-Indian form, but a type designation is not offered.

Site provenience, subsurface provenience, metric data, and specimen numbers by site are shown for the Group 2, Form 2 specimens in Tables 11-13.

\section{Group 3. Unstemmed with Concave Bases (39 specimens)}

Eorm 1. Complete Triangular (11 specimens)

Group 3, Form 1 specimens are all triangular in outline with concave bases. Eight specimens have convex blade edges, and three (Specimens 8, 10, and 11) have straight blade edges. Provenience and metric attribute data for Group 3, Form 1 thin biface specimens are given in Table 14. Five specimens are further described below.

Specimen 1: Apparently made from a 1 arge $\mathrm{f} 1 \mathrm{ake}$, this piece retains the curve of the flake. It was recovered from deposits at 41 LK 51 radiocarbon dated to the period from 5130 B.C. $(T X-4690)$ to 4450 B.C. $(T X-4691)$.

Specimen 3: Long and relatively narrow. Specimen 3 is made of fine-grained petrified wood. A cortex-covered striking platform is retained at the distal tip. This piece was recovered from undifferentiated Archaic deposits at 41 LK 53. 
TABLE 10. PROVENIENCE AND METRIC DATA FOR THIN BIFACES GROUP 2, FORM 1

\begin{tabular}{|c|c|c|c|c|c|c|c|c|c|}
\hline $\begin{array}{l}\text { Specimen } \\
\text { Number }\end{array}$ & Site & Lot & Unit & Level & Elevation & Length & Width & Thickness & Welght \\
\hline 1 & 41 LK 14 & 290 & N1010 E1002 & 3 & $99.60-99.50$ & 3.9 & 2.7 & 0.8 & 8.5 \\
\hline 2 & 41 LK 14 & $298-0$ & Surface & - & - & 4.3 & 2.4 & 0.9 & 9.4 \\
\hline 3 & 41 LK 14 & $300-0$ & Surface & - & - & 4.3 & 2.5 & 0.9 & 11.6 \\
\hline 4 & 41 LK 51 & 200 & N998 E981 & 6 & $99.30-99.20$ & 5.9 & 3.0 & 0.8 & 16.3 \\
\hline 5 & 41 LK 53 & $161-0$ & Surface & - & - & 4.9 & 3.0 & 0.5 & 7.4 \\
\hline 6 & 41 LK 74 & 51 & N987 E990 & 2 & $99.30-99.20$ & 3.5 & 2.1 & 0.6 & 4.7 \\
\hline 7 & $41 \quad$ LK 127 & $10-9$ & Surface & - & - & 3.7 & 2.4 & 0.6 & 6.8 \\
\hline 8 & 41 LK 127 & $10-18$ & Surface & - & - & 3.1 & 3.2 & 0.7 & 6.8 \\
\hline 9 & $4 I$ LK 128 & $46-2$ & Surface & - & - & $5.3^{*}$ & 3.5 & 0.8 & $14.7^{*}$ \\
\hline 10 & $4 I$ LK 128 & $46-11$ & Surface & - & - & 4.3 & 3.2 & 0.8 & 11.0 \\
\hline 11 & 41 LK 128 & $46-33$ & Surface & - & - & 6.5 & 3.1 & 0.8 & 18.3 \\
\hline 12 & 41 LK 133 & $17-11$ & Surface & - & - & 6.2 & 3.1 & 1.0 & 21.6 \\
\hline 13 & 41 LK 142 & $19-5$ & Surface & - & - & 3.7 & 2.6 & 0.7 & 7.0 \\
\hline 14 & 41 LK 185 & $53-30$ & Surface & - & - & 5.2 & 2.5 & 0.7 & 10.1 \\
\hline 15 & 41 LK 191 & $1-4$ & Surface & - & - & 5.3 & 3.2 & 1.3 & 18.6 \\
\hline 16 & 41 LK 197 & $1-0$ & Surface & - & - & 4.4 & 2.9 & 0.5 & 5.6 \\
\hline 17 & 41 LK 250 & 6 & Test Pit 1 & 6 & $50-60 \mathrm{~cm}$ & 6.6 & 3.4 & 1.0 & 19.8 \\
\hline 18 & 41 LK 253 & $1-10$ & Surface & - & - & 3.4 & 2.6 & 0.8 & 7.3 \\
\hline 19 & 41 MC 196 & $21-20$ & Surface & - & - & 6.0 & 2.4 & 0.9 & 12.5 \\
\hline 20 & 41 MC 213 & $2-16$ & Surface & - & - & 4.5 & 2.1 & 0.7 & 8.0 \\
\hline 21 & 41 MC 213 & $2-52$ & Surface & - & - & 4.2 & 2.5 & 0.6 & 5.5 \\
\hline 22 & 41 MC 213 & $2-67$ & Surface & - & - & 4.9 & 4.0 & 0.9 & 16.6 \\
\hline 23 & 41 MC 222 & $154-2$ & N100 E9l & $I$ & Surf. -98.80 & 5.0 & 2.0 & 0.4 & 3.4 \\
\hline 24 & 41 MC 234 & $1-0$ & Surface & - & - & 4.4 & 1.7 & 0.8 & 5.9 \\
\hline 25 & 41 MC 246 & 3 & Surface & - & - & 5.2 & 2.6 & 0.6 & 5.9 \\
\hline 26 & 41 MC 246 & 48 & Surface & - & - & $4.4 *$ & 2.7 & 0.7 & $9.8 *$ \\
\hline 27 & 41 MC 260 & $1-6$ & Surface & - & - & 5.6 & 2.0 & 0.9 & 8.8 \\
\hline 28 & 41 MC 275 & 7 & Shovel Test 2 & - & - & 6.2 & 3.1 & 1.0 & 17.3 \\
\hline 29 & 41 MC 276 & $1-27$ & Surface & - & - & 4.3 & 3.1 & 0.7 & 9.0 \\
\hline 30 & $41 M C 276$ & $1-30$ & Surface & - & - & 4.4* & 2.3 & 0.8 & 8.7 \\
\hline 31 & 41 MC 296 & $25-27$ & Surface & - & - & 5.9 & 3.0 & 0.9 & 18.5 \\
\hline 32 & 41 MC 296 & 75 & N1023 E985 & 6 & $99.00-98.90$ & 3.8 & 2.2 & 0.6 & 5.4 \\
\hline 33 & 41 MC 296 & 209 & N1026 E978 & 4 & $99.30-99.20$ & 4.0 & 2.5 & 0.6 & 4.3 \\
\hline
\end{tabular}


TABLE 11. METRIC DATA FOR CERTAIN UNSTEMMED THIN BIFACES

\begin{tabular}{|c|c|c|c|c|c|c|c|c|c|c|c|c|c|c|}
\hline \multirow[t]{2}{*}{ Group } & \multirow[t]{2}{*}{ Form } & \multirow{2}{*}{$\begin{array}{l}\text { Specimon } \\
\text { number }\end{array}$} & \multicolumn{3}{|c|}{ Length Range } & \multicolumn{3}{|c|}{ Width Range } & \multicolumn{3}{|c|}{ Thicknesa Range } & \multicolumn{3}{|c|}{ Weight Range } \\
\hline & & & Maximum & Minimum & Average & Maximum & Mlnimum & Averago & Maximum & MInImum & Averaga & Maximum & Minimum & Averago \\
\hline \multirow[t]{3}{*}{2} & 2 & 9.7 & $4.7^{*}$ & $3.0^{\circ}$ & $4.1^{\circ}$ & 4.7 & 3.5 & 4.2 & 1.2 & 0.9 & 1.1 & $29.6^{\circ}$ & $14.0^{\circ}$ & $22.3^{\circ}$ \\
\hline & & $8-11$ & $8.0^{\circ}$ & $4.5^{*}$ & $5.7^{*}$ & 3.5 & 2.6 & 3.1 & 1.1 & 0.8 & 1.0 & $32.7^{\circ}$ & $13.2^{*}$ & $20.1^{*}$ \\
\hline & & 12.44 & $6.3^{*}$ & $1.4^{*}$ & $3.4^{\circ}$ & 3.9 & 1.8 & 2.8 & 1.1 & 0.4 & 0.8 & $18.3^{\circ}$ & $2.9^{*}$ & $8.5^{\circ}$ \\
\hline & & & & & & & & & & & & & & \\
\hline \multirow[t]{3}{*}{3.} & 2 & $1-9$ & $7.6^{\circ}$ & $4.4^{\circ}$ & $5.4^{\circ}$ & 4.1 & 2.5 & 3.5 & 1.3 & 0.7 & 1.1 & $27.2^{\circ}$ & $12.9^{*}$ & $21.9^{\circ}$ \\
\hline & & $10-24$ & $4.7^{\prime \prime}$ & $1.8^{\circ}$ & $3.2^{\circ}$ & 3.2 & 2.3 & 2.8 & 1.0 & 0.4 & 0.7 & $13.4^{\circ}$ & $3.1^{\circ}$ & $7.4^{\circ}$ \\
\hline & & $25 \cdot 28$ & $4.9^{\circ}$ & $2.0^{\circ}$ & $3.3^{*}$ & 2.7 & 1.8 & 2.2 & 0.8 & 0.5 & 0.7 & $7.8^{\circ}$ & $2.8^{\circ}$ & $5.5^{\circ}$ \\
\hline \multirow[t]{4}{*}{4} & 4 & 1.92 & $4.8^{\circ}$ & $1.5^{\circ}$ & $3.3^{\circ}$ & 4.6 & 2.2 & 3.6 & 1.3 & 0.5 & 0.9 & $22.8^{*}$ & $3.3^{\circ}$ & $11.8^{\circ}$ \\
\hline & & $93-120$ & $5.8^{\circ}$ & $3.3^{\circ}$ & $4.5^{\circ}$ & 3.7 & 2.1 & 2.8 & 1.3 & 0.6 & 0.9 & $26.7^{\circ}$ & $6.6^{\circ}$ & $13.8^{\circ}$ \\
\hline & & $121-146$ & $7.7^{\prime \prime}$ & $2.6^{\circ}$ & $4.2 *$ & 6.7 & 3.8 & 5.2 & 1.3 & 0.6 & 1.0 & $57.6^{\circ}$ & $8.9^{\circ}$ & $25.9=$ \\
\hline & & $147-171$ & $4.4^{\circ}$ & $0.9^{\circ}$ & $2.3^{\circ}$ & 2.9 & 1.2 & 2.1 & 0.8 & 0.2 & 0.5 & $5.2^{\circ}$ & $0.4^{*}$ & $2.7^{\circ}$ \\
\hline
\end{tabular}

Specimen 5: This specimen was manufactured from fine-grained petrified wood.

Specimen 8: Typed as a McG1oin arrow point (Corbin 1974:41), this sma11 specimen was made from a thin $f l a k e$. The base is worked into a pronounced $V$ shaped notch. Specimen 8 was found in Late Prehistoric context at 41 MC 55. Deposits yielding the piece have been radiocarbon dated between A.D. 1230 and A.D. 1420 .

Specimen 11: This specimen is tentatively suggested to be a Guerrero arrow point (D. E. Fox 1979b). It was found in near surface deposits at 41 MC 296. These same deposits also yielded substantial amounts of presumed Late Prehistoric material, including Perdiz arrow points and pottery. A hand-forged iron knife blade recovered in close proximity to Specimen 11 lends credence to the presence of a historic aboriginal component at 41 MC 296 as would be indicated by the Guerrero type.

\section{Form 2. Proximal Fragments (28 specimens)}

Specimens 1-9: These nine specimens are the largest in this particular form grouping. Consisting of proximal fragments, most have convex remnant blade edges with concave bases. The thickness and rough flaking exhibited by most specimens suggest that they were preforms broken in the biface thinning process. The shape, thinness, and context of Specimen 6 suggest that it is probably a variety of "beveled knife" (see Group 4, Form 2 thin bifaces-described below), an artifact type diagnostic of the Late Prehistoric. However, this specimen has a concave base rather than the convex or semicircular base more typical of the "beveled knives" found in southern Texas.

Specimens 10-24: Specimens 10-24 are general1y thinner and better worked than specimens 1-9 described above. With two or three exceptions, they appear to have been in finished form and may have been broken either in the final stages of manufacture or in use. Specimen 22 is heavily patinated.

Specimens 25-28: A11 of these specimens are apparently Paleo-Indian tool types. Specimen 25, probably a Plainview point, was broken by impact and 
TABLE 12. SPECIMEN NUMBERS BY SITE--CERTAIN UNSTEMMED THIN BIFACES

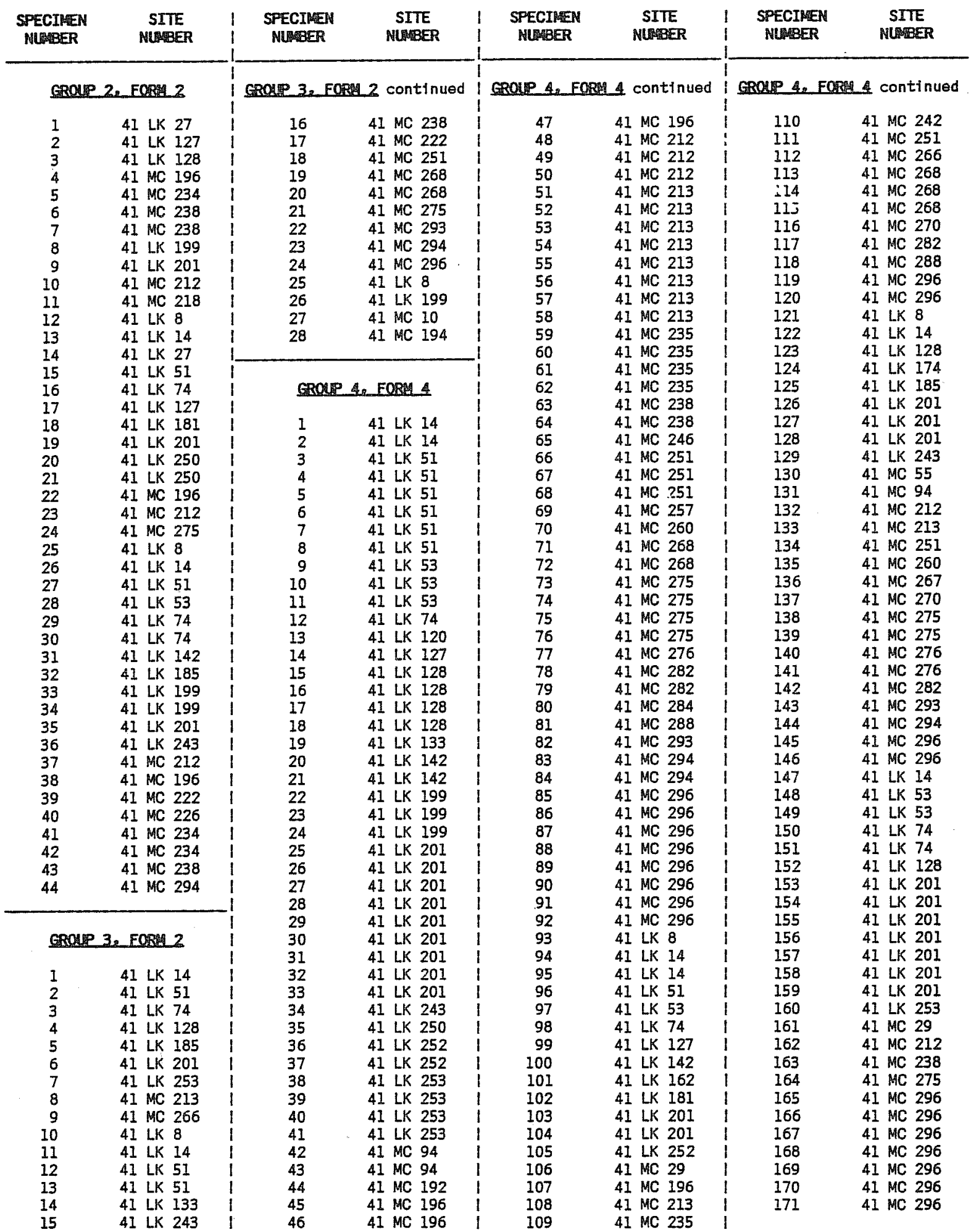


TABLE 13. PROVENIENCE OF CERTAIN UNSTEMMED THIN BIFACES RECOVERED IN EXCAVATIONS

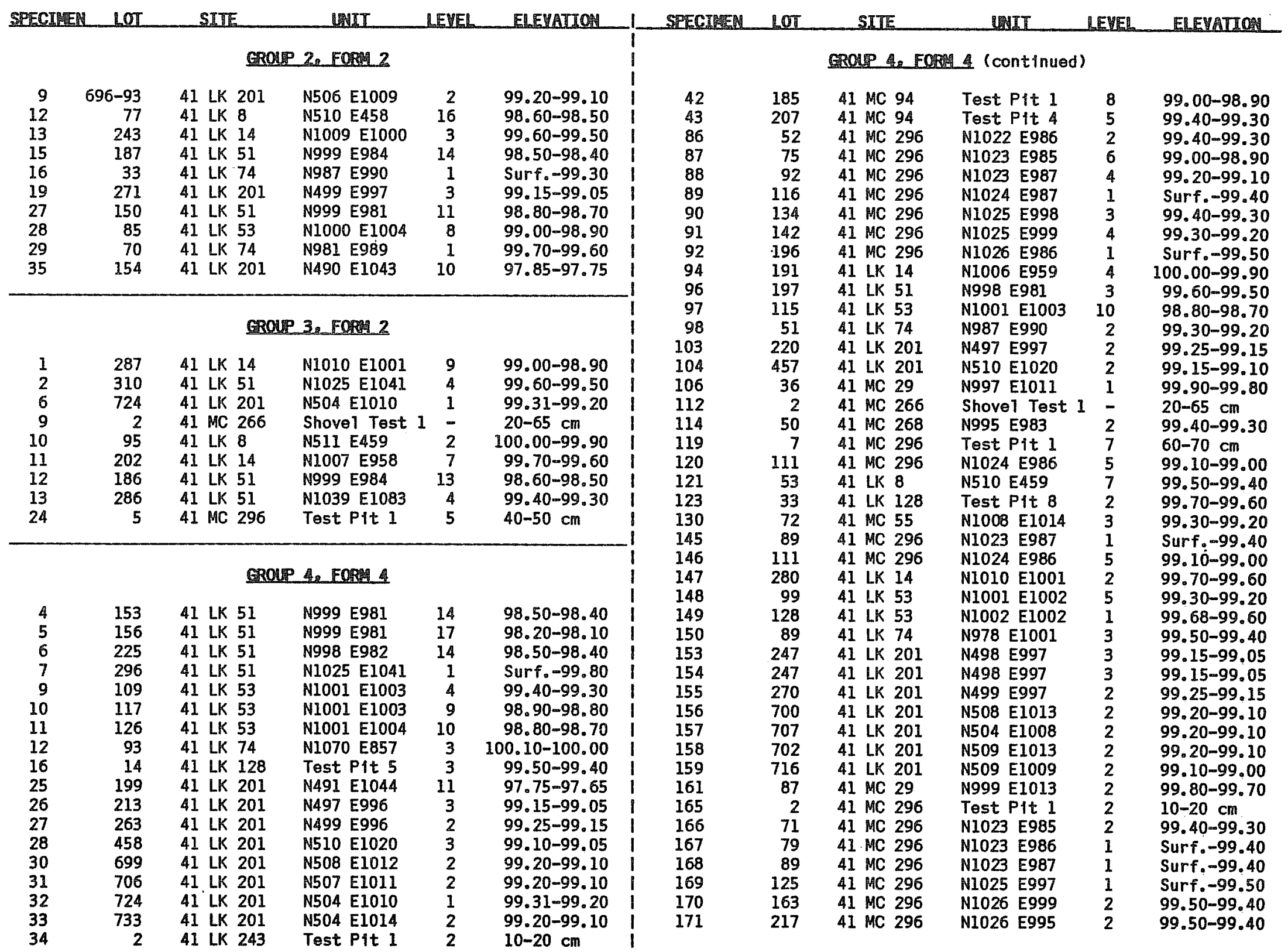


TABLE 14. PROVENIENCE AND METRIC DATA FOR THIN BIFACES GROUP 3, FORM 1

\begin{tabular}{|c|c|c|c|c|c|c|c|c|c|c|}
\hline $\begin{array}{l}\text { Specimen } \\
\text { Number }\end{array}$ & Site & Lot & Unit & Leve1 & Elevation & Length & Width & Thickness & Weight & $\begin{array}{l}\text { Figure } \\
\text { Number }\end{array}$ \\
\hline 1 & 41 LK 51 & 288 & N998 E982 & 17 & $98.20-98.10$ & 5.9 & 3.2 & 0.7 & 16.2 & 78 \\
\hline 2 & 41 LK 51 & 328 & N1025 E1042 & 4 & $99.60-99.50$ & 5.9 & 3.2 & 0.7 & 14.9 & 78 \\
\hline 3 & 41 LK 53 & 76 & N1000 El003 & 10 & $98.80-98.70$ & 10.2 & 2.8 & 0.9 & 27.7 & 78 \\
\hline 5 & 41 LK 185 & 37 & Shovel Test 1 & - & $0-10 \mathrm{~cm}$ & 5.0 & 2.2 & 0.8 & 7.7 & 78 \\
\hline 6 & 41 LK 201 & 417 & N500 E996 & 19 & $97.55-97.45$ & 4.8 & 2.3 & 0.6 & 7.9 & - \\
\hline 7 & 41 LK 253 & $1-9$ & Surface & - & - & $5.2^{*}$ & 3.9 & 0.9 & 18.4 & 78 \\
\hline 10 & 41 MC 226 & $4-0$ & Surface & - & - & 3.9 & 3.2 & 0.6 & 4.9 & - \\
\hline 11 & 41 MC 296 & 212 & N1024 E989 & 2 & $99.50-99.40$ & 2.1 & 1.0 & 0.2 & 0.4 & - \\
\hline
\end{tabular}




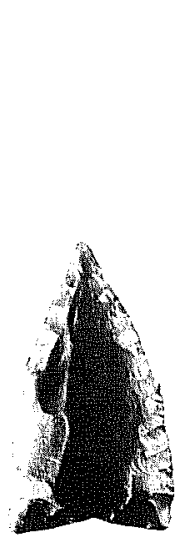

$3-1-1$

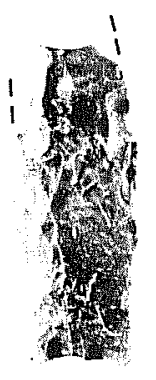

$3-2-4$

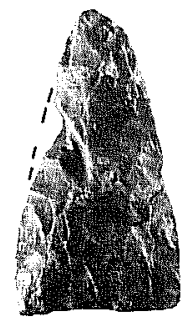

$3-1-2$

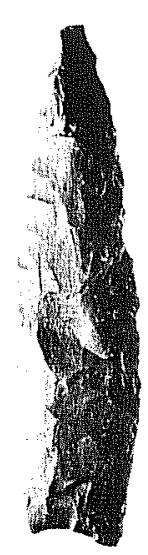

$3-1-3$

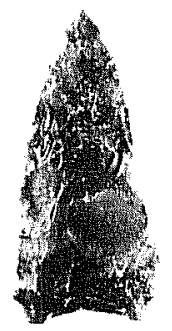

$3-1-4$

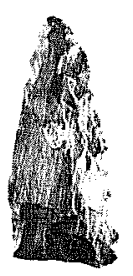

$3-1-5$

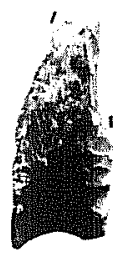

$3-2-25$

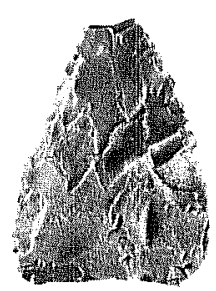

$3-1-7$
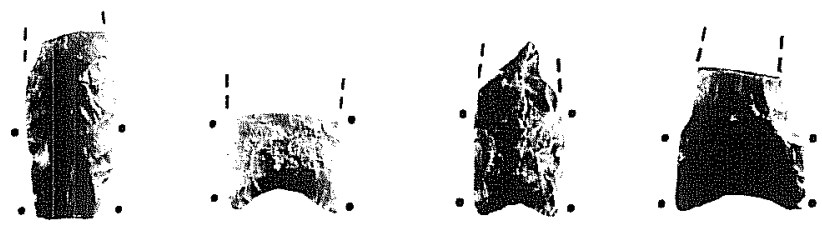

$3-2-27$

$3-2-28$
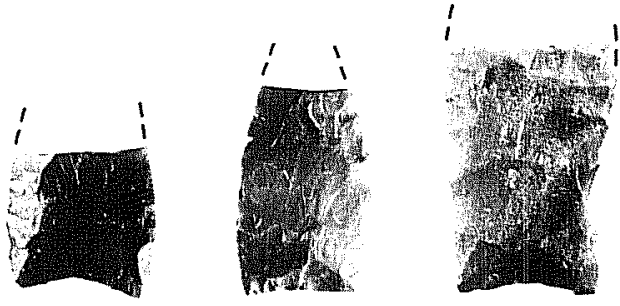

$3-2-5$

$3-2-19$

$3-2-14$

$3-2-20$

$3-2-24$

$3-2-11$

$3-2-1$

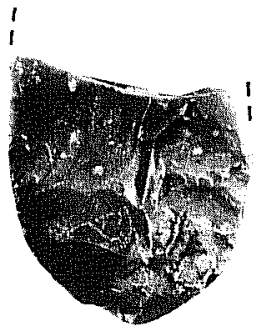

$4-2-18$

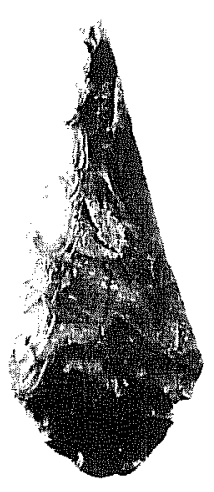

$4-2-21$
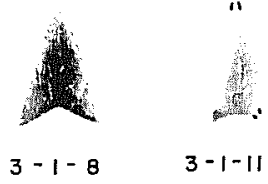

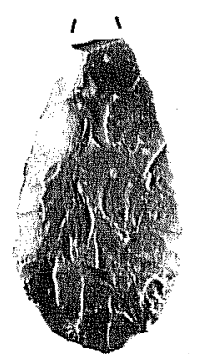

$4-2-19$

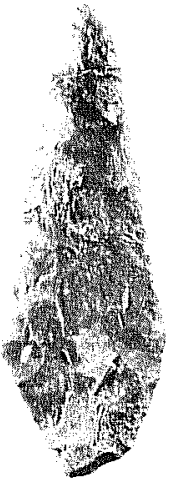

$4-2-17$

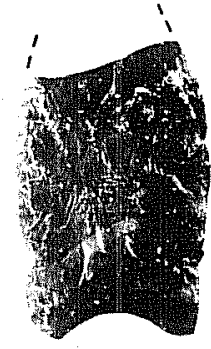

$3-2-8$

Figure 78. Thin Bifaces: Group 3, Forms 1 and 2 and Group 4, Form 2. Numbers beneath artifact indicate group, form, and specimen number, respectively. 
reworked along both edges of the break. Remnant blade edges are straight and have been very 1 ightly ground from the base upward $2.2 \mathrm{~cm}$. The piece is heavily patinated, including the surfaces of the impact break. The impact fractures terminated where the grinding ends. Specimen 26 is the basal portion of a Golondrina point. Remnant blade edges $(1.8-2.0 \mathrm{~cm}$ in 1 ength) are heavily ground. The base is deeply concave, and the basal corners flare out slightly. The basal concavity is also 1 ightly ground. Specimen 27, another Plainview fragment, exhibits heavy blade edge grinding from the base upward $2.1 \mathrm{~cm}$ on each side. The base is concave. This piece was apparently broken by impact fracture. The break was subsequently reworked to an irregular, asymmetrical point. It is heavily patinated. Specimen 28 is a reworked Golondrina point. Remnant b 1 ade edges measuring approximately $1.5 \mathrm{~cm}$ on each side give way to a beveled blade remainder that has been tapered by retouch. The base is broadly concave. It is not ground. The basal corners flare slightly.

A11 Group 3, Form 2 specimens are made of chert. Site provenience, subsurface provenience, metric data, and specimen numbers by site are shown for the Group 3, Form 2 artifacts in Tables 11-13.

\section{Group 4. Unstemmed ith Convex to Semicircular Bases (241 specimens)}

Eorm 1. Complete Triangular (20 specimens)

Specimens in this form grouping have convex or straight blade edges. In most cases, blade/base intersections are rounded. Specimens 3, 4, 19, and 20 have more angular basal corners. Configurations of various specimens in this group conform with descriptions given for Refugio, Abasolo, and Catän dart points (Suhm and Jelks 1962:165, 175, 241). Specimens 3 and 6 have pronouncedly beveled blades. Specimens 9, 11, and 14 are probably arrow point preforms. Specimens 10, 12, and 17 are atypical1y thick and rough $7 y$ flaked. They are likely preform manufacturing failures. Specimen 16 is made of white chalcedony 1 aced with gold. A11 others are of chert. Specimen 3 is moderately patinated. Provenience and metric data for the Group 4, Form 1 specimens are shown in Table 15.

\section{Form 2. Steeply Beveled B1ades (25 specimens)}

Thin biface Group 4, Form 2 category arbitrarily includes complete and fragmentary specimens of an artifact form so distinctive that even broken examples may be recognized as belonging to this form. In the past, this artifact has been referred to under the function-specific name of "beveled knife" (Sol1berger 1971). More recent1y, the term "quadrilateral two-beveled bifaces" has been applied to a distinctive form of the artifact type commonly found in southern Texas (Brown et a1. 1982:55-63). Brown (jbid.) provides a comprehensive discussion of the various manifestations of the type, its geographic distribution, use-wear indications, and possible functions. The Phase II research at Choke Canyon resulted in a substantial increase in the number of these specimens available for study. A number of radiocarbon assays on datable materials from deposits yielding the "beveled knives" provides better control over the temporal occurrence of the type. 
TABLE 15. PROVENIENCE AND METRIC DATA FOR THIN BIFACES GROUP 4, FORM I

\begin{tabular}{|c|c|c|c|c|c|c|c|c|c|c|}
\hline $\begin{array}{l}\text { Specimen } \\
\text { Number }\end{array}$ & Site & Lot & Unit & Level & Elevation & Length & Width & Thickness & Weight & $\begin{array}{l}\text { Figure } \\
\text { Number }\end{array}$ \\
\hline 1 & 41 LK 8 & 79 & N511 E458 & 2 & $100.00-99.90$ & 2.5 & 3.1 & 0.6 & 5.5 & - \\
\hline 2 & 41 LK 14 & 291 & N1010 E1002 & 4 & $99.50-99.40$ & 3.8 & 2.1 & 0.6 & 6.0 & 79 \\
\hline 3 & 41 LK 27 & $44-0$ & Surface & - & - & 2.7 & 2.3 & 0.7 & 4.4 & 79 \\
\hline 4 & 41 LK 27 & $44=0$ & Surface & - & - & $3.8^{*}$ & 2.5 & 0.6 & $6.6^{*}$ & 79 \\
\hline 5 & 41 LK 51 & 142 & N999 E981 & 3 & $99.60-99.50$ & $4.1 *$ & 2.0 & 0.8 & $7.7 *$ & - \\
\hline 6 & 41 LK 51 & 188 & N999 E984 & 15 & $98.40-98.30$ & $4.0 *$ & 2.8 & 0.7 & $10.7 *$ & - \\
\hline 7 & 41 LK 51 & 203 & N998 E981 & 9 & $99.00-98.90$ & 3.5 & 2.4 & 0.7 & 6.0 & - \\
\hline 8 & 41 LK 51 & 312 & N1026 E1042 & 3 & $99.70-99.60$ & 5.1 & 2.8 & 0.8 & 12.8 & - \\
\hline 9 & 41 LK 53 & 80 & N1000 E1004 & 3 & $99.50-99.40$ & 3.8 & 1.3 & 0.6 & 2.6 & - \\
\hline 10 & 41 LK 74 & 56 & N981 E988 & 1 & $99.70-99.60$ & 5.5 & 2.6 & 1.6 & 20.0 & - \\
\hline 11 & 41 LK 128 & $48-0$ & Surface & - & - & 3.1 & 2.1 & 0.5 & 3.3 & - \\
\hline 12 & 41 LK 133 & $17-9$ & Surface & - & - & 6.7 & 2.9 & 0.7 & 15.2 & - \\
\hline 13 & 41 LK 185 & $7-7$ & Surface & - & - & 4.8 & 2.1 & 1.0 & 8.0 & - \\
\hline 14 & 41 LK 201 & 301 & N500 E998 & 4 & $99.05-98.95$ & 5.3 & 1.9 & 0.5 & 5.4 & - \\
\hline 15 & 41 MC 94 & $227-0$ & Surface & - & - & 4.8 & 3.3 & 0.7 & 12.4 & 79 \\
\hline 16 & 41 MC 196 & $22-0$ & Surface & - & - & 4.4 & 2.7 & 0.6 & 7.7 & 79 \\
\hline 17 & $41 M C 2.13$ & $2-23$ & Surface & - & - & 5.9 & 4.0 & 1.1 & 26.5 & 79 \\
\hline 18 & 41 MC 213 & $2-62$ & Surface & - & - & 3.9 & 2.4 & 0.6 & 6.5 & - \\
\hline 19 & 41 MC 251 & $1-0$ & Surface & - & - & $2.9 *$ & 2.4 & $\quad 0.9$ & 10.7 & 79 \\
\hline 20 & $41 M C 251$ & $1=0$ & Surface & - & - & 5.1 & 2.1 & 0.8 & 9.0 & 79 \\
\hline
\end{tabular}


The Phase II collection of "beveled knives" contains 10 complete specimens, 14 proximal fragments, and one distal fragment. Blade outlines on complete specimens range from convex to concave to recurved, depending upon the degree to which each has been altered by retouch. In eight cases, blade retouch has been so extensive that distinct shou 1 ders have developed where the b 1 ade meets the basal portion. In most cases, the specimens are widest at the shoulders and contract or round out to semicircular bases. On all specimens retaining blade portions, the beveling was done along the left-hand edge of each face. This form of artifact is diagnostic of the Late Prehistoric and is often found along with Perdiz arrow points and aboriginal pottery.

In this assemb 1 age of beveled knives, Specimen 6 offers the best comp 1 ete example of a relatively unmodified knife. Although beveling has commenced, the blade edges are still convex, and there are no shoulders near the base. Edge angles are 10w. Specimens 3, 16, 18, and 22, al 1 proximal fragments, give an impression of the finished or near-finished width of the beveled knives before they start to be beveled and narrowed by retouch. Specimen 2 is an exceptionally narrow and thin example. Specimen 11 is made of finegrained petrified wood. Specimen 15 is the most heavily retouched of the group. Specimen 9 appears to have been broken and then reworked into an end scraper at the dista 1 end. Provenience and metric data for the Group 4 , Form 2 specimens are shown in Tab1e 16.

\section{Eorm 3. Oval to Elliptical (25 specimens)}

Specimens in Group 4, Form 3 vary considerably in size and degree of thinning. Most are probably dart point and/or arrow point preforms discarded due to manufacturing faiture. Specimens 1-3, 7-10, 13, 14, 16-18, and 22 are probably arrow point preforms, judging from their size, thinness, and context of recovery. Specimens 4-6, 12, 15, 19-21, and 23 are al1 relatively 1 arge and roughly flaked. Specimens 5 and 24 are heavily patinated. A11 are made of fine-grained chert. Provenience and metric data for the Group 4, Form 3 bifaces are shown in Table 17.

\section{Eorm 4. Fragments with Convex to Semicircular Ends (171 specimens)}

Sharing convex to semicircular ends as a common characteristic, this category of thin bifaces contains examples of workmanship ranging from thin and we 11 finished to thick and crudely flaked. Many are probably fragments of artifacts similar to the complete Group 4 specimens described above, broken either in the process of manufacture or in use. Another possibility, especially for surface-collected specimens, is that breakage occurred postdepositionaliy through exposure to weather and 1 arge animals (hoof damage). Although morphologically most similar to specimens in the other Group 4 categories, these Form 4 fragments could theoretical1y be preforms of any of the thin bifaces described herein.

Group 4, Form 4 bifaces are further subdivided into four categories based on size, out 1 ine configuration, and thickness. Specimens 1-92 represent the most common size of biface fragments in the group. They average $3.3 \mathrm{~cm}$ in length, $3.6 \mathrm{~cm}$ in width, $0.9 \mathrm{~cm}$ in thickness, and $11.8 \mathrm{~g}$ in weight. 
TABLE 16. PROVENIENCE AND METRIC DATA FOR THIN BIFACES GROUP 4, FORM 2

\begin{tabular}{|c|c|c|c|c|c|c|c|c|c|c|}
\hline $\begin{array}{l}\text { Specimen } \\
\text { Number }\end{array}$ & Sito & Lot & Unit & Level & Elevation & Length & Width & Th1ckness & Welght & $\begin{array}{l}\text { Figure } \\
\text { Number }\end{array}$ \\
\hline 1 & 41 LK 201 & 653 & N509 E1011 & 1 & 99.15 & $6.5^{*}$ & 3.3 & 0.9 & $14.0 *$ & - \\
\hline 2 & 41 LK 201 & 247 & N498 E997 & 3 & $99.15-99.05$ & 8.2 & 2.0 & 0.5 & 5.8 & - \\
\hline 3 & 41 LK 201 & $491-0$ & Surface & - & - & $4.7 *$ & 4.7 & 0.7 & * & - \\
\hline 4 & 41 LK 201 & 673 & N507 E1013 & 1 & $99.31-99.20$ & $5.1^{*}$ & 3.7 & 0.9 & \# & - \\
\hline 5 & 41 LK 201 & 694 & N507 E1013 & 2 & $99.20-99.10$ & $5.9 *$ & 3.3 & 0.9 & * & - \\
\hline 6 & 41 LK 201 & 651 & N508 E1011 & 1 & $99.23-99.10$ & 8.9 & 3.6 & 0.7 & 26.7 & - \\
\hline 7 & 41 LK 201 & 656 & N507 E1011 & 1 & $99.30-99.20$ & $4.4 *$ & 3.6 & 0.7 & * & - \\
\hline 8 & 41 LK 201 & 680 & N504 E1009 & 1 & $99.32-99.20$ & 7.2 & 3.6 & 0.6 & 15.9 & - \\
\hline 9 & 41 LK 201 & 689 & N509 E1010 & 2 & $99.10-99.00$ & 5.7 & 4.2 & 0.8 & 18.6 & - \\
\hline 10 & 41 LK 201 & 696 & N506 E1009 & 2 & $99.20-99.10$ & $4.1 *$ & 4.9 & 0.7 & * & - \\
\hline 11 & 41 LK 201 & 699 & N508 E1012 & 2 & $99.20-99.10$ & 8.5 & 4.4 & 0.8 & 25.3 & - \\
\hline 12 & 41 LK 201 & 701 & N509 E1012 & 2 & $99.20-99.10$ & 9.3 & 2.7 & 0.7 & 18.7 & - \\
\hline 13 & 41 LK 201 & 706 & N507 E1011 & 2 & $99.20-99.10$ & $2.5^{*}$ & 4.8 & 0.6 & * & - \\
\hline 14 & 41 LK 201 & 729 & N508 E1007 & 1 & $99.20-99.10$ & 8.5 & 4.0 & 0.8 & 22.6 & - \\
\hline 15 & 41 MC 55 & 106 & N1017 E999 & 4 & $99.10-99.00$ & $5.5^{*}$ & 3.8 & 0.9 & $15.1 *$ & 78 \\
\hline 16 & 41 MC 55 & 123 & Surface & - & - & $5.7^{*}$ & 4.4 & 0.6 & \# & - \\
\hline 17 & 41 MC 55 & $124-0$ & Surface & - & - & 9.8 & 3.3 & 0.6 & 22.8 & 78 \\
\hline 18 & 41 MC 294 & 4 & Surface & - & - & $4.9 *$ & 4.9 & 0.6 & * & 78 \\
\hline 19 & 41 MC 296 & $25-11$ & Surface & - & - & $6.3^{\#}$ & 3.5 & 0.7 & $19.4 *$ & 78 \\
\hline 20 & 41 MC 296 & $25-15$ & Surface & - & - & $3.2^{n}$ & 4.6 & 0.6 & * & - \\
\hline 21 & 41 MC 296 & 44 & N1022 E985 & 4 & $99.20-99.10$ & 9.7 & 3.9 & 0.8 & 26.9 & 78 \\
\hline 22 & 41 MC 296 & 71 & N1023 E985 & 2 & $99.40-99.30$ & $3.9 *$ & 5.4 & 0.5 & \# & - \\
\hline 23 & 41 MC 296 & 150 & N1026 E997 & 3 & $99.40-99.30$ & 8.4 & 3.9 & 0.7 & 24.0 & - \\
\hline 24 & 41 MC 296 & 201 & N1025 E995 & 1 & $99.60-99.50$ & 9.1 & 3.9 & 0.8 & 22.7 & - \\
\hline 25 & 41 MC 296 & 213 & N1026 E986 & 2 & $99.50-99.40$ & 4.7 " & 3.4 & 0.7 & \# & - \\
\hline
\end{tabular}




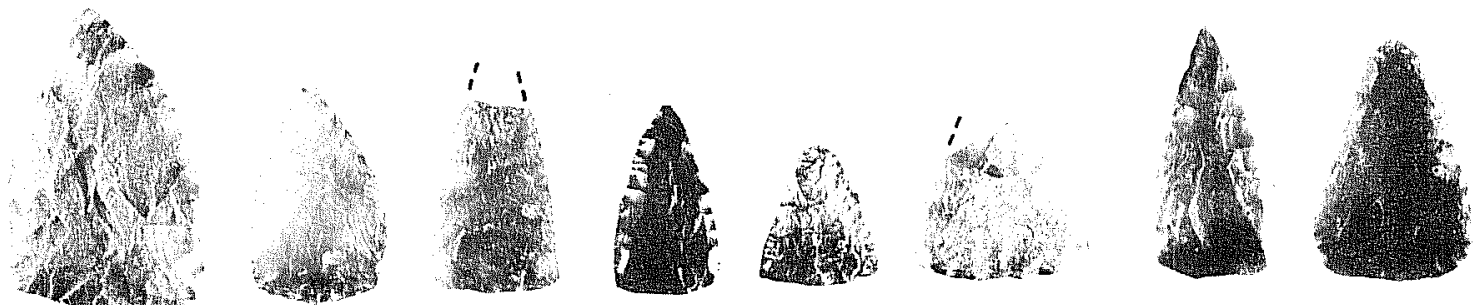

$4-1-17 \quad 4-1-16 \quad 4-1-4 \quad 4-1-2 \quad 4-1-3 \quad 4-1-19 \quad 4-1-20 \quad 4-1-15$
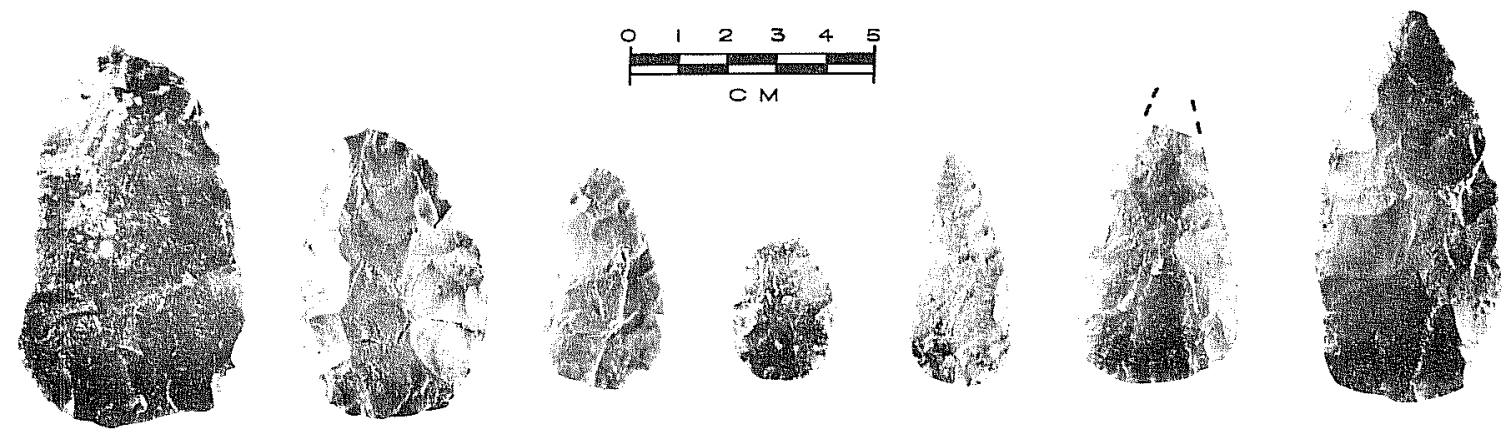

$4-3-23$

$4-3-6$

$4-3-18$

$4-3-1$

$4-3-3$

$4-3-20$

$4-3-19$
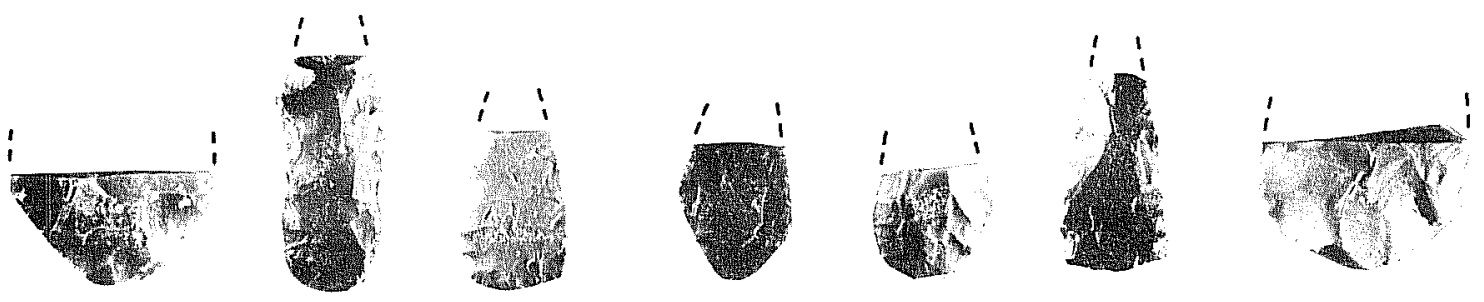

$4-4-92$
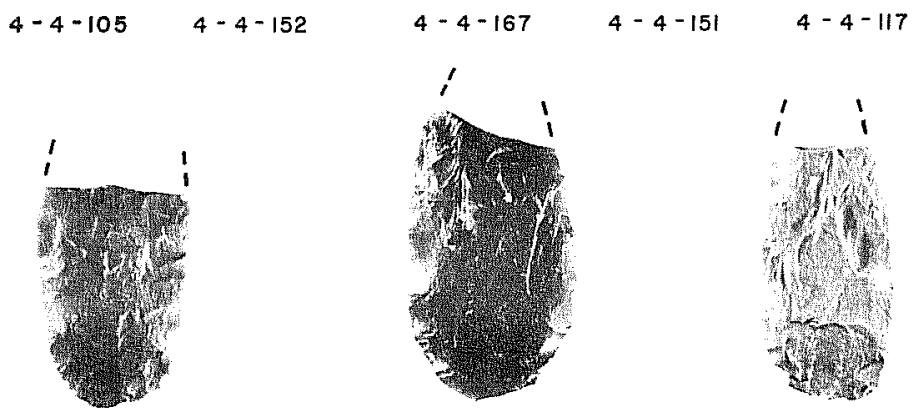

$4-4-85$
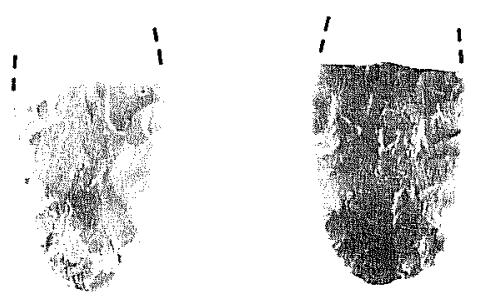

$4-4-113$

$4-4 \div 94$

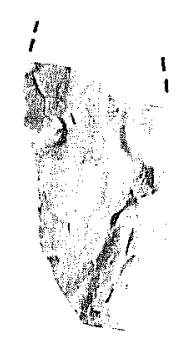

$4-4-108$

$4-4-107$

$4-4-113$

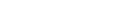

4-4-96

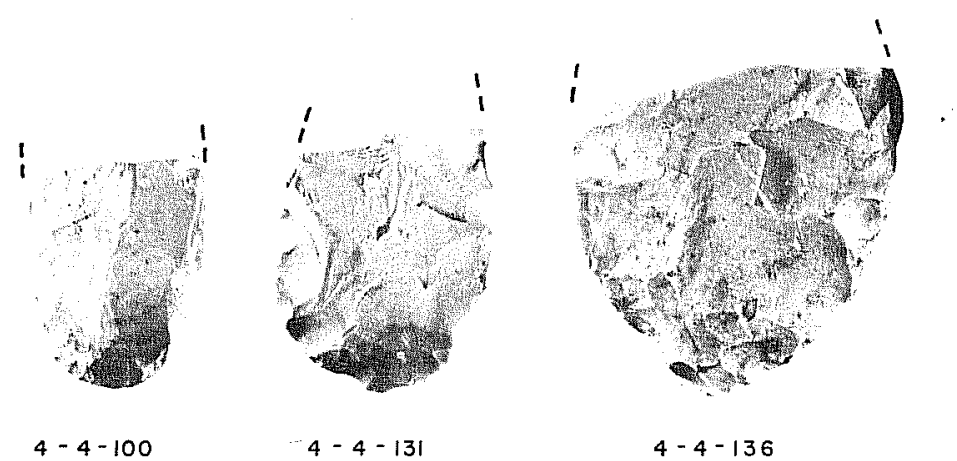

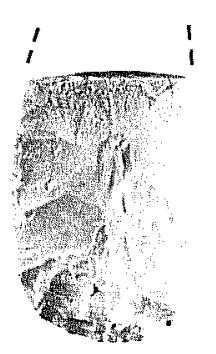

$4-4-116$

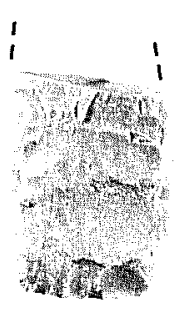

$4-4 \cdot 95$

Figure 79. Thin Bifaces: Group 4, Forms 1, 3, and 4. Numbers beneath artifact indicate group, form, and specimen number, respectively. 
TABLE 17. PROVENIENCE AND METRIC DATA FOR THIN BIFACES GROUP 4, FORM 3

\begin{tabular}{|c|c|c|c|c|c|c|c|c|c|c|}
\hline $\begin{array}{l}\text { Specimen } \\
\text { Number }\end{array}$ & Site & Lot & Untt & Level & Elevation & Length & Width & Thickness & Weight & $\begin{array}{l}\text { Figure } \\
\text { Number }\end{array}$ \\
\hline 1 & 41 LK 53 & 108 & N1001 E1003 & 3 & $99.50-99.40$ & 2.8 & 2.1 & 0.6 & 2.9 & 79 \\
\hline 2 & 41 LK 128 & 26 & Test Pit 7 & 3 & $99.50-99.40$ & 4.5 & 3.0 & 0.6 & 8.8 & - \\
\hline 3 & 41 LK 128 & $46-29$ & Surface & - & - & 4.7 & 2.1 & 0.4 & 4.3 & 79 \\
\hline 4 & 41 LK 133 & $17-13$ & Surface & - & - & 6.3 & 3.1 & 1.2 & 18.1 & - \\
\hline 5 & 41 LK 142 & $20-0$ & Surface & - & - & 5.4 & 3.3 & 0.9 & 15.8 & - \\
\hline 6 & 41 LK 173 & $1-1$ & Surface & - & - & 5.7 & 3.9 & 1.3 & 29.3 & 79 \\
\hline 7 & 41 LK 201 & 239 & N498 E996 & 2 & $99.25-99.15$ & 4.6 & 2.1 & 0.4 & 5.1 & - \\
\hline 8 & 41 LK 201 & 240 & N498 E996 & 3 & $99.15-99.05$ & 5.7 & 2.1 & 0.6 & 7.0 & - \\
\hline 9 & 41 LK 201 & 264 & N499 E996 & 3 & $99.15-99.05$ & 3.7 & 1.9 & 0.5 & 3.6 & - \\
\hline 10 & 41 LK 201 & 266 & N499 E996 & 5 & $98.95-98.85$ & 2.8 & 2.2 & 0.5 & 3.3 & - \\
\hline 11 & 41 LK 201 & 271 & N499 E997 & 3 & $99.15-99.05$ & 5.5 & 3.5 & 0.5 & 11.8 & - \\
\hline 12 & 41 LK 201 & $491-0$ & Surface & - & - & 6.1 & 3.5 & 0.7 & 16.9 & - \\
\hline 13 & 41 LK 201 & 659 & N506 E1008 & 1 & $99.29-99.20$ & 2.2 & 1.4 & 0.5 & 1.5 & - \\
\hline 14 & 41 LK 201 & 692 & N506 E1013 & 2 & $99.20-99.10$ & 3.2 & 2.2 & 0.4 & 3.7 & - \\
\hline 15 & 41 LK 201 & 700 & N508 E1013 & 2 & $99.20-99.10$ & 5.6 & 2.8 & 0.7 & 14.3 & - \\
\hline 16 & 41 LK 201 & 721 & N504 E1013 & 2 & $99.10-99.00$ & 2.8 & 1.6 & 0.5 & 1.7 & - \\
\hline 17 & 41 LK 201 & 734 & N505 E1014 & 2 & $99.20-99.10$ & 2.5 & 1.9 & 0.4 & 1.8 & - \\
\hline 18 & 41 LK 243 & $26-12$ & Surface & - & - & 4.5 & 2.6 & 0.6 & 5.9 & 79 \\
\hline 19 & 41 MC 196 & $20-2$ & Surface & - & $=$ & 8.0 & 3.6 & 1.1 & 33.2 & 79 \\
\hline 20 & $41 \mathrm{MC} 213$ & $2-6$ & Surface & - & - & 5.2 & 3.1 & 1.0 & 17.0 & 79 \\
\hline 21 & 41 MC 235 & $1-0$ & Surface & - & - & 6.3 & 3.7 & 1.1 & 30.3 & - \\
\hline 22 & 41 MC 251 & $1-0$ & Surface & - & - & 4.9 & 2.9 & 0.4 & 5.9 & - \\
\hline 23 & 41 MC 270 & $21-1$ & Surface & - & - & 7.7 & 4.6 & 1.0 & 40.0 & 79 \\
\hline 24 & 41 MC 294 & $4-0$ & Surface & - & - & 4.7 * & 3.1 & 0.7 & $12.7 *$ & - \\
\hline 25 & 41 MC 296 & 152 & N1026 E997 & 5 & $99.20-99.10$ & 5.0 & 3.0 & 0.7 & 11.1 & - \\
\hline
\end{tabular}


Specimens 93-120 are general1y longer relative to width than the other Form 4 specimens. Specimens 121-146 are fragments of exceptional1y 1 arge thin bifaces, most of which are likely manufacturing failures in the preform stage. Specimens 147-171 are probab1y a 11 arrow point preforms based on their small size, thinness, and context of recovery.

Site provenience, subsurface provenience, metric data, and specimen numbers by site are shown for the Group 4, Form 4 specimens in Tables 11-13.

\section{Group 5. Unstemned Leaf Shaped (12 specimens)}

Group 5 specimens are long and slender with a point at one end. They are semicircular, convex or slightly pointed at the other end. Most reach their maximum width at the midsection. Specimen 4 is made of frosted white chalcedony. The rest are fine-grained chert. Provenience and metric data for the Group 5 thin bifaces are shown in Table 18.

\section{Group 6. Circular to Subcircular (10 specimens)}

Group 6 specimens are roughly circular in out 1 ine, vary considerably in thickness, and are crudely flaked. Specimens 5 and 8 retain cortex on one face. Specimen 6 is heavily patinated. Provenience and metric data for the Group 6 specimens are shown in Table 19.

\section{Group 7. Diamond Shaped (two specimens)}

Group 7 specimens are widest at the midsection and taper to points at either end. Provenience and metric data are shown in Table 20.

\section{Group 8. Bifaces with Sharp Slender Projections (15 specimens)}

Having a variety of outline forms, Group 8 specimens have slender, need lel ike points and probably functioned as drilis or perforators. Specimens 1-7 were made on large, thin flakes. Specimens 1-5 have exceptionally long, finely worked "bits." Specimens 6 and 7 are the same, but the "bits" are missing. The basal or proximal portion of each of these is the original, relatively unmodified flake surface. This type of artifact is diagnostic of Late Prehistoric assemblages containing Perdiz arrow points and pottery. Specimens 8-15 are much larger, thicker, and more roughly flaked than Specimens 1-7. Projections worked on these pieces are sharp, but general1y shorter and broader. Cultural period affiliation is not as clear for Specimens 8-15 as for Specimens 1-7. However, most are probably Archaic in age. Provenience and metric data for the Group 8 specimens are shown in Table 21. 
TABLE 18. PROVENIENCE AND METRIC DATA FOR THIN BIFACES GROUP 5

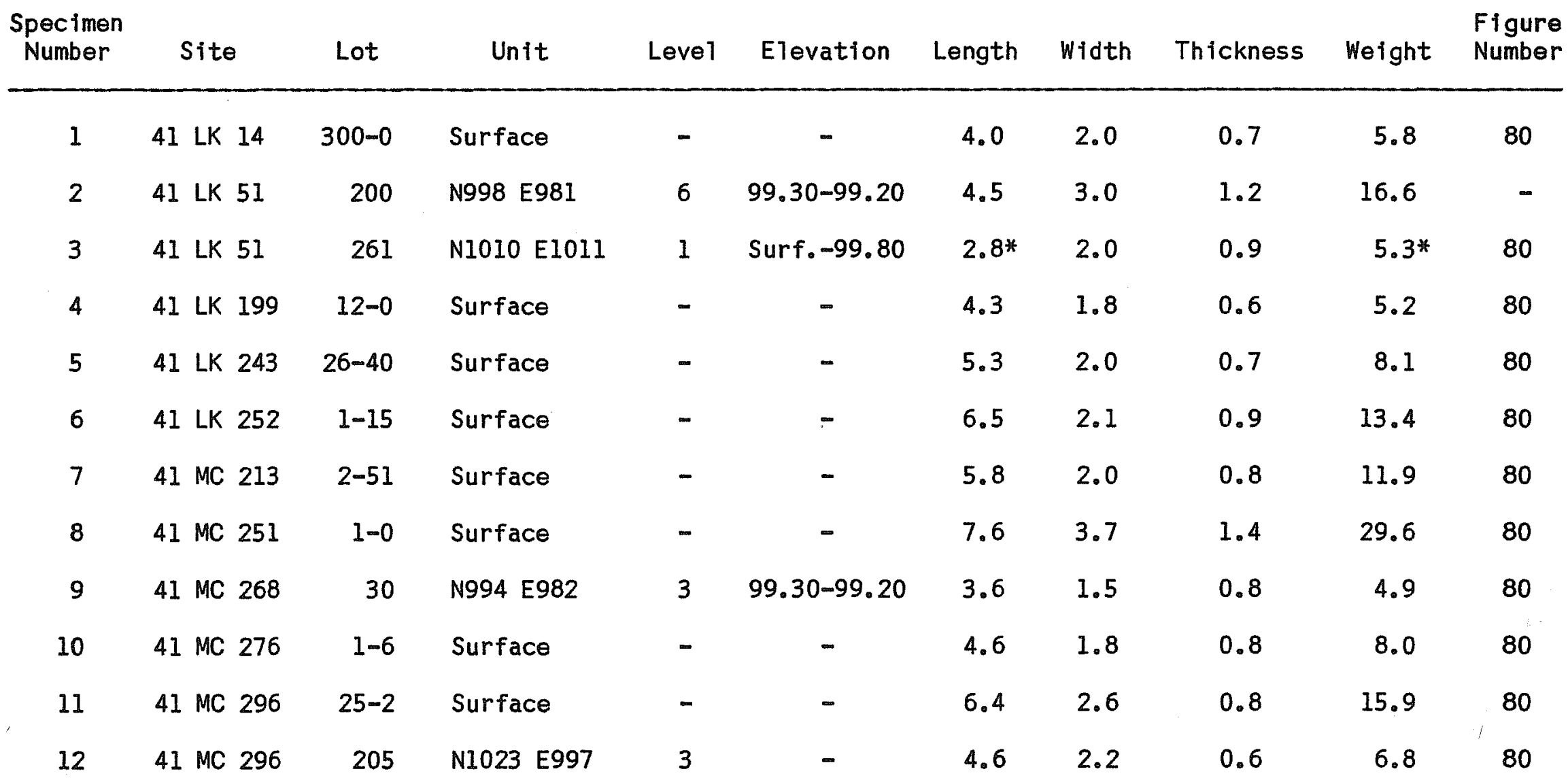



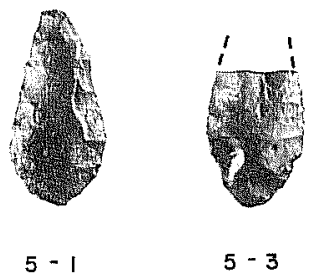

5-3

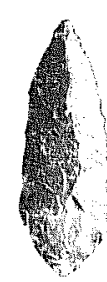

5- 5
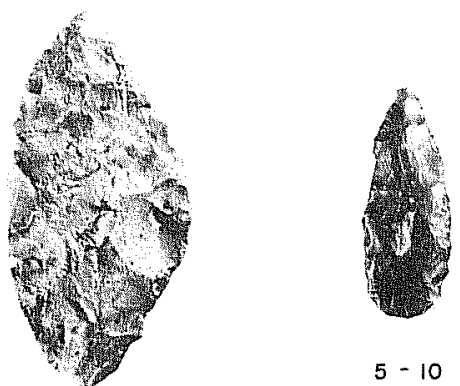

$5-10$

$$
5-8
$$

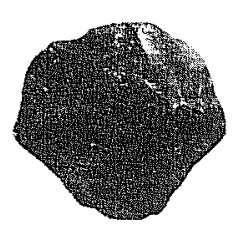

$6-1$

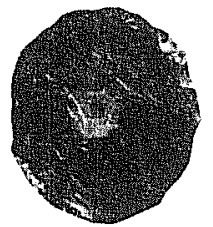

$6-3$

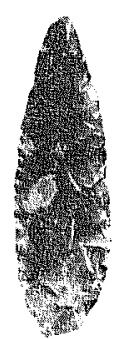

$$
\text { 5- } 6
$$

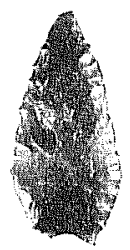

$5-12$

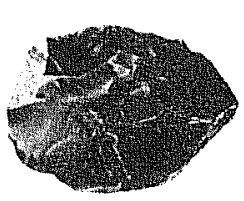

$6-4$

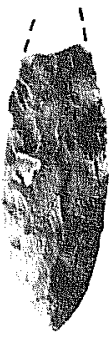

5-7

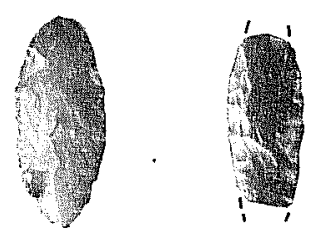

5- 4

5-9

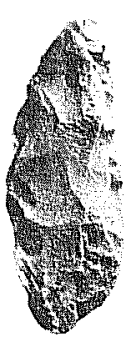

$5-11$

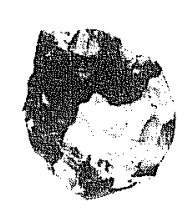

$6-7$

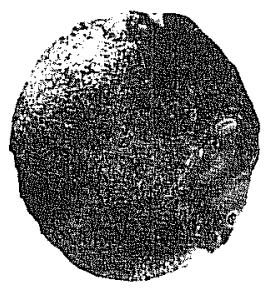

$6-8$

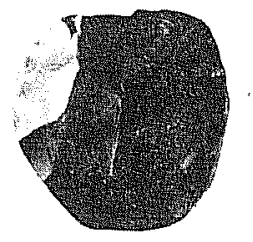

$6-9$

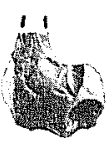

8- 7

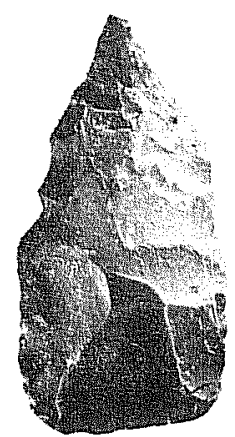

$8-15$

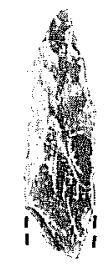

$8-14$

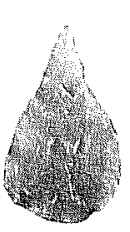

$8-13$

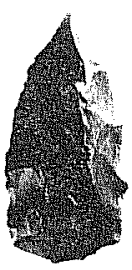

8- 8

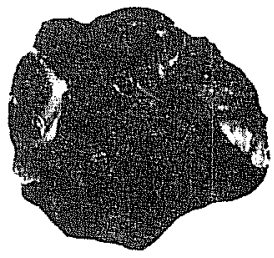

$6-5$

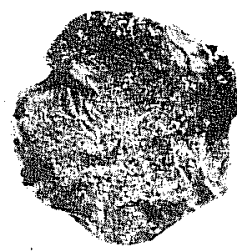

$6-6$

Figure 80. Thin Bifaces: Groups 5, 6, 7, and 8. Numbers beneath artifact indicate group and form number, respectively. 
TABLE 19. PROVENIENCE AND METRIC DATA FOR THIN BIFACES GROUP 6

\begin{tabular}{|c|c|c|c|c|c|c|c|c|c|c|}
\hline $\begin{array}{l}\text { Specimen } \\
\text { Number }\end{array}$ & Site & Lot & Unit & Leve1 & Elevation & Length & Width & Thickness & Weight & $\begin{array}{l}\text { Figure } \\
\text { Number }\end{array}$ \\
\hline 1 & 41 LK 128 & 37 & Test Pit 10 & 1 & Surf. -99.50 & 4.2 & 4.0 & 1.1 & 11.7 & 80 \\
\hline 2 & 41 LK 201 & 489-0 & Surface & - & - & 7.0 & 6.8 & 1.0 & 63.9 & - \\
\hline 3 & 41 MC 55 & 60 & N993 El015 & 1 & Surf. -99.30 & 4.4 & 3.9 & 0.8 & 17.3 & 80 \\
\hline 4 & 41 MC 213 & $2-68$ & Surface & - & - & 4.8 & 3.7 & 1.2 & 19.5 & 80 \\
\hline 5 & 41 MC 213 & $2-21$ & Surface & - & - & 5.2 & 4.7 & 1.3 & 40.1 & 80 \\
\hline 6 & 41 MC 251 & $1-0$ & Surface & - & - & 4.4 & 4.7 & 1.2 & 24.3 & 80 \\
\hline 7 & 41 MC 275 & $5-41$ & Surface & - & - & 3.8 & 3.0 & 1.1 & 9.8 & 80 \\
\hline 8 & 41 MC 275 & $5-42$ & Surface & - & - & 5.4 & 5.0 & 1.6 & 52.9 & 80 \\
\hline 9 & 41 MC 275 & $5-40$ & Surface & - & - & 4.5 & 4.2 & 1.2 & 31.7 & 80 \\
\hline 10 & 41 MC 276 & $1-22$ & Surface & - & - & 4.5 & 3.9 & 1.3 & 24.9 & 80 \\
\hline
\end{tabular}

TABLE 20. PROVENIENCE AND METRIC DATA FOR THIN BIFACES GROUP 7

\begin{tabular}{|c|c|c|c|c|c|c|c|c|c|c|}
\hline $\begin{array}{l}\text { Specimen } \\
\text { Number }\end{array}$ & Site & Lot & Unit & Leve] & Elevation & Length & Width & Thickness & Weight & $\begin{array}{l}\text { Figure } \\
\text { Number }\end{array}$ \\
\hline 1 & 41 LK 201 & 659 & N506 E1008 & 1 & $99.29-99.20$ & 2.7 & 0.9 & 0.4 & 0.9 & - \\
\hline 2 & 41 MC 268 & 41-59 & Surface & - & - & $3.8 *$ & 2.2 & 0.8 & $7.3 *$ & 80 \\
\hline
\end{tabular}


TABLE 21. PROVENIENCE AND METRIC DATA FOR THIN BIFACES GROUP 8

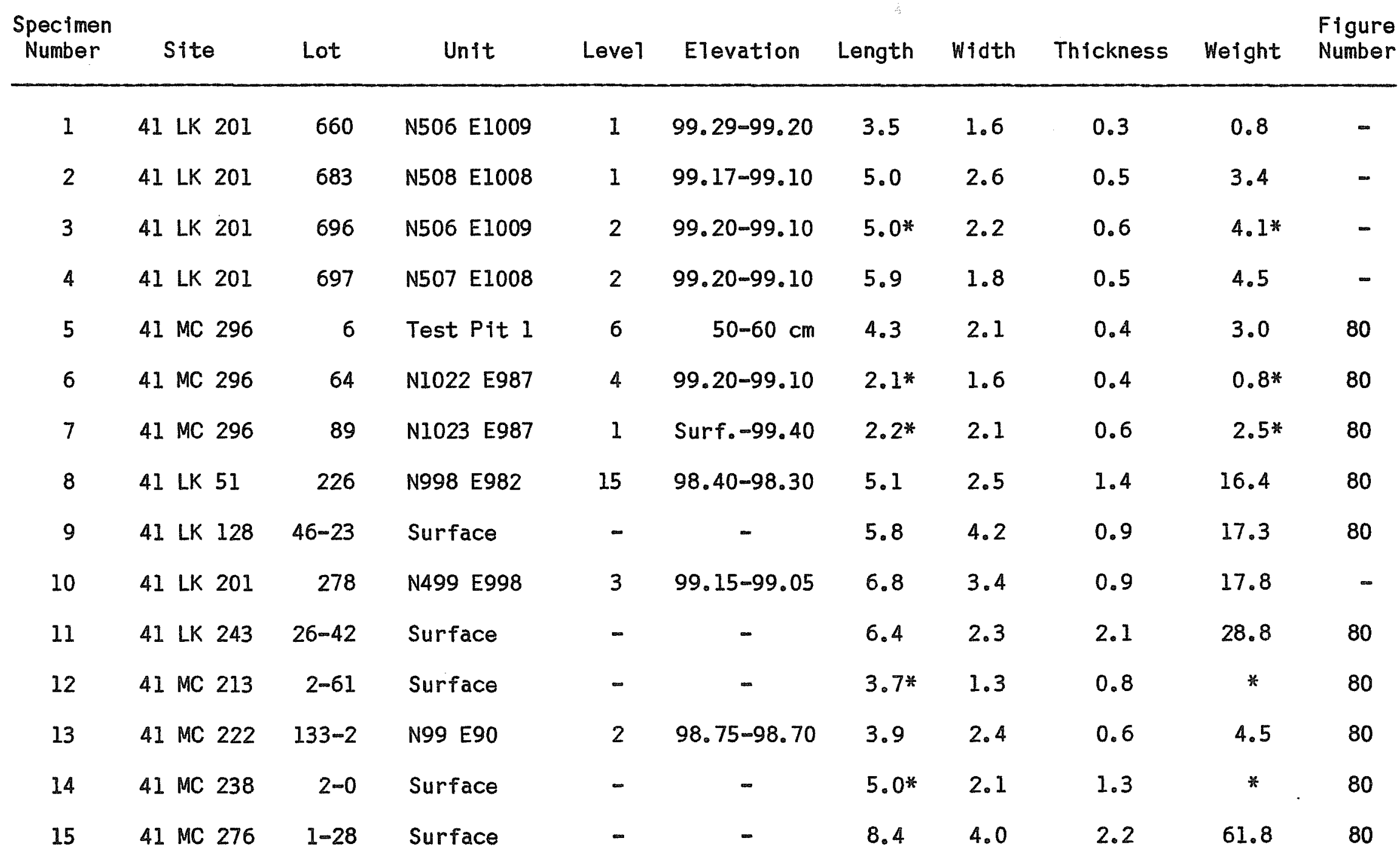




\section{Group 9. Fragments with Pointed Ends (196 specimens)}

Group 9 specimens are thin biface fragments with pointed ends. Workmanship varies from relatively thick and crudely flaked to thin and finely flaked. Depending upon whether breakage occurred during manufacture or use, these specimens could be fragments of preforms or of finished tools. Especially in the case of surface-collected specimens, breakage may al so have occurred postdepositionally through exposure to weather and large animals (hoof damage). The specimens are grouped by width: $4-5 \mathrm{~cm}$, 14 specimens; $3 \mathrm{~m}$ $3.9 \mathrm{~cm}, 47$ specimens; 2-2.9 cm, 64 specimens; $1-1.9 \mathrm{~cm}, 41$ specimens; and less than $1 \mathrm{~cm}, 30$ specimens. Probable arrow point fragments among the Group 9 pieces were found at 10 sites as follows: 41 LK 51 , one; 41 LK 53 , one; 41 LK 128, three; 41 LK 201, 23; 41 LK 243, two; 41 MC 55, one; 41 MC 94, two; 41 MC 196, one; 41 MC 222, four; and 41 MC 296, 16. One piece each of gray siliceous quartzite, dark red quartzite, and chalcedony was present in Group 9. A11 others were made of fine-grained chert. Provenience information for Group 9 specimens is provided in Table 22.

\section{Group 10. Lateral and Medial Fragments (267 specimens)}

Group 10 specimens are unclassifiable lateral and medial fragments of thin bifaces. The fragments may be derived from finished tools broken during use or from preforms broken during manufacture. Some breakage may al so be the result of postdepositional mechanical action (weather, animal tramping, farm/ranch machinery). The specimens are grouped by width: greater than $4 \mathrm{~cm}, 17$ specimens; $3-3.9 \mathrm{~cm}, 36$ specimens; 2-2.9 cm, 83 specimens; $1-1.9 \mathrm{~cm}$, 97 specimens; and 1 ess than $1 \mathrm{~cm}, 34$ specimens. Probable arrow point fragments were found at seven sites as follows: 41 LK 128, three; 41 LK 182, one; 41 LK 201, 25; 41 MC 29, two; 41 MC 55, two; 41 MC 222, one; and 41 MC 296, 13. One piece is chalcedony. The rest are chert. Provenience information for Group 10 specimens is provided in Table 22.

\section{Distally Beveled Bifaces and Unifaces}

Distally beveled bifaces and unifaces are chipped stone tools often referred to as "gouges." In the report of Phase I investigations at Choke Canyon (Ha11, Black, and Graves 1982:318), specimens such as these were also referred to as "distally beveled bifaces and unifaces" to avoid the functional implications of the name "gouge." The specimens share distal ends that are beveled and/or concave. Bifacial and unifacial specimens are included in this category with thicknesses ranging above and below the arbitrary thickness standard of $1.3 \mathrm{~cm}$ used to distinguish between thick and thin bifaces above. The distinctive beveled end is considered to be the single most important descriptive attribute. The extent of facial chipping (unifacial vs. bifacial) and artifact thickness are of secondary importance as classificatory criteria. Outline, bit morphology, and thickness are the principal attributes used to define the various groups described below. Discussions of type names, geographic distributions, chronological considerations, and possible functions for distally beveled bifaces and unifaces are provided in Hall, Black, and Graves (1982:338-348). The specimens are grouped into the following categories for descriptive purposes: 
TABLE 22. PROVENIENCE DATA FOR THIN BIFACES GROUPS 9 AND 10

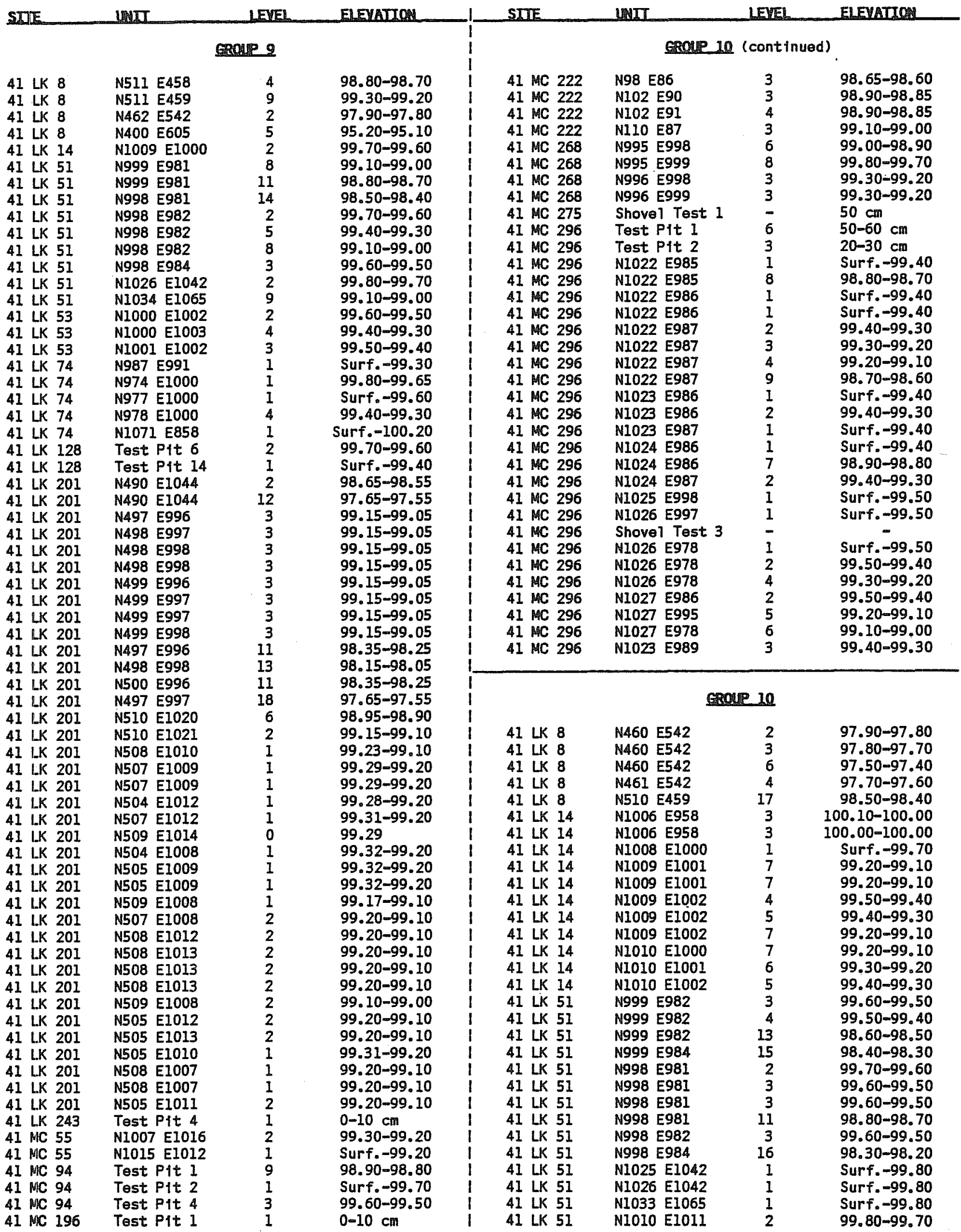


TABLE 22. (continued)

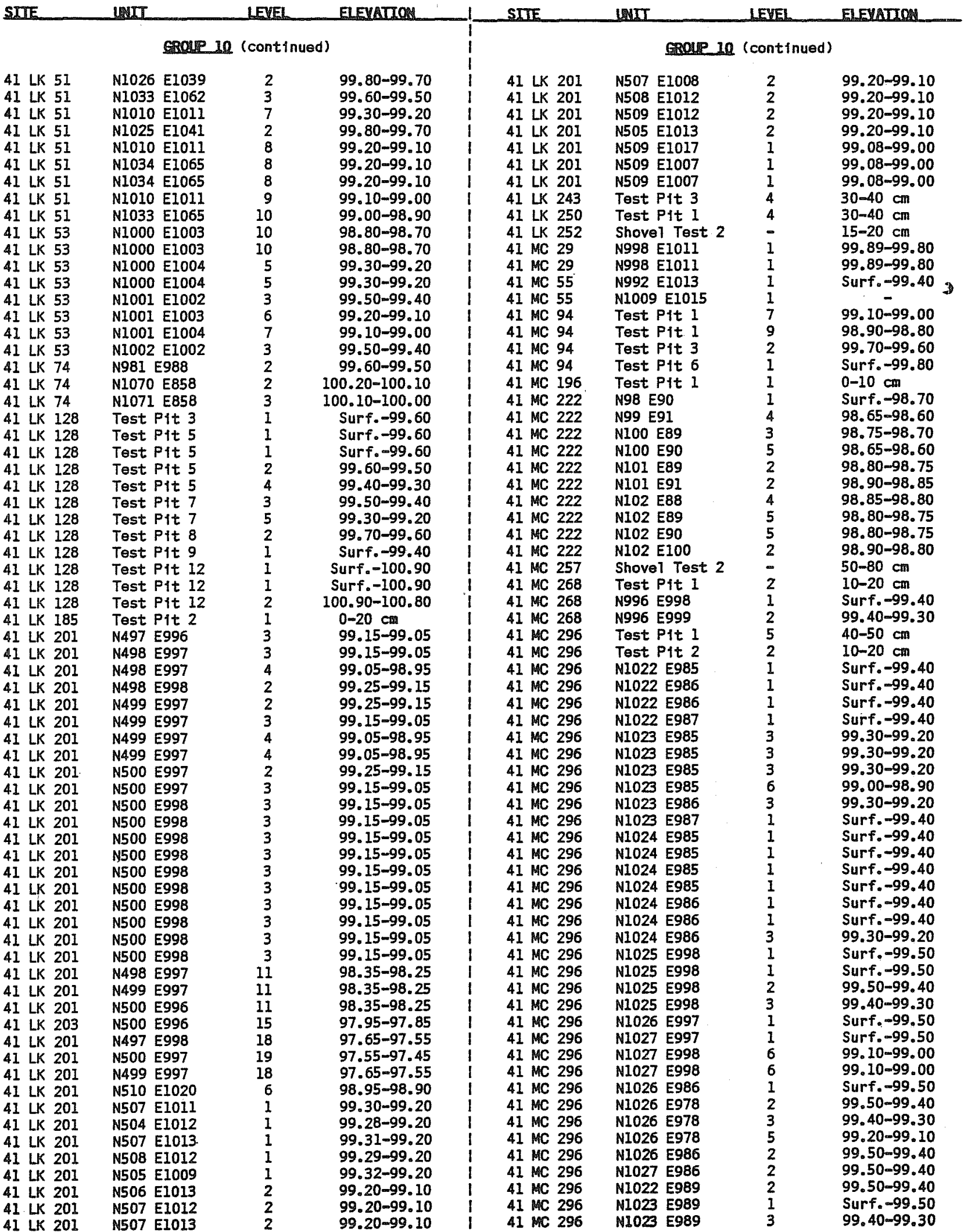


Group 1. Large Triangular to Subtriangular (Clear Fork gouge Type 1, after Ray 1941)

Group 2. Large, Elongate, Rectangu 1 ar to Subrectangu 7 ar (Clear Fork gouge Type 3, after Ray 1941)

Form 1. Long

Form 2. Short

Group 3. Short, Broad, Triangular to Subrectangular

Form 1. Triangular, Proximal End Pointed

Form 2. Triangular, Proximal End Rounded

Form 3. Rectangu 1 ar to Subrectangu 1 ar (Nueces scrapers after Hester, White, and White 1969)

Group 4. Small Triangular to Subtriangular

Group 5. Sma11. Narrow Distal Fragments

Group 6. Long, Narrow, El 1 iptical (Guadalupe adzes, after Campbel1 1976)

Group 7. Various Forms with Broad, Rounded, Low-Angle Bevels

Form 1. Elongate, Elliptical to Subrectangular

Form 2. Short, Broad, Subrectangular to Oval

Form 3. Subtriangular

Form 4. Distal Fragments

Group 8. Miscellaneous Forms

Form 1. Triangular to Subtriangular with Steep Bevels

Form 2. Steeply Beveled Sides

Form 3. Offset Bevels

Form 4. Broad, Flat, Triangular

Form 5. Odd Shapes

Group 9. Distal Fragments

Site provenience for distally beveled bifaces and unifaces is provided in Table 23. Individual specimen number provenience and metric attributes are presented following the description of each group.

Group 1. Large Triangu 1 ar to Subtriangular (Clear Fork gouge Type 1, after Ray 1941) (four specimens)

Group 1 specimens are triangu 1 ar to subtriangular in out 1 ine and have the bevel at the broad end. Al 1 are bifacially worked and biconvex in lateral cross section. On the ventral face, that is, the face opposite the bevel, there is a ridge running the length of each piece. The ridges impart a more convex appearance to the ventral faces in comparison to the dorsal surface. Lateral edges are straight to slightly convex. Proximal ends are rounded. Specimen 2 retains a cortex striking platform at its proximal end and is made of gray siliceous quartzite. Specimen 3 is made of petrified wood. Provenience and metric data for these four specimens are as follows:

\begin{tabular}{cccccccccccc}
$\begin{array}{c}\text { Specimen } \\
\text { Number }\end{array}$ & Site & Lot & Unit & Level & Elevation & Length & Width & Thickness & $\begin{array}{r}\text { Weight } \\
\text { Bevel } \\
\text { Angle }\end{array}$ & $\begin{array}{c}\text { Figure } \\
\text { Number }\end{array}$ \\
\hline 1 & 41 LK 27 & $44-0$ & Surface & - & - & 6.8 & 3.6 & 2.0 & 57.8 & $56^{\circ}$ & - \\
2 & 41 LK 121 & $1-0$ & Surface & - & - & 6.5 & 3.9 & 1.8 & 53.6 & $59^{\circ}$ & 81 \\
3 & 41 LK 128 & $1-0$ & Surface & - & - & 5.7 & 3.5 & 1.6 & 40.3 & $62^{\circ}$ & - \\
4 & 41 HC 192 & $1-0$ & Surface & - & - & 6.8 & 3.5 & 1.6 & 42.9 & $66^{\circ}$ & 81
\end{tabular}


TABLE 23. SITE PROVENIENCE FOR DISTALLY BEVELED BIFACES AND UNIFACES

\begin{tabular}{|c|c|c|c|c|c|c|c|c|c|c|c|c|c|c|c|c|c|c|c|}
\hline Stta & Group & Grou & up 2 & & Group 3 & & Group & Group & Group & & Gro & 7 & & & & Group 8 & & & Broup \\
\hline Number & 1 & Form 1 & Form 2 & Form 1 & Form 2 & Form 3 & 4 & 5 & 6 & Form 1 & Form 2 & Form 3 & Form 4 & Form 1 & Form 2 & Form 3 & Form 4 & Form 5 & $\mathbf{9}$ \\
\hline $41 \mathrm{LK} 8$ & & 1 & & & & & & & & & & & & & & & & & \\
\hline $41 \mathrm{LK} 14$ & & 1 & & & 1 & & 1 & A & & & & & & & & & & & \\
\hline 41 LK27 & 1 & & & & & & & $\mathrm{~L}$ & & & & & & & & & & & \\
\hline 41 LK51 & & & & 2 & & & & $L$ & & & & & & 1 & & & & & \\
\hline 41 LK53 & & & & & & & & & & & & & & & & & & & \\
\hline 41 LK 66 & & & & & & & & $\mathrm{~F}$ & & & & & & & & & & & \\
\hline $41 L \mathrm{~K} 69$ & & & 1 & & & & & A & & & & & & & & & & & \\
\hline 41 LK 74 & & & & & & & & 0 & & & & & & & & 1 & & & 1 \\
\hline $41 \mathrm{LK} 120$ & & & & & & & & $\mathrm{M}$ & & & & 1 & & & & & & & \\
\hline 41 LK 121 & 1 & & & & & & & & & & & & & & & & & & \\
\hline $41 \mathrm{LK} 122$ & & & & & & & & $\mathbf{P}$ & & & & & & & & & & & \\
\hline $41 L K 127$ & & & & 1 & & & & $H$ & & & & & & & & & & & \\
\hline $41 L K 128$ & 1 & & & & & & & $A$ & & & & & & & & & & & \\
\hline $41 \mathrm{LK} 133$ & & & & & & & & 5 & 1 & & & & & & & & & & \\
\hline 41 LK 142 & & & & & & & & $E$ & & & & & & & & & & & \\
\hline 41 LK145 & & & & & & & & & & & & & & & & & & & \\
\hline 41 LKI 149 & & & & & & & & 0 & & & & & & & & & & & \\
\hline $41 \mathrm{LK} 162$ & & & & & & & & $\mathrm{~N}$ & & & & & & & & & & & \\
\hline $41 L K 173$ & & & & & & & & $E$ & & & & & & & & & & & \\
\hline $41 L K 174$ & & & & & & & & & & & & & & & & & & & \\
\hline $41 \mathrm{LK} 176$ & & & & & & & & & & & & & & & & & & & \\
\hline 41LK181 & & & & & & & & & & & & & & & & & & & \\
\hline $41 \mathrm{LK} 182$ & & & & & & & 2 & & & & & & & & & & & & \\
\hline $41 \mathrm{LK} 185$ & & & & & & & & & & & & & & & & & & & 1 \\
\hline 41LK191 & & - & & & & & & & & & & & & 1 & & & & & \\
\hline 41 LK 197 & & & & & & & & & & & & & & & & & & & \\
\hline 41 LK 199 & & & & & 1 & & & & & & & & & & & & & 1 & \\
\hline $41 \mathrm{LK} 201$ & & & & & 1 & 1 & 2 & & & 1 & & & & & & & & & 2 \\
\hline $41 \mathrm{LK} 236$ & & & & & & & & & & & & & & & & & & & \\
\hline $41 \mathrm{LK} 243$ & & & & 1 & .1 & & 1 & & & & & & & & 1 & & 1 & & \\
\hline $41 \mathrm{LK} 247$ & & & & & & & & & & & & & & & & & & & \\
\hline $41 \mathrm{LK} 250$ & & & & & 1 & & & & & & & & & & & & & & \\
\hline $41 L K 252$ & & & & 1 & & & & & & & 1 & & & & & & & & \\
\hline $41 \mathrm{LK} 253$ & & & & & & 1 & & & & & & & & & & & & & \\
\hline & & & & & & & & & & & & & & & & & & & \\
\hline $41 \mathrm{MC7}$ & & & & & 1 & & & & & & & & & & & & & & \\
\hline $41 \mathrm{MC} 10$ & & & & & & & & & & & & & & & & & & & \\
\hline $41 \mathrm{MC} 14$ & & & & & & & & & & & & & & & & & & & \\
\hline $41 \mathrm{MC} 15$ & & & & & & & & & & & & & & & & & & & \\
\hline $41 \mathrm{MC} 17$ & & & & & & & & & & & & & & & & & & & \\
\hline $41 \mathrm{MC29}$ & & & & & 1 & & & & & & & & & & & & & & 1 \\
\hline 41 MC55 & & & & & & & & & & & & & & & & & & & \\
\hline $41 \mathrm{MC67}$ & & & & & & & & & & & & & & & & & & & \\
\hline $41 \mathrm{MC} 75$ & & & & 1 & & & & & & & & & & & & & & & \\
\hline $41 \mathrm{MC79}$ & & & & & & & & & & & & & & & & & & & \\
\hline $41 \mathrm{MCg} 4$ & & & & & 2 & & & & & & & & & & & & & & 1 \\
\hline $41 \mathrm{MC} 192$ & 1 & & 1 & 3 & & & & & & & & & & & & & & & \\
\hline $41 \mathrm{MC} 193$ & & & & & & & & & & & & & & & & & & & \\
\hline $41 M C 194$ & & & & & & & & & & & & & & & & & & & \\
\hline $41 M C 196$ & & & & $\frac{1}{1}$ & & 2 & 2 & & & & & & & & & & & 1 & 1 \\
\hline $41 M C 212$ & & & & 1 & 1 & & & & & & & & & & & & & & \\
\hline $41 \mathrm{MC} 213$ & & 1 & & & 3 & 2 & & & 1 & & & & & & & & & 1 & \\
\hline $41 \mathrm{MC214}$ & & & & & & & & & & & & & & & & & & & \\
\hline $41 \mathrm{MC} 222$ & & & & & & & & & & & & & & & & & & & \\
\hline $41 \mathrm{MC} 226$ & & 1 & & 2 & & & & & & & & & 1 & & & & 1 & & \\
\hline $41 \mathrm{MC} 234$ & & & & & & & & & & & & & & & & & & & \\
\hline $41 \mathrm{MC} 235$ & & & & & & & & & & & & & & & & & & & \\
\hline $41 \mathrm{MC238}$ & & & & 1 & & 2 & 1 & & & & 1 & & & & & & & & \\
\hline $41 \mathrm{MC} 242$ & & & & & & & & & & & & & & & & & & & \\
\hline $41 \mathrm{MC} 246$ & & & & & 1 & & & & & & & & & & & & & & \\
\hline $41 \mathrm{MC251}$ & & & & 1 & & 1 & & & & & & & & & & & & & \\
\hline $41 \mathrm{MC257}$ & & & & & & & & & & & & & & & & & & & \\
\hline $41 \mathrm{MC} 260$ & & & & & 2 & & & & & & & & & & & & & & \\
\hline $41 \mathrm{MC} 266$ & & & & & & & & & & & & & & & & & & & \\
\hline $41 \mathrm{MC} 267$ & & & & & & & & & & & & & & & & & & & \\
\hline $41 \mathrm{MC} 268$ & & & & 1 & 1 & 3 & & & & & & & & & & & & & \\
\hline$\$ 1 \mathrm{MC} 270$ & & & & & 1 & & & & & & & & & & & & & & \\
\hline $41 \mathrm{MC} 275$ & & & & & & & & & & & & & & & & & & & \\
\hline $41 \mathrm{MC276}$ & & & & 2 & & & & & & & & & & & & & & & \\
\hline $41 \mathrm{MC} 282$ & & & & 1 & & & & & & 1 & & & & 1 & & & & & \\
\hline $41 \mathrm{MC} 284$ & & & & & & & & & & & & & & $\frac{1}{1}$ & & & & & \\
\hline $41 \mathrm{MC} 28 \mathrm{~B}$ & & & & & & & & & & & & & & & & & & 2 & \\
\hline $41 \mathrm{MC293}$ & & & & & & & & & & & & & & & & & & & \\
\hline $41 \mathrm{MC} 294$ & & & & & & & & & & & & & & & & 1 & & & \\
\hline $41 \mathrm{MC} 296$ & & & & & & 2 & & & & & & & & & & & & & \\
\hline & & & & & & & & & & & & & & & & & & & \\
\hline
\end{tabular}



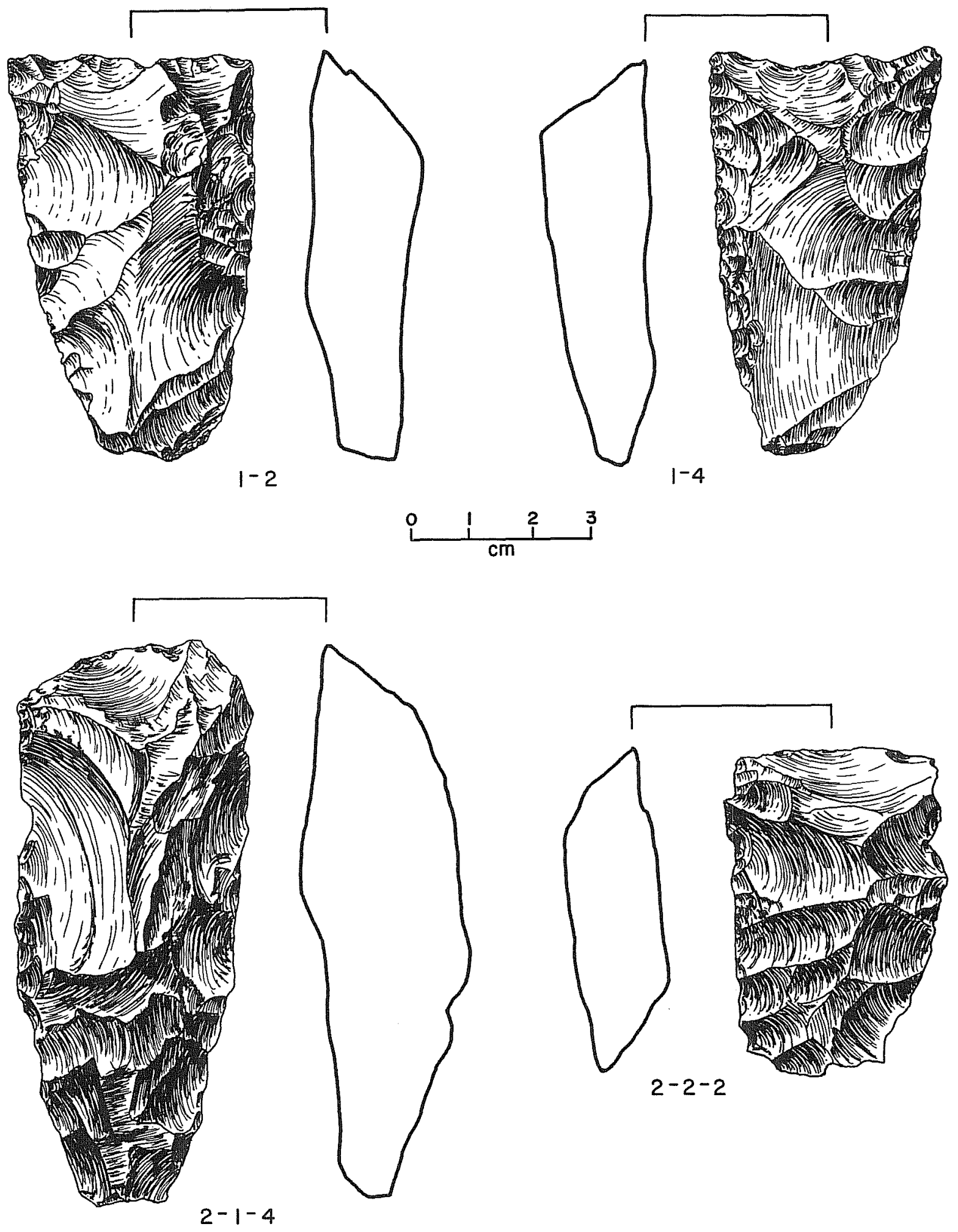

Figure 81. Distaliy Beveled Bifaces and Unifaces: Group 1 and Group 2, Forms 1 and 2. Two numbers beneath an artifact indicate group and specimen number; three numbers indicate group, form, and specimen number, respectively. 
Group 2. Large, El ongate, Rectangu lar to Subrectangu 1 ar (Clear Fork gouge Type 3, after Ray 1941) (six specimens)

Group 2 specimens are rectangular to subrectangular in out 1 ine, and all are bifacially worked. Bit (bevel) edges are convex. The bevels do not have the cusped or "scooped out" configuration characteristic of Group 1. Group 2 specimens are generally narrower in relation to length than are other distally beveled specimens, with the exceptions of Groups 5 and 6 . Group 2 is further divided into two forms based on length. Form 2 specimens are about half as long as those in Form 1 . Since all specimens in the group are so similar except for the length, it is suggested that the Form 2 pieces are simp $1 y$ worn-down and resharpened examples of Form 1.

Eorm 1. Long (four specimens)

Specimens 2 and 4 are biconvex in 1 ateral cross section. Specimens 1 and 3 are more rearly $p l a n o-c o n v e x$ with the flat surface on the dorsal face, that is, on the same side as the bevel. All specimens have pronounced ridges running down the length of the ventral face. On Specimen 4, both faces have this longitudinal ridge, and a diamond-shaped lateral cross section is formed. Specimen 2 is moderately patinated on one face. Provenience and metric data for Group 2, Form I are as follows:

\begin{tabular}{cccccccccccc}
$\begin{array}{c}\text { Specimen } \\
\text { Number }\end{array}$ & Site & Lot & Unit & Level & Elevation & Length & Width & Thickness & $\begin{array}{r}\text { Weight } \\
\text { Bevel } \\
\text { Angle }\end{array}$ & $\begin{array}{c}\text { Figure } \\
\text { Number }\end{array}$ \\
\hline 1 & 41 LK 8 & $196-0$ & Surface & - & - & 7.9 & 4.2 & 1.8 & 70.3 & $60^{\circ}$ & - \\
2 & 41 LK 14 & $300-0$ & Surface & - & - & 8.9 & 4.2 & 2.0 & 75.0 & $69^{\circ}$ & - \\
3 & 41 MC 213 & $2-46$ & Surface & - & - & 7.4 & 3.3 & 1.6 & 41.6 & $62^{\circ}$ & - \\
4 & 41 MC 226 & $4-0$ & Surface & - & - & 9.1 & 3.8 & 2.6 & 92.5 & $52^{\circ}$ & 81
\end{tabular}

Form 2. Short (two specimens)

\begin{tabular}{|c|c|c|c|c|c|c|c|c|c|c|c|}
\hline $\begin{array}{l}\text { Specimen } \\
\text { Number }\end{array}$ & Site & Lot & Unit & Lovel & Elevation & Length & Width & Thickness & Woight & $\begin{array}{l}\text { Bevel } \\
\text { Angle }\end{array}$ & $\begin{array}{l}\text { Figure } \\
\text { Number }\end{array}$ \\
\hline 1 & 41 LK 69 & $88-0$ & Surface & - & - & 5.7 & 3.5 & 1.9 & 38.0 & $48^{\circ}$ & - \\
\hline 2 & 41 MC 192 & $1-0$ & Surface & - & - & 5.4 & 3.6 & 1.5 & 34.9 & $54^{\circ}$ & 81 \\
\hline
\end{tabular}

Group 3. Short, Broad, Triangular to Subrectangular (48 specimens)

Group 3 specimens are generally distinguished from Group 1 by their smaller size and more variable outline, but there is nevertheless some overlap between Groups 1 and 3, especially with respect to Forms 1 and 2 described below. Group 3 specimens are as wide as those in Group 1, but are shorter, thinner, and more finely flaked. The width of Group 3 specimens approaches, and in some cases exceeds, the length. The group is further subdivided into three forms based on outline shape. Two of the forms are basically triangular in outline, one composed of specimens with pointed proximal ends and the other of specimens with slightiy rounded proximal ends. The third form contains specimens with rectangular to subrectangular out 7 ines. 
Eorm 1. Triangular, Proximal End Pointed (16 specimens)

Specimens 2, 5, 7, and 12 are unifacial 1 y worked. Specimens 2, 9, and 13 have concave bit edges; Specimen 12 has a convex, slightly offset bit edge; and the rest have straight bit edges. Specimens 2, 7, 10, and 14 are asymmetrically pyramidal in configuration. The apex of the pyramid is on the dorsal side of each specimen and is off center toward the bevel edge. Three distinct facets are formed on the dorsal surface by the intersection of the bevel with a pronounced ridge running back to the proximal end. These pyramid-shaped specimens are generally thicker than the others in the group. Specimens 5, 7, 10, and 15 retain sma 11 patches of cortex on their dorsal faces. Specimens 12 and 14 are made of gray siliceous quartzite; all other specimens are chert. Provenience and metric data for the Group 3, Form 1 specimens are as follows:

\begin{tabular}{|c|c|c|c|c|c|c|c|c|c|c|c|}
\hline $\begin{array}{l}\text { Specimen } \\
\text { Number }\end{array}$ & Site & Lot & Unit & Level & Elevation & Length & Width & Thtckness & Helght & $\begin{array}{l}\text { Bevel } \\
\text { Angle }\end{array}$ & $\begin{array}{l}\text { Flgure } \\
\text { Number }\end{array}$ \\
\hline 1 & $41 \mathrm{LK} 51$ & 282 & $\mathrm{~N} 1026 \mathrm{E} 1042$ & 2 & $99.80-99.70$ & 4.4 & 4.1 & 1.3 & 22.2 & $74^{\circ}$ & 82 \\
\hline 2 & 41 LK 51 & 315 & Surface & 8 & $99.20-99.10$ & 4.6 & 4.3 & 1.5 & 22.7 & $66^{\circ}$ & - \\
\hline 3 & 41 LK 127 & $10-10$ & Surface & - & - & 5.1 & 4.0 & 1.5 & 29.9 & $58^{\circ}$ & - \\
\hline 4 & 41 LK 243 & $27=0$ & Surface & - & - & 5.5 & 4.4 & 1.3 & 29.9 & $66^{\circ}$ & - \\
\hline 5 & 41 L.K 252 & $1-2$ & Surface & - & - & 5.1 & $4.5^{*}$ & 1.1 & 29.8 & $73^{\circ}$ & - \\
\hline 6 & $41 \mathrm{MC} 75$ & $34-0$ & Surface & - & - & $3.7 \%$ & 4.8 & 1.2 & 24.4 & $68^{\circ}$ & - \\
\hline 7 & 41 MC 196 & $23-0$ & Surface & - & - & 5.1 & 3.6 & 1.5 & 27.4 & $60^{\circ}$ & - \\
\hline 8 & 41 MC 212 & $1-0$ & Surface & - & - & 3.6 & 3.1 & 0.9 & 11.4 & $60^{\circ}$ & - \\
\hline 9 & 41 MC 226 & 4-0 & Surface & - & - & 4.8 & 4.1 & 1.2 & 23.5 & $61^{\circ}$ & 82 \\
\hline 10 & 41 MC 226 & $7-0$ & Surface & - & - & 4.0 & 4.5 & 1.6 & 23.8 & $64^{\circ}$ & - \\
\hline 11 & $41 M C 238$ & $2-0$ & Surface & - & - & 3.7 & 4.3 & 1.6 & 21.1 & $56^{\circ}$ & - \\
\hline 12 & 41 MC 251 & $1-0$ & Surface & - & - & 5.4 & 4.5 & 1.3 & 27.9 & $64^{\circ}$ & - \\
\hline 13 & 41 MC 268 & 49 & N995 E983 & 1 & Surf. -99.40 & 3.5 & 3.6 & 1.1 & 14.3 & $69^{\circ}$ & $=$ \\
\hline 14 & 41 MC 276 & $1-15$ & Surface & - & - & 4.4 & 3.3 & 1.5 & 19.2 & $68^{\circ}$ & - \\
\hline 15 & 41 MC 276 & $1-17$ & Surface & - & - & 5.1 & 3.8 & 1.6 & 27.7 & $49^{\circ}$ & - \\
\hline 16 & 41 MC 282 & $1-0$ & Surface & - & - & 3.3 & 3.0 & 0.9 & 10.4 & $58^{\circ}$ & - \\
\hline
\end{tabular}

Form 2. Iriangular, Proximal End Rounded (18 specimens)

Specimens 9, 15, 16, and 17 are unifacial 1 y worked. Specimens 6 and 7 have "scooped out" bits, but the bit edges are straight. Specimens 9, 10, 11, 15, 16, and 17 have the dorsal pyramid configuration described for Group 3 , Form 1 above. Specimen 14 is made of petrified wood. Specimen 15 is gray siliceous quartzite. All others are chert. Specimen 5 retains a small patch of cortex on the ventral face. Provenience and metric data for the Group 3 , Form 2 specimens are as follows: 


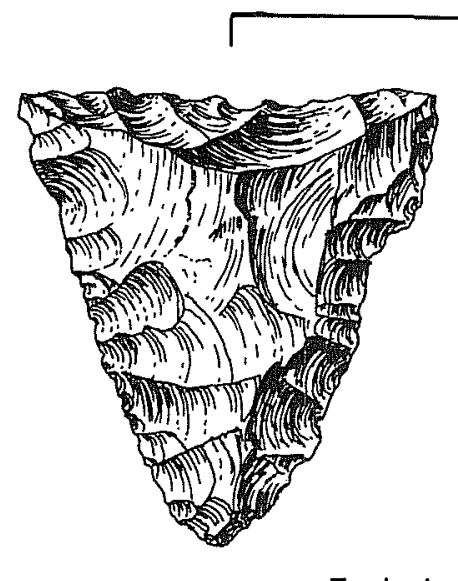

$3-1-1$
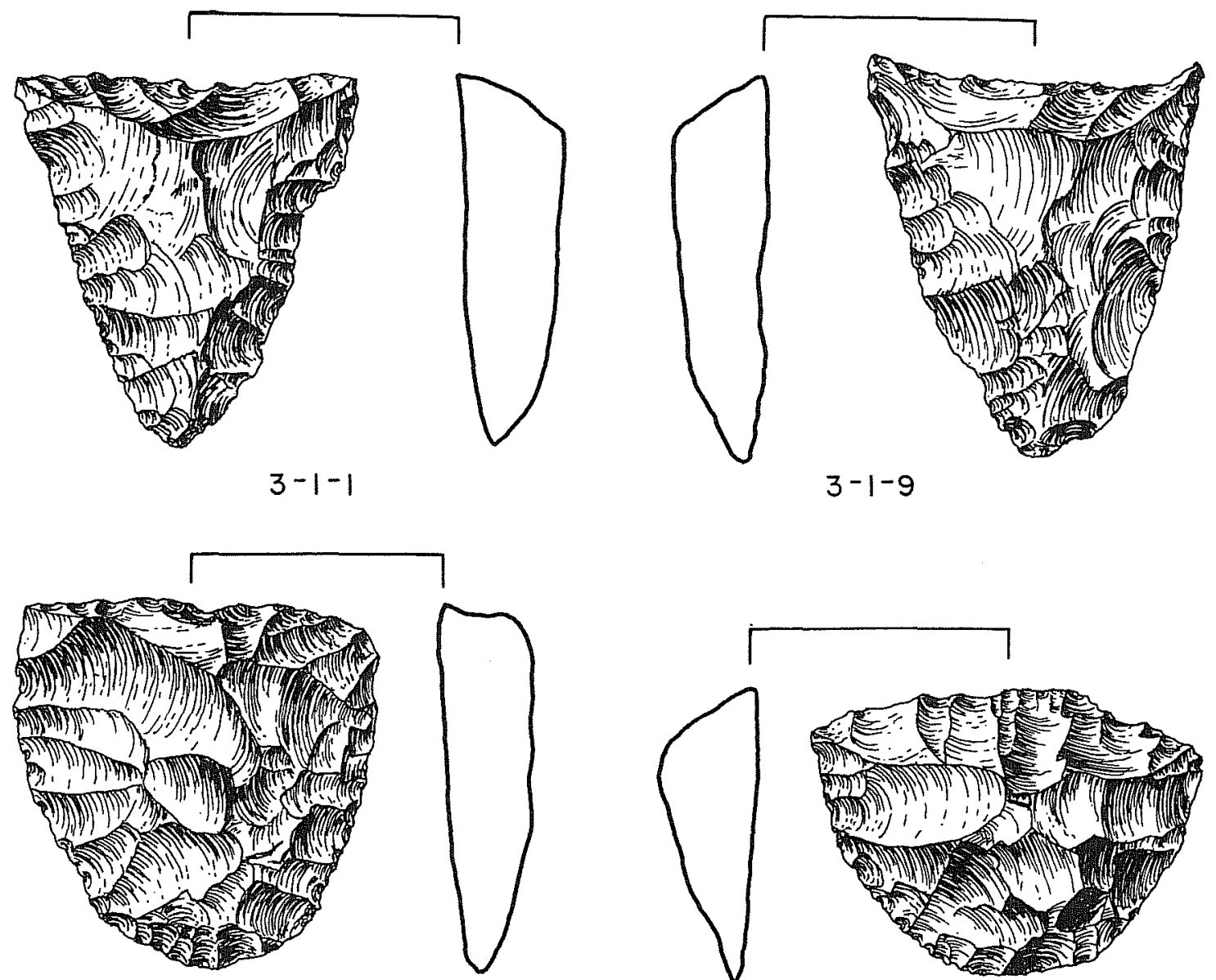

$3-2-9$

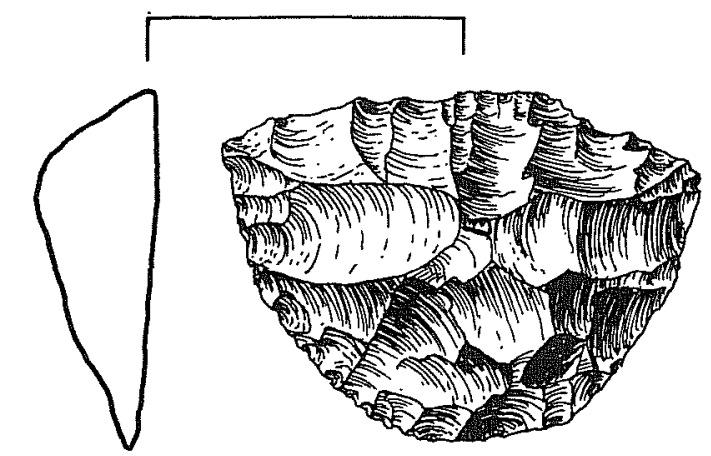

$3-2-16$

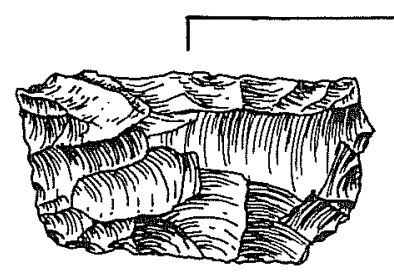

$3-3-2$
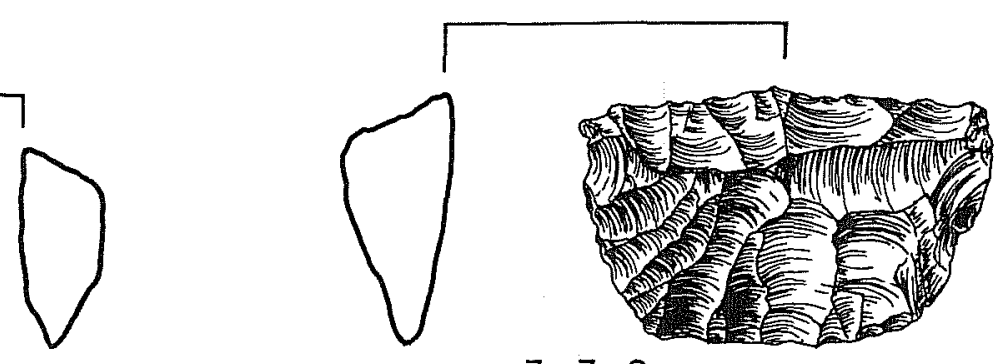

$3-3-9$
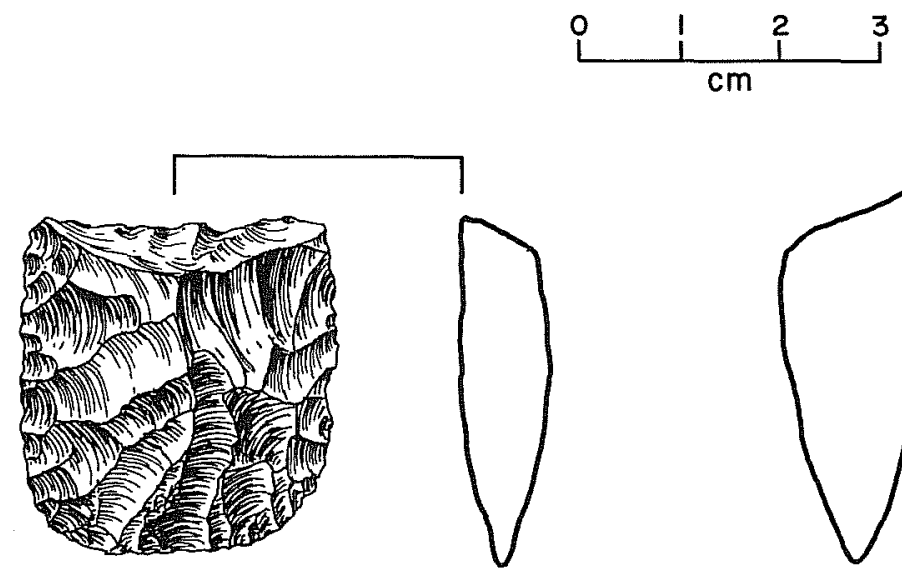

$$
\text { 3-3-3 }
$$

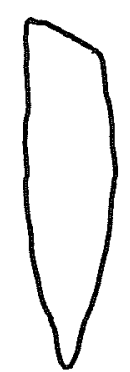

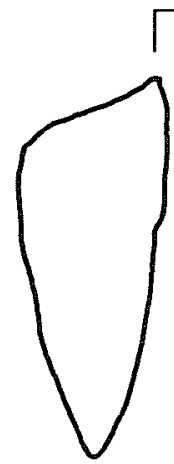

Figure 82. Distal1y Beveled Bifaces and Unifaces: Group 3, Forms 1, 2 , and 3. Numbers beneath artifact indicate group, form, and specimen number, respectively. 


\begin{tabular}{|c|c|c|c|c|c|c|c|c|c|c|c|}
\hline $\begin{array}{l}\text { Spectmen } \\
\text { Number }\end{array}$ & Site & Lot & Unit & Level & Elevation & Length & Width & Thickness & Welght & $\begin{array}{l}\text { Bevel } \\
\text { Angle }\end{array}$ & $\begin{array}{l}\text { Flgure } \\
\text { Number }\end{array}$ \\
\hline 1 & 41 LK 14 & $300-0$ & Surface & - & - & 4.9 & 4.2 & 1.5 & 28.6 & $73^{\bullet}$ & - \\
\hline 2 & 41 LK 199 & $2-0$ & Surface & - & - & 3.4 & 4.3 & 1.1 & 17.4 & $63^{\circ}$ & - \\
\hline 3 & 41 LK 201 & 371 & N500 E998 & 13 & $98.15-98.05$ & 3.7 & 4.8 & 1.0 & 19.4 & $61^{\circ}$ & - \\
\hline 4 & 41 LK 243 & $27-0$ & Surface & - & - & 5.0 & 4.1 & 1.3 & 27.5 & $53^{\circ}$ & - \\
\hline 5 & 41 LK 250 & $12-15$ & Surface & - & - & 4.3 & 4.4 & 1.4 & 26.9 & $81^{\circ}$ & - \\
\hline 6 & 41 MC 7 & $1-0$ & Surface & - & - & 5.3 & 4.7 & 1.3 & 34.4 & $54^{\circ}$ & - \\
\hline 7 & 41.MC 29 & $92-0$ & Surface & - & - & 4.9 & 5.0 & 1.5 & 38.7 & $53^{\circ}$ & - \\
\hline 8 & $41 M C 94$ & 198 & Test Pit 3 & 3 & $99.60-99.50$ & 3.4 & 3.9 & 1.3 & 15.2 & $55^{\circ}$ & - \\
\hline 9 & $41 \mathrm{MC} 94$ & 212 & Test Pit 5 & 1 & Surf. -99.80 & 4.4 & 4.4 & 1.3 & 27.2 & $79^{\circ}$ & 82 \\
\hline 10 & 41 MC 212 & $1-0$ & Surface & - & - & 4.0 & 4.0 & 1.5 & 25.0 & $72^{\circ}$ & - \\
\hline 11 & 41 MC 213 & $2-27$ & Surface & - & - & 3.9 & 3.3 & 1.3 & 20.0 & $48^{\circ}$ & - \\
\hline 12 & $41 M C 213$ & $2-56$ & Surface & - & - & 3.5 & 3.5 & 1.0 & 11.4 & $64^{\circ}$ & - \\
\hline 13 & $41 M C 213$ & $2-57$ & Surface & - & - & 3.6 & 5.1 & 1.3 & 23.6 & $52^{\circ}$ & - \\
\hline 14 & 41 LK 243 & $26-14$ & Surface & - & - & $4.8 *$ & 4.8 & 1.1 & 29.1 & $39^{\circ}$ & - \\
\hline 25 & $41 M C 260$ & 3 & Shovel Test 2 & - & - & 3.5 & 3.7 & 1.3 & 17.2 & $54^{\circ}$ & - \\
\hline 16 & 41 MC 260 & $1-11$ & Surface & - & - & 3.6 & 4.8 & 1.2 & 17.7 & $55^{\circ}$ & 82 \\
\hline 17 & 41 MC 268 & $91-57$ & Surface & - & - & 3.8 & 4.5 & 1.2 & 21.2 & $53^{\circ}$ & - \\
\hline 18 & 41 MC 270 & $21-3$ & Surface & - & - & 4.0 & 3.4 & 1.0 & 15.8 & $65^{\circ}$ & - \\
\hline
\end{tabular}

Eorm 3. Rectangular to Subrectangular (Nueces scraper after Hester, White, and White 1969) (14 specimens)

Specimen 9 is unifacially worked. Specimens 4,12 , and 13 retain patches of cortex. Cortex covers approximately $50 \%$ of the dorsal face of Specimen 12. On Specimen 13, the cortex occurs at the proximal end, apparentiy a remnant striking platform. Specimen 9 is heavily patinated on the bit and at the proximal end on the ventral face. Specimen 11 appears to have been the proximal portion of an unstemmed thin biface (concave base) that was reworked into a distally beveled biface. Provenience and metric data for the Group 3, Form 3 specimens are as foll lows:

\begin{tabular}{|c|c|c|c|c|c|c|c|c|c|c|c|}
\hline $\begin{array}{l}\text { Spec1men } \\
\text { Number }\end{array}$ & Site & Lot & Unit & Level & Elevation & Length & Width & Th1ckness & Weight & $\begin{array}{l}\text { Bevel } \\
\text { Angle }\end{array}$ & $\begin{array}{l}\text { Figure } \\
\text { Number }\end{array}$ \\
\hline 1 & $41 \mathrm{LK} 201$ & 184 & N491 E1043 & 11 & $97.75-97.65$ & 2.8 & 3.2 & 0.9 & 8.8 & $73^{\circ}$ & - \\
\hline 2 & 41 LK 253 & $1-25$ & Surface & - & - & 1.8 & 3.6 & 0.8 & 5.7 & $67^{\circ}$ & 82 \\
\hline 3 & $41 M C 196$ & $20-4$ & Surface & - & - & 3.3 & 3.2 & 1.0 & 12.8 & $67^{\circ}$ & 82 \\
\hline 4 & 41 MC 196 & $21-42$ & Surface & - & - & 4.1 & 3.8 & 1.3 & 22.7 & $53^{\circ}$ & - \\
\hline 5 & $41 M C 213$ & $2-58$ & Surface & - & - & 2.0 & 3.8 & 1.0 & 8.3 & $70^{\circ}$ & - \\
\hline 6 & $41 \mathrm{MC} 213$ & $2-63$ & Surface & - & - & 2.8 & 4.8 & 1.3 & 16.8 & $46^{\circ}$ & - \\
\hline 7 & $41 M C 238$ & $1-2$ & Surface & - & - & 3.6 & 4.6 & 1.1 & 25.7 & $48^{\circ}$ & - \\
\hline 8 & $41 \mathrm{MC} 238$ & $1-3$ & Surface & - & - & 4.0 & 4.9 & 1.5 & 28.6 & $64^{\circ}$ & - \\
\hline
\end{tabular}




$\begin{array}{rrrllcllllll}9 & 41 \text { MC 251 } & 1-0 & \text { Surface } & - & - & 2.5 & 4.1 & 1.0 & 11.9 & 55^{\circ} & 82 \\ 10 & 41 \text { MC 268 } & 8 & \text { Test P1t 2 } & 1 & 0-10 \mathrm{~cm} & 3.1 & 3.0 & 0.8 & 8.3 & 61^{\circ} & - \\ 11 & 41 \text { MC 268 } & 37 & \text { N994 E983 } & 6 & 99.00-98.90 & 3.9 & 3.2 & 1.0 & 14.9 & 55^{\circ} & - \\ 12 & 41 \text { MC 268 } & 1-40 & \text { Surface } & - & - & 3.1 & 5.6 & 1.6 & 31.9 & 58^{\circ} & - \\ 13 & 41 \text { MC 296 } & 82 & \text { N1023 E986 } & 4 & 99.20-99.10 & 1.7 & 3.1 & 0.9 & 4.5 & 68^{\circ} & - \\ 14 & 41 \text { MC 296 } & 244-0 & \text { Surface } & - & - & 3.9 & 4.1 & 1.6 & 28.1 & 68^{\circ} & 82\end{array}$

\section{Group 4. Small Triangular to Subtriangular (nine specimens)}

Much 1 ike the Group 1 specimens in their overal1 configuration, Group 4 specimens are distinguished by their diminutive size, straight to convex bit edges, thinness, and fine flaking. Specimens 1 and 4 have pronouncedly convex bit edges. Specimen 7 is, in essence, unifacially worked. Specimen 3 is made of petrified wood; the others are of chert. Provenience and metric data for Group 4 specimens are as follows:

\begin{tabular}{|c|c|c|c|c|c|c|c|c|c|c|c|}
\hline $\begin{array}{l}\text { Specimen } \\
\text { Number }\end{array}$ & Site & Lot & Unit & Level & Elevation & Length & Width & Th1ckness & Welght & $\begin{array}{l}\text { Bevel } \\
\text { Angle }\end{array}$ & $\begin{array}{l}\text { Figure } \\
\text { Number }\end{array}$ \\
\hline 1 & 41 LK 14 & 297-0 & Surface & - & - & 4.4 & 2.6 & 0.9 & 10.6 & $58^{\circ}$ & - \\
\hline 2 & 41 LK 182 & $1-0$ & Surface & - & - & 4.0 & 3.2 & 0.8 & 12.7 & $57^{\circ}$ & 83 \\
\hline 3 & 41 LK 182 & $1-0$ & Surface & - & - & 4.7 & 3.2 & 1.1 & 15.1 & $52^{\circ}$ & - \\
\hline 4 & 41 LK 201 & 323 & N497 E997 & 13 & $98.15-98.05$ & 6.6 & 3.7 & 1.2 & 37.2 & $61^{\circ}$ & - \\
\hline 5 & 41 LK 201 & 331 & N498 E997 & 11 & $98.35-98.25$ & 4.4 & 3.7 & 1.1 & 17.2 & $75^{\circ}$ & - \\
\hline 6 & 41 LK 243 & $26-39$ & Surface & - & - & 5.3 & 3.8 & 0.8 & 15.5 & $63^{\circ}$ & 83 \\
\hline 7 & 41 MC 196 & $27-0$ & Surface & - & - & 5.1 & 3.7 & 1.2 & 23.5 & $50^{\circ}$ & - \\
\hline 8 & 41 MC 196 & $21-38$ & Surface & - & - & 4.8 & 3.1 & 1.0 & 18.2 & $82^{\circ}$ & - \\
\hline
\end{tabular}

Group 5. Sma 11, Narrow Distal Fragments (three specimens, from Phase I investigations)

No examples of this distinctive distally beveled tool type were recovered during Phase II investigations at Choke Canyon. The three specimens shown in this report have been previously described (Hall, Black, and Graves 1982:330), but inadvertently were not 111 ustrated. The three Group 5 specimens are the narrowest of the distally beveled tools. They are rectangular, having a chisel1 ike appearance. A11 are bifacially worked. Perhaps significantly, each is broken into lengths ranging from 3.3 to $4.1 \mathrm{~cm}$, and they are much the same size in their other dimensions. Cross sections are biconvex. The beveled ends of Specimens 1 and 3 are "scooped out" very shal1owly and form a bit somewhat 1 ike those of the Group 2 specimens. The bevel on Specimen 2 is more angular, the bit edge slightly convex. The most distinctive feature of the Group 5 specimens is that they are so slender relative to their length. Al1 three are made of chert. $A$ possible Late Paleo-Indian or Early Archaic affiliation has been suggested for Group 5 based on findings made at 41 MC 57 (1b1d.:189-190). Provenience and metric data for the Group 5 specimens are as follows: 


\begin{tabular}{|c|c|c|c|c|c|c|c|c|c|c|c|}
\hline $\begin{array}{l}\text { Spec1men } \\
\text { Number }\end{array}$ & Site & Lat & Unit & Level & Elevation & Length & Width & Thickness & Weight & $\begin{array}{l}\text { Bevel } \\
\text { Angle }\end{array}$ & $\begin{array}{l}\text { Figure } \\
\text { Number }\end{array}$ \\
\hline 1 & 41 LK 52 & $1-17$ & Surface & - & - & $3.6 *$ & 2.4 & 0.9 & $10.3^{*}$ & $52^{\circ}$ & 83 \\
\hline 2 & 41 MC 57 & $14(1)$ & Surface & - & - & $3.3^{*}$ & 2.8 & 0.9 & $11.2^{*}$ & $57^{\circ}$ & 83 \\
\hline 3 & 41 MC 94 & $20(20)$ & Surface & - & - & $4.2^{*}$ & 2.5 & 1.1 & $12.5 *$ & $61^{\circ}$ & 83 \\
\hline
\end{tabular}

\section{Group 6. Long, Narrow. Elliptical (Guadalupe adzes) (two specimens)}

Group 6 specimens are the largest of the distally beveled bifaces and unifaces. They have previously been referred to as Guadalupe adzes (Calhoun 1965; Campbe11 1976). The specimens are long, narrow, and bifacially worked. Transverse cross sections are thickly plano-convex or trianguloid. The convex faces have pronounced medial ridges running the length of each specimen. A roughly prismatic or "keeled" appearance is imparted by the medial ridge. Beyond these observations, the two specimens recovered in Phase II investigations are somewhat different from the Phase I examp 1 es. Unlike the Phase I specimens, these pieces have the bevel on the same side as the medial ridge. On Specimen 2, this variance may be explained by a major flaw which has eliminated the medial ridge. No such explanation is apparent in the case of Specimen 1. Provenience and metric data for the Group 6 specimens are as follows:

\begin{tabular}{|c|c|c|c|c|c|c|c|c|c|c|c|}
\hline $\begin{array}{l}\text { Specimen } \\
\text { Number }\end{array}$ & Site & Lot & Unit & Level & Elevation & Length & Width & Thickness & Weight & $\begin{array}{l}\text { Bevel } \\
\text { Angle }\end{array}$ & $\begin{array}{l}\text { Figure } \\
\text { Number }\end{array}$ \\
\hline 1 & 41 LK 133 & $17-10$ & Surface & - & - & 10.8 & 3.9 & 3.2 & 116.8 & $49^{\circ}$ & 84 \\
\hline 2 & 41 MC 213 & $2-3$ & Surface & - & - & 10.8 & 4.3 & 2.6 & 130.2 & $64^{\circ}$ & 84 \\
\hline
\end{tabular}

A detailed discussion of the Guadalupe tool is provided by B1ack and McGraw (1985) in their report of findings at the Panther Springs Creek site (41 BX 228) in northern Bexar County.

Group 7. Various Forms with Broad, Rounded, Low-Angle Bevels (six specimens)

Group 7 specimens share a distal end morphology considerably different from those previously described. The distal ends on these specimens might best be described as "shovel-shaped." The edge of the beveled end is pronouncedly convex or rounded, whereas other distally beveled bifaces and unifaces have straight to only slightly convex bevel edges. None of the Group 7 specimens have the more angular or cusped corners marking the intersection of the bevel edge with the 1 ateral edges typical of previously described groups. The angle of beveling is generally so low that there is not a distinct bevel face on the specimens. In general, the Group 7 specimens are very thick and/or crudely flaked. It is possible that Group 7 contains preform examp 1 es of specimens in the groups described above. Provenience and metric data for the Group 7 specimens are as follows: 


\begin{tabular}{|c|c|c|c|c|c|c|c|c|c|c|c|c|}
\hline $\begin{array}{l}\text { Form } \\
\text { Number }\end{array}$ & $\begin{array}{l}\text { Spectmen } \\
\text { Number }\end{array}$ & site & Lot & Unft & Level & Elevation & Length & Width & Thtckness & Height & $\begin{array}{l}\text { Bevel } \\
\text { Angle }\end{array}$ & $\begin{array}{l}\text { Flgure } \\
\text { Number }\end{array}$ \\
\hline 1 & 1 & $41 \mathrm{LK} 201$ & 271 & N499 E997 & 3 & $99.15-99.05$ & 5.8 & 4.0 & 1.7 & 43.1 & $52^{\circ}$ & - \\
\hline 1 & 2 & $41 \mathrm{MC} 282$ & $1-0$ & Surface & - & - & $4.9 *$ & 4.0 & 1.6 & $39.6^{*}$ & $65^{\circ}$ & 83 \\
\hline 2 & 1 & 41 LK 252 & $1-28$ & Surface & - & - & $4.5^{*}$ & 5.1 & 1.4 & $39.9 *$ & $39^{\circ}$ & 83 \\
\hline 2 & 2 & $41 M C 238$ & $2-0$ & Surface & - & - & 5.9 & 5.1 & 1.2 & $46.8^{*}$ & $74^{\circ}$ & - \\
\hline 3 & 1 & 41 LK 120 & $1-0$ & Surface & - & - & 9.4 & 3.5 & 1.8 & 51.6 & $41^{\circ}$ & 85 \\
\hline 4 & 1 & 41 MC 226 & $4-0$ & Surface & - & - & \# & 3.8 & 1.2 & \# & $42^{\circ}$ & - \\
\hline
\end{tabular}

Form 1. Elongate, Elliptical to Subrectangular (two specimens)

Specimen 1 appears to have been burned based on its reddish brown color and craze lines visible on the surface. It is very roughly flaked and retains cortex on the convex face. Specimen 2 consists of a distal portion on $7 y$. It is relatively well flaked, and the distal end is distinctly formed into the characteristic "shovel shape."

Form 2. Short, Broad, Subrectangular to Oval (two specimens)

Form 2 specimens vary from subrectangular to subtriangular in out 1 ine. Specimen 1 is a distal fragment on $7 y$, while Specimen 2 is complete. Both are comparatively thin. Specimen 1 exhibits very distinctly the "shovel-shaped" distal end.

Eorm 3. Subtriangular (one specimen)

The Group 7, Form 3 specimen is very unusual looking; it is we $11 \mathrm{f} 1$ aked with the exception of a cortex-covered knot remaining near the proximal or pointed end. The convex face of the distal, rounded end was thinned by driving off four or five long, narrow flakes from the bit edge back toward the proximal end. Use-wear or perhaps intentional dulling is very apparent on the distal edge.

Eorm 4. Distal Fragment (one specimen)

The Group 7, Form 4 specimen is a distal end fragment with the distinctive "shove1-shaped" bit morphology.

Group 8. Misce11aneous Forms (14 specimens)

The five form categories in Group 8 are essentially distinct from one another, sharing only the distal end beveling as a common trait. 

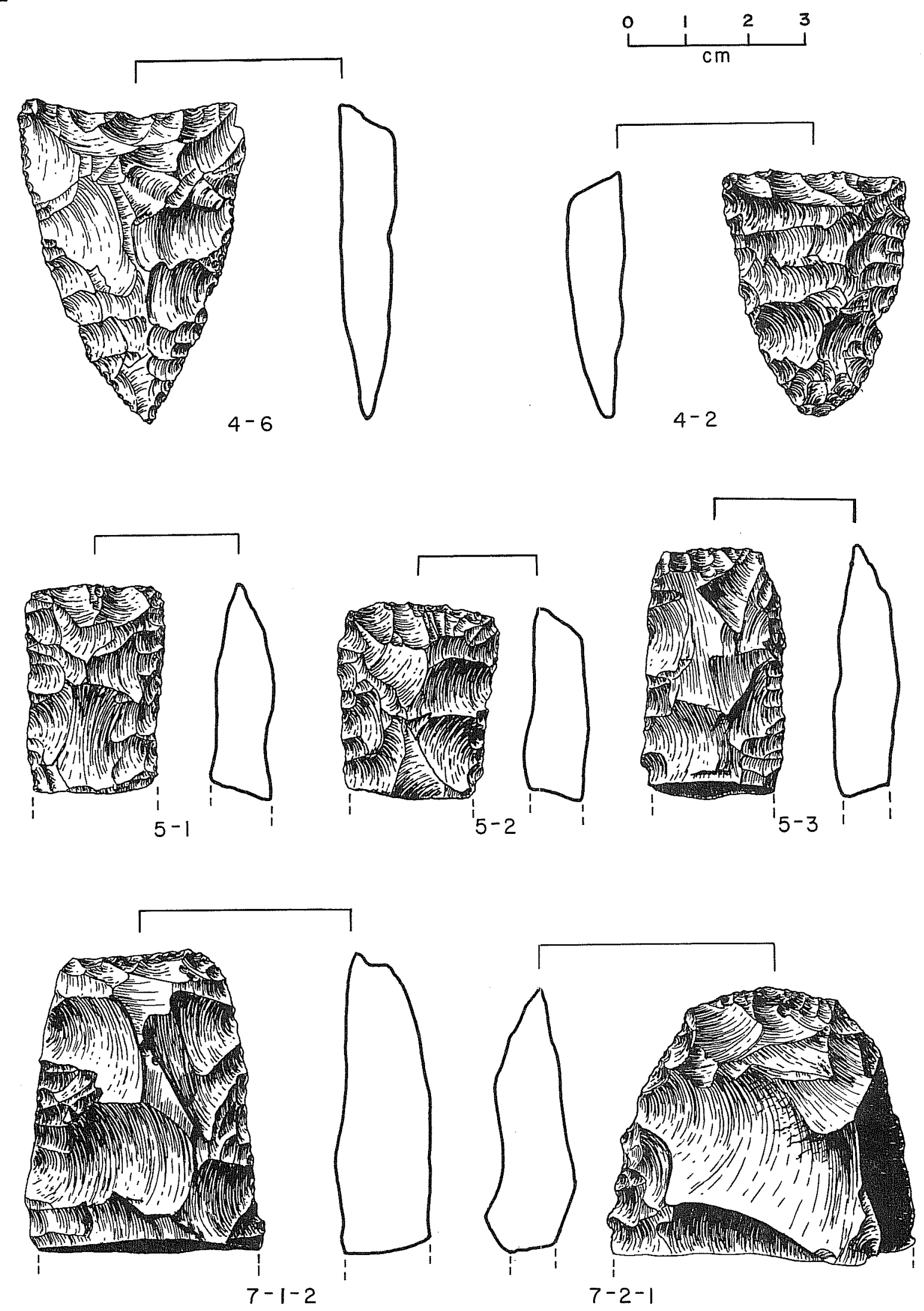

Figure 83. Distal1y Beveled Blfaces and Unifaces: Group 4, Group 5, and Group 7. Forms 1 and 2. Two numbers beneath an artifact indicate group and specimen number; three numbers indicate group, form, and specimen number. respectively. 

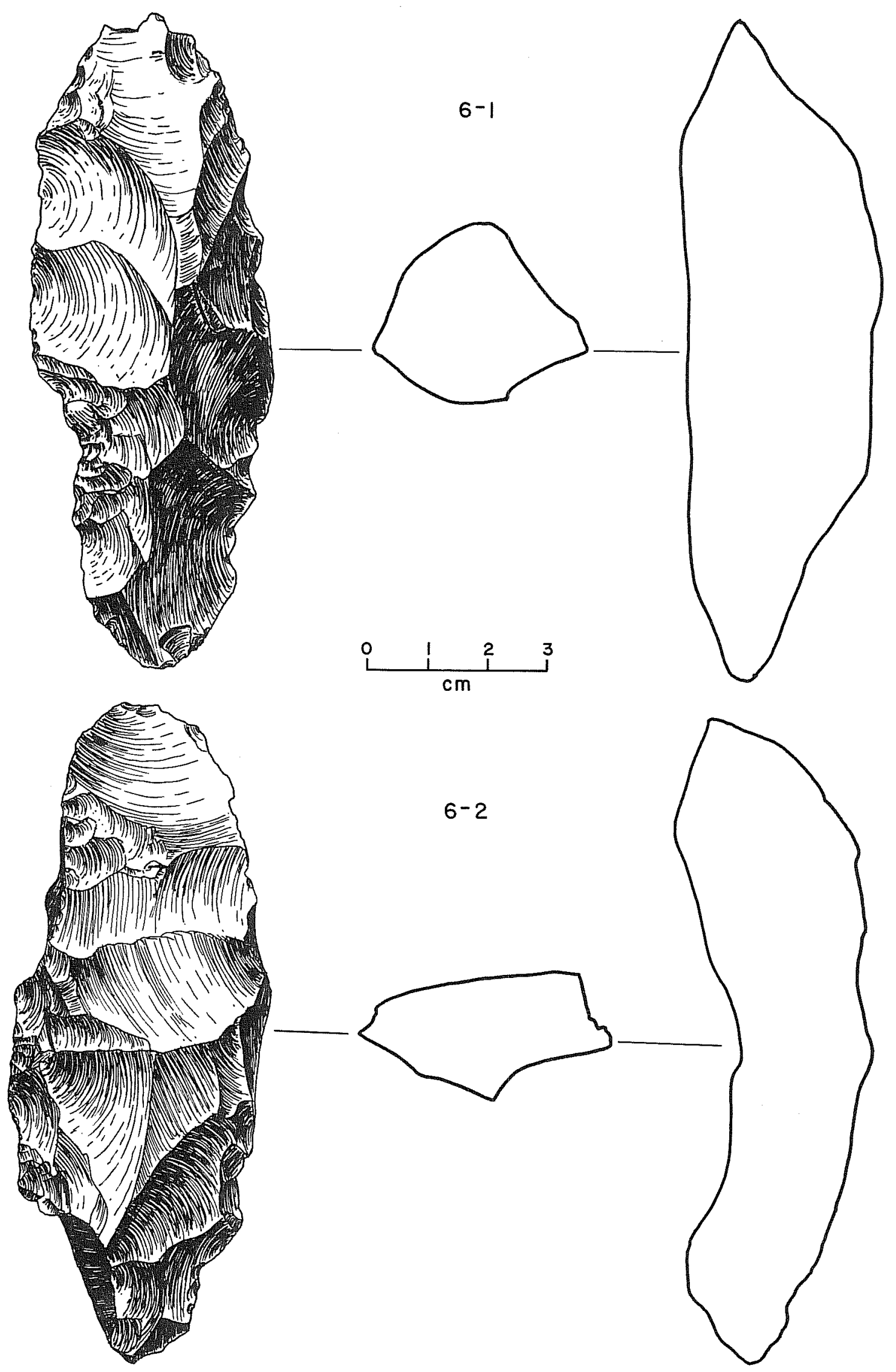

Figure 84. Distally Beveled Bifaces and Unifaces: Group 6. Numbers indicate group and specimen number. 
Eorm 1. Iriangular to Subtriangular with Steep Bevels (four specimens)

Group 8, Form 1 specimens are more-or-less triangular in outline. In contrast to the Group 1 and Group 4 triangular specimens, these pieces are abnormally thick and have very steep bevels. The thickness of the pieces, coupled with the steepness of the bevels and sides, imparts an asymmetric pyramidal configuration to the specimens.

Eorm 2. Steeply Beveled Sides (one specimen)

The Group 8, Form 2 specimen is irregularly triangular in outline. It is distinguished by steep dorsal sides which, in conjunction with the beveled bit, impart an asymmetrically pyramidal configuration to the dorsal face.

Eorm 3. Offset Bevels (two specimens)

Group 8, Form 3 specimens are distinguished by offset bevels. They are subtriangular in outline. Both are, in essence, unifacially worked. Specimen 1 is offset to the left, Specimen 2 to the right. Both retain some cortex on one face. Specimen 2 is moderately patinated.

Eorm 4. Broad, Flat, Iriangular (two specimens)

Triangu 7 ar in outline, Group 8, Form 4 specimens are unusual $7 y$ broad at the beveled end. They are also comparatively flat and have low-angle bits. Both are bifacially worked.

\section{Eorm 5. Odd Shapes (five specimens)}

Group 8, Form 5 specimens are characterized by eccentricities of out 1 ine, thickness, and dorsal face morphology. Specimen 1 is a distal fragment with an extremely steep bevel. It is quite wide and thick. Specimen 2 is subcircular in outline and has a very irregular bit. The proximal end comes to a rounded point. Specimens 3, 4, and 5 are elongate subrectangu 1 ar in outl ine with poorly formed distal bits. Specimen 5 is made of petrified palmwood.

Provenience and metric data for the Group 8 specimens are as follows:

\begin{tabular}{|c|c|c|c|c|c|c|c|c|c|c|c|c|}
\hline $\begin{array}{l}\text { Form } \\
\text { Number }\end{array}$ & $\begin{array}{l}\text { Specimen } \\
\text { Number }\end{array}$ & Site & Lot & Unft & Level & Elevation & Length & Width & Th Ickness & Welght & $\begin{array}{l}\text { Bevel } \\
\text { Angle }\end{array}$ & $\begin{array}{l}\text { Figure } \\
\text { Number }\end{array}$ \\
\hline 1 & 1 & 41 LK 51 & 298 & N1033 E1062 & 3 & $99.60-99.50$ & 6.4 & 3.1 & 1.6 & 27.5 & $53^{\circ}$ & - \\
\hline 1 & 2 & 41 LK 191 & $1-8$ & Surface & - & - & 4.2 & 3.4 & 1.9 & 25.6 & $62^{\circ}$ & - \\
\hline 1 & 3 & 41 MC 282 & $1-0$ & Surface & - & - & 4.2 & 4.2 & 2.1 & 35.6 & $76^{\circ}$ & 85 \\
\hline 1 & 4 & 41 MC 284 & 1 & Surface & - & - & 6.5 & 3.9 & 2.2 & 49.2 & $58^{\circ}$ & - \\
\hline 2 & 1 & 41 LK 243 & $26-4$ & Surface & - & - & 6.2 & 4.0 & 2.0 & 36.3 & $55^{\circ}$ & 85 \\
\hline 3 & 1 & 41 LK 74 & $110-0$ & Surface & - & - & 5.2 & 4.1 & 1.1 & 25.8 & $49^{\circ}$ & 85 \\
\hline 3 & 2 & 41 MC 294 & $4-0$ & Surface & - & - & 6.6 & 4.1 & 1.5 & 45.4 & $45^{\circ}$ & - \\
\hline
\end{tabular}




\begin{tabular}{|c|c|c|c|c|c|c|c|c|c|c|c|c|}
\hline 4 & 1 & 41 LK 243 & 5 & Test PIt 1 & 5 & $40-50 \mathrm{~cm}$ & 6.0 & 4.3 & 1.4 & 32.6 & $40^{\circ}$ & 85 \\
\hline 4 & 2 & 41 MC 226 & 4-0 & Surface & - & - & 5.4 & 3.7 & 1.1 & 22.1 & $58^{\circ}$ & - \\
\hline 5 & 1 & 41 LK 199 & $19-0$ & Surface & - & - & $2.6 *$ & 5.6 & 2.0 & 37.2 & $86^{\circ}$ & 85 \\
\hline 5 & 2 & 41 MC 196 & $20-19$ & Surface & - & - & 5.4 & 4.7 & 1.2 & 33.6 & $59^{\circ}$ & - \\
\hline 5 & 3 & 41 MC 213 & $2-61$ & Surface & - & - & 5.6 & 3.9 & 1.5 & 38.6 & $50^{\circ}$ & - \\
\hline 5 & 4 & 41 MC 288 & $8-15$ & Surface & - & - & 5.7 & 3.6 & 1.6 & 40.8 & $67^{\circ}$ & - \\
\hline 5 & 5 & 41 MC 288 & $8-17$ & Surface & - & - & 5.8 & 4.4 & 1.8 & 57.4 & $48^{\circ}$ & - \\
\hline
\end{tabular}

\section{Group 9. Distal Fragments (seven specimens)}

Group 9 specimens are distal (beveled end) fragments retaining too 1 ittle of the proximal section for inclusion in the above groups and forms. Most, if not al1, probably do belong in previously described categories, primarily Groups 2, 3, and 4. Provenience and metric data for the Group 9 specimens are as follows:

\begin{tabular}{|c|c|c|c|c|c|c|c|c|c|c|c|}
\hline $\begin{array}{l}\text { Spectmen } \\
\text { Number }\end{array}$ & Sito & Lot & Unit & Level & Elevation & Length & Width & ThIckness & Weight & $\begin{array}{l}\text { Bevel } \\
\text { Angle }\end{array}$ & $\begin{array}{l}\text { Figure } \\
\text { Number }\end{array}$ \\
\hline 1 & 41 LK 74 & $112-0$ & Surface & - & - & $3.6 *$ & $2.9 *$ & 0.9 & * & $57^{\circ}$ & - \\
\hline 2 & $41 \quad$ LK 185 & $45-22$ & Surface & - & - & \# & 3.6 & 1.0 & * & $61^{\circ}$ & - \\
\hline 3 & 41 LK 201 & 227 & N497 E997 & 10 & $98.45-98.35$ & * & 3.9 & 1.7 & * & $74^{\circ}$ & - \\
\hline 4 & 41 LK 201 & 402 & N498 E996 & 16 & $97.85-97.75$ & * & $*$ & 0.8 & \# & $63^{\circ}$ & - \\
\hline 5 & 41 MC 29 & $92-0$ & Surface & - & - & * & 3.9 & 1.6 & \# & $78^{\circ}$ & - \\
\hline 6 & $41 M C 94$ & 213 & Test Pit 5 & 2 & $99.80-99.70$ & * & $3.3^{*}$ & 1.0 & \# & $63^{\circ}$ & - \\
\hline 7 & 41 MC 196 & $20-15$ & Surface & - & - & \# & 4.3 & 1.5 & \# & $63^{\circ}$ & - \\
\hline
\end{tabular}

Unifaces (20 specimens)

A uniface is a $f l$ ake or $f l$ ake fragment exhibiting $f l$ ake scars over most or a 11 of one face. The opposite face is the unmodified ventral side of the original flake. A uniface is distinguished from a trimmed flake in that additional chipping has served to modify the overall shape of the piece so that it no longer resembles the original flake in outline form, as does the trimmed flake specimen. Often, but not always, the unifacial shaping has obliterated the flake's striking platform, bulb of percussion, and ventral termination features.

The following five descriptive groups contain artifacts suggested to have served as "scrapers," "gouges," "adzes," or "knives." However, these specimens have not been examined for use-wear. The above function-specific terminology is strictly subjective. Some may be preforms of chipped stone tools intended for the uses suggested, or for other uses altogether.

The distinction between unifaces described in the distally beveled bifaces and unifaces section and unifaces described below is somewhat arbitrary in a 

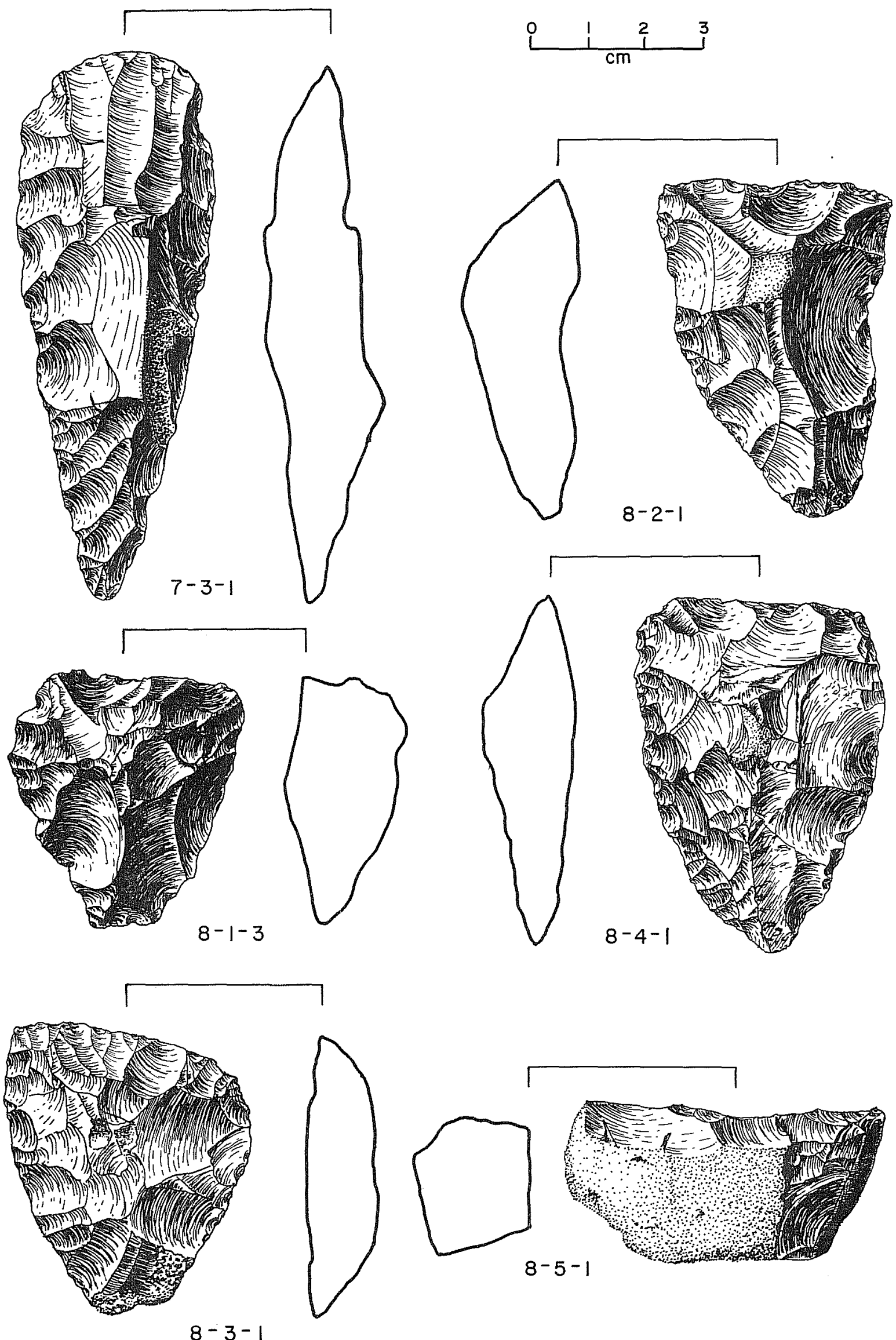

Figure 85. Distally Beveled Bifaces and Unifaces: Group 7, Form 3 and Group 8, Forms 1, 2, 3, 4, and 5. Numbers beneath artifact indicate group, form, and specimen number, respectively. 
number of cases, especially in the Group 3 unifaces category. It is probable that some or al1 of the specimens included in this category were manufactured to serve in the same capacity as were the distal1y beveled tools. These flakes, however, do not assume such distinctive forms, either in outline or distal bevel morphology, as do the distally beveled specimens.

The unifaces are divided into the fol lowing categories based primarily on shape:

Group 1. Large E11iptical

Group 2. Subcircular to Oval

Group 3. Triangular to Subtriangular

Group 4. Truncated or Fragmentary with Rounded Ends

Group 5. Irregular Shapes

Site provenience for the unifaces is provided in Tabie 24.

Group 1. Large Elliptical (two specimens)

Group 1 specimens are elliptical in outline and plano-convex in cross section. The convex, chipped faces are pronouncedly humped. A patch of cortex remains on the highest area of the convex face of Specimen 2. Provenience and metric data for these two specimens are as follows:

\begin{tabular}{|c|c|c|c|c|c|c|c|c|c|c|c|}
\hline $\begin{array}{l}\text { Specimen } \\
\text { Number }\end{array}$ & Site & Lot & Unit & Level & Elevation & Length & Width & Thtckness & Weight & $\begin{array}{l}\text { Bevel } \\
\text { Angle }\end{array}$ & $\begin{array}{l}\text { Figure } \\
\text { Number }\end{array}$ \\
\hline 1 & 41 LK 14 & 299-0 & Surface & - & - & 6.4 & 4.6 & 1.7 & 61.6 & $57^{\circ}$ & 86 \\
\hline 2 & 41 MC 246 & $2-0$ & Surface & - & - & 6.9 & 5.1 & 2.0 & 70.4 & $47^{\circ}$ & 86 \\
\hline
\end{tabular}

Group 2. Subcircular to Oval (six specimens)

Group 2 specimens are subcircular to oval in outline, plano-convex in cross section, and uniformly smaller than Group 1 specimens. The convex faces of Specimens 4 and 5 are pronounced 1 y humped. Specimens 4,5 , and 6 retain patches of cortex on the convex, chipped face. Provenience and metric data for the Group 2 specimens are as follows:

\begin{tabular}{|c|c|c|c|c|c|c|c|c|c|c|c|}
\hline $\begin{array}{l}\text { Spectmen } \\
\text { Number }\end{array}$ & Site & Lot & Unit & Level & Elevation & Length & Width & Thickness & Weight & $\begin{array}{l}\text { Bevel } \\
\text { Angle }\end{array}$ & $\begin{array}{l}\text { Figure } \\
\text { Number }\end{array}$ \\
\hline 1 & 41 LK 201 & $491-0$ & Surface & - & - & 4.3 & 4.5 & 1.2 & 22.7 & $80^{\circ}$ & - \\
\hline 2 & 41 MC 196 & $21-35$ & Surface & - & - & 4.8 & 4.3 & 1.8 & 38.9 & $44^{\circ}$ & 86 \\
\hline 3 & $41 \mathrm{MC} 234$ & $1-0$ & Surface & - & - & 4.1 & 3.8 & 1.7 & 27.5 & $57^{\circ}$ & 86 \\
\hline 4 & 41 MC 268 & 92 & Surface & - & - & 4.4 & 4.6 & 2.1 & 45.0 & $56^{\circ}$ & - \\
\hline 5 & $41 M C 276$ & $1-23$ & Surface & - & - & 4.5 & 4.9 & 2.3 & 61.6 & $77^{\circ}$ & 85 \\
\hline 6 & 41 MC 268 & $21-10$ & Surface & - & - & 5.7 & 5.7 & 1.7 & 63.2 & $64^{\circ}$ & 86 \\
\hline
\end{tabular}




\section{Group 3. Triangular to Subtriangular (five specimens)}

Group 3 unifaces are triangular to subtriangular in out 7 ine and $p 1$ ano-convex in cross section. They are beveled at the broad end and perhaps shou $1 \mathrm{~d}$ be grouped with the distally beveled forms. However, these specimens do not exhibit as distinctive a form either in outline or bevel morphology as do the distally beveled artifacts. Flaking is generally rougher, and specimens are thicker relative to their length than the distally beveled specimens. Except for Specimen 5, the Group 3 unifaces retain patches of cortex on the convex, chipped face. Specimens 3,4 , and 5 are asymmetrically pyramidal in configuration, and the convex faces have pronounced humps. Provenience and metric data for the Group 3 specimens are as follows:

\begin{tabular}{cccccccccccc}
$\begin{array}{c}\text { Specimen } \\
\text { Number }\end{array}$ & Site & Lot & Unit & Level & Elevation & Length & Width & Thickness & $\begin{array}{c}\text { Weight } \\
\text { Bevel } \\
\text { Angle }\end{array}$ & $\begin{array}{c}\text { Figure } \\
\text { Number }\end{array}$ \\
\hline 1 & 41 LK 128 & $59-0$ & Surface & - & - & 4.9 & 3.8 & 1.3 & 27.2 & $67^{\circ}$ & - \\
2 & 41 LK 133 & $17-16$ & Surface & - & - & 5.8 & 5.4 & 1.9 & 67.1 & $54^{\circ}$ & 86 \\
3 & 41 MC 29 & $92-0$ & Surface & - & - & 4.8 & 4.8 & 1.9 & 46.2 & $66^{\circ}$ & 86 \\
4 & 41 MC 246 & $1-0$ & Surface & - & - & 3.7 & 5.0 & 1.9 & 38.0 & $75^{\circ}$ & - \\
5 & 41 MC 282 & $1-0$ & Surface & - & - & 4.6 & 4.2 & 1.4 & 29.7 & $49^{\circ}$ & 86
\end{tabular}

Group 4. Truncated or Fragmentary with Rounded Ends (three specimens)

Group 4 unifaces vary considerably in out line, from irregularly subcircular to subrectangular. A11 are plano-convex in cross section. These specimens a 11 have a "stubby" appearance, and one end is worked to a rounded form. Provenience and metric data for the Group 4 specimens are as follows:

\begin{tabular}{|c|c|c|c|c|c|c|c|c|c|c|c|}
\hline $\begin{array}{l}\text { Specimen } \\
\text { Number }\end{array}$ & Site & Lot & Unit & Level & Elevation & Length & Width & Th1ckness & Weight & $\begin{array}{l}\text { Bevel } \\
\text { Angle }\end{array}$ & $\begin{array}{l}\text { Figure } \\
\text { Number }\end{array}$ \\
\hline 1 & 41 MC 29 & $92-0$ & Surface & - & - & 3.2 & 3.1 & 1.5 & 14.4 & $52^{\circ}$ & 86 \\
\hline 2 & $41 \mathrm{MC} 196$ & $20-7$ & Surface & - & - & $3.0 \%$ & 5.3 & 1.4 & 24.8 & $52^{\circ}$ & 86 \\
\hline 3 & 41 MC 296 & 201 & N1025 E995 & 1 & $99.60-99.50$ & $2.2^{\sharp}$ & 3.3 & 0.6 & 8.0 & $43^{\circ}$ & 86 \\
\hline
\end{tabular}

Group 5. Irregular Shapes (four specimens)

Specimen 1 is square in outline shape. A patch of cortex remains at one end. At the corners of the other end are two graverlike beaks that appear to have been intentionally worked onto the specimen. It is heavily patinated.

Specimen 2 is long and narrow, but thick in cross section. Steep sides and a medial ridge of cortex impart a prismatic configuration to the piece. The edges are quite sinuous.

Specimen 3 is subtriangular in outline and appears to be a uniface fragment.

Specimen 4 is subcircular in outl ine and appears to have been broken at either end. The intact lateral edges, both slightly rounded, are retouched. 


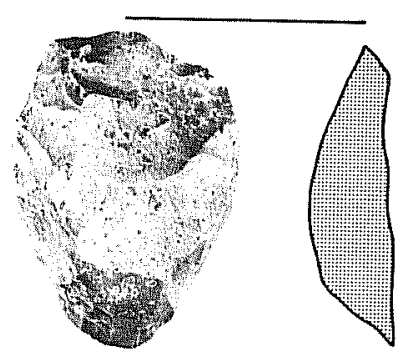

$1-1$

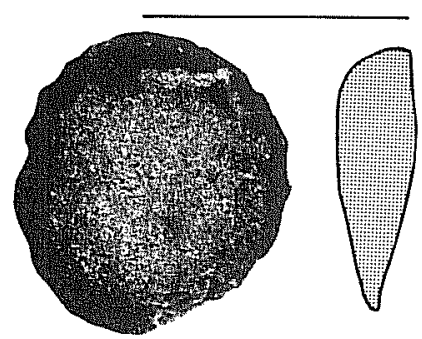

$2-6$

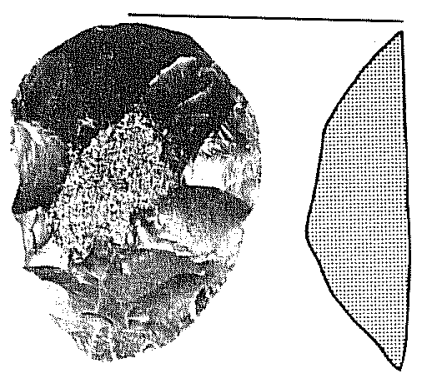

$1-2$
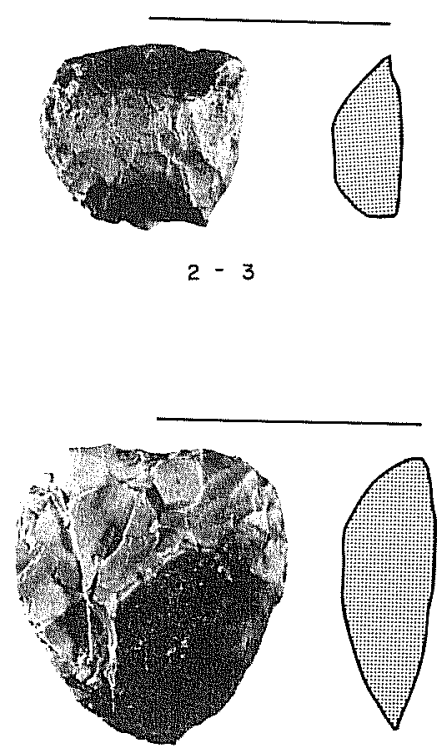

$3-2$

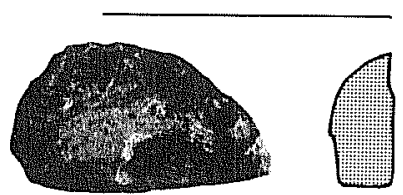

$4-2$

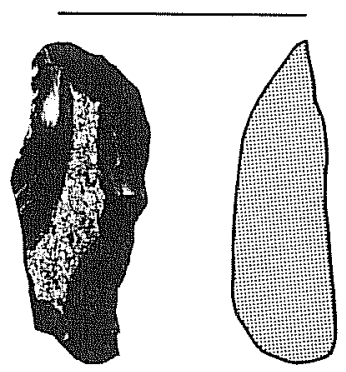

$5-2$

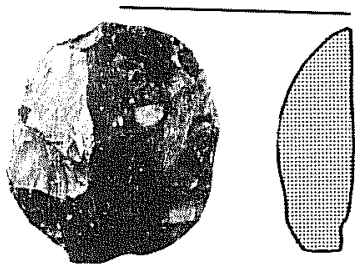

$2-2$

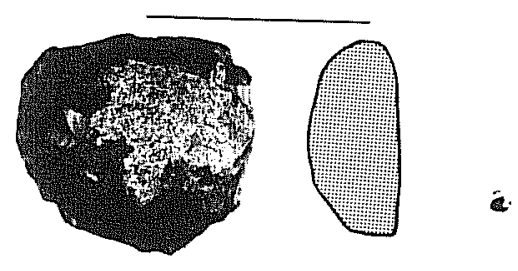

$2-5$

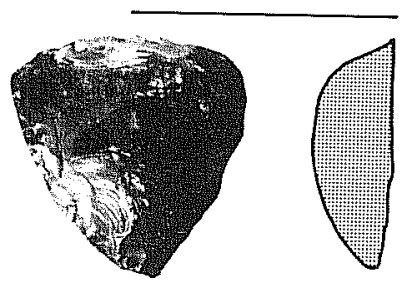

$3-3$
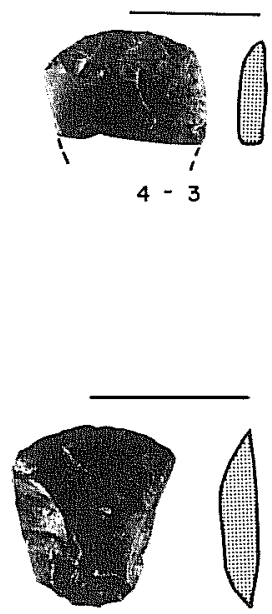

$5-4$

Figure 86. Unifaces: Groups 1, 2, 3, 4, and 5. Numbers beneath artifact indicate group and form number, respectively. 
Provenience and metric data for the Group 5 specimens are as follows:

\begin{tabular}{|c|c|c|c|c|c|c|c|c|c|c|c|}
\hline $\begin{array}{l}\text { Specimen } \\
\text { Number }\end{array}$ & Site & Lot & Unit & Level & Elevation & Length & Width & Th1ckness & Weight & $\begin{array}{l}\text { Bevel } \\
\text { Angle }\end{array}$ & $\begin{array}{l}\text { Figure } \\
\text { Number }\end{array}$ \\
\hline 1 & 41 LK 199 & $23-0$ & Surface & - & - & 3.9 & 3.7 & 2.1 & 30.9 & $72^{\circ}$ & 86 \\
\hline 2 & 41 LK 252 & $1-18$ & Surface & - & - & 6.6 & 2.8 & 2.0 & 36.5 & $62^{\circ}$ & 86 \\
\hline 3 & 41 MC 55 & 80 & N1015 E1010 & 1 & Surf. -99.30 & 4.2 & 3.3 & 1.2 & * & $50^{*}$ & - \\
\hline 4 & $41 M C 296$ & 99 & N1024 E985 & 2 & $99.40-99.30$ & $3.1 *$ & 3.7 & 0.9 & 4 & $52^{\circ}$ & 86 \\
\hline
\end{tabular}

\section{Irimmed Flakes (37 specimens)}

Trimmed flakes are $f l a k e s$ or $f l$ ake fragments exhibiting retouch to the extent that a working edge is formed. The $f 7$ aking on these specimens has not substantially altered the original shape of the flake or flake fragment upon which the tool has been made. Like the unifaces, trimmed flakes are suggested to have served in the functional capacities of "end scrapers," "side scrapers," and "knives." Trimmed flakes are divided into four groups, based primarily on outline shape and thickness:

Group 1. Circular to Subcircular

Group 2. Large, Oval to Elliptical

Group 3. Thin Blade Flakes and Flake Fragments

Form 1. Rectangular

Form 2. Triangular

Form 3. Convergent

Form 4. Divergent

Form 5. Distal Fragments

Group 4. Miscellaneous Thick Flakes and Flake Fragments

Provenience for trimmed flakes is provided in Table 25.

\section{Group 1. Circular to Subcircular (two specimens)}

Group I trimmed flake specimens are circular to subcircular in outline and plano-convex in cross section. On Specimen 1, roughly one-third of the convex face is covered with cortex. Specimen 2 retains cortex over $90 \%$ of one face. Both retain obvious striking platforms and bulbs of percussion on the unchipped face. About one-half of the circumference of specimen 1 is retouched. The working edge of Specimen 2 composes one-third of its circumference. Metric attributes and provenience for Group 1 specimens are as foll lows:

\begin{tabular}{|c|c|c|c|c|c|c|c|c|c|c|c|}
\hline $\begin{array}{l}\text { Specimen } \\
\text { Number }\end{array}$ & Site & Lot & Unit & Level & Elevation & Length & Width & Thickness & Weight & $\begin{array}{l}\text { Bevel } \\
\text { Angle }\end{array}$ & $\begin{array}{l}\text { Flgure } \\
\text { Number }\end{array}$ \\
\hline 1 & 41 LK 201 & $663-2$ & N504 E1012 & 1 & $99.28-99.20$ & 4.8 & 4.4 & 0.9 & 16.5 & $44^{\circ}$ & - \\
\hline 2 & 41 MC 296 & 235 & N1025 E995 & 6 & $99.10-99.00$ & 4.4 & 3.8 & 1.3 & 22.7 & $58^{\circ}$ & 87 \\
\hline
\end{tabular}


TABLE 24. SITE PROVENIENCE FOR UNIFACES

\begin{tabular}{|c|c|c|c|c|c|}
\hline $\begin{array}{l}\text { Site } \\
\text { Number }\end{array}$ & $\begin{array}{c}\text { Group } \\
1\end{array}$ & $\begin{array}{c}\text { Group } \\
2\end{array}$ & $\begin{array}{c}\text { Group } \\
3\end{array}$ & $\begin{array}{c}\text { Group } \\
4\end{array}$ & $\begin{array}{c}\text { Group } \\
5\end{array}$ \\
\hline \multicolumn{6}{|l|}{41 LK 8} \\
\hline 41 LK14 & 1 & & & & \\
\hline \multicolumn{6}{|l|}{$41 L K 27$} \\
\hline \multicolumn{6}{|l|}{ 41LK51 } \\
\hline \multicolumn{6}{|l|}{41 LK53 } \\
\hline \multicolumn{6}{|l|}{41 LK66 } \\
\hline \multicolumn{6}{|l|}{41 LK69 } \\
\hline \multicolumn{6}{|l|}{$41 \mathrm{LK} 74$} \\
\hline \multicolumn{6}{|l|}{$41\lfloor K 120$} \\
\hline \multicolumn{6}{|l|}{ 41LK121 } \\
\hline 41 LK 122 & & & & & \\
\hline $41 \mathrm{LK} 127$ & & & & & \\
\hline $41 \mathrm{LK} 128$ & & & 1 & & \\
\hline $41 \mathrm{LK} 133$ & & & 1 & & \\
\hline $41 \mathrm{LK} 142$ & & & & & \\
\hline $41 \mathrm{LK} 145$ & & & & & \\
\hline $41 \mathrm{LK} 149$ & & & & & \\
\hline $41 L K 162$ & & & & & \\
\hline $41 \mathrm{LK} 173$ & & & & & \\
\hline $41 L K 174$ & & & & & \\
\hline $41 L K 176$ & & & & & \\
\hline 41 LK 181 & & & & & \\
\hline 41 LK 182 & & & & & \\
\hline $41 L K 185$ & & & & & \\
\hline $41 \mathrm{LK}+91$ & & & & & \\
\hline 41LK197 & & & & & \\
\hline 41LK199 & & & & & 1 \\
\hline 41LK201 & & 1 & & & \\
\hline $41 \mathrm{LK} 236$ & & & & & \\
\hline 41 LK243 & & & & & \\
\hline $41 \mathrm{LK} 247$ & & & & & \\
\hline $41 \mathrm{LK} 250$ & & & & & \\
\hline 41 LK2 52 & & & & & 1 \\
\hline $41 \mathrm{LK} 253$ & & & & & \\
\hline $41 \mathrm{MC} 7$ & & & & & \\
\hline $41 \mathrm{MC} 10$ & & & & & \\
\hline $41 \mathrm{MC} 14$ & & & & & \\
\hline $41 \mathrm{MC} 15$ & & & & & \\
\hline $41 \mathrm{MC} 17$ & & & & & \\
\hline $41 \mathrm{MC} 29$ & & & 1 & 1 & \\
\hline $41 \mathrm{MC5} 5$ & & & & & 1 \\
\hline $41 \mathrm{MC67}$ & & & & & \\
\hline $41 \mathrm{MC} 75$ & & & & & \\
\hline $41 M C 79$ & & & & & \\
\hline $41 \mathrm{MC94}$ & & & & & \\
\hline $41 M C 192$ & & & & & \\
\hline $41 \mathrm{MC} 193$ & & & & & \\
\hline $41 \mathrm{MC} 194$ & & & & & \\
\hline $41 \mathrm{MC} 196$ & & 1 & & 1 & \\
\hline $41 \mathrm{MC} 212$ & & & & & \\
\hline $41 \mathrm{MC} 213$ & & & & & \\
\hline $41 \mathrm{MC} 214$ & & & & & \\
\hline $41 \mathrm{MC} 222$ & & & & & \\
\hline $41 \mathrm{MC} 226$ & & & & & \\
\hline $41 \mathrm{MC} 234$ & & 1 & & & \\
\hline $41 \mathrm{MC} 235$ & & & & & \\
\hline $41 \mathrm{MC} 238$ & & & & & \\
\hline $41 \mathrm{MC} 242$ & & & & & \\
\hline $41 \mathrm{MC246}$ & 1 & & 1 & & \\
\hline $41 \mathrm{MC} 251$ & & & & & \\
\hline $41 \mathrm{MC2} 27$ & & & & & \\
\hline $41 \mathrm{MC} 260$ & & & & & \\
\hline $41 M C 266$ & & & & & \\
\hline $41 M C 267$ & & & & & \\
\hline $41 M C 268$ & & 2 & & & \\
\hline $41 \mathrm{MC} 270$ & & & & & \\
\hline $41 \mathrm{MC} 275$ & & & & & \\
\hline $41 \mathrm{MC} 276$ & & 1 & & & \\
\hline $41 \mathrm{MC} 282$ & & & 1 & & \\
\hline $41 \mathrm{MC} 284$ & & & & & \\
\hline $41 \mathrm{MC} 28 \mathrm{~B}$ & & & & & \\
\hline $41 \mathrm{MC} 293$ & & & & & \\
\hline $41 \mathrm{MC} 294$ & & & & & \\
\hline $41 \mathrm{MC} 298$ & & & & 1 & 1 \\
\hline
\end{tabular}

TABLE 25. SITE PROVENIENCE FOR TRIMMED FLAKES

\begin{tabular}{|c|c|c|c|c|c|c|c|c|}
\hline \multirow{2}{*}{$\begin{array}{l}\text { Site } \\
\text { Number }\end{array}$} & \multirow{2}{*}{$\begin{array}{c}\text { Group } \\
1\end{array}$} & \multirow{2}{*}{$\begin{array}{c}\text { Group } \\
2\end{array}$} & \multicolumn{5}{|c|}{ Group 3} & \multirow{2}{*}{$\begin{array}{c}\text { Group } \\
4\end{array}$} \\
\hline & & & Form 1 & Form 2 & Form 3 & Form 4 & Form 5 & \\
\hline \multicolumn{9}{|l|}{$41 L K 8$} \\
\hline \multicolumn{9}{|l|}{$41 \mathrm{LK} 14$} \\
\hline $41 \mathrm{LK} 27$ & & 1 & & & & & & \\
\hline 41LK51 & & & & & & 1 & & \\
\hline $41 \mathrm{LK} 53$ & & & & & & & & \\
\hline 41 LK66 & & & & & & & & \\
\hline 41LK69 & & & & & & & & \\
\hline $41 \mathrm{LK} 74$ & & & & & & & & \\
\hline 41LK120 & & & & & & & & \\
\hline 41LK121 & & & & & & & & \\
\hline 41 LK 122 & & & & & & & & \\
\hline 41 LK 127 & & & & & & & & \\
\hline 41 LK 128 & & & 1 & 1 & & & & 1 \\
\hline $41 L K 133$ & & & & & & & & 1 \\
\hline $41 L K 142$ & & & & & & & & \\
\hline 41LK 145 & & & & & & & & \\
\hline $41 \mathrm{LK} 149$ & & & & & & & & \\
\hline 41LK162 & & & & & & & & \\
\hline 41 LK 173 & & & & & & & & \\
\hline $41 L K 174$ & & & & & & & & \\
\hline $41 \mathrm{LK} 176$ & & & & & & & & \\
\hline 41LK181 & & & & & & & & \\
\hline 41LK182 & & 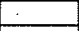 & & & & & 1 & \\
\hline $41 \mathrm{LK} 185$ & & & & & & & & \\
\hline 41LK191 & & & & & & & & \\
\hline 41LK197 & & & & & & & & \\
\hline $41 L K 199$ & & & & & & & & \\
\hline 41LK201 & 1 & & 3 & 3 & 1 & 1 & & 1 \\
\hline 41 LK236 & & & 1 & & & & & \\
\hline 41 LK243 & & & & 1 & & & & \\
\hline 41 LK 247 & & & & & & & & \\
\hline 41 LK250 & & & & & & & & 1 \\
\hline 41LK252 & & & & & & & & \\
\hline $41 \mathrm{LK} 253$ & & & & & & & & \\
\hline $41 \mathrm{MC7}$ & & & & & & & & \\
\hline $41 \mathrm{MC} 10$ & & & & & & & & \\
\hline $41 \mathrm{MC} 14$ & & & & & & & & \\
\hline $41 \mathrm{MC} 15$ & & & & & & & & \\
\hline $41 \mathrm{MC} 17$ & & & & & & & & \\
\hline $41 \mathrm{MC} 29$ & & & & & & & & \\
\hline $41 \mathrm{MC5} 5$ & & 1 & & & 1 & & 1 & \\
\hline $41 \mathrm{MC} 67$ & & & & & . & & & \\
\hline $41 \mathrm{MC75}$ & & & & & & & & 1 \\
\hline $41 \mathrm{MC} 79$ & & & & & & & & \\
\hline $41 \mathrm{MCg} 4$ & & & & & & & & \\
\hline $41 \mathrm{MC} 192$ & & & & & & & & \\
\hline $41 \mathrm{MC} 193$ & & & & & & & & \\
\hline $41 \mathrm{MC} 194$ & & & & & & & & \\
\hline $41 \mathrm{MC} 196$ & & & & & & & & 1 \\
\hline $41 \mathrm{MC2} 212$ & & & & & & & & \\
\hline $41 \mathrm{MC2} 213$ & & & & & & & & \\
\hline $41 \mathrm{MC2} 14$ & & & & & & & & \\
\hline $41 \mathrm{MC2} 22$ & & & & & & & & \\
\hline $41 \mathrm{MC2} 26$ & & & & & & & & \\
\hline $41 \mathrm{MC} 234$ & & & & & & & & \\
\hline $41 M C 235$ & & & & & & & & \\
\hline $41 \mathrm{MC} 23 \mathrm{~B}$ & & & & & & & & \\
\hline $41 \mathrm{MC} 242$ & & 1 & & & & & & \\
\hline $41 \mathrm{MC} 246$ & & & & & & & & \\
\hline $41 \mathrm{MC} 251$ & & & & & & & & \\
\hline $41 \mathrm{MC} 257$ & & & 1 & & & & & \\
\hline $41 \mathrm{MC} 260$ & & & & & & & & \\
\hline $41 \mathrm{MC} 266$ & & & & & & & & \\
\hline $41 \mathrm{MC} 267$ & & & & & & & & \\
\hline $41 \mathrm{MC} 268$ & & & & & & & & 1 \\
\hline $41 \mathrm{MC} 270$ & & & & & & & & 1 \\
\hline $41 \mathrm{MC275}$ & & & & & & & & \\
\hline $41 \mathrm{MC} 276$ & & & & & & & & \\
\hline $41 \mathrm{MC} 282$ & & & & & & & & 1 \\
\hline $41 \mathrm{MC284}$ & & & & & & & & \\
\hline $41 \mathrm{MC288}$ & & & 1 & & & & & \\
\hline $41 \mathrm{MC293}$ & & & & & & & & \\
\hline $41 \mathrm{MC294}$ & & & & & & & & 1 \\
\hline $41 \mathrm{MC296}$ & 1 & 1 & 2 & & & & 1 & \\
\hline
\end{tabular}




\section{Group 2. Large, Oval to Elliptical (four specimens)}

Group 2 specimens are the 1 argest of the trimmed flakes. The pieces are elongate and oval to el1 iptical in outline. Specimen 1 retains a cortex striking platform and bulb of percussion along one edge. There is a narrow band of cortex retained around roughly one-quarter the circumference of the piece. The cortex may have served as a "backing," permitting the artifact to be held comfortably in the hand while being used. This cortex band is opposite and slightly offset from the apparent working edge. Specimen 2 retains a platform and bulb of percussion at one end. The dorsal face is $90 \%$ covered with cortex. At the distal end, five $f l$ akes removed from the dorsal face form the apparent working surface of the tool. Like Specimen 1, Specimen 3 retains a cortex band around almost half its circumference. This cortex seems to have been left intentionally to form a "backing" opposite the working edge. The beveled working edge of Specimen 3 exhibits a somewhat steeper angle than do most of the other trimmed flakes. Specimen 4 has a cortex rim extending around the proximal end (striking platform) and halfway down each side. The configuration of a 11 Group 2 specimens suggests that they were designed to be pulled toward the user, perhaps as scraping tools. Metric attributes and provenience for Group 2 specimens are as fol 1ows:

\begin{tabular}{|c|c|c|c|c|c|c|c|c|c|c|c|}
\hline $\begin{array}{l}\text { Specimen } \\
\text { Number }\end{array}$ & Site & Lot & Unit & Level & Elevation & Length & Width & Thtckness & Weight & $\begin{array}{l}\text { Bevel } \\
\text { Angle }\end{array}$ & $\begin{array}{l}\text { Figure } \\
\text { Number }\end{array}$ \\
\hline 1 & 41 LK 27 & $44-0$ & Surface & - & - & 8.8 & 5.3 & 2.2 & 85.4 & $51^{\circ}$ & 87 \\
\hline 2 & $41 \mathrm{MC} 55$ & 88 & N998 E1017 & 2 & $99.30-99.20$ & 9.6 & 4.7 & 1.7 & 84.3 & $51^{\circ}$ & - \\
\hline 3 & 41 MC 242 & $4-0$ & Surface & - & - & 6.8 & 4.5 & 1.0 & 33.1 & $60^{\circ}$ & - \\
\hline 4 & 41 MC 296 & 133 & N1025 E998 & 2 & $99.50-99.40$ & 6.9 & 4.4 & 1.7 & 54.4 & $48^{\circ}$ & 87 \\
\hline
\end{tabular}

Group 3. Thin Blade Flakes and Flake Fragments (21 specimens)

Eorm 1. Rectangular (nine specimens)

Group 3, Form I specimens are long flakes that were apparently struck from prepared cores as evidenced by long, parallel flake scars and ridges running the length of the dorsal faces. The ridges impart a prismatic configuration to the flakes. Form 1 specimens are more-or-less rectangular in out 1 ine and prismatic in cross section, the plano surface being the ventral face of the flake. Striking platforms are retained at one end of each specimen, this end tending to be slightly narrower than the other end. Cortex patches remain on the striking platforms of three specimens and on the dorsal (convex) face of a fourth. Four specimens have been trimmed at the distal end on $7 y_{0}$ Three are trimmed at the distal end and along one edge. Two are trimmed at the distal end and along both edges. Trimmed flakes of this type are el sewhere referred to as "side scrapers" and "end scrapers" and are often found in Late Prehistoric context. A Late Prehistoric affiliation is strongly indicated for these Choke Canyon specimens also. Provenience and metric attributes for Group 3, Form 1 specimens are as follows: 


\begin{tabular}{|c|c|c|c|c|c|c|c|c|c|c|c|}
\hline $\begin{array}{l}\text { Specimen } \\
\text { Number }\end{array}$ & Sito & Lot & Unit & Level & Elevation & Length & Width & Thickness & Weight & $\begin{array}{l}\text { Bevel } \\
\text { Angle }\end{array}$ & $\begin{array}{l}\text { Figure } \\
\text { Number }\end{array}$ \\
\hline 1 & $41 \mathrm{LK} 128$ & 33 & Test Pit 8 & 2 & $99.70-99.60$ & 6.4 & 4.8 & 1.0 & 44.4 & $49^{\circ}$ & 87 \\
\hline 2 & 41 LK 201 & $660-19$ & N506 E1009 & 1 & $99.29-99.20$ & 5.0 & 3.0 & 0.5 & 7.3 & $44^{\circ}$ & - \\
\hline 3 & $41 \mathrm{LK} 201$ & $700-79$ & N508 E1013 & 2 & $99.20-99.10$ & 5.0 & 2.2 & 0.6 & 8.7 & $52^{\circ}$ & - \\
\hline 4 & 41 LK 201 & $730-190$ & N509 E1007 & 1 & $99.08-99.00$ & 4.8 & 2.1 & 0.9 & 7.6 & $51^{\circ}$ & - \\
\hline 5 & 41 LK 236 & $1-0$ & Surface & - & - & 6.0 & 2.5 & 0.9 & 14.8 & $80^{\circ}$ & 87 \\
\hline 6 & 41 MC 257 & $1-0$ & Surface & - & - & 3.0 & 1.7 & 0.3 & 1.9 & $51^{\circ}$ & - \\
\hline 7 & 41 MC 288 & $8-3$ & Surface & - & - & 6.5 & 3.0 & 1.3 & 25.5 & $39^{\circ}$ & 87 \\
\hline 8 & 41 MC 296 & 16 & Test Pit 2 & 2 & $10-20 \mathrm{~cm}$ & 3.6 & 2.2 & 0.5 & 4.1 & $75^{\bullet}$ & - \\
\hline 9 & 41 MC 296 & $243-0$ & Surface & - & - & 5.7 & 1.9 & 0.7 & 7.8 & $34^{\circ}$ & - \\
\hline
\end{tabular}

Eorm 2. Triangular ( $f$ ive specimens)

Form 2 specimens are much 7 ike Form 1 specimens except that the out 1 ine shape is triangular to subtriangular. Trimming has occurred primarily on the rounded distal ends. Specimens 2 and 5 evidence minor 1 atera 1 trimming. Specimen 1 retains cortex on the striking platform and over about 25\% of the dorsal surface. Artifacts like Specimen 1 are often referred to as "keelbacked scrapers." A 11 of the flakes out of which these Form 2 specimens are made have a pronounced curvature that gives a peculiar angle to the working edge. Provenience and metric attributes for the Group 3, Form 2 specimens are as fol lows:

\begin{tabular}{|c|c|c|c|c|c|c|c|c|c|c|c|}
\hline $\begin{array}{l}\text { Specimen } \\
\text { Number }\end{array}$ & Site & Lot & Unit & Level & Elevation & Length & Width & Thickness & Wefight & $\begin{array}{l}\text { Bevel } \\
\text { Angle }\end{array}$ & $\begin{array}{l}\text { Figure } \\
\text { Number }\end{array}$ \\
\hline 1 & 41 LK 128 & $1-0$ & Surface & - & - & 6.1 & 4.4 & 1.9 & 43.9 & $52^{\circ}$ & 87 \\
\hline 2 & 41 LK 201 & $655-13$ & N506 E1011 & 1 & $99.30-99.20$ & 5.8 & 3.7 & 0.9 & 19.1 & $71^{\circ}$ & - \\
\hline 3 & 41 LK 201 & $720-150$ & N504 E1012 & 2 & $99.20-99.10$ & 6.0 & 3.4 & 1.4 & 19.1 & $87^{\circ}$ & - \\
\hline 4 & 41 LK 201 & $730-188$ & N509 E1007 & 1 & $99.08-99.00$ & 6.0 & 3.5 & 1.6 & 22.0 & $59^{\circ}$ & - \\
\hline 5 & 41 LK 243 & $28-0$ & Surface & - & - & 4.5 & 2.1 & 0.9 & 6.2 & $42^{\circ}$ & 87 \\
\hline
\end{tabular}

\section{Eorm 3. Convergent (two specimens)}

Group 3, Form 3 specimens are triangular to subtriangular in outline, but un 7 ike the Form 2 specimens, they are broadest at the platform (proximal) end and taper to a narrow, rounded end. Both specimens are plano-convex in cross section and retain cortex at the broad platform end. The configuration of the distal ends is similar to specimens in the Form 1 and Form 2 groupings. Each specimen is trimmed on $7 y$ at the narrow, rounded end. Provenience and metric data for the Group 3, Form 3 specimens are as follows:

\begin{tabular}{cccccccccccc}
$\begin{array}{c}\text { Specimen } \\
\text { Number }\end{array}$ & Stte & Lot & Unft & Level & Elevation & Length & Width & Thickness & $\begin{array}{c}\text { Weight } \\
\text { Angle }\end{array}$ \\
\hline 1 & 41 LK 201 & 654 & N506 E1010 & 1 & $99.30-99.20$ & 4.2 & 3.7 & 1.9 & 23.2 & $71^{\circ}$ & - \\
2 & 41 KC 55 & 67 & N1007 E1015 & 2 & $99.40-99.30$ & 5.9 & 4.9 & 1.5 & 32.0 & $54^{\circ}$ & 87
\end{tabular}



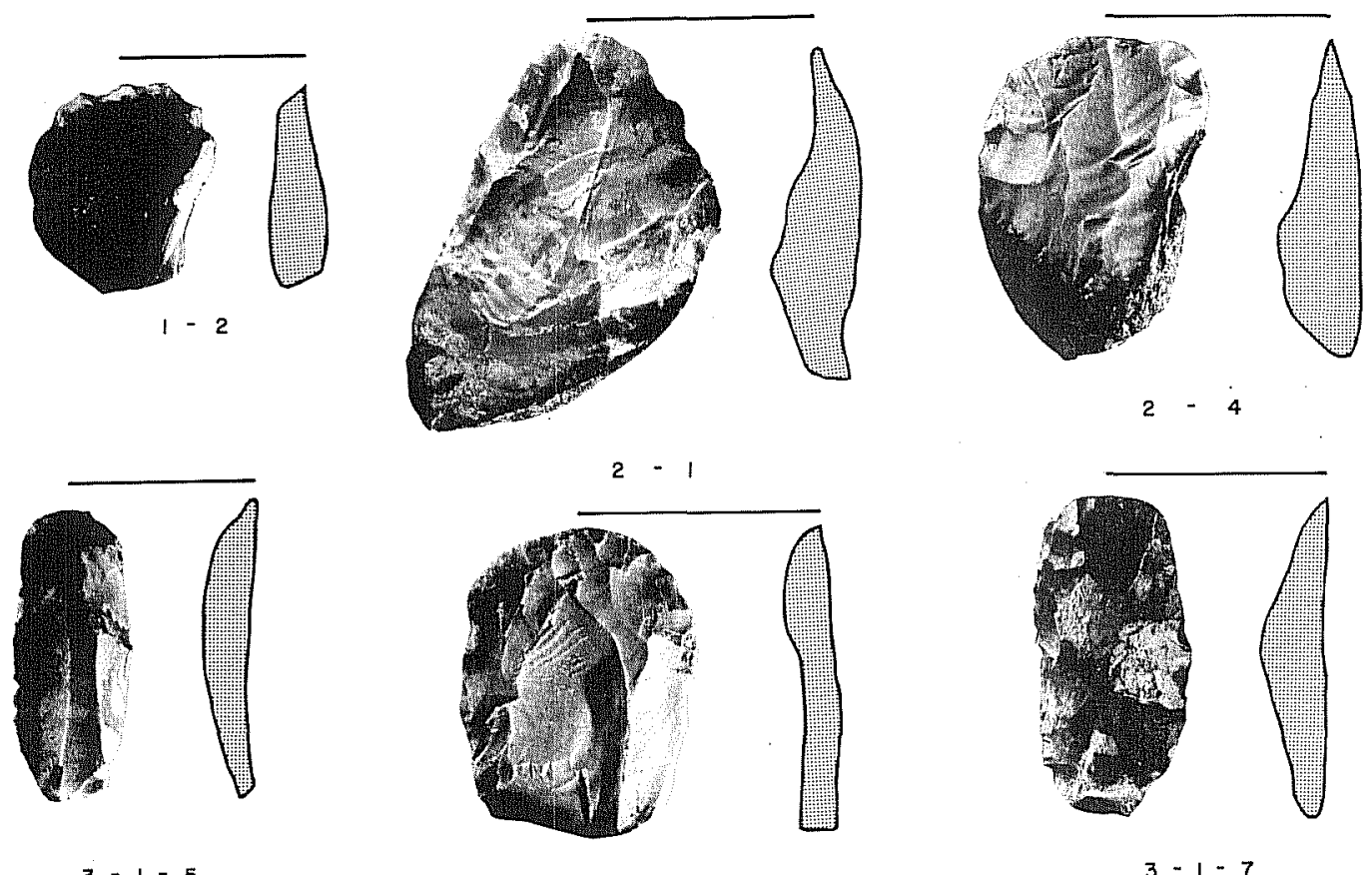

$3-1-5$

$3-1-1$
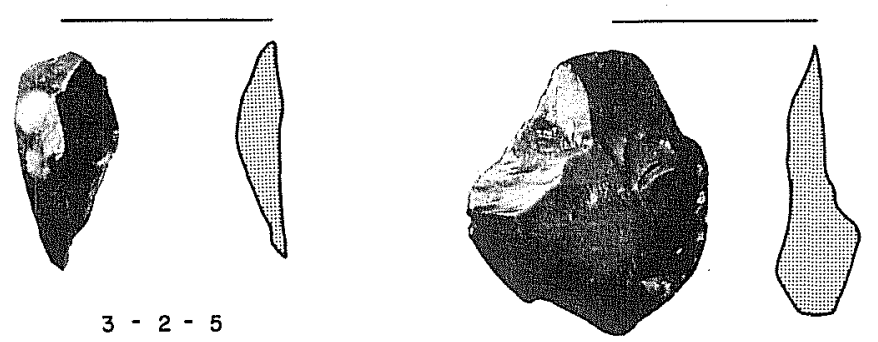

$3-3-2$
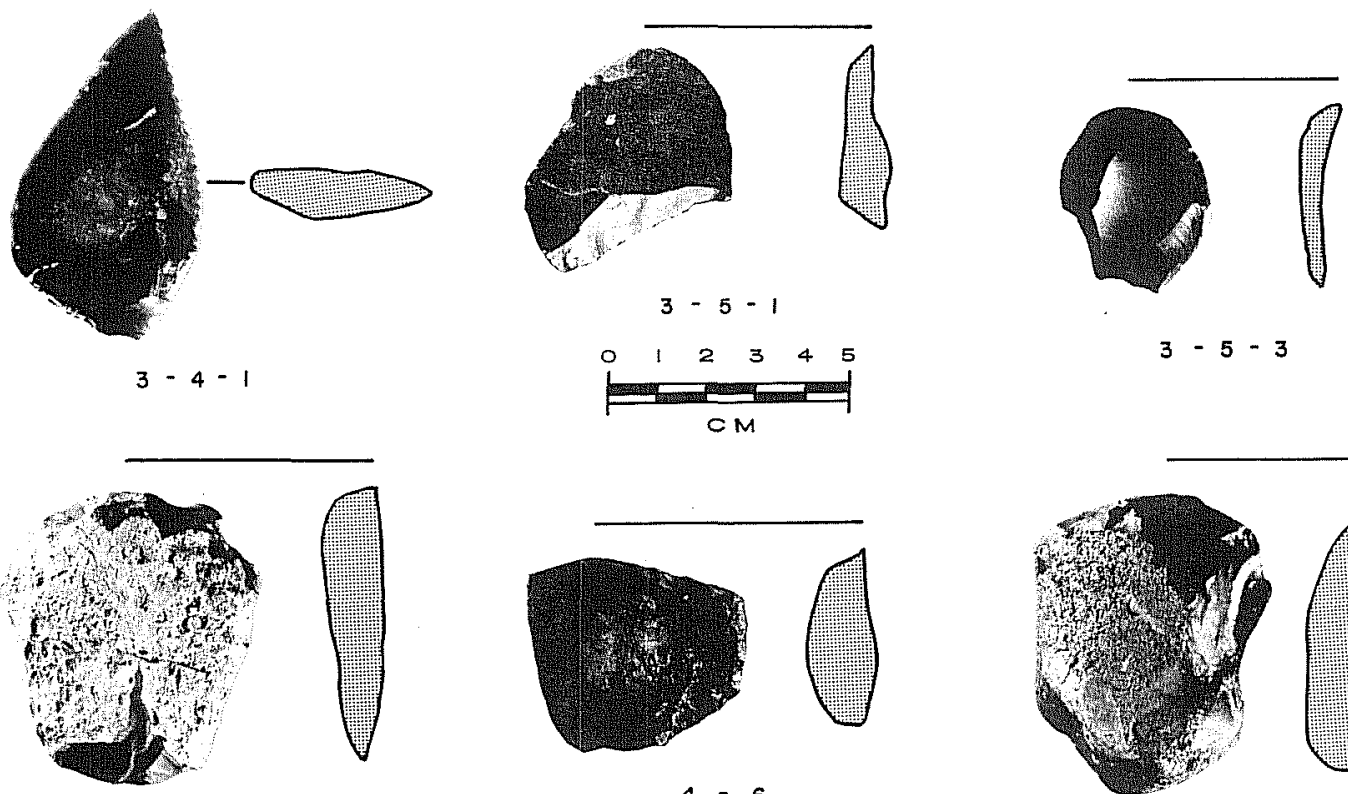

$4-10$
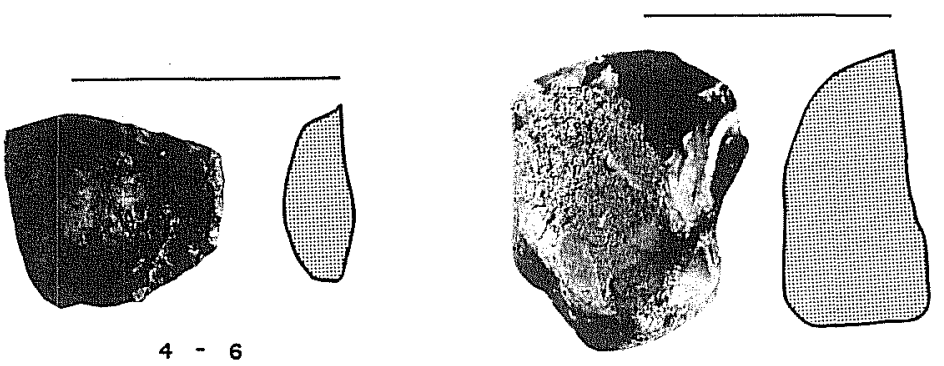

$4-1$

Figure 87. Trimmed F1akes: Groups 1,2,3 (Forms 1, 2, 3, 4, and 5), and 4. Two numbers beneath an artifact indicate group and specimen number; three numbers indicate group, form, and specimen number, respectively. 
Eorm 4. Divergent (two specimens)

Group 3, Form 4 trimmed flake specimens are irregularly shaped, but the lateral edges generaliy diverge from the striking platform. Specimen 1 is distinguished by a $6.8-\mathrm{cm}-1$ ong edge bearing sma 11, but pronounced serrations. It has the appearance of a saw blade. Specimen 2 is trimmed distally in the fashion of Forms 1, 2, and 3. Provenience and metric data for Group 3, Form 4 specimens are as follows:

\begin{tabular}{|c|c|c|c|c|c|c|c|c|c|c|c|}
\hline $\begin{array}{l}\text { Spectmen } \\
\text { Number }\end{array}$ & Site & Lot & Untt & Level & Elevation & Length & Width & Thickness & Welght & $\begin{array}{l}\text { Bevel } \\
\text { Angle }\end{array}$ & $\begin{array}{l}\text { Figure } \\
\text { Number }\end{array}$ \\
\hline 1 & 41 LK 51 & 226 & N998 E982 & 15 & $98.40-98.30$ & 6.9 & 3.9 & 1.0 & 23.5 & $35^{\circ}$ & 87 \\
\hline 2 & 41 LK 201 & $491-0$ & Surface & - & - & 5.7 & 4.3 & 0.9 & 20.0 & $77^{\circ}$ & - \\
\hline
\end{tabular}

Eorm 5. Distal Fragments (three specimens)

Group 3, Form 5 trimmed $f 1$ akes are very similar in appearance to the distal ends of other specimens in Group 3, especially Forms 1, 2, and 3. They are probably fragments of such complete forms. Provenience and metric data for Group 3, Form 5 specimens are as follows:

\begin{tabular}{|c|c|c|c|c|c|c|c|c|c|c|c|}
\hline $\begin{array}{l}\text { Specimen } \\
\text { Number }\end{array}$ & site & Lot & Unit & Level & Elevation & Length & Width & Thickness & Welght & $\begin{array}{l}\text { Bevel } \\
\text { Angle }\end{array}$ & $\begin{array}{l}\text { Flgure } \\
\text { Number }\end{array}$ \\
\hline 1 & 41 LK 182 & $1-0$ & Surface & - & - & $5.0^{*}$ & 4.2 & 1.0 & * & $74^{\circ}$ & 87 \\
\hline 2 & 41 MC 55 & 87 & N998 El017 & 1 & Surf. -99.30 & $2.4^{*}$ & 2.4 & 0.5 & * & $54^{\circ}$ & - \\
\hline 3 & $41 \mathrm{MC} 296$ & 149 & N1026 E997 & 2 & $99.50-99.40$ & $4.0^{*}$ & 3.1 & 0.5 & \# & $48^{\circ} *$ & 87 \\
\hline
\end{tabular}

\section{Group 4. Miscellaneous Thick Flakes and Flake Fragments ( 10 specimens)}

Specimen 1 is made on a small, split cobble and has cortex remaining over most of the dorsal surface. Trimming was done unifacially at the distal end to form a beveled working edge similar in configuration to those of Group 3, Forms 1, 2, and 3. The trimming was done on the cortex side, thus removing perhaps $25 \%$ of the cortex from that face. The cortex provides a comfortable "backing" opposite the working end.

Specimen 2 retains a pronounced bu $7 b$ of percussion at the proximal end. It diverges broadly to a unifacially trimmed working edge at the distal end.

Specimen 3 is an irregularly shaped flake. The trimmed edge is lateral to the bulb of percussion. The edge opposite the trimmed side retains cortex to form a comfortable "backing。"

Specimen 4 is heavily burned and irregular in outline shape. The trimmed edge is opposite the bulb of percussion.

Specimen 5 is subtriangular in outline shape and is similar in general configuration to Group 3 , Form 2 distally beveled bifaces and unifaces. However, it does not exhibit the intentional shaping characteristic of that particular group of artifacts. 
Specimen 6 is a thick $f 1$ ake that retains cortex over most of the dorsal face. The bulb of percussion is at the proximal end. The lateral edges are squared and expand slightly to the working edge opposite the bulb. Unifacial trimming on the cortex face forms the working edge.

Specimen 7 is subtriangular in out 1 ine shape and is trimmed on both 1 ateral edges expanding away from the bulb of percussion at the proximal end. The dista 1 end is untrimmed.

Specimen 8 is made on a thick cortex flake; the trimmed edge is opposite and slightly offset from the bulb of percussion at the proximal end.

Specimen 9 is very irregular in outline shape. This piece has a trimmed edge apparently worked over the flake's bulb of percussion. Opposite the working edge, there is a narrow band of cortex forming a backing.

Specimen 10 has a rounded broad end that tapers to the opposite end which is more squared. Each end is trimmed on the dorsal face with the intervening area retaining a cortex cover.

The provenience and metric data for Group 4 trimmed $f 1$ akes are as fol 1 ows:

\begin{tabular}{|c|c|c|c|c|c|c|c|c|c|c|c|}
\hline $\begin{array}{l}\text { Specimen } \\
\text { Number }\end{array}$ & Site & Lot & Unit & Level & Elevation & Length & Width & Thickness & Weight & $\begin{array}{l}\text { Bevel } \\
\text { Angle }\end{array}$ & $\begin{array}{l}\text { Figure } \\
\text { Number }\end{array}$ \\
\hline 1 & 41 LK 128 & 22 & Test Pit 6 & 3 & $99.60-99.50$ & 5.7 & 4.7 & 3.0 & 102.0 & $66^{\circ}$ & 87 \\
\hline 2 & 41 LK 133 & $17-14$ & Surface & - & - & 3.2 & 5.1 & 1.4 & 24.4 & $46^{\circ}$ & - \\
\hline 3 & 41 LK 201 & $720-146$ & N504 E1012 & 2 & $99.20-99.10$ & 3.8 & 3.9 & 1.1 & 17.4 & $46^{\circ}$ & - \\
\hline 4 & 41 LK 250 & 7 & Test Pit 1 & 7 & $60-70 \mathrm{~cm}$ & 3.3 & 4.3 & 1.1 & 16.5 & $42^{\circ}$ & - \\
\hline 5 & $41 M C 75$ & $34-0$ & Surface & - & - & 3.8 & 4.0 & 1.5 & 21.6 & $62^{\circ}$ & - \\
\hline 6 & 41 MC 196 & $26-0$ & Surface & - & - & 3.9 & 4.5 & 1.4 & 27.4 & $61^{\circ}$ & 87 \\
\hline 7 & 41 MC 268 & $21-9$ & Surface & - & - & 5.3 & 4.9 & 1.6 & 38.7 & $70^{\circ}$ & - \\
\hline 8 & $41 M C 270$ & $22-0$ & Surface & - & - & 4.4 & 5.4 & 1.7 & 44.1 & $50^{\circ}$ & - \\
\hline 9 & $41 M C 282$ & $1-0$ & Surface & - & - & 4.2 & 6.5 & 1.0 & 30.1 & $41^{\circ}$ & - \\
\hline 10 & 41 MC 294 & $4-0$ & Surface & - & - & 6.0 & 5.4 & 1.4 & 45.0 & $62^{\circ}$ & 87 \\
\hline
\end{tabular}

\section{Obsidian Core Eragment}

A sma 11 piece of obsidian bearing $f 1$ ake scars on both faces was recovered from Leve1 1 (surface to $99.81 \mathrm{~m}$ ) of Unit N1026 E1042 at 41 LK 51. Subcircular in outline shape; metric attributes for this piece are: length, $3.1 \mathrm{~cm}$; width, $2.4 \mathrm{~cm}$; thickness, $0.9 \mathrm{~cm}$; and weight, $4.9 \mathrm{~g}$. Results of trace element analysis and comments on the origin of this obsidian are provided in Appendix $V$.

\section{Debitage}

A total of 62,153 pieces of 1 ithic debitage was recovered from 18 prehistoric sites excavated during the Phase II investigation at Choke Canyon. Debitage 
totals by site are presented in Table 26. This total does not include debitage recovered from 4 I LK 201. The 41 LK 201 collection is reported by Highley (1986).

A11 debitage recovered from Phase II controlled excavations was sorted by catalog 1 ot (usually representing al1 debitage found in a $5-\mathrm{cm}$ or $10-\mathrm{cm}$ vertical level excavated in a $1-m^{2}$ unit) into the following categories: primary flakes, secondary flakes, tertiary flakes, chips, and chunks. A total and percentage for each category were recorded and are presented in Table 27. Pieces in each category were then classified according to flake platform characteristics (for flakes) and degree of cortex removal (for chips and chunks). Subtotals for these divisions were recorded within each category. The number of modified or trimmed pieces with in each division was recorded. A detailed presentation of the debitage data is in Appendix VI to this report.

TABLE 26. DEBITAGE TOTALS BY SITE

Site

41 LK 8

41 LK 14

41 LK 51

41 LK 53

41 LK 74

41 LK 128

41 LK 133

41 LK 142

41 LK 185
Total Pieces

4599

4680

10,346

4503

3868

2734

55

39

189
Site

41 LK 243

41 LK 250

41 MC 29

41 MC 55

41 MC 94

41 MC 196

41 MC 222

41 MC 268

41 MC 296
Iotal Pieces

663

317

683

2521

1503

321

4980

2729

17,423

Note: See Table 56 in Appendix VI for the site by site breakdown of debitage into the 53 analytical/descriptive units.

The following definitions of the debitage categories were adapted from studies by Crabtree (1972), Shafer (1969) and Mallouf (1976).

A primary flake retains cortex over its entire external or dorsal surface and is the result of the initial testing and/or removal of cortex from a cobble core. A primary flake may have a striking platform devoid of cortex.

A secondary flake retains $1-99 \%$ cortex on its external or dorsal surface as a result of having been struck from a core partially free of cortex.

A tertiary flake, including its striking platform, is devoid of cortex. 
TABLE 27. TOTAL AND PERCENTAGE OF DEBITAGE RECOVERED DURING PHASE II EXCAVATIONS

\begin{tabular}{|c|c|c|c|c|c|c|c|c|c|c|}
\hline \multirow[b]{2}{*}{ SITE } & \multicolumn{2}{|c|}{ PRIMARY FLAKES } & \multicolumn{2}{|c|}{ SECONDARY FLAKES } & \multicolumn{2}{|c|}{ IERTIARY FLAKES } & \multicolumn{2}{|c|}{ CHIPS } & \multicolumn{2}{|c|}{ CHUNKS } \\
\hline & COUNT & PERCENTAGE & COUNT & PERCENTAGE & COUNT & PERCENTAGE & COUNT & PERCENTAGE & COUNT & PERCENTAGE \\
\hline 41 LK 8 & 74 & 1.60 & 619 & 13.46 & 1230 & 26.75 & 2465 & 53.60 & 211 & 4.59 \\
\hline 41 LK 14 & 57 & 1.22 & 868 & 18.55 & 1486 & 31.75 & 2253 & 48.14 & 16 & 0.34 \\
\hline 41 LK 51 & 74 & 0.72 & 1236 & 11.95 & 2707 & 26.16 & 6112 & 59.08 & 217 & 2.09 \\
\hline 41 LK 53 & 25 & 0.55 & 502 & $11: 15$ & 1183 & 26.27 & 2600 & 57.74 & 193 & 4.29 \\
\hline 41 LK 74 & 59 & 1.53 & 657 & 16.98 & 985 & 25.46 & 2106 & 54.45 & 61 & 1.58 \\
\hline 41 LK 128 & 55 & 2.01 & 510 & 18.65 & 751 & 27.47 & 1414 & 51.72 & 4 & 0.15 \\
\hline 41 LK 133 & 3 & 5.45 & 7 & 12.73 & 12 & 21.82 & 31 & 56.36 & 2 & 3.64 \\
\hline 41 LK 142 & 3 & 7.69 & 11 & 28.21 & 7 & 17.95 & 16 & 41.03 & 2 & 5.12 \\
\hline 41 LK 185 & 3 & 1.59 & 38 & 20.11 & 46 & 24.34 & 88 & 46.56 & 14 & 7.40 \\
\hline 41 LK 243 & 6 & 0.91 & 121 & 18.25 & 150 & 22.62 & 352 & 53.09 & 34 & 5.13 \\
\hline 41 LK 250 & 9 & 2.84 & 58 & 18.29 & 59 & 18.61 & 188 & 59.31 & 3 & 0.95 \\
\hline 41 MC 29 & 15 & 2.20 & 134 & 19.62 & 206 & 30.16 & 324 & 47.44 & 4 & 0.58 \\
\hline 41 MC 55 & 28 & 1.11 & 315 & 12.50 & 518 & 20.54 & 1623 & 64.38 & 37 & 1.47 \\
\hline 41 MC 94 & 16 & 1.06 & 252 & 16.77 & 483 & 32.14 & 752 & 50.03 & 0 & 0 \\
\hline 41 MC 196 & 5 & 1.56 & 78 & 24.30 & 72 & 22.43 & 158 & 49.22 & 8 & 2.49 \\
\hline 41 MC 222 & 62 & 1.24 & 679 & 13.63 & 1331 & 26.73 & 2809 & 56.41 & 99 & 1.99 \\
\hline 41 MC 268 & 66 & 2.42 & 551 & 20.19 & 775 & 28.40 & 1285 & 47.08 & 52 & 1.91 \\
\hline 41 MC 296 & 162 & 0.93 & 2386 & 13.69 & 4556 & 26.15 & 9985 & 57.31 & 334 & 1.92 \\
\hline
\end{tabular}


A cortex platform flake possesses a platform of unmodified, weathered cortex.

A single facet $p$ latform flake possesses a $p l$ atform consisting of a single removal scar (facet) produced by previous knapping.

A multiple facet platform flake possesses a $p 1$ atform consisting of two or more facets produced by previous knapping. It has been subdivided into small $(<1 \mathrm{~cm})$ and large $(>1 \mathrm{~cm})$ according to the width of combined facets.

Lipped flakes "have multifaceted, lenticular-shaped striking platforms and a characteristic lip or ridge which is at right angles to the axis of removal on the ventral side. The striking platforms are bifacially prepared and multifaceted. The dorsal side of the flake is multifaceted and rarely exhibits cortex. Lipped flakes are characteristically thin and arched" (Shafer 1969:4).

A chip is a portion of a $f l$ ake which has no $p l$ atform because of breakage, crushing, or shattering. The chips are subdivided into primary secondary, and tertiary according to the amount of cortex remaining on the external surface.

A chunk is a fragment showing no striking platform and no force rings (bulbs of percussion) emanating from the direction of applied force. Thickness approaches maximum 1 ength and width. It is too small to be a core and too 1 arge and massive to qualify as a chip. Chunks are subdivided into primary, secondary, and tertiary according to the amount of cortex remaining on the external surface.

A modified flake or chip may have been used as a tool. Such use is evidenced by minute nicking, battering, or polish along the edge(s) of the flake or chip.

A trimmed flake or chip exhibits intentional edge preparation through removal of a uniform series of tiny $f 7$ akes along an edge. It is distinguished from modified $f 1$ akes and chips in that human alteration of the piece is unquestionable (Mal louf 1976).

For primary flakes, the "Other Platform Types" division was intended to include lipped and multiple facet platform flakes, both of which were very minor elements of the primary flake collection.

Among secondary and tertiary flakes, 1 ipping was a characteristic given precedence over platform faceting. Lipped flakes had either single facet or multiple facet platforms, but were always counted as 1 ipped flakes.

Modified $f l$ akes were recognized through unenhanced eye inspection of the debitage as it was being sorted. No microscopic inspection was attempted. It is therefore 7 ikely that some modified flakes were not seen and that some believed to be modified actually were not. 
HAMMERSTONES ( $s i x$ specimens)

Six cobbles or cobble fragments having the appearance of hammerstones were recovered. The hammerstone function for these objects is suggested on the basis of their overall configuration and the presence of battering on one or both of their ends. Provenience and metric data for the hammerstones are as follows:

\begin{tabular}{|c|c|c|c|c|c|c|c|c|c|c|c|}
\hline $\begin{array}{l}\text { Spectmen } \\
\text { Number }\end{array}$ & Sito & Lot & Unit & Level & Elevation & Length & Width & Th1ckness & Welght & $\begin{array}{l}\text { Beve1 } \\
\text { Angle }\end{array}$ & $\begin{array}{l}\text { F1gure } \\
\text { Number }\end{array}$ \\
\hline 1 & 41 LK 14 & 201 & N1007 E958 & 6 & - & 7.6 & 3.7 & 2.9 & 94.9 & - & 92,1 \\
\hline 2 & 41 LK 14 & 242 & N1009 E1000 & 2 & - & $2.7^{*}$ & 4.4 & 2.4 & $41.4^{*}$ & - & - \\
\hline 3 & 41 MC 55 & 65 & N1008 E1015 & 1 & - & 6.6 & 6.8 & 3.5 & 213.8 & - & - \\
\hline 4 & 41 MC 55 & 79 & N1009 E1016 & 2 & - & $2.3 *$ & 4.9 & 3.0 & $48.8^{*}$ & - & - \\
\hline 5 & 41 MC 55 & 83 & N1014 E1011 & 1 & - & 7.0 & 5.2 & 4.6 & 240.0 & - & 92,9 \\
\hline 6 & 41 MC 296 & $25-19$ & Surface & - & - & 5.6 & 4.1 & 3.0 & 94.9 & - & $92, h$ \\
\hline
\end{tabular}

Except for Specimen 3, a chert cobble, a 11 of these specimens are made of fine-to medium-grained quartzite. Specimens 1, 2, and 6 are grayish red to purple to red in color. Specimen 4 is a brown quartzite. Specimens 2 and 4 are fragmentary.

MODIFIED SANDSTONE (391 specimens)

The sandstone artifacts are divided into the following categories for descriptive purposes:

Group 1. Smoothed S1abs and S1ab Fragments with F1at and/or Concave Faces

Form 1. Large

Form 2. Medium

Form 3. Smal1

Group 2. Subcircular to Angular Pieces with Flat and/or Convex Faces

Form 1. Wedge-Shaped Cross Section

Form 2. Lenticular Cross Section

Form 3. Fragments

Group 3. Grooved Pieces

Specimens from each group (a) though not a 11 forms) are 111 ustrated in Figures 88-91. Site provenience is provided in Table 28, and provenience of subsurface specimens is shown in Table 29.

\section{Group 1. Smoothed Slabs and Slab Fragments with Flat and/ar Concave Faces (158 specimens)}

Group I modified sandstone is divided into three forms based on maximum length. Five essentially complete grinding 51 abs and numerous angular fragments are included which. by virtue of one or more smoothed faces, are thought to be portions of 51 abs similar to the complete specimens. Smoothed 
TABLE 28. PROVENIENCE OF MODIFIED SANDSTONE BY SITE

\begin{tabular}{|c|c|c|c|c|c|c|c|}
\hline \multirow{2}{*}{$\begin{array}{l}\text { Slto } \\
\text { No. }\end{array}$} & \multicolumn{3}{|c|}{ Group 1} & \multicolumn{3}{|c|}{ Group 2} & \multirow{2}{*}{$\begin{array}{c}\text { Group } \\
3\end{array}$} \\
\hline & Form 1 & Farm 2 & Form 3 & Form 1 & Form 2 & Form 3 & \\
\hline \multicolumn{8}{|l|}{41 LKB } \\
\hline $41 \mathrm{LK} 14$ & & & 1 & 1 & 1 & 1 & 1 \\
\hline \multicolumn{8}{|l|}{$41 \mathrm{LK} 27$} \\
\hline $41 \mathrm{LK5} 1$ & & 1 & 2 & & 3 & 6 & 3 \\
\hline $411 \mathrm{~K} 53$ & & & & 1 & & 3 & 3 \\
\hline \multicolumn{8}{|l|}{$41 \mathrm{LK} 66$} \\
\hline $41 \mathrm{LK} 69$ & & & & & & & \\
\hline $41 \mathrm{LK} 74$ & & 1 & & & & & \\
\hline $41 L K 120$ & & & & 2 & 1 & & \\
\hline $41 \mathrm{LK} 121$ & & & & & & & \\
\hline $41 \mathrm{LK} 122$ & & & & & & & \\
\hline $41 L K 127$ & & & & & & & \\
\hline $41 L K 128$ & & 1 & & & & & \\
\hline $41 \mathrm{LK} 133$ & & & & & & & \\
\hline 41 LK 142 & & & & & & & \\
\hline $41 \mathrm{LK} 145$ & & & & & & & \\
\hline 41 LK 149 & & & & & & & \\
\hline 41 LK 162 & & & & & & & \\
\hline $41 L K 173$ & & & & & & & \\
\hline $41 \mathrm{LK} 174$ & & & & & 2 & & 1 \\
\hline 41LK176 & & & & & & & \\
\hline 41 LK 181 & & & & & & & \\
\hline 41 LK 182 & & & & & & & \\
\hline 41 LK 185 & & & & & 1 & & 1 \\
\hline 41 LK 191 & & & 2 & & & & \\
\hline $41 \mathrm{LK} 197$ & & & & & & & \\
\hline 41 LK 199 & & & & & & & \\
\hline 41 LK 201 & & 4 & 24 & 5 & 2 & 5 & 7 \\
\hline $41 L K 236$ & & & & & & & \\
\hline 41 LK 243 & & & 4 & 1 & 3 & 2 & \\
\hline $411 K 247$ & & & & & & & \\
\hline 41 LK250 & 1 & & 2 & & 1 & & 1 \\
\hline $41 L K 252$ & & & & & & & \\
\hline $41 \mathrm{LK} 253$ & & & & & & & \\
\hline & & & & & & & \\
\hline $41 \mathrm{MC7}$ & & & & & & & \\
\hline $41 \mathrm{MC} 10$ & & & & & & & \\
\hline $41 \mathrm{MC} 14$ & & & & & & & \\
\hline $41 \mathrm{MC} 15$ & & & & & & & \\
\hline $41 \mathrm{MCl} 7$ & & & & & & & \\
\hline $41 M C 29$ & & & 2 & & 2 & 1 & -1 \\
\hline $41 \mathrm{MC} 55$ & & 1 & 4 & & & 2 & \\
\hline $41 \mathrm{MC} 67$ & & & & & & & \\
\hline $41 \mathrm{MC} 75$ & & & & & & & \\
\hline 41 MC79 & & & & & & & \\
\hline $41 \mathrm{MCg} 4$ & & 1 & 1 & 1 & & 2 & \\
\hline $41 M C 192$ & & & & & & & \\
\hline $41 \mathrm{MC} 193$ & & & & & & & \\
\hline $41 \mathrm{MC} 194$ & & & & & & & \\
\hline $41 M C 196$ & 2 & & 21 & 3 & 6 & 6 & \\
\hline $41 \mathrm{MC} 212$ & & & & & 1 & & \\
\hline $41 \mathrm{MC} 213$ & 3 & & & & & & \\
\hline $41 \mathrm{MC} 214$ & & & & & & & \\
\hline $41 \mathrm{MC} 222$ & 2 & 5 & 10 & & 9 & 20 & 4 \\
\hline $41 \mathrm{MC} 226$ & & & & & & & \\
\hline $41 \mathrm{MC} 234$ & & & & & & & \\
\hline $41 \mathrm{MC} 235$ & & & & & & & \\
\hline $41 \mathrm{MC2} 38$ & 1 & & 2 & & 3 & 1 & 1 \\
\hline $41 \mathrm{MC2} 42$ & & & 1 & & 1 & & \\
\hline $41 \mathrm{MC} 246$ & & & & & & & \\
\hline $41 \mathrm{MC251}$ & & & 1 & & & & \\
\hline $41 \mathrm{MC2} 257$ & 1 & & & & 1 & & \\
\hline $41 \mathrm{MC2} 60$ & & & 1 & 2 & & & 1 \\
\hline $41 \mathrm{MC266}$ & & & & & & & \\
\hline $41 \mathrm{MC} 267$ & & & & & & & \\
\hline $41 \mathrm{MC} 26 \mathrm{~B}$ & 1 & 3 & 8 & 3 & 15 & 7 & 3 \\
\hline $41 \mathrm{MC2} 70$ & & & 2 & & 3 & & \\
\hline $41 \mathrm{MC} 275$ & & 1 & 2 & & 1 & & \\
\hline $41 \mathrm{MC} 276$ & & & & & 1 & & \\
\hline $41 \mathrm{MC2} 82$ & 1 & & & & & & \\
\hline $41 \mathrm{MC} 284$ & & & & & & & \\
\hline $41 \mathrm{MC} 288$ & & & & & 2 & & \\
\hline $41 \mathrm{MC2} 293$ & & & & & 1 & & \\
\hline $41 \mathrm{MC294}$ & & & & 1 & 1 & & \\
\hline $41 \mathrm{MC} 296$ & 5 & 5 & 58 & 7 & 10 & 16 & 6 \\
\hline
\end{tabular}


TABLE 29. PROVENIENCE OF MODIFIED SANDSTONE RECOVERED IN EXCAVATIONS

\begin{tabular}{|c|c|c|c|}
\hline \multirow[t]{2}{*}{ STIE } & IATL & LEVEL. & \multirow[t]{2}{*}{ ELEYATIOA } \\
\hline & \multicolumn{2}{|c|}{ GROP 1, FORE } & \\
\hline $\begin{array}{l}41 \text { MC } 222 \\
41 \text { MC } 222 \\
41 \text { MC } 296\end{array}$ & $\begin{array}{l}\text { N101 E91 } \\
\text { N103 E90 } \\
\text { Tést Pit } 2\end{array}$ & $\begin{array}{l}3 \\
5 \\
8\end{array}$ & $\begin{array}{l}98.85-98.80 \\
98.90-98.85 \\
70-80 \mathrm{~cm}\end{array}$ \\
\hline \multicolumn{4}{|c|}{ EROLP 1 _ FORU 2} \\
\hline $\begin{array}{lll}41 & \text { LK } & 51 \\
41 & \text { LK } & 74 \\
41 & \text { LK } & 201 \\
41 & \text { LK } & 201 \\
41 & \text { LK } & 201 \\
41 & \text { LK } & 201 \\
41 & M C & 55 \\
41 & M C & 222 \\
41 & N C & 222 \\
41 & M C & 268 \\
41 & M C & 296 \\
41 & M C & 296 \\
41 & M C & 296 \\
41 & M C & 296\end{array}$ & $\begin{array}{ll}\text { N1010 E1011 } \\
\text { N1071 E857 } \\
\text { N499 E997 } \\
\text { N498 E997 } \\
\text { N504 E1012 } \\
\text { N506 E1011 } \\
\text { N994 E1017 } \\
\text { N102 E90 } \\
\text { N103 E89 } \\
\text { Test Pft I } \\
\text { N1023 E987 } \\
\text { N1024 E985 } \\
\text { N1025 E999 } \\
\text { N1027 E995 }\end{array}$ & $\begin{array}{r}8 \\
3 \\
3 \\
11 \\
2 \\
2 \\
2 \\
6 \\
8 \\
5 \\
4 \\
4 \\
3 \\
6\end{array}$ & $\begin{array}{r}99.20-99.10 \\
100.10-100.00 \\
99.15-99.05 \\
98.35-98.25 \\
99.20-99.10 \\
99.20-99.10 \\
99.30-99.20 \\
98.75-98.70 \\
98.75-98.70 \\
40-50 \mathrm{~cm} \\
99.20-99.10 \\
99.20-99.10 \\
99.40-99.30 \\
99.10-99.00\end{array}$ \\
\hline
\end{tabular}

\section{GOUP 1. FORP 3}

41 LK 14 41 LK 51

41 LK 51

41 LK 201

41 LK 201

41 LK 201

41 LK 201

41 LK 201

41 LK 201

41 LK 201

41 LK 201

41 LK 201

41 LK 201

41 LK 201

41 LK 201

41 LK 201

41 LK 201

41 LK 201

41 LK 201

41 LK 201

41 LK 201

41 LK 201

41 LK 201

41 LK 243

41 LK 250

41 MC 29

41 MC 29

41 MC 55

41 MC 55

41 MC 55

41 MC 55

41 MC 94

41 MC 196

41 MC 196

41 MC 196

41 MC 196

41 MC 196

41 MC 222

41 MC 222

41 MC 222
N1010 E1002

N998 E981

N1025 E104]

N491 E1042

N497 E998

N499 E996

N499 E997

N500 E996

N497 E996

N497 E997

N498 E996

N498 E996

N498 E996

N499 E996

N500 E996

N500 E996

N499 E997

N499 E997

N504 E1013

N506 E1010

N504 E1011

N508 E1007

N509 E1007

Hearth 14

Test Pit 1

N998 E1011

N998 E1012

N1008 E1015

N1014 E101I

N1016 E1011

N998 E1017

Test P1t 2

Test Pit 1

Tost Pit 1

Test Pit 1

Test Pit I

Test Pit 1

N100 E86

N100 E91

N101 E91
99.00-98.90

$99.20-99.10$

$99.40-99.30$

98.65-98.55

$99.15-99.05$

99.15-99.05

98.95-98.85

Surf. -99.25

98.45-98.35

98.15-98.05

98.15-98.05

$98.15-98.05$

98.05-97. 95

$97.95-97.85$

$97.95-97.85$

$97.95-97.85$

97.95-97.85

$97.95-97.85$

$99.28-99.20$

99. 20-99. 10

$99.33-99.20$

99. 20-99. 10

99.08-99.00

60-70 cm

99.90-98. 80

99.40-99.30

99.42-99.30

Surf. -99.30

Surf. -99.30

99.10-99.00

99.60-99.50

$0-10 \mathrm{~cm}$

$0-10 \mathrm{~cm}$

$10-20 \mathrm{~cm}$

10-20

20-30 cm

98. 70-98. 65

$98.65-98.60$

$98.90-98.85$
SIIE

UII

[FYE!

ELEVATION

GROAP Ie FOR 3 (continued)

41 MC 222

41 MC 222

41 MC 222

41 MC 222

41 MC 268

41 MC 268

41 MC 268

41 MC 268

41 MC 296

41 MC 296

41 MC 296

41 MC 296

41 MC 296

41 MC 296

41 MC 296

41 MC 296

41 MC 296

41 MC 296

41 MC 296

41 MC 296

41 MC 296

41 MC 296

41 MC 296

41 MC 296

41 MC 296

41 MC 196

41 MC 296

41 MC 296

41 MC 296

41 MC 296

41 MC 296

41 MC 296

41 MC 296

41 MC 296

41 MC 296

41 MC 296

41 MC 296

41 MC 296

41 MC 296

41 MC 296

41 MC 296

41 MC 296

41 MC 296

41 MC 296

41 MC 296

41 MC 296

41 MC 296

41 MC 296

41 MC 296

41 MC 296

41 MC 296

41 MC 296

N102 E88

N102 E91

N104 E85

N113 E83

N995 E982

N995 E982

N995 E982

N995 E99B

Test P1t 1

Test Pit 1

Test Pit 2

Test Pit 2

N1022 E985

N1022 E987

N1022 E987

N1022 E987

N1022 E987

M1022 E987

N1023 E985

N1023 E985

N1023 E986

N1024 E985

N1024 E985

N1024 E985

N1024 E985

N1024 E985

N1024 E985

N1024 E986

N1024 E986

N1024 E986

N1024 E986

N1025 E997

N1026 E998

N1027 E997

N1027 E997

N1027 E998

N1025 E995

N1027 E978

N1022 E989

N1022 E989

N1026 E978

N1026 E978

N1025 E995

N1027 E978

N1027 E978

N1027 E978

N1023 E989

N1023 E989

N1023 E989

N1024 E989

N1024 E989

N1024 E989

GROIP 2, FOBA 1

41 LK 14

41. LK 53

41 LK 201

41 LK 201

41 LK 201

41 LK 201

41 LK 201

41 MC 196

41 MC 196
N1009 E1002

N1002 E1002

N498 E997

N490 E1043

N499 E997

N510. E1020

N510 E1021

Test Plt

Test Pit 1
$98.90-98.85$

$98.85-98.80$

Surf. -98.90

98.90-98.80

99.40-99.30

$99.30-99.20$

$99.30-99.20$

$99.30-99.20$

$0-10 \mathrm{~cm}$

10-20 cm

$30-40 \mathrm{~cm}$

70-80 cm

99. 00-98. 90

$99.40-99.30$

$99.30-99.20$

99.20-99.10

$99.10-99.00$

98.80-98.70

Surf. -99.40

98. $90-98.80$

$99.30-99.20$

Surf. -99.40

99.40-99.30

$99.20-99.10$

99. 20-99.10

99.20-99.10

$99.10-99.00$

Surf. -99.40

Surf. -99.40

Surf. -99.40

98. $90-98.80$

$99.40-99.30$

$99.40-99.30$

Surf. -99.50

Surf. -99.50

99.20-99.10 
TABLE 29. (continued)

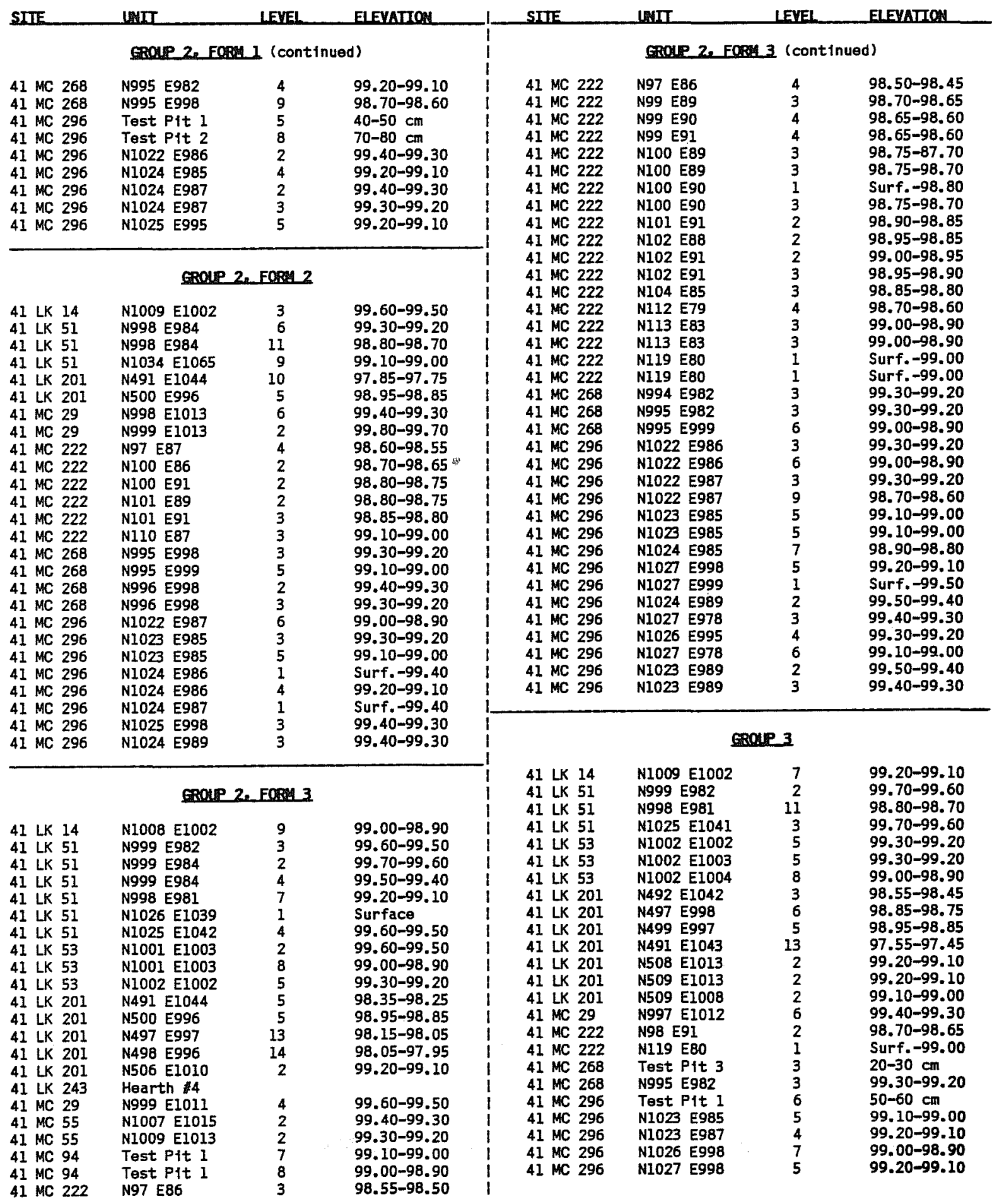



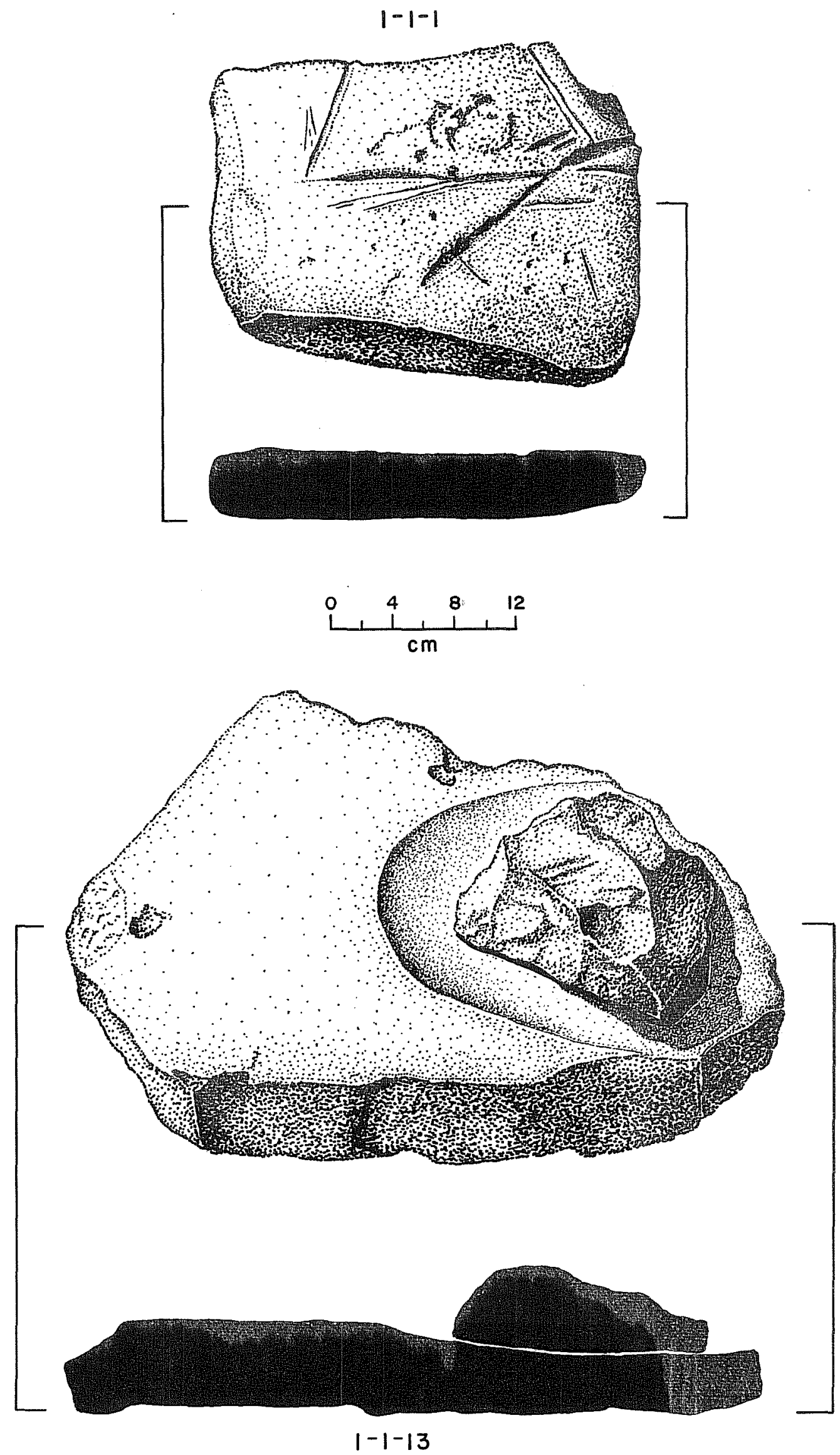

Figure 88. Modified Sandstone: Group 1, Form 1, Specimens 1 and 13. Numbers beneath artifact indicate group, form, and specimen number, respectively. 
faces of al1 specimens in Group 1 are either flat or shallowly concave. On the complete slabs, these smoothed surfaces are obviously grinding facets, usually assuming a long, oval shape. Smoothing and distinctive curvatures on the fragmentary specimens suggest that they were once part of whole grinding slabs. The assumed function of these slabs was to grind, pulp, or otherwise process vegetal products such as seeds, nuts, and fruit into edible form. The s 1 abs 1 ikely served in other capacities as we 11 . Fragments of broken slabs were also used as manos (Group 2) and abraders (Group 3).

\section{Form 1. Large (17 specimens)}

Group 1, Form 1 modified sandstone specimens range in maximum length from 15 to $54 \mathrm{~cm}$, in width from $15-33 \mathrm{~cm}$, and in thickness from $3.1-10.5 \mathrm{~cm}$. Individual descriptions of some of the complete and near complete s 1 abs follow.

Specimen 1 is a complete $\mathrm{s} 1 \mathrm{ab}$, approximately $30 \mathrm{~cm} 1 \mathrm{ong}, 21 \mathrm{~cm} \mathrm{wide,} \mathrm{and}$ $5.5 \mathrm{~cm}$ thick (Fig. 88). The specimen was surface collected at 41 LK 250. One face exhibits a relatively flat grinding facet, roughly rectangular in outline, that measures $14 \times 19 \mathrm{~cm}$. On the opposite face are four striations that probably served as abrading grooves for sharpening some type of imp 1 ement. Two of the grooves measure from 4 to $6 \mathrm{~cm}$ in 1 ength, are about $1.5 \mathrm{~cm}$ wide, and $0.5 \mathrm{~cm}$ deep. The other two grooves are from 8 to $10 \mathrm{~cm}$ in length, about $1 \mathrm{~cm}$ wide, and $0.5 \mathrm{~cm}$ deep.

Specimen 2, a complete sandstone s1ab. was surface collected at 41 MC 196 (Fig. 89). It is approximately $54 \mathrm{~cm}$ long, $29 \mathrm{~cm}$ wide, and $7.5 \mathrm{~cm}$ thick. There is an oblong grinding facet on one face that measures $14 \times 29 \mathrm{~cm}$. The face opposite the grinding facet is apparently unmodified.

Specimen 13 a large, but incomplete slab (Fig. 88), was found in controlled excavations at 41 MC 296, in Level $8(70-80 \mathrm{~cm})$ of Test Pit 2. Group 2, Form 1, Specimen 22, a wedge-shaped sandstone abrader, was found in position on top of this slab. Associated artifacts and radiocarbon assays indicate that the slab and related mano were deposited during a Late Archaic occupation of the site. Radiocarbon dates from the stratum yielding Specimen 13 range from 100 B.C. $(T X-4669)$ to A.D. 590 (TX-4680). Specimen 13 is approximately $46 \mathrm{~cm}$ in length, $20 \mathrm{~cm}$ in width, and $5.5 \mathrm{~cm}$ thick. There is an oblong grinding facet on one face that measures $18 \times 26 \mathrm{~cm}$. The opposite face does not seem to be modified.

Specimen 17 was surface collected at 41 MC 296, and is unusual in that it has two oblong facets on one face and is ground to a smooth, very flat surface on the opposite face (Fig. 89). This slab is $50.5 \mathrm{~cm}$ in length, $28 \mathrm{~cm}$ in width, and $6.5 \mathrm{~cm}$ thick. The oblong grinding facets measure $17-22 \mathrm{~cm}$ in 7 ength and are $12-16 \mathrm{~cm}$ in width. The shall ow facets are $1.0-2.0 \mathrm{~cm}$ deep.

\section{Form 2. Medium (23 specimens)}

Group 1. Form 2 modified sandstone specimens are 9-14 cm long and $1.5-1.7 \mathrm{~cm}$ thick. Outlines are irregular and angular. One, and sometimes two, face(s) 

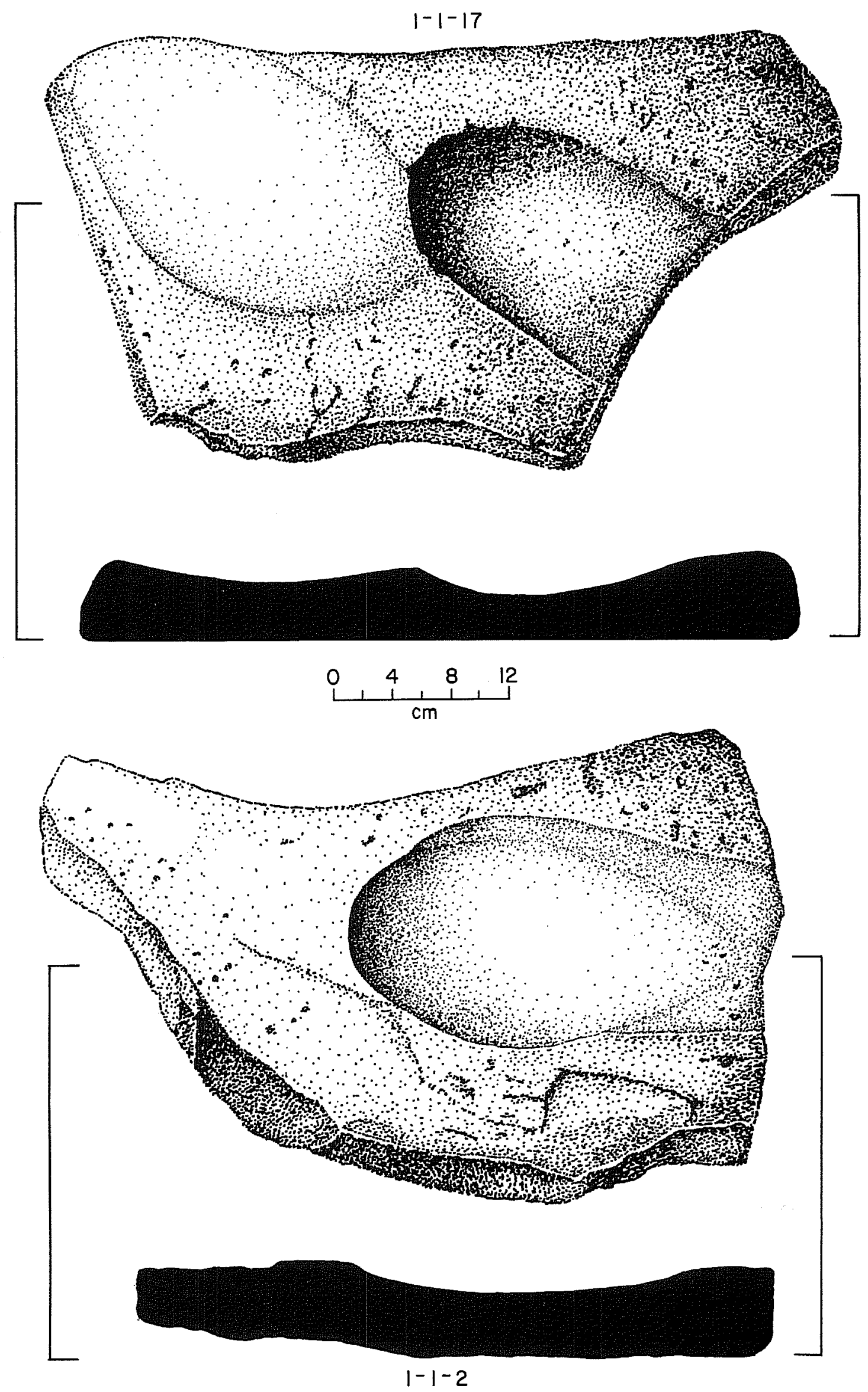

Figure 89. Modified Sandstone: Group 1, Form 1, Specimens 2 and 17. Numbers beneath artifact indicate group, form, and specimen number, respectively. 
of each plece has (have) been smoothed to either a flat or slightly concave shape. Complete grinding facets are not evidenced. Most Form 2 specimens appear to be fragments of 1 arger slabs with grinding facets and basins similar to those of Form 1. Form 2 specimens are not il lustrated.

Form 3. Small (118 specimens)

Group 1, Form 2 modified sandstone specimens are small fragments of smoothed slabs with both flat and basined facets on one or both faces. Length and width dimensions are $3-8 \mathrm{~cm}$, and the range for thickness dimensions are from 1.0-4.0 cm. Form 3 specimens are not 11 lustrated.

\section{Group 2. Subcircular to Angular Pieces with Flat and/or Convex Faces \\ (170 specimens)}

Sandstone pieces in Group 2 are subcircular to angular in outline. Lengths range from 3.3-17.0 cm, widths are 2-13 cm, and thicknesses are 2.2-5.3 cm. Smooth faces on these pieces are either flat or slightly convex. Smoothing 1 aps up onto the edges of many pieces, and the edges often appear to be intentionally rounded and shaped. Because of their size and the morphology of their faces and edges, Group 2 specimens are believed to be "manos," the sandstone piece held in the hand when food products were ground on slabs. Group 2 is divided into three forms based on cross section shape or degree of completeness.

\section{Form 1. Wedge-Shaped Cross Section (27 specimens)}

Outl ines of the Group 2, Form 1 specimens vary from subcircu 1 ar to triangu 1 ar to rectangular. A 11 are wedge shaped in cross section. Most are smoothed only on one face. Seven of the pieces exhibit smoothing on both faces. Lateral breakage noted among Group 2, Form 1 specimens recovered during Phase I investigations at Choke Canyon ( $\mathrm{Ha} 11$, B 1 ack, and Graves 1982:380) occurs on only two specimens. Specimen 22 was found on top of a grinding slab (Group 1, Form 1, Specimen 13; Fig. 88) at 41 MC 296. The range of dimensions for complete specimens is as follows:

\section{Maximum}

Length:

Width:

Thickness:

$\begin{array}{rr}14.3 & 9.0 \\ 13.0 & 6.7 \\ 4.0 & 2.6\end{array}$

\section{Form 2. Lenticular Cross Section (71 specimens)}

Most Group 2, Form 2 modified sandstone specimens are subcircular to oval in outline, but there are also pieces with rectangular and irregular outlines (Figs. 90 and 91). Most Form 2 pieces are plano-convex in cross section; some are biconvex or rectangular in cross section. Faces are flat or convex, 
328
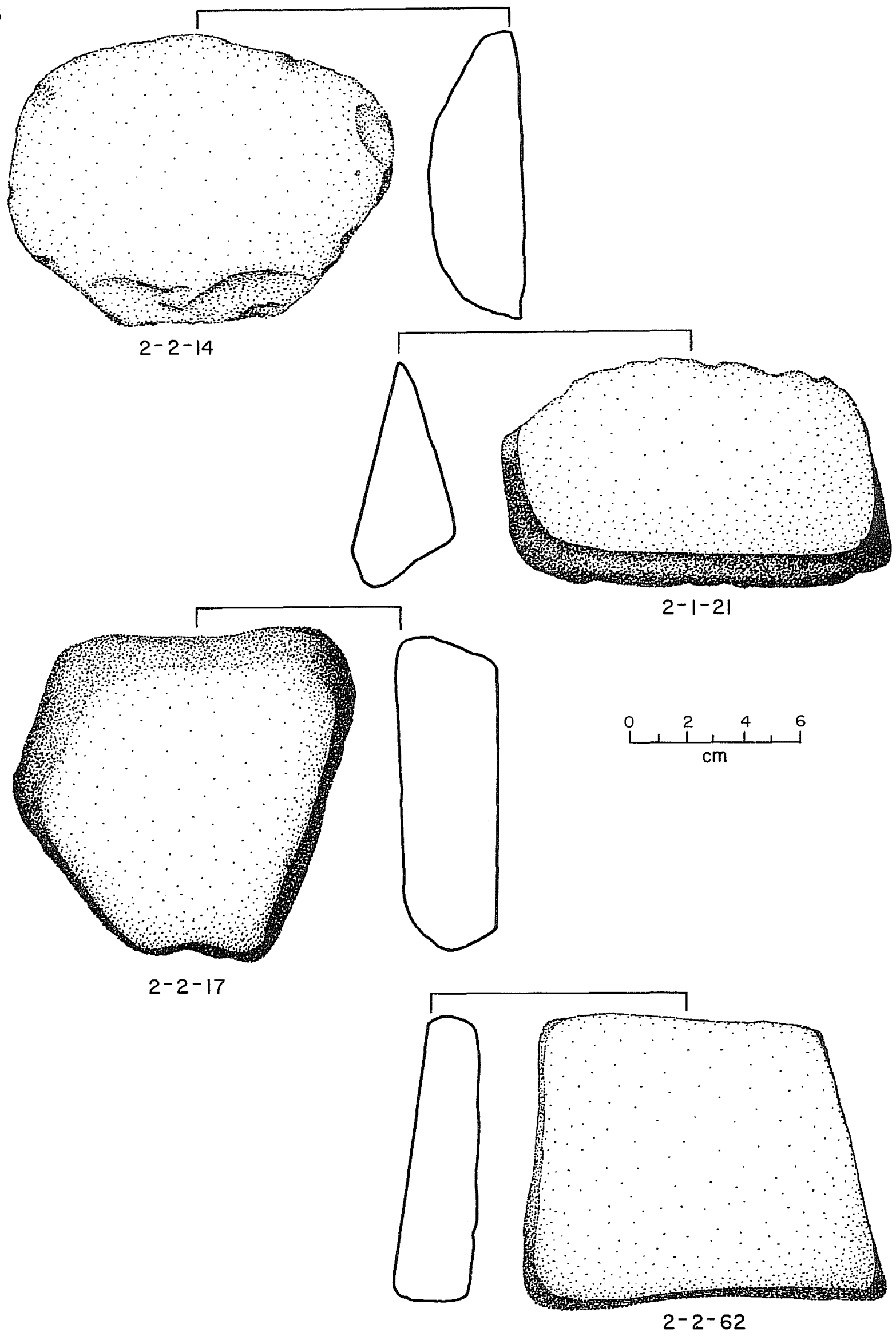

Figure 90. Modified Sandstone: Group 2, Forms 1 and 2. Numbers beneath artifact indicate group, form, and specimen number, respectively. 
edges rounded and/or smoothed. The range of dimensions for complete specimens is as follows:

Maximum Minimum

$\begin{array}{lrr}\text { Length: } & 17.0 & 8.3 \\ \text { Width: } & 12.0 & 6.8 \\ \text { Thickness: } & 5.3 & 2.4\end{array}$

Form 3. Fragments (72 specimens)

Group 2, Form 3 modified sandstone specimens bear one or more of the characteristics described for Forms 1 and 2 above. However, they are too fragmentary to permit definite assignment to either Forms 1 or 2. The range of dimensions for Form 3 is as follows:

Maximum Minimum

$\begin{array}{lll}\text { Length: } & 8.0 & 3.3 \\ \text { Width: } & 5.9 & 2.0 \\ \text { Thickness: } & 2.7 & 2.2\end{array}$

Group 3. Grooved Pieces (33 specimens)

Group 3 modified sandstone specimens are angular fragments with from one to five V-shaped or U-shaped grooves worked into their faces. Lengths are 3.3$14.0 \mathrm{~cm}$, widths are $2.1-10.0 \mathrm{~cm}$, and thicknesses are $1.0-4.5 \mathrm{~cm}$. In out 1 ine, most are irregularly angular. The assemblage has been broken down according to the number of grooves on each piece.

Number of Grooves

1

2

3

4

5

\section{Specimen count}

19

5

4

2

3

The grooves vary from $2.5-7.0 \mathrm{~cm}$ in 1 ength, $0.2-1.3 \mathrm{~cm}$ in width, and $0.1-$ $0.5 \mathrm{~cm}$ in depth. On the specimens with more than one groove, the grooves are often paral lel, but, in some cases, crisscross or are independent of one another at different angles. Two specimens, one from 41 LK 51 and the other from 41 MC 268, had broad $(3.9$ to $4.3 \mathrm{~cm})$ s shal 1 ow $(0.4$ to $0.6 \mathrm{~cm})$ grooves quite different from the rest of the Group 3 specimens (see Fig. 91).

MODIFIED QUARTZITE (five specimens)

A11 fragmentary, these five pieces of quartzite probably represent broken manos. Material color ranges from pink to gray. Specimens 2 and 3 exhibit end battering suggesting re-use as hammerstones. Specimen 1 was recovered in 


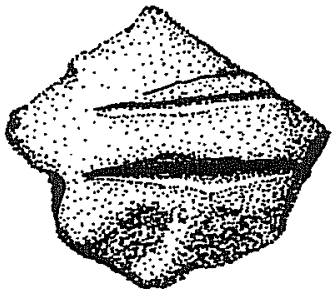

3-30
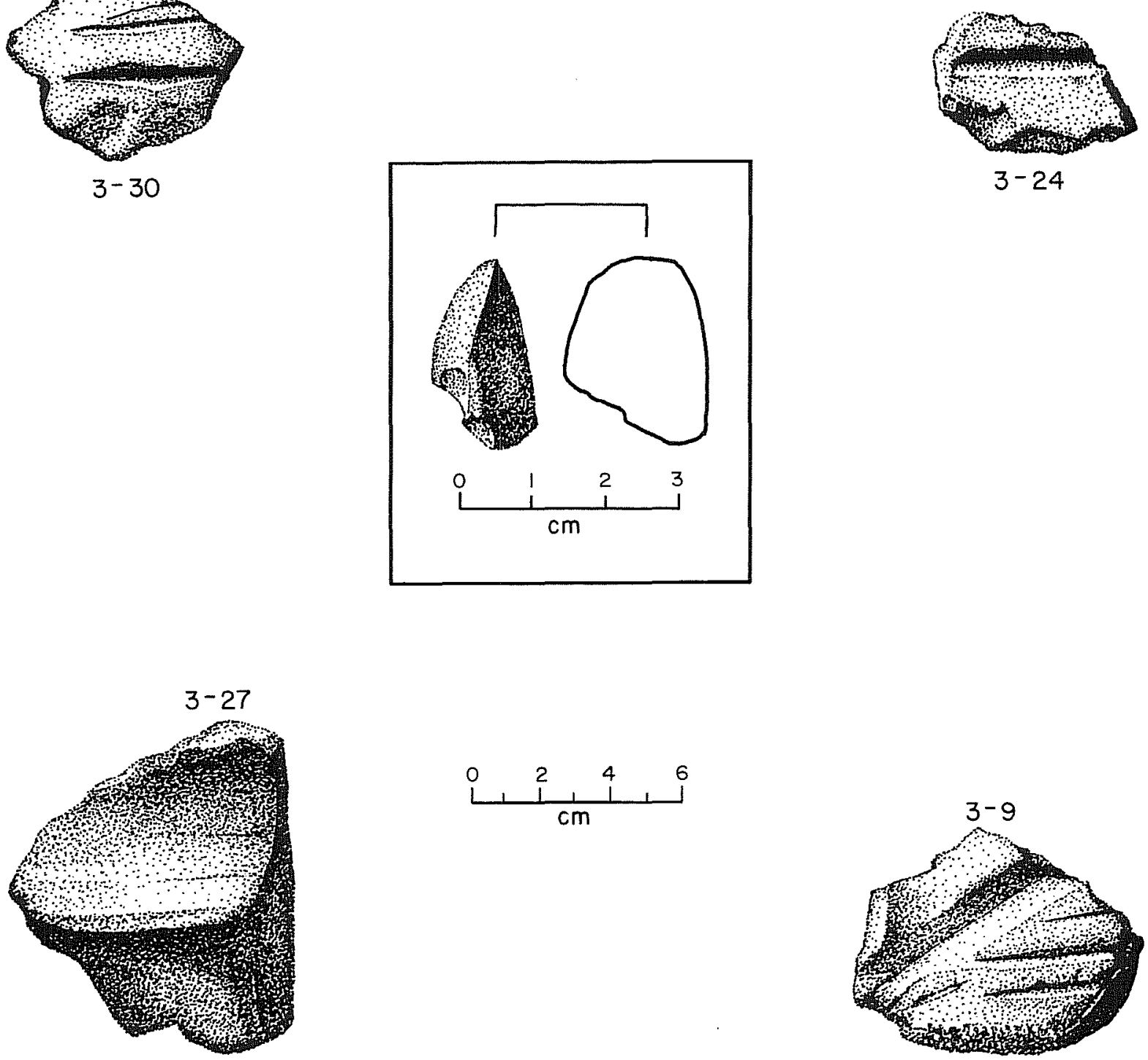

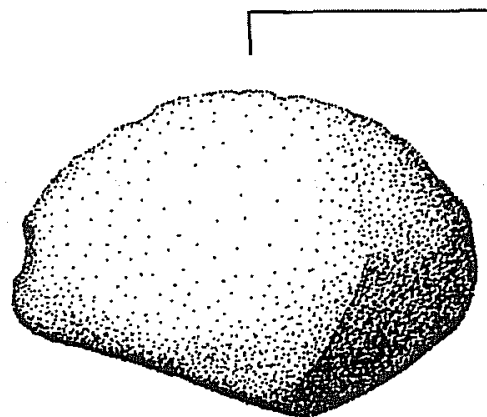

$2-1-11$

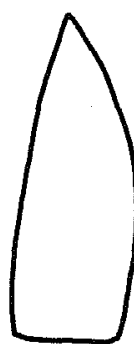

Figure 91. Modified Sandstone: Group 2, Form 1 and Group 3, and Modified Siltstone. Two numbers beneath artifact indicate group and specimen number; three numbers indicate group, form, and specimen number, respectively. 
Level 6 (99.40-99.30) of Unit N1025 El04I at 41 LK 51. The other specimens were surface collected. Site provenience and metric attributes for the modified quartzite specimens are as follows:

Specimen

Number

Site

Length

Width

Figure Number

$\begin{array}{llrlll}I & 41 \text { LK } 51 & 4.9^{*} & 3.6 * & 3.7 & - \\ 2 & 41 \text { LK } 69 & 4.9^{*} & 3.1^{*} & 3.6 & - \\ 3 & 41 \text { LK } 120 & 10.2^{*} & 6.4^{*} & 3.4 & 92, j \\ 4 & 41 \text { LK } 185 & 8.8^{*} & 7.2^{*} & 4.8 & 92, k \\ 5 & 41 \text { LK } 201 & 5.0^{*} & 4.4^{*} & 2.3 & -\end{array}$

\section{MISCELLANEOUS LITHIC ARTIFACTS AND MATERIALS}

\section{Satin Spar Gypsum (14 specimens)}

Satin spar gypsum specimens are stream-rolled cobbles, 4-10 cm 1ong, 1-3.4 cm wide, and 0.5-2.5 cm thick. Most have rounded ends. The ends are smoothed, sometimes slightly battered. Whether these alterations are intentional or natural cannot be determined. Gypsum of the satin spar variety is derived from the Frio Formation which runs through the midsection of the Choke Canyon project area. Occurrence of gypsum specimens on prehistoric sites suggests that the aboriginal inhabitants had some use for the mineral, but what that use may have been is currently unknown. Gypsum cobbles were found as grave inclusions at 41 LK 28, an Archaic cemetery site located a short distance east of Choke Canyon. Provenience data for the satin spar gypsum specimens are as follows:

Site Lot Unit Level Elevation

\begin{tabular}{|c|c|c|c|c|}
\hline 41 LK 14 & 231 & N1008 E1001 & 9 & $99.00-98.90$ \\
\hline 41 LK 51 & 328 & N1025 El042 & 4 & $99.60-99.50$ \\
\hline 41 LK 74 & 53 & N994 E986 & 2 & $99.00-98.90$ \\
\hline 41 LK 74 & 61 & N995 E985 & 1 & $99.13-99.00$ \\
\hline 41 LK 74 & 93 & N1070 E857 & 3 & $100.10-100.00$ \\
\hline 41 LK 128 & 4 & Test Pit 2 & 1 & Surface -99.60 \\
\hline 41 L.K 128 & $49-0$ & Surface & - & - \\
\hline 41 LK 191 & $2-0$ & Surface & - & - \\
\hline 41 LK 191 & $2-0$ & Surface & - & - \\
\hline 41 LK 201 & 502 & N491 El044 & 20 & $96.85-96.75$ \\
\hline 41 MC 55 & 112 & N1017 E999 & 10 & $98.50-98.40$ \\
\hline 41 MC 94 & 198 & Test Pit 3 & 3 & $99.60-99.50$ \\
\hline 41 MC 275 & $2-0$ & Surface & - & - \\
\hline 41 MC 296 & 175 & N1027 E997 & 7 & $99.00-98.90$ \\
\hline
\end{tabular}

Examples of satin spar gypsum are illustrated in Figure 92,d-f. 


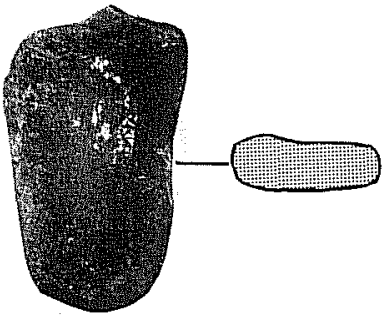

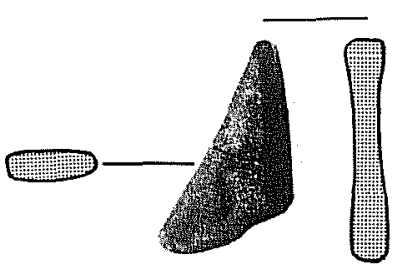

b
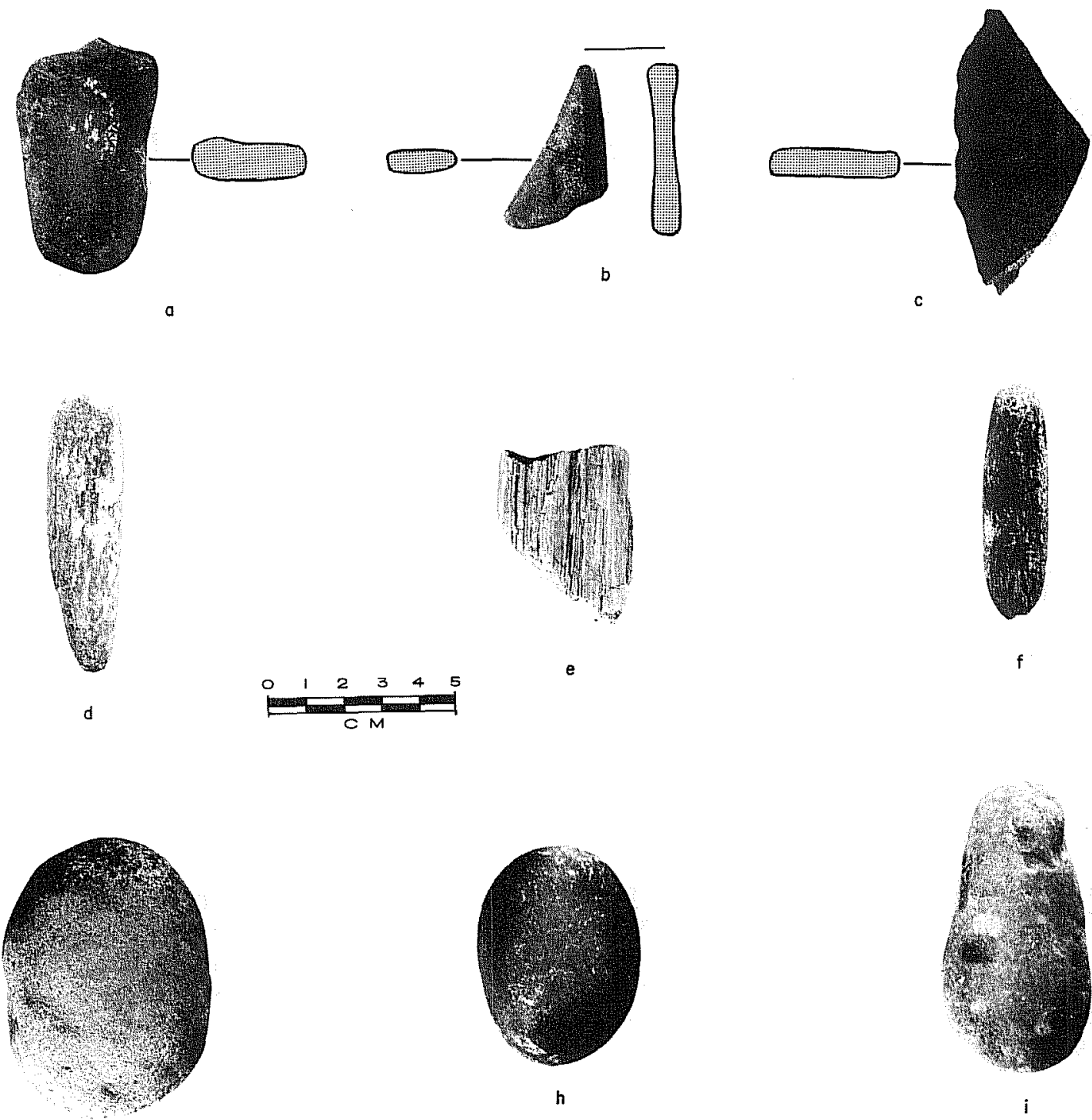

h

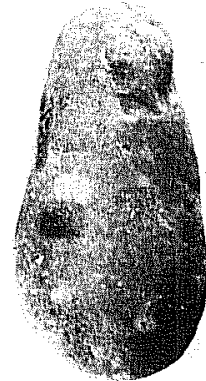

i

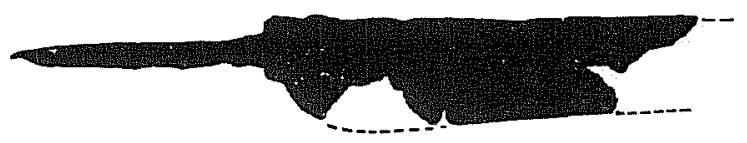

1

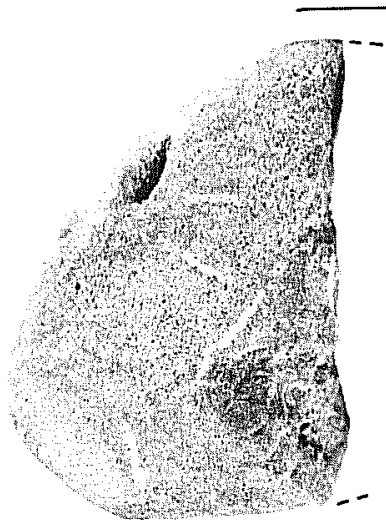

j
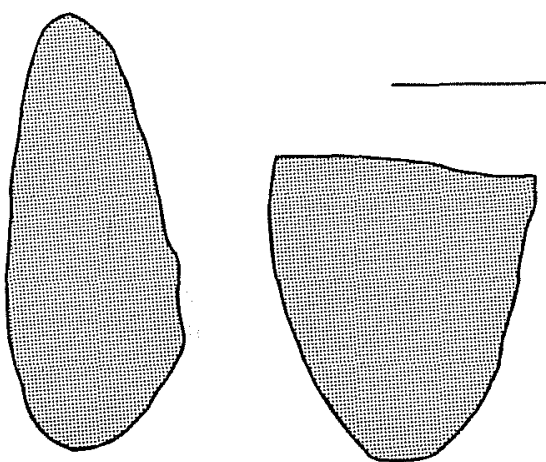

k

Figure 92. Artifacts of Ferruginous Sandstone, Gypsum, Hammerstones, Metal Knife Blade, and Modified Quartzite. a-c, ferruginous sandstone; $d=f$, gypsum; $g-i$, hammerstones; $j, k$, modified quartzite; 1 , metal knife blade. 


\section{Ferruginous Sandstone (three specimens)}

Specimen 1 was surface collected at 41 LK 185. It is orange tan in color and roughly triangular in outline. The specimen measures $4.8 \mathrm{~cm}$ in 1 ength, $2.0 \mathrm{~cm}$ in width, and $1.2 \mathrm{~cm}$ in thickness. It appears to have been ground into shape on both faces and the three edges. The grinding has formed concave facets on the faces. Grinding has resulted in a very smooth surface on this fine-grained, wel1-cemented material.

Specimen 2 was recovered in Leve1 6 (99.00-98.90) of Unit N995 E982 at 41 MC 268. It is a fine-grained piece of black or dark gray ferruginous sandstone that has been ground $f l$ at and very smooth on one face. The opposite face is unmodified. This fragmentary specimen measures $7.5 \mathrm{~cm}$ in length, $3.5 \mathrm{~cm}$ in width, and is $0.8 \mathrm{~cm}$ thick.

Specimen 3 was found in Level 2 (99.50-99.40) of Unit N1025 E999 at 41 MC 296. It is a fine-grained, yellow buff ferruginous sandstone. Fragmentary, this piece is subrectangular in outline shape. One face is flat and smoothed, the other unmodified. Dimensions for this specimen are: length, $6.2 \mathrm{~cm}$; width, $3.8 \mathrm{~cm}$; and thickness, $1.3 \mathrm{~cm}$.

These three specimens are illustrated in Figure $92, a-c$.

Hematite Concretions (three specimens)

Three hematite concretions were recovered during Phase II investigations, two at 41 MC 268 and one at 41 MC 296. There are no obvious signs of human a)teration of any of the specimens.

\section{Qcher*}

Small bits and pieces of ocher were recovered at four of the prehistoric sites excavated during the Phase II investigations at Choke Canyon. Provenience and quantity data for the ocher specimens are as follows:

Site Lot Unit Level Color Count Weight

$\begin{array}{llrlrlll}41 & \text { LK 51 } & 144 & \text { N999 E981 } & 5 & \text { Buff } & 1 & 0.3 \\ 41 & \text { LK 51 } & 233 & \text { N998 E984 } & 5 & \text { Yellow } & 1 & 1.3 \\ 41 & \text { LK 51 } & 240 & \text { N998 E984 } & 12 & \text { Red } & 1 & 0.3 \\ 41 \text { MC 29 } & 64 & \text { N998 El012 } & 3 & \text { Red } & 4 & 5.6 \\ 41 \text { MC 55 } & 59 & \text { N992 El015 } & 1 & \text { Orange } & 1 & 0.1 \\ 41 \text { MC 55 } & 81 & \text { N1008 E1016 } & 2 & \text { Yellow } & 1 & 1.3 \\ 41 \text { MC 55 } & 98 & \text { N999 El017 } & 5 & \text { Buff } & 1 & 0.2 \\ 41 \text { MC 296 } & 4 & \text { Test Pit 1 } & 4 & \text { Red } & 1 & 0.4 \\ 41 \text { MC 296 } & 64 & \text { N1022 E987 } & 4 & \text { Red } & 3 & 0.3 \\ 41 \text { MC 296 } & 104 & \text { N1024 E985 } & 7 & \text { Yellow } & 1 & 0.2\end{array}$

* Ocher from 41 LK 201 are not included in this report (see Highley 1986). 


\begin{tabular}{|c|c|c|c|c|c|c|c|}
\hline 41 MC 296 & 120 & $\mathrm{~N} 1024$ & E987 & 5 & Red & 1 & 0.9 \\
\hline 41 MC 296 & 141 & $\mathrm{~N} 1025$ & E999 & 3 & Red & 1 & 0.2 \\
\hline 41 MC 296 & 150 & N1026 & E997 & 3 & Red & 1 & 0.3 \\
\hline 41 MC 296 & 169 & $\mathrm{~N} 1027$ & E997 & 1 & Red & 1 & 1 \\
\hline 41 MC 296 & 173 & $\mathrm{~N} 1027$ & E997 & 5 & Red & 1 & 2 \\
\hline 41 MC 296 & 174 & N1027 & E997 & 6 & Buff & $i$ & 6.9 \\
\hline 41 MC 296 & 181 & N1027 & E998 & 6 & Red & $\overline{1}$ & 0.2 \\
\hline 41 MC 296 & 212 & $\mathrm{NIO} 24$ & E989 & 2 & Buff & 2 & 0. \\
\hline 41 MC 296 & 222 & $\mathrm{~N} 1027$ & E995 & $\overline{6}$ & Red & 1 & 0.7 \\
\hline
\end{tabular}

\section{Modified Siltstone (one specimen)}

This unusual beveled piece of buff yel low siltstone was recovered from Leve1 2 (98.80-98.70) of Unit N998 E1012 at 41 MC 29. The piece measures $2.9 \times 2.2 \times 1.4 \mathrm{~cm}$. The angle of the bevel is approximately $42^{\circ}$. The specimen appears to be fragmentary, as if broken off of a longer artifact. The specimen is illustrated in Figure 91.

\section{BONE ARTIFACTS (13 specimens)}

Thirteen artifacts of modified bone (nine bead specimens and four aw 1 or pin fragments) were recovered from Choke Canyon's prehistoric sites during the Phase II investigations. This total does not include a number of bone artifacts recovered at 41 LK 201 and described in a separate volume of the research series (Highley 1986). With two exceptions, the beads appear to have been manufactured from bird bones. Lacking articular ends, species of bird from which the bones are derived cannot be identified. The largest bead (Specimen 2) is made from the bone of a deer-sized animal. The smal lest bead (Specimen 1) is a fish or snake vertebra of unidentified species. Provenience and metric data for bone beads are as follows:

Specimen Number Site

Lot

Unit Leve1 Length

Figure

\begin{tabular}{|c|c|c|c|c|c|c|c|c|c|}
\hline 1 & 41 MC 296 & 71 & $\mathrm{~N} 1023$ & E985 & 2 & 0.6 & 0.6 & 0.3 & - \\
\hline 2 & 41 MC 296 & 82 & $\mathrm{~N} 1023$ & E986 & 4 & $4.0 *$ & 1.4 & $0.8 *$ & $93, b$ \\
\hline 3 & 41 MC 296 & 91 & N1023 & E987 & 3 & $2.1 *$ & 0.7 & 0.7 & - \\
\hline 4 & $41 \mathrm{MC} 296$ & 163 & $\mathrm{~N} 1026$ & E999 & 2 & $2.9 *$ & 0.3 & 0.3 & $93, a$ \\
\hline 5 & 41 MC 296 & 227 & $\mathrm{~N} 1024$ & E989 & 3 & 3.5 & 0.6 & 0.6 & $93, a$ \\
\hline 6 & 41 MC 296 & 237 & N1024 & E989 & 4 & $2.2^{*}$ & 0.6 & 0.4 & $93, a$ \\
\hline 7 & 41 MC 296 & 237 & N1024 & E989 & 4 & 3.3 & 0.6 & 0.4 & - \\
\hline 8 & 41 MC 296 & 237 & N1024 & E989 & 4 & $1.9 *$ & 0.5 & 0.5 & - \\
\hline 9 & 41 MC 296 & 238 & N1023 & E989 & 3 & $3.1 *$ & 0.5 & 0.5 & $93, a$ \\
\hline
\end{tabular}

No species identifications were possible for the aw 7 or pin fragments. Specimen 1 is a flat, rectangular, highly smoothed and polished medial fragment. Specimen 2 is $f l$ at and worked to a very sharp point. Specimen 3 is rounded, polished, and worked to a sharp point. Specimen 4 is a $\mathrm{flat}$ medial fragment. Provenience and metric data for aw $1 / p$ in fragments are as follows: 
Specimen

Number

Site Lot

Unit

Leve1 Length

Figure
Number

$\begin{array}{rrrrlllllll}1 & 41 & \text { LK } 51 & 182 & \text { N999 E984 } & 9 & 1.7 * & 0.7 & 0.2 & 92, \mathrm{C} \\ 2 & 41 & \text { MC } 222 & 229 & \text { N103 E90 } & 2 & 3.9 * & 0.5 & 0.2 & 92, f \\ 3 & 41 & \text { MC 296 } & 84 & \text { N1023 E986 } & 5 & 3.1 * & 0.7 & 0.6 & 92, e \\ 4 & 41 & \text { MC 296 } & 91 & \text { N1023 E987 } & 3 & 2.1 * & 0.6 & 0.3 & 92, d\end{array}$

MARINE SHELL ARTIFACTS ( $n$ ine specimens)

Nine marine shell artifacts were recovered from prehistoric sites during the Phase II investigations. This total does not include specimens found at 41 LK 201 (see Highley 1986). Provenience and metric data are as follows:

Specimen

Number

Site Lot

Unit

Level

Figure

\begin{tabular}{rrlrlllllll}
\hline 1 & 41 & LK 8 & 66 & N510 E458 & 5 & 1.2 & 0.7 & 0.5 & $93, j$ \\
2 & 41 & LK 8 & 101 & N511 E459 & 8 & 1.2 & 0.7 & 0.6 & $93, j$ \\
3 & 41 & LK 14 & 190 & N1006 E959 & 3 & $2.6 *$ & $1.7^{*}$ & 0.3 & $93, q$ \\
4 & 41 & LK 51 & 224 & N998 E982 & 13 & 1.2 & 0.7 & 0.5 & $93, j$ \\
5 & 41 & LK 51 & 246 & Surface & - & $7.3^{*}$ & $3.2^{*}$ & 0.3 & $93, \mathrm{r}$ \\
6 & 41 & LK 250 & $12-1$ & Surface & - & 3.2 & 1.1 & 1.1 & $93, \mathrm{i}$ \\
7 & 41 & MC 296 & 62 & N1022 E987 & 2 & 2.1 & 0.7 & 0.7 & $93, \mathrm{~g}$ \\
8 & 41 & MC 296 & 173 & N1027 E997 & 5 & $2.7 *$ & $1.7 *$ & 0.3 & $93, \mathrm{n}$ \\
9 & 41 & MC 296 & 230 & N1025 E995 & 5 & 1.1 & 1.0 & 0.4 & $93, \mathrm{~h}$
\end{tabular}

Specimens 1, 2, and 4 are beads made from whole shel 1s of the common At 1antic marginel1a (Prunuum [1eptegouana] apicina). These sma11 gastropod she11s were modified for suspension by abrading a hole through the body whorl near the aperture. This would allow a string to be passed through the abraded hole and out the aperture. These shel1s are common on the Texas coast, especial1y from Port Aransas south (Andrews 1981:61).

Specimens 3 and 5 are fragments of the giant Atlantic cockle (Laevicardium [Dinocardium] robustum). The specimens show no obvious signs of modification. This is a very common species along the Texas coast (Andrews 1981:110111).

Specimens 6 and 9 are tubular beads made from conch or whelk she 11 colume 11 as (Busycon sp.). Specimen 9 is a sma11, thin disk bead with a perforation diameter of $0.4 \mathrm{~cm}$. Specimen 6 is longer $(3.2 \mathrm{~cm})$ with a perforation diameter of $0.4 \mathrm{~cm}$. Specimen 6 is biconically drilled. Its exterior surface is very smooth and we 11 shaped.

Specimen 7 is made from a whole plicate horn shel1 (Cerithidea [Cerithideopsis] pliculosa). The small gastropod shel1 is perforated through the outer whor 1 near the aperture to form a hole suitable for suspension. The species is common along the Texas coast (Andrews 1981:21-22). 

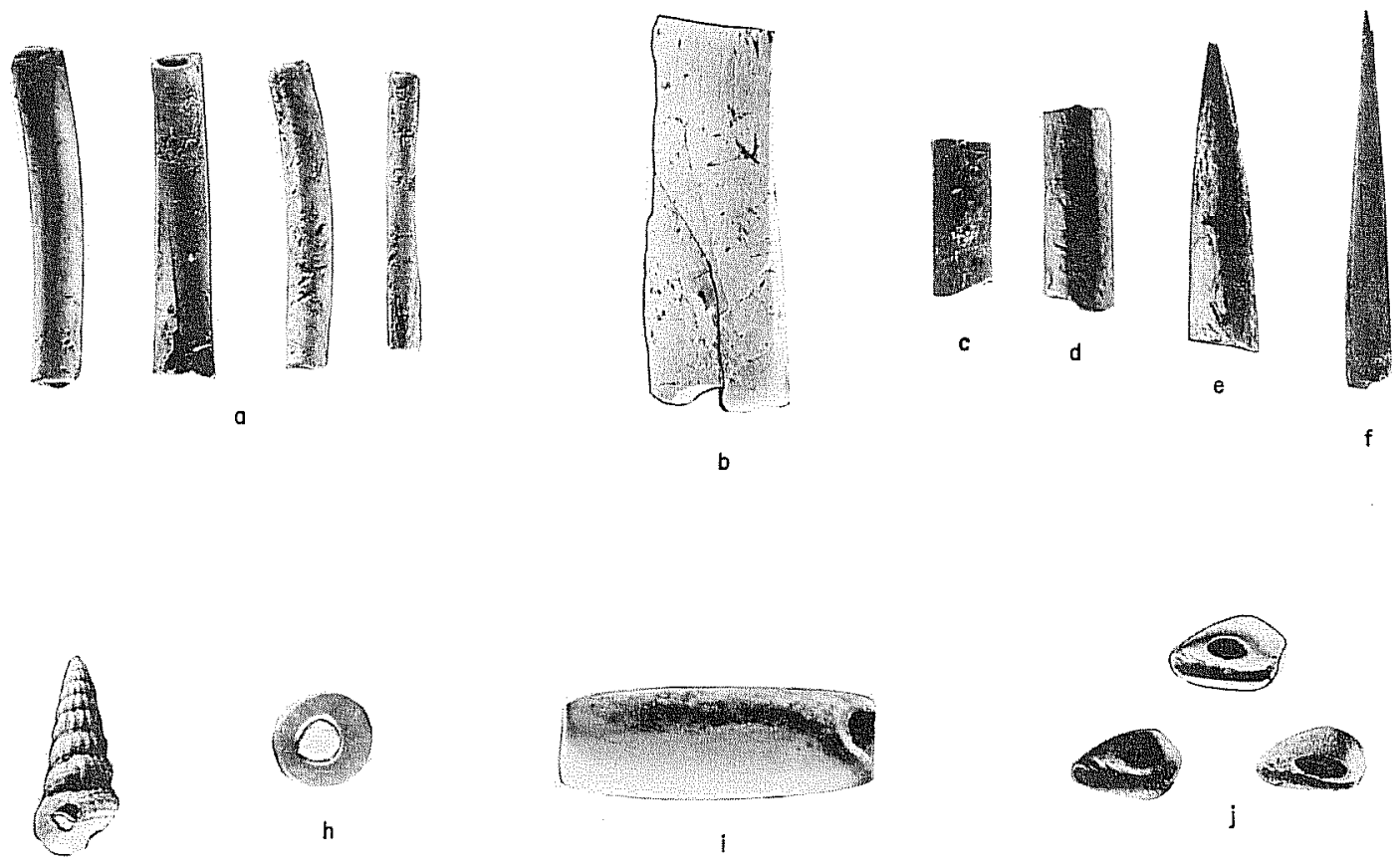

$g$

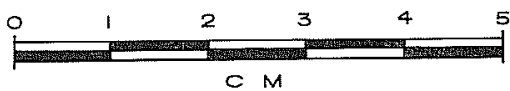

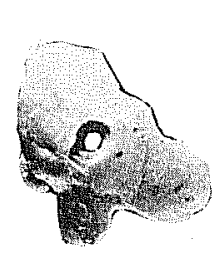

k

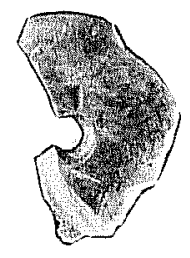

1

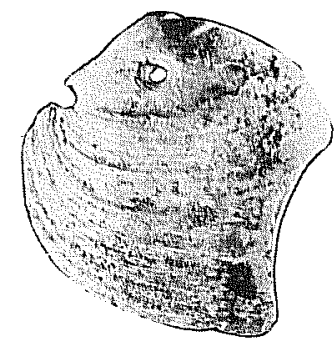

m

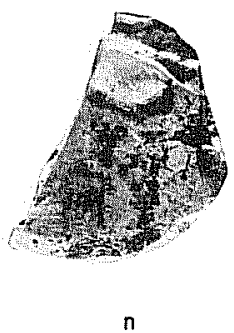

ก
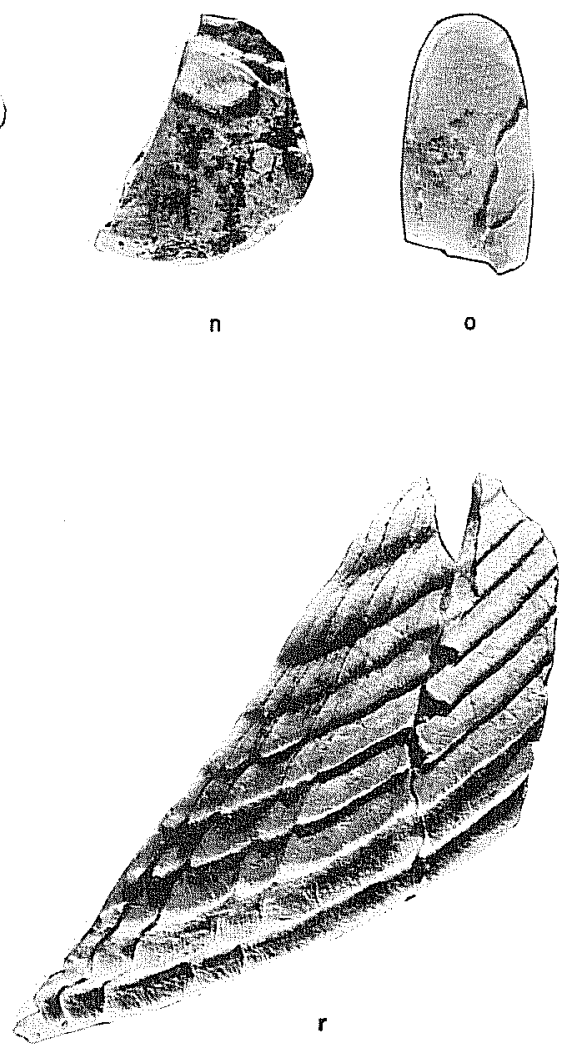

p

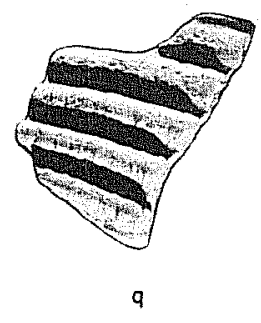

Figure 93. Bone Artifacts, Marine She11 Artifacts, and Modified Musse1 She11s. $a, b$, bone beads; $c-f$, aw 1/pin fragments; $g-j, n, q, r$, marine she11 artifacts; $k-m, 0, p$, mussel shel1s. 
Specimen 8 is made from an unidentifiable bivalve shell fragment.

MODIFIED MUSSEL SHELL (five specimens)

Five specimens of cut, shaped, or perforated mussel shell were recovered in the Phase II investigations. Provenience and metric data are as follows:

Specimen

Number

Site

Lot

Unit

Lever Length

Width Thickness

Figure

Number

\begin{tabular}{llllllllll}
\hline 1 & 41 LK 74 & 71 & N994 E986 & 3 & $3.2^{*}$ & 3.1 & 0.2 & $93, \mathrm{~m}$ \\
2 & 41 LK 74 & 73 & N995 E985 & 3 & 4.5 & 3.5 & 0.5 & $93, \mathrm{p}$ \\
3 & 41 LK 74 & 73 & N995 E985 & 3 & $2.3^{*}$ & $1.7 *$ & 0.5 & $93, \mathrm{~K}$ \\
4 & 41 LK 74 & 100 & N1071 E857 & 2 & $2.6^{*}$ & 1.3 & 0.3 & 93,0 \\
5 & 41 LK 94 & 191 & Test Pit 2 & 5 & $2.3^{*}$ & $1.7 *$ & 0.3 & 93,1
\end{tabular}

Specimen 1 is a fragmentary valve that has been conically perforated near the umbo. The perforation is $0.1 \mathrm{~cm}$ in diameter.

Specimen 2 is an angular fragment of a large, thick valve that was intentional $7 y$ cut or snapped along two edges. One of the cut edges seems to have been slightly smoothed.

Specimen 3 is another valve fragment that exhibits a conical perforation near the umbo.

Specimen 4 is a long, oval piece that has been shaped and smoothed into its present form. One end has been broken.

Specimen 5 is a relatively flat, conically perforated fragment.

\section{PREHISTORIC CERAMICS (Stephen L. Black)}

A total of 574 aboriginal ceramic fragments was recovered from 13 sites during the Phase II investigations at Choke Canyon. This total does not include the 36 sherds recovered from the Phase II investigations or the 1476 sherds recovered from the UTSA Summer Field School at 41 LK 201 (Highley 1986). The analysis of these artifacts was directed toward two goals: (1) a description of the ceramics and comparison with the Phase I ceramics; and (2) an interpretive summary of an aboriginal ceramic tradition in the Choke Canyon Reservoir area and surrounding region. The author conducted a detailed analysis of the Phase I ceramics (Black 1982). The Phase II ceramics were examined using a similar though simplified analytical approach. The ceramic background, terminology, and coding value sections of this report are repeated almost verbatim from the 1982 report. Minor revisions reflect additional data and a rethinking of certain aspects of the analysis. The Phase II site group descriptions follow a format similar to that used in Phase $I$. The concluding section presents a revised interpretive summary of the south Texas bone-tempered ceramic tradition. 


\section{CERAMIC BACKGROUND}

The archaeology of the interior portion of southern Texas was 1 argely unknown and uninvestigated until the last 20 years (Hal 1, Black, and Graves 1982). Prior to the 1 ate 1960 s, the presence of ceramics at prehistoric sites in southern Texas was undocumented (cf. Suhm, Krieger, and Jelks 1954:142). Hester (1968) and Hester and Hill (1969, 1971) published the first articles calling attention to the presence of ceramics in southern Texas. Since 1971, a relatively large number of archaeological investigations have been undertaken in south Texas resulting in a tremendous increase in the number of reported and recorded sites, many of which contain Late Prehistoric ceramicbearing components.

The initial study of south Texas aboriginal ceramics contained a descriptive ceramic classification based on a study of "large ceramic samples" from three sites in Dimmit County (Hester and Hill 1971). Hester and Hill defined seven descriptive groups and stated that "... sherds from southern Texas sites can usually be sorted into one or more of them." The importance of Hester and Hill's initial study is three-fold: (1) it called attention to the presence of ceramics at a number of southern Texas sites that were "remarkably similar" in appearance; (2) the paper discussed the distribution of the known ceramic-bearing sites, acknowledging the limited sample of sites; and (3) the paper summarized the known ceramics from areas adjacent to south Texas as possible antecedents of the south Texas bone-tempered ceramic tradition. Hester and $\mathrm{Hill}$ (ibid.) reviewed the known ceramic types such as Leon Plain (central Texas), the Rockport wares (central coastal Texas), and the Goliad wares (mission Indian ceramics from the south-central coastal plains). They also discussed the miscellaneous reports of unnamed bonetempered pottery noted at many coastal sites and a few sites in the TransPecos area. Hester and Hil1 (1971:199-200) suggested that "it seems most probable that the bone-tempered pottery of southern Texas was introduced by the Late Prehistoric peoples from central Texas (i.e., the Toyah Focus described by Jelks 1962)."

A number of smal1 scale descriptions of ceramics from specific sites or areas of southern Texas have been published in the 1 ast decade. These studies have been 1 imited to relatively brief descriptions of varying degrees of detail. The most detailed of these studies (Hester and Parker 1970) divided severa1 hundred bone-tempered sherds from the Berclair site in Goliad County into 10 groups based primarily on exterior surface color. In addition, they described several Rockport ware sherds; some sherds with various incised, punctated, and brushed finishes; some asphaltum-decorated sherds; and a partially restorable bone-tempered jar. Hester and Parker (ibid.) used a consistent format for describing each group. Other ceramic descriptions from south Texas are much less detailed and offer 1 ittle interpretive information (Creel et a 1. 1979, Live Oak County; Hester et a 1. 1977, J im We1 1 s County; Lynn, Fox, and O'Ma11ey 1977, Live Oak and McMul1en Counties). Hester (1980) provides a brief, updated summary of south Texas ceramics.

The 1 imitations of the ceramic descriptions from south Texas have also been noted for many of the plainwares described in Texas. Du 1 aney $(1977: 201)$ discusses the problem of "blurred distinctions" in Texas plainwares. He points out that this problem has most often been overcome, or perhaps 
ignored, by the use of "non-typological" approaches utilized by Story (1968), Hester and Parker (1970), Hester (1972), Fawcett (1976), Lynn, Fox, and O'Malley (1977), and Dulaney (1977). "Non-typological" descriptions are based on qualitative attributes determined by macroscopic and microscopic sherd examination. These attributes are used to define a number of categories of attribute groups. Once established, these groups can then be utilized for intersite and intrasite comparison. A major 1 imitation with "non-typological" studies is that the categories are, as Dulaney (ibid.:201) points out, "devoid of areal, temporal and spatial implications" That is to say, the sherds are sorted simply on the basis of appearance without regard to when or where a vessel was produced. In short, while "non-typological" studies have enabled some comparative studies, they serve only to describe the range or the variations of physical appearance. They te 11 us nothing (with the exception such as Story 1968) about where the ceramics were produced, about how they were produced, about when they were produced, or why they were produced. The categories based on subjective appraisal cannot be quantitatively demonstrated.

South Texas ceramics have not been subjected to the types of analysis which have 1 ong been utilized in other areas and are often considered basic (cf. Shepard 1976). These include petrographic examination, refiring tests, and a variety of recently developed or recently applied techniques termed "scientific analysis" by Peacock (1970). The value of such studies is not simply that it can be done--but rather that much more can be learned from the ceramics than is currently known. Among the techniques which have been successfully applied to ceramics are Differential Thermal Analysis (DTA), Atomic Absorbtion Spectrography (AAS), emission spectrography, $X-r a y$

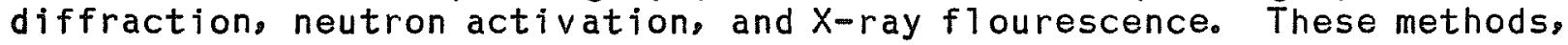
properly applied, can identify clay minerals, mineral inclusions, and minor and trace elements in the sherds, thus, providing clues to manufacturing localities and techniques.

Summarizing the avajlable background information on south Texas ceramics, bone-tempered pottery is known to occur across much of south Texas. Bonetempered pottery is associated with Late Prehistoric occupations and dates after A.D. 1200 at over 100 sites in south Texas according to Hester (1980:124). At many sites on 7 y a few sherds have been found, although sites yielding hundreds of sherds have been reported from several areas. South Texas bone-tempered pottery is usually undecorated, but incising, punctates, brushing, and asphaltum decoration have occasionally been reported. Vessel forms are restricted to simple functional forms (e.g., ollas, jars, and bow 7s). The method of manufacture is coil construction and presumably open firing at relatively low temperatures. The south Texas bone-tempered pottery tradition is believed to be 1 inked to a similar central Texas tradition commonly referred to as Leon P1ain (Hester and Hill 1971). Bone-tempered pottery a 1 so occurs in east Texas in the Caddoan area as we 11 as adjacent areas of Louisiana and Arkansas. It is possible that bone-tempered pottery making was introduced to south Texas from the east rather than from central Texas.

Along the south Texas Gulf coast, sandy paste ceramics known as Rockport wares (Campbe11 1962) are common. Rockport sherds have been found at several in 1 and sites such as the Berclair site (Hester and Parker 1970) and are 
usually cited as examples of coastal contact. Trade wares from distant regions have occasionaliy been found in south Texas. Huastecan ceramics have been found in extreme south Texas (MacNeish 1958). Mogollon ceramics have been found in Dimmit County (Hester and Hil1 1969). Southwestern ceramics have been found in Bexar County (Orchard and Campbel1 1959). These finds, although rare, clearly indicate some trade or indirect contact with cultures producing more sophisticated ceramics during the Late Prehistoric period.

\section{PHASE I CERAMIC ANALYSIS}

The Phase I ceramic analysis involved the examination of 576 ceramic fragments from 16 sites in the Choke Canyon Reservoir (B1ack 1982). The author began the Phase I ceramic analysis as a novice ceramist with an idealistic attitude toward solving the deficiencies in previous ceramic studies. A detailed research design was out 7 ined that emphasized a quantitative analysis. During the analysis the reality of working with small eroded plainware sherds caused the author to realize how unreal istic his initial research plans had been. The quantitative analysis was scraped in favor of a qualitative or "non-typological" descriptive analysis. A11 of the Phase I ceramics were examined macroscopically and microscopically and sorted into "site groupso"

Ideally, each site group would consist of sherds from a single vessel. Unfortunately, this is only possible if the ceramics are very well preserved. Most site ceramic collections evidence variable preservation. The tiny eroded sherds could rarely be sorted into discrete vessel groups. Hence, the site groups sometimes consisted of the sherds of a single vessel but more often consisted of sherds from several vessels with similar pastes and surface finishes. From one to seven site groups were defined for each of the Phase I sites containing ceramics. The ceramic collections from the sites with larger ceramic samples evidenced most of the variability noted for the entire collection.

The careful examination of the entire Phase I sample revealed considerable ceramic variation within relatively narrow limits. Virtually the entire sample consisted of bone-tempered ceramics (574 out of 576 fragments had bone temper). The ceramic fragments were attributed to 1 ocal1y produced pottery. Although no vessels were reconstructed, the vesse 1 fragments indicated that on 1y simple functional vessel forms were present. These forms included ol 1 as and bowls as well as occasional jars and pipe bowls. Considerable variation was noted in the paste content. Fine-grained pastes usually had more bone than did the sandy pastes. Sand was assumed to be an unintentional paste inclusion present in the natural clay sources in the area. Variation in sand grain size and morphology was attributed to differing clay sources. Although the ceramics were not 1 inked to specific clay source localities, most pastes were bel ieved to represent al luvial clay sources.

Except for the pipe bow1s, al1 vessel forms appear to have been made using coil construction techniques. The pipe bowls may have been made by the "pinch-pot" technique. The Phase I ceramics were al1 fired at relatively low temperatures. Fire clouds were common as was considerable variation in the degree of oxidation, the result of poorly controlled firing conditions. Most 
sherds have thick carbon streaks as the result of the firing conditions (10w temperatures and short duration).

Consistent patterns of surface finishing were observed. Most vessels had smooth, even exterior surfaces that had been burnished (polished). Most bowls also had smoothed and burnished interior surfaces. 011 as, probably the most numerous vessel form, had uneven poorly smoothed interior surfaces that were usually brushed while the clay was still wet. Surface finishes were often destroyed by postdepositional weathering and chemical corrosion or concealed by 7 ichen or calcareous coatings. Fine-grained pastes formed harder more durable burnished surfaces than did sandy pastes. A few sherds had sliplike thin coatings of fine-grained clay. Most of these were bel ieved to have been the result of surface floating and burnishing. One sherd had a definite applied slip composed of a fine clay that distinctly contrasted in color and texture from that of the paste matrix.

One surprising aspect of the Phase I ceramic analysis was the recognition of decoration on an estimated $18 \%$ of the vessels represented by the sherd sample. The major form of decoration was fugitive red filming. Fugitive red film is a thin ephemeral 7 ayer of red mineral pigment that was applied to the burnished exterior and interior (rare) surfaces of bow 7 forms. The pigment is an iron oxide mineral, probably earthy hematite (red ocher). Fugitive red filming had not been previously recognized in prehistoric contexts in south Texas, although the technique was known from mission Indian assemblages.

One Phase I sherd evidenced a second form of decoration, asphaltum banding. Asphaltum is more commonly associated with edge mending. A number of sites had sherds with traces of asphaltum along the sherd edges. Asphal tum was apparently used as a mending glue or waterproofing agent to repair cracked vesse 15. A simple chemical test, the "Lewis Method," was used to distinguish between asphaltum and other black coatings such as carbon sooting and other unidentified organic residues.

\section{CERAMIC TERMINOLOGY}

Ceramic analysis requires the understanding and use of a number of specialized terms and concepts which have been borrowed from other fields and used with specific meanings. One problem is that ceramic terminology has not been standardized; two researchers may use a single term to represent two different concepts (see Shepard 1976:365-368 for an excellent discussion of this problem). In an effort to clarify the meanings of many of the terms repeatedly used in this analysis the following definitions are provided. More detailed discussions of many of these terms or concepts can be found in Shepard (ibid.).

Burnishing The use of a hard tool such as a smooth pebble or a worn sherd to compact and polish a vessel surface. Burnishing is done when a vesse 1 is in a leather-hard state of drying. A fine clay and water solution may be used during the burnishing.

The fine clay may be the same clay in the paste or a different $c l$ ay which is referred to as a burnishing slip. A 
Core

Eloating

Eire Cloud burnished surface is smooth to the touch and has a luster or gloss. Functionally, a burnished surface strengthens the vessel and decreases the permeability (holds water longer).

The layer of unoxidized carbon usually visible in the cross section of a freshly broken sherd, also called the carbon streak. The core is often in the central portion of the cross section appearing as a noticeably darker color than the surface or near surface areas of the paste. The core may cover part or almost all of a cross section. Figure 94 shows the variations of core thicknesses common at Choke Canyon. Cores are usually centered but may be closer to the exterior or interior of a vessel wa11. A zoned core is one with distinct zonation in color.

The use of water or a paste slurry to bring the finer clay particles to the surface of a vessel. A floated surface has a thin layer of fine clay which often masks the temper particles just under the surface. This process is analogous to the final step of finishing concrete. A vessel surface is floated after the vesse 1 has been formed, shaped, and smoothed just before it is set aside to dry.

An unoxidized patch or cloud on a vessel surface caused during firing. The fire cloud results from 7 ack of oxygen and can be caused by direct contact of fuel against the vessel. Fireclouded surfaces have gray splotches or mottling on them. Fire clouding can be difficult to distinguish from soot on sma 11 sherds.

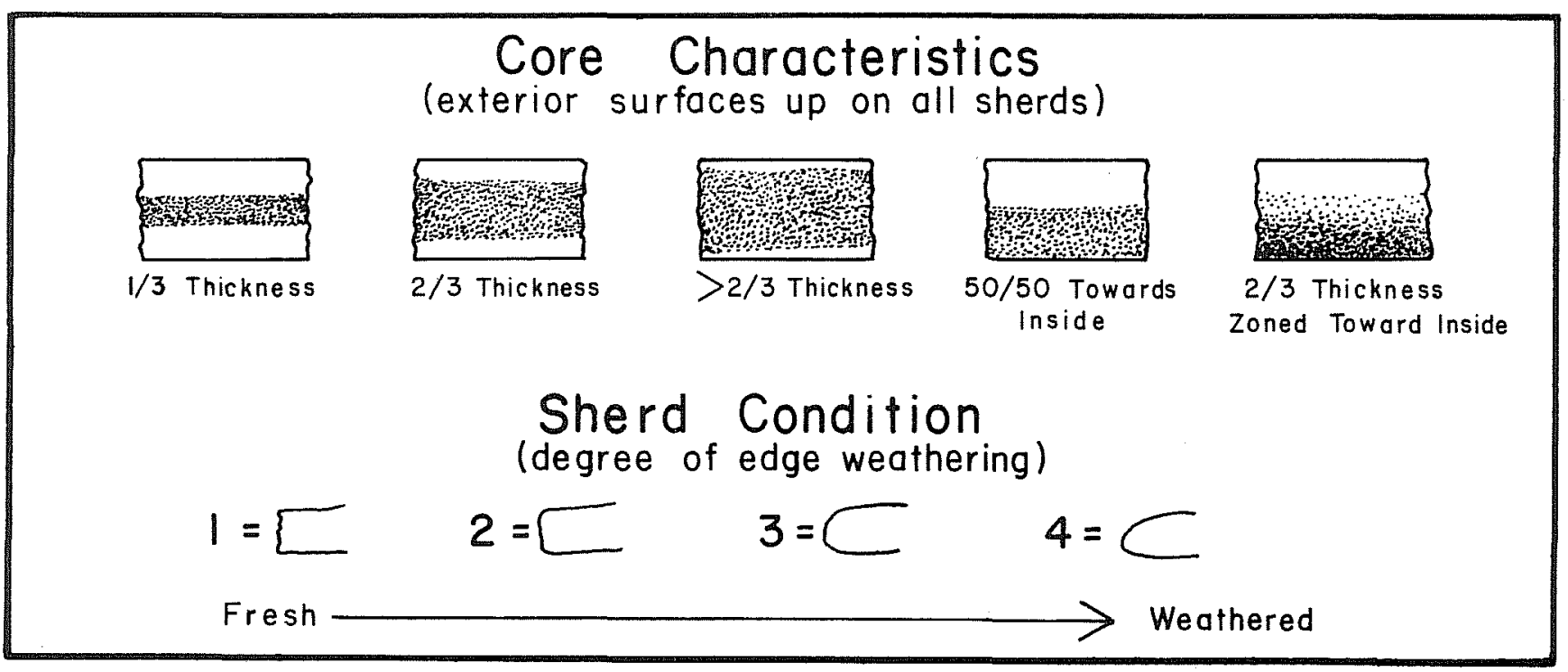

Figure 94. Core Characteristics and Sherd Condition of Prehistoric Ceramics. 
Oxidation

Paste

Paste

Inclusion

Rim

Slip

Smoothing

Sooting

Wet Brushing
To combine with oxygen. The carbonaceous matter in a ceramic paste needs oxygen in order to burn. An exidized vessel has absorbed the maximum amount of oxygen possible and contains no unburned carbonaceous materia 1. Iron compounds oxidize as we 11, and are very important in determining colors. We11oxidized vessels will have 1 ight clear colors such as red, tan, and orange.

The mixture of clay and temper used to form a vesse1. A paste may include a variety of constituents such as sand, clay, and silt. A compact paste has few visible pores. A porous paste has many visible pores. These terms are subjective as porosity is difficult to measure (Arnold 1975). A homogeneous paste is one in which the constituents are even ly distributed as opposed to a poorly mixed paste. In a convoluted paste, the constituents are aligned in folded irregular patterns. A patchy paste is one with distinct patches of untempered clay. The term fine-grained paste herein refers to the texture of the matrix to which the bone temper has been added. Since virtual1y a 11 the Nueces River project ceramics were bone tempered, bone was not considered in paste texture. See Shepard (1976:117-121) for an excel lent discussion of paste texture.

A nonclay constituent of a paste. A nonplastic inclusion is one that retains its structure when fired (e.g., bone or sand). A natural inclusion is one naturally present in the clay. Intentionally added inclusions are cal led temper.

The 1 ip or top edge of a vessel. A rim may be direct, tapered, tapered from the exterior ( $F$ ig. 95.b), tapered from the interior, thickened, or beveled.

A thin layer of fine clay particles applied to a vessel surface. Floating produces a self-slipped effect. A true slip is made from a different clay than used in the paste. A burnishing slip is a clay layer applied while polishing a surface.

The use of fingers or tools to make a vessel surface even. A wel1-smoothed surface has very even contours. A poorly smoothed surface has uneven, irregular contours.

Application of a thin layer of carbonaceous material on a vessel surface. Sooting can be intentional during firing or a by-product of cooking over an open fire. Sooting results in a black color which can be easily confused with fire clouding or asphaltum.

Use of a brushlike tool (possibly a frayed stick) to smooth the surface of a wet, freshly made vessel. This technique was frequently applied to the interior surfaces of Nueces River 

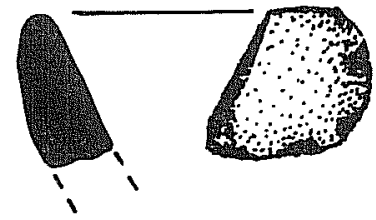

a

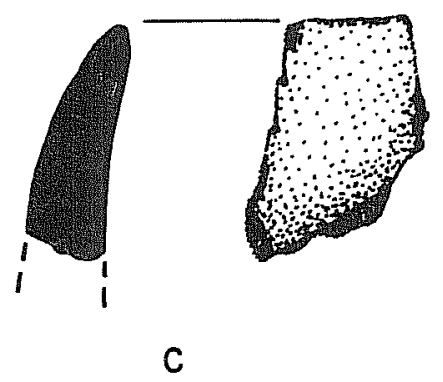

C

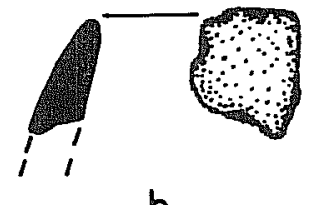

b

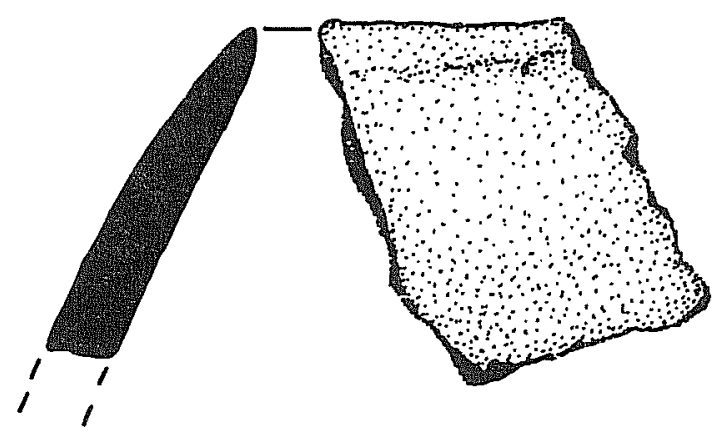

d
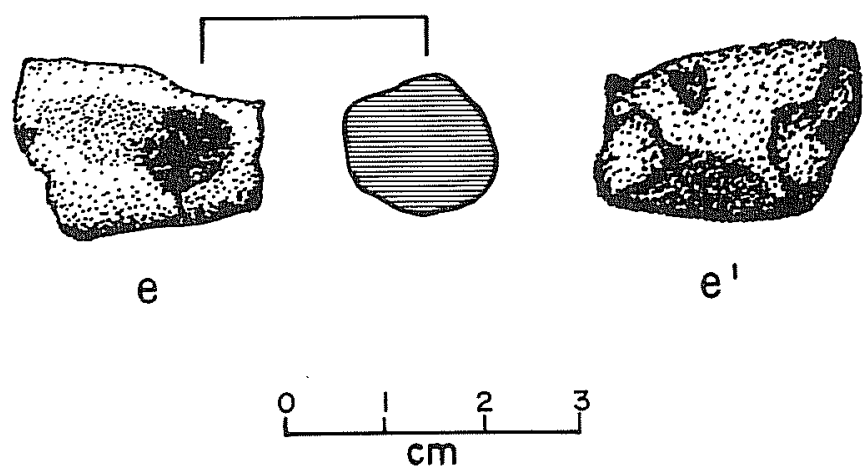

Figure 95. Rim Sherds and Figurine Fragment. a, rim sherd, Group 3 , 41 LK 51; b, rim sherd tapered from the exterior, Group I, 41 LK 74; c。 inverted rim bow 1, Group 1, 41 LK 185; d, closed rim (inverted) 1arge bow1, Group 10, 41 MC 55; e-e', figurine fragment, Group 17, 41 MC 55. 
vessels leaving a characteristic surface finish. The brush marks are usually parallel, but can be irregular.

\section{ATTRIBUTE CODING VALUES}

Numeric attribute coding was used during the Phase I analysis to simplify and standardize the descriptive process. The attribute coding values presented here are the same values used in Phase I except for the paste inclusion density values. During Phase $I$, five coding values ranging from very sparse (1) to very profuse (5) were used to estimate the density of each paste inclusion. Herein, as defined belows only three values are used. The simplification of the attribute coding speeds up the analysis and eliminates some inconsistency caused by narrowly defined limits. The attribute definitions and values presented below are applicable to bone-tempered ceramics from most areas of southern Texas.

\section{Momplastic Paste Inclusion Quantities or Density}

The Choke Canyon ceramics were quite varied in the density of nonplastic paste inclusions. This attribute was felt to be significant in distinguishing between paste or vessel groups. The density or relative frequency of paste inclusions in ceramics is a difficult attribute to quantify. The problems are analogous to those faced by sedimentologists and mineralogists trying to quantify particle or mineral composition frequencies. Most of the accurate methods are prohibitively time consuming and require special equipment. An alternative method which is less accurate, but much quicker is a visual comparison chart. Several methods of constructing visual comparison charts have been used, including the checkerboard method employed by Bennett (1974:105) and a more sophisticated method using irregular angu 1ar fragments (Terry and Chilingar 1955). The latter method is more realistic and contains both b lack fragments on a white background and white fragments on a black background. The comparison charts Terry and Chilingar illustrated were actually developed by a Russian sedimentologist, M. S. Shvetsov, and have been reproduced in readily accessible publications such as the American Geological Institute (A.G.I.) Sheets (No.6).

There are several problems inherent in estimating paste inclusion density which should be emphasized. Griffiths and Rosenfeld (1954) have clearly demonstrated that operator error is a significant concern in comparing this type of data. Different operators will estimate values differentiy and may consistentiy overestimate or underestimate. To verify the accuracy of the paste inclusion quantity estimate, it would be necessary to measure an operator's estimates against known values. This was not done with the Nueces River project ceramics. A further problem is that many sherd cross sections have a variety of color inclusions against a variety of background colors. Sand appears to be much harder to estimate than bone, perhaps because sand is often translucent or highly reflective. The paste inclusion quantity values should be regarded as relative estimates. Below are the percentage density ranges and Nueces River project values used to code this attribute. To reduce error, comparatively broad categories were selected. 
NUECES RIVER PROJECT CODING VALUES

PHASE I PHASE II

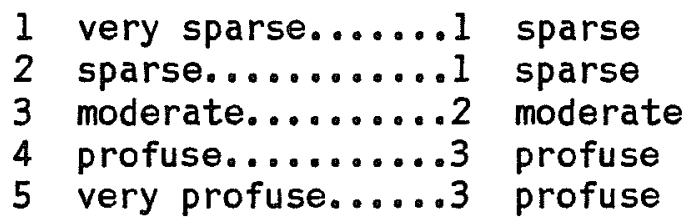

\section{Particle Shape or Degree of Roundness}

Considerable variation in sand grain shape was observed in the Choke Canyon ceramic collection. Sedimentologists have long been concerned with measuring sedimentary particle shape or rather sphericity or roundness. In general, given particles of similar hardness and minerology (quartz grains, for examp le) the greater the degree of roundness, the longer the distance the particle has been transported. The actual factors, which determine particle shape, are more comp 1 ex (A.G.I. Data Sheet 7); however, the size and degree of roundness in sand grains can indicate general depositional modes. A visual comparison chart (A.G.I. Data Sheet 7) was used to estimate particle shape or sphericity. Table 30 shows the correlation of terms with the Nueces River project shape values.

\section{Particle Sizes}

Particle size of nonplastic paste inclusions such as sand, bone, and hematite was determined by use of a micrometer installed in one of the lox eyepieces in the 01 ympus variable power binocular microscope. The micrometer was calibrated for 30X. Al1 measurements were taken at this magnification. Wentworth's size classification system (Shepard 1976:118) was used for a particle size scale as shown in Table 31 . The most visible particles observed in the ceramic cross sections ranged from very fine to very coarse and were coded numerically for convenience.

TABLE 30. ROUNDNESS OF SEDIMENTARY PARTICLES

Descriptive Term Shape Values

$\begin{array}{ll}\text { Very Angular } & - \\ \text { Angular } & 1 \\ \text { Subangular } & 2 \\ \text { Subrounded } & 3 \\ \text { Rounded } & 4 \\ \text { Well Rounded } & 5\end{array}$


TABLE 31. WENTWORTH'S SIZE CLASSIFICATION

Descriptive Term Diameter Limits Size Classes

Pebble

Granular

Very Coarse

Coarse

Medium

Fine

Very Fine

Silt

$\begin{array}{rr}64-4 \mathrm{~mm} & - \\ 4-2 \mathrm{~mm} & - \\ 2-1 \mathrm{~mm} & 5 \\ 1-0.5 \mathrm{~mm} & 4 \\ 0.5-0.25 \mathrm{~mm} & 3 \\ 0.25-0.125 \mathrm{~mm} & 2 \\ 0.125-0.062 \mathrm{~mm} & 1 \\ 0.062-0.0039 \mathrm{~mm} & -\end{array}$

\section{PHASE II METHODOLOGY}

The experience gained during the Phase I ceramic analysis enabled the author to simplify the analysis and reduce the amount of time necessary to examine the samp le. To begin with, it was recognized that the examination of very small eroded sherds provides very little analytical data. In fact, smali poorly preserved sherds can on ly provide data on the paste characteristics. The Phase I examination provided an adequate expectation of paste characteristics. The decision was made to examine only the sherds with comparatively wel 1-preserved surfaces. This effectively eliminated most of the smaller sherds. In addition, in cases where the ceramic sample from a site contained many sherds that appeared identical (i.e., from the same vesse1), only two or three of the best preserved sherds from an identical group were chosen for analysis. Using these criteria, each site collection was examined macroscopically, and a "select" sample was chosen. Thus, 77 sherds were selected for analysis from the total sample size of 574 .

The select sample contained examples of all of the macroscopically distinctive sherd groups. All rim sherds, decorated sherds, and appendages were examined. The intent was to examine a sample of all vessels represented by the collection without examining each sherd. In cases where the author was uncertain whether a 11 vesse 1 groups from a site were sampled or where the visible variation was suspected to represent differential preservation or firing conditions of a single vessel, additional sherds were examined, just to be sure. It should be emphasized that this sampling procedure may not be advisable for inexperienced analysts who are examining assemb 1 ages from unstudied areas.

Each sherd from the select sample was examined using a routine procedure. A. 1 though the sherds had been washed during the 1 aboratory processing some still had encrusted soil, lichen, or calcareous coatings. An ultrasonic cleaner was used to clean these sherds. A dilute solution of warm water and detergent specifically designed for ultrasonic cleaners adequately removed the encrusted material from most sherds after about 15 minutes of ultrasonic vibration. Ultrasonic cleaning may not remove all foreign coatings and may 
have an adverse effect on fugltive red filming, however, it is far superior to hand washing.

Each sherd was first examined macroscopically. A 1 ight rubbing with a soft rag was used to enhance the surface luster of burnished sherds. Burnishing and wet brushing were best seen macroscopically by holding the sherd at ob 1 ique angles to a bright incandescent 1 ight source. Burnishing or surface polish is easily weathered especially on sandy paste ceramics. After a brief macroscopic examination, each sherd was examined with a variable power binocular microscope. Both surfaces of a sherd were examined for details not seen macroscopically such as traces of fugitive red film or asphaltum. The best results were obtained by first using 10 power $(7 X)$ to scan and then "zooming up" to higher powers $(30-80 X)$ to look more closely at areas of interest.

After the sherd surfaces had been examined, each sherd was broken to obtain a fresh paste exposure. Slip-joint pliers with padded grips were used to break the sherds that could not be snapped by hand. The act of breaking the sherds provided information about the paste composition that was invariably confirmed by microscopic examination. Fine-grained compact pastes with bone temper were usually much harder to break than porous sandy paste sherds. In addition, sandy paste sherds usually crumbled while sherds with fine-grained pastes broke cleanly. Large inclusions such as small pebbles or chunks of hematite, usually caused the sherd to break at the inclusion.

The fresh breaks were then examined microscopically: first under low power for overall inclusion density and paste characteristics and then under higher power for detail and particle size. The particle sizes and paste texture were always evaluated at 30x. A consistent setting allowed easy comparison of sherds and simplified use of the micrometer. A micrometer was installed in the left eyepiece. Eyepiece micrometers must be calibrated for each power setting. At 30X, fine silt particles (less than $0.0156 \mathrm{~mm}$ ) are not visible, while coarse silt particles $(0.031-0.0625 \mathrm{~mm})$ are distinguishable. Sand grains are easily visible at 30x. With practice, one can determine particle sizes reasonably accurately at a quick glance without reference to the micrometer. It is usually on ly necessary to determine the predominate particle size range. Bone particle size was not determined during Phase II as the Phase I analysis had revealed that bone temper invariably consists of a wide range of particle sizes. Occasional sherds had uniform bone particle size as is noted in the site group descriptions. Magnification up to $80 x$ was used to examine unusual paste constituents.

A simple coding system was used to record information for each sherd. In addition to the attribute coding values already described, the vessel fragment and surface finishes were coded. The exact codes used are unimportant; a value was assigned for each attribute variation that was recorded. For example, the exterior surface finish was recorded as 1 (unburnished), 2 (1ightly burnished), or 3 (highly burnished); most sherds could be placed in one of these categories. A similar approach could be used with any ceramic assemblage using values appropriate to the problems under consideration. Using this system most sherds could be described with single digit codes for nine attributes: exterior finish, decoration, interior finish, vessel thickness, vessel fragment, paste matrix, bone, sand, and other 
inclusions. In addition, any significant variation not described by the attributes was noted. Thus, the major differences noted within the select sample were recorded on a few sheets of paper and could be easily compared. These sheets provided information used in the group descriptions.

After the select sherds had been examined and coded, the select sample sherds from each site were reexamined and $p l$ aced into site groups. The select sherd sample from sites that had been previously analyzed during Phase I were compared to the Phase I site group examples from the Nueces River Project Comparative Ceramic Collection. Some Phase II sherds could be assigned to the Phase I site groups. In the remaining cases, additional site groups were established for each distinctive sherd group with in the ceramic collection from each Phase II site. As was the case in Phase I, some sites had discrete groups that could be attributed to single vessels. At other sites, poor preservation or large heterogeneous ceramic collections made it difficult to distinguish individual vessel groups.

After the select sample had been sorted, the remaining sherds from each site were macroscopically compared to the new 1 y estab 1 ished site groups. The total sample size for each group was estimated. At some sites, such as 41 MC 296, the groups were distinctive enough so that the estimated sample sizes are very accurate. At other sites, such as 41 MC 55, the site groups were so numerous and similar that many tiny eroded sherds could not be associated with the defined groups.

Below, the site groups for each site are described using a slightly revised format from Phase I. Phase I site groups for each revisted site are briefly discussed. More complete site group descriptions are only repeated for Phase I site groups that were recognized in the Phase II collection.

\section{SITE GROUP DESCRIPTIONS}

\section{LK I4}

Total number of sherds: 7, Phase I; 21, Phase II.

Phase II select sample size: 6.

Phase II provenience: Controlled subsurface.

General discussion: Two groups of burnished bone-tempered ceramics were defined from the Phase I collection. More samples of both groups were recovered during Phase II. Revised descriptions of these groups are presented. A third group was defined from Phase II sherds. The remaining four sherds are tiny and very weathered. Additional vessels may be represented by these eroded sherds. 
41 LK 14 Group 1 (thick-walled, flat-bottomed burnished bowl)

Estimated sample size: 5, Phase I; 8, Phase II (2 select sample).

Vessel fragments: Body.

Sherd thickness: $\quad 0.6-0.9 \mathrm{~cm}$.

Sherd condition: $\quad 1-3$; varies.

Exterior surface: Smooth, floated, and burnished, temper-free surface; light brown to gray (clouded).

Interior surface: Partially smoothed and burnished; reddish 1 ight brown.

Paste matrix: $\quad$ Coarse silty paste; slightly porous.

Core: $\quad>2 / 3$ thickness.

Paste inclusions: $\quad$ Bone: quantity $=2$.

Sand: quantity $=1$; size $=2-3$; shape $=2-4$.

Other: occasional quartzite and hematite.

Estimated number of vessels:

1.

Comments:

Based on sherd morphology, Group 1 appears to represent a medium-sized bow1. The bow 1 had a flat bottom, fairly thick wa $17 \mathrm{~s}$, and a very we 11-finished exterior.

41 LK 14 Group 2 (thin-walled, burnished)

Estimated sample size: 2, Phase I; 5, Phase II (I select sample).

Vessel fragments: Body.

Sherd thickness: $\quad 0.5 \mathrm{~cm}$.

Sherd condition: $\quad 3$; weathered.

Exterior surface: Smoothed, floated, and highly burnished.

Interior surface: Smoothed; poorly preserved.

Paste matrix: Very fine, homogeneous paste.

Core: $\quad 2 / 3$ thickness; offset toward interior.

Paste inclusions: Bone: quantity $=3$. 
Estimated number of vesse1s:

1.

41 LK 14 Group 3 (sandy paste, poorly preserved)

Estimated sample size: 4; (1 select sample).

Vesse1 fragments: Body.

Sherd thickness: $\quad 0.7 \mathrm{~cm}$.

Sherd condition: $\quad 3$; weathered.

Exterior surface: Poorly preserved; red brown.

Interior surface: Poorly preserved; red brown.

Paste matrix: Sandy, porous paste.

Core: $\quad 1 / 3$ thickness; oxidized by exposure(?).

Paste inclusions: Bone: quantity $=2$.

Sand: quantity $=3$; size $=2-4$; shape $=2-3$.

Other: hematite pebble.

Estimated number of

vessels:

1.

Comments:

Poorly preserved group.

\section{1_K 51}

Total number of sherds: 51, Phase I; 41, Phase II.

Phase II

select sample size: 12.

Phase II provenience: Controlled subsurface.

General discussion: Two groups were defined from Phase I surface collections. The Phase II sherds do not fit the Phase I groups. Three additional groups are defined. Most Phase II sherds belong to Group 3. From the total site ceramic collection six groups are defined. Most groups have sandy pastes. A minimum of eight vessels contributed sherds to the 41 LK 51 collection. 


\section{LK 51 Groups 1 and 2}

See Phase I report (B1ack 1982:417-419) for descriptions of Groups 1 and 2.

41 LK 51 Group 3 (coarse sandy paste, thick-walled bow 1)

Estimated sample size: 31 (6 select sample).

Vessel fragments: Body and a rim sherd (Fig. 95,a).

Sherd thickness: $\quad 0.6-0.9 \mathrm{~cm}$.

Sherd condition: $\quad 1-3$; varies.

Exterior surface: Smooth, even, and 7ightly burnished; brown.

Interior surface: Wet brushed, even; brown with fire clouds.

Paste matrix: Coarse, porous sandy paste; many inclusions.

Core: Variable.

Paste inclusions: $\quad$ Bone: quantity $=2$.

Sand: quantity $=3 ;$ size $=3-5$; shape $=2-4$.

Other: occasional hematite chunk.

Estimated number of vessels:

1.

Comments:

This group probably represents a 1 arge bow 1 with thick wal is and a tapered rim.

41 LK 51 Group 4 (sparsely tempered, burnished)

Estimated sample size: 3 (1 select sample).

Vessel fragments: Body.

Sherd thickness: $\quad 0.7 \mathrm{~cm}$.

Sherd condition: 2.

Exterior surface: Well-finished burnished surface; light tan.

Interior surface: Uneven, wet brushed; gray tan.

Paste matrix: Coarse silty and fine sandy paste; sparsely tempered.

Core: $\quad 2 / 3$ thickness; light gray. 


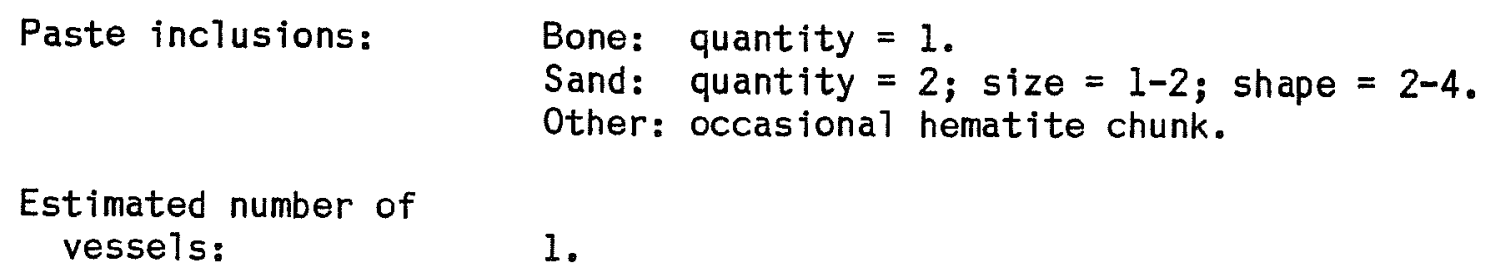

41 LK 51 Group 5 (miscellaneous thin-walled, bone-tempered)

Estimated sample size: 7 (4 select sample).

Vesse1 fragments: Body.

Sherd thickness: $\quad 0.5-0.6 \mathrm{~cm}$.

Sherd condition: $\quad 2$.

Exterior surface: Even, smooth, and burnished; well finished; tan to red tan.

Interior surface: Uneven, poorly smoothed; some wet brushed; some clouded; gray to tan.

Paste matrix: Fine to coarse silty paste; profuse temper.

Core: $\quad>2 / 3$ thickness.

$\begin{array}{ll}\text { Paste inclusions: } & \text { Bone: quantity }=3 \text {. } \\ & \text { Sand: quantity }=1 \text {; size and shape vary. }\end{array}$

Other: occasional hematite chunk.

Estimated number of vesse15:

2-4.

Comments:

Catch-a 11 group of sherds from several vessels with similar pastes and surfaces.

\section{LK 74}

Total number of sherds: 33, Phase II.

Phase II select sample size: $\quad 9$.

Provenience: Controlled subsurface.

General discussion: The ceramics from 41 LK 74 are very well preserved. Two distinctive vessel groups are defined. 


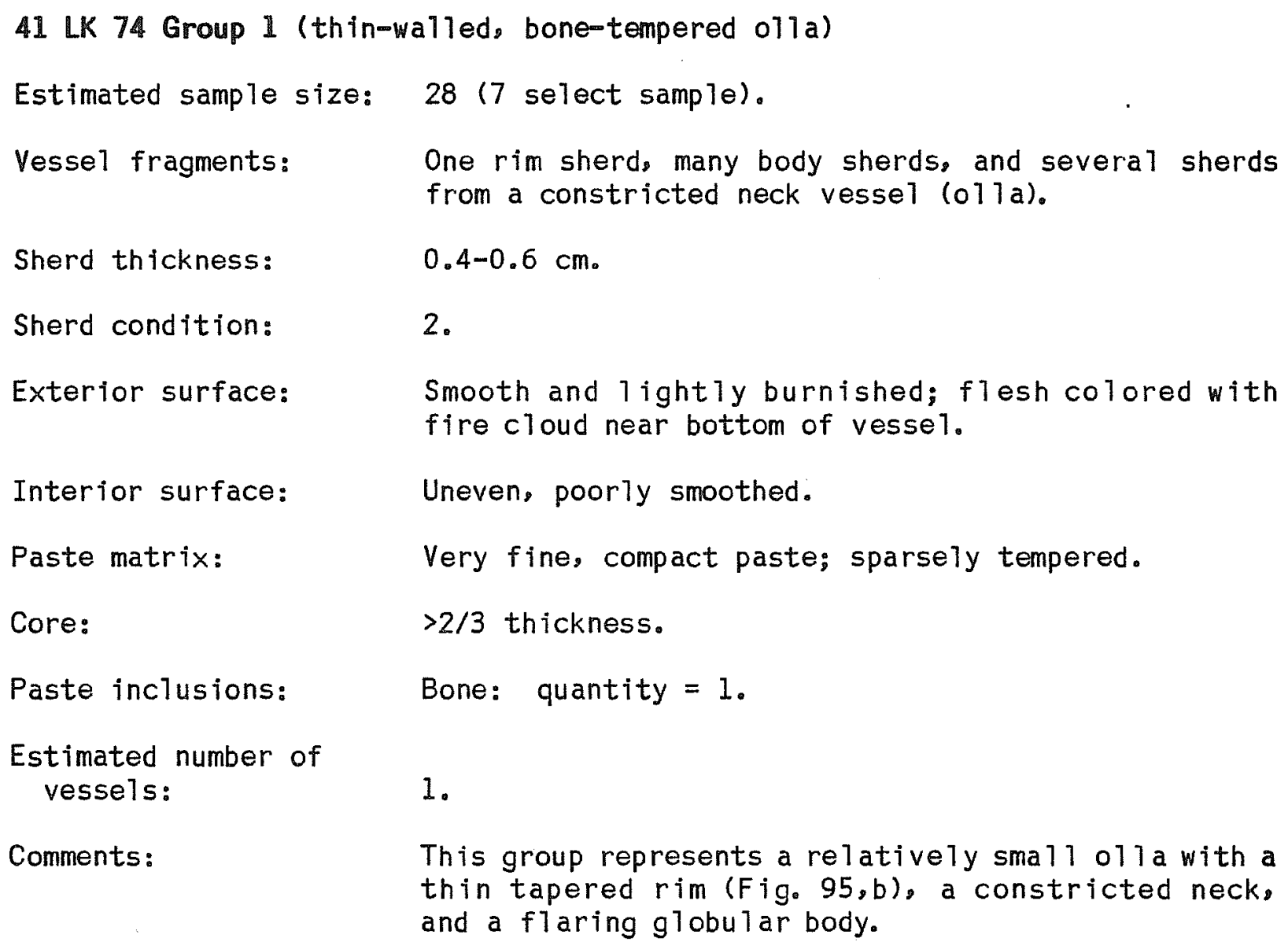

41 LK 74 Group 2 (sandy paste with sparse bone)

Estimated sample size: 5 (2 select sample).

Vessel fragments: Body.

Sherd thickness: $\quad 0.6 \mathrm{~cm}$.

Sherd condition: $\quad 1$.

Exterior surface: Smooth, even, and lightly burnished; some burnishing marks visible; brown with fire clouds.

Interior surface: Rough texture; wet brushed; unusual bright red color.

Paste matrix: Very homogeneous, porous sandy paste.

Core: $2 / 3$ thickness.

Paste inclusions: Bone: quantity $=1$ (very sparse).

Sand: quantity $=2 ;$ size $=2-3 ;$ shape $=1-2$.

Other: occasional hematite fragment. 
Estimated number of
vessels:

Comments:
1.

This group has an unusual paste and interior surface. The homogeneous angular sand suggests an upland clay source. This is a unique group in the Nueces River project collection and may be from outside the local area.

\section{LK 128}

Total number of sherds: 5, Phase II.

Phase II select sample size: 3 .

Provenience:

General discussion:
3. controlled surface; 2, control 1ed subsurface.

A 11 the sherds from 41 LK 128 are from a single vesse1.

41 LK 128 Group 1 (fugitive red and asphaltum decorated)

Estimated sample size: 5 (3 select sample).

Vessel fragments: Body.

Sherd thickness: $\quad 0.5-0.7 \mathrm{~cm}$.

Sherd condition: $\quad 1-2$; some 1 ichen.

Exterior surface: Even, smooth, floated, and burnished; fugitive red film and asphaltum decoration; tan with red and black.

Interior surface: Smooth, slightly uneven; gray tan.

Paste matrix: Very fine, compact, durable paste; well fired.

Core: $\quad>2 / 3$ thickness.

Paste inclusions: $\quad$ Bone: quantity $=2$; finely crushed.

Estimated number of vessels: 1 .

Comments:

This group represents a single vesse1, probably a we 17-made bow 1. The bow 1 originally had a strikingly decorated exterior with a bright red background and jet black designs. 


\section{LK 185}

Total number of sherds: 2, Phase II.

Phase II

select sample size: 1 .

Provenience:

General discussion:
Controlled surface.

One sherd is a well-preserved rim sherd, while the other is a poorly preserved body sherd. The pastes are similar, although the surfaces look different. Onty one group is defined.

41 LK 185 Group 1 (inverted rim bow T)

Estimated sample size: 2 ( 1 select sample).

Vessel fragments: One body and one rim sherd.

Sherd thickness: $\quad 0.3-0.7 \mathrm{~cm}$.

Sherd condition: $\quad 1$ and 3 .

Exterior surface: Smooth but uneven; 1ightly burnished around rim; red $\tan$.

Interior surface: $\quad$ Smooth but slightly uneven; cloudy tan to gray.

Paste matrix: Coarse silty paste with very fine sand.

Core: $\quad 2 / 3$ thickness; zoned toward inside.

Paste inclusions: $\quad$ Bone: quantity $=2$.

Sand: quantity $=2$.

Other: hematite patches (soft hematite) common.

Estimated number of vessels:

1.

Comments:

The rim sherd (Fig. 95,C) suggests a strongly inverted bow 1 form (tapered rim with a closed opening).

\section{LK 243}

Total number of sherds: 8 , Phase II.

Phase II

select sample size: 3. 
Provenience:

General discussion:
Controlled surface.

Three distinct groups are defined. A11 groups have sandy porous pastes. The clay sources are obviously different as the colors are very distinct between groups.

41 LK 243 Group 1 (sandy paste with bone temper)

Estimated sample size: 5 (1 select sample).

Vessel fragments: Body.

Sherd thickness: $\quad 0.5 \mathrm{~cm}$.

Sherd condition: $\quad 2-3$.

Exterior surface: Smooth, even, and 1 ightly burnished; flesh tan with 1 ight gray streak.

Interior surface: Wet brushed; light tan.

Paste matrix: Sandy, porous paste.

Core: $\quad 1 / 3$ thickness.

Paste inclusions: $\quad$ Bone: quantity $=2$.

Sand: quantity $=3 ;$ size $=2-4 ;$ shape $=2$.

Estimated number of vessels:

1.

41 LK 243 Group 2 (weathered, sandy paste)

Estimated sample size: 2 (1 select sample).

Vessel fragments: Body.

Sherd thickness: $\quad 0.8 \mathrm{~cm}$.

Sherd condition: 3 .

Exterior surface: Even with a rough texture; gray tan.

Interior surface: Even with a rough texture; fire clouded.

Paste matrix: Sandy, porous paste.

Core: $\quad>2 / 3$ thickness. 
Paste inclusions:

Estimated number of vesse15:

Comments:
Bone: quantity $=2$.

Sand: quantity $=3$; size (most $1-2$, occasional 5$)$; shape $=2$.
1.

Unusual surface finish. The edges are not too badly weathered, but the surfaces are as rough as sandpaper.

41 LK 243 Group 3 (red brown, sandy paste)

Estimated sample size: 1 ( 1 select sample).

Vessel fragments: Body.

Sherd thickness: $\quad 0.7 \mathrm{~cm}$.

Sherd condition: $\quad 3$; lichen.

Exterior surface: Smoothed and probably burnished; dark red brown.

Interior surface: Smoothed and probably burnished; brown.

Paste matrix: Sandy, porous paste.

Core: 2/3 thickness.

Paste inclusions: $\quad$ Bone: quantity $=2$.

Sand: quantity $=3 ;$ size $=1-4 ;$ shape $=2-3$.

Other: small hematite particles.

Estimated number of vessels:

1.

\section{MC 55}

Total number of sherds: 16, Phase I; 197, Phase II.

Phase II select sample size: 21 .

Provenience:

16. surface; 181, controlled subsurface.

General discussion:

Seven bone-tempered groups were defined during Phase I. Two of these were decorated; one with an asphaltum band and one with fugitive red. The large Phase II ceramic sample represents at least 10 additional vessel groups. Despite careful 
comparison, no examples of the Phase I groups were found among the Phase II ceramics.

The 10 vessel groups defined from the Phase II sample are three sandy paste groups, two asphaltum decorated groups, and five bone-tempered groups with coarse silt or fine pastes. Several unusual pastes are present including a clay-tempered paste, a hematite/silt paste, and a paste dominated by rounded coarse sand. One sandy paste ceramic appendage is believed to be a figurine fragment.

The most striking aspect of the total 41 MC 55 ceramic collection is the diversity. At least 18 separate ceramic objects ( 17 vessels and the figurinel contributed ceramic fragments to the collection. Many of the Phase II sherds are smal1 weathered fragments. Based on the diversity observed in the select sample, it is probable that additional vessels may be represented by the unexamined Phase II sherds. Because of the poor condition of many Phase II ceramic fragments not selected for analysis and the difficulty of distinguishing between groups lacking good surface preservation, no attempt was made to estimate the sample size of each group.

Several trends were noted in the 41 MC 55 ceramic collection. Most vessel groups had fine to coarse silty pastes; sandy pastes were less common (5 out of 17). Asphaltum decoration occurs on sherds from three groups.

\section{MC 55 Groups 1-7}

See Phase I report (B1ack 1982:431-434) for descriptions of Groups 1-7.

41 MC 55 Group 8 (asphaltum decorated, bone-tempered)

Estimated sample size: ? (1 select sample).

Vessel fragments: Body.

Sherd thickness: $\quad 0.6 \mathrm{~cm}$.

Sherd condition: 2 .

Exterior surface: $\quad$ Smootho slightly uneven; possibly burnished; with aspha 1 tum band at 1 east $0.5 \mathrm{~cm}$ wide; gray tan with black. 


\begin{tabular}{|c|c|}
\hline Interior surface: & Smooth; gray (clouded). \\
\hline Paste matrix: & Coarse silty paste. \\
\hline Core: & $>2 / 3$ thickness; offset toward interior. \\
\hline Paste inclusions: & Bone: quantity $=3$ \\
\hline
\end{tabular}

41 MC 55 Group 9 (burnished, bone and clay tempered olla)

Estimated sample size: At least several dozen; ( 7 select sample).

Vesse 1 fragments: Several neck sherds and many body sherds.

Sherd thickness: $\quad 0.4-0.5 \mathrm{~cm}$.

Sherd condition: $\quad 2-3$; generally well preserved.

Exterior surface: Well finished; smooth, even, and burnished; buff with clouding.

Interior surface: Unusual; uneven, irregular lumpy surface; bone and clay chunks protrude; looks 1 ike pulverized clay added to interior surface during construction; buff to buff pink with dark fire clouds.

Paste matrix:

Fine matrix with profuse bone and untempered clay chunks.

Core:

$>2 / 3$ thickness.

Paste inclusions: $\quad$ Bone: quantity $=3$.

Other: untempered clay chunks: quantity $=2$; size $=$ 4-5.

Estimated number of vessels:

Comments:
7.

Unusual group. A11 sherds appear to represent a single 011 a. The untempered clay is an unusual paste inclusion. The clay chunks are finer in texture and different in oxidized color than the paste matrix. This suggests that the clay chunks represent added temper. Very fine clay chunks without sand suggest an upland clay source. The clay was probably collected in a solidified form and pulverized. Some sherds are much better finished on the interior; these probably represent neck sherds. 
41 MC 55 Group 10 (bone-tempered, inverted rim bow 1)

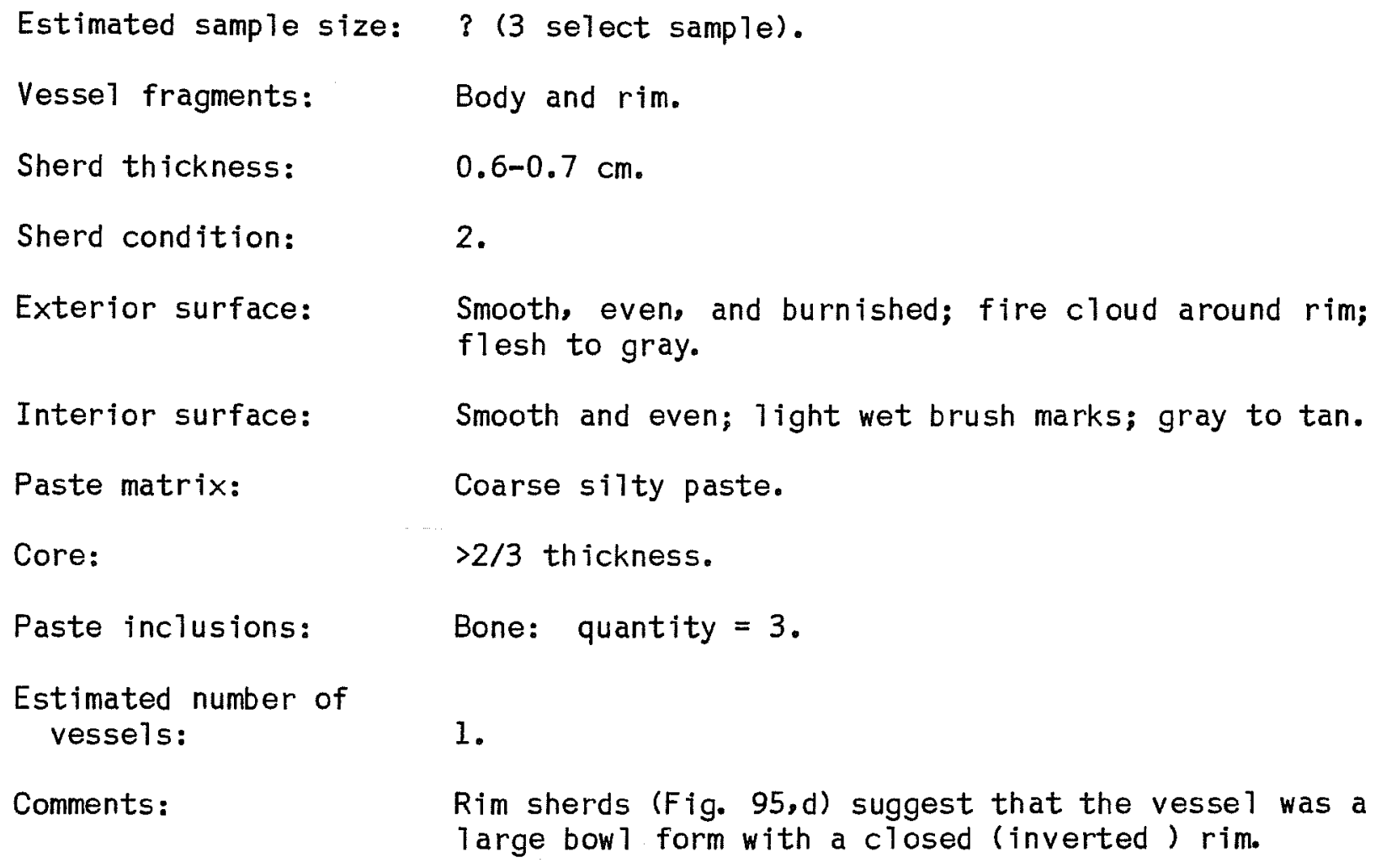

41 MC 55 Group 11 (bone-tempered, burnished with sooted interior)

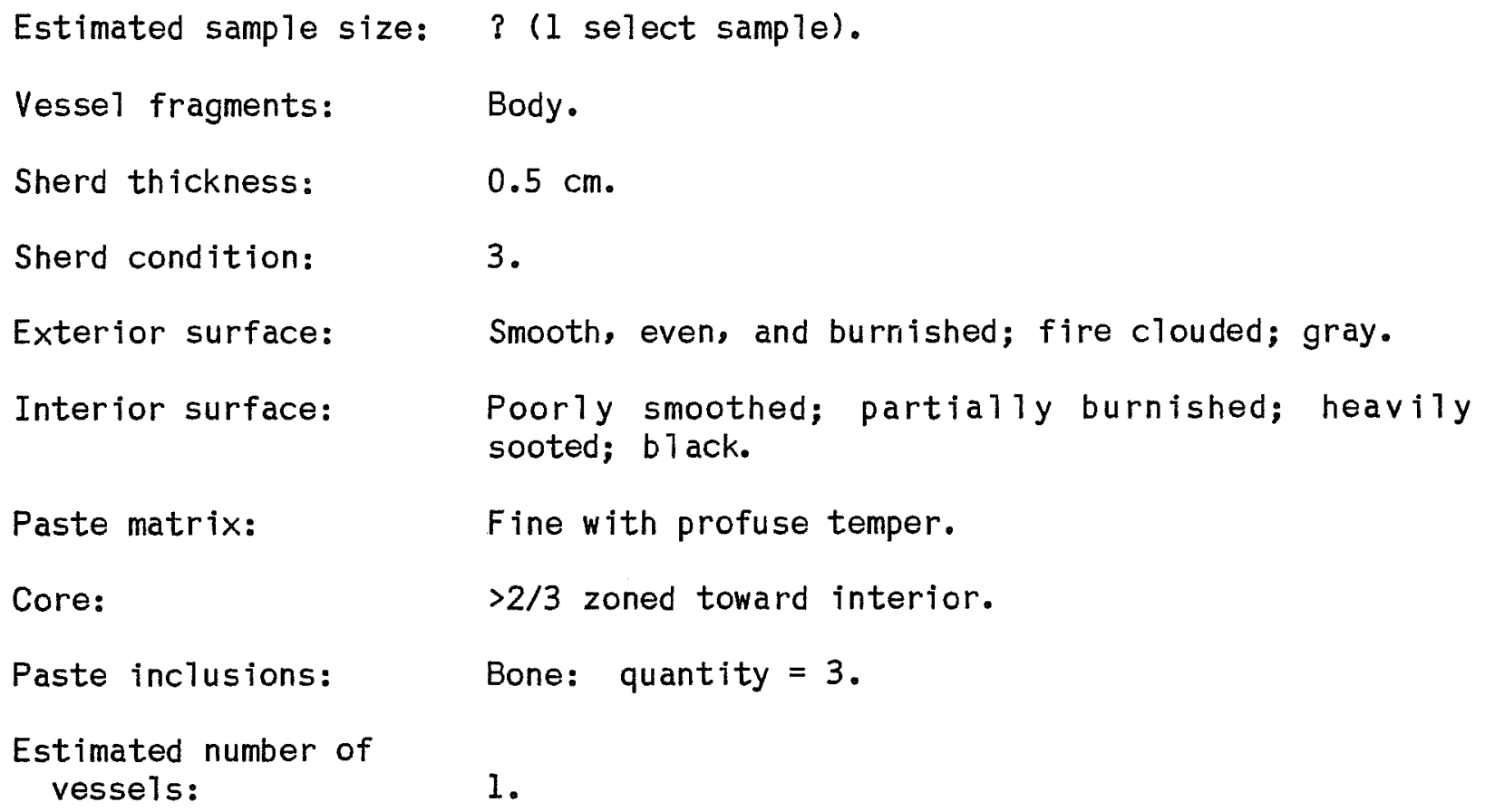


41 MC 55 Group 12 (sparsely tempered with uneven walls)

Estimated sample size: ? (3 select sample).

Vesse1 fragments: Body.

Sherd thickness: $\quad 0.5-0.9 \mathrm{~cm}$.

Sherd condition: 2.

Exterior surface: Smooth and well finished but uneven; burnished; tan.

Interior surface: Uneven; wet brushed; clouded; gray.

Paste matrix: $\quad$ Coarse silt with very fine sand; sparsely tempered.

Core: $\quad>2 / 3$ thickness; offset toward interior.

Paste inclusions: Bone: quantity $=1$.

Sand: quantity $=2 ;$ size $=1-2 ;$ shape $=1-2$.

Estimated number of vesse7s:

1.

Comments:

This vessel had a very uneven wall thickness with variable curvature. The poorly finished, oxidized interior suggests an olla form.

41 MC 55 Group 13 (bone-tempered with asphaltum decoration)

Estimated sample size: ? (2 select sample).

Vessel fragments: Body.

Sherd thickness: $\quad 0.6 \mathrm{~cm}$.

Sherd condition: $\quad 2-3$; variable.

Exterior surface: Smooth, even, and burnished; asphaltum band at least

$0.7 \mathrm{~cm}$ wide; gray to $\tan$ with black.

Interior surface: $\quad$ Even with protruding sand and 1 arge bone chunks.

Paste matrix: Coarse silt.

Core: $\quad>2 / 3$ thickness.

Paste inclusions: $\quad$ Bone: quantity $=2$.

Sand: quantity $=1 ;$ size $=4-5$; shape $=4-5$.

Other: occasional hematite. 
Estimated number of vesse1s: 1.

41 MC 55 Group 14 (burnished with hematite/silt paste)

Estimated sample size: ? (l select sample).

Vessel fragments: Body.

Sherd thickness: $\quad 0.5 \mathrm{~cm}$.

Sherd condition: 2 .

Exterior surface: Smooth, even, and partial1y burnished; burnish marks prominent; gray brown with red.

Interior surface: Wet brushed and streaked with occasional burnish marks; gray brown with red.

Paste matrix: Coarse silt with abundant hematite.

Core: $2 / 3$ thickness offset toward exterior.

Paste inclusions: $\quad$ Bone: quantity $=3$.

Sand: quantity $=1 ;$ size $=4-5$; shape $=2-3$.

Other: hematite throughout paste; finely pulverized to coarse chunks.

Estimated number of vessels:

1.

Comments:

Unusual paste. The paste has so much hematite that the uneven 1 y burnished surfaces look like fugitive red $f i l m$ ware.

41 MC 55 Group 15 (coarse sandy paste, burnished)

Estimated sample size: ? (1 select sample).

Vessel fragments: Neck.

Sherd thickness: $\quad 0.5-0.8 \mathrm{~cm}$.

Sherd condition: 2 .

Exterior surface: Smooth, even, and burnished; gray brown.

Interior surface: Smooth and burnished; red brown.

Paste matrix: Coarse sandy. 
Core:

Paste inclusions:

Estimated number of vesse1s:

Comments:

\section{$>2 / 3$ thickness.}

Bone: quantity $=1$.

Sand: quantity $=3 ;$ size $=3-5 ;$ shape $=3-5$.

1.

Unusual coarse sandy paste with rounded clear sand grains. The paste had enough fine clay to al low floated and well-finished surfaces. The sherd has a double curvature that suggests it represents a neck sherd from an $011 \mathrm{a}$.

41 MC 55 Group 16 (fine sandy paste with thick walls)

Estimated sample size: ? (l select sample).

Vessel fragments: Body.

Sherd thickness: $\quad 0.8-1.2 \mathrm{~cm}$.

Sherd condition: $\quad 3$.

Exterior surface: Smooth and even; weathered; light tan.

Interior surface: Uneven and wet brushed; light tan.

Paste matrix: Fine sandy paste with profuse temper.

Core:

$1 / 3$ thickness; 1ight gray; probably sun bleached.

Paste inclusions: Bone: quantity $=3$.

Sand: quantity $=3 ;$ size $=1-3 ;$ shape $=1-2$.

Estimated number of vessels:

1.

\section{MC 55 Group 17 ( $f$ igurine fragment)}

A sma 11 fragment of a modeled figurine was recovered (Fig. 95,e,e'). The object measures $2.8 \times 1.9 \times 1.4 \mathrm{~cm}$. It has a $\mathrm{flattened} \mathrm{cy} 7$ indrical shape with an oval cross section. The thick end of the object has been broken. The opposite end is more rounded but could al so be broken. The surface of the fragment has been smoothed but not burnished. Several indentations, a short groove, and several shaped depressions are apparent. When the object is viewed from certain directions the modifications look vaguely 1 ike zoomorphic features (head, eyes, and snout?). The object appears to be a section of a figurine. 
Surface:

Paste matrix:

Paste inclusions:

Comments:

\section{MC 222}

Total number of sherds: 47, Phase I; 159+, Phase II.

Phase II select sample size: 4

Provenience:

General discussion:

4.

Controlled subsurface.
Smooth with modifications; fire clouded; brown with b lack.

Sandy paste with no visible bone.

Sand: quantity $=3 ;$ size $=1-3 ;$ shape $=2-4$.

Very unusual ceramic object.
The Phase II ceramic collection represents the same vessel groups as those defined from the Phase I collection. This is the on $7 y$ revisited site that did not produce new groups. The fact that on $7 y$ four groups have been defined after extensive collection and excavation suggests that on $7 y$ a 1 imited number of vessels were discarded and/or broken at the site. In comparison with other excavated site ceramic assemblages, such as 41 LK 41 (Phase I), 41 LK 201 (Phases I and II), and 41 MC 55 (Phases I and II), the 41 MC 222 ceramic collection suggests a 1 imited occupation by ceramic using peoples.

Most of the Phase II sherds are from Group 3. Several sherd concentrations were uncovered. Two 1 arge sections of the vessel were restored. Unfortunately, both are body sections from a large $011 \mathrm{a}$, hence they provide comparatively little data on vessel form. The Phase I group descriptions for Groups 1, 2, and 4 remain unchanged and are on $7 y$ briefly summarized below. A revised description is provided for Group 3.

Six Phase II sherds fit Group 1 as defined from Phase I. Group 1 is made up of two subgroups, IA and 1B. Both are from a thin-walled, profusely bone-tempered bow 1. Group IB sherds had traces of fugitive red on the interior as well as some purple and gray stains that may represent some sort of organic or mineral pigment design. Both subgroups are quite likely from a single vessel. The paste has a silty matrix with frequent inclusions such as hematite, caliche(?), untempered clay, and sandstone as well as bone and some sand. The paste was poorly 
mixed, the large inclusions created weak spots along which the vessel broke. The exterior surface was variably finished from poorly smoothed to partially burnished with some fire clouding. The interior was similar and had faint wet brush marks.

Three Phase II sherds are from Group 2 as defined from Phase I. Group 2 represents a thick-walled sandy paste vessel very different from Group 1. The paste has a porous sandy texture with a coating of very fine silty dust over most sand particles. The exterior surface is smoothed and was probably burnished although, as with most sandy paste vessels, the surface is eroded. The interior is smoothed. Fire clouds are common on the exterior and rare on the interior. The unclouded surfaces are reddish 1 ight brown. The vessel was quite large and may have been an $011 \mathrm{a}$, although no form diagnostic sherds were recovered.

None of the Phase II sherds fit Group 4. Group 4 contained two fired clay 1 umps that may be accidently fired, as they are obviously not from a vesse1.

41 MC 222 Group 3 (bone-tempered olla) Revised Description

Estimated sample size: 4, Phase I; 150t, Phase II (3 select sample).

Vessel fragments: Body and basal.

Sherd thickness: $\quad 0.5-0.7 \mathrm{~cm}$.

Sherd condition: $\quad 1-3$.

Exterior surface: Smoothed, floated, and lightly burnished; the contours are more even than the interior but undulate; gray with fire clouding.

Interior surface: Wet brushed; irregular with some smoothed patches; gray with fire clouds.

Paste matrix:

Variable (poorly mixed), coarse silt/fine sandy with occasional inclusions in addition to bone and sand.

Core:

Varies.

Paste inclusions: $\quad$ Bone: quantity $=3$.

Sand: quantity $=1-2 ;$ size $=1-2 ;$ shape $=1-2$.

Other: occasional hematite and clay chunks. 
Estimated number of
vessels:

Comments:

\section{M 275}

Total number of sherds: 65, Phase II.

Phase II

select sample size: 4 .

Provenience:

Controlled surface; sherds were found in a single cluster.

General discussion: The sherd cluster represents a single vessel. Group 1 is a thick-walled sandy paste vessel similar to many other vesse1s represented by the Choke Canyon ceramic collection.

41 MC 275 Group 1 (thick-walled with sandy paste)

Estimated sample size: 65 (4 select sample).

Vesse1 fragments: Body.

Sherd thickness: $\quad 0.8-0.9 \mathrm{~cm}$.

Sherd condition: $\quad 3-4$.

Exterior surface: Smooth, even, very fine burnished surface; 1 ight brown with fire clouds.

Interior surface: Uneven, rough textured; red brown.

Paste matrix: $\quad$ Fine sand with sparse bone temper.

Core: Varies. 
Paste inclusions:

Estimated number of vesse1s:

Comments:
Bone: quantity $=1$.

Sand: quantity $=3 ;$ size $=1-3$ with occasiona 15 ; shape $=2$.
1.

A 11 sherds are from a single fairly 1 arge vessel, possibly an 011 a. The large collection illustrates the variable preservation problem. Only a very few of the sherds have a preserved exterior surface showing that the vessel had a thin, floated, very fine burnished finish. Most sherds have the eroded exterior that is typical of most sandy paste sherds from Choke Canyon.

\section{MC 293}

Total number of sherds: 1, Phase II.

Phase II

select sample size: 1.

Provenience:

Surface.

General discussion: A single undistinctive sherd.

41 MC 293 Group 1 (coarse silt/fine sandy paste)

Vesse1 fragment: Body.

Sherd thickness: $\quad 0.7 \mathrm{~cm}$.

Sherd condition: 2.

Exterior surface: Even, smooth, and burnished; gray with fire clouds.

Interior surface: Uneven, partially smoothed; tan to gray tan.

Paste matrix: $\quad$ Coarse silt and very fine sand.

Core: $\quad>2 / 3$ of fset toward exterior.

Paste inclusions: $\quad$ Bone: quantity $=2$.

Sand: quantity $=3 ;$ size $=1$; shape $=2$.

Estimated number of vessels:

1.

Comments:

This sherd is probably from an olla. 


\section{MC 294}

Total number of sherds: I, Phase II.

Phase II

select sample size: $\quad 1$.

Provenience: Surface.

General discussion: A single, poorly preserved sherd.

41 MC 294 Group 1 (eroded, sandy paste)

Vessel fragment: Body.

Sherd thickness: $\quad 0.8 \mathrm{~cm}$.

Sherd condition: $\quad 4$.

Exterior surface: $\quad$ Eroded; smoothed and probably burnished; red brown.

Interior surface: Same as exterior except gray (clouded).

Paste matrix: Sandy, porous.

Core: $\quad 2 / 3$ offset toward interior.

Paste inclusions: $\quad$ Bone: quantity $=2$.

Sand: quantity $=3$; size $=3-5 ;$ shape $=3-5$.

Estimated number of vessels:

1.

\section{MC 296}

Total number of sherds: 41, Phase II.

Phase II select sample size: 11.

Provenience:

Controlled subsurface.

General discussion:

The 41 sherds recovered from 41 MC 296 constitute a very unusual ceramic assemb 1 age for the Choke Canyon area. The occurrence of six fragments believed to be figurines is particularly unique. Single examples of ceramic figurine fragments were also recovered from $41 \mathrm{MC} 55$ (this volume) and 41 LK 67 (Chand 1 er 1978, 1982b). The appendage fraciments from 41 MC 296 represent four different objects. Unfortunately, none of the objects are complete 
enough to allow reconstruction of the completed form.

Another interesting aspect of the collection is the occurrence of grog temper and a unique mineral temper, hematite and chalk(?). The presence of so many unusual ceramic attributes in such a small collection combined with the absence of common attributes such as fugitive red filming and asphaltum suggests that the group responsible for the collection was different from the groups that produced most of the ceramics at Choke Canyon. The basic ceramic technology is stil1 bone-tempered plainwares, however, many differences are present. The unusual nature of the collection may be explained by the suggestion that 41 MC 296 had a historic Indian component (see site discussion of 41 MC 296 in this volume).

\section{MC 296 Group 1 (grog tempered)}

Estimated sample size: 16 (2 select sample).

Vesse1 fragments: Body.

Sherd thickness: $\quad 0.6-0.7 \mathrm{~cm}$.

Sherd condition: 2.

Exterior surface: Sightiy uneven, poorly smoothed, partially burnished; tan.

Interior surface: Uneven and rough textured; tan.

Paste matrix: Coarse silt/sand with grog and sparse bone.

Core: Varies.

Paste inclusions: $\quad$ Bone: quantity $=1$.

Sand: quantity $=2 ;$ size $=2-3$; shape $=2-3$.

Other: one whole juvenile land snail (Mesodon sp.?). Large grog (crushed sherd) chunks occur in variable quantities. Some sherd breaks do not show grog. Grog is sandy and does appear to have bone temper.

Estimated number of vessels:

Comments:
1.

Grog temper is unique in the Choke Canyon ceramic collection. 
41 MC 296 Group 2 (bone and hematite temper)

Estimated sample size: 1 (I select sample).

Vessel fragments: Body.

Sherd thickness: $\quad 0.5 \mathrm{~cm}$.

Sherd condition: $\quad 2$.

Exterior surface: Smooth, even burnished with traces of hematite; brown with red.

Interior surface: $\quad$ Smooth with visible smoothing marks; gray (clouded).

Paste matrix: $\quad$ Sandy with hematite and bone.

Core:

$>2 / 3$ offset toward interior.

Paste inclusions:

Bone: quantity $=1-2$.

Sand: quantity $=3 ;$ size $=2-4$; shape $=2-3$.

Other: fine hematite particles throughout paste, one snail fragment.

Estimated number of vessels:

1.

Comments:

The exterior seems to have traces of fugitive red filming. However, with the amount of hematite in the paste, the apparent filming may simply have been formed by polishing a surface with protruding hematite particles.

41 MC 296 Group 3 (thick-walled with silty paste)

Estimated sample size: 7 (3 select sample).

Vessel fragments: Body.

Sherd thickness: $\quad 0.8-0.9 \mathrm{~cm}$.

Sherd condition: $\quad 2$.

Exterior surface: Smooth, even, and burnished; tan.

Interior surface: Uneven and burnished; gray (clouded).

Paste matrix: $\quad$ Coarse silt with little sand.

Core: $\quad>2 / 3$ of fset toward interior. 
Paste inclusions: $\quad$ Bone: quantity $=2$.

Other: one snail fragment.

Estimated number of

vessels:

1.

Comments:

The burnishing on both surfaces suggests a bow 1 form.

41 MC 296 Group 4 (hematite and chalk tempered)

Estimated sample size: 11 (1 select sample).

Vesse1 fragments: Body.

Sherd thickness: $\quad 0.8-0.9 \mathrm{~cm}$.

Sherd condition: 2 .

Exterior surface: Smooth, even, and burnished; gray with sooting.

Interior surface: $\quad$ Slightly uneven and burnished; gray tan with black.

Paste matrix: Coarse silt with pulverized hematite and chalk(?); gray tan.

Core: $\quad>2 / 3$ thickness.

Paste inclusions: $\quad$ Bone: quantity $=3$.

Sand: very little.

Other: hematite and chalk; quantity $=1-2 ;$ size $=1-$ 3.

Estimated number of vessels:

1.

Comments:

Unique paste. The apparent chalk particles are bright white with very fine structure (no visible lamination or cell structure). The composition is unknown but is not shel1 or bone. It appears to be some type of minera1, perhaps chalk. Pulverized chalk and hematite occur throughout the paste.

Appendages:

Six fragments of ceramic appendages were recovered from 41 MC 296. These fragments are very different from any others found except as noted above. Due to the unusual nature of these artifacts they were not broken to examine the paste. They are described in four groups believed to represent four separate objects. 
41 MC 296 Group 5 (incised appendage with green mineral stain)

Sample:

Dimensions:

Surface:

Paste matrix:

Core:

Comments:
2 fragments, Lot 163; 1 fragment, Lot 185.

Largest fragment measures $3.0 \times 1.2 \times 1.0 \mathrm{~cm}$.

Smooth with many narrow incised 1 ines; gray tan with pink tinge and green discoloration near tip of largest fragment.

Based on surface, very fine sand with occasional coarse we11-rounded grains.

Thick, dark core.

The largest fragment is shaped roughly 1 ike a cornucopia (Fig. 96, $f, f^{\prime}$ ). The thick end is broken. The curving thin end forms a comparatively sharp point. A turquoise green stain is present on the first 2-3 mm of the tip. This substance appears to be a mineral pigment, possibly a copper mineral. The stain could have resulted from contact with copper or brass. This stain was carefully examined microscopically. It appears to be embedded in the pores of the surface and does not appear to be recently added or of some modern material (plastic, etc.).

A few millimeters further from the tip and extending to the break are a series of rough $7 y$ parallel zigzag 1 ines. These 7 ines are very tiny (ca. $0.01 \mathrm{~mm}$ ) and must have been executed with a very fine device, such as a cactus spine, while the clay was wet. The 1 ines are 1-4 $\mathrm{mm}$ apart and form a consistent pattern that varies on $7 y$ in spacing and angle of zigzag. Some adjacent lines are parallel, others zig while opposite 1 ines zag.

One of the smaller fragments was recovered with the larger fragment but does not fit. It has a series of paral le 1 -incised 1 ines, but they do not zigzag (Fig. 96,e). The third fragment has a rounded end that shows fire clouding. The opposite end is broken and has traces of three incised 1 ines (Fig 96,b, $\left.b^{\prime}\right)$. The paste is identical to other fragments except several tiny hematite fragments were observed. The broken edge seems to curve as if the fragment was protruding from a 1 arger mass at an angle. 


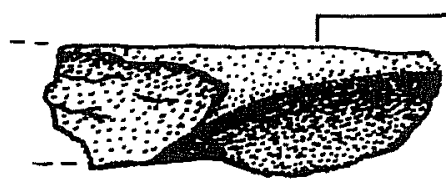

a

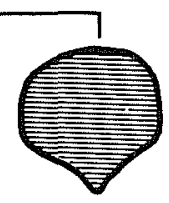

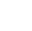
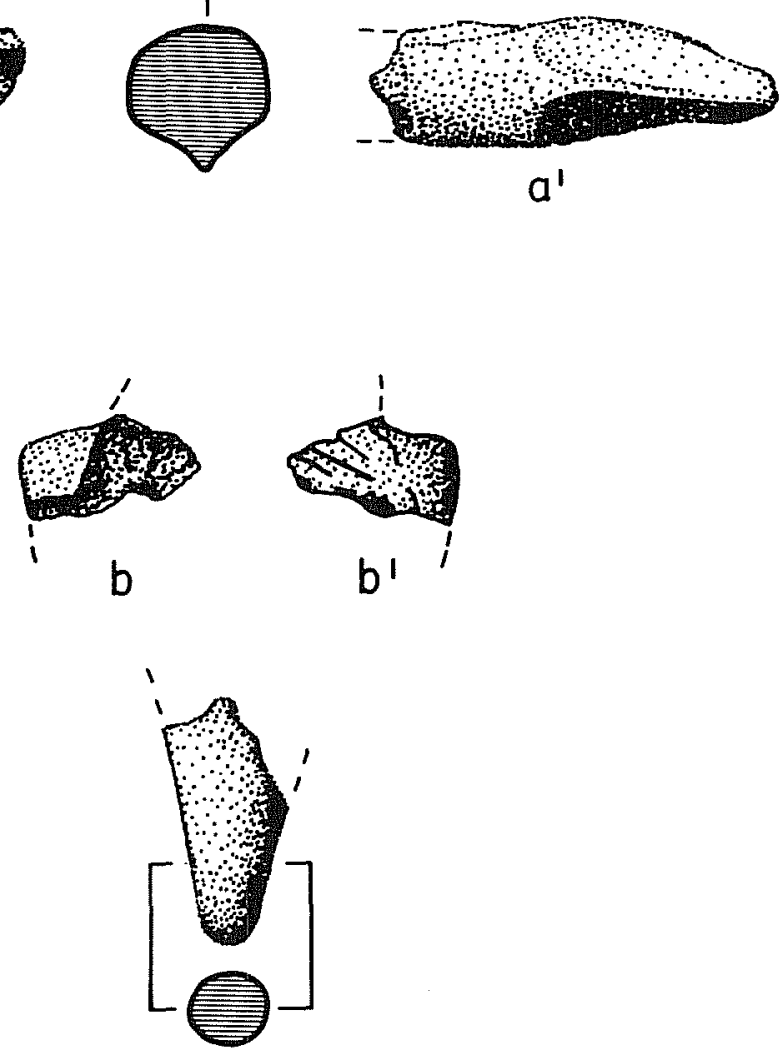

C

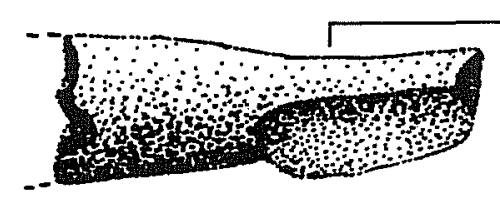

d

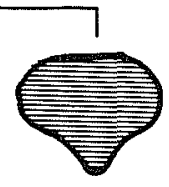

$f$

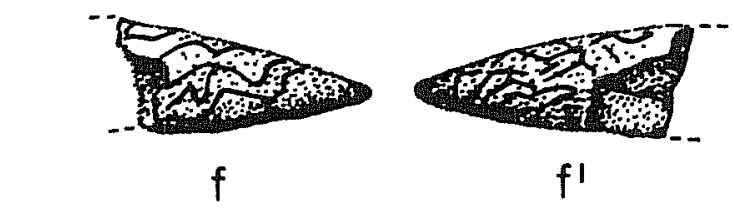

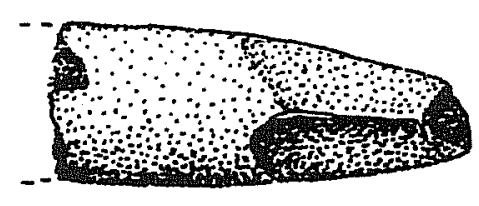

d'
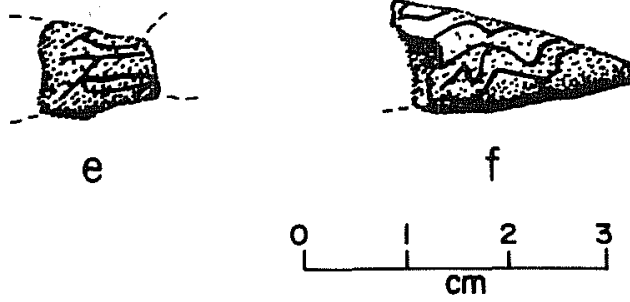

Figure 96. Figurine Fragments from 41 MC 296. a, a', Group 6, 41 MC 296, Lot 139; b, b', Group 5, 41 MC 296, Lot 185; c, Group 7, 41 MC 296, Lot 184; d,d', Group 8, 41 MC 296, Lot 141; e, Group 5, 41 MC 296, Lot 163; fof', Group 5, 41 MC 296, Lot 163. 
41 MC 296 Group 6 (pinched appendage with rounded end)

Samp 1e:

Dimensions:

Surface:

Paste matrix:

Core:

Description:
1 fragment, Lot 139.

$4.0 \times 1.6 \times 1.2 \mathrm{~cm}$.

Smooth but uneven; light tan with fire cloud.

Based on surface, very fine sand with occasional coarse-rounded grains.

Thick core with cracking in center of core.

Cy 1 indrical form with a pinched and rounded end (Fig. 96,a, $\left.a^{\prime}\right)$. The thick end is broken. The smaller end is rounded and is wedge shaped due to pinch on one edge. Similar to Group 6 specimen and could be from same artifact (probably not).

41 MC 296 Group 7 (pinched appendage with blunt end)

Sample:

Dimensions:

Surface:

Paste matrix:

Core:

Description:
1 fragment, Lot 184.

$4.3 \times 1.7 \times 1.5 \mathrm{~cm}$.

Smooth and carefully shaped; tan to gray; some dark gray stains which were not removed in ultrasonic cleaner; could be organic residue.

Based on surface, very fine sand with occasional hematite particle.

Thick core with cracking in center of core and some hol low voids ( $p$ lant fragment casts?).

Cylindrical form with a pinched and truncated blunt end (Fig. 96,C). The thick end is broken. The smaller end is rounded and is wedge shaped due to pinch on one edge. Similar to Group 5 specimen and could be from same artifact (probably not).

41 MC 296 Group 8 (blunt-pointed appendage)

Sample:

Dimensions:

Surface:

Paste matrix:
I fragment, Lot 141 .

$2.4 \times 1.2 \times 1.0 \mathrm{~cm}$.

Smooth; gray (clouded).

Based on surface, very fine sand. 
Core:

Description:
Thick dark core with some hollow voids (plant fragment casts?).

Different form from other appendages with a blunt pointed end (Fig. 96,d, d'). The thick end is broken. The smalier end is rounded and blunt and less smooth than other surface.

\section{ABORIGINAL CERAMICS--SLMMARY AND INTERPRETATIONS}

The remainder of this section will offer an interpretative summary of the aboriginal ceramics of the Choke Canyon Reservoir area. This summary is based on a 11 of the prehistoric ceramics recovered by the CAR-UTSA in the reservoir area including the Phase I collection (Black 1982), the Phase II collection, and the 41 LK 201 collection (Phase II and UTSA Summer Field School; Highley 1986). The total number of ceramic fragments recovered from a 11 of these investigations is 2346 .

Table 32 1ists a 11 the ceramic site groups that have been defined by the CARUTSA projects at Choke Canyon. The table summarizes some of the major ceramic attributes. A careful examination of Table 32 reveals several inconsistencies between the ceramic total presented above and some of the individual site group descriptions from Phase I (B1ack 1982). These inconsistencies are due to the fact that not a 11 of the Phase II ceramics were $\mathrm{placed}$ in site groups (tiny eroded sherds at several sites were disregarded) and also due to new information. For examp 7 e, 41 MC 222 Group 3 was originally estimated to represent two vessels (B1ack 1982:439). The Phase II collection showed that Group 2 actualiy represented a single vessel with considerable variation, hence Table 32 gives a vessel count of one for the group. Thus, Table 32 gives the final interpretation of a few key attributes on al 1 aboriginal ceramics recovered to date by the CAR-UTSA during the Choke Canyon Reservior project (some ceramics were recovered by the THC survey; Lynn, Fox, and O'Mal1 1ey 1977).

The various percentages of attribute variation that are given in the following section are based on Tab 1e 32. A minimum of 115 ceramic objects (vesse1s, pipe bow 1s, and figurines) are represented by the total collection. Note this does not include the miscel 1 aneous fired clay 1 umps that were recovered from several sites (4I LK 41 and 41 MC 222). Each percentage given is based on the proportion of the number of vessels that have a given attribute. For examp 1e, $76 \%$ of the vesse 1 s represented by the collection have burnished surfaces ( 88 out of 115).

\section{Choke Canyon Ceramic Technology}

The prehistoric ceramics recovered from the Choke Canyon Reservoir area during Phases I and II of the Nueces River project offer a look at technological aspects of pottery making along the lower Frio River drainage during the Late Prehistoric period. These observations are applicable to much of south and possibly central Texas. Viewed as a group, the ceramic collection 
exemp 1 ifies the widespread bone-tempered pottery tradition defined by Hester and Hill (1971). Crushed bone in varying amounts was added to almost every vessel represented by the collection. The majority of the sherds represent vessels made by coil construction techniques. With the exception of a few figurine fragments, the sherds represent a 1 imited range of functional forms such as ollas, bowls, jars, bottles, and pipe bowls. Surface treatment techniques were varied; but, in general, exterior surfaces were well smoothed and burnished while the interior surfaces were predictably less smooth, and usually brushed. Thus, in general terms, the ceramics are very similar. However, when one considers the specific combinations of attributes, the homogeneous picture gives way to a view of considerable variation within relatively restricted 1imits. The variety of combinations of paste, paste inclusions, surface finish, and firing conditions strongly suggests a widespread regional ceramic tradition in which bone temper seems to be the only mandatory ingredient in an otherwise flexible recipe. Specific aspects of the pottery making tradition merit individual discussion.

\section{Paste Composition and Inclusions}

Microscopic examination of fresh sherd breaks (cross sections) revealed considerable variation in paste characteristics. Paste in the collection ranges from highly compact homogeneous mixtures which were well fired (1 ight clear colors) to very friable porous heterogeneous mixtures which were incompletely fired, resulting in thick dark cores and dark, cloudy surface colors. This range in paste characteristics can be attributed to different clay sources, amounts of added temper, degrees of paste constituent admixture, and firing conditions.

Paste inclusions can be divided into unintentional or natural inclusions and intentional1y added inclusions or temper. Unintentional inclusions are those nonplastic (and a few plastic) paste constituents which naturally occur in the clay (e.g.s sand) or those accidentally mixed into the paste (e.g.s fragments of crushing tools). The intentional inclusions are bone, grog, untempered clay (in chunk form), hematite, and in a few cases, possibly sand. Each paste inclusion observed in the Choke Canyon ceramics will be discussed.

\section{Bone}

Crushed bone was added to all ceramic fragments with only a few exceptions. The amount of bone ranges from very sparse to very profuse. Particle size ranges from minute, very fine particles to granular particles measuring up to 4 or $5 \mathrm{~mm}$ in diameter. Bone comes in a variety of colors and shapes, a fact that has probably caused inexperienced archaeologists to misidentify bone. Bone may be black, gray, blue, brown, and white with many variations in hue. A1 1 of these colors may appear within a single sherd cross section.

Bone also comes in a myriad of shapes. Some fragments are 1ong, 1 ayered splinters, and some are amorphous chunks. Thin layers of bone and tiny holes are the most common bone structures visible. The thin parallel layers are known as "circumferential lamellar bone" which forms in the cortex of long bone. The tiny holes are osteoclasts which are filled in during the growth 
TABLE 32. CHOKE CANYON ABORIGINAL CERAMICS--SITE GROUP SUMMARY

Key Explanations to Attribute Codes

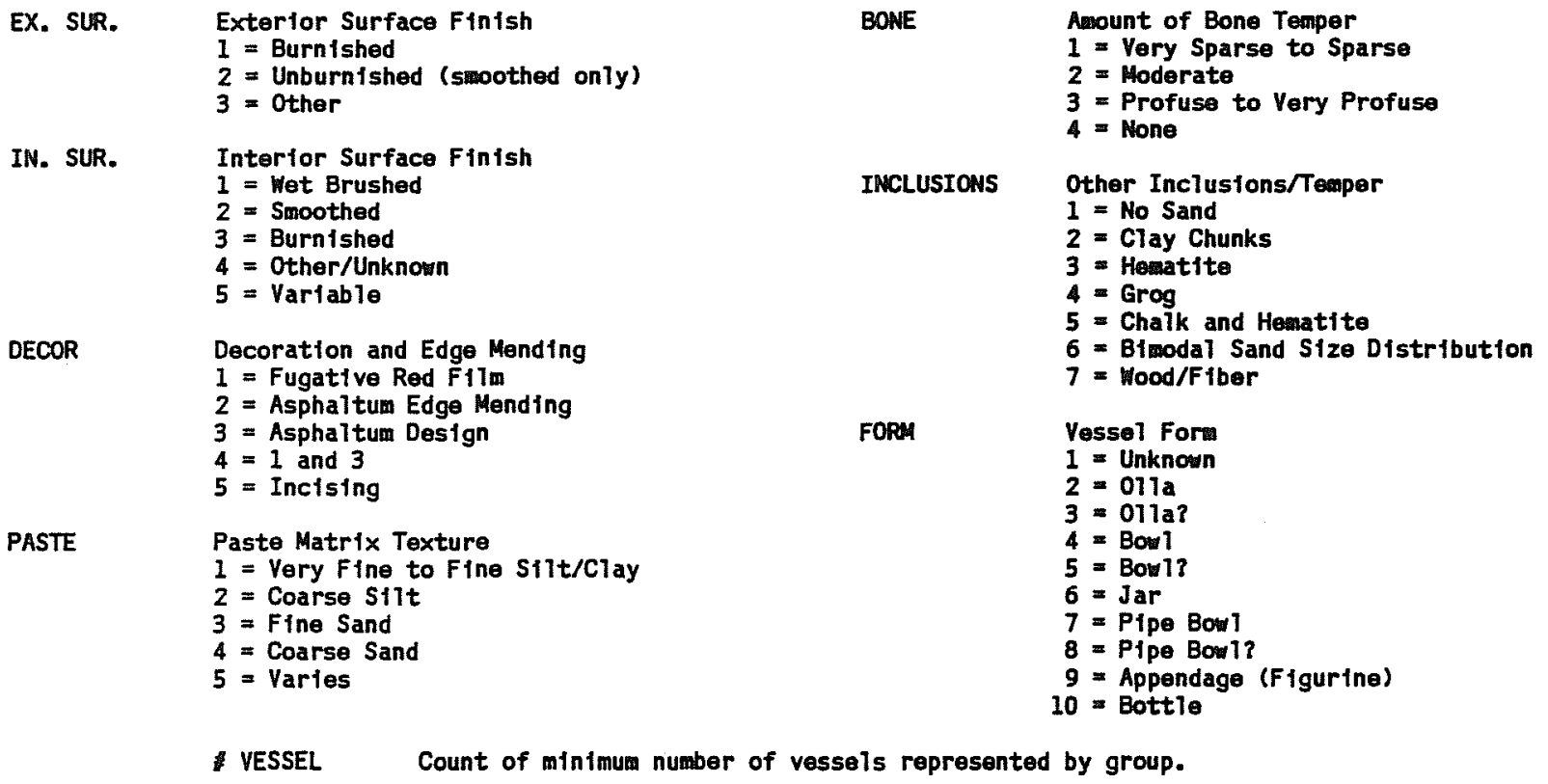

IN. SUR.

DECOR PASTE

BONE INCLUSIONS FORA VESSELS

41 LK 14 Group 1

41 LK 14 Group 2

41 LK 14 Group 3

41 LK 15 Group 1

41 LK 15 Group 2

41 LK 41 Group $1 A$

41 LK 41 Group IB

41 LK 41 Group 1C

41 LK 41 Group 10

41 LK 41 Group IE

41 LK 41 Group 2A

41 LK 41 Group 2B

41 LK 41 Group 2C

41 LK 41 Group $3 A$

41 LK 41 Group 3B

41 LK 41 Group 3C

41 LK 41 Group 4

41 LK 41 Group 5

41 LK 41 Group 6A

$4 I$ LK $4 I$ Group $6 B$

41 LK 41 Group 6C

41 LK 41 Group 60

$4 I$ LK $4 I$ Group $6 E$

41 LK 51 Group 1

41 LK 51 Group 2A

41 LK 51 Group 2B

41 LK 51 Group 2C

41 LK 51 Group 3

41 LK 51 Group 4

41 LK 51 Group 5

41 LK 67 Group 1

41 LK 67 Group 2

41 LK 67 Group 3

41 LK 67 Group 4

41 LK 67 Group 5

41 LK 74 Group 1

41 LK 74 Group 2

41 LK 128 Group 1

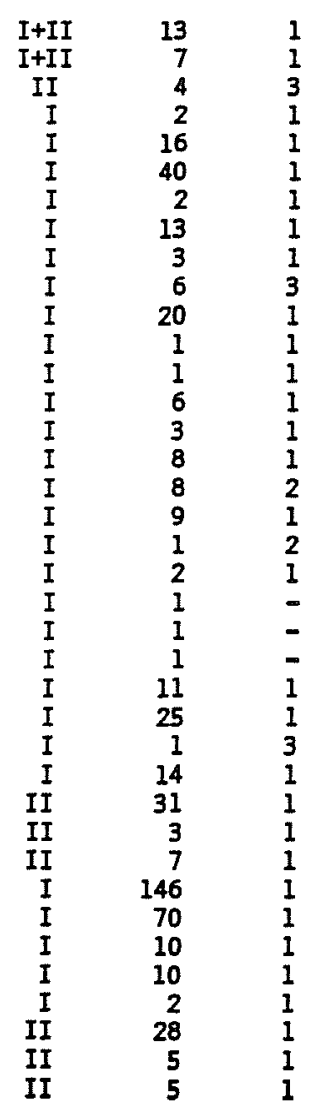

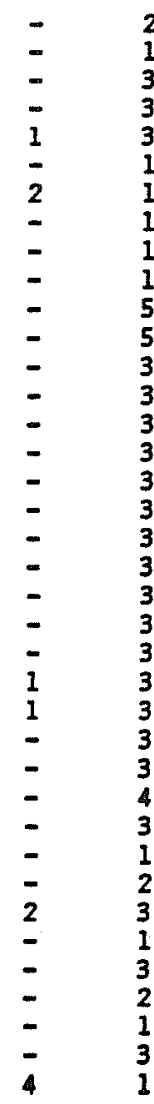

$$
\begin{aligned}
& 5 \\
& 5 \\
& 5 \\
& 5 \\
& 5 \\
& 5 \\
& 5 \\
& 5 \\
& 5 \\
& 5 \\
& 5 \\
& 5 \\
& 5 \\
& 5 \\
& 5 \\
& 5 \\
& 5 \\
& 5 \\
& 5 \\
& 5 \\
& 5 \\
& 5
\end{aligned}
$$

$\begin{array}{ll}5 & 1 \\ 1 & 1 \\ 1 & 1 \\ 1 & 1 \\ 4 & 1 \\ 1 & 2 \\ 1 & 1 \\ 4 & 2 \\ 1 & 1 \\ 1 & 1 \\ 1 & 4 \\ 1 & 1 \\ 1 & 1 \\ 1 & 1 \\ 1 & 1 \\ 1 & 1 \\ 1 & 1 \\ 1 & 3 \\ 3 & 1 \\ 1 & 0 \\ 1 & 0 \\ 1 & 0 \\ 1 & 0 \\ 1 & 1 \\ 1 & 1 \\ 1 & 1 \\ 4 & 1 \\ 5 & 1 \\ 1 & 1 \\ 1 & 2 \\ 1 & 2 \\ 2 & 1 \\ 1 & 1 \\ 5 & 1 \\ 1 & 1 \\ 2 & 1 \\ 1 & 1 \\ 5 & 1 \\ & \end{array}$


TABLE 32. (continued)

PHASE COUNT EX. SUR.

IN. SUR

DECOR

PASTE

BONE INCLUSIONS

FORM VESSELS

41 LK 185 Group 1 41 LK 201 Group IA 41 LK 201 Group 1B 41 LK 201 Group 2 41 LK 201 Group 3A 41 LK 201 Group 3B 41 LK 201 Group 3C 41 LK 201 Group 3D 41 LK 201 Group 3E 41 LK 201 Group 4 41 LK 201 Group 5 41 LK 201 Group 6 41 LK 201 Group 7 41 LK 201 Group 8 $4 I$ LK 201 Group 9 41 LK 201 Group 10 41 LK 201 Group 11 4I LK 201 Group 12 41 LK 201 Group 13 41 LK 201 Group 14 41 LK 201 Group 15 41 LK 201 Group 16 41 LK 201 Group 17 41 LK 201 Group 18 41 LK 201 Group 19 41 LK 243 Group I 41 LK 243 Group 2 41 LK 243 Group 3 41 MC 15 Group 1 41 MC 15 Group 2 41 MC 17 Group 1 41 MC 19 Group 1 41 MC 41 Group 1 41 MC 55 Group 1 41 MC 55 Group 2 41 MC 55 Group 3 41 MC 55 Group 4 41 MC 55 Group 5 41 MC 55 Group 6 41 MC 55 Group 7 41 MC 55 Group 8 41 MC 55 Group 9 41 MC 55 Group 10 41 MC 55 Group 11 41 MC 55 Group 12 41 MC 55 Group 13 41 MC 55 Group 14 41 MC 55 Group 15 41 MC 55 Group 16 41 MC 55 Group 17 $4 I$ MC 64 Group 1 41 MC 84 Group 1 41 MC 84 Group 2 41 MC 84 Group 3 41 MC 94 Group I 41 MC 222 Group 1 41 MC 222 Group 2 41 MC 222 Group 3 41 MC 222 Group 4 $4 I$ MC 223 Group 1 41 MC 275 Group I 41 MC 293 Group 1 41 MC 294 Group 1 41 MC 296 Group 1 41 MC 296 Group 2 41 MC 296 Group 3 41 MC 296 Group 4 41 MC 296 Group 5 41 MC 296 Group 6 41 MC 296 Group 7 41 MC 296 Group 8

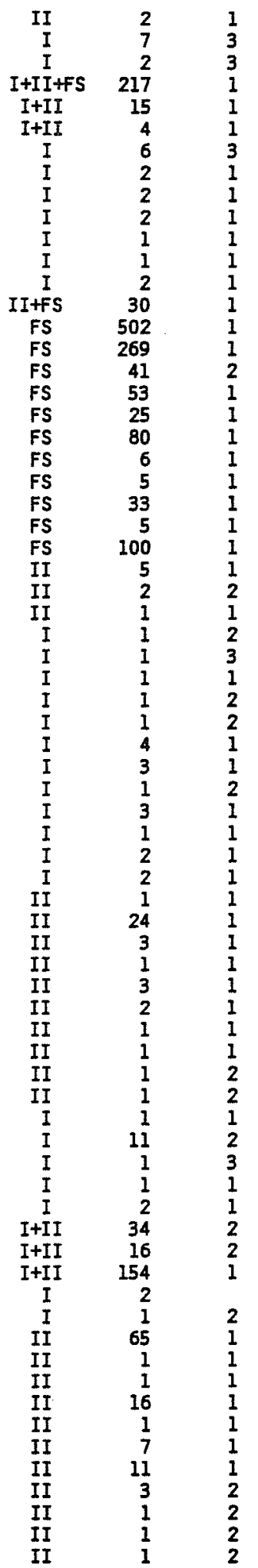

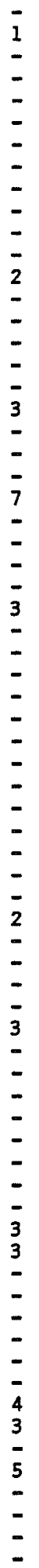

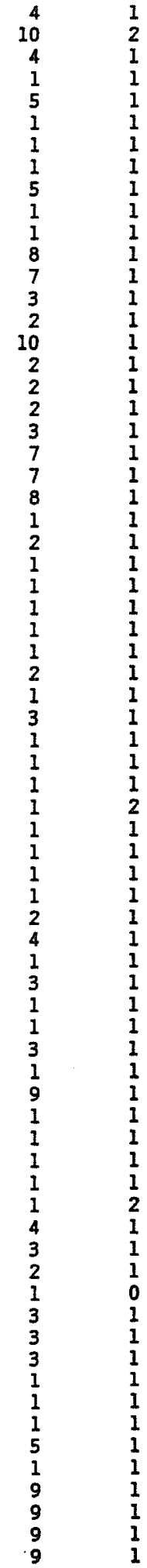


process, except for a tiny hole in the center of concentric 1 ayers of bone known as osteoblasts (Ubelaker 1978:64). The whole structure--the tiny hole and surrounding osteoblasts is known as as osteon. In addition to these shapes, spongy cel1-1ike structures are sometimes visible which appear to be cancellous bone tissue fragments. The faunal species utilized as bone temper are unknown, but most of the bone appears to be from 1 arge mammals such as deer or bison. This statement is based on intuition rather than any real scientific basis.

In attempting to reproduce bone-tempered pottery, it was discovered that weathered bone crushed more easily than fresh bone; however, it also disintegrates into a useless powder. The answer to the problem is to burn the fresh or partially weathered bone over an open fire for a few minutes. The burned bone crushes easily into the shapes and sizes observed in sherd cross sections.

If the bone is being burned and fire blackened to facilitate crushing, then why does the exposed bone appear white or unburned? The color of the bone is a result of oxidation. The more oxygen each particle receives during firing, the whiter the bone appears. Blackened (carbon-rich) bone will reoxidize during firing as long as sufficient oxygen penetrates the vessel. In genera1, the exposed bone on the vessel surface is always white, while bone within the paste may or may not be, depending upon localized oxidation conditions.

\section{Sand}

Siliceous detrital particles composed principally of quartz were observed in most site groups as a paste inclusion in varying amounts. Most of the sand can be attributed to natural inclusions present in the clay which were used to form the paste. The composition of the sand also varied in grain size and particle shape (degree of roundness). These attributes varied markedly between certain site groups and were often useful in distinquishing between sherds from similar vessels.

A good example of the variation in sand morphology is the 41 MC 55 ceramic collection. Certain site groups at 41 MC 55, such as Group 15, had very coarse sand grains that were very well rounded while others, such as Group 16, had fine to very fine angular to subangular sand grains. It can be inferred that Group 16 represents an upland clay source (angular and unabraided grains), while Group 15 represents an alluvial source (rounded and abraided grains). The presence of a large amount of comparatively we 11 sorted, stream-rolled sand in Group 15 may alternatively be interpreted as intentiona $11 \mathrm{y}$ added sand collected from a sand bar. This illustrates the problem of trying to determine whether sand has been intentionally added or is a natural inclusion.

Future researchers could attempt to solve this problem by comparing the sand grain morphology observed in locally made ceramics with clay samples collected from the study area in question. It is suggested that such an approach may offer the best method of determining source areas short of sophisticated trace element studies. 


\section{Hematite}

Iron oxide particles herein referred to as hematite were a common paste inclusion. These particles are usually recognizable by their bright red to rusty red appearance. Hematite typical1y occurred as rounded to we 11rounded, medium to granular (up to $6 \mathrm{~mm}$ ) particles. Differences in hardness, color, and particle shape probably reflect different compositions of iron oxide minerals such as hematite, goethite, limonite, and magnetite. In most site groups, hematite particles occurred on $7 y$ occasional $1 y$, although some groups, such as Group $1 \mathrm{~A}$ at $4 \mathrm{I}$ MC 222, contained numerous particles which were 1 arge enough to weaken the vessel wal15.

Most hematite particles are considered natural inclusions as they are known to occur in some local clay sources such as the clay from the oxbow adjacent to 41 LK 201. In a few cases, such as Groups 2 and 4 at 41 MC 296, finely pulverized hematite is present in comparatively large amounts and probably represents purposefully added temper.

\section{Clay}

Irregular to rounded patches or chunks (up to $7 \mathrm{~mm}$ ) which appear to be untempered clay were observed in some sherds. These clay patches are usually 1 ighter in color than the surrounding paste and are finer in texture because they do not contain bone particles. These clay inclusions were most common in upland clays (little sand or angular sand). It is suggested that the clay patches represent incompletely pulverized clay which was collected dry from an up 1 and source. Some of the 1 ighter colored patches may actually be a caliche.

Group 9 at 41 MC 55 has very 1 arge quantities of clay chunks both in the paste and added to sections of the vessel surface. This is interpreted as an intentional temper. Most occurrences of untempered clay chunks probab $1 y$ represent incidental inclusions.

\section{Resin Bubbles}

Clusters of tiny amber to orange bubbles were observed in many sherd cross sections. The composition of these resin bubbles is unknown. Resin bubbles seem to fill void or 1 arge pores in bone-tempered pottery. Resin bubbles possibly formed during firing by molten residue (which may be derived from animal bone) that flows and fills adjacent open spaces. Occasional1y. similar material occurs as spongy accumulations. No resin bubbles were ever observed on sherd surfaces or anywhere except obvious voids. The bubb $7 e s$ themselves are tiny round spheres less than $1 \mathrm{~mm}$ in diameter. The resin bubble clusters are shaped to fit the available space and may be $5 \mathrm{~mm}$ or more. 


\section{Quartzite and Sandstone}

Occasional1y, chunks up to $6 \mathrm{~mm}$ were observed which appeared to be quartzite and sandstone fragments. These are possibly fragments of quartzite and sandstone grinding implements used to crush the bone and/or the clay.

\section{Shell}

Occasionally, 7 and snail fragments were observed in the sherd cross sections. These appear as thin, bright white fragments. Examination under high magnification reveals a 1 aminated cross section that is typical of she 11. Several small whole juvenile land snails were observed (Mesodon sp?). Land snail fragments are obviously an unintentional inclusion.

\section{Grog}

One sherd out of over 2000 from the Choke Canyon area had grog temper. Grog is crushed ceramic material (sherds). These appear as angular or rectangular chunks that are often oxidized within the otherwise unoxidized core. The single example came from 41 MC 296 (Group 1) which has an unusual assemblage in many respects. Grog tempering is a common trait in east Texas and eastern North America.

\section{Surface Finish Techniques and Surface Coatings}

A variety of surface finish techniques were observed within the ceramic collection. A consistent pattern of even, smooth, and burnished exterior surfaces was noted (76\% of the vesse1s). Sherd surfaces were frequently destroyed by postdepositional weathering, calcareous coatings, and 1 ichen. Decoration was surprisingly common (at least 15\% of the vesse1s). Decorative techniques include fugitive red filming, asphaltum banding, and in one case, incising. Vessel surface colors were often concealed or marred by fire clouding or sooting. A few vessels seem to have had an exterior slip.

\section{Burnishing}

Most exterior surfaces and interior bow 1 surfaces were first smoothed and floated and then burnished. The degree of burnishing ranged from very slight patchy burnishing with a very low luster to extensive well-developed burnishing which left a high glossy surface. Burnishing frequently was accomplished in parallel strokes as evidenced by the tool marks.

\section{Slipping}

A few sherds have coatings of fine-grained clay on the exterior surface. These coatings are distinct in color from the paste. In the Phase I analysis, the coatings were termed burnishing slips; however, this may be erroneous. Burnishing (polishing) compacts the surface and may form a fine 
layer of 7 ustrous $c l$ ay that appears distinct from the paste, thus resembling a slipped surface (Shepard 1976:192). No Phase II sherds have a true slip; however, one sherd from 41 LK 41 (Group 2B) in Phase I had a brown contrasting color exterior coating that appeared to be a true slip. This slip may have functioned to improve surface appearance, to decrease permeability, or both (ibid.:191).

\section{Wet Brushing}

Wet brushing was evidenced on about a third of the vessels in the collection (32\%). This technique involves the use of some type of organic brush (frayed stick?) while the vessel surface is still wet. Wet brushing leaves a series of tiny (sometimes microscopic) ridges and furrows on the vessel surface. Parallel and irregular patterns of wet brushing were sometimes observed. With the exception of one or two vesse1s, wet brushing was always confined to the interior surface. It is suggested that the technique was used on restricted neck vessels such as ollas to smooth the vessel surface.

The brushing commonly present on the interior vessel surfaces in the Choke Canyon area is rarely as pronounced as the brushed wares produced by agricultural groups in the southwest and in eastern North America. The purpose of the brushing in southern Texas appears to have been to smooth the interior surface rather than to provide a decorative or functional texture.

\section{Eugitive Red Filming}

Traces of a thin $f i 1 \mathrm{~m}$ of red mineral pigment were observed on approximately 9\% of the vessels in the collection. Most examples appear to be from bow 1 forms, although a fugitive red decorated olla recovered from 41 LK 201 (Highley 1986) has been partially restored. Fugitive red occurs on the burnished exterior surfaces and occasionally on the interior surface. Fugitive red also occurs along the rim of bow 1 forms (Phase I, 41 LK 15 Group 2) and in combination with asphaltum. One site group, Group 1 from 41 LK 128, had traces of asphaltum over a fugitive red filmed surface. The vessel must have originally had quite a striking appearance.

Fugitive red $f i l m$ is extremely ephemeral; it is easily washed or rubbed off surfaces and usually remains on $7 y$ as traces. Most traces are only recognizable under careful microscopic examination. The composition of the red mineral is unknown, but appears to be an iron oxide such as earthy hematite (also called red ocher). Intact patches are bright red and have a metallic luster. Some examples of fugitive red $f i 1 \mathrm{~m}$ were a darker maroon color. Interesting $7 y$, one of the properties of hematite is that the red streak turns dark when heated (Hurlbut and Klein 1977:269). It is suggested that the dark maroon color indicates a fugitive red filmed vessel was used for cooking (exposed to heat). Given the ephemeral nature of fugitive red $f i 1 \mathrm{~m}$, one suspects that a large percentage of the ceramics were filmed original1y, and the substance has weathered away or was not observed during examination. Similar decoration has been described on Goose Creek red-filmed pottery along the upper Texas Gulf coast (Aten 1967) and on Goliad red-on-buff at Mission Espiritu Santo (Mounger 1959). 


\section{Asphaltum}

Aspha 7 tum, or natural tar, was present on many site groups and used as an edge mending glue or as a decorative coating. Evidence of edge mending was observed on the exterior surface and along one or more edges of several sherds. Other sherds had asphaltum bands or dots on the exterior surfaces that were not connected with an edge. These are interpreted as decorative coatings, although no clear designs could be reconstructed. As mentioned, asphaltum and fugitive red film were combined on a vessel from 41 LK 128.

A serious problem arose during the early stages of the Phase I analysis when distinction between asphaltum and heavy black sooting became impossible. Story (1968:17-19) encountered this same problem with ceramics from the Ingleside Cove site and was unable to solve it. Dr. Donald R. Lewis, Director of the newly formed Center for Archaeological Research Chemical Laboratory, came up with an easy, inexpensive, and rapid method (referred to as the "Lewis Method") for positively identifying asphaltum. The "Lewis Method" involves a three-step process outlined below (courtesy of D. R. Lewis).

\section{Test for Asphalt-Bitumen}

1. Place smal1 $\mathrm{flake}$ of material in one cup of a white porcelain spot plate.

2. Place one drop of isopentane (2-methy 1 Butane) on sample. Stir gently with fine clean point. If 1 iquid turns yel low or brown, the sample is probably from heavy crude oil. If liquid stays clear, al low to evaporate completely and go to Step 3.

3. Place one drop of Toluene on sample. Stirgently with fine clean point. If 1 iquid turns yellow or brown, the sample probably contains asphaltic material. If 1 iquid stays clear, the sample is probably coal, charcoal, soot, graphite, or pyrobitumen.

Using the "Lewis Method," it was determined that many of the black coats on sherd surfaces were not asphaltum. The site groups identified in the text as having asphaltum were positively identified using the "Lew is Method."

Asphaltum presumably was obtained along the Texas Gulf coast where it is common $7 y$ found along the beaches. The beach asphaltum is derived from offshore oil or tar seeps (D. R. Lewis, personal communication). The presence of asphaltum on the ceramics probably indicates coastal contact either direct or indirect through trade, al though surface tar seeps are known in the Uvalde area (G. L. Hammon, Department of Earth Science, The University of Texas at San Antonio, personal communication).

\section{Eoreign Coatings}

Several sherds with a dried black coat or film on one or more surfaces were found. The material is not asphaltum. The nature of this material is 
unknown; it may be postdepositional or an organic waterproofing agent such as mesquite sap. It also may be heavy carbon sooting, but it seems to have been a 1 iquid at one time.

\section{Burned Organic Residue}

Two sherds found during Phase I at 41 LK 201 (Group 2E) had a 7 ayer of dark, cracked organic material on the interior surface. During the UTSA Field School at 41 LK 201, 267 more sherds of the vessel were found (redefined as Group 10). The vessel form is unique in the area, a long-necked bottle. The organic residue is several millimeters in thickness and appears to be burned. It occurs only in the neck region of the vessel. The composition of the residue is unknown, but it may be a burned 1 iquid residue that was preserved through carbonization (see Highley 1986).

\section{Postdepositional Effects}

A variety of postdepositional conditions have adversely affected the ceramics: calcareous coating, lichen, sun bleaching, weathering, and chemical corrosion. These effects are difficult to detect and often mask the original surface treatment techniques so effectively that one is left wondering what the original vessel surface was like.

\section{Calcareous Coating}

A 1 ight gray or white coating was observed on many sherds. The coating covers all surfaces including old broken edges. This coating is apparently a calcareous (calcium carbonate) stain derived from alkaline soils. The calcareous coating is postdepositional and frequently masks surface characteristics.

\section{Lichen}

Tiny black patches which appear to be lichen were seen on some sherds (particularly surface-collected sherds). Similar coats were often observed on 1 ithic artifacts. Lichen are postdepositional and, 1 ike calcareous coatings, tend to obscure surface characteristics.

\section{Weathering}

Most sherds, especially surface-collected sherds, were adversely affected to varying degrees by the ravages of time. The combined effects of sun, rain, freezing, plowing, and animal and plant activity will eventually break down even the most resistant ceramics. The edges of the sherds go first. A fresh break weathers to a rounded edge as the condition attribute (Fig. 94) 117 ustrates. A number of sherds were lighter in color on exposed edges than in the center of a fresh break. These sherds may have been sun bleached or oxidized by exposure to the bright Texas sun for hundreds of years. 
Eventually, this process may entirely oxidize the sherd leaving no carbon core.

\section{Chemical Corrosion}

In some groups, particularly Group 1 at 41 LK 67 (Phase I), all exposed bone appears to be eaten away or chemically dissolved. This process is not understood and may be attributed to soil chemistry or to biological action (see discussion of Group 1 at 41 LK 67 for further details and speculation; Brown et a 1. 1982:34-35).

\section{Yessel Function}

The Nueces River project ceramics, while highly fragmented, offer some indications of vessel form and function. The only reconstructable vessels were recovered from 41 LK 201 (Highley 1986). The 41 LK 201 collection and some diagnostic rim and neck sherds from other sites suggest that vessel form was 1 imited to perhaps five forms: 011 as, bow $1 s$, bottles, $j a r s$, and pipe bow 1s. In addition, fragments of ceramic appendages have been recovered that are bel ieved to represent figurines. 011 as appear to be the dominate vesse 1 form followed by bowls. Jars, bottles, and pipe bowls are indicated by smaller numbers of sherds.

011 as are the 1 argest form represented by the collection and the most numerous. Approximately $41 \%$ of the vessels that could be assigned a tentative vessel form were ollas. An olla is a globular vessel with a constricted neck and an outward flaring rim. Handles or lugs were sometimes attached to 011 as. It is suggested that the 011 a form functioned as a water container. This function is suggested by the vessel form and the fact that none of the suspected ol la sherds show sooting as would be expected if used for cooking. The constricted neck served to minimize water spillage during transportation. The handles provided a better grip for handling a wet, slippery water container. Decoration seems to be rare on 011 a forms, a though one decorated 011 a has been partially restored from 41 LK 201.

The second most numerous form type is the bow 1 form; approximately $31 \%$ of the vesse1s that could be assigned a tentative form were bow 15 . Bow 1 forms show considerable variation in size and shape. Small rim sherds suggest at least three bow 1 forms: closed or inverted rim bow 15 , open rim bow 15 , and flaring rim bow 1 s. Fugitive red filming usual 1 y occurs on bow 1 forms. Bow 1 s are suggested to have functioned as cooking or serving containers. Heavily sooted exterior surfaces on several suspected bow 1 forms suggest a cooking function.

$\mathrm{Jar}$ and bottle forms are uncommon. The best evidence of these is a partially restored bottle and a 1 arge rim sherd from an apparent cylindrical jar. Both of these were recovered from 41 LK 201. The bottle obviously served as a 1 iquid container. The jar may have served as a storage container.

Several fragmentary examples of ceramic pipe bow $1 \mathrm{~s}$ were recovered. The function of these is readily apparent. A wooden or bone pipe stem was 
probably used in connection with the pipe bow1. The ceramic pipe bowls are similar in form and size to stone pipe bowls recovered from Archaic and Late Prehistoric contexts (Black n.d.). A number of stone pipe bowls were recovered from the Loma Sandia site (41 LK 28) in Archaic burial contexts. One of these was found with a bone stem stil1 in place (Hester 1980: Fig. 5.16).

The above ceramic forms obviously represent utilitarian functions: water storage, food processing, and smoking. The ceramic figurine fragments from 41 LK 67, 41 MC 55, and 4I MC 296 may represent objects with ritual significance. It is interesting to note that the possible nonutilitarian objects, the figurines, are also the only ceramic form that was not bone tempered. This may suggest that the figurines were not the product of the local tradition and may have been introduced from an outside area (the lower coast?).

The above discussion is presented as a tentative assessment of vessel function. The reconstruction of several vessels from 41 LK 201 will provide a more tangible picture of complete vessels (Highley 1986).

\section{Ceramic Chronology}

Radiocarbon assays were determined from five sites at Choke Canyon that may be associated with occupational components containing ceramic material. The associated dates are presented below. More complete radiocarbon assay data can be found in Table 36 in Hall, Black, and Graves (1982:652) and in Appendix VI in this volume.

The radiocarbon assay range for a ceramic-using occupation at Choke Canyon falls very closely to earlier estimates given in south Texas, after A.D. 1200 (Hester and Hi11.1971; Hester 1980). It is significant that in the Choke Canyon area, ceramics occur in association with both contracting stem arrow points (Perdiz) and expanding stem arrow points (Edwards and Scal1orn). However, ceramics were associated with Perdiz types more often than with the expanding stem arrow points. Based on the radiocarbon assays, ceramics appear to have been introduced into the area by A.D. 1200 and were in use for at least 400 years.

An attempt was made to distinquish ceramic attributes that could be 1 inked to temporal change. Some differences do occur between the earlier dated sites such as 41 MC 55 and 41 MC 222 and the later dated sites such as 41 MC 296 and 41 LK 201. However, these differences are not striking, and the dates somewhat overlap. A1so, the sites with the later dates were also sites that were repeatedly reoccupied by ceramic-using peoples, while 41 MC 222 appears to result from a short-term occupation. It may be significant that thickwalled sandy paste vessels occur at 41 MC 55 and 41 MC 222 but do not occur at 41 MC 296 and 41 LK 201. Alternatively, this may reflect the available clay source rather than a temporal change in ceramic technology.

Below, each site with radiocarbon assays associated with ceramic material is briefly discussed. Al1 radiocarbon dates given below are the MASCA calibration estimates (Ralph, Michael, and Han 1973). 


\section{LK 128}

Four radiocarbon assays ranging from A.D. 1180-1310 may date the ceramic occupation at 41 LK 128. Unfortunately, only a small ceramic sample was obtained from the site, hence association with the four dates is rather tentative.

\section{LK 201}

Two radiocarbon assays date the ceramic-using occupation at $41 \mathrm{LK} 201$. TX4667 and TX-4668 range between A.D. 1470 and A.D. 1590. These assays suggest that the extensive ceramic assemblage from the site dates comparatively late in the Late Prehistoric era. The site ceramic assemblage can be characterized as diverse in form (017as, bow 1s, jar(s), bottle(s), and pipe bow 1s), paste composition (sandy and silty pastes), and surface finish (burnished, fugitive red filmed, asphaltum, etc.). The only major ceramic type (as in attribute combination) that appears to be missing from the 41 LK 201 collection is the thick-walled sandy paste vessels recovered from many sites.

\section{MC 55}

Two radiocarbon assays, TX-4692 and TX-4693, date the occupation that contains ceramics at 41 MC 55. These assays range in date from A.D. 1230 to A.D. 1420. Thus, the ceramics from 41 MC 55 seem to be earlier in time than the 41 LK 201 collection. The 41 MC 55 collection is dominated by silty paste vessels but is also characterized by considerable diversity in most attributes. UnTike the 41 LK 201 collection, several thick-walled sandy paste vessels were present in the 41 MC 55 collection.

\section{MC 222}

Site 41 MC 222 appears to be a single component site. The four assays determined from wood charcoal from 41 MC 222 (one date on mussel she 11 is obvious7y too o1d), TX-2875, TX-2876, TX-4666, and TX-4694, range between A.D. 1260 and A.D. 1500. Because three out of the four dates are before A.D. 1400 it is suspected that the 41 MC 222 ceramic collection, 1 ike that from 41 MC 55, dates earlier than the 41 LK 201 assemblage. The problem in comparing the assemblages is that the 41 MC 222 collection on 1 y represents three vessels, probably resulting from a single occupational episode, while the other two sites are multicomponent sites with large numbers of ceramic vesse1s. Nonetheless, it is interesting to note that the 41 MC 222 collection 1 ike the 41 MC 55 collection contains a thick-walled, sandy paste ceramic vesse1 (probably an $017 \mathrm{l}$ ). The three vessels from the site are not as we 11 made as most of the vessels from 41 LK 201 or 41 MC 55.

\section{MC 296}

Seven radiocarbon assays date the ceramic occupation at site 41 MC 296 (TX4677. TX-4678, TX-4682, TX-4683, TX-4684, TX-4685, and $T X-4686$ ). The dates 
range between A.D. 1200 and A.D. 1610. The four assays from Levels 1 and 2, where most of the ceramics were recovered, date after A.D. 1430. This combined with a tentative indication of a historic Indian occupation (see site discussion of 41 MC 296 in this volume) at 41 MC 296 places the ceramic assemblage relatively 1 ate in the ceramic-using era. As noted, the 41 MC 296 collection has a number of unusual aspects such as grog tempering, hematite and chalk(?) tempering, and the four figurine fragments. No thick-walled sandy paste vessels are represented, a 1 though several thick-walled silty paste vessels were documented.

\section{THE BONE-TEMPERED CERAMIC TRADITION OF SOUTH AND CENTRAL TEXAS}

The analysis of the Choke Canyon ceramic collection offers a detailed look at many aspects of the bone-tempered pottery tradition of southern Texas defined by Hester and $\mathrm{Hill}$ (1971). This tradition represents the widespread practice of making bone-tempered utilitarian ceramics during the Late Prehistoric era, ca. A.D. 1200 to historic contact (A.D. 1530-1700).

Vessel forms are 1 imited to comparatively simple functional forms such as 011 as, bow 15 , bottles, jars, and pipe bow 1s. The only exception to this is provided by the sandy paste figurines that may be derived from the coastal region. A11 ceramic forms were made using coil construction techniques except for the figurines, and some of the pipe bow 7 s were made by the pinch pot method.

Crushed animal bone was added to almost every vessel in approximate inverse proportion to the amount of sand occurring naturally in the clay. Clay sources appear to have varied widely as evidenced by the paste color, paste texture, sand grain morphology, and minor inclusions.

The exterior surfaces of al1 vessels were smoothed and usual1y burnished. Decoration occurs in the area more frequently than had previously been recognized. Approximately 15\% of the vessels had definite evidence of fugitive red filming or asphaltum. The percentage of decorated vessels is probably higher due to the ephemeral nature of the fugitive red filming, the major form of decoration. Asphaltum was used as a mending glue to repair cracked vessels and as a decorative paint. Incising occurs on at least one figurine and may have been present on several other vessels. Several of the figurines also have shaped surfaces. Other forms of decoration such as punctating and brushing have been documented at other southern Texas sites (Hester and Parker 1970).

The origins of the south Texas ceramic tradition have been tentatively 1 inked to central Texas by previous researchers (Hester and Hil1 1971:199-200). Leon Plain is the type name applied to most central Texas bone-tempered pottery (Suhm, Krieger, and Jelks 1954). Hester and Hil 1 (1971:198-199) suggest that "Leon Plain has never been fully studied and seems to be an amalgamation of various $p 1$ a in ceramics found in Late Prehistoric central Texas." One unpublished study (Heartfield 1966) of Leon Plain documents considerable variation in central Texas ceramics, but concludes that Leon Plain should be considered a viable provisional type based on attribute consistency and geographic isolation. In the same paper, Heartfield suggests 
that the origin of Leon Plain 1 ies to the east in the fringe area between central Texas and the Caddoan area (east Texas).

Leon Plain and the bone-tempered pottery from southern Texas cannot be clearly separated in form, appearance, or spatial distribution. It is argued here that the differences one notices between a ceramic collection from a central Texas Late Prehistoric site and a southern Texas Late Prehistoric site are probably more due to an individual's technique, clay source variation, and fortuitous firing conditions rather than technology or tradition. The differences between the ceramic collections from different sites in the Choke Canyon area are similar in scope to the differences between central Texas and southern Texas ceramic assemblages. It is suggested here that Leon Plain and the south Texas bone-tempered ceramic tradition are virtually indistinguishable and should be considered a single tradition.

Most studies have suggested that the ceramic tradition in central Texas and southern Texas dates after A.D. 1200 (Je $1 \mathrm{ks} \mathrm{1962:88;} \mathrm{Hester} \mathrm{1980:124).} \mathrm{The}$ radiocarbon assays from the Choke Canyon area certainly support this dating. Recent excavations at the Panther Springs Creek site in Bexar County (southcentral Texas) suggest that pottery may have been introduced in the region several hundred years earlier (B1 ack and McGraw 1985). At the Panther Springs Creek site, a poorly made bone-tempered cylindrical jar was found in association with a charcoal feature radiocarbon dated to A.D. $980 \pm 60$ (TX3856, MASCA calibrated). This ceramic vessel was also associated with expanding stem arrow points (Scallorn and possibly Edwards). The occurrence of rather crudely made bone-tempered ceramics in south-central Texas several hundred years before the widespread occurrence of thinner, better made ceramics across much of central and southern Texas is significant.

Bone-tempered pottery appears to have been introduced into the region by A.D. 1000. The most likely source for the tradition is from the agricultural groups to the east who made bone-tempered ceramics as early as A.D. 500. Story (1981:146) notes that there were two early ceramic traditions in east Texas, a sandy paste and a grog and bone-tempered tradition.

It is argued that the bone-tempered ceramic tradition that is evidenced at many Late Prehistoric sites over much of south and central Texas survived until early historic times. Clark (1978:76-77) has observed that bonetempered ceramics very similar to Leon Plain have been found at many Spanish sites including Mission San Jose, Mission San Antonio de Valero, Presidio San Luis de Amaril1as, Mission Santa Cruz de San Saba, Mission Concepción, Mission Espiritu Santo, Mission Rosario, and Mission San Juan. These Spanish Colonial missions dealt mostly with Indian groups from southern and central Texas. It is suggested that bone-tempered ceramics were not found at the Lipan Apache mission. San Lorenzo de 1 a Santa Cruz (Tunnel 1 and Newcomb 1969). Mounger (1959:179-181) defined three variants of bone-tempered ceramics at Mission Espiritu Santo-Goliad Plain, Goliad red-on-buff, and Goliad black-on-buff. A comparison was made of the ceramics from Mission Espiritu Santo to the Rockport wares of the central Texas Gulf coast and to Leon Plain of central Texas. She found that, while the mission ceramic decoration was more similar to the Rockport wares, the color, porosity, and tempering were most similar to Leon Plain. Mounger (ibid.:181) apparently 
decided that Gollad wares were distinctive from Leon Plain solely on the basis of decoration: "No Leon Plain has even been reported in red or black, it may be concluded, Goliad ware is a local product and represents the ceramic tradition of the Aranama." The recognition of fugitive red filming and asphaltum painting on Late Prehistoric bone-tempered ceramics challenges the validity of the Goliad types.

In conclusion, it is argued that a single ceramic tradition is represented by the Late Prehistoric and mission period (early Historic) bone-tempered pottery in south and central Texas. Between A.D. 1000 and A.D. 1500, the tradition of making bone-tempered utilitarian ceramics was adopted by many inland hunting and gathering groups 1 iving in south and central Texas. Spanish expansion from the south and Apache and later Comanche expansion and raiding from the north and northwest, rapidiy decimated and displaced the native groups in the region during the 17th and 18th centuries (Campbell and Campbe11 1981:64). The surviving remnants, while sheltered in the Spanish missions, maintained their tradition of making bone-tempered pottery for a few decades longer. The bone-tempered ceramic tradition would include the fol 1 owing previously defined types: Leon Plain, "Doss Red Ware" (Kel ley 1947), Gollad Plain, Gollad red-on-buff, and Goliad black-on-buff, as we 11 as the untyped bone-tempered ceramics from south Texas and the Spanish missions. Considerable differences do occur within the bone-tempered tradition of south and central Texas. Most differences may be more a product of clay source variation, sample size, sample preservation, and individual style rather than distinct cultural practices. It is suggested that the above type names are no longer valid in view of the regional nature of the tradition. These names should be discarded in favor of simple descriptive labels until adequate distributional and descriptive data are available to define culturaliy meaningful types.

\section{METAL KNIFE BLADE (Grant D. Hal1)}

A badly corroded, fragmented metal knife blade was recovered from Level 2 $(99.80$ to $99.70 \mathrm{~m})$ of Unit N1027 E999 at 41 MC 296. The blade fragment measures $13.8 \mathrm{~cm}$ in length and has a maximum width of $2.1 \mathrm{~cm}$. The shank is $5.1 \mathrm{~cm}$ in length and tapers down to a twisted end. This type of $\mathrm{knife}$ is called a "case knife." It was popular in the Indian trade during the 18th century. The specimen is 117 ustrated in Figure 92,1.

\section{CONCLUSIONS}

The research reported in this volume represents the culmination of a series of archaeological investigations at Choke Canyon that began 18 years ago with a 1 imited pilot survey conducted by Wakefield (1968). The first large-scale survey efforts occurred in 1974 and 1976 under the auspices of the Texas Historical Commission. This field work was done in two phases during a three-year period because of changes in governmental jurisdiction over the project. Due partly to funding problems related to these changes and partly to the refusal of 1 andowners to permit archaeological surveys on their property, the THC investigators were able to survey on $7 y$ about 22,000 acres of the total 38,000 acres to become the bas in of Choke Canyon Reservoir. 
Recommendations for further field research, including test excavations and more survey, were publ ished in 1977 (Lynn, Fox, and OMa 11 ey 1977). These recommendations provided the framework for the CAR-UTSA Phase I investigations which began in July 1977. Two additional surveys, one conducted in 1977 and the other in 1979, finally completed the archaeological survey effort at Choke Canyon. Recommendations for Phase II work, formulated by the CAR staff on the basis of Phase I findings, had to include provisions for testing certain of the sites recorded in the final surveys.

Thus, due to scheduling problems of one kind or another, the sets of recommendations premising both major phases of field work at Choke Canyon were based on incomplete data collections. For Phase I. THC analysts 1 acked control over the full universe of detectable sites as they made their recommendations. In Phase II, provision had to be made for preliminary testing of a number of recently recorded sites to determine their eligibility for more intensive study (see Appendix I). The staggered fashion in which the archaeological data base was brought under control at Choke Canyon was a definite hindrance, making recommendations somewhat tentative at times when decisiveness would have been preferable.

\section{ESTABLISHING SITE SIGNIFICANCE}

Formulation of recommendations for Phase II archaeological investigations at Choke Canyon required development of a set of guidelines for establishing the relative significance of sites in the reservoir basin. These guidelines would aid in decisions as to which sites should receive additional investigative attention, how field time should be allocated, and what types of investigative procedures should be applied. In designing these guidelines, we defined "significance" as the potential a site has for yielding data pertinent to the major research problems currently recognized in south Texas prehistory. By this definition, all prehistoric sites have some degree of significance. However, the actual information yield from a site is totally dependent on state-of-the-art techniques of recovery and analysis. For us, the most significant sites were those that yielded the greatest variety of debris evidencing prehistoric human activity. In practice, this placed a premium on sites where animal bone and carbonized plant remains were preserved, in addition to the chipped stone, burned rock, mussel she11, and snail she11 that occurred on virtually every Choke Canyon site. Sites where cultural debris was stratified into two or more distinct zones were given special consideration because of their potential to yield information pertinent to cultural/chronologial problems. Presence of intact, wel1integrated habitational features was another factor adding to a site's significance. The perceived scarcity (or apparent absence) of definable components of Paleo-Indian and Early Archaic activity led us to pay special attention to localities where there was even the merest suggestion that such components might be found intact. According to this scheme, the most significant of the sites at Choke Canyon would be those that evidenced all of the characteristics just described. 


\section{THE CONDUCT OE PHASE II INVESTIGATIONS}

The Phase II Scope of Work (Appendix I) made provision for the investigation of 67 prehistoric sites at Choke Canyon. Thirteen of these sites were to receive a level of attention termed "intensive excavation." As Phase II field work commenced, only five of these intensive excavation sites were known. The balance of eight sites would be selected from the 62 sites tested during the course of Phase II field investigations. This necessary, but very arbitrary procedure had the unfortunate consequence of bringing on some difficult choices among the sites that were evaluated through the testing program. In discussions of excavation results presented in the preceding section of this report, there are several of the tested sites that obviously warranted further attention. These sites became victims of the value judgments that had to be made in dealing with a project on the scale of choke Canyon. Their exclusion from additional investigation was not so much a comment on each site's individual worth, but on the collective significance of al1 sites studied in Phase II. It was our opinion that available field time could be more beneficially expended elsewhere. Some recommendations for ways in which such decisions can be more judiciously made in the future wil1 be discussed below.

\section{A CULTURAL/CHRONOLOGICAL SLMMARY OF CHOKE CANYON PREHISTORY}

\section{THE PALEO-INDIAN PERIOD}

The combined efforts of archaeologists at Choke Canyon over the past 15 years have resulted in recovery or documentation of recognized Paleo-Indian period chipped stone artifacts from only 12 of the many prehistoric sites investigated. Sites, diagnostic forms recovered from each, and 1 andform settings are shown below.

41 LK 8

41 LK 14

41 LK 199

41 LK 204

41 MC 7

41 MC 10

41 MC 14

41 MC 84

41 MC 172

41 MC 194

41 MC 214

41 MC 234
Plainview, Scottsbluff Angostura (?)

Golondrina

Scottsbluff

Plainview or Angostura (?)

Plainview (several)

Plainview

proximal fragment with edge grinding

Plainview or Angostura (?) Golondrina

Angostura

medial thin biface fragment with ribbon flaking, edge grinding ancient floodplain terrace remnant ancient floodplain terrace remnant ancient floodplain terrace remnant upland valley margin

ancient floodplain terrace remnant ancient floodplain terrace remnant ancient floodplain terrace remnant valley margin slopes

ancient floodplain terrace remnant upland valley margin

valley margin slopes

ancient floodplain terrace remnant 
Also confirmed are surface finds, made by local residents, of a Folsom point in the vicinity of $41 \mathrm{MC} 7$ and $41 \mathrm{MC} 10$ and a Clovis point on Opossum Hi11 southwest of Opossum Creek (west of 41 MC 89).

Hester (1980:98-102) suggests the following ages for the Paleo-Indian diagnostics mentioned above:

$\begin{array}{ll}\text { Clovis } & 9200 \text { B.C. } \\ \text { Folson } & 8800 \text { B.C. to } 8500 \text { B.C. } \\ \text { Plainviet } & 8200 \text { B.C. } \\ \text { Golondrina } & 7000 \text { B.C. } \\ \text { Scottsbluff } & 6500 \text { B.C. } \\ \text { Angostura } & 6000 \text { B.C. }\end{array}$

Thus far, a 11 recognized Paleo-Indian diagnostics known from Choke Canyon have been found on site surfaces. No Paleo-Indian components have been defined in excavations. At virtual1y al1 locations where Paleo-Indian artifacts have been recovered there is also evidence of human activity postdating the Paleo-Indian period. It has therefore not been possible to expand our knowledge of the Paleo-Indian tool kit or subsistence habits as might otherwise be done through analysis of artifacts and other cultural residues present on sites where reliable diagnostics have occurred.

Review of the landform settings containing sites that have yielded PaleoIndian diagnostics are revealing, yet very likely deceptive. The settlement pattern was apparently oriented to the crests of high, old terrace remnants down on the floodplain of the Frio River and its major tributaries, such as San Miguel Creek and Salt Branch (south side of val1ey), and to the slopes and upland edge of the valley margin. It should be clearly emphasized here that the sampling universe is restricted to the Choke Canyon Reservoir basin. The data do not allow speculations of prehistoric settlement in upland areas away from the river val ley.

Although Paleo-Indian components have not yet been isolated in subsurface deposits at Choke Canyon, the bulk of regional data suggests that such buried components should exist here and there in the basin. Factors that may be dictating against discovery of buried Paleo-Indian components include: (1) the relatively small numbers of $\mathrm{Paleo-Indian}$ people that inhabited the region; (2) the shorter duration of their activity (3000 years for the PaleoIndian period compared to 8000 years for the Archaic and Late Prehistoric); and (3) the tendency, especial1y over the past 5000 or 6000 years, for the major drainages to be filling with alluvial and colluvial deposits. These factors combined 7 ikely influence heavily the modern perception of PaleoIndian settlement at Choke Canyon. A smaller number of Paleo-Indian people operating in a region over a shorter period of time would be expected to have generated proportionately less habitational debris at fewer sites than did succeeding Archaic period populations. If Paleo-Indian base camps were located on the banks of the river and its tributaries as they existed 10,000 years ago, the residues evidencing their encampments have probably been deeply buried as the valleys subsequently began to fill through processes of al luvial and colluvial deposition. 
The rare buried $\mathrm{Paleo-Indian}$ components that have come to 1 ight elsewhere on the coastal plain of southern Texas (Hester 1980) provide hope for the discovery of similar remains in the Choke Canyon region. Until such components are isolated and thoroughly investigated, it will be impossible to do much more than recognize that Paleo-Indlan people were active in the area as indicated by the occurrence of 1 anceolate biface types such as Plainview, Golondrina, Angostura, and Scottsbluff. These types are el sewhere clearly affiliated with Paleo-Indian cultural patterns and must surely indicate expressions of the same or similar traditions at Choke Canyon.

\section{THE PALEO-INDIAN TO EARLY ARCHAIC TRANSITION: THE CLEAR FORK QUESTION}

The discussion of the Paleo-Indian period at Choke Canyon presented above is arbitrarily exclusive, but technically correct, in 1 imiting definition of Paleo-Indian components to those sites yielding lanceolate point types that are well established as period diagnostics. The Clear Fork "gouge" (after Ray 1941) tool form is herein categorized as distally beveled tools, Group 1 and Group 2 (especial1y Form 1). The presence of 1 arge numbers of these artifacts, and the variability they exhibit, present a special problem in terms of their value as a temporally diagnostic item. For example, bifacial forms of Clear Fork, usually elongate and parallel-sided, are known to occur in Paleo-Indian contexts in northeastern Mexico, the lower Pecos River area, and in south-central Texas (Epstein 1969; Hester 1980:137-138). Furthermore, a 1 arge unifacial variant occurs in Early Archaic sites in south-central Texas (Hester and Kohnitz 1975; B1ack and McGraw 1985). Final1y, throughout much of southern Texas, smaller unifacial and bifacial Clear Fork implements occur entirely in Archaic contexts (Hester, Gilbow, and Albee 1973). Clearly, the use of the term Clear Fork can on ly refer to a 100 se morphological group of artifacts from both Paleo-Indian and Archaic times. Much additional research is needed to sort the various forms, if possible, into meaningful temporal types (cf. Turner and Hester 1985:205).

Listed below are sites at Choke Canyon where Clear Fork gouges--of all forms--have been recovered:

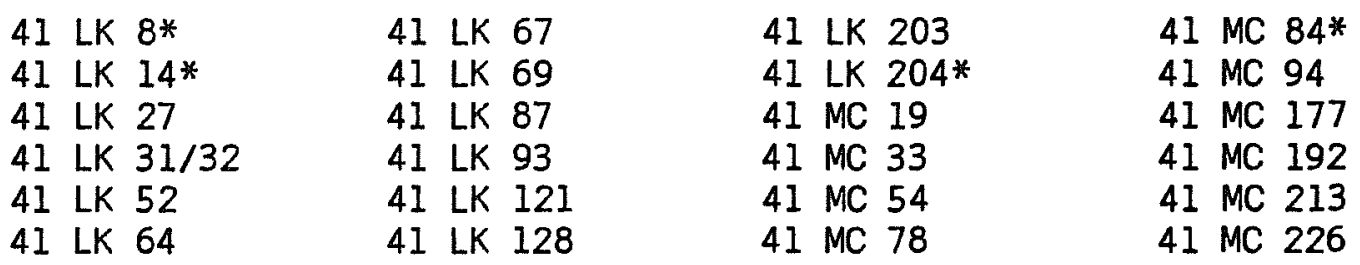

Asterisks (*) following site numbers indicate locations where Paleo-Indian diagnostics were also found. This 1 isting would seem to indicate that Clear Fork tools are not commonly associated with Paleo-Indian components at Choke Canyon. More probably, these artifacts are an indicator of Middle Archaic activity. As with sites yielding sound Paleo-Indian diagnostics, the sites where "classic" Clear Fork tools are found tend to be located on older terrace remnants in the river and creek valleys and along the valley margins.

There are indications that it may someday be possible to improve the dlagnostic capabilities of Clear Fork tools on the basis of minor 
morphological variations. Such a clarification will depend on location and investigation of sites containing the appropriate components as identified by diagnostic tool forms more reliable than the Clear Fork as currently defined.

\section{THE EARLY ARCHAIC PERIOD}

\section{Early Archaic Diagnostics: The Guadalupe Tool and Others}

A growing body of data has shown that the tool type known as the Guada 1 upe "adze," or "gouge," treated for descriptive purposes as Group 6 of distal1y beveled tools in this report, is a very reliable Early Archaic diagnostic form, specifical1y for the time period from 6000 B.C. to 3500 B.C. in central Texas (Hester and Kohnitz 1975; Hester 1980; B 1 ack and McGraw 1985). The following sites at Choke Canyon have yielded Guadalupe tools. Al1 are surface finds.

$\begin{array}{llllllll}41 \text { LK } 8 * & 41 \text { LK } 65 & 41 \text { MC } 52 & 41 & \text { MC } 174 \\ 41 \text { LK } 14 * & 41 \text { LK } 69+ & 41 \text { MC } 60 & 41 \text { MC } 189 \\ 41 \text { LK } 15 & 41 \text { LK } 74 & 41 \text { MC } 94+ & 41 \text { MC 213+ } \\ 41 \text { LK } 17 & 41 \text { LK } 133 & 41 \text { MC } 165 & \end{array}$

Asterisks (*) in the 1 ist above indicate sites where Paleo-Indian diagnostics were also recovered. Crosses $(t)$ show sites where Clear Fork specimens were found.

There are few additional Early Archaic diagnostic tool forms clearly recognized at Choke Canyon. Thin biface specimens tentatively advanced as Early Archaic types include stemmed dart points such as Be 11 (4l LK 52, 41 LK 122) and the generic "Early Expanding Stem" dart points (41 LK 8, 41 LK 51, and 41 LK 122). The specimen recovered from radjocarbon-dated deposits at 41 LK 51 is very similar to the Bandy type, an Early Archaic dart point common in the Trans-Pecos region (Word and Douglas 1970; Turner and Hester 1985). Another generic form, the "Early Triangular," is an unstemmed thin biface whose delicate workmanship makes it stand out in some assemblages in the Trans-Pecos and in central Texas (Hester 1980). Possible "Early Triangular" specimens have been recovered from sites 41 LK 53 (Group 2, Form 1. Specimen 5, thin bifaces) and 41 LK 197 (Group 2, Form 1, Specimen 16, thin bifaces) at Choke Canyon. The problem with the use of triangular thin biface forms as diagnostics in south Texas is that, unlike central Texas, the triangular form becomes extremely common in Middle Archaic and Late Archaic times (the best example is the Tortugas type). As a result, the "Early Triangular" form does not have the background of predominately stemmed dart points to make it stand out as distinctively as it does in central Texas (Ha 1 1, B 1ack, and Graves 1982:463).

\section{Buried Early Archaic Components}

Evidence recovered from 41 LK $31 / 32$ (Scott and Fox 1982) and observations made at three other sites investigated during the course of Phase I prehistoric research at Choke Canyon 1 ed to the statement that "1ow terraces along the Frio River, its relict channe1s, and its larger tributaries became 
major zones of intensive aboriginal settlement after 3500 B.C. (Ha11, Black, and Graves 1982:464). Findings made at 41 LK 51 during Phase II excavations reveal an even earlier buried component along Opossum Hol 10w.

At 41 LK 31/32, evidence was found of prehistoric cultural debris buried over two meters beneath the modern ground surface on a terrace beside the modern Frio River. In subsequent controlled excavations, a number of habitational features were exposed and recorded. Carbon in amounts adequate for radiocarbon assay were collected from three of the features. Assays of these samples yielded two absolute dates ranging from 3380 B.C. to 3350 B.C. on the early horizon in the site and an age range of 2360 B.C. to 2340 B.C. for a 1 iving surface which occurred a meter above the early horizon, a location roughly midway through the deposit (al1 dates MASCA corrected). These dates indicate that 41 LK $31 / 32$ contained Early Archaic and Middle Archaic components in its 1 ower reaches.

The Early Archaic component at 41 LK $31 / 32$ was manifest by a very distinct 1 iving surface across which clusters of habitational debris were distributed. These debris clusters were composed predominately of mussel shell and Rabdotus snail she11. Sandstone, chert cores, debitage, carbon, and soil discolorations were al so present (Scott and Fox 1982:31). Three proximal thin biface fragments, each broad and finely worked with a concave base, were recovered from this Early Archaic component. Bone was very infrequent, but turtle and drum fish were identified among vertebrate faunal remains recovered.

Phase II excavations at 41 LK 51 produced evidence of another Early Archaic component buried approximately $1.5 \mathrm{~m}$ below the modern ground surface beside the channel of Opossum Hollow. The horizon was sampled in on 1 y $51 \times 1-\mathrm{m}^{2}$ units. One habitational feature (Feature 6)--a cluster of tuff, sandstone, and fire-fractured rock--was isolated. Mussel she11, Rabdotus shel1, and a sma11 amount of bone were found around the feature. A number of thin biface specimens came out of this horizon. One of these specimens is a stemmed dart point (Group 1, Form 3, Specimen 19, thin bifaces), tentatively identified as the Bandy type. Also recovered were six unstemmed thin bifaces with straight (Group 2, Form 2, Specimen 15), concave (Group 3, Form 1, Specimen 1), or convex bases (Group 4, Form 1, Specimen 6; Group 4, Form 4, three specimens). A very large carbon sample gathered from a location $20 \mathrm{~cm}$ beneath Feature 6 yielded a radiocarbon age range of 5130 B.C. to 4450 B.C. (TX-4690 and TX4691, both MASCA corrected). As this carbon was s 1 ightly deeper than, and distinctly separate from Feature 6, it is possible that the feature would date to a somewhat younger time. The wood burned to form this carbon has been identified as either Prosopis or Acacia. This is an extremely significant determination in that it demonstrates the 1 ocal presence 6500 to 7000 years ago of a species that is a major element of modern brush communities in the region.

Though 1 imited in their extent of investigation, the Early Archaic components identified at 41 LK $31 / 32$ and 41 LK 51 are very important for several reasons. First, the simple fact that they have been found and identified is a major advance. In the future, investigators will know that such early components are to be expected and will have an idea of where they ought to be found. Further, since buried Early Archaic components are present and 
identifiable at Choke Canyon it becomes a 11 the more 1 ikely that burled Paleo-Indian components are also preserved and will someday be found.

The buried Early Archaic components at Choke Canyon have not been generous in providing distinctive chipped stone tool forms useful as diagnostics for the

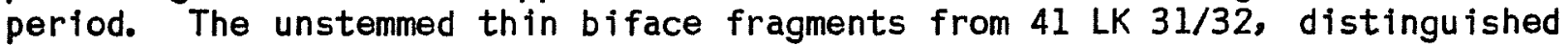
by their fine workmanship and broad, concave bases, will likely prove useful as local Early Archaic diagnostics. Likewise, the stemmed thin biface from 41 LK 51 suggested to be of the Bandy type, is a distinctive form and should make a good diagnostic. More generally, these few specimens are very important in that they are suggestive of a broad cultural/chronological pattern that occurs across south Texas, the Trans-Pecos (the Bandy type; Word and Douglas 1970), and central Texas (unstemmed thin bifaces with broad. concave bases; Weir 1976). It is speculated that future, more extensive investigations of buried Early Archaic components in southern Texas will reveal even stronger parallels to Trans-Pecos and central Texas Early Archaic diagnostic assemblages. The 1 imited probes of Early Archaic components at Choke Canyon have thus far not yielded any specimens of 1 arge, unifacial Clear Fork or Guadalupe tools, given the very smal1 areas actual1y excavated, this is 1 ikely to be a sampling error.

Again 1 imited by the extremely small sample, it is not possible to comment at any great 1 ength on the subsistence habits of Choke Canyon's Early Archaic peop 1es. As is so frequent1y the case in $10 \mathrm{cal}$ prehistoric context, it is musse1 she11. Rabdotus snai1 she11, a few shreds of animal bone, and perhaps some sandstone grinding implements, that may be cited as direct or indirect signs of what Early Archaic people were eating. In this respect, it can only be said that Early Archaic subsistence residues are not remarkably different from assemblages representing later periods. In comparing the Early Archaic and Middle Archalc habitational features defined at $41 \mathrm{LK} 31 / 32$, it is striking that the most carefully constructed and wel1-integrated rock clusters (suggested to be hearths intended for roasting or baking some type of food) occur in Middle Archaic context. Data from other sites, such as 41 LK 67 and 41 LK 201, support this apparent pattern (Brown et a 1. 1982; Highley 1986). The fact that wel1-constructed roasting/baking facilities are not yet definitely recognized in Early Archaic context at Choke Canyon may reflect a sampling bias. However, should this perceived pattern hold up in future research, a significant difference in subsistence orientation may be indicated.

\section{THE MIDDLE ARCHAIC AND LATE ARCHAIC PERIODS}

In this study, the terminus of the Early Archaic period and the starting date for the Middle Archaic period are arbitrarily set at 2500 B.C. This tentative determination is based partly on the approximate temporal juncture of these two periods in central Texas and the Trans-Pecos and partly on the radiocarbon date of 2360 B.C. to 2340 B.C. provided by a presumed Middle Archaic component at 41 LK $31 / 32$ (Scott and Fox 1982). Later radiocarbon ages for the Middle Archaic have also been obtained at 41 LK 67 (Brown et al. 1982), 41 LK 201 (Highley 1986), and at 41 MC 201 (Thoms, Montgomery, and Portnoy 1981). These later dates suggest a terminus of 400 B.C. for the Middle Archalc (see discussion in Appendix VI). 
Investigation of buried Middle Archaic components at 41 LK 31/32, 4 I LK 67, and 41 LK 201 permit, in a 1 imited way, characterization of the habitational residues representing the period. As mentioned above in the discussion of the Early Archaic, the Middle Archaic components contain very substantial, we 11-integrated rock cluster features suggested to have functioned as roasting or baking hearths. Distally beveled tools ("gouges") appear in radiocarbon-dated context for the first time, with specimens categorized into Groups 3 and 4 as being especially common. Stemmed dart points occur infrequentiy, and most specimens that have been found do not meet the criteria for established dart point typologies. Unstemmed thin bifaces are much more common, but equally difficult to classify.

Three stemmed dart point types found at Choke Canyon--Pedernales, Morhiss, and Langtry--are demonstrated Middle Archaic diagnostics in central Texas (Pedernales), in the Trans-Pecos area (Langtry), and on the Texas coastal plain northeast of Choke Canyon (Morhiss). Sites yielding these types at Choke Canyon are as follows:

\section{Pedernales}
41 LK 10
41 LK $31 / 32$
41 LK 51
41 LK 201
41 MC 201
41 MC 209
41 MC 213
41 MC 275

\section{Morhiss}

41 LK 8

41 LK 14

41 LK $31 / 32$

41 LK 201

41 MC 196

\section{Langtry}

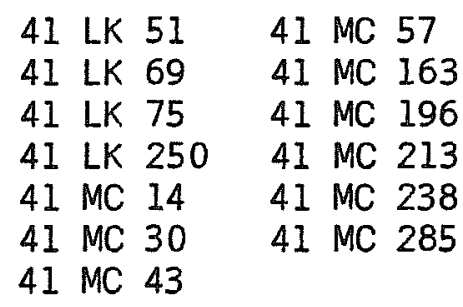

Most of these specimens were surface finds.

If recognition of Middle Archaic components at Choke Canyon was 1 imited to those localities yielding the specimens 1 isted above, there would appear to have been very little human activity in the area during the period. However, based on the 1 imited findings at 41 LK 31/32, 41 LK 67, and 41 LK 201, it appears likely that many of the unstemmed thin bifaces (thin bifaces Groups 2, 3, 4, [except Forms 2 and 3], and 5) and many of the dista $71 y$ beveled tools (especially Groups 3 and 4 ) are representative of the Middle Archaic period.

\section{Distally Beveled Tools of the Middle and Late Archaic Periods}

The diminutive "gouge" tools classified into distally beveled tools Groups 3 and 4 appear to be strongly affiliated with the Middle Archaic period and, to a lesser extent, with the Late Archaic. Phase I findings at Choke Canyon contribute much of the data permitting this association (Ha 1 1, B lack, and Graves 1982:340-346). Unfortunately, uncertainty about where Early Archaic, Middle Archaic, and Late Archaic temporal boundaries should be drawn led to assignment of a number of distally beveled tools to the Early Archaic and Late Archaic periods (Hal1, Black, and Graves 1982:345, Fig. 79). In truth, the radiocarbon age span of 2360 B.C. to 660 B.C. for the few dated Phase I specimens more accurately indicates Middle Archaic affiliation. Additional specimens (Groups 3 and 4) recovered during Phase II excavations at 41 LK 201 
provide more support for assignment of the forms to the Middle Archaic period. Less conclusive stratigraphic occurrences of these small distally beveled tools suggest more 1 imited usage on into the Late Archaic.

Distally beveled tools categorized into Group 3 (Forms 1-3) and Group 4 were recovered from 59 prehistoric sites at Choke Canyon (Phase I and Phase II research combined). Eleven (19\%) of these 59 sites also yielded one or more of the Pedernales. Morhiss, or Langtry Middle Archaic diagnostics discussed above. Probable Late Archaic diagnostics (to be discussed below) were found on $13(22 \%)$ of the 59 sites where Group 3 and Group 4 distally beveled tools were recovered. Sites where these particular tools were found are as follows (from site provenience tables in this report and $\mathrm{Ha} 11$, Black, and Graves 1982):

\begin{tabular}{|c|c|c|c|}
\hline 41 LK 10* & 41 LK 94 & 41 MC 18 & 41 MC 174 \\
\hline 41 LK 13 & 41 LK 127 & 41 MC 19 & 41 MC 196* \\
\hline 41 LK 14* & 41 LK 182 & $41 \mathrm{MC} 22$ & $41 M C 212$ \\
\hline 41 LK 15t & 41 LK 199 & 41 MC 25 & 41 MC $213^{*+}$ \\
\hline 41 LK 17 & 41 LK 201t & $41 \mathrm{MC} 28$ & $41 \mathrm{MC} 226$ \\
\hline 41 LK 27 & 41 LK 205t & 41 MC 29 & 41 MC 238* \\
\hline 41 LK 31/32* & 41 LK 206 & 41 MC 41 & $41 \mathrm{MC} 246$ \\
\hline 41 LK $51^{*}+$ & 41 LK 243 & 41 MC 50 & $41 \mathrm{MC} 251$ \\
\hline 41 LK 53 & 41 LK 250* & 41 MC 52 & 41 MC 260t \\
\hline 41 LK 67t & 41 LK 252 & 41 MC 55 & 41 MC 268t \\
\hline 41 LK 69* & 41 LK 253 & 41 MC 64 & $41 \mathrm{MC} 270$ \\
\hline 41 LK $74+$ & $41 \mathrm{MC} 11$ & 41 MC 75 & 41 MC 276 \\
\hline $4 I$ LK $75 *$ & 41 MC 13 & $41 \mathrm{MC} 84+$ & 41 MC 282 \\
\hline 41 LK 85 & 41 MC 14* & 41 MC 94t & 41 MC 296+ \\
\hline 41 LK 91 & $41 \mathrm{MC} 15+$ & 41 MC 95 & \\
\hline
\end{tabular}

Asterisks (*) indicate sites where Middle Archaic dart points were recovered. Crosses ( + ) designate sites yielding Late Archaic dart points (see below).

\section{Recognized Late Archaic Diagnostics}

A survey of al1 reports dealing with Choke Canyon's prehistoric sites, including the present study, yields a 1 ist of 44 sites from which stemmed dart points diagnostic of the Late Archaic period have been recovered. The point types are Ensor, Frio, Ellis, Marcos, and Fairland. Sites where these point types were found are 1 isted below.

\begin{tabular}{|c|c|c|c|}
\hline 41 LK 8 & 41 LK 185 & 41 MC 43 & $41 M C 250$ \\
\hline 41 LK 15 & 41 LK 201 & 41 MC 57 & 41 MC 257 \\
\hline 41 LK 51 & 41 LK 205 & 41 MC 84 & $41 \mathrm{MC} 259$ \\
\hline 41 LK 64 & 41 LK 234 & $41 \mathrm{MC} 85$ & 41 MC 260 \\
\hline 41 LK 67 & 41 LK 243 & 41 MC 94 & 41 MC 266 \\
\hline 41 LK 70 & 41 LK 247 & 41 MC 163 & 41 MC 268 \\
\hline 41 LK 74 & 41 LK 251 & $41 \mathrm{MC} 171$ & $41 M C 275$ \\
\hline 41 LK 87 & 41 LK 252 & 41 MC 184 & $41 \mathrm{MC} 280$ \\
\hline 41 LK 128 & $41 \mathrm{MC} 7$ & $41 \mathrm{MC} 213$ & 41 MC 288 \\
\hline 41 LK 159 & $41 \mathrm{MC} 15$ & 41 MC 247 & 41 MC 294 \\
\hline 41 LK 181 & 41 MC 17 & 11 MC 218 & 41 MC 296 \\
\hline
\end{tabular}


The Late Archaic period at Choke Canyon is suggested to span the time period from 400 B.C. to A.D. 900.

\section{The Middle and Late Acchaic: Aspects of Settlement and Subsistence}

By combining the sites at Choke Canyon that have yielded recognized Middle Archaic and Late Archaic stemmed dart point forms and the sites yielding distally beveled tools in Groups 3 and 4, a total of 99 sites is achieved. This comparatively vast number of sites suggests a period of intense human activity in the river valley for the periods represented. Sites in this group occur in virtually every physiographic setting found in the area. As previously discussed, the Middle Archaic component at 41 LK $31 / 32$ was radiocarbon dated at 2340 B.C. This is the ear 7 iest dated component designated Middle Archaic. Other radiocarbon dates for apparent Middle Archaic components range from 1800 B.C. to 800 B.C., and there is a notable clustering of dates in the 800 B.C. to A.D. 200 range (see Appendix VI). The latter end of this cluster--from 400 B.C. to A.D. 200--would, of course, carry over into the Late Archaic period as it is being defined in this study.

It is in this period of apparently intensive Middle Archaic activity that another distinctive phenomenon is manifested. The wel1-made roasting/baking hearths found at 41 LK 31/32, 41 LK 67, and 41 LK 201 have al ready been discussed. Here, attention is called to 14 sites (4I LK 17, 41 LK 69, 41 LK 207, 41 LK 250, 41 LK 252, 41 LK 253, 41 MC 196, 41 MC 201, 41 MC 209, 41 MC 213, 41 MC 220, 41 MC 260, 41 MC 266, 41 MC 296) where particularly massive quantities of burned rock--sandstone, tuff, or chert--have been noted and/or sampled.

These sites, too, apparently date to the 1 ater years of the Middle Archaic and to the Late Archaic. Where they have been exposed on the surface--such as at 41 LK 69, 41 LK 207, and 41 MC 266--the concentrations of burned rock assume subcircular or oval outline patterns with dimensions on the order of $10 \mathrm{~m} \times 20 \mathrm{~m}$. Even 1 arger surface exposures of burned rock occur at sites such as 41 MC 209 (Thoms, Montgomery, and Portnoy 1981) and 41 MC 220 (Ha11. B 1 ack, and Graves 1982). Where accumulations have been encountered in excavations, for example at 41 LK 17 and 41 LK 250, 1ayers of virtual 1y solid burned rock up to $40 \mathrm{~cm}$ thick have been documented. There is a tendency for sites bearing the burned rock deposits to be located either along valley margins or on the floodplains of tributary channels in their upper reaches, away from the river valley. However, to demonstrate that the rock masses are not confined to the higher reaches of the valley, site 41 LK 17 is located down on the floodplain beside a relict channel of the Frio River. It is stretching the inference very thin, but it is nevertheless interesting to note the modern-day proximity of groves of oak trees to sites such as 41 MC 209, 41 MC 220, and 41 MC 296. Some have attributed the development of "burned rock middens" in central Texas to the processing of acorns for human consumption during the Archaic (Weir 1976; Darrel Creel, personal communication).

The later years of the Middle Archaic period and the Late Archaic period may thus be characterized as times when numerous sites were periodically occupied in a 11 parts of the Choke Canyon basin. The primary tool kit, as 1 ithic 
evidence of it has survived in the archaeological record, consisted of sma11 distally beveled tools (for multipurpose woodworking and/or plant product harvesting tasks?), unstemmed thin bifaces that could have been used as knives or dart points, modified and trimmed chert flakes, and a limited number of stemmed thin bifaces that, again, might have served either as cutting tools or dart points. Grinding stones (manos and metates) are very common. Hearths, formed of substantial, we11-integrated clusters of rock, and masses of burned rock stand out as a major distinction for bracketing cultural periods and are interpreted as residues of a major subsistence interest, probably the cooking of roots or plant stalks. Mussel shell and Rabdotus snail shell are usually present and are beljeved to show that the flesh of mussels and snails was often eaten. Analysis of vertebrate faunal remains from 41 LK 201 (Steele 1986) and 41 MC 296 (Appendix III) provides an idea of the kinds of animals that Archaic people were hunting, trapping, or catching. Comparison of Archaic and Late Prehistoric fauna 1 assemb 7 ages from Phase I investigations led to the following speculation:

- - it appears that Archaic people were concentrating on the capture of smalier animals such as rodents, rabbits, snakes, 1 izards, fish, and turt 1es. Deer were also hunted. During Late Prehistoric times, a much broader and diversified hunting effort seems to have been underway. In addition to the smaller animals, Late Prehistoric people relied heavily upon procurement of 1 arger animals such as bison, antelope, deer, and javelina (Hall, Black, and Graves 1982:471).

With benefit of more extensive collections and careful identifications in Phase II, similar differences in Archaic and Late Prehistoric faunal remains have been clearly demonstrated (see Appendix III). Wood species identifications made from carbon recovered from Middle Archaic components at 41 LK 51 and 41 LK 201--specifical1y of Prosopis and Acaciam-demonstrate that major elements of the modern brush community were present in the region in prehistoric times. As producers of nutritious beans, the Prosopis and Acacia species may have provided a significant food contribution to the diets of prehistoric people. However, after finding that such species existed in Middle Archaic and Late Archaic times and recovering coeval sandstone grinding tools (presumed seed/nut/bean processing equipment), there is at present no hard data that 1 inks mesquite or acacia beans (or grass seeds, for that matter) to the manos and metates. Thus, the evidence permits only the suggestion that grinding implements indicate seed/nut/bean processing. The carbon identifications show what may have been available for processing.

\section{THE LATE PREHISTORIC PERIOD}

Being the 1 atest period in Choke Canyon's prehistoric cultural sequence, the Late Prehistoric offers some dramatic research advantages over its 1 ocal predecessors. Debris representing the period is highly visible. If not exposed on the surface, Late Prehistoric debris is seldom buried by more than $40 \mathrm{~cm}$ of deposit--usual1y 1ess. Due probably to the fact that chemical agencies and soil processes have not had as long a time to break them down, bone and charcoal are recovered much more frequently from Late Prehistoric components at Choke Canyon than they are from Archaic contexts. Finally, the 
most important characteristic of the Late Prehistoric components is that they normally yield a profusion of time diagnostics in the form of arrow points, potsherds, and certain other artifact types. Based on radiocarbon assays and differences in arrow point types, the period can be divided into two segments. Components bearing only Scallorn and/or Edwards arrow points tentatively date from A.D. 900 to A.D. 1400. Components yielding on 1 y Perdiz arrow points appear to date from A.D. 1400 to A.D. 1650 (see discussion of radiocarbon dates in Appendix VI).

Combined archaeological efforts at Choke Canyon over the past 15 years have resulted in definition of Late Prehistoric components at 61 sites. Arrow points of the Scallorn. Edwards, and Perdiz types and prehistoric aboriginal pottery were the diagnostics used to identify the components. The sites are 1 isted below according to the diagnostic(s) found at each.

Pottery only

41 LK 8

41 LK 15

41 LK 74

41 LK 85

41 LK 92

41 LK 176

41. LK 185

41 LK 236

41 MC 9
41 MC 14

41 MC 17

41 MC 41

41 MC 64

41 MC 194

41 MC 260

41 MC 266

41 MC 283

41 MC 293
Scallorn only

41 LK 49

41. LK 86

41 LK 246

41 MC 24

41 MC 28

41 MC 74

41 MC 83

41 MC 95

41 MC 264

41 MC 280

\section{Scallorn-pottery}

$4 I$ LK 243

41 MC 17

41 MC 84

41 MC 94

41 MC 165

41 MC 222

41 MC 298

\section{Scallarn-pottery-Perdiz}

Perdiz-Scallorn

41 LK 53
Perdiz only

41 LK 18

41 LK 55

$4 I$ LK 64

41 LK 181

41 MC 65

41 MC 79

41 MC 183

41 MC 242

41 MC 297
Perdiz-pottery
41 LK 51
41 LK 67
41 LK 94
41 LK 128
41 MC 19
41 MC 43
41 MC 55
41 MC 223
41 MC 275
41 MC 286
41 MC 294

Plotting the distribution of sites that produced Late Prehistoric diagnostics at Choke Canyon, a settlement pattern distinctly different from that of the Archaic is seen. Late Prehistoric camps are most often situated along the channels of major drainages, either of the Frio River or its principal local tributaries, and on natural levees beside relict channels of these same drainages. Preference for proximity to a water source is clearly indicated.

*Here, the Scallorn group includes Scallorn-1 ike expanding stem arrow points. 
A few Late Prehistoric sites occur along the valley margins, but they are not nearly so common as Archaic components in the same setting.

Two sites excavated during Phase II investigations, 41 MC 222 and 41 MC 55, serve well as examples of the temporally discrete subperiods recognized for the Late Prehistoric at Choke Canyon. Site 41 MC 222 (Skillet Mountain No. 4) yielded an assemblage containing arrow points of the Scal1 1orn and Edwards types. There are also examples of a currently untyped arrow point form having a straight stem. Several unstemmed thin bifaces, mano and metate fragments, a bone pin or aw 1 , and sherds of pottery round out the assemb 1 age for 41 MC 222. This collection is typical of the early phase of the Late Prehistoric period at Choke Canyon in the range of A.D. 900 to A.D. 1400. It corresponds, at least in part, to the Austin phase of central Texas.

The Late Prehistoric component at 41 MC 55 yielded Perdiz arrow points; a tiny, unstemmed arrow point (MCGloin type?); "beveled knives"; unifaces; trimmed flakes; and sherds of pottery. Site 41 LK 201 (Highley 1986) has a similar assemblage, and though some Scallorn points occur with Perdiz points and ceramics at 41 MC 296, it is also felt to be a good example of this late phase Late Prehistoric at Choke Canyon. Although there is an over 7 ap of radiocarbon dates from the Late Prehistoric sites, the assays from $41 \mathrm{MC} 55$, 41 MC 296, and 41 LK 201 tend to cluster 1ater than 41 MC 222 and other ear1y phase Late Prehistoric components. Such 1 ate phase materials have been referred to the Toyah horizon by Black (n.d.), based on excavations at site $41 \mathrm{JW} 8$.

\section{THE ARCHAIC AND LATE PREHISTORIC PERIODS: COMPARISONS}

Substantial changes in material culture, apparent subsistence pursuits, and settlement patterns al1 serve to distinguish the rough 1 y 800 years of the Late Prehistoric period in south Texas from the previous 7000 years of Archaic 1 ifeways. For the Archaic period, the appearance is that changes occurred slowly and were simply modifications on the same basic theme. The dart point, distally beveled tool ("gouge"), grinding implements, and chert flakes of no customary shape are the main classes of tools that survive to represent the Archaic.

With the appearance of the first Late Prehistoric occupations of the area around A.D. 900, the hal 1 marks of the Archaic tool kit--the dart point and gouge-disappear completely from the material culture inventory. They are replaced by the arrow point and a series of unifacially worked side- and end scrapers. Pottery comes into use. The Late Prehistoric people confine their activities much more to the banks of the river and major streams than did their predecessors. In particular, the Late Archaic period saw human activity resulting in accumulation of cultural debris at diverse locations throughout the Frio River valley and beyond.

Differences in perceived subsistence habits between the Archaic and Late Prehistoric are indicated by respective collections of vertebrate faunal remains and cooking facilities preserved in various components of each period. Generally speaking, the Archaic at Choke Canyon is represented by substantial features composed of stone and presumed to have functioned as 
cooking facilities. Rock clusters do certainly occur as habitational features in Late Prehistoric context, but they do not tend to be as massive or well integrated as those found in Archaic contexts. As shall be discussed in more detail below, the amount of rock concentrated in Archaic components as habitational features points to a heavy reliance on plant products for food.

Other archaeologically visible indicators of plant food utilization--grinding implements--are equal 1 y common in both the Archaic and Late Prehistoric periods. Probably used in the preparation of seeds, nuts, and/or beans, the grinding implements suggest that such foods were important to human subsistence throughout the prehistory of the Choke Canyon area.

With the apparent de-emphasis on use of certain kinds of plant foods in the Late Prehistoric came an increase in the quantity and variety of meat foods contributing to the diet (see discussion above and in Appendix III). Shells of 1 arge 1 and snails and of mussels, often combined in the same habitational features, evidence the continuing importance of these fauna for meat food through the entire span of the Archaic and Late Prehistoric periods.

The very clear differences between Archaic and Late Prehistoric adaptations recognized on the basis of findings made at Choke Canyon necessitate consideration of a basic problem in the study of south Texas prehistory. Were the changes in material culture, subsistence pursuits, and settlement patterns characteristic of the south Texas Late Prehistoric impressed on an indigenous population, that is, people descended from the Archaic groups who inhabited the region? Or, do these changes indicate an influx of people from other regions? We offer no solution to this problem other than to cal1 attention to the obvious differences revealed by the research at Choke Canyon. Future investigations should focus on the time period between A.D. 200 and A.D. 800, a 600-year span that is significantly underrepresented in the Choke Canyon radiocarbon analysis (see Appendix VI) and which serves as the temporal breach between solid Late Archaic and Late Prehistoric components. If it is to be argued that population replacement occurred, one obvious question that needs to be addressed is: what happened to the region's indigenous peop 1 e? The period between A.D. 200 and A.D. 800 is the time when the transition would have taken place. Prehistoric cultural components dating to this time should contain data that would help clarify this issue.

Regardless of the eventual resolution to the questions raised above, the Late Prehistoric data a 1 ready in hand, especially evidence for technological innovations such as the bow and arrow and pottery and the apparent shifts in subsistence orientation, give us the impression that quite profound changes occurred in the Late Prehistoric--changes unprecedented in the 7000 years of Archaic period cultural activity in the region.

\section{HISTORIC PERIOD ABORIGINAL OCCUPATIONS}

A1though Campbel1 and Campbel1 (1981) have detailed what is known of Historic era aboriginal populations in the Choke Canyon region, we have found only a few recognizable traces of their presence. At 41 LK 31/32, a metal arrow 
point of a form that can be 1 inked to 19th-century Indian groups (probably midd le to 1 ate 19 th century) was reported by Fox (Scott and Fox 1982). The occurrence of an earlier Historic period aboriginal occupation is 1 ikely at 41 MC 296. A corroded metal knife blade was found and is similar to those we have seen in collections from the Spanish Colonial missions in Texas and northeastern Mexico. In the same context was a 1 anceolate arrow point of the Guerrero type also found in the missions (Hester 1977; Fox 1979b; Hester 1980). Site 41 MC 296 also has cultural materials from the late phase Late Prehistoric. Indeed, such 7 ate materials may represent early Historic occupations elsewhere at Choke Canyon, but cannot be clearly distinguished without the presence of Spanish Colonial period diagnostics.

\section{SLGGESTIONS FOR FUTURE_RESEARCH}

In archaeological studies of reservoir basins and other 1 arge tracts of 1 and to be affected by whatever type of destructive modification, the prevalent attitude over the past 15 or 20 years has been that samp 1 ing of sites and the materials they contain should be broad and all-inclusive. Ideally, each kind of material manifestation resulting from past aboriginal activity would be identified and probed as necessary in an attempt to demonstrate what people were doing to generate that particular set of remains. In large part, this attitude came about as a response to WPA and River Basin Survey salvage operations that concentrated efforts on large, highly productive sites and ignored smaller, special activity 10ci. Greater emphasis on settlement pattern studies and recognition of the systemic aspects of culture have also acted to promote the broad spectrum approach to site investigations.

As a result of our experience at Choke Canyon, it may be suggested that the time has come for the pendulum to swing back to a more moderate position between the extremes. We would not argue that broad spectrum site investigation is bad in and of itself. The problem arises within the framework of a sponsored program where funds are generous, but nevertheless 1 imited, and the objective is mitigation of damages to a massive cultura 1 resource base spread over a large geographic area.

It is our opinion that sites holding the greatest potential for elucidating human 1 ifeways of the Paleo-Indian. Early Archaic, and Middle Archaic periods at Choke Canyon (and general1y throughout south Texas) are in deep, stratified deposits occurring as terraces beside the major drainages in the reservoir basin. Some good examples of such sites excavated during Phase I and Phase II investigations at Choke Canyon are 41 LK $31 / 32$ (Scott and Fox 1982), 41 LK 201 (Highley 1986; Hal1, Black, and Graves 1982), and 41 LK 51 (this volume). The major advantage recognized for these sites is that their stratification permits definition of discrete components, something impossible at the majority of sites where these early periods of activity are represented. Also, alluvial deposition over these terraces has tended to stabilize and protect habitational features much more satisfactorily than at most other locations in the valley (e.g.s. Pleistocene terraces, valley margin, and upland edge). A particularly vivid example of a fragile prehistoric feature preserved in such an environment is Feature 16 at 41 LK 31/32 (Scott and Fox 1982:43-44), consisting of some chert cores, debitage, a hammerstone, and some mussel she11. The integrity and definition 
of this cluster of remains is such that it requires no stretch of imagination to return to the scene the person who flaked the chert and satisfied an appetite with a meal of mussels. Thus, the process of terrace alluviation at Choke Canyon has provided resolution of human behavioral episodes not only down to the component level, but to an individual event in prehistory.

Beyond providing discrete units of cultural debris offering the potential for study of behavior and activity patterning, there is a tendency for the deep, stratified terrace sites to yield more vertebrate faunal material and carbon. The scarcity of these materials within prehistoric sites at Choke Canyon automatically places a premium on localities where they are preserved in relatively substantial amounts. Carbon recovered from habitational features provides samples for radiocarbon assay and for wood species identifications. When successful results are obtained from these types of analysis, cultural components can be dated, and elements of prehistoric floral communities are identified. Recognition of plant species aids in paleoenvironmental reconstruction and may also indicate plant products that were available as potential food sources to prehistoric people. Vertebrate faunal remains provide evidence of the meat foods that people were consuming and are also useful in paleoenvironmental reconstructions. Due to (1) the uniform absence of perishable materials in south Texas prehistoric sites; (2) the scarcity of pollen in these same sites; and (3) the infancy of regional phytolith ( $p$ lant opa 1) research. studies of carbonized plant remains and faunal materia 1 currently constitute the main avenues of research into paleoenvironment and prehistoric human subsistence.

It is in consideration of the factors and conditions out 1 ined above that we suggest the major thrust of future field research in the study of south Texas prehistory be directed at sites where it is possible to recognize discrete components (the finer the time/stratigraphic resolution the better) and which contain wel1-integrated habitational features, carbonized plant remains, and vertebrate faunal materials. We would contend that much more will ultimately be learned about prehistoric 1 ifeways in south Texas through the intensive study of a few sites with these characteristics than by attempting to equitably distribute effort over the full spectrum of sites existing within a given study area. In the concluding chapter of the recentiy published Prehistoric Hunter-Gatherers - The Emergence of Cultural Complexity, Brown and Price $(1985: 440-441)$ have said:

Improvements in the chronologies of prehistoric hunter-gatherer adaptations and refinements in the definition of major variables are essential to measure more accurately changes in natural productivity, technology, population, mobility, and the 1 ike. only with greater resolution in time and definition will information on the precise relations between these variables become clear.

\section{VISIBILITY AND ACCESSING THE BURIED REMAINS}

A related problem in the study of south Texas prehistory involves factors that result in older components receiving proportionately less attention than younger components. Late Prehistoric components on prehistoric sites at Choke Canyon are typically highly visible and easily recognizable. The 
cultural debris evidencing Late Prehistoric activity occurs within the upper $40 \mathrm{~cm}$ of deposit on most sites. Arrow points and ceramics are clearly diagnostic of a time period post-dating A.D. 900. Perhaps because they have been subjected to shorter periods of exposure to mechanical and chemica 1 action of soils, bone and carbon tend to be preserved more often in Late Prehistoric components at Choke Canyon. Late Prehistoric sites are thus shallow, well represented by cultural/temporal diagnostics, and tend to yield more bone and carbon than earlier components.

Archaic components in sites at Choke Canyon are typically very difficult to assign to more specific temporal units within the 7000-year span of the period in south Texas prehistory. This critical problem was recognized and addressed in concluding statements on the Phase I research at Choke Canyon (Ha11, Black, and Graves 1982:473-475). Refinement of the Archaic chronological sequence is hampered now by the same factors recognized then: there are at present too few diagnostic artifacts. This problem becomes especially acute on sites--constituting a decided majority at Choke Canyon--where there is 1 ittle or no recognizable stratigraphic separation between debris representing the presumed major periods of cultural activity. Such sites are often located on older, higher land surfaces where deposition has been slow or nonexistent. These same locations are frequently the ones that have suffered most from overgrazing and resultant degrading erosion in historic times.

The great need for a much more finely tuned Archaic period chronological framework in south Texas again accentuates the value of concentrating efforts on deep, stratified sites. Attempts at analyzing debris recovered from nonstratified or poorly stratified Archaic sites at Choke Canyon has not added substantially to our knowledge of 1 ifeways for the period.

Where an active depositional environment provides much-needed stratigraphic separation between sets of debris representing periodic encampments on a site, it also buries components, making them progressively more difficult to reach and investigate. The difficulty in reaching the deepest horizons or components on stratified terrace sites at Choke Canyon, such as 41 LK $31 / 32$ and 41 LK 5l, has dictated against the kind of thorough investigation we bel ieve will be necessary in the future.

At Choke Canyon, the most extensive contiguous horizontal excavations were conducted at 41 LK 67 (Brown et a 1. 1982). Controlled excavations occurred in two unit blocks measuring $10 \times 12 \mathrm{~m}$ and $8 \times 8 \mathrm{~m}$. Between the two blocks of controlled excavations, over an area of approximately $38 \times 74 \mathrm{~m}$, a bu11dozer was used to expose habitational features. This gross excavation technique, utilized on a site soon to be completely destroyed by dam construction, provided an opportunity to map feature distributions over a large area. Other relatively extensive controlled excavations occurred at 41 LK 31/32 (Scott and Fox 1982), 41 LK 201 (Highley 1986), 41 MC 55, and 41 MC 222. Of these, only the excavations at $41 \mathrm{LK} 31 / 32$ and 41 LK 201 entailed investigation of deep deposits containing Middle Archaic components. At the other sites, the components explored were very shallowly buried and, with the exception of 41 LK 67, represent on $7 y$ Late Prehistoric activity. 
One of the major reasons for conducting the horizontal $1 y$ more extensive excavations on the sites mentioned above was to gather data evidencing the patterning of human activities within the sites. We had hoped that by studying the activity patterns we might ultimately infer more about the behavior of the people who generated the debris. In retrospect, there are three problems recognized, two of which relate directly to the Choke Canyon investigation and a third which will be a major consideration in the conduct of future research.

First, the "extensive" excavations at Choke Canyon turned out to be not extensive enough. Remains of fascinating and very significant single, or individual activity events were recorded, but plots evidencing what might be termed community patterning were possible only at $41 \mathrm{LK} 67$, and this was but marginally accomplished due to the largest area being explored by stripping deposits with heavy machinery. If patterns of community activity are the objective, future excavations will need to be more extensive than those conducted at 41 LK 67.

A second problem involves the kinds of materials that are preserved in sites as evidence of prehistoric cultural activity. Stated very simply, the more varied the types of remains preserved in a site, the greater the interpretive potential. Less can be said about a site where cultural activity is evidenced predominately by burned rock, mussel shel1, chert debitage, and a few chipped stone tools than about a site where, in addition to the above materials, carbon and animal bone are also preserved. At Choke Canyon, the "poor" site characterized above is well exemp 7 ified by sites 41 LK 67 and 41 LK 31/32, while data-"wealthy" sites are those such as 41 MC 296, 41 LK 201, and 4I LK 51. As 41 LK 67 and 41 LK $31 / 32$ were located in the immediate area of Choke Canyon Dam and would be destroyed in the early stages of construction, they were the first to be extensively excavated. The decision to devote relatively great amounts of investigative effort to these two sites was based on site evaluation data available as Phase I field work was still underway in 1977. The excavations at both sites yielded useful and significant information. With benefit of hindsight, however, we believe that more would have been learned about Choke Canyon prehistory had the available time and resources for field work been allocated differently. Specifically, more excavation time should have been devoted to sites where vertebrate faunal remains and carbonized plant materials are preserved. As discussed above, these sites would also preferably be "pure," single component sites or we 1 1-stratified multicomponent sites.

The third problem is an outgrowth of the first two. If, as we suggest, excavations need to be much more extensive and would preferably occur in deeply stratified sites, what are the implications in terms of budgeting field time for a research program on the scale of Phase II investigations at Choke Canyon?

A good example of community patterning inferred from excavations is provided in the report of recent work at the Loeve-Fox site in Williamson County (Prewitt 1982:207). At Loeve-Fox, the Twin Sisters component (Late Archaic) in the site was heavily investigated. This component, buried about $1 \mathrm{~m}$ below the modern ground surface, was explored in three blocks of contiguous controlled excavation units. The largest unit block measured $8 \times 16 \mathrm{~m}$. Two 
smaller unit blocks brought the area of controlled excavations in the Twin Sisters component to a total of $154 \mathrm{~m}^{2}$, an area somewhat smal 1 er than the $184 \mathrm{~m}^{2}$ excavated at $41 \mathrm{LK} 67$. As at 41 LK 67, some additional distributiona 1 data concerning the Loeve-Fox Twin Sisters component was obtained through machinery excavation. It must be emphasized that the community patterning proposed for the Twin Sisters component at Loeve-Fox is hypothetical. Prewitt (personal communication, August 19, 1985) estimates that additional excavations on the order of three to five times the horizontal extent of the existing blocks would be necessary to test the community pattern model he has proposed.

Prewitt (personal communication) estimates that the field investigation of the Twin Sisters component at Loeve-Fox consumed roughly three-quarters $(6660$ person hours) of the total time expended in excavations at the site ( 8880 person hours). The investigation at 41 LK 67 required 4100 person hours to complete. Though a slightly smaller area of the Twin Sisters component was explored in comparison to the Archaic component revealed at $41 \mathrm{LK} 67$, the Loeve-Fox target zone was buried by about $1 \mathrm{~m}$ of deposit while the 41 LK 67 remains were buried by less than $40 \mathrm{~cm}$ of deposit. If we accept Prewitt's most conservative estimate of additional effort required to reveal community patterning in the Twin Sisters component at Loeve-Fox, we arrive at a 1 abor investment of 19,980 person hours (about 2500 person days). This would be the 1 abor committment necessary to adequately investigate one component buried to a depth of one meter. For a stratified terrace site such as 41 LK $31 / 32$ at Choke Canyon, having at least three distinct cultural components and a total depth of more than $3 \mathrm{~m}$, the figures above indicate that an effort totaling about 60,000 person hours (7500 person days) of field time would be needed to adequately study the three components.

The bottom 1 ine, then, is that investigations of the type proposed require a formidable investment. If such investigations in an area like Choke Canyon are to be carried out within the framework of existing federal guidelines, some fundamental changes in expectations for, and conduct of, field research wi 11 have to be made.

In future projects involving 1 arge 1 and areas, we suggest that the program of research be structured in two stages. In the first stage, the objective would be to locate and evaluate a 11 detectable sites in the project area. This objective should be accomplished by the most economical and efficient means possible. Rather than relying on costly and time-consuming controlled test excavations to evaluate sites, methods such as backhoe testing (McGuff and Fawcett 1978), shovel testing, augering, and examination of opportunistic exposures (walls of arroyos, borrow pits, river banks, etc.) should be app 1 ied. The information obtained should then be used to rank the sites according to their potential for elucidating area prehistory. At Choke Canyon, sites with high potential would have characteristics such as: (1) clear stratigraphy; (2) intact, wel 1-integrated habitational features; and (3) good preservation of vertebrate faunal material and carbonized plant remains. The criteria for establishing the research potential of sites in other project areas may vary from these at Choke Canyon, but the important thing is that they be drawn from the body of data expeditiously obtained in the first stage of investigations. It is critical that all definable sites be surveyed and evaluated before intensive, focused excavations begin. The 
piecemeal way in which the Choke Canyon project area was surveyed, tested, and excavated was a great hindrance to an organized program of evaluation. Important sites should be recognized in the initial stage of investigation. not in the final stage. No major excavations should occur until the site universe has been determined and appropriate means of calculating potential and relative significance are worked out.

In the second stage of overall project investigation, a highly select and 1 imited group of sites or components within sites should be subjected to extensive excavation. By way of defining what an extensive excavation would entai1, the projected estimate of 2500 person days needed to adequately explore the Twin Sisters component at the Loeve-Fox site is given as an example. In a research program such as Choke Canyon, the total field effort possible will be set by federally dictated funding levels. Invariably, the resources remaining as the second stage of field research commences will not be adequate to support an "ideal" program of data recovery. Insofar as possible, the inclination to reduce the level of effort committed to extensive excavations in individual sites or components in favor of 1 ess extensive investigations at more sites should be suppressed. The experience gained during the Phase I and Phase II investigations at Choke Canyon indicates that the kinds of information obtained in 1 imited excavations at many sites can be recovered in extensive excavations at a few careful1y selected sites, but the reverse is not true. It has not proved possible to forge a cultural mosaic of data gathered from numerous sites into a satisfactory, unified picture of 1 ifeways at any given period in prehistory.

Future progress in interpretation of prehistoric 1 ifeways in southern Texas will be heavily dependent on the extent to which methods can be developed for identifying the floral food products exploited by the region's aboriginal inhabitants. One need on $7 y$ briefly review findings made in the dry rockshe 1 ters of the Trans-Pecos (Wi 11 iams-Dean 1978; Stock 1983), 160 to 200 miles northwest of Choke Canyon, or in the caves of Tamaulipas s 1 ight 1 y farther to the south in Mexico (MacNeish 1958) to obtain a strong impression of the important contribution that a variety of $p l a n t$ foods made to the prehistoric human diet. The 1 imited ethnohistoric accounts available for south Texas also demonstrate this extensive reliance on plant foods (Campbel1 and Campbel1 1981). Some advances have been made through identification of carbonized botanical remains, but recognition of species in this way so far only permits gross speculations about the composition of prehistoric floral communities and on the possible contributions of this flora to human diet. Phytolith research offers great promise, especially in light of the demonstrated scarcity of pollen in the open prehistoric campsites typical of south Texas. This type of research, however, continues to be a complex and highly technical process. Much additional effort will be required to realize its ful1 potential.

Beyond carbon and phytoliths, the chemical and/or elemental "fingerprinting" of plant food residues may represent another productive avenue of future research. With this type of research, we would suppose that each kind of plant food might have an individual chemical or elemental constitution that would leave traces in the deposits of archaeological sites. 
With both the existing carbon and phytolith research tools, as well as the proposed "fingerprinting" program, there are two overarching problems to be dealt with. First, no effort has yet been made to identify all of the potentially edible foods provided by the plant communities of southern Texas, especially those plants whose presence we can now demonstrate archaeological1y. In this area, two things must be done. A complete 1 ist of products yielded by the modern floral communities must be developed, and the fitness (and seasonal availability) of each product for human consumption determined. Nutritional values should also be calculated (Everitt and Alaniz 1981). Second, systematic means of sampling for vestiges of these remains within prehistoric sites, via whichever technique discussed above, must be developed. The potential of carbonized remains is only now beginning to be fully realized with application of flotation recovery techniques in southern Texas (Black and McGraw 1985; Black n.d.). Where such material is preserved, flotation permits the recovery of minute carbonized plant parts (seeds, epidermiss etc.) that would normally be lost or destroyed as matrix is passed through even the smallest of screen meshes. We would suggest that the archaeological feature commonly identified as the "hearth" (i.e.s any locus where burning and/or food preparation is inferred by presence of carbon. burned rock, fired clay, or presumed food remnants such as animal bone, mussel shel1s, and snajl shel1s) is the likeliest place for collection of large matrix samples. Hearth features are recommended for intensive scrutiny primarily because they are usualiy immediately detectable to the field archaeologist. The ethnographic literature indicates that hearths are often the final "loci of concentration" in the process of plant food collection and preparation leading finally to consumption. The potential for sample bias created by concentrating on hearth features must be recognized and counterbalanced by sampling nonhearth matrices to the extent that reasonable doubts are eliminated. However, this strategy should not become so diffuse as to impair study of what we believe to be the truly important focus of analytical effort--the hearth and its related materials and matrices.

\section{SPECIFIC PROBLEMS FOR FUTURE RESEARCH}

Beyond our general recommendation that much more extensive excavations be carried out on individual sites and components, there are certain problems which we feel will require special attention and which should be the focus of research effort in coming years.

As is made clear in the cultural/chronological summary presented above, we really know very little about the Paleo-Indian, Early Archaic, and Middle Archaic periods in southern Texas. The time period from 2000 B.C. back into prehistory is represented by only five radiocarbon dates at Choke Canyon and by very 1 imited recovery of data from in situ, definable components. More data is needed on a 11 fronts--dating, diagnostic artifacts, subsistence pursuits, settlement patterns, and paleoenvironment. We must continue to seek out components of these early periods, excavate them extensively, and build a body of information suitable for comparison to the better-known Late Archaic and Late Prehistoric periods. There is simply not enough known about early cultures to do a reasonable job of comparing and contrasting them to later cultures in the region. As discussed in detail above, the best components of these periods are deeply buried in river terraces. Their very 
inaccessability is the reason we know so 1 ittle about them. Findings made at Choke Canyon have verified the existence of early components. In the future, specific steps should be taken to guarantee that these deep, hard-to-get-at early components receive at least as much attention as do the 1 ater components.

The later years of the Middle Archaic period and the Late Archaic period in southern Texas witnessed cultural developments that were apparently much more similar than previous 1 y suspected to trends in the prehistory of adjacent regions such as central Texas, the central coastal plain, and the Trans-Pecos area. Specifically at Choke Canyon, there is a marked increase in the number of sites representing the time period from 1500 B.C. up to A.D. 200. The amount of burned rock generated by people who were occupying these sites increased dramatically, which is believed to signify a heavier reliance on some type of plant food. A very short distance east of the Choke Canyon Dam. we know of the Loma Sandia cemetery where 280 people were buried around 500 B.C. (A. J. Taylor, personal communication). A11 of the signs point to a population increase in the Choke Canyon vicinity with correspondingly greater demands on local food resources and possibly the development of exclusive territories. As elsewhere in Texas, the conditions leading to the apparent population increase need to be studied. We need to analyze matrices in the south Texas "burned rock middens" in hopes of determining what people were doing to result in accumulation of so much burned rock. If it is true that burned rock middens in the Trans-Pecos region resulted from cooking sotol, lechuguilla, and similar plants, and from acorn processing in central Texas, then similar functions may be hypothesized for the south Texas burned rock accumulations. For south Texas prehistory, the specifics of this particular adaptation are important. From an interregional standpoint, the significant realization is that the people at Choke Canyon were apparently responding to a set of conditions or circumstances that were also influencing their contemporaries in adjacent regions.

Relative to the specific question about the origin of burned rock masses and more generally to prehistoric subsistence pursuits in the region, there is a desperate need for development of techniques that will permit us to identify plant foods being exploited at any given period in the past. As discussed above, the findings reported from dry caves in the Trans-Pecos and what we know from hunter-gatherer ethnographic studies very clearly demonstrate the important role that plant foods played in the survival of the prehistoric inhabitants of south Texas. We may reasonably assume that the availability of various kinds of plant food was a significant factor influencing settlement patterns, especial1y during the Archaic. Preservation is so poor in south Texas sites that success in recognition of plant food utilization is going to depend on development of some very sophisticated techniques. Phytolith research will hopefully continue and prove fruitful. Beyond this, we can on $1 y$ hope that ways of "fingerprinting" plants through chemical or elemental analysis will provide us with a helpful tool. This is a very complicated, but highly critical area of investigation badly in need of further research and development.

As we are able to see some similar interregional trends developing for the Middle Archaic and Late Archaic periods, so, too, do we see parallels between Choke Canyon and adjacent areas for the time period from A.D. 200 to 
A.D. 800. We have only one radiocarbon date at Choke Canyon for this period. This fact is unusual given the substantial number of radiocarbon assays representing the bracketing periods between 1500 B.C. and A.D. 200 at the early end and A.D. 900 and A.D. 1600 at the 7 ater end. The period from A.D. 200 to A.D. 800 represents the time when the transition from Archaic to Late Prehistoric adaptations occurred. Answers to the questions about what caused the changes distinguishing Archaic from Late Prehistoric 1 ifeways must 1 ie in cultural components dating to this 600-year span. With respect to this problem, the key questions would seem to be:

(1) What conditions or circumstances (climate, population, etc.) may be related to the changes?

(2) How were the distinctive technological innovations of the Late Prehistoric introduced to southern Texas?

(3) Were the changes wrought on indigenous people, or did new populations move into the region?

(4) If there was an influx of new populations into south Texas, what became of the indigenous peoples? We feel that the differences between Archaic and Late Prehistoric adaptations are so significant as to warrant study of this critical period of transition as a research unit in and of itself.

The Late Prehistoric period at Choke Canyon is the best known and most extensively studied of the prehistoric cultural units dealt with in this investigation. The reasons for our better understanding of this period are simple: Late Prehistoric components at Choke Canyon are shallowly buried, are prodigiously represented by time-diagnostic artifacts, and tend to exhibit the best preservation of all sites in terms of faunal material and carbonized plant remains. In future research, the shallow depth of Late Prehistoric components should be used to good advantage in conducting horizontally extensive, contiguous excavations aimed at demonstrating community patterning. Within the Late Prehistoric, it is now possible to recognize two subperiods general1y corresponding to the Austin and Toyah phases of central Texas. An important goal of future research in south Texas will be to demonstrate the significant changes in material culture that distinguish components of these two subperiods of the Late Prehistoric. Though the meat foods exploited by these people seem to be we 11 represented in our fauna 1 1ists, we again know very little about the contribution of $p 1$ ant foods to the Late Prehistoric diet. The comments made above concerning the need for means of detecting plant foods used in the Archaic apply also for the Late Prehistoric.

Final1y, the Phase II findings at Choke Canyon indicate to us that it wi11 be possible to find and recognize campsites that were occupied by aborigines who were in contact with Europeans in the early Historic period. Artifacts recovered from aboriginal components at 41 MC 55 and 41 MC 296 indicate that aborigines in contact with Anglo-European settlers were camping on some of the Choke Canyon sites. The smal1 amount of data in hand does not permit any substantial suggestion as to the nature of integration between cultures, 
except to the extent that the foreigners were supplying metal knives and arrow points to the aboriginal populace.

\section{NATIONAL REGISTER SITES}

Nine sites located around the margin of Choke Canyon Lake are recommended for nomination to the National Register of Historic Places. Eight of these are prehistoric sites as follows:
$4 I$ LK 250
41 MC 57
4 I LK 253
41 MC 84
41 MC 7
41 MC 220
41 MC 10
41 MC 275

The ninth site--41 MC 282--is a historic site (see Fox 1986 for further details).

Of the eight prehistoric sites 1 isted above, findings made at 41 MC 7 , 41 MC 10, 41 MC 57, 41 MC 84, and 41 MC 220 are discussed in the report of Phase I investigations at Choke Canyon (Hal1, Black, and Graves 1982). Information concerning the remaining three sites is presented in this volume. These sites would certainly not qualify as the most significant of the prehistoric resources identified in the Choke Canyon project area. Most of the best sites known in the area will be inundated by the 1 ake. It is our opinion that no practical ends will be served by placing these flooded sites on the National Register. The primary impact to these sites will be related to their submergence. Beyond this, the fact that the sites are under water wil1 reduce their exposure to certain other destructive impacts.

The eight prehistoric sites we are recommending for the National Register will be at or above the shoreline of Choke Canyon Lake. At these locations, they will be subject to impact from vandalism and any 1 akeshore modifications that may occur in the future. By placing these sites on the Register, we see a means of providing an additional measure of protection that might not otherwise be afforded these localities.

The sites 1 isted represent only a smal1 percentage of al1 prehistoric sites situated on the shore of the 1 ake. We have singled out these particular sites because we feel that each holds a particular potential for elucidating problems we have defined for future research. The following sites contain relatively massive accumulations of burned rock: 41 LK 250, 41 LK 253, 41 MC 220, and 41 MC 275. These sites--especially 41 MC 220--would be good places to gather data concerning the Middle Archaic and Late Archaic activities that resulted in generation of so much burned rock. The neighboring sites, 41 MC 7 and 41 MC 10, have yielded a number of Paleo-Indian diagnostics. Of a 11 known sites at Choke Canyon, they offer the best opportunity for definition of a Paleo-Indian component in the area. Likewise, sites 41 MC 57 and 41 MC 84 are locations where Early Archaic components may be preserved. Site 41 MC 57 in particular offers potential for a buried Early Archaic component. 
Given their location along the banks of Choke Canyon Lake, the eight sites will 1 ikely be subjected to wave wash and/or other destructive erosional processes during the 1 ifetime of the reservoir. We would encourage the USBR to facilitate excavations at these sites in the future, perhaps in the form of institutional field schools or other such programs. We predict that with the filling of the lake and subsequent fluctuations in floodpool level, significant prehistoric cultural remains will wash out of many sites in the reservoir basin. We again urge the USBR to consider making provisions for a Cultural Resource Manager at Choke Canyon.

\section{REFERENCES CITED}

Andrews, J. M.

1981 Shells and Shores of Texas. University of Texas Press, Austin and London.

Arnold, J. B. III

1975 Porosity and Refiring Tests on Ceramics from the George C. Davis Site, Texas. Bulletin of the Texas Archeological Society $46: 231-241$.

Aten, L. E.

1967 Excavations at the Jamison Site (41 LB 2), Liberty County, Texas. Houston Archeological Society, Report 1.

Beasley, T. S.

1982 Paleo-Indian Artifacts from a Site in McMulien County, Texas. La Tierra 9(3):34-38.

Bennett, M. A.

1974 Basic Ceramic Analysis. San Juan Valley Archaeological Project. Eastern New Mexico University, Contributions in Anthropology, Technical Series (6)l.

Black, S. L.

1982 Prehistoric Ceramic Artifacts. In Archaeological Investigations at Choke Canyon Reservoir, South Texas: The Phase I Findings, by G. D. Hal1, S. L. B 1 ack, and C. Graves:390-453. Center for Archaeological Research, The University of Texas at San Antonio, Choke Canyon Series 5.

n.d. The Clemente and Herminia Hinojosa Site, 41 JW 8: A Toyah Horizon Campsite in Southern Texas. Center for Archaeological Research. The University of Texas at San Antonio, Special Report 18 (in preparation). 
Black, S. L. and A. J. McGraw

1985 The Panther Springs Creek Site: Cultural Change and Continuity in the Upper Salado Creek Drainage, South-Central Texas. Center for Archaeological Research. The University of Texas at San Antonio, Archaeological Survey Report 100.

Blair, W. F.

1950 The Biotic Provinces of Texas. The Texas Journal of Science 2(1):93-117.

Brown, J. A. and T. D. Price

1985 Complex Hunter-Gatherers: Retrospect and Prospect. In Prehistoric Hunter-Gatherers - The Emergence of Cultural Complexity, edited by T. D. Price and J. A. Brown. Academic Press, Orlando.

Brown, K. M., D. R. Potter, G. D. Hall, and S. L. Black

1982 Excavations at 4 I LK 67, A Prehistoric Site in the Choke Canyon Reservoir, South Texas. Center for Archaeological Research, The University of Texas at San Antonio, Choke Canyon Series 7.

Bunker, R. C.

1982 The Geomorphic Framework of Human Occupation in the Frio River Val ley, Choke Canyon Dam Reservoir Area, Live Oak and McMul len Counties, Texas. Appendix II in Archaeological Investigations at Choke Canyon Reservoir. South Texas: The Phase I Findings:498-517. Center for Archaeological Research, The University of Texas at San Antonio, Choke Canyon Series 5.

Calhoun, C. A.

1965 Archeology of the Coasta 7 Bend. Paper given at a meeting sponsored by the Houston Archeological Society, 1965.

Campbe11, T. N.

1962 Origins of Pottery Types from the Coastal Bend Region of Texas. Bulletin of the Texas Archeological Society 36:331336.

1976 Archaeological Investigations at the Morhiss Site, Victoria County, Texas, 1932-1940. Transcribed from a recording of a talk presented at the annual meeting of the Texas Archeological Society, Victoria, Texas, November 3, 1962. In An Archaeological Survey of Coleto Creek. Victoria and Gol iad Counties, Texas, by A. A. Fox and T. R. Hester:81-85. Center for Archaeological Research. The University of Texas at San Antonio, Archaeological Survey Report 18. 
Campbe11 (continued)

1984 The Cacaxtle Indians of Northeastern Mexico and Southern Texas. La Tierra 11(1):4-20.

Campbe11, T. N. and T. J. Campbe11

1981 Historic Indian Groups of the Choke Canyon Reservoir and Surrounding Area, Southern Texas. Center for Archaeological Research, The University of Texas at San Antonio, Choke Canyon Series 1 .

1985 Indian Groups Associated with Spanish Missions of the San Antonio Missions National Historical Park. Center for Archaeological Research. The University of Texas at San Antonio, Special Report 16.

Center for Archaeological Research

1979 Final Recommendations for Phase II Archaeological Investigations in the Choke Canyon Reservoir. Nueces River Project, Texas. Unpublished document, on file at the Center for Archaeological Research, The University of Texas at San Antonio.

Chandler, C. K.

1978 Two Clay Figurines from the Central Coastal Region of Texas. Bul1etin of the Texas Archeological Society 49:341-348.

1982a Paleo-Indian Projectile Points from San Patricio County, Texas, Texas Coasta 1 Bend. La Tierra 9(3):26-33.

1982b Descriptions of Soapstone Pipe Ceramic Figurine. Appendix III in Excavations at 41 LK 67, A Prehistoric Site in the Choke Canyon Reservoir, South Texas, by K. M. Brown, D. R. Potter, G. D. Ha11, and S. L. B1 ack:169-176. Center for Archaeological Research. The University of Texas at San Antonio, Choke Canyon Series 7.

1983 Notes on Some Be11 Points from San Patricio County, Texas. La Tierra 10(3):7-10.

1984 Lithic Resources in the Texas Coastal Bend. La Tierra $11(1): 26-27$.

Chandler, C. K., F. Knolle, and M. M. Knolle

1983 Paleo-Indian Projectile Points from Jim Wel is and Nueces Counties, Texas. La Tierra 10(2):23-27. 
Clark, J.W.

1978 Mission San José y San Miguel de Aguayo, Archeological Investigations. Texas Historical Commission, Office of the State Archeologist. Report 29.

Corbin, J.E.

1974 A Model for Cultural Succession for the Coastal Bend Area of Texas. Bulletin of the Texas Archeological Society 45:29-54.

Crabtree, D. E.

1972 An Introduction to Flintworking. Occasional Papers of the Museum Idaho State University 28. Pocate110, Idaho.

Cree1, D., A. J. McGraw, F. Valdez, Jr., and T. C. Kelly

1979 Excavations at 41 LK 106, A Prehistoric 0ccupation Site in Live Oak County, Texas. Center for Archaeological Research. The University of Texas at San Antonio, Archaeological Survey Report 62.

Day, D. W.

1981 An Assessment of Archeological Sites 41 WY 71 and 41 WY 72, Wi 11 acy County, Texas. Prewitt and Associates, Inc.s Reports of Investigations 17. Austin.

Day, D. W., J. Laurens-Day, and E. R. Prewitt

1981 Cultural Resources Survey and Assessment in Portions of Hidalgo and Willacy Counties, Texas. Prewitt and Associates. Inc.s Reports of Investigations 15. Austin.

Dulaney, A. R.

1977 Ceramics from the Fayette River Project. In Archeological Investigations of the Fayette Power Project, Fayette County, Texas, by D.W. Ske1ton:198-209. Texas Archeological Survey, The University of Texas at Austin. Research Report 60.

Dusek, C.

1983 Cut Mussel Valve from 41 MC 320, The Nichols I Site, McMullen County, Texas. La Tierra 10(3):45-46.

Epstein, J.F.

1969 The San Isidro Site: An Early Man Campsite in Nuevo Leon, Mexico. Department of Anthropology. The University of Texas at Austing Anthropology Series 7. 
Epstein (continued)

1980

Some Reflections on the Nature of the Northeast Mexico Lithic Tradition and the Problem of Its Origin. In Papers on the Prehistory of Northeastern Mexico and Adjacent Texas, edited by J. F. Epstein, T. R. Hester, and C. Graves:81-92. Center for Archaeological Research. The University of Texas at San Antonio, Special Report 9.

Espey, Huston and Associates, Inc.

1981 Proposed Deepwater Channel and Multipurpose Terminal Construction and Operation Near Brownsvilie, Texas. Cultural Resources Technical Report. Espey, Huston and Associates, Inc., Austin.

Everitt, J. H. and M. A. Alaniz

1981 Nutrient Content of Cactus and Woody Plant Fruits Eaten By Birds and Mammals in South Texas. The Southwestern Natural ist $26(3): 301-305$.

Fawcett, W. B., Jr.

1976 The Artifacts and Artifact Typology. Appendix I in Prehistoric Archeological Investigations at Palmetto Bend Reservoir: Phase I, Jackson County, Texas, by P. R. McGuff:184-215. Texas Archeological Survey, The University of Texas at Austin, Research Report 58. Palmetto Bend Reservoir Series 3.

Fox, A. A.

1984 A Study of Five Historic Cemeteries at Choke Canyon Reservoir, Live Oak and McMu 11 en Counties, Texas. Center for Archaeological Research. The University of Texas at San Antonio, Choke Canyon Series 9.

1986 Archaeological Investigations at Historic Sites in the Choke Canyon Reservoir, Southern Texas. Center for Archaeological Research. The University of Texas at San Antonio, Choke Canyon Series 12.

Fox, D. E.

1979a Archaeological Investigations of Two Prehistoric Sites on the Coleto Creek Drainage, Goliad County, Texas. Center for Archaeological Research. The University of Texas at San Antonio, Archaeological Survey Report 69.

1979b The Lithic Artifacts of Indians at the Spanish Colonial Missions, San Antonio, Texas. Center for Archaeological Research. The University of Texas at San Antonio, Special Report 8. 
Gibson, E. C.

n.d. Archaeological Investigations in Zavala and Dimmit Counties, Texas. Center for Archaeological Research. The University of Texas at San Antonio, Archaeological Survey Report 110 (in preparation).

Griffiths, J. C. and M. A. Rosenfeld

1954 Operator Variation in Experimental Research. Journal of Sedimentary Petrology 62(1):74-91.

Grozier, R. U., D. C. Haht, A. E. Hulme, and E. E. Schroeder

1968 Floods From Hurricane Beulah in South Texas and Northeastern Mexico, September-October 1967. Texas Water Development Board, Report 83. Austin.

Ha11, G. D., S. L. Black, and C. Graves

1982 Archaeological Investigations at Choke Canyon Reservoir, South Texas: The Phase I Findings. Center for Archaeologica] Research, The University of Texàs at San Antonio, Choke Canyon Series 5.

Heartfield, L.

1966 An Analysis of Leon Plain Typology. Unpub 1 ished manuscript on file at the Center for Archaeological Research. The University of Texas at San Antonio.

Hester, T. R.

1968 Notes on Some Pottery-Bearing Sites in Southern Texas. The Bu 1 1-Roarer. University of Texas Anthropological Society News letter 3(2):9-11.

1972 The Surface Archaeology of Three Sites in Duval County, Texas. Bul letin. Lower Plains Archeological Society 2:45-71.

1977 The Lithic Technology of Mission Indians in Texas and Northeastern Mexico. Lithic Technology 6(1-2):9-12.

1980 Digging Into South Texas Prehistory. Corona Publishing Company, San Antonio, Texas.

Hester, T. R., F. A. Bass, Jr., A. A. Fox, E. S. Harris, and T. C. Kelly

1977 Archaeological Research at the Hinojosa Site (41 JW 8), Jim We1 15 County, Southern Texas. Center for Archaeological Research. The University of Texas at San Antonio, Archaeologica 1 Survey Report 42. 
Hester, T. R., D. Gilbow, and A. D. Albee

1973 A Functional Analysis of "Clear Fork" Artifacts from the Rio Grande Plain, Texas. American Antiquity 38(1):90-96.

Hester, T. R. and T. C. Hi1l, Jr.

1969 Mogol 1 an Ceramics from Southern Texas. The Artifact 7(3):1115.

1971 An Initial Study of a Prehistoric Ceramic Tradition in Southern Texas. Plains Anthropologist 16(53): 195-203.

1975 Some Aspects of Late Prehistoric and Protohistoric Archaeology in Southern Texas. Center for Archaeological Research, The University of Texas at San Antonio, Special Report 1.

Hester, T. R. and H. Kohnitz

1975 Chronological Placement of Guadalupe Tools. La Tierra $2(2): 22-25$.

Hester, T. R. and R. C. Parker

1970 The Berclair Site: A Late Prehistoric Component in Goliad County, Southern Texas. Bul1 letin of the Texas Archeological Society 41:1-24.

Hester, T. R., L. O. White, and J. White

1969 Archeological Materials from the Oulline Site (4I LS 3) and Other Sites in La Salle County, Southwest Texas. The Texas Journal of Science $21(2): 131-166$.

Highley, C. L.

1986 Archaeological Investigations at 41 LK 201, Choke Canyon Reservoir. Southern Texas. Center for Archaeological Research. The University of Texas at San Antonio, Choke Canyon Series 11 .

Hurlbut, C. Sa, Jr. and C. Klein

1977 Manual of Mineralogy (after James D. Dana). 19th edition. John Wiley \& Sons, New York.

Ingl is, J. M.

1964 A History of Vegetation on the Rio Grande Plain. Texas Parks and Wildife Department. Bulletin 45. Austin. 
Jelks, E. B.

1962 The Kyle Site, A Stratified Central Texas Aspect Site in Hill County. Texas. Department of Anthropology. The University of Texas at Austin. Archaeology Series 5.

Jurgens, C. J. and W. H. Whitsett

1981 Cultural Resources Inventory and Assessment of Proposed Wastewater Facilities. Aransas County Conservation and Reclamation District, Aransas County, Texas. Mimeographed report, Texas Department of Water Resources, Austin.

Kelley, J.C.

1947 The Lehmann Rock Shelter: A Stratified Site of the Toyah, Uvalde, and Round Rock Foci. Bulletin of the Texas ArcheoJogical Society 18:115-128.

Kel1y, T. C.

1983 The Brom Cooper Paleo-Indian Collection from McMul len County, Texas. La Tierra 10(3):17-39.

Kelly, T. C., P. Green, S. Bento, and I. W. Cox

n.d. The Chacon Creek Project: Archaeological Investigations in Maverick and Zavala Counties. Texas. Center for Archaeological Research. The University of Texas at San Antonios Archaeological Survey Report 112 (in preparation).

Kotter, S. M.

1980 Archeological Assessments at Site 41 ZP 73, Falcon State Recreation Area, Zapata County. Texas. Preuitt and Assocjates, Inc.s Reports of Investigations 9. Austin.

Lukowski, P.

1984 An Archaeological Survey of a Proposed Wel 1 Pad in the Vicinity of Lake Corpus Christi, San Patricio County, Texas. Center for Archaeological Research. The University of Texas at San Antonio, Archaeological Survey Report 134.

Lynn, W. Ma, D. E, Fox, and No OPMalley

1977 Cultural Resources Survey of Choke Canyon Reservoir, Live Oak and McMulien Counties. Texas. Office of the State Archeologist. Texas Historical Commission. Archeological Survey Report 20 . 
MacNeish, R. S.

1958 Preliminary Archaeological Investigations in the Sierra de Tamaul ipas, Mexico. Transactions, American Philosophical Society $48(6)$.

Mallouf, R. J.

1976 Archeological Investigations at Proposed Big Pine Lake, 19741975, Lamar and Red River Counties, Texas. Texas Historical Comission. Archeological Survey Report 18.

Mallouf, R., B. Baskin, and K. Killen

1977 A Predictive Assessment of Cultural Resources in Hidalgo and Wil 7 acy Counties. Texas. Texas Historical Commission, Archeologica 1 Survey Report 23.

McGraw, A. J.

1983 Arroyo de 105 Muertos and Other Prehistoric Terrace Sites Atong the Rio Grande, Laredo, Texas. Center for Archaeological Research. The University of Texas at San Antonio, Archaeological Survey Report 106.

n.d. Archaeology in the South Texas Sand Sheet: A Study of Chevron Properties in Brooks County. Center for Archaeological Research. The University of Texas at San Antonio, Archaeological Survey Report 129 (in preparation).

McGraw, A. J. and D. Knepper

n.d. The East Chacon Project: 11,000 Years of Prehistory Along the Upper Nueces River, Southern Texas. Center for Archaeological Research, The University of Texas at San Antonio, Archaeological Survey Report 125 (in preparation).

McGraw, A. J., B. Van Note, and C. Jones

n.d. Archaeology of the Brasada: A Cultural Resources Assessment of the Chevron Resources Company Properties in Northeastern Duval County, Texas. Center for Archaeological Research, The University of Texas at San Antonio. Archaeological Survey Report 113 (in preparation).

McGuff, P. R. and W. B. Fawcett, Jr.

1978 Phase II: Palmetto Bend Archeological Investigations, ReEvaluative Survey and Testing. Texas Archeological Survey, The University of Texas at Austin. Research Report 67, Palmetto Bend Reservoir Series 4. 
Mitchel1, J. L., C. K. Chandler, and T. C. Kelly

1984 The Rudy Haiduk Site (41 KA 23): A Late Archaic Burial in Karnes County. Texas. La Tierra 11(2):12-39.

Mounger, M. A.

1959 Mission Espiritu Santo of Coastal Texas: An Example of Historic Site Archeology. Unpublished Masters thesis, University of Texas at Austin.

Orchard C. D. and T. N. Campbel1

1959 Southwestern Pottery from Sites in the Vicinity of San Antonio. Texas Archeology 4(2):7-8.

Orton, R. B.

1964 The Climate of Texas and Adjacent Gulf Waters. U. S. Department of Commerce, Washington, D. C.

Peacock, D. P. S.

1970 The Scientific Analysis of Ancient Ceramics: A Review. World Archaeology 1(3):375-389.

Prewitt, E. R.

1982 Archeological Investigations at the Loeve-Fox, Loeve and Tombstone Bluff Sites in the Granger Lake District of Central Texas. In Archaeological Investigations at the San Gabriel Reservoir Districts, Central Texas. Institute of Applied Sciences, North Texas State University 4. Denton.

Prewitt, E. Ro, editor

1984 Archeological and Historical Investigations in the Proposed Baker's Port Project and Vicinity, Southern Live Oak Peninsula, San Patricio County. Texas. Prewitt and Associates, Incos Reports of Investigations 25. Austin.

Ralph, E. K., H. N. Michael, and M. C. Han

1973 Radiocarbon Dates and Reality. MASCA Newsletter 9(1):1-20.

Ray, C. N.

1941 Various Types of Clear Fork Gouges. Bulletin of the Texas Archeological and Paleontological Society 13:152-162. 
Roemer, E., Jr.

1981 The 1979 Archaeological Survey of Portions of the Choke Canyon Reservoir in Live Oak and McMullen Counties, Texas. Center for Archaeological Research. The University of Texas at San Antonio, Choke Canyon Series 4.

Scott, R. F. IV and D. E. Fox

1982 Excavations at Sites 41 LK $31 / 32$ and 41 LK 202 in the Choke Canyon Reservoir, South Texas. Center for Archaeological Research. The University of Texas at San Antonio, Choke Canyon Series 8.

Shafer, H. J.

1969 Archeological Investigations in the Robert Lee Reservoir Basin. West Central Texas. Texas Archeological Salvage Projects The University of Texas at Austin, Papers 17.

Shepard, A. 0 .

1976 Ceramics for the Archaeologist. Carnegie Institute of Washington, Publication 609.

Snavely, R.

1984 An Archaeological Survey of the Probst and McGriff Leases in Live Oak County, Texas. Center for Archaeological Research, The University of Texas at San Antonio, Archaeological Survey Report 139.

Sollberger, J. B.

1971 A Technological Study of Beveled Knives. Plains Anthropologist 16(53):209-218.

1978 A New Type of Arrow Point With Speculations as to Its Origin. La Tierra 5(4):13-20.

Steele, D. G.

1986 Analysis of Vertebrate Faunal Remains from 41 LK 201, Live Oak County, Texas. Appendix $V$ in Archaeological Investigations at 41 LK 201, Choke Canyon Reservoir, Southern Texas, by C. L. Highley. Center for Archaeological Research, The University of Texas at San Antonios Choke Canyon Series 11.

Stock, J. A.

1983 The Prehistoric Diet of Hinds Cave (4I VV 456), Val Verde County, Texas: The Coprolite Evidence. Master's thesis, Department of Anthropology. Texas A\&M University, College Station. 
Story, D. A.

1968 Archeological Investigations at Two Central Texas Gulf Coast Sites. Texas Historical Commission. State Bullding Commission. Report 13.

1981 An Overview of Archaeology of East Texas. Plains Anthropologist $26(92): 139-156$.

Suhm, D. A. and E. B. Jelks

1962 Handbook of Texas Archeology: Type Descriptions. Texas Archeological Society, Speclal Publication 1 and Texas Menorial Museum Bul 1etin 4. Austin.

Suhm, D. A., A. D. Krieger, and E. B. Jelks

1954 An Introductory Handbook of Texas Archeology. Bulletin of the Texas Archeological Society 25.

Terry, R. D. and G. V. Chilingar

1955 Summary of "Concerning Some Additional Aids in Studying Sedimentary Formations," by M. S. Shuetsov:229-234. Journa of Sedimentary Petrology (25)3.

Thoms, A. V., J. L. Montgomery, and A. W. Portnoy

1981 An Archaeological Survey of a Portion of the Choke Canyon Reservoir Area in McMul Ten and Live Oak Counties. Texas. Center for Archaeological Research, The University of Texas at San Antonio, Choke Canyon Series 3.

Tunne11, C. D. and W. W. Newcomb, Jr.

1969 A Lipan Apache Mission, San Lorenzo de 1 a Santa Cruz, 17621771. Texas Memorial Museums Bulletin 14. Austin.

Turner: E. So and T. R. Hester

1985 A Field Guide to Stone Artifacts of Texas Indians. Texas Monthly Press, Austin.

Ubelaker, D. H.

1978 Human Skeletal Remains. Aldine Publishing Co.s Chicago.

U. S. Department of the Interior

1975 Final Environmental Impact Statement, Nueces River Project. Choke Canyon Dam and Reservoir Sites Texas. Bureau of Reclamation, Southwest Region, Amari110. 
Wakefield, W. W.

1968 Archeological Survey of Palmetto Bend and Choke Canyon Reservoir, Texas. Texas Archeological Salvage Project, The University of Texas at Austin. Survey Report 5.

Warren, J.E.

1984a A Cultural Resources Inventory Around the Perimeter of Salt Lake, Aransas County. Texas. Privately printed, Report 106. George West, Texas.

1984b A Cultural Resources Reconnaissance of the City of Alice Sanitary Landfi11, Jim Wel1s County, Texas. Privately printed, Report 112. George West, Texas.

Weed, C. and H. J. Shafer

1981 Archaeological Testing and Collecting at Choke Canyon Reservoir, Nueces River Project, Texas. Center for Archaeological Research. The University of Texas at San Antonio, Choke Canyon Series 6.

Weir, F. A.

1976 The Central Texas Archaic. Ph.D. dissertation. Department of Anthropology, Washington State University, Pullman.

Williams-Dean, G. J.

1978 Ethnobotany and Cultural Ecology of Prehistoric Man in Southwest Texas. Ph.D. dissertation. Department of Botany, Texas A\&M University, College Station.

Woerner, M. C. and L. Highley

1983 The Bromley F. Cooper Col lection of Pre-Archaic and Archaic Dart Points from McMulien County. La Tierra 10(1):3-28.

Word, J. H. and C. L. Douglas

1970 Excavations at Baker Cave, Val Verde County, Texas. Bulletin of the Texas Memorial Museum 16. 


\author{
APPENDIX I. \\ SCOPE OF WORK \\ CULTURAL RESOURCE MANAGEMENT PLAN AND \\ PHASE II INVESTIGATIONS \\ CHOKE CANYON RESERVOIR, NUECES RIVER PROJECT, TEXAS \\ SOLICITATION NO. 5B-V0835
}

The work to be performed under this contract has been formulated with the intention of completing the documentation of the significance of Choke Canyon cultural resources and assuring that irreplaceable resources are not destroyed by direct impacts of reservoir construction. The data retrieval program does not pretend to be, nor should it be, the basis for the ideal pure research endeavor in archeology which might be undertaken given un 7 imited funding and time. The data retrieval, analysis, and reporting aspects of work to be accomplished under this contract (Phase II Investigations) will constitute the initial implementation stages of a 1 ong-term Management $P I$ an designed to preserve and protect the significant cultura 1 resources of the Choke Canyon Archeological District. The Management Plan wi 11 consist of (1) the specifications of work to be performed under this contract and (2) the long-term management recommendations formulated by the contractor (see below) as they may be modified by the WPRS after further consultation with the Advisory Council and the SHPO.

The Phase I program identified the significance of the Choke Canyon cultural resources by defining a set of scientific research objectives upon which those resources have a bearing. The Phase II Investigations will be designed to assure that the potential contribution of the resources to the accomplishment of those objectives is not impaired.

The Phase II Investigations will consist of a program of field investigations including the intensive testing and evaluation of 62 sites and further extensive excavation of 22 sites (the scope of these investigations and the rationale behind the selection of sites for investigation is defined below). Due to time restrictions, field seasons cannot be restricted to summers only. The investigations will include the analysis of data generated and the preparation and submittal to the Government of a Final Investigative Report (or set of reports) which wil1 document the research performed and present its findings.

The realization of the scientific objectives of the investigations and the formulation of a comprehensive long-term Cultural Resource Management Plan wel 1 in advance of the completion of construction ( $i . e$. , by the end of calendar year 1981) will require the continuous evaluation of data generated by investigations performed under this contract and the evaluation of the results of research performed under previously awarded contracts (al1 Phase I Final Investigative Reports are scheduled for completion by January 1980). Meticulous organization and highly competent staffing at al1 levels will be fundamental to the success of the program. 


\section{A. The Phase II Investigations}

1. Intensive Testing (an estimated 4,100 person-hours of field work)--Sixty-two sites will be intensively tested in accordance with procedures defined for intensive testing under the Phase I contract and UTSA Recommendations Report. These sites comprise two groups, Site Group A (30 of the 113 sites 1 ocated by Texas Tech in the Phase I survey) and Site Group B (32 sites which require intensive testing from among those located in the survey completed by UTSA in 1979). Level of effort is defined in terms of total person/hours based on prior experience with similar investigations in the project area. The actual time spent and extent of investigation at a given site wil1 depend on conditions encountered in the field. UTSA recommendations in terms of person/hours per site for Site Groups $A$ and $B$ are shown below:

Site Group A: (Cultural Resources Institute temporary field numbers are shown in parentheses following each permanent site number.)

Recommended for evaluative effort totaling 125 person/hours per site (3 sites): 41 LK 128 (11), 41 LK 176 (81), 41 MC 201 (45).

Recommended for evaluative effort totaling 75 person/hours per site (17 sites): 41 LK 121 (4), 41 LK 127 (10), 41 LK 133 (16), 41 LK 142 (25), 41 LK 145 (28), 41 LK 149 (32), 41 LK 170 (75), 41 LK 174 (79), 41 LK 181(86), 41 LK 182 (87), 41 LK $190(95), 41$ LK $199(106), 41$ MC 196 (40), 41 MC 209 (53), 41 MC 212 (56), 41 MC 213 (57), 41 MC 226 (110).

Recommended for evaluative effort totaling 25 person/hours per site (10 sites): 41 LK 122 (5), 41 LK 136 (19), 41 LK 150 (33), 41 LK 153 (36), 41 LK 158 (63), 41 LK 162 (67), 41 LK 173 (78), 41 LK 180 (85), 41. LK $185(90), 41$ LK 191 (96).

\section{Site Group B:}

Recommended for evaluative effort totaling 125 person/hours per site (3 sites): 41 MC 260, 41 MC 276, 41 MC 296.

Recommended for evaluative effort totaling 75 person/hours per site (20 sites): 41 LK 234, 41 LK 236, 41 LK 241, 41 LK 243, 41 LK 247, 41 LK 250, 41 LK 252, 41 LK 253, 41 MC 234, 41 MC 238, 41 MC 242, 41 MC 25l, 41 MC 266, 41 MC 268, 41 MC 275, 41 MC 280, 41 MC 282, 4I MC 286, 41 MC 293. 41 MC 294.

Recommended for evaluative effort totaling 25 person/hours per site (9 sites): 41 LK 239, 4 I LK 245, 41 MC 235, 41 MC 246, 41 MC 257 , 41 MC 270, 4I MC 284, 4I MC 288, 41 MC 290.

2. Extensive Excavation--The decision to open substantial areas of contiguous squares at any given site (extensive excavation) will be based on the application of the following criteria as stated in the UTSA Recommendations Report: 
Achieving representation of the occupation of the different geological formations and 1 and forms of the reservoir area, of the range of postulated functional site types, and of the range of cultural stages present. Additional consideration will be given to anticipated productivity of cultural residues, the presence of stratigraphy, site condition, presence of intact occupational features, site specific preservation factors, potential for yielding information on the pre-mid Archaic time period, presence of unusual artifactual remains, factors promoting or impeding data retrieval, and the anticipated impact of project construction to the site.

Site Group C: Twelve sites of those which have al ready been tested have been determined to meet the above criteria so completely that their extensive excavation is known to be required for Phase II Investigation. These sites (designated Site Group C) consist of the following:

Historic Sites (7)

\section{Site}

41 LK 66

41 MC 15

41 MC 17

41 MC 192

41 MC 193

41 MC 194

41 MC 214
Estimated person/hours required for (field) investigation
200

Total 850

Prehistoric Sites (5)

Site

41 LK 8

41 LK 14

41 LK 201

41 MC 29

41 MC 222
Estimated person/hours required for (field) investigation

200

150

$170+2$ days backhoe time

$150+1 / 2$ day backhoe time

180

Total

850

Site Group D: The remaining 10 sites (Group D sites) whose extensive excavation will complete Phase II field investigations will be selected according to the above criteria from a "pool" of 95 sites. As a number of the criteria are oriented toward achieving representation of different categories of sites, the characteristics of the 15 sites (Group C 
and 41 LK 31/32, 41 LK 67, and 41 LK 202) at which extensive excavation has been completed, or is known to be required for Phase II, will heavily influence the selection of the remaining 10 (Group D) sites.

The "pool" from which the Group D sites are ultimately to be selected consists of:

a. Ten sites which have already been evaluated and which UTSA has advanced for additional consideration: 41 LK 52, 41 LK 53, 41 LK 74, 41 MC 13, 41 MC 15, 41 MC 39, 41 MC 55, 41 MC 56, 41 MC 84, and 41 MC 94.

b. Seventeen sites at which testing and evaluation procedures wi11 be completed during 1979 under the Phase I contract: 41 LK 51, 41 LK 73, 41 LK 85, 41 LK 86, 41 LK 87, 41 LK 88, 41 LK 92, 41 LK 93, 41 LK 94, 41 LK 97, 41 MC 18, 41 MC 83, 41 MC 90, 41 MC 91, 41 MC 92, $41 \mathrm{MC} 93$, and $41 \mathrm{MC} 171$.

C. Six sites advanced as significant from among 19 evaluated by the Texas A\&M Anthropology Research Laboratory crew: 41 LK 56, 41 MC 60 , 41 MC 186, 41 MC 187, and 41 MC 188.

d. The 30 Group A sites (see above).

e. The 32 Group B sites (see above).

It is estimated that up to 1.500 person/hours and 1.5 days of backhoe time will be required to complete field investigations at the Group $D$ sites.

In order to assure thorough organization and efficient comprehensive reporting of progress, a detailed and specific research framework for field work, analysis, and report preparation shall be specified by offerors. This framework sha 11 consist of the definition of decision-making processes to be followed for (1) decisions related to the extent of testing and/or extensive excavations at specific sites (field decisions), (2) decisions on which sites to investigate (definition of research priorities), and (3) decisions on recommended preservation procedures (1ong-term management plan components).

\section{B. Field Decisions}

Previous Choke Canyon cultural resource investigation contracts have defined levels of effort to be performed at specific sites. The extent and depth of a site and the density of artifact deposits is often not fully realized until investigations are well underway. It has been suggested that future contracts specify that the number of person-hours expended at a particular site be determined by the Principal Investigator in the field (to reflect actual practice). This suggestion is incorporated; it will be the responsibility of the Principal Investigator to determine when each site has been adequately tested and/or excavated (the final approval of the "adequacy" of investigations still rests with the Contracting Officer). Thus the Principal Investigator will be responsible for "budgeting" the overall scope of work (defined above) between sites. The means by which these field 
decisions will be reached must be clearly defined in the proposals of offerors.

A decision-making matrix approach (see attachment B) is suggested as appropriate. The approach to reaching field decisions, defined by the offeror, shall clearly define an objective and systematic framework for reaching those decisions. The advance definition of the approach to reaching field decisions shou $1 d$ a 110 the contractor, without extensive narrative description, to document the rationale behind field decisions, the general nature of deposits encountered during investigation, and progress in investigation. The approach to be defined shall also clearly commit the contractor to field techniques of the same or better quality as those employed during Phase I and the previously completed mitigative excavation programs. A policy statement by the offeror should be sufficient and include details of excavation strategy such as: use of arbitrary vs. natural excavation units, mechanical equipment, screening, treatment of features, sample collection, and recording standards and procedures.

\section{Definition of Research Priorities}

Research priorities relate primarily to the application of the criteria defined above to the selection of Group D sites for extensive excavation and to timing of a 11 investigative efforts to insure program success. Staffing, adequate to provide for continuous analysis of data generated by field work and its evaluation along with the results of previously awarded contracts, will be necessary.

The work will be organized in a fashion which will allow the formu 1 ation of year 1 y progress reports. These reports wil1 document work performed, outline upcoming field work, suggest such changes in investigation strategy as new information and experience dictate, and assess progress toward program objectives. Such documentation is not only required as a matter of Federal procurement policy, but the WPRS will a 1 so require such documentation as the basis of periodic consultation with the SHPO and Advisory Council on progress of the program toward realizing research objectives. An additional determinant of the need to organize Phase II Investigations to allow comprehensive documentation of both work progress, and evaluation of progress toward achieving research objectives is related to the extent possibility that Phase II Investigations may discover resources of such scope and significance that their responsible investigation cannot be accomplished within the scope of work of the contract. Should substantial investigations be required beyond the scope of Phase II, congressional authorization to allocate additional funds will be required.

It is possible that cultural resources not previously discovered will be found. If so, required documentation should be completed as soon as possible so as to prevent costly construction delays or the destruction of important cultural resources by the construction contractor.

The framework presented below is suggested for the organization of work to be performed under the Cultural Resource Management Plan. Phase II Investigations contract. Offerors' proposals will comment upon the 
framework: reasoned criticism and a 1ternative suggestions are encouraged. Offerors' proposals will expand upon the framework, presenting the specifics of task assignment and staffing required to accomplish the work.

D. Proposed Organizational Framework

1. Initial period of advance planning and orientation.

2. First field season:

a. testing and evaluation of the 30 sites identified during the Texas Tech field work (Group A sites),

b. initiation of work at those of the 12 sites definitely scheduled for extensive excavation (Group C sites) at which more than one field season of work is anticipated or at which early construction impacts are possible, and

c. ongoing 1 aboratory analysis and processing of data.

3. Interim

evaluation,

a. evaluation of the results of previous contracts,

b. ongoing analysis of data generated by field work and its

c. preparation of yearly progress report (report to be submitted at least 60 calendar days before the planned date for the initiation of the next field season), and

d. consultation period (with WPRS and SHPO).

4. Second field season:

a. testing and evaluation of the 30 sites identified by UTSA in 1979 survey (Group B sites),

b. completion of work at the 12 Group C sites,

c. initiation of work at Group D sites which can be designated at that time as constituting components of the sample of 10 from the 95 site pool, and

d. ongoing 1 aboratory analysis and processing of data.

5. Interim

evaluation.

a. evaluation of the results of previous contracts,

b. ongoing analysis of data generated by fleld work and its 
c. preparation of yearly progress report (as in 3.c. above) and presentation of the proposed long-term Cultural Resource Management Plan (to be submitted 90 calendar days prior to initiation of next field season), and

d. consultation (with WPRS and SHPO).

6. Third and finat field season:

a. completion of all excavation field investigation,

b. completion of al1 preservation activities, and

c. ongoing laboratory analysis and processing of data.

7. Wrap-up:

final field season.

a. submittal of yearly Progress Report within 3 weeks of

b. completion of the analysis of all data generated by the field work, and

c. prepare and submit finat investigative report(s) within 52 months after date of award of contract.

\section{E. Cultural Resource Management Plan Components}

The contract and the recommendations resulting from Phase II Investigations will form a comprehensive Cultural Resource Management Plan for the Choke Canyon Archeological District. Accordingly, the nature and structure of those investigations will be influenced throughout by concerns for long-term in situ data preservation.

Many aspects of field work will be wholly or partially determined by the kind of project impacts anticipated. Such matters as detailed site mapping, placement of permanent datum points, the specifics of site excavation strategy, and the decision to backfill are aspects of field investigation strategy which could be considered as related to long-term data presentation.

Decisions on which sites to investigate (definition of research priorities) will also depend on balancing the need to collect data to evaluate site significance and the need to preserve the data base intact in situ wherever possible. Ninety calendar days prior to the initiation of the final field season, the contractor will furnish a draft of a detailed longterm Cultural Resource Management Plan (to take the form of the major portion of a Yearly Progress Report). Most of the initial phases of this plan will have al ready been accomplished through the recovery of important information in previous field seasons. The final season will complete the initial phase of the plan by completing those data recovery and preservation-related activities defined as the contractor's responsibility. The long-term 
Cultural Resource Management $P 1$ an will recommend long-term and major structural programs to the Government, which it will be the Government's responsibility to put into operation.

Offerors will define in their initial proposals the nature of preservation-related activities to be performed by the contractor. The National Inundation Study, previously completed Choke Canyon investigations, the State Historic Preservation Officer, and other appropriate sources should be consulted. Such activities might include detailed mapping and/or placement of permanent datum markers, backfilling, application of soil cement, or other techniques to preserve unexcavated portions of sites.

Long-range programs or major structural activities which the contractor might recommend, but for which the Government and not the contractor would be responsible for implementing, might include: structural stabilization of portions of the future lakeshore and the development of a program to foster pub $1 \mathrm{ic}$ awareness of the importance and fragility of the Choke Canyon cultural resources (possibly including the development of some sites as in situ displays).

The activities to be performed by the contractor shall be defined in offeror's proposals and the recommendations to the Government in the final yearly Progress Report. 


\title{
APPENDIX II.
}

\section{MACROBOTANICAL ANALYSIS OF PHASE II MATERIALS FROM THE CHOKE CANYON RESERVOIR AREA, TEXAS}

\author{
Richard G. Holloway
}

\section{INTRODUCTION}

Pollen and plant macrofossil evidence of past vegetational assemblages from the region of south-central Texas are general1 y 1 acking, and the existing data base is in dire need of expansion. At least in part, this may be due to factors directly related to the environment of preservation or the type of site being investigated. The results presented here are a continuation of the recovery and analysis of botanical remains from the Choke Canyon area and as such are an important addition to our understanding of past vegetational assemb lages.

Charcoal remains were recovered from five archaeological sites excavated in the Choke Canyon Reservoir area: 41 LK 51, 41 LK 128, 41 LK 201, 41 MC 55, and 41 MC 296. Preliminary data from site 41 LK 201 have previously been reported by Dering (1982), whereas the remaining four sites represent new data points.

These sites are located in both Live Oak and McMul1en Counties in the Tamaulipan Biotic Province (B1air 1950, 1952). The modern vegetation in this region forms something of a mosaic pattern. A southeast facing escarpment near Tilden is dominated by Acacia sp., which supports a 1 most a shrub 1 and type of vegetation. Beneath the escarpment at 1 ower elevations, mesquite (Prosopis sp.) dominates. Along river courses are located riparian communities including ash (Fraxinus spo), willow (Salix spo), elm (Ulmus sp.), hackberry (Ce1tis sp.), and some oak (Quercus sp.).

\section{METHODS AND MATERIALS}

The samples recovered during the excavations were generally sma 11 and fragmentary. The largest specimens from each 1 evel were examined and identified to the lowest possible taxonomic category. Clear transverse surfaces were examined by the snap method (Leney and Casteel 1975). In almost a 11 cases the individual specimens of charcoal were too sma 11 to a 11 ow either tangential or longitudinal sections to be made in addition to the transverse section. Thus, al1 identifications are based on transverse sections.

\section{RESULTS AND DISCUSSION}

The results of this study are provided in Tables 33-37. This form of data presentation is somewhat easier to interpret than site by site descriptions of what was identified. The data are arranged by site, by horizonta] provenience, and depth provenience. 
TABLE 33. RESULTS OF CHARCOAL ANALYSIS FROM 41 LK 51

\begin{tabular}{|c|c|c|c|c|c|}
\hline Prove & enience & Level & Depth & Identification & Comments \\
\hline $\begin{array}{l}\text { N998 } \\
\text { N998 }\end{array}$ & $\begin{array}{l}\text { E981 } \\
\text { E981 }\end{array}$ & $\begin{array}{r}6 \\
12\end{array}$ & $\begin{array}{l}99.30-99.20 \\
98.70-98.60\end{array}$ & $\begin{array}{l}\text { too smal1 to identify } \\
\text { Acacia sp./Prosopis sp. }\end{array}$ & fragmentary \\
\hline $\begin{array}{l}\text { N998 } \\
\text { N998 } \\
\text { N998 } \\
\text { N998 } \\
\text { N998 }\end{array}$ & $\begin{array}{l}\text { E984 } \\
\text { E984 } \\
\text { E984 } \\
\text { E984 } \\
\text { E984 }\end{array}$ & $\begin{array}{l}3 * \\
4^{*} \\
4^{*} \\
4^{*}\end{array}$ & $\begin{array}{l}99.60-99.50 \\
99.50-99.40 \\
99.50-99.40 \\
99.50-99.40\end{array}$ & $\begin{array}{l}\text { Fabaceae } \\
\text { hardwood } \\
\text { cf. Carya sp. } \\
\text { Acacia sp./Prosopis sp. } \\
\text { Acacia sp./Prosopis sp. }\end{array}$ & $\begin{array}{l}\text { badly fragmented } \\
\text { large pieces }\end{array}$ \\
\hline $\begin{array}{l}\text { N998 } \\
\text { N998 } \\
\text { N998 }\end{array}$ & $\begin{array}{l}\text { E982 } \\
\text { E982 } \\
\text { E982 }\end{array}$ & $\begin{array}{l}13 \\
15 \\
15\end{array}$ & $\begin{array}{l}98.60-98.50 \\
98.40-98.30 \\
99.40-99.30\end{array}$ & $\begin{array}{l}\text { hardwood } \\
\text { cf. Acacia sp./Prosopis sp. } \\
\text { cf. Acacia sp. }\end{array}$ & $\begin{array}{l}\text { very fragmentary } \\
\text { branch nodes or knobs }\end{array}$ \\
\hline $\begin{array}{l}\text { N999 } \\
\text { N999 }\end{array}$ & $\begin{array}{l}\text { E981 } \\
\text { E981 }\end{array}$ & $\begin{array}{r}3 \\
17\end{array}$ & $\begin{array}{l}99.60-99.50 \\
98.20-98.10\end{array}$ & $\begin{array}{l}\text { cf. Acacia sp./Prosopis sp. } \\
\text { Salicaceae }\end{array}$ & \\
\hline $\begin{array}{l}\text { N999 } \\
\text { N999 }\end{array}$ & $\begin{array}{l}E 982 \\
\text { E982 }\end{array}$ & $\begin{array}{l}5 \\
5\end{array}$ & $\begin{array}{l}99.40-99.30 \\
99.30-99.20\end{array}$ & $\begin{array}{l}\text { hardwood } \\
\text { Acacia sp./Prosopis sp. }\end{array}$ & very fragmentary \\
\hline N999 & E981 & 13 & $98.60-98.50$ & cf. Acacia sp./Prosopis sp. & \\
\hline N998 & E981 & 12 & $98.70-98.60$ & Acacia sp./Prosopis sp. & \\
\hline N998 & E992 & 15 & $98.40-98.30$ & hardwood & $\begin{array}{l}\text { highly fragmented, no } \\
\text { clear surface }\end{array}$ \\
\hline $\begin{array}{l}\text { N1010 } \\
\text { N1010 }\end{array}$ & $\begin{array}{ll}0 & \text { ElO11 } \\
0 & \text { El011 }\end{array}$ & $\begin{array}{l}4 \\
7\end{array}$ & $\begin{array}{l}99.60-99.50 \\
99.30-99.20\end{array}$ & $\begin{array}{l}\text { Acacia sp./Prosopis sp. } \\
\text { Acacia sp./Prosopis sp. }\end{array}$ & \\
\hline N1010 & D El014 & 7 & & Salicaceae & either Salix sp. or Populus sp. \\
\hline
\end{tabular}

*Feature 2 
TABLE 34. RESULTS OF CHARCOAL ANALYSIS FROM 41 LK 128

\begin{tabular}{|c|c|c|c|c|}
\hline Proventence & Leve1 & Depth & Identification & Comments \\
\hline $\begin{array}{l}\text { Hearth } 2 \\
\text { Hearth } 12 \\
\text { Hearth } 13 \\
\text { Hearth } 13 \\
\text { Hearth } 17 \\
\text { Test Pit } 5 \\
\text { Test Pit } 5 \\
\text { Test Pit } 5 \\
\text { Test Pit } 5 \\
\text { Test Pit } 5 \\
\text { Test Pit } 6 \\
\text { Test Pit } 6 \\
\text { Test Pit } 7 \\
\text { Test Pit } 7 \\
\text { Test Pit } 7 \\
\text { Test Pit } 7 \\
\text { Test Pit } 7 \\
\text { Test Pit } 7 \\
\text { Test Pit } 8 \\
\text { Test Pit } 8 \\
\text { Test Pit } 8 \\
\text { Test Pit } 8 \\
\text { Test Pit } 9 \\
\text { Test Pit } 9 \\
\text { Test Pit } 9 \\
\text { Test Pit } 10 \\
\text { Test Pit } 12 \\
\text { Test Pit } 12 \\
\text { Test Pit } 13 \\
\text { Test Pit } 14 \\
\text { Test Pit } 16\end{array}$ & $\begin{array}{l}2 \\
3 \\
5 \\
6 \\
7 \\
2 \\
2 \\
1 \\
2 \\
2 \\
3 \\
4 \\
6 \\
1 \\
2 \\
3 \\
4 \\
1 \\
1 \\
2 \\
2 \\
1 \\
2 \\
1 \\
1 \\
1\end{array}$ & $\begin{array}{l}99.60-99.50 \\
99.50-99.40 \\
99.30-99.20 \\
99.20-99.10 \\
99.10-99.00 \\
99.70-99.60 \\
99.60-99.50 \\
\text { Surface-99.60 } \\
99.60-99.50 \\
99.60-99.50 \\
99.50-99.40 \\
99.40-99.30 \\
99.20-99.10 \\
\text { Surface-99.70 } \\
99.70-99.60 \\
99.60-99.50 \\
99.50-99.40 \\
\text { Surface-99.40 } \\
\text { Surface-99.40 } \\
99.40-99.30 \\
99.50-99.40 \\
\text { Surface-100.90 } \\
100.90-100.80 \\
\text { Surface-99.40 } \\
\text { Surface-99.40 } \\
\text { Surface-99.60 }\end{array}$ & $\begin{array}{l}\text { cf. Diospyros sp. } \\
\text { cf. Acacia sp./Prosopis sp. } \\
\text { cf. Acacia sp./Prosopis sp. } \\
\text { cf. Prosopis sp. } \\
\text { Acacia sp./Prosopis sp. } \\
\text { Acacia sp./Prosopis sp. } \\
\text { hardwood } \\
\text { cf. Acacia sp./Prosopis sp. } \\
\text { hardwood } \\
\text { cf. Prosopis sp. } \\
\text { cf. Acacia sp./Prosopis sp. } \\
\text { Acacia sp./Prosopis sp. } \\
\text { hardwood } \\
\text { bone } \\
\text { Acacia sp./Prosopis sp. } \\
\text { Acacia sp./Prosopis sp. } \\
\text { hardwood } \\
\text { bone } \\
\text { Acacia sp./Prosopis sp. } \\
\text { cf. Acacia sp. } \\
\text { hardwood } \\
\text { Carya sp. } \\
\text { Salix sp. } \\
\text { bone } \\
\text { hardwood } \\
\text { hardwood } \\
\text { cf. Acacia sp./Prosopis sp. }\end{array}$ & $\begin{array}{l}\text { fragmentary } \\
\text { charred } \\
\text { charred } \\
\text { too fragmentary to identify } \\
\text { charred } \\
\text { too fragmentary to identify }\end{array}$ \\
\hline
\end{tabular}


TABLE 35. RESULTS OF CHARCOAL ANALYSIS FROM 41 LK 201

Provenience Level Depth Identification Comments

\section{AREA A}

Feature 5

N490 El043

N491 E1043

$\begin{array}{ll}12 & 97.65-97.55 \\ 12 & 97.65-97.55\end{array}$

$97.65-97.55$

Feature 2

N491 E1043

AREA B

N497 E997

N497 E996

N498 E997

11

15

15

$98.35-98.25$

$97.95-97.85$

98.95-98. 85

Feature 7

N498 E997
$97.25-96.92$

cf. Prosopis sp.

Acacia sp./Prosopis sp. Acacia sp./Prosopis sp.
Acacia sp./Prosopis $s p$. cf. Prosopis sp.

too fragmentary to identify very fragmentary

10 samples - fragmentary 
TABLE 36. RESULTS OF CHARCOAL ANALYSIS FROM 41 MC 55

\begin{tabular}{|c|c|c|c|c|}
\hline Provenience & Leve1 & Depth & Identification & Comments \\
\hline N993 E1015 & 1 & Surface -99.30 & bone & charred \\
\hline N994 El013 & 1 & Surface -99.30 & Acacia sp./Prosopis sp. & \\
\hline N994 E1015 & 2 & $99.30-99.20$ & cf. Diospyros sp. & \\
\hline N1008 E1014 & 2 & $99.40-99.30$ & she17, cf. Acacia sp./Prosopis sp. & \\
\hline N1008 E1015 & 1 & $99.40-99.30$ & Acacia sp./Prosop is sp. & \\
\hline N1009 E1014 & 1 & Surface -99.30 & Acacia sp./Prosopis sp. & \\
\hline N1009 E1013 & 1 & Surface -99.30 & no specimen recovered & \\
\hline N1009 E1015 & 2 & $99.30-99.20$ & cf. Acacia sp./Prosopis sp. & \\
\hline N1008 E1014 & 3 & $99.30-99.20$ & hardwood & very fragmentary \\
\hline N1008 E1015 & 2 & $99.30-99.20$ & hardwood & \\
\hline N1007 E1015 & 3 & $99.30-99.20$ & Acacia sp./Prosopis sp. & very fragmentary \\
\hline N1009 El013 & 2 & $99.30-99.20$ & cf. Prosopis sp. & many small fragments \\
\hline N1007 E1016 & 2 & $99.30-99.20$ & hardwood & distorted by heat \\
\hline N1009 E1016 & 2 & $99.30-99.20$ & cf. Prosopis sp. & many sma 11 fragments \\
\hline N1008 E1016 & 2 & $99.30-99.20$ & hardwood & \\
\hline N1015 E1012 & $\overline{1}$ & Surface-99.20 & cf. Acacia sp./Prosopis sp. & \\
\hline N1007 E1014 & 2 & $99.40-99.30$ & & too fragmentary to identify \\
\hline N998 E1017 & 2 & $99.30-99.20$ & Acacia sp./Prosopis sp. & \\
\hline N999 E1017 & 2 & $99.30-99.20$ & cf. Acacia sp./Prosop is sp. & knotty portion \\
\hline N999 E1017 & 4 & $99.10-99.00$ & cf. Acacia sp./Prosopis sp. & fragmentary \\
\hline N1017 E999 & 1 & Surface -99.30 & & too fragmentary to identify \\
\hline N1017 E999 & $\overline{9}$ & $98.60-98.50$ & & $\begin{array}{l}\text { charcoal embedded in soil } \\
\text { too fragmentary to identify }\end{array}$ \\
\hline N1018 E999 & 1 & Surface-99.30 & & too fragmentary to identify \\
\hline N1018 E999 & 2 & $99.30-99.20$ & cf. Acacia sp./Prosopis sp. & \\
\hline N1018 E999 & $\overline{3}$ & $99.20-99.10$ & Acacia sp./Prosopis sp. & \\
\hline N1018 E999 & 4 & $99.10-99.00$ & hardwood & \\
\hline N1018 E999 & 8 & $98.70-98.60$ & cf. Acacia sp./Prosopis sp. & \\
\hline
\end{tabular}


TABLE 37. RESULTS OF CHARCOAL ANALYSIS FROM 41 MC 296

\begin{tabular}{|c|c|c|c|c|}
\hline Provenience & Level & Depth & Identification & Comments \\
\hline $\begin{array}{l}\text { Lot } 256 \\
\text { Test Pit } 1 \\
\text { Test Pit 1 } \\
\text { Test Pit } 1 \\
\text { Test Pit } 1 \\
\text { Test Pit } 1 \\
\text { Test Pit } 1 \\
\text { Test Pit } 1 \\
\text { Test Pit } 1 \\
\text { Test Pit } 1 \\
\text { Test Pit } 1 \\
\text { Test Pit } 1 \\
\text { Test Pit } 2 \\
\text { Test Pit } 2 \\
\text { Test Pit } 2 \\
\text { Test Pit } 2 \\
\text { Test Pit } 2 \\
\text { Test Pit } 2 \\
\text { Test Pit } 2 \\
\text { Test Pit } 2 \\
\text { Test Pit } 2 \\
\text { Test Pit } 2 \\
\text { N1022 E985 } \\
\text { N1022 E985 } \\
\text { N1022 E985 } \\
\text { N1022 E985 } \\
\text { N1022 E985 } \\
\text { N1022 E985 } \\
\text { N1022 E986 } \\
\text { N1022 E986 } \\
\text { N1022 E986 } \\
\text { N1022 E986 } \\
\text { N1022 E986 } \\
\text { N1022 E986 }\end{array}$ & $\begin{array}{l}1 \\
1 \\
2 \\
3 \\
4 \\
4 \\
5 \\
6 \\
7 \\
8 \\
9 \\
2 \\
3 \\
3 \\
4 \\
4 \\
5 \\
5 \\
6 \\
8 \\
9 \\
2 \\
5 \\
6 \\
7 \\
8 \\
9 \\
2 \\
5 \\
6 \\
6 \\
7 \\
8\end{array}$ & $\begin{array}{c}40-50 \mathrm{~cm} \\
50-60 \mathrm{~cm} \\
70-80 \mathrm{~cm} \\
80-90 \mathrm{~cm} \\
99.40-99.30 \\
99.10-99.00 \\
99.00-98.90 \\
98.90-98.80 \\
98.80-98.70 \\
98.70-98.60 \\
99.40-99.30 \\
99.10-99.00 \\
99.00-98.80\end{array}$ & $\begin{array}{l}\text { cf. Acacia sp./Prosopis sp. } \\
\text { Acacia sp./Prosopis sp. } \\
\text { Acacia sp./Prosopis sp. } \\
\text { cf. Fabaceae } \\
\text { Acacia sp./Prosopis sp. } \\
\text { Acacia sp./Prosopis sp. } \\
\text { Acacia sp./Prosopis sp. } \\
\text { Fabaceae } \\
\text { cf. Acacia sp./Prosopis sp. } \\
\text { Acacia sp./Prosopis sp. } \\
\text { Fabaceae } \\
\text { Acacia sp./Prosopis sp. } \\
\text { Acacia sp./Prosopis sp. } \\
\text { Acacia sp./Prosopis sp. } \\
\text { Acacia sp./Prosopis sp. } \\
\text { hardwood } \\
\text { Acacia sp./Prosopis sp. } \\
\text { Acacia sp./Prosopis sp. } \\
\text { cf. Prosopis sp. } \\
\text { cf. Fabaceae } \\
\text { cf. Fabaceae }\end{array}$ & $\begin{array}{l}\text { no clear sections } \\
\text { very smal } 1 \\
\text { too fragmentary to identify } \\
\text { Lot } 28 \\
\text { Lot } 29 \\
\text { too fragmentary to identify } \\
\text { too fragmentary to identify } \\
\text { heat fractured } \\
\text { too fragmentary to identify } \\
\text { very fragmentary } \\
\text { Lot } 33 \\
\text { too fragmentary to identify } \\
\text { Lot } 34 \\
\text { too fragmentary to identify } \\
\text { Lot } 37 \\
\text { too fragmentary to identify }\end{array}$ \\
\hline
\end{tabular}


Table 37. (continued)

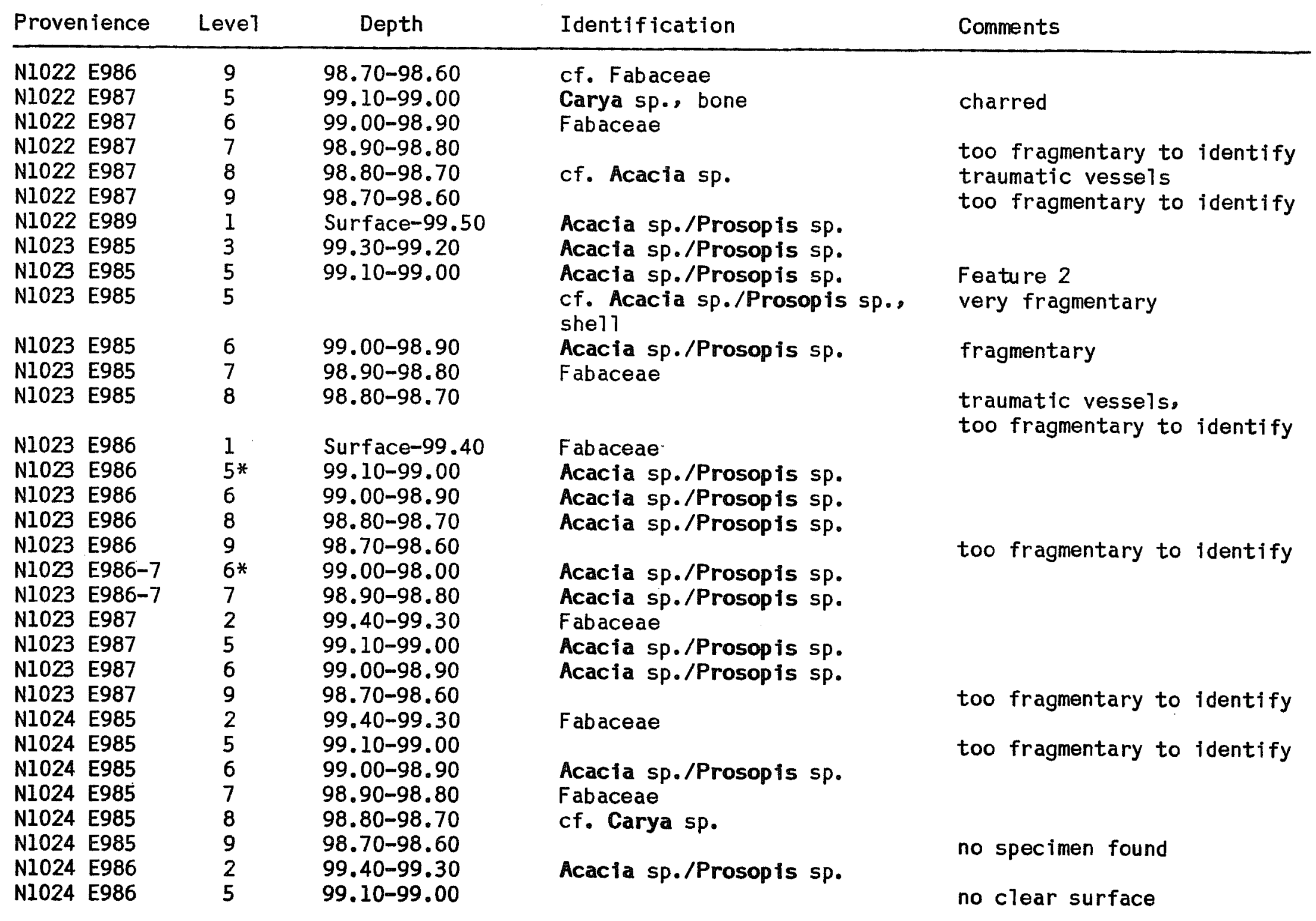


Table 37. (continued)

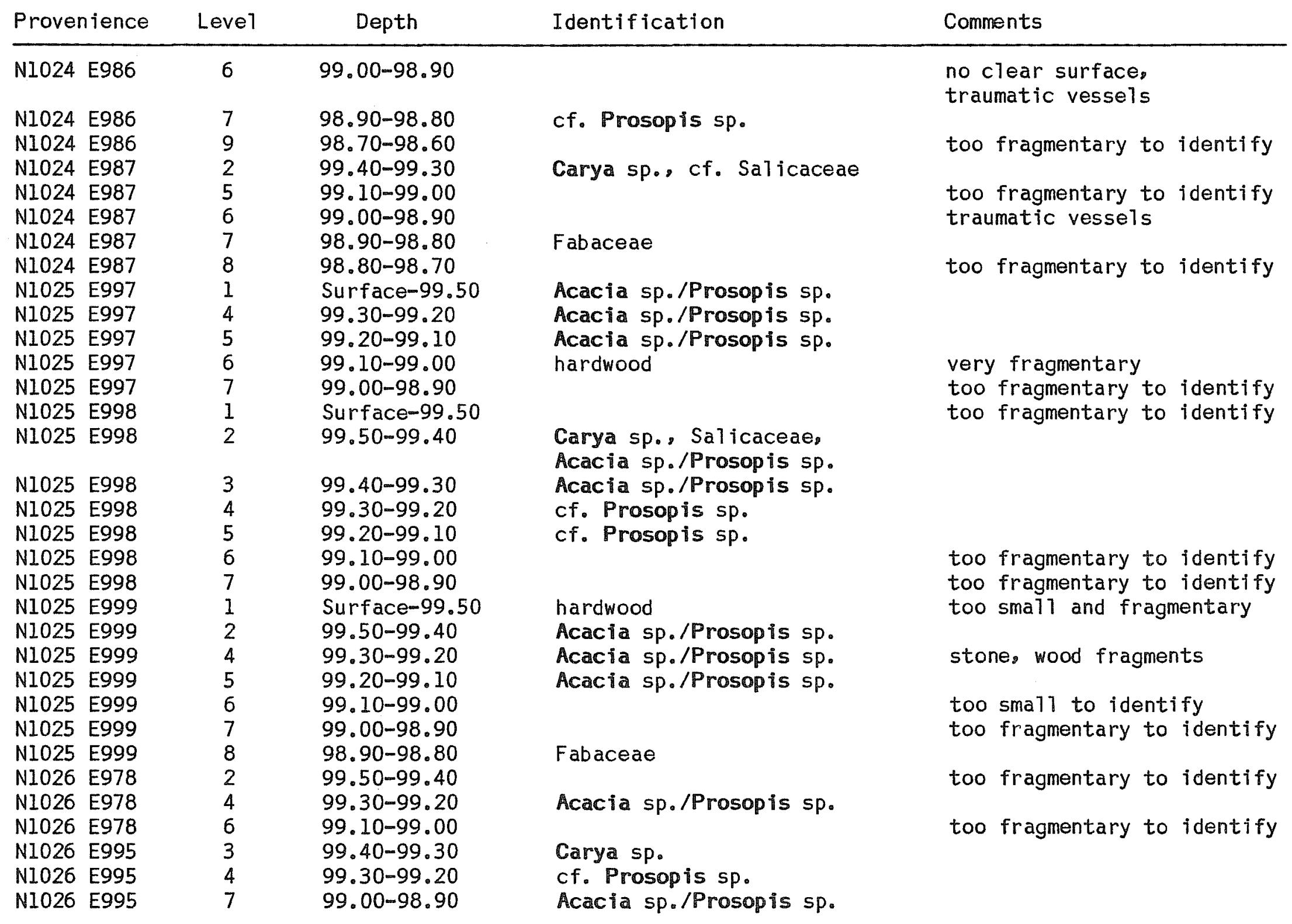


Table 37. (continued)

\begin{tabular}{|c|c|c|c|c|c|}
\hline Prove & nience & Leve1 & Depth & Identification & Comments \\
\hline $\mathrm{N} 1026$ & E998 & & & \multirow{3}{*}{ Acacia sp./Prosopis sp. } & too fragmentary to identify \\
\hline N1026 & E998 & 3 & $99.40-99.30$ & & \\
\hline N1026 & E998 & 4 & $99.30-99.20$ & & too fragmentary to identify \\
\hline N1026 & E998 & 5 & $99.20-99.10$ & \multirow{3}{*}{$\begin{array}{l}\text { Acacia sp./Prosopis sp. } \\
\text { Acacia sp./Prosopis sp. }\end{array}$} & \\
\hline N1026 & E998 & 6 & $99.10-99.00$ & & \\
\hline N1026 & E998 & 7 & $99.00-98.90$ & & too fragmentary to identify \\
\hline $\mathrm{N} 1026$ & E999 & 5 & $99.20-99.10$ & \multirow{4}{*}{$\begin{array}{l}\text { Acacia sp./Prosopis } s p . \\
\text { Acacia sp./Prosopis sp. } \\
\text { Acacia sp./Prosopis } s p .\end{array}$} & \\
\hline NIO26 & E999 & 6 & $99.10-99.00$ & & \\
\hline $\mathrm{N} 1027$ & E978 & 2 & $99.50-99.40$ & & \\
\hline N1027 & E978 & 3 & $99.40-99.30$ & & $\begin{array}{l}\text { too brittle to identify } \\
\text { too fragmentary to identify }\end{array}$ \\
\hline N1027 & E978 & 5 & $99.20-99.10$ & \multirow{4}{*}{$\begin{array}{l}\text { cf. Carya sp. } \\
\text { Salicaceae, } \\
\text { Acacia sp./Prosopis sp. }\end{array}$} & \\
\hline N1027 & E978 & 6 & $99.10-99.00$ & & \\
\hline N1027 & E986 & 3 & $99.40-99.30$ & & too fragmentary to identify \\
\hline N1027 & E986 & 4 & $99.30-99.20$ & & too fragmentary to identify \\
\hline N1027 & E997 & 2 & $99.50-99.40$ & \multirow{3}{*}{$\begin{array}{l}\text { cf. Prosopis sp. } \\
\text { Acacia sp./Prosopis sp. } \\
\text { Acacia sp./Prosopis sp. }\end{array}$} & \\
\hline $\mathrm{N} 1027$ & E997 & 5 & $99.20-99.10$ & & \\
\hline $\mathrm{N} 1027$ & E997 & 6 & $99.10-99.00$ & & too fragmentary to identify \\
\hline N1027 & E998 & 1 & $99.60-99.50$ & \multirow{4}{*}{$\begin{array}{l}\text { Juniperus sp. } \\
\text { cf. Prosopis sp. } \\
\text { cf. Prosopis sp. }\end{array}$} & \\
\hline N1027 & E998 & 3 & $99.40-99.30$ & & \\
\hline N1027 & E998 & 4 & $99.30-99.20$ & & \\
\hline N1027 & E998 & 5 & $99.20-99.10$ & & too fragmentary to identify \\
\hline N1027 & E998 & 6 & $99.10-99.00$ & \multirow{3}{*}{$\begin{array}{l}\text { hardwood } \\
\text { Acacia sp./Prosopis sp. } \\
\text { Acacia sp./Prosopis sp. }\end{array}$} & \\
\hline N1027 & E998 & 7 & $99.00-98.90$ & & \\
\hline N1027 & E999 & $\begin{array}{l}\text { Soil Column } \\
\text { North Wall }\end{array}$ & 99.13 & & \\
\hline N.1027 & E999 & 1 & Surface-99.5 & \multirow{6}{*}{$\begin{array}{l}\text { Acacia sp./Prosopis sp. } \\
\text { Fabaceae } \\
\text { Acacia sp./Prosopis sp. }\end{array}$} & too fragmentary to identify \\
\hline N1027 & E999 & 4 & $99.30-99.20$ & & \\
\hline $\mathrm{N} 1027$ & E999 & 5 & $99.20-99.10$ & & \\
\hline $\mathrm{N} 1027$ & E999 & 6 & $99.10-99.00$ & & \\
\hline $\mathrm{N} 1027$ & E999 & 6 & & & too fragmentary to identify \\
\hline N1027 & E999 & 7 & $99.00-98.90$ & & no clean break \\
\hline
\end{tabular}

*Feature 2 
Radiocarbon analyses of these sites are quite wide ranging. Site 41 LK 51 dated between $5860 \pm 80$ and $6360 \pm 90$ years B.P. However, these dates were recovered from Level 15. The upper levels of the site quite possibly are not contemporaneous, but at present are undated. The deeper levels (Levels 1217) from site 41 LK 201 were dated between $2450 \pm 60$ and $3090 \pm 80$ years B.P. While these deeper level excavations provide older materials, the dates are st111 more recent than those from site 41 LK 5l. Site 41 MC 296, from which the greatest amount of macrobotanical material was recovered, dated between $2090 \pm 60$ years B.P. and A.D. 1430-1610. Site 41 LK 128 dated between A.D. 980-1310 and site 41 MC 55 between A.D. 1330-1420.

Most of the charcoal recovered from these sites (Tables 32-37) was identified as belonging to either Acacia or Prosopis. Both genera are members of the Fabaceae family, both inhabit the same ecological habitats, and both are present in the region today. Lack of adequate comparative materials which would reveal the extent of species variation in wood anatomy precluded the positive identification beyond this very general level. In a few cases, the specimens were noted as comparing very favorably (cf.) to one genus or the other.

The materials recovered from site 41 LK 51 dated older than any other materials recovered from the Choke Canyon region. Yet the charcoal analysis reveals similar, if not identical, taxa available for selection as fuel sources as were present in the more recent sites. This strongly argues for a stable environment which may have persisted in this region for 6000 years.

Data recovered from these botanical remains suggest that a minimum of two habitats were consistently exploited for fuel. A primary source was probably restricted to more up 1 and and drier sites which may have provided the bulk of the Acacia sp./Prosopis sp. woods. These species are semiarid in requirements, and their dominance in the fossil record suggests their proximity and perhaps, somewhat easier acquisition.

A secondary plant community 1 ikewise exploited, but with less frequency, would be the riparian communities located along the watercourses. These communities provided the occasional specimens of hickory (Carya sp.), Salicaceae (most likely Salix sp. [willow]), and persimmon (Diospyros sp.). The low numbers of these woods in comparison to the Acacia sp./Prosopis sp. also suggest that they were not heavily exploited.

There is no readily discernible pattern to the distribution of the riparian taxa throughout the date ranges assigned. They appear almost randomly distributed throughout the levels. Thus, they provide no evidence to support a hypothesis based on shifting climates. Neither do they support an interpretation of decreasing availability through utilization as suggested by Minnis (1981) for the Mimbres occupation in southwestern New Mexico. The pattern emerges that for possibly the past 6000 years this region was occupied by a mosaic of both semiarid shrubs and riparian elements.

Dering (1982) reported similar results from his previous study of the Choke Canyon area. The main differences between his study and the current investigations is his identification of ash (Fraxinus sp.) and hackberry (Celtis sp.) charcoal. This should not invalidate any of the possible 
interpretations herein presented as both ash (Fraxinus sp.) and hackberry (Celtis sp.) are typical components of the riparian community.

Dering (1982) identified both Acacia sp. and Prosopis sp. charcoal from sites 41 LK $31 / 32$ which had been dated between $4360-4340$ years B.P. Thus, Dering's (1982) 4300-year record compares quite favorably with the 6000-year record of these taxa from the local area.

Bryant (1977a) and Bryant and Riskind (1980) have attempted to summarize the available pollen data from the Chihuahuan Desert region of south Texas and northern Mexico. In both studies, they concluded that the region had been relatively stable during the past 3000 years. Bryant (1977a) reported evidence of increasing trends to aridity in levels dated post-7000 B.P. from deposits recovered from the Amistad Reservoir area. He also noted a very short-lived mesic period dated around 2800 B.P. This mesic interval was not Identifiable in the charcoal record from the Choke Canyon region. Bryant and Riskind (1980) did note a more mesic pollen assemblage from a single sample recovered from Cueva de la Zona de Derrumbes, northern Mexico. However, this may be a local phenomenon as it was present in only a single sample.

Steele (1986) has recently analyzed the faunal remains recovered from site 41 LK 201. He notes the mixture of both eastern and southern elements and interprets these as perhaps representing mixtures of components of both the TamauTipan and Eastern Woodland Biotic Provinces. Steele's (1986) data are comparable with the present botanical evidence in that they are indicative of a mosaic pattern of biological communities. The available evidence (pollen, faunal, and charcoal) all suggest a relatively stable environment characterized by increasing aridity. From the available radiocarbon dates. this community distribution has been present in the region for 6000 years.

Gunn et a 1. (1982) have recent 1 y proposed an a 1 ternative model of climate change for the region of south Texas. Utilizing current climatic records and subjecting these data to factor analysis, Gunn et al. (1982) have proposed a series of alternating periods of wet and dry which may have been operating to control Holocene climate and vegetation.

Additional7y, Gunn et a1. (1982) cite phytolith evidence (Robinson 1979, 1982) which purports to substantiate their model. The phytolith data is then compared with previously published sequences of cultural and geological data.

Both Gunn et a 1. (1982) and Robinson (1982) rely heavily on the Identification of a definable Hypsithermal interval. The radiocarbon dates recovered from 41 LK 51 place these strata within the classic Hypsithermal period. However, the charcoal assemblages reported herein show no change in composition of taxa which would suggest changes of the magnitude associated with the Hypsithermal as originalyy defined by Deevey and Flint (1957). Steele's (1986) faunal data 1 ikewise fail to suggest the presence of this climatic interval. Furthermore, pollen analysis of a number of sites located throughout Texas (Bryant 1969, 1977b; Potzger and Tharp 1954; Graham and Heimsch 1960) fails to support the identification of this interval. Based on the combined evidence of the charcoal, fauna, and pollen, a re-evaluation of Gunn et a1.'s (1982) model is indicated. 
The data presented in this report has an immediate bearing on several questions related directly on the biogeography of certain taxa. Dering (1982) reported the single occurrence of Juniperus sp. charcoal and, based on supporting evidence by Adams (1977), has suggested the presence of relict stands of Juniperus ashel in the region of Choke Canyon. While Dering (1982) may be correct in his interpretation, the results of my analysis have not supported the presence of Juniperus sp. at 2200 B.P. A single specimen of Juniperus sp. charcoal was recovered from Leve1 1 at site 41 MC 296, but this level was dated between A.D. $1400-1600$, about 1500 years too recent to compare with Dering's (1982) estimate.

A second major biogeographical problem concerns the migration of mesquite (Prosopis sp.) into the area. Johnston (1963) has proposed this migration occurred historically as a result of overgrazing by cattle. Due to 1 ack of corresponding data, I can only propose a tentative identification of Prosopis sp. from this region. Some of the specimens identified did compare quite favorably to the characteristics of the genus Prosopis and, thus, it is quite possible that this taxon has a much longer history in this region than has previously been proposed. Dering (1982) 1 ikewise proposed the presence of Prosopis sp. in this region for the past 2000 years. Based on data recovered during the present investigation, Prosopis sp. may have been present in this region for a much longer period of time than previously suspected.

\section{CONCLUSIONS}

The macrobotanical evidence recovered from these sites suggests a long-term stable environment. The stability of this region is somewhat longer than previously suggested, by about 2000 years, extending back approximately 6000 years B.P. The vegetational assemblages appear to have formed something of a mosaic configuration in the 1 andscape composed primarily of a xeric plant community dominated by leguminous woody species. Interspersed with this plant community were more mesic and presumably smaller stands dominated by riparian taxa.

Unfortunately, lack of precision has precluded any positive statement concerning the migration of Prosopis into this region. It would not be unexpected, however, for this taxon to have been a common component of the vegetation. Perhaps, palynological data, if forthcoming, can elucidate the problem. The results of the present study cannot substantiate the proposed range extension of Juniperus sp. into the Choke Canyon region as earlier suggested by Dering (1982). 


\section{REEERENCES CITIED}

Adams, R. P.

1977 Chemosystematics--Analysis of Populations Differentiation and Variability of Ancestral and Recent Populations of Juniperus ashei. Annals of the Missouri Botanical Garden 64:184-209.

Blair, W. F.

1950 The Biotic Provinces of Texas. The Texas Journal of Science $2: 93-117$.

1952 Mammals of the Tamau 7 ipan Biotic Province in Texas. The Texas Journat of Science $4: 230-250$.

Bryant, V. M., Jr.

1969 Late Ful $1 \mathrm{glacia} 1$ and Postglacial Pollen Analysis of Texas Sediments. Ph.D. dissertation. The University of Texas at Austin.

1977a Late Quaternary Pol 1en Records From the East-Central Periphery of the Chihuahuan Desert. In Transactions of the Symposium on the Biological Resources of the Chihuahuan Desert Region United States and Mexico, edited by R. H. Wauer and D. $H_{0}$ Riskind. U.S. Department of the Interior, Nationa 1 Park Service Transactions and Proceedings, Series 3.

1977b A 16,000 Year Pollen Record of Vegetational Change in Central Texas. Palynology 1:143-156.

Bryant, V. M., Jro and D. H. Riskind

1980 The Paleoenvironmental Record for Northeastern Mexico: A Review of the Pollen Evidence. In Papers on the Prehistory of Northeastern Mexico and Adjacent Texas, edited by J. F. Epstein. T. R. Hester, and C. Graves. Center for Archaeological Research. The University of Texas at San Antonio. Special Report $9: 7-31$.

Dering, $P$.

1982 Analysis of Carbonized Botanical Remains From the Choke Canyon Reservoir Area. In Archaeological Investigations at Choke Canyon Reservoir, South Texas: The Phase I Findings, by G. D. Hal 1, S. L. Black, and C. Graves. Center for Archaeological Research. The University of Texas at San Antonio, Choke Canyon Series $5: 518-530$. 
Deevey, E. S. and R. F. Flint

1957 Postglacial Hypsithermal Interval. Science 125:182-184.

Graham, A. and C. Heimsch

1960 Pollen Studies of Some Texas Peat Deposits. Ecology 41:785790.

Gunn, J., T. R. Hester, R. Jones, R. L. Robinson, and R. A. Mahula

1982 Climatic Change in Southern Texas. In Archaeological Investigations at Choke Canyon Reservoir, South Texas: The Phase I Findings, by G. D. Ha 11, S. L. B I ack, and C. Graves. Center for Archaeological Research. The University of Texas at San Antonio, Choke Canyon Series 5:578-596.

Johnston, M. C.

1963 Past and Present Grass 1 ands of Southern Texas and Northeastern Mexico. Ecology $44: 456-466$.

Leney, L. and R. Castee 1

1975 Simplified Procedure for Examining Charcoal Specimens for Identification. Journal of Archaeological Science 2:153-159.

Minnis, P. E.

1981 Economic and Organizational Responses to Food Stress by NonStratified Societies: An Example From Prehistoric New Mexico. Ph.D. dissertation, University of Michigan.

Potzger, J. E. and B. C. Tharp

1954 Pollen Study of Two Bogs in Texas. Ecology 35:462-466.

Robinson, R. L.

1979 Biosilica and Climatic Change at 41 GD 21 and 41 GD 21A. In Archaeological Investigations of Two Prehistoric Sites on the Coleto Creek Drainage, Goliad County, Texas, by D. E. Fox:102113. Center for Archaeological Research, The University of Texas at San Antonio, Archaeological Survey Report 69.

1982 Biosilica Analysis of Three Prehistoric Archaeological Sites in the Choke Canyon Reservoir, Live Oak County, Texas: Preliminary Summary of Climatic Implications. In Archaeological Investigations at Choke Canyon Reservoir. South Texas: The Phase I Findings, by G. D. Ha11, S. L. B 1 ack, and C. Graves. Center for Archaeological Research, The University of Texas at San Antonio, Choke Canyon Series 5:597-610. 
Steele, D. G.

1986 Analysis of Vertebrate Faunal Remains From 41 LK 201, Live Oak County, Texas. Appendix $V$ in Archaeological Investigations at 41 LK 201, Choke Canyon Reservoir, Southern Texas, by C. L. Highley. Center for Archaeological Research. The University of Texas at San Antonio, Choke Canyon Series 11.

Tharp, B. C.

1939 The Vegetation of Texas. Texas Academy of Science Publications in Natural History, Non-Technical Series 1. 


\section{APPENDIX III.}

\section{ANALYSIS OF VERTEBRATE FAUNAL REMAINS FROM 41 MC 222 AND 41 MC 296, MCMULLEN COUNTY, TEXAS}

\section{Gentry Steele and Cristi Assad Hunter}

The present report, part of the continuing study of the faunal remains recovered from the basin of Choke Canyon Reservoir in south Texas, analyzes the bony remains of vertebrates recovered from 41 MC 222 (Tab1e 38) and 41 MC 296 (Table 39). Additional reports on the faunal remains recovered from the basin include an examination of the unionids recovered during the first phase of the archaeological excavation (Murray 1982), a study of the remains of vertebrates recovered from 41 LK 201 (Steele 1986), and the analysis of the value of fine screening for vertebrate remains in south Texas (DeMarcay and Steele 1986).

Prior to interpreting human behavior based upon the analysis of the faunal remains recovered from 41 LK 201, Steele (1986) examined the nature of the bone assemblage itself. Since the conclusions reached based on that assemblage are pertinent to the examination of the two assemblages considered here it is worth summarizing those points. When researchers examine the 1 ithic or ceramic assemblages recovered from a site it is generaliy safe to assume that humans were the predominant, if not the only agent, which created the artifacts. It is usually safe to also assume that the 1 ithic and ceramic artifacts have not been differentially destroyed or removed from the site. If they have, there is usually clear-cut evidence of another agent, such as water transportation, which has affected the assemblage. When we examine the bone assemblage, however, such assumptions are not as safe to make. A variety of authors (Steele 1986; Binford 1981; Brain 1981; Shipman 1981; Behrensmeyer and Hi11 1980; Hester 1975a, 1980; Hester et a1. 1975) have pointed out that humans may not have been the only contributors to the bone assemblage at a site. Nonhuman predators co-occupying the site with the humans or occupying the site at different times could have contributed to the assemblage. A1so, animals inhabiting the site after the human occupation, could have died and their bones been incorporated into the assemb lage.

Just as humans may not have been the only agents creating the bone assemblage, it is also clear that not al1 of the animals utilized by humans will be represented in the bone assemblage at the site. Very 1 arge animals such as bison may have been killed and butchered away from the site and only the flesh returned to the site, thus no bones would have accrued in the habitation site to mark the event. Similarly, other animals large or small could have been killed, processed, and consumed away from the site. Again, the result would be that no bones would have been added to the assemblage at the site. Even the bony remains which are carried back to the site are subject to being deleted from the site prior to the excavation. Scavengers (canids most commonly in North America) could have destroyed some of the bones, or differential preservation could have removed the smaller and more fragile remains. Humans themselves could have destroyed some of the bones as they modified them into tools, or ground them for meal or pottery temper. In south Texas, awls, pressure flaking tools, billets, beads, and needles made from bone have been recovered (Hester 1980), and one of the main pottery 
TABLE 38. LIST OF THE VERTEBRATE TAXA RECOVERED FROM 41 MC 222

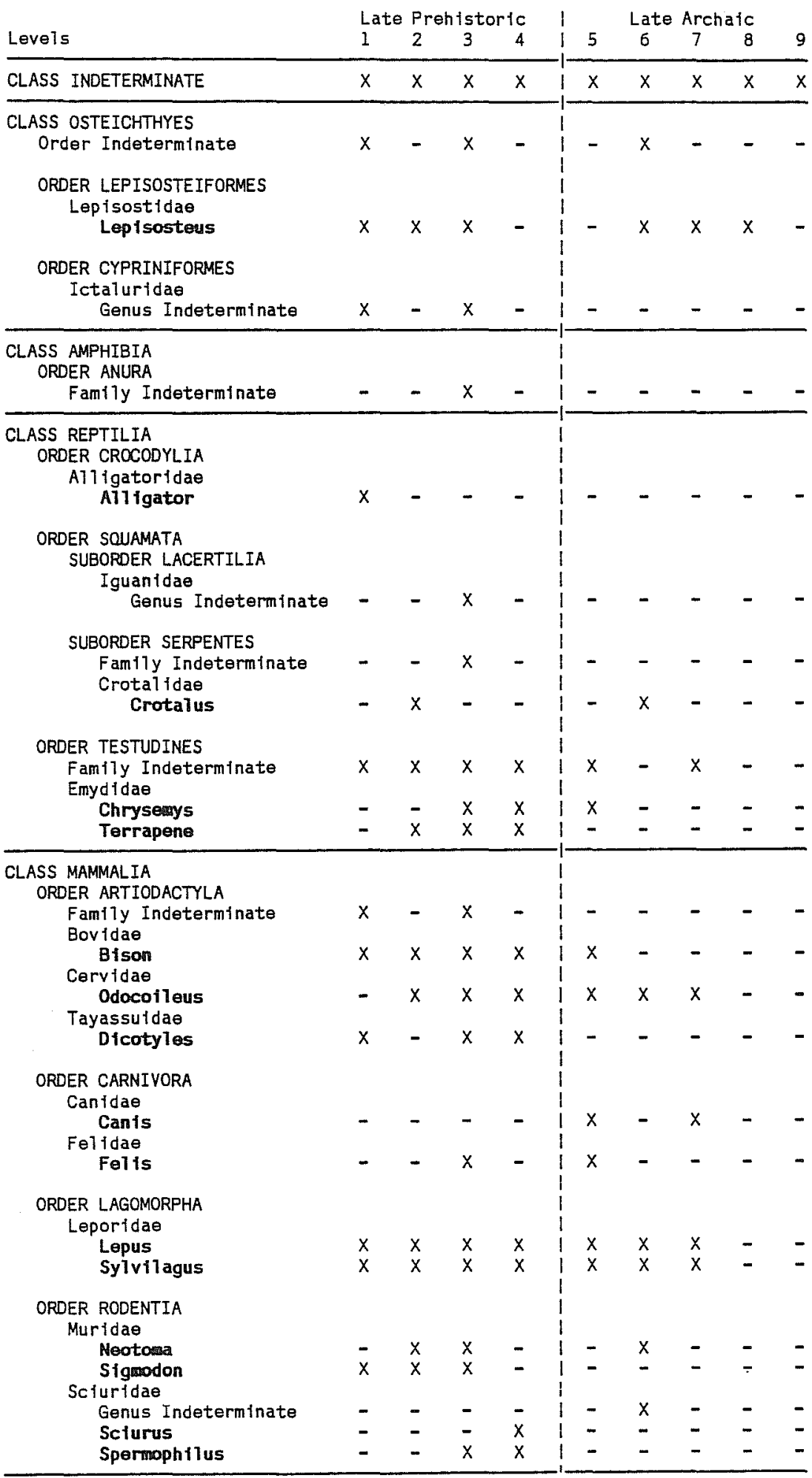

$X=$ presence of the taxon with in the assemblage from the level indicated. - = absence of the taxon withtn the assemblage from the level indicated.

Note: Common names for the taxa are provided in the Description of Taxa section of the text. 
TABLE 39. LIST OF THE VERTEBRATE TAXA RECOVERED FROM 41 MC 296

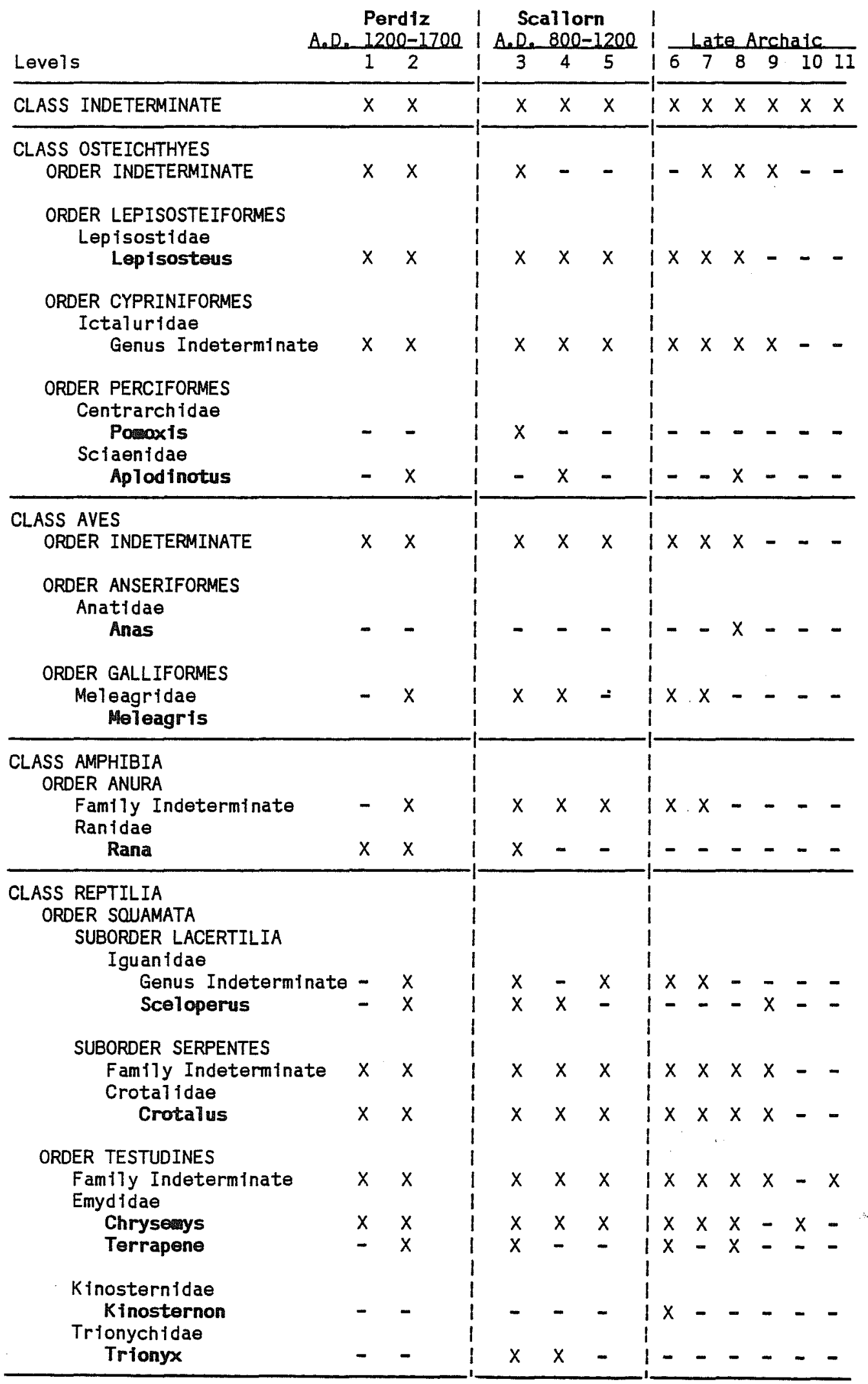


TABLE 39. (continued)

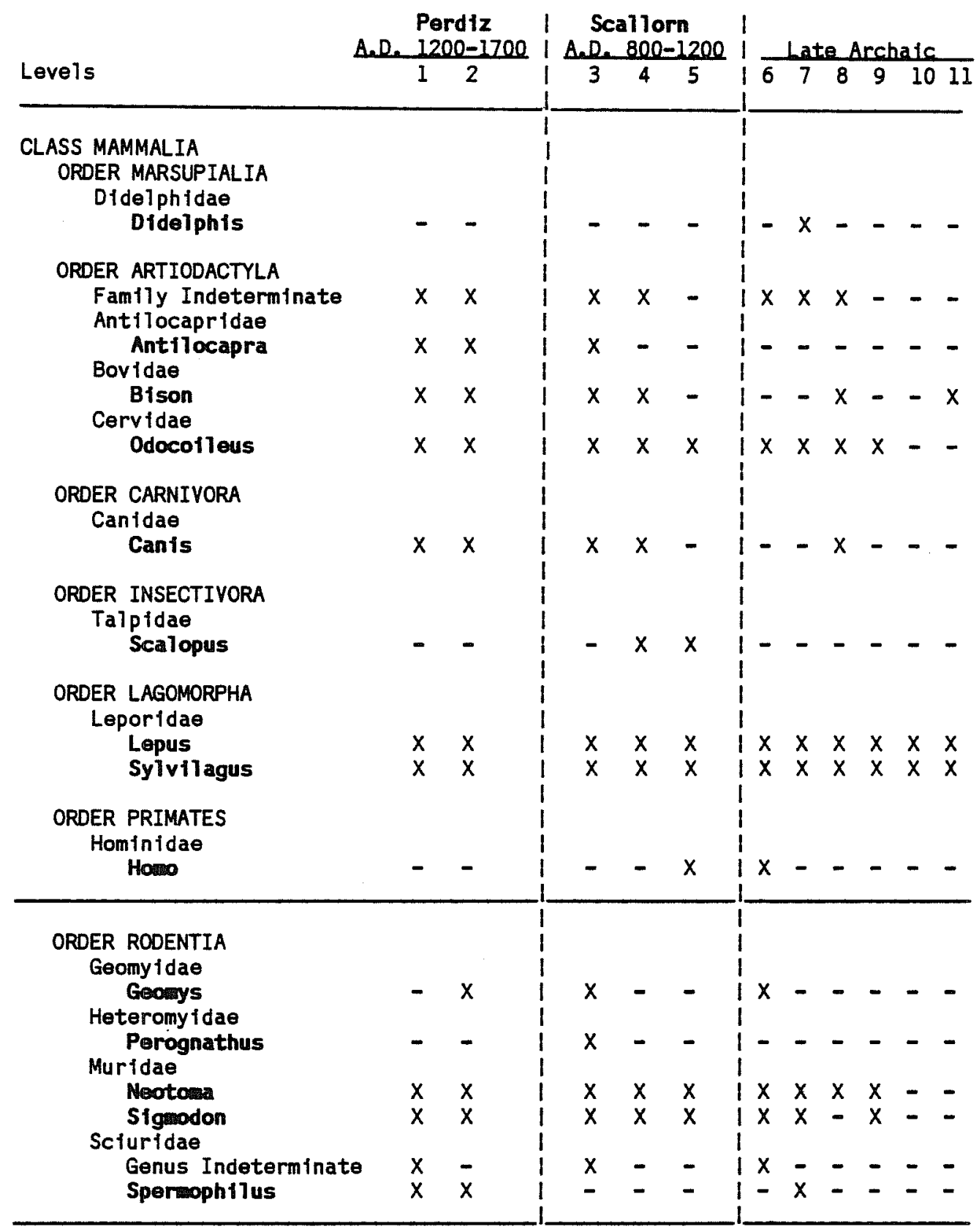

$X=$ presence of the taxon within the assemblage from the level indicated. - = absence of the taxon within the assemblage from the level indicated.

Note: Common names for the taxa are provided in the Description of Taxa section of the text. 
traditions in the area consists of sherds tempered with bone (Hester and Hill 1971; Hester 1980). Finally, recovery techniques could preferentially recover the larger bones, thus deleting small bones from the sample which was studied. Recognizing these factors, which structure the bone assemb 1 age, does not lessen the significance of the assemblage, but it does establish the parameters for interpretations based upon the assemblage.

Another factor which must be taken into account is the size of the assemblage itse 1f. Grayson (1984), who has most closely examined the relationship between sample size and the structure of the sample, has noted two particularly interesting phenomena. The first is that smaller bone assemblages will have fewer taxa because the rarer species are less likely to be represented. Second, in smaller assemblages each taxa will be represented by fewer bones. What creates this effect is that as the sample size increases there is a greater chance of recovering additional bones of the individuals represented.

Because of these characteristics of bone assemblages, 1 arger assemblages from human habitation sites may give the illusion that the inhabitants were sampling a more diverse fauna, or that they were bringing more complete carcasses of the game back to camp. This problem can be particularly troublesome when comparing samples of different ages at a site. The older assemb 1 ages are general1y fewer in number and smal1er in size, therefore. they commonly have fewer taxa. This may give the illusion that Paleo-Indians utilized fewer species than Archaic humans, and in some cases that Archaic hunters harvested fewer taxa than Late Prehistoric hunters. Sample size is usually not a problem at dry cave sites where good preservation and uniformly 1 arge samples have indicated a diverse diet for central and south Texas hunters and gatherers over a very long period of time (Hester 1978; Lord 1984). However, sample size must be taken into account when examining the fauna from open air stratified sites such as 41 LK 201 and 41 MC 296.

Given the history and development of the bone assemblages then, the following interpretations are presented with caution.

\section{DIETARY PATTERNS}

One is immediately struck by the diversity of the faunal assemblages recovered from 41 MC 222 and 41 MC 296. Twenty-three taxa including 16 genera of vertebrates were recovered from 41 MC 222, and 35 taxa including 26 genera were recovered from 41 MC 296. From both sites fish, amphibians, reptiles, birds, and mammals have been recovered. In these respects, the assemb lages compare quite favorably with the faunal assemblages recovered from 41 LK 201 (4l taxa including 32 genera). The differences in the number of taxa between the sites is probably a reflection of the size of the samples, since the ranking of the sites by number of taxa is the same as the ranking of the sites by the number of bones recovered from each site. On the basis of the diversity of the fauna from these three sites, it appears that the human inhabitants of the Choke Canyon basin were quite opportunistic hunters, catching and consuming all major classes of vertebrates. 
This diversity of faunal remains recovered from habitation sites in south Texas has been noted by Hester (1975b, 1980), Hester and Hi 11 (1972, 1975), and Steele (1986). While it is known that factors can add bones to the assemblage at a site, the authors feel confident that virtual 1 y al 1 taxa found at 41 MC 222 and 41 MC 296 probably represented food refuse, and probably that of humans. A11 taxa were represented by incomplete skeletons and fragmented bone exhibiting spiral fractures, conditions indicative of food refuse. The assumption that the refuse probably represented the refuse of humans is that they are the one identified occupant of the site.

When we compare the classes, mammalian remains represent the largest portion of the assemblage; more bones of mammals were present, and more taxa of mammals were identified. Certainly, some of this disparity is a reflection of differential preservation, recovery, and identification. The smaller vertebrates, mostly small amphibians, reptiles, and fish, have smaller and more friable bones so they rarely preserve as we 11 as the denser and 1 arger bones of the mammals. Similarly, the bones of these smaller vertebrates commoniy slip through the 1/4-inch mesh screen used to recover most of the faunal remains. Even though a portion of the matrix was fine screened and analyzed at 41 MC 222 and 41 MC 296, a technique recommended by Hester (1980) and DeMarcay and Steele (1986) for south Texas sites, it was impractical to fine screen al1 matrix. Consequentiy, the smaller assemblage recovered by fine screening had fewer taxa represented.

Mammalian remains are also more easily identified. Variances between taxa in mammalian teeth and articular ends of long bones make taxa within this class easier to identify. In spite of these caveats, the disparity in numbers of recovered remains between the classes leads the authors to the tentative conclusion that consistently more mammals were harvested than members of the other classes. There is probably a good reason for this greater reliance on mamma 15 by humans. For humans, mamma $7 \mathrm{~s}$ are probably easier to hunt than some of the classes, such as birds. Mammalian habitats are more accessible to humans than the habitats of other classes, such as fishes. Mammals are also more likely to be active during all seasons than some classes, such as amphibians and reptiles.

There is an additional consideration supporting the view that mammals are of greater sustenance value. Simply because more species of mammals are 1 arger than species of the other classes, they would have provided a larger portion of the usable meat consumed by the humans. This is particularly important when we consider the artiodacty 15 , the remains of which are found in a 11 three sites and from virtual1y a 111 ayers. The on $7 y$ species of the other classes of vertebrates which is of comparable size is the alligator, and only a single dermal scute has been recovered from 41 MC 222. Given these 1 ines of evidence, the conclusion that mammals were of greater value as a food resource than the other classes is supportable.

The foregoing conclusion does not diminish the significance of species of the other classes at particular times of the year or during particularly critical times. The amphibians, reptiles, and fishes must surely have taken on increasing significance to the humans during the spring and summer when these species became more available and more easily hunted. Amphibians and reptiles, such as turtles, become more active in the spring and can be more 
easily collected then along the banks of streams and ponds. Fish, particularly spring spawning freshwater drum and crappie, al so become more easily harvested in the spring, and these two species were recovered from 41 MC 296, while the freshwater drum was recovered from 41 LK 201. It should be noted also that other species of fish appear to have been taken at a 11 three sites but these remains could not be identified to genera because they were too fragmentary or comparable remains were not in the reference collections.

Birds occur infrequently at 41 MC 296 and not at a 11 in the bone assemb 1 age from 41 MC 222. On the basis of this negative evidence, this class does not appear to have been particularly significant in the dietary regime of the human inhabitants. One should note, however, that 1 ike the amphibians birds will be underrepresented in most faunal assemblages simply because of the fragile nature of the skeletal elements.

When we examine the mammalian portion of the faunal assemblage it is clear that artiodacty 15 , rodents, and lagomorphs were the most consistently utilized mammals during the entire period of occupation of both sites. Within the sample of artiodactyl remains, deer represents the most frequent genus, with bison occurring far less frequently in both sites. Pronghorn remains were recovered on 1 y from $41 \mathrm{MC} 296$, and coll ared peccary remains were recovered only from 41 MC 222. Bones of leporids were represented in both sites and at all levels. At both sites a large variety of leporid, either the jackrabbit or swamp rabbit, and a smaller variety, either the desert cottontall rabbit or eastern cottontail rabbit, were present in the bone assemb 1 age. The most commonly recovered rodent remains were those of the pack rat and the cotton rat. The relative high frequency of pack rats and cotton rats in south Texas sites has also been noted by Hester and Hill (1972), Hester (1975b), and Steele (1986).

Utilizing counts of identified elements (NISP) of the artiodactyls, rodents, and 1 agomorphs, we get a reasonab 1 y accurate assessment of their relative numbers to one another, if not the actual numbers of animals taken or consumed. Tables 40-42 1 ist the number of identified elements for the artiodacty 1s, rodents, and lagomorphs; and Figures 97-99 i11ustrate the relative frequencies of the three orders at 41 MC 222, 41 MC 296, and 41 LK 201. At 41 MC 222, artiodactyls and 1agomorphs are the most frequently recovered taxa, but there appears to be no other consistent trend recognizab 1e. At $41 \mathrm{MC} 296$, however, rodents and 1 agomorphs are the most frequent1y recovered taxa. There also appears to be a long-term trend recognizable; as the remains of artiodactyls decrease in frequency through time at the site, the number of rodent and 1 agomorph bones increases through Level 6, and then decreases. This inverse relationship between the frequency of the artiodactyls versus the rodents and lagomorphs was noted in the examination of faunal remains from 41 LK 201 by Steele (1986), who suggested that it reflected a human dietary shift between Late Prehistoric and Late Archaic times.

To test this hypothesis al1 Late Prehistoric faunal elements (Levels 1-4) were pooled and compared to al1 Late Archaic elements of each taxon (Levels 5-11). Table 43 presents the 2-way tab les for the chi-square test for sites 41 MC 296 and 4I LK 201, while Figures 100 and 101 11 lustrate the 
TABLE 40. LISTING OF THE NUMBER OF IDENTIFIED ELEMENTS (NISP) RECOVERED FROM EACH 10-CM LEVEL OF 41 MC 222 FOR THE ARTIODACTYLS, LAGOMORPHS, AND RODENTS

\begin{tabular}{lrrrl} 
Levels & 1 & 2 & 3 & 4 \\
\hline M Excavated & 13.0 & 11.0 & 5.4 & 2.4 \\
Artiodactyla & 34 & 15 & 25 & 1 \\
$\quad$ Indeterminate & - & 1 & - & 1 \\
$\quad$ Bison & 27 & 5 & - & - \\
$\quad$ Antilocapra & - & - & 24 & 1 \\
Odocoileus & 4 & 5 & - & - \\
Dicotyles & 3 & 4 & 2 & 2 \\
Rodentia & 11 & 11 & 2 & 2 \\
$\quad$ Indeterminate & - & 9 & - & - \\
$\quad$ Neotoma & 4 & 1 & - & - \\
$\quad$ Sigmodon & 7 & 1 & 51 & 4 \\
$\quad$ Lagomorpha & 45 & 60 & 24 & 2 \\
$\quad$ Lepus & 24 & 30 & 27 & 2 \\
Sylvilagus & 21 & 30 & &
\end{tabular}

Note: The number of elements 1 isted for the artiodactyls, rodents, and 1 agomorphs includes al 1 elements identified for al 1 of the taxa in that order. In addition to the 1 isting for these three orders, the table includes the number of identified elements for the most commonly recovered genera within each of these orders. The original squares for 41 MC 222 were excavated in $5-\mathrm{cm}$ levels, we have converted the data to $10-\mathrm{cm}$ levels so the data will be comparable with the unitlevels from 41 MC 296 and 41 LK 201. Consequently, Level 1 of this chart includes the combined bone assemb 7 age from the $5-\mathrm{cm}$ Levels 1 and 2 in the original excavation, and so forth. 
TABLE 41. LISTING OF THE NUMBER OF IDENTIF IED ELEMENTS (NISP) RECOVERED FROM EACH 10-CM LEVEL OF 41 MC 296 FOR THE ARTIODACTYLS, LAGOMORPHS, AND RODENTS

\begin{tabular}{lrrrrrrrrrrr} 
Levels & 1 & 2 & 3 & 4 & 5 & 6 & 7 & 8 & 9 & 10 & 11 \\
\hline M Excavated & 10.0 & 9.6 & 9.6 & 9.6 & 8.0 & 8.0 & 6.8 & 4.0 & 4.0 & 1.6 & 0.8 \\
Artiodactyla & 35 & 29 & 29 & 14 & 6 & 16 & 5 & 4 & 2 & - & 1 \\
$\quad$ Indeterminate & 22 & 10 & 17 & 3 & 1 & 3 & 1 & 1 & - & - & - \\
$\quad$ Bison & 2 & 2 & 3 & 2 & - & - & - & 1 & - & - & 1 \\
$\quad$ Antilocapra & 1 & 1 & 1 & - & - & - & - & - & - & - & - \\
$\quad$ Odocoileus & 10 & 16 & 8 & 9 & 4 & 13 & 4 & 2 & 2 & - & - \\
Dicotyles & - & - & - & - & 1 & - & - & - & - & - & - \\
Rodentia & 30 & 45 & 44 & 32 & 41 & 62 & 37 & 16 & 7 & - & - \\
$\quad$ Indeterminate & 10 & 7 & 14 & 15 & 14 & 3 & 11 & 12 & - & - & - \\
$\quad$ Neotona & 19 & 26 & 27 & 12 & 12 & 43 & 7 & 4 & 4 & - & - \\
$\quad$ Sigmodon & 1 & 12 & 3 & 5 & 15 & 16 & 19 & - & 3 & - & - \\
Lagomorpha & 47 & 71 & 95 & 72 & 100 & 58 & 42 & 20 & 10 & 2 & 3 \\
$\quad$ Lepus & 17 & 31 & 46 & 38 & 42 & 32 & 16 & 7 & 6 & 1 & 1 \\
$\quad$ Sylvilagus & 30 & 40 & 49 & 34 & 58 & 26 & 26 & 13 & 4 & 1 & 2
\end{tabular}

Note: The number of elements 1 isted for the artiodacty 1 s, rodents, and 1 agomorphs includes al 1 elements identified for al1 of the taxa for that order. In addition to the 1 isting for these three orders, the table includes the number of identified elements for the most commonly recovered genera within each of these orders. 
TABLE 42. LISTING OF THE NUMBER OF IDENTIFIED ELEMENTS (NISP) RECOVERED FROM EACH 10-CM LEVEL OF 41 LK 201 FOR THE ARTIODACTYLS, LAGOMORPHS, AND RODENTS

\begin{tabular}{|c|c|c|c|c|c|c|c|c|c|c|c|c|c|}
\hline Levels & 1 & 2 & 3 & 4 & 5 & 6 & 7 & 8 & 9 & 10 & 11 & 12 & 13 \\
\hline$M^{3}$ Excavated & 26.4 & 23.2 & 12.0 & 8.0 & 8.0 & 8.0 & 8.0 & 8.0 & 6.4 & 6.4 & 6.4 & 6.4 & 6.4 \\
\hline Artiodactyla & 64 & 89 & 36 & 5 & 3 & 1 & 5 & 9 & 4 & 2 & - & - & - \\
\hline Indeterminate & 12 & 4 & 22 & - & 1 & - & 2 & - & - & 2 & - & - & - \\
\hline Bison & 12 & 2 & 1 & - & - & - & - & - & - & - & - & - & - \\
\hline Ant 1locapra & 4 & $\overline{9}$ & - & - & - & - & - & - & - & - & - & - & - \\
\hline Odocolleus & 35 & 73 & 13 & 4 & 2 & 1 & 3 & 9 & 4 & - & - & - & - \\
\hline Dicotyles & 1 & 1 & - & 1 & - & - & - & - & - & $\infty$ & - & - & - \\
\hline Rodentfa & 36 & 27 & 7 & 5 & 2 & - & - & 1 & - & 1 & 4 & 2 & 3 \\
\hline Indeterminate & - & - & 3 & - & - & - & - & 1 & - & - & 3 & 1 & 3 \\
\hline Neotoma & 29 & 27 & 4 & 4 & - & - & - & - & - & 1 & 1 & 1 & - \\
\hline Sigmodon & 7 & - & - & - & - & - & - & - & - & - & - & - & - \\
\hline Lagomorpha & 37 & 46 & 10 & 8 & 3 & 5 & 3 & 1 & 1 & 14 & 12 & 8 & 8 \\
\hline Lepus & 5 & 3 & 4 & 5 & 1 & 3 & - & - & - & 6 & 6 & - & 3 \\
\hline Sylvilagus & 32 & 43 & 6 & 3 & 2 & 2 & 3 & 1 & 1 & 3 & 6 & 8 & 5 \\
\hline
\end{tabular}

\begin{tabular}{|c|c|c|c|c|c|c|c|c|c|c|c|c|}
\hline Levels (continued) & 14 & 15 & 16 & 17 & 18 & 19 & 20 & 21 & 22 & 23 & 24 & 25 \\
\hline$M^{3}$ Excavated & 6.4 & 6.4 & 6.4 & 6.4 & 6.4 & 2.8 & 1.6 & 1.2 & 1.2 & 1.2 & 1.2 & 1.2 \\
\hline Artfodactyla & - & 4 & 3 & - & - & - & - & - & - & - & - & - \\
\hline Indeterminate & - & - & 1 & - & - & - & - & - & - & - & - & - \\
\hline Bison & - & - & 1 & - & - & - & - & - & - & - & - & - \\
\hline Antllocapra & - & - & - & - & - & - & - & - & - & - & - & - \\
\hline Odocolleus & - & 4 & 1 & - & - & - & - & - & - & - & - & - \\
\hline Dicotyles & - & - & - & - & - & - & - & - & - & - & - & - \\
\hline Rodentia & - & - & - & - & - & - & - & - & - & - & - & - \\
\hline Neotoma & - & - & - & - & - & - & - & - & - & - & - & - \\
\hline Sigmodon & - & - & - & - & - & - & - & - & - & - & - & - \\
\hline Lagomorpha & 2 & - & 1 & - & 4 & - & - & - & - & - & - & - \\
\hline Lepus & 1 & - & 1 & - & - & - & - & - & - & - & - & - \\
\hline Sylvilagus & 1 & - & - & - & 4 & - & - & - & - & - & - & - \\
\hline
\end{tabular}

Note: The number of elements 1 isted for the artlodactyls, rodents, and lagomorphs includes all elements identified for all of the taxa for that order. In addition to the 1 isting for these orders, the tab $1 e$ includes the number of identified elements for the most commoniy recovered genera within each of these orders. Data is from Steele (1986). 
BONE DENSITY BY LEVEL
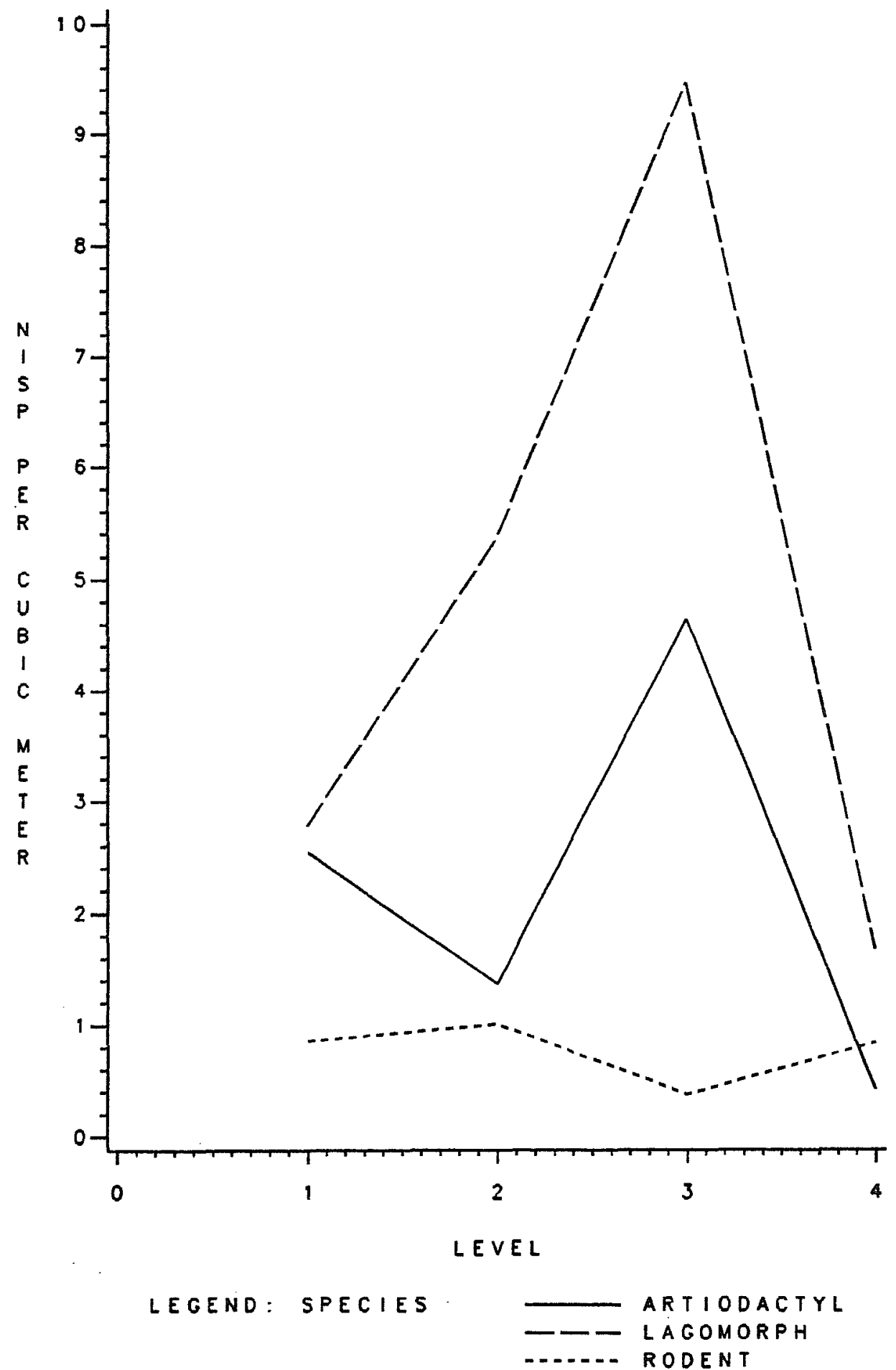

Figure 97. Distribution of the Number of Identified Elements per Cubic Meter (NISP) for the Artiodacty 1s, Lagomorphs, and Rodents Recovered from 41. MC 222. The number of identified elements and cubic meters excavated for each level are presented in Table 40 . Levels are $10 \mathrm{~cm}$ in depth. 
41 MC 296

BONE DENSITY BY LEVEL

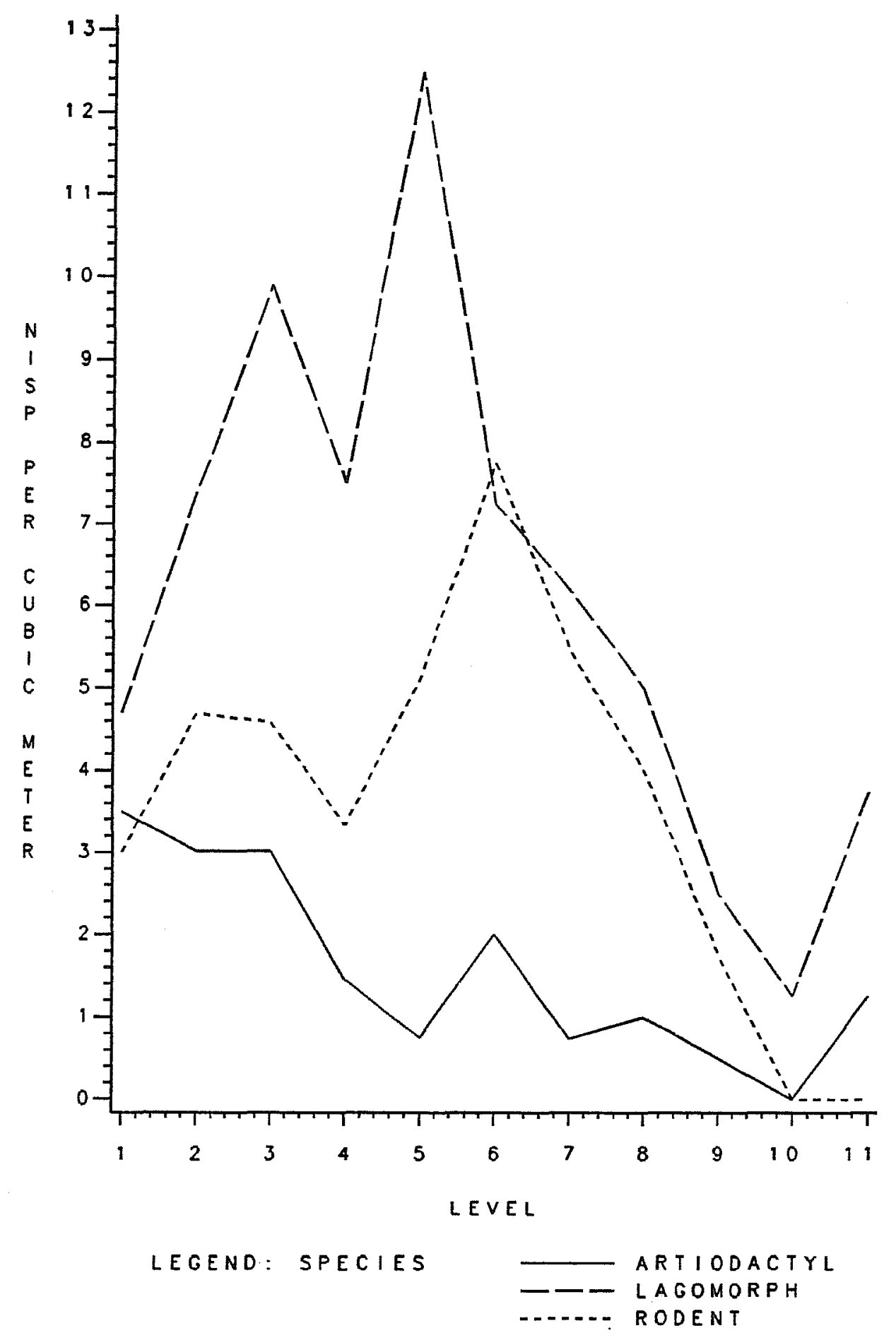

Figure 98. Distribution of the Number of Identified Elements per Cubic Meter (NISP) for the Artiodacty 1s, Lagomorphs, and Rodents Recovered from 41 MC 296. The number of identified elements and cubic meters excavated for each level are presented in Table 41. 
41 LK 201

BONE DENSITY BY LEVEL

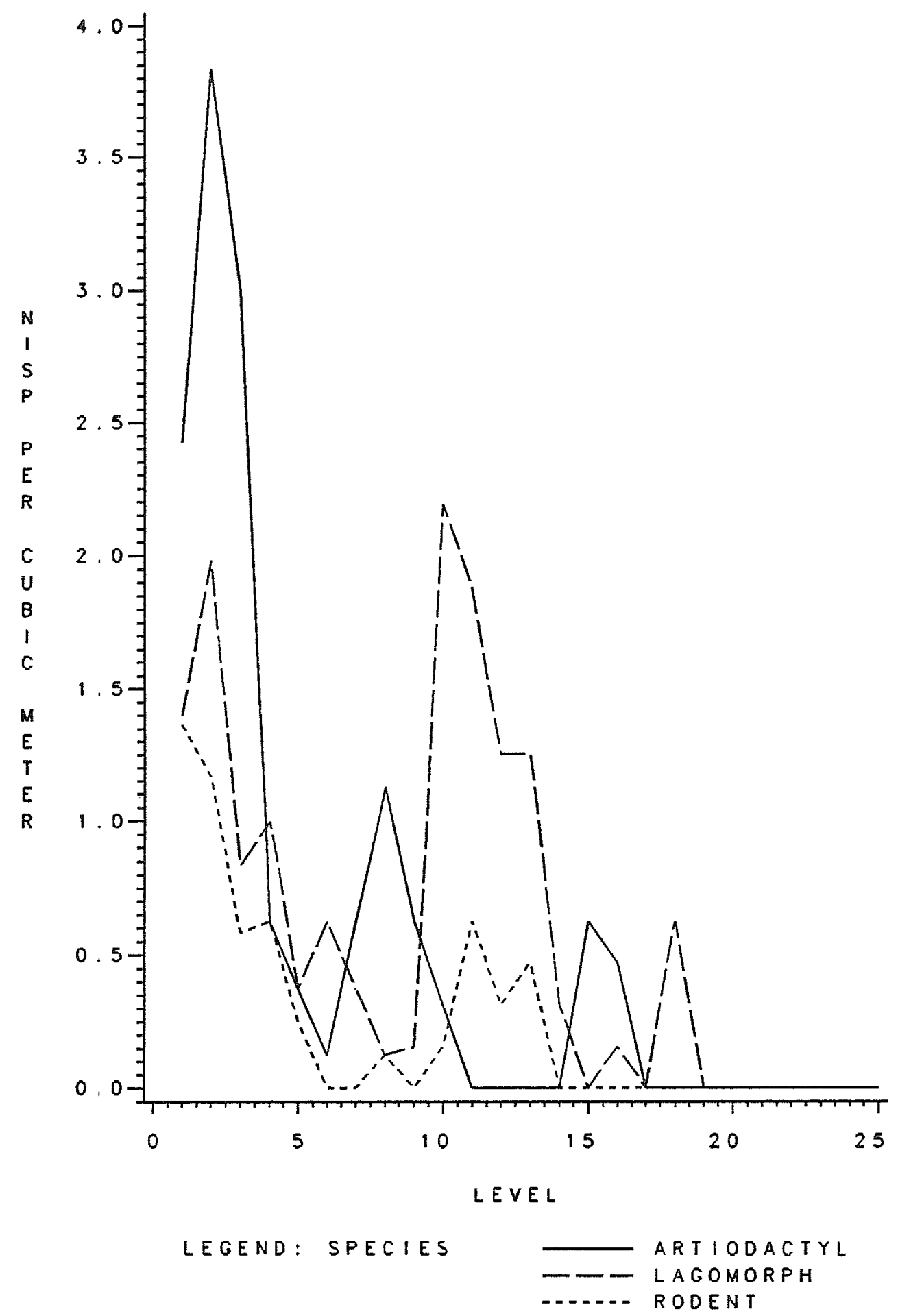

Figure 99. Distribution of the Number of Identified Elements per Cubic Meter (NISP) for the Artiodacty 1s, Lagomorphs, and Rodents from 41 LK 201. The number of identified elements and cubic meters excavated for each level are presented in Table 42. 
TABLE 43. TWO-WAY TABLES OF BONE FREQUENCIES FOR THE ARTIODACTYLS, RODENTS, AND LAGOMORPHS RECOVERED FROM 41 MC 296 AND 41 LK 201

\section{SITE 41 MC 296}

Artiodactyls Rodents Lagomerphs

$\begin{array}{lcc}\text { Late Prehistoric } & & \\ \text { Bone frequency } & 113 & 192 \\ \text { Expected frequency } & 99.8 & 222.2 \\ \text { Row percent } & 16.38 & 27.83 \\ \text { Column percent } & 80.14 & 61.15 \\ & & \\ \text { Late Archaic } & 28 & 122 \\ \text { Bone frequency } & 41.2 & 91.8 \\ \text { Expected frequency } & 9.82 & 42.81 \\ \text { Row percent } & 19.86 & 38.85 \\ \text { Column percent } & & \\ & & \\ \text { Statistics for 2-way tables: } & & \\ \text { Chi-square }=22.730, \text { Degrees of Freedom }=2, \text { Probability }=0.0001\end{array}$

385

368.0

55.80

74.04

135

152.0

47.37

25.96

Statistics for 2-way tables:

Chi-square $=22.730$, Degrees of Freedom $=2$, Probability $=0.0001$

SITE 41 LK 201

Artiodactyls Rodents Lagomorphs

Late Prehistoric

Bone frequency

194

176.4

Expected frequency

52.43

86.22

75

101

Row percent

Column percent

31

48.6

30.39

13.78
69.0

20.27

35.23

13

19.0

12.75

14.77
124.6

27.30

63.52

Statistics for 2-way tables:

Chi-square $=31.325$, Degrees of Freedom $=2$, Probability -0.0001

Note: The table for each site 1 ists the observed frequency, the expected frequency, the row percent, and the column percent. The chi-square figure, degrees of freedom, and probability of significance is 1 isted at the bottom of each table. 


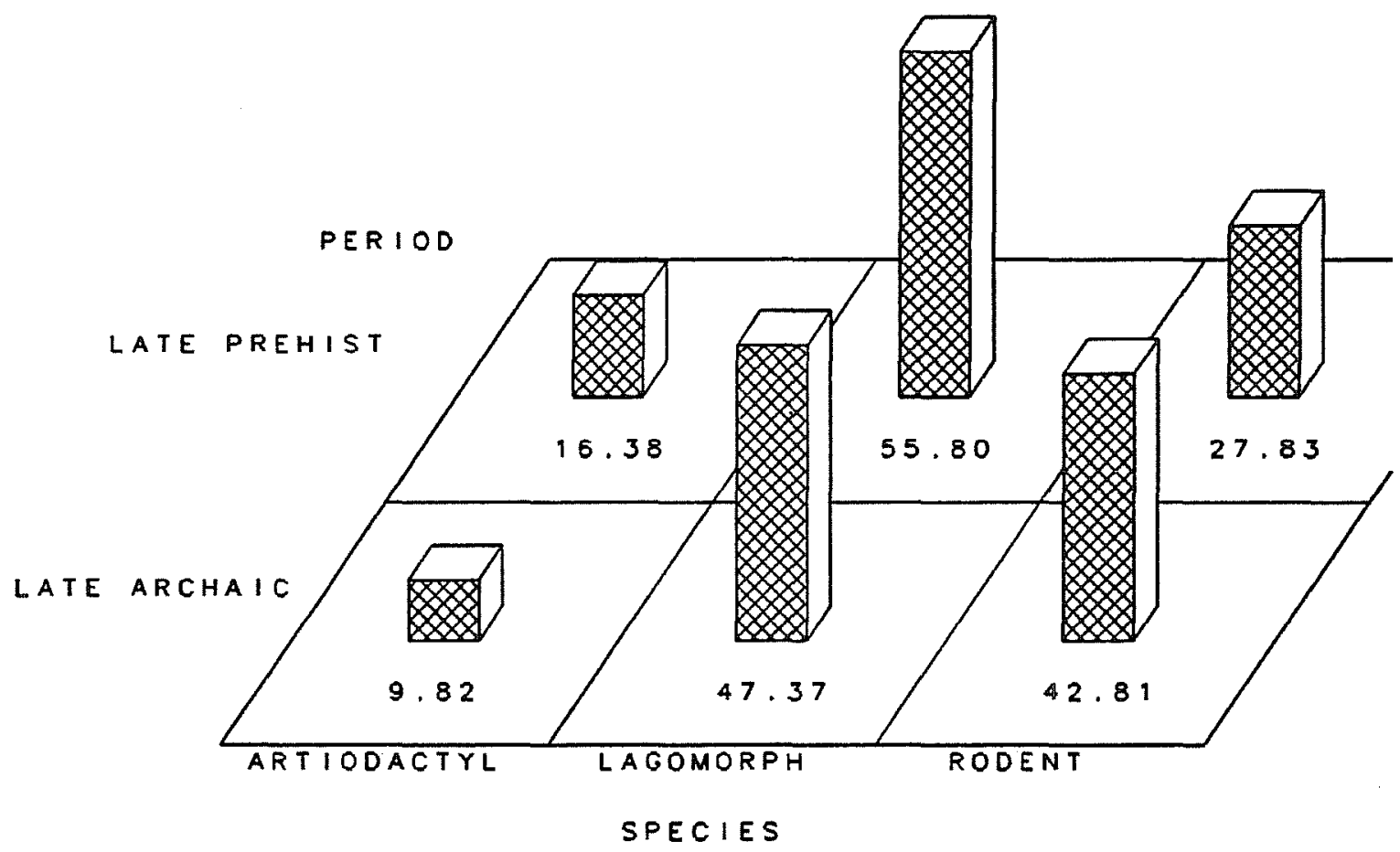

Figure 100. Block Chart Il 1 ustrating the Relative Percentages During the Late Prehistoric and Late Archaic of the Artiodacty 15 , Lagomorphs, and Rodents Recovered from 41 LK 296. 
41 LK 201

PERCENTAGE OF ELEMENTS BY PERIOD

PERCENTAGE BLOCK CHART

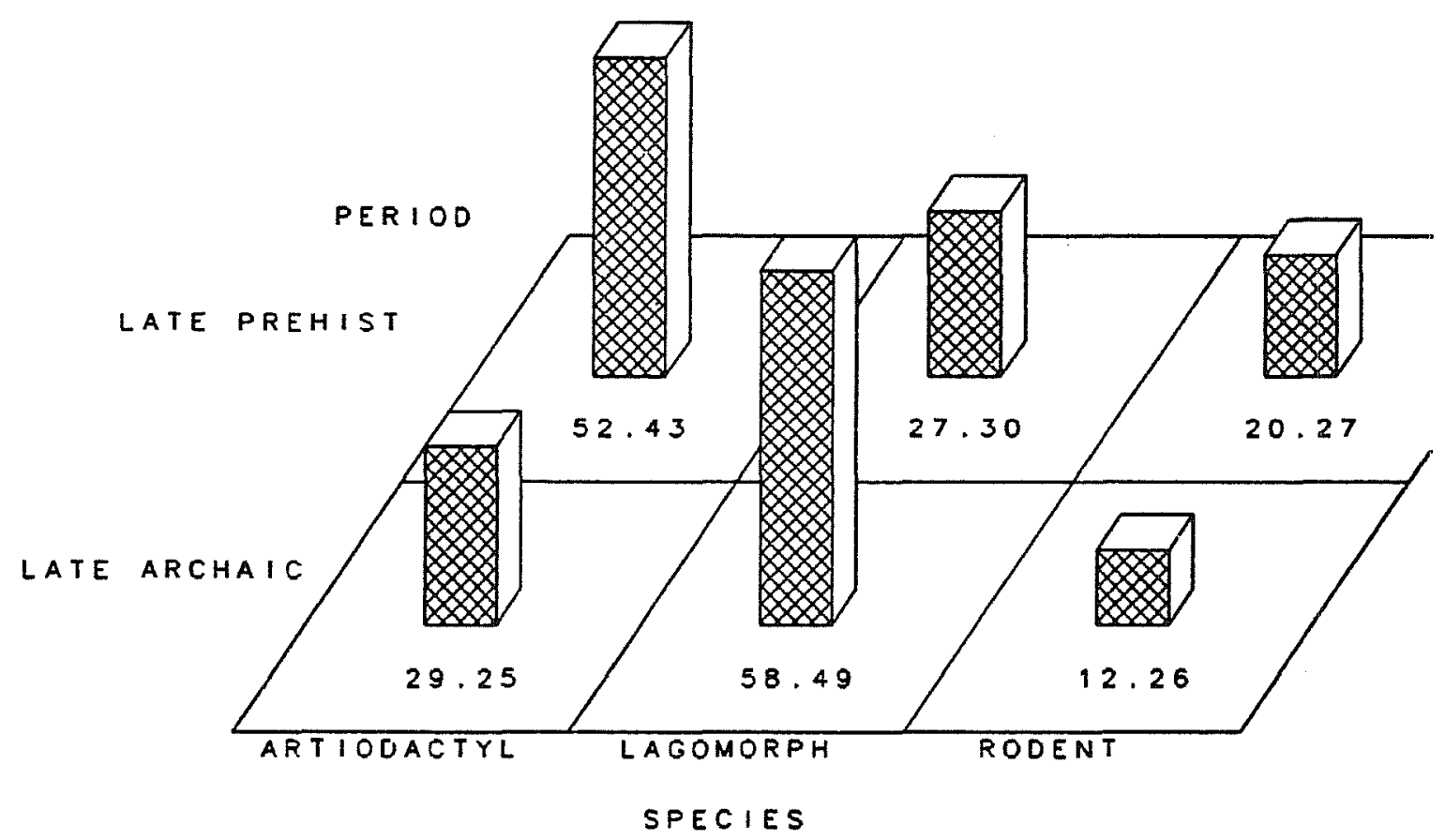

Figure 101. Block Chart I1 lustrating the Relative Percentages During the Late Prehistoric and Late Archaic of the Artiodactyls, Lagomorphs, and Rodents Recovered from 41 LK 201. 
relative frequencies of the artiodacty 15, rodents, and 1 agomorphs during the Late Prehistoric and Late Archaic times at 41 MC 296 and 41 LK 201. Examining 41 MC 296, first we see that artiodactyls account for $16.38 \%$ of the total of these three taxa during the Late Prehistoric, but on y $9.82 \%$ during the Late Archaic. This drop is also seen at 41 LK 201 where the artiodactyls account for $52.43 \%$ of the faunal remains during the Late Prehistoric, but on 1 y 29.25\% of this sample during the Late Archaic. For both of these sites, the differences in the frequencies of the three taxa (artiodactyls, rodents, and 1 agomorphs) between Late Prehistoric and Late Archaic times is high $1 \mathrm{y}$ significant $(0.0001$ probability). On the basis of this evidence then, we feel that a human dietary shift did indeed occur in the Choke Canyon basin between Late Archaic and Late Prehistoric times.

Now that such a dietary shift has been documented, a second related question can be raised. What prompted such a dietary shift? Is this a reflection of humans having increased artiodactyls, particularly bison, to hunt? Or, is it a reflection of increased efficiency of hunting, with the bow and arrow a constantly available resource? Certainly, one of the causes for the increased frequency of artiodacty 1 remains in the Late Prehistoric is the greater number of recovered bison elements during this time. Unfortunately, what prompted this increase in bison in particular, and artiodactyls in general, cannot be determined from the analysis of the faunal remains (see the discussion of bison in the description of taxa section).

A7so, when we compare the artiodacty1s, rodents, and 1 agomorphs during Late Prehistoric and Late Archaic times at the two sites there appears to have been spatial1y different foraging patterns for these taxa. At 41 MC 296 during the Late Archaic times, rodents and 1agomorphs were both harvested in approximately equal proportions, $42.81 \%$ and $47.37 \%$, respectively. During Late Prehistoric times, however, as artiodactyls became increasingly important lagomorphs also increased in frequency, but rodents dropped to approximately half their previous frequency. Different frequencies for these taxa are observable at 41 LK 201. Here, during the Late Archaic, artiodacty $1 \mathrm{~s}$ account for $29.25 \%$ of these three taxa, but by Late Prehistoric times artiodactyls represented $52.43 \%$ of the sample. For the small mammals a different pattern emerges. During the Late Archaic, the 1 agomorphs accounted for $58.49 \%$ of the samp 1e, and rodents accounted for $12.26 \%$. During Late Prehistoric times at 41 LK 201, 1 agomorphs decreased in frequency and rodents Increased in frequency, the opposite of the pattern seen at 41 MC 296.

When we examine the NISP counts for the genera of rodents and lagomorphs we see that both SyIvilagus and Lepus increase in frequency during the Late Prehistoric at 41 MC 296, and both Neotoma and Sigmodon decrease in frequency (see Tab1e 41). At 41 LK 201 both genera of lagomorphs decrease in frequency, but it is on $7 y$ Neotoma among the rodents which increases dramatical1y, particularly in Levels 1 and 2 (Table 42). Interpretations of adaptive strategies based on these bone counts can only be tentative, but it appears that at 41 MC 296 a variety of habitats were equally utilized during the Late Archaic times for hunting the smal1 mamma1s, and while smal1 mammals decreased in importance during the Late Prehistoric times, no change in hunting patterns can be discerned. At 41 LK 201 though, it appears that the greater numbers of Neotoma taken during Late Prehistoric times may indicate a 
greater utilization of the more arid shrub and grasslands at this time compared to the Late Archaic.

The above discussion has concentrated on identifying which species were most commonly hunted, and this provides one 1 ine of evidence as to which species were most important in the human diet. It is also possible to ask which species provided the most meat irrespective of how many animals were consumed, and which species provided the most consistently avallable meat. If we consider meat weight alone, then the artiodacty $1 \mathrm{~s}$ in general and the deer in particular appear to have provided the most meat consumed at the site. Deer, however, may not have provided the most consistently available meat resource. Campbe11 and Campbe11 (1981:17-18) stated that the Mariame Indians of south Texas acquired deer only occasionally. If this were true for the inhabitants of 41 MC 222 and 41 MC 296 as wel1, then a more consistently available meat resource such as the 1 agomorphs and rodents, even if they represented smaller portions, would have been more important from a dietary viewpoint. A variety of authors have suggested this, including Hester (1975b, 1980), Hester and Hil 1 (1975), Steele (1986), and Steele and Mokry (n.d.).

\section{SEASONAL UTILIZATION OF SITES}

Because of the we 11-known nomadic nature of hunters and gatherers one wonders if any of the examined sites within Choke Canyon basin were occupied on $7 y$ during specific seasons, or if the sites served as bases during more than one season. For 41 LK 201, there was substantial evidence for the site being occupied during the spring and early summer, and some slight evidence (a moderately worn deciduous premolar of a deer and an antler fragment which may have been in velvet at the time of the deer's death) indicated that the site was occupied during the late summer or fall as well. For 41 MC 222 and 41 MC 296, there is also abundant evidence for spring and/or summer occupation. The amphibians and reptiles are most active in the spring and summer and would in all probability have been collected then. Similarly, the crappie and freshwater drum (Leve1s 2, 4, and 8) suggest a 1 ate winter or early spring occupation of the site. A fall and/or winter occupation of 41 MC 296 (Leve1 9) is indicated by the presence of a left u 1 na of a duck (cf. pintai1). Ducks, including the pintail, are migratory birds arriving in south Texas during the fall and leaving the area for their breeding grounds in the spring. During their time of Texas residency, they can be found along the streams and in the ponds throughout the area.

In summary then, it appears that the three sites examined al1 document spring and/or summer occupation. Additionally, sites 41 LK 201 and 41 MC 296 document occupation 1 azer in the year as we11. While these bits of information indicate that these sites were at least occupied at these times, there are many questions left unanswered or at least inadequately answered. For instance, were 41 LK 201 and 41 MC 296 occupied throughout the year, or were they occupied intermittently at different times of the year? While the evidence is decidedly weak, the minimal remains of fal1 waterfow 1 and the virtual lack of evidence of deer killed while in antler suggest that the occupation of these sites in the latter part of the year was less common or less intense. 


\section{ENYIRONEENTAL RECONSTRUCTION}

Reconstruction of environments around sites in Choke Canyon basin involve two different but related questions. The first concerns what kinds of habitats were available for the people to exploit. The second concerns what the general environmental conditions around the site were 1 ike.

Table 44,a lists animals which have reasonably specific habitat preferences and the types of habitats which they prefer. A review of the table illustrates that humans from both sites were hunting animals in a 11 three habitats (grassland, riparian forest, and aquatic), just as the humans did who occupied 41 LK 201 (Steele 1986). In this respect, it is apparent that al1 three sites served as satisfactory bases from which the inhabitants could forage a mosaic of habitats.

Reconstructing the general environment of the site is a more complex issue. Today, fauna characteristic of the southern, western plains, and eastern parts of the northern hemisphere reside in Texas south of the Balcones Escarpment and east of the Nueces River. Recognizing the uniqueness of this biological diversity, Blair $(1950,1952)$ identified the region as the Tamaulipan Biotic Province. More recently, Steele (1986) addressed the question of the antiquity of the faunal diversity within the region. The presence of the southern fauna could be documented in Late Prehistoric times with Baiomys, Liomys, and Dicotyles, and in Late Archaic times with Liomys and Dicotyles. The eastern fauna was represented in the region during Late Prehistoric times by Sylvilagus audubonii and Ondatra, and during Late Archaic times by $S_{\text {. auduboni }}$ a and Microtus. The plains fauna was represented in Late Prehistoric times by Taxidea, Antilocapra, and Bison, and in the Late Archaic by Bison alone. On the basis of this evidence, Steele concluded that the Tamaulipan Biotic Province (at least the faunal component) could be traced back to Late Archaic times, but that indeed the fauna was even more diverse than it is today. This antiquity suggests that impact upon the region by European culture was not the major force creating the Tamaulipan Biotic Province. The greater diversity of the faunal assemb 1 age, Steele felt, indicated that milder summers and winters may have existed during these times than exist today.

Table 44,b summarizes the information for interpreting past environmental conditions at 41 MC 222 and 41 MC 296. As at 41 LK 201 fauna from all three regions are present, thus the Tamaulipan Biotic Province can be traced back into Late Prehistoric times at these sites. This supports the antiquity of the fauna to this point in time as had been.proposed on the basis of the fauna from 41 LK 201. Unfortunately, the biotic province cannot be traced into Late Archaic times. The assemblage from 41 MC 222 contains only Late Prehistoric remains, and the Late Archaic assemblage from 41 MC 296 is too meager to determine the nature of the biotic province of the 1ocality.

\section{DESCRIPTION OF TAXA}

Presented below is the description by taxon of the faunal remains recovered from 41 MC 222 and 41 MC 296. Fol lowing the documentation of the provenience and nature of the faunal remains recovered from each site are the notes about 
TABLE 44. HABITATS AND FAUNAL AFFINITIES FROM 41 MC 222 AND 41 MC 296

a. HABITATS

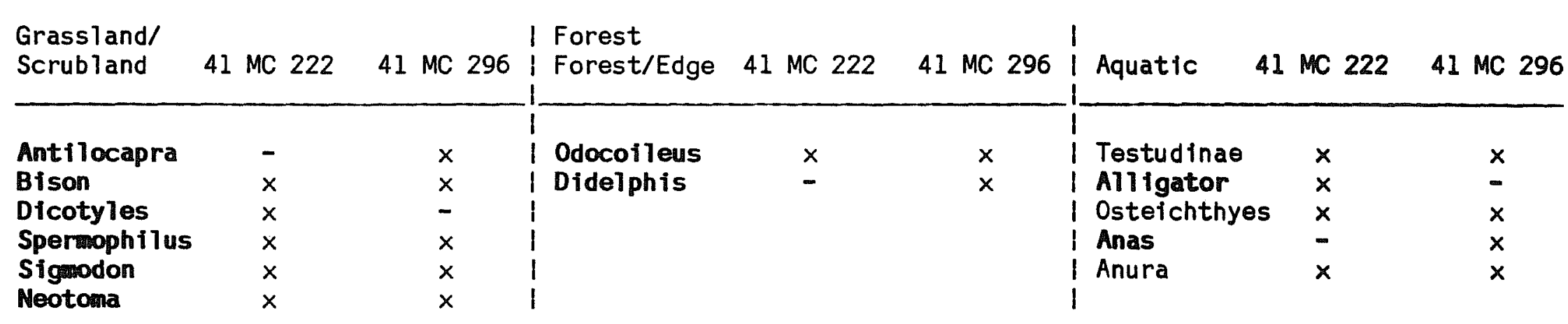

b. FAUNA AFFINITIES

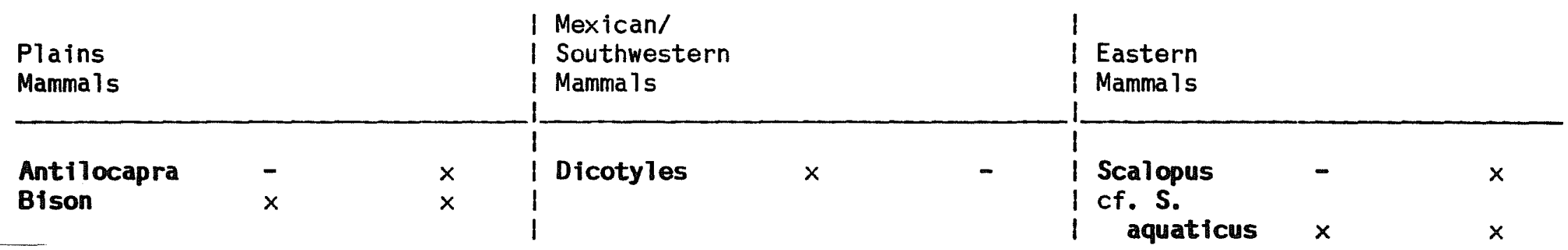

$x=$ presence of the species for each site.

- = absence of the species for each site.

Note: Habitats: The three major kinds of habitats interpreted as present surrounding the site are 1isted. Below the habitat is a listing of the species associated with that habitat.

Fauna Affinities: Listing of taxa recovered from 41 MC 222 and 41 MC 296 which are assoctated with a specific biotic community are listed below the name of the community. 
the species which are pertinent for interpreting human behavior or environmental reconstruction. Classification of the fishes follows Blair et a 1. (1968). Classification of the amphibians and reptiles follows Conant (1975). Classification of the birds follows Robbins, Brunn, and Zim (1966). Classification of the mamma 15 follows Davis (1974), Hall (1981), Schmidly (1977, 1983), and Steele (1986). Where these authors differ we have followed Steele (1986). Tables 47 and 48, proveniences by 1 ot number, are presented following the description of taxa.

\section{PHYLUM CHORDATA}

SUBPHYLUM VERTEBRATA class indeterminate (vertebrates)

Referred Material: From al1 levels and squares of both 41 MC 222 and 41 MC 296. Material consists of the fragments of unidentifiable bone.

Remarks: Material in this category includes bone from a wide variety of species, but the bulk of the material consists of fragmented long bone material from large mammals. Like the unidentified material from 41 LK 201, much of this material was broken while fresh, burned and scarred by humans during processing and consumption, and by nonhumans as the bone was gnawed upon. This large bone accumulation is typical of localities which have served as human habitation sites.

\section{CLASS OSTEICHTHYES}

ORDER indeterminate (bony fishes)

Referred Material from 41 MC 222: N101 E91, Lot 170; N102 E90, Lot 190; N103 E9l, Lot 247. Material consists of vertebrae from Levels 1,3 , and 6 .

Referred Material from 41 MC 296: Test Pit 1, Lots 2,4; N1022 E987, Lots 61, 62, 63, 64, 65, 67, 69; N1023 E985, Lot 78; N1023 E986, Lot 87; N1023 E989, Lot 238; N1024 E986, Lot 107; N1026 E997, Lot 154; N1027 E986, Lot 214. Material consists of vertebrae and one dorsal spine from Levels $1,2,3,7,8$, and 9.

Remarks: The fish remains, mostly specimens of vertebral centra, can be classified as fish, but more specific classifications cannot be mada. It is apparent, however, that a variety of sizes of fish were harvested, including some specimens too small to have been taken by spear or hook. 


\section{ORDER LEPISOSTEIFORMES}

FAMILY LEPISOSTIDAE

Lepisosteus

SPECIES indeterminate (gar)

Referred Material from 41 MC 222: $N 99$ E91, Lots 136, 137; N102 E88, Lots 179, 180; N102 E90, Lot 190; N102 El00, Lot 197; N103 E88, Lot 217; N103 E89, Lot 226; N103 E91, Lot 247. Material consists of scales and cranial fragments recovered from Leve1s 1-3, 6, 7, and 8 .

Referred Material from 41 MC 296: Test Pit 1, Lots 1, 2, 3, 4; N1022 E985, Lot 47; N1022 E986, Lots 51, 52; N1022 E987, Lots $61,62,63,64,65,67,68$; N1023 E985, Lots 70, 72, 75; N1023 E986, Lots 79, 80, 81, 87, 113, 114; N1023 E987, Lots 89, 92; N1023 E989, Lots 233, 238; N1024 E985, Lots 98, 99, 100, 102; N1024 E986, Lots 107, 109; N1024 E989, Lot 212; N1026 E986, Lots 213, 228; N1027 E986, Lot 214. Material consists of scales and cranial fragments recovered from Levels 1-8.

Remarks: While the family of gars is monogeneric, there are three species of gar within the state of Texas. Distinguishing these on the basis of the fragmentary remains recovered was not possible.

\section{ORDER CYPRINIFORMES}

FAMILY ICTALURIDAE

GENUS indeterminate (catfish)

Referred Material from 41 MC 222: N101 E91, Lot 170; N102 E90, Lot 190. Material consists of vertebrae from Levels I and 3.

Referred Material from 41 MC 296: Test Pit 1, Lots 2, 4; N1022 E987, Lots 61, 62, 63, 64, 65, 66, 67, 69; N1023 E985, Lot 78; N1023 E986, Lot 87; N1023 E987, Lots 94, 95; N1023 E989, Lot 238; N1024 E985, Lot 103; N1023 E986, Lot 113; N1026 E986, Lot 228; N1026 E997, Lot 154. Material consists of vertebrae from Levels 1-9.

Remarks: There are six genera and 24 species of catfish found in the southern half of the United States, and distinguishing which of these were represented by the fragmentary remains was not possible. 


\section{ORDER PERCIFORMES}

\section{FAMILY CENTRARCHIDAE}

\section{cf. Pomoxis (crappie)}

Referred Material from 41 MC 296: N1022 E987, Lot 63. Material consists of an otolith from Level 3.

Remarks: The family Centrarchidae, the sunfishes, is a large family, and one abundantly represented in Texas. The otolith recovered from the site has been tentatively identified as crappie which is one of the larger species. Crappie spawn in the shallow waters of streams during the spring in south Texas today where they can be relatively easily harvested. If the identification of the otolith is correct, then this specimen may indicate that 41 MC 296 was at least occupied in the spring.

\section{FAMILY SCIAENIDAE}

\section{Aplodinotus grunniens (freshwater drum fish)}

Referred Material from 41 MC 296: N1022 E987, Lot 68; N1024 E986, Lot 110; N1026 E999, Lot 163. Material consists of a maxillary fragment and two dorsal spines recovered from Levels 2, 4, and 8.

Remarks: Like crappie, freshwater drum spawn in the shallower waters of the streams in the spring where they can most easily be harvested, so these specimens too may suggest that 41 MC 296 was occupied in the spring.

\section{CLASS AVES}

ORDER indeterminate (birds)

Referred Material from 41 MC 296: N1022 E985, Lot 43; N1022 E987, Lots 64, 65, 66, 67, 68; N1023 E985, Lot 74; N1023 E987, Lot 89; N1023 E987, Lot 73; N1024 E986, Lot 108; N1024 E989, Lot 227. Material consists of 1 ong bone fragments from Levels 1-8.

Remarks: These remains consist of bird bones unassignable to family. Based upon size several species are represented in the faunal assemblage. 


\section{ORDER ANSERIFORMES}

\section{FAMILY ANATIDAE}

Anas cf. A. acuta (pintail duck)

Referred Material from 41 MC 296: Test Pit 1, Lot 8. Material consists of a left ulna from Level 8.

Remarks: The surface feeding ducks comprising this genus are winter migrants to the state, so recovery of this material within the faunal assemblage from 41 MC 296 is a strong indication that the site was occupied sometime between early fall and early spring. The pintail duck more commonly winters along the coastal margin near the bays, but they may al so be found inland.

\section{ORDER GALLIFORMES}

\section{FAMILY MELEAGRIDAE}

\section{Meleagris gallapavo (wild turkey)}

Referred Material from 41 MC 296: Test Pit 1, Lot 4; N1023 E985, Lot 73; N1023 E989, Lot 238; N1024 E985, Lot 104 ; N1024 E986, Lots 110, 112; N1024, E989, Lot 212. Material consists of a left humerus, a left metacarpus, a right femur, two metatarsals, a tibia, and a spur. Material was recovered from Levels $2,3,4,6$, and 7 .

Remarks: Positive identification of turkey remains can usually be made because of the large size of the bird and because the family is monotypic.

\section{CLASS AMPHIBIA}

ORDER ANURA

FAMILY indeterminate (frogs and toads)

Referred Material from 41 MC 222: N107 E87, Lot 259. Material consists of a long bone from Level 3.

Referred Material from 41 MC 296: N1022 E987, Lots 65, 66, 67; N1026 E997, Lot 151; N1027 E998, Lot 177; N1023 E989, Lot 238; N1024 E986, Lot 109. Material consists of 1 ong bone fragments from Leve $152,3,4,5,6,7$.

Remarks: Remains of frogs and toads, while seasonally abundant and relatively easy to harvest, rarely are recovered in faunal assemblages because of the small and fragile nature of the 
skeletal elements. Like the fish remains, these amphibian remains suggest an occupation of the two sites during the spring, summer, or early fall portion of the year.

FAMILY RANIDAE

Rana

SPECIES indeterminate (frogs)

Referred Material from 41 MC 296: N1022 E989, Lot 226; N1023 E989, Lot 238; N1024 E986, Lot 109; N1026 E997, Lot 149. Material consists of long bone elements from Levels 1, 2, and 3 .

Remarks: While most of this material could not be identified to species, three long bones from Level 1 (N1022 E989, Lot 226) and one vertebra from Leve1 2 (N1026 E997, Lot 149) appear to be within the size range of Rana catesbiana.

\section{CLASS REPTILIA}

ORDER CROCODYLIA

\section{FAMILY ALLIGATORIDAE}

Alligator mississipiensis (American al1igator)

Referred Material from 41 MC 222: N125 E72, Lot 291. Material consists of a single dermal scute from Level 1.

Remarks: Al1igators are present today in the Nueces River drainage so their presence at the site is not unexpected. It is interesting to note that on $1 \mathrm{y}$ the scutes were recovered, and this was all that was identified as alligator from 41 LK 201. The presence of scutes alone could be nothing more than a sampling bias since far more dermal scutes would be available for recovery than cranial and postcranial skeletal materia1. On the other hand, if the pattern of finding on $1 y$ scutes continues at other sites, it may reflect a preferential use of alligator skins. 
ORDER SQUAMATA

SUBORDER LACERTILIA

FAMILY IGUANIDAE

GENUS indeterminate (1izards)

Referred Material from 41 MC 222: N99 E91, Lot 138. Material consists of a smal1 vertebral centrum and a long bone fragment from Level 3.

Referred Material from 41 MC 296: N1022 E987, Lots 62, 63, 65, 66, 67; N1023 E989, Lot 233. Material consists of small vertebral centra and long bone fragments from Levels 2, 3, 5, 6, and 7 .

Remarks: Little can be inferred from these 1 imited remains other than that the human inhabitants, and probably their domesticated dogs if they were present at the site, were harvesting the reptile fauna available to them as well as the mammalian fauna.

\section{Sceloperus}

SPECIES indeterminate (spiny 1izards)

Referred Material from 41 MC 296: N1022 E987, Lots 62, 63, 64, 69. Material consists of mandible and vertebral fragments from Levels $2,3,4$, and 9.

Remarks: Sceloperus is a common genus of 1 izard found throughout the southwest. Of the 10 species 1 isted for this genus by Conant (1975), six are found in the general vicinity of the site.

\section{SUBORDER SERPENTES}

FAMILY indeterminate (snakes)

Referred Material from 41 MC 222: N98 E86, Lot 117. Material consists of a vertebral centrum from Level 3.

Referred Material from 41 MC 296: N1022 E985, Lot 45; N1022 E986, Lots 51, 52, 54, 55; N1022 E987, Lots 61, 62, 63, 64, $65,66,67,68,69 ; \mathrm{N} 1023 \mathrm{E985}$, Lot 74; N1023 E986, Lots 80, 82, 84, 85, 87; N1024 E985, Lots 98, 99, 105; N1024 E986, Lot 112; N1026 E986, Lot 213; N1026 E998, Lot 155; N1027 E999, Lot 185. Material consists of isolated vertebrae recovered from Levels 1-9. 
Remarks: Although only the genus Crotalus has been identified at this taxonomic level, the range of size in the vertebrae included in the assemblage of unidentified snake remains clearly indicates that a variety of these reptiles were being harvested.

FAMILY CROTALIDAE

Crotalus

SPECIES indeterminate (rattlesnakes)

Referred Material from 41 MC 222: N102 E9l, Lot 204; N103 E91, Lot 247. Material consists of vertebral elements from Levels 2 and 6.

Referred Material from 41 MC 296: Test Pit 1, Lot 6; Test Pit 2, Lot 21; N1022 E987, Lots 65, 69; N1023 E985, Lots 70, 71, 72, 76; N1023 E986, Lot 86; N1023 E987, Lots 89,90 ; N1023 E989, Lots 231, 233, 238, 242; N1024 E985, Lots 100, 102; N1024 E986, Lot 114; N1024 E989, Lots 195, 212, 237; N1026 E978, Lot 197; N1026 E998, Lot 156; N1026 E999, Lots 162, 163; N1027 E997, Lot 170. Material consists of vertebrae recovered from Levels 19.

Remarks: Like amphibians, the snakes are more active in the spring, summer, and early fall portions of the year, so the presence of remains of snakes in the faunal assemblages of both sites indicates that they were occupied during this time period.

\section{ORDER TESTUDINES}

FAMILY indeterminate (turties)

Referred Material from 41 MC 222: N99 E90, Lot 133; N102 E90, Lot 190; N102 E91, Lots 206, 207; N103 E89, Lots 221, 225; N103 E90, Lot 228; N103 E91, Lot 243; N107 E87, Lot 259; N113 E83, Lot 277. Material consists of scute fragments from Leve1s $1-5$ and 7.

Referred Material from 41 MC 296: Test Pit 1, Lots 2, 3, 5, 6, 7; Test Pit 2, Lots 16, 17, 18, 20, 41; N1022 E985, Lots 41, 42, 44, 45, 48; N1022 E986, Lots 52, 53, 54, 55, 56, 57, 59; N1022 E987, Lots 63, 65, 67, 68, 69; N1023 E985, Lots 70, 71, 74, 76, 78; N1023 E986, Lots 82, 84, 86, 88; N1023 E987, Lots 90, 91, 92, 93, 94, 96, 97; N1023 E989, Lots 231, 233, 242; N1024 E985, Lots 98, 99, 100, 101, 102, 103, 104, 105; N1024 E986, Lots 102, 109, 111, 112, 113; N1024 E989, Lots 212, 237; N1026 E978, Lots 197, 209, 211, 229; N1026 E986, Lot 228; N1026 E995, Lots 218, 241; N1026 E997, Lots 150, 151, 153, 154; N1026 E998, 
Lots 156, 157, 158, 159, 161; N1026 E999, Lots 162, 163, 164, 167; N1027 E978, Lots 215, 224, 232; N1027 E986, Lot 234; N1027 E995, Lot 222; N1027 E997, Lots 171, 173, 174; N1027 E998, Lots 177, 179; N1027 E998, Lots 180, 181; N1027 E999, Lots 185, 187. 188, 189. Material consists of scute fragments from Levels $1-9$ and 11 .

Remarks: Turtie shell fragments are scattered throughout both sites, and in all layers. It is difficult to evaluate the importance of turtles in human diets based upon an examination of the frequency of shel1 remains for two reasons. The first reason is that fragmented shelis result in a high number of identifiable elements per individual, thus in raw bone counts turtles are overrepresented. It is also difficult to assess the dietary importance of turtle because the shells were used for tools and ornaments. Like the other cold-blooded vertebrates, turtles are usually most active in the spring, summer, and early fall and would therefore more $1 \mathrm{ikely}$ be harvested during this time.

\section{FAMILY EMYDIDAE}

\section{Chrysemys}

SPECIES indeterminate (water turt7e)

Referred Material from 41 MC 222: N102 E90, Lot 190; N102 E91, Lot 206; N103 E90, Lot 233; N103 E91, Lot 246. Material consists of scutes from Levels 3-5.

Referred Material from 41 MC 296: Test Pit 1, Lot 5; Test Pit 2, Lots 21,24 ; N1022 E985, Lots 42, 43; N1022 E986, Lots 51, 58; N1022 E987, Lots 61, 62, 64, 66, 67; N1023 E985, Lots 72, 73, 74, 75, 77; N1023 E986, Lots 79, 80, 81, 85; N1023 E987, Lot 89; N1023 E989, Lot 238; N1024 E985; Lots 99, 102; N1024 E986, Lots 107, 110; N1026 E986, Lots 213, 236; N1026 E997, Lot 152; N1026 E998, Lots 156, 160; N1027 E978, Lot 225; N1027 E986, Lots 199, 214, 223. Material consists of carapace and $\mathrm{p} l$ astron fragments from Levels $1-8$ and 10.

Remarks: There are two species of Chrysemys which occur within the state today, both species are aquatic in their habitat preference. It is interesting to note that more elements were identifiable to this taxon from 41. MC 296 than either 41 MC 222 or 41 LK 201. This may suggest that 41 MC 296 was located nearer slow moving or stagnant water which is the preferred habitat for Chrysemys. 


\section{Terrapene}

SPECIES indeterminate (box turties)

Referred Material from 41 MC 222: N98 E90, Lot 119; N99 E86, Lot 127; N101 E90, Lot 168. Material consists of carapace and plastron shel1 fragments from Levels 2, 3. and 4.

Referred Material from 41 MC 296: N1023 E985, Lots 71, 75, 77; N1027 E999, Lot 185. Material consists of she11 and postcranial skeletal fragments from Levels 2, 3, 6, and 8.

Remarks: There are two species of box turtles in Texas, Terrapene ornata and T. carol ina. Both of these species are terrestrial, but $T$. carolina is more commonly found in wooded terrain while T. ornata is a resident of the more arid prairies. Today, only T. ornata is found in the vicinity of the sites. Identification to species was not possible for the recovered fragmentary remains.

FAMILY KINOSTERNIDAE

\section{Kinosternon}

SPECIES indeterminate (mud turtle)

Referred Material from 41 MC 296: $\quad$ N1024 E986, Lot 112. Material consists of one femur fragment from Leve 16.

Remarks: There are two species of Kinosternon resident in Texas today, $K_{0}$. $f 1$ avescens and $K_{\text {. }}$ subrubrum. Identification to species was not possible for the recovered remains.

\section{FAMILY TRIONYCHIDAE}

Trionyx cf. T. spiniferus (spiny softshell turtle)

Referred Material from 41 MC 296: Test Pit 1, Lot 4; N1022 E985, Lot 43. Material consists of shel 1 fragments from Levels 3 and 4 .

Remarks: Shell material of the spiny softshell turtle is readily identifiable so the meager amount of material recovered from these two sites probably indicates that this species of turtle was not harvested as abundantly at these sites as the species was at 41 LK 201. 


\section{CLASS MAMMALIA}

ORDER MARSUPIALIA

\section{FAMILY DIDELPHIDAE}

Didelphis cf. D. virginiana (Virginia opossum)

Referred Material from 41 MC 296: N1026 E997, Lot 154. Material consists of a left mandible from Level 7.

Remarks: The 1 imited number of remains representing arboreal species was noted in the 41 LK 201 faunal assemblage, and it was suggested that this reflected underharvesting of these species by the human occupants of the site (Steele 1986). The suggested reason for this underrepresentation was ineffective hunting techniques for these species or not hunting when these species were active. The underrepresentation of nocturnal, arborea 1, and fossorial species also is a pattern seen at 41 MC 222 and 41 MC 296 as wel1. The consistency in the pattern among the three sites seems to support the hypothesis.

\section{ORDER ARTIODACTYLA}

FAMILY indeterminate (cloven-hooved ungulates)

Referred Material from 41 MC 222: N97 E86, Lot 104; N101 E89, Lot 162; N101 E90, Lot 167. Material consists of 1 ong bone fragments from Levels 1 and 3.

Referred Material from 41 MC 296: Test Pit 1, Lots 1, 2, 4; Test Pit 2, Lot 20; N1022 E985, Lots 41, 42; N1022 E986, Lots 51, 56, 57; N1022 E987, Lots 61, 63, 68; NI022 E989, Lot 226; N1023 E985, Lot 71; N1023 E986, Lot 81; N1023 E987, Lot 89; N1024 E985, Lots 99, 102, 103; N1024 E986, Lot 107; N1026 E986, Lot 213; N1027 E986, Lot 214. Material consists of 1 ong bone fragments from Leve1s $1-4,6,7$, and 8 .

Remarks: The unidentified artiodacty 7 remains indicate the degree of marrow processing practiced by the human inhabitants at the two sites. Most of the fragments represent greatly reduced long bone elements which were broken while the bones were green. This pattern of breakage has been associated with carnivore bone reduction performed by nonhuman carnivores, but the bone in this case is commonly scarred with gnaw marks. The bone from 41 MC 222 and 41 MC 296 showed 1 ittle evidence of gnaw marks, which further supports the contention that the bone reducers were human. 
FAMILY ANTILOCAPRIDAE

Antilocapra americana (pronghorn)

Referred Material from 41 MC 296: Test Pit 1, Lot 1; N1023 E985, Lot 72; N1026 E986, Lot 213. Material consists of two upper molars and a left metatarsal fragment from Leve1s 1-3.

Remarks: The pronghorn, although not found in the region today, was a part of the local fauna within historic times and has been recorded in faunal assemblages from 41 LK 201. This species is associated with grassland habitat.

FAMILY BOVIDAE

Bison bison (bison)

Referred Material from 41 MC 222: N97 E86, Lot 104; N97 E8687. Lot 114; N99 E89, Lot 130; N100 E89, Lot 142; NI00 E90, Lot 148; N101 E89, Lots 162, 163; N104 E89, Lots 182, 183; N103 E89, Lot 221; NI03 E90, Lot 233; N125 E72, Lot 290. Material consists of a left scaphoid, a left trapezoid, distal phalanges, sesmoids, unidentified carpal fragments, a medial phalanyx, unidentified long bone fragments, a proximal femur fragment, a right humerus fragment, two mandibular incisors, and one unidentified tooth fragment from Levels $1,2,3,4$, and 5 .

Referred Material from 41 MC 296: Test Pit 1, Lot 2; Test Pit 2. Lots 16, 40; N1022 E987, Lot 63; N1023 E985, Lot 70; N1023 E986, Lots 79, 87; N1023 E989, Lots 238, 242; N1024 E989, Lots 195, 212, 227, 237; N1027 E986, Lots 199, 223. Material consists of fragments of phalanges, metapodials, vertebra centra, long bone shaft fragments, and isolated teeth from Leve $1 \mathrm{~s} 1-4,8$, and 11 .

Remarks: The bison remains appear in all levels associated with Late Prehistoric times at both sites, but appear less frequently in the Late Archaic levels at 41 MC 296. This pattern mirrors the temporal distribution of bison remains at 41 LK 201 and appears to be a reflection of relative abundance in the sample. Two alternative explanations have been proposed to explain this pattern of abundance and scarcity of bison remains. Dillehay (1974) proposed that there were three periods during which bison were present on the southern plains and two periods during which they were scarce or absent. He felt that this pattern was a reflection of changing climatic conditions in the southern plains. On the basis of a more detailed review of the evidence in north-central Texas, Lynott (1979) felt that the evidence in his study area could not be used to support Dillehay's hypothesis. Rather, Lynott felt that the evidence on $7 y$ suggested that the bison, which were 
general1y scarce, were relatively more abundant from A.D. 1200 to 1600. The data from 41 LK 201, 41 MC 222, and 41 MC 296 substantiate the relative scarcity of bison in the Late Archaic and the relatively greater abundance in the Late Prehistoric time periods. Dibble (1968:73) also noted the relative scarcity of bison remains during the Late Archaic in central Texas and suggested that the bison probably represented a relative minor part of the biomass in central Texas, and also was of minor significance in the dietary regimen of the hunters and gatherers of the region. Dibble's conclusions seem to be valid for south Texas as well. What the data does not do is contradict Dillehay's model or provide sufficient data to confirm Dillehay's model.

\section{FAMILY CERVIDAE}

\section{Odocoileus virginianus (white-tailed deer)}

Referred Material from 41 MC 222: N99 E86, Lot 126; N99 E89, Lot 131; N99 E90, Lot 133; N100 E91, Lot 155; N101 E89, Lot 163; N101 E90, Lot 167; N101 E91, Lot 172; N103 E88, Lot 215; N103 E89, Lots 223, 224, 225; N103 E91, Lot 245; N107 E87, Lot 259. Material consists of a right and a left astragalio a left calcaneus, distal and medial phalanges, sesmoid elements: a right tibia fragment, a left metatarsal fragment, a fragment of the basicranium, and an antler tyne collected from Levels $2,3,4,5,6$, and 7 .

Referred Material from 41 MC 296: Test Pit 1, Lots 2, 3, 6: Test Pit 2, Lots 18, 19, 20, 21 ; N1022 E985, Lots 42, 47, 49; N1022 E986, Lots 51, 52, 59; N1022 E987, Lots 63, 64, 66; N1022 E989, Lot 194; N1023 E985, Lots 70, 74; N1023 E986, Lots 80,$85 ; \mathrm{N} 1023 \mathrm{E987}$, Lots 93, 96; N1023, E989, Lots 223 , 238, 242; N1024 E985, Lots 98, 99, 101, 104, 105; N1024 E986, Lots 107, 112; N1024 E989, Lot 237; N1026 E978, Lots 209, 229; N1026 E985, Lot 213; N1026 E995, Lot 217; N1027 E978, Lots 223, 224; N1027 E986, Lot 214; N1027 E999, Lot 184. Material consists of dental, cranial, and postcranial skeletal fragments from Levels 1-9.

Remarks: While the referred material could be assigned to the genus on the basis of structural features, identification of the material to 0 . virginianus is presumed since the other species of deer within the state, the mule deer, is restricted today to the Big Bend and High Plains regions of the state.

The remains of the white-tailed deer are the most abundant of any of the larger sized mammals. It is also apparent that whole carcasses of the animals were consistentiy returned to the site since a wide range of skeletal elements have been recovered in the faunal assemblage. These two 1 ines of evidence support the common contention that deer were one of 
the most important faunal resources for human inhabitants in south Texas.

Most of the deer remains are from adult deer, but one specimen (41 MC 296. N1024 E989, Lot 212, Level 2) is a femur fragment with an unfused epiphysis, a condition found in subadult deer. The element, however, was from a deer older than a fawn so no statement can be made as to the season when the animal was taken.

Two specimens (41 MC 222, N99 E90, Lot 13 and 41 MC 296, N1023 E989, Lot 242) were modified antler tynes which document the use of antler remains as tools at these sites.

\section{FAMILY TAYASSUIDAE}

\section{Dicotyles tajacu (collared peccary)}

Referred Material from 41 MC 222: N100 E90, Lot 148; N101 E89, Lot 162; N101 E90, Lot 167; N102 E90, Lot 192. Materia1 consists of a left third metacarpal, a carpal element, a distal phalange, a distal fragment of a metapodial, and a distal metapodial epiphysis from Leve1s 1, 3, and 4.

Remarks: The recognition that the collared peccary was endemic in south Texas during the Late Prehistoric and possibly the Late Archaic is a relatively recent discovery. To date, material representing this species has been recovered from 41 MC 222, 41 LK 201 (Steele 1986), 41 NU 102 (Steele and Mokry n.d.), 41 NU 103 (Steele and Mokry n.d.), and 41 KL 13 (Herman Smith, personal communication 1983). While the remains from no one site are frequent enough to suggest that the peccary was a major component of the diet of the peoples, the fact that the peccary has been recovered from five sites does indicate that the species was common enough in the region to have been hunted.

\section{ORDER CARNIVORA}

FAMILY CANIDAE

\section{Canis}

SPECIES indeterminate (coyotes, dogs, and wolves)

Referred Material from 41 MC 222: N103 E88, Lot 215; N103 E89, Lots 223, 225; NI03 E9l, Lot 250. Material consists of a tarsal element, one distal phalange, and one medial phalange from Levels 5 and 7 . 
Referred Material from 41 MC 296: Test Pit 1, Lots 4, 8; N1022 E985, Lot 41; N1022 E986, Lots 51, 54; N1022 E987, Lots 63, 68; N1027 E986, Lot 214. Material consists of fragments of distal phalanges, metapodials, and a right second lower molar from Levels $1-4$ and 8.

Remarks: Distinguishing the species of Canis on the basis of bony remains is extremely difficult. The material recovered from both 41 MC 222 and 41 MC 296 fall within the size range of the coyote as well as medium to 1 arge size domesticated dogs.

FAMILY FELIDAE

Felis cf. F. rufus (bobcat)

Referred Material from 41 MC 222: N102 E90, Lot 191; N103 E88, Lot 215. Material consists of one proximal metacarpal and one distal metapodial from Levels 3 and 5.

Remarks: These remains have been tentatively referred to as bobcat because of the similarity in size and structure. The species is present throughout Texas today and has been reported from the region during late $P$ leistocene times (Lundelius 1972) and from Late Archaic levels of the Holocene (Stee 1e 1986).

\section{ORDER INSECTIVORA}

\section{FAMILY TALPIDAE}

Scalopus cf. S. aquaticus (eastern mole)

Referred Material from 41 MC 296: N1023 E985, Lot 74; N1026 E997, Lot 151. Material consists of a right mandibular fragment and a right humerus from Levels 4 and 5.

Remarks: The eastern mole prefers 10ose, well-drained soils because of their burrowing habitats. For south Texas these conditions are usually found near waterways or in wooded patches.

ORDER LAGOMORPHA

FAMILY LEPORIDAE

cf. Lepus callifornicus (jackrabbit)

Referred Material from 41 MC 222: N98 E9l, Lot 123; N99 E86, Lot 127; N99 E89, Lot 131; N99 E90, Lot 133; N99 E91, 
Lots 136, 138; N100 E86, Lots 140, 141; N100 E89, Lots 143, 144, 145; N100 E90, Lots 147, 148; N100 E91, Lots 154, 155; N101 E88, Lots 159, 160; N101 E90, Lots 166, 167, 168; N101 E91, Lots 172, 173; N102 E89, Lots 183, 184, 186; N102 E90, Lot 190; N102 E91, Lots 206, 207; N102 E100, Lot 197; N103 E88, Lots $215,216,217$; N103 E89, Lot 223; N103 E90, Lots 231, 232, 233, 235; N103 E91, Lots 245, 246; N107 E87, Lot 259; N110 E87, Lots 264, 266. Material consists of cranial, dental, and postcranial remains from Levels 1-7.

Referred Material from 41 MC 296: Test Pit 1, Lots 1, 2, 3, $5,6,7,8$; Test Pit 2, Lots 17, 18, 19, 20, 21, 22, 40; N1022 E985, Lots $41,43,44,45,47,50$; N1022 E986, Lots 51, 52 , $54,55,56,57,59$; N1022 E987, Lots 61, 62, 63, 64, 65, 66, 67, 69; N1023 E985, Lots 70, 71, 73, 74, 76; N1023 E986, Lots 79, 80, 82, 85, 87; N1023 E987, Lots 91, 92, 93, 94, 95, 97; N1023 E989, Lots 233, 238, 242; N1024 E985, Lots 98, 99, $100,101,102,103,104,105$; N1024 E986, Lots 108, 109, 110, $111,112,113,114 ;$ N1024 E989, Lot 237; N1026 E978, Lots 198, 208, 211; N1026 E985, Lots 213, 228, 236; N1026 E995, Lots $217,218,239$; N1026 E997, Lots 148, 150, 151, 152, 153; N1024 E998, Lots 157, 158, 159; N1026 E999, Lots 163, 164, 165, 166, 167; N1026 E978, Lots 215, 22.4, 225; N1027 E986, Lots 214, 223; N1027 E995, Lots 219, 221, 222; N1027 E997, Lots $170,173,174,175$; N1027 E998, Lots 177, 178, 180, 181; N1027 E999, Lots 185, 186, 187, 188. Material consists of fragments of dental, cranial, and postcranial skeletal elements recovered from Levels 1-1l.

Remarks: Hulbert (1979) has noted the difficulty in distinguishing between Lepus and the 1 argest species of Sylvilagus, S. aquaticus. For this reason the identification of these remains as Lepus is tentative. Where tentative identifications for $\mathbf{S}$. aquaticus were made, they were included in that genus sample. While there are six species of jackrabbits recognized by $\mathrm{Ha} 11$ (1981), on 1 y the black-tailed jackrabbit is found within the state today, and the remains recovered from both sites compare favorably in size with this species. This species is predominately an inhabitant of the prairie and scrublands, and its probable presence in the two sites indicates that these habitats were present in the region during prehistoric times as well.

\section{Sylvilagus}

SPECIES indeterminate (cottontail rabbits)

Referred Material from 41 MC 222: N98 E90, Lot 118; N98 E91, Lots 121, 124; N99 E86, Lot 126; N99 E89, Lot 129; N99 E91, Lot 137; N101 E89, Lot 164; N101 E90, Lots 167, 168, 169; N101 E91, Lots 171, 172, 173, 174; N102 E89, Lots 182, 183, 184; N102 E90, Lots 188, 190, 192, 193, 194; N102 E91, 
Lots 206, 207; N102 El00, Lot 196; N103 E88, Lots 216, 217; N103 E89, Lots 220, 224; N103 E90, Lots 233, 234, 235; N103 E91, Lots $241,243,245,246,247,248$; N104 E85, Lot 255; N107 E87, Lot 259; N110 E87, Lots 261, 264, 266; NI12 E79, Lot 269; N119 E80, Lot 283. Material consists of cranial, dental, and postcranial remains from Levels 1-7.

Referred Material from 41 MC 296: Test Pit 1, Lots 3, 4, 5, 6, 8, 10; Test Pit 2, Lots 17, 18, 19, 21, 40; N1022 E985, Lots $41,42,43,44,45$; N1022 E986, Lots 51, 53, 54, $55,56,57$; N1022 E987, Lots 61, 62, 66, 67, 68, 69; N1022 E989, Lots 63, 64, 65; N1023 E985, Lots 70, 71, 72, 73, 74, $75,76,77,78$; N1023 E986, Lots 79, 80, 81, 82, 84, 85, 86; N1023 E987, Lots 91, 92, 93; N1023 E989, Lots 231, 233, 238, 242; N1024 E985, Lots 98, 100, 101, 102, 103, 104, 105; N1024 E986, Lots 108, 109, 110, 111, 114; N1024 E989, Lots 212, 227, 237; N1026 E978, Lots 197, 198, 208, 211, 229; N1026 E985, Lots 213, 228; N1026 E995, Lots 217, 241; N1026 E997, Lots $149,150,151,152,153,154$; N1026 E998, Lots 156, 157, 158, 159, 160; N1026 E999, Lots 163, 164, 165, 166, 167; N1027 E978, Lots 210, 215, 224, 225, 232; N1027 E995, Lot 221; N1027 E986, Lots 223, 224; N1027 E997, Lots 171, 173, 174, 175; N1027 E998, Lots 178, 179, 182; N1027 E999, Lots 183, 185, 186, 187, 188. Materia 1 consists of dental, cranial, and postcranial skeletal elements from Levels 1-11.

Remarks: Steele (1986) reviewed the taxonomy of the cottontail rabbits, and we follow that report. For most of the material, identification was not made to species because of the fragmentary nature of the material.

Adding to the difficulty of dealing with highly cominuted material is the fact that the four species of leporids found within the state today grade in size from the sma 11 desert cottontail rabbit to the large California jackrabbit. Not on $7 y$ do they grade in size, the size range of each species overlaps with the next 1 argest species. Hulbert (1979) noting these similarities in size felt that subjective identification of leporids to species was unreliable; therefore, he developed discriminant functions utilizing measurements of the cranium and mandible to distinguish the species. Unfortunately, the material recovered from Choke Canyon basin sites was too cominuted, so the necessary measurements to utilize Hulbert's discriminant functions could not be made. In spite of these difficulties we felt, as did Steele (1986), that some of the material could be assigned to specific species.

While the ranges of each species overlaps, the means are not overlapping, and the smaller specimens of each spectles are outside the range of the larger specimens of the species closest in size. To illustrate this, Table 45 
TABLE 45. COMPARATIVE MEASUREMENTS FOR LAGOMORPHS INDIGENOUS TO TEXAS

\begin{tabular}{llll|lll|rrr} 
& LDL & S.D. & RANGE & LTL & S.D. & RANGE & MD & S.D. & RANGE \\
\hline L. cal ifornicus & 21.1 & 1.29 & $18.6-25.2$ & 17.9 & 0.92 & $16.1-20.5$ & 13.2 & 1.05 & $10.8-16.3$ \\
S. aquaticus & 18.2 & 0.97 & $16.9-20.7$ & 17.7 & 0.68 & $16.5-18.9$ & 11.7 & 0.74 & $10.6-13.6$ \\
S. floridanus & 14.3 & 1.12 & $12.0-17.1$ & 13.6 & 0.70 & $11.8-15.8$ & 8.8 & 0.60 & $7.2-10.6$ \\
S. auduboni i & 13.3 & 0.83 & $11.7-14.9$ & 12.4 & 0.56 & $11.4-14.0$ & 9.3 & 0.64 & $8.1-11.0$
\end{tabular}

\section{Iotal Length Range}

L. californicus

S. aquaticus

S. floridanus

S. audubonit

$465-630$
$530-540$
$375-463$
$350-420$

\section{Hind Foot Length Range}

$112-145$
$105-110$
$87-104$
$75-100$

$\mathrm{LDL}=1$ ower diastema length of the mandible from the incisors to the anterior premolar (from Hulbert 1979).

S.D. = standard deviation.

$\mathrm{LTL}=$ lower tooth row length of the premolar and molars (from Hulbert 1979).

MD = mandible depth.

Total length = head and body length; minimum and maximum given (from Hal1 1981 ).

Hind foot length = length of hind foot; minimum and maximum given (from Hal1 1981 ). 
provides measurements of total length and hind foot length after Hall (1981), and lower diastema length, mandible depth, and lower tooth row length after Hulbert (1979). On this basis, the smallest of the Sylvilagus specimens were assigned to $S$. auduboni $i$ and the largest of the sma 11 specimens tentatively assigned to $S$. floridanus. Similarly, the largest of the large leporids were tentatively assigned to Lepus, while the smaller specimens of the large leporids were tentatively assigned to $S$. aquaticus.

To test at least a portion of these subjective assessments a discriminant function developed by Assad and Carlson

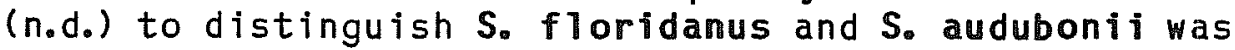
utilized to assign six of the small leporid mandibles to ejther of these species. Table 46 presents the discriminant function formula, the sectioning point, the percent accuracy, and the measurements of the six mandibles from 41 LK 201 and 41 MC 296. Al1 six specimens were assigned to $S$. auduboni with a high probability of accuracy.

In summary then, minimally two species of leporids can be recognized in the faunal assemblages. The largest 1eporid, assigned to Lepus, falls outside the range of the sma 11 species of Sylvilagus. The other leporid species which can be confidentiy recognized is Sylvilagus audubonil, recovered from $4 I$ LK 201 and 41 MC 296. In addition to these two species, $S$. floridanus and $S$. aquaticus may have also been present. S. floridanus was tentatively identified at 41 LK 201 and 41 MC 296. So aquaticus was identified at 41 MC 222 and 41 MC 296. These 1 ast two identifications were based upon subjective evaluations alone, however, and need further substantiation.

Today, Lepus cal ifornicus, So audubonit, and So floridanus occur within the Choke Canyon basin (Ha11 1981). Sy 1 vilagus aquaticus, an eastern species, occurs as far west as the Colorado and San Antonio Rivers, approximately 70 miles east of the sites. Interpreting this material conservatively, it appears that at least as many species of leporids were present in the basins in the past as there are today. There is also the possibility that $S$. aquaticus may also have been present in the area as wel1. If this is a correct identification, it would represent evidence for a greater westward distribution of this species than it currently has. Hulbert (1979) reexamined leporid remains from Friesenhahn Cave in Bexar County and Kincaid Shelter in Uvalde County, and felt that $S$. aquaticus was represented in the bone assemblages from both of these sites. The Friesenhahn Cave sample is 1 ate Pleistocene in age and is associated with a more mesic fauna than is present in Bexar County today. The Kincaid Shelter 
TABLE 46. THE DISCRIMINANT FUNCTION, SECTION POINT FOR DISTINGUISHING SYLVILAGUS AUDUBONII AND S. FLORIDANUS

Discriminant function: $4.8414(L T L)-3.9091$ (MD) -27.474

Section point: Negative score = Sylvilagus audubonii

Positive score $=$ S. floridanus

Percent accuracy on study sample: $88 \%$

SITE 41 LK 201

Unite Let, Level

N505 E1011, Lot 727, Leve1 1 N509 E1012, Lot 701, Level 2 N509 E1010, Lot 652, Leve1 1 N506 E1013, Lot 692, Leve1 2

N1024 E985, Lot 104, Level 7 N1026 E997, Lot 154, Level 7
LIL MD

13.4

11.4

11.5

11.3
10.4

8.0

8.9

10.5

\section{Discriminant}

Function Probable Score

Accuracy

\section{$-3.254$ \\ 0.96}

$-3.555$

$-6.589$

0.97

1.00

$-13.812$

1.00

\section{SITE 41 MC 296}

$\begin{array}{llll}11.7 & 10.9 & -13.439 & 1.00 \\ 13.6 & 10.6 & -3.0674 & 0.96\end{array}$

$L T L=$ lower tooth row length.

$M D=$ mandibular depth taken beneath the talonid of the third premolar.

Note: The discriminant function, section point for distinguishing Sy 1 vilagus auduboni $i$ and S. floridanus, the percent accuracy of the function in distinguishing the study sample, and the probability of a correct assessment is presented. Fol lowing the function are the locations, measurements, and discriminant function scores for the six unknown mandibles tested. Al1 six specimens were assigned to $S$. audubonil on the basis of their negative functions scores. 
material assigned to $S$. aquaticus 1 acked provenience. If the assessment of the material from Choke Canyon basin is correct then, it provides evidence for a greater range for the species during the Holocene.

\section{ORDER PRIMATES}

\section{FAMILY HOMINIDAE}

Homo sapiens (humans)

Referred Material from 41 MC 296: Test Pit 1, Lot 5; N1026 E995, Lot 240. Material consists of a right clavicle and an isolated premolar of indeterminate number and size. Material was recovered from Levels 5 and 6.

Remarks: Isolated fragments of human remains not uncommoniy turn up in North American habitation sites (Col1ins, Hester, and Weir 1969; Hester 1969; Steele 1975). In Late Prehistoric sites in south Texas these remains are commonly modified (Col1 ins, Hester, and Weir 1969; Hester 1969). The remains recovered from 41 MC 296, however, evidence no modifications, nor is there any evidence as to how they came to be a part of the bone assemblage at the site.

ORDER RODENTIA

FAMILY GEOMYIDAE

Geomys

SPECIES indeterminate (eastern pocket gopher)

Referred Material from 41 MC 296: N1022 E987, Lot 66; N1023 E989, Lots 233, 238. Material consists of fragments of a maxillary incisor, a right humerus, and a left femur from Leve 1 s 2,3 , and 6 .

Remarks: The genera of gophers found in Texas can be distinguished from one another by the structure of the labial surface of the maxillary incisors, Geomys being marked by two 1 ines paral1el to the length of the tooth (Davis 1974). Therefore, the incisor recovered can be positively assigned to genus. The humerus and femur on the other hand are on 1 y tentatively identified to genus. of the three species of Geomys occurring in Texas, G.

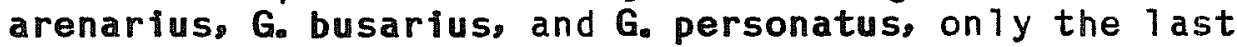
two are found near the locality of the site today. G. arenarius is restricted to the mountainous area of far west Texas and is unlikely to have ever existed in south Texas. 
FAMILY HETEROMYIDAE

Perognathus cf. P. hispidus (hispid pocket mouse)

Referred Material from 41 MC 296: N1023 E985, Lot 72. Material consists of a maxillary fragment from Level 3.

Remarks: Hal1 (1981) 1 ists two species of pocket mice as occurring in the area of the site today, $P_{0}$ hispidus and $P_{0}$ flavus (Davis identifies $P$. flavus as $P$. merriami). Of these two species, $P$. hispidus is more similar in size to the material recovered from 41 MC 296. The on $7 y$ other comparable sized pocket mouse is P. pencillatus, and it is known on $7 y$ from the Trans-Pecos region. Both $P_{0}$. hispidus and P. flavus are 1 isted by Davis (1974) as preferring friable soil with sparse vegetation cover.

FAMILY MURIDAE

Neotoma

SPECIES indeterminate (pack rat)

Referred Material from 41 MC 222: N102 E90, Lot 190; N102 E90, Lot 204; N103 E88, Lot 212; N103 E91, Lots 241, 242, 247. Material consists of two right mandibles, a right upper first molar, a left second lower molar, an unidentified molar fragment, and a right tibia from Levels 2,3 , and 6 .

Referred Material from 41 MC 296: Test Pit 2, Lots 16, 21; N1022 E985, Lot 42; N1022 E987, Lots 61, 62, 63, 64, 65, $66,67,68,69 ; \mathrm{N} 1023 \mathrm{E985}$, Lots 70, 74, 75, 77; N1023 E986, Lots 79, 85; N1023 E987, Lot 94; N1023 E989, Lots 233, 238, 242; N1024 E985, Lots 98, 100, 103; N1024 E989, Lots 212, 227, 237; N1026 E978, Lot 208; N1026 E995, Lot 240; N1026 E997, Lots 149, 150, 151, 152, 153, 154; N1026 E998, Lot 158; N1026 E999, Lots 163, 165; N1027 E986, Lots 223, 224; N1027 E997, Lot 170; N1027 E998, Lots 177, 179; N1027 E999, Lots 185, 186. Material consists of denta 1, cranial, and postcranial skeletal elements from Leve1s 1-9.

Remarks: The four species of pack rat currently found in

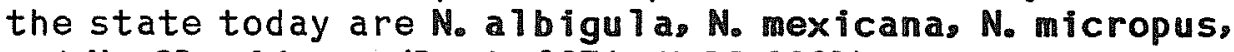
and N. floridanus (Davis 1974; Ha 71 1981).

Sigmodon cf. S. hispidus (hispid cotton rat)

Referred Material from 41 MC 222: N98 E90, Lot 118; N103 E89, Lot 220; N103 E90, Lot 228; N103 E91, Lot 241. Material 
consists of a right mandible, one right first upper molar, one ulna, and one right humerus from Levels 1-3.

Referred Material from 41 MC 296: Test Pit 1, Lots 1, 4; N1022 E985, Lots 42, 43; N1022 E986, Lot 54; N1022 E987, Lots 61, 62, 63, 64, 65, 66, 67, 69; N1023 E985, Lots 71, 75; N1023 E987, Lots 94, 95; N1023 E989, Lots 233, 242; N1024 E985, Lots 99, 104; N1024 E986, Lots 110, 111. Material consists of dental and postcranial skeletal elements from Levels $1-7$ and 9.

Remarks: Of the two species of cotton rats found within the state today $S$. ochrognathus is restricted to the higher elevations of the Chisos Mountains while S. hispidus is found throughout the state (Davis 1974). S. hispidus prefers heavily grassed habitat.

\section{FAMILY SCIURIDAE}

\section{GENUS indeterminate (squirrels)}

Referred Materials from 41 MC 222: N103 E91, Lot 252. Material consists of a right distal fragment of a humerus from Leve1 6.

Referred Material from 41 MC 296: N1022 E985, Lots 41, 43; N1022 E986, Lot 56. Material consists of a left calcaneus and the distal end of a right humerus from Levels 1, 3, and 6.

Remarks: Material assigned to this taxon could not be classified to genus. One comment which can be made concerns the relative paucity of recovered material assigned to this family considering how relatively abundant they are in both grass 1 and and wooded habitats. It is possible, however, that the fossorial or arboreal niches they occupy made them difficult game to capture.

\section{Sciurus}

SPECIES indeterminate (tree squirrels)

Referred Material from 41 MC 222: N101 E91, Lot 173. Material consists of one right calcaneus from Leve1 4.

Remarks: Species of this genus are generally restricted to the riparian forest and oak mott in south Texas and are a good indication of the Indians harvesting food within this environment. 


\section{Spermophi1us}

SPECIES indeterminate (ground squirrels)

Referred Material from 41 MC 222: N101 E91, Lot 173; N102 E89, Lot 183; N102 E90, Lot 190. Material consists of two distal fragments of the tibia and a right calcaneus from Levels 3 and 4.

Referred Material from 41 MC 296: N1022 E987, Lot 67; N1023 E987, Lot 89; N1026 E998, Lot 156. Material consists of a maxillary fragment containing molars and premolars of a subadult from Leve1 7, a near 1 y comp lete skeleton from Leve 1 , and a left edentulous mandible from Level 2.

Remarks: While the fragmented remains indicate that this genus served as food for the human inhabitants or their dogs, one nearly complete specimen recovered from Level 1 may we11 represent the intrusive remains of a ground squirrel which occupied the area of the site and died there when the locality was not occupied by humans.

\section{ACKNOWLEDGMENTS}

The authors would 1 ike to thank David L. Carlson for assistance in statistical analyses and computer generated il1ustrations; David Car1son, Gary DeMarcay, and Harry Shafer for critically reviewing the manuscript; and the secretarial staff of the Department of Anthropology, Texas A\&M University for typing the manuscript. 
TABLE 47. PROVENIENCE BY LOT NUMBER FOR SITE 41 MC 222

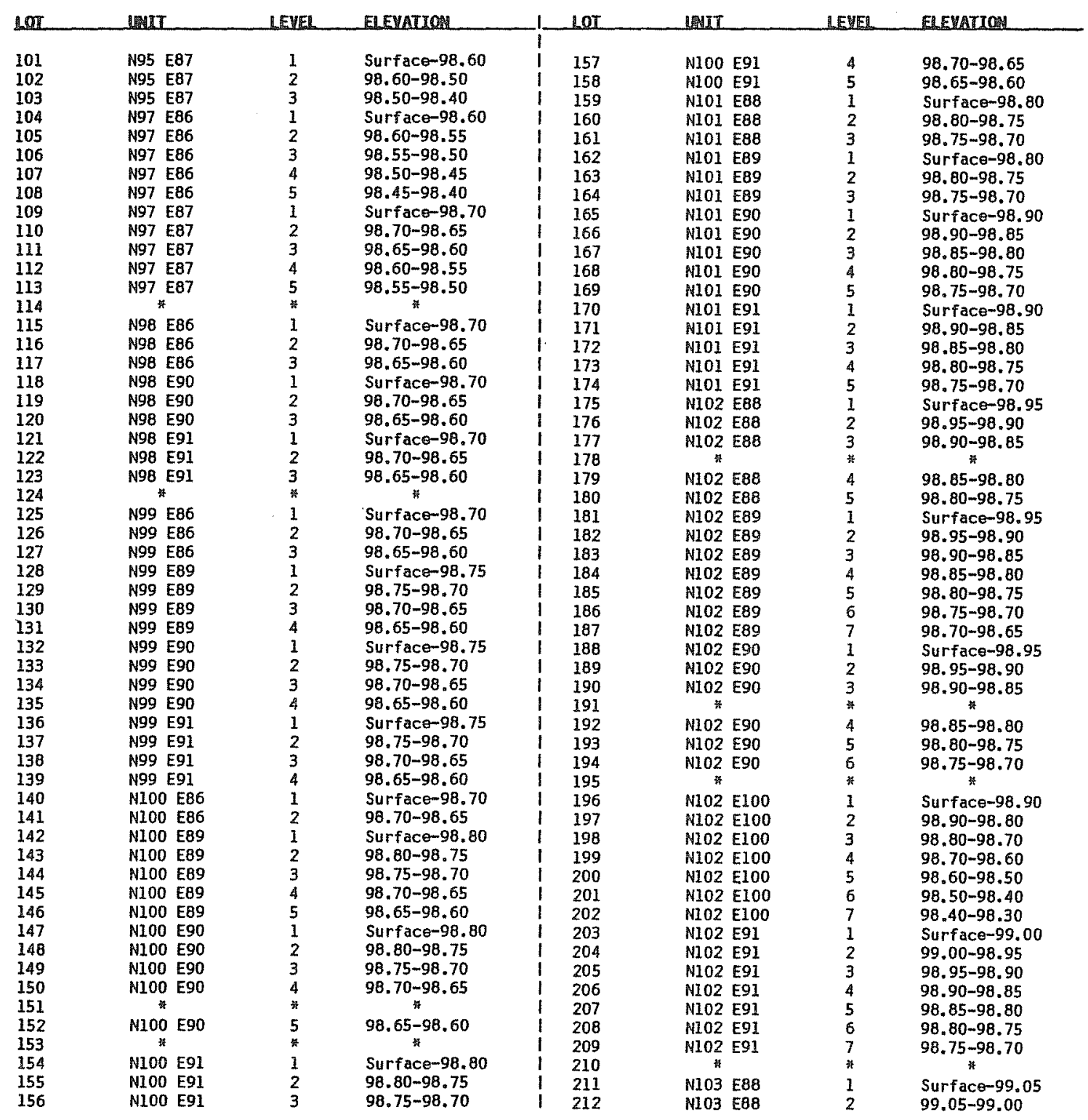


TABLE 47. (continued)

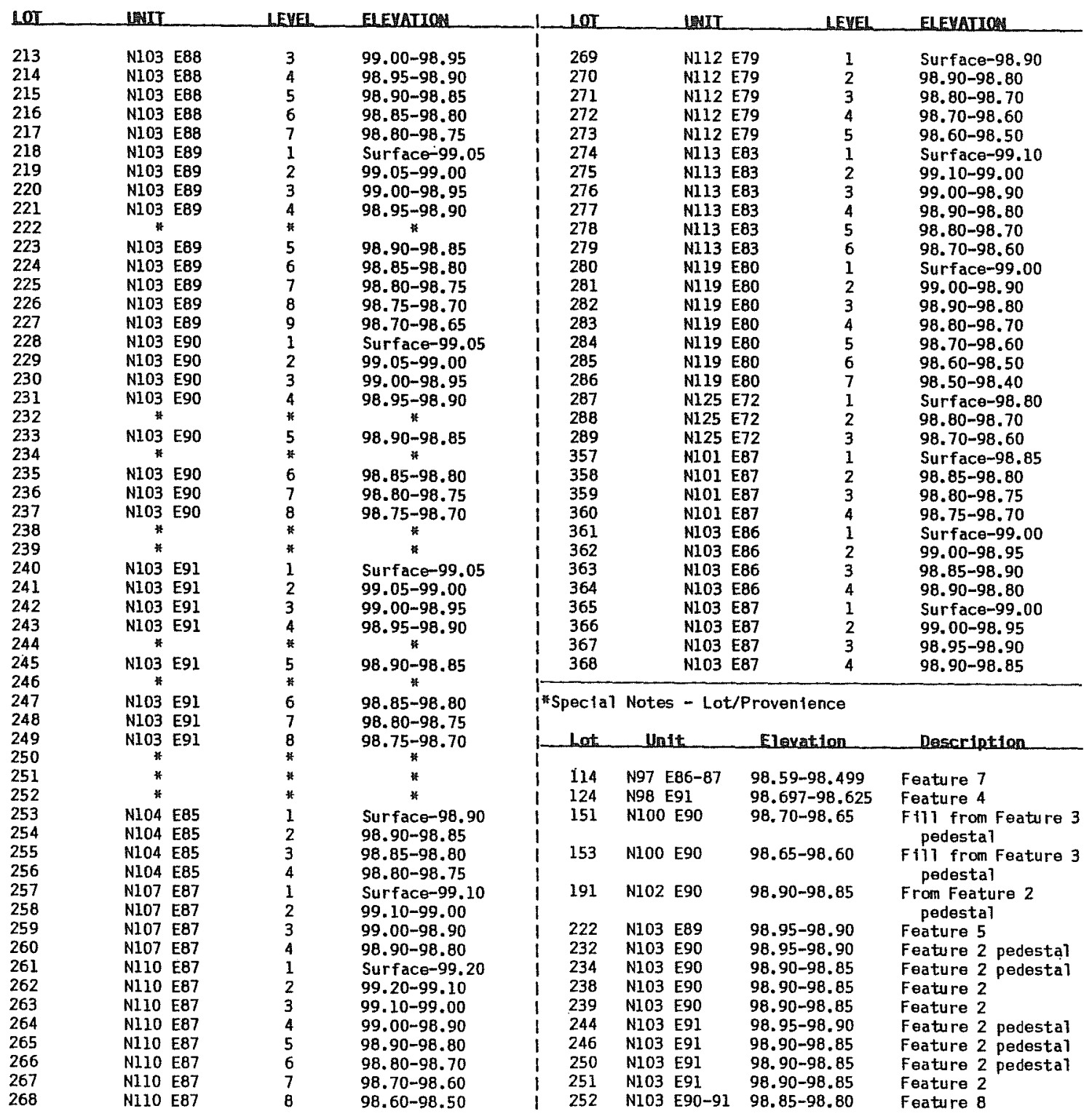


TABLE 48. PROVENIENCE BY LOT NUMBER FOR SITE 41 MC 296

\begin{tabular}{|c|c|c|c|c|c|c|c|}
\hline Lor & UNDT & LEVEL & ELEYAIION & LOI & UNII & LEVEL & ELEYATION \\
\hline 1 & Test Pit 1 & 1 & $0-10 \mathrm{~cm}$ & 77 & $\mathrm{~N} 1023 \mathrm{E985}$ & 8 & $98.80-98.70$ \\
\hline 2 & Test Pit 1 & 2 & $10-20 \mathrm{~cm}$ & 78 & N1023 E985 & 9 & $98.70-98.60$ \\
\hline 3 & Test Pit I & 3 & $20-30 \mathrm{~cm}$ & 79 & N1023 E986 & 1 & Surface -99.40 \\
\hline 4 & Test Pit 1 & 4 & $30-40 \mathrm{~cm}$ & 80 & N1023 E986 & 2 & $99.40-99.30$ \\
\hline 5 & Test Pit 1 & 5 & $40-50 \mathrm{~cm}$ & 81 & N1023 E986 & 3 & $99.30-99.20$ \\
\hline 6 & Test Pit I & 6 & $50-60 \mathrm{~cm}$ & 82 & $\mathrm{~N} 1023$ E986 & 4 & $99.20-99.10$ \\
\hline 7 & Test Pit 1 & 7 & $60-70 \mathrm{~cm}$ & 83 & * & * & * \\
\hline 8 & Test Pit 1 & 8 & $70-80 \mathrm{~cm}$ & 84 & NI023 E986 & 5 & $99.10-99.00$ \\
\hline 9 & Test Pit 1 & 9 & $80-90 \mathrm{~cm}$ & 85 & N1023 E986 & 6 & $99.00-98.90$ \\
\hline 10 & Test Pit 1 & 10 & $90-100 \mathrm{~cm}$ & 86 & N1023 E986 & 7 & $98.90-98.80$ \\
\hline 11 & Test Pit 1 & 11 & $100-110 \mathrm{~cm}$ & 87 & N1023 E986 & 8 & $98.80-98.70$ \\
\hline 12 & Test Pit 1 & 12 & $110-120 \mathrm{~cm}$ & 88 & NI023 E986 & 9 & $98.70-98.60$ \\
\hline 13 & Test Pit 1 & 13 & $120-130 \mathrm{~cm}$ & 89 & $\mathrm{~N} 1023 \quad \mathrm{E} 987$ & I & Surface-99.40 \\
\hline 14 & Test Pit I & 14 & $130-140 \mathrm{~cm}$ & 90 & N1023 E987 & 2 & $99.40-99.30$ \\
\hline 15 & Test Pit 2 & 1 & $0-10 \mathrm{~cm}$ & 91 & N1023 E987 & 3 & $99.30-99.20$ \\
\hline 16 & Test Pit 2 & 2 & $10-20 \mathrm{~cm}$ & 92 & N1023 E987 & 4 & $99.20-99.10$ \\
\hline 17 & Test Pit 2 & 3 & $20-30 \mathrm{~cm}$ & 93 & N1023 E987 & 5 & $99.10-99.00$ \\
\hline 18 & Test Pit 2 & 4 & $30-40 \mathrm{~cm}$ & 94 & N1023 E987 & 6 & $99.00-98.90$ \\
\hline 19 & Test Pit 2 & 5 & $40-50 \mathrm{~cm}$ & 95 & N1023 E987 & 7 & $98.90-98.80$ \\
\hline 20 & Test Pit 2 & 6 & $50-60 \mathrm{~cm}$ & 96 & NI023 E987 & 8 & $98.80-98.70$ \\
\hline 21 & Test Pit 2 & 7 & $60-70 \mathrm{~cm}$ & 97 & N1023 E987 & 9 & $98.70-98.60$ \\
\hline 22 & Test Pit 2 & 8 & $70-80 \mathrm{~cm}$ & 98 & NI024 E985 & 1 & Surface- 99.40 \\
\hline 23 & Test Pit 2 & 9 & $80-90 \mathrm{~cm}$ & 99 & N1024 E985 & 2 & $99.40-99.30$ \\
\hline 24 & * & * & * & 100 & N1024 E985 & 3 & $99.30-99.20$ \\
\hline 41 & N1022 E985 & 1 & Surface-99.40 & 101 & N1024 E985 & 4 & $99.20-99.10$ \\
\hline 42 & N1022 E985 & 2 & $99.40-99.30$ & 102 & NI024 E985 & 5 & $99.10-99.00$ \\
\hline 43 & N1022 E985 & 3 & $99.30-99.20$ & 103 & N1024 E985 & 6 & $99.00-98.90$ \\
\hline 44 & N1022 E985 & 4 & $99.20-99.10$ & 104 & $\mathrm{NIO24} \mathrm{E985}$ & 7 & $98.90-98.80$ \\
\hline 45 & N1022 E985 & 5 & $99.10-99.00$ & 105 & N1024 E985 & 8 & $98.80-98.70$ \\
\hline 46 & N1022 E985 & 6 & $99.00-98.90$ & 106 & NI024 E985 & 9 & $98.70-98.60$ \\
\hline 47 & N1022 E985 & 7 & $98.90-98.80$ & 107 & N1024 E986 & 1 & Surface -99.40 \\
\hline 48 & $\mathrm{~N} 1022 \mathrm{E} 985$ & 8 & $98.80-98.70$ & 108 & N1024 E986 & 2 & $99.40-99.30$ \\
\hline 49 & N1022 E985 & 9 & $98.70-98.60$ & 109 & N1024 E986 & 3 & $99.30-99.20$ \\
\hline 50 & N1022 E985 & 10 & $98.60-98.50$ & 110 & NIO24 E986 & 4 & $99.20-99.10$ \\
\hline 51 & N1022 E986 & I & Surface -99.40 & 111 & N1024 E986 & 5 & $99.10-99.00$ \\
\hline 52 & N1022 E986 & 2 & $99.40-99.30$ & 112 & N1024 E986 & 6 & $99.00-98.90$ \\
\hline 53 & N1022 E986 & 3 & $99.30-99.20$ & 113 & N1024 E986 & 7 & $98.90-98.80$ \\
\hline 54 & N1022 E986 & 4 & $99.20-99.10$ & 114 & N1024 E986 & 8 & $98.80-98.70$ \\
\hline 55 & N1022 E986 & 5 & $99.10-99.00$ & 115 & N1024 E986 & 9 & $98.70-98.60$ \\
\hline 56 & N1022 E986 & 6 & $99.00-98.90$ & 116 & N1024 E987 & 1 & Surface -99.40 \\
\hline 57 & N1022 E986 & 7 & $98.90-98.80$ & 117 & N1024 E987 & 2 & $99.40-99.30$ \\
\hline 58 & N1022 E986 & 8 & $98.80-98.70$ & 118 & N1024 E987 & 3 & $99.30-99.20$ \\
\hline 59 & N1022 E986 & 9 & $98.70-98.60$ & 119 & N1024 E987 & 4 & $99.20-99.10$ \\
\hline 60 & $N 1022 E 986$ & 10 & $98.60-98.50$ & 120 & N1024 E987 & 5 & $99.10-99.00$ \\
\hline 61 & N1022 E987 & 1 & Surface -99.40 & 121 & N1024 E987 & 6 & $99.00-98.90$ \\
\hline 52 & N1022 E987 & 2 & $99.40-99.30$ & 122 & N1024 E987 & 7 & $98.90-98.80$ \\
\hline 63 & N1022 E987 & 3 & $99.30-99.20$ & 123 & N1024 E987 & 8 & $98.80-98.70$ \\
\hline 64 & N1022 E987 & 4 & $99.20-99.10$ & 124 & N1024 E987 & 9 & $98.70-98.60$ \\
\hline 65 & N1022 E987 & 5 & $99.10-99.00$ & 125 & N1025 E997 & 1 & Surface -99.50 \\
\hline 66 & $\mathrm{~N} 1022 \mathrm{E} 987$ & 6 & $99.00-98.90$ & 125 & N1025 E997 & 2 & $99.50-99.40$ \\
\hline 67 & $\mathrm{~N} 1022$ E987 & 7 & $98.90-98.80$ & 127 & NI025 E997 & 3 & $99.40-99.30$ \\
\hline 68 & N1022 E987 & 8 & $98.80-98.70$ & 128 & N1025 E997 & 4 & $99.30-99.20$ \\
\hline 69 & N1022 E987 & 9 & $98.70-98.60$ & 129 & $\mathrm{~N} 1025$ E997 & 5 & $99.20-99.10$ \\
\hline 70 & $\mathrm{~N} 1023 \mathrm{E} 985$ & I & Surface -99.40 & 130 & N1025 E997 & 6 & $99.10-99.00$ \\
\hline 71 & N1023 E985 & 2 & $99.40-99.30$ & 131 & $\mathrm{~N} 1025 \mathrm{E997}$ & 7 & $99.00-98.90$ \\
\hline 72 & N1023 E985 & 3 & $99.30-99.20$ & 132 & $\mathrm{~N} 1025 \mathrm{E} 998$ & 1 & Surface -99.50 \\
\hline 73 & $N 1023 E 985$ & 4 & $99.20-99.10$ & 133 & N1025 E998 & 2 & $99.50-99.40$ \\
\hline 74 & $\mathrm{~N} 1023$ E985 & 5 & $99.10-99.00$ & 134 & N1025 E998 & 3 & $99.40-99.30$ \\
\hline 75 & N1023 E985 & 6 & $99.00-98.90$ & 135 & N1025 E998 & 4 & $99.30-99.20$ \\
\hline 76 & NI023 E985 & 7 & $98.90-98.80$ & 136 & N1025 E998 & 5 & $99.20-99.10$ \\
\hline
\end{tabular}


TABLE 48. (continued)

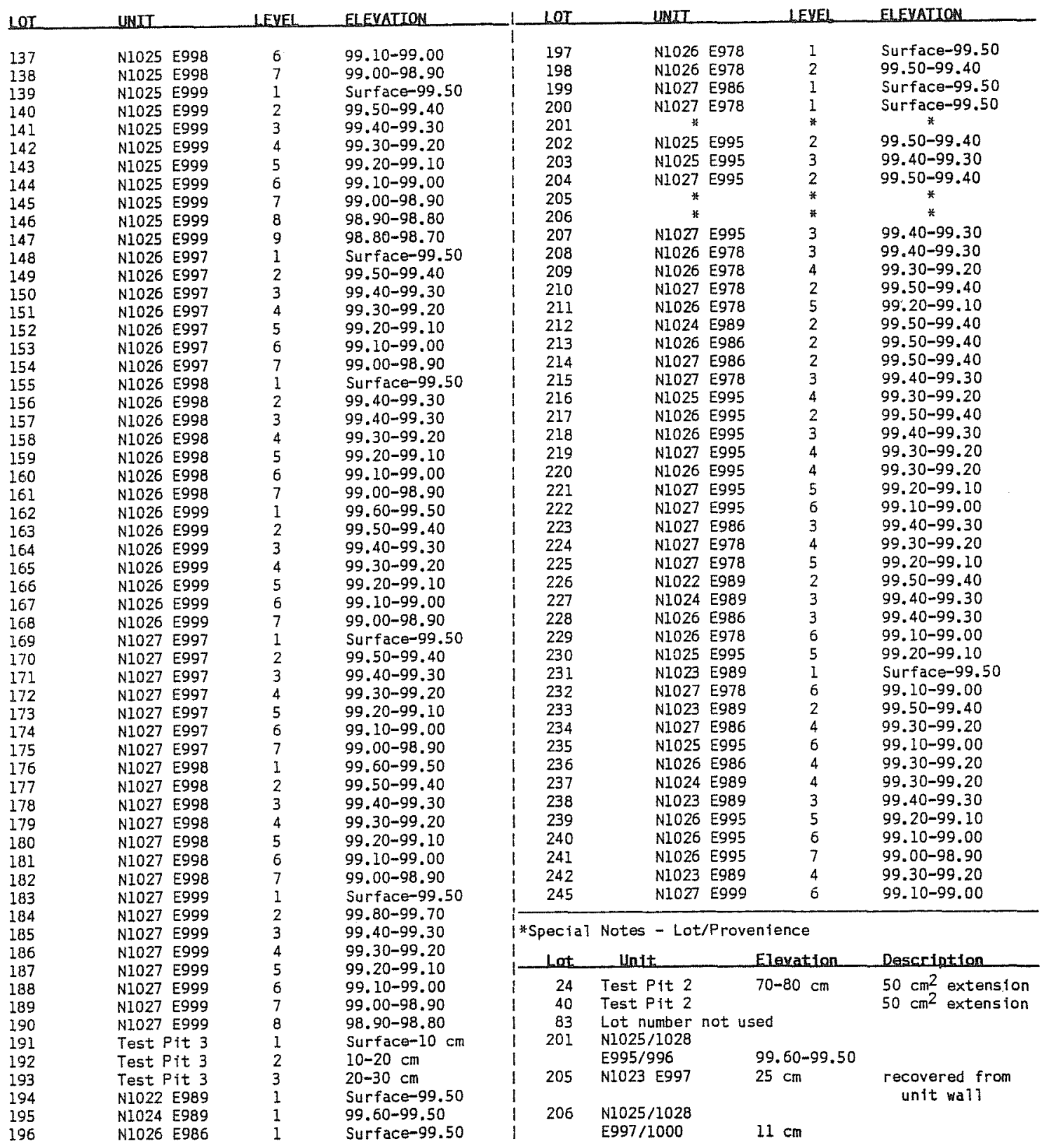




\section{REFERENCES CIIED}

Assad, C. and D. L. Carlson

n.d. Osteological Identification of the Eastern and Desert Cottonta17. Manuscript on file, Department of Anthropology, Texas A\&M University, College Station.

Behrensmeyer, $A_{0} K_{0}$ and $A_{0} P_{0} H i 11$

1980 Fossils in the Making: Vertebrate Taphonony and Paleocology. The University of Chicago Press, Chicago.

Binford, L. R。

1981 Bones: Ancjent Men and Modern Myths. Academic Press, New York.

BTair, W. F。

1950 The Biotic Provinces of Texas. The Texas Journal of Science 2:93-117.

1952 Mamma $7 s$ of the Tamaulipan Biotic Province in Texas. The Texas Journal of Science $4: 230-250$.

Blair, W. F., A. P. Blair, P. Brodkorb, F. R. Cagle, and G. A. Moore

1968 Vertebrates of the United States. McGraw-Hill Book Company, Inc., New York.

Brain, C. K.

1981 The Hunters or the Hunted? An Introduction to African Cave Taphonomy. The University of Chicago Press, Chicago.

Campbe11, T. N. and T. J. Campbel1

1981 Historic Indian Groups of Choke Canyon Reservoir and Surrounding Area, Southern Texas. Center for Archaeological Research. The University of Texas at San Antonio, Choke Canyon Series 1.

Collins, M. B., T. R. Hester, and Fo Weir

1969 Two Prehistoric Cemetery Sites in the Lower Rio Grande Val ley of Texas. Part 1: The Floyd Morris Site (4I CF 2) a Prehistoric Cemetery Site in Cameron County. Texas. Bulletin of the Texas Archeological Society 40:119-146. 
Conant, R.

1975 A Field Guide to Reptiles and Amphibians of Eastern and Central North America. Houghton Miffl in Company, Boston.

Davis, W. B.

1974 Mammals of Texas. Texas Parks and Wildi ife Department, Bul 1 etin 41, Austin, Texas.

DeMarcay, G. B. and D. G. Steele

1986 The Value of Fine Screening on Inland Based Hunter-Gatherer Habitation Sites. Appendix VI in Archaeological Investigations at 41 LK 201, Choke Canyon Reservoir, Southern Texas, by C. L. Highley. Center for Archaeological Research. The University of Texas at San Antonio, Choke Canyon Series 11.

Dibble, D. S.

1968 Part I: Archeology. In Bonfire Shelter: A Stratified Bison Kill Site, Val Verde County, Texas, by D. S. Dibble and D. Lorrain. Texas Memorial Museum, Miscell 1 aneous Papers 1, Austin.

Dillehay, T. D.

1974 Late Quaternary Bison Population Changes on the Southern Plains. Plains Anthropologist 19(65):180-196.

Grayson, D. K.

1984 Quantitative Zooarchaeology: Topics in the Analysis of Archaeological Faunas. Academic Press, New York.

$H a 11, E . R$.

1981 The Mammals of North America. John Wiley and Sons, New York. Hester, T. R.

1969 Human Bone Artifacts from Southern Texas. American Antiquity $34(3): 326-328$.

1975a The Natural Introduction of Mollusca in Archaeological Sites: An Example from Southern Texas. Journal of Field Archaeology $2: 273-274$.

1975b Late Prehistoric Cultural Patterns Along the Lower Rio Grande of Texas. Bulletin of the Texas Archeological Society 46:107125. 
Hester (continued)

1978 Prehistoric Subsistence and Settlement Systems on the Rio Grande Plain. Southern Texas. In Background to the Archaeology of Chaparrosa Ranch, Southern Texas, by $T_{0} R_{0}$ Hester:37-39. Center for Archaeological Research, The University of Texas at San Antonio, Special Report 6(1).

1980 Digging Into South Texas Prehistory: A Guide for Amateur Archaeologists. Corona Publishing Company, San Antonio, Texas.

Hester, T. R. and T. C. Hill, Jro

1971 An Initial Study of a Prehistoric Ceramic Tradition in Southern Texas. Plains Anthropologist 16(52):195-203.

1972 Prehistoric Occupation at the Holdsworth and Stewart Sites on the Rio Grande Plain of Texas. Bulletin of the Texas Archeological Society $43: 33-75$.

1975 Some Aspects of Late Prehistoric and Protohistoric Archaeology in Southern Texas. Center for Archaeological Research, The University of Texas at San Antonio, Speciai Report 1.

Hester, T. R, , T. C. Hill, Jr., D. Gifford, and S. Holbrook

1975 Archaeological Salvage at Site 41 ZV 152, Rio Grande Plain of Texas. The Texas Journal of Science $26(1-2): 223-228$.

Hulbert, R. C., Jr.

1979 Linear Discriminant Analysis and Variability of Pleistocene and Holocene Leporidae of Texas. Unpublished Master's thesis, University of Texas at Austin.

Lord, K. J.

1984 The Zooacheology of Hinds Cave, Val Verde County, Texas. Department of Anthropology. Texas A\&M University, College Station.

Lundel ius, E. L., Jr.

1972 Fossil Vertebrates from the Late Pleistocene Ingleside Fauna, San Patricio County, Texas. Bureau of Economic Geology, The University of Texas at Austin, Reports of Investigations 77:174 .

Lynott, M. J。

1979 Prehistoric Bison Populations of North Central Texas. Bulletin of the Texas Archeological Society $50: 89-102$. 
Murray, H.D.

1982 An Analysis of Unionoids (Freshwater Musse1s) Recovered in Phase I Archaeological Investigations at Choke Canyon Reservoir. In Archaeological Investigations at Choke Canyon Reservoir, South Texas: The Phase I Findings, by G. D. Hal1, S. L. B1ack, and C. Graves:541-555. Center for Archaeological Research. The University of Texas at San Antonio, Choke Canyon Series 5.

Robbins, C. S., B. Brunn, and H. S. Zim

1966 A Guide to Field Identification Birds of North America. Golden Press, New York.

Schmidly, D. J.

1977 The Mamma 15 of Trans-Pecos Texas. Texas A\&M University Press, College Station, Texas.

1983 Texas Mamma 15 East of the Balcones Fault Zone. Texas A\&M University Press, College Station, Texas.

Shipman, P.

1981 Life History of a Fossi1. Harvard University Press, Cambridge, Massachusetts.

Steele, D. G.

1975 Analysis of a Human Tooth. Appendix in A Prehistoric Athapaska Campsite in Northwestern A1berta, by $A_{0} K_{0}$ Bryan and G. Conaty:88. The Western Canadian Journal of Anthropology 5.

1986 Analysis of Vertebrate Faunal Remains From 41 LK 201, Live Oak County, Texas. Appendix $V$ in Archaeological Investigations at 41 LK 201, Choke Canyon Reservoir, Southern Texas, by C. L. Highley. Center for Archaeological Research. The University of Texas at San Antonio, Choke Canyon Series 11.

Steere, D. G. and E. R. Mokry

n.d. Archeological Investigations of Seven Prehistoric Sites Along Oso Creek. Nueces County, Texas. Bulletin of the Texas Archeologica Society. In press. 


\title{
APPENDIX IV. \\ COMPUTER DOCUREENTATION: THE PHASE II PRIPEER
}

\author{
Elizabeth G. Frkuska
}

\begin{abstract}
Appendix VI in "Archaeological Investigations at Choke Canyon Reservoir, South Texas: The Phase I Findings" (Ha 11, Black, and Graves 1982) describes the development of the NRP project computer based data retrieval system. The section includes word definitions, specific information on file structures, data quality control, management programs, and storage or retrieval parameters. The purpose of this guide is to act as a supplement to be utilized in conjunction with that of Phase I. The Phase II guide will explain the data structure, system programs, and storage or retrieval procedures.
\end{abstract}

\section{DATA OUALTIY CONTROA}

During the course of the Phase I computer study we were able to determine changes that would be advantageous for the Phase II study, a though the basic 80 column card image remained the same as Phase I (see Gunn, Frkuska, and Mahula 1982:556, NRP System Data File--File Structure section). As a result the data collection forms have been slightly amended (Fig. 102). These changes aided in quality control. Data quality control remained high during Phase II since a consistent few performed the analysis and recording tasks. Lynn Highley supervised all laboratory analysis. Biasing should be minima1. I supervised al1 data entry and verification procedures. Darrel Baker aided in the data entry and verification process.

\section{SYSTEMS PROGRAMS}

Phase II continued to utilize the main system programs written by Dr. Joel Gunn for Phase I. I have augmented these programs with specific Phase II FORTRAN programs. These programs are available upon request to the CAR-UTSA. In addition to these programs I continued to utilize SPSS standard statistical programs for numerical tallies.

After the data had been keypunched and verified it was indexed (see Gurn, Frkuska, and Mahula 1982:572). After these steps are accomplished the data file is ready to be used with the main system program. NRP FORTRAN. The system program requires a parameters file which contains all requested data from a given site. For examp le, it might be necessary to examine whether bone occurred with bifaces, grinding stone, or manos at a given area at site 41 LK 201. We will call this Studyl. Studyl information is requested through the parameters file Study l Param (Fig。 103). Once the data file is extracted it can be used alone as a table for a report by utilizing a heading routine Studyl FORTRAN (Fig. 104) or as a data set for a SPSS program Studyl SPSS (Fig. 105). Just from the extraction of four variables several questions can be answered. For example, are proximal fragments of bifaces more commoniy found with bone fragments or do bifaces of any kind occur with 
MATERIAL ANALYSIS FOPM

CHOKE CANYON PROJECT

PHASE II
ANALYST

DATE

ANALYSIS TIME
UNIOUE NO.

UNIT

LEVEL $\begin{array}{cc} & F \\ & 0 \\ I & R \\ T & M \\ E & A \\ M & T\end{array}$

1. I2

2. I9

Q 3 CARD NO.

3. I5

UNIQUE NO.

4. I5 _. $\ldots$ N COORDINATE _. . - E COORDINATE

1. 12

e 4 Card No.

2. I9 Unique No.

BOCK.

\begin{tabular}{|c|c|c|}
\hline 3. & I7 & $\underline{0} \mathbb{1} \ldots \ldots$ Tuff Count \\
\hline 4. & I7 & 002 - - - Tuff Weight \\
\hline 5. & 17 & $003----$ Pebble Count \\
\hline 6. & I7 & $004---$ Pebble Welght \\
\hline 7. & I7 & Q $Q 5$ - - - Sandstone Count \\
\hline 8. & I7 & $0 \unrhd 6 \ldots$ \\
\hline 9. & I7 & Q $\varrho I \ldots-\ldots$ Fire Fractured Ct. \\
\hline 10. & I7 & Q 0 \& _ _ _ Fire Fractured Wt. \\
\hline 11. & I7 & Q $02 \ldots \ldots$ Cobbte Count \\
\hline 2. & I7 & Misc. Rock Count \\
\hline
\end{tabular}

MUSSEL SHELL

13. I7 Q121_-_ Umbo Count

14. I7 $212 \ldots--$ Shell/Umbo Wt. SNAILS

15. I7 $013 \ldots \ldots$ Aquatic Count

16. 17 $014 \ldots \ldots$ Rabdotus $C t$.

17. I7 $215 \ldots \ldots$ Polygyra $C t$.

18. I7 $016 \ldots \ldots$ Helicina Ct.

19. I7 017 L $\ldots$ Praticolella $C t$.

20. I7 018 으. - Succinea Ct.

BONE

21. I7 Q19_-_- Fragment Ct.

22. I7 $020--\ldots$ Total Weight $\begin{array}{cc} & F \\ & 0 \\ I & R \\ T & M \\ E & A \\ M & T\end{array}$

5. 12

6. I6

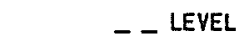

7. 16

8. 13

_ _ _ _ _ TOP ELEVATION

_ _ _ - BOTTOM ELEVATION

_ _ - UNIT SIZE

MARINE SHELLL

23. 17

Q 2 1 - - Count ABORIGINAL CERAMICS

24. I7 $022 \ldots-$ Count

BIFACES

25. I7 $223 \ldots \ldots$ Whole Count

26. $17 \quad 024 \ldots-$ Proximal Count

27. I7 $225 \ldots \ldots$ Medfal Count

28. I7 $226 \ldots--D 1 s t a 1$ Count

29. I7 12 I__- Lateral Count

30. I7 $\ell 2$ 요 - - Misc. Fragment Count UNIEACES

31. I7 $022 \ldots \ldots$ Count

HAMMERSTONES

32. 17

Q 3 Q $\ldots$ - Count

GROUND STONE

33. I7 $231 \ldots \ldots$ Grooved Abrader

34. I7 $232 \ldots \ldots$ Grinding $57 a b$

35. I7 $033 \ldots \ldots$ Mano

36. I7 $234 \ldots \ldots$ Gypsun Rods

CORES

37. I7 $235---$ Count

CHARCOAL

38. $17 \quad 036---1=p r e s e n t ;$ 


\section{ELAKES}

\begin{tabular}{|c|c|}
\hline 39. I7 & 은 1 - - Primary Total \\
\hline 40. 17 & $\begin{array}{l}\text { Q } 3 \text { 8 } 8--- \text { Primary Corticate } \\
\text { Plat. }\end{array}$ \\
\hline 41. 17 & Q $329---\begin{array}{l}\text { Primary Corticate } \\
\text { Plat. Modified }\end{array}$ \\
\hline 42. 17 & $\begin{array}{l}0 \leq 0--- \text { Primary Corticate } \\
\text { Plat. Trimmed }\end{array}$ \\
\hline 43. 17 & 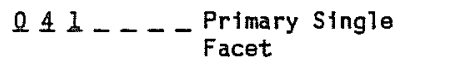 \\
\hline 44. I7 & $\underline{0} 42 \ldots--\begin{array}{l}\text { Primary Single } \\
\text { Facet Modiffed }\end{array}$ \\
\hline 45. I7 & $\begin{array}{l}Q 43-D-\text { Primary Single } \\
\text { Facet Trimmed }\end{array}$ \\
\hline 46. 17 & $\underline{0} 44 \ldots--$ Primary-Other \\
\hline 47. I7 & Q4 5 - - - Primary-0ther \\
\hline & $046---$ Primary-Other $_{\text {Trimmed }}$ \\
\hline 49. $I 7$ & Q 4 I _ $\ldots$ Secondary Total \\
\hline 50. I7 & $\begin{array}{l}048--- \text { Secondary Cortficate } \\
\text { Plat. }\end{array}$ \\
\hline
\end{tabular}

51. 17

52. 17

Q 4 2 - - - Secondary Cortlcate

2 1 - - - Plat. Trimed

53. I7

Q 5 I - - Secondary Singlo

54. 17

Q 52 - $--\frac{\text { Secondary Single }}{\text { Facet Mod Ifled }}$

55. 17

$023---$ Secondary Single

56. I7

Q 5 4 4 - - Secondary Sma11 Multifacet

57. I7

Q 55 _. - Secondary Smal1 Multifacet Modified

58. I7

Q 5 6 _ - - Secondary Smal1 Multifacet Trimned

59. I7

Q 5 I _. - Secondary Large Multifacet

60. 17

모요 8 _. - Secondary Large Multifacet Modifled

61. 17

Q 5 . 9 - Secondary Large

62. I7

으으 으 _ _

63. I7

Q 6 I _- - - Secondary Lipped

64. I7
65. 17

66. 17

67. 17

68. 17

69. 17

70. 17

71. 17

72. 17

72. 17

73. 17

74. 17

(75.

75. 17

76. 17

77. I7

78. 17

79. 17

80. 17

81. 17

82. I7

83. 17

84. 17

85. 17

86. 17

87. 17

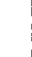

i

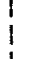

i.

i 91.17
Q 6 프 - - Tertiary Total

으 도 4 - - Tertlary Single

으도 5 - - - Tertiary Single

2드 6 - - Tertfary Single

Q 61 . - - Tertiary Sma11

으을 - - Tertiary Small

Multifacet Modifled

Q 6 2 - - - Tertiary Small

Multifacet Trimmed

Q 7 으 - - Tertfary Largo

Multifacet

Q 71 - - - Tertfary Large

Multifacet Modified

Q I 2 _ - - Tertfary Large

Multifacet Trimed

Q $I 3$ _. - Tertiary Lipped

Q 74 - - - Tertiary Lippod Q 15 - - - Tertiary Lipped

CHIPS

Q 16 _. - Chip Total

Q I I _ - Chip Corticate

Q 7 B - - - Corticate Modified

Q I 2 - - - Chip Corticate

Q 8 0 - - Chip Partialiy

Q 8 I _ - Chtp Partially Corticate Modified

Q 8 2 - . - Chip Partially Corticate Trimmod

Q 13 . - - Chip Decorticate

Q 8 4 _. Chip Decorticate

2 8 5 - - - Chip Decorticate

\section{CHUNKS}

88. 17 요 요 6 - - Chunks Total

89. I7 $\Omega$ 8 $7 \ldots \ldots$ Corticate

90. I7 $Q 888$ 8 _- Partially Corticate

Figure 102. (continued) 
FILE: STUDY1 PARAM A U T S A SAN ANTONIO TX 78285 UTSA4341

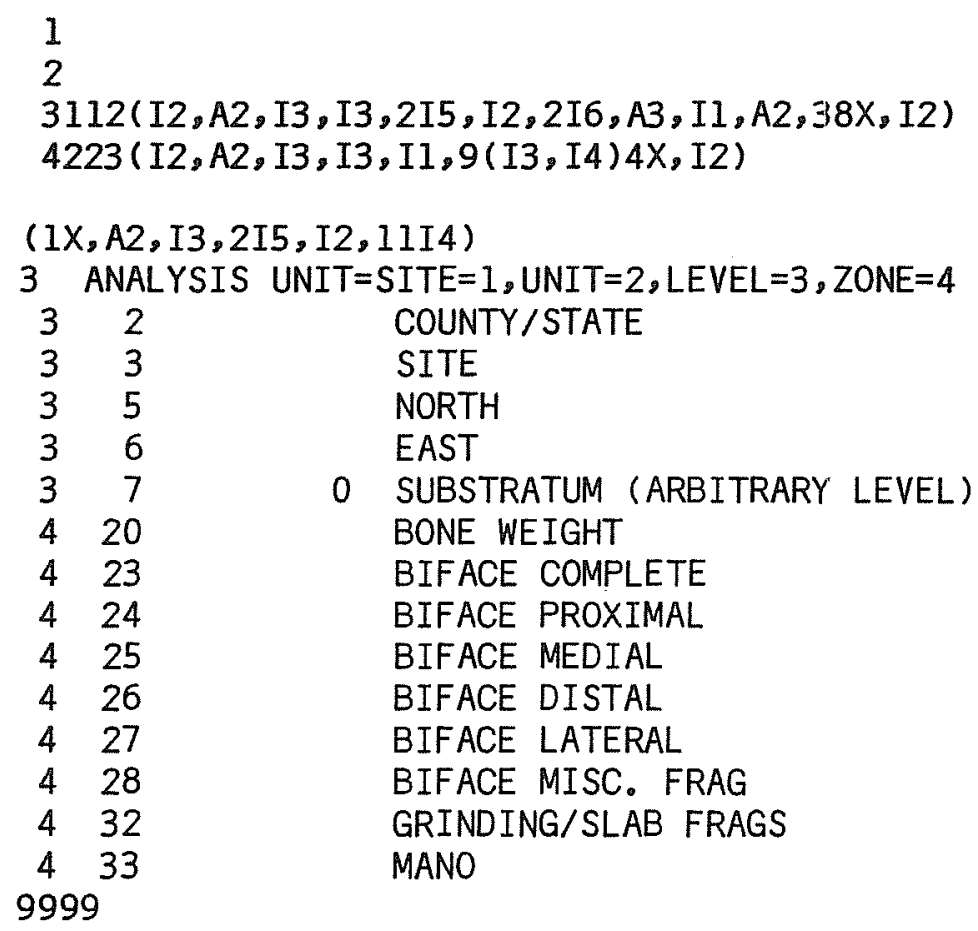

Figure 103. An Example of a Parameters File Used in Conjunction with NRP's Main System Program to Generate Data Sets. 
DISTRIBUTION STUDY

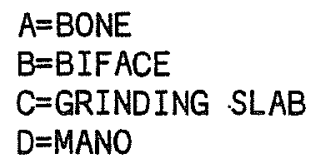

$\begin{array}{lllrrrrl}\text { SITE } & \text { NORTH } & \text { EAST } & \text { LEV } & \text { A } & \text { B } & C & \text { D } \\ \text { LK201 } & 490 & 1042 & 1 & 0 & 0 & 0 & 0 \\ \text { LK201 } & 490 & 1042 & 2 & 2 & 0 & 0 & 0 \\ \text { LK201 } & 490 & 1042 & 3 & 2 & 0 & 0 & 0 \\ \text { LK201 } & 490 & 1043 & 1 & 1 & 0 & 0 & 0 \\ \text { LK201 } & 490 & 1043 & 2 & 1 & 0 & 0 & 0 \\ \text { LK201 } & 490 & 1043 & 3 & 4 & 0 & 0 & 0 \\ \text { LK201 } & 490 & 1043 & 4 & 7 & 0 & 0 & 0 \\ \text { LK201 } & 490 & 1043 & 5 & 16 & 1 & 0 & 0 \\ \text { LK201 } & 490 & 1043 & 6 & 4 & 0 & 0 & 0 \\ \text { LK201 } & 490 & 1043 & 7 & 1 & 0 & 0 & 0 \\ \text { LK201 } & 490 & 1043 & 8 & 6 & 0 & 0 & 0 \\ \text { LK201 } & 490 & 1043 & 9 & 2 & 0 & 0 & 0 \\ \text { LK201 } & 490 & 1043 & 10 & 4 & 2 & 0 & 0 \\ \text { LK201 } & 490 & 1043 & 11 & 17 & 0 & 0 & 0 \\ \text { LK201 } & 490 & 1043 & 12 & 35 & 0 & 0 & 0 \\ \text { LK201 } & 490 & 1043 & 13 & 12 & 0 & 0 & 0 \\ \text { LK201 } & 490 & 1043 & 14 & 2 & 0 & 0 & 0 \\ \text { LK201 } & 490 & 1043 & 15 & 3 & 0 & 0 & 0 \\ \text { LK201 } & 490 & 1043 & 16 & 3 & 0 & 0 & 0 \\ \text { LK201 } & 490 & 1043 & 17 & 3 & 0 & 0 & 0 \\ \text { LK201 } & 490 & 1043 & 18 & 5 & 0 & 0 & 0 \\ \text { LK201 } & 490 & 1043 & 19 & 4 & 0 & 0 & 0 \\ \text { LK201 } & 490 & 1044 & 1 & 10 & 0 & 0 & 0 \\ \text { LK201 } & 490 & 1044 & 2 & 1 & 0 & 0 & 0 \\ \text { LK201 } & 490 & 1044 & 3 & 1 & 0 & 0 & 0 \\ \text { LK201 } & 490 & 1044 & 4 & 1 & 0 & 0 & 0 \\ \text { LK201 } & 490 & 1044 & 5 & 1 & 0 & 0 & 0 \\ \text { LK201 } & 490 & 1044 & 6 & 10 & 0 & 0 & 0 \\ \text { LK201 } & 490 & 1044 & 7 & 10 & 0 & 0 & 0 \\ \text { LK201 } & 490 & 1044 & 8 & 2 & 0 & 0 & 0 \\ \text { LK201 } & 490 & 1044 & 9 & 1 & 0 & 0 & 0 \\ \text { LK201 } & 490 & 1044 & 10 & 2 & 1 & 0 & 0 \\ \text { LK201 } & 490 & 1044 & 11 & 1 & 0 & 0 & 0 \\ \text { LK201 } & 490 & 1044 & 12 & 1 & 1 & 0 & 0 \\ \text { LK201 } & 490 & 1044 & 13 & 0 & 0 & 0 & 0 \\ \text { LK201 } & 490 & 1044 & 14 & 1 & 0 & 0 & 0 \\ \text { LK201 } & 490 & 1044 & 15 & 1 & 0 & 0 & 0 \\ \text { LK201 } & 490 & 1044 & 16 & 1 & 0 & 0 & 0 \\ \text { LK201 } & 490 & 1044 & 17 & 0 & 0 & 0 & 0 \\ \text { LK201 } & 490 & 1044 & 18 & 1 & 0 & 0 & 0 \\ \text { LK201 } & 490 & 1044 & 19 & 0 & 0 & 0 & 0 \\ \text { LK201 } & 491 & 1042 & 1 & 1 & 0 & 0 & 0 \\ \text { LK201 } & 491 & 1042 & 2 & 12 & 0 & 1 & 0 \\ \text { LK201 } & 491 & 1042 & 3 & 126 & 0 & 0 & 0 \\ \text { LK201 } & 491 & 1043 & 1 & 0 & 0 & 0 & 0\end{array}$

Figure 104. An Example of a Table That Can be Generated Utilizing the NRP Data Based Computer System. 


\begin{tabular}{|c|c|c|c|c|c|c|c|c|c|c|c|c|c|c|}
\hline \multirow{2}{*}{\multicolumn{3}{|c|}{$\begin{array}{l}\text { FILE: STUDYI } \\
\text { VARIABLE LIST }\end{array}$}} & SPSS & A & \multicolumn{3}{|c|}{ U T S A } & \multicolumn{2}{|c|}{ SAN ANTONIO } & \multicolumn{2}{|c|}{ TX 78285} & \multicolumn{3}{|c|}{ UTSA4341 } \\
\hline & & & \multicolumn{12}{|c|}{$\begin{array}{l}\text { DSIT, SITE, NORTH, EAST, STRAT, TUFF, SAND, FIRE, UMBO, MUSS, RAB, } \\
\text { BONE, MAR, ABORC, BIFI, BIF 2, BIF3, BIF } 4 \text {, BIF5, BIF6, GRAB, GRSL, } \\
\text { MANO, GYRO, CORES, PRIM, SEC, TERT }\end{array}$} \\
\hline \multicolumn{3}{|c|}{ INPUT MEDIUM } & \multicolumn{12}{|l|}{ CARD } \\
\hline \multirow{2}{*}{\multicolumn{3}{|c|}{$\begin{array}{l}\text { INPUT FORMAT } \\
N \text { OF CASES }\end{array}$}} & \multicolumn{12}{|c|}{ FIXED $\quad(1 X, A 2$} \\
\hline & & & \multirow{2}{*}{\multicolumn{12}{|c|}{$\mathrm{BIFACE}=\mathrm{BIF} 1+\mathrm{BIF} 2+\mathrm{BIF} 3+\mathrm{BIF} 4+\mathrm{BIF} 5+\mathrm{BIF} 6$}} \\
\hline \multicolumn{3}{|c|}{ COMPUTE } & & & & & & & & & & & & \\
\hline \multicolumn{15}{|c|}{ READ INPUT DATA } \\
\hline LK201 & 490 & 10421 & 0 & 0 & 1 & 2 & 2 & 10 & 0 & 0 & 0 & 0 & 0 & \\
\hline LK201 & 490 & $1042 I$ & 0 & 0 & 0 & 0 & 0 & 0 & 0 & 0 & 0 & 0 & 0 & 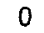 \\
\hline LK201 & 490 & 10422 & 5 & 0 & 1 & 3 & 18 & 87 & 2 & 0 & 0 & 0 & 0 & \\
\hline LK2OI & 490 & 10422 & 0 & 0 & 0 & 0 & 0 & 0 & 0 & 0 & 0 & 0 & 2 & 2 \\
\hline LK201 & 490 & 10423 & 0 & 0 & 3 & 3 & 21 & 78 & 2 & 0 & 1 & 0 & 0 & \\
\hline LK20I & 490 & 10423 & 0 & 0 & 0 & 0 & 0 & 0 & 0 & 0 & 0 & 0 & 2 & 3 \\
\hline LK201 & 490 & 10431 & 0 & 0 & 2 & 0 & 3 & 1 & 1 & 0 & 0 & 0 & 0 & \\
\hline LK201 & 490 & 10431 & 0 & 0 & 0 & 0 & 0 & 0 & 0 & 0 & 0 & 0 & 1 & 0 \\
\hline LK201 & 490 & 10432 & 18 & 0 & 1 & 2 & 17 & 34 & 1 & 0 & 0 & 0 & 0 & \\
\hline LK20I & 490 & 10432 & 0 & 0 & 0 & 0 & 0 & 0 & 0 & 0 & 0 & 0 & 1 & 2 \\
\hline LK201 & 490 & 10433 & 17 & 1 & 23 & 8 & 43 & 285 & 4 & 0 & 0 & 0 & 0 & \\
\hline LK2OI & 490 & 10433 & 0 & 0 & 0 & 0 & 0 & 0 & 0 & 0 & 0 & 2 & 1 & \\
\hline LK201 & 490 & 10434 & 33 & 83 & 74 & 9 & 76 & 0 & 7 & 0 & 0 & 0 & 0 & \\
\hline LK20I & 490 & 10434 & 0 & 0 & 0 & 0 & 0 & 0 & 0 & 0 & 1 & 0 & 5 & \\
\hline LK20I & 490 & 10435 & 43 & 0 & 1 & 4 & 39 & 1 & 16 & 0 & 0 & 0 & 1 & \\
\hline LK201 & 490 & 10435 & 0 & 0 & 0 & 0 & 0 & 0 & 0 & 0 & 0 & 0 & 1 & 5 \\
\hline LK201 & 490 & 10436 & 14 & 0 & 39 & 5 & 41 & 0 & 4 & 0 & 0 & 0 & 0 & \\
\hline LK20I & 490 & 10436 & 0 & 0 & 0 & 0 & 0 & 0 & 0 & 0 & 0 & 0 & 1 & 2 \\
\hline LK20I & 490 & 10437 & 29 & 0 & 1 & 4 & 39 & 0 & 1 & 0 & 0 & 0 & 0 & \\
\hline LK20I & 490 & 10437 & 7 & 0 & 0 & 0 & 0 & 0 & 0 & 0 & 0 & 0 & 1 & 2 \\
\hline LK201 & 490 & 10438 & 0 & 0 & 2 & 2 & 9 & 0 & 6 & 0 & 0 & 0 & 0 & \\
\hline LK20I & 490 & 10438 & 0 & 0 & 0 & 0 & 0 & 0 & 0 & 0 & 0 & 0 & 0 & \\
\hline LK20I & 490 & 10439 & 27 & 0 & 4 & 4 & 30 & 13 & 2 & 0 & 0 & 0 & 0 & \\
\hline LK20I & 490 & 10439 & 0 & 0 & 0 & 0 & 0 & 0 & 0 & 0 & 0 & 0 & 1 & 1 \\
\hline LK20I & 490 & 104310 & 12 & 0 & 17 & 2 & 9 & 15 & 4 & 0 & 0 & 0 & 1 & \\
\hline LK20I & 490 & 104310 & 0 & 1 & 0 & 0 & 0 & 0 & 0 & 0 & 1 & 0 & 2 & - \\
\hline LK20I & 490 & 104311 & 0 & 0 & 12 & 29 & 151 & 18 & 17 & 0 & 0 & 0 & 0 & \\
\hline LK20I & 490 & 104311 & 0 & 0 & 0 & 0 & 0 & 0 & 0 & 0 & 2 & 5 & 10 & \\
\hline LK201 & 490 & 1.04312 & 379 & 0 & 108 & 17 & 58 & 29 & 35 & 0 & 0 & 0 & 0 & \\
\hline LK20I & 490 & 104312 & 0 & 0 & 0 & 0 & 0 & 0 & 0 & 0 & 2 & 4 & 15 & \\
\hline LK20I & 490 & 104313 & 64 & 0 & 46 & 6 & 7 & 20 & 12 & 0 & 0 & 0 & 0 & \\
\hline LK20I & 490 & 104313 & 0 & 0 & 0 & 0 & 0 & 0 & 0 & 0 & 0 & 0 & 3 & \\
\hline LK201 & 490 & 104314 & 45 & 0 & 5 & 0 & 5 & 10 & 2 & 0 & 0 & 0 & 0 & \\
\hline LK20I & 490 & 104314 & 0 & 0 & 0 & 0 & 0 & 0 & 0 & 0 & 0 & 0 & 2 & 4 \\
\hline LK201 & 490 & 104315 & 161 & 0 & 109 & 3 & 6 & 29 & 3 & 0 & 0 & 0 & 0 & \\
\hline LK201 & 490 & 104315 & 0 & 0 & 0 & 0 & 0 & 0 & 0 & 0 & 0 & 0 & 1 & II \\
\hline LK201 & 490 & 104316 & 25 & 58 & 72 & 4 & 32 & 8 & 3 & 0 & 0 & 0 & 0 & \\
\hline LK2OI & 490 & 104316 & 0 & 0 & 0 & 0 & 0 & 0 & 0 & 0 & 0 & 0 & 0 & \\
\hline LK20I & 490 & 104317 & 31 & 20 & 110 & 1 & 13 & 2 & 3 & 0 & 0 & 0 & 0 & \\
\hline LK20I & 490 & 104317 & 0 & 0 & 0 & 0 & 0 & 0 & 0 & 0 & 0 & 0 & 0 & \\
\hline LK201 & 490 & 104318 & 491 & 18 & 55 & 3 & 9 & 8 & 5 & 0 & 0 & 0 & 0 & \\
\hline LK201 & 490 & 104318 & 0 & 0 & 0 & 0 & 0 & 0 & 0 & 0 & 0 & 1 & 0 & \\
\hline LK20I & 490 & 104319 & 292 & 4 & 1 & 2 & 11 & 25 & 4 & 1 & 0 & 0 & 0 & \\
\hline LK20I & 490 & 104319 & 0 & 0 & 0 & 0 & 0 & 0 & 0 & 0 & 0 & 0 & 3 & 4 \\
\hline & 50 & & ? & $0 ?$ & $.0,1$ & . & 0 & 0 & 60 & & & & & \\
\hline
\end{tabular}

Figure 105. Data Set for a SPSS Program Studyl SPSS. 
grinding slabs or manos? From this kind of analysis hypotheses can be drawn about the material culture of the site dwellers.

Since NRP Phase II contains 1 arge quantities of data that could be studied in the future, all data sets have been stored on magnetic tapes. The character set is EPCIDIC, and the density is $1600 \mathrm{bp} i$. A guide to NRP Phase II systems operations is available upon request from the CAR-UTSA. This guide includes a) 1 data sets, programs, and tape drive operation procedures.

\section{REFERENCES CITED}

Hal1, G. D., S. L. B1 ack, and C. Graves

1982 Archaeological Investigations at Choke Canyon Reservoir, South Texas: The Phase I Findings. Center for Archaeological Research, The University of Texas at San Antonio, Choke Canyon Series 5.

Gunn, J., E. G. Frkuska, and R. Mahula

1982 Computer Documentation: A Guide to the Collection, Storage, and Retrieval of the Phase I Data. Appendix VI in Archaeological Investigations at Choke Canyon Reservoir, South Texas: The Phase I Findings, by G. D. Hal1, S. L. B Tack, and C. Graves:556-577. Center for Archaeological Research. The University of Texas at San Antonio, Choke Canyon Series 5. 


\title{
APPENDIX V.
}

\section{TRACE ELEMENT AND GEOLOGIC SOURCES STUDIES OF AN OBSIDIAN ARTIFACT FROM SITE 41 LK 51, LIVE OAK COUNTY, TEXAS}

\author{
Thomas R. Hester, Frank Asaro, Helen Michel, \\ Fred Stross, and Fred W. Nelson
}

\section{INIRODLCTION}

We describe here the results of trace element analysis, using the techniques of nuclear chemistry, of an obsidian artifact excavated at a prehistoric site in southern Texas. This site, 41 LK 51, was studied as a part of Phase II archaeological investigations in the Choke Canyon Reservoir basin. The analyses are important not only for Choke Canyon, but also address a 1 arger issue in obsidian trace element research in Texas.

The senior author has been engaged for about a dozen years in tracing the geologic origins of obsidian artifacts found at prehistoric Texas sites. The initial studies were done in the early 1970 s in collaboration with Robert $N$. Jack; over the past decade, the project has involved Asaro, Michel, and Stross, scientists at the Lawrence Berkeley Laboratory (LBL), University of California, Berkeley (Hester, Asaro, and Stross 1980:12-13).

Obsidian, a volcanic glass does not occur in geologic outcrops in Texas. Leo Byerley (personal communication to Hester, October 1983) has observed "fistsize"l obsidian nodules at Mule Ear Peak in the Big Bend National Park. However, the materials reported there and at some other localities in the Big Bend area do not appear to be of artifact-quality obsidian. Rather, we have to look to major obsidian sources outside of Texas, principally those known to have been exploited in ancient times, in Mexico, New Mexico, and Arizona, and as far away as Obsidian Cliff in Yellowstone Park, Wyoming (cf. Hester et a 1. 1975; Hester, Asaro, and Stross 1980, 1982; Hester et a 1. 1980; Hester et a 1. ms.; Mitche11 et a1. 1980).

\section{OBSIDIAN SOURCE ANALYSES}

We have now analyzed more than 100 Texas obsidian artifacts. For some, we have been able to identify specific geologic sources (e.g., in New Mexico, Mexico, and Wyoming). A number of specimens, however, fall into groups with chemical characterizations for which we have no currentiy recognized geologic source. Among these groups, as we will discuss 1 ater, was one known as "Escondido Ranch."

The obsidian artifact from 41 LK 51 is a subcircular specimen with bifacial flake scars; it may be a core fragment or a reworked biface. It is $3.1 \mathrm{~cm}$ long, $2.4 \mathrm{~cm}$ wide, and $0.9 \mathrm{~cm}$ thick; weight is $4.9 \mathrm{~g}$. Based on the stratigraphic context at the site (Level I, Unit N1026 E1042), this excavated specimen is Late Prehistoric in age (ca. A.D. 1000-1600). It was initial1y submitted to the $L B L$ for $X$-ray fluorescence (XRF) analysis, by using a nondestructive procedure. It was 1 abeled as "TEX $22^{\prime \prime}$ in the 1 aboratory. 
When the trace element analysis was obtained, the specimen was found to fall with the Escondido Ranch group of Texas obsidians. The Escondido Ranch group was first recognized in 1972 by R. N. Jack, after his analysis of a number of Texas obsidian artifacts found at various sites in the state. Since the geologic source of this group was not known, Jack assigned it the "Escondido Ranch" name, after a ranch in Dimmit County, Texas, where an obsidian artifact of this composition was initially discovered. Since that time, other Texas obsidian artifacts analyzed at the LBL were also found to match chemically the Escondido Ranch type. The Barium (Ba) content of this type, -1500 parts-per-mil1ion (ppm), is distinctive because it is unusualiy high, but none of the source samples from the southwestern United States or Mexico previously measured at LBL conformed to the observed chemical profile.

However, a recent report on analyses of western obsidians (Nelson 1984) contained XRF data on source obsidian from Malad. Idaho, and the chemical abundances seemed close to those of the Escondido Ranch type. Samples of this source rock were generously made available by Fred W. Nelson for a collaborative study, by neutron activation measurements, with Hester and the LBL group.

High precision neutron activation analyses (NAA) were made at LBL on two Malad source obsidian samples and on the artifact from 41 LK 51 (TEX-22). These results are shown in Table 49. It is seen that the agreement is usualiy consistent with the measurement errors. Exceptions are the $\mathrm{Na}$ abundance which is slightly different (3.2\%) for the two Malad source samples and the $\mathrm{Sm}$ abundance, which is $0.9 \%$ different for the two source samples.

The source sample MALAD-1 and artifact TEX-22, however, agree as closely as can be expected from the measurement errors. The average difference for the abundances of the 15 elements is on 1 y 1.5\%, which shows conclusively the artifact has a provenience of Malad, Idaho. Deviations of individual $\mathrm{Na}$ abundances of up to $10 \%$ have been occasionally detected in obsidian groups which were otherwise chemically homogeneous (Table 50). The Sm variation of 0.9\% in the source samples may be related to the Na variations, although normal1y deviations of 1 ess than $2 \%$ are not considered significant in provenience determinations.

Table 51 shows less precise nondestructive XRF measurements made on TEX-22, seven other artifacts from southern, south-central, and north-central Texas, and the two source samples from Malad. Idaho. Although the agreement is considerably poorer than for the NAA measurements, it is as good as is expected from this type of measurement, and it is 1 ikely that the other artifacts as wel1 as TEX-22 also have the same origin as the source samples. The XRF results obtained by $R$. N. Jack, which have been correlated by procedures used at LBL, are also shown on Table 51 and are seen to match with in the limits of the correlation.

\section{DISTRIBUTION AND DATIMG OF MALAD MATERIALS}

While Tables 51 and 52 show the results of analyses of several Texas specimens of Escondido Ranch type and compare these with analysis of source samples from Malad, in southeastern Idaho, we should point out that there are 
TABLE 49. ABUNDANCES OF ELEMENTS BY NEUTRON ACTIVATION ANALYSIS IN PARTS PER MILLION (exCePt where otherwise indicated)
A1
$\mathrm{Ba}$
Ce
Co
Cs
Dy
Eu

$\begin{array}{llllllll}\text { MALAD-1 } & 6.35 \pm .14 & 1487 \pm 24 & 64.16 \pm .32 & .51 \pm .05 & 2.455 \pm .064 & 4.91 \pm .14 & .606 \pm .011 \\ \text { MALAD-2 } & 6.50 \pm .07 & 1512 \pm 25 & 64.70 \pm .32 & .42 \pm .05 & 2.497 \pm .065 & 5.02 \pm .14 \\ \text { TEX-22 } & 6.47 \pm .08 & 1498 \pm 24 & 64.13 \pm .32 & .50 \pm .05 & 2.346 \pm .064 & 5.15 \pm .15 & .609 \pm .010\end{array}$

\begin{tabular}{cccccccc}
\hline & & & & & & \\
& Fe\% & $K \%$ & $\mathrm{La}$ & $\mathrm{Lu}$ & $\mathrm{Mn}$ & $\mathrm{Na \%}$ & $\mathrm{Rb}$ \\
MALAD-1 & $.711 \pm .011$ & $4.04 \pm .27$ & $31.55 \pm .57$ & $.482 \pm .023$ & $205.4 \pm 2.5$ & $2.77 \pm .02$ & $137.9 \pm 6.2$ \\
MALAD-2 & $.709 \pm .011$ & $4.05 \pm .27$ & $32.49 \pm .52$ & $.468 \pm .023$ & $208.1 \pm 2.6$ & $2.86 \pm .02$ & $130.6 \pm 6.0$ \\
TEX-22 & $.703 \pm .011$ & $3.92 \pm .27$ & $32.10 \pm .52$ & $.477 \pm .023$ & $206.1 \pm 2.6$ & $2.77 \pm .02$ & $135.0 \pm 6.1$
\end{tabular}

Sc

Sb

$\mathrm{Sm}$

Ta

Th

U

Yb

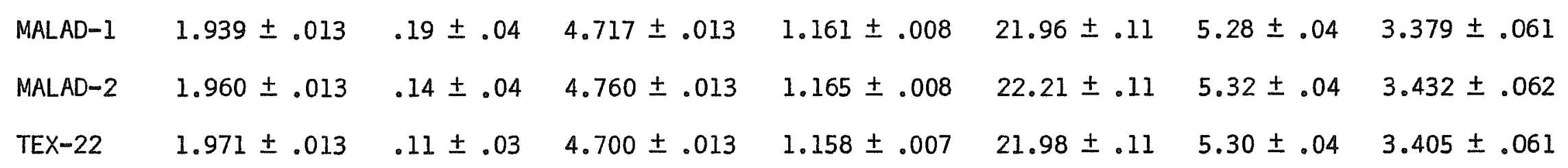


TABLE 50. SEPARATION OF SOURCE HETEROGENEITY FROM PROCEDURAL ERRORS (SAMPLES TEX-22, MALAD-1 AND 2)

Element $\quad \operatorname{RMSD}(\%) \quad$ Counting Error $(\%) * \quad$ Residuat Error $(\%)$

Values based on run 2161 only

$\begin{array}{lll}\mathrm{Na} & 1.78 & .64 \pm .32 \\ \mathrm{Sm} & .65 & .28 \pm .14 \\ \mathrm{Ta} & .30 & .69 \pm .35 \\ \mathrm{Sc} & .83 & .66 \pm .33 \\ \mathrm{Th} & .63 & .50 \pm .25 \\ \mathrm{U} & .35 & .81 \pm .40\end{array}$

Values based on run 2170 onty

$\begin{array}{llll}\mathrm{Na} & 1.31 \pm .65 & .69 & 1.11 \pm .65 \\ \mathrm{Sm} & 1.83 \pm .92 & .34 & 1.80 \pm .92 \\ \mathrm{Ta} & 1.25 \pm .63 & .60 & 1.10 \pm .63 \\ \mathrm{Sc} & .91 \pm .46 & .65 & .64 \pm .46 \\ \mathrm{TH} & 1.35 \pm .68 & .46 & 1.27 \pm .68 \\ \mathrm{U} & 2.26 \pm 1.13 & .91 & 2.07 \pm 1.13\end{array}$

*Estimate of one standard deviation of error arising from gamma ray counting statistics.

Comments: The first column is the root mean square deviation (RMSD), calculated as a percentage, of the average value of the abundances of the array of elements measured. If there are no errors introduced in the measuring technique and the source is chemically homogeneous, the RMSD of the abundances for a given element in number of samples will be equal to the counting error (c.e.) with an uncertainty of equal to: $c_{0} e_{0} / \sqrt{2(n-1)}$. If the RMSD is much 1 arger than the counting error, the uncertainty in the RMSD is approximately: RMSD $\sqrt{2(n-1)}$. Since the uncertainty in the error decreases with the number of samples, it is relatively 1 arge in our case, where only three samples are being analyzed. After the uncertainties in counting gamma rays are removed from the RMSD, the remaining uncertainties are shown in the third column as Residual Error. The RMSDs for run 2161 indicate the source is homogeneous, at the $1 \%$ level, except possibly for the $\mathrm{Na}$ value. In the second run (2170), the residual error in most elements is 1 arger than 1\%. We believe that this error is probably due to procedura 1 problems in the reactor irradiation. Samples are rotated periodically (about every hour) during the ful1 power irradiation to provide al1 samples with the same flux and energy distribution of neutrons. It is likely that this periodic rotation for run 2161 was fortuitously adequate for the desired precision and accuracy, while that for run 2170 was not. A continuous rotation of the samples eliminates this problem.

Our conclusion is that the Malad source, as represented by the samples available, is homogeneous at the $1 \%$ level. 
TABLE 51. XRF RESULTS ON ESCONDIDO RANCH TYPE ARTIFACTS AND MALAD, IDAHO, SOURCE SAMPLES

\begin{tabular}{llcll} 
Designation & $\begin{array}{c}\mathrm{Ba}^{*} \\
(\mathrm{ppm})\end{array}$ & $\begin{array}{c}\mathrm{Zr^{* }}(\mathrm{ppm}) \\
\mathrm{Rb} / \mathrm{Zr}\end{array}$ & $\mathrm{Sr} / \mathrm{Zr}$ \\
\hline
\end{tabular}

LBL

TEX-1
TEX-13
TEX-19
TEX-22
TEX-23
HORN-2
HAM-8
HAM-9
HAM-10
HAM-11
HAM-12
1490

1570

1690

1550

1450

1660

1570

1540

1680

1530

1510
Escondido Ranch Type Artifacts

$\begin{array}{rl}105 & 1.223 \pm .062 \\ 97 & 1.233 \pm .059 \\ 106 & 1.264 \pm .097 \\ 101 & 1.231 \pm .045 \\ 101 & 1.255 \pm .022 \\ 105 & 1.188 \pm .054 \\ 104 & 1.267 \pm .055 \\ 106 & 1.180 \pm .052 \\ 106 & 1.261 \pm .057 \\ 113 & 1.253 \pm .058 \\ 126 & 1.150 \pm .055\end{array}$

$.791 \pm .030$

$.754 \pm .028$

$.722 \pm .054$

$.759 \pm .026$

$.755 \pm .022$

$.742 \pm .031$

$.712 \pm .032$

$.693 \pm .030$

$.708 \pm .032$

$.740 \pm .033$

$.762 \pm .033$

RN Jack**

Spec \#2

41 BL 104

Sanderson, Tex
114

102

96
1.20

1.23

1.30
.69

.66

.72

LBL

Malad, Idaho Source

$\begin{array}{lrrrr}\text { MALA-1 } & 1510 & 104 & 1.249 \pm .057 & .705 \pm .039 \\ \text { MALA-1 } & 1520 & 99 & 1.318 \pm .062 & .724 \pm .034\end{array}$

* The absolute values of the abundances are only approximate and contain errors due to the variable sample shapes.

**Dr. Jack's data, obtained in counts per second, were intercalibrated and converted to absolute units by a procedure described in a letter (Asaro et a). to Hester) dated, January 4, 1979. 
TABLE 52. CONCORDANCE OF ANALYZED ARTIFACTS OF ESCONDIDO RANCH TYPE FROM TEXAS AND SOURCE SAMPLES ANALYZED FROM MALAD, IDAHO

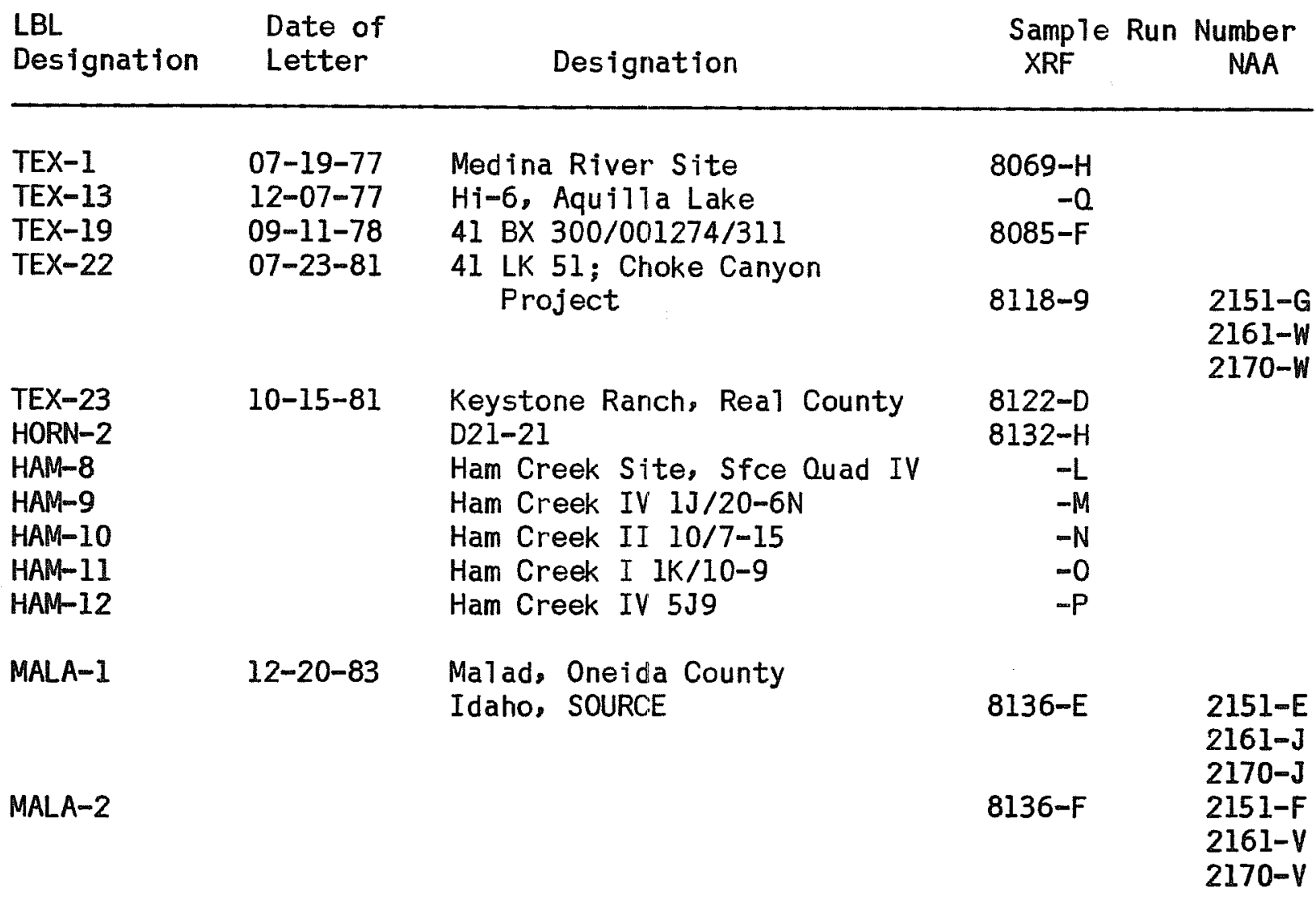


a number of other specimens of Escondido/Malad type from Texas, earlier analyzed by $R_{0} N_{0}$ Jack. We will briefly review the distribution and context of these 27 analyzed Escondido/Malad obsidian artifacts.

The artifacts are widely dispersed from southern Texas, to south-central Texas and then to the north-central part of the state (Fig. 106). One specimen probably linked to this type has been found in western Texas (Fig. 106, see number 13 on the map). With this one exception, the other Escondido/Malad artifacts seem to be distributed along the periphery of the Edwards Plateau. Some 1 ie on the edge of the Plateau (e.g., 41 BX 300; Medina River site), others are just within the southern and eastern portions of the Plateau (e.g., Real County site; San Saba and Llano Counties sites; Travis County site), and others on the coastal plain (Escondido Ranch; 41 LK 51), or the prairies east and south of the Plateau (Ham Creek site: Aquilla Lake site). It will be interesting to learn, upon analysis of further specimens, whether this clustering in a north-south "corridor," in terms of distribution, will continue. If so, it should suggest to archaeologists something about the exchange systems which led to the spread of these obsidian artifacts.

In terms of context, some of the specimens are surface finds from multicomponent sites and cannot be dated in terms of cultural associations (Table 53). Several are from Late Prehistoric deposits (41 LK 51; San Saba County specimens; 41 ME 29--see Addendum), or are of Late Prehistoric artifact type (e.g., Medina River site), others are from Late to Transitiona 1 Archaic or Late Prehistoric associations (e.g.9 Ham Creek site; 4 I HI 34--see Addendum), and from Late to Transitional Archaic deposits (Horn Rockshelter; Evoe Terrace [41 BL 104]). However, as a glance at Table 53 will indicate, most of the specimens tend to be late in the Texas sequence, from Late/Transitional Archaic to Late Prehistoric times (i.e., from ca. A.D. 250 to A.D. 1700). Many of the Texas obsidian artifacts from other geologic sources that we have analyzed are surface finds and cannot be dated. We are thus fortunate to have all but five of the Escondido/Malad obsidian specimens with reasonably secure chronological contexts.

Most of the artifacts from this group are gray-tinted obsidian. sometimes varying to a "clear gray" color. Most are flakes, two are unifacially chipped tools (scrapers), and six others are bifaces. Of the 1 atter, there is a side-notched projectile point from the Medina River site; it is the size of an arrow point and no doubt dates to the Late Prehistoric period. Other arrow points come from 41 SS 2, 41 TE 98, and Escondido Ranch (see Table 53). The corelike morphology of the specimen from 41 LK 51 suggests that some Escondido/Malad obsidian might have appeared in the Texas area as cores or nodules. The shaping of such items would lead, of course, to multiple flakes and flakes with "biface thinning" attributes, of the sort found in site 41 SS 2 in San Saba County.

\section{POSSIBLE TRADE NETMORKS FOR MALAD DISTRIBUTION}

The most challenging question that results from this analysis focuses on how Malad obsidian was transported from its source, some $1250 \mathrm{miles}$ from 41 LK 51, into various areas of Texas. We have a clue that it might have 


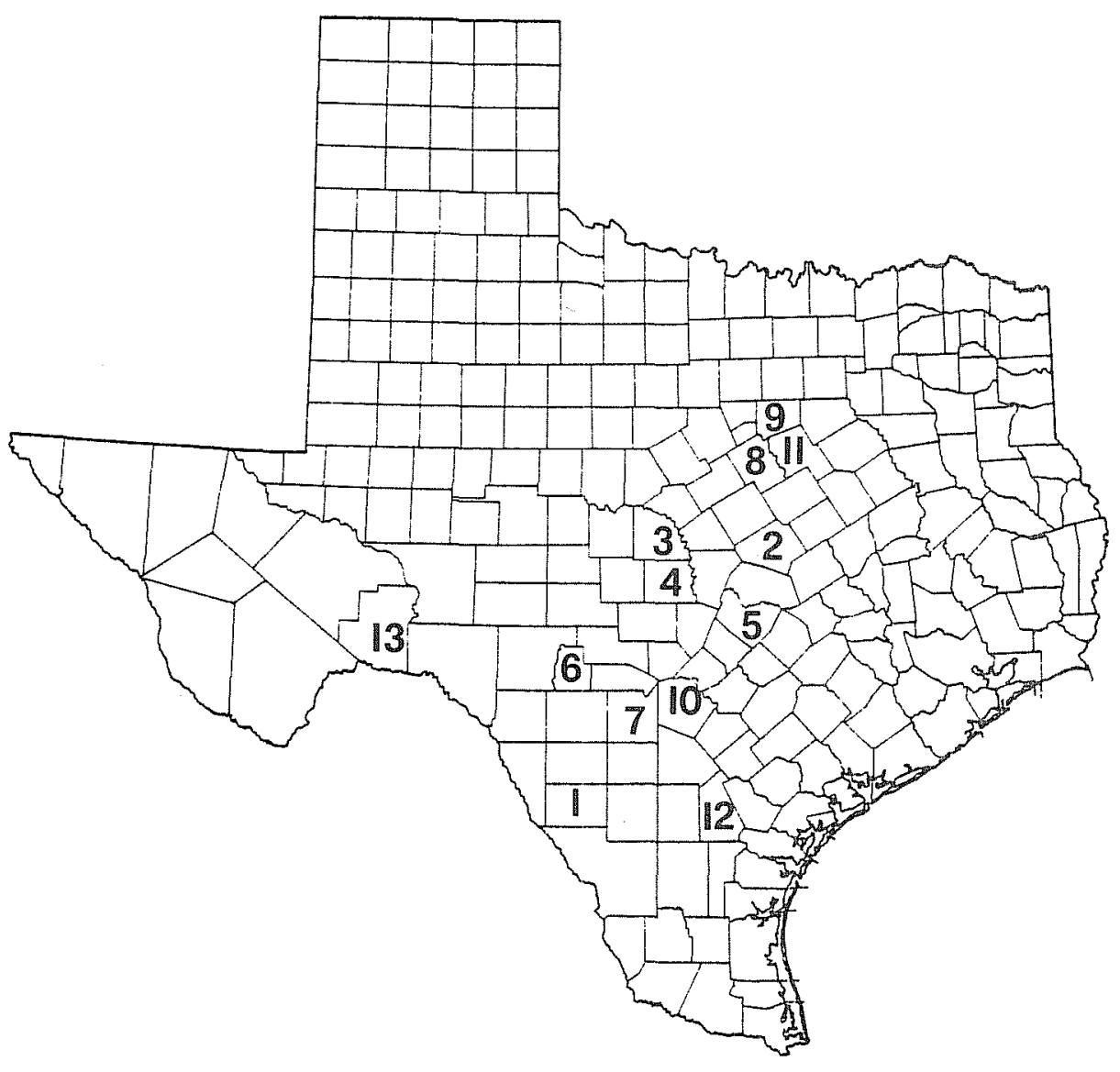

Figure 106. Location of Sites ith Escondido/Malad Obsidian in Texas. Each site represents a locality at which one or more pieces of obsidian representing the Escondido Ranch group, now 1 inked to a source in Malad, Idaho, was found. Numbers may be correlated by referring to Table 53 . 
TABLE 53. PROVENIENCE AND CONTEXT OF ESCONDIDO/MALAD OBSIDIAN ARTIFACTS FROM TEXAS SITES

\begin{tabular}{|c|c|c|c|c|}
\hline $\begin{array}{l}\text { Figure } \\
106\end{array}$ & Designation & Proventence & Context/Date & Description \\
\hline 1 & Escond1do Ranch & Escondido Ranch, Dimmit County & surface & stemmad point \\
\hline 2 & $41 \mathrm{BL} 104$ & Evoe Terrace site, Bell County & Late Archalc(Zone 4$)$ & flake \\
\hline 3 & $\begin{array}{l}41 \text { SS } 2 \\
\text { (8 specimens) }\end{array}$ & Fal1 Creek site, San Saba County & $\begin{array}{l}\text { Late Prehistoric } \\
\text { in most cases }\end{array}$ & $\begin{array}{l}1 \text { arrow point frag- } \\
\text { ment; } 2 \text { unifaces: } \\
5 \text { flakes }\end{array}$ \\
\hline 4 & $41 \mathrm{LL} 4$ & Buchanan Reservoir: Llano County & Late.Prehistoric & flake \\
\hline 5 & $\begin{array}{l}41 \text { TV } 133 \\
\text { (4 specimens) }\end{array}$ & $\begin{array}{l}\text { Trammel Rockshelter, } \\
\text { Travis County }\end{array}$ & excavated; date? & flakes \\
\hline 6 & $\begin{array}{l}\text { Keystone Patch } \\
\text { (LBL TEX-23) }\end{array}$ & Near Leakey, Real County & surface & flake \\
\hline 7 & $\begin{array}{l}\text { Medina River* } \\
\text { (LBL TEX-1) }\end{array}$ & Judson site; Medina County & $\begin{array}{l}\text { buried: context? } \\
\text { (Late Prehistor Ic) }\end{array}$ & $\begin{array}{l}\text { side-notched } \\
\text { arrow point }\end{array}$ \\
\hline 8 & $\begin{array}{l}41 \text { BO } 46 \\
\text { (LBL HORN-2) }\end{array}$ & Horn Shelter No. 2, Bosque County & Late Archaic & flake \\
\hline 9 & $\begin{array}{l}\text { Ham Creek site } \\
\text { (LBL TEX-8-12) } \\
\text { (5 specimens) }\end{array}$ & Johnson County & $\begin{array}{l}\text { Late Prehistoric to } \\
\text { Transitional Archaic }\end{array}$ & $\begin{array}{l}1 \text { biface fragment } \\
5 \text { flakes }\end{array}$ \\
\hline 10 & $\begin{array}{l}41 \mathrm{BX} 300 \\
(L B L \text { TEX-19) }\end{array}$ & Bexar County & Late Prehistoric & flake \\
\hline 11 & $\begin{array}{l}\text { X41 HI } 130 \\
\text { (LBL TEX-13) }\end{array}$ & "Hi-6": Aqu111a Lake & surface & blface \\
\hline 12 & $\begin{array}{l}41 \text { LK } 51 \\
\text { (LBL TEX-22) }\end{array}$ & Choke Canyon. Live Oak County & Late Prehistoric & core? \\
\hline 13 & 41 TE 98** & rockshelter. Terrell County & Late Prehistoric & stemmed arrow point \\
\hline
\end{tabular}

*erroneously attributed to site $41 \mathrm{BX} 229$ in earlier descriptions.

*:probably Escondido/Malad; erroneously linked to Guadalupe Victorla, Mexicos. in earlier studies. 
involved some sort of trade network with origins in the Idaho and Wyoming area, in that at 41 SS 2 and at 41 TV 133, obsidians of both Malad and Obsidian Cliff, Wyoming, sources are found together.

Little is currently known about the importance in ancient times of Malad obsidian. Nelson (1984:56) notes its presence in the Sevier, Late Sevier, and Shoshone periods (ca. A.D. 600 to historic times) at sites in northern Utah. However, it is clear that Obsidian $\mathrm{Cl}$ iff (Yellowstone Park, Wyoming) was a major source from Paleo-Indian times (some fluted points of this material have been found), through the Archaic and Wood 1 and, and into the Late Prehistoric and even Historic periods (Griffin, Gordus, and Wright 1969). The use of Obsidian Cliff obsidian is best documented, in terms of long-distance exchange or transport, at Hopewe 11 sites in the Middle West (ibido). Such sites date somewhat earlier than many Texas specimens we have discussed in that most Hopewel1 sites are thought to date between 200 B.C. and A.D. 500. The exchange systems that carried Obsidian C iff materia1. grizzly bear teeth, and other items from the Western Rockies into the Hopewe 11 sites of the Middle West have not been, to our knowledge, described in any definitive form. Wright (1974) presents a detailed review of exchange networks as they may have operated within Hopewell sites after obsidian and other exotics had reached their region.

As to the Escondido/Malad specimens from Texas, a great distance from the Malad, Idaho, source, currently we cannot offer any detailed scenario as to what trade or exchange mechanisms were involved. Spielmann (1983) has provided a lengthy review of trade systems involving the Pueblo peoples of the Southwest and peoples on the Southern Plains. Trade or exchange on the Southern Plains around A.D. 1450 "was part of a 1 arger system of huntergatherer/horticultural interaction which encompassed populations from central Kansas to western OK 1ahoma" (ibid.:257). She also notes (Spielmann 1983:269) the role of wide-ranging itinerant Indian traders in historic times on the Plains.

We suspect that such exchange systems existed in earlier times and perhaps interacted with another exchange system (or systems) that moved Obsidian Cliff and Malad obsidian either into the Southwest or the Southern Plains, and through exchange systems operating to the south, into Texas. One area of speculation is that peoples of the Sevier-Fremont and Shoshone periods in Utah, where sites with Malad obsidian have been found (Nelson 1984), could have included such obsidian in their interactions with Pueblo peoples to the south. Some Malad material might then have moved through the PuebloanSouthern Plains exchange system posited by Spielmann (1983). This would bring Malad obsidian into close proximity with the northernmost distribution of this obsidian type in Texas.

However, Nelson has analyzed obsidian from these areas--Utah, the Puebloan area, and New Mexico--and sees no evidence for Malad obsidian reaching Ok 1 ahoma and Texas via this route.

Timothy Baugh (personal communication) is of the opinion that the Malad obsidian is representative of a north-south trade network through the Plains, perhaps original1y associated with the Obsidian Cliff network into the Hopewell area. He believes that this network may have ceased around 
A.D. 1450 when a greater emphasis was placed on a Southern Plains/Southwest network. He and Nelson have documented Malad obsidian at five west OK lahoma sites with dates that clearly overlap with the Texas Malad specimens (see Table 54). The dating and the north-south "trajectory" indicated by the Ok Tahoma-Texas materials centainly lend credence to Baugh's suggestion of a Plains trade network.

In closing, we wish to restate the importance of the 41 LK 51 obsidian artifact. Through the NAA analysis of this specimen and the fortunate timing of Nelson's definition of the Malad source, we are now able to 1 ink a number of Texas obsidian artifacts, previously known as the Escondido Ranch type and of unknown source, to a known geologic outcrop near Malad, southeastern Idaho. We believe that the definition of this 1 ink will have significant consequences in the future study of prehistoric exchange systems in Texas, Ok 1 ahoma, and adjacent areas.

\section{ADDENDUM}

Since the completion of this manuscript, the Lawrence Berkeley Laboratory (LBL) has analyzed, by $X$-ray fluorescence, two additional obsidian artifacts from Texas, and has found that they are also derived from the Malad source. One specimen is a corner-notched arrow point (LBL 8142) found at site 41 ME 29 (Medina County: see Fig. 106 from area of 7) during control1ed excavations by archaeologists of the Texas Department of Highways and Public Transportation. It is datable to Late Prehistoric times based both on stratigraphic context and morphology of the specimen.

The second obsidian artifact is a biface thinning flake (LBL 8141-0) found in the fill of a prehistoric burial pit at site 41 HI 34 (Hill County; see Fig. 106 from area of 11). Although the stratigraphic placement is not certain, the excavator (C. K. Chandler) believes that a Late Archaic-to-Late Prehistoric date is very likely.

Detailed data on both of these artifacts of Malad source will be published in the near future. 
TABLE 54. OBSIDIAN OF THE MALAD SOURCE FROM OKLAHOMA ARCHAEOLOGICAL SITES*

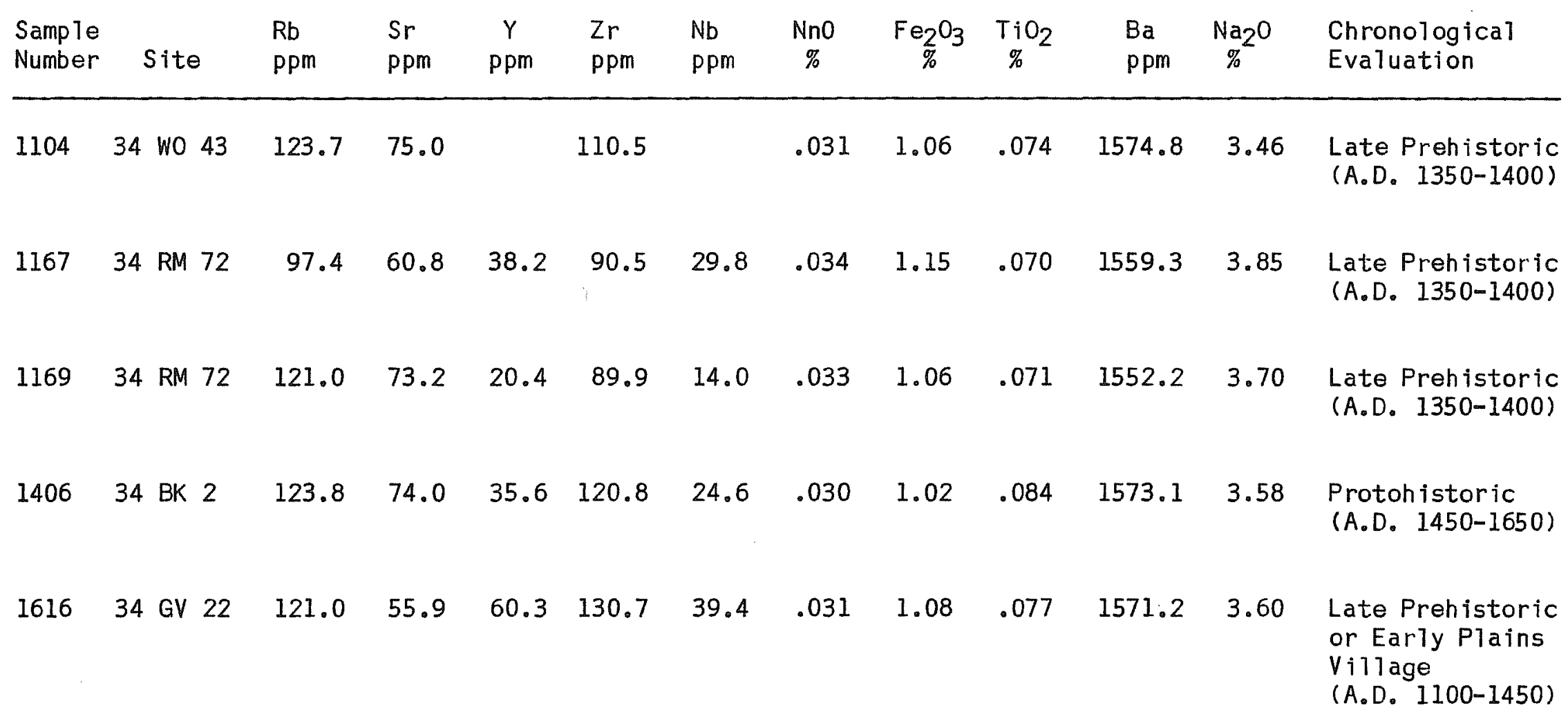

*Data reported here are courtesy of Fred W. Ne1son. They were originally presented in a paper by Nelson and Timothy G. Baugh at the Society for American Archaeology meetings, April 1984, in Portland, Oregon. 


\section{REFERENCES CITED}

Griffin, J. B., A. A. Gordus, and G. A. Wright

1969 Identification of the Sources of Hopewellian Obsidian in the Middle West. American Antiquity 34(1):1-14.

Hester, T. R., F. Asaro, and F. Stross

1980 Source Analysis of Obsidian Artifacts in Texas: New Results. Newsletter, Houston Archaeological Society 68:12-16.

1982 Results of Some Recent Studies by the Texas Obsidian Project. Journal, Houston Archaeological Society 73:8-10.

Hester, T. R., F. Asaro, F. Stross, and S. A. Skinner

ms. Trace Element Analysis of Obsidian Artifacts from North Central Texas. Manuscript submitted to Archaeology Research Program, Southern Methodist University. 7 pp.

Hester, T. R., J.W. House, R. N. Jack, and F. H. Stross

1975 X-Ray Fluorescence of Obsidian Artifacts from the Rio Grande Plain, Southern Texas. The Texas Journal of Science 26(12) : 286-289.

Hester, T. R., J. L. Mitchel1, F. Asaro, and F. Stross

1980 Further Notes on Obsidian Artifacts from Dimmit County, Southern Texas. La Tierra $7(3): 30-33$.

Mitchel1, J. L., T. R. Hester, F. Asaro, and F. Stross

1980 Notes on Trace Element Analysis of Obsidian from Hutchinson and Roberts Counties in the Texas Panhandle. Bulletin of the Texas Archeological Society 51:301-308.

Nelson, F. W.

1984 X-Ray Fluorescence Analysis of Some Western North American Obsidians. In Obsidian Studies in the Great Basin, edited by R. E. Hughes:27-62. Contributions of the University of Cal ifornia Archaeological Research Facility 45. Berkeley.

Spielmann, K. A.

1983 Late Prehistoric Exchange Between the Southwest and Southern Plains. Plains Anthropologist 28(102):257-272

Wright, G. A.

1974 Archaeology and Trade. An Addison-Wesley Module in Anthropology 49. 


\section{APPENDIX VI. \\ GENERAL DATA TABLES}

\section{MATERIAL ANALYSIS RECORDS}

KEY TO COLUAN ENTRIES FOR TABLE 55.

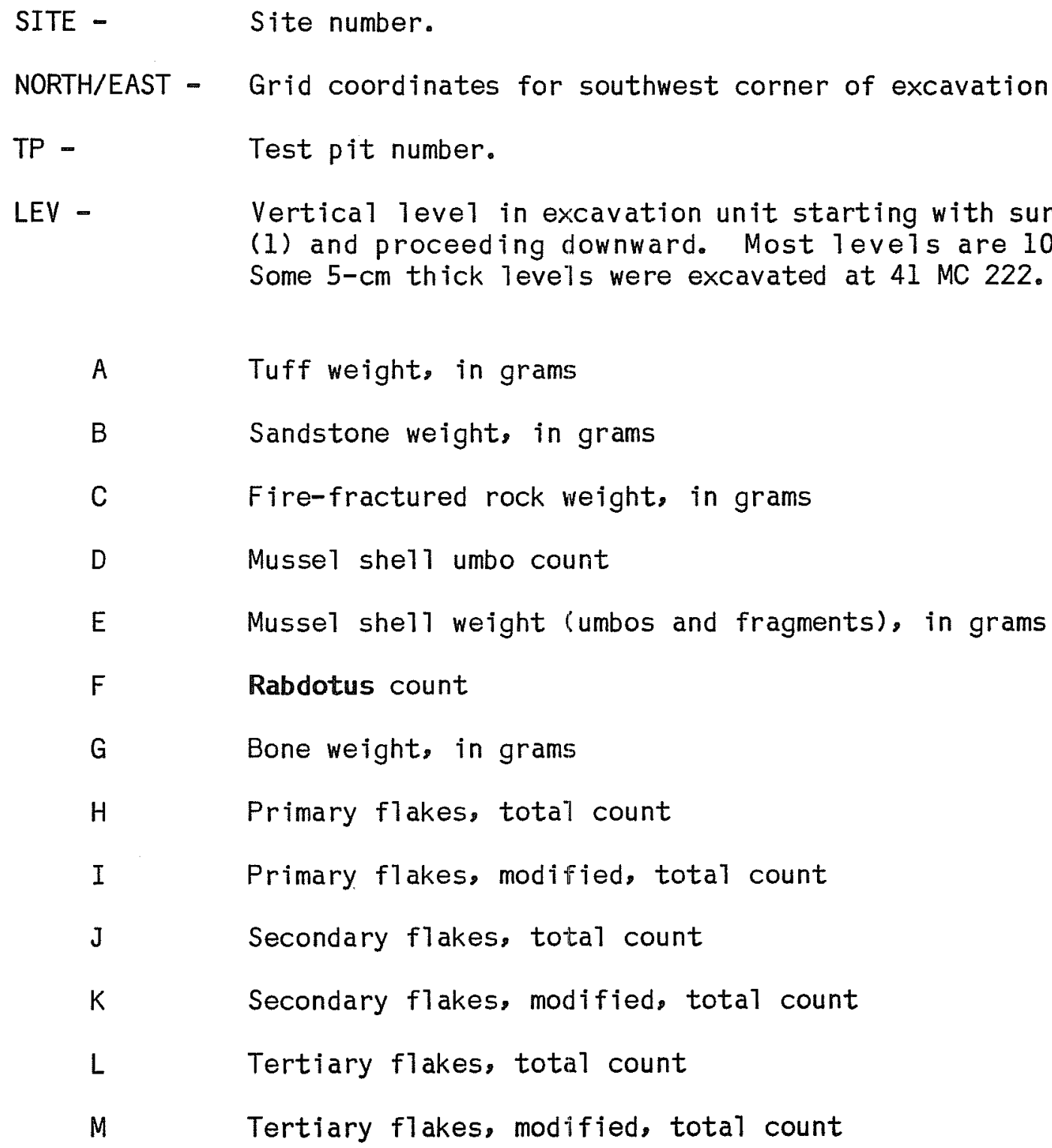


TABLE 55. MATERIAL ANALYSIS RECORDS

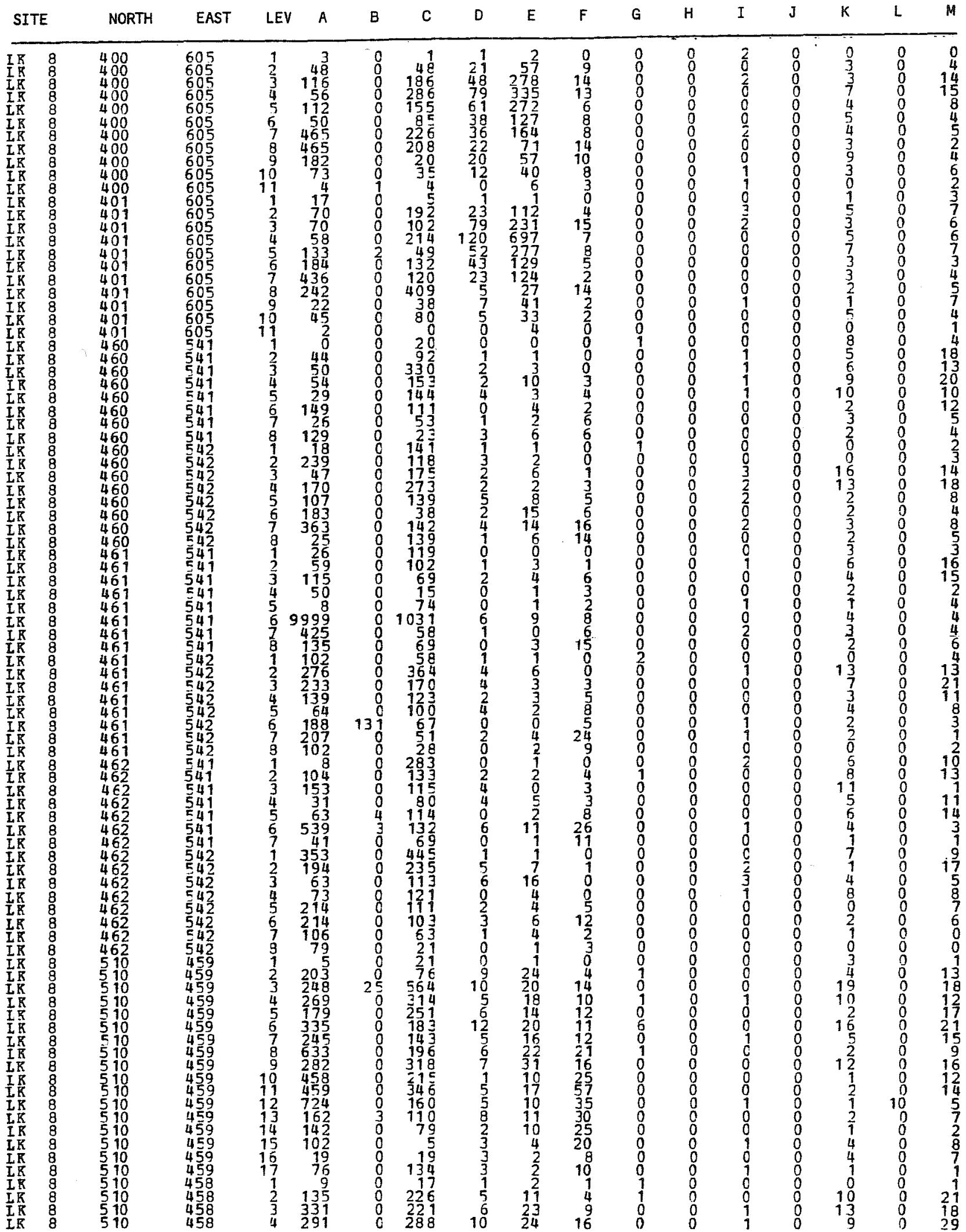


TABLE 55. (continued)

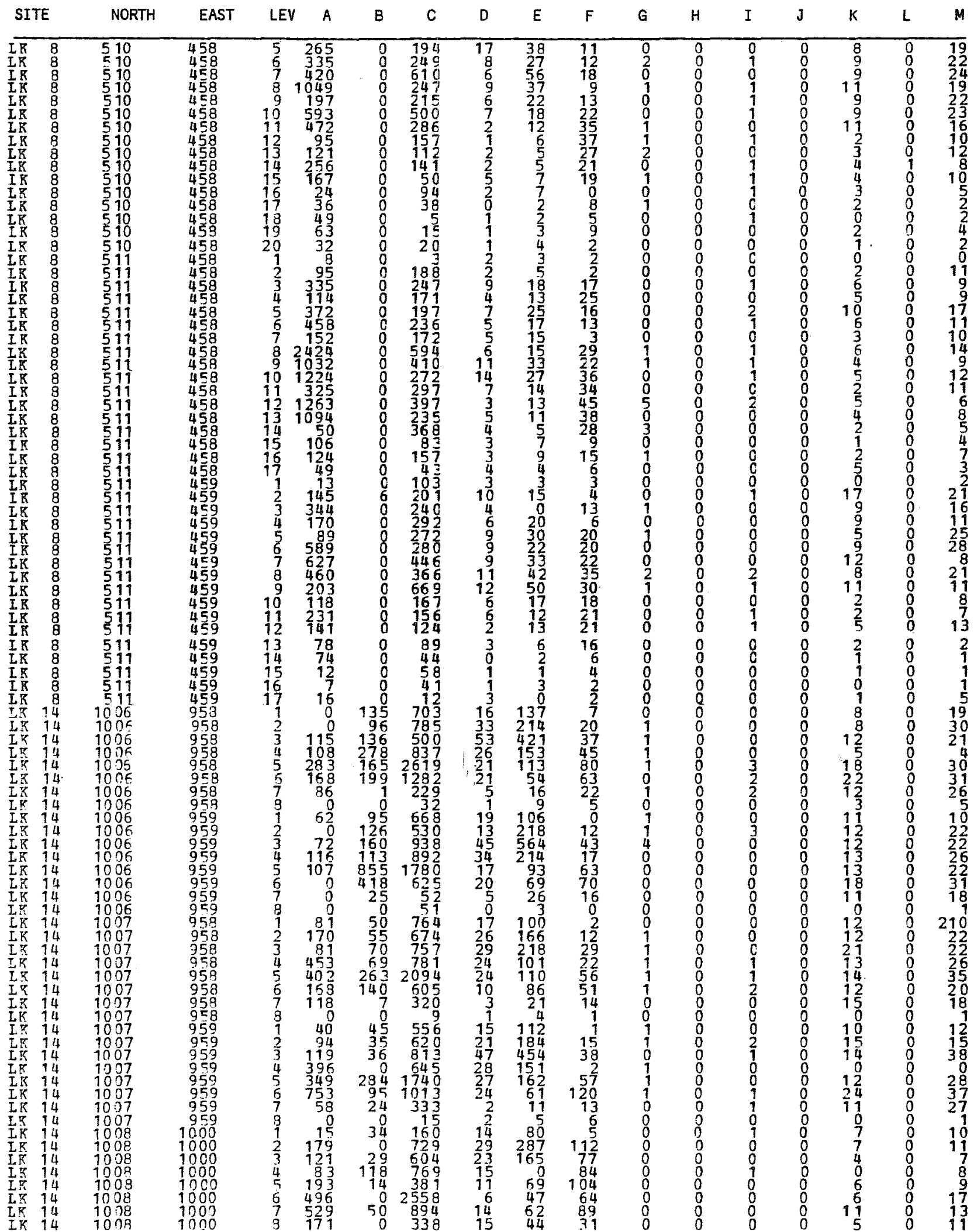


TABLE 55. (continued)

\begin{tabular}{|c|c|c|c|c|c|c|c|c|c|c|c|c|c|c|c|c|}
\hline SITE & NORTH & EAST & LEV & A & B & C & D & $E$ & $F$ & G & H & I & $\mathrm{J}$ & $k$ & L & $M$ \\
\hline 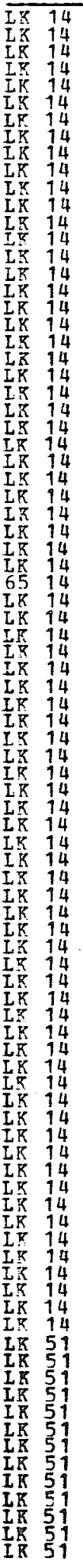 & $\begin{array}{l}1008 \\
1009 \\
1008 \\
1008 \\
1008 \\
1008 \\
1003 \\
1008 \\
1008 \\
1008 \\
1008 \\
1008 \\
1008 \\
1008 \\
1009 \\
1008 \\
1008 \\
1008 \\
1008 \\
1008 \\
1008 \\
1009 \\
1009 \\
1009 \\
1009 \\
1009 \\
1009 \\
1009 \\
1009 \\
1009 \\
1009 \\
1009 \\
1009 \\
1009 \\
1009 \\
1009 \\
1009 \\
1009 \\
1009 \\
1009 \\
1009 \\
1009 \\
1009 \\
1009 \\
1009 \\
1009 \\
1009 \\
1009 \\
1010 \\
1010 \\
1010 \\
1010 \\
1010 \\
1010 \\
10010 \\
1010 \\
1010 \\
1010 \\
1010 \\
1010 \\
1010 \\
1010 \\
1010 \\
1010 \\
1010 \\
1010 \\
1010 \\
1010 \\
1010 \\
1010 \\
1010 \\
1010 \\
1010 \\
1010 \\
1010 \\
1010 \\
1010 \\
9999 \\
999 \\
999 \\
999 \\
999 \\
999 \\
999 \\
999 \\
999 \\
999 \\
9999 \\
999 \\
999\end{array}$ & $\begin{array}{l}1000 \\
1000 \\
1000 \\
1001 \\
1001 \\
1001 \\
1001 \\
1001 \\
1001 \\
1001 \\
1001 \\
1001 \\
1002 \\
1002 \\
1002 \\
1003 \\
1002 \\
1002 \\
1002 \\
1002 \\
1002 \\
1000 \\
1000 \\
1000 \\
1000 \\
1000 \\
1000 \\
1000 \\
1000 \\
1000 \\
1001 \\
1001 \\
1001 \\
1001 \\
1001 \\
1001 \\
1001 \\
1001 \\
1001 \\
1002 \\
1002 \\
1002 \\
1002 \\
1002 \\
1002 \\
1002 \\
1002 \\
1000 \\
1000 \\
1000 \\
1000 \\
1000 \\
1000 \\
1000 \\
1000 \\
1000 \\
1000 \\
1000 \\
1000 \\
10001 \\
1001 \\
1001 \\
1001 \\
1001 \\
1001 \\
1001 \\
1001 \\
1001 \\
1002 \\
1002 \\
1002 \\
1002 \\
1003 \\
1002 \\
1002 \\
1002 \\
1002 \\
9081 \\
9081 \\
9081 \\
901 \\
9081 \\
9081 \\
9811 \\
9081 \\
9981 \\
9981 \\
981 \\
990 \\
9081\end{array}$ & 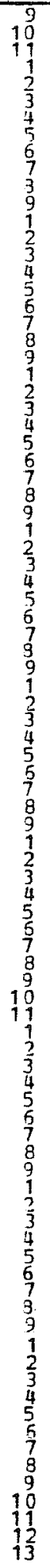 & 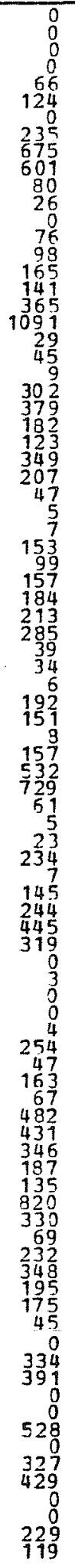 & 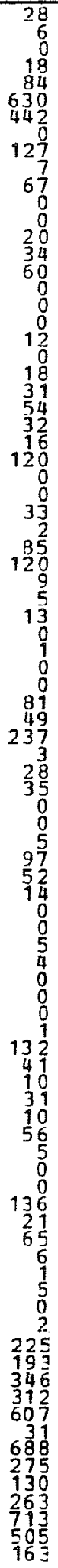 & 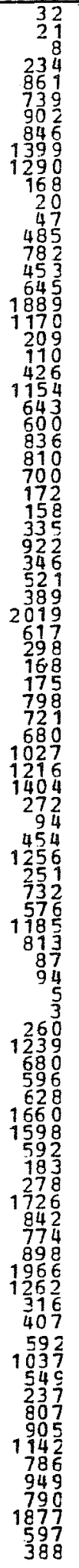 & 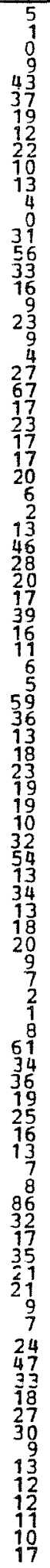 & 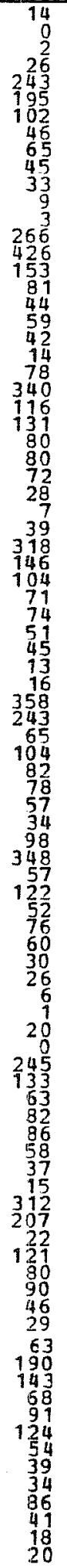 & 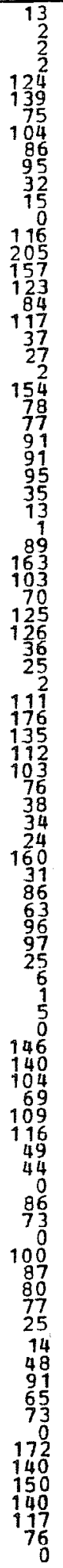 & $\begin{array}{l}\text { O } \\
0 \\
0 \\
0 \\
0 \\
0 \\
0 \\
0 \\
1 \\
1 \\
1 \\
0 \\
0 \\
0 \\
0\end{array}$ & $\begin{array}{l}0 \\
0 \\
0 \\
0 \\
0 \\
0 \\
0 \\
0 \\
0 \\
0 \\
0 \\
0 \\
0 \\
0 \\
0 \\
0 \\
0 \\
0 \\
0 \\
0 \\
0 \\
0 \\
0 \\
0 \\
0 \\
0 \\
0 \\
0 \\
0 \\
0 \\
0 \\
0 \\
0 \\
0 \\
0 \\
0 \\
0 \\
0 \\
0 \\
0 \\
0 \\
0 \\
0 \\
0 \\
0 \\
0 \\
0 \\
0 \\
0 \\
0 \\
0 \\
0 \\
0 \\
0 \\
0 \\
0 \\
0 \\
0 \\
0 \\
0 \\
0 \\
0 \\
0 \\
0 \\
0 \\
0 \\
0 \\
0 \\
0 \\
0 \\
0 \\
0 \\
0 \\
0 \\
0 \\
0 \\
0 \\
0 \\
0 \\
0 \\
0 \\
0\end{array}$ & $\begin{array}{l}0 \\
0 \\
0 \\
0 \\
1\end{array}$ & $\begin{array}{l}0 \\
0 \\
0 \\
0 \\
0 \\
0 \\
0 \\
0 \\
0 \\
0 \\
0\end{array}$ & 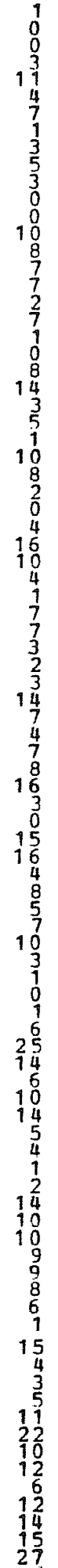 & $\begin{array}{l}0 \\
0\end{array}$ & $\begin{array}{r}5 \\
0 \\
0 \\
2 \\
8 \\
10 \\
10 \\
6 \\
17 \\
18 \\
9 \\
1 \\
18 \\
18 \\
275 \\
11 \\
13 \\
12 \\
5 \\
2 \\
17 \\
17 \\
10 \\
12 \\
14 \\
13 \\
8 \\
4 \\
4 \\
13 \\
6 \\
6 \\
9 \\
25 \\
7 \\
1 \\
18 \\
8 \\
15 \\
15 \\
13 \\
12 \\
10 \\
11 \\
10 \\
1 \\
15 \\
24 \\
5 \\
13 \\
10 \\
11 \\
22 \\
6 \\
3 \\
0 \\
12 \\
13 \\
16 \\
12 \\
10 \\
16 \\
14 \\
13 \\
19 \\
15 \\
14 \\
10 \\
14 \\
24 \\
19 \\
22 \\
26 \\
23 \\
23 \\
20 \\
46 \\
20 \\
20 \\
29 \\
30 \\
53 \\
5\end{array}$ \\
\hline
\end{tabular}


TABLE 55. (continued)

\begin{tabular}{|c|c|c|c|c|c|c|c|c|c|c|c|c|c|c|c|c|}
\hline ITE & NORTH & EAST & LEV & A & $B$ & C & D & $\mathrm{E}$ & $F$ & G & $H$ & I & $\mathrm{J}$ & K & $L$ & $M$ \\
\hline 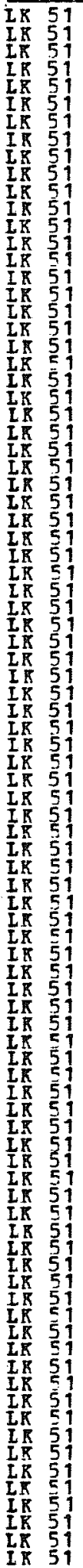 & 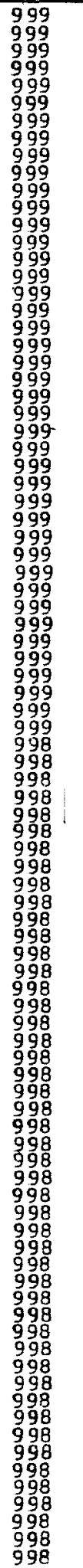 & 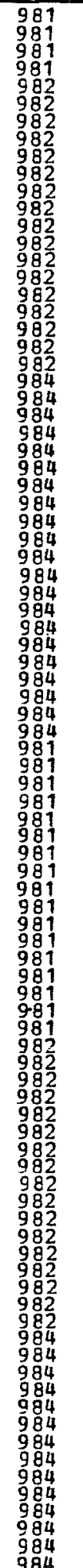 & 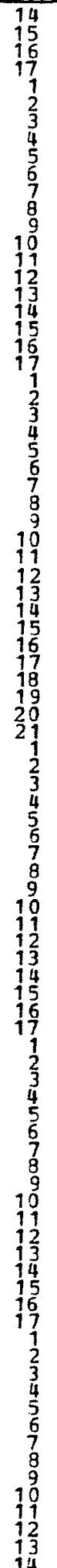 & $\begin{array}{r}173 \\
0 \\
0 \\
0 \\
0 \\
0 \\
0 \\
0 \\
157 \\
0 \\
0 \\
0 \\
327 \\
167 \\
90 \\
9 \\
0 \\
0 \\
0 \\
0 \\
1 \\
8 \\
205 \\
0 \\
0 \\
0 \\
0 \\
0 \\
0 \\
463 \\
0 \\
0 \\
0 \\
0 \\
0 \\
0 \\
0 \\
0 \\
0 \\
0 \\
0 \\
0 \\
0 \\
0 \\
0 \\
0 \\
0 \\
0 \\
0 \\
0 \\
0 \\
0 \\
0 \\
0 \\
0 \\
0 \\
0 \\
0 \\
0 \\
0 \\
0 \\
0 \\
0 \\
0 \\
0 \\
0 \\
0 \\
0 \\
0 \\
0 \\
0 \\
0 \\
0 \\
0 \\
0 \\
0 \\
0 \\
0 \\
0 \\
0 \\
0 \\
0 \\
0 \\
0 \\
0 \\
0 \\
0 \\
14 \\
88 \\
0\end{array}$ & 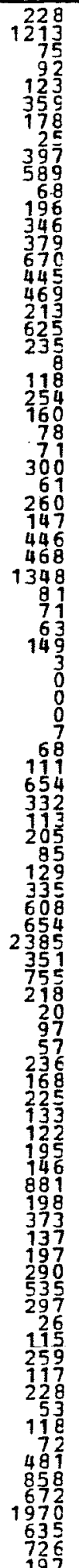 & 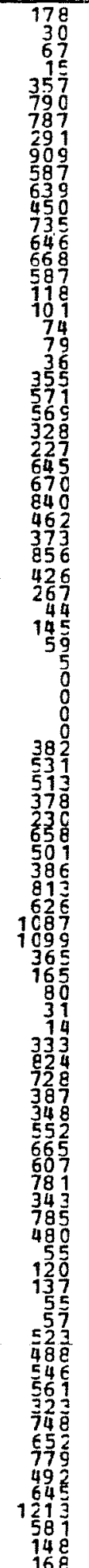 & 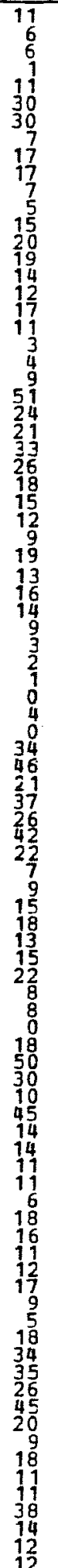 & 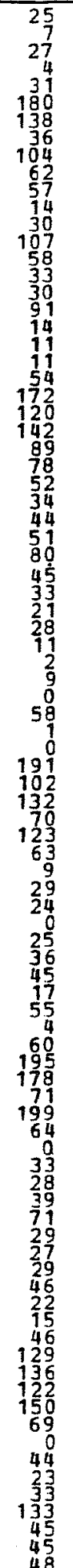 & 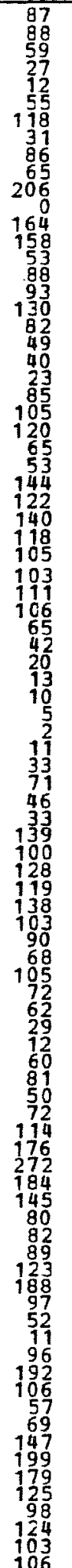 & $\begin{array}{r}0 \\
0 \\
0 \\
0 \\
1 \\
1 \\
9 \\
1 \\
2 \\
0 \\
2 \\
1 \\
0 \\
1 \\
0 \\
0 \\
0 \\
1 \\
2 \\
0 \\
1 \\
19 \\
114 \\
3 \\
7 \\
5 \\
0 \\
3 \\
1 \\
1 \\
0 \\
0 \\
1 \\
0 \\
0 \\
0 \\
1 \\
1 \\
0 \\
0 \\
0 \\
0 \\
1 \\
1 \\
33 \\
3 \\
4 \\
6 \\
2 \\
5 \\
4 \\
0 \\
1 \\
3 \\
0 \\
1 \\
3 \\
1 \\
0 \\
0 \\
1 \\
2 \\
5 \\
2 \\
4 \\
1 \\
0 \\
0 \\
1 \\
0 \\
0 \\
0 \\
3 \\
1 \\
0 \\
1 \\
1 \\
2 \\
11 \\
71 \\
25 \\
8 \\
2 \\
1\end{array}$ & $\begin{array}{l}0 \\
0 \\
0 \\
0 \\
0 \\
0 \\
0 \\
0 \\
0 \\
0 \\
0 \\
0 \\
0 \\
0 \\
0 \\
0 \\
0 \\
0 \\
0 \\
0\end{array}$ & $\begin{array}{l}0 \\
0 \\
0 \\
1 \\
0 \\
0 \\
0 \\
0 \\
0 \\
1 \\
0 \\
1 \\
2 \\
0 \\
0 \\
2 \\
0 \\
0 \\
0 \\
0 \\
1 \\
0 \\
1 \\
0 \\
0 \\
0 \\
0\end{array}$ & $\begin{array}{l}\text { D } \\
0 \\
0 \\
0 \\
0 \\
0 \\
0 \\
0 \\
0 \\
0 \\
0 \\
0 \\
0 \\
0 \\
0 \\
0 \\
0 \\
0 \\
0 \\
0 \\
0 \\
0\end{array}$ & 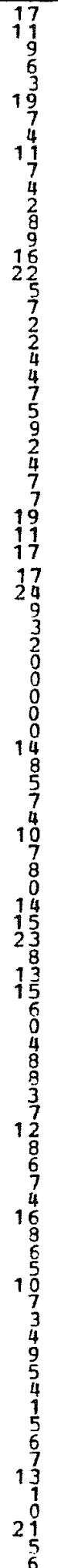 & $\begin{array}{l}0 \\
1 \\
0 \\
0 \\
0 \\
0 \\
0 \\
0 \\
0 \\
0 \\
0 \\
0 \\
0 \\
0 \\
0 \\
0 \\
0\end{array}$ & 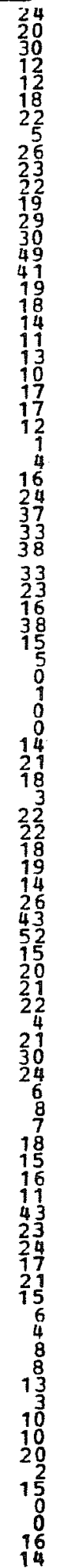 \\
\hline
\end{tabular}


TABLE 55. (continued)

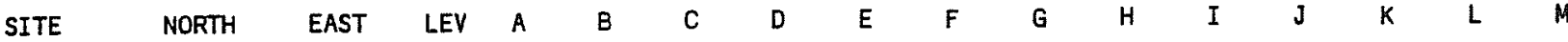

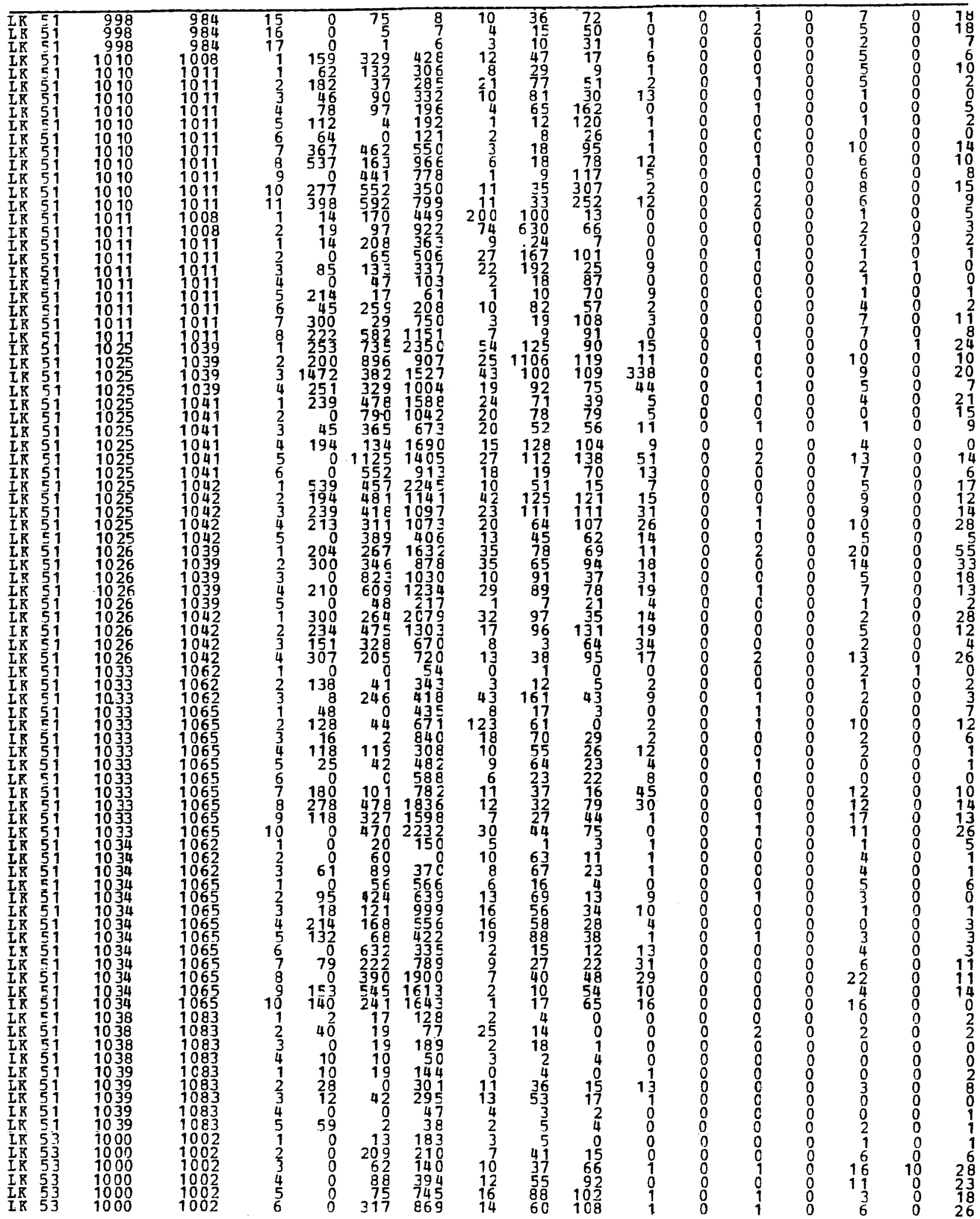


TABLE 55. (continued)

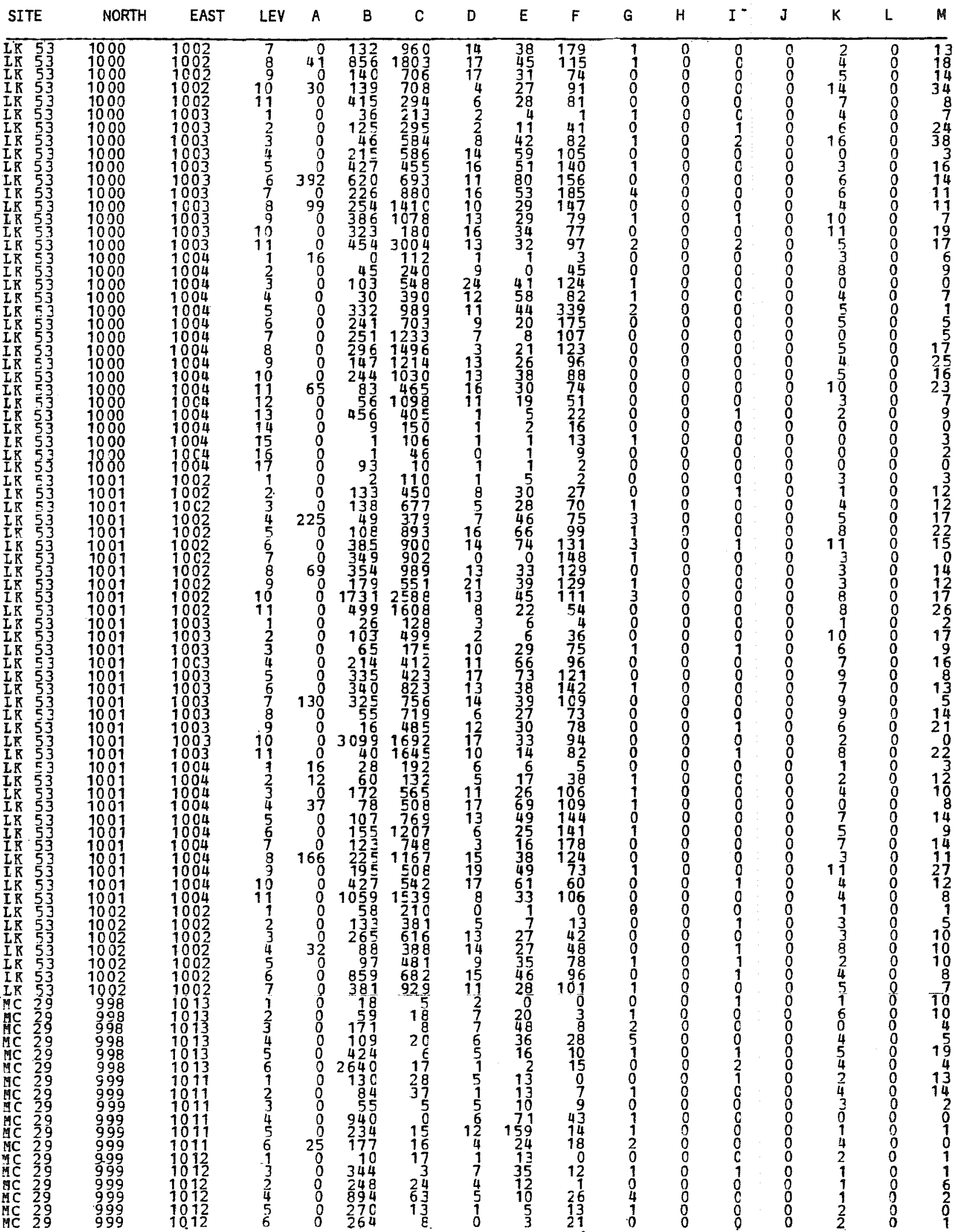


TABLE 55. (continued)

$\begin{array}{llllllllllllllllllllll}\text { SITE NORTH } & \text { EAST LEV A } & \text { B } & \text { C } & D & E & F & G & H & I & J & K & L & M\end{array}$

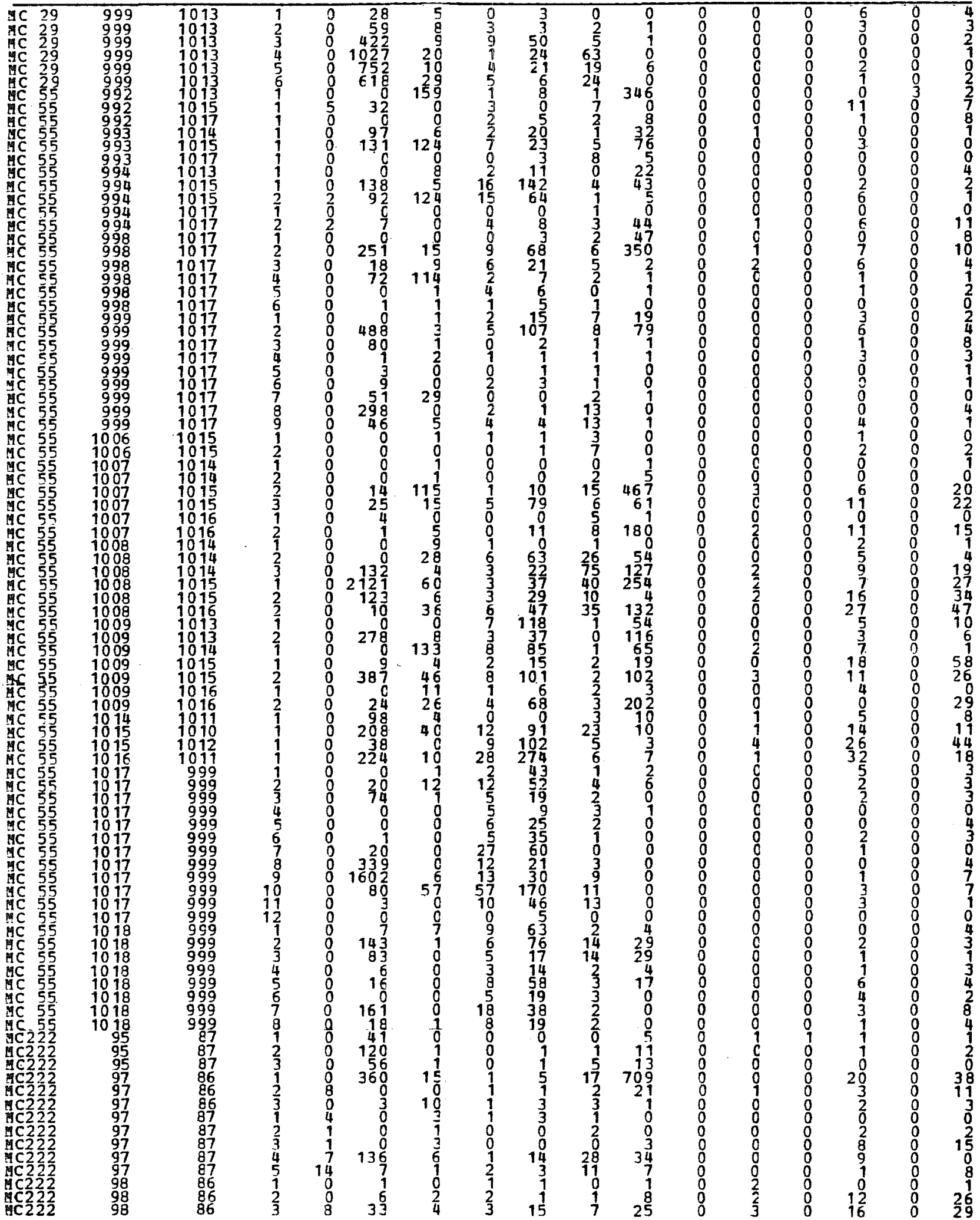


531

TABLE 55. (continued)

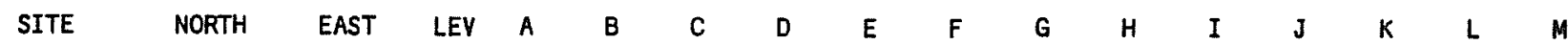

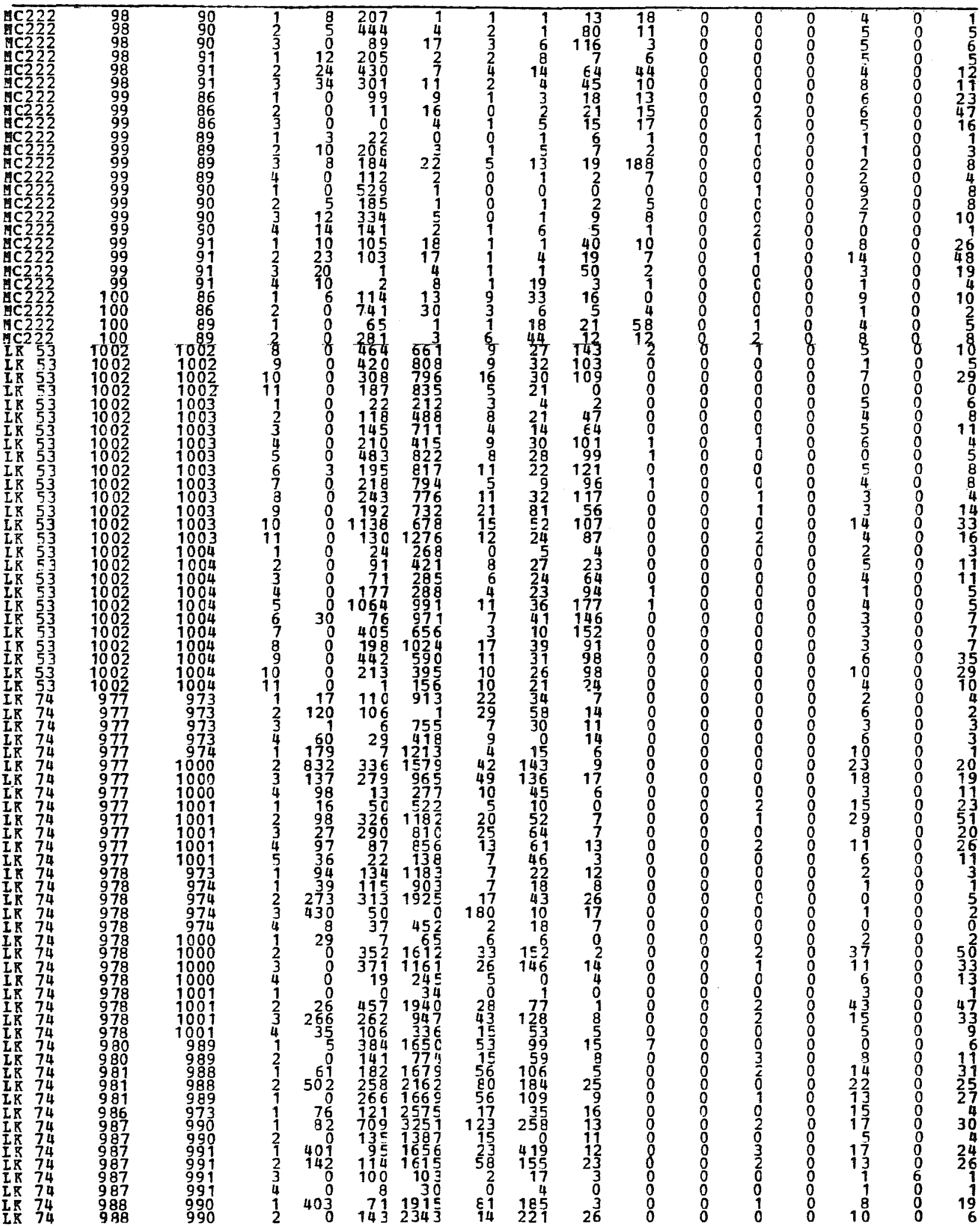


TABLE 55. (continued)

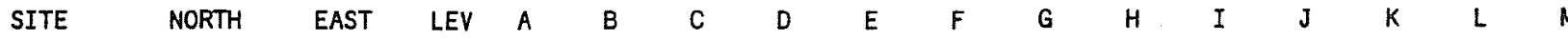

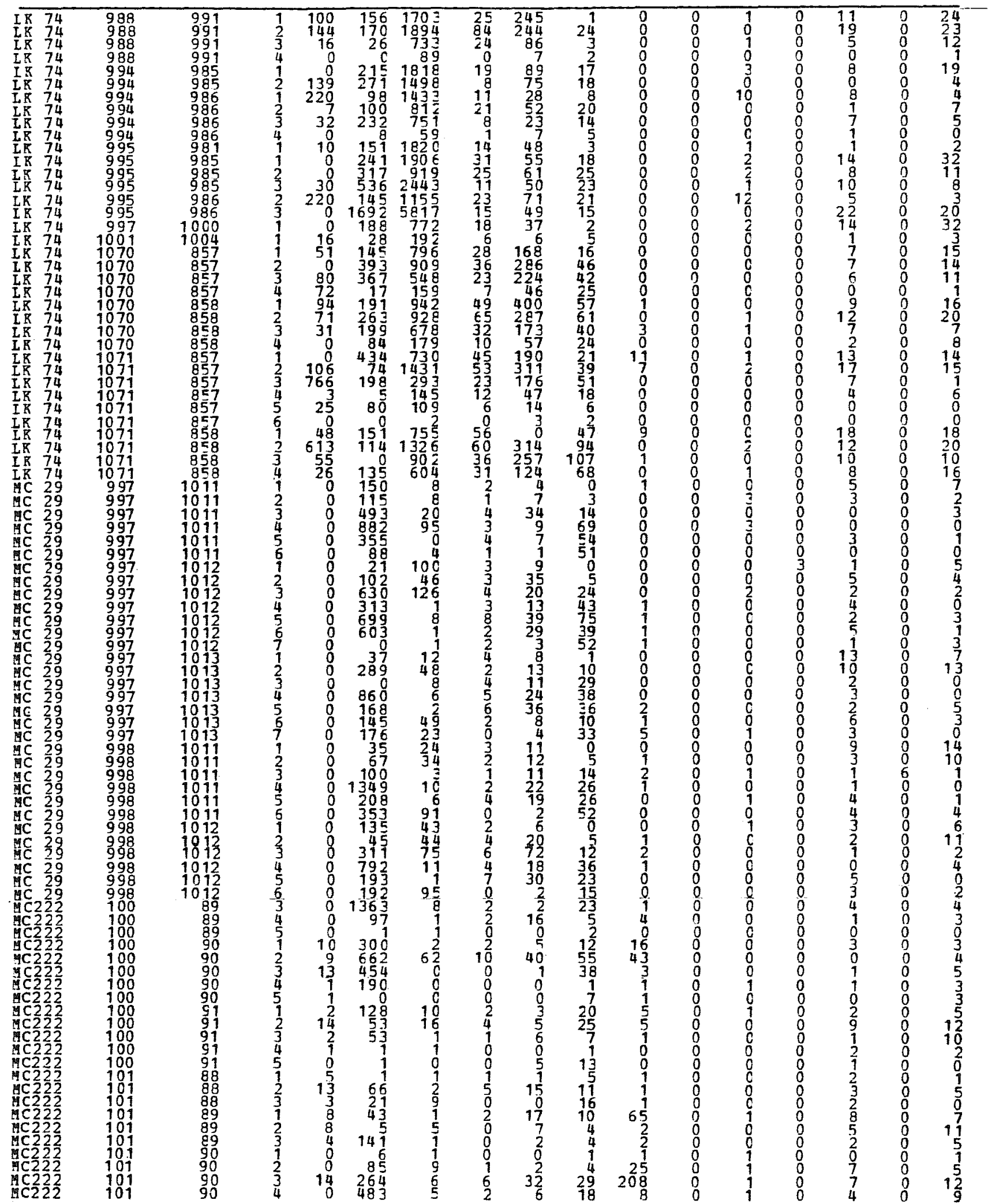


TABLE 55. (continued)

$\begin{array}{llllllllllllllllllll}\text { SITE NORTH } & \text { EAST } & \text { LEV } & \text { A } & \text { B } & \text { C } & \text { D } & \text { E } & \text { F } & \text { G } & \text { H } & \text { I } & \text { J } & K & \text { L } & \text { H }\end{array}$

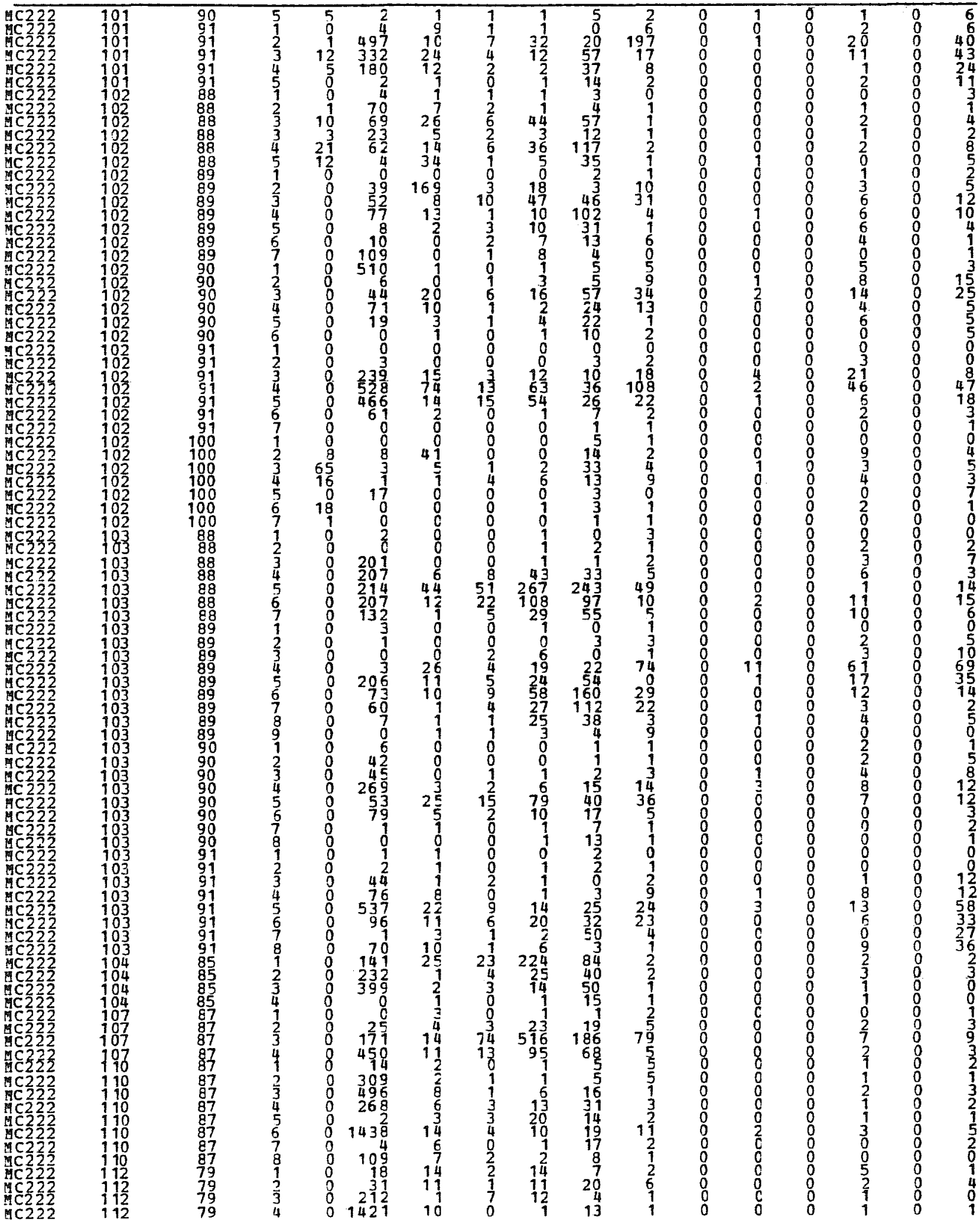


TABLE 55. (continued) $\begin{array}{llllllllllllllllllll}\text { SITE NORTH EAST LEV } & \text { A } & \text { B } & \text { C } & \text { D } & \text { E } & F & G & H & I & J & K & L & M\end{array}$

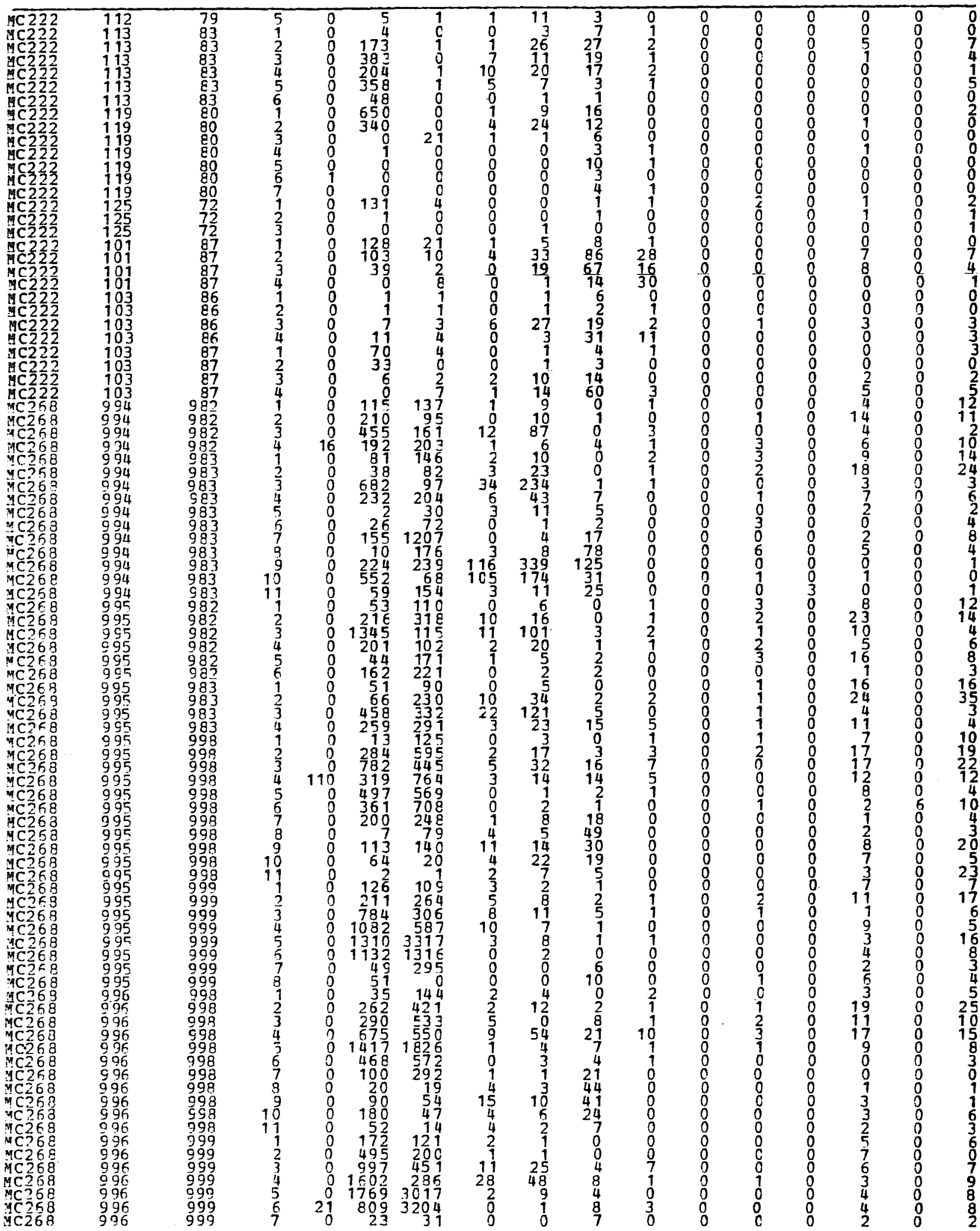


TABLE 55. (continued)

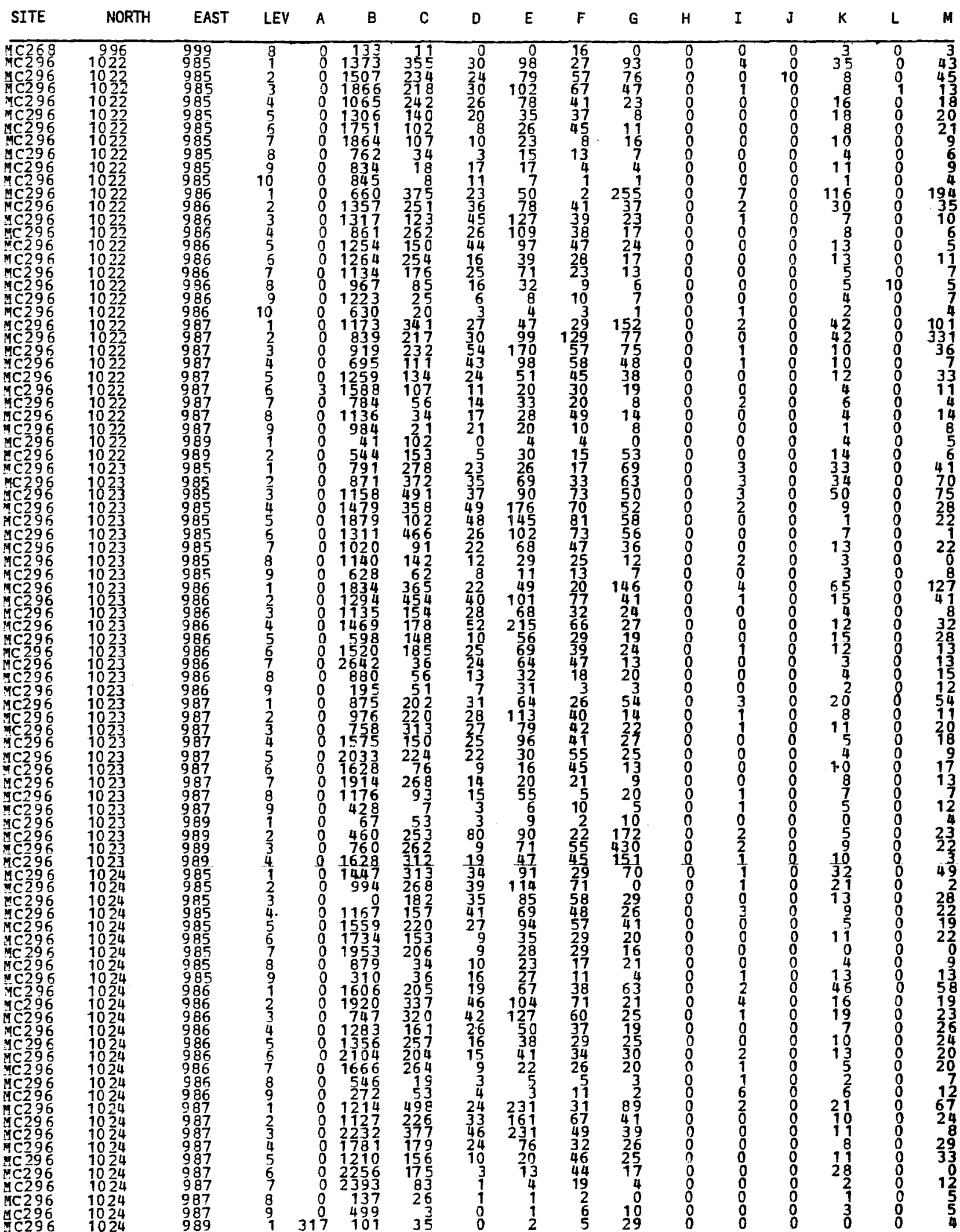


TABLE 55. (continued)

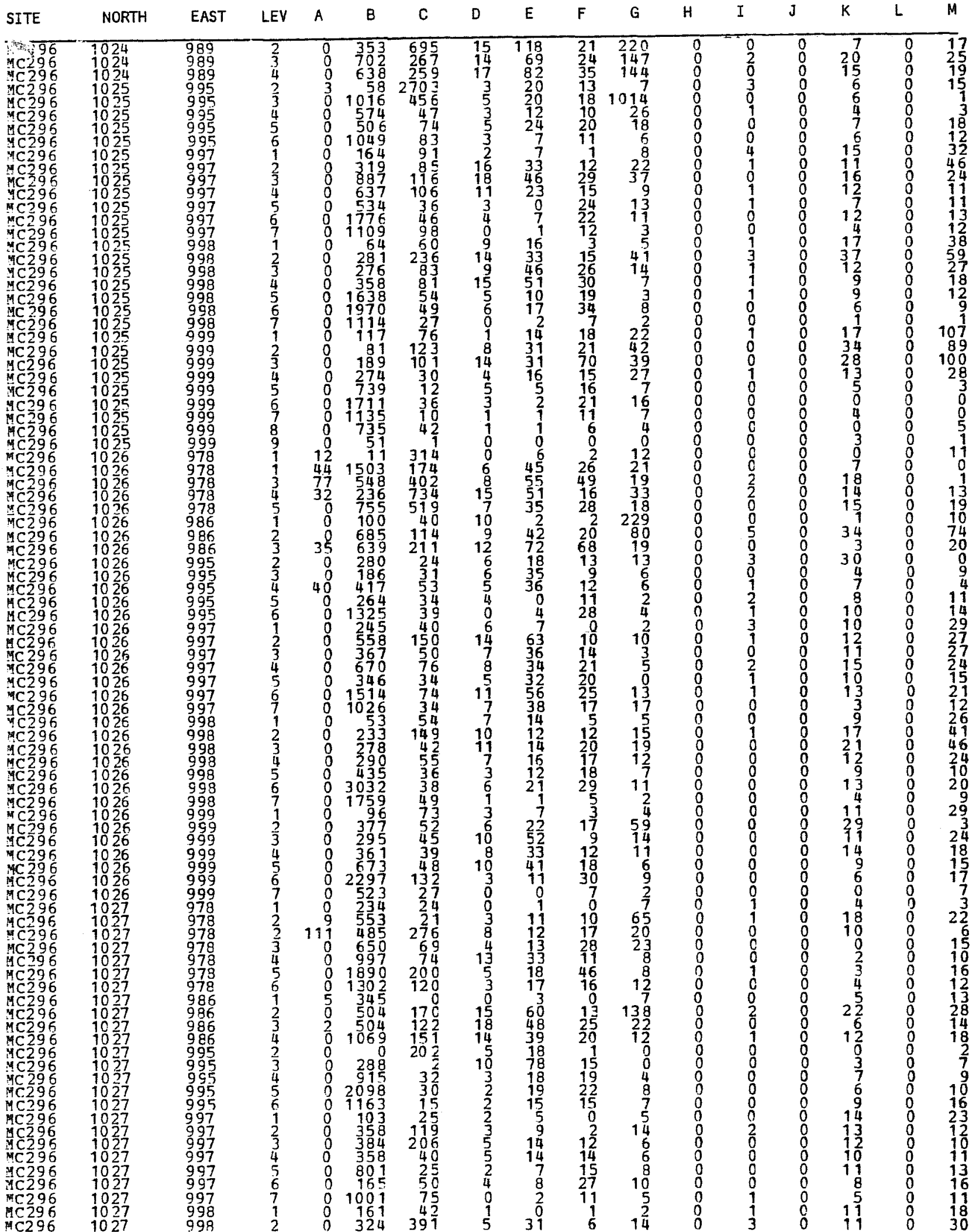


TABLE 55. (continued)

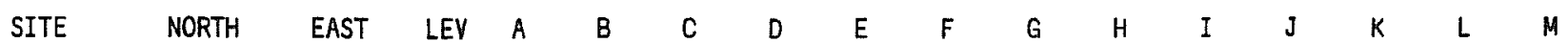

\begin{tabular}{|c|c|c|c|c|c|c|c|c|c|c|c|c|c|c|c|c|}
\hline $\begin{array}{l}\text { MC296 } \\
\text { MC296 } \\
M C 296 \\
M C 296 \\
M C 296 \\
M C 296 \\
\text { MC296 } \\
\text { MC296 } \\
4 C 296 \\
\text { MC296 } \\
\text { MC296 } \\
M C 296 \\
M C 296\end{array}$ & $\begin{array}{l}1027 \\
1027 \\
1027 \\
1027 \\
1027 \\
1027 \\
1027 \\
1027 \\
1027 \\
1027 \\
1027 \\
1027 \\
1027\end{array}$ & $\begin{array}{l}998 \\
998 \\
998 \\
998 \\
998 \\
999 \\
999 \\
999 \\
999 \\
999 \\
999 \\
999 \\
999\end{array}$ & $\begin{array}{l}3 \\
4 \\
5 \\
5 \\
7 \\
1 \\
2 \\
3 \\
4 \\
5 \\
6 \\
7 \\
8\end{array}$ & $\begin{array}{l}0 \\
0 \\
0 \\
0 \\
0 \\
0 \\
0 \\
0 \\
0 \\
0 \\
0 \\
0 \\
0\end{array}$ & $\begin{array}{r}82 \\
443 \\
771 \\
1231 \\
1437 \\
153 \\
378 \\
353 \\
380 \\
489 \\
875 \\
1306 \\
620\end{array}$ & $\begin{array}{r}128 \\
64 \\
45 \\
42 \\
131 \\
67 \\
187 \\
58 \\
41 \\
47 \\
42 \\
33 \\
70\end{array}$ & $\begin{array}{r}3 \\
10 \\
4 \\
3 \\
0 \\
7 \\
7 \\
9 \\
8 \\
7 \\
6 \\
0 \\
0\end{array}$ & $\begin{array}{r}11 \\
9 \\
9 \\
4 \\
2 \\
22 \\
27 \\
29 \\
19 \\
26 \\
24 \\
1 \\
0\end{array}$ & $\begin{array}{r}13 \\
10 \\
16 \\
24 \\
2 \\
2 \\
7 \\
7 \\
12 \\
10 \\
14 \\
8 \\
4\end{array}$ & $\begin{array}{r}9 \\
9 \\
7 \\
7 \\
1 \\
2 \\
15 \\
20 \\
11 \\
6 \\
5 \\
1 \\
0\end{array}$ & $\begin{array}{l}0 \\
0 \\
0 \\
0 \\
0 \\
0 \\
0 \\
0 \\
0 \\
0 \\
0\end{array}$ & $\begin{array}{l}3 \\
0 \\
0 \\
0 \\
0 \\
0 \\
1 \\
0 \\
2 \\
1 \\
0 \\
0\end{array}$ & $\begin{array}{l}0 \\
0 \\
0 \\
0 \\
0 \\
0 \\
0 \\
0 \\
0 \\
0 \\
0 \\
0 \\
0\end{array}$ & $\begin{array}{r}4 \\
18 \\
10 \\
38 \\
15 \\
10\end{array}$ & $\begin{array}{l}0 \\
0 \\
0 \\
0 \\
0 \\
0 \\
0 \\
0 \\
0 \\
0 \\
0 \\
0 \\
0\end{array}$ & $\begin{array}{r}12 \\
13 \\
13 \\
28 \\
8\end{array}$ \\
\hline
\end{tabular}

\begin{tabular}{|c|c|c|c|c|c|c|c|c|c|c|c|c|c|c|c|}
\hline SITE & TP & LEV & A & B & C & $D$ & $E$ & $F$ & G & $H$ & I & $\mathbf{J}$ & $k$ & L & $M$ \\
\hline 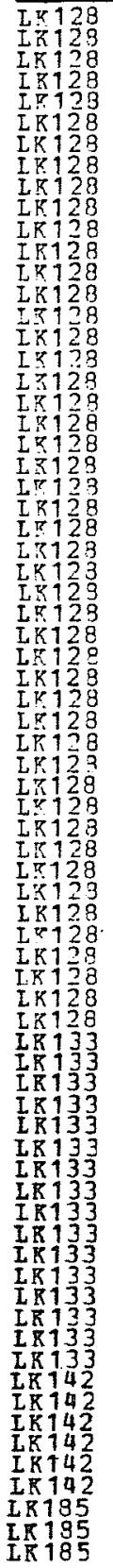 & $\begin{array}{l}1 \\
1 \\
2 \\
2 \\
3 \\
3 \\
3 \\
3 \\
4 \\
4 \\
4 \\
5 \\
5 \\
5 \\
5 \\
5 \\
5 \\
5 \\
6 \\
6 \\
6 \\
6 \\
7 \\
7 \\
7 \\
7 \\
7 \\
7 \\
7 \\
7 \\
8 \\
8 \\
8 \\
8 \\
9 \\
10 \\
11 \\
11 \\
11 \\
11 \\
11 \\
12 \\
12 \\
9 \\
10 \\
13 \\
14 \\
16 \\
1 \\
1 \\
1 \\
1 \\
1 \\
1 \\
1 \\
1 \\
1 \\
2 \\
2 \\
2 \\
2 \\
2 \\
2 \\
2 \\
1 \\
1 \\
1 \\
1 \\
1 \\
1 \\
1 \\
1 \\
1\end{array}$ & $\begin{array}{l}1 \\
2 \\
1 \\
2 \\
1 \\
2 \\
3 \\
4 \\
1 \\
2 \\
1 \\
2 \\
3 \\
4 \\
5 \\
6 \\
7 \\
9 \\
1 \\
2 \\
3 \\
4 \\
1 \\
2 \\
3 \\
4 \\
5 \\
6 \\
7 \\
8 \\
1 \\
2 \\
3 \\
4 \\
1 \\
1 \\
1 \\
2 \\
3 \\
4 \\
5 \\
1 \\
2 \\
2 \\
2 \\
1 \\
1 \\
1 \\
1 \\
2 \\
3 \\
4 \\
5 \\
6 \\
7 \\
8 \\
9 \\
1 \\
2 \\
3 \\
4 \\
5 \\
6 \\
7 \\
1 \\
2 \\
3 \\
4 \\
5 \\
6 \\
1 \\
2 \\
3\end{array}$ & $\begin{array}{r}6 \\
0 \\
0 \\
68 \\
0 \\
88 \\
0 \\
0 \\
0 \\
0 \\
0 \\
0 \\
166 \\
0 \\
0 \\
0 \\
0 \\
0 \\
0 \\
8 \\
0 \\
51 \\
0 \\
36 \\
0 \\
138 \\
360 \\
0 \\
0 \\
0 \\
0 \\
0 \\
0 \\
0 \\
11 \\
0 \\
0 \\
0 \\
0 \\
0 \\
0 \\
0 \\
101 \\
0 \\
0 \\
0 \\
5 \\
0 \\
33 \\
14 \\
100 \\
96 \\
2 \\
26 \\
90 \\
0 \\
0 \\
86 \\
28 \\
0 \\
29 \\
0 \\
0 \\
0 \\
0 \\
6 \\
0 \\
0 \\
0 \\
0 \\
46 \\
9 \\
19\end{array}$ & 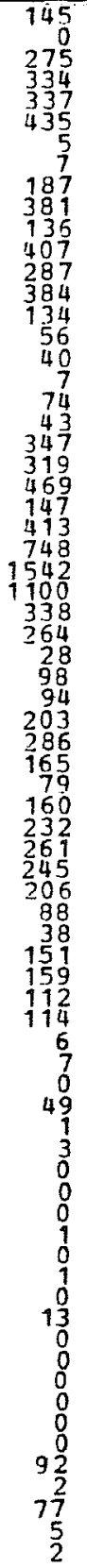 & 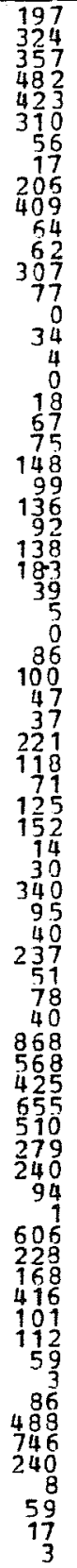 & 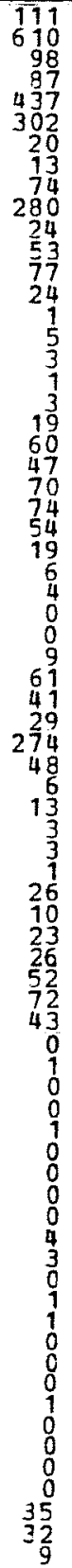 & $\begin{array}{r}378 \\
1103 \\
250 \\
253 \\
274 \\
1017 \\
65 \\
0 \\
175 \\
259 \\
130 \\
300 \\
422 \\
10 \\
13 \\
34 \\
18 \\
30 \\
9 \\
74 \\
388 \\
143 \\
430 \\
447 \\
317 \\
0 \\
14 \\
13 \\
2 \\
22 \\
47 \\
398 \\
212 \\
112 \\
3135 \\
259 \\
48 \\
86 \\
28 \\
21 \\
142 \\
41 \\
143 \\
273 \\
308 \\
576 \\
264 \\
8 \\
5 \\
1 \\
0 \\
13 \\
0 \\
114 \\
17 \\
69\end{array}$ & $\begin{array}{r}99 \\
99 \\
23 \\
39 \\
4 \\
14 \\
2 \\
0 \\
12 \\
17 \\
108 \\
329 \\
278 \\
258 \\
15 \\
18 \\
11 \\
6 \\
65 \\
155 \\
352 \\
173 \\
219 \\
344 \\
161 \\
167 \\
94 \\
118 \\
23 \\
26 \\
27 \\
200 \\
192 \\
159 \\
375 \\
103 \\
39 \\
143 \\
113 \\
95 \\
124 \\
124 \\
124 \\
191 \\
170 \\
105 \\
202 \\
89 \\
99 \\
77 \\
49 \\
40 \\
25 \\
15 \\
28 \\
17 \\
77 \\
92 \\
45 \\
30 \\
25 \\
34 \\
16 \\
12 \\
49 \\
49 \\
79 \\
61\end{array}$ & 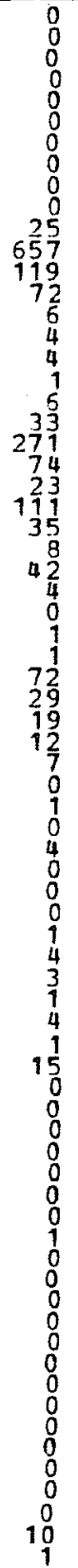 & $\begin{array}{l}0 \\
0 \\
0 \\
0 \\
0 \\
0 \\
0 \\
0 \\
0 \\
0 \\
0 \\
0 \\
0 \\
0 \\
0 \\
0 \\
0 \\
0 \\
0 \\
0 \\
0 \\
0 \\
0 \\
0 \\
0 \\
0 \\
0 \\
0 \\
0 \\
0 \\
0 \\
0 \\
0 \\
0 \\
0 \\
0 \\
0 \\
0 \\
0 \\
0 \\
0 \\
0 \\
0 \\
0 \\
0 \\
0 \\
0 \\
0 \\
0 \\
0 \\
0 \\
0 \\
0 \\
0 \\
0 \\
0 \\
0 \\
0 \\
0 \\
0 \\
0 \\
0 \\
0 \\
0 \\
0 \\
0 \\
0 \\
0 \\
0 \\
0 \\
0 \\
0\end{array}$ & 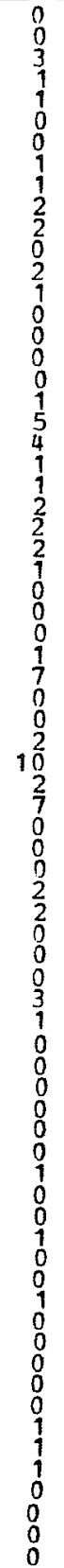 & $\begin{array}{l}0 \\
0 \\
0 \\
0 \\
0 \\
0 \\
0 \\
0 \\
0 \\
0 \\
0 \\
0 \\
0 \\
0 \\
0 \\
0 \\
0 \\
0 \\
0 \\
0 \\
0 \\
0 \\
0 \\
0 \\
0 \\
0 \\
0 \\
0 \\
0 \\
0 \\
0 \\
0 \\
0 \\
0 \\
0 \\
0 \\
0 \\
0 \\
0 \\
0 \\
6 \\
0 \\
0 \\
0 \\
0 \\
0 \\
0 \\
0 \\
0 \\
0 \\
0 \\
0 \\
0 \\
0 \\
0 \\
0 \\
0 \\
0 \\
0 \\
0 \\
0 \\
0 \\
0 \\
0 \\
0 \\
0 \\
0 \\
0 \\
0 \\
0 \\
0 \\
0 \\
0 \\
0 \\
0\end{array}$ & $\begin{array}{r}7 \\
3 \\
9 \\
13 \\
12 \\
12 \\
5 \\
4 \\
0 \\
10 \\
21 \\
25 \\
8 \\
6 \\
1 \\
3 \\
0 \\
0 \\
5 \\
30 \\
35 \\
13 \\
53 \\
29 \\
19 \\
8 \\
7 \\
4 \\
0 \\
0 \\
30 \\
66 \\
3 \\
4 \\
17 \\
13 \\
8 \\
4 \\
3 \\
2 \\
1 \\
10 \\
4 \\
2 \\
4 \\
5 \\
8 \\
6 \\
1 \\
1 \\
0 \\
0 \\
0 \\
0 \\
0 \\
0 \\
1 \\
2 \\
0 \\
0 \\
1 \\
1 \\
0 \\
0 \\
0 \\
1 \\
2 \\
1 \\
7 \\
0 \\
0 \\
33 \\
3\end{array}$ & $\begin{array}{l}0 \\
0\end{array}$ & $\begin{array}{r}5 \\
7 \\
4 \\
14 \\
4 \\
14 \\
7 \\
9 \\
6 \\
8 \\
39 \\
32 \\
13 \\
4 \\
0 \\
0 \\
1 \\
0 \\
7 \\
40 \\
24 \\
13 \\
73 \\
43 \\
22 \\
14 \\
11 \\
5 \\
1 \\
0 \\
33 \\
105 \\
22 \\
29 \\
20 \\
17 \\
8 \\
8 \\
3 \\
2 \\
1 \\
24 \\
4 \\
3 \\
17 \\
14 \\
30 \\
10 \\
1 \\
4 \\
0 \\
2 \\
1 \\
0 \\
0 \\
0 \\
0 \\
0\end{array}$ \\
\hline
\end{tabular}


TABLE 55. (continued)

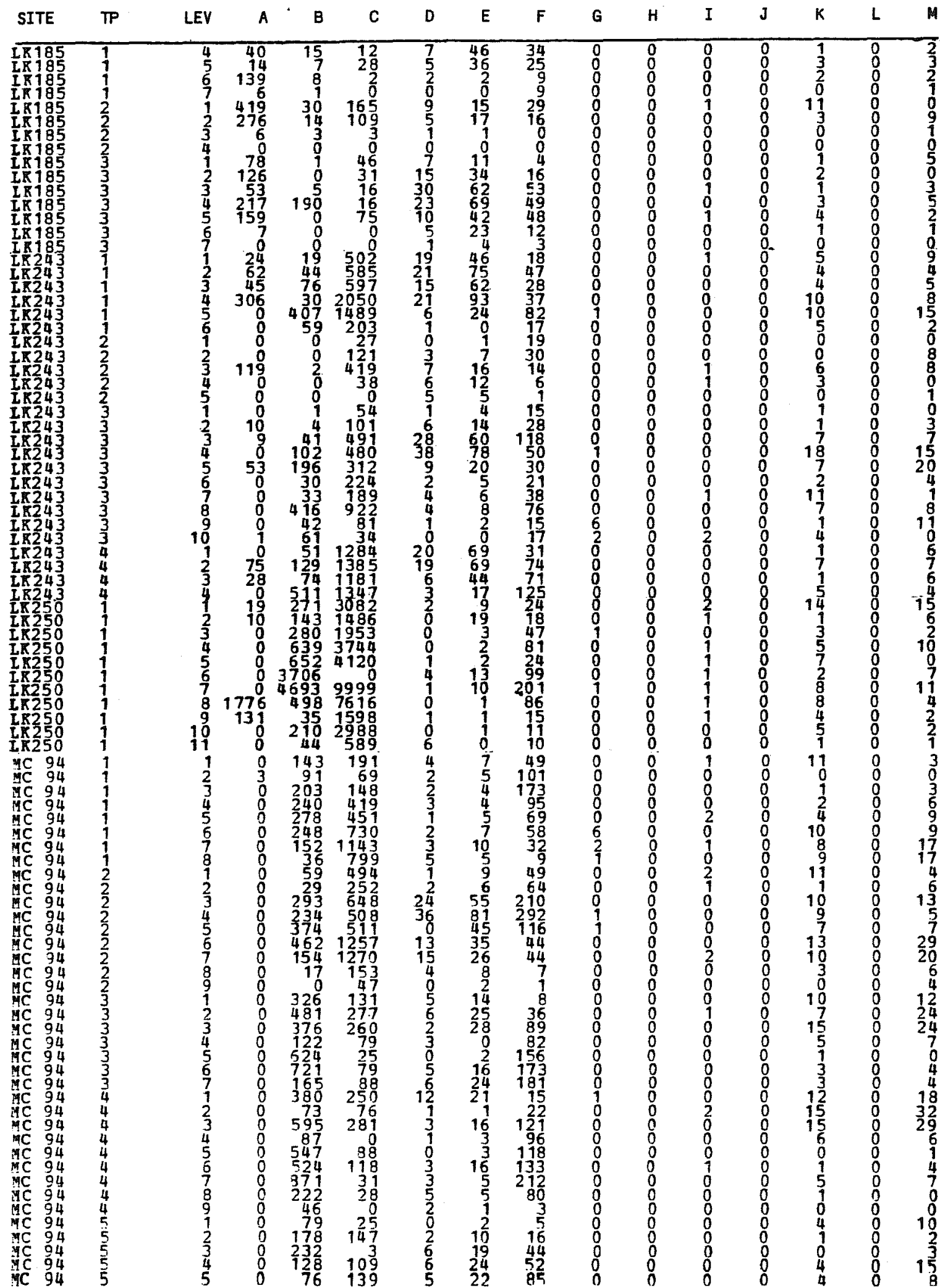


TABLE 55. (continued)

\begin{tabular}{|c|c|c|c|c|c|c|c|c|c|c|c|c|c|c|c|}
\hline SITE. & $\mathbb{T}$ & LEV & A & B & C & D & $E$ & $F$ & G & $H$ & I & J & K & L & 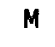 \\
\hline 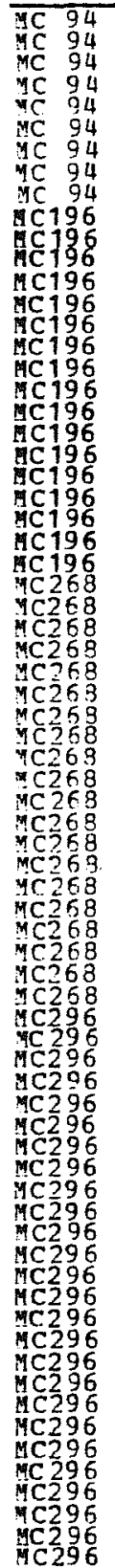 & $\begin{array}{l}5 \\
6 \\
6 \\
6 \\
6 \\
6 \\
6 \\
6 \\
6 \\
1 \\
1 \\
1 \\
1 \\
1 \\
1 \\
2 \\
2 \\
2 \\
2 \\
2 \\
2 \\
2 \\
3 \\
3 \\
3 \\
3 \\
3 \\
1 \\
1 \\
1 \\
1 \\
1 \\
1 \\
1 \\
2 \\
2 \\
2 \\
2 \\
2 \\
2 \\
2 \\
2 \\
2 \\
3 \\
3 \\
3 \\
3 \\
3 \\
3 \\
1 \\
1 \\
1 \\
1 \\
1 \\
1 \\
1 \\
3 \\
1 \\
2 \\
1 \\
1 \\
1 \\
1 \\
1 \\
1 \\
1 \\
1 \\
2 \\
2 \\
2 \\
2\end{array}$ & $\begin{array}{r}6 \\
1 \\
2 \\
3 \\
4 \\
5 \\
6 \\
7 \\
8 \\
1 \\
2 \\
3 \\
4 \\
5 \\
6 \\
1 \\
2 \\
3 \\
4 \\
5 \\
6 \\
1 \\
2 \\
3 \\
4 \\
5 \\
1 \\
2 \\
3 \\
4 \\
5 \\
6 \\
7 \\
1 \\
2 \\
3 \\
4 \\
5 \\
6 \\
7 \\
8 \\
1 \\
2 \\
3 \\
4 \\
5 \\
1 \\
2 \\
3 \\
4 \\
5 \\
6 \\
7 \\
8 \\
9 \\
10 \\
11 \\
12 \\
13 \\
14 \\
1 \\
2 \\
3 \\
4 \\
5 \\
6 \\
7 \\
8 \\
9 \\
1 \\
2 \\
3 \\
\end{array}$ & $\begin{array}{r}0 \\
0 \\
0 \\
0 \\
54 \\
0 \\
0 \\
0 \\
0 \\
0 \\
10 \\
0 \\
0 \\
0 \\
0 \\
0 \\
0 \\
0 \\
0 \\
0 \\
0 \\
0 \\
0 \\
0 \\
0 \\
0 \\
0 \\
3 \\
0 \\
0 \\
0 \\
0 \\
0 \\
0 \\
0 \\
0 \\
0 \\
0 \\
0 \\
0 \\
0 \\
1 \\
6 \\
143 \\
7 \\
0 \\
0 \\
10 \\
0 \\
0 \\
0 \\
0 \\
0 \\
0 \\
0 \\
0 \\
0 \\
0 \\
0 \\
0 \\
0 \\
0 \\
0 \\
0 \\
0 \\
0 \\
0 \\
0 \\
0 \\
0 \\
0 \\
0\end{array}$ & $\begin{array}{r}178 \\
178 \\
29 \\
207 \\
47 \\
131 \\
10 \\
1 \\
19 \\
5500 \\
4328 \\
3280 \\
968 \\
162 \\
30 \\
17 \\
11 \\
25 \\
249 \\
529 \\
26 \\
1114 \\
982 \\
707 \\
1109 \\
792 \\
54 \\
54 \\
13 \\
1 \\
22 \\
80 \\
019 \\
319 \\
336 \\
335 \\
424 \\
469 \\
380 \\
12 \\
295 \\
198 \\
314 \\
1545 \\
265 \\
84 \\
406 \\
1343 \\
1364 \\
1285 \\
2140 \\
4070 \\
3628 \\
2547 \\
1405 \\
535 \\
23 \\
66 \\
0 \\
010 \\
36 \\
391 \\
368 \\
523 \\
235 \\
377 \\
207 \\
230 \\
379 \\
33 \\
50 \\
35\end{array}$ & $\begin{array}{r}113 \\
21 \\
24 \\
5 \\
72 \\
20 \\
23 \\
13 \\
18 \\
2700 \\
6148 \\
500 \\
384 \\
66 \\
12 \\
44 \\
44 \\
42 \\
241 \\
1269 \\
161 \\
194 \\
390 \\
126 \\
432 \\
2769 \\
10 \\
15 \\
11 \\
66 \\
30 \\
12 \\
37 \\
324 \\
425 \\
581 \\
398 \\
548 \\
110 \\
104 \\
24 \\
275 \\
199 \\
1196 \\
922 \\
136 \\
86 \\
166 \\
159 \\
166 \\
142 \\
77 \\
121 \\
63 \\
54 \\
18 \\
1 \\
2 \\
20 \\
50 \\
58 \\
85 \\
26 \\
42 \\
68 \\
43 \\
37 \\
10 \\
110 \\
1 \\
1\end{array}$ & 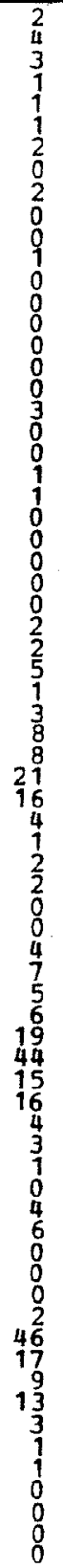 & $\begin{array}{r}13 \\
10 \\
10 \\
3 \\
3 \\
19 \\
1 \\
5 \\
5 \\
1 \\
1 \\
1 \\
0 \\
0 \\
0 \\
0 \\
0 \\
0 \\
0 \\
0 \\
0 \\
0 \\
0 \\
29 \\
3\end{array}$ & 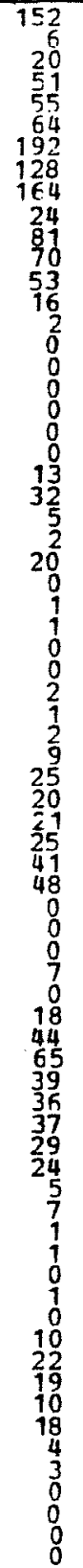 & 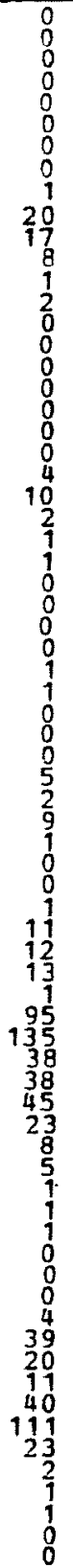 & $\begin{array}{l}0 \\
0 \\
0 \\
0 \\
0 \\
0 \\
0 \\
0 \\
0 \\
0 \\
0 \\
0 \\
0 \\
0 \\
0 \\
0 \\
0 \\
0 \\
0 \\
0 \\
0 \\
0 \\
0 \\
0 \\
0 \\
0 \\
0 \\
0 \\
0 \\
0 \\
0 \\
0 \\
0 \\
0 \\
0 \\
0 \\
0 \\
0 \\
0 \\
0 \\
0 \\
0 \\
0 \\
0 \\
0 \\
0 \\
0 \\
0 \\
0 \\
0 \\
0 \\
0 \\
0 \\
0 \\
0 \\
0 \\
0 \\
0 \\
0 \\
0 \\
0 \\
0 \\
0\end{array}$ & $\begin{array}{l}2 \\
0 \\
0 \\
0 \\
1 \\
0 \\
0 \\
0 \\
0 \\
3 \\
0 \\
1 \\
0 \\
0 \\
0 \\
0 \\
0 \\
0 \\
0 \\
0 \\
0 \\
0 \\
0 \\
0 \\
0 \\
1 \\
0 \\
0 \\
0 \\
0 \\
0 \\
0 \\
0 \\
2 \\
0 \\
1 \\
1 \\
1 \\
0 \\
1 \\
0 \\
2 \\
5 \\
7 \\
1 \\
0 \\
3 \\
3 \\
1 \\
0 \\
1 \\
0 \\
0 \\
0 \\
0 \\
0 \\
0 \\
0 \\
0 \\
0 \\
0 \\
0 \\
4 \\
4 \\
1 \\
0 \\
0 \\
1 \\
0 \\
0 \\
1 \\
1 \\
0 \\
0\end{array}$ & $\begin{array}{l}0 \\
0 \\
0 \\
0 \\
0 \\
0 \\
0 \\
0 \\
0 \\
0 \\
0 \\
0 \\
0 \\
0 \\
0 \\
0 \\
0 \\
0 \\
0 \\
0 \\
0 \\
0 \\
0 \\
0 \\
0 \\
0 \\
0 \\
0 \\
0 \\
0 \\
0 \\
0 \\
0 \\
0 \\
0 \\
0 \\
0 \\
0 \\
0 \\
0 \\
0 \\
0 \\
0 \\
0 \\
0 \\
0 \\
0 \\
0 \\
0 \\
0 \\
0 \\
0 \\
0 \\
0 \\
0 \\
0 \\
0 \\
0 \\
0 \\
0 \\
0 \\
0 \\
0 \\
0 \\
0 \\
0 \\
0 \\
0 \\
0\end{array}$ & 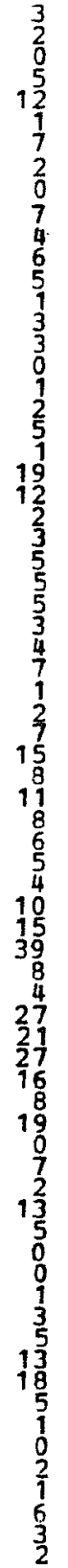 & $\begin{array}{l}0 \\
0 \\
0 \\
0 \\
0 \\
0 \\
0 \\
0 \\
0 \\
0 \\
0 \\
0 \\
0 \\
0 \\
0 \\
0 \\
0 \\
0 \\
0 \\
0 \\
0 \\
0 \\
0 \\
0 \\
0 \\
0 \\
0 \\
0 \\
0 \\
0 \\
0 \\
0 \\
0 \\
0 \\
0 \\
0 \\
0 \\
0 \\
0 \\
0 \\
0 \\
0 \\
0 \\
0 \\
0 \\
0 \\
0 \\
0 \\
0 \\
0 \\
0 \\
0 \\
0 \\
0 \\
0 \\
0 \\
0 \\
0 \\
0 \\
0 \\
0 \\
0 \\
0 \\
0 \\
0 \\
0 \\
0 \\
0 \\
0 \\
0 \\
0 \\
0\end{array}$ & $\begin{array}{r} \\
2 \\
8 \\
1 \\
20 \\
8 \\
2 \\
1 \\
6 \\
3 \\
0 \\
6 \\
5 \\
8 \\
4 \\
2 \\
14 \\
19 \\
19 \\
14 \\
13 \\
1 \\
4 \\
1 \\
32 \\
29 \\
59 \\
27 \\
47 \\
37 \\
40 \\
45 \\
15 \\
27 \\
15 \\
15 \\
19 \\
4 \\
1 \\
0 \\
0 \\
83 \\
23 \\
23 \\
17 \\
18 \\
10 \\
5 \\
3 \\
2 \\
6 \\
\end{array}$ \\
\hline
\end{tabular}




\section{DEBITAGE TABLE}

In Table 56, the debitage recovered from prehistoric sites excavated during the Phase II investigation is broken down into the 53 units used in the debitage analysis. Each debitage category is represented in the table by a code number. Code numbers and corresponding debitage categories are presented below:

CODE CODE

$\begin{array}{llll}37 & \text { Primary Flakes - Total } & 64 & \text { Single Facet Platform } \\ 38 & \text { Cortex Platform } & 65 & \text { Modified } \\ 39 & \text { Modified } & 66 & \text { Trimmed } \\ 40 & \text { Trimmed } & 67 & \text { Small Multiple Facet Platform } \\ 41 & \text { Single Facet Platform } & 68 & \text { Modified } \\ 42 & \text { Modified } & 69 & \text { Trimmed } \\ 43 & \text { Trimmed } & 70 & \text { Large Multiple Facet Platform } \\ 44 & \text { Other Platform Types } & 71 & \text { Modified } \\ 45 & \text { Modified } & 72 & \text { Trimmed } \\ 46 & \text { Trimmed } & 73 & \text { Lipped } \\ 47 & \text { Secondary Flakes - Total } & 74 & \text { Modified } \\ 48 & \text { Cortex Platform } & 75 & \text { Trimmed } \\ 49 & \text { Modified } & 76 & \text { Chips - Total } \\ 50 & \text { Trimmed } & 77 & \text { Cortex } \\ 51 & \text { Single Facet Platform } & 78 & \text { Modified } \\ 52 & \text { Modified } & 79 & \text { Trimmed } \\ 53 & \text { Trimmed } & 80 & \text { Partial Cortex } \\ 54 & \text { Small Multiple Facet Platform } & 81 & \text { Modified } \\ 55 & \text { Modified } & 82 & \text { Trimmed } \\ 56 & \text { Trimmed } & 83 & \text { No Cortex } \\ 57 & \text { Large Multiple Facet Platform } & 84 & \text { Modified } \\ 58 & \text { Modified } & 85 & \text { Trimmed } \\ 59 & \text { Trimmed } & 86 & \text { Chunks - Total } \\ 60 & \text { Lipped } & 87 & \text { Cortex } \\ 61 & \text { Modified } & 88 & \text { Partial Cortex } \\ 62 & \text { Trimmed } & 89 & \text { No Cortex } \\ 63 & \text { Tertiáry Flakes - Total } & & \\ & & & \end{array}$

It is important to note that the code numbers 1 isted above are different from those used in the analysis of debitage recovered during the Phase I investigations (Ha11, Black, and Graves 1982:620). However, the debitage categories and their ordering are exactiy the same.

Headings for Table 56 provide: (1) Site Number, (2) Excavation Area, Unit, or Test Pit (TP), and (3) either "Horizon" assignments or the term "ALL." The "Excavation Area" heading indicates that debitage collections from a number of contiguous units have been combined to yield the totals presented. In most cases, "Unit" and "Test Pit" represent $1-\mathrm{m}^{2}$ excavations. Horizon assignments are indicated by the column headings "lst," "2nd," "3rd," "4th," etc. Horizons consist of one or more vertical excavation levels $(5-\mathrm{cm}$ or $10-$ $\mathrm{cm}$ thick in most cases) yielding markedly greater amounts of cultural residues than levels immediately above or below. They have been defined based on the vertical distribution of materials as shown in the Material Analysis 
TABLE 56. DEBITAGE ANALYSIS FOR PHASE II INVESTIGATIONS

\begin{tabular}{|c|c|c|c|c|c|c|c|c|c|c|c|}
\hline \multirow[b]{3}{*}{ CODE } & \multicolumn{8}{|c|}{41 LK 8} & \multicolumn{3}{|c|}{4 LK 14} \\
\hline & & Area A & & & & & & SITE & 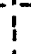 & & \\
\hline & 1st & 2nd & $3 r d$ & lst & 2nd & Ist & 2nd & TOTAL & 1 & lst & 2nd \\
\hline 37 & 9 & 11 & 11 & 18 & 11 & 9 & 5 & 74 & i & 29 & 9 \\
\hline 38 & 3 & 3 & 4 & 10 & 3 & 2 & 2 & 27 & $i$ & 11 & 6 \\
\hline 39 & 0 & 0 & 0 & 0 & 0 & 0 & 0 & 0 & 1 & 0 & 0 \\
\hline 40 & 0 & 0 & 0 & 0 & 0 & 0 & 0 & 0 & 1 & 0 & 1 \\
\hline 41 & 5 & 5 & 5 & 5 & 8 & 5 & 3 & 36 & i & 18 & 4 \\
\hline 42 & 0 & 0 & 0 & 0 & 0 & 0 & 0 & 0 & 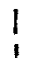 & 0 & 0 \\
\hline 43 & 0 & 0 & 0 & 0 & 0 & 0 & 0 & 0 & 1 & 0 & 0 \\
\hline 44 & 1 & 3 & 2 & 19 & 0 & 2 & 0 & 27 & 1 & 2 & 0 \\
\hline 45 & 0 & 0 & 0 & 0 & 0 & 0 & 0 & 0 & 1 & 0 & 0 \\
\hline 46 & 0 & 0 & 0 & 0 & 0 & 0 & 0 & 0 & 1 & 0 & 0 \\
\hline 47 & 161 & 119 & 63 & 143 & 57 & 46 & 30 & 619 & $i$ & 327 & 175 \\
\hline 48 & 56 & $4 I$ & 27 & 55 & 28 & 13 & 17 & 237 & 1 & 80 & 53 \\
\hline 49 & 10 & 0 & 0 & 1 & 1 & 0 & 0 & 12 & 1 & 6 & 3 \\
\hline 50 & 12 & 0 & 0 & 0 & 3 & 0 & 0 & 15 & 1 & 3 & 0 \\
\hline 51 & 26 & 10 & 4 & 21 & 4 & 6 & 3 & 74 & 1 & 73 & 37 \\
\hline 52 & 10 & 1 & 0 & $I$ & 0 & 0 & 0 & 12 & 1 & 4 & 2 \\
\hline 53 & 5 & 10 & 0 & 1 & 2 & 0 & 0 & 18 & 1 & 0 & 1 \\
\hline 54 & 11 & 21 & 3 & 8 & 3 & 6 & 6 & 58 & 1 & 5 & 2 \\
\hline 55 & 0 & 6 & 0 & 0 & 0 & 0 & 0 & 6 & 1 & 0 & 0 \\
\hline 56 & 0 & 6 & 0 & 0 & 0 & 0 & 0 & 6 & 1 & 0 & 0 \\
\hline 57 & 5 & 15 & 1 & 8 & 2 & 2 & 1 & 34 & I & 1 & 0 \\
\hline 58 & 0 & 0 & 11 & 0 & 0 & 0 & 0 & 11 & $i$ & 0 & 0 \\
\hline 59 & 0 & 0 & 6 & 0 & 0 & 0 & 0 & 6 & $i$ & 0 & 0 \\
\hline 60 & 66 & 48 & 33 & 66 & 19 & 19 & 3 & 254 & 1 & 155 & 83 \\
\hline 61 & 0 & I & 6 & 0 & 0 & 0 & 0 & 7 & 1 & 1 & 1 \\
\hline 62 & 6 & 0 & 0 & 2 & 0 & 0 & 0 & 8 & 1 & 1 & 0 \\
\hline 63 & 344 & 264 & 135 & 251 & 119 & 77 & 40 & 1230 & 1 & 487 & 374 \\
\hline
\end{tabular}


TABLE 56. (continued)

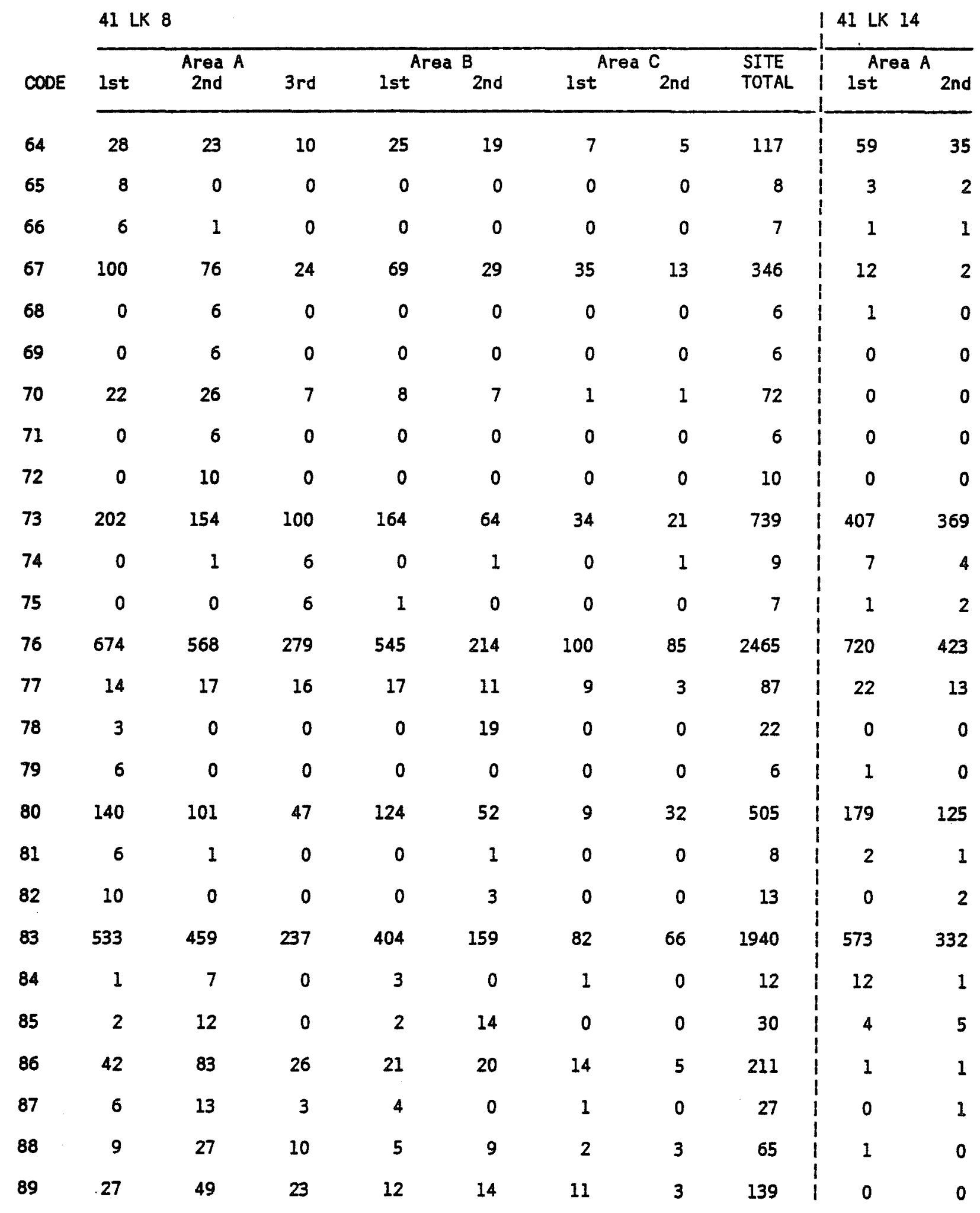


TABLE 56. (continued)

\begin{tabular}{|c|c|c|c|c|c|c|c|c|c|c|}
\hline \multirow[b]{2}{*}{ CODE } & \multicolumn{2}{|c|}{ Area B } & \multirow{2}{*}{$\begin{array}{l}\text { SITE } \\
\text { TOTAL }\end{array}$} & \multirow{2}{*}{ 1st } & \multicolumn{2}{|c|}{ Area A } & \multirow[b]{2}{*}{ 4th } & \multicolumn{2}{|c|}{ Area B } & \multirow[b]{2}{*}{ A11 } \\
\hline & 1st & 2nd & & & 2nd & $3 \mathrm{rd}$ & & Ist & 2nd & \\
\hline 37 & 7 & 12 & 57 & i 93 & 240 & 54 & 18 & 2 & 3 & 1 \\
\hline 38 & 1 & 4 & 22 & $i$ & 1 & 7 & 2 & 0 & 3 & 1 \\
\hline 39 & 0 & 0 & 0 & 10 & 0 & 0 & 0 & 0 & 0 & 0 \\
\hline 40 & 0 & 0 & 1 & 1 & 0 & 0 & 0 & 0 & 0 & 0 \\
\hline 41 & 5 & 6 & 33 & $i$ & 11 & 7 & 5 & 2 & 0 & 0 \\
\hline 42 & 0 & 0 & 0 & 1 & 0 & 0 & 0 & 0 & 0 & 0 \\
\hline 43 & 0 & 0 & 0 & $i$ & 0 & 0 & 0 & 0 & 0 & 0 \\
\hline 44 & 1 & 2 & 5 & 0 & 0 & 2 & 1 & 0 & 0 & 0 \\
\hline 45 & 0 & 0 & 0 & 1 & 0 & 0 & 0 & 0 & 0 & 0 \\
\hline 46 & 0 & 0 & 0 & 0 & 0 & 0 & 0 & 0 & 0 & 0 \\
\hline 47 & 185 & 181 & 868 & 164 & 232 & 310 & 151 & 14 & 36 & 28 \\
\hline 48 & 43 & 47 & 223 & I 53 & 92 & 110 & 65 & 5 & 17 & 14 \\
\hline 49 & 0 & 1 & 10 & 0 & 1 & 0 & 0 & 0 & 0 & 0 \\
\hline 50 & 2 & 0 & 5 & 0 & 1 & 0 & 0 & 0 & 0 & 0 \\
\hline 51 & 46 & 40 & 196 & 40 & 50 & 56 & 33 & 3 & 4 & 4 \\
\hline 52 & 0 & 3 & 9 & 0 & 0 & 0 & 0 & 1 & 0 & 0 \\
\hline 53 & 0 & 2 & 3 & $i$ & 0 & 0 & 0 & 0 & 0 & 0 \\
\hline 54 & 9 & 4 & 20 & 11 & 22 & 23 & 18 & 2 & 8 & 7 \\
\hline 55 & 1 & 0 & 1 & 1 & 0 & 0 & 0 & 0 & 1 & 0 \\
\hline 56 & 0 & 0 & 0 & 1 & 0 & 0 & 0 & 0 & 1 & 0 \\
\hline 57 & 2 & 0 & 3 & i & 10 & 12 & 4 & 3 & 5 & 1 \\
\hline 58 & 0 & 0 & 0 & 1 & 1 & 0 & 1 & 0 & 0 & 1 \\
\hline 59 & 0 & 0 & 0 & $i$ & 0 & 0 & 0 & 0 & 0 & 0 \\
\hline 60 & 93 & 90 & 421 & 50 & 57 & 110 & 31 & 2 & 2 & 2 \\
\hline 61 & 0 & 0 & 2 & 1 & 0 & 0 & 0 & 0 & 0 & 0 \\
\hline 62 & 0 & 0 & 1 & 10 & 0 & 0 & 1 & 0 & 0 & 0 \\
\hline 63 & 295 & 330 & 1486 & i 375 & 538 & 720 & 400 & 23 & 57 & 33 \\
\hline
\end{tabular}


TABLE 56. (continued)

\begin{tabular}{|c|c|c|c|c|c|c|c|c|c|c|}
\hline \multirow[b]{2}{*}{ CODE } & \multicolumn{2}{|c|}{ Area B } & \multirow{2}{*}{$\begin{array}{l}\text { SITE } \\
\text { TOTAL }\end{array}$} & \multirow{2}{*}{ lst } & \multicolumn{2}{|c|}{ Area A } & \multirow[b]{2}{*}{ 4th } & \multicolumn{2}{|c|}{ Area B } & \multirow[b]{2}{*}{ A 11} \\
\hline & $1 s t$ & 2nd & & & 2nd & 3 rd & & Ist & 2nd & \\
\hline 64 & 45 & 35 & 174 & 81 & 115 & 140 & 57 & 3 & 7 & 0 \\
\hline 65 & 4 & 1 & 10 & 1 & 1 & 2 & 0 & 0 & 0 & 0 \\
\hline 66 & 0 & 0 & 2 & 1 & 0 & 0 & 0 & 0 & 0 & 0 \\
\hline 67 & 10 & 3 & 27 & 60 & 152 & 184 & 128 & 13 & 39 & 26 \\
\hline 68 & 0 & 0 & 1 & 10 & 1 & 0 & 0 & 0 & 1 & 0 \\
\hline 69 & 1 & 0 & 1 & 1 & 0 & 0 & 0 & 0 & 0 & 0 \\
\hline 70 & 0 & 2 & 2 & 1 & 18 & 14 & 13 & 3 & 6 & 1 \\
\hline 71 & 0 & 0 & 0 & 1 & 0 & 0 & 0 & 0 & 0 & 0 \\
\hline 72 & 0 & 0 & 0 & 10 & 0 & 0 & 0 & 0 & 0 & 0 \\
\hline 73 & 284 & 292 & 1352 & 224 & 271 & 440 & 201 & 4 & 5 & 6 \\
\hline 74 & 0 & 0 & 11 & 1 & 0 & 1 & 0 & 0 & 0 & 0 \\
\hline 75 & 0 & 1 & 4 & 10 & 0 & 1 & 0 & 0 & 0 & 0 \\
\hline 76 & 602 & 508 & 2253 & 691 & 1003 & 1368 & 742 & 111 & 174 & 179 \\
\hline 77 & 9 & 11 & 55 & 21 & 24 & 35 & 20 & 2 & 7 & 6 \\
\hline 78 & 0 & 0 & 0 & 10 & 0 & 0 & 0 & 0 & 0 & 0 \\
\hline 79 & 1 & 0 & 2 & 10 & 0 & 0 & 0 & 0 & 0 & 0 \\
\hline 80 & 140 & 127 & 571 & 152 & 216 & 319 & 179 & 50 & 42 & 64 \\
\hline 81 & 1 & 1 & 5 & 10 & 1 & 0 & 0 & 0 & 0 & 0 \\
\hline 82 & 2 & 0 & 4 & 10 & 1 & 0 & 0 & 0 & 1 & 0 \\
\hline 83 & 452 & 369 & 1726 & $\left\{\begin{array}{l}497 \\
\end{array}\right.$ & 795 & 1043 & 543 & 60 & 125 & 109 \\
\hline 84 & 0 & 1 & 14 & $!$ & 4 & 4 & 0 & 0 & 0 & 0 \\
\hline 85 & 5 & 2 & 16 & 1 & 3 & 1 & 0 & 0 & 0 & 0 \\
\hline 86 & 0 & 0 & 2 & 15 & 40 & 35 & 16 & 6 & 10 & 5 \\
\hline 87 & 0 & 0 & 1 & 1 & 11 & 2 & 8 & 2 & 4 & 0 \\
\hline 88 & 0 & 0 & 1 & 1 & 13 & 9 & 3 & 3 & 2 & 2 \\
\hline 89 & 0 & 0 & 0 & 8 & 16 & 24 & 5 & 1 & 4 & 3 \\
\hline
\end{tabular}


TABLE 56. (continued)

$4 I$ LK $5 I$

41 LK 53

\begin{tabular}{|c|c|c|c|c|c|c|c|c|c|c|c|}
\hline \multirow[b]{2}{*}{ CODE } & \multirow{2}{*}{ Area C } & \multicolumn{2}{|c|}{ Area D } & \multirow[b]{2}{*}{ A11 } & \multirow[t]{2}{*}{ Area $\mathrm{E}$} & \multirow{2}{*}{$\begin{array}{l}\text { SITE } \\
\text { TOTAL }\end{array}$} & \multirow{2}{*}{ 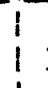 } & \multirow[b]{2}{*}{ lst } & \multirow[b]{2}{*}{ 2nd } & \multirow[b]{2}{*}{$3 r d$} & \multirow[b]{2}{*}{4 th } \\
\hline & & lst & 2nd & & & & & & & & \\
\hline 37 & 12 & 5 & 2 & 1 & 2 & 433 & $i$ & 7 & 7 & 10 & 1 \\
\hline 38 & 7 & 2 & 2 & 0 & 1 & 30 & i & 1 & 3 & 3 & 0 \\
\hline 39 & 0 & 0 & 0 & 0 & 0 & 0 & $i$ & 0 & 0 & 0 & 0 \\
\hline 40 & 0 & 0 & 0 & 0 & 0 & 1 & $i$ & 0 & 0 & 0 & 0 \\
\hline 41 & 5 & 3 & 0 & 1 & 1 & 39 & $i$ & 5 & 4 & 8 & 1 \\
\hline 42 & 0 & 0 & 0 & 0 & 0 & 0 & $i$ & 0 & 0 & 0 & 0 \\
\hline 43 & 0 & 0 & 0 & 0 & 0 & 0 & $i$ & 0 & 0 & 0 & 0 \\
\hline 44 & 0 & 0 & 0 & 0 & 0 & 3 & ! & $I$ & 0 & 1 & 0 \\
\hline 45 & 0 & 0 & 0 & 0 & 0 & 0 & $i$ & 0 & 0 & 0 & 0 \\
\hline 46 & 0 & 0 & 0 & 0 & 0 & 0 & $i$ & 0 & 0 & 0 & 0 \\
\hline 47 & 151 & 26 & 102 & 14 & 7 & 1235 & 11 & .22 & 171 & 207 & 2 \\
\hline 48 & 76 & 10 & 34 & 8 & 2 & 486 & $i$ & 31 & 82 & 92 & - \\
\hline 49 & 0 & 0 & 0 & 0 & 0 & 1 & 1 & 0 & 2 & 1 & 0 \\
\hline 50 & 0 & 0 & 0 & 0 & 0 & 1 & i & 0 & 0 & 0 & 0 \\
\hline 51 & 31 & 5 & 24 & 3 & 1 & 254 & $i$ & 31 & 39 & 36 & 0 \\
\hline 52 & 0 & 0 & 1 & 0 & 0 & 2 & $i$ & 0 & 1 & 1 & 0 \\
\hline 53 & 0 & 0 & 0 & 0 & 0 & 0 & $i$ & 1 & 0 & 0 & 0 \\
\hline 54 & 26 & 7 & 5 & 1 & 2 & 132 & $i$ & 20 & 21 & 22 & 0 \\
\hline 55 & 0 & 0 & 1 & 0 & 0 & 2 & 1 & 2 & 0 & 1 & 0 \\
\hline 56 & 0 & 1 & 0 & 0 & 0 & 3 & 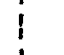 & 6 & 0 & 1 & 0 \\
\hline 57 & 21 & 3 & 1 & 1 & 1 & 70 & 1 & 12 & 6 & 9 & 1 \\
\hline 58 & 1 & 0 & 0 & 1 & 0 & 5 & 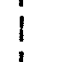 & 10 & 0 & 0 & 0 \\
\hline 59 & 0 & 0 & 0 & 0 & 0 & 0 & 1 & 0 & 10 & 0 & 0 \\
\hline 60 & 26 & 1 & 38 & 1 & 1 & 321 & $i$ & 34 & 36 & 41 & 1 \\
\hline 61 & 0 & 0 & 0 & 0 & 0 & 0 & 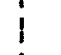 & 1 & 10 & 0 & 0 \\
\hline 62 & 0 & 0 & 0 & 0 & 0 & 1 & 1 & 0 & 0 & 0 & 0 \\
\hline 63 & 392 & 40 & 101 & 12 & 16 & 2707 & 12 & 253 & 356 & 560 & 14 \\
\hline
\end{tabular}


TABLE 56. (continued)

41 LK 51

I 41 LK 53

\begin{tabular}{|c|c|c|c|c|c|c|c|c|c|c|}
\hline \multirow[b]{2}{*}{ CODE } & \multirow{2}{*}{ Area C } & \multicolumn{2}{|c|}{ Area D } & \multirow[b]{2}{*}{ A1ו } & \multirow[b]{2}{*}{ Area $\mathrm{E}$} & \multirow[b]{2}{*}{$\begin{array}{l}\text { SITE } \\
\text { TOTAL }\end{array}$} & \\
\hline & & 1st & $D_{\text {2nd }}$ & & & & 1st & 2nd & $3 r d$ & 4 th \\
\hline 64 & 27 & 8 & 18 & 1 & 2 & 459 & 45 & 54 & 88 & 0 \\
\hline 65 & 1 & 0 & 0 & 0 & 0 & 5 & 1 & 1 & 10 & 0 \\
\hline 66 & 1 & 0 & 1 & 0 & 0 & 3 & 0 & 0 & 6 & 0 \\
\hline 67 & 203 & 23 & 26 & 4 & 12 & 870 & 86 & 152 & 220 & 0 \\
\hline 68 & 0 & 0 & 1 & 0 & 0 & 3 & 10 & 0 & 1 & 0 \\
\hline 69 & 5 & 0 & 0 & 0 & 0 & 5 & 0 & 0 & 1 & 0 \\
\hline 70 & 20 & 3 & 6 & 1 & 1 & 94 & 3 & 17 & 22 & 0 \\
\hline 71 & 2 & 0 & 0 & 0 & 0 & 2 & $i$ & 10 & 0 & 0 \\
\hline 72 & 0 & 0 & 0 & 0 & 0 & 0 & 10 & 10 & 0 & 0 \\
\hline 73 & 151 & 4 & 72 & 6 & 1 & 1385 & 132 & 164 & 258 & 14 \\
\hline 74 & 1 & 0 & 1 & 0 & 0 & 4 & i & 2 & 11 & 0 \\
\hline 75 & 2 & 0 & $I$ & 0 & 0 & 4 & 0 & 1 & 10 & 0 \\
\hline 76 & 1221 & 190 & 275 & 81 & 77 & 6112 & 476 & 781 & 1100 & 18 \\
\hline 77 & 29 & 8 & 6 & 4 & 5 & 167 & $i$ & 25 & 38 & 1 \\
\hline 78 & 0 & 0 & 0 & 0 & 0 & 0 & 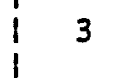 & 0 & 0 & 0 \\
\hline 79 & 0 & 0 & 0 & 0 & 0 & 0 & 16 & 0 & 0 & 0 \\
\hline 80 & 320 & 56 & 68 & 29 & 16 & 1511 & 125 & 173 & 239 & 1 \\
\hline 81 & 2 & 0 & 1 & 0 & 0 & 4 & 1 & 10 & 1 & 0 \\
\hline 82 & 1 & 0 & 1 & 0 & 0 & 4 & 0 & 6 & 0 & 0 \\
\hline 83 & 862 & 126 & 199 & 46 & 56 & 4461 & 350 & 584 & 894 & 16 \\
\hline 84 & 4 & 0 & 2 & 2 & 0 & 18 & $i$ & 7 & 4 & 0 \\
\hline 85 & 5 & 0 & 2 & 1 & 0 & 12 & $i$ & 0 & 8 & 0 \\
\hline 86 & 62 & 6 & 10 & 3 & 9 & 217 & 34 & 84 & 75 & 0 \\
\hline 87 & 14 & 1 & 4 & 1 & 1 & 49 & 8 & 19 & 20 & 0 \\
\hline 88 & 16 & 1 & 5 & 0 & 3 & 63 & 13 & 19 & 28 & 0 \\
\hline 89 & 32 & 4 & 1 & 2 & 5 & 105 & 13 & 46 & 48 & 0 \\
\hline
\end{tabular}


TABLE 56. (continued)

\begin{tabular}{|c|c|c|c|c|c|c|c|c|c|c|}
\hline \multirow[b]{2}{*}{ CODE } & 1 LK 53 & \multicolumn{3}{|c|}{$41 \mathrm{LK} 74$} & \multirow[b]{2}{*}{ Area C } & \multirow[b]{2}{*}{ Area D } & \multirow[b]{2}{*}{ Aroa $F$} & \multirow[b]{2}{*}{ Area $\mathbf{G}$} & \multirow[b]{2}{*}{ Aroa $\mathrm{H}$} & \multirow[b]{2}{*}{$\begin{array}{l}\text { SITE } \\
\text { TOTAL }\end{array}$} \\
\hline & $\begin{array}{l}\text { SITE } \\
\text { TOTAL }\end{array}$ & Area A & lst $^{A}$ & Bnd & & & & & & \\
\hline 37 & 25 & 12 & 6 & 2 & 10 & 6 & 21 & 0 & 0 & 57 \\
\hline 38 & 7 & 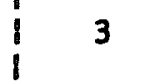 & 2 & 0 & 3 & 1 & 11 & 0 & 0 & 20 \\
\hline 39 & 0 & i & 0 & 0 & 0 & 0 & 0 & 0 & 0 & 0 \\
\hline 40 & 0 & $i$ & 0 & 0 & 0 & 0 & 0 & 0 & 0 & 0 \\
\hline 41 & 18 & $i$ & 3 & 2 & 14 & 4 & 4 & 0 & 0 & 33 \\
\hline 42 & 0 & 1 & 0 & 0 & 0 & 0 & 0 & 0 & 0 & 0 \\
\hline 43 & 0 & 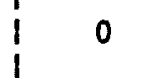 & 0 & 0 & 0 & 0 & 0 & 0 & 6 & 6 \\
\hline 44 & 2 & i & 1 & 0 & 2 & 1 & 1 & 0 & 6 & 14 \\
\hline 45 & 0 & i & 0 & 0 & 0 & 0 & 0 & 0 & 6 & 6 \\
\hline 46 & 0 & 0 & 0 & 0 & 0 & 0 & 0 & 0 & 0 & 0 \\
\hline 47 & 502 & 233 & 94 & 44 & 101 & 57 & 83 & 5 & 25 & 642 \\
\hline 48 & 205 & 41 & 23 & 7 & 39 & 13 & 28 & 2 & 15 & 168 \\
\hline 49 & 3 & 1 & 1 & 0 & 0 & 0 & 1 & 0 & 0 & 3 \\
\hline 50 & 0 & $i$ & 1 & 1 & 0 & 0 & 0 & 0 & 0 & 4 \\
\hline 51 & 106 & 33 & 18 & 12 & 21 & 13 & 22 & 0 & 4 & 123 \\
\hline 52 & 2 & 1 & 0 & 0 & 6 & 0 & 1 & 0 & 0 & 8 \\
\hline 53 & 1 & 1 & 0 & 0 & 0 & 0 & 8 & 0 & 0 & 9 \\
\hline 54 & 63 & $i$ & 2 & 1 & 15 & 0 & 2 & 2 & 6 & 32 \\
\hline 55 & 3 & 1 & 0 & 0 & 0 & 0 & 0 & 0 & 0 & 0 \\
\hline 56 & 7 & 1 & 0 & 0 & 0 & 0 & 0 & 0 & 0 & 0 \\
\hline 57 & 28 & $i$ & 4 & 1 & 14 & 0 & 1 & 1 & 0 & 26 \\
\hline 58 & 10 & $i$ & 0 & 0 & 6 & 0 & 0 & 0 & 0 & 6 \\
\hline 59 & 10 & 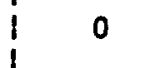 & 0 & 0 & 0 & 0 & 0 & 0 & 0 & 0 \\
\hline 60 & 112 & 150 & 47 & 24 & 34 & 31 & 29 & 0 & 3 & 318 \\
\hline 61 & 11 & 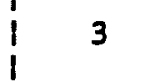 & 2 & 0 & 0 & 0. & 6 & 0 & 0 & 11 \\
\hline 62 & 0 & 2 & 1 & 1 & 0 & 0 & 6 & 0 & 0 & 10 \\
\hline 63 & 1183 & 366 & 129 & 60 & 171 & 93 & 103 & 4 & 24 & 950 \\
\hline
\end{tabular}


TABLE 56. (continued)

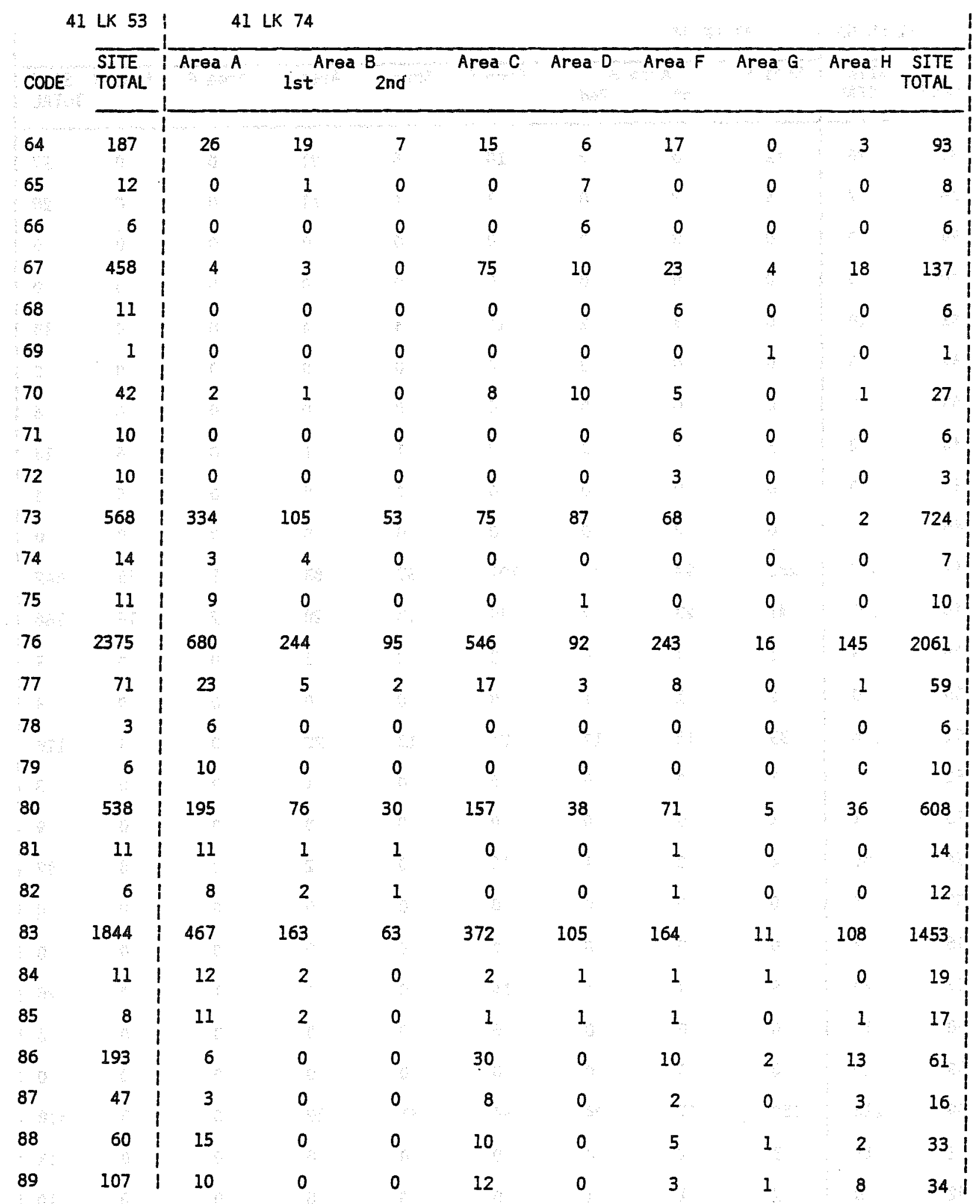


TABLE 56. (continued)

41 LK 128

\begin{tabular}{|c|c|c|c|c|c|c|c|c|c|c|}
\hline COOE & $\begin{array}{r}T P \\
1\end{array}$ & $\begin{array}{r}\mathrm{TP} \\
2\end{array}$ & $\begin{array}{r}T P \\
3\end{array}$ & $\frac{T P}{4}$ & $\begin{array}{r}\mathrm{TP} \\
5\end{array}$ & $\begin{array}{l}\mathrm{TP} \\
6\end{array}$ & $\begin{array}{c}\mathrm{TP} \\
7\end{array}$ & ${ }_{8}^{\mathrm{TP}}$ & $\begin{array}{c}\text { TP } \\
9\end{array}$ & $\begin{array}{l}\text { TP } \\
10\end{array}$ \\
\hline 37 & 0 & 4 & 2 & 3 & 5 & 11 & 8 & 8 & 2 & 1 \\
\hline 38 & 0 & 2 & 0 & 1 & 0 & 3 & 1 & 5 & 2 & 0 \\
\hline 39 & 0 & 0 & 0 & 0 & 0 & 0 & 0 & 0 & 0 & 0 \\
\hline 40 & 0 & 0 & 0 & 0 & 0 & 1 & 0 & 0 & 0 & 0 \\
\hline 41 & 0 & 2 & 2 & 2 & 4 & 4 & 7 & 5 & 0 & 0 \\
\hline 42 & 0 & 0 & 0 & 0 & 0 & 0 & 0 & 0 & 0 & 0 \\
\hline 43 & 0 & 0 & 0 & 0 & 0 & 0 & 0 & 0 & 0 & 0 \\
\hline 44 & 0 & 0 & 0 & 0 & 1 & 1 & 0 & 0 & 0 & 0 \\
\hline 45 & 0 & 0 & 0 & 0 & 0 & 0 & 0 & 0 & 0 & 0 \\
\hline 46 & 0 & 0 & 0 & 0 & 0 & 0 & 0 & 0 & 0 & 0 \\
\hline 47 & 9 & 21 & 22 & 10 & 64 & 82 & 116 & 101 & 19 & 16 \\
\hline 48 & 2 & 6 & 6 & 4 & 13 & 22 & 18 & 18 & 6 & 6 \\
\hline 49 & 0 & 0 & 1 & 0 & 0 & 0 & 2 & 0 & 0 & 0 \\
\hline 50 & 0 & 0 & 0 & 0 & 0 & 1 & 1 & 1 & 0 & 0 \\
\hline 51 & 2 & 6 & 5 & 7 & 27 & 17 & 32 & 16 & 4 & 1 \\
\hline 52 & 1 & 1 & 0 & 0 & 0 & 1 & 2 & 1 & 0 & 1 \\
\hline 53 & 0 & 0 & 0 & 0 & 0 & 0 & 0 & 0 & 0 & 0 \\
\hline 54 & 0 & 0 & 1 & 2 & 1 & 2 & 3 & 2 & 0 & 0 \\
\hline 55 & 0 & 0 & 0 & 0 & 0 & 0 & 0 & 1 & 0 & 0 \\
\hline 56 & 0 & 0 & 0 & 0 & 0 & 1 & 0 & 0 & 0 & 0 \\
\hline 57 & 0 & 0 & 0 & 0 & 0 & 1 & 1 & 1 & 0 & 1 \\
\hline 58 & 0 & 0 & 0 & 0 & 0 & 0 & 0 & 0 & 0 & 0 \\
\hline 59 & 0 & 0 & 0 & 0 & 0 & 0 & 0 & 0 & 0 & 0 \\
\hline 60 & 5 & 9 & 10 & 4 & 23 & 40 & 63 & 70 & 15 & 8 \\
\hline 61 & 0 & 0 & 0 & 1 & 0 & 0 & 0 & 0 & 0 & 0 \\
\hline 62 & 0 & 0 & $I$ & 0 & 0 & 0 & 1 & 1 & 0 & 0 \\
\hline 63 & 12 & 18 & 34 & 13 & 98 & 84 & 169 & 168 & 23 & 28 \\
\hline
\end{tabular}


TABLE 56. (continued)

41 LK 128

\begin{tabular}{|c|c|c|c|c|c|c|c|c|c|c|}
\hline CODE & $\begin{array}{r}\mathrm{TP} \\
1\end{array}$ & $\begin{array}{r}\mathrm{TP} \\
2\end{array}$ & $\begin{array}{r}T P \\
3\end{array}$ & $\begin{array}{r}T P \\
4\end{array}$ & $\begin{array}{r}\mathrm{TP} \\
5\end{array}$ & $\begin{array}{r}\mathrm{TP} \\
6\end{array}$ & $\begin{array}{r}\mathrm{TP} \\
7\end{array}$ & $\begin{array}{r}\mathrm{TP} \\
\mathbf{8}\end{array}$ & $\begin{array}{r}\mathrm{TP} \\
9\end{array}$ & $\begin{array}{l}\text { TP } \\
10\end{array}$ \\
\hline 64 & 2 & 5 & 3 & 3 & 9 & 9 & 15 & 16 & 0 & 0 \\
\hline 65 & 0 & 0 & 0 & 0 & 0 & 0 & 0 & 1 & 0 & 0 \\
\hline 66 & 0 & 0 & 0 & 0 & 0 & 1 & 0 & 1 & 0 & 0 \\
\hline 67 & 0 & 0 & 0 & 0 & 1 & 3 & 1 & 2 & 0 & 0 \\
\hline 68 & 0 & 0 & 0 & 0 & 0 & 0 & 0 & 0 & 0 & 0 \\
\hline 69 & 0 & 0 & 0 & 0 & 0 & 0 & 0 & 0 & 0 & 0 \\
\hline 70 & 0 & 0 & 0 & 0 & 0 & 0 & 1 & 1 & 0 & 1 \\
\hline 71 & 0 & 0 & 0 & 0 & 0 & 0 & 0 & 0 & 0 & 0 \\
\hline 72 & 0 & 0 & 0 & 0 & 0 & 0 & 0 & 0 & 0 & 0 \\
\hline 73 & 10 & 13 & 31 & 10 & 79 & 72 & 152 & 149 & 23 & 27 \\
\hline 74 & 0 & 1 & 2 & 0 & 2 & 0 & 1 & 1 & 0 & 0 \\
\hline 75 & 0 & 0 & 0 & 0 & 1 & 0 & 0 & 1 & 0 & 0 \\
\hline 76 & 12 & 46 & 43 & 17 & 163 & 142 & 322 & 309 & 57 & 48 \\
\hline 77 & 1 & 4 & 3 & 2 & 6 & 6 & 13 & 24 & 2 & 1 \\
\hline 78 & 0 & 0 & 0 & 0 & 0 & 0 & 0 & 0 & 0 & 0 \\
\hline 79 & 0 & 0 & 0 & 0 & 0 & 0 & 0 & 0 & 0 & 0 \\
\hline 80 & 4 & 5 & 12 & 7 & 45 & 43 & 102 & 70 & 13 & 9 \\
\hline 81 & 0 & 0 & 0 & 0 & 0 & 1 & 1 & 0 & 0 & 0 \\
\hline 82 & 0 & 0 & 0 & 0 & 0 & 1 & 1 & 1 & 0 & 0 \\
\hline 83 & 7 & 37 & 28 & 8 & 112 & 93 & 107 & 115 & 42 & 38 \\
\hline 84 & 1 & 0 & 0 & 0 & 1 & 0 & 0 & 1 & 0 & 0 \\
\hline 85 & 0 & 0 & 0 & 0 & 1 & 2 & 0 & 2 & 0 & 0 \\
\hline 86 & 0 & 0 & 0 & 0 & 1 & 0 & 1 & 2 & 0 & 0 \\
\hline 87 & 0 & 0 & 0 & 0 & 0 & 0 & 0 & 0 & 0 & 0 \\
\hline 88 & 0 & 0 & 0 & 0 & 0 & 0 & 1 & 2 & 0 & 0 \\
\hline 89 & 0 & 0 & 0 & 0 & 1 & 0 & 0 & 0 & 0 & 0 \\
\hline
\end{tabular}


TABLE 56. (continued)

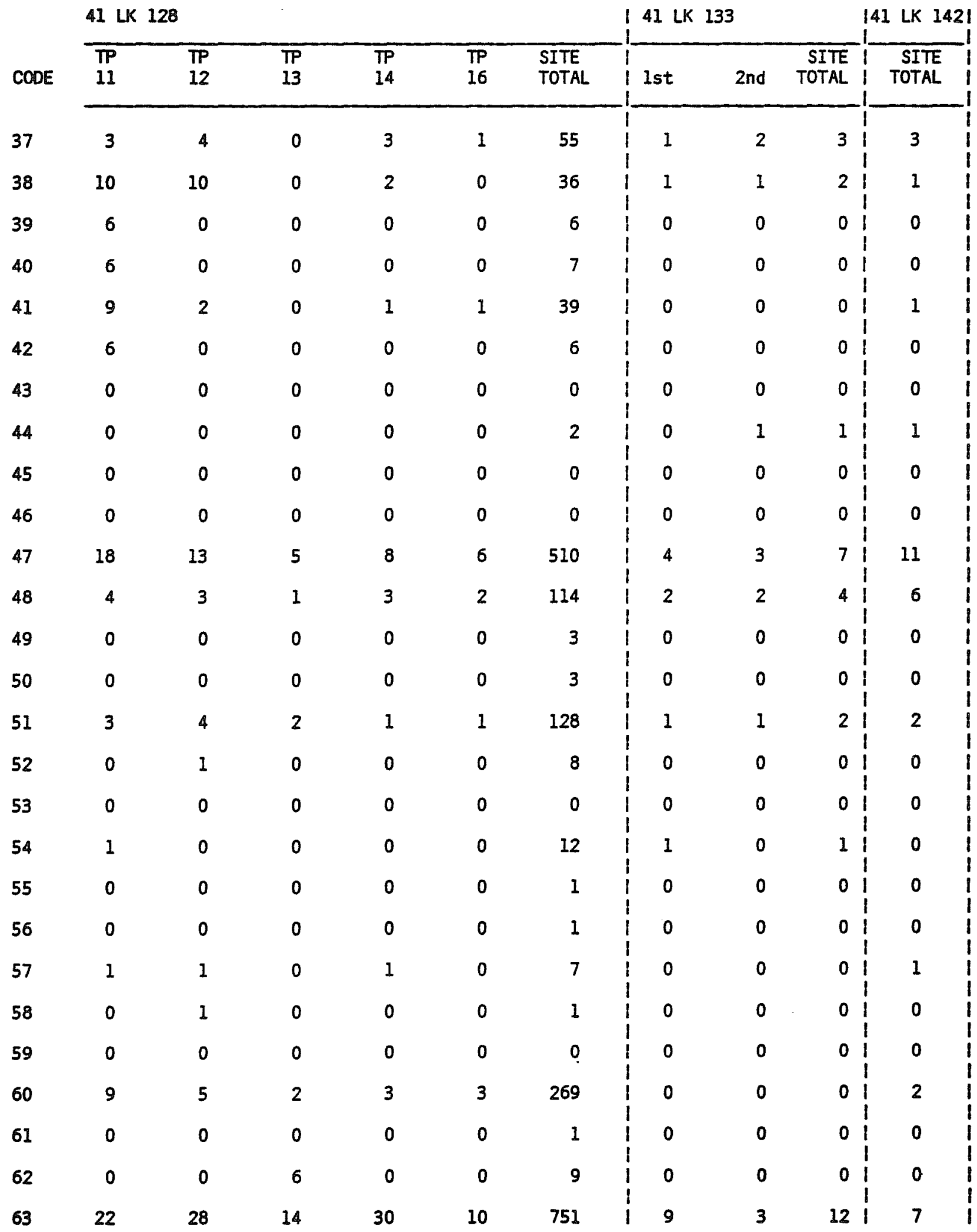


TABLE 56. (continued)

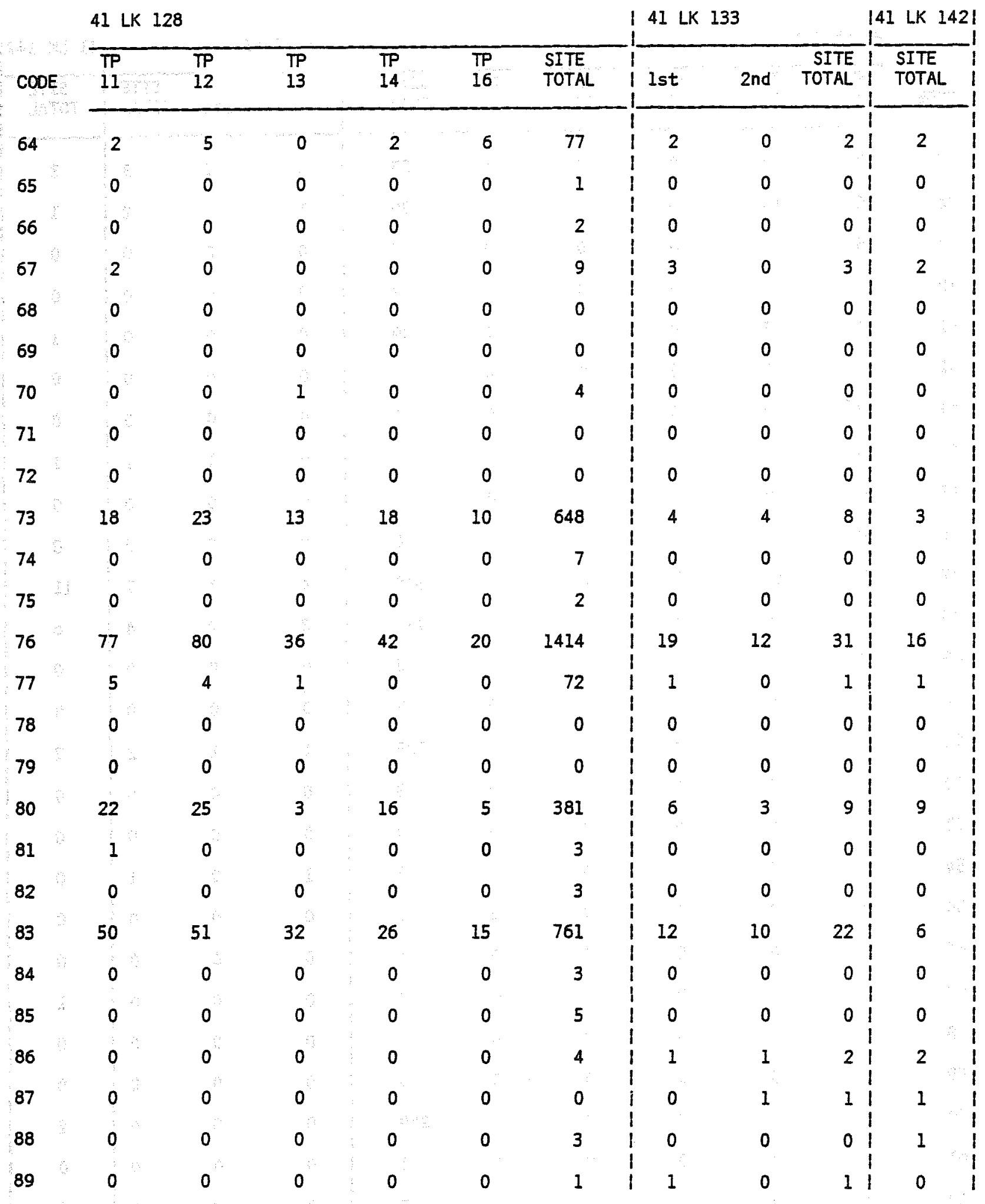


TABLE 56. (continued)

\begin{tabular}{|c|c|c|c|c|c|c|c|c|c|c|}
\hline \multirow[b]{2}{*}{ CODE } & \multicolumn{6}{|c|}{41 LK 185} & \multicolumn{4}{|c|}{ I 41 LK 243} \\
\hline & $\begin{array}{l}\overline{T P 1} \\
\text { lst }\end{array}$ & 2nd & $\begin{array}{l}\mathrm{TP2} \\
\mathrm{A} 11\end{array}$ & $\begin{array}{l}\text { TP3 } \\
\text { lst }\end{array}$ & 2nd & $\begin{array}{l}\text { SITE } \\
\text { TOTAL }\end{array}$ & $\begin{array}{l}\text { TP1 } \\
\text { lst }\end{array}$ & 2nd & $\begin{array}{l}\text { TP2 } \\
\text { A11 }\end{array}$ & $\begin{array}{l}\text { TP3 } \\
\text { Ist }\end{array}$ \\
\hline 37 & 0 & 0 & 1 & 1 & 1 & 3 & 1 & 0 & 2 & 0 \\
\hline 38 & 0 & 0 & 0 & 0 & 1 & 1 & 1 & 0 & 1 & 0 \\
\hline 39 & 0 & 0 & 0 & 0 & 0 & 0 & 0 & 0 & 0 & 0 \\
\hline 40 & 0 & 0 & 0 & 0 & 0 & 0 & 0 & 0 & 0 & 0 \\
\hline 41 & 0 & 0 & 1 & $I$ & 0 & 2 & 0 & 0 & 1 & 0 \\
\hline 42 & 0 & 0 & 0 & 0 & 0 & 0 & 0 & 0 & 0 & 0 \\
\hline 43 & 0 & 0 & 0 & 0 & 0 & 0 & $i$ & 0 & 0 & 0 \\
\hline 44 & 0 & 0 & 0 & 0 & 0 & 0 & 1 & 0 & 0 & 0 \\
\hline 45 & 0 & 0 & 0 & 0 & 0 & 0 & 0 & 0 & 0 & 0 \\
\hline 46 & 0 & 0 & 0 & 0 & 0 & 0 & 1 & 0 & 0 & 0 \\
\hline 47 & 6 & 6 & 14 & 4 & 8 & 38 & 13 & 25 & 9 & 35 \\
\hline 48 & 1 & 1 & 3 & 1 & 4 & 10 & $i$ & 9 & 4 & 11 \\
\hline 49 & 0 & 0 & 0 & 0 & 0 & 0 & 0 & 0 & 0 & 1 \\
\hline 50 & 0 & 0 & 0 & 0 & 0 & 0 & $i$ & 1 & 0 & 0 \\
\hline 51 & 3 & 3 & 8 & 1 & 3 & 18 & 1 & 6 & 1 & 6 \\
\hline 52 & 0 & 0 & 0 & 0 & 0 & 0 & 1 & 0 & 0 & 0 \\
\hline 53 & 0 & 0 & 0 & 0 & 0 & 0 & 1 & 0 & 0 & 0 \\
\hline 54 & 1 & 2 & 2 & 2 & 1 & 8 & 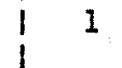 & 0 & 0 & 0 \\
\hline 55 & 0 & 0 & 0 & 0 & 0 & 0 & $i$ & 0 & 0 & 0 \\
\hline 56 & 0 & 0 & 0 & 0 & 0 & 0. & 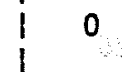 & 0 & 0 & 0 \\
\hline 57 & 0 & 0 & 1 & 0 & 0 & 1 & 2 & 0 & 0 & 0 \\
\hline 58 & 0 & 0 & 0 & 0 & 0 & 0 & 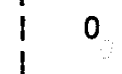 & 0 & 0 & 0 \\
\hline 59 & 0 & 0 & 0 & 0 & 0 & 0 & 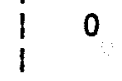 & 0 & 0 & 0 \\
\hline 60 & 1 & 0 & 0 & 0 & 0 & 1 & 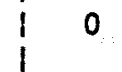 & 10 & 4 & 16 \\
\hline 61 & 0 & 0 & 0 & 0 & 0 & 0 & $i$ & 1 & 0 & 1 \\
\hline 62 & 0 & 0 & 0 & 0 & 0 & 0 & $!$ & 1 & 0 & 1 \\
\hline 63 & 12 & 8 & 10 & $\tilde{\delta}$ & 8 & 46 & 18 & 24 & 17 & 44 \\
\hline
\end{tabular}


554

TABLE 56. (continued)

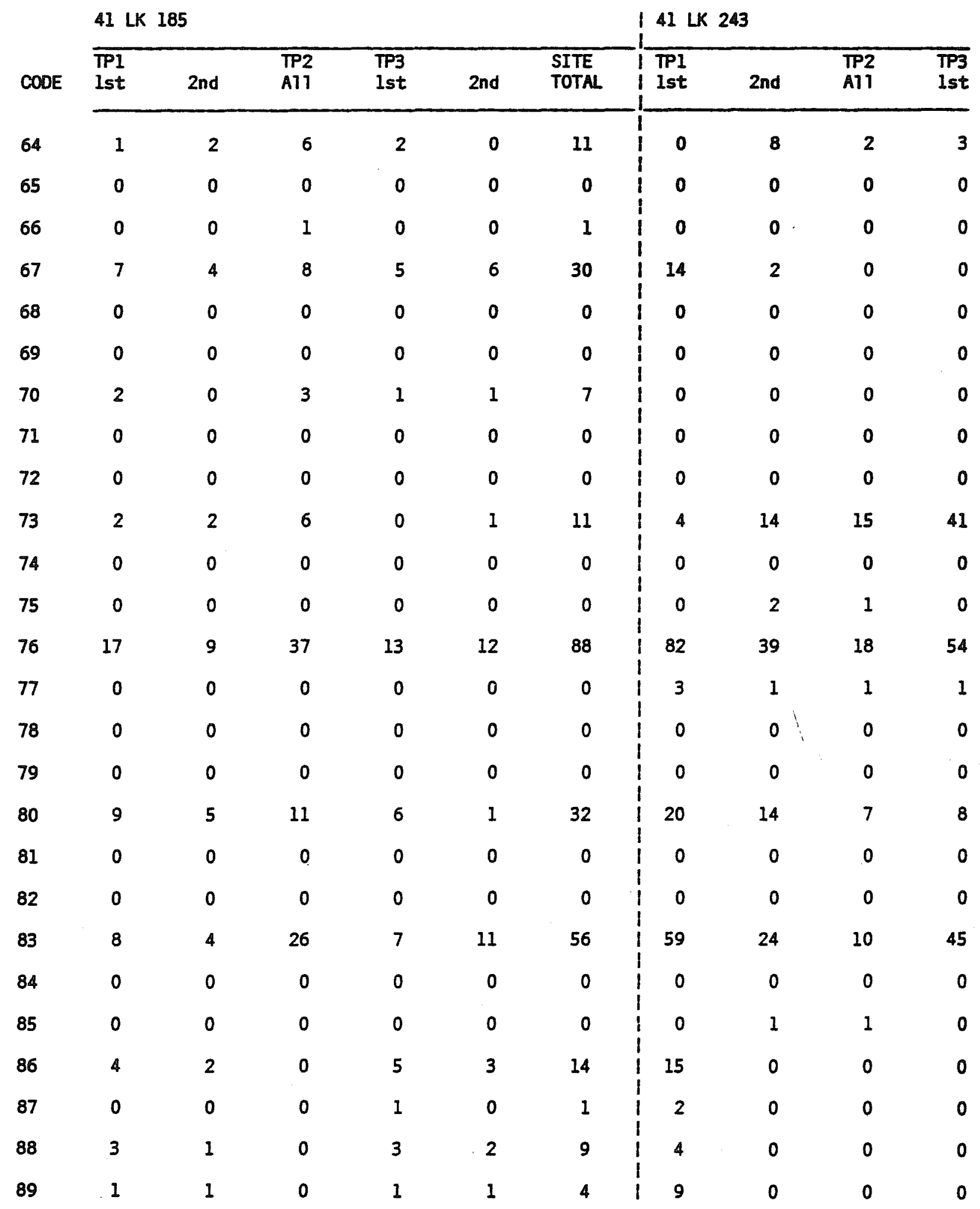


555

TABLE 56. (continued)

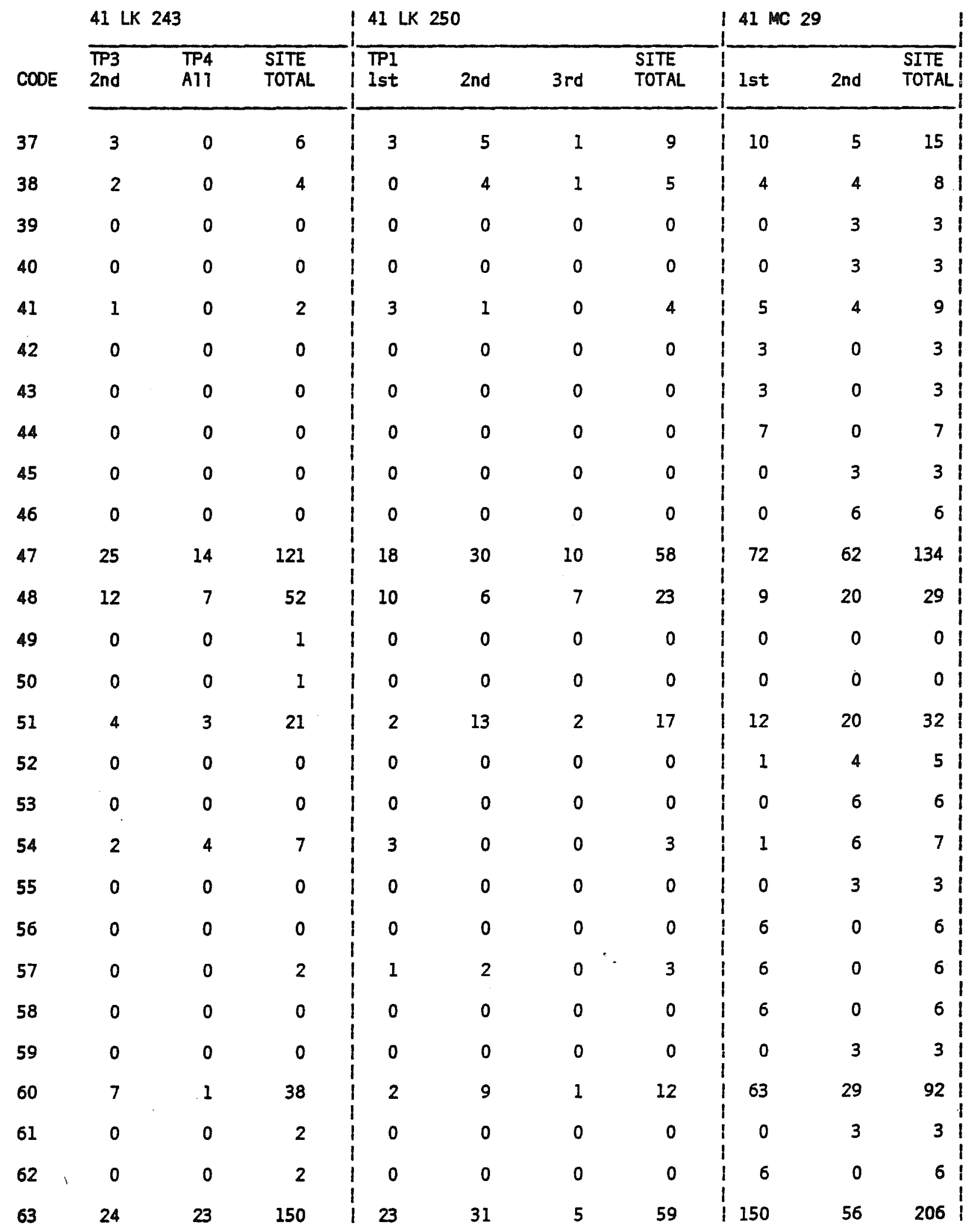


TABLE 56. (continued)

\begin{tabular}{|c|c|c|c|c|c|c|c|c|c|c|}
\hline \multirow[b]{2}{*}{ CODE } & \multicolumn{3}{|c|}{41 LK 243} & \multicolumn{4}{|c|}{41 LK 250} & \multicolumn{3}{|c|}{41 MC 29} \\
\hline & $\begin{array}{l}\overline{T P 3} \\
\text { 2nd }\end{array}$ & $\begin{array}{l}\text { TP4 } \\
\text { A11 }\end{array}$ & $\begin{array}{l}\text { SITE } \\
\text { TOTAL }\end{array}$ & $\begin{array}{l}\text { TP1 } \\
\text { lst }\end{array}$ & 2nd & $3 r d$ & $\begin{array}{l}\text { SITE } \\
\text { TOTAL }\end{array}$ & lst & 2nd & $\begin{array}{l}\text { SITE } \\
\text { TOTAL }\end{array}$ \\
\hline 64 & 3 & 3 & 19 & 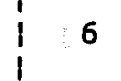 & 7 & 2 & 15 & 13 & 9 & 22 \\
\hline 65 & 0 & 0 & 0 & 1 & 0 & 0 & 0 & 1 & 3 & 4 \\
\hline 66 & 0 & 0 & 0 & 10 & 1 & 0 & 1 & 10 & 3 & 3 \\
\hline 67 & 0 & 15 & 31 & 111 & 12 & 0 & 23 & 12 & 4 & 6 \\
\hline 68 & 0 & 0 & 0 & $i$ & 1 & 0 & 1 & $i$ & 0 & 6 \\
\hline 69 & 0 & 0 & 0 & 1 & 0 & 0 & 0 & 1 & 0 & 6 \\
\hline 70 & 0 & 0 & 0 & $i$ & 1 & 0 & 1 & $i$ & 0 & 4 \\
\hline 71 & 0 & 0 & 0 & $i$ & 0 & 0 & 0 & $i$ & 6 & 6 \\
\hline 72 & 0 & 0 & 0 & $i$ & 0 & 0 & 0 & $i$ & 6 & 6 \\
\hline 73 & 21 & 5 & 100 & $i$ & 11 & 3 & 16 & 138 & 54 & 192 \\
\hline 74 & 0 & 0 & 0 & 1 & 1 & 1 & 2 & 1 & 0 & 4 \\
\hline 75 & 0 & 0 & 3 & 1 & 0 & 0 & 0 & 1 & 0 & 6 \\
\hline 76 & 55 & 104 & 352 & 82 & 86 & 20 & 188 & $i^{225}$ & 99 & 324 \\
\hline 77 & 5 & 11 & 22 & $i$ & 11 & 1 & 20 & $i$ & 3 & 7 \\
\hline 78 & 0 & 0 & 0 & $i$ & 0 & 0 & 0 & i & 3 & 3 \\
\hline 79 & 0 & 0 & 0 & 1 & 0 & 0 & 0 & $i$ & 6 & 6 \\
\hline 80 & 18 & 28 & 95 & 37 & 30 & 4 & 71 & 165 & 40 & 105 \\
\hline 81 & 0 & 0 & 0 & 1 & 0 & 0 & 0 & $i$ & 1 & 4 \\
\hline 82 & 0 & 0 & 0 & $i$ & 0 & 0 & 0 & $i$ & 0 & 6 \\
\hline 83 & 32 & 65 & 235 & 33 & 45 & 15 & 93 & 129 & 55 & 184 \\
\hline 84 & 0 & 0 & 0 & 1 & 0 & 0 & 0 & 1 & 4 & 5 \\
\hline 85 & 0 & 0 & 2 & $i$ & 0 & 0 & 0 & $i$ & 6 & 9 \\
\hline 86 & 2 & 17 & 34 & $i$ & 0 & 1 & 3 & $i$ & 0 & 4 \\
\hline 87 & 2 & 3 & 7 & $i$ & 0 & 0 & 1 & $i$ & 0 & 6 \\
\hline 88 & 0 & 8 & 12 & $i$ & 0 & 1 & 2 & $i$ & 0 & 4 \\
\hline 89 & 0 & 6 & 15 & 0 & 0 & 0 & 0 & 0 & 3 & 3 \\
\hline
\end{tabular}


TABLE 56. (continued)

41 MC 55

\begin{tabular}{|c|c|c|c|c|c|c|c|c|c|c|}
\hline \multirow[b]{2}{*}{ CODE } & \multicolumn{2}{|c|}{ Area A } & \multicolumn{2}{|c|}{ Area B } & \multirow{2}{*}{$\begin{array}{c}\text { Area C } \\
\text { A1 } 1\end{array}$} & \multirow{2}{*}{$\begin{array}{c}\text { Area D } \\
\text { Al1 }\end{array}$} & \multirow{2}{*}{$\begin{array}{c}\text { Area E } \\
\text { Al1 }\end{array}$} & \multirow{2}{*}{$\begin{array}{l}\text { SITE } \\
\text { TOTAL }\end{array}$} & \multirow{2}{*}{$\begin{array}{l}\text { TPI } \\
\text { Ist }\end{array}$} & \multirow[b]{2}{*}{ 2nd } \\
\hline & lst & 2nd & Ist & 2nd & & & & & & \\
\hline 37 & 0 & 0 & 3 & 0 & 2 & 16 & 7 & 28 & 1 & 3 \\
\hline 38 & 0 & 0 & 1 & 0 & 0 & 7 & 4 & 12 & 1 & 0 \\
\hline 39 & 0 & 0 & 0 & 0 & 0 & 0 & 0 & 0 & 0 & 0 \\
\hline 40 & 0 & 0 & 0 & 0 & 0 & 0 & 0 & 0 & 0 & 0 \\
\hline 41 & 0 & 0 & 2 & 0 & 1 & 5 & 3 & 11 & 0 & 2 \\
\hline 42 & 0 & 0 & 0 & 0 & 0 & 0 & 0 & 0 & 0 & 0 \\
\hline 43 & 0 & 0 & 0 & 0 & 0 & 0 & 0 & 0 & 0 & 0 \\
\hline 44 & 0 & 0 & 0 & 0 & 1 & 4 & 0 & 5 & 0 & 1 \\
\hline 45 & 0 & 0 & 0 & 0 & 0 & 0 & 0 & 0 & 0 & 0 \\
\hline 46 & 0 & 0 & 0 & 0 & 0 & 0 & 0 & 0 & 0 & 0 \\
\hline 47 & 12 & 25 & 23 & 9 & 28 & 142 & 76 & 315 & 14 & 31 \\
\hline 48 & 3 & 9 & 5 & 3 & 17 & $39^{\circ}$ & 15 & 91 & 6 & 4 \\
\hline 49 & 0 & 0 & 0 & 0 & 1 & 0 & 1 & 2 & 0 & 0 \\
\hline 50 & 0 & 0 & 0 & 0 & 1 & 0 & 0 & 1 & 0 & 0 \\
\hline 51 & 3 & 9 & 11 & 2 & 2 & 50 & 22 & 99 & 6 & 5 \\
\hline 52 & 0 & 0 & 0 & 0 & 0 & 0 & 0 & 0 & 0 & 0 \\
\hline 53 & 0 & 0 & 1 & 0 & 0 & 3 & 0 & 4 & 0 & 0 \\
\hline 54 & 0 & 0 & 3 & 2 & 4 & 60 & 17 & 86 & 0 & 0 \\
\hline 55 & 0 & 0 & 0 & 0 & 0 & 3 & 0 & 3 & 0 & 0 \\
\hline 56 & 0 & 0 & 1 & 0 & 6 & 1 & 0 & 8 & 1 & 0 \\
\hline 57 & 0 & 0 & 2 & 0 & 4 & 11 & 2 & 19 & 0 & 0 \\
\hline 58 & 0 & 0 & 0 & 0 & 3 & 0 & 0 & 3 & 0 & 0 \\
\hline 59 & 0 & 0 & 0 & 0 & 10 & 1 & 0 & 11 & ! & 0 \\
\hline 60 & 6 & 7 & 2 & 2 & 7 & 19 & 20 & 63 & 2 & 22 \\
\hline 61 & 0 & 0 & 0 & 0 & 3 & 0 & 0 & 3 & 0 & 0 \\
\hline 62 & 0 & 0 & 0 & 0 & 10 & 0 & 1 & 11 & 0 & 0 \\
\hline 63 & 17 & 47 & 35 & 12 & 33 & 296 & 78 & 518 & 112 & 52 \\
\hline
\end{tabular}


TABLE 56. (continued)

\begin{tabular}{|c|c|c|c|c|c|c|c|c|c|c|}
\hline \multirow[b]{2}{*}{ CODE } & \multicolumn{8}{|c|}{$41 M C 55$} & \multicolumn{2}{|c|}{41 MC 94} \\
\hline & $\overline{\text { lst }}$ & 2nd & 1st ${ }^{A}$ & Bnd & $\begin{array}{c}\text { Area C } \\
\text { A11 }\end{array}$ & $\begin{array}{c}\text { Area D } \\
\text { A11 }\end{array}$ & $\begin{array}{c}\text { Area } E \\
\text { A11 }\end{array}$ & $\begin{array}{l}\text { SITE } \\
\text { TOTAL }\end{array}$ & $\begin{array}{l}\text { TP1 } \\
\text { lst }\end{array}$ & 2nd \\
\hline 64 & 5 & 5 & 5 & 3 & 9 & 29 & 4 & 60 & 2 & 5 \\
\hline 65 & 0 & 0 & 0 & 1 & 0 & 15 & 0 & 16 & 0 & 0 \\
\hline 66 & 0 & 0 & 0 & 0 & 0 & 5 & 0 & 5 & 0 & 0 \\
\hline 67 & 6 & 9 & 13 & 1 & 13 & 188 & 45 & 275 & 0 & 1 \\
\hline 68 & 0 & 0 & 1 & 0 & 0 & 11 & 3 & 15 & 0 & 0 \\
\hline 69 & 0 & 0 & 0 & 0 & 1 & 7 & 1 & 9 & 0 & 0 \\
\hline 70 & 0 & 1 & 1 & 0 & 2 & 18 & 2 & 24 & 0 & 0 \\
\hline 71 & 0 & 0 & 0 & 0 & 0 & 10 & 0 & 10 & 0 & 0 \\
\hline 72 & 0 & 0 & 0 & 0 & 0 & 10 & 0 & 10 & 0 & 0 \\
\hline 73 & 6 & 32 & 16 & 8 & 3 & 92 & 27 & 184 & 10 & 46 \\
\hline 74 & 0 & 0 & 0 & 1 & 0 & 10 & 1 & 12 & 0 & 0 \\
\hline 75 & 0 & 0 & 0 & 0 & 0 & 3 & 0 & 3 & 0 & 0 \\
\hline 76 & 32 & 77 & 118 & 25 & 117 & 989 & 265 & 1623 & 28 & 104 \\
\hline 77 & 2 & 8 & 8 & 2 & 8 & 65 & 13 & 106 & 2 & 4 \\
\hline 78 & 0 & 0 & 0 & 0 & 0 & 10 & 0 & 10 & 0 & 0 \\
\hline 79 & 0 & 0 & 0 & 0 & 0 & 10 & 0 & 10 & 0 & 0 \\
\hline 80 & 8 & 19 & 39 & 4 & 63 & 263 & 80 & 476 & 8 & 18 \\
\hline 81 & 0 & 0 & 1 & 0 & 0 & 3 & 0 & 4 & 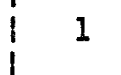 & 0 \\
\hline 82 & 0 & 0 & 0 & 0 & 0 & 1 & 0 & 1 & 0 & 0 \\
\hline 83 & 21 & 50 & 71 & 19 & 43 & 676 & 188 & 1068 & 18 & 82 \\
\hline 84 & 0 & 0 & 1 & 1 & 0 & 3 & 22 & 27 & i & 1 \\
\hline 85 & 1 & 0 & 0 & 0 & 0 & 2 & 11 & 14 & $i$ & 0 \\
\hline 86 & 2 & 1 & 4 & 0 & 3 & 26 & 1 & 37 & $i$ & 0 \\
\hline 87 & 1 & 0 & 3 & 0 & 0 & 7 & 0 & 11 & 1 & 0 \\
\hline 88 & 1 & 1 & 11 & 0 & 2 & 7 & 0 & 22 & $i$ & 0 \\
\hline 89 & 0 & 0 & 13 & 0 & 1 & 9 & 1 & 24 & 0 & 0 \\
\hline
\end{tabular}


TABLE 56. (continued)

41 MC 94 (continued)

\begin{tabular}{llccccccccc} 
CODE & $\begin{array}{l}\text { TP2 } \\
\text { 1st }\end{array}$ & 2nd & $\begin{array}{l}\text { TP3 } \\
\text { lst }\end{array}$ & 2nd & $\begin{array}{l}\text { TP4 } \\
\text { lst }\end{array}$ & 2nd & $\begin{array}{l}\text { TP5 } \\
\text { 1st }\end{array}$ & 2nd & $\begin{array}{l}\text { TP6 } \\
\text { lst }\end{array}$ & 2nd \\
\hline 37 & 3 & 2 & 1 & 0 & 2 & 1 & 0 & 2 & 1 & 0 \\
38 & 1 & 0 & 0 & 0 & 1 & 0 & 0 & 0 & 0 & 0
\end{tabular}

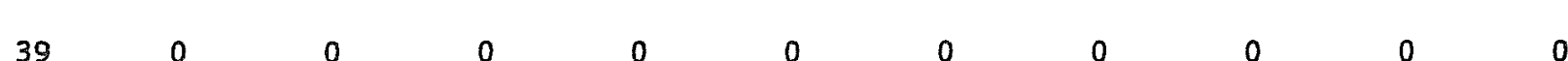

$\begin{array}{lllllllllll}39 & 0 & 0 & 0 & 0 & 0 & 0 & 0 & 0 & 0 & 0 \\ 40 & 0 & 0 & 0 & 0 & 0 & 0 & 0 & 0 & 0 & 0\end{array}$

$\begin{array}{llllllllll}41 & 2 & 2 & 1 & 0 & 1 & 0 & 0 & 2 & 1\end{array}$

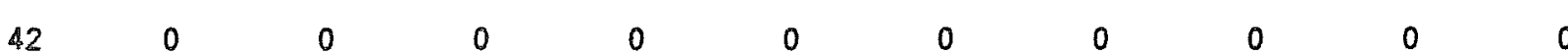

4300

44000

45000

$46 \quad 0 \quad 0 \quad 0$

$47 \quad 30$

48

49

50

51

52

5

5400

55

56

5

58

59

60

61

62

63

3

27

66

67

30

0

0

0

0

0

0

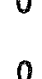

0

I

0

0

0

0

48

0

0

0

0

0

.

$48 \quad 7$

7

37

2

12

7

3

00

0

0

1

0

31

1

0

0

$0 \quad 0$


TABLE 56. (continued)

41 MC 94 (continued)

\begin{tabular}{|c|c|c|c|c|c|c|c|c|c|c|}
\hline CODE & $\begin{array}{l}\text { TP2 } \\
\text { Ist }\end{array}$ & 2nd & $\begin{array}{l}\text { TP3 } \\
\text { lst }\end{array}$ & 2nd & $\begin{array}{l}\text { TP4 } \\
\text { lst }\end{array}$ & 2nd & $\begin{array}{l}\text { TP5 } \\
\text { lst }\end{array}$ & 2nd & $\begin{array}{l}\text { TP6 } \\
\text { lst }\end{array}$ & 2nd \\
\hline 64 & 3 & 3 & 3 & 0 & 1 & 0 & 1 & 2 & 3 & 0 \\
\hline 65 & 0 & 0 & 0 & 0 & 0 & 0 & 0 & 0 & 0 & 0 \\
\hline 66 & 0 & 0 & 0 & 0 & 0 & 0 & 0 & 0 & 0 & 0 \\
\hline 67 & 0 & 0 & 0 & 0 & 0 & 0 & 0 & 0 & 0 & 1 \\
\hline 68 & 0 & 0 & 0 & 0 & 0 & 0 & 0 & 0 & 0 & 0 \\
\hline 69 & 0 & 0 & 0 & 0 & 0 & 0 & 0 & 0 & 0 & 0 \\
\hline 70 & 0 & 0 & 0 & 0 & 0 & 0 & 0 & 0 & 0 & 0 \\
\hline 71 & 0 & 0 & 0 & 0 & 0 & 0 & 0 & 0 & 0 & 0 \\
\hline 72 & 0 & 0 & 0 & 0 & 0 & 0 & 0 & 0 & 0 & 0 \\
\hline 73 & 24 & 63 & 64 & 8 & 84 & 12 & 28 & 21 & 74 & 23 \\
\hline 74 & 0 & 0 & 0 & 0 & 0 & 0 & 0 & 0 & 0 & 0 \\
\hline 75 & 0 & 0 & 1 & 0 & 0 & 0 & 0 & 0 & 0 & 0 \\
\hline 76 & 50 & 90 & 103 & 11 & 128 & 24 & 75 & 39 & 53 & 47 \\
\hline 77 & 1 & 2 & 3 & 1 & 7 & 0 & 0 & 1 & 8 & 0 \\
\hline 78 & 0 & 0 & 0 & 0 & 0 & 0 & 0 & 0 & 0 & 0 \\
\hline 79 & 0 & 0 & 0 & 0 & 0 & 0 & 0 & 0 & 0 & 0 \\
\hline 80 & 12 & 13 & 30 & 3 & 24 & 6 & 16 & 4 & 34 & 17 \\
\hline 81 & 0 & 0 & 0 & 0 & 1 & 0 & 0 & 0 & 0 & 0 \\
\hline 82 & 0 & 0 & 0 & 0 & 0 & 0 & 0 & 0 & 0 & 0 \\
\hline 83 & 37 & 37 & 70 & 7 & 97 & 18 & 59 & 34 & 199 & 30 \\
\hline 84 & 0 & 0 & 0 & 0 & 1 & 0 & 0 & 0 & 0 & 0 \\
\hline 85 & 0 & 0 & 1 & 0 & 0 & 0 & 0 & 1 & 0 & 0 \\
\hline 86 & 0 & 0 & 0 & 0 & 0 & 0 & 0 & 0 & 0 & 0 \\
\hline 87 & 0 & 0 & 0 & 0 & 0 & 0 & 0 & 0 & 0 & 0 \\
\hline 88 & 0 & 0 & 0 & 0 & 0 & 0 & 0 & 0 & 0 & 0 \\
\hline 89 & 0 & 0 & 0 & 0 & 0 & 0 & 0 & 0 & 0 & 0 \\
\hline
\end{tabular}


TABLE 56. (continued)

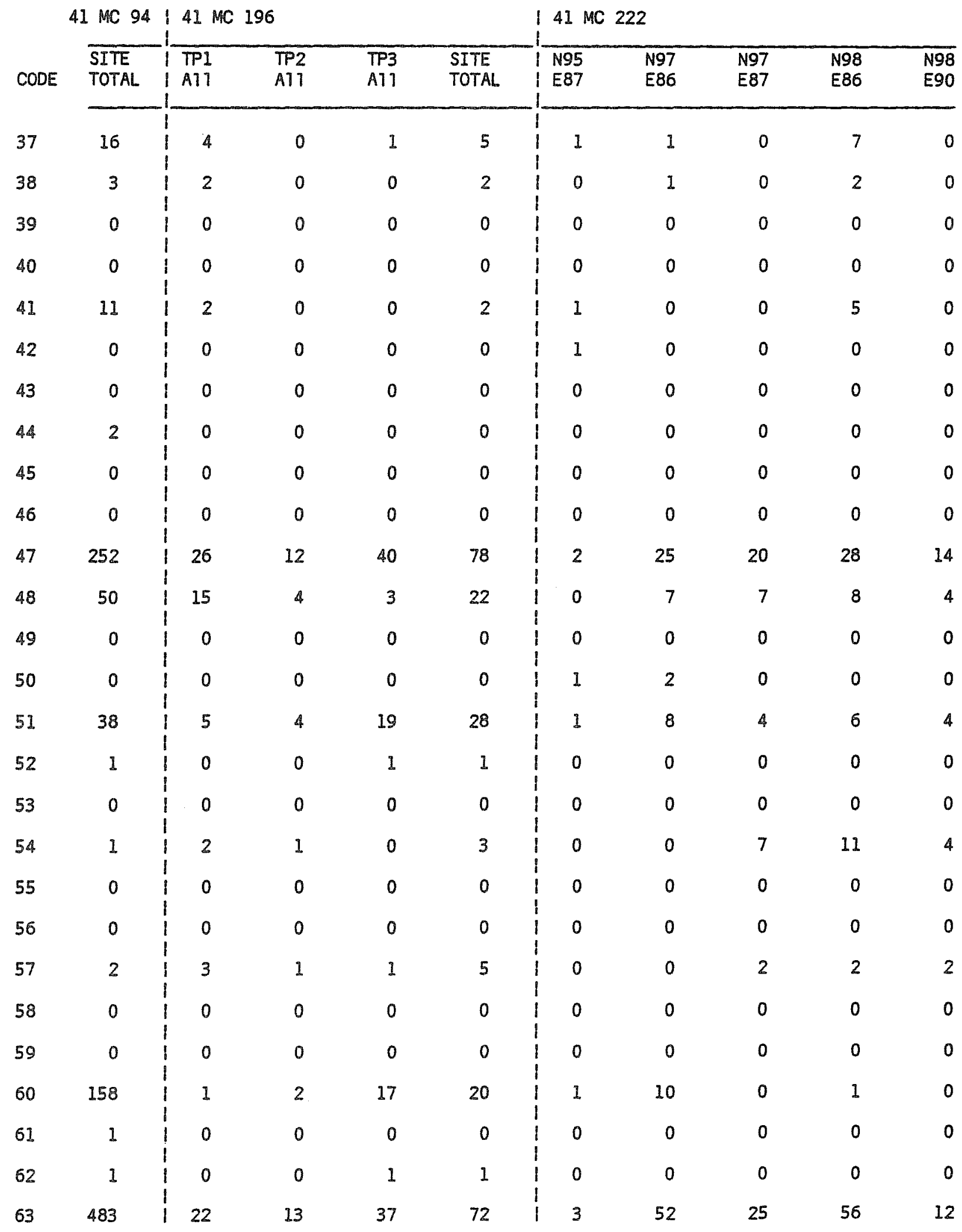


TABLE 56. (continued)

\begin{tabular}{|c|c|c|c|c|c|c|c|c|c|c|c|}
\hline \multirow[b]{2}{*}{ CODE } & \multirow{2}{*}{$\begin{array}{l}1 \text { MC } 94 \\
\text { SITE } \\
\text { TOTAL }\end{array}$} & \multicolumn{4}{|c|}{ I 41 MC 196} & \multicolumn{6}{|c|}{$41 M C 222$} \\
\hline & & $\begin{array}{l}\text { TP1 } \\
\text { A11 }\end{array}$ & $\begin{array}{l}\mathrm{TP2} \\
\mathrm{A} 11\end{array}$ & $\begin{array}{l}\text { TP3 } \\
\text { A11 }\end{array}$ & $\begin{array}{l}\text { SITE } \\
\text { TOTAL }\end{array}$ & $\begin{array}{l}\mathrm{Ng} \\
\mathrm{EB}\end{array}$ & & $\begin{array}{l}\text { N97 } \\
\text { E86 }\end{array}$ & $\begin{array}{l}\text { N97 } \\
\text { E87 }\end{array}$ & $\begin{array}{l}\text { N98 } \\
\text { E86 }\end{array}$ & $\begin{array}{l}\text { N98 } \\
\text { E90 }\end{array}$ \\
\hline 64 & 23 & 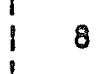 & 10 & 14 & 32 & 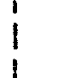 & 0 & 3 & 7 & 3 & 3 \\
\hline 65 & 0 & $i$ & 1 & 0. & 1 & $i$ & 0 & 0 & 0 & 0 & 0 \\
\hline 66 & 0 & 1 & 0 & 0 & 0 & 1 & 0 & 0 & 0 & 0 & 0 \\
\hline 67 & 2 & $i$ & 1 & 3 & 6 & $i$ & 0 & 6 & 33 & 46 & 8 \\
\hline 68 & 0 & $i$ & 0 & 0 & 0 & $i$ & 0 & 0 & 0 & 0 & 0 \\
\hline 69 & 0 & $i$ & 0 & 0 & 0 & 1 & 0 & 0 & 0 & 0 & 0 \\
\hline 70 & 0 & $i$ & 2 & 0 & 8 & $i$ & 0 & 2 & 4 & 5 & 1 \\
\hline 71 & 0 & $i$ & 0 & 0 & 0 & 1 & 0 & 0 & 0 & 0 & 0 \\
\hline 72 & 0 & i & 0 & 0 & 0 & $i$ & 0 & 0 & 0 & 0 & 0 \\
\hline 73 & 457 & 1 & 1 & 20 & 27 & 1 & 3 & 41 & 4 & 2 & 0 \\
\hline 74 & 0 & $i$ & 0 & 0 & 0 & 1 & 0 & 0 & 0 & 0 & 0 \\
\hline 75 & 1 & $i$ & 0 & 0 & 0 & 1 & 0 & 0 & 0 & 0 & 0 \\
\hline 76 & 752 & 85 & 11 & 62 & 158 & 1 & 3 & 12 & 61 & 136 & 43 \\
\hline 77 & 29 & $i$ & 0 & 0 & 2 & $i$ & 0 & 3 & 2 & 3 & 0 \\
\hline 78 & 0 & $i$ & 0 & 0 & 0 & $i$ & 0 & 0 & 0 & 0 & 0 \\
\hline 79 & 0 & $i$ & 0 & 0 & 0 & $i$ & 0 & 0 & 0 & 0 & 0 \\
\hline 80 & 185 & 27 & 3 & 12 & 42 & $i$ & 0 & 12 & 22 & 46 & 11 \\
\hline 81 & 2 & 1 & 0 & 0 & 0 & 1 & 0 & 0 & 0 & 0 & 0 \\
\hline 82 & 0 & $i$ & 0 & 0 & 0 & $i$ & 0 & 0 & 0 & 0 & 0 \\
\hline 83 & 688 & i 55 & 8 & 50 & 113 & $i$ & 3 & 34 & 37 & 87 & 32 \\
\hline 84 & 2 & 1 & 0 & 0 & 1 & 1 & 0 & 1 & 0 & 0 & 0 \\
\hline 85 & 2 & $i$ & 0. & 0 & 0 & 1 & 0 & 0 & 0 & 0 & 0 \\
\hline 86 & 0 & $i$ & 0 & 0 & 8 & $i$ & 0 & 0 & 0 & 10 & 3 \\
\hline 87 & 0 & $i$ & 0. & 0 & 2 & $i$ & 0 & 0 & 0 & 6 & 0 \\
\hline 88 & 0 & $i$ & 0 & 0 & 3 & $i$ & 0 & 0 & 0 & 4 & 2 \\
\hline 89 & 0 & 3 & 0 & 0 & 3 & 1 & 0 & 0 & 0 & 0 & 1 \\
\hline
\end{tabular}


TABLE 56. (continued)

41 MC 222 (continued)

\begin{tabular}{|c|c|c|c|c|c|c|c|c|c|c|}
\hline CODE & $\begin{array}{l}\overline{N 98} \\
\text { E91 }\end{array}$ & $\begin{array}{l}\text { N99 } \\
\text { E86 }\end{array}$ & $\begin{array}{l}\text { N99 } \\
\text { E89 }\end{array}$ & $\begin{array}{l}199 \\
E 90\end{array}$ & $\begin{array}{l}\text { N99 } \\
\text { E91 }\end{array}$ & $\begin{array}{l}\text { N100 } \\
\text { E86 }\end{array}$ & $\begin{array}{l}\text { N100 } \\
\text { E89 }\end{array}$ & $\begin{array}{l}\text { N100 } \\
\text { E90 }\end{array}$ & $\begin{array}{l}\text { N100 } \\
\text { E91 }\end{array}$ & $\begin{array}{r}\mathrm{N} 101 \\
\mathrm{E} 87\end{array}$ \\
\hline 37 & 0 & 2 & 1 & 3 & 1 & 0 & 3 & 1 & 1 & 0 \\
\hline 38 & 0 & I & 0 & 0 & 1 & 0 & 1 & 0 & 1 & 0 \\
\hline 39 & 0 & 0 & 0 & 0 & 0 & 0 & 0 & 0 & 0 & 0 \\
\hline 40 & 0 & 0 & 0 & 0 & 0 & 0 & 0 & 0 & 0 & 0 \\
\hline 41 & 0 & 1 & 1 & 3 & 0 & 0 & 2 & 0 & 0 & 0 \\
\hline 42 & 0 & 0 & 0 & 0 & 0 & 0 & 0 & 0 & 0 & 0 \\
\hline 43 & 0 & 0 & 0 & 0 & 0 & 0 & 0 & 0 & 0 & 0 \\
\hline 44 & 0 & 0 & 0 & 0 & 0 & 0 & 0 & 1 & 0 & 0 \\
\hline 45 & 0 & 0 & 0 & 0 & 0 & 0 & 0 & 0 & 0 & 0 \\
\hline 46 & 0 & 0 & 0 & 0 & 0 & 0 & 0 & 0 & 0 & 0 \\
\hline 47 & 17 & 17 & 6 & 15 & 26 & 10 & 17 & 5 & 15 & 10 \\
\hline 48 & 5 & 8 & 2 & 4 & 4 & 0 & 2 & 2 & 4 & 0 \\
\hline 49 & 0 & 0 & 0 & 0 & 0 & 0 & 0 & 0 & 0 & 5 \\
\hline 50 & 0 & 0 & 0 & 0 & 1 & 0 & 0 & 0 & 0 & 0 \\
\hline 51 & 4 & 3 & 2 & 2 & 1 & 2 & 7 & 3 & 1 & 2 \\
\hline 52 & 0 & 0 & 0 & 3 & 0 & 0 & 0 & 0 & 0 & 0 \\
\hline 53 & 0 & 0 & 0 & 0 & 1 & 1 & 0 & 0 & 0 & 2 \\
\hline
\end{tabular}

$\begin{array}{lllll}54 & 3 & 1 & 2 & 5\end{array}$

55000

56

$0 \quad 0$

57

58

59

60

61

62

63

3
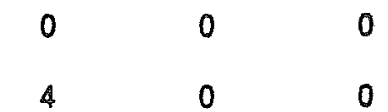

\section{3}
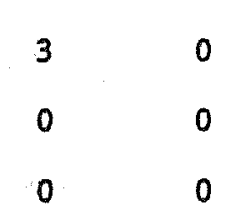

5

0

o

0

0

0

0

0

0

0

57

$$
4
$$

$$
0
$$

0

0

1

0

0

2

0

0

0

59000

601

10

5

0

0

0

0

$0 \quad 0$

010

0

0

0

1

o

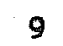

0

0

0

0

0

16

27

88

12

20

17

29 
TABLE 56. (continued)

41 MC 222 (continued)

\begin{tabular}{|c|c|c|c|c|c|c|c|c|c|c|}
\hline CODE & $\begin{array}{l}\text { N98 } \\
\text { E91 }\end{array}$ & $\begin{array}{l}\text { N99 } \\
\text { E86 }\end{array}$ & $\begin{array}{l}\text { N99 } \\
\text { E89 }\end{array}$ & $\begin{array}{l}\text { N99 } \\
\text { E90 }\end{array}$ & $\begin{array}{l}\text { N99 } \\
\text { E91 }\end{array}$ & $\begin{array}{l}\text { N100 } \\
\text { E86 }\end{array}$ & $\begin{array}{l}\text { N100 } \\
\text { E89 }\end{array}$ & $\begin{array}{l}\text { N100 } \\
\text { E90 }\end{array}$ & $\begin{array}{l}\text { N100 } \\
\text { E91 }\end{array}$ & $\begin{array}{r}\text { N101 } \\
\text { E87 }\end{array}$ \\
\hline 64 & 6 & 4 & 3 & 3 & 3 & 0 & 4 & 3 & 0 & 1 \\
\hline 65 & 0 & 0 & 0 & 0 & 0 & 0 & 0 & 0 & 0 & 0 \\
\hline 66 & 0 & 0 & 0 & 0 & 0 & 0 & 0 & 0 & 0 & 0 \\
\hline 67 & 0 & 5 & 10 & 20 & 1 & 0 & 15 & 0 & 2 & 0 \\
\hline 68 & 18 & 0 & 0 & 0 & 0 & 0 & 0 & 0 & 0 & 0 \\
\hline 69 & 0 & 0 & 0 & 0 & 0 & 0 & 0 & 0 & 0 & 0 \\
\hline 70 & 0 & 0 & 1 & 3 & 1 & 0 & 0 & 1 & 0 & 0 \\
\hline 71 & 1 & 0 & 0 & 0 & 0 & 0 & 0 & 1 & 0 & 0 \\
\hline 72 & 0 & 0 & 0 & 0 & 0 & 0 & 0 & 0 & 0 & 0 \\
\hline 73 & 2 & 77 & 2 & 1 & 83 & 12 & 1 & 13 & 27 & 10 \\
\hline 74 & 0 & 0 & 0 & 0 & 1 & 0 & 0 & 0 & 0 & 0 \\
\hline 75 & 0 & 0 & 0 & 0 & 0 & 0 & 0 & 0 & 0 & 0 \\
\hline 76 & 92 & 148 & 54 & 56 & 168 & 31 & 42 & 32 & 42 & 24 \\
\hline 77 & 2 & 2 & 1 & 2 & 4 & 2 & 3 & 2 & 1 & 3 \\
\hline 78 & 0 & 0 & 0 & 0 & 0 & 0 & 0 & 0 & 0 & 0 \\
\hline 79 & 0 & 0 & 0 & 0 & 0 & 0 & 0 & 0 & 0 & 0 \\
\hline 80 & 25 & 25 & 17 & 19 & 30 & 3 & 15 & 5 & 11 & 5 \\
\hline 81 & 0 & 0 & 0 & 0 & 0 & 0 & 0 & 2 & 0 & 0 \\
\hline 82 & 0 & 0 & 0 & 0 & 0 & 0 & 0 & 0 & 0 & 0 \\
\hline 83 & 65 & 121 & 36 & 30 & 134 & 26 & 24 & 25 & 30 & 16 \\
\hline 84 & 0 & 1 & 0 & 0 & 1 & 0 & 0 & 0 & 0 & 0 \\
\hline 85 & 0 & 0 & 0 & 0 & 0 & 0 & 0 & 0 & 0 & 0 \\
\hline 86 & 8 & 3 & 2 & 10 & 10 & 1 & 12 & 1 & 0 & 0 \\
\hline 87 & 0 & 0 & 0 & 2 & 0 & 1 & 3 & 0 & 0 & 0 \\
\hline 88 & 3 & 0 & 1 & 5 & 4 & 0 & 3 & 0 & 0 & 0 \\
\hline 89 & 5 & 3 & 1 & 3 & 6 & 0 & 6 & 1 & 0 & 0 \\
\hline
\end{tabular}


TABLE 56. (continued)

41 MC 222 (continued)

\begin{tabular}{|c|c|c|c|c|c|c|c|c|c|c|}
\hline CODE & $\begin{array}{l}\text { N101 } \\
\text { E88 }\end{array}$ & $\begin{array}{l}\text { N101 } \\
\text { E89 }\end{array}$ & $\begin{array}{l}\text { N10I } \\
\text { E90 }\end{array}$ & $\begin{array}{l}\text { NIOI } \\
\text { E91 }\end{array}$ & $\begin{array}{l}\mathrm{N} 102 \\
\mathrm{E} 88\end{array}$ & $\begin{array}{l}\text { N102 } \\
\text { E89 }\end{array}$ & $\begin{array}{l}\text { N102 } \\
\text { E90 }\end{array}$ & $\begin{array}{l}\text { N102 } \\
\text { E91 }\end{array}$ & $\begin{array}{l}\mathrm{N} 102 \\
\text { E100 }\end{array}$ & $\begin{array}{r}\mathrm{N103} \\
\mathrm{E} 86\end{array}$ \\
\hline 37 & 0 & 1 & 5 & 1 & 1 & 1 & 3 & 7 & 1 & 1 \\
\hline 38 & 0 & 0 & 2 & 0 & 1 & 0 & 0 & 4 & 1 & 0 \\
\hline 39 & 0 & 0 & 0 & 0 & 0 & 0 & 0 & 0 & 0 & 0 \\
\hline 40 & 0 & 0 & 0 & 0 & 1 & 0 & 0 & 0 & 0 & 0 \\
\hline 41 & 0 & 0 & 2 & 1 & 0 & 1 & 3 & 3 & 0 & 1 \\
\hline 42 & 0 & 0 & 0 & 0 & 0 & 0 & 0 & 0 & 0 & 0 \\
\hline 43 & 0 & 0 & 0 & 0 & 0 & 0 & 0 & 0 & 0 & 0 \\
\hline 44 & 0 & 1 & 0 & 0 & 0 & 0 & 0 & 0 & 0 & 0 \\
\hline 45 & 0 & 0 & 0 & 0 & 0 & 0 & 0 & 0 & 0 & 0 \\
\hline 46 & 0 & 0 & 0 & 0 & 0 & 0 & 0 & 0 & 0 & 0 \\
\hline 47 & 7 & 15 & 19 & 35 & 6 & 26 & 37 & 77 & 18 & 3 \\
\hline 48 & 0 & 2 & 4 & 10 & 9 & 8 & 12 & 12 & 10 & 2 \\
\hline 49 & 0 & 0 & 0 & 0 & 0 & 0 & 0 & 0 & 0 & 0 \\
\hline 50 & 0 & 0 & 0 & 1 & 0 & 0 & 0 & 0 & 0 & 0 \\
\hline 51 & 2 & 4 & 9 & 7 & 3 & 8 & 16 & 17 & 5 & 0 \\
\hline 52 & 0 & 0 & 0 & 1 & 0 & 0 & 0 & 1 & 0 & 0 \\
\hline 53 & 0 & 0 & 0 & 0 & 0 & 0 & 0 & 1 & 0 & 0 \\
\hline 54 & 0 & 0 & 5 & 0 & 1 & 0 & 5 & 3 & 3 & 0 \\
\hline 55 & 0 & 0 & 0 & 0 & 0 & 0 & 0 & 0 & 0 & 0 \\
\hline 56 & 0 & 0 & 0 & 0 & 0 & 0 & 0 & 0 & 0 & 0 \\
\hline 57 & 0 & 2 & 1 & 2 & 0 & 1 & 2 & 3 & 0 & 0 \\
\hline 58 & 0 & 0 & 0 & 0 & 0 & 0 & 0 & 1 & 0 & 0 \\
\hline 59 & 0 & 0 & 0 & 0 & 0 & 0 & 0 & 0 & 0 & 0 \\
\hline 60 & 7 & 7 & 0 & 16 & 9 & 9 & 2 & 42 & 0 & I \\
\hline 61 & 1 & 0 & 0 & I & 0 & 0 & 0 & 0 & 0 & 0 \\
\hline 62 & 0 & 0 & 0 & 0 & 0 & 0 & 0 & 1 & 0 & 0 \\
\hline 63 & 5 & 23 & 33 & 123 & 23 & 35 & 58 & 77 & 20 & 6 \\
\hline
\end{tabular}


TABLE 56. (continued)

41 MC 222 (continued)

\begin{tabular}{|c|c|c|c|c|c|c|c|c|c|c|}
\hline CODE & $\begin{array}{l}\mathrm{NIO1} \\
\mathrm{E} 88\end{array}$ & $\begin{array}{l}\text { N101 } \\
\text { E89 }\end{array}$ & $\begin{array}{l}\text { N101 } \\
\text { E90 }\end{array}$ & $\begin{array}{l}\text { N101 } \\
\text { E91 }\end{array}$ & $\begin{array}{l}\mathrm{NIO2} \\
\mathrm{E} 88\end{array}$ & $\begin{array}{l}\mathrm{N} 102 \\
\text { E89 }\end{array}$ & $\begin{array}{l}\mathrm{N} 102 \\
\mathrm{E} 90\end{array}$ & $\begin{array}{l}\text { N102 } \\
\text { E91 }\end{array}$ & $\begin{array}{l}\text { N102 } \\
\text { E100 }\end{array}$ & $\begin{array}{r}\mathrm{N} 103 \\
\mathrm{E} 86\end{array}$ \\
\hline 64 & 0 & 1 & 10 & 5 & 5 & 8 & 12 & 9 & 6 & 1 \\
\hline 65. & 0 & 0 & 0 & 0 & 0 & 0 & 0 & 0 & 0 & 0 \\
\hline 66 & 0 & 0 & 0 & 0 & 0 & 0 & 0 & 0 & 0 & 0 \\
\hline 67 & 0 & 0 & 20 & 2 & 0 & 5 & 40 & 2 & 9 & 0 \\
\hline 68 & 0 & 0 & 0 & 0 & 0 & 0 & 0 & 0 & 0 & 0 \\
\hline 69 & 0 & 0 & 0 & 0 & 0 & 0 & 0 & 0 & 0 & 0 \\
\hline 70 & 0 & 0 & 1 & 0 & 0 & 0 & 3 & 2 & 3 & 0 \\
\hline 71 & 0 & 0 & 0 & 0 & 0 & 0 & 0 & 0 & 0 & 0 \\
\hline 72 & 0 & 0 & 0 & 0 & 0 & 0 & 0 & 0 & 1 & 0 \\
\hline 73 & 5 & 22 & 2 & 116 & 18 & 22 & 3 & 64 & 2 & 6 \\
\hline 74 & 0 & 0 & 0 & 1 & 0 & 0 & 0 & 0 & 0 & 0 \\
\hline 75 & 0 & 0 & 0 & 0 & 0 & 0 & 0 & 1 & 0 & 0 \\
\hline 76 & 14 & 33 & 64 & 173 & 27 & 84 & 197 & 122 & 64 & 17 \\
\hline 77 & 0 & 0 & 1 & 4 & 0 & 0 & 6 & 7 & 0 & 0 \\
\hline 78 & 0 & 0 & 0 & 0 & 0 & 0 & 0 & 0 & 0 & 0 \\
\hline 79 & 0 & 0 & 0 & 0 & 0 & 0 & 0 & 0 & 0 & 0 \\
\hline 80 & 4 & 7 & 24 & 33 & 6 & 30 & 35 & 32 & 15 & 3 \\
\hline 81 & 0 & 0 & 0 & 0 & 0 & 0 & 0 & 1 & 0 & 0 \\
\hline 82 & 0 & 0 & 0 & 0 & 0 & 0 & 0 & 0 & 0 & 0 \\
\hline 83 & 10 & 26 & 39 & 128 & 21 & 52 & 156 & 76 & 49 & 9 \\
\hline 84 & 0 & 0 & 0 & 0 & 0 & 2 & 0 & 0 & 0 & 0 \\
\hline 85 & 0 & 1 & 0 & 0 & 0 & 0 & 0 & 1 & 0 & 0 \\
\hline 86 & 0 & 0 & 12 & 1 & 0 & 0 & 7 & 0 & 1 & 0 \\
\hline 87 & 0 & 0 & 4 & 0 & 0 & 0 & 3 & 0 & 0 & 0 \\
\hline 88 & 0 & 0 & 5 & 0 & 0 & 0 & 2 & 0 & 1 & 0 \\
\hline 89 & 0 & 0 & 3 & 1 & 0 & 0 & 2 & 0 & 0 & 0 \\
\hline
\end{tabular}


TABLE 56. (continued)

41 MC 222 (continued)

\begin{tabular}{|c|c|c|c|c|c|c|c|c|c|c|}
\hline CODE & $\begin{array}{l}\overline{\mathrm{N103}} \\
\mathrm{E} 87\end{array}$ & $\begin{array}{l}\text { N103 } \\
\text { E88 }\end{array}$ & $\begin{array}{l}\text { N103 } \\
\text { E89 }\end{array}$ & $\begin{array}{l}\text { N103 } \\
\text { E90 }\end{array}$ & $\begin{array}{l}\text { N103 } \\
\text { E91 }\end{array}$ & $\begin{array}{l}\text { N104 } \\
\text { E85 }\end{array}$ & $\begin{array}{l}\text { N107 } \\
\text { E87 }\end{array}$ & $\begin{array}{l}\text { N112 } \\
\text { E79 }\end{array}$ & $\begin{array}{l}\text { N113 } \\
\text { E83 }\end{array}$ & $\begin{array}{r}\text { N119 } \\
\text { E80 }\end{array}$ \\
\hline 37 & 0 & 2 & 6 & 4 & 4 & 0 & 0 & 0 & 0 & 0 \\
\hline 38 & 0 & 0 & 2 & 0 & 2 & 0 & 0 & 0 & 0 & 0 \\
\hline 39 & 0 & 0 & 7 & 0 & 0 & 0 & 0 & 0 & 0 & 0 \\
\hline 40 & 0 & 0 & 2 & 0 & 0 & 0 & 0 & 0 & 0 & 0 \\
\hline 41 & 0 & 2 & 4 & 4 & 2 & 0 & 0 & 0 & 0 & 0 \\
\hline 42 & 0 & 0 & 0 & 0 & 0 & 0 & 0 & 0 & 0 & 0 \\
\hline 43 & 0 & 0 & 0 & 0 & 0 & 0 & 0 & 0 & 0 & 0 \\
\hline 44 & 0 & 0 & 0 & 0 & 0 & 0 & 0 & 0 & 0 & 0 \\
\hline 45 & 0 & 0 & 0 & 0 & 0 & 0 & 0 & 0 & 0 & 0 \\
\hline 46 & 0 & 0 & 1 & 0 & 0 & 0 & 0 & 0 & 0 & 0 \\
\hline 47 & 7 & 33 & 64 & 22 & 37 & 7 & 11 & 9 & 6 & 2 \\
\hline 48 & 1 & 10 & 14 & 7 & 17 & 2 & 3 & 3 & 2 & 1 \\
\hline 49 & 0 & 0 & 38 & 0 & 0 & 0 & 0 & 0 & 0 & 0 \\
\hline 50 & 0 & 0 & 10 & 0 & 0 & 0 & 0 & 0 & 0 & 0 \\
\hline 51 & 1 & 13 & 15 & 3 & 10 & 3 & 3 & 1 & 2 & 0 \\
\hline 52 & 0 & 0 & 0 & 1 & 0 & 0 & 0 & 0 & 0 & 0 \\
\hline 53 & 0 & 0 & 3 & 0 & 0 & 0 & 0 & 0 & 0 & 0 \\
\hline 54 & 0 & 17 & 3 & 0 & 1 & 0 & 0 & 0 & 2 & 1 \\
\hline 55 & 0 & 0 & 0 & 0 & 0 & 0 & 0 & 0 & 0 & 0 \\
\hline 56 & 0 & 0 & 0 & 0 & 0 & 0 & 0 & 0 & 0 & 0 \\
\hline 57 & 0 & 3 & 1 & 0 & 0 & 0 & 2 & 1 & 0 & 0 \\
\hline 58 & 0 & 0 & 0 & 0 & 0 & 0 & 0 & 0 & 0 & 0 \\
\hline 59 & 0 & 0 & 1 & 0 & 0 & 0 & 0 & 0 & 0 & 0 \\
\hline 60 & 5 & 3 & 31 & 11 & 7 & 2 & 3 & 4 & 0 & 0 \\
\hline 61 & 0 & 0 & 0 & 0 & 0 & 0 & 0 & 0 & 0 & 0 \\
\hline 62 & 1 & 0 & 22 & 0 & 0 & 0 & 0 & 0 & 0 & 0 \\
\hline 63 & 10 & 47 & 100 & 44 & 178 & 5 & 16 & 6 & 17 & 2 \\
\hline
\end{tabular}


TABLE 56. (continued)

41 MC 222 (continued)

\begin{tabular}{|c|c|c|c|c|c|c|c|c|c|c|}
\hline CODE & $\begin{array}{l}\text { N103 } \\
\text { E87 }\end{array}$ & $\begin{array}{l}\text { N103 } \\
\text { E88 }\end{array}$ & $\begin{array}{l}\text { N103 } \\
\text { E89 }\end{array}$ & $\begin{array}{l}\text { N103 } \\
\text { E90 }\end{array}$ & $\begin{array}{l}\mathrm{N} 103 \\
\mathrm{E} 91\end{array}$ & $\begin{array}{l}\text { N104 } \\
\text { E85 }\end{array}$ & $\begin{array}{l}\text { N107 } \\
\text { E87 }\end{array}$ & $\begin{array}{l}\text { N112 } \\
\text { E79 }\end{array}$ & $\begin{array}{l}\mathrm{N} 113 \\
\mathrm{E} 83\end{array}$ & $\begin{array}{r}\text { N119 } \\
\text { E80 }\end{array}$ \\
\hline 64 & 2 & 10 & 14 & 13 & 45 & 3 & 1 & 2 & 2 & 1 \\
\hline 65 & 0 & 0 & 40 & 0 & 0 & 0 & 0 & 0 & 0 & 0 \\
\hline 66 & 0 & 0 & 3 & 0 & 0 & 0 & 0 & 0 & 0 & 0 \\
\hline 67 & 0 & 31 & 5 & 11 & 44 & 0 & 1 & 0 & 11 & 1 \\
\hline 68 & 0 & 0 & 0 & 0 & 0 & 0 & 0 & 0 & 0 & 0 \\
\hline 69 & 0 & 0 & 1 & 0 & 0 & 0 & 0 & 0 & 0 & 0 \\
\hline 70 & 0 & 2 & 4 & 3 & 5 & 1 & 1 & 0 & 2 & 0 \\
\hline 71 & 0 & 0 & 0 & 0 & 0 & 1 & 0 & 0 & 0 & 0 \\
\hline 72 & 0 & 0 & 0 & 1 & 0 & 0 & 0 & 0 & 0 & 0 \\
\hline 73 & 8 & 4 & 77 & 16 & 83 & 0 & 13 & 4 & 2 & 0 \\
\hline 74 & 0 & 0 & 0 & 0 & 1 & 0 & 0 & 0 & 0 & 0 \\
\hline 75 & 0 & 0 & 37 & 0 & 0 & 0 & 0 & 0 & 0 & 0 \\
\hline 76 & 7 & 94 & 107 & 72 & 604 & 42 & 21 & 33 & 32 & 11 \\
\hline 77 & 0 & 6 & 3 & 0 & 7 & 0 & 0 & 0 & 1 & 0 \\
\hline 78 & 0 & 0 & 0 & 0 & 0 & 0 & 0 & 0 & 0 & 0 \\
\hline 79 & 0 & 0 & 0 & 0 & 0 & 0 & 0 & 0 & 0 & 0 \\
\hline 80 & 3 & 26 & 27 & 25 & 85 & 16 & 4 & 11 & 12 & 5 \\
\hline 81 & 0 & 0 & 0 & 1 & 0 & 0 & 0 & 0 & 0 & 0 \\
\hline 82 & 0 & 0 & 0 & 0 & 0 & 0 & 0 & 0 & 0 & 0 \\
\hline 83 & 4 & 61 & 77 & 45 & 509 & 24 & 17 & 22 & 19 & 6 \\
\hline 84 & 0 & 0 & 0 & 1 & 3 & 0 & 0 & 0 & 0 & 0 \\
\hline 85 & 0 & 0 & 2 & 0 & 0 & 0 & 0 & 1 & 0 & 0 \\
\hline 86 & 0 & 7 & 1 & 0 & 3 & 0 & 0 & 0 & 4 & 3 \\
\hline 87 & 0 & 0 & 1 & 0 & 0 & 0 & 0 & 0 & 1 & 1 \\
\hline 88 & 0 & 1 & 0 & 0 & 2 & 0 & 0 & 0 & 1 & 1 \\
\hline 89 & 0 & 5 & 0 & 0 & 3 & 0 & 0 & 0 & 2 & 1 \\
\hline
\end{tabular}


TABLE 56. (continued)

\begin{tabular}{|c|c|c|c|c|c|c|c|c|c|c|}
\hline \multirow[b]{2}{*}{ CODE } & \multicolumn{2}{|c|}{41 MC 222} & \multicolumn{8}{|c|}{ I 41 MC 268} \\
\hline & $\begin{array}{l}\text { N125 } \\
\text { E72 }\end{array}$ & $\begin{array}{l}\text { SITE } \\
\text { TOTAL }\end{array}$ & 1st & $A_{2 n d}$ & A71 & Ist & B 2nd & A11 & $\begin{array}{l}\text { TP1 } \\
\text { A11 }\end{array}$ & $\begin{array}{l}\overline{T P 2} \\
\text { A11 }\end{array}$ \\
\hline 37 & 2 & 62 & 11 & 0 & 5 & 9 & 1 & 19 & 0 & 6 \\
\hline 38 & 1 & 20 & 4 & 0 & 2 & 1 & 6 & 5 & 0 & 1 \\
\hline 39 & 0 & 7 & 0 & 0 & 0 & 0 & 6 & 0 & 0 & 0 \\
\hline 40 & 0 & 1 & 10 & 0 & 0 & 0. & 3 & 0 & 0 & 0 \\
\hline 41 & 1 & 37 & 5 & 0 & 3 & 4 & 4 & 13 & 0 & 4 \\
\hline 42 & 0 & 1 & 0 & 0 & 0 & 0 & 3 & 0 & 0 & 0 \\
\hline 43 & 0 & 0 & 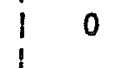 & 0 & 0 & 0 & 0 & 6 & 0 & 0 \\
\hline 44 & 0 & 2 & 2 & 0 & 0 & 1 & 0 & 11 & 0 & 1 \\
\hline 45 & 0 & 0 & 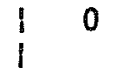 & 0 & 0 & 0 & 0 & 6 & 0 & 0 \\
\hline 46 & 0 & 1 & 0 & 0 & 0 & 0 & 0 & 6 & 0 & 0 \\
\hline 47 & 2 & 679 & 110 & 30 & 72 & 39 & 8 & 127 & 26 & 63 \\
\hline 48 & 0 & 186 & 32 & 7 & 27 & 8 & 0 & 29 & 9 & 18 \\
\hline 49 & 0 & 43 & 1 & 0 & 1 & 0 & 0 & 7 & 0 & 0 \\
\hline 50 & 0 & 15 & 2 & 0 & 0 & 0 & 0 & 10 & 0 & 0 \\
\hline 51 & 1 & 173 & 31 & 7 & 23 & 9 & 3 & 29 & 11 & 18 \\
\hline 52 & 0 & 6 & 1 & 0 & 3 & 0 & 0 & 6 & 1 & 1 \\
\hline 53 & 0 & 8 & 6 & 0 & 1 & 1 & 0 & 0 & 0 & 0 \\
\hline 54 & 1 & 83 & 11 & 0 & 4 & 1 & 0 & 2 & 0 & 0 \\
\hline 55 & 0 & 0 & 10 & 0 & 0 & 0 & 0 & 0 & 0 & 0 \\
\hline 56 & 0 & 0 & 10 & 0 & 0 & 0 & 0 & 0 & 0 & 0 \\
\hline 57 & 0 & 31 & 7 & 1 & 1 & 0 & 0 & 1 & 0 & 0 \\
\hline 58 & 0 & 1 & 1 & 0 & 0 & 0 & 0 & 0 & 0 & 0 \\
\hline 59 & 0 & $I$ & 1 & 3 & 0 & 0 & 0 & 0 & 0 & 0 \\
\hline 60 & 0 & 224 & 144 & 21 & 25 & 21 & 5 & 69 & 7 & 28 \\
\hline 61 & 0 & 12 & 10 & 6 & 0 & 0 & 0 & 1 & 0 & 0 \\
\hline 62 & 0 & 25 & 1 & 6 & 0 & 0 & 0 & 0 & 0 & 0 \\
\hline 63 & 4 & 1331 & 143 & 60 & 97 & 53 & 14 & 139 & 28 & 85 \\
\hline
\end{tabular}


TABLE 56. (continued)

\begin{tabular}{|c|c|c|c|c|c|c|c|c|c|c|}
\hline \multirow[b]{2}{*}{ CODE } & \multicolumn{2}{|c|}{41 MC 222} & \multicolumn{8}{|c|}{$41 M C 268$} \\
\hline & $\begin{array}{l}\text { N125 } \\
\text { E72 }\end{array}$ & $\begin{array}{l}\text { SITE } \\
\text { TOTAL }\end{array}$ & 1st & A 2 nd & A 11 & $1 s{ }^{A}$ & B 2 nd & A11 & $\begin{array}{l}\text { TP1 } \\
\text { A11 }\end{array}$ & $\begin{array}{l}\text { TP2 } \\
\text { A11 }\end{array}$ \\
\hline 64 & 1 & 194 & 15 & 10 & 18 & 8 & 1 & 13 & 7 & 21 \\
\hline 65 & 0 & 40 & 0 & 0 & 6 & 0 & 0 & 0 & 0 & 0 \\
\hline 66 & 0 & 3 & 0 & 1 & 6 & 0 & 0 & 0 & 0 & 0 \\
\hline 67 & 2 & 330 & 10 & 1 & 10 & 0 & 0 & 3 & 0 & 2 \\
\hline 68 & 0 & 18 & $i$ & 0 & 6 & 0 & 0 & 0 & 0 & 0 \\
\hline 69 & 0 & 1 & 10 & 0 & 3 & 0 & 0 & 0 & 0 & 0 \\
\hline 70 & 0 & 45 & 4 & 0 & 4 & 0 & 0 & 2 & 0 & 0 \\
\hline 71 & 0 & 3 & 0 & 0 & 6 & 0 & 0 & 0 & 0 & 0 \\
\hline 72 & 0 & 2 & 16 & 0 & 0 & 0 & 0 & 0 & 0 & 0 \\
\hline 73 & 1 & 746 & 134 & 43 & 80 & 45 & 13 & 121 & 21 & 62 \\
\hline 74 & 0 & 3 & 13 & 0 & 2 & 0 & 0 & 0 & 0 & 0 \\
\hline 75 & 0 & 38 & 11 & 0 & 0 & 0 & 0 & 1 & 0 & 0 \\
\hline 76 & 6 & 2809 & 277 & 99 & 143 & 113 & 13 & 285 & 52 & 122 \\
\hline 77 & 0 & 75 & 20 & 3 & 6 & 9 & 0 & 15 & 1 & 5 \\
\hline 78 & 0 & 0 & $i$ & 3 & 0 & 0 & 0 & 0 & 0 & 0 \\
\hline 79 & 0 & 0 & $i$ & 3 & 0 & 0 & 0 & 0 & 0 & 0 \\
\hline 80 & 3 & 652 & 65 & 36 & 43 & 40 & 4 & 92 & 14 & 32 \\
\hline 81 & 0 & 4 & $i$ & 6 & 0 & 1 & 0 & 0 & 0 & 0 \\
\hline 82 & 0 & 0 & 1 & 3 & 0 & 0 & 0 & 0 & 0 & 0 \\
\hline 83 & 3 & 2053 & 189 & 66 & 100 & 63 & 9 & 178 & 37 & 85 \\
\hline 84 & 0 & 9 & 1 & 0 & 4 & 0 & 0 & 0 & 1 & 3 \\
\hline 85 & 0 & 5 & $i$ & 0 & 6 & 0 & 0 & 0 & 0 & 0 \\
\hline 86 & 0 & 99 & $i$ & 0 & 6 & 0 & 1 & 2 & 0 & 0 \\
\hline 87 & 0 & 22 & $i$ & 0 & 6 & 0 & 1 & 1 & 0 & 0 \\
\hline 88 & 0 & 35 & $i$ & 0 & 6 & 0 & 0 & 1 & 0 & 0 \\
\hline 89 & 0 & 43 & 0 & 0 & 3 & 0 & 0 & 0 & 0 & 0 \\
\hline
\end{tabular}


TABLE 56. (continued)

\begin{tabular}{|c|c|c|c|c|c|c|c|c|c|c|}
\hline \multirow[b]{2}{*}{ CODE } & \multicolumn{2}{|c|}{41 MC 268} & \multicolumn{8}{|c|}{ | 41 MC 296} \\
\hline & $\begin{array}{l}\overline{\mathrm{TP3}} \\
\mathrm{A} 71\end{array}$ & $\begin{array}{l}\text { SITE } \\
\text { TOTAL }\end{array}$ & 1st & $\begin{array}{l}\text { Area A } \\
\text { 2nd }\end{array}$ & $3 r d$ & lst & $\begin{array}{l}\text { Area B } \\
\text { 2nd }\end{array}$ & 3 rd & & $\bar{c}$ \\
\hline 37 & 15 & 66 & 122 & 11 & 6 & 40 & 14 & 19 & 2 & 5 \\
\hline 38 & 8 & 27 & 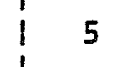 & 4 & 2 & 15 & 4 & 7 & 0 & 3 \\
\hline 39 & 0 & 6 & 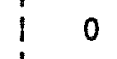 & 0 & 0 & 0 & 0 & 0 & 0 & 0 \\
\hline 40 & 0 & 3 & $i$ & 0 & 0 & 0 & 0 & 0 & 0 & 0 \\
\hline 41 & 5 & 38 & 15 & 4 & 4 & 20 & 8 & 9 & 2 & 2 \\
\hline 42 & 0 & 3 & 0 & 0 & 0 & 0 & 0 & 0 & 0 & 0 \\
\hline 43 & 0 & 6 & 0 & 0 & 0 & 0 & 0 & 0 & 0 & 0 \\
\hline 44 & 2 & 17 & 2 & 3 & 0 & 5 & 2 & 3 & 0 & 0 \\
\hline 45 & 0 & 6 & 0 & 0 & 0 & 0 & 0 & 0 & 0 & 0 \\
\hline 46 & 0 & 6 & 0 & 0 & 0 & 0 & 0 & 0 & 0 & 0 \\
\hline 47 & 76 & 551 & 311 & 229 & 184 & 571 & 212 & 306 & 30 & 53 \\
\hline 48 & 26 & 156 & 50 & 42 & 32 & 162 & 62 & 125 & 9 & 11 \\
\hline 49 & 0 & 9 & 3 & 0 & 2 & 4 & 0 & 7 & 0 & 1 \\
\hline 50 & 0 & 12 & 10 & 1 & 1 & 3 & 1 & 6 & 0 & 1 \\
\hline 51 & 19 & 150 & 43 & 43 & 31 & 144 & 50 & 71 & 8 & 19 \\
\hline 52 & 0 & 12 & 10 & 1 & 5 & 19 & 5 & 2 & 0 & 0 \\
\hline 53 & 0 & 8 & 11 & 0 & 2 & 3 & 12 & 3 & 0 & 0 \\
\hline 54 & 15 & 33 & 6 & 3 & 2 & 75 & 35 & 20 & 6 & 4 \\
\hline 55 & 0 & 10 & 0 & 2 & 0 & 0 & 0 & 6 & 0 & 0 \\
\hline 56 & 0 & 10 & 10 & 0 & 0 & 1 & 0 & 10 & 0 & 0 \\
\hline 57 & 13 & 23 & 13 & 2 & 3 & 21 & 10 & 31 & 4 & 0 \\
\hline 58 & 0 & 6 & 0 & 0 & 0 & 0 & 1 & 10 & 0 & 0 \\
\hline 59 & 0 & 3 & 0 & 0 & 1 & 0 & 0 & 6 & 0 & 0 \\
\hline 60 & 3 & 223 & 209 & 139 & 112 & 205 & 70 & 110 & 3 & 19 \\
\hline 61 & 0 & 7 & 2 & 0 & 0 & 21 & 1 & 1 & 0 & 0 \\
\hline 62 & 0 & 7 & 1 & 0 & 0 & 19 & 1 & 1 & 0 & 0 \\
\hline 63 & 156 & 775 & 657 & 457 & 315 & 1282 & 405 & 543 & 58 & 69 \\
\hline
\end{tabular}


TABLE 56. (continued)

\begin{tabular}{|c|c|c|c|c|c|c|c|c|c|c|}
\hline \multirow[b]{2}{*}{ CODE } & \multicolumn{2}{|c|}{$41 M C 268$} & \multicolumn{8}{|c|}{$41 M C 296$} \\
\hline & $\begin{array}{l}\overline{T P 3} \\
\text { A11 }\end{array}$ & $\begin{array}{l}\text { SITE } \\
\text { TOTAL }\end{array}$ & 1st & $\begin{array}{c}\text { Area A } \\
\text { 2nd }\end{array}$ & $3 r d$ & $1 s t$ & $\begin{array}{l}\text { Area B } \\
\text { 2nd }\end{array}$ & $3 r d$ & lst & $\mathrm{C}_{2 \mathrm{nd}}$ \\
\hline 64 & 21 & 114 & 61 & 38 & 30 & 115 & 46 & 63 & 7 & 7 \\
\hline 65 & 0 & 6 & 14 & 0 & 1 & 1 & 1 & 16 & 0 & 0 \\
\hline 66 & 0 & 7 & 1 & 1 & 0 & 2 & 0 & 10 & 0 & 0 \\
\hline 67 & 98 & 114 & 3 & 1 & 2 & 357 & 105 & 195 & 25 & 2 \\
\hline 68 & 0 & 6 & 10 & 0 & 0 & 8 & 0 & 11 & 1 & 0 \\
\hline 69 & 0 & 3 & 10 & 0 & 0 & 5 & 3 & 11 & 0 & 0 \\
\hline 70 & 18 & 28 & i 4 & 2 & 1 & 34 & 7 & 22 & 1 & 1 \\
\hline 71 & 0 & 6 & 10 & 1 & 0 & 16 & 0 & 0 & 0 & 0 \\
\hline 72 & 0 & 6 & $i 0$ & 0 & 0 & 0 & 15 & 2 & 0 & 0 \\
\hline 73 & 19 & 538 & 625 & 416 & 283 & 827 & 254 & 344 & 25 & 59 \\
\hline 74 & 0 & 15 & 18 & 2 & 1 & 5 & 2 & 16 & 0 & 1 \\
\hline 75 & 0 & 12 & 11 & 2 & 2 & 2 & 0 & 10 & 1 & 1 \\
\hline 76 & 181 & 1285 & $i^{1057}$ & 712 & 446 & 2985 & 1131 & 1314 & 198 & 136 \\
\hline 77 & 23 & 82 & 27 & 12 & 11 & 109 & 34 & 78 & 8 & 4 \\
\hline 78 & 0 & 3 & 10 & 0 & 0 & 0 & 0 & 6 & 0 & 0 \\
\hline 79 & 0 & 3 & 10 & 0 & 0 & 0 & 0 & 0 & 0 & 0 \\
\hline 80 & 254 & 580 & 256 & 134 & 94 & 754 & 238 & 354 & 43 & 32 \\
\hline 81 & 0 & 7 & $i$ & 0 & 0 & 2 & 11 & 3 & 0 & 0 \\
\hline 82 & 0 & 4 & 0 & 1 & 0 & 5 & II & 2 & 0 & 0 \\
\hline 83 & 329 & 1056 & 11011 & 625 & 332 & 3256 & 883 & 984 & 147 & 100 \\
\hline 84 & 0 & 10 & $i$ & 2 & 3 & 10 & 4 & 11 & 0 & 0 \\
\hline 85 & 0 & 8 & $i$ & 4 & 0 & 20 & 5 & 19 & 0 & 1 \\
\hline 86 & 43 & 52 & 1 & 2 & 2 & 97 & 37 & 91 & 8 & 3 \\
\hline 87 & 9 & 17 & $i$ & 1 & 0 & 17 & 10 & 32 & 1 & 0 \\
\hline 88 & 12 & 19 & $i$ & $I$ & 2 & 22 & 12 & 28 & 4 & 1 \\
\hline 89 & 22 & 25 & 2 & 0 & 0 & 73 & 15 & 35 & 3 & 2 \\
\hline
\end{tabular}


TABLE 56. (continued)

41 MC 296 (continued)

\begin{tabular}{|c|c|c|c|c|c|c|c|c|}
\hline \multirow[b]{2}{*}{ CODE } & \multirow[b]{2}{*}{ Ist } & \multirow{2}{*}{$\begin{array}{c}\text { Area D } \\
\text { 2nd }\end{array}$} & \multirow[b]{2}{*}{$3 r d$} & \multicolumn{2}{|c|}{ Area $\mathrm{E}$} & \multirow[b]{2}{*}{ lst } & \multirow{2}{*}{$\begin{array}{c}\text { Area G } \\
\text { 2nd }\end{array}$} & \multirow[b]{2}{*}{$3 \mathrm{rd}$} \\
\hline & & & & lst & 2nd & & & \\
\hline 37 & 6 & 2 & 3 & 7 & 1 & 2 & 4 & 1 \\
\hline 38 & 2 & 2 & 0 & 2 & 0 & 0 & 1 & 1 \\
\hline 39 & 0 & 0 & 0 & 0 & 0 & 0 & 0 & 0 \\
\hline 40 & 0 & 0 & 0 & 0 & 0 & 0. & 0 & 0 \\
\hline 41 & 3 & 0 & 3 & 4 & 1 & 2 & 1 & 0 \\
\hline 42 & 0 & 0 & 0 & 0 & 0 & 0 & 0 & 0 \\
\hline 43 & 0 & 0 & 0 & 0 & 0 & 0 & 0 & 0 \\
\hline 44 & 1 & 0 & Q & 1 & 0 & 0 & 2 & 0 \\
\hline 45 & 0 & 0 & 0 & 0 & 0 & 0 & 0 & 0 \\
\hline 46 & 0 & 0 & 0 & 0 & 0 & 0 & 0 & 0 \\
\hline 47 & 36 & 30 & 44 & 61 & 20 & 32 & 34 & 29 \\
\hline 48 & 8 & 8 & 12 & 15 & 6 & 7 & 15 & 10 \\
\hline 49 & 0 & 0 & 1 & 1 & 0 & 0 & 0 & 0 \\
\hline 50 & 0 & 0 & 0 & 1 & 1 & 0 & 0 & 0 \\
\hline 51 & 8 & 8 & 6 & 9 & 5 & 16 & 7 & 6 \\
\hline 52 & 0 & 1 & 1 & 0 & 1 & 0 & 0 & 0 \\
\hline 53 & 0 & 1 & 0 & 0 & 0 & 0 & 0 & 0 \\
\hline 54 & 1 & 2 & $I$ & 6 & 2 & 13 & 14 & 4 \\
\hline 55 & 0 & 0 & 0 & 0 & 0 & 0 & 0 & 0 \\
\hline 56 & 0 & 0 & 0 & 0 & 0 & 0 & 0 & 0 \\
\hline 57 & 0 & 5 & 0 & 4 & 0 & 4 & 5 & 1 \\
\hline 58 & 0 & 0 & 0 & 0 & 0 & 0 & 0 & 0 \\
\hline 59 & 0 & 0 & 0 & 1 & 0 & 0 & 0 & 0 \\
\hline 60 & 19 & 6 & 25 & 27 & 7 & 0 & 0 & 7 \\
\hline 61 & 0 & 0 & 0 & 0 & 0 & 0 & 0 & 0 \\
\hline 62 & 0 & 0 & 0 & 0 & 0 & 0 & 0 & 0 \\
\hline 63 & 17 & 33 & 80 & 124 & 52 & 40 & 37 & 47 \\
\hline
\end{tabular}


TABLE 56. (continued)

41 MC 296 (continued)

\begin{tabular}{|c|c|c|c|c|c|c|c|c|}
\hline \multirow[b]{2}{*}{ CODE } & \multirow{2}{*}{\multicolumn{2}{|c|}{$\begin{array}{c}\text { Area D } \\
\text { 2nd }\end{array}$}} & \multirow[b]{2}{*}{$3 r d$} & \multicolumn{2}{|c|}{ Area E } & \multirow[b]{2}{*}{ lst } & \multirow{2}{*}{$\begin{array}{c}\text { Area G } \\
\text { 2nd }\end{array}$} & \multirow[b]{2}{*}{$3 r d$} \\
\hline & & & & lst & 2nd & & & \\
\hline 64 & 34 & 5 & 6 & 7 & 3 & 9 & 11 & 8 \\
\hline 65 & 0 & 0 & 1 & 1 & 0 & 0 & 0 & 0 \\
\hline 66 & 0 & 0 & 0 & 0 & 0 & 0 & 1 & 0 \\
\hline 67 & 11 & 14 & 0 & 34 & 26 & 25 & 59 & 22 \\
\hline 68 & 0 & 0 & 0 & 0 & 0 & 2 & 2 & 0 \\
\hline 69 & 1 & 0 & 0 & 2 & 0 & 1 & 0 & 0 \\
\hline 70 & 2 & 2 & $I$ & 2 & 0 & 2 & 5 & 3 \\
\hline 71 & 0 & 0 & 0 & 0 & 0 & 0 & 0 & 0 \\
\hline 72 & 0 & 0 & 0 & 0 & 0 & 0 & 0 & 0 \\
\hline 73 & 34 & 12 & 73 & 81 & 23 & 4 & 5 & 21 \\
\hline 74 & 1 & 0 & 0 & 0 & 1 & 0 & 0 & 0 \\
\hline 75 & 1 & 0 & 2 & 0 & 0 & 0 & $I$ & 0 \\
\hline 76 & 132 & 109 & 71 & 301 & 120 & 207 & 334 & 162 \\
\hline 77 & 10 & 3 & 1 & 8 & 5 & 7 & 14 & 8 \\
\hline 78 & 0 & 0 & 1 & 0 & 0 & 0 & 0 & 0 \\
\hline 79 & 0 & 0 & 0 & 0 & 0 & 0 & 0 & 0 \\
\hline 80 & 35 & 41 & 23 & 70 & 32 & 77 & 128 & 61 \\
\hline 81 & 0 & 0 & 0 & 1 & 0 & 0 & 0 & 0 \\
\hline 82 & 0 & 0 & 0 & 0 & 0 & 0 & 1 & 0 \\
\hline 83 & 87 & 65 & 47 & 223 & 83 & 119 & 192 & 93 \\
\hline 84 & 2 & 0 & 1 & 2 & 0 & 1 & 0 & 0 \\
\hline 85 & 2 & 0 & 1 & 1 & 2 & 0 & 1 & 1 \\
\hline 86 & 3 & 16 & 0 & 6 & 3 & 18 & 25 & 13 \\
\hline 87 & 0 & 4 & 0 & 3 & 0 & 4 & 4 & 3 \\
\hline 88 & 1 & 5 & 0 & 1 & 1 & 5 & 12 & 5 \\
\hline 89 & 2 & 7 & 0 & 2 & 2 & 9 & 9 & 5 \\
\hline
\end{tabular}


TABLE 56. (continued)

41 MC 296 (continued)

\begin{tabular}{|c|c|c|c|c|c|c|c|c|c|}
\hline CODE & $\begin{array}{l}\overline{T P 1} \\
\text { lst }\end{array}$ & 2nd & $3 r d$ & $\begin{array}{l}\text { TP2 } \\
\text { lst }\end{array}$ & 2nd & $3 r d$ & $\begin{array}{l}\text { TP3 } \\
\text { lst }\end{array}$ & 2nd & $\begin{array}{l}\text { SITE } \\
\text { TOTAL }\end{array}$ \\
\hline 37 & 6 & 1 & 1 & 4 & 2 & 2 & 1 & 0 & 162 \\
\hline 38 & 4 & 0 & 0 & 2 & 0 & 1 & 0 & 0 & 55 \\
\hline 39 & 0 & 0 & 0 & 0 & 0 & 0 & 0 & 0 & 0 \\
\hline 40 & 0 & 0 & 0 & 0 & 0 & 0 & 0 & 0 & 0 \\
\hline 41 & 2 & 1 & 0 & 2 & 2 & 1 & 1 & 0 & 87 \\
\hline 42 & 0 & 0 & 0 & 0 & 0 & 0 & 0 & 0 & 0 \\
\hline 43 & 0 & 0 & 0 & 0 & 0 & 0 & 0 & 0 & 0 \\
\hline 44 & 0 & 0 & 1 & 0 & 0 & 0 & 0 & 0 & 20 \\
\hline 45 & 0 & 0 & 0 & 0 & 0 & 0 & 0 & 0 & 0 \\
\hline 46 & 0 & 0 & 0 & 0 & 0 & 0 & 0 & 0 & 0 \\
\hline 47 & 47 & 43 & 55 & 8 & 31 & 9 & 9 & 2 & 2386 \\
\hline 48 & 14 & 22 & 29 & 2 & 8 & 5 & 0 & 0 & 654 \\
\hline 49 & 0 & 0 & 0 & 0 & 0 & 0 & 0 & 0 & 19 \\
\hline 50 & 0 & 0 & 0 & 0 & 0 & 0 & 0 & 0 & 15 \\
\hline 51 & 18 & 12 & 14 & 1 & 15 & 3 & 1 & 0 & 538 \\
\hline 52 & 1 & 0 & 0 & 0 & 0 & 0 & 0 & 0 & 36 \\
\hline 53 & 0 & 0 & 0 & 0 & 0 & 0 & 0 & 0 & 22 \\
\hline 54 & 2 & 0 & 1 & 2 & 0 & 0 & 1 & 0 & 200 \\
\hline 55 & 0 & 0 & 0 & 0 & 0 & 0 & 0 & 0 & 8 \\
\hline 56 & 0 & 0 & 0 & 0 & 0 & 0 & 0 & 0 & 11 \\
\hline 57 & 3 & 2 & 3 & 0 & 4 & 1 & 1 & 0 & 105 \\
\hline 58 & 0 & 0 & 0 & 0 & 0 & 0 & 0 & 0 & 11 \\
\hline 59 & 0 & 0 & 0 & 0 & 0 & 0 & 0 & 0 & 8 \\
\hline 60 & 10 & 7 & 18 & 3 & 4 & 0 & 6 & 2 & 1008 \\
\hline 61 & 0 & 0 & 0 & 0 & 0 & 0 & 0 & 0 & 25 \\
\hline 62 & 0 & 0 & 1 & 0 & 0 & 0 & 0 & 0 & 23 \\
\hline 63 & 78 & 55 & 82 & 30 & 40 & 38 & 12 & 5 & 4556 \\
\hline
\end{tabular}


TABLE 56. (continued)

41 MC 296 (continued)

\begin{tabular}{|c|c|c|c|c|c|c|c|c|c|}
\hline CODE & $\begin{array}{l}\text { TP1 } \\
\text { lst }\end{array}$ & 2nd & $3 \mathrm{rd}$ & $\begin{array}{l}\text { TP2 } \\
\text { lst }\end{array}$ & 2nd & $3 r d$ & $\begin{array}{l}\text { TP3 } \\
\text { lst }\end{array}$ & 2nd & $\begin{array}{l}\text { SITE } \\
\text { TOTAL }\end{array}$ \\
\hline 64 & 29 & 22 & 40 & 8 & 11 & 10 & 0 & 0 & 570 \\
\hline 65 & 0 & 0 & 1 & 1 & 0 & 0 & 0 & 0 & 27 \\
\hline 66 & 0 & 0 & 0 & 0 & 0 & 0 & 0 & 0 & 15 \\
\hline 67 & 11 & 13 & 19 & 4 & 8 & 6 & 0 & 0 & 942 \\
\hline 68 & 0 & 0 & 0 & 0 & 0 & 0 & 0 & 0 & 24 \\
\hline 69 & 0 & 0 & 0 & 0 & 0 & 0 & 0 & 0 & 23 \\
\hline 70 & 5 & 5 & 13 & 2 & 9 & 3 & 0 & 0 & 127 \\
\hline 71 & 1 & 0 & 0 & 0 & 0 & 0 & 0 & 0 & 18 \\
\hline 72 & 0 & 0 & 0 & 0 & 0 & 0 & 0 & 0 & 17 \\
\hline 73 & 31 & 14 & 62 & 16 & 12 & 19 & 12 & 5 & 3257 \\
\hline 74 & 0 & 0 & 0 & 0 & 0 & 0 & 0 & 0 & 37 \\
\hline 75 & 0 & 0 & 0 & 0 & 0 & 0 & 0 & 0 & 33 \\
\hline 76 & 114 & 27 & 139 & 77 & 116 & 68 & 17 & 12 & 9985 \\
\hline 77 & 5 & 4 & 6 & 2 & 7 & 3 & 0 & 0 & 366 \\
\hline 78 & 1 & 0 & 0 & 0 & 0 & 0 & 0 & 0 & 8 \\
\hline 79 & 0 & 0 & 0 & 0 & 0 & 0 & 0 & 0 & 0 \\
\hline 80 & 32 & 26 & 52 & 21 & 31 & 24 & 2 & 2 & 2562 \\
\hline 81 & 0 & 1 & 1 & 0 & 0 & 0 & 0 & 0 & 19 \\
\hline 82 & 0 & 1 & 0 & 0 & 0 & 0 & 1 & 0 & 22 \\
\hline 83 & 125 & 86 & 142 & 51 & 78 & 45 & 15 & 10 & 8799 \\
\hline 84 & 1 & 3 & 0 & 3 & 0 & 0 & 1 & 0 & 48 \\
\hline 85 & 1 & 1 & 0 & 0 & 0 & 0 & 0 & 0 & 67 \\
\hline 86 & 0 & 0 & 2 & 0 & 4 & 2 & 0 & 0 & 334 \\
\hline 87 & 0 & 0 & 0 & 0 & 0 & 0 & 0 & 0 & 79 \\
\hline 88 & 0 & 0 & 1 & 0 & 1 & 1 & 0 & 0 & 103 \\
\hline 89 & 0 & 2 & 1 & 0 & 3 & 1 & 0 & 0 & 173 \\
\hline
\end{tabular}


Records, Table 55. The Horizon assemblages are suggested to reflect more realistically the successive periods of cultural activity resulting in accumulation of debitage at each site. The column heading "ALL" signals the combination of debitage from all levels of a unit or area. This is done when no horizons are definable, or when the deposit is bel ieved to represent a 1 imited time period or single cultural event. In certain cases, presentation of both horizons (i.e.s. 1st, 2 nd, etc.) and "ALL" totals beneath a particular excavation are discernible in some of the unit collections, but not in others. Table 57 shows area, unit, and level groupings and horizon combinations for each site.

\section{RADIOCARBON ASSAYS}

Thirty carbon samples recovered from seven prehistoric sites excavated during the course of the Phase II investigation at Choke Canyon were submitted for assay to the Radiocarbon Laboratory. The University of Texas at Austin. Assay results are shown, along with provenience information and MASCA corrections, in Table 58. For three of the sites, 41 LK 201, 41 MC 29, and 41 MC 222, the results of additional radiocarbon assays have been previously published (Ha11, B1ack, and Graves 1982:652).

Fourteen of the carbon samples submitted for assay were paired, that is, the amount of carbon collected in seven cases was adequate for division into two samples. The paired samples are as follows:

\begin{tabular}{|c|c|c|}
\hline TX-Number & Site & $\begin{array}{l}\text { CA Correcte } \\
\text { B.P. Age }\end{array}$ \\
\hline 1. $\begin{array}{l}T X-4690 \\
T X-4691\end{array}$ & $\begin{array}{lll}41 & \text { LK } & 51 \\
41 & \text { LK } & 51\end{array}$ & $\begin{array}{c}7060-7080 \\
6400\end{array}$ \\
\hline 2. $\begin{array}{r}T X-4674 \\
T X-4671\end{array}$ & $\begin{array}{lll}41 & \text { LK } & 128 \\
41 & \text { LK } & 128\end{array}$ & $\begin{array}{l}970 \\
770\end{array}$ \\
\hline 3. $\begin{array}{r}T X-4675 \\
T X-4676\end{array}$ & $\begin{array}{lll}41 & \text { LK } & 128 \\
41 & \text { LK } & 128\end{array}$ & $\begin{array}{l}770 \\
650\end{array}$ \\
\hline 4. $\begin{array}{r}T X-4688 \\
T X-4689\end{array}$ & $\begin{array}{l}41 \text { MC } 29 \\
41 \text { MC } 29\end{array}$ & $\begin{array}{c}2360 \\
1940-2010\end{array}$ \\
\hline 5. $\begin{array}{r}T X-4692 \\
T X-4693\end{array}$ & 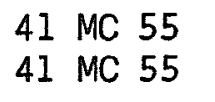 & $\begin{array}{l}530 \\
720\end{array}$ \\
\hline 6. $\begin{array}{l}T X-4679 \\
T X-4680\end{array}$ & $\begin{array}{lll}41 & M C & 296 \\
41 & M C & 296\end{array}$ & $\begin{array}{c}1900-1920 \\
1360\end{array}$ \\
\hline 7. $\begin{array}{l}T X-4681 \\
T X-4669\end{array}$ & $\begin{array}{l}41 \text { MC } 296 \\
41 \text { MC } 296\end{array}$ & $\begin{array}{c}1790 \\
1960-2050\end{array}$ \\
\hline
\end{tabular}

The differences in ages yielded by the paired assays range from a minimum of 120 years (Pair No. 3) to a maximum of 660 years (Pair No. 1). The average 
TABLE 57. AREA, UNIT, AND LEVEL GROUPINGS AND HORIZON COMBINATIONS FOR EACH SITE

Site Area Units Letal Lels lst $\begin{aligned} & \text { Horizon/Level Combinations } \\ & 2 \text { Le } 3 \text { rd } 4 \text { th }\end{aligned}$ ALL

\begin{tabular}{|c|c|c|c|c|c|c|c|c|}
\hline 41 LK 8 & A & N510 E459 & 17 & $1-6$ & $7-11$ & $12-17$ & - & - \\
\hline 41 LK 8 & A & N510 E458 & 20 & $1-6$ & $7-11$ & $12-20$ & - & - \\
\hline 41 LK 8 & A & N511 E458 & 17 & $1-6$ & $7-11$ & $12-17$ & - & - \\
\hline 41 LK 8 & A & N511 E459 & 17 & $1-6$ & $7-11$ & $12-17$ & - & - \\
\hline 41 LK 8 & B & N460 E541 & 8 & $1-4$ & $5-8$ & - & - & - \\
\hline 41 LK 8 & B & N460 E542 & 8 & $1-4$ & $5-8$ & - & - & $=$ \\
\hline 41 LK 8 & B & N461 E54I & 8 & $1-4$ & $5-8$ & - & - & - \\
\hline 41 LK 8 & B & N461 E542 & 8 & $1-4$ & $5-8$ & - & - & - \\
\hline 41 LK 8 & B & N462 E541 & 7 & $1-4$ & $5-7$ & - & - & - \\
\hline 41 LK 8 & B & N462 E542 & 8 & $1-4$ & $5-8$ & - & - & - \\
\hline 41 LK 8 & C & N400 E605 & 11 & $1-6$ & $7-11$ & - & - & - \\
\hline 41 LK 8 & C & N401 E605 & 11 & $1-6$ & $7-11$ & - & - & - \\
\hline $41 \mathrm{LK} 14$ & A & N1008 E1000 & 11 & $1-5$ & $6-11$ & - & - & - \\
\hline 41 LK 14 & A & N1008 E1001 & 9 & $1-5$ & $6-9$ & - & $=$ & - \\
\hline 41 LK 14 & A & N1008 E1002 & 9 & $1-5$ & $6-9$ & - & - & - \\
\hline $41 \mathrm{LK} 14$ & A & N1009 E1000 & 9 & $1-5$ & $6-9$ & - & - & - \\
\hline 41 LK 14 & A & N1009 El001 & 9 & $1-5$ & $6-9$ & - & - & - \\
\hline $41 \mathrm{LK} 14$ & A & N1009 El002 & 9 & $1-5$ & $6-9$ & - & - & - \\
\hline 41 LK 14 & A & N1010 E1000 & 11 & $1-5$ & $6-11$ & - & - & - \\
\hline $41 \mathrm{LK} 14$ & A & N1010 E1001 & 9 & $1-5$ & $6-9$ & - & - & - \\
\hline 41 LK 14 & A & N1010 E1002 & 9 & $1-5$ & $6-9$ & - & - & - \\
\hline 41 LK 14 & B & N1006 E958 & 8 & $1-4$ & $5-8$ & - & - & - \\
\hline 41 LK 14 & B & N1006 E959 & 8 & $1-4$ & $5-8$ & - & - & - \\
\hline 41 LK 14 & B & N1007 E958 & 8 & $1-4$ & $5-8$ & - & - & - \\
\hline 41 LK 14 & B & N1007 E959 & 8 & $1-4$ & $5-8$ & - & - & - \\
\hline 41 LK 51 & A & N998 E981 & 17 & $1-4$ & $5-9$ & $10-13$ & $14-17$ & - \\
\hline 41 LK 51 & A & N998 E982 & 17 & $1-4$ & $5-9$ & $10-13$ & $14-17$ & - \\
\hline 41 LK 51 & A & N998 E984 & 17 & $1-4$ & $5-9$ & $10-13$ & $14-17$ & - \\
\hline 41 LK 51 & A & N999 E981 & 17 & $1-4$ & $5-9$ & $10-13$ & $14-17$ & - \\
\hline 41 LK 51 & A & N999 E982 & 17 & $1-4$ & $5-9$ & $10-13$ & $14-17$ & - \\
\hline 41 LK 51 & A & N999 E984 & 21 & $1-4$ & $5-9$ & $10-13$ & $14-21$ & - \\
\hline 41 LK 51 & B & N1010 E1008 & 1 & - & - & - & - & 1 \\
\hline 41 LK 51 & B & N1010 El011 & 11 & $1-4$ & $5-11$ & - & - & - \\
\hline 41 LK 51 & B & Ni011 E1008 & 2 & - & - & - & - & $1-2$ \\
\hline 41 LK 51 & B & N1011 E1011 & 8 & - & - & $=$ & - & $1=8$ \\
\hline 41 LK 51 & C & N1025 E1039 & 4 & - & - & - & - & $I-4$ \\
\hline 41 LK 51 & C & $\mathrm{N} 1025 \mathrm{E} 1041$ & 6 & - & - & - & - & $1-6$ \\
\hline 41 LK 51 & C & N1025 El042 & 5 & - & - & $=$ & - & $1-5$ \\
\hline 41 LK 51 & C & N1026 E1039 & 5 & - & - & - & - & $1-5$ \\
\hline 41 LK 51 & C & N1026 E1042 & 4 & - & - & - & - & $1-4$ \\
\hline 41 LK 51 & D & N1033 E1062 & 3 & - & - & - & $=$ & $1-3$ \\
\hline 41 LK 51 & D & N1033 E1065 & 10 & $1-5$ & $6-10$ & $=$ & - & - \\
\hline 41 LK 51 & D & N1034 E1062 & 3 & - & - & - & - & $1=3$ \\
\hline 41 LK 51 & D & N1034 E1065 & 10 & $1-5$ & $6-10$ & - & - & - \\
\hline 41 LK 51 & $E$ & N1038 E1083 & 4 & - & - & $=$ & - & $1-4$ \\
\hline
\end{tabular}


TABLE 57. (continued) Site Area Units Lotal Levels lst $\begin{aligned} & \text { Horizon/Level Combinations } \\ & \text { 2nd 3rd 4th ALL }\end{aligned}$

\begin{tabular}{|c|c|c|c|c|c|c|c|c|}
\hline 41 LK 128 & - & Test Pit 14 & 1 & - & - & - & - & 1 \\
\hline 41 LK 128 & - & Test Pit 16 & 1 & - & - & - & - & 1 \\
\hline 41 LK 133 & - & Test Pit 1 & 9 & $I-4$ & $5-9$ & - & - & - \\
\hline 41 LK 133 & $=$ & Test Pit 2 & 7 & $1-3$ & $4-7$ & - & - & - \\
\hline 41 LK 142 & - & Test Pit I & 6 & - & - & - & - & $1-6$ \\
\hline 41 LK 185 & - & Test Pit I & 7 & $1-3$ & $4-7$ & - & - & - \\
\hline 41 LK 185 & - & Test Pit 2 & 4 & - & - & - & - & $1-4$ \\
\hline 41 LK 185 & - & Test Pit 3 & 7 & $1-3$ & $4-7$ & - & - & - \\
\hline 41 LK 243 & - & Test Pit 1 & 6 & $1-3$ & $4-6$ & - & - & - \\
\hline 41 LK 243 & - & Test Pit 2 & 5 & - & - & - & - & $1-5$ \\
\hline 41 LK 250 & - & Test Pit 1 & 11 & $I-3$ & $4-8$ & $9-11$ & - & - \\
\hline 41 MC 29 & - & N997 E1011 & 6 & $1-3$ & $4-6$ & - & - & - \\
\hline 41 MC 29 & - & N997 E1012 & 7 & $1-3$ & $4-7$ & $=$ & - & - \\
\hline 41 MC 29 & - & N997 E1013 & 7 & $1-3$ & $4=7$ & - & $=$ & - \\
\hline 41 MC 29 & - & N998 E1011 & 6 & $1-3$ & $4-6$ & - & - & - \\
\hline 41 MC 29 & - & N998 E1012 & 6 & $1-3$ & $4-6$ & - & - & - \\
\hline 41 MC 29 & - & N998 E1013 & 6 & $1-3$ & $4-6$ & $=$ & - & - \\
\hline 41 MC 29 & - & N999 E1011 & 6 & $1-3$ & $4-6$ & - & - & - \\
\hline 41 MC 29 & - & N999 E1012 & 6 & $1-3$ & $4-6$ & $=$ & - & - \\
\hline 41 MC 29 & - & N999 E1013 & 6 & $1-3$ & $4-6$ & - & - & - \\
\hline 41 MC 55 & $A$ & N1017 E999 & 12 & $1-3$ & $4-12$ & $=$ & - & - \\
\hline 41 MC 55 & A & N1018 E999 & 8 & $1-3$ & $4-8$ & - & - & - \\
\hline $41 M C 55$ & $B$ & N998 E1017 & 6 & $1-3$ & $4-6$ & - & - & - \\
\hline 41 MC 55 & $B$ & N999 E1017 & 9 & $1-3$ & $4-9$ & - & - & - \\
\hline 41 MC 55 & C & N992 E1013 & 1 & - & - & - & - & - \\
\hline 41 MC 55 & C & N992 E1015 & 1 & - & - & - & - & 1 \\
\hline 41 MC 55 & C & N992 E1017 & 1 & - & - & - & - & 1 \\
\hline 41 MC 55 & C & N993 E1014 & 1 & - & - & - & - & 1 \\
\hline 41 MC 55 & C & N993 E1015 & 1 & - & - & - & - & 1 \\
\hline 41 MC 55 & C & N993 E1017 & 1 & - & - & - & - & 1 \\
\hline 41 MC 55 & C & N994 E1013 & 1 & - & - & - & - & 1 \\
\hline 41 MC 55 & C & N994 E1015 & 2 & - & - & - & - & $1-2$ \\
\hline 41 MC 55 & C & N994 E1017 & 2 & - & - & - & - & $1-2$ \\
\hline 41 MC 55 & D & N1006 E1015 & 2 & - & - & - & - & $1-2$ \\
\hline 41 MC 55 & D & N1007 E1014 & 2 & - & - & $\infty$ & - & $1-2$ \\
\hline 41 MC 55 & $\mathrm{D}$ & N1007 E1015 & 3 & - & - & - & - & $1-3$ \\
\hline 41 MC 55 & D & N1007 E1016 & 2 & - & - & - & - & $1-2$ \\
\hline 41 MC 55 & D & N1008 E1014 & 3 & - & $=$ & - & - & $1-3$ \\
\hline 41 MC 55 & D & N1008 E1015 & 2 & - & - & - & - & $1-2$ \\
\hline 41 MC 55 & $D$ & N1008 E1016 & 2 & - & - & - & - & $1-2$ \\
\hline 41 MC 55 & $D$ & N1009 E1013 & 2 & - & - & - & - & $1-2$ \\
\hline $41 M C 55$ & $D$ & N1009 E1014 & 1 & - & - & $=$ & - & 1 \\
\hline 41 MC 55 & $D$ & N1009 E1015 & 2 & - & - & - & - & $1-2$ \\
\hline 41 MC 55 & $D$ & N1009 E1016 & 2 & - & - & - & - & $1-2$ \\
\hline 41 MC 55 & $E$ & N1014 E1011 & 1 & - & - & - & - & 1 \\
\hline 41 MC 55 & $E$ & N1015 E1010 & 1 & - & - & - & - & 1 \\
\hline 41 MC 55 & $E$ & N1015 E1012 & 1 & - & - & - & - & 1 \\
\hline 41 MC 55 & $E$ & N1016 E1011 & 1 & - & - & - & - & 1 \\
\hline
\end{tabular}


TABLE 57. (continued)

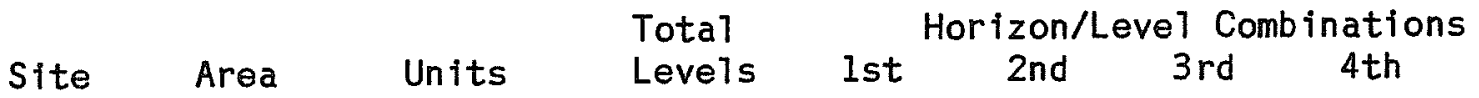

ALL

41 LK 51

41 LK 53

41 LK 53

41 LK 53

41 LK 53

41 LK 53

41 LK 53

41 LK 53

41 LK 53

41 LK 53

41 LK 74

41 LK 74

41 LK 74

41 LK 74

41 LK 74

41 LK 74

41 LK 74

41 LK 74

41 LK 74

41 LK 74

41 LK 74

41 LK 74

41 LK 74

41 LK 74

41 LK 74

41 LK 74

41 LK 74

41 LK 74

41 LK 74

41 LK 74

41 LK 74

41 LK 74

41 LK 74

41 LK 74

41 LK 74

41 LK 128

41 LK 128

41 LK 128

41 LK 128

41 LK 128

41 LK 128

41 LK 128

41 LK 128

41 LK 128

41 LK 128

41 LK 128

41 LK 128

41 LK 128
E N1039 E1083

- N1000 E1002

- N1000 El003

- N1000 E1004

- N1001 E1002

- N1001 E1003

- N1001 E1004

- N1002 E1002

- N1002 E1003

- N1002 El004

A N977 E1000

A N977 E1001

A N978 E1000

A N978 E1001

B N1070 E857

B N1070 E858

B N1071 E857

B N1071 E858

C N987 E990

C N987 E991

C N988 E990

C N988 E991

D N980 E989

D N981 E988

D N981 E989

F N994 E985

F N994 E986

F N995 E98I

$\mathrm{F} \quad \mathrm{N} 995 \mathrm{E985}$

$\mathrm{F} \quad \mathrm{N} 995 \mathrm{E} 986$

G N986 E973

H N977 E973

H N977 E974

H N978 E973

H N978 E974

- Test Pit 1

- Test Pit 2

- Test Pit 3

- Test Pit 4

- Test Pit 5

- Test Pit 6

- Test Pit 7

- Test Pit 8

- Test Pit 9

- Test Pit 10

- Test Pit 11

- Test Pit 12

- Test Pit 13

Levels lst 2nd 3rd

1-5

\begin{tabular}{|c|c|c|c|c|}
\hline 5 & - & - & - & - \\
\hline 11 & $1-3$ & $4-7$ & $8-11$ & - \\
\hline 11 & $1-3$ & $4-7$ & $8-11$ & - \\
\hline 17 & $1-3$ & $4-7$ & $8-11$ & $12-17$ \\
\hline 11 & $1-3$ & $4-7$ & $8-11$ & - \\
\hline 11 & $1-3$ & $4-7$ & $8-11$ & - \\
\hline
\end{tabular}

$11 \quad 1-3 \quad 4-7 \quad 8-11$

$11 \quad 1-3 \quad 4-7 \quad 8-11$

$11 \quad 1-3 \quad 4-7 \quad 8-11$

II

4

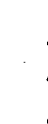

4

(1)

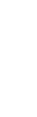

$(4)$

(4)

(1)

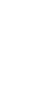

2

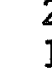

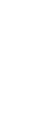


TABLE 57. (continued) Site Area Units Lotal Levels 1st $\begin{aligned} & \text { Horizon/Level Combinations } \\ & \text { 2nd 3rd 4th ALL }\end{aligned}$

41 MC 94 - Test Pit 1

41 MC 94 - Test Pit 2

41 MC 94 - Test Pit 3

41 MC 94 - Test Pit 4

41 MC 94 - Test Pit 5

41 MC 94 - Test Pit 6

41 MC 196 - Test Pit 1

41 MC 196 - Test Pit 2

41 MC 196 - Test Pit 3

41 MC 222 - N95 E87

41 MC 222 - N97 E86

41 MC 222 - N97 E87

41 MC 222. - N98 E86

41 MC 222 - N98 E90

41 MC 222 - N98 E91

41 MC 222 - N99 E86

41 MC 222 - N99 E89

41 MC 222 - N99 E90

41 MC 222 - N99 E91

41 MC 222 - N100 E86

41 MC 222 - N100 E89

41 MC 222 - N100 E90

41 MC 222 - N100 E91

41 MC 222 - N101 E87

41 MC 222 - N101 E88

41 MC 222 - N101 E89

41 MC 222 - N101 E90

41 MC 222 - N101 E91

41 MC 222 - N102 E88

41 MC 222 - N102 E89

41 MC 222 - N102 E90

41 MC 222 - N102 E91

41 MC 222 - N102 El00

41 MC 222 - N103 E86

41 MC 222 - N103 E87

41 MC 222 - N103 E88

41 MC 222 - N103 E89

41 MC 222 - N103 E90

41 MC 222 - N103 E91

41 MC 222 - N104 E85

41 MC 222 - N107 E87

41 MC 222 - N112 E79

41 MC 222 - N113 E83

41 MC 222 - N119 E80

41. MC 222 - N125 E72

41 MC 268 A N995 E998

41 MC 268 A N995 E999

41 MC 268 A N996 E998

\begin{tabular}{|c|c|c|c|c|c|}
\hline 8 & $1-4$ & $5-8$ & - & - & - \\
\hline 9 & $1-4$ & $5-9$ & - & - & - \\
\hline 7 & $1-4$ & $5-7$ & - & - & - \\
\hline 9 & $1-4$ & $5-9$ & - & - & - \\
\hline 6 & $1-4$ & $5-6$ & - & - & - \\
\hline 8 & $1-4$ & $5-8$ & $=$ & - & - \\
\hline 6 & - & - & - & - & $1-6$ \\
\hline 6 & - & - & - & - & $1-6$ \\
\hline 5 & - & - & - & - & $1-5$ \\
\hline 3 & - & - & - & - & $1-3$ \\
\hline 3 & - & - & - & - & $1-3$ \\
\hline 5 & - & - & - & - & $1-5$ \\
\hline 3 & - & - & - & - & $1-3$ \\
\hline 3 & - & - & - & - & $1-3$ \\
\hline 3 & - & - & - & - & $1-3$ \\
\hline 3 & - & - & - & - & $1-3$ \\
\hline 4 & - & - & - & - & $1-4$ \\
\hline 4 & - & - & - & - & $1-4$ \\
\hline 4 & - & - & - & - & $1-4$ \\
\hline 2 & - & - & - & - & $1=2$ \\
\hline 5 & - & - & - & - & $1-5$ \\
\hline 5 & - & - & - & - & $1-5$ \\
\hline 5 & - & - & - & - & $1-5$ \\
\hline- & - & - & - & - & - \\
\hline 3 & - & - & - & - & $1-3$ \\
\hline 3 & - & - & - & - & $1-3$ \\
\hline 5 & - & - & - & - & $1-5$ \\
\hline 5 & - & - & - & - & $1-5$ \\
\hline 5 & - & - & - & - & $1-5$ \\
\hline 7 & - & - & - & - & $1-7$ \\
\hline 6 & - & - & - & - & $1-6$ \\
\hline 7 & - & - & - & - & $1-7$ \\
\hline 7 & - & - & - & - & $1-7$ \\
\hline 4 & - & - & - & - & $1-4$ \\
\hline 4 & - & - & - & - & $1-4$ \\
\hline 7 & - & - & - & - & $1-7$ \\
\hline 9 & - & - & - & - & $1-9$ \\
\hline 8 & - & - & - & - & $1-8$ \\
\hline 8 & - & - & - & - & $1-8$ \\
\hline 4 & - & - & - & - & $1-4$ \\
\hline 4 & - & - & - & - & $1-4$ \\
\hline 5 & - & - & - & - & $1-5$ \\
\hline 6 & - & - & - & - & $1-6$ \\
\hline 7 & - & - & - & - & $1-7$ \\
\hline 3 & - & - & - & - & $1-3$ \\
\hline 11 & $1-6$ & $7-11$ & - & - & - \\
\hline 8 & - & - & - & - & $1-8$ \\
\hline 11 & $1-6$ & $7-11$ & - & - & - \\
\hline
\end{tabular}


582

TABLE 57. (continued)

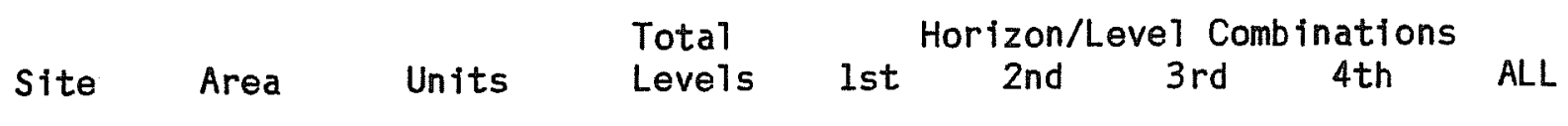

\begin{tabular}{|c|c|c|c|c|c|c|c|c|}
\hline 41 MC 268 & A & N996 E999 & 8 & - & - & - & - & $1-8$ \\
\hline 41 MC 268 & $\mathrm{~B}$ & N994 E982 & 4 & - & - & $=$ & - & $1-4$ \\
\hline $41 M C 268$ & $B$ & N994 E983 & 11 & $1-6$ & $7-11$ & - & - & - \\
\hline 41 MC 268 & $\mathrm{~B}$ & N995 E982 & 6 & - & - & - & - & $1-6$ \\
\hline 41 MC 268 & $B$ & N995 E983 & 4 & - & - & - & - & $1-4$ \\
\hline 41 MC 268 & $B$ & Test Pit 1 & 7 & - & - & - & - & $1-7$ \\
\hline 41 MC 268 & $B$ & Test Pit 2 & 8 & - & - & - & - & $1-8$ \\
\hline 41 MC 268 & $B$ & Test Pit 3 & 5 & - & - & - & - & $1-5$ \\
\hline 41 MC 296 & A & N1025 E997 & 7 & $1-2$ & $3-4$ & $5-7$ & - & - \\
\hline 41 MC 296 & A & N1025 E998 & 7 & $1-2$ & $3-4$ & $5-7$ & - & - \\
\hline 41 MC 296 & A & N1025 E999 & 9 & $1-2$ & $3-4$ & $5-9$ & - & - \\
\hline 41 MC 296 & A & N1026 E997 & 7 & $1-2$ & $3-4$ & $5-7$ & - & - \\
\hline 41 MC 296 & A & N1026 E998 & 7 & $1-2$ & $3-4$ & $5-7$ & - & - \\
\hline 41 MC 296 & $A$ & N1026 E999 & 7 & $1-2$ & $3-4$ & $5-7$ & - & - \\
\hline 41 MC 296 & $A$ & N1027 E997 & 7 & $1-2$ & $3-4$ & $5-7$ & - & - \\
\hline 41 MC 296 & A & N1027 E998 & 7 & $1-2$ & $3-4$ & $5-7$ & - & - \\
\hline 41 MC 296 & $A$ & N1027 E999 & 8 & $1-2$ & $3-4$ & $5-8$ & - & $=$ \\
\hline 41 MC 296 & $\mathrm{~B}$ & N1022 E985 & 10 & $1-2$ & $3-4$ & $5-10$ & - & - \\
\hline 41 MC 296 & $\mathrm{~B}$ & N1022 E986 & 10 & $1-2$ & $3-4$ & $5-10$ & - & - \\
\hline 41 MC 296 & $B$ & N1022 E987 & 9 & $1-2$ & $3-4$ & $5-9$ & - & - \\
\hline 41 MC 296 & $B$ & N1023 E985 & 9 & $1-2$ & $3-4$ & $5-9$ & - & - \\
\hline 41 MC 296 & $B$ & N1023 E986 & 9 & $1-2$ & $3-4$ & $5-9$ & - & - \\
\hline 41 MC 296 & $\mathrm{~B}$ & N1023 E987 & 9 & $1-2$ & $3-4$ & $5-9$ & - & - \\
\hline 41 MC 296 & $B$ & N1024 E985 & 9 & $1-2$ & $3-4$ & $5-9$ & - & - \\
\hline 41 MC 296 & B & N1024 E986 & 9 & $1-2$ & $3-4$ & $5-9$ & - & - \\
\hline 41 MC 296 & $B$ & N1024 E987 & 9 & $1-2$ & $3-4$ & $5-9$ & - & - \\
\hline 41 MC 296 & C & N1022 E989 & 2 & $1-2$ & - & - & - & - \\
\hline 41 MC 296 & $\mathrm{C}$ & N1023 E989 & 4 & $1-2$ & $3-4$ & - & - & - \\
\hline 41 MC 296 & $\mathrm{C}$ & N1024 E989 & 4 & $1-2$ & $3-4$ & - & - & - \\
\hline 41 MC 296 & D & N1025 E995 & 6 & $1-2$ & $3-4$ & $5-6$ & - & - \\
\hline 41 MC 296 & D & N1026 E995 & 6 & $1-2$ & $3-4$ & $5-6$ & - & - \\
\hline 41 MC 296 & $\mathrm{D}$ & N1027 E995 & 6 & $1-2$ & $3-4$ & $5-6$ & - & - \\
\hline 41 MC 296 & $E$ & N1026 E986 & 3 & $1-2$ & 3 & - & - & - \\
\hline 41 MC 296 & $\bar{E}$ & N1027 E986 & 4 & $1-2$ & $3-4$ & - & - & - \\
\hline 41 MC 296 & $G$ & N1026 E978 & 5 & $1-2$ & $3-4$ & 5 & - & - \\
\hline 41 MC 296 & $\bar{G}$ & N1027 E978 & 6 & $1-2$ & $3-4$ & $5-6$ & - & - \\
\hline 41 MC 296 & - & Test Pit 1 & 14 & $1-2$ & $3-4$ & $5-14$ & - & - \\
\hline 41 MC 296 & - & Test Pit 2 & 9 & $1-2$ & $3-4$ & $5-9$ & - & - \\
\hline 41 MC 296 & - & Test Pit 3 & 3 & $1-2$ & 3 & - & - & - \\
\hline
\end{tabular}


TABLE 58. RADIOCARBON ASSAYS FOR.PHASE II INVESTIGATIONS

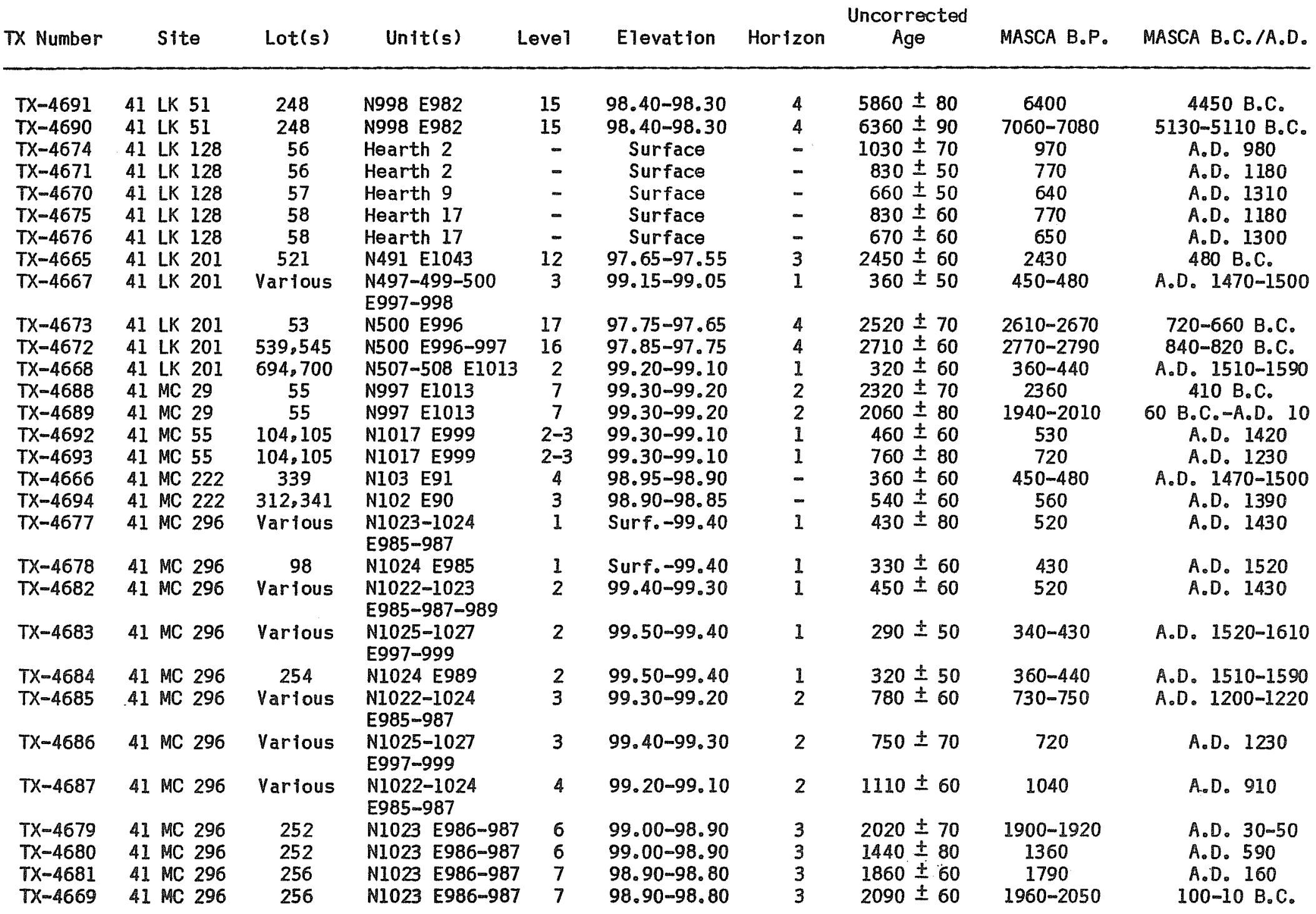


difference in age for all seven paired samples is 318 years. No explanation is offered for the variances shown between assays in the paired samples. The samples were large and relatively free of impurities (rootlets, soi 1, etc.). The average standard deviation for the 14 assays (reflecting 1 atitude for experimental error) is 69 years. The comparatively low standard deviation for the individual assays reflect an acceptable degree of reliability for the samples at the radiocarbon 1 aboratory.

\section{RADIOCARBON DATA SLMAARY}

The Nueces River project is responsible for the largest sample of radiocarbon assays yet assembled from any area of south Texas. In fact, the total number of assays obtained during the project probably exceeds the total number of assays currently available from all other archaeological contexts in south Texas. A total of 47 assays has been determined from samples col lected in the Choke Canyon Reservoir area during the project. This total includes four assays of burned mussel shel1 and 43 assays of wood charcoal. Fu11 provenience data and MASCA cal ibrations for a 1147 dates are presented in Table 36 in Ha11, Black, and Graves 1982 and in Table 58 in this volume. The purpose of this discussion is to summarize the radiocarbon data and to provide a calibrated presentation using the most recent radiocarbon calibration (K lein et a 1. 1982).

It should be noted that the 47 radiocarbon samples that were processed from the Choke Canyon Reservoir work were al1 from comparatively we 11-control1ed contexts. That is, all of the samples were from contexts that were felt to be related to specific cultural components. Most of the samples were collected from sites that were extensively tested or excavated. Thus, the resulting assays can be related in most cases to specific cultural assemb lages. Numerous other charcoal samples collected from less secure contexts were not processed precisely because of their questionable associations.

Table 591 ists 42 assays obtained from wood charcoal, which are felt to be the most reliable basis for dating. The four mussel shel 1 assays did not have a consistent relationship to the matching wood charcoal assays. One wood charcoal assay from 41 LK 67, TX-2911, had a one sigma error estimate of 830 years, indicating an inadequate amount of carbon; hence, this sample was not used. The remaining 42 assays were calibrated by reference to the calibration tables in Klein et a1. (1982:124-144), arranged from earliest to 1 atest beginning date and plotted in Figure 107.

In the last decade a number of radiocarbon correction curves or tables (calibrations) have been constructed and published following the recognition that the radiocarbon content of atmospheric carbon dioxide has varied through time. These calibrations have been accomp 1 ished by comparing the radiocarbon assays of a series of tree ring samples that were accurately dated by dendrochronology. Earlier calibrations such as those by Ralph, Michael, and Han (1973), Damon et a 1. (1974), and Clark (1975) are based on various subsamples of the total number of tree ring dates which have been radiocarbon dated. These calibrations are generally in agreement on the major variations of atmospheric radiocarbon but differ on the minor variations. In addition, 
TABLE 59. RADIOCARBON DATES FROM PHASE II EXCAVATIONS AT CHOKE CANYON RESERVOIR

ID Number(\#) TX Number(\#) Site Assay

\begin{tabular}{|c|c|c|c|}
\hline 1 & 2920 & 41 LK $31 / 32$ & $4710 \pm 80$ \\
\hline 2 & 2921 & 41 LK $31 / 32$ & $4690 \pm 80$ \\
\hline 3 & 2922 & 41 LK $31 / 32$ & $3970 \pm 160$ \\
\hline 4 & 2909 & 41 LK 67 & $2600 \pm 70$ \\
\hline 5 & 2910 & 41 LK 67 & $2530 \pm 70$ \\
\hline 6 & 3021 & 41 LK 67 & $3300 \pm 60$ \\
\hline 7 & 3607 & 41 LK 88 & $1080 \pm 60$ \\
\hline 8 & 3022 & 41 LK 201 & $3090 \pm 80$ \\
\hline 9 & 2873 & 41 MC 29 & $2240 \pm 50$ \\
\hline 10 & 3020 & $41 \mathrm{MC} 201$ & $2950 \pm 70$ \\
\hline 11 & 2875 & 41 MC 222 & $700 \pm 150$ \\
\hline 12 & 2876 & 41 MC 222 & $710 \pm 50$ \\
\hline 13 & 4691 & 41 LK 51 & $5860 \pm 80$ \\
\hline 14 & 4690 & 41 LK 51 & $6360 \pm 90$ \\
\hline 15 & 4674 & 41 LK 128 & $1030 \pm 70$ \\
\hline 16 & 4671 & 41 LK 128 & $830 \pm 50$ \\
\hline 17 & 4670 & 41 LK 128 & $660 \pm 50$ \\
\hline 18 & 4675 & 41 LK 128 & $830 \pm 60$ \\
\hline 19 & 4676 & 41 LK 128 & $670 \pm 60$ \\
\hline 20 & 4665 & 41 LK 201 & $2450 \pm 60$ \\
\hline 21 & 4667 & 41 LK 201 & $360 \pm 50$ \\
\hline 22 & 4673 & 41 LK 201 & $2520 \pm 70$ \\
\hline 23 & 4672 & 41 LK 201 & $2710 \pm 60$ \\
\hline 24 & 4668 & 41 LK 201 & $320 \pm 60$ \\
\hline 25 & 4688 & 41 MC 29 & $2320 \pm 70$ \\
\hline 26 & 4689 & 41 MC 29 & $2060 \pm 80$ \\
\hline 27 & 4692 & 41 MC 55 & $460 \pm 60$ \\
\hline 28 & 4693 & 41 MC 55 & $760 \pm 80$ \\
\hline 29 & 4666 & 41 MC 222 & $360 \pm 60$ \\
\hline 30 & 4694 & 41 MC 222 & $540 \pm 60$ \\
\hline 31 & 4677 & 41 MC 296 & $430 \pm 80$ \\
\hline 32 & 4678 & 41 MC 296 & $330 \pm 60$ \\
\hline 33 & 4682 & 41 MC 296 & $450 \pm 60$ \\
\hline 34 & 4683 & 41 MC 296 & $290 \pm 50$ \\
\hline 35 & 4684 & 41 MC 296 & $320 \pm 50$ \\
\hline 36 & 4685 & 41 MC 296 & $780 \pm 60$ \\
\hline 37 & 4686 & 41 MC 296 & $750 \pm 70$ \\
\hline 38 & 4687 & 41 MC 296 & $1110 \pm 60$ \\
\hline 39 & 4679 & 41 MC 296 & $2020 \pm 70$ \\
\hline 40 & 4680 & 41 MC 296 & $1440 \pm 80$ \\
\hline 41 & 4681 & 41 MC 296 & $1860 \pm 60$ \\
\hline 42 & 4669 & 41 MC 296 & $2090 \pm 60$ \\
\hline
\end{tabular}

* See Table 36 in Hal1, Black, and Graves (1982) for full provenience and corrected dates for assays 1-12. See Table 58 in this report for ful1 provenience and corrected dates for assays 13-42. The ID Number is used in Figures 107 and 108 to identify each assay. 


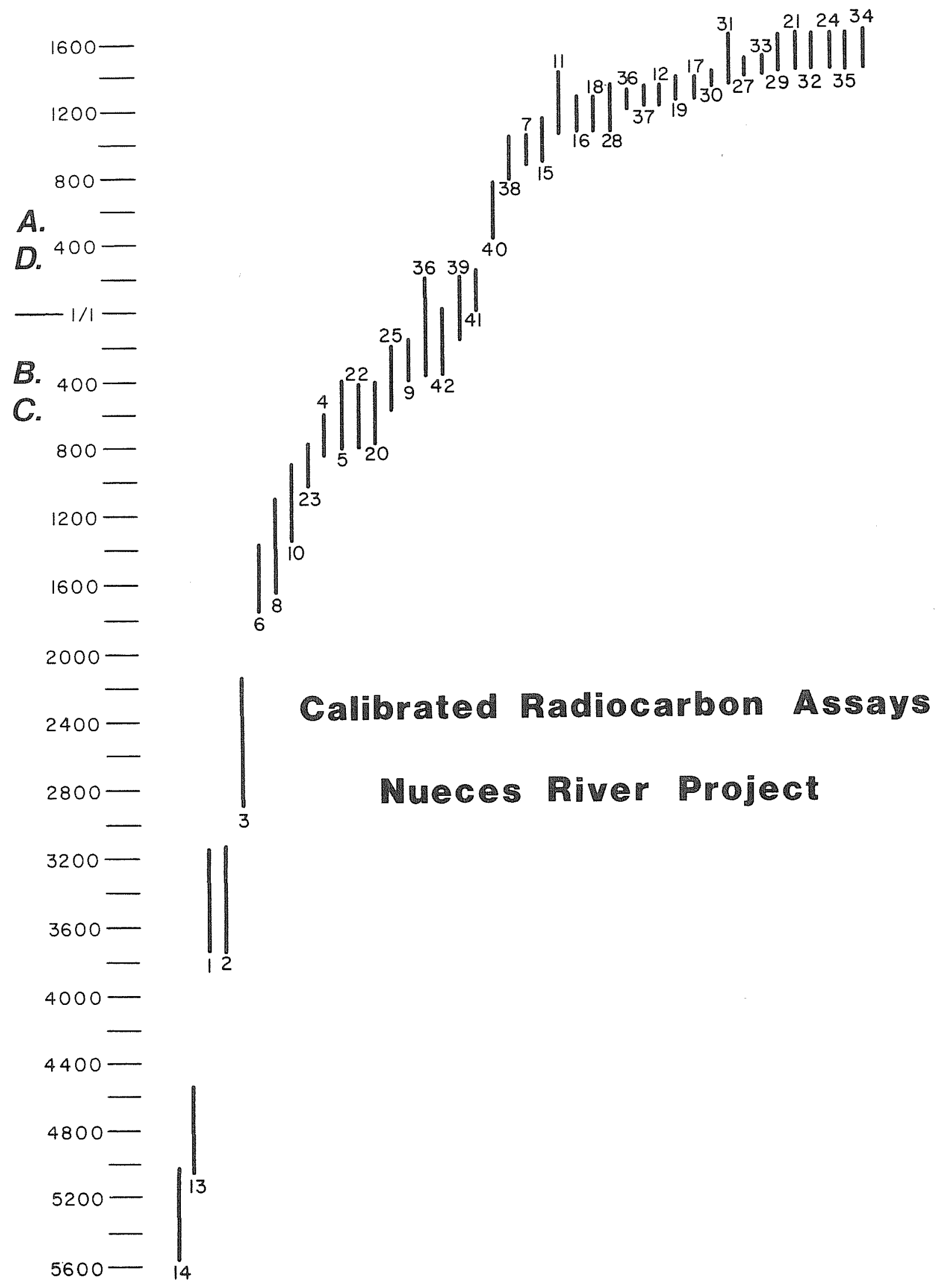

Figure 107. Calibrated Radiocarbon Assays, Nueces River Project. 
the cal ibrations are expressed in different formats, with some being much more difficult to use than others. The new calibration is the result of a major workshop held by radiocarbon scientists from al1 over the wor $1 d$ in 1979 in Tucson (Michael and Klein 1979). This calibration is based on the combined data of a number of major radiocarbon 7 aboratories and is, thus, more accurate than the earlier calibrations based on subsets of the total sample. In addition, the Klein et al. (1982) calibration is presented in an unambiguous format.

One of the most important aspects of the Klein et a 1. (1982) calibration is that it is set up to yield two sigma assay ranges. By international agreement, all radiocarbon laboratories report their assays by reference to the 1950 radiocarbon present (years $B_{0} P_{0}$ ) with a one sigma error estimate. For example, assay 18 in Table 59, TX -4675 (4l LK 128), was reported as 830 \pm 60 years B.P. The one sigma error estimate of 60 years means that, statistical1y, two out of three assays of this particular sample would yield a midpoint between 770 and 890 B.P. To put this another way, actual age of the sample only has a statistical chance of $66 \%$ of falling within the reported assay range or radiocarbon age. The Klein et a 1. (1982) calibration tables yield two sigma assay ranges. This means that the black bars shown in Figure 107 indicate the date range within which the actual date has a 95\% statistical chance of occurring. It is important to realize that radiocarbon dating is a statistical method of estimating the actual date that yields an estimated range rather than a fixed date.

Figure 107 shows a time span of some 7200 years within which the 42 calibrated radiocarbon assays from the Choke Canyon Reservoir range. As noted elsewhere in this report, this does not cover the full range of occupation in the area as we lack samples from the earliest occupations. With in the time span in which we do have radiocarbon assays, one can observe a very sparse sample of dates prior to 2000 B.C. From about 1700 B. . $_{\text {. }}$ forward in time, we have increasingly 1 arger numbers of dates that form an a 1 most unbroken sequence of overlapping assays. The patterning of these dates may say something about the prehistoric occupation in the area, a though it is clearly recognized that samp 1 ing and preservation problems are a factor in the scarcity of early dates.

Two sites, 41 LK $5 I$ and $4 I$ LK $31 / 32$ provide al1 of the assays that date before 2000 B.C. These few assays do not form much of a basis for discussion. Beginning around 1700 B.C., the assays are much more numerous and represent 1 arger numbers of sites. Five apparent breaks in the assay continuum can be defined. It should be emphasized that these are only apparent breaks which may not represent cultura 1 rea 1 ities but rather the result of sampling gaps. The first break occurs at 800 B.C. Four dates from 41 LK 67, 41 LK 201 (two dates), and 41 MC 201 range between 1700 and 800 B.C. A second cluster of four dates occurs between 800 and $400 \mathrm{~B}_{0} \mathrm{C}_{\text {. }}$ Two of these assays are from 41 LK 67 and 41 LK 201. A second break at about $400 \mathrm{~B}_{0} \mathrm{C}_{0}$ is partially obscured by the overlap of a paired set of assays from 41 MC 29, as wi 11 be discussed 1 ater. Between 400 B.C. and A.D. 200, five assays occur, including two assays from 41 MC 29 (not including the abberant assay, \#25) and three assays from 41 MC 296. 
Perhaps the most interesting break in the radiocarbon assay distribution occurs between A.D. 200 and A.D. 800. Only one assay falls within this period, \#40, from 41 MC 296. Given the fact that three assays from comparable contexts at 41 MC 296, including a matching sample, \#39, from the same cultural feature, al 1 date to before A.D. 200 , assay $\$ 40$ is considered aberrant. The absence of assays for this 600-year (or more) period is considered highly significant in view of the substantial number of assays earlier and later in time. Elsewhere in this report, this break is interpreted as a break in settlement in the area.

Beginning at around $A_{0}$ D. 800, the radiocarbon assays form an unbroken span of some 800 years. A minor break or rather a 'thin point' in the sequence comes at about A.D. 1350. This would appear to be correlated with the change from expanding stem arrow point (Austin horizon) to contracting stem arrow point (Toyah horizon) occupations (B1 ack n.d.).

\section{Paired Samples}

As mentioned earlier, seven pairs of assays were submitted for radiocarbon dating. All of these pairs were from archaeologically secure contexts. In each case the pairs were judged to be archaeologically identical, that is to say they were from the same specific contexts. Each pair was pulled from the same field collection bag (aluminum pouches). A11 of the pairs were of chunk wood charcoal and were large enough to yield assays with comparatively low, one sigma error ranges. It should be noted that these samples were not identical from a radiocarbon scientist's perspective, as they were not split after combined sample pretreatment (Sam Valastro, personal communication). However, these samples were identical from an archaeologist's perspective. As has been stated, the seven pairs had an average uncorrected midpoint difference in age of 318 years. In order to further examine the differences in the radiocarbon evaluations of these seven pairs the cal ibrated ranges (K lein et a1. 1982) were plotted in Figure 108.

As Figure 108 indicates, the results of the paired assays were inconsistent. Two of the pairs overlapped strongly, three pairs overlapped siightly, and two pairs did not overlap. It should be remembered that these are two sigma assay ranges, hence a second assay from a given sample should have a $95 \%$ chance of occurring within the range of the first assay. Moreover, since we can expect the radiocarbon assays to be normally distributed within the probability range (two sigma range) then most of the dates should cluster near the center (midpoint) rather than on the edge of the distribution. Thus the paired assays are rather disappointingly inconsistent; on 1 y two pairs comfortably overlap. We are unable to explain this 1 ack of consistency.

\section{CONCLUDING COMMENTS ON RADIOCARBON DATING IN SOUTH TEXAS}

The Nueces River Project has contributed significantiy to the refinement of regional and local chronology in south Texas, however, it is apparent that many temporal gaps and questions remain. The chronology remains poorly defined for almost al1 periods of prehistory in southern Texas. Even for the best dated and presumably the briefest cultural period, the Late Prehistoric, 


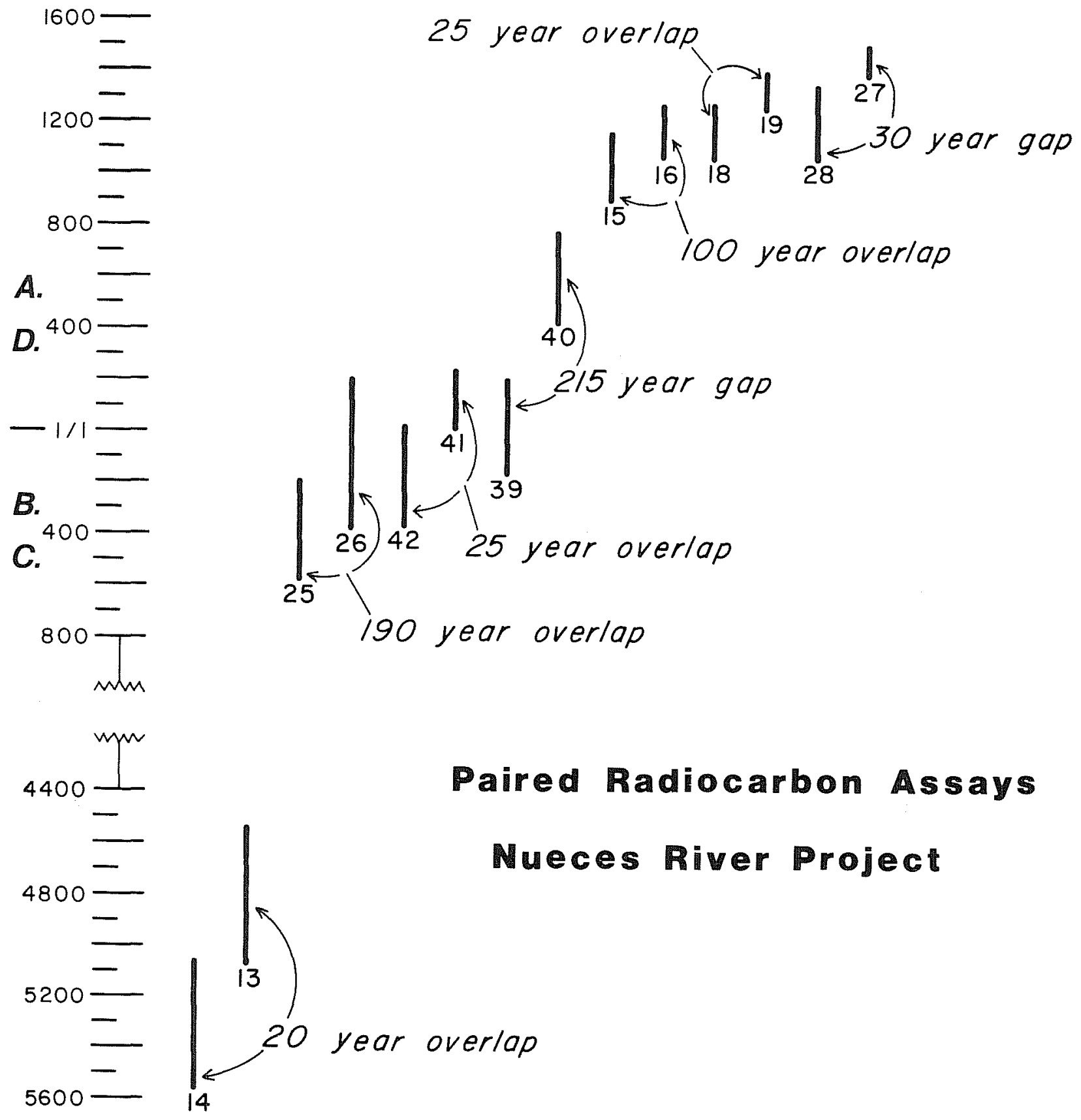

Figure 108. Cal ibrated Radiocarbon Assay Pairs. Dates are arranged in chronological order; note site numbers at top of vertical bars. Vertical bars reflect 2-sigma deviation possible for each date. The dates shown here are calibrated following the "Workshop on Calibrating the Radiocarbon Time Scale" (K1ein et a1. 1982). 
we still are in need of a series of assays from stratigraphically discrete components (cf. Black n.d.). For all other periods, the need is even greater. Thus, archaeological projects should continue to emphasize the recovery of datable material. However, the results presented here suggest that a change in radiocarbon dating strategy is necessary to effectively refine the prehistoric chronology.

Up until now, the attitude often taken toward radiocarbon sampling has been that one tries to collect charcoal whenever possible and to obtain assays whenever funding is available. Effectively, this has meant that numerous assays have been run on samples from questionable contexts. The main questionable aspect of these contexts is that given very $1 \mathrm{imited}$ sondage testing (a common source of radiocarbon samples in south Texas), one cannot understand the ful1 context of the sample. Thus, while an assay may he $1 p$ date a given level at a given site only an adequate sample of the cultural component being dated will place the assay in meaningful cultural context. The rationale that has been used to justify this approach is that we know so 1 ittle about the absolute dating of south Texas prehistory that any assay could potentially be of use. This rationale is no longer viable given the 1 imitations inherent in radiocarbon dating.

The Nueces River Project's paired sampling and multiple sampling from discrete contexts and components as we 11 as recent work at the Hinojosa site, $41 \mathrm{JW} 8$ (B1ack $n_{0} d_{0}$ ), underscore the 1 imitations of radiocarbon dating. The repeated failure of multiple dates from a single feature or component to closely agree (i.e., overlap within the first sigma) raise the question of what is an adequate sample of radiocarbon assays. In fact at sites in south Texas that have had multiple dates from archaeologically discrete contexts, the Choke Canyon sites discussed above and $41 \mathrm{JW} 8$, many of the dates do not strongly over 1 ap. This imp 1 ies that single dates cannot be expected to accurately reflect the actual date of a given component or feature. Thus, archaeologists should exercise extreme caution in relying on small numbers of radiocarbon dates. It cannot be emphasized enough that radiocarbon dating is a statistical method that yields statistical estimates of actual dates rather than actual dates itse 1 .

It is recommended that archaeologists seek to recover and process as many samples from discrete components as is possible. This will not be possible without intensive excavation strategies aimed at uncovering 1 arge areas of wel1-preserved site components. The alternative, smal1 numbers of samples from 1 imited testing, wil1 not yield a radiocarbon data base which can be effectively evaluated. Thus, it is recommended that the focus for dating archaeological remains in southern Texas be shifted from processing a few samples wherever possible to concentrating on the smal1 percentage of sites which can provide adequate numbers of samples from discrete contexts.

It is argued that a single assay or even two or three assays from a given site component, no matter how unquestionable the context, cannot be assumed to yield a confident chronological appraisal. Smal1 numbers of radiocarbon assays from we 11-defined cultural contexts will add to the regional and 1 ocal data base. However, the statistical results yielded by radiocarbon dating must be viewed within the context of the most extensive sample of dates that can be assembled from a given component or cultural construct. Story and 
Valastro's (1977) work at the Davis site in east Texas show the necessity for large numbers of samples to accurately date site components. Thus, while the Nueces River Project's radiocarbon data can be regarded as a major contribution to the ongoing effort to refine the chronology of southern Texas prehistory, much more dating remains to be done.

\section{REFERENCES CITED}

Black, S. L.

n.d. The Clemente and Herminia Hinojosa Site, $41 \mathrm{JW}$ 8: A Toyah Horizon Campsite in Southern Texas. Center for Archaeological Research. The University of Texas at San Antonio, Special Report 18 (in preparation).

Clark, R. M.

1975 A Calibration Curve for Radiocarbon Dates. Antiquity 49:251266.

Damon, P. E., C. W. Fergusson, A. Longs and E. I. Wallick

1974 Dendochronologic Calibration of the Radiocarbon Time Scale. American Antiquity $39(2): 350-366$.

Ha11, G. D., S. L. Black, and C. Graves

1982 Archaeological Investigations at Choke Canyon Reservoir, South Texas: The Phase I Findings. Center for Archaeological Research, The University of Texas at San Antonio, Choke Canyon Series 5.

Klein, J., J. C. Lerman, P. E. Damon, and E. K. Ralph

1982 Calibration of Radiocarbon Dates. Radiocarbon 24:103-150.

Michael, H. N. and J. KTein

1979 An International Calibration for Radiocarbon Dates. MASCA Journa $1(2): 56-57$.

Ralph, E. K., H. N. Michael, and M. C. Han

1973 Radiocarbon Dates and Reality. MASCA Newsietter 9(1):1-20.

Story, D. A. and S. Valastro, Jr.

1977 Radiocarbon Dating and the George C. Davis Site. Texas. Journal of Field Archaeology 4(1977):63-89. 
APPENDIX VII. PERMANENT SITE MARKER INFORMATION

PAGE 592 REDACTED 